
(2)

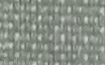

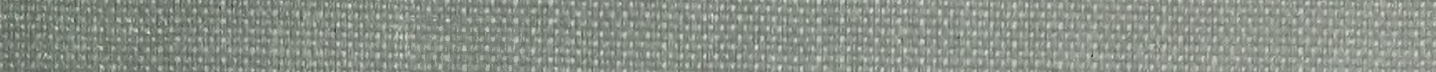

H.

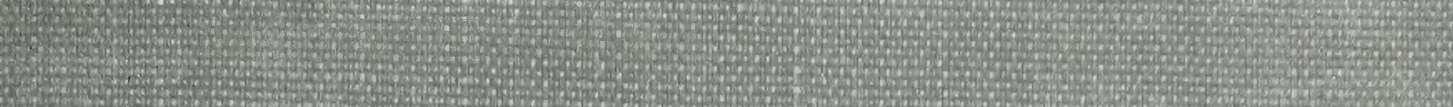
W. (2) 


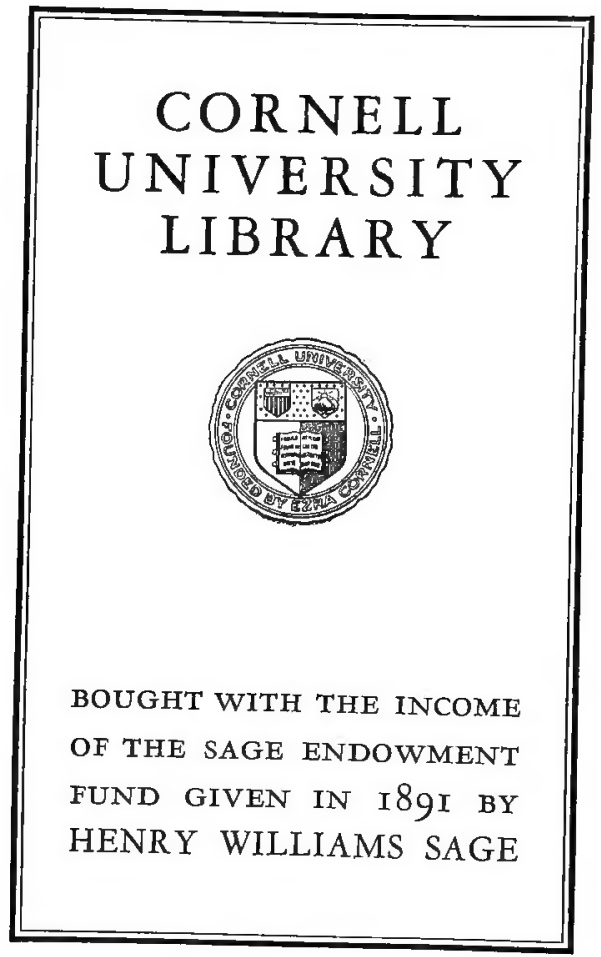

\section{RETURN TO \\ ALBERT R. MANN LIBRARY \\ ITHACA, N. Y.}


Cornell University Library

The fishes of Great Britain and Ireland.

3 1924002869000 


\section{Cornell University Library}

The original of this book is in the Cornell University Library.

There are no known copyright restrictions in the United States on the use of the text. 


\section{THE FISHES}

OF

\section{GREAT BRITAIN AND IRELAND.}

BY

\section{FRANCIS DAY, F.L.S., \& F.Z.S.,}

KNIGHT OF THE CROWN OF ITALY, HON. MEMBER DEUTSCHER FISCHEREI-VEREIN, AND OF THE AMERICAN FISHERIES SOCIETT, MEMBER OF THE ASTATIC SOCLETY OF CALCUTTA AND OF THE CO'SWOLd NATURALISTS' FIELD CLLD, ETC, DEPUTY SORGEONGENERAI MADRAS ARMY, (RETIRED,) AND FORMERLY IN,8PECTORGENERAL OF FISHERIES IN INDIA.

IN TWO VOLUMES.

VOLUME II.

WILLIAMS AND NORGATE,

14, HENRIETTA STREET, COVENT GARDEN, LONDON ; AND 20, SOUTH FREDERICK STREET, EDINBURGH. 
LONDON :

G. YORYAN AND SON, PRINTERS, HART STREET,

COVENT GARDEN. 


\title{
FISHES OF GREAT BRITAIN AND IRELAND.
}

\section{B. Anacanthini Pleuronectoidei.}

The structure of the head is apparently unsymmetrical on the two sides.

\section{Family, IV-PLEURONECTID E, Risso.}

\author{
Heterosomata, Bonaparte. Diprosopa, Latreille.
}

Branchiostegals six to eight: pseudobranchiæ well developed. Gills four. Body strongly compressed, flattened, with one of its sides coloured, the other being colourless or having merely some spots. Both eyes (except in the very young) situated on the upper or coloured surface, sometimes they are rudimentary. The two sides of the head not equally developed, one remaining almost rudimentary. The jaws and dentition may be nearly equally developed on both sides, or more so on the blind than in the coloured. A single, long, dorsal and anal fin. Pectorals when present may be rudimentary. Scales present or absent. Lateral-line on the coloured side single, double, or triple: curved or straight. Air-bladder absent.

The members composing this family are commonly known as flat-fishes, but it must be observed there are two groups of "flat-fishes." The one being as it were flattened from above, as we see in rays and skates, wherein the upper surface is the back. It is not so however among the Pleuronectidr or "side swimmers," which are flattened from side to side, except the head, which appears distorted and likewise flattened. When referring to the pleuronectoids the terms right (dextral) or left (sinistral) are employed with reference to the position of the upper or coloured side: to ascertain this the fish is placed with its tail towards the observer, the dorsal fin above and the anal beneath. Reversed examples are such as have the eyes situated on the side of the body opposite to the one in which it is generally seen. Double examples are those in which both sides of the body are coloured.

Adams remarked (Voyage of the Samarang) that such as frequent coral reefs often have their tails ornamented with rather vivid colours, and their upper sides marked with somewhat striling patterns; whereas those that are half buried are as dall and dingy as the surface is where they are found. They are evidently aware how efficacious their colours prove for the purpose of concealment, and when pursued sink down to the bottom, where they lie quite still on the ground, the colour of which assimilates to that of their own upper surface.

The Pleuronectoids, or flat-fishes, are among the most remarkable of vertebrate animals, as for about a week or more after birth they swim on edge in a way similar to other fishes, having their dorsal fin above, their anal fin below them, and possessing an eye on either side of the head. But as they grow older this erect position becomes lost, their sides become their upper and lower surfaces, while both eyes are on the superior or coloured side of the body. The adult, when at rest or swimming, usually keeps near the buttom of the water, and progresses by means of a sort of undulating motion of the whole body, and of the unpaired fins. These fish are of a broad, flat shape, and margined in almost 
their entire extent by the dorsal, caudal, and anal fins; while not only the muscles, but the skin, the gills, gill-covers, and eren the pectoral fin-rays are less developed on the blind (or normally under surface) than on the coloured side, the mouth also being, as it were, bent round to this eyeless side, towards which the anterior part of the face seems to be twisted. From a very early age it had been known that these fishes when first emerging from the ova, and while in a pellucid condition, have an eye on either side of the head; that by degrees the eye, on what eventually will be the eyeless side, becomes depressed, while at the same time a dark spot appears on the opposite side of the head, so that the fish almost seems to possess three eyes. By degrees this dark spot becomes a distinct eye, while that on the other side gradually disappears; in short, the eye apparently migrates from what is henceforth known as the blind side of the fish. Van Beneden (1853) and many others, considered that this abnormal position of the eyes in adult flat-fishes was due to a greater or less torsion of the entire head on the axis of the body, or else to a twisting of the face alone. Ten years subsequently (1863) Professor Steenstrup, having obtained examples of young flounders, demurred to this explanation. He observed that if such were effected by simple torsion, the nerves and muscles belonging to the upper eye must necessarily pass over the frontal bone of the blind side, and permanently continue in that position, which, however, is not found to be the case, they being at the bottom of the orbit; and he considered that the eye must have first passed under the frontal bones, and subsequently upwards and through them. The eye, when leaving its original site, attempts to carry the frontal bone of its own side with it, but the greater portion of that bone resists, remaining in its place. Professor Steenstrup consequently came to the conclusion that the eye on the blind side undertakes a movement deeper and deeper, passing under the half roof formed by the frontal bone of its own side, and is thus brought up through its vault; so that in order to find room for itself, it partially separates one frontal bone from its fellow, and partly makes its way through the substance of the frontal bone itself; in short, that the eye, in attaining its final position, first passes obliquely inwards, and then ascends upwards through the head, emerging on the opposite side. Professor Wyville Thompson* considered that the eye of the blind side passes to the coloured or eyed-side of the body, not through the vault of the head, bnt under the integument, displacing in its progress the frontal bone of its own side; that the space through which the nervous and vascular connections pass is indicated in the mature skull by the unsymmetrical posterior half of the articulating process of the prefrontal of the blind side, the eye haring maintained its normal relation to its associated bone, the frontal, of the coloured side throughont. The eye changes but little in actual position with the growth of the fish, the associated parts being, as it were, developed past it and thus producing this singular obliquity. Traquair (Trans. Linn. Soc. 1866, xxv, p. 263) beliered that bere we had a real case of asymmetry in the supposed absence of the additional processes of the os frontis anterius and proprium. But Hr. Malm† considered this conclusion to be erroneous, and he observed that the young flat-fish is obliged, owing to the depth of its body, increased by the development of its vertical fins, to remain on one side while resting on the ground, the horizontal fins not being sufficiently developed to sustain it in a vertical position. The eye of the "blind" side has a tendency to turn towards the light, and in doing so carries with it the cartilaginous framework of the skull, which eventually is only apparently asymmetrical. He gives excellent figures of the first stages of these fishes. + Professor Alexander Agassiz

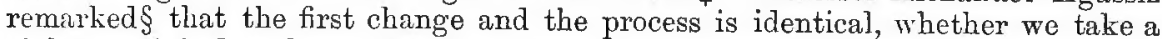
right or a left flounder. First there is a slight advance towards the snout of the eye about to be tranferred: so that the transverse axis, passing through the pupil of the eyes, no longer makes a right angle with the longitudinal axis. This movement of translation is soon followed by a slight movement of rotation, so

* Ann. and Mag. Nat. Hist. 1865, p. 361 .

$\dagger$ Srensk. Vet. Akad. Handl. vii, no. 4, 1868.

Fee also Gervais, Aleb. Zool. Exp. 1877, p. 193, t. vi, and Iacaze-Duthiers, 1.c. p. 305.

$\$$ A. Agassiz, Pro: Amer. Acad. Arts and Sciences, xiv, $1879,1, \mathrm{l}$. vii-x. 
that when the young fish is seen in profile, the eyes of the two sides no longer appear in the same place, that on the blind side being now slightly above and in advance of that on the coloured side. With increasing age the eye on the blind side rises higher and higher towards the median longitudinal line of the head. The dorsal fin gradualiy extends towards the nostrils, and finds its way behind the eye which has come from the blind side. The eye is transferred at such an early period that the bones of the skull are cartilaginous, and the transfer is carried out by a combined process of translation and rotation. In some cases it was observed to be transferred, as described by Malm, round the head by the snout, and in others to actually pass through the soft tissues of the head, and this divergence appeared to be due solely to the generic differences in the position of the dorsal fin.

Some flat-fishes have the eyes normally on the right side of the body, others on the left, but reversed instances, or those in which the coloured side is on that which is as a rule uncoloured, are not uncommon among most genera of Pleuronectoids. Such is very frequently observed in flounders, these fishes, living close in shore, being more exposed to the actions of currents than those genera which live in the deep sea. In this way they become in their very early life forced on to the side which is not the normal one. Such variations are more commonly perceived in some localities than in others, and will generally be found due to local disturbing causes. Professor Agassiz kept young flounders in glass vases, raised high above the table, and found that, notwithstanding the fact that here no disturbance could occur, seven out of fifteen were noticed endeavouring to force the eye round the wrong way, by lying down on the opposite side. But all the seven soon died, and this may account for the comparative scarcity of reversed flatfishes. He also observed that the presence of ligbt on all sides failed to arrest, or even to delay, the transfer of the eye, and the consequent change in the colonr of the under side, which invariably became white with advancing age, when that organ passed over to the upper surface. Thus it would appear that the absence of light is not the primary or sole cause of the want of colour on the under side of the flat-fishes.

While the eye is progressing from the one side of the head to the opposite where it is to find its final resting place, its course is occasionally arrested, and it may remain permanently stationary on the upper surface of the head, and this is commonly seen in what is known as "double flat-fishes,"* or those coloured on both sides. $\dagger$ Donovan obtained a young double turbot, and thinking he had discovered an unknown fish, termed it Pleuronectes cyclops, and which he figured on plate xc. "So singularly different," says that anthor, "is this from the rest of the Plentronectes that it seems to militate even against the character of the genus, which requires that both eyes should be placed on one side. We were almost tempted, from this consideration, to constitute a new genus for this curious fish." Yarrell remarks, "The Pleuronectes cyclops of Mr. Donovan, I believe to be an example of the young fry of the turbot, the head of which is not perfectly formed." Double fishes have been observed in flounders, turbot, plaice, soles, etc., and they are seen to swim vertically, and to be more frequently found near the surface of the water than those which progress in a normal manner. All who have eaten these double flat-fishes know how they are most deservedly held in greater estimation for the table than others which have an uncoloured as well as a coloured side. Then there are albinos or those which are uncoloured or nearly white on both sides (being almost or quite double albinos) and still retaining their normal form; but in some that have been carefully examined no sexual parts could be detected.

* These would appear to be examples in which the ancestral form has been more strongly developed than has the adopted. The early lives of these fishes afford excellent illustrations of these two distinct phenomena, or of ancestral or inherited form and adopted modification. For in the earlier stages of their existence after leaving the egg, they swim on edge with an eye on either side of the head as in other fishes; but in a definite period they assume their adopted form of both eyes being on the same side. No matter through how many countless generations these pleuronectoids may pass, still the embryonic or early fry condition, or an eye on either side of the head, will continue to be apparent, just as the visceral clefts in the human embryo are.

$\dagger$ In many double flat-fiches the eyes are in their normal position. 
In the majority of albino examples only patches or portions of the body are thas affected, and it has been suggested whether such may not occasionally be due to a cross having occurred between a normal and a reversed example of the same species giving rise to a sort of piebald colour.

Among these fishes it appears as if the female sex largely preponderated over that of the male. It also seems probable that their eggs float when deposited in the sea (see page 27). In the earlier stages of their existence during the spring months, pleuronectoids pass their lives close in shore; they swim on the surface and appear more active if the wind is setting in shore, perhaps taking advantage of it to return towards home.

Many legends doubtless are in existence throughout the universe regarding how these fishes became coloured on one side only. Klunzinger tells us that in Upper Egypt a tradition is prevalent that Moses was once cooking a fish, but by the time it had been broiled until it was brown on one side, the fire or the oil gave out. Moses, in a temper the reverse of amiable, threw the fish into the sea, where, although half broiled, it came to life again, and its descendants have up to the present day preserved the same peculjar appearance, being white or colourless on one side and coloured on the other. In Constantinople a similar story is told of these fishes, but Moses retires in favour of the Sultan, Mohammed II, the conqueror of Stamboul. In the Isle of Man, Patterson states that there is a legend accounting for how the mouths of flat-fishes became twisted; the finny tribes bethought themselves that it was time to select a king to decide disputes, and for which purpose they all assembled, putting on their best appearance. The plaice, however, remained so long at home adorning himself with red spots in order to be selected their chief, that he did not arrive until all was over and the shad had been elected "king of the sea." On hearing the result, the indignation of the plaice was aroused, and curling his mouth to one side, he remarked with disdain, "Fancy a simple fish like a herring being king of the sea." And his mouth has continued awry ever since.*

In some of the genera forming this family it is very interesting to observe the different plans on which the eyes are modified and protected. Thus, the plaice or the flounder are able to move these organs horizontally, or even vertically, and it appears as if the two eyes, to a certain extent, act independently one of the other. In the turbot this organ can be covered, for not only does a thick skin invest the upper and lateral portions of the globe, as in most of the pleuronectide, but being insufficient to protect the eye from the irritation of the sand wherewith it covers itself, it is able to elevate a thick lower eyelid, or else to depress the transparent portion of the globe of the eye beneath this fold of skin.

Respecting the means of capturing these fishes, it is found that they mostly reside in localities where the beam-trawl can be employed; while due to their great commercial value for food they are sought for throughout the year. It was observed at Great Grimsby, during the cold winter of 1881, that the catch of soles had increased, as then they retired into deep water. By an old law of the Cinque Ports, no one might capture soles between the lst of November and the 15th of March: neither was any one permitted to fish from sun-setting to sun-rising, that the fish might enjoy their night's food (Pennant, 1776). Constant complaints are heard respecting the diminution in the quantity of flat-fishes and the undersized ones that are sent to market. Thus, in Land and Water of September 17th, 1881, Mr. Epton remarks on this as a fisherman and what he has observed during the last few years off Great Grimsby. Now these fish have decreased so that the captures by each fishing smack are much less than formerly, but the supply has been kept up by increasing the number of vessels. It has been suggested that beam trawlers ought not to fish in water of less depth than twelve fathoms, or they would be injuring the brood-grounds. Once captured in a trawl, there would be but little use in returning the small fish to the sea, as they are usually too much injured. body.

* The muscles of these fishee are more developed on the coloured than on the blind side of the 
Dr. Sauvage has remarked that the various degrees of development of the termination of the vertebral column in the genera Rhombus, Solea, and Pleuronectes are in accordance with their geological appearance (Compt. Rend., April, 1872), while, geologically speaking, they are a modern family of fishes, having been found in a fossil state in the early Tertiary deposits (Rhombus solea), but no remains of allied forms occur associated with those of the bony fishes of the Cretaceous and Jurassic rocks.

Geographical distribution.-These littoral forms are mostly found where the sea possesses a sandy bottom, or else in muddy or sandy rivers, rarely existing at great depths, and but seldom frequenting rocky or precipitous coasts; while due to the deficiency of an air-bladder they live at the bottom. Pleuronectoids are most numerous towards the tropics, where, however, they do not attain to so large a size as those which reside in temperate or cold regions; they are absent from very high latitudes. Some, as the common flounder, are anadromous forms, but the majority are strictly marine; while a few of the marine species have naturally, or consequent upon experiments made by man, been acclimatized in fresh water.

\section{Synopsis of Genera.}

A. Jaws and dentition about equally developed on both sides.

1. Hippoglossus.-Eyes on the right side. Teeth in the upper jaw in two rows. The dorsal fin commences above the upper eye. Scales cycloid.

2. Hippoglossoides.-Eyes on the right side. Teeth small and in a single row. The dorsal fin commences above the upper eye. Scales ctenoid.

3. Rhombus. -Eyes on the left side. Teeth in a band in both jaws and prescnt on the vomer.

4. Zeugopterus.-Eyes on the left side. Teeth in a band. The dorsal fin commences before the eyes. Scales ctenoid or spinate.

5. Arnoglossus.-Eyes on the left side. Teeth in one or two rows in the jaws. Dorsal fin commences on the snout. Scales deciduous.

\section{B. Jaws and dentition most developed on the blind side.}

6. Pleuronectes.-Eyes on the right side. Teeth of moderate size. The dorsal fin commences above the upper eye. Both pectorals present.

7. Solea.-Eyes on the right side. Teeth small, only on the blind side. The dorsal fin commences before the upper eye and is not confluent with the caudal. Pectorals may be well developed, rudimentary, or absent. Scales ctenoid.

Genus I-Hippoglossus, Cuvier.

Platysomatichthys, Bleeker (lateral-line having a curved anterior portion).

Branchiostegals seven: pseudobranchice present. Eyes on the right side. Cleft of mouth deep. Gill-rakers few, compressed and short. Teeth in the upper janv in two rows, the outer of which is composed of conical ones: those in the lower jaw conical and widely set: none on vomer, palatines or tongue. Dorsal fin commences above the orbit: caudal free: dorsal and anal fin rays (except the last few) unbranched. Scales small, cycloid and not extended on to the vertical fins. Lateral-line straight or with a curve in its anterior portion.

Habitat.-North Atlantic to the south coast of England, and stragglers off France: and on the American coast from Newfoundland to Cape Hatteras. In the North Pacific it has been taken from Kamtskatka to California.

These fishes are mostly captured off banks at some distance from the coast, and at depths up to 150 fathoms. They attain to a large size. Storer records an American example which weighed $3 \mathrm{cwt}$.

\section{Hippoglossus vulgaris, Plate XCIV.}

Hippoglossus, Rondel. xi, c. 16, p. 325; Willughby, p. 99, t. F6 ; Ray, Syn. p. 33; Gesner, pp. 669, 787 ; Aldrov. ii, c. 43, p. 238. Passerum genus najus, 
Schoner. p. 62. Pleuronectes, sp. Artedi, Synon. p. 31, no. 3, and Gen. p. 17, no. 3 ; Gronov. Zooph. no. 247. Passer, sp. Klein, Pisc. Miss. iv, p. 33, no. 2. Helleflynder, Pontop. Norg. Nat. Hist. ii, p. 220; Ström. Söndm. i, p. 300. Hippoglossus Rondeletii, Rutty, Co. Dublin, 1772, i, p. 350 . Holibut, Pennant, Brit. Zool. (ed. 1776) iii, p. 226 (ed. 1812) iii, p. 302. Fletan, Duhamel, Pêches, ii, sect. ix, p. 271, pl. vii, f.1. The Holibut, Low, Fauna Orcad. p. 211.

Pleuronectes hippoglossus, Linn. Syst. Nat. i, p. 456; Bloch, t. xlvii ; Bl. Schn. p. 147; Gmel. Linn. p. 1227 ; Lacép. iv, p. 601 ; Bonnaterre, Ency. Ich. p. 74 , pl. xxxix, f. 156 ; Donovan, Brit. Fish. iv, pl. Ixxv; Shaw, Zool. iv, p. 295 ; Pallas, Zoogr. Roos. As. iii, p. 421 ; Turton, Brit. Fanna, p. 95 ; Faber, Fische Isl. p. 148; Gronor. ed Gray, p. 87; Schlegel, Dieren Neder. p. 173, pl. $x \mathrm{v}, \mathrm{f} .1$.

Hippoglossus vulgaris, Flem. Brit. An. p. 199; Jenyns, Man. p. 460 ; Yarrell, Brit. Fish. (Ed. 1) ii, p. 230, c. fig. (Ed. 2) ii, p. 321 (Ed. 3) i, p. 630; Parnell, Wern. Mem. vii, p. 372 and Fish. Firth of Forth, p. 212; Templeton, Mag. Nat. Hist. 1837 (2) i, p. 411 ; Johnston, Berwick. Nat. Hist. Club, 1838, i, p. 174; De Kay, New York Fauna, Fish. p. 294, pl. xlix, f. 157 ; White, Catal. p. 101 ; Thompson, Nat. Hist. Ireland, iv, p. 199; Günther, Catal. iv, p. 403; Malgr. GEfv. Sren. Vet. Akard. Förh. 1865, p. 527 ; Gilpin, Proc. and Trans. Nov. Scot. Inst. Nat. Sci. ii, 2, 1869, p. 20; Collett, Norges Fiske, p. 134; McIntosh, Fish. St. Andrew's, p. 179 ; Winther, Ich. Dan. Mar. p. $36^{\circ}$; Morean, Poiss. France, iii, p. 287 (? Ayres, Proc. Cal. Acad. 1859, p. 30).

Hippoglossus maximus, Gottsche, Wiegm. Arch. 1835, p. 164; Kröyer, Dan. Fisk. ii, p. 381, c. fig. ; Nilsson, Skan. Fauna, iv, p. 631.

Mippoglossus gigas, Swainson, Fishes, ii, p. 302 ; Bonap. Pesc. Eur. 47.

Hippoglossus Limnei, Malm, p. 508.

Holibut, Couch, Fish. Brit. Isles, iii, p. 149, pl. clix.

B. vii, D. 99-107, P. 14-18, V. 6, A. 73-82, C. 15-18, Cœe. pyl. 4, Vert. 16/34.

Length of head $4 \frac{1}{2}$, of caudal fin $6 \frac{1}{2}$, height of body 3 to $3 \frac{1}{4}$ in the total length. Eye-diameter $5 \frac{1}{2}$ to 6 in the length of the head and nearly or quite equals the extent of the snout, and from $\frac{3}{4}$ to 1 diameter apart; anteriorly the two eyes reach to the same level ; interorbital space smooth, scaleless. The greatest height of the head does not quite equal its length. Lower jaw prominent; the posterior extremity of the maxilla reaches to beneath the middle or hind edge of the orbit; the length of the maxilla equals about $1 / 3$ of that of the head. Teeth-conical, in the anterior two-thirds of the upper jaw in two rows, the outer consisting of distantly separated and large ones: posteriorly a single row; in the lower jaw six to eight distantly placed conical ones; none on the palate or tongue. Fins-the dorsal commences above the first third or middle of the upper orbit, and terminates before it reaches the caudal fin, the length of the interspace being equal to the depth of the free portion of the tail; all the rays are simple and unbranched except the last few ; the highest rays are about its centre where they cqual about one-third that of the body beneath them, the anterior and posterior rays are short. Pectoral on the coloured side half as long as the head, slightly shorter on the blind side; Ventral short, being scarcely half the length of the pectoral, while it does not quite reach to above the commencement of the anal, which latter fin is low at first but at about the end of its first third the rays become so long as to be equal to at least $1 / 3$ of that of the body above it, the fin terminates beneath the end of the dorsal, its last few rays bifurcated. Caudal emarginate. Scales-minute, and cycloid over the body and head on the coloured side and some on the end of the maxilla, none between the rays of the dorsal and anal fins. Blind side of body scaled. No spine in front of the anal fin. Lateral-line -anteriorly curved above the pectoral fin, the height of the curve being about equal to one-fourth of its length. Gitl-ralerscompressed, wide but short, the length of each not being equal to half that of the orbit. Colours - right or coloured side of an olive marbled all over with darker: fins similarly coloured except in the young, when the basal halves of the dorsal and anal are light colonred.

Names.- Said by Ray (1713) to have been termed but, also turlut or turbot. 
Lady fluke. Turbot, Moray Firth, also bradan leathan or "flat salmon," while at Aberdeen the large ones are called turbot, very old and black ones blachismiths, and young ones birdies (Sim). Also known as workhouse turbot. De Heilbot, Dutch. Le Flétan, French.

Habits.-This is the largest form of the family taken off the British shores. It feeds close to the ground, but often inhabits deep and rocky situations, while Lacépède observed that in Greenland it appeared to prefer localities alsó frequented by the cod, as the p probably seek the same food. Pennant remarked (1776) that during the preceding year there had been two instances of holibuts swallowing the lead weight at the end of lines with which seamen were sounding, one occurring off Flamborough Head, the other when going into Tinmouth Haven. Thompson took from the stomach of one weighing about $120 \mathrm{lb}$. the remains of a ray : from another ten full grown sprats and a fragment of Millepora polymorpha: another was crammed with crabs and a valve of Venus cassina. On the Dogger bank it is said to consume large quantities of shell fish, also flat-fish and crustacea.

Means of capture.-Baits employed on very strong hooks and lines, as it sometimes offers a most determined resistance when hooked, and which may be very formidable in large examples. This, according to Thompson, is not in accordance with the experience of Irish fishermen, who assert that it is a simple fish, easily killed, and they never lose one in consequence of its weight. Off Ireland it is said to be generally taken on cod-lines, the Buccinum undatum being mostly employed as a bait. In the Orkneys they are most commonly captured in the slack water and eddies occasioned by the various islands in the race of the tides.

Baits.-Generally those employed for the cod and turbot. In the Moray Firth a piece of plaice is mostly used.

Breeding.-April in Cornwall (R. Couch) : off Scotland in the spring (Parnell). The roe is of a pale red colour, and the ova very numerous (Buckland).

Diseases.-Thompson states that upon all he has examined were specimens of the parasite Hirudo hippoglossus, Müller; and McIntosh remarks that Epibdella hippoglossi is often seen on the caligus of this fish, in fact Udonella caligorum is common.

Uses.- Said to be more famed for its size than for its quality, and is sold throughout the year except during May and June.

As food.-It is little esteemed in England and does not obtain a ready sale among the general public, unless other fish is scarce; Mr. Rowell, however, observes (Land and Water, July 16th, 1881), that at Newcastle they are termed "turbot" and greatly esteemed, and as a test observes cod is retailed at $4 d$ a lb. ling at $5 d$ or $6 d$ and halibut at $10 d$ or $1 s$, these three prices showing their respective local estimation. He continues: "Let any one get a piece of halibut from a small one, season it with nutmeg, pepper, and salt, and bake it in the oven, and I know nothing so fine-no fish, turbot, sole, or salmon, can excel it; it does not do to boil, it is too soft, I think, and it is too thick to fry, and it does not do to slice it, but cut a piece of three or four pounds or more, and bake it, it makes a most delicious fish dinner."

In Cheltenham and elsewhere, Jews are frequent purchasers of halibut, but they must have an entire fish with its head and gills intact. Thompson considered it very good for the table : Low asserted that it is a large, coarse and dry fish, except the head and fins which are reckoned excellent, while a small one is far from bad. The skin is thick and oily, as also the bones, from which latter a quantity of pure oil may be obtained. The Greenlanders are said to cut them into large strips which are dried in the sun.

Habitat.-From the coasts of Spitzbergen to Iceland, Finland and Scandinavia to the British and French shores, but it is rare in the Channel. One was taken in 1874 at Biarritz, and likewise at Boulogne (Moreau). It is abundant off the Orkneys, especially in eddies or where two tides meet, one captured in such a locality was $7 \frac{1}{2}$ feet long and thick in proportion; it is also common in Zetland (Baikie). Frequently met with along the east coast of Scotland (Parnell) : and 
thrives on the immense sandy plain between there and Norway (Buckland). Reid has obtained it up to $231 \mathrm{lb}$. weight at Wick : also found in the Moray Firth, more particularly during the month of March: at Banff in deep water (Edward) : Aberdeen (Sim): not rare at St. Andrew's (McIntosh). Resident off the Yorkshire coast and in moderate numbers, but seldom caught now at Flamborough where thirty or forty years ago it was very numerons (Yorkshire Vertebrata). In the Norwich papers of February 15th, 1873, one is mentioned as having been taken off Yarmouth, measuring $5 \frac{1}{3}$ feet long, $2 \frac{1}{2}$ broad, and weighing $7 \frac{1}{2}$ stone, and Buckland, another, 6 feet long, weighing $161 \mathrm{lb}$. obtained from the same locality in 1867. In the Norfolk Chronicle of April 29th, 1876, it is recorded that Messrs. Parker exhibited a halibut from the deep sea off the eastern counties weighing over $300 \mathrm{lb}$. and above seven feet in length. It has been captured off Sussex (Merrifield) : it is occasionally taken off Devonshire but not sought after (Parfitt) : on April 14th, 1870, one weighing $102 \mathrm{lb}$. was sectred at Mevagissey : it is not common off Cornwall, and has been taken up to $122 \mathrm{lb}$. off Land's End, and one weighing about a cwt. is recorded by Mr. Cornish in the Zoologist, as captured on a spiller in Mount's Bay on May 15th, 1882. Pennant mentions it

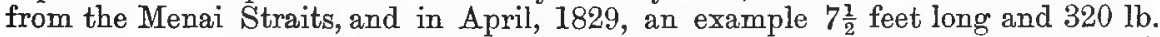
weight was recorded from off the Isle of Man (Mag. Nat. Hist. 1829, i, p. 84) and is, perhaps, the example stated by Parnell to have sent to the Edinburgh market (1828).

In Ireland.-It is talken occasionally on all parts of the coast from December antil March. In Portrush, county of Antrim, it is occasionally captared in winter on the cod-lines, baited either with Buccinum undatum or the flesh of various fishes, chiefly Labridoe (Zool. 1876, p. 4754).

The example figured is 26 inches in length and came from the North Sea. It attains to at least $500 \mathrm{lb}$. weight in Europe. Olasson mentioned one exceeding this from Iceland, and which was said to have been little short of 20 feet in length : while Couch was informed of a still larger example captured on the banks of Newfoundland. 


\section{Genus II-Hippoglossoides, Gottsche.}

Branchiostegals eight: pseudobranchice present. Eyes on the right side. Cleft of mouth deep. Pointed teeth in a single row in the jaws, none on the palate. The dorsal fin conmences above the upper eye, its rays, as well as those of the anal, unbranched. Scales small and ctenoid, a row along each dorsal and anal ray. Lateral-line without any curve anteriorly.

Geographical distribution.-Coasts of the northern seas of Europe, extending to and around the British Isles. Also found on the Atlantic shores of America.

\section{Hippoglossoides limandoides, Plate XCV.}

Pleuronectes limandoides, Bloch. t. clexxvi; B1. Schn. p. 146; Gmel Linn. p. 1232 ; Bonn. Ency. Ich. p. 76, pl. xc, f. 374; Lacép. iv, p. 635 ; Shaw, Zool. ir, p. 300 ; Faber, Isis, 1828, p. 878; Nilss. Slzan. Fauna, iv, p. 629 ; Schlegel, Dieren Neder. p. 171.

Pleuronectes linguatula, Müll. Prod. p. 377.

Hippoglossoides limanda, Gottsche, Wiegm. Arch. 1835, p. 168.

Pleuronectes limandanus, Parnell, Edin. New Phil. Journal, 1835, p. 210.

Platessa limandoides, Parnell, Wern. Mem. vii, p. 368, t. xxxviii, and Fish. Firth of Forth, p. 208, t. xxxviii ; Yarrell, Brit. Fish. (Ed. 1) ii, p. 224, c. fig. (Ed. 2) ii, p. 312 (Ed. 3) i. p. 625 ; Jenyns, Man. p. 459; Johnston, Berw. Nat. Field Club, 1838, i, p. 174 ; Fries och Eks. Skand. Fisk. p. 117, pl. xxvii ; Kröyer, Dan. Fiske, ii, p. 358, c. fig.; White, Catal. p. 101.

Hippoglossoides limandoides, Günther, Catal. iv, p. 405 ; Collett, Norges Fiske, p. 136 ; Malm, p. 509 ; Winther, Ich. Dan. Mar. p. 37.

Pleuronectes limandoides, Malmg. Wieg. Arch. 1864, p. 293.

Long rough $a a b$, Couch, Fish. Brit. Isles, iii, p. 153, plate clx.

B. viii, D. $76-87$, P. 10, V. 6, A. $60-69$, C. $14-16$, L. 1. 85-95, Cœe. pyl. 4, Vert. 45.

Length of head $4 \frac{2}{3}$ to 5 , of caudal fin 6 , height of body 3 to $3 \frac{1}{4}$ in the total length. Eyes-divided by a narrow but scaled ridge, diameter about $1 / 4$ of the length of the head and nearly 1 diameter from the end of the snout. The anterior margin of each eye is on the same vertical line. Cleft of mouth deep, the maxilla equals nearly half the length of the head, and reaches posteriorly to beneath the middle of the orbit, the lower jaw the longer. Teeth-pointed, the anterior being the longest, the front ones are placed somewhat distantly apart and in one row in each jaw. Gill-rakers-about $1 / 2$ as long as the diameter of the orbit and placed somewhat distantly apart. Fins-the dorsal commences above the first third of the upper eye, but is not continued as far as the base of the caudal fin, its rays are simple, the longest being equal to about three times the height of the body below them, and are situated about midway between the hind edge of the head and the base of the caudal fin. Right pectoral nearly half the length of the head, its rays simple. Right ventral, inserted anterior to the base of the pectoral, consisting of six rays, it is two-thirds as long as the pectoral but does not extend quite to the base of the anal, which latter fin has a short spine directed forwards at its base,* just where it commences on a vertical line beneath the middle of the pectoral: it ends similarly to the dorsal: its highest rajs are slightly below the centre of its length and are similar to those of the dorsal fin. Caudal wedge-shaped, its central rays being slightly the longest; they are bifurcated at their extremity. Free portion of the tail two-thirds as long as high. Scales-ctenoid covering head, including jaws and body as well as a row on each

* Dr. Günther says that in this species there is "no spine before the anal fin." Parnell recorded its existence in the examples now in the national cullection, and $I$ find one most listinct in my specimens. But it must not be forgotten that the British Museum specimens were only dried skins. 
fin ray. Lateral-line-nearly straight anteriorly, becoming quite so opposite the hind end of the pectoral fin. Cocal appendages-four. Colours-on upper surface of a pale brownish gray or sandy : under surface white. Occasionally it is said to be slightly spotted.

Names.-Rough dab, or long-rough dab: bastard-sattie, Aberdeen : also yellow dab, Banff: Long-fleut, and sandsuclier, Edinburgh, the last name being due to the erroneous idea that it feeds on nothing but sand: lemon sole, Scotland. De lange schar, Dutch.

Habits.-It frequents sandy shores, is captured along with plaice and other pleuronectoids, and, according to Parnell, several may be daily seen in the Edinburgh markets from May to July: Parnell found what appeared to be fragments of some species of Asterias in the stomach of one he examined. Cock's specimen had its stomach filled with the shells of Turritella terebra, two-thirds of which contained hermit crabs, Pagurus.

Means of capture.-It appears to be usually taken with the beam trawl.

Breeding.-Asserted by Conch to spawn in May and June.

As food.-Its flesh is said to be sweet and good, but rather dry.

Habitat.-Atlantic coasts of North Europe and shores of the German Ocean : Bloch appears to have first received it from Heligoland.

The first record of the occurrence of this fish in the British seas was by Parnell in 1835 (l.c.) : Yarrell received an example from Dr. Harwood in 1833, captured during the autumn at St. Leonard's, and in the succeeding summer two from Berwick.

It is rare off Banff (Edward) : found at Aberdeen (Sim) : frequent during May, June and July, in the Firth of Forth (Parnell): not rare off Berwick (Johnston): Sunderland (G. Fox) : inhabits deep waters in the North Sea and is occasionally taken at Whitby (Yorkshire Vertebrata) : Hastings (Yarrell) : rare off Devonshire according to Parfitt: I have received numerous examples from Brixham: Falmouth (Cocks).

In Ireland Mr. Todhunter obtained a specimen off Cape Clear in the winter of 1848, and which is now in the Dublin University Museum.

The example figured js nine inches in length and was captured at Brixham, along with several more, in the summer of 1880 . The largest British specimen recorded measured fifteen inches in length. 


\section{Genus III-Rномвоs, Cuvier.}

\section{Scophthalmus and Bothus, Rafnesque. Psetta, Swainson.}

Branchiostegals seven: pseudobranchio present. Eyes on the left side. Cleft of mouth deep. Teeth in a narrow band without canines in the jaws, present on the vomer. Dorsal fin commences on the snout, most of its rays and those of the anal branched. Gill membranes but slightly united at the throat. Gill-rakers long and lanceolate. Scales, when present, small.

The turbot was formerly preserved by the Romans in salt water ponds, so as to be readily available for the market. The largest appear to have been preferred, and it has been asserted that the Emperor Domitian convened the senate as to how a mighty fish of this kind should be cooked. Respecting the food of the turbot and flat-fishes generally, it is often difficult to institute investigations, as they are mostly at once disembowelled by fishermen when captured, because after death decomposition rapidly attacks their intestines, and injures the fish in a very few hours. By Act i, c. 28, of George I, a turbot under 16 in. long, brill under 14, codling 12 , whiting 6 , bass and mullet 12 , sole 8 , plaice or dab 6 , and flounder 7 in. long, were forbidden to be sold.

Geographical distribution.-North Atlantic, German Ocean, Mediterranean, and Adriatic to the Black Sea.

\section{Synopsis of Species.}

1. Rhombus maximus, D. 61-72, A. 45-56. No scales but tubercles.

2. Rhombus loevis, D. $82-85$, A. $60-63$, scaled.

3. Rhombus megastoma, D. 85-87, A. 67-69, scaled.

\section{Rhombus maximus, Plate XCVI.}

$\Psi \tilde{\eta} \tau r a$, Arist. iv, c. 11, v, c. 9, ix, c. 37 ; Allian, iv, c. 3; Oppian, i, p. 5. Rhombus, Pliny, ix, c. 15, 20, 42 ; Belou. De Aquat. p. 139 ; Klein, Pisc. Miss. iv, p. 35, t. viii, f. 2. Rhombus aculeatus, Rondel. xi, c. 2, p. 310; Gesner, Aquat. iv, pp. 661, 670; Schoner. Ich. p. 60; Aldrov. ii, c. 48, p. 248; Jonston, i, c. 3, art. 2 , punct. 2 , p. 66 , t. xxii, f. 12 ; Willughby, p. 93 , t. F 8 , f. 3 ; Ray, Syn. p. 32 ; Klein, Miss. iv, p. 34, no. 1, t. viii, f. 1 and t. ix, f. 1. Rhombus maximus, ... Will. p. 94, t. F 2 ; Ray, p. 31; Rutty, Co. Dublin, i, p. 350 ; Pleuronectes, sp. Artedi, Syn. p. 32, no. 7, Gen. p. 18, no. 9 ; Gronov. Zooph. no. 254, and Mus. ii, p. 10, no. 159. Turbot, Pennant, Brit. Zool. (ed. 1776) iii, p. 233 (ed. 1812) iii, p. 315, pl. xlix; Duhamel, Pêches, iii, sect. 9, p. 261, pl. iii ; Low, Fauna Orcad. p. 214 .

Pleuronectes maximus, Linn. Syst. Nat. i, p. 459 ; Brünn. Ich. Mass. p. 35 ; Bloch, t. xlix ; Bl. Schn. p. 153; Gmel. Linn. p. 1236; Bonn. Ency. Ich. p. 77, pl. xlii, f. 163; Quensel, Vet. Akad. Handl. 1806, p. 203; Risso, Ich. Nice, p. 314; Faber, Isis, 1828, p. 892 ; Donovan, Brit. Fish. ii, pl. xlvi; Ekst. Vet. Akad. Handl. 1834, p. 56 and Fische Mörkö, p. 250 ; Flem. Brit. An. p. 196 ; Jenyns, Man. p. 461 ; Templeton, Mag. Nat. Hist. 1837 (2) i, p. 411; Johnston, Berwick. Nat. Field Club, 1838, i, p. 174; Thompson, Nat. Hist. Ireland, iv, p. 200; Schlegel, Dieren Neder. p. 162, pl. xv, f. 2.

Pleuronectes turbot, Lacép. iv, p. 645.

Pleuronectes tuberculatus, Shaw, Zool. iv, p. 312, pl. xlv ; Turton, p. 97.

Bothus imperialis, Raf. Caratt, p. 23.

Scophthalmus maximus, Raff. Indice, p. 14.

Rhombus maximus, Cuv. Règne Anim.; Risso, Eur. Merid. iii, p. 250; Yarrell, Brit. Fish. (Ed. 1) ii, p. 233, c. fig. (Ed. 2) ii, p. 324 (Ed. 3) i, p. 634; Parnell, Wern. Mem. vii, p. 373 and Fish. Firth of Forth, p. 213; Bonap. Fauna 
Ital. Pesc. ; Nilsson, Skand. Fauna, iv, p. 636 ; Kröyer, Dan. Fiske, ii, p. 424, c. fig. ; Costa, Fauna Nap. ii, p. 15 ; Canestr. Arch. Zool. i, p. 25, tav. iii, f. 1 ; Günther, Catal. iv, p. 407; Malm, p. 510; Malmgr.Wiegm. Arch. 1864, p. 293; Collett, Norges Eiske, p. 137; Steind. Ich. Span. u. Port. 1868, p. 48; Winther, Ich. Dan. Mar. p. 37 ; Giglioli, Pesc. Ital. p. 38 ; Morean, Poiss. France, iii, p. 338.

Pleuronectes tuberculatus, Shaw, Zool. iv, p. 312 ; Turton, Brit. Fauna, p. 97. Pleuronectes cyclops, Donovan, iv, pl. xc; Turton, p. 97; Jenyns, Manual, p. 466 (Toung).

Platessa cyclops, Fleming, p. 199 (young).

Rhombus aculeatus, Gottsche, Wiegm. Arch. 1835, p. 172.

Psetta maxima, Swainson, Fish. ii, p. 302; Bonap. Pesc. Eur. 49; White, Catal. p. 102 ; McIntosh, Fish. N. Uist, P. Roy. Soc. Edin. V, 1862-66, p. 614.

Pleuronectes rhombus, Gronov. ed. Gray, p. 90.

Turbot, Conch, Fish. Brit. Isles, iii, p. 155, pl. clxi.

B. vii, D. 61-72, P. 11-12, V. 6, A. 45-56, C. 15-16, Vert. 12/19, Cœe. p5l. 2.

Length of head $3 \frac{1}{2}$, of caudal fin $5 \frac{1}{4}$ to $5 \frac{1}{2}$, height of body $1 \frac{3}{4}$ to 2 in the total length. Eyes-diameter $1 / 6$ to $1 / 10$ of the length of the head, 1 transverse diameter apart, lower eye $1 / 2$ a diameter in advance of the upper eye and $1 \frac{1}{4}$ to $2 \frac{1}{2}$ diameters from the end of snout. Not only does opaque and thick skin cover the upper and lateral portions of the eye, but it can raise a thick lower eyelid or else depress the transparent portion of the globe below this fold of skin, while a portion of the iris forms a semilunar veil at the upper part of the pupil. Cleft of mouth deep, oblique, lower jaw the longer, the length of the maxilla is equal to half that of the head. Teeth-small, numerous, and in several rows in both jaws. Fins-dorsal commences on the snout in advance of the eyes, its rays are branched, at first low they increase in length to just beyond the centre of the fin where they are about half as long as the head from thence they gradually decrease, ending a very short distance from the base of the caudal fin. Pectoral with branched rays, its length equals two-fifths of that of the head. Ventral commences under the throat, its rays simple, the longest equals two-thirds the length of the pectoral. Anal commences slightly before the base of the pectoral, its rays increase in length to the 18th or 20 th which are nearly as high as the highest in the dorsal fin. Caudal rounded. The skin on the coloured side is studded with numerous bony tubercles, the blunt points of which are directed forwards, those on the head are smaller than those on the body. Latral-line-with a curve anteriorly, and becoming straight opposite the posterior end of the pectoral fin. Colours superiorly sandy brown covered with more or less distinct dark spots and blotches, these being likewise continued on to the fins, giving them a mottled appearance. Under surface of the body white.

Varieties in form.-Examples are occasionally met with having a notch or depression at the summit of the head. McIntosh (Fish. St. Andrew's) figures an abnormal form, and in his account of the fish of North Uist, observes apon one with an eye on either side of its head, as shown in Pleuronectes cyclops of Donovan. Conch instances a turbot coloured on both sides, in which a process 3 inches in length, thin in substance and nearly as broad as a finger, projected from before its eyes, and was not connected with the fin rays.

In colour, varieties are numerous, there are such as are partially albinos: also reversed and double ones. On August 2nd, 1874, a double one weighing $11 \mathrm{lb}$. was taken at Montrose, where, remarks Mr. Johnson, "we see sometimes in the course of the year two or three of them, and then for years won't see any." It has been observed that these fish from our northern coasts and brought by the Dutch, are darker than those from the S.W. coast of England.

Names.-Turbot, formerly spelt turbolt. Rod, Orkneys. Roddan or roan fleuk, barncock (from its round shape) and gunner-fleuk, or fleut, east coast of Scotland. Neill observes that it is termed rawn fleuts or "fleuk in roe," because it is deemed best for the table when in "rawn" or "roe." Brat, turbrat or roddans, Northumberland. In Cornwall, according to Borlase, it used to be termed brett, in an old Cornish journal it is called luggatee. Bint- or byrte-fish or breat 
is alluded to in all ordinances as this or allied fishos. De Tarbot, Dutch: Le Turbot, French.

Habits.-Frequents sandy bays and likewise muddy localities: it appears to constantly change its residence, migrating into deep water during cold weather similarly to the soles (see page 40). It is very retentive of life when captured. Its principal food is small fish, crustaceans and molluscs. In an example taken in Torbay, which Mr. Gosden of Exeter, examined when quite fresh, he found Montagu's crab (Xantho florida), the angled crab (Gonoplax angulata), velvet fidler crab (Portunus puber), the long-haired porcelain crab (Porcelanus, longicornus), the olive squat lobster (Galathea squamifera), the spider crab (Stenorynchus phalangium), brittle starfish (Ophiostrix fragilis), and the Eurynome aspera (Land and Water, January 17th, 1880). Pontoppidan remarks that it feeds on young crabs and small fishes, sea eggs or sea urchins, of which it is very fond.

Means of capture.-At the commencement of the season, trawls, but as the fish retires to deeper water and rougher ground, long lines or boulters are employed: it is taken by trammel and beam-trawl nets. In calm weather when the sun is bright, it may be speared. In County Down they employ a spear 32 or 33 feet long armed at its extremity with an iron barb: the fishermen even drive it down on them when beyond their reach. In many places, fishing for turbot with long lines has had to be discontinued owing to their being destroyed by steam-trawlers, while in several localities these fish which used to be abundant have almost disappeared. It is to be regretted that numbers of the young of these tish are destroyed by travlers, or inshore nets having a small mesh as used by shrimpers.

Baits.-These must be very fresh, alive if practicable, and shining if possible: the lampern is deemed one of the best, and largely used by the Dutch. In the Moray Firth, during July and August, it is often taken with herrings or sand eels used as a bait. It will take a slice of fresh fish as those named, also Cottus, haddock, mackerel, pilchard, sand smelt, garfish, and likewise worms, mussels, limpets, or even bullock's liver.

Breeding.-Breeds in summer: in February 15th, 1882, I found a female with nearly mature ova. This fish has a large number of very small ova, and in a $23 \mathrm{lb}$. fish which had a roe weighing $5 \mathrm{lb} .9 \mathrm{oz}$. Buckland found 14,311,200 eggs.

Hermaphrodites.-Quelch (Proc. Zool. Soc. 1862, p. 473) published a description of a supposed hybrid between this fish and the brill, Rhombus loevis. Messrs. Pile reported to Land and Water (November 28th, 1881) from Dublin having obtained a similar hybrid weighing $17 \frac{1}{2} \mathrm{lb}$. "It had the ordinary large turbot head, fins, and unusually large 'wings,' but the belly, though quite white like the turbot, had large scales on it not unlike brills, the back was of a very dark colour and covered with small lumps. The fish was fully matured and in splendid condition."

Iife history.-The young turbot would appear to swim for a longer period "on edge" than the generality of our flat-fishes. I received from Mr. Dunn an example captured Angust 20th, 1880, which was about $1 \frac{1}{2}$ inches in length and supposed to be two months old. It showed the eye still in transit passing round the bones of the head. Mr. Dunn considers they are hatched in June or July: for the first month they are quite black and swim on edge like a John Doree. Then their skin commences to mottle with white and brown, and their right eye begins to pass over to the left side of the head. Next they become white underneath, and of a light leaden colour on the upper surface, and during the period they remain of this shade on the back, which is until they have passed two months of age, they swim on the surface of the sea. If they descend to the bottom during this period it can only be occasionally. What the rate of growth of these fish is, very different opinions may be given. Some young, measuring three inches across, were obtained from shrimpers and placed in the Southport Aquarium. In two and a half years they had attained to $10 \mathrm{lb}$. each in weight, after two years more they further augmented to $20 \mathrm{lb}$. or an annual average increment of about $4 \frac{1}{2} \mathrm{lb}$. each. In the Proceedings of the Zoological Society of London, December, 1879, will be found the result of some observations made 
on these fishes in Ballinskellings Bay in Ireland, which seemed to point out that the annual increment in the sea was about $1 \mathrm{lb}$. yearly.

Diseases.-Mr. Cornish has taken turbot cut in the belly by, presumably, one of the weevers (see Trachinus, $i$, p. 78). When hooked and on the long lines, the myxine or hag will devour the turbot.

Uses.-A large proportion of our turbot are taken along our east coast, on or near the various sandbanks. But the Dutch are more successful at capturing this fish than our native fishermen, and are estimated to supply one-fourth of the quantity of this fish which is consumed. Their fishing commences about the end of March, a few leagues to the south of Schevelingen. As the warm weather approaches the fishery is gradually advanced to the northwards . and the fishing terminates about the middle of August. The Dutch were computed to have realized $£ 80,000$ yearly by the sale of turbot to the London markets and the Danes $£ 12,000$ to $£ 15,000$ per annum for lobsters wherewith to form the sauce (see Fisheries, in Introduction).

As food.-The most highly valued among flat-fishes. In L'Estange's Household Book, sixteenth century, the merits of the turbot appear to have been recognized: one is mentioned as purchased for two shillings and fourpence, while ten plaice cost but tenpence (Lubbock). Rutty, in 1772, says it used to be termed in Dublin "the pheasant of the water." Low, in the Orkneys, that it is a much better fish than the halibut. If at all tainted it is liable to occasion nausea and sometimes severe symptoms. This fish is generally boiled for the table, aud lemon juice rubbed over it is reputed to preserve its whiteness.

Habitat.-The coasts of the northern seas of Europe, plentiful in the German Ocean, and extending to the seas of Britain and round the coast of France, and through the Mediterranean to the Adriatic.

Low obserred that during seven years in the Orkneys he had seen but two or three specimens: not rare in Orkney and Zetland (Baikie): Banff (Edward): Aberdeen (Sim) : common at St. Andrew's (McIntosh): but large ones are rare until the English coast is approached. A considerable fishery exists along Berwickshire, Northumberland and Yorkshire (Yarrell).

Resident off the coast in moderate abundance (Yorkshire Vertebrata) : rare in the Norfolk estuary (Gurney): very fine ones are taken at the back of the "Falls" near Margate (Buckland): in the vicinity of Dorer, the Varna and the Ridge sandbanks, the first about seven miles distant and the latter about twelve on the French coast, also afford good fishing ground at certain seasons for these fish. A considerable amount is likewise captured off the Devonshire coast where, however, it is not so common as off Yorkshire: in Cornwall not uncommon, also captured in the Bristol Channel.

In Ireland it is taken round the coast and is plentiful to the north (Templeton): at Portrush, common (Ogilby).

The example figured is fourteen inches in length, from the Yorkshire coast. As to the size it attains in this country, accounts vary, as in some places the halibut is termed a turbot. Thompson mentions one $44 \frac{1}{2} \mathrm{lb}$. weight captured in a trammel in four fathoms of water at Springvale, County Down. Buckland took a cast of one which weighed $32 \mathrm{lb}$. Parnell records on hearsay, one weighing $190 \mathrm{lb}$. and Couch possessed a note of one $70 \mathrm{lb}$. in weight.

\section{Rhombus lævis, Plate XCVII.}

Rhombus loevis, Rondel. xi, c. 3, p. 312 ; Gesner, Aquat. iv, p. 663 ; Aldrov. ii, c. 48 , pp. 249,250 ; Schonev. p. 60 ; Jonston, i, c. 3 , art. 2, punct. 2, p. 66 , t. xxii, f. 13; Willugh. p. 96; Ray, p. 32. The pearl, Pennant, Brit. Zool. (ed. 1776 ) iii, p. 238 (ed. 1812) iii, p. 321, pl. 50.

Rhombus alter Gallicus, Belon. de Aquat. p. 141.

Rhombus non aculeatus, Will. p. 95, t. F1; Ray, p. 31. Pleuronectes, sp. Artedi, Syn. p. 31, no. 5, and Genera, p. 18, no. 8. Pleuronectes laevis, L. Westg. Res. p. 178. Thom tus, no. 3, Klein, Pisc. Miss. iv, p. 35; Gronov. Zooph. p. 73; Bartue, Dubam. Pêches, iii, sect. 9, c. 1, p. 26:- pl. ir. 
Pleuronectes rhombus, Linn. Syst. i, p. 458; Brünn. Ich. Mass. p. 35 ; Bloch, Fische Deuts. ii, p. 36, t. xliii ; Gmel. Linn. p. 1235; Bl. Schn. p. 152; Bonn. Ency. Ich. p. 77, pl. xli, f. 162 ; Lacép. iv, p. 649; Donovan, Brit. Fish. iv, pl. xcv ; Shaw, Zool.iv, p. 315 ; Turton, Brit. Fauna, p. 97 ; Risso, Ich. Nice, p. 315 ; Flem. Brit. Anim. p. 196 ; Jenyns, Manual, p. 462; Templeton, Mag. Nat. Hist. (2) 1837 , i, p. 411; Johnston, Berwick. Nat. Hist. Club, 1838, i, p. 174; Thompson, N. H. Ireland, iv, p. 201; Gronov. ed. Gray, p. 90 ; McIntosh, Fish. St. Andrew's, p. 180.

Pleuronectes cristatus, Licht. in Bl. Schn. p. 153.

Rhombus vulgaris, Cuv. Règne Anim.; Yarrell, Brit. Fish. (Ed. 1) ii, p. 240, c. fig. (Ed. 2) ii, p. 331 (Ed. 3) i, p. 641 ; Parn. Wern. Men. vii, p. 375 and Fish. Firth of Forth, p. 315 ; Costa, Fauna Nap. ii, p. 10, t. xlii ; Kröyer, Dan. Fiske, ii, p. 405, c. fig. ; T. Ogilby, Zoologist, 1876, p. 4754 .

Pleuronectes lioderma, Nardo. Ich. Adr. no. 132.

Rhombus barbatus, Risso, Europ. Mérid. iii, p. 251.

Bothus rumolo, Rafin. Caratt. 23.

Scophthalmus rhombus, Rafin. Indice, p. 14.

Rhombus lcevis, Gottsche, Wiegm. Arch. 1835, p. 175 ; Bonap. Faun. Ital. iii, p. 23, t. f. 2 ; Cauest. Arch. Zool. i, p. 27, t. ii, f. 4; Nilss. Skand. Faun. Fisk. iv, p. 638 ; Günther, Catal. iv, p. 410 ; Collett, p. 137 ; Stein. Ich. Span. u. Port. 1868 , p. 48 ; Winther, Ich. Dan. Mar. p. 37 ; Giglioli, Pesc. İtal. p. 38 ; Moreau, Poiss. France, iii, p. 340.

Rhombus Linnei, Malm, p. 513.

Pleuronectes passer, Gronov. ed. Gray, p. 90.

Psetta rhombus, Bonap. Pesc. Eur. 49; White, Catal. p. 102 ; McIntosh, Fish. North Uist, P. R. S. Edin. $\nabla, 1862-64$, p. 614.

Brill, Couch, Fish. Brit. Isles, iii, p. 161, pl. clxii.

B. vii, D. (63) 76-85, P. 11-12, V. 6, A. (50) 53-63, C. 15-17, L. 1. 150, Cœe. pyl. 2, Vert. 12/24.

Length of head $3 \frac{3}{4}$ to $4 \frac{1}{2}$, of caudal fin $5_{4:}^{3}$ to 6 , height of body 2 to $2 \frac{1}{2}$ in the total length. Eyes-on the left side, the lower $1 / 2$ (1/4 in the young) in advance of the upper: 1 diameter apart. Interorbital space flat. Its eye is not so elevated at its base as in the plaice or flounder, consequently it is not so lateral; externally it is similar to that of the turbot (page 12). Lower jaw projecting and the longer: the maxilla $2 / 5$ the length of the head, and reaches to below the posterior third or bind edge of the lower orbit; anterior nostril with a valve; the posterior open. Teeth-small ones in jaws and on vomer, none on the palatine bones. Fins-dorsal commences on the snout, its first few rays having broad fringes which divide so as to give them a brush-like appearance: its rays are branched and the longest behind the middle of the fin. Pectoral on coloured side half as long as the head and longer than its fellow. Ventrals not attached to the anal : caudal rounded. Gill-rakers-about $1 / 2$ as long as the eye, thick, about 12 in the lower branch of the outer branchial arch. Scales-small, cycloid, continned on to the head and vertical fin rays : no tubercles on the body. No spine before the anal fin. Lateral-line-with a strong curve anteriorly reaching to some little distance beyond the extremity of the pectoral fin when it becomes straight. Colours - of a sandy brown on the left side, usually speckled with white or light dots or spots : fins slightly marbled. Under surface white with sometimes a few black or gray spots along the bases of the vertical fins.

Varieties. - Apparent hybrids between the turbot and brill have been alluded to (see page 13). Yarrell figures the deformed head of one of these fish, see also Zoologist, 1855, p. 4596. Double brill are not rare. I obtained one on

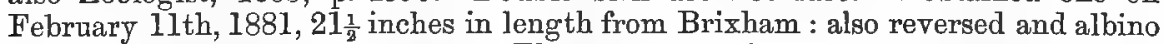
ones are occasionally observed. Thompson mentions an example which was covered over with large, stellate, white markings on a very rich-coloured dark "ground," looking precisely as if a shower of snow had fallen on it. Couch remarked upon having seen an example intensely black, with a few whita specks on the anal fin. According to Moreau, some examples of this fish from France 
would appear to have less rays in the dorsal and anal fins than observed off the coasts of Great Britain. He also remarks upon a Mediterranean variety in which the anterior rays of the dorsal fin are much less branched than is usual, Pleuronectes pavonina, Costa, is the young of this species.

Names.-Pearl, Tite, brett, "brit" in Cornish means "spotted." Upon the coasts of Deronshire and Cornwall it is known by the name of "kite" (Pennant, ed. 1812). Bastard turbot, Moray Firth: siller fluke, Aberdeen: bonnet fluek, Aberlady Bay: used to be termed lug-a-leaf in Cornwall (Willughby). La Barbue, French.

Habits.-Found in sandy bays, also in deep water, and occasionally enters the estuaries formed by large rivers. It feeds on crustacea, small fish and food similar to that consumed by the turbot.

Means of capture. - Similar to what are adopted for the turbot. In the Firth of Forth it is mostly taken by the hook, bat not so along the Cornish coast.

Breeding.- Said to spawn in spring (Parnell).

As food.-Abundant in our markets, but not held in so much esteem as the turbot, yet is superior to the plaice. In Ireland it is most esteemed in spring.

Habitat.-Coasts of Europe, becoming rarer towards the north. It is found round the British Isles and through the Mediterranean. It is rare in the Orkneys and Zetland (Baikie) : also off Banff (Edward) : it is taken at Aberdeen (Sim) : occasionally in the Moray Firth, while it is abundant at St. Andrew's (McIntosh). Neill records it at Aberlady Bay, Parnell in the Firth of F'orth: while off Yorkshire it is resident and not uncommon (Yorkshire Vertebrata) : Norfolk estuary common (Paget) : it is found generally along the east coast becoming, however, abundant along the south coast.

In Ireland it is common round the coast, taken with, but much more abundant on sand banks than the turbot, on the north-east coast at least four to one (Thompson).

The example figured was from the south coast. As to the size it attains on our shores, Yarrell states that it rarely exceeds $8 \mathrm{lb}$. in weight, Parnell $10 \mathrm{lb}$. while Thompson's finest example was two feet in length. 


\section{Genus IV-Zeugopterus, Gottsche.}

Rhombus (part), Lepidorhombus, and Phrynorhombus, Günther.

Branchiostegals seven: pseudobranchice present. Eyes on the left side and close together. Cleft of mouth deep. Sharp villiform teeth in a band in either jaw, present or absent from the vomer. The dorsal fin commences before the upper eye, its rays and those of the anal are nearly all branched. Caudal not united to the vertical fins. The ventrals either free from or united to the anal. Scales ctenoid. Lateral-line having a strong curve anteriorly.

Steenstrup (Overs. Dansk. Vid. Selsk. 1865, pp. 95-112) pointed out that a large opening exists in the septum which is normally situated between the gills of the two sides: that he observed such in Rhombus megastoma, Donovan: $\boldsymbol{R}$. cardina, Fries.: R. punctatus, Bloch : and $R$. unimaculatus, Risso, considering this as indicative that all these forms belong to the same genus, he adopted Gottsche's nomenclature of Zeugopterus.

Geographical distribution.-Shores of northern Europe, to the south coasts of Great Britain and France.

The British forms may be subdivided as follows :-

A. Ventrals not united to the anal.

1. Zeugopterus unimaculatus, D. 70-80, A. 61-68. Teeth absent from the vomer.

B. Ventrals united to the anal.

2. Zeugopterus punctatus, D. 87-101, A. 69-80. Teeth present on the vomer.

A. Ventrals not united to the anal.

\section{Zeugopterus unimaculatus, Plate XCIX.}

La petite Limandelle, Duhamel, Pesc. iii, sect. 9, p. 270, pl. vi, f. 5.

Pleuronectes punctatus, Flem. Wern. Mem. ii, p. 241, Phil. Zool. t. iii, f. 2, and Brit. An. p. 196; Jenyns, Manual, p. 462; Steenstrup, Orers. Dansk. Vid. Selsk. 1865.

Rhombus punctatus, Yarrell, Brit. Fishes (Ed. 1) ii, p. 247, c. fig. (Ed. 2) ii, p. 338 (Ed. 3) i, p. 650; Thompson, Ann. Nat. Hist. ii, p. 271, and Nat. Hist. Ireland, iv, p. 201.

Rhombus unimaculatus, Risso, Eur. Mérid. iii, p. 252, f. 35 ; Nilss. Skan. Fauna, iv, p. 645.

Rhombus cardina (Cuv.) Kröyer, Dan. Fiske, ii, p. 464.

Scophthalmus unimaculatus, Bonap. Pesc. Eur. p. 49 ; Steind. Ich. Span. u. Port. 1868, p. 49.

Rhombus uniocellatus, Nardo, Prod. Ich. Adriat. no. 135.

Zeugopterus punctatus, White, Catal. p. 104; Winther, Ich. Dan. Mar. p. 38.

Phrynorhombus unimaculatus, Günther, Catal. iv, p. 414; Canestr. Fauna Ital. p. 161 ; Giglioli, Pesc. Ital. p. 38.

Pleuronectes unimaculatus, Moreau, Poiss. France, iii, p. 323.

Eckström's topknot, Couch, Fish. Brit. Isles, iii, p. 175, pl. clxvii.

B. vii, D. 70-80, P. 10.12, V. 5, A. 61-68, C. 16. 
Length of head $3 \frac{3}{3}$, of caudal fin $7 \frac{1}{2}$, height of body 2 in the total length. Eyes-on the left side the lower one (which is said to be occasionally provided with a tentacle) slightly in advance of the upper, while they are divided by a narrow elevated ridge, diameter about $1 / 4$ of the length of the head, and 1 diameter from the end of the snout. Lower jaw prominent, cleft of mouth very oblique, the length of the maxilla equals more than half of that of the head. Gill rakers rather widely set and about half as long as the diameter of the orbit. Teeth-fine ones in the jaws: none on the palate. Fins-the dorsal commences over the posterior nostril, and is continued nearly to the base of the caudal fin, its first ray is setiform, and of varying length, while the highest point of the fin is above the blotch on the posterior third of the lateral-line. Pectoral on the coloured side upwards of two-thirds the length of the head, and having its upper rays prolonged : on the blind side it is much shorter. Ventral not conjoined to the anal: the last fin of a similar shape to the dorsal. Caudal rounded. The fin rays are branched at their extremities, and each has a row of scales. Sialessmall and strongly ctenoid, each having from four to six spines at its posterior extremity. They are continued over the head, jaws, and fin rays. Those on the blind side are also spinate. Lateral-line-forms a curve over the pectoral, becoming straight opposite the last third of that fin. Colours-reddish brown, covered with large, irregularly placed and dark round spots and blotches, one very distinct being situated at the commencement of the last third of the straight portion of the lateral-line. Under surface white.

Dr. Günther considers this fish the type a new genus Phrynorhombus, Günther, while Steenstrup remarks that it could only form a sub-genus.

Names.-Bloch's topknot. Le Pleuronecte unimaculé, French.

Habits.-These have not been recorded.

Means of capture.-Trawls and appliances useful for taking flat-fish.

Habitat.-From the coasts of Denmark, round the British Isles to the Mediterranean, in which sea it is rare, but more frequent off the coast of Italy.

Off Zetland one example was procured by Fleming, where the fishermen stated it was not common. Berwickshire (Johnston): in 1860 one off Redcar, in Yorkshire (Ferguson). Examples are in the British Museum from Plymouth, also Weymouth, from which latter locality Henslow sent it to Yarrell. Cornish obtained one, August 26th, 1880, in Cornwall; while Couch alludes to it from the British Channel in 1863. It is evidently far more rare than Zeugopterus punctatus.

Ireland-North-east coast, one $4_{4}^{3}$ inches long, taken June 16th, 1838, by Dr. Drummond, dredging within the entrance of Belfast Bay. August 19th, 1844, Mr. Hyndman, dredging in Belfast Bay, between Carrickfergus and Graypoint, in from 3 to 6 fathoms water, captured two, each 3 inches long.

The example figured is in the national collection. The fish has been recorded up to about 5 inches in length from British waters.

\section{B. Ventrals united to the anal.}

\section{Zeugopterus punctatus, Plate C.}

Smear-dab, Pennant, Brit. Zool. (ed. 1776) iii, p. 230, pl. xli, Topknot (ed. 1812) iii, p. 322, pl. lvii. Grosse Plie ou Targeur, Duhamel, Pesc. iii, sect. 9 , pl. v, f. 4 .

Pleuronectes punctatus, Bl. 1787, t. clxxxix; Bonn. Ency. Ich. p. 78, pl. xci, f. 378 ; Bl. Schn. p. 155 ; Shaw, Zool. p. 316 (part).

Pleuronectes kitt, Bl. Schn. p. 162.

Pleuronectes hirtus, Abilgaard in Müll. Zool. Dan. 1788, iii, p. 36, t. ciii ; 'Thompson, Proc. Zool. Soc. 1837, p. 60, and Nat. Hist. Ireland, ir, p. 203; 
Jenyns, p. 463; Johnston, Berwick. Nat. Hist. Field Club, 1838, i, p. 174; Fries, Wiegm. Arch. 1840, p. 32 ; Moreau, Poiss. France, iii, p. 321.

p. 103.

Zeugopterus hirtus, Gottsche, Wiegm. Arch. 1835, p. 178; White, Catal.

Scophthalmus hirtus, Bonap. Pesc. Eur. p. 49.

Whiff, Couch, Linn. Trans. xiv, p. 78.

Rhombus hirtus, Yarrell, Brit. Fish. (Ed. 1) ii, p. 243, c. fig. (Ed. 2), ii, p. 334 (Ed. 3) i, p. 646; Parnell, Wern. Mem. vii, p. 376, and Fish. Firth of Forth, p. 216 ; Nilss. Skand. Fauna, iv, p. 646; Ross, Zool. 1843, p. 106, c. fig.

Rhombus punctatus, Günther, Catal. iv, p. 413.

Zeugopterus punctatus, Collett, Norges Fiske, p. 139 ; Malm, p. 518; Winther, Ich. Dan. Mar. p. 38. clxvi.

Muller's and Bloch's topknot, Couch, Fish. Brit. Isles, iii, pp. 170, 173, pl. clxv,

B. vii, D. $87-101$, P. 10, V. 6, A. 69-80, C. 14-16, Vert. 12/25, Coec. pyl. 0.

Length of head $3 \frac{1}{2}$ to $3 \frac{2}{3}$, of caudal in 7 to $7 \frac{1}{2}$, height of body about 2 to $2 \frac{1}{4}$ in the total length. Eyjes - on the left side, upper margin covered by a thick skin, the lower eye slightly in advance of the upper, 1 diameter from the end of the snout, and $\frac{1}{4}$ to $\frac{1}{5}$ of the length of the head. Interorbital space narrow but not elevated. Cleft of mouth very oblique: the lower jaw rather projecting anteriorly. Teeth -in a villiform band in the jaws, present also on the vomer. Gill-rakersclosely set, the longest about $2 / 3$ the diameter of the eye. Fins-dorsal commences on the snout, its anterior rays not so long as the diameter of the eye: they gradually increase in length, becoming longest in the commencement of the last third of the body where they equal half the length of the head: the posterior ones short, and the fin passing beneath the base of the caudal, becomes almost conjoined with the anal, which is similarly turned under the tail. Left pectoral nearly half as long as the bead, right pectoral half as long as left. Ventral commencing under the throat, is joined posteriorly to the anal: the skin from this fin passes to the posterior surface of the base of the anal rays, a groove being formed for the vent. Caudal rounded. Scales-spinate on the coloured side, present on rays of vertical and caudal fins. Smooth on the blind side. Lateralline-forms a curve over the base of the pectoral fin, after which it becomes straight. Colours-of a rich dark brown, having a wide black, light-edged band passing backwards and outwards from each eye. Three or four round black marks on the back, and some irregular dark blotches and occasionally numerous light spots. Jaws blackish. Fins dark brown, with some irregular bands and blotches, more especially on the dorsal or anal. Under surface white.

Pennant's figure in his edition of 1776,1 . c., erroneously termed smear-dab, is reversed, due most probably to an artistic error.

Varieties.-According to Mr. R. Couch this fish is very subject to malformation of the anterior end of the dorsal fin, causing it to form an arch over the eyes. $J$. Couch observed upon having seen this fish with almost the whole of its upper surface, except the head and a small patch near the tail, without colours or scales, like the lower surface: the border of the dorsal and anal fins yellowish red, and with only two or three rays having scales; on the tail the rays extended beyond the border of the membrane. In another instance there was no caudal portion, so that where the dorsal and anal fins were brought closely together the body terminated.

Names.-Browny in Cornwall : little black hairy fluke, Edinburgh market. At Penzance I obtained this fish and the fishermen insisted that it was a young brill. Le Pleuronecte Targeur, French.

Habits.-Frequents sandy bays, with low shelving rocks covered with seaweed, where it conceals itself. It is very remarkable how difficult it is to find in an aquarium, as it hides itself in the darkest corners.

Means of capture.-Trammels, or nets set for sur-mullets. In the Firth of Forth occasionally taken in crab-cages.

Breeding.- "Summer and autumn, and in winter, the young are of about 
1 or 2 inches in length, and may occasionally be found under stones at low watermark" (R. Couch).

As food.-Mr. Cornish found its flesh to be excellent.

Habitat.-From the coasts of northern Europe, round Great Britain to France, where, however, it is very rare.

Round the British coast it is by no means rare, and even common off Cornwall. Several examples have been obtained in the Orkneys (W. Baikie); it occurs at intervals off Banffshire and along the whole line of coast (Edward); Aberdeen (Sim) ; not common at St. Andrew's (McIntosh); Firth of Forth (Smith), where Parnell observes that it is rarely seen except during stormy weather; off Berwickshire rare (Johnson). Mr. Anderson Smith obtained three examples in 1882 from Loch Creram in Argyleshire. Two examples, taken in February, 1852, at Redcar (Rudd, Zoologist, p. 3504), and a third recorded by Ferguson; also, in 1836, several found there on the beach, but none for the succeeding eight years (Meynell); in fact it is of rare occurrence in Yorkshire (Yorkshire Vertebrata), one at Bridlington on May 27th, 1881 (Boynton); the Medway (Henslow). Along the south coast it has been very frequently taken; at St. Leonards, in 1872 (Bowerbank, Zool. p. 2996); August 23rd, 1865, one at Bovisand, Devon, another March 12th, 1873 (Parfitt), while off that county it is frequent during the spring months (Baker); at Weymouth, in August, 1854, a fine example was taken by a trawler (Gosse); off Teignmouth, in January, 1843, one $6 \frac{2}{2}$ inches long was captured in a drift net. I obtained it at Penzance on Angust 13th, 1881, and heard of many more along the coast, some of which I saw ; in fact Mr. Cornish (1866, Zool. p. 311), recording one taken in May at Penzance, remarked that he had obtained 48 examples since 1858 . Bristol Channel (Baker) ; Swansea (Dillwyn); Anglesea (Gosden).

In Ireland one, $6 \frac{1}{2}$ inches in length, was taken March 25th, 1835, at Ardglass, co. Down; September 30th, 1842, Dr. Ball obtained one, $7 \frac{3}{4}$ inches long, off Kingston Pier; 2 more were purchased in the Dublin market and sent to the University Museum ; in 1865 one was captured in the winter (Blake-Knox, Zool. 1866, p. 508); in 1853 another, $5 \frac{1}{2}$ inches long, at Dalkey Sound, in 8 or 10 fathoms of water, and presented to the Dublin Nat. Hist. Soc. (Kinahan, Zool. 1853, p. 3990).

The example figured was from Penzance. In British waters this fish attains to 7 or 8 inches in length. 


\section{Genus V-Arroglossus, Bleeker.}

Branchiostegals six or seven: pseudobranchice present. Eyes on the left side. Cleft of mouth deep. Teeth small and one or two rows in both jaws: present or absent from the vomer: none on the palatines. Gill-membranes broadly united below the throat : gill-raleers fine. Dorsal fin commences on the snout and is not conjoined to the caudal. Preanal spines may be present. S'cales of moderate size and deciduous. Lateral-line with a curve in the first portion of its course.

Geographical distribution.-From the seas of northern Europe, through the Mediterranean and the East Indian archipelago.

\section{Arnoglossus megrastoma, Plate XCVIII.}

Passer Cornubiensis, Jago in Ray, Syn. Pisc. p. 163, f. 2. Whiff, Pennant, Brit. Zool. (ed. 1776) iii, p. 238 (ed. 1812) iii, p. 324, pl. lii. Pleuronectes, sp. 30, Walb. Art. iii, p. 120. Carter, Couch, Trans. Linn. Soc. xiv, p. 78.

Rhombus cardina, pt. Cuv. Règne Anim.

Pleuronectes megastoma, Donovan, Brit. Fish. iii, pl. li ; Turton, Brit. Fanna, p. 97 ; Fleming, p. 196 ; Jenyns, p. 464; Templeton, Mag. Nat. Hist. 1837 (2) i, p. 411; Thompson, Proc. Zool. Soc. 1835 , p. 81, and Nat. Hist. Ireland, iv, p. 203 ; Yarrell, Brit. Fishes (Ed. 1) ii, p. 251, c. fig. (Ed. 2) ii, p. 342 (Ed. 3) i, p. 654; Johnston, Berw. Nat. Field Club, 1838, i, p. 174; Bonap. Pesc. Eur. p. 47 ; Düben and Koren, Vet. Akad. Handl. 1844, p. 102 ; White, Catal. p. 104; Schlegel, Dieren Neder. p. 165, pl. xv, f. 4; Moreau, Poiss. France, iii, p. 332.

Pleuronectes pseudopalus, Pennant, Brit. Zool. (ed. 1812) iii, p. 324, pl. lii.

Pleuronectes Boscii, Risso, Ich. Nice, p. 319, pl. vii, f. 33; Bonap. Faun. Ital. c. fig.; Canest. Arch. Zool. t. i, p. 19, pl. ii. f. 2 ; Moreau, Poiss. France, iii, p. 330 .

Hippoglossus Boscii, Risso, Eur. Mérid. iii, p. 246.

Rhombus megastoma, Nilss. Skand. Fauna, iv, p. 641; Günther, Catal. iv, p. 411; Malm, p. 516.

Zeugopterus velivolans, Richards. Yarrell, Brit. Fish. (Ed, 3) i, p. 656 a. Zengopterns megastoma, Collett, Norges Fiske, p. 138.

Arnoglossus boscii, Günther, Catal. iv, p. 416.

Zeugopterus Gottsche, Wintber, Ich. Dan. Mar. p. 38. clxiv.

Sail-fluke and Carter, Couch, Fish. Brit. Isles, iii, pp. 163, 167, pp. clxiii and

B. vii, D. $85-89$ (91), P. 13, V. 6, A. $61-71$ (75), C. 15, L.1. 104-110, Cœe. pyl. 2, Vert. 11/30.

Length of head 4, of caudal fin $5 \frac{1}{2}$, height of body 3 in the total length. $\boldsymbol{E} y e s-$ on the left side, the lower nearly one-half in advance of the upper, diameter 1/4 of length of head, 1 diameter from the end of the snout, and only divided by a very narrow and ridged interorbital space. Lower jaw prominent; cleft of mouth oblique; the length of the maxilla equals nearly $1 / 2$ the length of the head. Teeth-in jaws rather small, and in about 2 rows; some on vomer: none on the palate. Fins - the dorsal fin commences in front of the upper eye, and is continued to within a moderately short distance of the base of the caudal fin, its longest rays being in the last third of the fin, most of them and also of anal fin are branched. Pectoral half as long as the head, ventral not conjoined to the anal, which latter fin terminates similarly to the dorsal. Caudal wedgeshaped. Free portion of the tail as long as high at its base. Scales-strongly ctenoid covering the head and body, also a row along each fin ray. Laterat line -with an almost semi-circular curve above the pectoral fin. No spine before the anal in. Gill-rakers closely set and about half as long as the diameter of the eye. Colours-of a brownish yellow with obscure spots : under side white, some- 
times tinged with red. Donovan mentions one which, he observes, had ten or twelve large dusky circular spots on the back, eight of which formed a circle not very indifferently represented by Mr. Jago in the figure given by Ray.

Varieties.-Mr. R. Couch remarked that the dark side is mottled in individuals which inhabit rough ground. Couch observed that the Orkney fish were plumper than those from the south coast. Professor Giglioli first drew my attention to Arnoglossus boscii being this species.

Names.-Whiff, merry sole a term applied due to its active movements when in the water. Carter, lantern referring to its semi-transparency when held up against the light. Sail-fluke, Orkneys. She sole, Belfast; ox- or white-sole, Dublin. De sharretong, Dutch. Le Pleuronecte mégastome ou Cardine, French.

Habits.-Resides in Cornwall from about 4 to 15 miles from shore, and rarely enters sandy bays. Its large prominent eyes give the impression that its habitat is the deep sea. Off the Orkneys, Mr. Scarth says, it seldom comes to the shore earlier than October or later than April, though it is often driven by storms on the beach entangled among the sea-weed. He tells us the black-backed gulls capture numbers. Dr. Duguid observes that this fish does not take a bait, and he only once saw it caught in a net, but, he adds, off sandy shores and in calm weather it comes ashore spontaneously, with its tail erected above the water, like a boat under sail, whence its name. In these favoured places dogs are trained to catch them! The period when this fish exhibits its gambols is most frequently before a storm, or when a thaw sets in, according to Mr. Scarth. These accounts, Couch observes, have been confirmed by Mr. Thompson, of North Ronaldshay, in which distant island the fish is not rare. Thompson found a Callionymus dracunculus 3 inches long, and 3 small Gadi in one; in a second 3 examples of Merlangus vulgaris 3 inches long; in a third only sbrimp-like crustacea.

Means of capture.-The beam trawl, while it also takes a bait along the southwest coast, althongh it is said never to do so in the Orkneys.

Baits.-Similar to those employed for other flat fishes, which they take readily, especially a slice of a pilchard or mackerel.

Breeling.-Thompson, on October 31st, at Belfast, procured one which had just shed its ova, only a few mature ones remaining.

As food.-Of but little value, or, as Borlase remarked, good for nothing. In the Orkneys, however, Dr. Duguid observes that it is highly prized as an article of food, its flesh being white and firm; but that it loses its flavour by a single day's keeping.

Habitat.-From the northern seas round the British to the French coasts.

It is found in the Orkneys; is rather rare off Banff (Edward); Aberdeen (Sim); rare in Berwickshire (Johuston); resident in moderate numbers off Yorkshire (Yorkshire Vertebrata). Has been taken along the south coast, appears to be common off Devonshire and Cornwall. Mr. Dunn observes that it is not uncommon to see 30 or 40 brought in by a trawler in one day. It has been captured off Somersetshire (Baker); Carnarvonshire (Donovan); Flintshire (Pennant).

In Ireland it is occasionally taken from north to south along the east coast. From Down and Belfast single individuals are brought to the Belfast market. It is obtained at all seasons. Bell had it from Dublin and Youghal. During the winter of 1865 it was rather plentiful (Blake-Knox, Zool. 1866, p. 508).

The example figured was 10 inches in length. For it $I$ ana indebted to $\mathrm{Mr}$. D'Urban, of the Exeter Museum, in the market of which town it does not appear to be uncommon. As to the size it may attain, the four largest Thompson records were from 22 to $23 \frac{1}{2}$ inches in length. Donovan observes that one brought to him, October 31st, 1775 , was 18 inches long.

\section{Arnoglossus laterna, Plate XCIX, fig. 2.}

Arnoglossus, Rondel. xi, c. 14, p. 324; Aldrov. ii, c. 43, p. 237 ; Jonston, i, tit. 1, c. $2 a$, punc. 1, p. 58; Gesnex, Aquat. iv, p. 668 ; Wil. p. 102, t. F 8, f. 7 . Smouth sole, Pennant, Brit. Zool. (ed. 1776) iii, p. 232 and scald-fish (ed. 1812) n. 32.5 
Pleuronectes laterna, Walb. Art. iii, p. 121; White, Catal. p. 104.

Pleuronectes casurus, Hanmer, in Pennant, I.c. (ed. 1812) iii, p. 325, pl. li i; Bonap. Pesc. Eur. p. 47.

Pleuronectes diaphanus, Shaw, Zool. iv, p. 309.

Pleuronectes Leotardi, Risso, Ich. Nice, p. 318.

Rhombus nudus, Risso, Eur. Mérid. iii, p. 251 ; Cuv. Règ. Anim.

Pleuronectes pellucillus, Nardo, Ich. Adriat. no. 134.

Pleuronectes arnoglossus, Bl. Schn. p. 157; Turton, p. 97 ; Fleming, p. 197 ; Bonap. Faun. Ital. Pesc. c. fig.; Jenyns, p. 465; Canestr. Arch. Zool. i, p. 14, tav. i, f. 4; Thompson, Nat. Hist. Ireland,.iv, p. 205; Moreau, Poiss. France, iii, p. 328.

Rhombus arnoglossus, Yarrell, Brit. Fish. (Ed. 1) ii, p. 254, c. fig. (Ed. 2) ii, p. 345 (Ed. 3) i, p. 644.

Hippoglossus arnoglossus, Costa, Fauna Nap. ii, p. 32.

Arnoglossus laterna, Günther, Catal. iv, p. 4il5; Steind. Ich. Span. u. Port. 1868, p. 50; Collett, Norges Fiske, p. 140; Canestr. Fauna Ital. p. 162 ; Giglioli, Pesc. Ital. p. 38.

Megrim, Couch, Fish. Brit. Isles, iii, p. 177, pl. clxviii.

B. vii, D. $87-90$, P. 10-11, V. 6, A. $64-68$, C. 15, L. 1. 48.

Length of head $4 \frac{1}{2}$, of caudal fin $6 \frac{1}{2}$, height of body $2 \frac{3}{4}$ to 3 in the total length. Eyes - on the left side, separated by a narrow, elevated and scaleless ridge: lower eye slightly in advance of the upper: diameter $4 \frac{1}{2}$ in the length of the head, 1 diameter from the end of the snout. Lower jaw slightly the longer: the maxilla equals 2/5 of the length of the head. Teeth-in a single row in either jaw, those in the mandibles somewhat the largest. Fins-the dorsal commences on the snout, its first few rays being occasionally somewhat separated one from the others and a little elevated: the longest rays in the fin, which are half as long as the head, are behind its middle, none of them or of the anal are branched: the vertical fins are continued almost to the root of the caudal, which latter fin is rounded. Left pectoral more than half the length of the head. The length of the base of the left ventral wide, extending from the throat to the vent, behind it are two prominent spines. Scales-rather large, deciduous: present on the gillcovers, none on the vertical fins. Lateral-line-anteriorly with a somewhat semi-circular curve becoming straight opposite the end of the pectoral. Free portion of the tail higher than long. Colours - of a brownish or pinkish on the left side : white beneath.

Varieties.-J. Edward (Zool. 1856, xiv, p. 5065) describes a fish $2 \frac{3}{4}$ inches long, taken from the stomach of a cod. Dorsal commences in advance of upper eye, not confluent with caudal. V. very small. Anal commences below gill cover. Eyes on left side, even. Scales not large, deciduons. L. l. straight. Pointed teeth in both jaws. Coloured side flesh-colour, at regular distances on extreme edge of D. and A. fins are seven black spots? Pleuronectes diaphanus. Has seen three specimens. Black spots present in all.

In Yarrell's collection were three species of a fish termed Arnoglossus lophotes, Güntber, but whence they came has not been recorded, D. 95, A. 77, L. 1. 60. They appear to be very closely allied to A. laterna. Yarrell (Ed. 1) p. 255 , remarks upon possessing a Mediterranean skin of this species. Couch, iii, p. 178, introduces this as a British species.

Names.-Scald-fish, derived from its appearance when captured, as it then appears as if it had been dipped in scalding water, for not only does slight friction cause its scales to drop off but likewise rubs off its skin. Megrim, Cornwall : Lanthern-fish, Cornwall apud Halliwell: smooth sole. Le Pleuronecte Arnoglosse, French.

Habits. - Of these but little appears to be known, but the majority of British examples have been captured along the S.W. coast, usually on a sandy bottom and at some considerable depth. It is said to be a favourite food of congers and other large fishes which frequent deep waters.

Means of capture.-Does not appear to take a bait, perhaps due to the small 
size of its mouth, as well as to its living at depths where only large hooks are tried. It is often captured off Cornwall with the beam trawl.

Breeding.-Risso observes that in the Mediterranean it is very prolific.

As food.-It is not of sufficient size to be of use for the table.

Habitat.-From the coast of Norway to those of Great Britain and Ireland, also through the Mediterranean, in which last locality it is tolerably abundant.

Off Banffshire it is very scarce (Edward) : Devonshire not common (Parfitt) : but has been recorded from Plymouth (Hanmer) and Weymouth (Jenyns) : off Cornwall Mr. Cornish observed that it is not common and considers it a variety of the "carter:" one example appears to have been obtained at Swansea (Dillwyn).

In Ireland an example was taken off the Galway coast by Mr. Todhunter, September, 1848, which is now in the Dublin University Museum. Has also been taken off the coast of Cork (Ball) : and several from Dingle Bay in 25 fathom water (Yarrell). "Was trawled abundantly off this (Dublin) coast last winter and spring. I saw some hundreds used for baiting crab-pots in the spring" (H. Blake-Knox, Zool. 1866, p. 508).

Couch has recorded one $6 \frac{1}{2}$ inches in length, and observes that it attains to 7 inches. 


\section{Genus VI-Pledronectes, Artedi.}

Platessa, Cuvier; Limanda, Microstomus, and Glyptocephalus, Gottsche: Platichthys, Girard; Clidoderma, Pseudopleuronectes, Brachyprosopon, Bleeker.

Branchiostegals five to seven: pseudobranchio present. Eyes on the right side: the upper not in advance of the lower. Cleft of mouth shallow. Teeth of a moderate size, in a single or double row in each jaw, and which are most developed on the blind side: none on the vomer or palate. Dorsal fin commences above the eyes: both pectorals present. Vertical fins not confluent. Scales small or rudimentary.

Considerable differences are observable in the species composing this genus, as may be perceived when observing the numerous sub-divisions into which it has been subjected. Irrespective of this, considerable variations are found among individuals belonging to the same species, as has been already remarked upon as a family characteristic (see page 3). While Gill has observed a species in which the male has rough and the female smooth scales, while during the breeding season the teeth are movable in both sexes.

As bait for these fishes on foul ground lug-worms and pieces of the flesh of the conger or herring are much used. But the majority along the British coasts are obtained by means of the beam trawl. I shall defer the consideration of this mode of fishing until arriving at the valuable genus of Solea (page 37).

The British forms belonging to this genus have been thus divided :-

\section{A. Teeth lanceolate and compressed.}

a. Lateral-line nearly or quite straight.

1. A spine before the anal fin.

1. Pleuronectes platessa, D. 66-77, A. 50-57. Rough interorbital ridge.

2. Pleuronectes microcephalus, D. 85-93, A. 70-76. Yellowish, blotched with darker patches.

\section{No spine before the anal fin.}

3. Pleuronectes cynoglossus, D. 102-115, A. 86-97.

b. Lateral-line strongly curved anteriorly.

4. Pleuronectes limanda, D. 65-78, A. 50-62.

B. Teeth conical.

a. Lateral-line with a slight curve anteriorly.

5. Pleuronectes flesus, D. 60-62, A. 39-45. Ossicles at base of dorsal and anal rays.

A. Teeth lanceolate and compressed.

a. Lateral-line nearly or quite straight.

1. A spine before the anal fin.

\section{Pleuronectes platessa, Plate CI.}

Passer vulgaris and Quadratulus, i, p. 143; Belon. i, p. 142 . Passer, pt. Rondel. xi, c. 7, p. 316; Gesner, pp. 664, 670; Schonev. p. 61; Ray, p. 31. Alia passeris species, Rondel. xi, c. 8, p. 318. Passer losvis, Aldrov. ii, c. 47 , p. 243 ; Jonston, i, tit. iii, c. 3 , art. 2, punct. i, t. zxii. Pleuroncetes, sp. Artedi, 
Gen. p. 17, no. 1, Spec. p. 57, no. 1, Synon. p. 30, no. 1; Gronov. Zooph. no. 24.6. Passer, spec. Klein, Pisc. Mss. iv, p. 34 , no. 6, t. vii, f. 3. Passer Bellmii, Willughby. p. 96 , t. F. 3 ; Rutty, co. Dublin, 1772, p. 350 . Plaise, Pennant, Brit. Zool. (Ed. 1776) iii, p. 228, and (Ed. 1812) iii, p. 304. Carrelet ou Carreau, Duhamel, Pêches, ix, p. 264, pl. v, f. 1, 2, and Pli, l. c. p.265, pl. v, f.3. The Plaice, Low, Faran. Orcad. p. 212.

Pleuronectes platessa, Linn. Syst. Nat. i, p. 456 ; Bloch, Fische Deuts. ii, p. 31, t. xlii ; Gmel. Linn. p. 1228; Bl. Schn. p. 14t; Bonn. Ency. Ich. p. 74; Lacép. iv, p. 628; Donovan, Brit. Fish. i, pl. vi; Shaw, Zool. iv, p. 297, pl. xliii; Quensel, Vet. Alad. Handl. 1806, p. 211 ; Turton, Brit. Fauna, p. 96; Pallas, Zoogr. Ross.-As. iii, p. 423; Faber, Fische Isl. p. 135, and Isis, 1828, p. 865; Nilss. Skand. Frun. iv, p. 612; Swainson, Fishes, ii, p. 302; Gronov. ed. Gray, p. 87; Günther, Catal. iv, p. 440; Schlegel, Dier. Ned. p. 166, pl. xvi, f. 1; Ogilby, Zool. 1876 , p. 4755 ; McIntosh, Fish. St. Andrew's, p. 180 ; Collett, Norges Fiske, p. 144; MaIm, p. 525; Winther, Ich. Dan. Mar. p. 39 ; Giglioli, Pesc. Ital. p. 38.

Platessa vulgaris, Fleming, Brit. An. p. 198; Gotts. Wiegm. Arch. 1835, p. 134; Fleming, p. 198; Jenyns, Manual, p. 454; Yarrell, Brit. Fish. (Ed. 1) ii, p. 209, c. fig. (Ed. 2) ii, p. 297 (Ed. 3) i, p. 605 ; Parne'll, Wern. Mem. vii, p. 361, t. xxxvi, and Fish. Firth of Forth, p. 201, t. 37; Gottsche, Wiegm. Arch. 1835, p. 140 ; Kröyer, Dan. Fiske, ii, p. 347, c. fig.; Templeton, Mag. Nat. Hist (2) 18.37, i, p. 411 ; Bonap. Catal. p. 403, and Pesc. Eur. 48; Johnston, Berwick. Nat. Club, 1838, i, p. 174; Thompson, Nat. Hist. Ireland, iv, p. 192 ; White, Catal. p. 98 ; Moreau, Poiss. France, iii, p. 291.

Plaice, Couch, Fish. Brit. Isles, iii, p. 181, pl. clxix.

B. vii, D. 66-77, P. 10-11, V. 6, A. 50-57, C. 17-18, Vert. 14,29, Cœc. pyl. 2

Leingth of head $4 \frac{1}{3}$, of caudal fin $5 \frac{1}{1}$, height of body $2 \frac{2}{3}$ in the total length. $E y e s$ - on the right side, the lower one-fourth to half in advance of the upper, nearly 1 diameter from the end of the snout, while the two are divided by a narrow, smooth, ridge. During life they are much elevated. Lower jaw in advance of the upper with a knob at symphysis: the length of the maxilla equals that of the orbit, while it reaches posteriorly to beneath the first third of the eye. The anterior nostril tubular: the posterior oval and patent. The interorbital ridge is continued as several rough tubercles to the lateral-line. Teeth-compressed and truncated at their summits, 20 to 24 in the upper jaw on the blind side, those on the other side being few and smaller; those in lower jaw similar to those in the upper. Gill-rakers few, short, and widely set. Fins-the dorsal commences above the middle of the eye, and ceases a little before the base of the caudal fin, the interspace being less than the depth of the free portion of the tail below it: the 35 th to the 38 th ray the longest, and more than half as long as the head. The pectorals on both sides of equal length and 2/5 that of the head. Caudal rounded. A spine directed forwards is situated just before the base of the anal fin. Scales-from 90 to 100 rows, cycloid; some on cheeks, none between the eyes. None along bases of dorsal and anal fins. Lateral-line-slightly curved above the pectoral fin, the extent of the depth of which is less than the length of the pectoral fin: the greatest depth between its straight portion and the anal fin is less than the length of the head. Intestines-two short coecal appendages; the length of the intestinal tract, in a specimen eight inches long, from the pylorus to the vent was 7 inches. Colours - of a chestnut or rich brown on the right side, covered with large orange and sometimes black-edged spots.

Varieties.-Buckland mentions a variety destitute of spots. Reversed examples are not rare, piebald ones common. These fish rapidly assume the colour of the ground on which they are residing. Canestrini considers Pleuronectes italicus, Günther, to be this species.

Names.-Plaice, diamond plaice, Sussex, from its lozenge-shaped spots. Plash fletk, Moray Firth. Fage or facq, Anglo-Saxon. De scho7, Dutch. La Plie Francle ou C'arrelct, French. 
Habits.-In the Orkneys, according to Low, it keeps much to sand banks and muddy ground. During the summer months on the east coast of Scotland it appears to frequent rocky localities, but in February and March seeks sandy places where it can deposit its spawn. In Cornwall it has been observed to select water of a moderate depth, and in May to arrive inshore, also in the autumn it is found in shoals in the quiet bays, but when the frost sets in it retires to the deep. When disturbed it will shoot away suddenly for a short distance, and can work itself rapidly into the sand where it lies concealed with only its eyes being apparent. Has great tenacity of life; one 10 inches long taken in January lived thirty hours after removal from the water : it was kept ten hours in a very warm room where it lay all the time on a dry plate (Thompson).

Thompson found in the intestinal canal of some taken in Belfast Bay, Tellina tenuis, fragments of Mactria solida and Mytilus edulis. In June large ones contained some Aphrodita aculeata, portions of Buccinum undatum, with the remains of Decapod Crustacea, April Lucina radula, \&c.

In East Friesland it has been transferred to freshwater ponds where it thrives.

Means of capture.-Low says that in the Orkneys " a few are caught on small lines made on purpose ; but they are not much sought after." A round the British coast they are taken by lines or beam trawls. Spillers also are shot in sheltered sandy bays, the bait employed being the lug-worm or a mollusc removed from its shell.

They are speared in the seas of northern Europe where the water is very clear, heavily leaded doubly barbed spears being employed according to Pontoppidan.

Breeding.-The plaice appears usually to breed about February and March, but sometimes in autuman and early winter. On February 4th this year, 1882, I obtained a male, which weighed $1 \frac{1}{2} \mathrm{lb}$., full of milt. Mr. Jackson, in sending some ova of this fish to Mr. Buckland, remarked that they were obtained from a ripe and enormously distended female in one of the tanks in the Southport Aquarium. The ova ran freely, and at first floated on the surface, but when the vessel was perfectly still they slowly settled to the bottom. The slightest motion of the water occasioned them to float. The young are "first seen in April, close to land, swimming on the surface of the sea, on their edge, with an eye on each side. In about a week after being first seen, they may be found in pools near the shore, about the size of a baby's finger nail" (Dunn). Buckland found that a plaice which weighed $4 \mathrm{lb} .15 \mathrm{oz}$. contained $1 \mathrm{lb} .9 \mathrm{oz}$. of roe, or $144,600 \mathrm{eggs}$, which were of a large size as compared with those of the turbot. Thompson obtained examples 3 inches long in January, 1835.

Life history. - The opinion was formerly entertained that the plaice is descended from a shrimp, and Dr. Deslandes investigated the subject. He first placed some of the shrimps in a vessel of salt water, and after twelve or thirteen days he discovered eight or nine young plaice. The next year be placed some of these fish in two different salt-water receptacles, and to one lot he added a few of the shrimps, not so to the other. Both lots spawned, but it was only where the shrimps were that any young were produced. On examining the shrimps, he discovered the ova attached to the under surface of these crustaceans, and he felt persuaded that their maternal care is a necessity for bringing forth the fry. But Lacépède suggested that the shrimps eat the ova of flat-fishes, and some may become glued to their under surface when they are unable to devour them. Comparatively rare as the male is, as already observed, I obtained one full of milt in February, 1882. Respecting how it is that in some localities the number of plaice appears to have decreased (see page 37).

As food.-This fish is in the best condition about May, and Mr. Mayhew computed that upwards of three millions are annually consumed in London. Off Devonshire its quality, observes Parfitt, depends upon the nature of the ground on which it is captured, for, if muddy or sandy, the taste partakes more or less of either. When from sand it is firm and sweet; if from mud, the reverse. In Banffshire it is held in little estimation; it is usually deemed poor as food, but bears carriage well. In Ireland, however, Thompson states that it is held in general esteem. 
Habitat.-From Iceland, along the coasts of northern Europe, to the British and French shores: what was believed to be this species was recorded extending in diminished numbers into the Mediterranean, and in 1878 for the first time to the Adriatic (F. Trois, Alti Ist. Venet. (5), iv, 1878, p. 321).

Found all round our coasts. In the Orkneys and Zetland abundant (Baikie) : Moray Firth common, especially during April : Banff (Edward) : Aberdeen (Sim) : St. Andrew's (McIntosh) : Firth of Forth (Parnell): Berwickshire (Johnston): Yorkshire resident, very common, but Mr. Mudd informs us that it is becoming more scarce, and that it is found in greatest numbers in or near the Dogger Bank (Yorkshire Vertebrata) : at Great Grimsby its diminution is causing alarm to some of the fishermen: Norfolk common (Lowe) : found all along the south coast, the largest said to come from Sussex (Jenyns) : off Mevagissey in Cornwall they swarm in shoals during the antumn (Dunn) and Mr. Cornish observes that those from a hard, close, killas sand are usually good, edible fish : those from a loose gravelly sand are valueless.

In Ireland it is abundant round the coast; to the north it is the most common species of flat-fish. At Belfast an example $12 \mathrm{lb}$. in weight was taken and sent to the University Museum.

Although one of these fish, weighing 6 or $7 \mathrm{lb}$. is a fine example, Donovan and others have recorded it up to $15 \mathrm{lb}$. weight.

\section{Pleuronectes microcephalus, Plate CII.}

Rhombus loevis cornubicus, Jago in Ray, p. 162, f. 1. Smear Dab, Pennant, Brit. Zool. (ed.1776), iii, p. 230, pl. xli, (ed. 1812), iii, p. 309, pl. xlvii. Duhamel, Pêch. pt. ii, sect. 9, p. 268, pl. vi, f. 3-4.

Pleuronectes microcephalus, Donovan, Brit. Fish. ii, pl. xlii; Turton, Fauna, p. 96 ; Fries, Vet. Akad. Handl. 1838, p. 173, and Wiegm. Arch. 1840, p. 24; Nilss. Skand. Faun. iv, p. 609; Günther, Catal. iv, p. 447 ; McIntosh, Fish. St. Andrew's, p. 180 ; Steind. SB. Ak. Wien, lrxx, Abth. i, p. 165 ; Schlegel, Dieren Neder. p. 170, pl. xvi, f. 5 ; Collett, p. 145; Malm, p. 40.

Pleuronectes lavis, Shaw, Zool. iv, p. 299; Turton, 1. c. p. 96.

Pleuronectes Quenselii, Holb. Bohasl. Fisk. Göth. Vet. and Vitt. Sællsk. nya Handl. iv, p. 59, c. fig.

Pleuronectes quadridens, Fabr. Kongl. Dansk. Vid. Selsk. Afhandl. i, p. 39, t. i, f. 10 and 11 ; Faber, Fische Isl. p. 138, and Isis, 1828, p. 884 .

Pleuronectes microstomus, Faber, Isis, 1828, p. 886, and Tids. Nat. $\nabla$, p. 243; Nilss. Prod. Ich. Scand. p. 53.

Platessa microcephala, Flem. Brit. An. p. 198; Jenyns, Man. p. 457 ; Parnell, Wern. Mem. vii, p. 366, t. xxxviii, and Fish. Firth of Forth, p. 206, t. xxxviii; Yarrell, Brit. Fish. (Ed. 1) ii, p. 221, c. fig. (Ed. 2) ii, p. 309 (Ed. 3) i, p. 622; Thompson, Proc. Zool. Soc. 1835, p. 81, and Nat. Hist. Ireland, iv, p. 196; Templeton, Mag. Nat. Hist. 1837 (2), i, p. 411 ; Johnston, Berwick. Nat. Club, 1838, i, p. 174; Kröyer, Fiske Dan. ii, p. 316, c. fig. ; Moreau, Poiss. France, iii, p. 294 .

Pleuronectes cynoglossus, Nilss. Prod. Ich. Scand. p. 53 (not Skand. Fauna).

Microstomus latidens, Gotts. Wiegm. Arch. 1835, p. 150.

Cynoglossa microcephala, Bonap. Pesc. Eur. 48.

Platessa lcevis, White, Catal. p. 99.

Smear-dab, Couch, Fish. British Isles, iii, p. 187, pl. clxxi. $13 / 35$.

B. vii, D. $85-93$, P. 10, V. 5-6, A. 70-76, C. 15 ; L. 1. 130, Cooc. pyl. 4. Vert.

Length of head $6 \frac{1}{4}$ to $6 \frac{1}{2}$, of candal fin 6 , height of body $2 \frac{1}{2}$ to 3 in the total length. Eyes-the lower slightly in advance of the upper, placed close together, and not $1 / 2$ a diameter from the end of the snout. Jaws of equal length in front: the maxilla not reaching to beneath the front eye. Anterior nostril tubular ; the posterior round and patent. Teeth-conical, rather compressed and blunted, from 
11 to 13 in either jaw on the blind side. Gill-raleers-very short: not numerous. Fins-dorsal commences above the centre of the upper eye; its rays are longest in the posterior half of the body, where they equal about 1/2 the length of the head. Pectorals of about equal size, and 1 $1 \frac{s}{4}$ in the length of the head. Ventrals free. No spine before the anal fin, which latter is similar to the dorsal. Candal rounded. Scales-cycloid, covering the head (except the snout), body, and minute ones on the coloured surface of the vertical tin rays. No filament on the head. Lateralline-on both sides, at first makes a slight curve, more pronounced in some examples than in others, the convexity of which is above, it is then continued almost direct to the centre of the base of the caudal fin. Colours-dull yellowish, blotched, and with dark spots, more especially over the chest and along the base of the anal fin. Dark blotches and spots likewise on the anal, caudal, and ventral fins. A dark base to pectoral, which has also some cloudy markings. On the under surface Pennant observed that it was sometimes marked with fine large dusky spots, but that such were not persistent.

Varieties.-Thompson took an example similar to Donovan's, March 3rd, 1835, D. 93, P. 9, V. 5, A. 76 ; it was free from spots, obscurely marked on the upper side and vertical fins with many shades of brown, gray and dull yellow: the orange stripe round the base of the operculum being very conspicuous: it and another had a lemon mark about an inch behind the base of the pectoral on the coloured side.

Names.-Smear-dab, due to its being frequently covered with slime; lemon$d a b$ or lemon-sole (Belfast) owing to its colours; Mary sole, Scotland, Devonshire and Cornwall, in which last county it has likewise been known as kit; smooth-dab or bastard-sole; town-dab, Hastings; French sole, Youghal; sole-fleuk, Moray Firth; sand-fleut, Edinburgh. De Tongschar, Dutch. Le Plié microcéphale, French.

Habits.-Parnell observes that in the Firth of Forth it appears during the spring, but two or three seasons pass when not half-a-dozen of these fish are seen in the Edinburgh market. In 1835 they were unusually plentiful, particularly in February, but after March they were scarcely ever met with. Having shed their spawn about April they retire to rocky ground for the remainder of the year. They feed on shell fish and crustacea. Thompson found a Nereis in one.

Means of capture.-Beam trawl, and with small hooks.

Baits.-Soft molluscous animals.

Breeding.-Spawns in May and June. Thompson fonnd one in roe in March, 1835 , but omits to mention if the ova were well developed or the contrary.

As food.-Thompson considered it "a much better fish than plaice, although not so good as sole nor so sweet as the dab." R. Couch says, "it is but little esteemed as food ;" and Cornish, that it is a very excellent fish.

Its body is rather thicker than the common dab, and Yarrell considered its flesh equally good, while Parnell says, some people reject it becanse it possesses a strong disagreeable tarry flavour, while others believe no flat-fish surpasses it in excellence, the flesh being firm and well tasted. The difference depends apon the period of the year when captured, it being good during December, January and February, and unwholesome during April, May and June.

Habitat.- From Iceland and the northern coast of Europe to the British Isles and French coast. It has likewise been captured off Kamstchatka (Steindachner).

In the Orkneys and Zetland Dr. Duguid obtained one in August, 1848, and Mr. Iverach in July: Moray Firth (Harrison): Banff, not very common (Edward): Aberdeen (Sim) : St Andrew's, common (McIntosh) : Seton Sands and Aberlady Bay (Neill) : during February, March and April, off the Fifeshire coast: Firth of Forth, not common, but mostly seen in spring months (Parnell) : Berwick, not common (Johnston): Yorkshire, resident and common (Yorkshire Vertebrata) : Norfolk (Lowe) : Sussex coast (Yarrell) : Devonshire (Montagu): Weymouth, several (Gosse), Cornwall, rather rare (Couch), but I found it to be common: also Brixham and Sussex coast, where it is in season during the autumn 
and winter months. At Plymouth it is known as "merry sole :" at Hove, as " the kit:" at Penzance, as "the queen" or "queen fish" (Pennant): South Wales (Donovan) : Swansea (Dillwyn).

Ireland.- "Occasionally taken around the coast, but not in large numbers in any part of it" (Thompson), and at all seasons.

Portrush, county Antrim, "not uncommon, as several specimens may alnoost always be picked out of a night's trawling" (Ogilby, Zool. 1876, p. 4755): the largest example measured 17 inches (Ogilby).

The example figured, 12 inches long, was from Brixham.

\section{2.-No spine before anal fin.}

\section{Pleuronectes cynoglossus, Plate CIII.}

Pleuronectus, sp. Gronov. Mus. Ich. i, p. 14, no. 39 (diagn. and synon. exclu.) and ii, p. 11, no. 39, and Act. Helv. iv, p. 263 , no. 145 and Zooph. p. 74, no. 252. Craig-flute, Parnell, Edin. New Phil. Journ. I835, p. 210.

Pleuronectes cynoglossus, Linn. Syst. Nat. i, p. 456 ; Bonn. Atl. Ich. p. 74; Gmel. Linn. p. 1228 ; Fries, Wiegm. Arch. 1840, p. 19; Nilss. Skand. Faun. iv, p. 263; Gronov. ed. Gray, p. 88; Günther, Catal. iv, p. 449; C..llett, p. 147; Malm, p. 527; Winther, Ich. Dan. Mar. p. 40; Goode and Bean, Pro. U.S. Nat. Mus. i, p. 19.

Pleuronectes savicola, Faber, Tsis, 1828, p. 877.

Pleuronectes nigromanus, Nilss. Prod. Scand. iv, p. 55 ; Cuv. Règ. Anim. Ill. Poiss. pl. crii.

Glyptocephalus saxicola, Gotts. Wiegm. Arch. 1835, p. 156.

Platessa pola, Cuv. Règ. Anim.; Jenyns, Manual, p. 458; Parnell, Wern. Mem. vii, p. 370, t. xxxviii, and Fish. Firth of Forth, p. 210, t. xxxviii; Bonap. Wiegm. Arch. 1835, p. 157; Thompson, Proc. Zool. Soc. 1837, p. 58, and An. Nat. Hist. 1838, p. 16, and Nat. Hist. Treland, iv, p. 196; Yarrell, Brit. Fish. (Ed. 1) ii, p. 227, c. fig. (Ed. 2) ii, p. 315 (Ed. 3) i, p. 616; White, Catal. p. 99. Platessa saricola, Kröyer, Dan. Fiske. ii, p. 338, c. fig.

Platessa elongata, Yarrell, Supp. Brit. Fish. and (Ed. 2) ii, p. 318, c. fig. (Ed. 3) i, p. 619; White, Catal. p. 99 ; Higgins, Zoologist, 1861, p. 7317.

Pleuronectes elongatus, Günther, Catal. iv, p. 450; Day, Proc. Zool. Soc. 1879, p. 755 , pl. lxi.

Platessa cynoglossus, Moreau, Poiss. France, iii, p. 296.

Pole and Long-flounder, Couch, Fish. Brit. Isles, iii, pp. 190, 193, pls. clxxiii and clxxir.

B. v, D. 102-115, P. 10-12, V. 5-6, A. 86-100, C. 18, L. 1. 115.

Length of head $6 \frac{1}{4}$ to $6 \frac{1}{2}$, of caudal fin $6 \frac{1}{2}$, height of body $3 \frac{1}{4}$ to 4 in the total length. Eyes-on the right side, and separated from each other by a very narrow ridge, which is scaleless in small, minutely scaled in large examples: lower eye $1 / 3$ in advance of the upper, and 2 diameters in the postorbital portion of the head. Lower jaw slightly the longer, and with a tubercle below the symphysis. Maxilla $2 / 3$ as long as the orbit, and extending to beneath the front edge of the lower eye. Body very thin, its greatest thickness equalling $1 / 6$ of its greatest height, excluding the vertical fins. Teeth-in a single row, compressed, with their crowns somewhat obtuse: most developed on the blind side. Finsdorsal commences over the centre of the upper eye, its rays undivided, the longest being at its middle, where they are $3 / 5$ the length of the head: posteriorly it terminates almost close to the root of the caudal fin, which latter is wedge-shaped. Anal similar to the dorsal, but its middle rays not so elongated. A small spine directed anteriorly is situated in front of the base of the anal fin. Both pectorals with 12 rays, the left $1 / 2$ as long as the head, the right $1 / 4$ longer than the left. Ventrals each with 6 rays, and $1 / 2$ as long as the pectorals. Scales-cycloid on the blind side, feebly ctenoid on the coloured: some very fine ones over the fin-rays 
in adult examples. Lateral-line-with a slightly oblique descent above the pectoral fin, from whence it proceeds direct to the centre of the base of the caudal: it has a dorsal branch on the occiput. Gill-rakers-short, spinate, and widely separated. Coucal-appendages-two, moderately developed. Colours-right side brown, with a gray tint, being darkest about the head. A small blackish mark on the upper half of the pectoral fin. Vertical fins of a grayish slate colour, the anterior dorsal rays tipped with white. Left side white.

Varieties.-Thompson, when examining large numbers of this species, found in one lot the males, in another the females, almost exclusively prevailed: also that the form of the body and the height of the dorsal and anal fins varied considerably in both sexes. Yarrell described $P$. elongatus from a somewhat elongated specimen, probably a skin, the height of the body in his figure being $\frac{1}{4}$ of the total length: Couch, who figured from a skin, shows the height of his specimen as about $3 \frac{1}{2}$ in the total length: whereas mine is $3 \frac{1}{4}$ from a fresh example.

Names.-Pole or craig-fluke, pole-dab. White sole, county Down. La Plie Cynoglosse, French.

Habits.-Frequents sandy localities : in some years being much more common than in others. Parnell found small crabs and star-fishes in the stomach of one he examined.

Means of capture.-The beam traw].

Breeding. - May and June.

As food.-Is considered good by some, especially the French, who esteem it to be equal to the sole. In Dublin it is looked upon as very inferior, and Thompson remarks upon having had it dressed, when he found it a passably good fish, but not at all flavoured like, nor equal to, the sole.

Habitat.-It extends from the coasts of the North Sea around Great Britain and Ireland to the shores of France. It is also found on the North American coast (Goode and Bean).

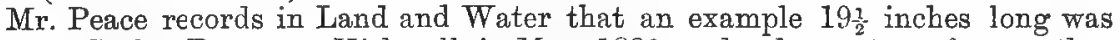
taken in Scalpa Bay, near Kirkwall, in May, 1880, and a day or two after another and smaller one, the only ones he had ever heard of in that locality : Banff, rare (Edward) : Aberdeen (Sim) : Firth of Forth, occasionally obtained during April, May and June. Parnell secured fifteen examples: along the south coast the same author recorded three examples from Brixham, from which locality I received three on January 10th, 1880, and have seen many from there in May, 1881, and also since that date. Mr. Dunn has sent it me from Mevagissey, where it is very rare, and Mr. Cornish considers it rare along the Cornish coast. I have also seen a Plymouth example. Higgins obtained two at Weston-super-Mare, and Mr. Baker two at Stolford, in Somersetshire.

In Ireland it is found on the north-east, east, and south-west coasts. On April 26th, 1837, six examples, from 12 to $14 \frac{3}{4}$ inches long, were obtained by Thompson at Belfast, and on March 25th, 1839, about 120 were brought in at one time to the market at Newcastle. They had all been captured by trawling, and about 70 more were said to have been also taken, but this was a quite exceptional take. On May 5th one was captured at Ardglass.

The example figured is 9 inches long, and was obtained by Mr. Dunn at Mevagissey, November 6th, 1879. It attains to at least 14 inches in length on the British coast, and Thompson records one $16 \frac{1}{2}$ inches long from Ireland.

\section{B. Lateral-line strongly curved anteriorly.}

\section{Pleuronectes limanda, Plate CIV.}

Passer asper, Rondel. xi, c. 9, p. 319 ; Schonev. p. 61; Aldrov. ii, c. 46, p. 242 ; Willughby, p. 97, t. F. 4 ; Ray, Syn. p. 32 ; Rutty, Nat. Hist. County of Dublin, i, p. 350. Limanda, Belon. De Aquat. p. 145; Gesner, pp. 665, 781. Pleuronectes, sp. Artedi, Gen. p. 17, no. 2, Species, p. 58, no. 11, Synon. p. 33, no. 9. Sand- 
flynder, Ström, Söndm. i, p. 278. Dab, Pennant, Brit. Zool. (ed. 1776), iii, p. 230 (ed. 1812), iii, p. 308. La Limanda, Duhamel, Pêches, ix, c. i, p. 267, pl. vi, f. 1,2 .

Pleuronectes limanda, Linn. Syst. Nat. i, p. 457 ; Bl. Fische Deuts. ii, p. 45, t. xlvi ; Gmel. Linn. p. 1231 ; Lacép. iv, p. 621 ; Bl. Schon. p. 145 ; Bonn. Enc. Ich. p. 75 ; Quensel, Vet. Akad. Handl. 1806, p. 220 ; Donovan, Brit. Fish. ii, p. 44; Shaw, Zool. iv, p. 298; Turton, Brit. Fauna, p. 96 ; Faber in Isis, 1828, p. 881; Fries and Eks. Skand. Fisk. p. 150, pl. xxxiv; Nilss. Skand. Fauna, iv, p. 627 ; Thompson, Nat. Hist. Ireland, iv. p. 195 ; H. Malm. Wiegm. Arch. 1864, p. 293; Günther, Catal. iv, p. 446 ; Schlegel, Dier. Ned. p. 169, pl. xvi, f. 3 ; Collett, p. 146; Malm, p. 525; McIntosh, Fish. St. Andrew's, p. 180 ; Winther, Ich. Dan. Mar. p. 39.

Pleuronectes platessoides, Faber, Fische Isl. p. 140 (not Fabr.).

Platessa limanda, Flem. Brit. An. p. 198 ; Jenyns, Man. p. 456; Templeton, Mag. Nat. Hist. 1837 (2), i, p. 411 ; Yarrell, Brit. Fishes (Ed. 1), ii, p. 219, c. fig. (Ed. 2), ii, p. 307 (Ed. 3), i, p. 628; Kröyer, Dan. Fiske, ii, p. 298; Parnell, Wern. Mem. vii, p. 365, t. xxxvii, and Fish. Firth of Forth, p. 205, pl. xxxvii; Johnston, Berwick. Field Club, 1838, i, p. 174; White, Catal. p. 100 ; McIntosh, Fish. N. Uist, Pro. R. S. Edin. v. 1862-66, p. 614.

Limanda vulgaris, Gottsche, Wiegm. Arch. 1835, p. 160 ; Moreau, Poiss. France, p. 289.

Limanda oceanica, Bonap. Cat. no. 412.

$D a b$, Couch, Fishes of Brit. Isles, iii, p. 185, pl. clxx.

B. vii, D. $65-78$, P. 10-11, V. 6, A. 50-62, C. 14, L. 1. 86-96, Cœe. pyl. 4, Vert. 39-40.

Length of head $4 \frac{3}{4}$ to 5 , of caudal fin $5 \frac{2}{3}$, height of body $2 \frac{2}{3}$ in the total length. Eyes-the lower slightly anterior to the upper, diameter $5 \frac{1}{2}$ to 6 in length of the head, $\frac{1}{2}$ to 1 diameter from end of snout, and separated by a narrow osseous ridge. Lower jaw prominent: the maxilla, which is as long as the orbit, extends to beneath the first third of the eye. Teeth-a row of about 22 closely set, lanceolate ones on the blind side. Fins - the dorsal commences above the middle of the upper eye, the rays gradually increase in length to about the centre of their number (37 or 40) when they commence decreasing in height: the fin does not reach the base of the caudal, leaving an uncovered space equal to about $1 / 2$ the height of the free portion of the tail. Pectoral as long as the postorbital portion of the head. Ventral not joined to anal. A small spine, directed forwards, at the commencement of the anal fin. Caudal slightly rounded. Scales-on coloured side with ctenoid margins, those between the eyes and on the cheeks smaller than those on the body. A row along each dorsal and anal ray. Lateral-line-smooth : at its commencement it has a semi-circular curve above the pectoral fin, while it sends a branch over the occiput. Intestines-three or four short cœcal appendages. Colours-Brownish, with some cloudy markings and spots : dorsal and anal fin, with whitish margins. Occasionally white spots are seen on the coloured side of the body.

Varieties.-Thompson observed in some examples he took at Ballyhome Bay (co. Down), in September, that they had a few black spots and markings orer the body and fins: also at the base of the dorsal fin about six round white spots at regular distances, and abont four similar white spots regularly disposed at the base of the anal fin.

Names.-Common dab, the term "dab" is considered to be one of contempt, as in Lincolnshire it refers to an insignificant fellow : sattie, Aberdeen (Sim) : saltwater fluke, Edinburgh : grey fleuk, Moray Firth : grey back, Portrush, co. Antrim (Ogilby). De Schar, Dutch: La Limande, French.

Habits.-Frequents most sandy localities around the coasts, and Parnell found it in shallow water. It feeds on marine worms and small crustacea. Thompson found in the stomach of one, captured in March, at Belfast, "fragments of one of the bivalve shells, solen (neither of the two smaller species), and of corallines, among which Sertularia dichotoma was apparent." Johnston remarked that off Berwickshire its favourite food appeared to be the pretty Pecter obsoletus. 
Means of capture.-Beam trawl; seine (Montagru); hand-lines and deep sea lines, being more easily taken by hooks than any other flat fish.

Baits.-Marine sandworms and bodies of testaceous molluses.

Breeding.-April, May and June. Many as small as $\mathbf{1}^{3}$ inches long were received from the mouth of the Thames in November, 1880.

As food.-A high flavoured and excellent fish (Thompson), but if waters are muddy the taste partakes of such; it is largely eaten among the poor of London and Paris. It is in the best condition from February to April in some places, from August to December in Cornwall.

Habitat.-From the shores of northern Europe to those of the Pritish Isles, and extending to the coasts of France, being abundant off Brittany and Poitou, but less common in the Gulf of Gascogne.

It is found on most parts of the British coasts, being tolerably frequent in the Orkneys and Zetland (Baikie); abundant at times in the Moray Firth, also pretty frequent off Banff (Edward); Aberdeen (Sim); not uncommon at St. Andrew's (McIntosh); common in the Edinburgh market (Neill) ; Berwick (Johnston); off Yorkshire it is resident, very abundant, and known as the sand-dab at Redcar (Yorkshire Vertebrata); Yarmouth, Norfolk (Lowe). It is by no means uncommon along the south coast, especially Devonshire (Montagu), and very common off Brixham and Cornwall.

In Ireland it is not rare round the coast, and has been recorded from Dublin (Rutty) : Waterford (Smith) : Youghal (Ball) : Galway coast (McCalla) : county Down (Thompson): Belfast and Strangford Loughs (Thompson): while at Portrush, county Antrim, it is the most frequent kind brought up by the trawl, rarely, however, exceeding 12 inches in length (Ogilby).

The example figured, 10 inches long, was from the south-west coast. It has been recorded off the British Isles, by Parnell, up to 15 inches in length.

\section{B. Teeth conical.}

a. Lateral-line with a slight curve anteriorly.

\section{Pleuronectes flesus, Plate CV.}

Passer fluviatilis vulgo flesus, Belon. p. 144; Willughby, p. 98, t. F 5 ; Rsy, p. 32 ; Rutty, co. Dublin, p. 350 . Passeris tertia species, Rondel. xi, c. 10, p. 319; Gesner, pp. 666, 782, 788. Pleuronectes, Artedi, Synon. p. 31, no. 2, and Gen. p. 17 , no. 4, and Spec. no. 4 ; Gronov. Zooph. no. 248. Passer, sp. Klein, Pise. Miss. iv, p. 33, no. 1, t. ii, f. 4, t. vii. f. 1. Flet, Duhamel, ix, p. 273, pl. vii, f. 2. The flounder, Pennant, Brit. Zool. (Ed. 1776) iii, p. 229 (Ed. 1812) iii, p. 305 ; Low, Farun. Orcad. p. 212.

Pleuronectes flesus, Linn. Syst. Nat. i, p. 457 ; Bl. Fische Deuts. p. 39, t. xliv ; Bonn. Ency. Ich. p. 75, t. xl, fig. 159; Bl. Schn. p. 146; Gmel. Linn. p. 1229; Lacép. iv, p. 633; Donovan, Brit. Fish. iv, pl. xciv; Shaw, Gen. Zool. iv, p. 301; Turton, Brit. Faun. p. 96; Faber, Fische Isl. p. 144, and Isis, 1828, p. 873; Ekstr. Fische Mörkö, p. 247; Pallas, Zoog. Rus.-As. iii, p. 422 ; Nilsson, Skan. Faun. iv, p. 618 ; Gronov. ed. Gray, p. 88 ; Günther, Catal. iv, p. 450 ; Schlegel, Dier. Ned. p. 168, pl. xvi, f. 2; MeIntosh, Fish. N. Uist, P. R. S. Edin. v, 1862-66, p. 614 and Fish. St. Andrew's, p. 180; Collett, p. 146; Malm, p. 530; Winther, p. 41.

Platessa flesus, Flem. Brit. Anim. p. 198; Bowdich, Brit. F. W. Fish, no. 25; Jenyns, Man. p. 455; Gottsche, Wiegm. Arch. 1835, p. 146; Yarrell, Brit. Fish. (ed. 1) ii, p. 215, c. fig. (ed. 2) ii. p. 303 (ed. 3) i, p. 612; Parn. Wern. Mem. vii, p. 363, pl. xxxvii ; Templeton, Mag. Nat. Hist. 1837 (2) i, p. 411 ; Johnston, Berwick. Nat. Club, 1838, i, p. 174; Bonap. Pesc. Eur. 48; Thompson, Nat. Hist. Ireland, iv, p. 194; Siebold, Süsswass. fische Mittleurope, p. 77 ; Kröyer, Dan. Fiske, ii, p. 276, c. fig.; White, Catal. p. 98 ; H. Malmgren, Wiegm. Arch. 1864, p. 293 ; Blanchard, Poiss. France, p. 267, c. fig. 


\section{Varieties in colour.}

Pleuronectes passer, Linn. Syst. Nat. i, p. 459 ; Bloch, 1. c. p. 57, t. 1 .

Pleuronectes roseus, Shaw, Nat. Misc. vii, p. 238, and Gen. Zool. iv, p. 302, pl. $43 . .^{*}$

Platessa carnaria, Brown, Edin. Journ. of Nat. and Geol. ii, p. 99, t. ii. f. 1 .

Platessa flesus, var. marmorata, Nord. in Demid. Voy. Rass. Pisc. pl. xxviii,

F'lesus vulgaris, Morean, Poiss. France, iii, p. 299.

\section{Varieties in form.}

Platessa flesus, Thompson, Proc. Zool. Soc. 1837, p. 60, and Ann. Mag. Nat. Hist. 1865 (3), $x \nabla$, p. 361, pl. xviii.

Flounder, Couch, Fish. Brit. Isles, iii, p. 195, pl. clxxv.

B. $\nabla$, D. $60-62$, P. 10, V. 6, A. 39-45, C. 14, L. 1. 85, Cœe. pyl. 2, Vert. 12/23-24.

Length of head 4, of candal fin $5 \frac{9}{3}$, height of body $2 \frac{1}{3}$ in the total length. Eyes-less than 1 diameter apart, and the lower slightly in advance of the apper. The eyes are so prominent that they are capable of observing objects on both sides of the head. Lower jaw in advance of the upper. The length of the maxilla equals about $1 / 4$ that of the head, but does not reach to beneath the eyes. Anterior nostril tubular, having a small opening: posterior one oval with wide lips. An obtuse ridge passes from the interorbital space to the lateral-line. Teethconical, blunted, two rows in the upper and one in the lower jaw: the outer row on the upper jaw of the blind side consists of 15 teeth; the corresponding row in the lower jaw of about 17. Fins-dorsal commences opposite the middle of the upper eye, its longest rays are in the posterior half of the body. Pectorals on the two sides similar, and about $1 / 4$ as long as the head. Ventrals free. A strong spine, pointing forwards, exists before the base of the anal fin, which latter is similar to the dorsal. Candal cut square. Scales-small, cycloid: rudimentary ones on the cheeks. A rounded and rough tubercle between the bases of the dorsal and anal rays. Lateral-line-commencing opposite the angle of the mouth, curves round the lower eye, and having joined the interorbital ridge, is continued to the centre of the base of the caudal fin. Coecal pylori short. Colours-vary very considerably, and depend upon that of the ground of the locality which they inhabit, but even then scarcely two will be found to be exactly similar. The colour of the upper side is generally olivaceous-brown, with or without darker blotches. Occasionally examples are very dark, when they are termed seaflounders. The under surface is white.

Young plaice and flounders of equal size may be distinguished, prior to the appearance of tubercles along the bases of the dorsal and anal rays of the latter, by the plaice having distinct scales, whereas they are rudimentary in the flounder.

Pleuronectes flesus, $P$. luscus, and P. Italicus are considered one species by Steindachner (Sitz. Ak. Wiss. Wien. 1868, lvii, p. 719).

Varieties in colour. - Double examples or such as are colonred on both sides are not uncommon: also reversed ones. These last the fishermen persuaded Donovan were a distinetion of sex : Linnæus, Bloch, \&c., considered such to be distinct species. Some are partially or entirely albinos. Newman (Zool. xiii, 1855, p. 4596) records an albino-flounder with red eyes. "In 1862 an albino variety was brought to me. Both sides were white, and the fins and eyes pink" (Lowe, Norfolk Faun.). In some there are orange spots somewhat similar but usually less vivid than seen in the plaice. On February 22nd, 1882, I obtained a number from Brixham all having orange spots similar to the plaice, and was informed that this is an appearance peculiar to spring-time. Thompson observes that the examples he examined thus marked were taken in March. Some are of a rosy hue, termed Pleuronectes roseus (Shaw) : or of a flesh-red, with irregularly but distantly placed dark-coloured spots, Platessa carnaria (Brown). Higgins (Zool. xiii, 1855, p. 4596) remarks on one he terms Platessa melanogaster, notched above 
the eyes and of a very dark brown colour almost black on both sides. Newman (1. c. p. 4914) continues that it is a favourite trick of the fisher boys to cut a notch in the place indicated when they catch a flounder too small to be saleable. As the notch heals the edges recede, so the dorsal fin appears to commence further back than is normally the case. Whether this is the explanation of all such varieties is questionable, as it may be due to an arrest of development as observed in the plaice, turbot, \&c. Thompson (Proc. Zool. Soc. 1837, p. 60) refers to the malformed head of one resembling Yarrell's brill.

Names.-Flounder and mud-flounder : flounder lantern, Cornwall : fresh-water fleuk and bigger fleut, Moray Firth: mayock fleuk, Edinburgh : fleuk, Northumberland, also flewke and fuck: butt, Yarmouth: sea bague, Isle of Man (Crellin): black back, Belfast Bay. De Bot, Dutch. Le Flet commun, French.

Habits.-It is found round our coasts ascending rivers to far above tidal influence, and is able to live in very impure water.

There is not much to say of its habits. Its name flounder has been asserted to be derived from the Swedish word Flundra, denoting its swimming close to the ground. Here it buries itself in the sand or soil by working down first one side of the body and then the other, and thus its back becomes covered, while its elevated eyes and mouth remain clear for the purpose of seeing and capturing its prey. In some rivers it is found among stones, or on the side of sandy banks in mid-stream; but muddy holes are reputed not to be the places where it usually resorts. It will wriggle itself up the sides of posts when under the water, as may be seen any day at the Westminster Aquarium, and it retains its hold by means of its vertical fins. It is a greedy and voracious feeder, eating worms, slugs, crabs, young fish, and animal substances. Thompson found in one he examined at Belfast, the remains of Rissoa ulvo, and Johnston off Berwickshire obtained from them Pecten obsoletus.

That this fish ascends into fresh water is very certain. If we turn to Belonius, De Aquatilibus, published in 1553, we find the flounder described as Passer fluviatilis, vulgo flesus. It is said by Bloch and others that this name was given owing to its colour being similar to that of a sparrow, and because it inhabited rivers. The flounder is found in the sea and at the mouths of all the larger rivers round our coasts, and is common in the North Sea and Baltic. Donovan observed that it inhabits both salt and fresh waters: Montagu that it is taken in the Avon to within three miles of Bath: Yarrell that it exists in the Thames as high as Sunbury: Parnell that it ascends rivers to a considerable distance, particularly when the waters are discoloured and increased in size by heary rains. Personally I have a recollection of taking flounders with a worm, about thirty years since, from the Severn at Shrewsbury, a little above the English Bridge. Mr. Henry Shaw, the well-known naturalist of that town, observes: "Flounders were caught thirty-five or forty years ago about Shrewsbary, and a long way above, in considerable numbers: but since the weirs about Worcester and Gloucester have been made, their ascent has been stopped. The Peplows (fishermen) used to lay what they termed sprigtail lines for them, in the early spring months, on the sandy places they frequented. This sprigtail consisted of a crooked pin with a double bend, having the form of two knees; to this was affixed about four horse hairs, and baited with part of a worm. The flounder swallowed it, and, as soon as he began to pull, the pin became crosswise. They used to employ two to three hundred at a time on a long line, and lay them at night time." Were the weirs on the Severn destroyed, they would immediately remount that river at least to as high as Shrewsbury.

Means of capture.-Low observes that in the shallower parts of the loch of Stenness he has seen vast numbers taken with a seine net. Thompson mentions having observed a fisherman at the mouth of the Bann using an implement as follows:-it was in the form of two sides of a garden reel with a spike which was stuck into the ground: to this about forty yards of line were attached, having a very heavy sinker at its extremity, and hooks along its whole length, which were baited with pieces of crab. By flinging out the sinker the line became carried into the water its entire length. 
In November, 1862 , flounders at Gothenburg and its vicinity were so abundant after a severe storm on the coast of Denmark that although $2 \frac{1}{2}$. millions were captured the sea literally remained full of them : 500 men were engaged day and night in this capture and at last they were unable to salt such a number. Pontoppidan relates that when the fishermen row their boats over sandy ground where the flounders are seen in clear weather lying in heaps together, they drop a line with a heavy lead to it under which a little lance is fixed, which by the weight of the lead sticks into the flounder, and it is pulled up with the line.

Baits.-The angler finds a well-scoured lobworm much approved of, but they will also take a piece of fish; the novice has to be warned not to strike too soon, as the worm is sucked in some little time prior to its being gorged, while, owing to the size of the fish's mouth, a small hook has to be employed. In' some localities it is found to bite best in the early morning. It lives long after removal from its native element, being very tenacious of life. This makes its carriage and transference to distant places easy.

Breeding.-It spawns from February to about April or even later. At Mevagissey numerous young were observed in April. Harmer recorded finding $1,357,400$ eggs in one $24 \frac{1}{4} \mathrm{oz}$. in weight : 351,026 in a second of $6{ }_{4}^{3} \mathrm{oz} .225,568 \mathrm{in}$ a third of $3 \frac{1}{\mathrm{O}} \mathrm{oz}$ : and 133,407 in a fourth of $2 \frac{1}{4} \mathrm{oz}$.

Life history.-The development of the eyes of these fishes and the changes the young undergo has been referred to at page 3 .

Diseases.-Lowe mentions having frequently seen specimens from the Ouse "affected with a peculiar skin disease resembling epithelioma-large fungous growths cropping out over the whole body-the granulations large and roe-like - under the microscope consisting of large nucleated cells."

This fish is largely eaten by the cormorant and other birds.

Uses.-In Norfolk it is fished for in order to be used as a bait for the lobster fishery (Lubbock).

As food.--It is watery, poor eating, and inferior to the plaice, both as to flavour and size; but authors are not agreed as to whether the marine or river forms are the best for the table, while it has been stated to be equally good from both localities, the flavour depending on the food it has been living on. It is considered nutritive and easy of digestion. Lacépède observes that its flesh is softest in the fresh-water examples, due to their more rapid growth. In this country such as come from the Thames are generally deemed firmest, and superior to those from any other river. Memel, in the Baltic, has long been celebrated for its flounders. The Frieslanders esteem this fish so much that they naturalize it in fishponds. Thompson observes that is is not much esteemed at Belfast. Low considered that if fried it is delicate eating.

Habitat.-From the coasts of northern Europe to those of the British Isles, while off France it is common in the Channel and along Brittany, Poitou, the Gulf of Gascogne and Arachon (Moreau).

This fish is abundant around the British coast and is especially partial to the mouths of large muddy creeks: when not impeded by artificial or natural obstructions it ascends rivers long distances. It inhabits all the bays and creeks of the Orkneys, especially if the ground is flat and sandy : abundant in the Moray Firth, ascending the Lossie nearly as high as Elgin (Gordon): is pretty frequent off Banff (Edward): Aberdeen (Sim) : abundant at St. Andrew's (McIntosh): during July and August captured in large numbers in the Firth of Forth in the salmon nets particularly above Queensferry, as well as in Leith harbour with the hook (Parnell): Berwick, common (Yarrell): resident in Yorkshire along the coast and rivers, in which its ascent is mostly stopped by weirs : every year in the Ribble from May to September: common in the Norfolk estuary: down the east and along the south-west coast and Bristol Channel: common round the coast of Ireland (Thompson).

It attains to about 8 or 9 inches in length and $4 \mathrm{lb}$. weight. Donovan recorded one $4 \frac{1}{2} \mathrm{lb}$. and Pennant another of $6 \mathrm{lb}$. 


\section{Genus VII-Solea (Klein) Cuvier.}

\section{Monochir, Cuvier. Monochirus, Yarrell.}

Cleft of mouth narrow, twisted round to the left side. Eyes on the right side, the upper being partially or entirely in advance of the lower. Nostrils variously formed. Dentition most developed on the blind side, where the teeth in the jaws are in villiform rows, none on the vomer or palate. The dorsal fin commences on the snout, and is not confluent with the caudal: pectorals present or absent. Scales small, ctenoid. Lateral-line straight.

\section{This genus has been subdivided:-}

A. Pectorals developed, Microtunglossus.

a. Nostrils on blind side not dilated, Solea.

b. One of the nostrils on the blind side dilated and broadly fringed, Pegusa.

B. Pectorals on both sides rudimentary or small, Buglossus.

C. Pectorals absent, Aseraggodes.

Geographical distribution.-All temperate as well as tropical seas, except the southern portion of the south temperate zone, and though normally a marine and littoral form, still some enter fresh waters in which they have been acclimatized, and thriven. On retaining some in fresh and others of a like weight in saline water, the first at the end of a year were found to have increased at twice the rapidity of those which were kept in salt water.

Among the flat-fishes annually captured around the British coast, none exceed the sole in value as food, while they are esteemed both by rich and poor. Their value is often enhanced by the locality they come from, thus Torbay, Folkestone and other places are more or less famed for the quality of the fish which are taken from their waters.

A most important subject, and one which deserves a more searching investigation than it has yet received, is whether the fish are decreasing in quantity around our coasts, and, if so, the reason? To illustrate one side of this question I give an extract from a letter from an east coast fisherman which speaks for itself:--"It is well known among fishermen that there is a falling off in the supply of plaice and soles to an alarming extent, whaterer may have been said to the contrary by smack-owners and fish salesmen. To explain this, I shall have to carry you back to the time when we first went to fish off the Sylt, about ten years ago; at which time very nearly all the ground from Horn Reef to Heligoland was covered, as it were, with shoals of small plaice, and intermixed with these plaice were a good many soles, both large and small. We have got as many as eighty baskets of small plaice and ten baskets of soles for one night when we first went there, and very nearly all the plaice would be thrown overboard, and you may be aware that they always die after they have been hove on board a trawler. These fish are so small that I have counted two hundred and fifty in one basket, such as we use at Grimsby. The small plaice that are brought to London market are the largest picked out, and then the others are tlırown away. Now, we have fished there every summer, heaving big bags of small plaice on board and throwing them away for the sake of the soles, till by destroying the young brood, full-grown plaice have grown very scarce. At the present time very small plaice will sell well, so that now the soles have grown scarce off the Sylt, the small plaice, being saleable, make up, so you see they are bound to be caught unless stringent measures are taken for their preservation. You must remember that the quantity has decreased during these last few years, twenty baskets being the most 
you would get for a night now. My opinion of the matter is this, that as the ground from Horn Reef to Langeroog, within a less depth than twelve fathoms, is a natural nursery for young brood, if the wanton destruction of it continues as it has done, we shall soon find it extremely difficult to find even a moderate supply of full-grown plaice, but if stopped I have no doubt that both they and soles would be more plentiful. It is to the interest and benefit of everyone in the fish trade that no English trawler should be permitted to fish within the above depth."

Mr. Mann, writing from Bournemouth to the Field, in April, 1882, observed, "I have just weighed a sole of one ounce, and a turbot of four ounces which were exposed for sale here. They were selected from many others of like size. Sixteen pounds' weight were captured on one occasion, the largest not exceeding eight ounces. The bulk were taken in long-shore nets, known as 'tucks,' of small mesh, from which nothing can escape ; but this form of net does not kill the fish, which ought to be at once returned to its native element." Small turbots and soles are often placed in the bottom of the pads and boxes sent to the London markets, but the balk of them are sold in the towns and villages along the sea coast.

It has again and again been brought prominently to notice, especially about the fishing grounds of the North Sea, that the supply of soles taken in British waters is yearly decreasing as evidenced by the trawlers having to go further out to sea, that an increased number of vessels capture only an amount similar to what formerly were obtained by fewer boats manned with less hands, and likewise that the fish supplied to the markets consists of such as are much smaller than used to be the case. Mr. E. Jex, of Billingsgate, remarked (January 7th, 1882), "there have been during the past year some thousands of boxes of soles in this market from Yarmouth, Lowestoft and Ramsgate, while not more than one-fourth of the contents of each box consisted of fish that ought to bave been caught-three-fourths of each box nothing but slips and tongues."

When at Weston-super-Mare in 1879 some new trawling ground was tried, and the large size and quantity of these fishes that were taken amply recompensed the trawlers. But such localities are often over-fished and soon become exhausted and thus quantity has to be made up by those of a smaller size. This is possibly what is found to occur in most places. Thus, Mr. Dunn observes, that his father was the first fisherman who employed a beam trawl in Mevagissey Bay: he captured enormous numbers of fish, so much so that he kept a record, which has, unfortunately, been lost. When the Plymouth trawlers first commenced their operations in new localities off the south-west coast (which was about the time the Californian gold-fields were discovered), they termed their new grounds "California," as illustrating the amount and value of their captures.

It has been pointed out by Mr. Epton and others, that a large fleet of smacks towing orer the same ground will in a short time clear off the fish which are there. But the main cause of the diminution in the North Sea is generally asserted to be due to the numbers of undersized fish which are wantonly destroyed in shallow water, or their natural brood-grounds by trawling smacks, steam trawlers and shrimp catchers, more especially by smacks along the German coast during the spring and summer months.

But while it has been proposed to legislate for this state of affairs by prohibiting the exposure for sale of soles under 6 inches ( 7 inches, Buckland) in length a difficulty arises which would first have to be investigated. Thus at certain seasons the "thick-backed sole," Solea variegata, which rarely exceeds $6 \frac{1}{2}$ inches in length, is common in the Plymouth markets, and perhaps finds its way to London; while the "little sole," Solea lutea, abounds along the southwest coast, and is generally thrown overboard as useless, or sold as manure. Any prohibition against the capture of soles under a certain size would cause taking these forms to be penal. This opens up the question-what, if these small forms alone are permitted to increase off the sonth-west coast, will be the effect on the food of the Pleuronectidce in general? For should the useless forms be protected and if they live on the same diet as the useful table sole, it appears as if such legislation might cause more injury than benefit to the fisheries. 


\section{Synopsis of Species.}

\section{A. Pectoral fins developed on both sides.}

a. Nostrils on the blind side not dilated.

1. Solea vulgaris, D. 73-86, A. 61-73, L.1. 160.

b. One of the nostrils on the blind side dilated and fringed.

2. Solea impar, D. 82-88, A. 67-71, L. 1. 130-140.

B. Pectoral fins on both sides very small.

3. Solea variegata, D. 65-72, A. 53-57, L. 1. 85.

4. Solea lutea, D. 65-72, A. 50-56, L. 1. 72.

\section{A. Pectoral fins developed on both sides.}

a. Nostrils on the blind side not dilated.

\section{Solea vulgaris, Plate CVI.}

Solea, Ovid, v. 124; Pliny, ix, c. 16; Klein, Pisc. Miss. iv, p. 31, no. 1, and p. 32, no. 2, tab. ii, f. 3. Buglossus seu Solea, Belonins, De Aquat. p. 145; Rondel. xi, c. 11, p. 320; Gesner, Aquat. iv, pp. 666, 671, and Icon. Aquat. p. 101 ; Schonev. p. 63 ; Aldrov. ii, c. 43 , p. 235 ; Jonston, i, tit. 3 , c. 2 , a. 2, punct. 1, p. 82 ; Willughby, Hist. Pisc. p. 100, t. F 7; Ray, p. 33 . Pleuronectes, sp. Artedi, Synon. p. 32, no. 8, Genera, p. 18, no. 6, and Species, p. 60, no. 5 ; Gronov. Zooph. no. 251 and Mus. i, p. 14. The Sole, Borlase, Cornwall, p. 266, pl. xxvi, f. 2; Pennant, Brit. Zool. (Ed. 1776) iii, p. 231, and (Ed. 1812) iii, p. 311; Low, Fauna Orcad. p. 213; Couch, Fishes of the British Islands, iii, p. 200, pl. clxxvi. La Sole Duhamel, iii, sect. 9, p. 257, pl. i.

Pleuronectes solea, Linn. Syst. Nat. i, p. 457 ; Brunn. Ich. Mass. p. 34 ; Bloch, Fische Deuts. ii, p. 42, t. xlv; Bl. Schn. p. 146; Bonn. Ency. Ich. p. 76, p. xli, f. 160; Lacépède, iv, p. 623 ; Donovan, Brit. Fishes, iii, pl. lxii ; Shaw, Zool. iv, p. 302 ; Turton, Brit. Fauna, p. 96; Fries and Ekström, Skand. Fisk. p. 165, t. xxxix; Gronov. ed. Gray, p. 89.

Solea vulgaris, Quensel, Vet. Akad. Handl. 1806, p. 230 ; Risso, Eur. Mérid. iii, p. 247; Fleming, Brit. Anim. p. 197; Nilss. Skand. Fauna, Fisk. p. 651; Holb. Götheb. Vet. Sällsk. Handl. iv, p. 56, c. fig.; Gottsche, Wiegm. Arch. 1835, p. 182 ; Jenyns, Brit. Vert. p. 466 ; Yarrell, Brit. Fish. (ed. 1) ii, p. 256, c. fig. (ed. 2) ii, p. 347 (ed. 3) i, p. 657; Parnell, Wern. Mem. vii, p. 378, and Fish. Firth of Forth, p. 218; Bonap. Fauna Ital. Icon. p. 26, c. fig.; Templeton, Mag. Nat. Hist. 1837 (2) i, p. 412 ; Costa, Faun. Nap. ii, p. 34; Canest. Arch. Zool. v, p. 41, t. iv, f. 2 ; Johnston, Berwick. N. Hist. Club, 1838, i, p. 174; Swainson, Fishes, ii, p. 303 ; Kröyer, Dan. Fiske, ii, p. 467, c. fig.; White, Catal. Brit. Fish. p. 105; Thompson, Nat. Hist. Ireland, iv, p. 205; Nilss. Skand. Fauna, iv, p. 651; Schlegel, Dieren. Neder. p. 175, pl. xiv, f. 5; Günther, Catal.iv, p. 463; T. Ogilby, Zoologist, 1876, p. 4755 ; Steind. Ich. Span. u. Port. 1868, p. 54; McIntosh, Fish. St. Andrew's, p. 180; Collett, p. 148; Winther, Ich. Dan. Mar. p. 41 ; Giglioli, Pesc. Ital. p. 39 ; Moreau, Poiss. France, iii, p. 304.

Solea buglossa, Rafin. Indice, sp. 45.

Solea linnei, Malm, p. 532.

B. vii, D. 73-86 (97), P. 7, V. 5-6, A. $61-73$ (83), C. 16, L. 1. 160, Vert. 9/39-40. 
Length of head $5 \frac{1}{2}$ to $5 \frac{3}{4}$, of caudal fin $7 \frac{1}{2}$ to 8 , height of body 3 to $3 \frac{1}{4}$ in the total length. Eyes-the upper slightly in advance of the lower: interorbital space somewhat concave and exceeding 1 diameter of the eje in width. Jaws of about the same length in front. Cleft of the mouth extends to beneath the middle of the lower eye. Some short filaments on the snout and on the blind side of the head. Nostrits-on coloured side just in front of lower eye, the posterior one patent with a thick lip on the upper side: the anterior one tubular. On the blind side the anterior nostril is above the centre of the upper lip and scarcely tubular: the posterior nostril is as far behind the anterior as the latter is from the end of the snout, it is patent with slightly elevated edges. Teeth-small, but distinct on the blind side. Gill-rakers-rudimentary. Fins-the dorsal commences in front of the upper eye. The two pectorals of the same size, and $22_{2}^{1}$ in the length of the head. Ventrals free. Caudal rounded. Scales-ctenoid, and continued on to the fin-rays. Lateral-line-straight. Colours -brown or gray on the coloured side, frequently blotched with black. Vertical fins with a narrow, white, outer edge. Pectoral usually with a black blotch in its outer half, which is very distinct in the joung. "The colour of the sole depends upon and varies according to the quality and depth of the feeding ground: (at Weymouth) there are four presailing varieties:-(1) a dark sole; (2) a shrub sole, from the markings on the back having the appearance of shrubs; (3) a lemon sole; and (4) a spotted sole. No. 1 is, I believe, caught in the shallowest water; no. 2 next; and nos. 3 and 4 in the deepest water." (W. Thompson, Zool. 1851, p. 3375.$)$

Steindachner 1.c. observes that Solea azevia, Capello, from Portugal, is this species.

Varieties.-M. Capello states that examples from the coasts of Portugal vary in the number of their fin rays from D. $45-95$, A. $7+4-78$ (Journ. Sc. Matt. phys. e. nat. Lisbon, no. ii, 1867, p. 164). Near the mouth of the Ouse a variety is talien termed cardine, its head is large and elongated, but its flesh is rather coarse. Reversed examples are not rare ( $\mathrm{I}$ obtained one from Brixham 14 inches long in January, 1881), neither are donble ones or such as are coloured on both sides. On February 11th, 1881, I obtained from Brixham a double sole $11 \frac{1}{2}$ inches in length, with the eyes placed as normally in this species. There are also semi-albino or piebald specimens.

Thompson observes that those from the north of Ireland vary considerably in form and colour, some being narrower than others, and tapering more towards the tail. I obtaincd an example 12 inches long from Brixham in which the caudal fin had been lost, and a new one formed continuous with the dorsal and anal.

Names.-Sole, as the Greelss considered it would form a fit sandal for an ocean nymph : slips, or tongues, the market terms for the young: also tongue-soles in the Moray Firth, and lobsters in Suffolk. La sole commune, French. Je Tong, Dutch.

Hatits.-Appears to prefer sandy or gravelly shores, and is retentive of life, but rather uncertain in its migrations, for although mostly appearing at certain spots almost at a given time, and usually decreasing in numbers by degrees: in other seasons they disappear at once as suddenly as they arrived. "The finest soles have been taken," observes Andrews (Zool. 1853, p. 3848), "in the Arun River, miles above the tideway, and where they breed and remain throughout the year." "In the estuary of the Humber," observes Mrr. Eagle Clarke, "they are captured from May until August inclusive, all are either in spawn or shotten. The young are very numerous in the shallow water at the edge of the tides." Yarrell, on the authority of a correspondent, remarks that they breed in the River Arun, frequenting it from the mouth five miles upwards, which is nearly to the town of Arundel, and remain in it the whole year, burying themselves in the sand during the cold months. It is not unusual for them to ascend rivers to some distance, while they will live and thrive in fresh water. Along our sea-coasts they retire to the deep as frosts set in, revisiting the shallows about May if the weather is warm, their migrations being influenced by temperature. Although very large examples are occasionally taken in Lynn Deeps this fish, similar to the whiting, only attains about $2 / 3$ the size off Norfolk and Suffolk that it does off Devonshire. 
In Ireland (October) Dr. Farran found Cardium elongatum abundantly, a few Bulla aperta, and a number of Echinocyamus pusillus. (November) Amphidesma Boysii, a Dentalium, and a few Amphidesma prismatica. (December) Amphidesma prismatica, a Lysteri, an Anomia, and Donax trunculus. The sole has been reputed to eat the eggs and fry of other fishes and sea urchins, \&c.

Means of capture.-Generally the trawl. The principal English trawling ground lies from Dover to Devonshire. They may be taken by spillers, but are not commonly captured with hooks : it is suggested that one reason may be that spillers are mostly used by day, whereas the sole is a night feeder. In-shore trawling, shrimping and fine meshed netting during the spring months occasion great injury to the young of these fishes, as do also hose nets set for shrimps. Mr. Welton, of Bridgewater, purchased all the fish taken in two of these nets in one day, and thus obtained $18 \mathrm{cwt}$. of the fry of soles, plaice, herrings, whiting, \&c.

Baits.-Major Holland (Sc. Gossip, 1872, p. 261) employs soft- or soldier-crabs, lug-worm, mussel, shrimp and rag-worm, with long gut snoods, but these fish feed mostly at night, and the most favourable time is after a blow, when the water is thick, while a land breeze answors better than a sea breeze.

Breeding.-They spawn late in the year and during the spring months. I have obtained them in full roe this year up to April 15th. A sole of $11 \mathrm{~b}$. weight carries about 134,000 eggs (Buckland).

Hermaphrodites.-Have been recorded by Yarrell.

Life history.--The very young swim on edge as has been already referred to, but they do not appear to be commonly found so far out at sea as some other species. They are first seen along our south coast about the end of March or commencement of April.

Diseases.-Buckland mentions having received a sole in which its entire lower surface was studded with hairs from $1 / 8$ to $1 / 2$ an inch in length. On a microscopic examination being made they turned out to be the hairs of the "sea mouse," Aphrodite aculeata.

Uses.-The skin of the sole was much used, according to Parnell, for fining coffee, being found a good substitute for isinglass: also as a material for artificial baits.

As food.-The flesh of this fish is white, firm, and of excellent flavour, those from the deepest waters being generally preferred: during the time of breeding, and for a short period subsequently, they are soft and watery. Those on the west coast and to the south are larger as a rule than those towards the north of these islands. Mayhew tells us that London requires annually 97,520 soles, while that market is principally supplied from the Norfolk coast and the English Channel.

Habitat.-It extends from the seas of Scandinavia and the Baltic southwards, round all the coasts of France, and is found in the Mediterranean.

It is taken in the Orkneys and Zetland, but is rare (Baikie): it is not very common off Banff (Edward): but found off Aberdeen (Sim): is common in the Moray Firth, but not much sought after: frequent at St. Andrew's (McIntosh): sparingly at the mouth of the Firth of Forth (Parnell). Resident and common off Yorkshire. Has once occurred at Goode, in the estuary of the Hamber, near the mouth of the Ouse (Yorkshire Vertebrata): the Great Grimsby fishermen assert that they capture most of their small soles off the Dutch coast. Common in the Norfolk estuary (Lowe): abundant off the south coast from Sussex to Devonshire, and common off Cornwall. Also found in the Bristol Channel, and generally around Great Britain.

In Ireland soles occur all round the coast, while Ogilby observes that they are common at Portrush, and Thompson remarks that those in the north vary considerably in form and colour from those more to the south. As to the size it attains Thompson's largest example was 20 inches in length. Mr. Grove, of Charing Cross, received one from Torbay on February 1st, 1882, 24 inches long, and which weighed $6 \frac{1}{2} \mathrm{lb}$. A correspondent of the Field alludes to one weighing $7 \frac{1}{2} \mathrm{lb}$. captured at Bridgewater, on June 4th, 1881: and casts of a pair from Ireland which weighed together $12 \mathrm{lb}$. are in the Buckland Museum. Yarrell mentions one 26 inches long and very thick, the largest he had ever heard of, which was brought to the Totness market, and weighed $0 \mathrm{lb}$. 


\section{B. One of the nostrils on the blind side dilated and fringed.}

\section{Solea lascaris, Plate CVII.}

Pleuronectes lascaris, Risso, Ich. Nice, p. 311, pl. vii, f. 32.

? Pleuronectes nasutus, Pall. Zoogr. Ross.-As. p. 427.

Solea impar, Bennett, Proc. Zool. Soc. i, p. 147; Günther, Catal. iv, p. 468.

Solea lascaris, Risso, Eur. Mérid. iii, p. 249; Bonap. Fauna, Ital. Pesc.; Canestr. Arch. Zool. i, p. 38, t. iv, f. 1; Günther, Catal. iv, p. 467 ; Canestr. Faun. Ital. Pesc. p. 165; Moreau, Poiss. France, iii, p. 307.

Solea pegusa, Yarrell, Zool. Journ. iv, pp. 467, 508, pl. xvi, Brit. Fish. (ed. 1) ii, p. 260, c. fig. (ed. 2) ii, p. 351 ; Jenyns, Man. p. 467 ; Thompson, Nat. Hist. Ireland, iv, p. 206; White, Catal. p. 106 (not Lacép. or Risso).

Solea nasuta, Nordm. in Demid. Voy. Russ. Mérid. Zool. iil, Poiss. p. 536, pl. xxxi ; Kessler, Bull. Soc. Nat. Mosc. 1859, pt. ii, p. 442; Richardson, in Yarrell, Brit. Fish. (ed. 3) i, p. 662 ; Steind. Ich. Span. u. Port. 1868, p. 58.

Solea aurantiaca, Günther, Catal. iv, p. 467 ; Steind. Ich. Span. u. Port. 1868, p. 58.

Lemon Sole, Couch, Fish. Brit. Isl. iii, p. 205, pl. clsxviii. 46.

B. vii, D. (65) 82-88, P. 10, V. 5, A. (32) 67-71, C. 15, L. 1. 130-140. Vert.

Length of head $5 \frac{2}{3}$ to $6 \frac{1}{2}$, of caudal fin 8 to $8 \frac{2}{3}$, height of body $2 \frac{2}{8}$ to $2 \frac{3}{4}$ in the total length. Eyes-the superior 1/2 in advance of the inferior: about $1 \frac{1}{2}$ diameters from the end of the snout, and about I diameter apart. This species is rather thicker than $S$. vulgaris. Upper jaw slightly longer than the lower but not produced into a lobe. The cleft of the mouth extends to beneath the middle of the lower eye. Some filaments on the snout, very numerous on the blind side of the head and also on the few first dorsal rays. Nostrils on the coloured side tubular, the anterior one being the longer. One of the nostrils on the blind side is nearly circular, very wide, and encircled by short and branched filaments. Teeth-distinct on the blind side. Fins-the dorsal commences in front of the upper eye: most of the fin-rays branched. The two pectoral fins are equally long and $2 \frac{1}{2}$ in the length of the head. Gill-rakers-absent or exceedingly minute. Scales-ctenoid, continued on to the fin-rays. The mucous membrane of the gullet has longitudinal folds which are continued into the stomach: the intestine bejond the pylorus is wider than the stomach: externally both have sereral large papillæ on them. Colours-of an orange or lemon yellow, marbled with darker and covered with numerous small black blotches and dots, among which are some light or even white ones. Pectoral fin with a large black blotch, surmounted by a light ring in its posterior half. Vertical fins of the same colour as the body. In some examples the yellow colour is entirely lost after they have been a few weeks in alcohol, leaving the fish gray marbled with darker.

Yarrell appears to have been the first British author who distinguished this fish and considered it identical with Pleuronectes pegusa (Risso) : Jenyns, however, observed that it is not Risso's fish, and appears to be undescribed by any foreign authors. Richardson next located it as Pleuronectes nasutus (Pallas): while subsequently Dr. Günther believed it to be undescribed and named it Solea aurantiaca. It seems to be S. lascaris (Risso) as suggested by Moreau, and agrees with S. lascaris (Bonap.) : while Steindachner identifies S. lascaris (Risso) with S. scriba (Val.).

Names.-The lemon sole from its colour: sand-sole from the localities it frequents: French sole. Borhame, Northumberland. Le Sole Lascaris, French.

Habits. - Frequents sandy bottoms and appears to be captured throughout the year, a good number were daily in the Cheltenham fish shops from April until December, 1881, and January, 1882.

Means of capture.-Usually by the trawl, it has been thought by some authors that it prefers deeper wator than the common sole. 
As food.- It is not in request for the table, being tasteless and wanting in firmness, but is occasionally slipped in amongst such as have been prepared for filletting at the fishmongers.

Habitat.-From the shores of Great Britain and Ireland, through the Mediterranean, and is found off Nice and Naples (Giglioli). Rare in Banffshire (Edward) : Northumberland: resident and not uncommon in Yorkshire (Yorkshire Vertebrata) : found off Sussex. Occasional in Devonshire (Parfitt) : I bave seen large numbers from Torbay: Weymouth two examples (Gosse, Zool. 1854) : rare in Cornwall (Cornish): off Somersetshire (Baker): occasionally taken in the weirs at Swansea (Dillwyn). 1848 .

In Ireland numerous examples were captured from one place off Galway in

It attains to 14 inches in length (Buckland); the one figured was from Brixham, and measures $8 \frac{1}{2}$ inches.

\section{B. Pectoral fins on both sides very small.}

Solea variegata, Plate CVIII, fig. 1.

Pole panachée, Duham. iii, sect. 9, p. 259, pl. ii, f. 3.

Pleuronectes variegatus, Donovan, Brit. Fishes, 1801, pl. cxvii.

Pleuronectes microchirus, Delaroche, An. Mus. xiii, 1809, p. 356, f. 2.

Monvchir microchir, Cuv. Règne Anim.; Guichen. Exp. Sc. Algeria, p. 107.

Pleuronectes mangili, Risso, Ich. Nice, 1810, p. 310.

Pleuronectes lingula, Hanmer in Pennant, Brit. Zool. (Ed. 1812) iii, p. 313, pl. xlviii.

Rhombus mangili, Risso, Eur. Mérid. iii, p. 255.

Pleuronectes fasciatus, Nardo Naccari, Giorn. Fis. Pav. iii, Adr. Itt. p. 9.

Solea mangili, Bonap. Faun. Ital. Pesc. iii, p. 27, c. fig.; Canest. Arch. Zool. i, p. 29, tav. iii, f. 3, Fauna d'Ital. p. 166.

Solea lingula, Jenyns, Manual, p. 468.

Monochirus lingula, Costa, Faun. Nap. ii, p. 50.

Monochirus variegatus, Thompson, An. Nat. Hist. ii, p. 404, and Nat. Hist. Ireland, iv, pp. 207-211; Yarrell, Brit. Fish. (ed. 1) ii, p. 262, c. fig. (ed. 2) ii, p. 353 , c. fig. (ed. 3) i, p. 664 .

Microchirus lingula, Bonap. Pesc. Enr. p. 50, no. 429.

Monochir variegatus, White, Catal. p. 106.

Solea variegata, Flem. Brit. An. p. 197 ; Scouler, Mag. Nat. Hist. vi. (1833) p. 530; Günther, Catal. iv, p. 469; Steind. Ich. Span. u. Port. 1868, p. 60; Giglioli, Pesc. Ital. p. 39.

Microchirus variegatus, Morean, Poiss. France, iii, p. 317.

Variegated sole, Couch, Fish. Brit. Isles, iii, p. 203, pl. clexvii.

B. vii, D. $65-74$, P. r. 4-5, 1. 2-3, V. 5, A. 55-58, C. 15, L. 1. 85-90, Vert. $10 / 30$.

Length of head $5 \frac{1}{4}$ to $5 \frac{1}{2}$, of caudal fin $6 \frac{1}{2}$ to 7 , height of body $3 \frac{1}{4}$ to $3 \frac{1}{3}$ in the total length. Eyes-on the right side, scarcely half a diameter apart, and 1 diameter from the end of the snout. The upper eye one-half in advance of the lower: interorbital space scaled, anterior nostril tubular. Teeth-very minute. Fins-dorsal commences above the front edge of the upper eye, and nearly reaches the base of the caudal fin, its rays are branched and the highest are opposite the middle of the length of the body. Right pectoral fin very short, not equalling the length of the orbit: left pectoral still more minute. Ventral not attached to anal, which latter fin terminates similarly to the dorsal. Caudal somewhat rounded at its extremity. Scales-ctenoid extending on to the fin rays. Lateral-line-nearly straight. Free portion of the tail about three times as high as long. Colours - of a rich chestnut brown with six or seven vertical dark bands which are a little more than one-third the width of the interspace between each. These bands become broken up with advancing age, but may even be seen in large specimens mostly as dark marks at the bases of and passing on to the dorsal and 
anal fins. Caudal with a dark band in its last third, having a light outer edge. Dorsal and anal fins usually edged with white.

Thompson observes Solea lingula and S. variegata are brought together as synonymous by Yarrell and Jenyns. "In placing individuals together the most obvious differences appear in the dark blotches and transverse bands of $\mathcal{A}$. variegata contrasted with the comparatively uniform tint of $S$. lingula: the scales of $S$. variegata are very much smaller and its eyes being relatively to each other placed more vertically : in the dorsal and anal fins being rather more distant from the caudal fin: and in the general form of the body, which tapers less towards the tail : the rays too of the dorsal and anal fins are considerably fewer in number than in S. lingula." The Banksian copy of Pennant has the following MIS. remark: "This fish is sometimes taken at Torbay in the trawling nets. It differs at first sight from the common sole in the edges of the scales being strongly ciliated, and in wanting the numerous small beards that hang from the lower side of the head of the common sort." This appears to be the "red-back" described from E. Hanmer's MS. in the 1812 edition of Pennant (iii, p. 313, pl. slviii) but there is no reference to this figure (P. Z. S. 1849, p. 83).

Names. - Thiclibacl, Devonshire, so termed owing to its being thicker than the common sole : bastard sole, Weymouth. It was first observed from our coast by Donovan, in April, 1807, when it was brought to Billingsgate market.

Habits.--On the south const of Great Britain it appears in the spring and continues through most of the year.

Means of capture.--Trawling, and is often taken in rel'y great numbers along the south coast.

As food.-Largely consumed in Devonshire and Cornwall where it is held in great estimation.

Habitat.-From the British coasts to France and the Mediterranean, and common off Italy (Giglioli) : frequent along the coasts of France and extends into the Mediterranean, Trieste (Giglioli). Met with occasionally off Banff (Edward): off Rothsay and the Isle of Bute in Scotland (Scouler) : in October, 1851, Mr. Hussey (Zool. p. 3282) observed upon many having been captured at Brighton, one pair weighing upwards of $6 \mathrm{lb}$. : but Mr. Thompson (Zool. p. 3375) says they were merely varieties of the common sole, continuing, "the true rariegated sole I have ncver seen exceed $5 \frac{1}{2}$ inches (French measure) and I have seen twenty pairs at a time and not half-an-inch difference in the whole lot, and many of them had roe. They are called here (Weymouth) "bastard soles." During August, 1881, I found they were being landed in thousands at Plymouth from the trawlers and sold as "thickbacks," they had been captured during at least the three previous months. Mr. Dunn, in the last week in February, 1881, forwarded to me one with the information that they were being taken neal Plymouth in hundreds, averaging about six to a pound, and were being sold in pads separated from the other soles as offal.

In Ireland one was dredged at Belfast, June 16th, 1838, by Mr. Drummond, and in Ventry harbour it is not uncommon (Andrews).

The example figured is $6 \frac{2}{2}$ inches long, and was obtained at $\mathrm{Plymouth}$, it attains to 9 inches in length according to Buckland.

\section{Solea lutea, Plate CVIII, fig. 2.}

Solea parva s. lingula, Rondel. xi, c. 15, p. 324; Gesner, Aquat. iii, lib. iv, p. 669 ; Aldrov. ii, c. 43 , p. 237 ; Jonston, Pisc. ii, lib. 1, tit. 3, c. 2 , a. 2, punct. i, p. 58; Willughby, p. 102, t. F 8, f. 1; Klein, Pisc. Miss. iv, p. 32, no. 4. Solonette, Dubamel, iii, sect. 9 , p. 258 , pl. ii, f. 1, 2.

Pleuronectes luteus, Risso, Ich. Nice, p. 312.

Rhomlus luteus, Risso, Furop. Mérid. iii, p. 257.

Monochirus minutus, Parnell, Roy. Soc. Edinburgh, 1837, c. fig. and Mag. Zool. and Bot. i, 1837, p. 527, c. fig.

Monochirus linguatulus, Cuv. Rigne Anim.; Thompson, Ann. Nat. Hist. ii, 
p. 405, and Nat. Hist. Ireland, iv, p. 206 ; Yarrell, Brit. Fish. (ed. 2) ii, p. 355, c. fig. (ed. 3) i, p. 666 (not Pl. linguatula, Linn.). Solea lingula, Jenyns, Man. Brit. Vert. p. 468; Thompson, Proc. Z. S. 1837, p. 58, and Nat. Hist. Ireland, iv, p. 206.

Pleuronectes trichodactylus, Naccari, Ich. Adri. p. 11.

Monochirus luteus, Costa, Faun. Nap. ii, p. 49; Bonap. Catal. no. 428 ; Moreau, Poiss. France, iii, p. 316, c. fig.

Synaptura lingula, Kaup, Wiegm. Arch. 1858, p. 97.

Solea luteu, Bonap. Faun. Ital. Pesc. c. fig.; Canest. Arch. Zool. i, p. 32, tav. 3, f. 4, Fauna Ital. p. 167 ; Günther, Catal. iv, p. 469; Steind. Ich. Span. u. Port. 1868 , p. 60.

Monochir linguatula, Swainson, Fish. ii, p. 303; White, Catal. p. 107.

Solea minuta, Günther, Catal. iv, p. 470; McIntosh, Fish. St. Andrew's, p. 180; Steind. Ich. Span. u. Port. 1868, p. 61 .

Solonette, Couch, Fish. Brit. Isles, iii, p. 207, pl. clxxix.

B. viii, D. $65-72$, P. r. 5, 1. 3, V. 5, A. 50-56, C. 19 , L. 1. 72.

Length of head $4 \frac{1}{2}$ to $4 \frac{2}{3}$, of caudal fin 6 to $6 \frac{1}{2}$, height of body $3 \frac{1}{4}$ in the total length. Eyes-on the riglht side, rather close together, the upper being one-third in advance of the lower. Cleft of mouth extends to beneath the middle of the lower eye. Anterior nostril tubular. Teeth-pointed and minute. Fins-Dorsal commences on the snout before the upper eye and ceases close to the base of the caudal fin, its rays are branched and the highest are opposite the middle of the length of the body. Right pectoral very short, its upper ray twice as long as the others, left pectoral still more minute. Ventral rays two-thirds as long as the first few of the anal fin, which latter terminates similarly to the dorsal. Caudal somewhat rounded at its extremity. Scales-ctenoid extended on to the fin rays. Lateral-line-nearly straight. Colours-right side of a stone gray covered with numerous small brown or dark spots, also three or four rows of moderately sized dark blotches placed very wide asunder, but sometimes entirely wanting. Dorsal and anal fins colourless, but every here and there a ray (from the fourth to the seventh) quite black, portions of others also dark, and some dark spots along the bases of these fins. Caudal spotted. Pectoral with a black blotch in its centre.

Some of the specimens described by more than one author as belonging to this species, appear to be small examples of the "variegated sole."

Varieties. - If the colours shown in Couch's figure are correct, are the proportions such as he copied from nature? I think he must have had some other species under his eye than $S$. minuta.

Names.-Zittle sole: Red sole. Le Microchire Jaune, French.

Habits.-Appear to resemble those of the "variegated sole."

Means of capture.-Trawling.

Uses.-Parfitt observes (Fauna of Devon, p. 28), "sometimes taken in large numbers in the trawl nets: but as they are of no use for the market they are thrown again into the sea."

Habitat.-From the shores of Great Britain and Ireland to those of France and through the Mediterranean. Off Banffshire it is more common than the "lemon sole" (Edward): common at St. Andrew's (McIntosh). Reputed to have been taken at Whitby (Yorkshire Vertebrata): common at Weymouth (P. Gosse): Mr. Cornish records (Zool. 1873, p. 3697) capturing a star-fish in August, holding one of these fishes, three inches in length, in its feelers. An example was captured in November, 1880 , ten miles at sea off Mevagissey, and sent to me by Mr. Dunn.

In Ireland it is taken on the N.E., E., S. and West coasts. Ball obtained it in Dublin: McCoy observed (Ann. and Mag. 1841, vi, p. 408) that he found it tolerably abundant in the Bay between the lightship and the harbour: McCalla took it in county Down, and Thompson mentions three dredged off Dundrum in the same county.

The example figured, life size, came from Mevagissey : the largest specimen I have obtained is $4 \frac{1}{4}$ inches in length, but it is said to reach to 5 inches. 


\section{Order III-PHYSOSTOMI, Müller.}

All the fin rays articulated, with the exception of the first in the dorsal and pectoral, which are frequently more or less ossified (some genera belonging to the family Sternoptychidæ have a rudimentary first dorsal fin). Ventral fin when present abdominal and spineless. Air-bladder when existing having a pneumatic duct (except in the family Scombresocidm).

\section{FAMILY, I-STERNOPTYCHID无.}

Margin of the upper jaw formed partly by the premaxillaries and partly by the maxillaries, both of which are provided with teeth. Opercular bones not fully developed. Gill opening wide: pseudobranchiæ present or absent. An adipose dorsal fin may be present or rudimentary. Body scaleless or scaled. Rows of round luminous bodies along the lower surface of the abdomen, and occasionally some also on various parts of the body and head. Air-bladder when present, simple. Eggs enclosed in the sac of the ovaries, and excluded by oviducts.

These fishes are all of small size and appear to be mostly pelagic, while some may be abyssal forms.

This family bas been subdivided into three groups by Dr. Günther, who, however, failed to detect scales in Maurolicus, in which genus they are present, but deciduous. The divisions would consequently have to be altered as follows:

Group A.-Pseudobranchiæ present: a rudimentary spinous dorsal fin Scaleless. Sternoptychina.

1. Argyropelecus.-A single row of teeth in the jaws.

Group B.-Pseudobranchiæ present : no spinous dorsal fin. Scaled. Coccia. 2. Maurolicus.-Lower jaw prominent.

Group C.-Pseudobranchiø absent : no spinous dorsal fin. Scaled. Chauliodontina.

The two forms of this family, Argyropelecus and Maurolicus, which have been obtained off the coasts of Great Britain and Ireland, in common with some otber pelagic forms found elsewhere, possess eye-like spots of a circular form which are either impressions or prominences on the skin. Their uses have been a fertile subject for speculation, and possibly much still remains to be discovered. MacCulloch remarked that considering at a depth of 800 or 1000 feet, the light of the sun ceases to be transmitted in the ocean, it may be that animal luminousness is a substitute for that light, and if so these organs would take the place of minature lanterns. Professor Reinhardt observed of Astronethes Fieldii, Val., which is common in the Atlantic Ocean between $23^{\circ}$ and $6^{\circ}$ north latitude, that in two instances he captared the fish alive, when he saw that it sent forth two strong and vivid greenish lights, which intermitted momentarily and ceased altogether when the fish died (Zool. 1854, p. 4300). Dr. Guppy (Ann. and Mag. Nat. Hist. March, 1882, p. 202) remarked that on November 7th, 1881, latitude 
35॰17' south, longitude $17^{\circ} 43^{\prime}$ east, two Scopeli were caught; one had some life remaining and displayed a faint, though an undoubted luminosity in the pearly bodies of the pectoral region : direct irritation had no effect. Professor Leuckart, in 1865, suggested whether some at least might not be regarded as accessory organs of sight, a position shown by Leydig to be untenable. In $1879 \mathrm{Dr}$. Ussow (Bull. Soc. Moscow, liv, 1879, p. 79) of St. Petersburgh, remarked that among these fish belonging to seven genera which he had examined these organs could be arranged in two series: the first he regarded as constituting accessory eyes, the second as special glandular organs. Leydig, in 1881 (Die augen. Organe der Fische, Bonn.), added another group, viz., mother-of-pearl like organs, which are not sensory in function, and he considers they bear the closest resemblance to the electric, or pseudo-electric organs of other fishes, with probably a secondary illuminating function.

\section{Group A.-Pseudobranchiæ present. A rudimentary spinous dorsal fln. Body scaleless.}

\section{Genus I-Argrropelecus,* Cocco.}

\section{Pleurothysis, Lowe.}

Branchiostegals nine: pseudobranchice present. Head large, it and the trunte elevated and very compressed, the latter passing suddenly into the tail which is narrow. Eyes large, directed upwards and outwards, separated by a very narrow interspace. Cleft of mouth vertical and deep, with the lower jaw prominent. The margin of the upper jaw is formed of the premaxillary and maxillary, which have a single row of fine teeth, a row also in the lower jaw. First dorsal short, preceded by an osseous plate formed from neural spines: adipose dorsal, if present, rudimentary. Pectorals well developed. Ventrals small. Gill-openings wide: gill-rakers long. Body covered with a silvery pigment but no distinct scales. Humeral arch and pubic bones prolonged into flat, pointed processes, which project along the median line of the abdomen, intermediate between which are some scutes. Air-bladder present. Four pyloric appendages.

Examples of this genus are said to have been dredged in the Challenger expedition at 1100 fathoms, a statement upon which discredit has been thrown. In the Mediterranean it would appear not to be found at very great depths, and may be a night feeder, at which time it ascends to the surface as is seen in the Scopelida.

Geographical distribution.-Atlantic Ocean and Mediterranean. One species has been found off the coast of Norway.

\section{Argyropelecus hemigymnus, Plate CIX, fig. 1 .}

Argyropelecus hemigymnus, Cocco, Giorn. Sc. Sic. 1829, fasc. lxxvii, p. 146 ; Bonap. Faun. Ital. Pesc.; Cuv. and Val. xxii, p. 398; Günther, Catal. v, p. 385, and Ann. and Mag. (4) 1874, xiii, p. 139; Canestr. Fauna Ital. p. 119 ; Moreau, Poiss. France, iii, p. 498; Giglioli, Pesc. Ital. p. 39.

Sternoptyx Mediterranea, Cocco, Giorn. il Faro, 1838, iv, p. 7, f. 2 ; Bonap. 1. c. c. fig.

Sternoptyx hemigymnus, Cuv. Règ. Anim. Ill. Poiss. pl. ciii, f. 3.

B. ix, D. $6+7-8$, P. 10, V. 6, A. 11-12, C. 19.

The greatest height of the body equals half the total length. Posterior to the vent the caudal portion of the body becomes abruptly narrowed, while it is everywhere compressed, its greatest width merely equalling 1/4 of its height. Caudal fin $1 / 5$ of the total length. Eye-high up, directed outwards and slightly

- From some error, Agassiz thought this might be the yuung of Zous faber. 
upwards. The interorbital space very narrow, 1 diameter distance from the end of the snout, and a like distance from the posterior end of the head. Posterior inferior angle of preopercle, with two triangular spines, the upper directed backwards, the lower downwards. Cleft of mouth deep, the lower jaw projecting beyoud the upper, and the posterior angle of the maxilla armed with a triangular spine. Gill-raleers-very long. Teeth-in a single row of somewhat incurved ones, largest in the mandible. Those in the premaxillaries are ctirected somewhat backwards, as are also a patch in the contiguous and posterior part of the maxilla, but those in the posterior half of this latter bone are directed upwards. Fins-the dorsal consists of two portions, the anterior being prolongations of about 6 neural spines, the last two being the longest and largest, they are connected together by a thin plate: the rayed portion is higher than the first part: a rudimentary adipose dorsal fin is sometimes present. Pectoral rather longer than the head : ventral small, anal somewhat similar to the rayed part of the dorsal : caudal forked. Skin of the body covered with a silvery pigment, while in various places it possesses what have been termed eye-like spots, one anterior to the eye, usually two behind it, six smaller ones on the tliroat and branchiostegous rays, and six larger ones on the chest and humeral arch : twelve along the pubic plate, and eight on a line a little above this commencing above the axilla, the two anterior of which are the largest. Near the lower edge of the body and behind the ventral fin are four large ones, the last almost reaching the base of the anal, and six more over the last half of the base of the anal fin. Colours - the body brilliant silvery, the tail portion yellowish. A few black spots on the head and an irregular band along the base of the dorsal fin. On the side of the tail above the hind edge of the anal fin are two small silvery spots, with fine black bars radiating from them : a black band at the base of the caudal fin. As a rule the eye-like spots along the lower edge of the body have a black edge.

Habits. -Of these but little is known.

Breeding.-Eggs large.

Habitat.-Atlantic and Mediterranean.

An example in the British Museum is stated to have been dredged in 540 fathoms, between Shetland and the Faroe Islands by the Porcupine, along with several other Mediterranean forms in 1869. 


\title{
Group B.-Pseudobranchiø present: no spinous dorsal fin. Scalod.
}

\author{
Genus II-Madroliods, Cocco.
}

Gonostomus, sp. Cocco. Ichthyococcus, sp. Bonaparte.

Branchiostegals eight or nine: pseudobranchice well developed. Body oblong, it and the head compressed. Oleft of mouth deep and oblique, lower jaw prominent. Maxilla large and wide. Eyes of medium size. Teeth in a single row in the jaws. Gill-opening wide : gill-rakers very long. Dorsal fin in the posterior half of the body, also a rudimentary adipose fin. Pectoral and ventral present. Anal fin long, commencing on a line posterior to the termination of the first dorsal, its last rays are concealed by stin. Caudal forked. Scales very deciduous and large, covering the body: one or two roves of luminous spots along the lower side of the head, body and taib. Cocal appendages in moderate numbers.

These fishes appear to belong to the pelagic fauna, and as a rule are only captured off our shores subsequent to considerable disturbances in the deep sea. During the early part of this year (1882) storms were unusually prevalent, and Mr. Sim obtained from the beach at Aberdeen about 170 examples. As comroborative proof it may be mentioned that Trachypterus arcticus was thrown on shore on February 16th near Berwick, another on April 17th near Flamborough, and four days subsequently a third at Burghead. On April 15th an example of Regalecus Banksii came ashore in the Firth of Forth, while during the month of April I heard of four specimens of Lamargus borealis being captnred, one in the Firth of Forth and the three others off Aberdeen. The largest of the examples of Maurolicus obtained by $\mathrm{Mr}$. Sim in $1881 \mathrm{had}$ fally developed ova, and they may have been approaching the shore for breeding purposes, because all the large examples of the 170 taken at the same period this year show developed ova and milt ready for shedding : or they may have been on the surface of the sea for this purpose, and so come within the influence of storms.

Müller considered the structure of the jaws of this genus Scopeloid, most correctly observing that the premaxillaries reach to the angle of the mouth, and it is only beyond that angle that the toothed maxillary appears.

\section{Maurolicus Pennantii, Plate CIX, fig. 2.}

Sheppy Argentine, Pennant, Brit. Zool. (Ed. 1776) iii, p. 327, pl. lxv (Ed. 1812) iii, p. 432, pl. lxxvi; Low, Fauna Orcad. p. 225.

Argentina Pennantii, Walb. Artedi, 1792, iii, p. 47.

Argentina sphyrcena, Turton, Brit. Fauna, 1807, p. 105; Bonn. Atl. Ich. p. 177, pl. Ixxiii, f. 301 (not Linn.).

Serpe Humbolti, Risso, Ich. Nice, 1810, p. 358, pl. x, f. 38.

Scopelus Humbolti, Risso, Eur. Mérid. iii, p. 467; Cuv. Règne Anim. t. ii, p. 315; Yarrell, Brit. Fishes (Ed. 1) ii, p. 94, c. fig. (Ed. 2) ii, p. 161, and Mag. Nat. Hist. 1838 (2) ii, p. 25; Jenyns, Brit. Vert. p. 433; Clarke, Mag. Nat. Hist. 1838 (2) ii, p. 22, c. fig.; De Kay, Fauna New York, Fish. p. 246, pl. xxxviii, f. 121.

Scopelus borealis, Nilss. Obs. Ich. p. 9, and Skand. Fauna, Fiske, p. 479 ; Cur. and Val. xxii, p. 438; Thompson, Ann. and Mag. Nat. Hist. (2) 1847, p. 171, and Nat. Hist. Ireland, iv, p. 175; Günther, Catal. v, p. 389 ; Collett, Norges Fiske, p. 150 .

Maurolicus amethystino.punctatus, Cocco, Lett. в. Salmon, 1838, p. 32, t. iv: f. 12; Bonap. Faun. Ital. Pesc. c. fig.; Günther, Catal. v, p. 390; Canestr. Faun. Ital. p. 120; Moreau, Poiss. France, iii, p. 509; Giglioli, Catal. Pesc. Ital. p. 40. 
Scopelus Pennantii, Cuv. and Val. xxii, p. 436; Yarrell, Brit. Fish. (Ed. 3) i, p. 330 ; White, Catal. p. 82.

Scopelus maurolici, Cuv. and Val. xxii, p. 439.

Maurolicus Mülleri, Kröyer, Dan. Fisk. iii, p. 113.

Argentina hebridica (pt.) Günther, Catal. vi, p. 203.

Argentine, Couch, Fish. Brit. Isles, iv, p. 301, pl. cexxxiii.

B. ix, D. $10\left(\frac{2}{8}\right)$, P. 16, V. 7, A. $10+12+4-13$, C. 19 , L. 1. 28, L. tr. 6, Cœc. pyl. 8 , Vert. 32 .

Length of head 4 to $4 \frac{1}{2}$, of caudal fin $6 \frac{1}{2}$ to $7 \frac{1}{4}$, height of body 5 to $5 \frac{1}{2}$ ( $4 \frac{1}{4}$ in the young) in the total length. Eye-diameter $2 \frac{3}{4}$ to $3 \frac{1}{2}$ in the length of the head, $3 / 4$ to nearly 1 diameter from the end of the snout, and rather more than half a diameter apart : interorbital space concave from side to side, with a ridge running down its centre. Body and head compressed: the greatest width of the body does not quite equal half its height. Cleft of mouth deep, the maxilla wide and reaching to below the middle of the orbit: lower jaw prominent. Teeth-fine ones in a single row in both jaws, none on the vomer or palate. Fins-the rayed dorsal commences midway between the hind edge of the eye and the base of the caudal fin: its highest rays rather exceed one-half the height of the body below the fin: the adipose dorsal is very rudimentary, being apparently absent in some examples. Pectoral about half as long as the head. Ventral about as long as one diameter of the orbit, and inserted on a vertical line almost immediately beneath the first dorsal ray, and not quite reaching the insertion of the anal. The anal fin arises on a line somewhat posterior to the base of the last dorsal ray : the first ten rays are somewhat similar to, but rather shorter than, those in the dorsal fin, the succeeding ones are smaller, and the last few in some specimens again increase in size, but owing to their fragility, and being imbedded among the muscles and scales, it becomes extremely difficult to ascertain their numbers : in some I have only been able to discover about 26 in all : in the fine example figured there seem to be 33. Scales-cycloid, higher than wide, very deciduous, but distinct : although in the British Musenm catalogue it is remarked that there are no regular scales, this is due to their having been abraded, leaving the subjacent silvery pigment visible : still even in the Redcar specimens some can be seen if a magnifying glass is employed. Luminous spots, not elevated but level with the surface of the skin, are very distinct, one on the preorbital, one beneath the chin, one at the posterior angle of the lower jaw : six on the branchiostegal rays : six on the chest, in a line terminating posteriorly at the upper part of the base of the pectoral fin: twelve along the lower edge of the abdomen between the humeral arch and the base of the ventral fin: parallel to this last row and commencing at the upper edge of the base of the pectoral fin, and terminating above the base of the ventral are eight more : six more in a single row between the bases of the ventral and anal fins: fifteen along the base of the anal, and eight more along the lower edge of the body hetween that fin and the caudal: over the commencement of the anal fin exists a single spot a little higher up than the anal row. Stomach coecal, with longitudinal well developed rugæ: in those opened no food existed, but small gravel was present in the mouth and fauces: eight large and rather long coecal appendages: intestines making only two curvatures: testicles and ovaries very long, reaching almost the entire length of the abdominal cavity. Pseudobranchin well developed. Colours - back of a glossy brown or black, with, during life, two zig-zag lighter lines along either side of the back: sides of the head and body of a burnished silvery lustre: a dark band just before the base of the caudal fin : a black mark at the base of most of the luminous spots.

Varieties.-I have examined numerons examples and find that the number of rays in the aval fin may vary from twenty-six to thirty-seven, owing I suppose to injuries due to friction. No other essential differences being apparent, these scarcely appear sufficient to constitute distinct species. The height of the body in small examples is considerably greater in proportion than that in larger ones. Hutton (Trans. New Zealand Inst. vii, p. 250, pl. xi, f. 90 l) described Maurolicus Australis, from examples captured at Milford Sound and Cuttle Cove, New 
Zealand, and which he doubtfully separated from $M$. borealis. Dr. Günther (An. Nat. Hist. (4) xvii, p. 399) having examined a specimen pronounced it to be Maurolicus amethystino-punctatus, Cocco, from the Mediterranean. Hutton, 1. c. viii, p. 215, states that it is a Gonostoma. The figure gives the impression that the fish is Maurolicus Pennantii.

Names.-Pennant first termed this fish the Sheppy argentine, the latter designation gave rise to great inconvenience due to its not being an "argentine." Yarrell proposed the unobjectionable name of "Pearl sides."

Habits.-Of these but little is known. During their breeding season, or from January until May, they are thrown on our shores in varying numbers and in proportion to the violence of the weather, and it is only in the examples obtained by Higgins in Somersetshire that we possess a record of their capture so late in the season as July.

Means of capture.-Generally it is thrown on shore by the violence of the sea.

Breeding.-As the ova, which are large, were ready for shedding in examples captured in February and the milt was similarly forward, it appears that off Scotland they must breed during the earlier portion of the year.

Habitat.-From the coasts of Scandinavia, to the British Isles, shores of France and through the Mediterranean: off Italy, Giglioli observes, it is rare, but obtained at Niza, and Messina in July and September.

Low states that his single example from the Orkneys was given him by a boy, who found it at the edge of the water among the sea ware, since then several specimens have been procured by Dr. Duguid and Mr. Heddle (W. Baikie, Zool. 1853): Mr. Peach recorded it from Wick: Edward remarked that it is a regular winter visitant off the Banff coast, being never absent during January, and from 1 to 3 inches in length: Mr. Sim has collected for me at Aberdeen during the last two winters nearly two hundred examples, it being cast on the beach in great abundance during the months of January, February and March: four specimens up to nearly 2 inches in length were taken in April, 1833, from the Firth of Forth (Clarke, l. c.): two or three specimens are in the Glasgow Museum: Mr. Rudd first obtained this fish at Redcar in May, 1841: in 1843 he found thirteen specimens : in February, 1851, four: and in February and March, 1852, forty (Zool. 185\%, p. 3504) : it has been taken off Devonshire as recorded by Walcott (Yarrell) : Higgins obtained three specimens at Weston-super-Mare in the month of July (Zool. 1861, p. 7317) : Pennant's specimen came from sea at Downing, off Flintshire.

Its capture in Ireland has been reported March 11th, 1847, at Killiney Bay, near Dublin (Thompson, Ann. and Mag. 1847, p. 171).

The example figured life-size was taken at Aberdeen by Mr. Sim.

Note.-Paralepis. Dunn observes, "one of this genus was driven on shore alive by porpoises at Polkerris, near Par, June 2nd, 1869. I sent it to Mr. Couch, who says it is the first known in Fngland. Its length was about 14 inches, depth $1 \frac{1}{2}$ inches. The sides of the fish were of an uniform silvery colour. It was covered with scales, but so delicate that they came off on being bandled." 


\section{FAMILY II-SALMONID E, Mütler.}

Pseudobranchiæ present. Margin of the upper jaw formed by the premaxillaries and maxillaries. No barbels. Anteriorly a rayed dorsal fin, and posteriorly an adipose one. Pyloric appendages as a rule present, and usaally numerous. Body scaled. Head scaleless. Air-bladder large, simple, and with a pneumatic duct. The ova pass into the cavity of the abdomen before being extruded.

Geographical distribution.-Marine and freshwater forms, some of the former being exclusively inhabitants of the deep sea, others again being anadromons, periodically ascending rivers in order to deposit their spawn. Normally they are confined to the Arctic and temperate portions of the northern hemisphere, with the exception of one species which bas been found existing in New Zealand. Some of the genera among the salmonoids furnish most valuable food to the human race, consequently it has been an object to extend their range into the waters of distant lands. In introducing exotic fishes, one of the first considerations must necessarily be to ascertain whether any representatives of the family are normally resident in the region it is desired to stock, and if they are whether the race is a thriving or a diminutive one; for it has been maintained that if the latter the chances of success are too small to render the attempt worth making, as the region is probably unsuited for their development. By retarding the germination of the ova by means of ice (see Introduction), eggs of salmonidæ have been safely carried to Tasmania and elsewhere, and the races successfully introduced. In $1866 \mathrm{I}$ attempted to similarly convey trout into the waters of the table lands on the Neilgherries and adjacent hills in Madras. These mountain ranges embrace a geographical area extending over 268,494 square miles: their peaks vary from 5000 to 8000 feet above the sea, and Ootacamund, where the experiment was tried, is 7426 feet above the sea-level, with an annual mean temperature of $58^{\circ} 68^{\prime}$. Although I failed, two years subsequently Mr. McIvor succeeded by bringing out the young fish from Scotland, and they have bred in their new home, enabling me to give a figure in the third part of my Fishes of India, published August, 1877, taken from an Indian born tront.*

\section{Synopsis of Genera.}

1. Salmo.-Maxillary long: dentition strong and complete. Scales small. Anal rays in moderate numbers (14 or less). Pyloric appendages numerous.

2. Osmerus.-Maxillary long: dentition complete, with fang-like teeth on the vomer and tongue. Scales of medium size. Pyloric appendages few.

3. Coregonus.-Maxillary short: teeth if present minute. Anterior dorsal fin with few rays. Scales of moderate size. Pyloric appendages numerons.

4. Thymallus.-Maxillary short: small teeth in the jaws, vomer, and on the palatine bones. Anterior dorsal fin many rayed. Scales of moderate size. Pyloric appendages numerous.

5. Argentina.-Maxillary short: teeth absent from jaws. Anterior dorsal fin with few rays. Scales rather large. Pyloric appendages few or in moderate numbers.

* On recurding my firat failure, Dr. Günther as editor of the Zoological Record, remarked, as " has been foreseen by all acquainted with the nature of salmonoid fishes." And sinco it sncceeded, in his "Introduction to the Study of Fishes," 1880 , p. 641 , be has observed "the altempt of transferring them into the low streams of India ended (as could be foreseen) in a total failure." 


\section{Genus I-SALMO, Artedi:}

\section{Fario and Salar, Cuvier: Trutta and Salvelini, Nilsson.}

Branchiostegals nine to thirteen: pseudobranchice present. Eyes lateral. Cleft of mouth deep, the posterior extremity of the upper jaw reaching to beneath the hind edge of the eye or even beyond. Teeth conical, present on jaws, vomer, palatine bones and tongue, absent from the pterygoids. Anterior dorsal fin with a moderate number of rays (10-15) : anal with rather few (10-13). Scales small and cycloid, none on the kead. Lateral-line straight. Coecal appendages numerous. A pancreas present.

Geographical distribution.-This family of physostomatous fishes is found in Europe, Asia and America, and is most abundant in the Arctic or colder regions, in contradistinction to the distribution of the carps and siluroids, which augment in numbers the nearer we approach the tropics. The groups of salmon and trout are so intimately connested one with another that a common origin to both would scarcely be denied, and here arises the inquiry of whether their ancestors were originally marine or inhabitants of the fresh waters. Several structural reasons appear to point to the sea having originally been the place of their abode. If we look at the salmon we observe that although it ascends into the fresh waters to breed, so soon as it leaves the sea and enters rivers it begins to deteriorate in condition, its flesh becomes softer in quality and paler in colour, while the silvery lustre of the scales commences to change to a more muddy hue.

The indigenous species belonging to this genus have been placed in three sub-generic groups, and to a certain extent arbitrarily separated from one another in the following manner:-

A. Anadromous species, with deciduous vomerine teeth, which are usually shed at an early age. Salmo.

B. Non-migratory fresh water species, with decidnous vomerine teeth. Fario.

C. Non-migratory fresh water species, in which the vomerine teeth are restricted to near the head of that bone. Salvelini.

The two first of these groups not being separated one from the other by any impassable barrier, I propose in the following remarks to allude generally both to the sub-genus Salwrones or salmons, and trout, leaving observations upon the Salvelini or charrs, until that group comes specially under consideration.

During the present century much has been written in this country respecting the salmon and the trout, their natural history and economic uses. Founded possibly upon the views of sportsmen, naturalists, and fishermen, laws have been enacted from which but insufficient benefits have accrued, making one reflect whether our ancestors may not have been more practically acquainted with the habits of these fish and the requirements of fisheries, than are the legislators of the present century.

It may not be waste of space, when referring to the important family of Salmonidoe, first to ascertain what have been the views held by the best known of our later naturalists concerning the species or varieties of true Salmonidoe which are found in or around these islands; for the genus Salmo has been divided into (1) Salmones, or true salmons, wherein the body of the vomer is toothed at some period of their lives, and (2) the Salvelini or charrs, whick have the vomerine teeth restricted to near the head of that bone.

Donovan, in his British Fishes (1802-1808), referred to the (1) sewen or Salmo cambricus, of which he tells us, among other indicativns, that the head is shorter than in the common salmon, and the tail more forked-this he considered to be an anadromous form peculiar to Wales; (2) the common salmon, Salmo salar; (3) the trout, Salmo fario, which he observed to be subject to many variations. He alluded to that from the Llynteifi, a lake of South Wales, termed Coch y dail, and marked with black spots as large as sixpences; to a crooked-tailed variety in the Einion, a river not far from Machynllaeth, and also to a similar form being in 
the Snowdon lakes; to the Gillaroo trout of Ireland, remarkable for the great thickness of its stomach, though it does not otherwise differ from the common trout; and, lastly, to some in Scotch lakes that are spotted very differently from the common sorts, which he suspected to be a distinct species, but of which be makes no further mention. He likewise alluded to how trout vary in size, and referred to the Fordwich form, in Kent, which attains to nearly that of the salmon; to the Buddaghs of Lough Neagh, in Ireland, some of which have been known to weigh $30 \mathrm{lb}$. He also remarked upon trout, the flesh of which was both of the red and white kind, although captured during the same season in two contiguous streams in Cardiganshire, one of which invariably produced the red and the other the white variety.

Turton admitted into the British famna, 1807-(1) the salmon, Salmo salar; (2) the shewen, Salmo eriox, to which he referred Donovan's sewen; (3) the salmon trout, Salmo trutta; (4) the common trout, Salmo fario; (5) the white salmon, Salmo phinoc; and (6) the samlet, Salmo salmulus.

Fleming, in his History of British Animals, 1828, gave first those anadromous forms that have a forked tail, as (1) the common salmon, Salmo salar; (2) the bull tront, Salmo hucho, which is little inferior to the salmon in size, bat more elongated, and has white and insipid flesh, but which he states has no teeth on the vomer; (3) the phinock or white trout, Salmo albus, which seldom attains to a foot in length, and is common in the seas and rivers of Scotland and the North of England. Secondly, anadromous forms with even tails, as (4) the sea trout, Salmo trutta, of which he considered the samlet or parr to be the young of this or of the salmon, the migrations of the two almost coinciding; (5) the gray tront, Salmo eriox, including S. cambricus, and found in the sea and in rivers. Lastly, forms stationary in rivers, as (6) the common trout, salmo fario, remarking of the Gillaroo variety that when it feeds on shell-fish the coats of the stomach acquire a thickness similar to the gizzards of birds.

Agassiz, Brit. Assoc. 1834, only admitted (1) Salmo salar; (2) S. trutta; S. fario, and (4) the charr S. umbla.

Jenyns, in his Manual of British Vertebrate Animals, 1835, included (1)

the common salmon; (2) the bull trout or gray salmon, S. eriox; (3) the sea trout, S. trutta, inhabiting the sea and rivers, identical with the salmon-trout of the London markets and the white trout of Pennant and Fleming; (4) the common trout, S. fario, with its variety the Gillaroo; (5) the great lake trout, S. ferox, which he believed to be identical with S. lacustris, of Berkenhout, though Agassiz believed not of continental authors.

Yarrell, in his History of British Fishes, 1836, gave (1) the salmon; (2) the bull trout or gray trout, S. eriox and S. cambricus; (3) the salmon trout, S. trutta; (4) the parr or samlet, $S$. salmulus; (5) the common trout; (6) the great lake trout; and in a later edition (7) the Loch Leven trout, S. levenensis.

Knox added Salmo estuarius in 1855.

Parnell in 1838, in his prize essay on the Fishes of the Firth of Forth, entered very fully into his views respecting the Salmonidoe. He admitted (1) the salmon; (2) the bull trout, $S$. eriox, of which he enumerates and figures the following varieties which he has obtained in the Firth of Forth:-a salmon spotted bull trout, a few spotted bull trout, a thickly spotted bull trout, a large headed bull trout, a curved spotted bull trout, a crescent tailed bull trout, a Norway bull trout, and a salmon bull trout identical with S. trutta of Jenyns and Yarrell ; (3) salmon trout, $S$. trutta, which is likewise the same as $S$. albus of Fleming; (4) the parr; (5) the common trout; (6) the Loch Leven trout.

Jardine, in his British Salmonidæ, 1839, figured (1) the salmon; (2) the phinock; (3) the great lake trout; (4) the common trout and varieties; (5) the Solway migratory trout; (6) the salmon trout.

White, in the list of the specimens of British animals in the National Museam enumerated in 1851 (1) the common salmon; (2) the sea trout; (3) the bull or gray trout; (4) the common trout; (5) and the great lake trout.

Thompson, in his Natural History of Ireland, 1856, gave-(1) the salmon, including the parr; (2) the gray or bull trout, S. erive; (3) the salmon trout; (4) 
the common trout, including the Gillaroo, which variety he recorded having met with in most fresh water races; (5) the great lake trout.

Dr. Günther, in a catalogue of fishes in the British Musenm, described in 1866 the following anadromous forms:-(1) Salmo salar, Vertebræ, 59 (60), Coecal appendages, 51 to 77 ; (2) S. argenteus, Cooc. pyl. 61-67; (3) S. trutta, Vert. 59-60, Cœc. pyl. 43-61; (4) S. orcadensis, Vert. 56-57, Coe. pyl. 50; (5) S. brachypoma, Vert. 59, Coc. pyl. 45-47; (6) S. cambricus, Vert. 59, Cooc. pyl. 33-52. And of the non-migratory fresh water forms, admitted-(7) S. levenensis, Vert. 57-59, Coøc. pyl.49-90; (8) S. fario, variety Gaimardi, Vert. 59-60, Coe. pyl. 33-46, variety ausonii, Vert. 57-58, Coec. pyl. 38-47; (9) S. ferox, Vert. 56-57, Cooc. pyl. 43-49; (10) S. stomachicus, Vert. 59-60, Coe. pyl. 44; (11) S. gallivensis, Vert. 59, Cœc. pyl. 44; (12) S. nigripinnis, Vert. 57-59, Coec. pyl. 36-42.

From the foregoing we find that Donovan, Turton, Fleming, Jenyns, Yarrell, Parnell, Jardine, Thompson, and White admitted the existence of five or six British species of true salmons in our waters, which Günther increased to twelve, as well as two varieties of the common trout.

A thorough investigation into these various forms possesses more than a passing interest, for if we have many species of true salmon and trout in our waters and they interbreed, it first becomes a consideration as to what are the probabilities of sterility occurring in the offspring? On the other hand, should trout from two apparently distinct species be crossed and no unusual phenomenon occur, except improvement in the breed, while signs of sterility do not follow, the supposition must be raised that we are dealing with local races and not with different species, and that the young are mongrels and not hybrids.

Here I must shortly allude to how I propose discriminating between local races or varieties and species, for what one naturalist considers a variety another looks upon as a species. I shall consider species among the true salmons to be an assemblage of individuals which agree together in their structure and in the development of the sexes, but differ in some structural character from all other fishes. Also that functionally they are capable of fertile union together, but not to an equal extent or not at all with the members of any other group of fishes. Even within the limits of a single species we find no two exactly similar, but a tendency to divergence from the original type appears to exist, which power of divergence is most likely to preserve and accumulate useful variations. For it has been abundantly proved that artificially, by judicious selection and breeding from individuals which are possessed of some desired variation, such may become permanent in future generations; while natural selection (perhaps assisted by some unknown factor) would similarly tend to favour the continuation in a wild state of such forms as possess variation favourable to the life of the animal, and thus produce and continue certain local varieties or races. If, however, the variations from the type, present in certain examples, are not of a persistent character, nor exceed the differences between the limits laid down for a species, these cannot be considered as indicating a distinct species; for to render such valid, we must have a permanence of variation from the original type (see vol. $i$, p. 245). Thus, among the sticklebacks we find in the ten-spined form some, due to local causes, possessing ventral fins, others destitute of them; but their difference not being permanent merely resolves itself into a local race or variety. The number of vertebro and the coecal appendages have been asserted to bo constant characters which may materially assist in fixing a species among the Salmonidoe, and I propose investigating in detail some of these various structural and functional differences that have been brought forward for the purpose of establishing species among the true salmon, Salmones. Dr. Günther has pointed out nine constant characters of variation in his elaborate treatment of these fishes, and which I shall commence alluding to as my conclusions differ from those he has so elaborately set forth.

1. The number of vertebroe. The constancy of this character we are told "is truly surprising," as an excess over the normal number by two, or a decrease to the same extent, is of rare occurrence. But the inquirer finds that in the recorded number of these bones in the migratory species, tho variation has been restricted 
by Dr. Günther to between fifty-nine and sixty, and among the reputed seven non-migratory forms to between fifty-six and sixty. Occasionally two small rertebræ take the place of one large one, as if a division had occurred; while in others may be observed an abnormally large one, as if two had coalesced, as shown by the normal number of hemal spines for two bones being present. Dr. Günther instances a case "where three vertebræ were united," and Cobbold "of the coalescence of numerous vertebral centra." - In a fish wherein these bones normally number about sixty, an extreme variation of five (especially as such has not been proved to be constant) does not by itself appear to be beyond what might be anticipated in a single species; and inconstant variations would scarcely justify the creation of a new specific name for the reception of such, unless conjoined to other circumstances. Among a number of common trout which I captured at Colesbourne, on the Cotswold Hills in Gloucestershire, some had fifty-seven, others fifty-eight vertebræ; while in a few received from Cardiganshire I ascertained that this variation extended to between fifty-seven and sixty. As the extreme limits of variation recorded in this country among the common trout have been between fifty-six and sixty, and as these examples of an undoubted single species captured in one locality gave from fifty-seven to sixty, it would seem to be a rash conclusion to formulate species of Salmonidos solely consequent upon an enumeration of the number of vertebræ as ascertained in a few specimens. Only one fact appears to be rendered exceedingly probable, which is, that anadromous forms generally possess an excess of one or two vertebræ over such as are more strictly residents only in fresh waters.

2. The number of coecal appentages. - This has been adduced as a character which may materially aid in discriminating a species. If the list of British Salmones already referred to is examined, it will be seen that these appendages in the common salmon may vary between fifty-one and seventy-seven, and in the Loch Leven trout between forty-nine to ninety. (It must be noticed that personally I have observed larger variations than are here recorded, but I have purposely restricted myself to the numbers given in the British Museum catalogue.) These coeca are capable of distension, of subdivision, of amalgamation between two or more, or of being longer or shorter than is commonly the case. The difficulty does not appear in discovering variations, but in determining within what fixed number they exist in a given species. At Colesbourne, I found in the common brook trout already referred to, from thirty-four to thirty-nine cœcal appendages, and up to fortyfour in the Cardiganshire examples, the same as in S. ferox. The question forces itself on our consideration whether in any form of trout the number of these appendages are persistent or inconstant, and whether change of climate or food may occasion any variation. Here I must refer to the results obtained from the examination of trout that have leen reared in distant localities, but descended from British breeds. Mr. Arthur (Transactions of the Otago Institute, July 9,1878 ) refers to the stock of common trout "which were liberated in our streams in November, 1869, and from these and their descendants the ova for stocking the rivers in Otago have been obtained." The original ova came from Tasmania, the trout existing there being the proceeds from three batches of eggs supplied from England through the kind offices of Mr. Francis Francis and Mr. Frank Buckland. They were obtained from streams in Buckinghamshire and Hampshire, and reputed to be the eggs of the common brook trout. The number of coecal appendages is recorded in six instances from Otago, and they varied from forty-three to fifty-four, whereas the limits in the British race is restricted in the British Museum catalogue to between thirty-three and forty-seven. Even were these hybrids, and their existence was pointed out by Willughby, the number of their cocal appendages would still exceed, by at least seven, any recorded among the British non-migratory forms, except the Loch Leven trout, and are consequeritly an excellent instance of the inconstancy of their number. Here I must refer to Mr. Senior's observations on these trout, now in a wild state, as he has observed them in some parts of Tasmania. Owing to the abundance of winged insects, beetles, grasshoppers, \&c., it seldom rises at the artificial fly; when hooked it has lost the energy of its ancestors, for after one rush if baffled it 
tamely.gives in, while at table it is muddy and coarse, like an English tench. Perhaps were its digestion more rapid its vigour would increase and it seems as if nature is now angmenting the number of its coecal appendages, and consequently increasing the extent of its intestinal area. As regards the Loch Leven trout, reasons exist for suspecting the race to be more nearly allied to the anadromous than to the true fresh water species. We may thus be dealing with a race that is changing from a marine to a fresh water form, living as it now does in fresh water, but having the colour of a sea-trout. Some examples in the British Museum, captured during the month of April, have the coecal appendages fewer in number than commonly perceived in the Salmo levenensis, but they are wider than normal, and may be instances of a confluence of two or more into one, but it is suggestive that this character is very inconstant in this species, which seems to be in a transitional condition; perhaps their diameter will gradually diminish, until in time cœeca similar to such as are found in the common brook-trout will be present. Whatever the result of such an investigation might be, it is still evident that the number of ccocal appendages in the various species of trout or salmon is inconstant, and consequently should be most guardedly employed for the purpose of constituting a species. British marine salmonidæ possess more of these appendages than do the strictly fresh water forms, while a change of climate to the antipodes seems to increase the necessity for these organs, and as a result in their numbers, in such as are bred there.

Here I shall refer to one of the so-called inconstant variations, or changes of colour, such being closely relating to the foregoing remarks apon the Loch Leven trout, the tints of which resemble those of sea forms as much as do the number of their cœcal appendages.

Variations in colour must be due to some cause acting directly or indirectly on the fish. Thus, among the young of the members of the Salmonidoe, we perceive that dark bands or bars down their sides are almost universal, being evidently hereditary throughout the family. This same banding of the young is seen in some of the horse-mackerel, Caranx, flying-fish, Exocoetus, the gar-fish, Belone, etc. It has been erroneously asserted that the young of the migratory forms of salmon and trout possess two or three more bars than the non-migratory brook trout. These bars, as well as the black and red spots on the sides, are almost invariably lost in the anadromous forms when they are in a condition to migrate into salt water, and assume their silvery smolt stage (with or without $X$-shaped black spots). In rivers it is rare for bends to be retained in adult trout, while most of the black and red ocellated spots as a rule remain, although instances have been recorded in which they have entirely disappeared. In streams where, due to some local cause, the trout are small, it is not uncommon to perceive the bars as well as the black and red ocellated spots retained throughout life. I found this obtained among some from brooks near Penzance; in fact, they were as brilliant as young parrs, to which, except for the white edging to some of their fins, they bore rather a striking resemblance: in a few instances $I$ have also observed this, but to a much fainter degree, in trout taken at Colesbourne, in Gloucestershire. Examples of brook trout have been found on emigrating to the sea, as a rule (to which there are exceptions), to assume the brilliant silvery livery of the migrating salmonoids, as well as their X-shaped black spots. Mr. Harvie Brown remarked (June 12th, 1882) on having caught at Durness several so-called "sea trout" from a sea pool, or first pool at the mouth of the river, fresh water at low tide, salt or brackish at high tides. From their silvery appearance they are known as "sea trout," but are the river form acclimatized to brackish or nearly salt water, or else periodically visiting the same between tides. Mr. Lockington (American Naturalist, May, 1880, p. 368) observed the same phenomenon in the Western hemisphere, where the Salmo iridens, a resident in all Californian brooks and rivers, descends in the antumn to the sea, and when in salt water changes its colour to a steel blue, while its spots mostly disappear.

But although we may generally anticipate the non-migratory forms to be more vividly coloured than such as are strictly marine, still among the former there are numerous variations in tints and markings which have been explained in more 
than one manner, as the nuptial season, the offects of temporary emotions, of age, or the state of the creature's health, or its food. It has been observed that a residence in sea or brackish water causes the fish to assume a general silvery or steel colour, with or without black spots, and that these latter are not surrouuded by a light circle. Clear water in rapid rivers or lakes,* especially when the bottom is pebbly, is similarly seen to contain somewhat silvery fishes, with black $\mathrm{X}$-shaped spots. Sir William Jardine remarked that a variety very frequent among trout in small Alpine lochs in Scotland had large dark or red spots placed in a pale or clear surrounding field, these marks being very large, while tho principal part of the spotting was confined to the centre of the body. The colour, depth, and character of the water also have an influence on the fish, the presence of moss and peat, or a muddy bottom, usually causing a dark tint, while some captured in dark holes or caves have been seen nearly black. The colours of the Salmones may be shortly summed up as silvery, with or without black spots among the marine, and some resident in large clear pieces of water, as lochs or rivers: more or less speckled with black and red when non-migratory and living in fresh waters : while should the race be small, a persistence of the transverse bars or bands on the body, which are present in most of the young, may be observed even in adults.

Irrespective of changes in colour externally, a difference in food may occasion it in the flesh of these fish, whether such alteration in diet is due to choice or to necessity. Thus crustacea and their allies may be absent from the locality they frequent, or if present the fish may not relish that food so much as some other which exists in the water. In certain rivers there are trout with white and others with red flesh, the two forms being in good health and equally delicate for the table. This has also been observed in the American charr, Salmo fontinalis, introduced into this country, and in which it has been clearly traceable to the food it lives upon.

3. The form of the preopercle in adult fish. The shape of this bone varies in species belonging to the true Salmones with the age of the fish, while it has likewise been remarked that in some races the development of its lower limb is much more pronounced that it is in others obtained from different localities. This, however, merely shows that in the marine as in the fresh water races there are fish subject to variations in the shape of this bone. The limb is very short in the young, elongating with age in some forms, but not so in others; while an arrest of development may easily take place even on opposite sides of the head of a specimen, which were this the sole criterion of species, might, and

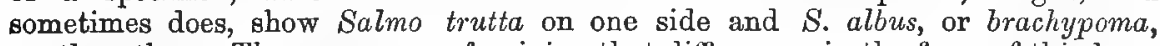
on the other. Thompson was of opinion that differences in the form of this bone may sometimes be due to sex.

4. The width and strength of the maxillary in adult fish. This will depend upon the food which the fish has subsisted upon during its lifetime. If this organ has been much called into action, it will greatly exceed in size and strength what is found in examples in which it has been less employed. It appears to be almost invariable that the lower jaw is more developed in the male than in the female, besides which in the former it is often provided with a hook at its extremity.

5. The size of the maxillary and of the vomerine teeth. The same remarks are suitable to this form of variation as apply to the maxillary bone.

6. The arrangement and perinanence of the vomerine teeth. These vary so

* Percy St. John, in Wild Sports of the West, p. 240, remarks that he " never observed the effect of bottom soil upon the quality of fish so strongly marked as in the trout taken in a small lake in the county of Monaghan. The water is a long irregular shect, of no great depth, one shore bounded by a bog, the other by a dry and gravelly surface. On the bog side the trout are of the dark and shapeless species peculiar to moory loughs, while the other affords the beautiful and sprightly variety, generally inhabiting rapid and sandy streams. Narrow as the lake is, the fish appear to confine themselves to their respective limits: the red trout being never found upon the bog moiety of the lake, nor the black where the under surface is hard gravel."

t It cannot be admitted that the black X-shaped spots are due to the influence of salt water, as we see them present in our strictly fresh water grayling, Thymallus. 
much in different specimens of the same species that it would be very unsafe to base any specific differences upon such a slender substrata of fact.

7. The form of the caudal fin in specimens of a given size, age, and sexual development. Here again the locality which the fish inhabited must be taken into consideration, for it has a great bearing upon the formation of the fins, being required of a much greater strength in rapid streams than in such as are sluggish. Age is no criterion as to size : and sexual development depends upon some, at present, unknown factor, for it seems that temporary sterility is not absent among the salmon.

8. A great development of the pectoral fins when constant in individuals from the same locality. Here sex has an undoubted influence on the size of this fin, it being frequently most developed in the males. Variations in the size of fins do not show sufficient differences on which to constitute species, while in the shape, more especially of the caudal, we find them frequently varying with age, being more or less emarginate in the young compared to what it becomes in the semi-adult and adult stages.

9. The size of the scales. Here the number of rows existing in a line from the back of the adipose dorsal fin to the lateral-line certainly affords one of the most constant characters, but the number along the lateral-line is much more deceptive.

Having enumerated the characters stated to be most constant among the two first sub-generic groups in the genus Salmo, I arrive at the conclusion that most of them are fallacious, and that too great a stress having been placed upon them, many errors have resulted. The consequence has been that the number of species has been unduly augmented, and local races having been accorded generic rank, intermediate forms have not been searched for, but new ones constantly hunted up. Thus the synonymy will be a cause of endless confusion to future ichthyologists. Besides this every little variety of form, colour or structure, has been accounted for by terming such hybrids.

The proportions of different parts of the body vary with age among the Salmonidae as they do in other fishes, and even more considerably in some anadromous forms which have been subjected to unnatural retention in fresh waters, insufficiency of food or sickness from any cause. While the head of the male is usually longer than that of the female, although in barren males the disproportion is not very considerable.

A few remarks are here necessary upon hybridism among the Salmonidce, for from our earliest authors on ichthyology down to the present period the existence of such has been remarked upon, and of late years artificial propagation has clearly proved that such may occur. Experiments in order to test this question were instituted by Professor Rasch in 1867, and he found that the ova of the sea and river trout are developed regularly, whatever forms were the parent ones, and that the offspring were fertile. That of the ova of the charr fertilized by the milt of the trout, thirty to forty per cent. were developed, but that many young fish perished after being hatched. Trout ova, fertilized by the milt of the charr, only gave ten per cent. of young, many of which were misshapen. Salmon ova fertilized with trout milt yielded forty per cent. of young fish, but more if the milt of the charr were employed. The ova of a hybrid between a trout and a charr could not be fertilized by means of a trout milt.

The foregoing facts are suggestive that a very close relationship exists between the anadromous marine trout and the non-migratory form inhabiting fresh waters. Thus we are informed that the anadromous sewin, or anadromous trout of Welsh rivers, very commonly interbreeds with the brook trout, hybrids being the result.

In the British Museum may be seen a beautiful series of these fishes presented by the Rev. A. Morgan from the Rhymney, a few of which have been retained in fresh water after the normal period for their descent to the sea had arrived. Some have elongated bodies, others comparatively long pectoral fins; and, again, hybrids are said to be present between the sewin and the brook trout, a conclusion seemingly arrived at because their teeth are more developed than in the sea-going form, while their pectoral fins and colour approximate to those of the non-migratory 
brook trout. Sterility, however, does not appear to normally exist in these so-called hybrids which raises a suspicion that we may be dealing with developing varieties and not with hybrids at all. And as these forms have facilities for retarning to the sea, did they desire to do so, we are led to ask whether some of them may not be changing their conditions of life, and as a result developing structural differences, or even whether they and the brook trout can be really distinct species." At Sir James Gibson Maitland's fish farm at Howietoun, some of the young of the Loch Leven trout take on cannibal propensities, and if small their colour is yellow, their teeth become abnormally developed, and they grow very rapidly. It is thus evident that under certain circumstances we may find trout provided with stronger teeth than is usual in the species. If we look at examples of sewin retained some time in fresh water ponds we see their pectoral fins more pointed and usually longer than in their sea-going relatives. This leaves chiefly for consideration whether these silvery forms with black $X$-shaped spots could, under any conditions, assume the deep coloured and spotted appearance of the common brook trout, or anything approaching to it.

At Howietoun this general yellow tint shows itself when the fish has arrived at about its fourth year, but is also affected by seasons and food. When fed upon horseflesh they remain of a gray colour, if clams (Pecten obtusata) are given they assume the yellow colour. Overcrowding large ones, or such as are $4 \mathrm{lb}$. or upwards, induces rusty spots; if the numbers are reduced, and regetable food given, as lilies and clover, they became gray; while silvery scales are a sign that they are in their primest condition. The young parrs may retain red spots up to eighteen months old, but such are almost absent between that age and three years. Red spots on large fish are mostly perceived in examples intermediate between kelts and trout in their primest condition, but occasionally they are present all the year round. During the breeding season the males, if healthy, assume a brownish orange colour, or if from considerable depths a darker tint, while the females are golden or orange red. It consequently appears that conditions of health and changes of food may occasion alterations not only in the superficial colour of these trout, but likewise in their more deeply-seated colour spots.

The foregoing point out that as the colour of Loch Leven trout may be altered by food and conditions of health, there exists no reason why the same changes may not occur among examples of sewin which take on a fresh water state of existence, more especially as the British Musenm possesses some of these so-called hybrids from the Copenhagen Museum. In the series of Welsh fishes the whole of the changes from the anadromous sewin may be explained as natural sequences to ascertained causes and without accepting the theory of their being non-sterile hybrids.

Much discussion has arisen why some of the salmon breed earlier in certain rivers than in others, whether this is due to the temperature of the water, or occasioned by alterations in the physical conditions of the bed of the stream and its affluents; or, lastly, to the local breed being an early or late one. This last question involves the consideration of whether necessity having compelled the change from what was an early breeding river into a late one, the descendants of the fish removed to suitable localities would still adhere to the late period of spawning of their immediate progenitors, or return to the earlier time of their ancestral stock.

In looking at these questions it will be necessary first to consider whether any general rules as to dates of spawning among this family of fishes can be deduced from what occurs in different localities. The period in Great Britain among the salmon may be roughly estimated (excluding local exceptions and climatic eccentricities) at from the commencement of September until the middle of January.

Sir Humphrey Dary, writing from Southorn Austria, remarked that "the charr I got this morning with mature eggs was just about to spawn, yet in England

* If, as asserted, these are hybrids between two species, the sewin and the brook trout, it is difficult to nnderstand why these is a regular gradation between the two forms. 
they spawn in the winter. If summer is the spawning time of the charr and trout of the lakes of Southern Austria, it is connected with or owing to the waters at that time being of the temperature best fitted for the purpose, most of these lakes being fed by mountain streams, frozen in the winter, and full in summer from the melting of the snow." In Sweden, Artedi remarked that the salmon spawned in the middle of the summer. Dr. Heysham stated that in Cumberland salmon at first prefer spawning in the warmer streams, leaving the snow-fed ones until later on. Yarrell considered that " rivers issuing from large lakes afford early salmon, the waters having been purified by deposition in the lakes; on the other hand, rivers swollen by melting snows in the spring months are later in their season of producing fish, and yield their supply when the lake rivers are beginning to fail." I think that without multiplying instances the fact may be fairly assumed that temperature has some influence in the locality selected by salmon for breeding purposes, the colder and more exposed streams being usually left until somewhat later than the warmer ones, while in very cold regions spawning may be deferred even until the summer months.

Were the foregoing views correct, and if temperature irrespective of geographical location has a marked influence upon the time these fishes spawn, we ought to be able to observe such among the trout and Anadromous Salmonoids despatched in the form of ova to Tasmania from this country. Turning to Mr. Allport's account (Proc. Zool. Soc., 1870, p. 25) we find a most marked corroboration of these views. We know the cold season in that portion of the globe corresponds with our summer, and the very first brook trout which were spawned in Tasmania occurred on July 3, 1866; by the 7th of August fourteen females had been stripped, and shortly afterwards five pair of trout were observed constructing redds in the River Plenty. During June, July and August, 1867, the trout were again stripped of their ova artificially. In this country, as observed by Buckland, trout spawn at different periods in different rivers from about September to February. The very first Tasmanian bred trout hatched from English trout eggs have not selected the month for spawning adopted by their ancestors in this hemisphere, but have chosen others which are better suited for their purpose, clearly demonstrating the possibility of trout being capable under changed conditions of varying the period of the breeding season.

But because temperature exercises a manifest influence as to when and where the eggs of Salmonidace are deposited, it does not follow that it is the temperature of the water which is the sole canse the salmon has under consideration as to the period at which it shall enter certain rivers, some of which are known to possess spring fish, or such as ascend from March until June, whereas in others they more commonly pass up during and after September.

I will first give an instance of a river which was originally an early one, but was found to become a late one by the Earl of Home, who, in 1837, observed " that in the Tweed a very great change has taken place within these twenty or thirty years; a considerable portion of the breeding fish not arriving into breeding condition until long after the time they had formerly been in the habit of doing so." But here the question arises whether this had happened consequent upon any changes in the river, or alteration in the natural period of spawning in the fish irrespective of the condition of the waters. The river itself, it is observed, had changed due to the draining of the sheep farms on the hills, the effect produced being that a little summer flood which took a fortnight or three weeks to run off previous to 1795 , is now completely run out in eight hours. The bogs on the hill sides, which were the feeders to the river, have the water at once carried off by drains, causing sudden but short floods, which have all run off before the river has had time to clear itself. Sir H. Davy compared the Tweed district as it was prior to these drains, to what it had become subsequent to their construction-to two houses, the one covered with thatch, and the other with slate; the first dripping for hours after the rain has fallen, the other ceasing when the rain stops.

If sufficient water for ascent does not exist, if no safe-holding pools are present, as observed by Mr. Brandon, a spring salmon would have but little chance of 
ascent, or if it did the great probabilities are that as the water became low it would be knocked on the head. And though he supposes these early fish breed similar descendants, we have but little proof of it, although many excellent fishermen hold the same view. In some Irish rivers the breed of early fish was almost extinguished by allowing the nets to capture all for a season or two, when it very soon came to the point that there was nothing to capture.

Kelts and what to do with them has exercised many minds, and I cannot resist thinking that, doubtless, unintentionally, the opinion of some of our older authors have been either misunderstood or misquoted. Without more than just touching upon this subject it seems that it may be divided as follows :-That the salmon subsequent to the spawning season becomes sickly, and is as well destroyed as kept; that while mending it consumes more young salmon, trout, and other fish than it is worth ; that kelts might be eaten.

After spawning salmon becomes much exhausted and very easily susceptible to disease and capture. It has been proposed to kill all the male kelts from the commencement of February; and all of either sex from the commencement of March. That the act of fertilizing ova is not invariably fatal to the salmon appears easy of proof, for the male parr possesses milt capable of fecundating ova. It is, therefore, evident that such must be evacuated or retained, and if the latter disease would be induced. Trout kept in confinement may be spawned more than once, omitting the consideration of whether such only takes place on alternate years. A correspondent of the Field observed, " a few years ago a fine male fish of about $20 \mathrm{lb}$. was used for spawning purposes at Stormontfield; a mark was put on him by means of a copper wire, and two years afterwards he was got when nearly $30 \mathrm{lb}$. weight on the same ford and at the same season; and, after doing duty again was returned to the river, hale and strong, but was not traced afterwards."

Mr. Brown records how, on May 4, 1861, he hooked a kelt weighing $16 \mathrm{lb}$, and having fastened round his tail a copper medal, on which was stamped "Athol, No. 78." It had been caught on the preceding April 1, when it only weighed $13 \frac{1}{2} \mathrm{lb}$, thus showing an increase of $2 \frac{1}{2} \mathrm{lb}$. in five weeks. The results of the Duke of Athol's experiments are too well known to need recapitulating. Dr. Günther suggests that old males or those possessing a hook to the mandible, perish after the efforts of propagation, and cites the observations of Stella, Pallas, and Richardson on the salmonoids of Kamtschatka and North-Western America. He observes of kelted salmon: "Probably those which reach the sea alive perish there." Sir John Richardson, however, remarked: "The destruction by poachers in the higher parts of the rivers of the large enfeebled kelts, or fish which have completed their spawning operations, is also extremely prejudicial, for these individuals (almost utterly useless as food at the time alluded to) would, if allowed to descend to the salubrious sea, ere long revisit their native streams, greatly increased in size, and full of health and vigour."

During the period a kelt is mending it lives mostly on small fish, especially young salmon and trout; and Mr. Francis Francis suggests whether, this being the case, it is worth its keep. That by destroying so many small fish, the kelt, it is true, may return of a larger size, but it is questionable whether the river regains so great an aggregate weight of salmon as if numbers of the kelts were slaughtered.

It has likewise been proposed that people should be permitted to kill and eat these kelts, which otherwise probably become lost as food. But prior to such a proceeding being sanctioned, it might not be amiss to inquire whether they would be wholesome. Certainly a correspondent of the Field remarks: "I was going to Ilfracombe lately, and saw many old back fish being hawked about. These old salmon come back to the tidal waters to recover before going to sea, and are caught by the score, and have been sold for fourpence a pound." But if eaten they may occasion poisonous symptoms. Thus Buckland, rolates how a waterbailiff, who was a strong, healthy man, ate a portion of one, and was made so ill that he was confined to his bed for two days. Dr. Gerald Boate, writing from Ireland in 1645 , tells us leprosy was caused "through the foul gluttony of the 
inhabitants in the unwholesome devouring of foul salmon when they are out of season, which is after they have cast their spawn, upon which they do not only grow very weak and flabby, but so unwholesome as it would loathe any man to see them." Not many months since I saw some unseasonable salmon in the possession of a fisherman, and inquired what he intended to do with them. $\mathrm{He}$ informed me they were useless in the market, because if cooked their flesh would become more or less black; but, with a grin, continued, that they did excellently well kippered!

\section{A.-Deciduous vomerine teeth (Salmones)."}

\section{SYNOPSIS OF SPECIES.}

a. About eleven rows of scales in an oblique line from adipose dorsal fin to the lateral-line.

1. Salmo salar, D. 13-14, P. 14, V. 9, A. 11, L. 1. 120-125.

\section{b. Fourteen or more rows of scales in an oblique line from adipose dorsal fin to the lateral-line.}

2. Salmo trutta, D. 12-14, P. 14-15, V. 9, A. 10-12, L. 1. 120-130.

2 A. Salmo levenensis, D. 13-14, P. 14-15, V. 9, A. 10-12, L. 1. 115-130.

2 B. Salmo fario, D. 13-15, P. 14-15, V. 9, A. 10-12, L. 1. 115-130.

The true salmons which are included in this division of the genus Salmo consist of fishes which normally reside in the sea (although in some latitudes they live in lakes), and migrate to rivers in which their ova are deposited and the young hatched and reared. Here we have true anadromous forms, and as the salmon or salmon-trout have the same peculiarity in selecting suitable localities for breeding, differentiated by the fish ascending to nearer the sources of rivers, I propose giving a brief outline of how reproduction is carried on.

Salmon enter our rivers in varying numbers throughout the year, unless impurities (as in the Thames) have annihilated the breed. At certain times, as during the cold season, they ascend for the purpose of reaching their spawning beds, and having deposited their eggs in redds or nests, they descend to the sea in a miserable condition, many of the males succumbing from exhaustion. Rondeletius and also Gesner, who wrote upon the salmon upwards of three and a quarter centuries ago, were both upholders of the doctrine that salmon spawned in the sea, one which, were it believed in and acted upon, would be disastrous to our salmon fisheries, as it might be advanced that these fishes could as well breed in the ocean as in rivers, consequently on their behalf no necessity arises for keeping our fresh waters pure, or having free passes in our streams in order to allow them to reach their spawning-beds. It was probably from such views sprang the notion of the parr being a distinct species, and even now there are some who doubt whether our "last springs" are the young of Salmo salar. Willughby, in his History of Fishes, published in 1686, lib. iv, adduces his reasons for disputing the correctness of Rondeletius's and Gesner's opinions; while Pontoppidan, in 1755, in his Natural History of Norway, returned to Gesner's views, asserting that he was well assured that salmon chiefly eject their roe at the mouths of rivers, where they empty themselves into the sea, or else a little above the salt water. Mr. Brander (Field) remarked upon having observed during the preceding summer some holes scooped out in the gravel close to the month of the small river Lopie (near the Spey), and within the reach of the salt water, and here he found in January, 1882, a few salmon working at their redds, which were within a mile and a half of the sea, and covered once a fortnight at spring tides with quite salt and undrinkable water, for perhaps an hour's time. Sir James Matheson, in Davy's Philosophical Researches (p. 261 ), has recorded at the mouth of the Greamster, in the Island of Lewis, a sinilar instance, continuing that the spot is covered with 
"brackish water" only for about two hours at each high tide, but not at all during the neaps, while this brackish water is so diluted as to differ but little from fresh water in specific gravity, the tide serving as a dam to the river water, and by obstructing its free ontflow, causing its accumulation and overflow. The foregoing instances occurred near the mouths of small rivers, and should their state be such - due to pollutions or insufficiency of water-that Salmonidoe are unable to ascend, they may drop or deposit their ova in the sea or at the mouths of rivers; but suppose it is thus deposited, experiments have proved that the presence of salt water is fatal to the fertilizing property of the milt, as also to the life of the impregnated egg, should it come in contact with it.

Sir J. Matheson, during the winter of 1860-61, had the following experiment made upon two batches of fertile salmon ova. One lot was placed on a wire cloth in a glass vase, wherein was brackish water which was daily changed, but they all died at the end of the tenth day. The remainder were similarly treated, but with fresh water, and in due time they all arrived at maturity. Mr. Sinclair (Field, February 4th, 1882) remarks upon having taken about one hundred eyed ova, of which two portions were enclosed in wicker baskets and buried in separate streams, one of which was reached every tide by salt water, whereas the other was entirely fresh. They were examined in about three weeks after one set of spring tides, when all which had been reached by the salt water were found to be dead: not so those in which the stream was entirely fresh water. The remaining third were batched in a wash-hand basin, in which was fresh water changed once a day. Dr. Davy also instituted somewhat similar experiments with artificial saline water, from which it appeared that a degree of saltness, almost or quite equal to that of sea water, is pretty speedily fatal both to the ovum of the salmon and to the young fish : that the same effect is produced on the young fish by brackish water of specific gravity 1016, but in a longer time, and that, when the solution is so diluted as to be reduced to the specific gravity 1007 , the advanced ovam may be hatched in it, and the life of the young fish may be sustained in it for a few days, but with diminished powers.

The eggs of the salmon are small, round, elastic bodies, of a clear white, pink, or even coral colour. Due to their tough outer coat they are rery elastic, as may be seen by throwing one on the ground, from whence it will rebound like an indiarubber ball. This strength and elasticity we know must be an exceedingly important property if we remember where these eggs are deposited and what an amount of pressure they may have to undergo. Young salmon are hatched from eggs deposited in rivers, not near to its mouth, where the tide or the current would be too strong for the young fish to live in, but in small and often mountainous streams, where the water is pure and shallow, having a gravelly bed which permits the redd or nest to be constructed, while deep pools in the vicinity allow the breeding fishes to retire into them for rest. The salmon ascends our rivers to a suitable spot, and in the gravel at the bottom of the stream constructs its redd, which work would seem to be the occupation of the female. She lies on one side, and, by moving her tail rapidly from one side to the over, fans up the gravel until she gradually sinks into a kind of trough, the male remaining near, ready to give battle to any intruder. For this purpose his lower jaw is furnished at this period with an offensive weapon in the shape of a cartilaginous, hook-like process. The female (waited upon by the male) now deposits her eggs in the trough she had made, and these are fertilized by the male, and subsequently covered with gravel to some feet in depth, the whole forming a redd.

She now falls back into one of the deep pools, until she has acquired sufficient strength to again shed more eggs. During this period the salmon (similar to the shad and many other fishes) is indisposed to feed, and lives on the stock of fat it has laid ap while resident in the sea. It has been computed that every female salmon deposits about nine hundred eggs to each pound of its weight, and that only nine hundred of these in every 17,000 shed in British rivers ever attain the parr stage. As might be anticipated, eggs deposited in a running stream are very liable to be carried away by the current, and the places selected by salmon for 
their redds are often the localities where trout have previously deposited their eggs, which now become routed up and carried away down stream to be devoured by every hungry fish.

The time that salmon eggs may take before they are hatched is subject to variations as great as from 35 to 148 days, which last period occurred at the Crystal Palace in experiments instituted there, and 144 in the Wenham Lake ice vaults. While acting upon previous experience, Mr. Youl succeeded in transmitting salmon eggs to the Antipodes in small boxes packed in ice, and which retarded hatching until the 145 th day. Mr. Branden examined a redd that appeared to have been left dry, but on opening it found that a little water was trickling through the stones and gravel, which was sufficient to keep the ova healthy. Having scraped a hole, he obtained a considerable number of eggr, and these he transferred to a pail of water, where two-thirds hatched within periods varying from five minutes to twenty-four hours. About a week subsequently he returned to the same spot, and had another dig for salmon eggs (no rise having occurred in the river during the interval). He collected more, and putting them into the water, they hatched as the former ones had done. He very fairly advances that this may be a provision to prevent ova deposited in localities where the depth of the stream is liable to considerable fluctuations, from becoming lost or killed, as must occur unless a delay, to obtain a suitable time, could be provided for. For as the floods come and sweep up these redds, the imprisoned ova are let loose, at a time when they are ready to burst and the young to emerge. In fact, like the chrysalis, the eggs may be able to abide a suitable time.

But salmon eggs, even in redds, are not permitted to rest in peace and hatch in security : they have many accidents to escape from and numerous enemies whose vigilance must be avoided. Not only may floods prematurely sweep away redds with their unripe eggs, but during the continuance of such, spawning fish, are unable to avail themselves of their usual breeding grounds because they are too deep in the water. They consequently may have to shed their eggs in the stream, when they will become lost, or covered with mud, or else push higher up to where there will be more chance of their redds being left dry, and the ova perishing; even in their annual spawning grounds, where their eggs may have been deposited, severe seasons of drought may occasion most disastrous results. Irrespective of the seasons, the eggs have numerous water enemies, as the fresh water shrimp, which hunts out the nest, when they are merciless to the eggs, the larva of the may-fly and of the dragon-fly and even some birds as the dabchick. While swans and ducks enjoy nothing so much as the spawn of fishes, in which taste the vole or water-rat appears to coincide. Due to the many destructive agencies at work an ingenious plan of artificial hatching and rearing has been adopted with great success, while by regulating the water, droughts and fluods are prevented, and many enemies are excluded which run riot among fish eggs left in a state of nature in our rivers.

Supposing some young fish have come forth, it does not follow that the little ones are strong and healthy. The temperature of the water ought to range out of doors about $42^{\circ}$ or $46^{\circ}$, nor permitted to sink below $35^{\circ}$, while if it reaches freezing point, such will most probably be fatal. Should it rise to $50^{\circ}$ the eggs may become prematurely hatched: the higher the temperature the sooner the young appear, and the more weakly they may be expected to be. Sometimes the jaws are deformed in the fry, or the spinal column is curved, even two fish may be connected together, like the Siamese twins : likewise two or even three heads have been seen fixed to one body.

When these little fish emerge from the eggs they have a large bag (the umbilical vesicle) attached to their stomachs: this contains the nourishment which is to serve them for several (three to eight) weeks' subsistence, and they do not commonly take in any food by the mouth until it is absorbed. Weighed down by it they lie quietly among the stones at the bottom of the stream and seek concealment from fish larger than themselves, water insects, and other enemies which now commence to feed on them.

The salmon is rare in our rivers in comparison with the number of fry 
hatched, and which would be quite sufficient to form a good sapply had they a chance in the battle for life in the lower waters. The paucity of these fish is due (excluding poaching) to three main causes: (1) Difficulty in the ascent of breeding fish owing to natural or artificial obstructions in the river; (2) immoderate netting; and (3) pollution of the water.

It is commonly observed that the interests of the proprietors of salmon fisheries are not identical throughout the entire extent of the stream, occasioning a clashing of views which are inimical to the fisheries, and consequently to the general public. The proprietors of fisheries living in the higher waters of our rivers argue that pollutions are permitted unchecked access in the lower reaches, that immoderate netting is almost continuously carried on, giving the fish, except in the close time, but little chance of escape. Thus the upper proprietors see but few fish, excepting during the breeding season, when it is illegal to capture them. They are in a manner "clucking hens," whose duties seem to be to take care the eggs are latched, rear the fry, and speed the parting guest as it descends to the sea, from whence nets and other obstructions and pollutions in the lower portions of the river will most probably prevent their ever re-ascending ; or else merely in sufficient numbers to maintain a sufficient supply for the lower waters. Official statistics are misleading, as they ought to show the yearly quantity of salmon taken in each portion of every river, not the number of boxes of salmon received at Billingsgate. It cannot be a source of surprise if the breeding grounds are not strictly preserved: for the rearing of salmon is asserted to be done at the expense of the local fish, which are residents of the upper waters.

A. Deciduous teeth on the body of the vomer, which are usually shed at an early age (Salmones).

a. About eleven rows of scales in an oblique line from the adipose dorsal fin to the lateral-line.

1. Salmo salar,* Plate CX, fig. 1 (old), 2 (young), and CXI, fig. 1.

Salmo, Salv. p. 100 ; Aldrov. iv, p. 483 ; Belon. De Aquat. i, p. 277, c. fig.; John. Pisc. I. ii, t. i, c. i, p. 100, t. xxi, f. 12; Rondel. De Pisc. Fluv. p. 167; Willugh. p. 189, t. N 2, fig. 1, 2; Schonev. p. 64; Gesner, De Aquat. p. 969; Ray, p. 63, and pl. cxi, fig. 1. Salmo, no. i, Artedi, Synon. p. 22, and Spec. p. 48 ; Linn. Faun. Suce. p. 115. Salmo, no. 2, Artedi, Species, p. 50. Saumon, Dulam. Peches. ii, p. 192, pl. i, f. 1, 2. Salmon, Pennant, Brit. Zool. (ed. 1776) iii, p. 284, pl. lviii, f. 143 and (ed. 1812) iii, p. 382, pl. lxix. Samlet, Pennant, 1. c. (ed. 1776) iii, p. 303, pl. lix (ed. 1812) iii, p. 404, pl. Ixx.

Salmo salar, Limn. Syst. Nat. i, p. 509; Müller, Prod. Zool. Dan. p. 48; Bloch, i, p. 175, t. xx (female) t. xcviii (male); Gmel. Linn. p. 1364; Bl. Schn. p. 398 ; Lacép. v, p. 154 ; Turton, Brit. Fauna, p. 103 ; Bonn. Ency. Ich. p. 159, pl. lxv,f. 261, 262 ; Fleming, Brit. Anim. p. 179; Faber, Fische Isl. p. 156 ; Nilsson, Skan. Fauna, Fisk. p. 370 ; Jardine, Edin. New Phil. Journ. viii, p. 46, and Brit. Salmonidæ, pl. i, ii, vii and viii; Richards. Faun. Bor. Amer. Fish. p. 140, pl. xci, f. 1 (head); Jenyns, Manual, p. 421; Yarrell, Brit. Fish. (Ed. 1) ii, p. 1, c. fig. (Ed. 2) ii, p. 1 (Ed. 3) i, p. 155 ; Parnell, Fish. Firth of Forth, p. 118, pl. xxx, xxxi, and xxxii, f. 1, 2; Agassiz, Poiss. d'eau douce, pl. i and ii ; Swainson, Fishes, ii, p. 287; Wbite, Catal. p. 74; Gronov. ed. Gray, p. 151 ; Kröyer, Dan. Fiske, ii, p. 540; Mitchill, Fauna New York, p. 434; De Kay, p. 241. pl. xxxviii, fig. 122 ; Thompson, Nat. Hist. Ireland, iv, p. 143 ; Schlegel, De Dieren. p. 126, pl. xiii, f. I ; Blanchard, Poiss. France, p. 448 ; Günther, Catal. vi, p. 11 ; Collett, Norges Fiske, p. 155; Malm, Fauna, p. 534; Morean, Poiss. France, iii, p. 525.

Śalmo salmo, Cuv. and Val. xxi, p. 169, pl. 614.

Salmo salmulus, Ray, p. 63; Turton, Brit. Fauna, p. 104; Jardine, 1. c. xviii, p. 56; Jenyns, Manual, p. 426; Parnell, Wern. Mem. vii, p. 278, pl. xxxii, fig. 1 and pl. xxx, and Fish. Firth of Forth, p. 138, pl. xxxii (young).

Śalmo nobilis, Olafs. Isl. Reise, i, p. 83; Pallas, Zoo. Rus. Asiat. iii, p. 342.

* The literatnre belonging to this fish is so extensive that it has been necessary to omit a large number of references. 
Salmo hamatus, Cuv. Règno Anim.; Cuv. and Val. xxi, p. 212, pl. 615.

Salmo gracilis, Couch, Report, Royal Cornwall Polytec. Soc. 1859 and Fish. Brit. Isles, iv, p. 216, pl. ccxvi.

Salmo argenteus, Günther, Catal. vi, p. 86 (not Cuv. and Val.).

Salmon, Russell, 1864, pp. 234; Couch, Fish. Brit. Isles, iv, p. 163, pl. ccxi.

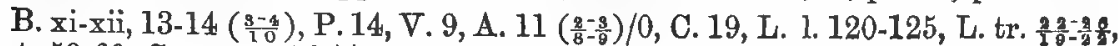
Vert. 59-60, Cooc. pyl. 53-77.

Body rather elongate, with the abdominal profile more curved than that of the back. The proportions of one part of the body to the remainder vary considerably in this fish, thus in the young we find a comparatively large head and ejes, a short snout and rounded body, \&c. : but as the adult stage is attained there is greater depth of the body due to a more prominent abdomen. After breeding, the kelts are recognizable by low, lanky bodies and long heads. The length of the head varies with age and sex, being comparatively slightly longer in the parr than in the female grilse or salmon, while in the male salmon it is longer than in the female. Length of head from $4 \frac{1}{4}$ to $4 \frac{3}{4}$ or even 5 in the parr and male salmon to 5 or $5 \frac{1}{4}$ in the female salmon and grilse, while in barren males it is similar to what is seen in females, of caudal fin from 6 in the parr to $7 \frac{1}{2}$ in the salmon, height of body, which is greatest beneath the origin of the dorsal fin, $4 \frac{1}{2}$ to 5 in the total length. Eye-situated slightly in front of the middle of the length of the head (or in the middle of that length in breeding males) and comparatively much smaller in adult than in young fish: interorbital space convex and equal to about $2 / 3$ the length of the postorbital portion of the head. Snout much prodaced in the male, and during the broeding season the extremity of the lower jaw is provided with a strongly curved prominence which precludes the closure of the two jaws. The posterior extremity of the maxilla reaches to beneath the middle of the eye in the parr but beyond its posterior extremity in the adult: while it is comparatively wider in the young than in the adult. Opercle higher than wide, from about $1 / 5$ more in the parr, or $1 / 4$ in the grilse or young salmon, and $1 / 2$ in large salmon : subopercle from $1 / 2$ to $1 / 3$ of the height of the opercle, while its posterior margin forms a semi-circular curve along with that of the opercle.* Preopercle with its angle rounded and having a rather distinct lower limb. Teeth-in a single row in maxillary ones being rather stouter the maxillary and palatine ones are are often found to be larger in the females. Head of the vomer without row along its body, and which are mencing from behind forwards, so salmon only 1 to 4 are present, the in a double row : in the parr and the body of the vomer which 4 teeth placed in a single row.

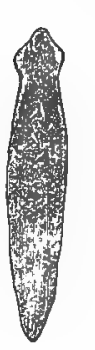
the jaws and palatines, the prethan those in the mandibles, while still smaller. In adults the teeth jaws of males than in those of teeth, which are mostly in a single gradually lost at an early age, comthat in a half-grown or adult anterior 2 of which are occasionally smolt a double row exists along anteriorly is usually armed with Three to six sharp curved teeth on each side of the tongue. Fins-Mature fish have the fins shorter and more rounded than is seen in sterile ones. The rayed dorsal fin is a little longer at its base than is its highest ray. Pectoral in adults as long as the head excluding the snout, and does not reach half-way to the ventral, whereas in the parr it extends $2 / 3$ of the distance. Ventral in adults reaches half-way to the base of the anal in the parr 2/3, anal one-fourth higher than its base is long. The form of the caudal alters with sexual development: in the young parr it is deeply cleft (see pl. cx, f. 2) up to 2 or $2 \frac{1}{2}$ feet in length, it is as a rule truncated, while with advancing age it becomes more square. Scales-in the caudal portion of the body they are larger in this than any other British species of the genus, there being from 11 to 12 rows in an oblique line running from behind the adipose dorsal fin downwards and

* In Yarrell it is correctly cbserved that what distinguishes Salmo salar from all other species is the form of the opercular bones, which show a rounded outline to the posterior edge of the gill-covers, the longest diameter of which to the nose would be in a line through the eye, while in all other Britiah migratory species the anme line would pass below the eje. 
forwards to the lateral-line. The skin on the back of old males both during and subsequent to the spawning season becomes thickened and spongy, causing the scales to be imbedded. Cœcal appendages varying from about 50 to 80 . Colours.-In adults superiorly of a steel blue, becoming lighter on the sides and beneath. Mostly a few rounded or x-shaped spots scattered over the body above the lateral-line and upper half of the bead, being more numerous in the female than in the male. Dorsal, caudal, and pectoral fins dusky black : ventral and anal white, the former grayish internally. Prior to entering fresh waters these fish are of a brilliant steel blue along the back which becomes changed to a muddy tinge when they enter rivers. After these fish have passed into fresh waters for the purpose of breeding, numerons orange streaks appear in the cheeks of the male, and also spots, or even marks of the same, and likewise of a red colour on the body. It is now termed a "red-fish." The female, however, is dark in colour and known as a "black-fish." Smolts are bluish along the upper half of the body, silvery along the sides, due to a layer of silvery scales being formed over the trout-like colours, while they have darker fins than the yearling pink but similar lateral bands and spots (see pl. cx. fig. 2) which can be seen (as in the parr) if the example is held in certain positions of light. Parr have two or three black spots only on the opercle, and black spots, also orange ones along the upper half of the body and no dark ones below the lateral-line, although there may be orange nnes which are seen along its course. Along the side of the body are a series (12 to 15) of transverse bluish bands wider than the ground colour and crossing the lateral-line, while in the upper half of the body the darker silvery colour of the back forms an arch over each of these bands. A row of spots along the middle of the rayed dorsal fin, and the adipose orange tipped.

Varieties.-Although among the British Salmonidoe, when not kept in any unnatural condition, the salmon is perhaps the species in which the fewest variations are seen, still some, affecting either its form or its colour, are sometimes present.

in form.-Are more commonly perceived among the young artificially hatched, two or even more heads may be found, one with three heads was born in the spring of 1879 , but as soon as the yolk sac was absorised the fish died (Anglers' Note Book, p. 79). Arrests of development, as of the upper or under jaw, of one or more fins, or other portions of the body, or spinal curvatures are occasionally observed. It may be mentioned that fish salesmen and some fishermen believe they can tell from external appearances the river the various salmon have come from. Sulmo argenteus, Günther,* is a kelt-like form, its elongated condition being due to disease or starvation, probably the latter as it had been kept in a fresh water pond. It is another form of Salmo gracilis, Couch. Degeneration in size when present may be quite distinct from degeneration in structure or function.

In colour.-Occasionally quite brown salmon are captured in fresh waters, especially towards the close of the season, which would appear to be due to a prolonged fresh water residence. Mr. Ffennel recorded having captured them of a copper colour in the early lakes having the ova not very far advanced.

Names.-Speaking generally this fish in its full-grown condition is known as the salnnon; one on its second return from the sea is often termed a gerling in the Severn, or a botcher on its first return when under 5lb. weight; although the more general designation is gritse; when under 2lb. weight it is usually termed salmon-peal by fishmongers. From one to two years old, before it has gone to the sea it is known as a parr, pink, smolt, smelt, salmon-fry, sprag, or salmon-spring (Northumberland), samlet, bronuling, fingerling, black-fin, blue-fin, sherl, skegger, gravelling, helper, laspring, gravel laspring, slicrling, or sparling in Wales. A third year salmon is known as a pug (Halliwell). In Northumberland a "milter" or spawning male is known as a summer-cock or git-fish, and a salmon

* The spots on the head, dorsal fin, and body are more what is generally seen on Salmo trutta, otherwise the fish is identical with $S$. salar, but reliable chalacters would scarcely be expected to be well marked in a fish either ill or neirly starved, anyhow as lean and lanky as a kelt (pl. cxi, fig. 1). 
as a simen. In the Severn a salmon which has remained in fresh water during the summer without going to the sea is termed a laurel. After spawning this fish is a leelt or slat, but a male is generally termed a kipper, and a female a shedder or a baggit. In the Ribble, according to Willughby, salmon of the first year are termed smelts, of the second year sprods, of the third year morts, of the fourth year fork-tails, of the fifth year half-fish, of the sixth year salmon. Dr. Davy also observes that mort and sprod are names used in Cumberland indiscriminately to the salmon and salmon-trout. In an old work we are told that in the north of Scotland the fry were termed brood and cocksper. In Treland, Sampson remarked upon a samlet or jerkin which Tighe terms a ginkin, but the term parr is more frequently employed to the north and gravel-ing to the south. At Kerry a kelt is termed judy, and Rutty stated that a grilse was known as a grawl. Welsh, cawg, male salmon: cemyw hwyddell, female salmon: spawning, maran, or a salmon on his third return from the sea (Severn). De Zalm, Dutch. Le Saumon, French.*

Habits.-The salmon, as already observed, is an anadromous fish, which enters rivers mostly for the purpose of depositing its spawn in a locality where its eggs will be hatched and its fry reared, while it has also been surmised that some do so to get rid of the marine parasites adhering to them. During the summer months it roams along our coasts in search of food, and may be found close in shore many miles from where any fresh water enters the sea, loitering in estuaries and also at the mouths of rivers at which it purposes ascending. Clean salmon are much earlier in some rivers than in others, as the Thurso in Scotland, which contains them in December and January, as does also the Naver in Sutherlandshire. As a general rule such Scotch rivers as debouch into the German Ocean and Pentland Firth are early rivers, while those emptying themselves into the Atlantic are late. It has been suggested by Mr. Young that the German Ocean is a cold sea, and the slight difference between its water and those of the rivers, induces salmon to ascend early. Whereas rivers on the west coast mostly descend from snow-fed sources and are consequently cold, much colder than the Atlantic, consequently the salmon wait until the snow-floods have ceased. But the Dee, in Aberdeenshire, also the Spey, are early rivers, although snow-fed at their sources. In Yorkshire their ascent as fresh run fish varies greatly, and is dependent upon the state of the rivers-if either July, August, or September are wet the salmon commence running from the sea-if otherwise, their ascent is delayed until the autumn rains set in (Yorkshire Vertebrata, p. 126). Migrating up rivers commences as the water is fining subsequent to a flood, or on the occurrence of a spate or rise, and the fish passes up with an inflowing tide.

In their migrations from the sea to their breeding grounds these fish have to overcome any obstructions as weirs, which frequently can only be surmounte 1 during a heavy flood. They are found to be alarmed at tempests or violent noises, on the occurrence of which they may even return towards the ocean, which they will likewise do should very cold or frosty weather set in. If the season, however, is mild and their course unimpeded they sport from pool to pool, and thus gradually ascend to the higher reaches of the river. In some streams it appears most probable that the larger fish head the ascending shoal, because fishermen have observed that should any such be netted a large haul generally follows, whereas, if smaller fish are taken the main body seems to have passed.

During their ascent the fish have mostly to keep to the middle or deepest an 1 safest part of a river, where, however, they are constantly pursued by the netter, this causes them to become shy and they will not lie up, but push on to their breeding grounds. In their course it is very remarkable what difficulties they will overcome. Fleming asserted that he had known a salmon leap up over a fall of 30 feet, probably he meant in a succession of jumps from one pool to another, as from 8 to 10 feet in perpendicular height is rarely exceeded. At impassable cascades they have been observed to die, consequent upon repeated but fruitless exertions in attempting to ascend.

* Years ago when I used to fish in the Severn, at or near Shrewshury, we knew the younger stagrs of salmon, especially the March, April, and May shoals, formed of the parr as salmon-fry and the autumn smolt as the samlet. 
The salmon appears to possess a homeing instinct which induces them to seek to return to the rivers where they were originally bred, but instances are occasionally brought to notice where such could not have been the case. Thus scarcely a year passes but grilse or salmon are captured off the mouth of the Thames, from which all these fish have long since been destroyed, due to the polluted state of its waters. The majority enter rivers prior to the commencement of the breeding season, others, especially grilse, much earlier, or in companies : many appear to return to the ocean before they re-ascend at the time of the regular immigration. A few would seem to pass up and down the river several times during one year.* In the Rhine, Barfurth observed in 1874, that spawners ascend from September to Norember, while there is likewise a barren winter variety coming sporadically and for a brief season from September until May.

Buckland tells us how a friend of his who owns a well-known island on the west coast of Scotland, netted a certain pool in his fishery, and out of a number of fish which he canght, he carefully marked some 20 or $30:$ he then put these fish on board his yacht, and keeping them alive sailed right round his island, then up a creek to the mouth of the river, and turned them into a lake about half a mile from the source of the stream from which they had been brought, which, though close to it, was in no way connected, rising from a different watershed. It was as though the salmon had been carried from one heel of an enormous horseshoe round to the other heel, and then taken right into the middle of the horseshoe and then let loose. During the same season some of these marked ones were caught in or near their own pool, to do which they must have come back a circuit of at least 40 miles, and passed by six or seven tributaries.

When descending seawards a heavy flood often carries away down the stream weak and spawned fish, but when migrating seawards it would appear that the fish usually pass gradually into the sea. The migrating salmon fry or smolts keep to the sides of the river, but having once arrived at the ocean would appear to seek its depths.

The food consumed by salmon is somewhat varied, for while living in the ocean they appear to lay in a sufficient stock of fat around the stomach and cocal appendages to last them when residing in fresh water, or at least until the spawning season has passed. I have found the remains of sand-eels, Ammodytes, herrings, crustacea and echinodermata in their stomachs. Jardine remarked that on the Sutherland shores they are often captured on haddock lines baited with sand-eels. Thompson, in Treland, also found these fish eating sand-eels, and that they are occasionally taken in Dundrum Bay upon lines baited with pieces of mackerel which were laid for mullet. Morrison records having captured salmon within flood mark, some of which contained two, others three, full sized herrings. In the British Museum are the remains of a gar-fish, Belone, taken out of a salmon captured in fresh water, but evidently only lately from the sea. One of $24 \mathrm{lb}$. being opened, two trout (size six to a pound) were found inside it (Fishing Gazette, December 20th, 1879). Parnell remarks upon having discovered the remains of some food in the lower intestines even when the stomach was empty. As a rule very little food is found in those residing in fresh waters, while if in roe they are almost invariably found to be quite empty.

The young parr takes any bait with avidity, and at almost any time, even when the trout refuses to rise, while their stomachs are often found gorged with the larva of aquatic insects. MIr. Tegetmeier observed (Proc. Zool. Soc. 1868) that the smolts which left the Stormontfields ponds in May that year were much larger than those of the previous season, dne to their diet having been changed from boiled ox liver rabbed down to coarse powder. This season the aquatic weeds in the ponds had become covered with Limnea peregra, on which they fed greedily and to which the great increase in size was undoubtedly to be attributed.

Fisheries.-As accurate statistics of what at present exist in the British Isles are unobtainable and fancy has filled in what facts have not proved, I restrict

* Günther observes that a salmon changing from salt to fresh water and vice vars $A$ several timea yearly, only occurs in rivers filling into the Moray Firth (Introduction, Study of Fisb, p. 640). 
myself to such figures as appear reliable. The returns of the number of boxes averaging $112 \mathrm{lb}$. each sent to Billingsgate Market (Young, British Industries, p. 299), and divided into quinquenial periods, give the following annual average results :-

\begin{tabular}{|c|c|c|c|c|c|c|c|c|}
\hline glish and & Welsh & 1847-51. & 1852-56. & $\begin{array}{r}1857-61 . \\
333\end{array}$ & 1862-66. & $1867-71$. & $1872-76$ & 831. \\
\hline & $-\quad$ & 18,372 & $\begin{array}{r}85 \\
17,872\end{array}$ & $\begin{array}{r}333 \\
16,850\end{array}$ & $\begin{array}{r}860 \\
22,086\end{array}$ & $\begin{array}{r}1,079 \\
23,110\end{array}$ & $\begin{array}{r}1,220 \\
26,775\end{array}$ & $\begin{array}{r}1,330 \\
24,214\end{array}$ \\
\hline rish & 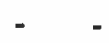 & 4,218 & 5,131 & 4,911 & 8,130 & 6,858 & 6,626 & 5,94 \\
\hline
\end{tabular}

The annual value of the British salmon fisheries has been estimated as follows: England $£ 100,000$, Scotland $£ 250,000$, Ireland* $£ 400,000$.

It has been questioned whether the amount of salmon in our rivers is really much less than was formerly the case. It can be shown that they have been exterminated from the Stour, the Itchen, the Medway, the Avon, and the Thamest in England. In Scotland, the Fifeshire Leven no longer contains salmon, in the Tay district the Almond, Ericht and Dighty are ruined from pollutions, and many other rivers are greatly injured. While stopping pollutions has been found so difficult and expensive, that the polluters appear to have it all their own way.

Mr. Blake, in 1874, writing of his Irish district, extending from Wicklow Head to Rossan Point, says that due to pollutions nearly every river in the connty Down has been destroyed as a salmon producer. One reason which has been advanced as a proof of the diminution in the supply of those rivers which still contain salmon is stated to be (and likewise denied) that formerly in indentures of apprenticeship a proviso was usually inserted that the apprentice should not be compelled to eat salmon more than three days a week. It has been advanced that this regulation, if it ever existed, may have been for the purpose of preventing masters giving their apprentices "kelts" as food, which are readily captured after spawning and might have been salted down. This seems very unlikely, for if kelts were probibited by British Legislators from being used by the rebellious Irish as food (see p. 62) so early as 1645, it is improbable they would have permitted masters in England feeding their servants upon them. That such probibitions were not unknown in other countries can be demonstrated, thus in Eastern Pomerania on the River Oder and its affuents, the monastic accounts show that a regulation was in force prohibiting salmon being given as food more than three days in a week (Gadow).

In Notes and Queries for May, 1857, the following quotation is given from Coursell's History of Gloucester, "It was a standing condition of apprenticeship that the apprentice should not be obliged to eat salmon more than thrice a week, the object being to render him less liable to the leprosy, which after the crusades in the Middle Ages was a formidable disease, that was supposed to be brought on or aggravated by the eating of fish." In a History of Worcester (1808, p. 48) the existence of this proviso is asserted as a well known fact. Mr. Rowell (Land and Water, July 16th, 1881) observes that this stipulation existed in the north as may be shown in a very old history of Newcastle, written during the last century, when salmon were taken there in amazing quantities. The Cromwellian trooper, Captain Franks, writing of Stirling remarked that "the burgomasters, as in many other parts of Scotland, are compelled to reinforce an ancient statute, that commands all masters and others not to force or compel any servant or an apprentice to feed upon salmon more than thrice a week." At Inverness a century later Burt tells us salmon sold at one penny a pound.

But we are reminded that it is difficult to compare the price charged a

* In 1879 Ireland exported to England 45,039 boxes of salmon, each averaging $150 \mathrm{lb}$. weight; and 50,517 in 1880 .

$\dagger$ We are informed that for several centuries a tithe of Thames salmon had been claimed and allowed to the Abbot of St. Peter's at Westminster, on the plea that when St. Peter (according to the legend) came and consecrated that church, he promised the fisherman who ferried him across the river a plentiful supply of fish provided he ceased fishing on Sundays and gave a tithe of his captures to the Abbot. This was paid until 1382 and then stopped, and this is said to be doubtless the reason why the last salmon was killed in 1833 ! 
century since to what obtains at the present time, because so many disturbing influences have occurred. And due to temporary large hauls a local superabundance of salmon must have occurred along the banks of some of our best fishing streams, while want of carriage precluded their being distributed througbout the country in ways now practicable, due to steamers, railways, improved roads and modes of carriage. Thus in or near seaports, as Berwick, Pennant, writing in 1776, informs us that the Tweed fish were sent fresh to London in baskets by sailing vessels, unless the craft was disappointed by contrary winds, when they were relanded, boiled, pickled and kitted and so dispatched, while other fresh ones replaced them in the baskets. At the commencement of the season, when a ship was on the point of sailing, a fresh, clean salmon would sell from $1 s$ to $1 s 6 d$ a pound, and the price at such periods was from $5 s$ to $9 s$ a stone of $18 \mathrm{lb}$. $10 \frac{1}{2} \mathrm{oz}$. weight, but the value rose and fell according to the plenty or paucity of fish and the prospect of a fair or a foul wind. In the month of July, when they were said to be more plentiful, the cost has been known to be as low as $8 d$ per stone, but in 1775 never less than $1 s 4 d$ and from that to $2 s 6 d$. While to pay the expenses of the salmon fisheries, Pennant estimated it would be necessary to capture 208,000 fish annually. About 1780 a Scotch Laird called Dempster of Dunnichen discovered that salmon packed in ice could be conveyed long distances and in good condition.

Legislation.-From time to time laws have been enacted in order to secure a free passage for breeding salmon from the sea to their spawning-beds, and a safe descent from thence when unfit for food or too small for cousumption. Also for the purpose of prohibiting any individual riparian proprietor from increasing the efficiency of his methods of capture to the injury of his neighbour or that of the general interest. For rivers only hold a supply to a limited amount, and should a disproportionate capture be made at one spot among the migratory shoals, this unduly diminishes the share which would otherwise accrue to the owners of fisheries in the upper waters. It has therefore been held that each fishery is merely entitled to its share of the general supply. From this fair division, as I shall have to show, the stationary net-fishers along the foreshores of Scotland, although of comparatively recent erection, have somehow managed to obtain exemption, and those structures, never, I believe, legalized, are employed to the detriment of the river fisheries, and doubtless at some future date will have to be placed under stringent regulations or prohilited as nuisances, as have been those in rivers and estuaries which existed for centuries.

The many phases through which salmon legislation in the British Isles has passed would for its due record require volumes for its full and olear explanation. At first the primary consideration appears to have been the good of the fisheries, and devices injuriously affecting them were in the earliest periods of English law reprobated as public nuisances. Especial attention was drawn in Magna Charta to how the Crown had attempted to disregard these laws, and permitted certain individuals to set up cruives or weirs, and it was enacted that "all weirs from henceforth shall be utterly put down by Thames and Medway, and through all England, except the sea-coast." What this exception referred to is now a mystery, as no fixed engines existed along the sea-coast in those times. We find especial enactments subsequently in the English statutes respecting allowing salmon a close time. The 13th Edward IV, cap. 47, prohibited the taking of salmon from the Nativity of Our Lady (September 8th), until St. Martin's Day (November 12th), in the Humber, Ouse, Trent, Done, Arre, Derwent, Wharfe, Nid, Yore, Swale and Tees. And in an Act of 1861, polluting and poisoning of rivers, and the use of lights and spears; was prohibited: fixed engines were declared public nuisances, and abolished, unlcss an ancient right to such prior to Magna Charta could be shown, and even then dams and weirs were directed to possess serviceable fish-passes or gaps : the mesh of all nets was restricted to 2 inches between knot and knot of the mesh, and placing gratings across side streams was declared illegal. Unclean spawning and young fish were to be protected, and an annual close-time was imposed generally in England between September 1st and February 6th inclusive with nets, or by angling to November Ist, these times being susceptible of alteration 
by an order from the Home Office, but not apparently to increase their length but merely to vary their incidence. A weekly close-time from noon Saturday to 6 A.M. on Monday was also imposed. The employment of fish roe for angling, or the possession of salmon roe or unseasonable tish, subjects the individual to a fine. In 1863 the export of unseasonable fish was prohibited, as it was found that just as large a quantity were being sent out of the country during the illegal as during the legal season, and the export in $186^{\circ} 2$ was double that of 1861 .

In the Severn some of the principal regulations which existed in 1740 are contained in the British Angler, of which the following are a synopsis:-A close-time between September 8th and November 11th, and no young fish to be captured from the middle of April to June 24th. Salmon nets were to have the mesh $2 \frac{1}{3}$ inches from knot to knot, nor to be above 20 yards long and 2 broad: or not less than above 50 long and 6 broad in the wing of the net from Ripplelock Stake (a little above Tewkesbury) to Gloucester Bridge: or above 60 in length below Gloucester Bridge: nor shall fish with more than one of these nets at once.

In a digest of the present fishery laws for the Severn district I find the following regulations among many others:-Annual close-time from August 31st to February 2 nd, except for anglers, who are permitted to angle to November lst: a weekly close-time of 36 hours. Salmon nets to have the mesh 2 inches from knot to knot. While it has been unsuccessfally proposed to increase the number of hours of the weekly close-season, to restrict the length of the nets above Tewkesbury (Ripplelock Stake) to 100 yards long and 8 broad, and also the shooting of nets so immediately one after another, as is done near Worcester.* While some are in favour of abolishing night-netting entirely, as giving the fish more rest, which if it does diminish the takes to a certain extent likewise removes the necessity for a night gang (see p. 91).

In Scotland, so long ago as A.D. 1424, we find that a close-time for salmon existed, and if a poacher exercised his vocation during this period he had to lose his life or purchase it. The Tweed Act of 1857 was, perhaps, the commencement of a new era in the Scotch salmon fisheries; fixed nets were abolished in estuaries and rivers (but from then until now their legality along the foreshore has not been decided) : leistering or spearing was prohibited, a weekly close-time legalized, and the mesh of the nets fixed at $1 \frac{3}{4}$ inches between knot and knot. Both the period of time and the distance which should extend between the working of nets was likewise laid down, while the killing of foul fish was prohibited during the legal season for capture. Subsequently other laws, somewhat similar to the English ones, have been passed, except fixed engines in the sea have been left alone.

Space will not permit remarks upon the nature of the tenure by which salmon fisheries are held. Russell observes that in England they were recognized, protected and regulated as property by Magna Charta, and both in England and Ireland began to be legislated for as property at least 600 years ago, while in Scotland the property, besides having legal recognition equally ancient, has in $\mathrm{mu}$ 'titudes of cases been separated for centuries from the soil.

The legalized open season for salmon fishing in the United Kingdom this year was with few exceptions as follows:-

England. Rods from Feb. 1st to May 1st until Sept. 30th to Nov. 29th.

$\begin{array}{llll} & \text { Nets " Feb. 2nd "April 1st " Aug. 14th "Sept. 30th. } \\ \text { Scotland . Rods " Jan. 11th" Feb. 25th " Sept. 14th " Nov. 20th. } \\ \text { Ireland Nets " Feb. 5th "Feb. 25th " Aug. 26th "Sept. 14th. } \\ \text { - Rods " Jan. 1st "June 1st " Sept. 14th " Nov. 1st. } \\ \text { Nets " Jan. 1st "June 1st ", July 16th "Sept. 30th. }\end{array}$

The reason why angling is permitted for some time after net fishing has ceased is to give persons in the upper reaches of rivers some chance of capturing

* One of the most killing plans of taking salmon I have seen is carried on in the tidal waters below Chepstow. A line of boats is anchored across a tideway, and a large lave net is let over the side of each with its mouth to the incoming tide. The bag of the net is sufficiently long to be brought under the boat and held by the hand on the up-river side. On a salmon striking this lave net the bag end is let go, and the lave net side (resembling w huge landing net) is elevated: and thus sulmon are tuken in quantities. 
The best adapted rod, the reel, the line, and more especially the description of flies employed, differ in different waters, and as the last resemble nothing that is to be found in the air, earth, or silvery streams, the would-be-angler bad best consult local adepts in the gentle craft and cunning books on this engrossing subject.

Breeding.-The number of eggs which each female salmon produces has been estimated at about 900 for every pound weight of the parent fish, but they may exceed these, thus one weighing $20 \mathrm{lb}$. contained 27,850 eggs. The period of spawning varies to a certain extent with the locality, seasonableness or the reverse of the weather, and several other circumstances, but is usually considered as extending from the commencement of September until the middle of January. At Stormontfield on the Tay netting for spawning salmon usually commences about Martinmass (November 11th), but in 1881 no tish were ripe until December 22nd or 23rd. The time during which a salmon is in a river for spawning purposes can rarely be less than three months, but such must be regulated by many causes as distance to be traversed, accessibility, temperature, etc. But there are certain fishes in which abnormal development occurs, and fresh run salmon with developing ova have been captured at unusual seasons of the year, thus in the Field of April 30th, 1881, one $15 \mathrm{lb}$. weight, with ova the size of number six shot, was recorded as having been lately captured in the Severn above Shrewsbury. In July this year I saw a male salmon from the Severn in its full breeding livery.

It has been pointed out that clean salmon ascend rivers late in the winter or in the early spring, but as they swim deeper than spawners they are less likely to ascend fish passes. While netting the Teith on December 23rd, 1881, five were taken (Land and Water, January 28th, 1882): these fish could not have been ascending to spawn, so must have passed the winter in the sea, showing that it is not an invariable rule that they breed every year. On the other hand, Buist saw a grilse spawned at the Tay fishery wbich was carefully marked and returned to the water, the following year at the same spot it was captured as a salmon full of ova. After a certain age they cease propagation and overgrown ones are found to be barren, while male parr are mature at seven or eight inches in length.

Late fish when forming their redds frequently rout up those which were existing in the same spot and consequently many ova are carried away down stream. It has been remarked that this procedure permits of any diseased eggs being carried away and not left to contaminate the good ones: but it does not seem improbable that such treatment is worse than the disease. In some seasons when the water in the rivers is too low for breeding fish to ascend they deposit their ora at the mouths or in the sea, occasioning the loss of the year's supply of eggs. For when the ova are ripe for extrusion the female has no power to retain them, and even the muscular exertion of swimming might cause their expulsion as she possesses no sphincter muscle to assist in their retention. It is different in the male which is furnished with a duct for the ejection of the milt.

I have already observed (p. 65) upon salt water or impurities proving destructive to the eggs of the salmon, while muddy or deep rivers would be equally inappropriate for forming redds in. These fish consequently push up to where the water is clear and form their nests in the main stream or one of its tributaries. Mr. Jackson has made some juteresting observations upon whether the male salmon impregnates the whole stream, which has an important bearing upon the question of hybrids. He found that on placing the spermatozoa under the microscope no two touched one auother; they all moved slowly about, and kept constantly at or near the same distance apart as possible. On being further diluted with water, the same result was produced, the distance being enlarged, and it was not until the water was supplied to such a degree that it was impossible to suppose they could fill it and yet preserve communication with one another that the regularity of the pattern disappeared, and even then they kept far away from one another. It appeared as if the phenomena observed were intended to distribute the milt in such a manner that no egg could possibly miss getting hit if it came within range, which led him to conclude that the whole water of a salmon river, or at least of the small tributaries in which they 
principally breed, is thoroughly impregnated: he likewise remarked that the milt kept in water retained vitality for three days. Should the male by any accident be killed during the time the female is spawning she consoles herself with another mate, and it is possible that even a parr would be sufficient in order to render the ova fertile. In January, 1837, Shaw took a female salmon 14 lb. weight from its spawning bed and a male parr $1 \frac{1}{2}$ oz. in weight, impreguating some of the eggs of the former with the milt of the latter, and the young were similar to those raised from two adult salmon. The male as a rule keeps guard near his partner, probably for the purpose of keeping other males at a distance, and it is recounted in the Zoologist $(1847$, p. 1650$)$ that two had an encounter in the spawning season between Glenferness and Dulcie Bridge, apparently for the possession of a female, and at last one floundered dead to the surface, the victor having torn off the flesh along the back from the head to the tail, and down to the very bone. It has been held by some that during the breeding season there is an excess of male fish over females; others account for this by the males being in a more exhausted condition than those of the feminine-gender, consequently more of them are taken : females likewise appear to be more crafty.

Salmon eggs, though apparently tough and elastic, are nevertheless exceedingly delicate, and Mr. Nichols tells us how Mr. Ramsbottom was carrying three sodawater bottles containing some salmon ova, slung in a handkerchief to prevent concussion, one slipped from the hand and fell to the earth, and not a single orum out of this bottle was hatched, while those in the others taken at the same time did well. Even pouring water on eggs in a careless manner has been known to kill the ova, and the like result is recorded due to using a nail instead of a screw in fastening a small box of ova. It has been shown that the nearcr the eggs are to hatching the better will they bear transmission.

It has been calculated by Stoddart and others that if salmon eggs are left to nature the produce is about four or five fish fit for table for every 30,000 ova deposited, whereas the same number are obtained from every 800 eggs artificially protected. Although these figures are founded upon calculations some of which may be fallacious, still it is ahundantly obvious that the number of reared fish from eggs left to nature is far less than what obtains in those artificially propagated. In the Tay the augmentation in the number of fish was as much as 10 per cent., an increase not apparent in rivers in which this mode of fish cultivation was not carried on. Consequently a plan commenced being adopted of obtaining the ova from the fish and rearing them artificially. The number of eggs thus removed is but a small percentage of those in the stream, and it has been ascertained that eggs still retain their vitality in a female salmon that has been dead two hours or even more, and that they have been successfully vivified from the milt of a live male.

The mode in which fish are stripped varies; should the examples be very ripe, slight pressure will occasion eggs to pass from the female and milt from the male, or a little extra pressure may be necessary. Some add the milt to the ora when the latter are in water, others prefer omitting the use of water. The eggs are now removed to a place prepared for their hatching and rearing the young fish, and where a constant supply of water, at a required temperature, is artificially kept up.

During incubation these eggs should be kept dark and the opaque ones removed, or they contaminate others in their vicinity. Too great a temperature affects the eggs as already observed (page 65). Sir J. Gibson-Maitland has remarked that the eggs taken early in the season are the most fruitful and produce the strongest fry. The young begin to pine when the thermometer marks many degrees above $55^{\circ}$ : they require an increased flow of water and conceal themselves under any available shade as the light affects them. Other fish, some mammals, birds, crustacea, and insects seek them out as food, irrespective of which they are liable to gill fever or a fungus due to uncleanliness may appear upon the back of the weaker fish. The young, after the absorption of the umbilical sac, are fed upon various animal substances, care being necessary that such food is wholesome, and that the supply does not exceed the demand. 
Mr. Youl and Mr. Wilson first attempted the introduction of salmon and trout into Australasia in 1860, the experiment failed as did also that tried in 1862. Dr. Davy in his experiments upon salmon eggs ascertained that when exposed to dry air at the ordinary temperature they rapidly died; that their vitulity was as well preserved in moist air as in water, while ova placed in ice were not affected unless lowered many degrees below the freezing-point. If the water in which the eggs were, was heated to $80^{\circ}$ or $82^{\circ} \mathrm{Fah}$., they could stand it with impunity for a moderate period, but $84^{\circ}$ or $85^{\circ}$ was fatal.

Sir J. Richardson (Yarrell, Brit. Fish. ed. 3, 1859, p. 215) remarked, "Dr. Dary's observations lead one to believe that the attempts which are making to transfer salmon and trout from England to Tasmania and New Zealand, will not succeed, unless the temperature of the water be kept down by ice during the passage through warm latitudes." Mr. Youl, however, was the first person who successfully employed ice for the purpose of conveying trout and salmon ova through the tropics. It would appear that some trout ova which he had placed amongst moss in a deal box and imbedded in the ice room on board "The Beautiful Star," lived from March 4th to May 17th when the ice failed. Further investigations showed that for the preservation of the vitality of salmon ova a continuous stream of water is not essential : that partial deprivation of air is not fatal, while light is not necessary.*

Life history.-The young salmon, generally known as a parrt or pink, and hatched out early in the year, is adorned with hrilliant trout-like colours, as have been already described (page 68). These young fish reside two years (or in rare instances one) in our rivers, and migrate in the succeeding or third spring, to the sea as smolts. Many discussions have arisen as to whether a parr is or is not the young of the salmon, or even a hybrid between it and the trout, and though there exists a strong family resemblance between the young of the various species of salmonidæ, most of the fresh water or anadromous forms passing through a parr stage, still it has been abundantly proved that the young salmon itself invariably commences life as a parr. It was long since pointed out that in rivers destitute of salmon there were no parrs: while if salmon existed parrs were pregent. This point has now been most conclusively decided by hatching out eggs taken direct from the salmon and artificially propagated and the young reared, the result being parrs as may be seen at the present day in any fish-breeding establishment. It has also been shown that similar parr, passing through the same subsequent changes and growing at about the same rate, were raised by the artificially propagated eggs of smolts and salmon: grilse and salmon: pure grilse : or pure salmon. At the same establishment a suggestion which had been advanced that the anomaly of some parrs migrating after one year the remainder after two seasons was due to the first being the produce of salmon and the second of grilse was refuted. The whole of the fry, numbering about 200,000 , were the produce of 19 male and 31 female salmon spawned in 1859, some remained as parr while others migrated as smolts. Although about two centuries since it was shown that parr were young salmon, such was not generally admitted until Mr. Shaw, in the Transactions of the Royal Society of Edinburgh, furnished the public with a trustworthy account of the changes occurring in the young salmon. He took seven small ones (parrs) on July 17th, 1833, and placed them in a pond supplied by a stream of wholesome water: they throve until April 1834, when a change came over their external character they having assumed the state of salmon smolts. In March, 1835, the same observer transferred twelve parrs, each about six inches long, from the river to a pond, and they, by the end of April, assumed the smolt stage. From the foregoing he concluded that the larger parr present in the rivers in autumn, winter, and early spring is in reality the actual salmon fry advancing to the conclusion of its second year, and that the smaller parr, termed in some places, "summer

* Detailed information may be found in Fish Culture, by Mr. Francis Francis, and Fish Hatching, by the late Frank Buckland; also in several other works.

+ Jartine considered "the parr not only distinct, but une of the best and most constantly marked species we Lave" (Jamieson's Phil. Juarnal, 1835). 
parr," is the younger individnal of the same species only entering upon its second year. On instituting a careful examination on May 15th, 1834, of a river where salmon had spawned the preceding winter, Mr. Shaw found a vast number of very small but active fish above an inch in length, some of which were placed in two ponds. In May, 1835, these fish were on an average $3 \frac{1}{2}$ inches in length and corresponded in every respect with the parr of the same age which occurred in the river, in May, 1836, they were transmuted into smolts and measured $6 \frac{1}{2}$ inches in length.

A number of parr were placed in the Brighton Aquarium in a fresh water tank, and when the month of May came round some had assumed the livery or protecting silvery scales of the migratory smolt. Sea water was now gradually introduced and all became smolts, thus showing that saline water is not necessarily fatal to parr as generally supposed, at least at the time they are on the verge of attaining their smolt condition.

Mr. Ashworth, in certain experiments which were instituted at Stormontfield, near Perth, showed that a portion of the parr assumed the smolt dress and descended to the sea shortly after the close of the first year of their existence, returning again as grilse weighing from 5 to $9 \frac{1}{2} \mathrm{lb}$. within 20 months subsequent to the deposition of the ova, while some of the same lot remained behind as parrs, weighing an ounce at the period of the return of their brothers and sisters above referred to. It has also been remarked that whether a river is an early or late one the descent of the smolt generally occurs during the spring, between March and June. Mr. Dunbar who annually hatches about 500,000 in the Thurso river, in the county of Caithness, informed Mr. Young that about eight per cent. became smolts at the end of the first year, and about 60 per cent. at the end of the second year, and the remainder or 32 per cent. at the end of the third year.

Having thus far traced the salmon egg to the pink or parr, and on to the stage of migratory smolt, which congregates in shoals, it becomes necessary to follow this latter fish until it has migrated to the sea, from which it never returns, similar to the fish which descended there, but instead a larger form, weighing more pounds than it did ounces, a miniature salmon in short, and termed grilse, ascends in shoals. The scales of the silvery smolt come off very readily on the fish being handled, and underneath may be seen transverse bars, the livery of the parr.

Mr. W. Brown (Stormontfield Experiments, 1862, p. 7) observed upon having in February, 1836, caught a dozen and a half of parr in the Tay, he kept them confined in a stream of ranning water, and by the month of May the whole of them had become smolts; but some had leaped out of their confinement in their struggle to find their way to the sea, and were found dead upon the side of the pond. Mr. Upton, in the auturnn of 1835 and the following spring, according to Yarrell, transferred some "pinks," none of which exceeded $3 \frac{1}{2}$ inches in length, from the Lune to a lake termed Lillymere, and which has neither outlet from other waters by which fish can obtain access, or any obtain exit, and no communication with the sea. In August, 1837, two salmon peal, measuring 14 inches in length and weighing 14 onnces, were taken with a fly, in excellent condition in every way, and in July, 1838, another small salmon was caught equal to the first in condition and colour, about 2 inches longer and 3 ounces heavier. A " pink" was transferred to a well at Whitewell in November, 1837, and removed thence as a smolt $6 \frac{1}{4}$ inches long in July, 1838. These and other similar instances would appear to point out that, as in the trout so in the salmon, the larger the extent of the water in which the fish resides, so much the more probable is it that it will rapidly attain a larger size.

From the foregoing it appears that it is the natural course for smolt to migrate to the sea, but that a compulsory detention in fresh water is not necessarily fatal, a subject to which $I$ shall refer further on (see p. 80). When at Montrose at the end of June this year, several smolts were taken from the stomach of a saithe, Gadus virens, captured in the sea a couple of miles from the coast. A similar occurrence was noticed at the same place in December last year, the fish which had eaten the smolt being a whiting. When at Aberdeen in July, 1882, Mr. Sin 
showed me some smolts similarly procured from the stomach of a marine fish. In fact this has been constantly observed at different localities, proving conclusively that the migratory smolt passes into the ocean.

Smolts which descend seawards have been proved to return to the rivers as grilse. In the Tweed in various years numbers of these smolts have been marked by a silver wire having been passed through and fastened to the back part of their tails. None were obtained the same year, but the experiment was continued the succeeding season, and several were taken as grilse. The Duke of Roxburghe, on May 14th, 1855, had a smolt marked by the insertion of a peculiar shaped wire through its gills ; it was retaken July 21 st, 1856 , as a grilse, weighing $6 \frac{1}{2} \mathrm{lb}$. On the other hand we are told that in May, 1855, 1300 smolts were marked at Stormontfield by cutting off the adipose fin, and 22 were recaptured as grilse the same summer, the first on July 7th, 1855, when it weighed $3 \mathrm{lb}$. Some excellent observers are disinclined to believe that it is possible these fish can increase so rapidly in size that a smolt descending in May a few ounces in weight, could be capable of returning within two or three months as a grilse of some pounds, but it is not impossible that as we see differences in the periods of descent of the parr as smolt, so some smolts may return in one season, the remainder in the succeeding year. It is very remarkable that grilse do not commence ascending until two or three months subsequent to the descent of smolts, whereas had they been upwards of a year in the sea it would appear strange why some few at least had not put in an appearance, this invariable absence from the nets almost seeming to point out the probability that they are not present.

Some salmon appear to ascend almost any month of the year, but the grilse come in large shoals, do not loiter about the mouths of rivers, and may be said to be summer and autumn visitors. It has been advanced that grilse are not young salmon, ignoring the fact that only in salmon rivers are there true grilse, and where they exist there are also salmon. I have in the preceding pages shown that they are transformations of parr, raised from eggs taken directly from salmon, that they breed with salmon and that the young are indistinguishable from those raised when both parents are the true Salmo salar. These grilse return to the sea as grilse kelts, which reappear in our rivers as salmon. Mr. Young states that he has often marked grilse and that they have returned from the sea as salmon. A grilse kelt of 2 lb. weight was marked on March 31st, 1858, and was recaptured on August 2nd of the same year as a salmon of $8 \mathrm{lb}$.

Respecting the rapidity of growth of salmon various experiments have been instituted. In 1859 the Duke of Athol had three salmon captured, while migrating seawards, weighing $10,11 \frac{1}{2}$, and $12 \frac{1}{2} \mathrm{lb}$. respectively. These were marked by a copper wire being placed round their tails, and six months subsequently they were recaptured as they were returning to fresh water, and their weight was ascertained to have augmented to 17,18 and $19 \mathrm{lb}$. respectively.

Having thus briefly detailed the life history of this fish from the egg to the adult, it becomes necessary to revert to those forms which have completed spawning. Those, commonly termed kelts, drop down from pool to pool in a very exhausted condition, the males much more so than the females. They generally remain in the river in a debilitated state, feeding upon whatever fish comes in their way, not rejecting the young of their own species. At this period they are readily captured, and very prone to attacks of disease, often dying in vast numbers, while a heavy flood carries them off towards the sea, but they as a rule continue some time in the brackish water of the tideway before seeking the ocean. Although doubtless a few of these kelts mend in the rivers, recovering their silvery lustre prior to reaching the sea, and others return at a futare period in a healthy state from the salt water, it seems questionable whether too many are not now permitted to mend upon the salmon fry, thus reducing the amount of stock in the river (see page 62). In olden times poachers, assisted by otters, kept the number of kelts in check.

During the winter season of $1881-82$ the salmon disease seriously affected the Tay and its tributaries killing vast numbers of kelts, and by some people a greatly diminished catch was prognosticated for the season of 1882. But the 
spring and summer fishing was fairly favourable, while in August there was a large increase both in grilse and salmon: the effects of the mortality seemed to show itself in the decreased weight of the individual salmon and the pancity of exceptionally heavy fish, none attaining $40 \mathrm{lb}$. until the commencement of June. This would go towards favouring the contention that kelts when mended do return to the river, but that a great destruction of them does not necessarily involve a greatly diminished take of salmon the ensuing year.

An experiment of permitting kelts to be destroyed in one river for a single year, and ascertaining the effect on the stock of salmon and grilse the succeeding season, appears well worthy of a fair trial.

The question here arises what is an "unclean" and "unseasonable" salmon? these terms being employed in Parliamentary language. Certainly a "kelt" would come under this designation as would also one that is about to spawn or "red fish" if a male, "black fish" if a female. But the latter could hardly be termed a foul fish being in its way as good food as is a laying hen or many an animal. By a clean salmon, on the contrary, is meant one in good health, and not on the point of spawning.

Siebold has shown that certain individuals are not sexually developed, and he believed this sterility extended thronghout their existence, a view opposed by Widegren and others, who contend such to be temporary and merely affecting a few individuals.

Hybridism in a natural state appears to be rare as regards the salmon, but that such may take place has been proved by Rasch who fertilized their ova with the milt of the trout and of the charr (see p. 59). It might be worth a trial whether sach hybrids could not be raised for the purpose of populating waters in rivers wherein pollutions in its lower portions or other causes precludes the ascent of of the fish. Probably most bybrids would be sterile, and possibly they would not attempt to migrate, if so the angler could supply his district with fish which would be good for sport and likewise for the table.

Whether salmon conld be permanently retained and breed in fresh waters is a subject upon which various opinions have been given. The difficulty of offering an opinion upon this question is that it seems occasionally questionable whether the recorded instances of such having been successfully accomplished, the observer refers to Salmo salar, or a sea-trout. Lloyd (Field Sports North of Europe, i, p. 301) remarks that near Katrineberg there is a valuable fishery for salmon, eleven or twelve thousand of these fish being taken annually. They are bred in the lake, and in consequence of cataracts cannot have access to the sea. They are small in size and inferior in flavour. The year 1820 furnished 21,817. Bertram observing upon having been present at Stormontfield at the yearly exodus of smolts in 1861, when they were found to be large and in fine condition-continues, "one fish, which has been detained for three years for the purpose of discovering whether the species will grow in fresh water without being permitted to visit the sea, was found to be fully twice the size of the largest smolt" (Harrest of the Sea, p. 110). It must not be overlooked in experiments of this nature that the extent of the fresh water in which these fish are confined must exercise a considerable influence upon the result, and also on the amount of food which is available for their consumption.

Professor Rasch, of the Christiania University, remarked, "some years ago Hetting hatched out a number of salmon ora, which he subsequently turned loose in the Tyri-fiord, and during the last two years fish have been caught in that lake resembling in every respect 'salmon proper.' It is impossible for them to return thither, even should they succed in reaching the sea" (Land and Water, 1866, pp. 221,245$)$.

Kipper is a term sometimes used for males after breeding, but which has also hecome employed for members of the salmon family that have been detained in fresh water, and as a consequence become sick, lean and unseasonable (see S. argenters, pl. cxi). This term is also employed to old males, and means bony gristle, which grows from their lower jaw resembling a "hawk's bill," and nnless absorbed, may hinder them from feeding, causing them to pine away and die. 
Diseases or causes of destruction.-Under this head poaching devices will not be included, but mortality or sickness otherwise induced. For many years, perhaps from time immemorial, a fungus, Saprolegnia ferax (see Introduction), has existed to a slight extent in fresh waters, as in our salmon rivers, but which, due to some cause at present unknown, took an epidemic character in 1878. Since then it has been chiefly seen in the spring of the year, in some rivers even in the autumn, and although at first it appeared to be restricted to kelts or fishes in an enfeebled condition, it has been lately observed to attack clean fish. The fact appears to be that once this fungus has infected a fish, it may be the nucleus from which infection spreads, and within twenty-four hours thousands of zoospores, which may be termed minute germs or seeds provided with cilia, rendering them capable of spontaneous movements, may become diffused through the water. These germs arriving at a suitable spot develop into a fungus, and such a place is found in a fish, where its roots strike downwards into the flesh and its free extremities come to the surface, forming the white fungus appearance so distinctive of fish suffering from this disease, and which proves almost invariably fatal from exhaustion, irritation, or suffocation due to the organs of respiration being affected. Although sea water appears to check and in some rare instances seems to cure the disease, it is not improbable that it may only cause it to remain dormant, so that on returning to fresh waters it is again roused into activity. The following figures show the virulence of this disease :-In the annual report for 1881 of the Tweed district it is stated that during the last winter the number of fish that died or were killed in consequence of the fungus disease was 14,627, making a total for three years of 22,756. As each diseased fish is in itself a focus of infection, doubtless they ought to be immediately removed from the river and buried. Salmon are much affected by tape worms, Bothriocephalus, which seem especially to like the coecal appendages as places in which to reside: a species of $L$ ernea also externally attacks them when in the sea. They are likewise affected with other internal and external parasites.

In 1882 a whitling Salmo trutta, $\frac{8}{4}$ lb. weight, was captured in the Tay, and in it were 300 fertile salmon ova; while Mr. Ashworth took upwards of 500 salmonoid eggrs from the maw of a trout. Mill-wheels not unfrequently cause the death of salmon passing beneath them, by direct blows. Obstructions to ascent and descent are also secondary causes of disease, while pollutions are great sources of mortality, more especially to the young fish. Smolts and even salmon are largely destroyed while in the sea and estuaries by porpoises, seals, members of the cod-fish family, and other marine enemies.

As food.-These fish are highly esteemed and cannot be eaten too fresh, while in selecting them care should be taken, provided there is any choice, to choose those which are bright and silvery, rejecting such as are of a muddy tinge. During the winter those which are out of season are dull in colour, their flesh is soft and white, and they are wanting in flavour if dressed. If the fish is newly captured it is usual, in order to set the curd, to put it into boiling instead of into cold water. It may be boiled, but should be removed from the water as soon as done, or both its appearance and flavour will deteriorate. It is generally dressed with cucumber and anchovy, lobster, or shrimp sauce. This tish may be baked, done in slices, or served in a hot or cold pudding.

Salmon is cured in different ways as by simply drying, salting or pickling. "Kippered" is well-cleansed salmon which has received several dry rubbings of pepper and salt, then dried either in the air or artificially by means of the smoke of peat or juniper berries.

Habitat.-This fish ranges in the northern hemisphere between latitudes $45^{\circ}$ and $75^{\circ}$, and examples have even been captured as high as $80^{\circ} \mathrm{N}$. Lat. In the United States' report it is stated to range from the Polar regions to Cape Cod. It extends throughout the seas and countries of Northern Europe, around the British Isles, and also the Atlantic coast of France, but does not occur in rivers which flow into the Mediterranean.

It is rare in the Orkneys and Zetland (Baikie), and is found in all suitable rivers of England, Scotland, Wales, and. Ireland, where it has not been destroyed 
by pollutions, or obstructions render its ascent impracticable. In Great Britain most numerous towards Scotland: it abounds in all Yorkshire rivers, unless excluded by pollutions (Yorkshire Vertebrata), less common down the east coast of Lincolnshire, Norfolk, and round the south coast, the English Channel, but more frequent in the Bristol Channel, while the Severn salmon are among those which are most esteemed.

A salmon weighing $25 \mathrm{lb}$. was captured off Lowestoft in a trawl net (Colman, Land and Water, May 10th, 1879), being only the second instance since 1849.

Sir T. Browne, 1662, stated that it was no common fish in the rivers in his time, though many were taken in the Ouse, in the Bure, and in the Waveney, in the Norwich river but seldom, and in the winter. Paget observes, respecting Yarmouth, that small ones have very rarely been captured in the mackerel nets. Of late years they have almost disappeared from the Norfolk coast, and one taken December 1st, 1873, in a flooded meadow at Lakenbam, was considered such a curiosity that it was sent to London for identification and preservation; it is now in the Norwich Museum (Lowe). Yarrell remarks that the last Thames salmon was captured in June, 1833.

The size to which this fish attains depends upon the extent and character of the water it inhabits, the quantity and quality of its food, temperature, and other circumstances. It has been surmised that the very small salmon sometimes captured are really grilse, which having failed to ascend have to defer such to the succeeding year, when they have become salmon. The reason why some Dutch fish are so large is believed to be owing to so many kelts escaping capture.

Pennant mentions one of $74 \mathrm{lb}$. Buckland cast one of $70 \mathrm{lb}$., 4 feet 5 inches long, taken from the Tay. In 1867 one was taken in the Severn, near Lydney, in July, weighing over $42 \mathrm{lb}$; ; another the next month at Beachley, nearly $52 \mathrm{lb}$; ; and a third in the Wye, near Tintern, over $40 \mathrm{lb}$. In 1873 one weighing $70 \mathrm{lb}$. was taken in June at Littleton. In Ireland, Ball recorded two, each weighing $52 \mathrm{lb}$., captured at the same time at Blackwater: several instances of $70 \mathrm{lb}$. fish are alluded to by Thompson, and in July, 1881, an Irish fish upwards of $84 \frac{8}{4} \mathrm{lb}$. weight was exhibited at a fishmonger's in Manchester.

The figure of the salmon, plate cx, fig. 1 , is of a male 32 inches long, taken from the Severn. The parr, fig. 2, is slightly reduced from one captured in the Teme in the month of May. The figure of the kipper, plate cxi, fig. 1, is from Dr. Günther's type specimen of Salmo argentus (not Cuv. and Val.), a femalo 26 inches long, which had been kept for a short time in a fresh water pond.

\section{b. Fourteen or more rows of scales between the soft dorsal fin and the lateral-line.}

Prior to giving descriptions of the various forms of Salmones, included by some authors under this head, it appears most appropriate to explain why it is that I find myself unable to accept these numerous species, believing those ichthyologists more correct who have considered them modifications of only one, which, as Salmo trutta, includes both the anadromous and non-migratory fresh water forms. In following ont this inquiry, it will be perhaps best to show (1) that marine salmonoids may take on a fresh water existence; (2) that Salmo trutta and B. canbricus can be hoth traced into the fresh water forms of the common brook trout (see paige 5.), while crossing the ova of one with the milt of the other gives rise to no remarkable symptoms, and the progeny, if hybrids, are not sterile. Sir J. Gibson-MLaitland, in the winter of 1881, crossed the ova of the Loch Leven trout with the milt of the sea-trout, and about 95 per cont. hatched.

In order, however, to facilitate reference and draw attention to some phenomena still requiring elucidation, I have placed as distinct Salmo trutta, with its very deciduous vomerine teeth, and $S$. fario, or the brook-trout, with them more persistent, in short by the parr dentition being contiuued through life, and a somewhat different geographical distribution. Also S. levenensis which appears to be in a transition state from an anadromous marine to a non-migratory fresh water lake variety.

If sea-trout which having entered fresh water in order to treed, are prevented returning to the ocean, it may result, as detailed by a correnpondent in the Field 
(January 8th, 1881), that they become, as he found them, big-headed, lank, and black looking. But there may be a reason for this, as insufficiency or inappropriateness of the food in their now home, which precludes their thriving or even continuing in health. Should, on the contrary, the place prove appropriate, they may thrive even though they are unable to return to the sea. McCulloch (Journ. Roy. Inst., no. xxxiv, p. 211) has stated that the salmon-trout is now a permanent resident in a fresb water lake in the island of Lismore, one of the Hebrides, and without the power of leaving it or reaching the sea. There it has been known for a long course of years, perfectly reconciled to its prison, and propagating without any apparent difficulty. Eggs of the sea-trout having been transmitted to Tasmania, some of the young retained in a fresh water pond (see pages 84,86 ) have bred showing no symptoms of sterility. This breeding has taken place each successive year since, and the fertility of the ova seems to be exceptional, for every one of the 142 ova sent to the Otago Acclimatization Society produced a fish.

It is evident that our anadromous sea-trout may take on a fresh water state of existence, and breed there; irrespective of which by imperceptible changes we find it in every country passing from one form into the other, as I shall give instances when treating of the different varieties. This, of course, raises the question of which form Salmo orcadensis, S. estuarius, \&c., most resemble, the anadromous S. trutta or the fresh water S. fario. Admitting the two latter as being merely the extreme limits of one species, it becomes unnecessary to decide whether the diminution in the number of the romerine teeth* is symptomatic of the fresh water form developing towards its larger relative the anadromous sea trout, or whether it is the sea trout retrograding towards its parr dentition, or that which is persistent in the Salmo fario. Colours, it is true, are not very reliable, but these forms more nearly approach the fresh water than the saline varieties, a change which appears invariably to occur sooner or later in anadromous forms which become permanent residents in fresh water.

But although the foregoing tends to prove that anadromous forms may pass into fresh water non-migratory species, further proofs are necessary that it does so in this particular instance. Tho distinction between the two races being seen first in the comparatively more complete system of dentition in the fresh water forms, their generally longer beads and decreased number of coecal appendages. The dentition varies excessively; thus we find examples possessing the colours, form, \&c., of the brook-trout resident in brackish waters or even the sea, but mostly not invariably possessing the limited number of vomerine teeth of the anadromous form. On the other hand we find anadromous forms (in colour) passing into fresh water, and the teeth assuming that present in the brook-trout or retaining their parr dentition. I am unable to see in this, as has been suggested, hybridization, or more properly speaking, a "graduated hybridization," for every gradation can be seen, the links in the chain are perfectly complete, as may be perceived at the British Maseum, in the Welsh series of S. cambricus, or in the S. trutta of the Tweed. On the other hand, in the same institution are so called hybrids between the S. gallivensis, Günther, and the brook-tront. The comparative length of the head is likewise subject to variation, there being both the long-headed and short-headed races of the more south and west sewin, and also of the sea trout on the east coast of Britain. And, lastly, as regards the number of coecal appendages asserted as a character which may materially aid in discriminating a species. I have already (p. 56) given reasons for declining to accept this in respect to our fresh water trout, and will now adduce further ones to show that neither is it reliable in the sea forms. A very instructive instance is to be found in the case of the ova of sea-trout, which were transmitte. to Tasmania, and one of the adult progeny of which, 18 inches in length, was

* Whether the vomerine teeth are at once replaced when lost, or at certain periods shed, is a question admitting of doubt. Mr. Harvie Brown has personally observed that the lingual teeth are shed in June, July, and Angust in the brook-trout, new ones mostly taking their place, loose in their sockets at first and not filling the cavities made by the old cast-off ones. Should this be invariable it shows that the size of the lingual teeth is no criturion as to species. 
received in the British Musenm in 1874; it externally shows the normal form of the common sea-trout (plate cxi, fig. 2), but has only 36 coecal appendages, so that (if Dr. Günther's theory were correct) it ought to be a sewin, S. cambricus. This difficulty is surmounted by suggesting that this fish is a hybrid, but as the sewin and the sea-trout are asserted by Dr. Günther to reside in different districts, and as only anadromous sea trout were deprived of eggs and milt, by the manipulators such an occurrence could not have occurred. These salmon-trout eggs arrived in Tasmania, May 5th, 1866, were placed in the breeding ponds, and from them 900 fry were reared. A number, Mr. Nichol* informs us, of these fry were put into a specially constructed pond, fed by a small rill of bright cool water, where they were disturbed as little as possible. By the middle of October, 1867, many of these prisoners had put on the smolt dress and no doubt feeling the migratory impulse, leaped upon the bank in some numbers and perished. In July, 1869, they spawned in the ponds. It is thus clear that this fish with anadromous instincts was raised from the eggs transmitted from England, and distinctly demonstrating that the number of cœea are subject to variations, so useless as a definite guide to epecies. If, as shown, changes in climate and food can induce such a marked difference, that in the Antipodes two forms of sea trout may be detected in one specimen: if the anadromous forms can be traced step by step and link by link into the brook-trout, or vice versâa: if breeding the two forms together causes no unusual phenomenon, I cannot resist agreeing with Widegren, $\uparrow$ Malmgren, Collett, Feddersen, Malm, and others, that we are dealing with a single species subject to almost innumerable modifications in accordance with variations in clinate, locality, and food.

Lastly, it must not be supposed that because (as stated at page 57) British anadromous salmonoids possess more coecal appendages than are normally found in non-migratory trout, that such is everywhere the case. In the British Museum, these appendages vary among specimens of the Loch Leven tront between 49 and 90 , due either to the convergence of several into one, or the subdivision of one into two or more. Bat in this case the fish are residing in a large lake, and do not appear to be many generations removed from their marine ancestry. It seems that this large number in lake forms is likewise not unknown elsewhere; thus the Salmo marsilii from the lakes in Upper Austria has up to 100, S. lacustris from Lake Constance, which Siebold considers the same species, has up to 74 . S. venernensis, Günther, from Sweden, which Malm gives as a variety of the common brook-trout has at least 62 , while our larger forms of lake-trout, S. ferox, have been found possessing a few in excess of those which inhabit streams.

The observations of pisciculturists and field naturalists, respecting the varieties of trout and the modifications to which they are susceptible, may prove most raluable in unravelling the confusion which has been imported into this genus. In the following pages I have purposely omitted the enumeration of some continental forms that doubtless will at a future date be abundantly proved to be merely species created by naturalists, but unable to stand the test of a rigorous examination carried on in an extended scale by competent inquirers.

2. Salmo trutta, Plate CXI, fig. 1, and Plate CXII, fig. 1, 2.

Trutta salmonata, Schonev. Ich. p. 65; Willughby, p. 193; RaJ, Synopsis, p. 63. Salmonata, Sibbald, Scot. no. 25. Salmo cinereus aut griseus, Willughby, p. 193 ; Ray, p. 63. Salmo trutta, Linn. Fauna Suec. p. 347 ; Gronov. Zooph. no. 367. Salmo, no. 3 and 5, Artedi, Synom. pp. 23, 24, Genera, p. 12, and Species, p. 51 ; Klein, Pisc. Miss. V, p. 16, t. v, f. 1. Sea-trout, Pennant, Brit. Zool. (Ed. 1776 ) iii, p. 296 (Ed. 1812) iii, p. 347. Bull-trout, Low, Fanna Orcad. p. 222.

Sulmo trutta, Linn. Syst. Nat. i, p. 509 ; Bloch, Fische Dents. i, p. 143, t. xxi; Bl. Schn. p. 399 ; Gmel. Linn. p. 1366 ; Bonn. Ency. Ich. p. 159, pl. lxv, f. 263 ;

* "The acclimatization of the salmonidæ at the Antipodes."

$\dagger$ Lacépede considered the Salmo trutta identical with S. fario. 
Turton, Brit. Fauna, p. 103; Risso, Ich. Nice, p. 323 ; Flem. Brit. An. p. 180 ; Nilss. Skand. Fauna, p. 406 ; Jenyns, Manual, p. 423; Kröyer, Dan. Fiske, ii, p. 582; Jardine, Salmonidæ, pl. iii (half grown) ix, $\mathbf{x}$, and xi, and Edin. New Phil. Journ. xviii, p. 49; Yarrell, Brit. Fish. (ed. 1) ii, p. 36, c. fig. (ed. 2) ii, p. 77 ; Parnell, Fish. Firth of Forth, p. 133, pl. xxxiv, and Wern. Møm. vii, p. 293, pl. xxxiv, f. 11; Thompson, Nat. Hist. Ireland, iv, p. 151; White, Catal. p. 75 ; Gronov. ed. Gray, p. 151; Günther, Catal. vi, p. 22; Steind. Sitz. Ak. Wiss. Wien. 1866, liv, p. 22; Houghton, British Freshwater Fishes, p. 93, c. fig.; Malm, Fauna, p. 538.

Salmo goedenii, Bloch, p. 135, t. cii (young).

Salmo huchu, Flem. Brit. An. p. 179 (not Linn.).

Salmo argenteus, Bonn. Ency. Ich. p. 160, pl. lxvii, no. 269 ; Bl. pl. ciii.

Fario argenteus, Cur. and Val. xxi, p. 294, pl. 616; Yarrell, Brit. Fish.

(ed. 3) i, p. 250, c. fig. ; Lacépède, v, p. 187 ; Kröyer, Dan. Fisk. ii, p. 602.

Salmo eriox, Nilss. Skan. Faun. p. 395; Collett, Norges Fiske, p. 157 ;

Feddersen, Danske Ferskvanstiske, p. 77.

Salmo truttula, Nilss. Prod. p. 5 (young).

Salmo microps, Hardm. Ofvers. Vet. Ak. Förh. 1861, p. 383.

Trutta variabilis, Gerv. Boul. p. 137.

Salmon-trout, Richards. Faun. Nor, Amer. Fishes, p. 140, pl. xcii, f. i, A and

B. Peal, sewen, sea-trout, salmon-trout, blue-poll, Conch, Fish. Brit. Isles, iv, pp. 214-22], pl. cexiii-cexv (see page 88).

Salmo venernensis, Günther, Catal. vi, p. 110.

Trutta lacustris and T. trutta, Siebold, Süsswasserfische, pp. 301, 314.

Trutta marina, Morean, Poiss. France, iii, p. 537.

Variety a.-Salmo albus, Plate CXII, fig. 2.

White salmon, Pennant, Brit. Zoól. (Ed. 1776) iii, p. 302, and (Ed. 1812) iii, p. 396.

Salmo albus, Walb. Artedi, iii, p. 75 ; Bonnaterre, Enc. Ich. p. 161 ; B1. Schn. p. 409 ; Lacép. $\nabla$, p. 219 ; Fleming, Brit. An. p. 180 ; Jardine, Edin. New Phil. Journal, xviii, p. 50, and Salmonidm, plate no. ïi; Cur. and Val. xxi, p. 206; Jenyns, Manual, p. 424.

Salmo phinoc, Turton, Brit. Fauna, p. 103.

Herling, Jardine, Berwick. Nat. Club, ii, p. 103.

Salmo eriox, Jenyns, Brit. Vert. An. p. 422; Parnell, Wern. Mem. vii, p. 288, pl. xxxi-xxxiv, and Fish. Firth of Forth, p. 128, pl. xxxi-xxxiv; Flem. Manual, p. 180.

Salmo trutta, Thompson, Nat. Hist. Ireland, iv, p. 151.

Salmo brachypoma, Günther, Catal. vi, p. 87; Houghton, British Fishes, p, 107, c. fig.

This form has been deemed a distinct species, principally due to its comparatively small head and rather elongated body: while its preopercle has hardly any lower limb. Among four examples in the British Museum from Dr. Parnell's collection, that ichthyologist considered the largest as $\mathcal{S}$. eriox, and the remaining three as $S$. fario. It is the short-headed race of salmon-trout, mostly found on the east coast of Scotland and in the Ouse: Jardine states also, in the Solway Firth. The example figured was 14 inches long.

This variety was known as the White salmon (Pennant), Salmo albus (Artedi), S. phino (Turton), S. brachypoma (Günther); but by the majority of recent authors is placed as a synonym to $S$. trutta. Pennant described his white salmon from the Esk in Cumberland, where he observed that it was found from July until September, that it never exceeded a foot in length, and that "this is the fish called by the Scots Phinoc." Fleming also termed it the "Whitling, Hirling, common in the sea and rivers of Scotland and the north of England," and that it spawned in August and September. Jardine figured it, pl. iii, as Salmo albus, Fleming, the young of a migratory trout, but not identical with the bull-trout of the Tweed. It is locally known as herling or hirling, whiting, phinock, moudietrout, silverwhite, and blacktail, in different Scotch districts. It was about this 
time that S. albus began to be suppressed under the belief that it was the young or a variety of the salmon- or sea-tront. Jenyns observed that neither he nor Yarrell could see any appreciable difference between them. It is abundantly evident, however, that Yarrell in his Salmo trutta includes the sewin of the south, Wales, and Ireland, as well as the phinock or hirling of Scotland, which he observes is the S. albus, but that he could not distinguish it from his S. trutta. Agassiz looked upon these forms as one, so did also Parnell, White, and Thompson. Dr. Günther reverted to the views of Pennant, remarking how the species in his opinion differed from S. trutta, five out of seven of his types being from Yarrell's and Parnell's collections. But he placed all the synonyms of S. al.bus under the head of S. trutta, even when the authors had referred to both as species. It thus came to pass that this northern species, or $S$. albus, has since 1866 been known as $S$. brachypoma, Günther, which is the more remarkable, as prior to the publication of the volume of the Catalogue in which it was first thus named, the anthor was able to record in the Addenda, p. 357, that he had received examples from the Beauly, "and that they are named there 'Phinok." "

Although a chain of examples, passing from this form into the river trout, has not been recognized, I shall, when describing the short-headed fresh water Loch Leven trout, give my reasons for supposing that it is most probably a descendant of this short-headed marine variety, and also show how it does not appear improbable that it, under certain conditions, may pass into and be lost in the Salmo fario. These numerous deviations from the type tend to demonstrate the adaptability of the species to varying conditions of life, and as we do not perceive such in the salmon, one would expect to find the trout in one or other of its forms extending further, or accommodating itself to greater ranges of the globe, and this is exactly what we observe in nature.

\section{Variety b.-Salmo cambricus, Plate CXII, fig. 1.}

Salmulus, Willughby (young). The grey salmon, part, Pennant, Brit. Zool. (Ed. 1776 ) iii, p. 295, and (Ed. 1812) iii, p. 394. Salmo, no. 2, Artedi, Genera, p. 12, Synon, p. 23, Spe. 50 ; Linn. Fauna Suec. p. 116, no. 307.

Salmo cambricus, Donovan, Brit. Fishes, iv, pl. xci; Richards. Faun. Bor. Amer. Fisb. p. 141, pl. хci, fig. 2; Günther, Catal. vi, p. 34; Houghton, Brit. F. W. Fishes, p. 99, c. fig.

Sewen and Blue poll, Couch, Fish. Brit. Isles, iv, pp. 208, 219, pls. ccxiii, ccxvi.

Salino erioe, Gmel. Linn. p. 1366; Bon. Ency. Ich. p. 159; Turton, Brit. Fauna, p. 103; Flem. Brit. An. p. 180; Jenyns, Manual, p. 422 ; Yarrell, Brit. Fish. (ed. 1) ii, p. 31, c. fig. (ed. 2) ii, p. 71 (ed. 3) i, p. 231 ; Kröyer, Dan. Fiske, ii, p. 602; Thompson, Proc. Zool. Soc. 1837, p. 57, and Nat. Hist. Ireland, iv, p. 148 ; Nilss. Skan. Fauna, p. 395 ; White, Catal. p. 76 ( part).

The sewin of the south coast, Wales, and Ireland, similarly to the salmon-tront of the east coast of Scotland, has both a long- and a short-headed variety.* Two examples of sewin from Rosshire, presented by Mr. Godman, are in the British Museum. So similar, however, is this fish externally to the salmon-trout, and passes into it so exactly, that of one of Yarrell's examples in the national collection being a skin destitnte of any record of its coecal appendages, Dr. Günther has remarked that "it is one of those specimens in which the distinctive characters of the species are very little developed: and it is quite possible that the specimen came from Scotland, and belongs to Salmo trutta." Having thus shown how difficult, if not impossible, it may be to discriminate between these two forms, I will pass on to how physical causes may occasion changes, so that it has become very nncertain which of the two that is under examination, and for this purpose I must again revert to the Tasmanian experiment. Anadromous salmon ova were collected in this country, and transmitted to the Antipodes, where they arrived in May, 1866. Some

* In Plate CXX of Salmo fontinalis the great difference occasioned through physical causes in the comparative length of the head in a salmonoid fish is shown. 
of the fry were retained in a fresh water pond, bred there, and one of these examples, which exceeded 18 inches in length, was received at the British Museum in April, 1874. Its external appearance was similar to the typical Salmo trutta, but internally it possessed only 36 coecal appendages, demonstrating that either $S$. trutta may possess less than 43 , or that $S$. cambricus may externally develop into S. trutta, or lastly, that $S$. albus may have a preoperculum with a distinct lower limb.

It seems evident that the external form and number of coecal appendages are insufficient to discriminate it from the salmon-trout, and I now arrive at the consideration whether it can or cannot be distinctly differentiated from the brook-trout, a subject already adverted to (page 83). A fine series from Wales, in the national collection, shows an unbroken series in external form, in colour, and in dentition between the two, and asserted to be hybrids.* Other specimens from Copenhagen are likewise present. The number of coeal appendages in these forms were found to be from 41 to 46 . They are said to be locally known as Twb-y-dail or "fall of the leaf," indicative of their colour, but in Owen's Welsh Dictionary I find this local term employed for the chub, Leuciscus cephalus. And finally, it may be repeated that breeding the two forms together does not produce sterile hybrids but fertile varieties.

In 1879 a correspondence commenced respecting the blue poll and blue cock of the Fowey in Cornwall, Salmo cambricus, they are also termed Candlemass fish, and are sold in Billingsgate as "Cornish salmon." Some which used to be taken at the beginning of the year were said to have been unmended kelts, while an example sent from that river in December, 1879, to Mr. Frank Buckland, proved to be a male with the milt fully developed and ready for extrusion. In a memorial from fishermen and others at or near the Fowey to the conservators, it is stated that these fish ascend the river from "September to Christmas in accordance with their natural habits," and although bearing spawn it was suggested that the fishermen ought to be allowed to capture them during the close season $f$ because spawning sea fish are not protected, and that it is only at this period that the fishing could be successfully prosecuted. Leave was requested that this petition should be granted, but was very properly refused. In the Towy, in Wales, the same variety termed Salmon glasback, "little blue salmon," largely ascend for the purpose of spawning in the last week in January and the first half of February, and we are told that thirty years ago, prior to the re-institution of a close season, all the males were crimped and sent to the Severn district as a clean run fish, while the females were dispatched there as they were.

In the British Museum are other examples from the Lossie river and Moray Firth on the Seotch coast, passing from the typical salmon-trout by a graduated series into the river-trout: they are also recorded as hybrids.

Parncll, under Salmo eriox, comprised in the Wernerian Memoirs the following varieties found in the Firth of Forth. Salmon spotted bull-trout, plate xxxiii, f. 4: few spotted bull-trout, plate xxxiii, f. 5 : thiclly spotted bull-trout, plate xxxiii, f. 6: large headed bull-trout, plate xxxiii, f. 7: curved spotted bull-trout, plate xxxiii, f. 8: salmon bull-trout, plate xxxiii* : crescent-tailed bull-trout, plate xxxiv, f. 9: Norway bull-trout, plate xxxiv, f. 10. While under Salmo trutta he gave

* Although hybrids among the salmonidxe had been observed as existing from the time of Willughby, edited by Ray (1686), Dr. Günther remarks, "no instance had been clearly made out until we were enabled, through the liberality of the Rev. Augustus Morgan, to convince ourselves of the existence of a hybrid between the sewin (S. cambricus) and the river-trout (S. fario)" (Catal. vi, p. 8). Further on he continues "We have never had an opportunity of observing a naturally sterile individual "(p. 47).

$\dagger$ In the Coquet, H.M. Inspectors of Fisheries were led to believe that the bull-trout only or mostly ascended during the close season, and that they were destroying the breed of the salmon. Elsewhere we are told they get first to the spawning beds ousting the Salmo salar. So in 1868 leave was given by the Home Office to fish during the close months. In four years 61,689 bulltrout were captured, and in each of the four years as follows: 26,350, 15,464, 10,687, and 9188 . Destroying this form is said to have been a failure, but the result of such a license is evident, for in the first year nearly half the entire captures for the four years occurred, the takes annually decrcasing until the fourth year, the last that Buckland recorded. 
S. allus, Fleming, and the individual specimen the base of Parnell's figtare, plate xxxii, fig. 3 , is in the British Museum collection as one of the types of $S$. brachypoma, Günther. It is evident that only the local east coast of Scotland races formed the basis of his paper.

Yarrell's S. eriox and S. trutta, as seen by his collection now in the British Museum, included the sewin or S. cambricus, also the S. albus. Two were S. trutta, about twenty S. cambricus besides many small ones, and one S. albus forming one of the types of S. brachypoma, Günther.

Thompson observes that his $S$. trutta is identical with $S$. albus, the Scotch Herling sent him by Captain Fayrer, and that he found a perfect agreement between them, while his $S$. eriox he asserted to be $S$. cambricus or the sewin.

Couch largely augmented the nominal species of salmonidæ and gave the five following:- Salmo trutta which he terms Peal, and obserres that under several names it is known in considerable abundance through the whole extent of the British Island, S. cambricus or sewin, Sea-trout from the Fowey in Cornwall, evidently identical with the so-called hybrids of the sewin. S. trutta no. 2, termed salmon-trout, which he asserts to be more a fish of the north than the generality of this genus, and seems to be identical with $S$. eriox, Yarrell, or a compound of $S$. allus and $S$. cambricus. This author appears to bave been misled by two circumstances; first, he accepted without due investigation the numerous subdivisions into which he found this species being divided by those who held every little difference to be diagnostic of a distinct form or the result of hybridization, and any who questioned such were deemed incompetent observer's suffering from confused ideas.* As a result he seems on finding what he conceived to be some fresh but slight modification to have supposed he had discovered another new species, thus adding to the confusion already existing. In fact (at p. 204) he remarks upon the difficulty of assigning to his specimens the names given by the writers on the continent, and supposed as a reason "that there exists several kinds of the Salmonidoe which are not yet clearly defined," and that not a few of the known varieties will be discovered to be distinct species. Secondly, it would seem that his descriptions were, at least in several instances, made from his drawings, which, if artistic, are scarcely accurate.

Widegren (Ofv. Vet. Alad. Förh. 1863) gare an interesting paper in which he asserted that the anadromous sea-trout and non-migratory fiesh water forms were all variatious of one species, the differences being due to the localities they inhabited. Sterile forms, or rather those suffering from temporary sterility, having the caudal fin generally (but not invariably) more forked, and their colours more silvery than is seen in such as are in a breeding condition. In these conclusions Malmgren generally agreed, and they appear to coincide with the results of the experiment I have alluded to and the series of examples in our national collection.

B. x-xii, D. 12-14 $\left(\frac{s-\frac{s}{0}}{0}\right) / 0$, P. 13-14, V. 9, A. 11-13 $\left(\frac{s-4}{\frac{8}{-1}}\right)$, C. 18-19, L l. 115-130, L t. $\frac{24-27}{38} \cdot \frac{2}{2}$, Vert. 59-60, Cœe. pyl. 33-61.

Body rather elongated, and the abdominal profile more curved than that of the back. The proportions of one part of the body to the renainder, more especially the length of the head, vary considerably in this species, and thongh 1 consider the fresh water brook-trout specifically the same, the following measurements and remarks solely refer to the anadromous form, unless otherwise stated. The young in most respects are similar to the young of the salmon, while in the adult fish the head in the male is generally longer than in the female. Length of head $4 \frac{1}{2}$ to $5 \frac{1}{2}$, of caudal fin from $7 \frac{1}{4}$ to 8 , height of body from $4 \frac{1}{2}$ to $5 \frac{1}{2}$ in the total length. Eyje-diameter about 7 to $7 \frac{1}{2}$ in examples exceeding 15 inches in length, about 2 to $2 \frac{1}{4}$ diameters from the end of the snout, and the same distance apart: it is comraratively larger in the young. Interorbital space convex, and

* Fitzinger when asserting Salmo Schiffermuelleri, Bloch, to be a hybrid (Sitz. Ak. Wien, Ixxii, $1876, \mathrm{p} .255$ ) seemed to have been mainly guided in his decision by ascertuining that the reproductive organs only exist in a rudimentary condition in the young stage, degenerating into adipose
tissue in the adult. 
equal to about the length of the snout. During the breeding season a knob frequently exists at the upper side of the anterior end of the lower jaw in the males. The posterior extremity of the upper jaw reaches to beyond the hind edge of the eye in full-grown examples, and it is stronger in some varieties than in others. The form of the gill-covers in this fish has been held to almost denote species with some authors, to be dependant on sex according to others, or to be of no signification at all. In some, as the typical $S$. trutta (see plate cxi), the posterior edge of the preopercle is somewhat sinuous, while it has a distinct lower limb: in the sewin this latter is less distinctly marked (plate cxii), but in the white salmou, or herling, there is hardly a trace of it; but, however, every intermediate form may be found, or they may even differ on the opposite sides of the head in the same specimen. The posterior edge of the opercle and subopercle form a semi-circle, in which the subopercle generally, but not invariably, forms the most prominent point. Several raised and curved lines are mostly present upou the outer edge of the subopercle and opercle. Teeth - in the young similar to those in the salmon fry: there is a double row along the body of the vomer and a transverse row where it joins the palatines. At an early age these vomerine teeth become lost more quickly in sume examples than in others, but generally there is only a single row in examples a foot or upwards in length: the example in plate cxi, which was 14 inches long, had a double row of six teeth on the vomer, besides a transverse row of four anteriorly. The teeth in the jaws and palatines in a single row. Three to six strong, sharp recurved ones on either side of the tongue. Fins-in large examples the fins are comparatively shorter than in smaller ones, and the pectoral rarely extends half-way to the base of the ventral, which latter is situated beneath the middle of the dorsal. The dorsal fin is comparatively small : while the caudal is subject to considerable diversities of form, in large fish being mostly almost square at its posterior extremity, or it may be notched, or should the ends of its lobes be drawn asunder, it appears to bo lunated. Scales14 or 15 rows in an oblique line from the hind edge of the adipose dorsal fin, downwards and forwards to the lateral-line. The scales in this species, more particularly in the young, are very deciduous. Coecal appendages vary considerably in number, and though I am satisfied that their enumeration recorded as existing in the British Museum specimens is correctly recorded in the Catalogue, I find reason to believe a much wider difference can be found in nature. Mr. Brotherton, of Kelso, sent me in August a fine specimen from the Tweed, termed "bulltrout" (similar externally to the figure in plate cxi, fig. 2), it was a female, with small ova, only two teeth remained on the forepart of the vomer, its tail was almost square at its extremity, and it only possessed 33 cœcal appendages. Colours-Back bluish gray, becoming lighter on the sides and beneath, having a purplish gloss when in the highest condition, but which takes on a muddy hue after having been some time in fresh water. Small black spots, mostly of an X-shape, exist along the gill covers and upper two-thirds of the body, or merely upon the upper half of the gill covers, where they may be surrounded by a light margin, while on the body they frequently are not seen below the lateral-line. Some are densely, others sparsely spotted, with every intermediate variety. The dorsal fin similarly may be destitute of spots, thickly or thinly covered by them. Pectoral of a bluish lilac, often darkest externally. Caudal gray, or even dark coloured. During the spawning season the head of the male is of an olive brown, and the body of a ding'y orange, or reddish brown, while the female is of a blackish gray. Thompson alludes to one example which had a series of deep orange longitudinal stripes, probably a male in the breeding livery. Parr or orange fins are marked almost similarly to the young of the salmon, but the dorsal fin has generally a white upper edge anteriorly, with a black basal band, which often passes along almost the entire extent of the upper fifth of the fin, and similar to the colours seen in the brook-trout. In the grilse state the caudal is usually blackish.

Varieties - These are referred to under the head of Salmo albus (page 85), and S. cambricus (page 87): while the fresh water forms will be discussed under S. levenensis (page 93), and S. fario (page 95). 
Names.-The term salmon-trout was originally employed under the supposition that these fish were hybrids between the salmon and the trout. Mort or Sprod, Cumberland and Lancashire. White trout, salmon-trout, bull-trout if large and coarse : the scurf, Johnston. In the grilse stage in Scotland, phinot, herling, whitliny, black-tail, silver-white, smelt, sprod, herring-sprod: and lammasmen, Edinburgh market. During the first year or two parr, orange fins or yellow fins: sit-bodiam, Welsh, which descend to the sea as smolts. Pennant gives the Welsh names as gwyn-iâd "white pate," and gleis-iâd "blue pate."

Hatits. - This species has generally the habits of the salmon but not to so game an extent, nor is it so powerful, still it is active and appears to move more of an evening and during the night than during the day, and frequently selects more sluggish waters than suit the salmon, even where the bottom is sandy or muddy. It is often found at the tail of a pool or where the waters are quiet, but is of a roving disposition. It is a wary and sharp-sighted form, always suspicious, and the angler requires a long line when attempting to take it. It dashes at flies but appears in some streams to lie rather deep in the water and hardly to be a surface form. It is very destructive to small fish and by no means averse to consuming the eggs or the young of the salmon. In an example 14 inches long from the Dee, taken in July, 18isz, I removed four sand launces, Ammodytes, from its maw. Sir W. Jardine found the common food to be the sand hopper, Talitrus locusta.

In the mackerel drift nets employed from March until May in the British Channel, single examples of this fish are frequently taken. Also at the mouths of rivers in Cornwall during summer and autumn in hang or moored nets. While even in the rivers a few are captured throughout the year, showing that similar to the salmon it is not in rariably absent, but it more generally becomes abundant at the end of summer or in the autumn. The migrations of the Salmo trutta and its varieties, correspond to a great extent with those of the salmon, but it appears to possess somewhat less power, and consequently is not so capable of ascent and overcoming obstructions. Some very interesting figures are adduced by Russell showing the proportionate number of these fishes captured in the Tweed during the eight and a half open months of the year. One-tenth were taken in the first three and a half months, or from the middle of February to the end of May; and nine-tenths during the remaining five and a half months extending from June lst to the middle of October. In fact, in Iune they suddenly augmented by 300 per cent. and in July stood at the highest figure : but a change now occurred, the fish becoming of less average weight, pointing to a large proportion being young. In some of the Irish rivers the salmon trout runs very early. Mr. Congreve considers bull-trout to be sterile examples of this species which have ceased breeding and discontinued their annual migrations, while their flesh may be either white or pink.

Means of capture.-These fish are very wary and it has been observed in the Tweed and neighbouring fisheries that they will not freely enter the chambers of the fixed nets, the proportion of them captured there being one for every nine grilse or four salmon. But in the drifting hang nets at the mouths of the rivers or in the estuaries three or four trout are taken for every salmon, and in about equal numbers with the grilse. The same is observed elsewhere, and in the estuaries of South Wales sewin of from $1 \mathrm{lb}$. to $4 \mathrm{lb}$. weight are frequently captured during March and April.

Anglers find in rivers these fish will mostly take a worm if the waters are muddy, as it begins to clear a spinning bait, when fine a fly. If hooked they often display considerable cunning in their attempts to break the line with a blow from the tail, or impetuously dart off when a similar result ensues, should it not run readily off the reel. In Scotland an hour or two's white tront fishing when the fish are in the humour, is esteemed good sport as they often take a fly well, up to 6 or $7 \mathrm{lb}$. weight; while in Wales the sewin similarly are sought after, especially of an evening, with fine tackle and a small fly. But large examples, as ball-trout, appear to refuse bait or flies. The smaller ones in salt water readily take a spinning bait and are often thus fished for on the 
west coast of Sootland, while whiffers for pollack on the south coast of Englnnd not unfrequently take a sewin. In Ireland a few salmon-trout are taken in the mullet nets: in Belfast Bay they are captured in large quantities early in the morning, if possible before day-break, by drawing sandy bays. In the Bristol Channel, where the Severn, Wye, and Usk debouch, there exist certain fixed engines termed putts and putchers, which, although capturing more salmon and grilse than sewin, still are employed to take this fish. These fixed engines were declared nuisances and illegal, unless proved to have been in existence prior to Magna Charta: even then an annual close time was decreed, as well as a weekly one. The fish Commissioners in 1879 were requested by the fishermen to aid their endeavours to make it legal to omit the weekly close time, provided the yearly close season were extended from September lst to February 1st (practically it did not pay to commence before March or April) to from September lst to March 18th, and now, due to the Commissioners' report, week days and Sundays alike this fishing goes on without a weekly close time (Field, August 2nd, 1879).

Breeding. - The number of eggs deposited by the Salmo trutta is very similar to what obtains in the salmon, and the remarks already made (p. 75) may be referred to. In a very severe winter Couch found the sewin depositing its eggs as late as January 22nd in the Fowey in Cornwall. The impurities and enemies affecting those of one form are similarly inimical to those of the other (p. 65), and as showing how anadromous species may deem it useless spawning in salt water, I will quote Mr. Jackson, Land and Water (June 10th, 1876), who observes that the "Salmon-trout cast their ova in the salt water in the Southport Aquarium, without assuming the appearance of kelts, or even leaving off feeding greedily on shrimps. They did not attempt to make a bed, and the spawn was immediately eaten by their fellows." While the eggs of this species, similarly to those of the salmon, have been safely conveyed to and hatched at the antipodes.

life history.-The young Salmo trutta, as already observed, is very similar to the young of the salmon, having its parr stage, and though it has been asserted that anadromous forms are distinguisbable by the number of transverse bands or finger marks along their sides, it will be found that such a means of diagnosis fails in practice among live fish. The parr of the salmon-trout goes through the smolt and grilse stage, similarly to the young of the salmon, while its parr are equally voracious (p. 70).*

As food.- Those possessing yellowish, pink, or red flesh are almost equally good as the salmon : the "bull-trout," however, of the Coquet is inferior, having light coloured or white flesh, as has that fish sometimes taken from the Beauly, but in some places those in which it is white are of a superior description. It is remarkable that those from the Coquet are almost wortbless, whereas the Tweed form is very valuable, this being probably dne to difference in water or food. As a general rule large examples are found to be coarse.

Diseases. -Those affecting salmon (p. 81) are similarly found attacking the sea trout. Even so long ago as Pontoppidan (Natural History of Norway, 1755, p. 139) we find allusions to disease affecting these fish. He asserts the salmontrout, Trutta taurina, to be a very common fish in the fresh lakes and rivers, but many of them are subject to a sort of disease so that they cannot be eaten. The head grows very large and the body emaciated, while in their entrails are found pimples resembling millet seed. Some ascribed it as due to the sawdust from the mills falling into the river, while others considered it to be retained roe which had become diseased. This complaint was asserted not to affect the non-migratory fresh water trout.

Habitat.-In this, only the marine variety is alluded to, and it is found in northern Europe ascending rivers falling into the Baltic, North Sea, the seas surrounding the British Isles, and the Seine and the Loire in France. trout.

* The various kinds of food suitable for roung salmon are equally good for the salmon- 
In the Orkneys, Low observed that it exists in great quantities in the Loch of Stenness, through the whole summer. They do not grow so large as the true trout, Salmo fario, neither are they so much esteemed, their flesh being white and only moderately good. During harvest they ascend to the smallest streams to spawn subsequent to which they return to the sea. It is common along the east coast of Scotland, and Russell calculated that in the Tweed it is as numerous as the salmon and grilse combined: to the south of the Tweed fifty to every salmon and grilse, while in the Forth and Tay and other large and inaccessible rivers in the north the bull-trout is almost a stranger. It is also found along the north-east coast of England, more especially the Coquet, Tyne, Tees, and Wear. It is less frequent on the west coast of Scotland than on the east. In Yorkshire very abundant along the coast and present in all the rivers frequented by the salmon (Yorkshire Vertebrata). In Norfolk it is frequently taken in the Ouse and the estuary (Lowe). Excepting the "Fordwich trout" from Kent, which is of the typical Salmo trutta form, S. cambricus is generally found from the south of England and Wales, extending up the west coast of Scotland.

In Ireland it is common around the coast.

As to the size it attains there exists the head of one in the British Museum 10 inches long from the Tweed, which measurement would seem to show the fish must have been nearly 4 feet in length.

The figure, plate exi, fig. 2, is from a male in the British Museum, 18 inches long, from the Tweed, which contained 57 coecal appendages, and is similar to a female I have from the same locality with only 33 . In the variety $S$. albus figured, there were 53 coecal appendages, the specimen was a female; the example of S. cambricus was taken off Penzance in a trammel, August 13th, 1881, it was a female 14 inches long, with the ova half developed, it had 40 corcal appendages: a young male 13 inches long from Wales possessed 41.

\section{A. Salmo Levenensis, Plate CXVI, fig. 2 and $2 a$.}

(?) Salmo Cumberland, Lacépède, $\nabla$, p. 696.

Salmo Levenensis, Walker, Wern. Men. i, p. 541 ; Yarrell, Brit. Fishes (ed. 2) ii, p. 217 (ed. 3) i, p. 257 ; Günther, Catal. vi, p. 101 ; Couch, Fishes Brit. Isles, iv, p. 243, pl. ccxx; Houghton, Brit. Freshwater Fishes, p. 123, c. fig.

Salmo cacifer, Parnell, Fish. Firth of Forth, p. 146, pl. xxx, and Wern. Mem. vii, p. 306, pl. $x \times x$.

Loch Leven trout, Richardson, Faun. Bor.-Amer. Pisc. p. 143.

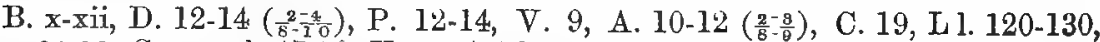
L. tr. $\frac{24-2}{30}-\frac{2}{2}$, Cœe. pyl. $47-90$, Vert. $57-59$.

Body rather elongated, with the abdominal profile a little more curved than that of the back. Length of head about $4 \frac{3}{4}$ to $5 \frac{1}{4}$, rather longest in the males, of caudal fin 8 , height of body $4 \frac{1}{2}$ to 5 in the total length. Eye-diameter in an example about $\frac{3}{4} \mathrm{lb}$. weight, $5 \frac{1}{2}$ to 6 in the length of the head, $1 \frac{1}{2}$ diameter from the end of the snout, and the same distance apart: it is of greater comparative size in smaller specimens, but smaller in larger ones. Interorbital space convex. Maxilla rather feeble, it reaches to slightly behind the hind edge of the eye: lower jaw with a hook or knob at the upper end of the mandible. Lower limb of preopercle generally, but not invariably, indistinct. Teeth-of pooderate strengtb, a double row along the body of the vomer, which are sometimes more or less lost, and a transverse row of 3 or 4 opposite its junction with the palatines. In some few cases a single row of teeth has been observed along the body of the vomer, but in no instance have I found this to be the case in the Howietown fish, all of which have a double row similar to the brook-trout. Fins-these vary in the Locls Leven as well as in other forms of tront, and are due to the same causes. The pectoral is more pointed than is generally seen in the brook-trout, but like that of the white sea-trout, and reaches to about half-way to the base of the ventral, 
which latter fin is inserted under the middle or hind third of the first dorsal, and extends above half-way to the origin of the anal. Caudal emarginate, becoming square in large examples. Scales there are 13 to 15 rows in an oblique line running from behind the base of the adipose dorsal fin downwards and forwards to the lateral-line, cœeal appendages varying in this species: Richardson found 73 , Parnell 80, Günther 49 to 90 , due either to several becoming confluent into one stem, or one subdividing into several, but anyhow demonstrating inconstancy in numbers. In a female example with the ova developing, the length of the fish being 8 inches, received from Howietown in June, 1882, there were 47 coecal appendages, and mostly shorter than in the brook-trout: the length of the head was $4 \frac{3}{1}$ in that of the total length. Colours - generally grayish or greenish along the back, becoming lighter on the sides and beneath. Numerous, moderate numbers, or few round black spots, encircled by a light ring on the gill covers and upper surface of the head, while the upper half, or two-thirds of the body, has numerous $\mathrm{X}$-shaped or even rounded black spots scattered over its surface. Dorsal fin gray, with numerous black white-edged spots, but without any white tip to the fin: frequently black marks upon the adipose dorsal. Usually the upper half of the caudal fin is spotted. At Howietown, where such excellent opportunities exist for trying the effects of various forms of food and watching the results, it has been observed (page 61) that on arriving at the fourth year a general yellow tinge shows itself. On first seeing a pond of these fish which have been fed upon clams, and as they come to the surface in large numbers, when a little food is thrown in, they give the observer the idea that he is looking at the common brook-trout, and it is not until some have been removed from the water and their comparatively short heads seen, that the illusion is dispelled. In the tanks in which horse-flesh and vegetables are given as food an apparently very different sort comes to the surface, having a bright silvery hue with black spots, and it seems difficult to realize the fact that this is almost entirely due to change of diet.

I have also alluded to (page 61) how these fish when in the parr stage retain their red spots up to the period of eighteen months, or even three years, but that such may likewise be perceived in these trout when intermediate between kelts and fresh run or well-mended fish. Although in some few examples they may be present all the year round.

Lacépède's species from the lakes of Cumberland and Scotland, having a small head, with white flesh, and externally of a gray colour, is very probably this species. Dr. Knox (Journ. Linn. Soc. Dec. 19th, 1854), observes, at first he had thought this a specific form, "although anatomical investigations had not hitherto confirmed it." He remarked that it was in the highest condition from December until March.

This form of trout agrees with the variety of the sea-trout termed Salmo albus, in its same short head, preopercle with a very indistinct lower limb, and pointed pectoral fins, but it differs in the inconstant character of the number of coecal appendages. The most positive difference is in the character of its vomerine teeth, possessing as it does a double row along the body of that bone. In early life all fishes of this genus are well provided with vomerine teeth, which are more deciduous in anadromous than in fresh water forms. This would appear to point out that a fresh water existence is more conducive to their retention than living in the sea is, consequently it might be anticipated that were marine forms to take in a permanent fresh water condition of life these teeth would be less deciduous. This in fact is the distinction between the Loch Leven trout and the white sea-trout, and in the sewin we perceive a graduated series (page 59) from the sea to the fresh water form, whereas in this instance all communication between the two has ceused to exist. Unless the example from Howietown which I dissected is an exception, it would seem that change of locality to a smaller piece of water has been coincident with a decrease in the number of the pyloric appendages, coupled with a decided lengthening of the head.

Habits.-These are similar to what have been remarked in the brook-trout. During the breeding season it has been observed that some adults possess abraded 
noses, due apparently to rubbing or routing up the ground for eggs, but as such is not seen among unripe fish it is suggested that it may be occasioned by their searching for suitable places in which to form redds.

At Sir J. Gibson-Maitland's Howietown fishery, one fact was very patent, that the form of trout least alarmed at the presence of strangers was the Loch Leven, coming immediately to the surface for food, making the water bubble with their numerous forms, while they allowed themselves to be removed by means of a handnet; the American charr kept more to the mid-water; but the common brooktrout were so cunning that the very sight of a net caused them to dive down and remain at the bottom. It may be that this difference in character is due to inberited instinct and that by the time the Loch Leven trout have been exposed to capture for several generations they will be as crafty as the Salmo fario has now become. Some of the young raised at Howietown are observed to take on cannibal propensities, if small their colour becomes yellow, their teeth abnormally developed, while they rapidly augment in size. At Loch Leven during the breeding season these fishes are observed to push up rivers to deposit their spawn, and in these localities the young are hatched and the parr reared. In fact its habits appear to be migratory to a qualified extent, the parr not leaving the burns for the loch until they are from ten to eighteen months of age.

Knox found that they were filled with entomostraca in the month of Jannary, but that during the remainder of the year they lived on Buccinum: at Howietown they thrive on clams, horseflesh, or even vegetable diet.

If we turn to Sir Robert Sibbald's History of Kinross-shire, compiled about a hundred and seventy years ago, we read "Loch Leven abounds with fine fisb, such as salmon taken in summer;" while showing to how recent a date anadromous forms have been recorded there, we find in Graham, "General view of the agriculture of Kinross and Clackmannan," published towards the commencement of the present century, that among other fishes "flounders are also found in Loch Leven." These instances agree with the general traditions of that part of the country, that marine fish formerly had free ingress into and egress from Loch Leven, but when this ceased is questionable. Prior to 1830 the loch covered a superficial space of 4312 acres, but in the month of December that year it was reduced to 3543 acres by the completion of a drainage scheme, promoted partly by landowners in the vicinity to reclaim land and partly by mill owners on the river Leven to give a regular supply of water to their mills. Through the new cut the water has since been carried, reducing the level of the loch nine feet below what it previously stood at. Sea fish cannot possibly obtain ingress, a matter of not so much consequence, as the bleach and other works on the river render the water too poisonous for any fish to pass up them alive.

These drainage works do not appear to have proved beneficial to the trout in the loch, where from 1846 to 18.55 the captures principally taken by net averaged annually 13,200 , subsequent to which I have not obtained the figures until 1872 , when 18,000 were taken by anglers and $2000 \mathrm{ly}$ net: and in 1873, when 13,394 were taken by the rod. Latterly this loch has been much frequented by anglers, and as the fisb (probably due to the excessire lowness of the burns), appear now to be less favourable for breeding, artificial stocking bas been resorted to.

Sir J. Gibson-Maitland (Field, Sept. 23rd, 188.) shows the results of stocking this loch from his establishment at Howietown :-

1875 , fry turned in 9000 : captures 5013 : avcrage weight each $1 \cdot 113 \mathrm{lb}$.

\begin{tabular}{|c|c|c|c|c|c|c|c|c|c|}
\hline $1870^{\circ}$ & 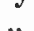 & & 50.000 & & $3 \cdots \cdot 7$ & & & & $1.0 \times 001 \mathrm{~b}$ \\
\hline 1877 & $"$ & " & 70,000 & , & $6286:$ & " & 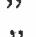 & , & $.901 \mathrm{lb}$. \\
\hline 1878 & ", & ", & ? & ", & $13,51 !:$ & $"$ & $"$ & $"$ & $1-1$ \\
\hline 1879 & $"$ & 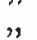 & none & ", & $21,491:$ & $"$ & $"$ & , & .7781 \\
\hline 1880 & $"$ & $"$ & none & $"$ & $19,642:$ & $"$ & $"$ & 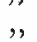 & 80010. \\
\hline 1881 & $"$ & $"$ & none & $"$ & 16,811: & $"$ & $"$ & ", & $1.050 \mathrm{I}$ \\
\hline & ," & ", & 50,000 & ", & $9 \cdot 018$ : & ," & ", & , & ? \\
\hline
\end{tabular}

It is pointed out that it takes two seasons for the fry to "attain to a size worth taking, a conclusion which agrees with the figures, also that with the increased captures at first there is a diminution in the weight of the individual fisl. 
Breeding.-Similar to the brook-trout, at Loch Leven they ascend the streams for this purpose towards the end of September or commencement of October. Sir J. Gibson-Maitland crossed the ova of the Loch Leven trout with the milt of the sea-trout in the winter of 1881 , and 95 per cent. were hatched. It appears to me that the progeny will not be hybrids, but merely two varieties of one form breeding together with the result of non-migratory Loch Leven trout having perhaps more migratory instincts.

Before passing on to the next species, I cannot resist remarking upon the magnificent fish-breeding establishment at Howietown, raised by the energetic skill and capital of Sir J. Gibson-Maitland. Here, although charr and brooktrout are reared, it is the Loch Leven trout that is more especially cared for. The hatching-houses are capable of hatching and raising 12,000,000 eggs and young fry up to the period when they can feed themselves, when they are transferred to the rearing-ponds, which are in a regular series, so that each year's produce is kept by itself. To show what good management and judicious skill may effect, I would instance the pond for the six-year old fish, 80 yards by 40 yards, with a stream passing through it: here, when I visited this interesting establishment, were 1200 Loch Leven trout from 4 to $7 \mathrm{lb}$. weight each, and all in excellent condition, conclusively demonstrating how watery wastes can be turned into excellent food-producing reservoirs. If the experiment proves a financial success, as appears highly probable, its owner hopes to see similar institutions elsewhere, which would be the means of extending to an almost unlimited extent the fish-producing properties of the country now so lamentably wasted, from the apathy of the owners, the greed of the fishermen and the want of onergy and knowledge in our legislators.

Diseases. - These fishes are affected with disease similarly to the salmon and the trout, while bay-salt has been used with success at Howietown in order to arrest a fungus which has from time to time appeared in the ponds. I was informed that crows after having eaten diseased fish moulted and became most miserable objects and three or four were thought to have become leprous.

As food. - The Loch Leven trout is generally very highly esteemed, not only for the red colour of its flesh, but because it possesses a peculiar delicacy of flavour.

Habitat.-This non-migratory fresh water trout is found in Loch Leven in Fifeshire, and other lochs in the south of Scotland and the north of England; while due to the success of the artificial fish-breeding at Howietown the variety is being extended all over the kingdom to as far south as Hampshire. Whether in a few years all trace of them will have been lost, and they will assume the colour and proportions of the brook-trout, only time can demonstrate. In the English edition of Linnæus incorporated into the Encyclopedia Londinensis, p. 53, it is observed, "that it is not above fifty years ago that Mr. Copland conveyed perch into the Ken-loch and the River Urr, where they have thriven remarkably well: as has been the case with the tront taken from the River Leven and deposited into Loch Long in the county of Renfrew." While Parnell recorded having met with this form so far north as Sutherlandshire.

As to the size this fish attains, six-sear-old examples, some weighing as much as 7 lb., were found at the Howietown ponds in 1882. In Loch Leven on A pril 27th, one $10 \mathrm{lb}$. weight was netted; while in the New Statistical Account of Scotland mention is made of two examples captured previous to that date, one being nearly $9 \mathrm{lb}$, the other almost $18 \mathrm{lb}$.

The example figured is 12 inches in length, and one of a pair sent me from Loch Leven by the late Mr. Alston.

2 B. Salmo fario, Plates CIX, fig. 3, and CXIII, CXIV, and CXVI, fig. 1.

Trutta fluviatilis, Will. p. 199 ; Ray, p. 65 ; Sibbald, Scot. Illus. no. 25. Trout, Pennant, Brit. Zool. (Ed. 1776) iii, p. 297, pl. lix, and (Ed. 1812) iii, p. 399, pl. lxx.

Salmo fario, Linn. Syst. Nat. i, p. 509; Bloch, Ich. t. xxii, xxiii; Gmel. Linn. p. 1367 ; Bl. Schn. p. 400 ; Turton, Brit. Fauna, p. 103 ; Bonn. Ency. Ich. 
p. 160, pl. Ivi, f. 266; Donovan, Brit. Fishes, iv, pl. Ixxxv; Risso, Ich. Nice, p. 322 and Eur. Mérid. iii, p. 160 ; Flem. Brit. An. p. 181; Jardine, Edin. New Phil. Journal, xviii, p. 51 and Salmonidæ, t. v-xii ; Richards. Faun. Bor. Amer. p. 144, pl. xcii, fig. 3 ; Jenyns, Manual, p. 424; Parnell, Wern. Mem. vii, p. 304, t. $x \times x$, and Fish. Firth of Forth, p. 144, t. xxx; Kröyer, Dan. Fiske, ii, p. 625, c. fig.; Nilss. Skand. Faun. p. 415 ; White, Catal. p. 77 ; Günther, Catal. vi, p. 59; Gronov. ed. Gray, p. 152; Giglioli, Catal. Pesc. Ital. p. 44; Steind. Ak. Wiss. Wien. liii, 1866, p. 203.

Salmo trutta, Lacépède, v, p. 189.

Salmo fario, var. Forestensis, Bl. Schn. p. 400.

Salar ausonii, Cuv. and Val. xxi, p. 319.

Furio lemanus, Cuv, and Val. xxi, p. 300, pl. 617.

Trutta fario, Siebold, Suss. w. f. p. 319; Canestrini, Fanna d'Italia, Pesci, p. 24; Morean, Poiss. France, iii, p. 533.

\section{Variety a.-Salmo orcadensis, Plate CXIV, fig. 1.}

The Salmon, Low, Fauna Orcad. p. 220.

Salmo orcalensis, Günther, Catal. vi, p. 91 ; Houghton, Brit. Freshwater Fishes, p. 121, c. fig.

"Mr. Low says, in the Loch of Stenness, Orkneys, is found the gray tront: also a trout of $36 \mathrm{lb}$. weight or more, along with the common trout, occurs both there and in Zetland." This large form Richardson considered to be 's almo ferox, and Günther a new species which he termed S. orcadensis. This loch is the largest in the Orkneys, about 9 miles long and $1 \frac{1}{2}$ broad, fresh in the upper portion, brackish or even salt in the lower. Dr. Günther defines this fish as "a nonmigratory trout," very similar to S. nigripinnis, but distinguished from it by a broader and stronger maxillary, larger scales on the tail and a greater number $(50)$ of pyloric appendages, instead of from 36 to 42 , while $S$. ferow has at least 49. The teeth along the body of the vomer form a single or double row which are more or less persistent. Richardson was evidently correct in associating it with S. ferox possessing saline proclivities.

\section{Variety b.-Salmo ferox, Plate CXVI, fig. 1, monstrosity.}

Salmo lacustris, Berkenhout's Syn. Ed. 1795, i, p. 79, sp. 3.

Salmo ferox, Jardine, Ency. Brit. (ed. 7) Art. Angling, p. 142, and Edin. New Phil. Journal, xviii, p. 55, and Salm. pl. iv ; Jensns, Manual, p. 425; Yarrell, (ed. 1) ii, p. 60, c. fig. (ed. 2) ii, p. 110 (ed. 3) i, p. ㅅr's; Ricbards. Fauna Bor.Amer. Fish, p. 144; Nilss. Skan. Faun. p. 412 ; White, Catal. p. 78 ; Güuther, Catal. vi, p. 92.

Salar ferox, Cur. and Val. xxi, p 338.

Lake trout or Buddagh, Couch, Fish. Brit. Isles, iv, p. 222.

This seems to be a trout which has taken on cannibal propensities (see page 94) and its food appears to be almost exclusively fish. It attains a large size, while Richardson alluded to a variety occurring in Loch Loyal, in Sutherland, of a purplish brown above, blackish gray beneath, and the entire body covered with dark sepia-coloured spots, smallest below the lateral-line. It is known as Buddagh or "big fat fellow" in Lough Neagh and some parts of Ireland (Harris, Hist. Co. Down, 1744, p. 236), and is said to be a deep water form confined to lakes, seldom wandering to rivers or to the sea, mostly taken by trolling, though sometimes with a fly. It has been known to return a second or third time to the bait even after it has been dragged 40 or 50 yards. It ascends a short distance up xivers to spawn: Thompson found one from 10 to $12 \mathrm{lb}$. weight contained 4620 ova. Its flesh is of a dull orange colour and generally coarse. It has been found in the lochs of the north of Scotland and as far south as Ulswater and Derwentwater: also Llanberris in Walcs, and in many Irish lakes as Lough Neagh, L. Melvin, L. Eske, L. Erne, and most of the larger ones.

Among our earlier British ichthyologists we find that Berkenhout termed the 
"great lake-trout" S. lacustris (under which name it appears in Sampson's Londonderry and Dubourdieu's Co. Down), supposing it to be identical with the continental variety; but of late years differences have been asserted to exist between the British and foreign race. Jardine and Selby termed ours S. ferow, the specific name having been chosen to characterize its size and ferocious habits. Jurine believed in the specific identity of all the forms of trout in the Lake of Genera; and it would be but reasonable to expect that if the British S. furio under favourable conditions could attain the size of $S$. ferox, the continental S. fario, which is the same species, would, under like conditions, also arrive at being a great lake-trout. Moreau (vol. iii, p. 534) places among the synonyms of Trutta (or Sulmo) fario, "La Forelle du Lac Lëman, Fario Lemanus ;" and at p. 536 observes, "La Truite fèroce, Trutta ferox, Valenc., des eaux du Foretz est une simple variété de la Truite vulgaire, et nullement une espèce particulière."

Although these authors have, in my opinion, been perfectly correct, still there existed the statement of Dr. Günther that structural differences existed among the specimens in the British Museum, showing that $S$. ferox possessed 56 to 57 vertebræ and 43 to 49 cæca, while $S$. fario had 57 to 60 vertebræ and 33 to 47 cæca. I have, however, now shown (page 56) that examples of $S$. fario may have from 56 to 60 vertebræ, and likew ise from 33 to 54 cæca; thus overlapping the entire amount of variations ascribed to British forms. Sir William Jardine stated that " the dorsal fin in $S$. ferox contains 15 rays, and appears to be constant in that number ;" and that "in form it is generally shorter proportionally and deeper than in large specimens of S. fario." Sir J. Richardson distinguished between the great lake-trout and brook-trout by the size attained. The tail "in adults is perfectly square, or might even be described as slightly rounded at its extremity; in the young it is slightly forked, and appears to fill up gradually as the fish advances in age." The relative position of the fins and the number of rays in the dorsal, were said to vary from $2-4 / 11$ or a total of from 13 to 15 . Thompson observes that he found from 33 to 49 cæca in various examples of $S$. ferox from 12 to 17 inches in length.

I possess undoubted examples of the common brook-trout having from 13 to 15 dorsal rays: Morean likewise in French specimens of the brook-trout found 3 or 4 undivided and 9 to 11 divided rays in the dorsal fin: likewise 3 undivided and 7 to 9 divided anal rays : while as to the caudal fin being square in adults, so it also is in large examples of the brook-trout. Yarrell (ed. 3, i, p. 281) gives an illustration of a large Thames trout (a locality not frequented by S. ferox according to authors), in which the caudal fin is as rounded as in any examples of great laketrout of similar size. It was a male, 28 inches long, having a hooked lower jaw, while it weighed $11 \mathrm{lb}$. The comparative length of the head and height of the body are almost identical with what obtains in an example of $S$. ferox, 20 inches long, from Llanberris, and which is in the British Museum. I examined a few years since a specimen (which is still preserved) of trout, weighing upwards of $13 \mathrm{lb}$, taken from a large sheet of water at Alresford in Hampshire, which is well stocked with coarse fish. This was one of about a dozen that some years previously had been transferred from the contiguous stream, to which they conld not subsequently obtain access. Without a history of from whence the fish came, I maintain that no ichthyologist could be certain whether any given specimen is or is not a " great lake-trout."

"The trout," says Dr. J. Davy, "when it feeds principally upon fish must be extremely active and strong; and consequently, from its predatory mobile habits, acquires large teeth, large fleshy fins, thick skin, and great pectoral fins for turning."

Variety c.-Salmo Cornubiensis, Plate CXIII, fig. 2.

Trout, Borlase, Cornwall, p. 263, pl. xxvi, f. 1.

Salmo Cornubiensis, Walb. Artedi, iii, p. 65; Bl. Schn. p. 421.

This is a form mostly residing in small streams, and in which the parr finger marks are continued through life, unless under changed conditions it increases beyond its usual size, when these markings disappear. 


\section{Variety d.-Salmo nigripinnis, Plate CXV, fig. 2.}

Salmo nigripinnis, Günther, Catal. vi, p. 96 ; Houghton, British Freshwater Fishes, p. 120, c. fig.

I now propose alluding to Salmo nigripinnis, Günther, which is similar to S. Cornubiensis as described by Borlase, Artedi, etc., and which for many reasons may be considered as a variety which in suitable localities frequently developes into $S$. ferox. I have been most liberally supplied with specimens from Cardiganshire, through the kindness of Sir Pryse Pryse; and among them is one form which was alluded to by Barrington, in the Transactions of the Royal Society for 1774, as the "Hog-backed Trout of Plinlimmon" (Plate CXI, fig. 1), which Dr. Günther, as I believe correctly, considered identical with his S. nigripinnis. My example, which is about 11 inches in length, is peculiarly interesting, as forming a link between S. nigripinnis and S. ferox, pertaining partly to one form and partly to the other. The following are the differences noted in the British Museum Catalogue:-

\section{Salmo nigripinnis.}

D. 14, A. 12 , P. 13 , Сæc. $36-42$; Vert. 57.59.

Head small. Snout not much produced in males. No mandibular hook observed. Head of vomer with a transverse band of teeth, on body generally in a single series. Female mature at 7 inches. Largest example observed, 16 inches.

These reputed two species bave been found residing in nearly or quite the same localities in England, Scotland, Wales, and Ireland. The size of the specimens examined is important, as tending to modify the conformation of the opercular pieces, as well as of the fins, the character of the scaling, the proportionate diameter of the eye, and the existence or the reverse of the teeth on the front of the body of the vomer. The teeth being present on the anterior part of the body of the vomer in the smaller S. nigripinnis, but absent from the same place in the larger ones, $S$. ferox, is symptomatic of endentulation due to age. The same argument applies to the mandibular hook, it being well known that among the Salmonidø this production is absent in young males, as may be readily observed in the parr which possess milt ready for shedding. The number of pectoral rays is immaterial, as I find, even in the British Museum specimens, examples of $S$. nigripinnis, S. ferow, and S. furio possessing from 13 to 15 .

The foregoing leaves the following as Dr. Günther's primary reasons for dividing these two so-called species:-S. nigripinnis has D. 14, A. 12; head of the romer-toothed, and generally a single row aloug the body of that bone; candal fin with pointed lobes. S. ferox: D. 13, A. 10-11; no teeth on the head of the vomer, but a double row along the body of the bone; caudal fin truncated.

The example of the "hog-backed trout" in my collection has D. 14, teeth on the front portion of the body of the vomer, and a distinct lower limb to the preopercle, thus belonging to S. nigripinnis. Likewise A. 11, a double line of teeth along the body of the vomer, and the caudal fin almost square at its extremity or becoming similar to what is given as diagnostic of S. ferox.

I have likewise six smaller examples of $S$. nigripinnis in which teeth are present on the front portion of the body of the romer and in a zigzag line along the body of that bone; the caudal fin in the smallest has pointed lobes, which have become rounded in larger specimens; the coecal appendages varied from 35 to 44 . In some of these fish the posterior margin of the preopercle was 
rounded, and had no distinct lower limb. The maxilla was much feebler than seen in some other local races of brook-trout, which was remarkably the case on comparing it with a beautiful Yorkshire variety sent me by Mr. G. Brooks, F.L.s.; but even among the Yorkshire speeimens I found great differences to exist. These Cardiganshire fish in the Tivy are found to $4 \mathrm{lb}$. or $5 \mathrm{lb}$. weight, but rarely if ever take a fly when so large, but are to be caught by means of a minnow. Small ones removed to a pond attain in about 3 years to $3 \mathrm{lb}$. or $3 \frac{1}{2} \mathrm{lb}$. in size, their flesh is pinkish, and their flavour said to be excellent. Out of 8 examples, 6 had no red spots, one had them along the lateral-line: and the last had them both on the lateral-line and in one or two rows below it.*

If a trout, normally belonging to a small race, as S. Cornubiensis, is transferred to a lake or reservoir, as in the one near Penzance, where food is plentiful, it attains a size to which it never reaches in its ancestral stream, showing capacity for growth to be inherent, and called into action by luxuriant living. In Scotland the largest examples are in lochs; so also in Wales and Ireland, although occasionally a large one may be found in a sluggish stream, especially if such passes over a rich soil. Should food be plentiful, a brook-trout may attain to many pounds in weight in suitable localities -in fact to as large a size as the great lake-trout, which I hold to be merely a form of $S$. fario which indulges in luxurious living, or cannibal propensities.

\section{Variety e.-Salmo estuarius, Plate CIX, fig. 3.}

Salmo estuarius, Knox, Zoologist, 1855, xiii, p. 4662.

Salmo gallivensis, Günther, Catal. vi, p. 88; Houghton, Brit. Freshwater Fishes, p. 105, c. fig.

The most characteristic peculiarity of this form is said to be found in the small size of the coecal appendages: also that it is at once recognized from Salmo trutta by the excessive shortness of the tubes on the lateral-line. Four examples were recorded and four more passing into the brook-trout, termed hybrids. It is similarly coloured to freshwater forms. Knox's example had sixty vertebræ, similar to the number present in the British Museum specimen, and the name he gave well denotes the chief characteristic of this variety. The example figured is 19 inches long, and came from Waterford. Mr. J. Harvie-Brown took in June, 1882, from a sea-pool or fish-pool at the mouth of the river, freshwater at low tide, salt or brackish at high-water, brown-river trout, periodically visiting the brackish localities, and taking on a silvery sheen of scales, much as he found them in North Uist. They are said to lose condition about spawning time, then disappear but not to ascend streams to breed. Couch alludes to Knox's estuary trout and observes upon its being a fish which has gone to the sea, and that he had received examples migrating seawards in May towards the deep.

\section{Variety f.-Salmo stomachicus.}

The Gillaroo, Barrington, Phil. Trans. Royal Soc. 1774, 1xiv, p. 116; Watson, 1. c. p. 121 ; Hunter, l. c. p. 210 ; Sowerby, Brit. Misc. t. Ixi ; Yarrell, Brit. Fish, (ed. 3) i, p. 283 ; Thompson, Nat. Hist. Ireland, iv, p. 154; Couch, Fish. Brit. Isles, iv, p. 240, pl. ccix.

Salmo stomachicus, Günther, Catal. vi,.p. 95 : Houghton, Brit. F. W. Fishes, p. 125, c. fig.

This has been considered distinct, due to the abnormal thickness of the middle coat of its stomach, otherwise, observes Mr. Barrington, there are no exterior marks by which the species can be distinguished from the common trout. Pennant asserted that the increased thickness of the stomach proceeds from the superior quantity of shell-fish which it finds in the waters it inhabits, and which may call more frequently for the use of its comminuting powers than is requisite

* I intend depositing all these forms, along with my British collection of fish, in the South Kensington Museum. 
in those of our trout. Thompson (1. c.) observes that the coats of other species of Salmones than S. fario (of which only the Gillaroo is set down as a variety) become muscular from the same cause. Healluded to having found it in S. ferox. Sir J. Richardson observes:- "We may here note the existence of a strongly-marked and peculiar variety, called the Gillaroo trout of Galway. It is remarkable for feeding on shell-fish, in consequence of which (it is supposed) the coats of the stomach acquire a great degree of thickness, from which peculiarity it is sometimes called the gizzard trout." * Sir H. Davy remarks that " the charr of the lakes of Southern Austria feeding similarly (to the Gillaroo trout) have a like thick stomach." It generally prefers a rocky bottom, and is said to breed in lakes in their shallower parts, and not to ascend rivers for this purpose. But it is found in the Shannon, Lough Corrib, Lough Mask, Lough Derg, Lough Melvin, \&c. The colours of this variety may be due to the character of the food it indulges in, while in some localities its flavour is considered excellent, in others quite the reverse. In Lough Melvin it is somewhat hog-backed, fine in colour, and well flavoured: in Lough Derg, soft, colourless, and inferior. Its stomachs are occasionally served up in Ireland as gizzards. Thompson obtained from the stomach of one example, abont 8 inches long, above 1000 shells of Limneus pereger, Valvata obtusata, and a few Cyclas cornea. Stoddart observes: this variety is found in a small tarn or loch, situated on a shoulder of Ben More, in Sutherlandshire, about three miles from Innisnadamph, named Mulach Corry.

\section{Variety g.-Swaledale trout. Plate CXV, fig. 1.}

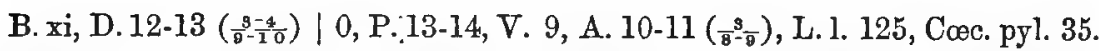

This variety, which is comparatively rather broad, was given me by $\mathrm{Mr}$. G. Brooks, F.L.S., who informs me that it is found in Oxnop Beck, Swaledale, Yorkshire. The example figured is a female 10 inches in length. There is a considerable difference in the form and proportions of the several examples. Colours-it is the most beautifully-tinted form that I have seen, being finely studded with black dots placed in a light circle, and likewise with numerous blue marks and red spots. Its dorsal fin is finely spotted, but the white anterior edge, so constant in most freshwater forms, is indistinct or absent. Scales-fifteen rows between the posterior edge of the base of the adipose dorsal in a line passing downwards and forwards to the lateral-line. Stomach thickened and similar to the variety termed Gillaroo, which form, Dr. Günther observes, possesses forty-four cœca, consequently if a variation in the number of such are diagnostic of distinct species, this is a variety of the Gillaroo. Respecting its exact habitat, Mr. Brooks observes that the upper part of the beck runs over millstone grit, but as it leares the moor it gets upon mountain limestone, and from this point, for a mile and a half, to the point where it joins the Swale, it is composed of numerous small falls, with intervening little dark pools in which the trout lie. The beck is overhung all the way (on the limestone) by trees, mostly alder, silver birch and hazel, but with a good sprinkling of elm, mountain ash, \&c. The beck is closely overhung and is in a narrow ravine.

\section{Variety $h .-$ Crassapuill trout.}

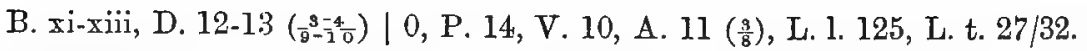

Six examples of this exceedingly interesting variety were sent me by $\mathrm{Mr}$. Harvie-Brown in June, 1882. They were taken in Sutherlandshire, at Loch Crassapuil, where they are looked upon as land-locked sea-tront. Their fin rays are similar to those of Salmo levenensis; a transverse row of teeth is present across the anterior portion of the vomer, and a double row along its body. The preopercle has a distinct lower limb in some, indistinctin others, while the shape of the subopercle

* Hunter's experimeuts with hard and soft food on gulls, showed thickening of the muscular wall of the stomach occurred due to increased use. 
varies. Fins-the pectoral is as long as the head excluding the snout, it is not quite so pointed as in the Loch Leven form, nor so rounded as in the common brook-trout, but intermediate between the two. Scales-125 rows along the lateral-line, 15 from the base of the adipose dorsal to the lateral-line, 25 from the lateral-line to the base of the ventral fin. Coecal appendages 46 in the one examined. Length of head $4 \frac{2}{3}$ to 5 in the total length. Colours-silvery, with the upper two thirds of the body and head closely covered with $x$-shaped or round black spots, and in two of the examples a few red spots but mostly confined to the lateral-line. The loch has a pure white sandy bottom, which probably accounts for their silvery colour. When fresh caught their backs are of a vivid green, varying to pale sea-green and dark olive, in accordance with the depth of the water in which they live. Dorsal fin covered with black spots.

These fish have the silvery appearance of anadromous forms, and externally strongly resemble the Loch Leven variety, but the number of coecal appendages is different, being almost identical with that observed in a Loch Leven example raised at Howietown, and one step nearer removed from its marine ancestry than is the true $S$. levenensis. Did this species run up rivers, doubtless they would take on the colours of the brook-trout, as they have its dentition. They attain to $3 \mathrm{lb}$. or $4 \mathrm{lb}$. weight.

Mr. J. Harvie-Brown (Land and Water) observes that at a far inland locality in Sutherlandshire, brown trout, dark and spotted, were caught in 1877 , and introduced to a chain of lochs in the same county, which have their sources in innumerable springs of clear water from granite and limestone mountains (principally the former, as the limestone, for the most part, is at a lower level). These fish became, in a single year, silvery and covered with minute bright scales like sea-tront, and grew to the size of $1 \mathrm{lb}$. weight in twelve months, from at most $\frac{1}{4}$ of a lb. The food in the loch is shell-fish and tadpoles, and the bottom granite, gravel, and sand.

Monstrosities.-Hog-backed trout of Plinlimmon, Cambridge Quart. Mag. 1833, p. 391 ; Cobbold, Edinb. Now Phil. Journ. ii, 1855, pl. vi.

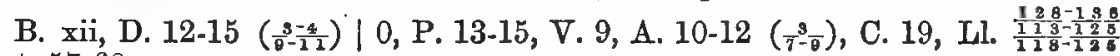
Vert. 57-60.

Length of head $4 \frac{1}{4}$ to $4 \frac{3}{4}$ (in old breeding males $3 \frac{1}{2}$ ), of caudal fin 7 to $7 \frac{1}{2}$ height of body $4 \frac{1}{4}$ to 5 in the total length. Head much more pointed in some forms than in others. Eyes-diameter $4 \frac{1}{2}$ to 6 in the length of the head, varying with the size and age of the specimen, $1 \frac{1}{4}$ to 2 diameters from the end of the snout and the same apart. In old breeding males the eyes are comparatively smaller, and as much as 3 or $3 \frac{1}{2}$ diameters from the end of the snout and also apart. Teeth-in a double zigzag row along the body of the vomer, and in a transverse row across the anterior portion of that bone where it is joined with the palatine arch. Fins-the first dorsal (except in old breeding males), as a rule, commences somewhat nearer to the suout than to the base of the upper caudal ray; the height of the anterior ray usually exceeds the length of its base. Origin of adipose dorsal fin about midway between the anterior insertion of the base of the rayed dorsal and the posterior extremity of the upper caudal lobe. Pectoral as long as the postorbital portion of the head, or even of the entire head excluding the snout, in some examples it is more pointed than it is in others. Ventral inserted beneath the middle or last third of the base of the dorsal fin. Caudal forked in the very young, emarginate in those of a medium size, becoming square in large examples, or even rounded. Scales-from 13 to 15 rows between the hind end of the adipose dorsal fin in a row passing downwards and towards the lateral-line. About 26 or 27 rows from the lateral-line to the base of the ventral fin. Coecal appendages-these differ considerably, apparently being influenced to a great extent by the locality they inhabit and the food which they can obtain. Colours-these vary as has already been observed (see page 57), not only with locality but also owing to changes of food. Those from Wales and along the S.W. coast are of a somewhat darker appearance than those from the Midland counties and towards the north, and have rather more black but less red spots. 
I have already (p. 57) alladed to the parr marks of the young being occasionally continued throughout life in small forms, evidently adding to the confusion respecting what is a parr.

Varieties. - Tront, as already remarked, are exceedingly liable to variation, due to several causes. Some of these abnormal productions would seem to be hereditary; in others the same exciting cause continuing in action occasions results as in previous generations. Giraldus Cambrensis, lib. iii, c. $x$, the Archdeacon of Brecon, who attended Baldwin, Archbishop of Canterbury, in a progress through Wales in 1188 , tells us of eels, trout and perch existing in the lakes of Snowdon which only possessed the right eye, but being invariably blind with the left. The Fischau, near Mandorf in Germany, was reputed to contain blind trout (Fr. Erm. Bruckmanni Epist. Itin. xxxvi, Wolfenb. 1734, p. 10). A deformed race of tront is asserted to exist in a small loch in Invernesshire near Pitmain ; among them there appears to be an arrest of development in the upper jaw, giving their heads a slight resemblance to those of bulldogs, due to the projection of the lower jaw (Encyc. Brit. 7th ed., art. Ang.). Similar malformations are seen in the "ground trout" of Penyghent (Yorkshire Vertebrata) and many other places. In Loch Islay exists a race of tailless trout, Salmo Islayensis, Thomson (Traquair, Joum. Anat. Phy. vi, p. 411, pl. xix, and Thompson, Science Gossip, 1872, p. 85), which in some streams has been traced to be due to the action of deleterious matter in the water (see Angler's Note Book, 1880, p. 66). Mr. J. Harvie-Brown observed, about 1876, in the river Carron that a contraction of the rays of the tail fins of the trout commenced, due it was universally believed to continuous pollution of the water through the agency of paper mills. At Malham Tarn, in Yorkshire, 1240 feet above sea level, the trout are distinguished by a deficiency or malformation of the gill-covers in about one in every fifteen captured. As I have seen the same result from breeding in confined places, I believe such to be one at least of the causes, perbaps conjoined with gill-fever when young. On Plinlimmon, and in adjacent parts of Wales, are "hunch-backed" trout, having deformed vertebral columns as already alluded to. In some, at least, of these instances the young are reared where cascades are falling over heights into a series of pools, and it has seemed to me not unlikely that either the egg or the fry coming within the reach of such, might suffer injury, and consequent disease of the spine (so common in fishes) be set up. Barrington (Phil. Trans. 1767) remarking apon some examples crooked near the tail continues, "these trout are only caught in a small basin, eight or nine feet deep, which the river forms after a fall from the rocks." Perch were found to be similarly affected, the same cause acting apparently on both forms. There are likewise races in which some Jocal cause has set up local action, as of the stomach alone. This variety, the Gillaroo (see page 99), due to the food it indulges in, has the muscular coat of its stomach thickened, which abnormal structure has been reproduced in succeeding generations. For it must not be assumed, because in certain examples we are unable to find Limnea and other shells, that the fish has never consumed any; they may have been digested, or it may have varied its food, or the shells may have been temporarily unobtainable. In County Derry, in the river Glenlark in the Munterloney Mountains, "Mr. Sinclaire states that the water and stones are deeply tinged with a rast colour, of which the trout likewise partake. Their flesh is very bad and of a metallic flavour; so bad are they that the country people will not eat them, and as they are not fished for, the river abounds in them" (Thompson, iv, 153).

Lunel remarking upon the various specific names that had beon given to the varieties of this species, asserted S'almo fario, S. lemanus, S. rappii and S. lacustris, of Lake Constance to belong to one form which he proposed terming S. variabilis. Steindachner (Ak. Wiss. Wien, lii, 1865, Nov. 30th) identified S. detex, Heck. with $\$$. fario. Pavesi (Pesci nel Ticino) considered the lake and river-trout of the Canton to be mercly varieties of one species. "Unquestionably," observes Stoddart (Angler's Companion, 1847, p. 3), "there exists no species of fish which, judging of it by the external marks, holds claim to so many varieties fir the common freshwater-trout. In Scotland almost every lake, river, and 
streamlet possesses a breed peculiar in outward appcarance to itself." Lord Home (Yarrell's Fishes) observes of two streams, the Whitadder and its tributary the Blackadder, that the first flows along a very rocky and gravelly bed, while the latter rises in mosses, also goes through them in the first half of its course, but subsequently along a rich and highly cultivated district. The trout in the first are silvery in colour: while those from the Blackadder are dark with orange fins. The many varieties are dependent upon external causes and chiefly to the abundance or the reverse of food and the nature of the water they reside in, the soil over which it flows, and other causes already treated of (pp. 57, 58).

That this conclusion is based upon proof may be demonstrated by the result of what has become of the progeny bred from the brook-trout eggs taken in Hampshire or Bucks, by Buckland or Francis, and transmitted in 1866 to Tasmania, some of which have become great lake-trout. Mr. Arthur (Trans. Otago Institute, July 9th, 1878) tells us that unlike the Scotch trout which according to Stoddart show a yearly increase of about one-third of a pound in weight, ${ }^{*}$ in Otago they grow so rapidly and are so fat that they have reached an average yearly increment of from $1 \mathrm{lb}$. to $2 \frac{3}{4} \mathrm{lb}$. Already the various streams have stamped the trout with local peculiarities : in some they are plump almost to deformity; their proportions are not constant neither are their colours. He tells us that examples were said to have been seen up to $20 \mathrm{lb}$. in weight. This year, 1882, one 31 inches long and weighing $19 \mathrm{lb}$. was caught at Temuka, its flesh was of a pale orange : last year Mr. Gwatkin captured one in Canterbury, that turned the scale at $21 \mathrm{lb}$. The foregoing facts corroborate my views that all our forms of trout are varieties of one species, and the so-called hybrids are not mules but mongrels, being the result of the crossing of varieties. Consequently, sterility need not be anticipated ; but, on the contrary, improvement is more likely to ensue (should there be no deficiency in food) than when the stock is bred in and in.

It also tends to show that where small, but not malformed, breeds of trout exist, riparian proprietors had far better investigate the condition of the foodsupply and nature of the waters in their streams than rely upon the introduction of larger races. For, sooner or later, new stock will become indistinguishable from the original local breed in colour, form, and size.

Hybrids.-That hybrids exist among the Salmonidæ and can be artificially produced by the pisciculturist, $\uparrow$ I have already pointed out (p. 59). It was with much interest that I received in July, 1882, from Sir Pryse Pryse an undoubted hybrid between the brook-trout and the American charr (Salmo fontinalis). The example was 9 inches long, having the number of rows of scales descending to the lateral-line intermediate between the two forms; the fins similarly modified, while a row of teeth passed in an irregular manner along the body of the vomer. The organs of generation were undeveloped, the example for this season at least was certainly sterile; some American charr of about the same size, received a few days subsequently from Howietown, had the eggs and milt in a forward condition.

Names.-Aller-float or aller trout, this refers to a large one frequenting a hole in a retired or shady portion of a brook under the roots of an alder tree. In Herefordshire there is a country proverb respecting the "aul " or "alder :"

"When the bad of the aul is as big as a trout's eje

Then that fish is in season, in the river Wye."

* "A correspondent of the New Sporting Magazine, for November, 1840, observes that a friend of his has kept trout in a kind of store stream, and having fed them with every kind of food, has had some increase from $1 \mathrm{lb}$. to $10 \mathrm{lb}$. in four years. Mr. Toomer placed a trout of $3 \frac{1}{2} \mathrm{lb}$. which he caught in the river in a stew, and in about four years it had grown to about 9 lb." (Daniel, Rural Sports). At Howietown, a Loch Leven trout hatched in 1875 weighed over $8 \mathrm{lb}$. in October, 1882.

$\dagger$ At Sir J. Gibson-Maitland's, November 14th, 1882, I was given a living hybrid 11 inches long, it was the produce of a Loch Leven female milted from a salmon on November $25 \mathrm{th}, 1879$, and hatched in 1880 , consequently nearly three years old, in fact a sterile grilse. 1250 living parrs in the boxes up to 4 inches in length, were the produce of 20,000 eggs of Loch Leven female trout milted from the salmon, December 24th, 1881, and hatched March 9th, 1882. Their dorsal ins had the anterior white edge usually seen in the brook-trout. One had 78 coecal appendages, a second 61 . 
Rack (Northumberland) also rack-rider, a small trout: Shot (Westmoreland). Breac-precht, Highlands of Scotland. Alevin, fry before it commences to feed by the mouth. Sceota, Anglo-Saxon, a "shooter" or "darter:" also truht. Triotht is an old mode of spelling the name of this fish.

De forel, Datch. Truite, French.

Habits.-Bold, voracious, cunning and shy, it possesses keen sight, while it dreads anything novel it may observe. In some of our streams which are constantly fished it appears to have become almost insensible to the charms of the artificial fly, while, should it have been hooked, it would seem to remember the circumstance. When an outlying fish is disturbed it dashes away and seems to warn its neighbours by its flight. Sometimes it is so hungry that it appears to take almost anything : thunderstorms or darkness may canse it to cease from feeding. A correspondent of the Zoologist (1847, p. 2030) remarks upon a trout kept in confinement, and on a minnow being thrown in, it would immediately ascend nearly to the surface, hover over its prey like a hawk for a few seconds, then dash down and seize it by the head. The larger fish mostly move about in search of food of an evening and during the night-time, while they generally swim low, especially in cold weather. A favourite haunt is often behind a stone, or bank, while it appears to prefer a bush which gives shade from overhead. It requires moderately pure water, for a carp will live where a trout will die. It is alarmed by shadows falling over its haunts and the presence of pike, which take a heavy toll from these fish in some localities, prevents its feeding freely, cansing its condition to be poor and the sport it affords to be small. It used to be said that chub drive out trout during the four hot months. If some trout esteem food which causes their flesh to be tinged with red, while others in the same water appreciate a different sustenance, and consequently are not thos tinged, if the Gillaroo eats shells, occasioning thickening of the middle coat of its stomach, while such diet, as a rule, is rejected by the common variety of brook-trout, it appears to point out that the tastes of some differ from those of their companions, while it is a well-known fact that certain forms of food promote fish-growth more rapidly than others. As already observed, those tront which principally subsist upon freshwater shrimps, Gammari, are generally of the most brilliant tints, and the most pinky-coloured flesh, while vegetable diet appears to generally canse a silvery hue and sometimes a dull appearance.

One about $1 \frac{1}{2} \mathrm{lb}$. weight, taken in June, 1882, in the Tweed, was found to contain 11 small tront and one minnow. They do not object to small fish, as minnows, loaches, sticklebacks, \&c., water-rats, young birds, frogs, snails, slugs, worms, leeches, maggots, flies, beetles, moths, and even water-spiders. They will even swallow one of their own kind two-thirds as large as themselves.

In Mr. Buckland's museum existed an example, the stomach of which was distended by 2470 eggs of the salmon.

They are out of condition sabsequent to the breeding season, and in England Devonshire is considered one of the earliest counties in which they come into condition, and are fished for as early as the commencement of February. Elsewhere there are rivers equally forward.

Parfitt found river mollusca, as Valvata yicinalis, Planorbis marginalis, Physa fontinalis, Limneus pereger, in the stomachs of some taken in May, in Powderham Park, Devonshire, but food varies with streams, \&c.

Means of capture.-These may be either netting, spearing, tickling, poisoning, or angling. For the methods of netting these fish I mast refer to the introduction. In the dry weather, at the Orkneys in 1882, the water in the Loch of Harray, on the west mainland, was reduced in volume and rendered tepid by a succession of hot days. The trout assembled in shoals at the mouths of the burns and were slanghtered in thousands by netting. Spearing is not now permissible, although it used to be employed by torchlight. Tickling for these fish in small streams is occasionally employed with success. The angler has several modes of procedure at his command, if the fish are large, spinning bait may be employed; or ground fishing with worms, or fly-fishing either with the real or imitation insect. Different rivers, seasons, and even periods of the day have their peculiar varieties 
of winged insects acceptable to these fish; as a rule if the water is clear and low, and wind is absent, small ones are most suitable : if clearing after a flood, or full but not discoloured the fly-fisher has more chance of sport, as well as if late in the season when few flies are born. When the water is opaque a worm or spinning bait may be tried with success. In small streams real flies and grasshoppers may be used as bait for hooks on a short line, which is bobbed on to the surface of the stream from over a bush. If once pricked by the hook it is generally but not invariably shy : while it is disturbed by flies clumsily thrown or splashing into the water. Frosty weather checks trout moving, and while snow water, or that derived from the nelting of snow, is running into a stream it is almost useless attempting to use the rod.

Baits.-Worms as brandling, gilt-tail meadow worm, tag worm and red worm-for a large one a well scoured dew worm. A minnow or any small silvery fish, a loach, or a boll-head with its fins removed.

Breeding.-The number of eggs produced by each female- trout has been roughly estimated at 800 for every pound's weight of the fish, which computation has been observed at the Howietown breeding ponds to be fairly accurate. But the size of the parent exercises a considerable influence on that of the eggs, thus in $\operatorname{Sir}$ J. Gibson-Maitland's fish house we found the following average numbers to be present along each line of grilles. Brook-trout 29 to 30 eggs; Loch Leven trout, the parents of which were hatched in 1875,27 or 28 , or from those hatched in 1877, 32 eggs ; and the American charr 36 to 38.* The colour of the eggs are as various as observed in the salmon, and I have seen some orange, others strawcoloured, from two fish taken together out of the same stock pond.

The period at which these fish breed varies in different rivers and districts, extending from September until February and even March. Mr. Harvie-Brown at Loch Gorm, in Sunderland, which is greatly fed by snow water from the Bact of Beumore, has taken trout heavy with spawn in June and July. $\dagger$ It has been questioned whether these fish are annual or biennial breeders, and Dr. J. Dary came to the conclusion, after examining a large number captured in open streams, that only half spawned annually. At Howietown, on the contrary, it would seem to be the rule that an annual spawning occurs, and though such a question is difficult to settle an instance in point has been observed. A marked example of Loch Leven trout was spawned at Sir J. Gibson-Maitland's on November 27th, 1874, and again on November 25th, 1875. At Howietown, where about one million of gallons of water flow through the ponds every twenty-four hours, the fish develop spawn and milt as regularly as in their native habitat, some even pass up the aerating channels forming redds there. But in ponds destitute of streams, certainly no young are produced, either spawn not being developed, remaining unfertilized, or else from being deposited in an unsuitable place (see page 91). It has been generally considered that when the ova of these fish have arrived at a certain stage the female has no power to retain them but they must be extruded, a conclusion Sir J. Gibson-Maitland has found reason to doubt, as it seemed to him that a certain amount of pressure is necessary to assist in the discharge of the eggs, and which is normally effected by pressing against the gravel forming the redds. Acting on this opinion he has found it possible to retard the extrusion of of the eggs for as much as a fortnight or eren three weeks, by placing the fish in a wooden box through which a current of water flows.

A trout's redd or nest is a mound of gravel which would fill one or even two wheelbarrows, and probably by causing a shallow, assists in aerating the water. The eggs themselves lie loose among the gravel at from one to two feet below the surface. Eggs when shed are elastic, but soft and sink in water: when artificially propagated the milt of the male is generally added to the eggs in the pan prior to the addition of water, subsequently water is added and the mass is gently stirred

* The rough calculation of egge of Salmonida is that Balmo salar gives 25,000 to the gallon, S. levenensis 30,000 , S. fario 40,000 , S. fontinalis 80,000 .

$t$ Mr. Ugilby (co. Tyrone) observes that there is not a month in the year, during which it is legal to fish, in which trout do not spawn. 
with the hand. After a short period the eggs become adherent but gradually absorb water, distend and are like little round balls. The period for which milt will remain serviceable after removal from the fish is an interesting subject. On October $23 \mathrm{rd}$, 1874, some was obtained at Howietown at 9 A.M. from a Salmo fario, then carried to Loch Leven in a tightly corked tube, and used at 1.20 P.M., the impregnation being perfect. Ora or milt may be kept alive for some hours, but on the addition of water, death rapidly occurs.

Respecting the artificial propagation of these fish, I think I can do no better than give a summary of the excellent article on "stocking," by Sir J. GibsonMaitland. Skill and knowledge are requisite in order to select the fish from which the milt and the ova are to be collected, and likewise to ensure perfect impregnation. The ova should be laid down on glass grilles in the hatching boxes from whence dead ones can be readily removed before the fungus which grows upon them has time to damage by spreading to such as are in its vicinity. When the eyes of the embryo commence to be visible an increased supply of oxygen is necessary. When the embryo is sufficiently developed to enable the eggs to be handled with impunity, they may be packed in trays, on damp swansdown, and forwarded to their ultimate destination. Care has to be taken that the water for the hatching-house is constant in its supply, equable as to its temperature, and not loaded with sand or any impurities, that frost is kept out, and though early eggs are the best, eyed ova should not be sent to a cold locality where it would have to battle with one or two months' continuous frost, on the other hand transmitting it to a warmer climate care must be taken to meet the temperature en route which almost of necessity sets the eggs hatching.

These eyed eggs are turned down into artiticially and carefully constructed redds, scattered all over the district in close proximity to the best feeding grounds and ripples for the fry. Such absolute purity of the water flowing over the redds is not required for eyed ova as it is for the eggs prior to this period, still discoloured water shonld never be employed. It is also requisite that the redd be situated near a stream of less pure water, as the absence of fine particles so necessary for the health of the embryo, is not satisfying to an active young trout of a few weeks old. A natural river temperature of $50^{\circ}$ will always produce ample food for the young fry. Prior to the absorption of the umbilical sac they should not be placed in ponds or muddy water. They will not bear much handling but bear carriage very well : a 40 -gallon tank being sufficient for the conveyance of about 15,000 which have been feeding for more than a month, except for very long journeys when a supplementary small tank requires to be added, which altogether saves the necessity of handling the fry. They can be reared in small properly constructed ponds and subsequently turned into deep water.

The normal period eggs take hatching is fonnd when the water is kept at about 44. 10 degrees to be as follows at Howietown:-Salmo fario, 71 days; S. levenensis, 7.; S'. fontinalis, 73; S. levenensis crossed by S. salur, 75; and S. salar, 77 days. But as already observed lowering temperature delays hatching, increasing it hastens such on (see pages 65 and 107 ).

For the purpose of stocking pieces of water with trout, either eggs or young fish may be obtained from a breeding establishment. It is higbly desirable, prior to receiving such, that a careful examination should be made that the nurseries do not contain their enemies, as bull heads, Cottus gobio, which will eat them as rapidly as it can find them. At the Howietown fishery* it is suggested that streams with sediment in the water or a liability to floods are unsuited for depositing ova, and fry are recommended instead.

In transmitting ova those which are partially eyed are recommended, and are laid down in gravel redds in some small streams contiguous to the rivers or lakes it is desired to stock. Eggs being kept in glass grilles give the strongest embryos and healthiest fry.

The time necessary for preparing young trout for transport varies from three or four days in the case of yearlings, to as many weeks for large examples. The 
yearlings are sufficiently strong to find their own food, thus avoiding the principal cause of mortality among fry, which is starvation. They soon accommodate themselves to new pieces of water. Two-year-olds are found to succeed best where coarse fish or large fish already exist in the water. It has been found that there is no difficulty in conveying trout in iced water for any journey not exceeding twenty-four hours. That unless the water which is to be stocked is of similar temperature some loss will arise from inflammation of the gills, they are consequently carried best in cold weather.

Hybrids. - At Howietown the following crosses were made:-November 27th, 1874, between a female Loch Leven trout and a male sea-trout, they hatched March 20th and 21st, 1875. On December 3rd, between a female common burn or brook-trout and the milt of the sea-trout, they hatched March 21st, 1875 . Seatrouts' eggs with burn trout milt commenced to hatch on the 116th day: the young have become indistinguishable from the common stock. On November 15th, 1882, Sir James Gibson-Maitland commenced the following experiments at Howietown while I was present. 8000 ova of Salmo fontinalis were milted from a S. levenensis, and were placed in hatching box no. 104. 3000 ova of S. levenensis were milted from a S. fontinalis and deposited in box no. 108. 9000 ova of $S$. fontinalis were milted from a charr which has been termed $S$. struanensis, and placed in box no. 115 .

Life history.-All the various forms of trout have their parr stage. The normal rate of growth in the ponds at Howietown I have already alluded to (see page 103). Mr. Stoddart gives the result of an interesting experiment on young trout:- "Fish were placed in three separate tanks, one of which was supplied daily with worms, another with live minnows, and the third with those small dark-coloured water-flies which are to be found moving about on the surface under banks and sheltered places. The trout fed on worms grew slowly, and had a lean appearance; those nourished on minnows-which, it was observed, they darted at with great voracity -became much larger; while such as were fattened upon flies only, attained in a short time prodigious dimensions, weighing twice as much as both the others together, although the quantity of food swallowed by them was in nowise so great." The size to which they attain depends upon the suitability of the water inhabited and the amount of available food. Thus in some mountainous districts they may never exceed 3 or 4 ounces in weight, while young hatched from the same batch of eggs may attain to pounds. They are a long-lived fisb : one was twenty-eight years in a well in Dumbarton Castle; another is said to have been fifty-three years in a well in the orchard of Mr. Mossop, of Board Hall, near Broughton-in-Furness.

As food.-Its value differs with the waters from whence it has been taken. Its old name was " the venison of the waters," and denotes the general estimation in which it was, and is still, held. It is in the best season from May until the end of September, deteriorating in and after the breeding period. Some consider the females as food to be better than the males.

Habitat.-The colder and temperate portions of the northern hemisphere, descending in Asia as far south as the Hindoo Koosh, but not normally present in any portion of Hindostan. Heber, mistaking a spotted carp, Barilius, for a trout, asserted they were found on the Himalayas, on which authority Couch gave India as one of its habitats. It has been introduced on the Neilgherry range of hills in Southern India. It has been artificially introduced into many countries in the southern hemisphere. In the Orkneys it is found in great plenty in every burn, and generally extended throughout the rivers and lakes of the British Isles when unchecked by pollutions. Some exceptions, however, to this general rule would seem to occur, thus in Norfolk, we are told, it is found in small numbers in the higher parts of the Bure, the Ware, and some of their tributaries, but not in the Waveney (Lubbock).

A trout upwards of $21 \mathrm{lb}$. and measuring $41 \frac{1}{2}$ inches in length, was taken in a small tributary of the Trent at Drayton Manor, and sent by Sir Robert Peel to Yarrell. In 1880 Buckland made a cast of one $17 \mathrm{lb}$, weight, captured at Reading. July 11th, 1882, one $20 \mathrm{lb}$. weight was secured in Lough Derg, an expansion of the Shannon (S. Hurley). 


\section{B. Vomerine teeth restricted to near the head of that bone (Salvelini).}

When treating of the group Salmonies (p. 53) I gave a short synopsis of the views held by our later naturalists respecting which each considered to be species or referred to varieties. I propose taking the same course with the charrs Salvelini.

Willughby (1686) places under one head Umbla minor, Gesner the Reutele of South Germany, the Torgoch of Wales and Westmoreland, and the red charr of Windermere, table no. 7. He also alludes to the gelt or gilt charr of Westmoreland, which he refers to Carpio lacus Benaci of Rondelet; he likewise figures it table no. 5 .

Ray (1713) held the same views as Willughby.

Pennant (1776) figures the charr, and asserts his opinion that the case charr, the gelt or silver charr, i.e., one which has not spawned the preceding season, and on that account is reckoned to be in the greatest perfection, the red charr, and those of Loch Inch in Scotland, are all probably one species. He observes that the variety case charr spawns about Michaelmas, while the gilt charr does so from the beginning of January to the end of March. He also alludes to the Welsh charr.

Donovan (1804) gave a figure of what he considered the gilt charr of Pennant, Salmo alpinus, Linn.; also a plate of Salmo savelinus, Bloch, the torgoch of the Welsh, then said to be confined to the waters of Llyn Cawellyn, one of the Alpine lakes situated in the deep valley on the west side of Snowdon. $\mathrm{H}_{\theta}$ considered that it differed from the charrs of Windermere.

Turton (1807) agreed with Donovan, as did also Fleming (1828). Jenyns (1835) held the same opinions, but termed the Alpine charr of Donovan S. umbla. Yarrell (1836) held the same views as Jenyns, but in his second edition (1841) as well as in his third (1859), all our British forms are held to be varieties of one species.

Agassiz (1834) believed that all our British forms were identical with the Ombre chevalier of the Lake of Geneva.

Richardson (1835) placed (1) S. umbla as synonymons with $S$. alyinus and S. salvelinus of Linnæus, and also with the species found in the Lake of Geneva, but be desired his readers to remember that the history of the charr, whether one or more kinds, had not up to that time been clearly made out. In Windermere he considered that the case charr ascended rivers, spawning about Michaelmas, while the red charr deposited its ova along the shores of the lake, and not until the end of December or the beginning of the year.

Parnell (1838) classed our northern charr as S. umbla, Linnæus.

Thompson (1840), and subsequently in 1851, held that all the forms of British and Irish charr are varieties of one species, the $S$, umbla, Linnæus.

White (1851) placed all the British examples in his catalogue of the fish in the National Museum as pertaining to S. umbla.

Dr. Günther (1866), as in the Salmones so in the Salvelini, has largely augmented the number of what he considered British species, although be rejects S. umbla and S. salvelinus as British forms. He gives (1) S. alpinus, vertebræ 59-62, cœcal appendages $36-42 ;(2)$ S. killinensis, vert. 62 , cœc. pyl. 44-52; (3) S. Willughbii, vert. $59-62$, cœc. pyl. $32-44$; (4) S' perisii, vert. 61 , cœe. pyl. 36 ; (5) S. grayi, vert. 60 , coec pyl. 37 ; (6) S. Colii, vert. 63 , coec. pyl. 42.

Sir J. Gibson-Maitland (1881) added S. struanensis.

S. fontinalis, or the American charr, has likewise to be added to the British forms, being now extensively distributed throughout the country.

Up to 1866 Pennant, Agassiz, Yarrell, and White admitted one form of charr as British, while Donovan, Turton, Fleming, and Jenyns believed in two. Günther increased them to six, subsequently $S$. struanensis was added, and the American charr widely propagated.

Widegrem (1864) asserted that in Scandinavia there exist two races of charr, the larger being found in Lapland, Lake Wetter, and other lakes; while the smaller is present in pieces of water of less size as those of Jemtland, Wermland, 
Smaland and Norway. These two races he held to be simply modifications of one species, Sulmo alpinus, the sæbling of South Germany of which S. umbla is a synonym. Holding these opinions which were identical with those of Agassiz and others, he entered his protest against the validity of Dr. Günther's new species, which he deemed as merely so many additions to the synonymy of S. alpinus. Collett, Norges Fiske (1875), considers all the charr to pertain to one form, so also does Malm, and Moreau in his Fishes of France (1881) arrives at the conclusion that all the charrs of that country are a single species, $S$. umbla, which he considers identical with S. salvelinus.

In the Zoological Record of 1864, Dr. Günther disputes the possibility of the size of the teeth having any bearing on the food these fish consume, maintaining that such may even be a reason towards instituting a species. However, in the artificial rearing of Salmonoids it has been found that some young do take on cannibal propensities and are furnished with larger teeth than their neighbours. Referring to the size of the eggs Dr. Günther likewise differs with the Scandinavian zoologists, holding that those who may have a more extensive knowledge of fishes "know that the size of the ova is not only invariably the same in individuals of whatever size, but, as far as our experience reaches, is even often characteristic of the species of a genus." Here I must refer to page 105, where I have shown that the size of the eggs may depend on the age of the fish.

There appear to be three different main reasons for dividing the British charrs into several species, the colour, the number of vertebræ, and of the cocal appendages.

The colours in the charr do not vary to so great an extent as they do in the trout, due to their residing in deeper waters and usually merely ascending towards the surface at night time to feed, while other changes in tint are consequent upon the breeding season. In the Lakes of Cumberland, Westmoreland, and Lancashire, observes Jenyns, this fish in its ordinary state is the case charr of Pennant; when exhibiting the bright crimson belly which it assumes before spawning, it is called the red charr; when out of season the spawn having been shed, it is distinguished by the name of the gilt charr. Thompson observed that he had examined in a fresh state charr from Windermere, from Lock Grannock (Scotland), and Lough Melvin (Ireland), and preserved in spirits or dry from nine other lakes in Scotland or Ireland. Examinations of these led him to believe that there exists but one species : one, however, that like the Salmo fario is subject to extraordinary variety. In one lake the male fish can at a glance be distinguished from the female either by colour or by the many characters which are comprised under "form." In another, so similar are the sexes in every external character, that without the aid of dissection they cannot be determined. In size we find the species ordinarily attain twice the length and several times the weight in one lake that it does in another, although the area of their waters is of similar extent; indeed, in some of the largest lakes this fish will be found not to attain near the size it does in some others, which are but pools in comparison; there are, however, various influences which account satisfactorily for such differences. In the form of the body again, we find the species, when in equally high condition, to be in one lake herring-like and in another approximating to the roundness of the eel. So manifold are the differences presented by the charr from various localities, that it would be tedions and perhaps useless to point them out in every case. A correspondent in The Field (April 22, 1882), speaking of the white trout of Quebec, observes that the best authorities seem to agree that the sea-trout of the provinces is simply a Salmo fontinalis that has migrated into salt water and changed its colour by that means. This leads us to inquire whether we ought to agree with Agassiz, Thompson, and others that the number of species of charr in these islands is limited to one which is subject to great variations in form, in colour, and other characters due to physical causes? $\mathrm{Or}$ should we adopt the theories of those who see at least half-a-dozen species in the British Isles, and anticipate many more being discovered when the lochs of Scotland and the loughs of Ireland have been exhaustively explored?

The number of vertebre.-The six forms described by Dr. Günther are said 
to have these varying between 59 and 63 , but as in type examples of two forms in the British Museum we are informed from 59 to 62 were present, the existence of an additional one in a specimen of $S$. colii can therefore hardly be a reason for instituting an additional species (see page 55).

The number of coecal appendages. - The extreme variation in all the foregoing six species is given at from 36 to 52 , while we are informed that in $S$. Willughbii from $32^{*}$ to 44 are present in examples in the National Collection. I have already shown how inconstant are the numbers of these appendages among the Salmonidæ (see page 56).

If we seek to investigate the history of these fishes from the earliest times, and inquire of geologists as to what account they are able to furnish, we are told that the Salmonidac are a comparatively recently evolved family, their very existence in a fossil form (if we exclude Mallotus) being unknown. Mr. Symonds, in the last edition of the Records of the Rocks, observes: "I have fished in and visited many of the lakes in Great Britain, where the charr, Coregoni, and great lake-trout (Salmo ferox) are known, but I never saw one in which they still exist that is not either a glacier lake, or rock basin, or that is not dammed or otherwise surrounded by glacial moraine matter. They are also inhabitants of the lakes of Sweden and Norway, which everywhere bear traces of the glacial epoch and its close, and seem to me to be (like the Alpine plants that still linger among the mountains) fishes of that colder period when the last of the glaciers still hung to the combes of the Highlands of Scotland and Wales."

Doubtless the charr prefer the colder north to the more temperate portions of the globe; and moderately still waters. Among the fishes brought by the late Arctic expeditions were examples of charr very similar, if not identical with British forms, thus seeming to show a near relationship one with the other. While in Nordenskiold's Arctic royages it is recorded that the young of S.alpinus, three inches long, were captured on the eastern side of Wijde Bay in June, 1861.

Mr. Brooke, writing respecting a species of Irish charr, observes that "Lough Eske (where it was captured) was the crater of an extinct volcano, as suggested by Dr. Wilde, of Dublin."

Many and various reasons have been advanced by different persons against the enactment of laws for the protection of fishes, especially charr, and I observe that Mr. Houghton, in his British Freshwater Fishes, considers that "the extension of the Salmon Act to charr is a great mistake. The only time-and that time is of short duration-when charr can be taken in any numbers is in October and Norember, when they leave their deep-water haunts for the shallower parts of the lakes. The destructive agency of man, limited as it is to one or two months' duration, could have but little effect in causing a diminution of the species in the extensive depths of our great lakes, which, for five-sixths of the year, provide safe and unassailable harbours." On the other hand it has been asserted that the charr of Lough Neagh, in Ireland, have been exterminated by man within the last forty years, showing his power, when nnchecked by legislative enactments, of effectually accomplishing such a destruction. In Land and Water for December 27, 1879, is an interesting article upon the result following the preservation of the Llanberris charr. Two large freshwater lakes exist, joined together by a small river. In November the charr pass up this stream to the lower portion of the upper lake to spawn, having accomplished which they return to the lower lake. The proprietors, acting on the principle enunciated above, used to net them at the spawning period; but the Salmon Act of 1873 prohibited the capture of these fish between October 1 and February 1 , so the killing of these spawning charr bas been stopped. Prior to 1874 they were only to be seen here and there in shoals of a score or so, whereas now they may be observed in hundreds, averaging about nine fish to $2 \mathrm{lb}$. weight. In September, 1879, an angler, with a worm bait, captured in one evening $23 \mathrm{lb}$. weight of charr, and as soon as the news got abroad many others took to angling for these fish, and all

* I have examined one from the Lakes which only had 28. 
had good sport. This continued until close-time, and some days hundreds of quarrymen might be seen fishing, some in boats, others from the shore, while as much as $45 \mathrm{lb}$. a day has fallen to the share of one rod, a bait having been almost invariably used, although a few were taken with a fly.

A correspondent of The Field, October 28, 1882, remarks upon night fishing for charr with well scoured brandlings and line tackle in North Wales. All is done by feel, and, when a vigorous ting occurs at your line, one has to strike; at the approach of day the charr begin to bite savagely, as dawn commences the biting ceases, and the fish disappear as if by magic.

Respecting the Windermere fishing for 1881 it was remarked in Land and Water, November 26, 1881, that the charr fishing was, as usual, very profitable. There can be no better argument in favour of a close season and protection than the great increase in the value of the charr fisheries since such was applied and protection afforded to the fish.

The mode which is generally carried on by the fishermen as described in The Field is with what is termed a plumb line, which is free to all, and a great number of the natives on the shores of the lake gain a good livelihood by supplying the strangers and hotels with the fish.

Charr fishing with the plumb line usually commences about the beginning of March, and at that time the fish are got about thirty yards from the surface and in the deepest parts of the lake. As the weather gets warmer they gradually approach the top, and although they are frequently to be seen on a warm day leaping at the flies on the water, yet it is an unheard-of thing on Windermere to cast for them with a rod. The plumb line for charr is made of strong cord, and varies in length according to the number of baits which are to be put on it; but it is usually between forty and fifty yards long, and this is sufficient to carry five baits. At the end of the line is a lead sinker, weighing about $1 \frac{1}{2} l b$., having a small wing fixed in it, which assists in preventing it from revolving, although it is fixed to the main line with a strong swivel. To this line is attached at intervals of six or seven yards, short lines, or, as they are called by the fishermen, droppers, varying in length from six to ten yards, the shortest line being that nearest the bottom of the main line. What is generally used at Windermere, is a "phantom" made by the fishermen themselves, from sheets coppered on one side and silvered or clear on the other, which can be procured from any coppersmith or ironmonger. The fishermen cut them out with a pair of strong scissors, shaping them to their taste. A small treble hook is put on the phantom, and two yards of strong gut, having at least two swivels, and the remainder of the short line, or "dropper," may be of fine cord. Two lines such as are here described are always used in fishing for charr, one on each side of the boat.

Having reached the fishing ground, the boat mast be rowed slowly, and the sinker is put over the side, and the line allowed to sink until the dropper next to it is reached, when the main line is temporarily fixed, until the "dropper" and phantom is put out; the main line is then loosened and sunk further, until the next "dropper" is reached and put out, and so on until the whole line is out. This baving been done the end of the main line is attached to the top of a strong rod (a young sapling does very well), about fourteen or sixteen feet long, supple at the top, but not too much so, and then the rod is made to rest over the stern of the boat at the side upon which the line has been put out, and the butt end securely fixed in the bottom of the boat. When this has been done the second line may be put out at the side of the boat, in the same way as the first line, and secured with a rod. Care must be taken to have the boat always moving, otherwise the lines will foul.

It would appear that the preservation of charr leads to a substantial increase in their numbers, and angmentation in the food-producing property of the lake where such is carried out. While these fishes are not so very indifferent to bait and flies as some persons would lead us to believe, the angler with a bait appears to have more chance of sport than the fly-fisher, but the charr of Windermere usually will not rise to the fly, while the Welsh torgoch takes it freely. 
Mr. Harvie-Brown informs me of a chain of lochs in Scotland containing charr. In one small, deep pool of crystal-clear water they are of a larger size than those inhabiting the lochs lower in the valley. In a perfectly dead calm they rise, sometimes freely, to a certain $\mathrm{fly}$, but cease whenever a ripple disturbs the surface. As many as six dozen have been taken by one rod in a single day. One can see several feet down into this basin of pure water in a calm, and perceive the fish floating upwards and sucking in the fly, as they seldom dash at it like a trout.

Charr, says Mr. Jackson, except for a few weeks in the year when it appears to live on flies, preys on all small fish and captures them, even larger than would be supposed possible by any one who has not taken (as I have) a perch nearly two inches long out of a charr about nine inches in length.

\section{Salmo alpinus,* Plate CXVII, fig. 1.}

Umbla minor, Gesner, p. 1201 ; Willughby, p. 196, t. N. 7; Ray, p. 65. Salmo Lemani lacus seu Umbla, Rondel. ii, p. 160 ; Willughby, p. 197, t. N. 5 : Ray, p. 66 (Gilt charre). Charr, Pennant, Brit. Zool. (Ed. 1776), iii, 305, pl. lx and (Ed. 1812) iii, p. 407, pl. Ixi. ; Low, Fauna Orcad. p. 234.

Salmo alpinus, Linn. Faun. Suec. p. 117, no. 310, Syst. Nat. i, p. 510; Gmel. Linn. p. 1370 ; Bonn. Enc. Ich. p. 162, pl. lxvii; f. 272; Nilss. Skand. Faun. Fisk. p. 426 ; Jardine, Brit. Ass. vol. iv, p. 614: Günther, Proc. Zool. Soc. 1863, p. 8 and Catal. vi, p. 127 ; Collett, Norges Fiske, p. 160.

Salmo umbla, Linn. Syst. Nat. p. 511; Bloch, t. ci; Gmel. Linn. p. 1371; Bonn. Enc. Ich. p. 164 ; Jurine, Poiss. Lac Leman, pl. v; Agassiz, Poiss. d'eau douce, pl. ix, $x$ and xi ; Cuv. and Val. xxi, p. 233 ; Parnell, Mem. Wern. Soc. vii, p. 308 and Fish. Firth of Forth, p. 148; White, Catal. Brit. Fish. p. 78; Thompson, Nat. Hist. Ireland, iv, p. 160; Heckel and Kner, Süsswasserf. p. 285; Günther, Proc. Zool. Soc. 1862, p. 39 and Catal. vi, p. 125 ; Moreau, Poiss. France, iii, p. 530 , f. 207.

Salmo salvelinus, Linn. Syst. Nat. p. 511 ; Bloch, t. xcix ; Gmel. Linn. p. 1370 ; Bonnaterre, Ency. Ich. p. 162, pl. lxvii, f. 273; Cuv. and Val. xxi, p. 246; Yarrell, Brit. Fish. (ed. 3), i, p. 241 ; Günther, Proc. Zool. Soc. 1862, p. 38, 1863, p. 7 and Catal. vi, p. 126 ; Blanchard, Poiss. France, p. 444, f. 115.

Alpine charr, Couch, Fish. Brit. Isles, iv, p. 272 , pl. ccxxvi.

Salvelinus alpinus, Malm, Bohusläus Fauna, p. 540 .

\section{Variety a.-Salmo perisii, Plate CXIX, fig. 2.}

Torgoch, Willughby, p. 196. Umbla minor, Gesner; Farrington, Phil. Trans. Roy. Soc. 1755, p. 210. Torgoch, Pennant, Brit. Zool. l. c. Red charre or Torgoch, Ray, 1. c.

Salmo salvelinus, Donovan, Brit. Fish. v, pl. cxii ; Turton, p. 104; Jenyns, Brit. Vert. p. 428; Yarrell, Brit. Fish. (ed. 1), ii, p. 70, c. fig. (ed. 2), ii, p. 121.

Salmo umbla, Jenyns, p. 427.

Salmo cambricus, Günther, Proc. Zool. Soc. 1862, p. 49, pl. vi (not Donovan).

Salmo perisii, Günther, Ann. and Mag. Nat. Hist. 1865, xv, p. 75, and Catal. vi, p. 133 ; Houghton, British Freshwater Fishes, p. 141, c. fig.

Torgoch, Couch, Fish. Brit. Isles, iv, p. 264, pl. cexxiii.

D. 12-13(3-4) | O, P. 12, V. 9, A. 11-12( $\left(\frac{3-4}{8}\right)$, C. 21, L.1. 125-135, Vert. 61, CœC. pyl. 36 .

This form has the teeth of moderate size and the edges of the anterior nostril forming a small flap. Gill covors overlapping the root of the

\footnotetext{
* Space will only permit a selection of references being made.
} 
pectoral fin." Rayed dorsal fin 2/3 the length of the head: pectoral reaching more than half the distance to the base of the ventral. Sides with numerous red spots: belly red in the adult: pectoral, ventral and anal fins with white uppor or anterior edges. There are said to be 170 rows of scales descending to the lateral-line.

Stated to be a smaller form than the Windermere charr, seldom exceeding 12 or 13 inches in length. charr.

Names.-Torgoch in Wales signifies tor "a belly", and goch "red": the red

Habits.-Said to emerge from the depths of the lakes seeking the shallows for a short period in midwinter. Rises to a fly.

The example figured is one of the British Museum specimens $9 \frac{1}{2}$ inches in length, sent from the Lake of Llanberris by Mr. T. Ellis. It has 135 scales along the lateral-line.

\section{Variety b.-Salmo Willughbii, Plate CXVII, fig. 2.}

Charr of Windermere, Willugh. 1. c. ; Case charr, Pennant, 1. c. and Ray, 1. c. Salmo alpinus, Donovan, Brit. Fish. pl. lxi; Turton, Brit. Fauna, p. 104; Fleming, Brit. An. p. 180. p. 439.

Salmo umbla, Jenyns, Brit. Vert. p. 427; Thompson, Ann. and Mag. 1840, vi,

Salmo Willughbii, Günther, Proc. Zool. Soc. 1862, p. 46, pl. v, 1863, p. 11, and Catal. vi, p. 131.

Salmo struanensis, Gibson-Maitland, Field, Oct. 8th, 1881, p. 516.

Willughby's charr, Couch, Fish. Brit. Isles, iv, p. 262, pl. cexxii.

D. $12-13\left(\frac{3-4}{10}\right) \mid$ 0, P. $13-14$, V. 9-10, A. $11-12\left(\frac{3}{8}-\overline{8}\right)$, C. 19, L.1. 126, Vert. 59-62, Cœe. pyl. 28-44.

Teeth-Of moderate strength, 4 in each premaxillary; 20 in each maxillary. Fins-pectoral reaches more than half-way to the root of the ventral. Colourssides with red dots: belly red: pectoral, ventral and anal with white margins.

Scales - said to bave 180. The one figured, from a specimen 8 inches long, (S. Struanensis) had 126 along the lateral-line. Eight others from the Lakes had from 118 to 128.

\section{Variety c.-Salmo Killinensis, $\nmid$ Plate CXVIII, fig. 1.}

Günther, Proc. Zool. Soc. 1865, p. 699, pl. xl, and Catal.vi, p. 130 ; Houghton, Brit. Freshwater Fish. p. 145. c. fig.

? Salmo arcturus, Günther, Proc. Zool. Soc. 1877, p. 294, pl. xxxiii.

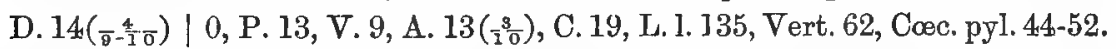

Length of head $4 \frac{1}{2}$, of caudal fin $6 \frac{1}{4}$, height of body $4 \frac{2}{2}$ in the total length. Eyes-diameter about $1 / 6$ of the length of the head, 2 diameters from the end of the snout, and also apart. Form of preopercle varies in different specimens; subopercle mostly short and high. Maxilla reaches to behind the orbit. Teeth-small. Fins-dorsal, pectoral, and ventral well developed. Scales-D. Günther counts 180 rows descending on to the lateral-line; in the example figured there were 135 pierced scales along the lateral-line. Coloursdark, sides with few light spots. In some the anterior edges of the lower fins are light coloured.

The example figured is $12 \frac{1}{4}$ inches long in the National collection: it was obtained by the late Mr. Gould from Loch Killin, Inverness-shire, in October : it has been disembowelled.

* These appearances are not peculiar to this variety.

† S. arcturus, Günther, the most northern Salmonoid recorded, N. lat. $80^{\circ} 28^{\prime}$ by $34^{\prime}$ is differentiated from S. killinensis owing to its being a little more slender! Malmgren ( \&f Akad. Förk. 1865, p. 534) remarks upon an example of Salmo alpinus, 76 millim. long, found in a river in Northern Spitzbergen. 


\section{Variety d.-Salmo Grayii, Plate CXIX, fig. 1.}

Salmo Alpinus, Dubourdieu, Hist. Co. Antriz, i, p. 119; Thompson, Ann.

Mag. Nat. Hist. 1840, vi, p. 448.

Salmo umbla, Thompson, 1. c. p. 439 (young) and Nat. Hist. Ireland, iv, p. 160.

Salmo Grayi, Günther, Proc. Zool. Soc. 1862, p. 51, pl. vii, and 1863, p. 12, and Catal. Fish. Brit. Museum, vi, p. 136; Houghton, Brit. Freshwater Fishes, p. 139, c. fig.

Gray's charr, Couch, Fish. Brit. Isles, iv, p. 267, pl. ccxxiv.

D. $13-14\left(\frac{\left.3-\frac{4}{9}-\frac{1}{3}\right)}{\mid}\right.$ | 0, P. 13-14, V. 9, A. $12\left(\frac{3}{8}\right)$, C. 21 , L. 1. 125-140, L. tr. $31 / 30$, Cooc. pyl. 37, Vert. 60 .

Lower jaw feeble. Teeth-small, 4 on each premaxillary and about 16 on each maxillary. Fins-Dorsal commences slightly nearer the snout than in the other forms, the fin being in the centre of the length of the back. Pectoral terminates at no great distance from the ventral : fins well developed. Scales19 rows from the hind edge of the adipose dorsal fin downwards and forwards to the lateral-line : 25 rows between the lateral-line and the base of the ventral fin: 125 to 140 rows along the lateral-line. Colours - sides with orange dots : fins with or without a light edge.

Thompson observes of the charr of Lough Melvin, that "the males are generally more gracefully formed than the females, and most of them are rather brighter in colour, but there is no external character so strikingly different as to lead to a certain knowledge of the sex : some of the largest finned are females." They are termed "fresh-water herrings" in Lough Melvin. When cooked the flesh is pale and its taste insipid.

Breeding.-Mr. Houghton received some from Lough Melvin in November, the males had not parted with their milt, nor the females with their ova.

The example figured is from a male in the British Museum collection, $10 \cdot 2$ inches in length.

\section{Variety e.-Salmo Colii, Plate CXVIII, fig. 2.}

Salmo Colii, Günther, Proc. Zool. Soc. 1863, p. 12, pl. and Catal. Fish. Brit. Mus. vi, p. 138; Houghton, British Freshwater Fishes, p. 138, c. fg.

Coles charr, Conch, Fish. Brit. Isles, iv, p. 269, pi. ccxxv.

D. 13-14 $\left(\frac{\left.\frac{8}{8}-\frac{4}{1}\right)}{\frac{1}{0}}\right)$ 0, P. 13, V. 9, A. $12\left(\frac{3}{8}\right)$, C. 19, L. 1. 125-128, L. tr. 31/30. Cœc. pyl. 42, Vert. 63.

Teeth-very small, 4 to 6 in each premaxillary, 14 to 17 in each maxillary. Fins-Pectoral not reaching nearly to the ventral. Ventral and anal fins with a narrow white anterior edge. Scales-125 rows along the lateral-line, and 160 descending to it: 18 rows between the hind edge of the adipose dorsal fin and the lateral-line : and 25 from the lateral-line to the base of the ventral fin.

The form of $S$. Colii appears to be principally distinguished from $S$. Grayi by the comparative shortness of its pectoral fins.

The figure is from a male example, $8 \cdot 2$ inches in length, in the National Mnseum, from Lough Eske ( $E s k$ or Yesk, "a fish"), the crater of an extinct volcano. It is also found in L. Dan.

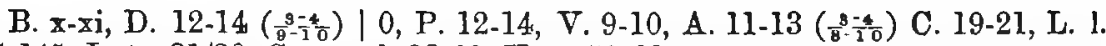
125-145, L. tr. 31/30, Cœe pyl. 28-62, Vert. 59-63.

Length of head $4 \frac{9}{4}$ to $5 \frac{1}{4}$, of caudal fin 6 to $6 \frac{1}{2}$, height of body $4 \frac{1}{2}$ to $5 \frac{1}{2}$ in the total length. Eyes-size depends much on age, sex, and nature of locality from whence procured : usually situated just in front of the middle of the length of the head, from $1 \frac{1}{4}$ to 2 diameters from the end of the snout and the same distance apart. In some the comparative height of the body is much greater than in others, and dependant on food, bealth, and the vicinity of the breeding season, the kelts becoming emaciated. The maxilla in some extends to beneath the last third of the orbit, in others to bejond the vertical from its hind margin, while it 
is likewise slightly more strongly developed in some than it is in others. The lower jaw in some varieties, as the torgoch of Wales, may be longer anteriorly than the upper jaw. The opercular pieces are of as diverse shapes in the charr as described in the trout, and frequently are dissimilar in the opposite sides of the head. Teeth-present in the jaws and in a line across the vomer near its anterior extremity, and opposite the teeth of the palatine arch, none along the body of the vomer. Fins-dorsal usually commences about midway between the end of the snout and the base of the candal fin, in some examples a little nearer the snout. The pectoral and other fins are of varying lengths in accordance with locality, sex, and other varying conditions. Scales-small and a much larger number of rows descending from the back of the lateral-line, than there are of pierced rows along its whole extent (see below). Ccecal appendages-these vary considerably, in Loch Inch 38 (Thompson); L. Rannoch, 28; the Lakes, 28-44, Dr. Günther detected from 36 to 52 , and the smallest number in those from Windermere, 36 , from the same locality I possess an example with 28 , and found the same number in a specimen received as $S$. struanensis. It is evident they are as inconstant as in the trout. Colours - these again vary, but as a general rule the belly, prior to spawning, becomes of a crimson or claret colour, while there are generally some light-coloured orange or black spots on the body and head. The front edge of the dorsal, ventral, and caudal as well as the upper edge of the pectoral are often of a pure white or orange colour. The variation in tints and shades are not so great as in the trout (see page 109). In some, the ventral, anal, lower portion of the pectoral, and hind edge of the caudal partake of the scarlet colour of the abdomen.

Varieties in colour.-_"By such alone," observes Dr. Günther, "fresh specimens of Salmo salvelinus and S. umbla, of S. Grayii and S. Willughbii, may be always distinguished," and in his interesting division of the British species into many, he divides it first in accordance with the development of the jaws and size of the teeth, an inconstant character, as I have observed (page 109). It is then subdivided in respect to the length of the pectoral fins: but here it is evident that the question of sez, locality where hatched and reared, and many other local circumstances, must be taken into consideration. I examined eight specimens received from the lakes, and found as follows:-All were from $8 \frac{1}{2}$ to 9 inches in leugth; in two the pectoral extended just half the distance to the base of the ventral, and in the remainder $1 \frac{5}{8}, 1 \frac{3}{11}, 1 \frac{1}{2}, 1 \frac{3}{4}, 2 \frac{3}{2}$, and $2 \frac{1}{6}$ in the interspace, clearly showing that this is not a character on which too much reliance should be placed.

The next subdivision is into whether the dorsal fin contains 13 or 14 rays. Such an enumeration is evidently open to uncertainty, unless it is taken into consideration and recorded how many undivided and how many branched rays are present. The first few which are undivided are minute, one or two may even be wanting. Thus in the 8 examples from the same locality already referred to I found from 3 to 4 undivided, and 9 to 10 divided rays in the dorsal fin, and similarly in the anal, 3 to 4 undivided and 8 to 9 divided rays. Moreau, in France, finds D. $\frac{4-5}{8-\frac{5}{10}}$, A. $\frac{3-\frac{4}{7}}{9}$. This character, therefore, is unreliable.

As to the comparative height of the body that varies with sex, season and food, and cannot be otherwise than a very uncertain element in the discrimination of a species.

As regards external characters, Dr. Günther observed (1862) that "dried and stuffed specimens of charr are of little or no use." One would have supposed from this that the colours, scales, and size of the fins would afford no criterion as to species. In 1864 the same author remarked that "the difference in the size of the scales is one of the most constant and important characters in salmonoids."

In examining numerous examples of Salmo fontinalis reared in this country, one cannot resist being struck with the considerable differences which occur as to the number of the scales, and the consequent inconstancy of this factor as a criterion for species. Taking the pierced scales along the lateral-line, I possess specimens which have from 122 to 142 : but it is in the number of irregular rows which descend from the back to the lateral-line where the greatest diversity occurs, 
while it is here that Dr. Güntber counts. Althongh in 8 of my British examplcs the difference in the number of pierced scales along the lateral-line does not exceed 20, I find from 185 to 235 rows descending to the lateral-line, or a variation of 50 scales. Taking the whole of the reputed British species, the extreme variation recorded is 70 rows. If, therefore, among 8 examples of American charr received from two localities I can observe a difference in number of at least 50 rows of scales descending from the back to the lateral-line, the extreme variation of 70 among specimens of charr obtained throughout the extent of Great Britain and Ireland appears hardly sufficient grounds for instiluting distinct species. Sir W. Jardine considered that "the northern, or Sutherland charr," has more elongated scales than the "southern charr," the scales of which he described as being more orbicular.

"The charr of Hawswater," observes Dr. J. Davy, "which is known to feed a good deal on insects, is a small and slender fish in comparison with the charr of Windermere, which feeds more at the bottom and has a less precarious supply, especially of Squille, which abound in the lake. The one takes the artificial fly freely; the other-that of Windermere-is rarely so tempted and seldom caught, except by trolling with the minnow. In short," he remarks, "so various are they that in no two lakes do they perfectly agree, either in their average size, form, colouring, or even in their habits." In examining 8 examples from the above locality I found the following variations:-D. $\frac{3-4}{\frac{3}{10}}$, A. $\frac{8-4}{8-9}$, L. 1. 118-128, Coec. pyl. (in one example) 28, (32-44, Günther). The number of rows of scales descending to the lateral-line varied from 166 to 180 . Passing on to the Loch Rannoch charr, S. struanensis (Maitland), we see certain differences present (see plate cxvii, fig. 2). the L. 1 .

D. $\frac{3}{9}$, A. $\frac{3-4}{8-\frac{4}{9}}$, L. 1. 120, Coec. pyl. 28,160 scales descended from the back to

The fins in some examples are more developed than in others, and may be said to be in many respects intermediate between $S$. alpinus and $S$. Fillinensis, but the most peculiar feature is the dark colour of the specimens. Among the examples sent to me by Sir J. Gibson-Maitland was a common trout from Loch Ranooch, which showed the same dark colours and well-developed fins. The eye in some of these charr was ratber large, which, taken in conjunction with the dark colours of the body and somewhat developed fins, would seem to indicate its living at some considerable depth.

Names. - Charr or char. Torgoch ("red belly"), Wales. Red-uame, Scotland. $L$ 'ombre-chevalier, French.

In olden time the credulous were tanght that three sons of the Church introduced these fishes into Wales from Rome, and placed two in each of the Lakes of Llanberris, Llynumber, and Trevennyn.

Habits.-A gregarious and usually deep swimming fish, shy of taking a bait and feeding largely at night-time. The common food of the trout has been found in its stomach, while when in confinement it can be similarly fed. It appears to require very pure and mostly deep water for its residence, but is found in some Irish lakes which are not very deep.

It has been observed to have disappeared from some lakes due to the entrance therein of poisonous matter as from lead mines," but in other localities where no such deleterious substances have obtained access, as Loch Leven, and some of the Irish Loughs, it has been suggested that such may be dependant upon the diminution or disappearance of such entomostraca as previously formed its watural food. It does not bear confinement well, but may be kept for a short period in tronghs throngh which a supply of water flows. Thompson, in 1835, observed that they were thus kept at Coniston water at the hotel and sold at $10 \mathrm{~s}$ a dozen.

Charr have been accused of destroying the eggs and young of the trout.

Knox found in examples from Windermere some entomostraca. Sir J.

* It has been stated to descend to the sea, and it has been asserted that some were captured there or at the mouths of rivers on the Welsh const after they had been driven out of Llanberris by poisoned waters. Further evidence on this point is required. 
Gibson-Maitland found the food in the stomach of all be examined from Lake Rannock distended with water fleas, Daphnia pulex. Thompson found in some from L. Inch that their stomachs were crammed with insect larvæ, entomostracous crustacea, a small Notonecta or boat-fly, bivalve shells of the genus Pisidium, and minute gravel.

Means of capture.-Fishing by bait is best in spring, but is carried on throughout the summer : very fine tackle is necessary. The best places are the deepest parts of the lake. They come in autumn into shallow water (see pp. 110, 111, 112).

Baits.-The artificial fly, spinning minnow, or spinning spoon, worms.

Breeding.-Dr. J. Davy found 1230 ova in an example weighing about half a pound, and that the principal spawning season in the lake district is from about the first week in November to the first in December. Whether, he observes, this is the only season is somewhat doubtful, as the fishermen at Windermere speak of a later one in which it is believed by them that fish of the larger size and few in number deposit their spawn in February and March. He "never heard of one being taken or seen in the Brathay after December." The locality chosen for forming a redd is in gravelly shallows in the lakes. They rarely ascend streams towards their source to spawn, but restrict themselves to near their outlet or portions where the current is not very rapid although a shallow is necessary. Thompson observes respecting the time of breeling, that the Loch Killin charr contained ova the size of peas on September 26th or 27th, whereas in the neighbouring lake of $\mathrm{L}$. Corr they were in high condition. This is one out of numerous instances which might be adduced respecting the different periods of spawning in contiguous localities. In Bavaria in the Konigsee, near Berchtesgarten, some of these fish taken at the latter part of June, July and August were found ready for spawning.

Dr. Davy informs us that Mr. Reynolds, in 1850-51, found none hatched in less than 60 days, the greater number on the $70 \mathrm{th}$, and from that to the $75 \mathrm{th}$, and some few as late as the 90th: the average temperature in the breeding boxes being about $40^{\circ}$. At about $55^{\circ}$ the process has been completed in 411 dajs, and there were some of the same egg's took 90 days in Mr. Reynolds' hatching boxes. Some eggs of the lake-trout were fertilized with the milt of the charr and commenced hatching in 70 days.

It was found by Dr. J. Davy that running water is not essential to the development of the eggs of the charr, from which he concluded that its breeding place being distinct from that of the trout it is not likely to give rise to hybrids. "That salt water, even of greater saltness than sea water, is not immediately fatal to the embryo, even when not included in its shell: moreover, that in slightly brackish water a partial development of the ovum may take place, and that the young fish can exist some days in such water, rendering it probable that the adult may be capable of existing in a tidal stream or even in the sea, where it is stated that the Welsh charr has been caught."

Life history. - The young when artificially reared appear to be somewhat more delicate than the trout. In Austria it is observed to grow much more rapidly in some lakes than it does in others. ' Yarrell states that in the autumn of 1839, Mr. Upton, near Sedberg, put into the Lillymere Lake, near the reservoir, some charr taken from Windermere, each weighing about $\frac{1}{2}$ lb., and on Angust 23rd, 1840, took with a fly two $2 \mathrm{lb}$. weight each, in the finest possible season, well fed and beautifully coloured.

Hybrids.-In Upper Austria, C. Peyrer observes a cross between Salmo salvelinus and the brook-trout is propagated and exceis the pure breed in many respects, the eggs of the former are milted from the latter. I have seen two specimens of hybrids over two years of age, the one between a salmon and a Loch Leven trout, the other between an American charr and a brook-trout; both were sterile, but as to whether merely temporarily or. permanently I cannot offer any opinion.*

* Lenchart observes upon hybrids between the salmon and brook- or sea-trout that his experiments led him to conclude that the hybrids are fertile and their offspring not sterile. Anil Professor Haack has fertilized the ova of hybrids between charr and trout with the milt of trout (see p. 59 ante). 
As food.-The flesh of these fishes varies, in some localities it is pink in colour, in others white. At the lakes they are in the greatest perfection from July until October. As they soon lose their delicate flavour after removal from the water they are potted and thus considered a great delicacy.

Habitat.- In Norway the red charr lives from a sea level up to 600 metres above it: in the S.E. portions of the country it is rare, in West Norway more common and captured in large numbers with a fly. Its flavour varies as greatly as does that of the trout, and it appears to thrive best in lakes where the temperature is somewhat uniform, without bottom springs and not having too large an amount of brook-water flowing in. It extends to Great Britain and Ireland, France, Southern Germany, and in the clear lakes of the Alps of Upper Austria, Tyrol, Bavaria, Switzerland, also in the Carpathian lakes up to 6000 feet above the sea.

The Orkneys, being occasionally captured in Loch Stenness, and three were obtained in Waas, in 1832 (W. Baikie): also from North Uist in the Hebrides. Examples from Sutherlandshire are in the British Museum, while Mr. J. HarvieBrown informs me that there is a charr loch about twenty-five miles from Durness, on Ben Hope, where they are taken up to $1_{9}^{1} \mathrm{lb}$. weight. At midsummer they are only known to rise at one part of the loch, on its S.E. side, between the exit of the stream and the island. In September numbers are taken with both worm and fly.. Mr. Bantock says that charr abound in scores of the Sutherlandshire lochs, and mentions the one referred to on Ben Hope, and another small loch (Borley) near the Manse at Durness; they are also found in the upper end of Loch Assynt. Thompson recorded their existence and obtained specimens from Loch Corr, Loch Moy and Loch Killin, Inverness-shire. Specimens from Loch Dochart, in Perthshire, were in the British Museum according to White, and Sir J. Gibson-Maitland has taken them in Loch Rannoch. Pennant recorded them in Loch Inch, Wigtownshire, and Thompson in Loch Grannoch, Kirkcudbrightshire. Also an example from Loch Bruiach is in the national collection. Black, 1844, observed that this fish had of late years disappeared from Loch Leven.

In England the lake districts of Cumberland, Nortbumberland, and part of Lancashire, more especially in Windermere, Keswick, Crummoch Water, Buttermere, Ennerdale, Coniston Water, Westwater and Hawswater, the area of which is estimated at 35,320 acres, are those where charr do or did frequent. Windermere, we are informed (1878), is very productive, while in Coniston the fish have been poisoned by the mines; they are also found in Rydal. In Windermere they are somewhat restricted to the deep waters, and spawn in the River Brathay, avoiding the Rothay, which is more frequented by trout. Some spawn in November and some are said to do so in February.

In Wales this fish is still fonnd near Snowdon, in the Lake of Llanberris, Llyn Cawellyn, Coss-y-gedawl and Bettew Festiniog in Merionethshire.

In Ireland. In the connty of Donegal it has been taken in Lough Esk (Camden), also from near Dunfanaghy (Templeton), L. Gartan, L. Kindun, L. Shessuch, L. Keel (Thompson), and L. Derg (Field, June, 1879), and L. Elvyn (Couch). In Antrim from L. Neagh (Dubourdien): Thonpson visited this place in 1834, and was informed that none had been captured for the last ten years, although twenty years previously they had been abundant. An old fisherman explained the reason as follows:- "That they once went down the River Bann to the sea and never came back again." In Monaghan at Lough Eaghish (incorrectly spelt Esk) according to Templeton, who stated they had become very rare and were all but extinct. In Fermanagh at Lough Melvin and L. Erne (Thompson), Westmeath in Belvidere Lake (Ball), county of Caran in Drumlane Lake (Thompson); in county of Mayo, Castlebar (Daniel) and Lough Conn (Pack); county of Galway in Lough Corrib, and L. Bofin (Thompson), Longford at Lough Nabrach (Ball), Connemara in Lough Ourad (Davy), Wicklow in Lough Dan (Thompson) and L. lada (Couch), Waterford in four mountain lakes (Smith), and at Inchigeelagh in the county of Cork ( $V_{y s e}$ ).

In figuring all the reputed species of British charr, as much as possible, examples have been selected in the National collection in order to prevent the 
possibility of any error of identification occurring. In the Lake districts they average from $1 \frac{1}{2}$ to over $2 \mathrm{lb}$. but they have been obtained many pounds heavier in weight.

\section{Salmo fontinalis, Plate CXX, figs. 1, 2.}

Salmo fontinalis, Mitchell, Trans. Lit. and Phil. Soc. New York, i, p. 435; Richards. Faun. Bor.-Amer. iii, p. 176, pl. lxxxiii, f. 1 and pl. lxxxvii, f. 2; Storer, Report Fish. Mass. p. 106; Kirtl. Report, Zool. Ohio, p. 169, and Boston Journ. Nat. Hist. 1843 , pt. iv, p. 305, pl. xiv, f. 2; DeKay, Fauna New York. Fish. p. 235, pl. xxxviii, f. 120; Ayres, Boston Journ. Nat. Hist. iv, 1843, p. 273; Cuv. and Val. xxi, p. 266 ; Bingelow, Bost. Journ. Nat. Hist. vi, 1850, p. 49; Günther, Catal. vi, p. $15 \%$.

Salmo hoodii, Richards. 1. c. iii, p. 173, dese. part. (spec. from River Mingan).

Salmo nigrescens, Rafin. Ichth. Ohiens. p. 45.

Baione erythrogaster, DeKay, Faun. New York. Fish. p. 236, pl. xxxix, f. 126.

Hucho fontinalis, Günther, Catal. vi, p. 152.

B. $x-x i$, D. $12-13\left({ }^{3-4}\right) \mid$ 0, P. $12-13$, V. $8-9$, A. $10-11\left(\frac{8}{7}-\bar{y}\right)$, C. 19 , L. 1. $122-$ 140, L. tr. 36-50/51-63, Coe. pyl. 34, Vert. 59-62.

Length of head $4 \frac{1}{2}$ to $5 \frac{2}{3}$ ( $4 \frac{3}{4}$ in a male), of caudal fin $6 \frac{3}{4}$, height of body $4 \frac{2}{3}$ to 5 in the total length. Eyes - diameter of each from $4 \frac{1}{2}$ to 5 or $5 \frac{1}{2}$ in the length of the head, 1 to $1 \frac{1}{2}$ diameters from the end of the snout, and from 1 to $1 \frac{3}{4}$ apart. Hind edge of preopercle regularly curved and with a very short but distinet lower limb. Height of opercle equals twice its greatest width; height of subopercle equals half the length of its lower edge which, with its hind margin, forms a regular curve. The form of the various opercular pieces in these fishes is liable to great variation frequently due to an apparent arrest of development; this is also seen at Howietown among examples which have had gill-fever in their infancy, and is considered to be one of its results. In one example the subopercle differs on the two sides of the same fish. The maxilla reaches to beneath the hind edge of the eye. Teeth-4 or 5 across the anterior portion of the vomer where that bone joins the palatine arch but none along its body. In a single row along the palatines and in the jaws. Fins - the rayed dorsal commences slightly nearer to the end of the snout than to the base of the caudal fin, its third or fourth ray is the longest and somewhat exceeds the length of the base of the fin. Pectoral extends about half-way (in some examples more, in others less) to the base of the ventral, which latter is inserted below the centre of the rayed dorsal fin, laid flat it does not quite reach the vent. Caudal forked in the young, but becoming square with age, as seen in the trout. Scales- 40 to 49 rows from the lateral-line to the base of the ventral fin : 21 to 26 rows from the hind edge of the base of the adipose dorsal fin downwards and forwards to the lateral-line; from 185 to 235 rows pass from the back to the lateral-line. Colours-greenish along the back, becoming lighter on the sides and beneath, the whole being beautifully shot with purple and gold. Numerous round or oval spots along the back becoming fewer below the lateral-line; anteriorly from the head to the dorsal fin many coalesce. Red spots above, on, and sometimes below the lateral-line. White edges with black bases to the upper margin of the pectoral and the anterior edges of the ventral and anal. Sinuous bands of black or rings on the dorsal fin: the upper and lower edges of the caudal barred. During the breeding season, the lower surface of the body of the male is frequently of an intense velvety black.

Varieties.-The following refers to an example 9 inches long, which was hatched from eggs received from Lake Huron, and which lived some years in a tank at the Westminster Aquarium.

B. $x$, D. $13\left(\frac{4}{9}\right)$, P. 11, V. 8, A. $10\left(\frac{3}{7}\right)$, C. 19

Length of head $4 \frac{1}{3}$, of caudal fin $7 \frac{1}{2}$, length of body $5 \frac{2}{3}$ in the total length. Eyes-diameter 6 in the length of the head, $1 \frac{2}{3}$ diameter from the end of the snout and 2 diameters apart. Subopercle nearly twice as long as deep. Scales43 rows from the lateral-line to the base of the ventral fin; 24 from the hind edge 
of the base of the adipose dorsal fin to the lateral-line. The figure is on plate cxx, fig. 2, along with one, fig. 1, raised at Howietown.

Halits. - Similar to our charr and, like it, appears to prefer deep water. Is generally considered to have great roving propensities and is not often found rising to the fly after having attained a pound in weight. A "conservator" writing from Shropshire to the Field, remarked that he considered it useless for turning into a running water, as it drops down stream, while it does not attain to the size of our brook-trout, and in a lake will not rise well to the fly. $\mathrm{He}$ thought it as bad as pike in destroying other fish, consequently he did not recommend it, although it is excellent eating, and fights well when hooked. Mr. Andrews at Guildford, states that he found that his yearlings ran from $8 \mathrm{oz}$. to $10 \mathrm{oz}$. and two-year-olds from $1 \frac{1}{2}$ to $2 \mathrm{lb}$. each; three-year-olds averaged $4 \mathrm{lb}$, and four-year-olds go $5 \frac{1}{2} \mathrm{lb}$. to $6 \frac{1}{2} \mathrm{lb}$. (Land and Water, July 22, 1882.)

Breeding.-The eggs as already remarked (page 105) are only about half the size of those of the brook-trout, and although in some localities it has been observed to deposit its ova earlier than the trout, it does so mostly at about the same period. "One very striking character in rearing Salmo fontinalis, is the remarkable difference in the growth of individuals in a single brood of fry from the same batch of ora: some at great speed outstrip their brethren in a short space of time, while the majority are probably $\frac{2}{9}$ less than these in size at the end of the first few months" (Carrington, Zool. 1876, p. 5112). It is by no means uncommon to find some take on cannibal propensities similar to the tront (page 94).

Hybridism.-In June, 1882, I received from Sir Pryse Pryse, Cardiganshire, an example 9 inches long, evidently a hybrid between this form and the brooktrout.

B. $x$, D. $14\left(\frac{4}{10}\right)$, P. 14, V. r. 9, 1. 8, A. $11\left(\frac{3}{6}\right)$, C. 19, L. 1. 119, L. tr. $27 / 39$.

Length of head 5 , of caudal fin $5 \frac{1}{3}$, height of body 5 in the total length. $E_{y j e s-d i a m e t e r}$ of each $1 / 5$ of the length of the bead, $1 \frac{1}{4}$ diameters from the end of the snout, and $1 \frac{3}{4}$ apart. Cleft of moutb deep, the maxilla reaching posteriorly to beneath the hind edge of the orbit. Hind edge of preopercle with a slight angle at its centre, also where it commences to form its lower limb, which latter is distinct. Width of opercle equal to two-thirds of its height. Height of subopercle at its base $2 \frac{1}{4}$ in that of the opercle, and having a rounded posterior margin. Teeth-two at the anterior portion of the vomer where it joins the palatine arch, 6 along the body of that bone at first in alternate rows, but the last two single, the most posterior one the largest. Scales-170 rows descend from the back to the lateral-line, 19 from the hind edge of the adipose dorsal in a line downwards and forwards to the lateral-line; 29 rows from the lateral-line to the base of the ventral fin. Fins-the dorsal commences midway between the end of the snout and the base of the caudal fin; the length of its base equals $3 / 4$ of its height. Candal emarginate. Colours-those of S. fontinalis being gray rivulated with yellowish-white and wide serpentine bands, or forming rings round gray blotches, which have a light central spot. A few red spots along the lateral-line, but none apparent above or below it. Dorsal, caudal, and ventral fins coloured similarly to $S$. fontinalis but the anal with a less distinct black border at the base of its white outer edge. red.

As food.-It is excellent, the flesh may be white, perfectly pink, or of a deep

Habitat.-The fresh waters of British North America, and contiguous portions of the United States. It has, during the last twenty years, been acclimatized in this country, and thrives in most places where it has been turned out, either in Scotland, England, or Wales.

In Norfolk it is said to grow twice as quickly as the brook-trout. It does well in the stock-ponds at Howietown, near Stirling, also near Guildford, and in other localities.

The tirst plate, cxx, fig. 1, is from an example $8 \frac{1}{2}$ inches long, from Howietoun, and fig. 2 from an example kept for some years in a tank at the Westminster Royal Aquarium. 


\section{Genus II-Osmerus, Artedi.}

Branchiostegals seven or eight: pseudobranchice rudimentary. Body somewhat elongated. Cleft of mouth deep. The maxilla almost extending to beneath the hind edige of the orbit. Teeth in upper jaws smaller than those in the lower, in a transverse band across the vomer, some being fang-like, also strong ones along the palatine and pterygoid bones. Large fang-like teeth anteriorly on the tongue and posteriorly smaller ones. Scales of moderate size. Pyloric appendages few and short. Ova small.

In Newfoundland, $O$. viridescens ascends the smaller streams in thousands as the ice disappears (Saxby, Zool. 1871, p. 2553). A nearly allied genus, Thaleichthys, exists on the Pacitic coast of North America, and so full of oil are they that their common name is candle-fish, or oolachan, as after having been sun dried they can be lighted, and will burn with a spluttering flame to the end (Angler's Note-book, p. 124). An oil, reputed to be medicinal, has been introduced into this country under the head of Oolachan oil, and is scarcely distinguishable from cod-liver oil (Nature, May 12th, 1881).

Geographical distribution.-Atlantic coasts of temperate and northern portions of Europe and North America, ascending rivers to spawn and frequently becoming resident there. One species from California.

Its growth is said to be frequently much retarded when passing from a marine to a fresh-water existence, in some parts of northern Europe it is acclimatized where there is no available outlet to the ocean.

\section{Osmerus eperlanus, Plate CXXI, fig. 1.}

Eperlanus, Belon. De Aquat. p. 288 ; Rondel. ii. 196 ; Aldrov. iv, c. 12, p. 536 ; Jonston, ii, c. 2, t. xxiv, f. 3; Will. p. 202, t. N. 6, f. 4; Ray, p. 66. Spirinchus, Jonston, t. xlvii, f. 6 ; Schonev. p. 70, t. vii. Osmerus, No. 1, Artedi, Gen. p. 10, Synon. p. 21, and Spec. p. 45. Salmo, sp. Gronov. Zooph. No. 373. Eperlanus Schonfoldii, Rutty, Nat. Hist. Dublin, i, p. 358. Trutta, sp. Klein, Pisc. Miss. v, p. 20, no. 12, t. iv, f. 2-4. Smelt, Pennant, Brit. Zool. (Ed. 1776), iii, p. 313. pl. Ixxi (Ed. 1812), iii, p. 416, pl. lxxii. Salmo eperlanus var. marinus, Walb. Artedi, iii, p. 57.

Salmo eperlanus, Linn. Syst. Nat. i, p. 511 ; Bloch, i, p. 176, t. xxviii, f. 2; Gmel. Linn. p. 1375 ; Bonnaterre, Ency. Ich. p. 164, pl. lxviii, fig. 276 ; Bl. Schn. p. 410; Donovan, Brit. Fish. ii, pl. xlviii; Turton, Brit. Faun. p. 104; Pallas, Zoo. Ros.-As. iii, p. 386; Gronov. ed. Gray, p. 152.

Salmo eperlano-marinus, Bl. i, p. 128, t. xxviii, f. 1.

Osmerus eperlanus, Lacép. $\nabla$, pp. 229, 231 ; Richardson, Faun. Bor.-Amer. iii,

p. 185 ; Flem. Brit. Anim. p. 181 ; Ekstr. Vet. Akad. Handl. 1834, p. 7 and Wische v. Mirkö, p. 191 ; Jenyns, Man. p. 429 ; Yarrell, Brit. Fish. (ed. 1) ii, p. 75, c. fig. (ed. 2) ii, p. 129 (ed. 3) i. p. 295; Cuv. and Val. xxi, p. 371, pl. 620; Parnell, Wern. Mem. vii, p. 312 and Fish. Firth of Forth, p. 152; Johnston, Berwick. Nat. Club, 1838, i, p. 173 ; Nilss. Skand. Fauna, p. 433; Kröyer, Danm. Fisk. iii, p. 1; Cuv. and Val. xxi, p. 371, pl. 620; Siebold, Süsswas. p. 271; White, Catal. p. 79 ; Schlegel, Dieren van Neder. p. 131; Thompson, Nat. Hist. Ireland, iv, p. 167; Malm. Wiegm. Arch. 1864, p. 339 and Fauna, p. 549 ; Günther, Catal. vi, p. 166; McIntosh, Fish. St. Andrews, p. 181; Blanchard, Poiss. France, p. 441, fig. cxiv; Winther, Ich. Dan. Mar. p. 44; Houghton, Brit. Freshwater Fishes, p. 161, c. fig.; Collett, Norges Fiske, p. 162; Feddersen, Danske F. Fiske, p. 78 ; Morean, Poiss. France, iii, p. 541.

Salmu (Osmerus) spirinchus, Pall. Zoogr. Ross.-As. iii. p. 387.

Eperlanus vulgaris, Gaim. Voy. Isl. and Gronl. Poiss. pl. xviii, f. 2.

Osmerus spirinchus, Cuv. and Val, xxi, p. 387. 
Smelt, Couch, Fish. Brit. Isles, iv, p. 276, pl. cexxvii.

B. vii-riii, D. $10-12$ |0, P. 11-12, จ. 8-9, A. 13-16 (17), C. 19, L. 1. 60-65, L. tr. 7/11, Cœe. pyl. 7, Vert. 60-62.

Length of head $4 \frac{1}{2}$ to $5 \frac{1}{4}$, of caudal fin $6 \frac{1}{2}$ to 7 , height of body 6 to $6 \frac{1}{2}$ or eren 7 in the total length. Eyes - diameter of each $4 \frac{1}{2}$ to $6 \frac{1}{2}$ in the length of the head, $1 \frac{1}{4}$ to 2 diameters from the end of the snout, and 2 apart. Its back is more rounded than its abdominal edge; sides rather flattened. Lower jaw the longer; the posterior extremity of the maxilla reaches to beneath the hind edge of the orbit. Teeth-those in the upper smaller than those in the lower jaw, where they are in two rows, the inner the larger, they increase in size posteriorly. Large fanglike ones on the vomer. Teeth also present on the tongue. Fins-The first dorsal commences midway between the hind edge of the eye and the base of the caudal fin; the second or adipose dorsal over the middle of the anal. Ventrals inserted below the anterior rays of the dorsal fin. Caudal forked. Scales-cycloid and deciduous; 6 rows between the lateral-line and the base of the ventral fin. Lateral-line-indistinct after the first few scales. Coecal pylori-seven very short ones, scarcely perceptible except after the intestines have been distended. Colours - of a light olive-green, superiorly, becoming silvery shot with purple on the sides and beneath. A wide silvery band passes along each side, numerous fine black dots are present on the head, back, dorsal and caudal fins more especially in large examples. Caudal dark edged. Eyes silvery.

Varieties - Linnæus considered that in the Baltic there were two forms, one termed nors possessed a foul odour, which in the early spring when the peasants come to buy it, fills all the streets of Upsal with the smell; adding that at this period agues prevail there. Valenciennes considered this to be O. spirinchus, Pallas, having a shorter body than the common form, and that it must have been from one of this variety that Bloch figured his fish in plate xxviii. Bloch erroneously believed that the same cause occasioned like results in London.

Names:-Smelt is said to be derived from its possessing a peculiar odour: resembling cucumbers, violets, or rushes. Jonston imagined that the term smelt was used in the sense of smelting metals, and derived from the transparent appearance of the fish, as if it were going to melt away. Sir J. Browne termed them spirinches, and a small one a priame. The Germans, owing to its aroma, term it the "stinkfisch," and Linnæus observes that the odour from some, warrants the German epithet: Taylor (Hardw. Sc. Gossip) has known the smelts to come up in such numbers that it was easy to detect the peculiar cucumber smell which distinguishes them, by walking along the river side. Sparling is a corruption of the French term "Eperlan," or else the two words are of a similar origin. Sprot is termed by Palsgrare to be a "sprat" or a "smelt." Skurring, Northumberland: Prim is the fry (East). Sibbald (Scotia, Illustrata) has an Apua vera, which he termed Sparling, Apua or Aphia were names which used to be applied to a goby. De spiering or spierling, Dutch. Eperlan, French.

Habits.-A gregarious and voracious species, remaining with us throughout the year, and passing a portion of each season in fresh, and the remainder, as a rule, in salt water, but irrcgular in its migrations, continuing in some rivers five or six months, in others hardly as many weeks. It is generally found in rivers or fresh waters, from August until May. In the Thames it rarely ascends above Woolwich, but Buckland in March, 1868, received three live ones captured nearly as high as Teddington, while others were taken near Kew Bridge. This year (1882) some were present at the end of September, and had selected their spawning quarters in the tideway opposite Chiswick Mill, and Strand-on-theGreen.

One fully 9 inches long was captured while bleak fishing at Wooden-bridgecreek, Hammersmith. It drives the dace before it, these latter fish ascending to Richmond, Isleworth, \&c. (Field). Lubbock observed the same migrations of roach and dace in Norfolk, fleeing from the snielts, ${ }^{*}$ which regularly ascend the

* M. de la Blanchère observes that the odour of the smelt drives other fish away, and thus protects it lrom its enemies. 
rivers in spring to spawn, and only stops its upward course at some insurmountable barrier. It appears to be particularly partial to small fish and shrimps. In some parts of Sweden, Nilsson found that they remained in lakes which possess sandy bottoms all the year round: in the spring they migrate to the shallow portions and ascend rivers.

Colonel Meynell, of Yarm, in Yorkshire, kept these fish for four years in a fresh-water pond, which had no communication with the sea; and Yarrell states that they continued to thrive and propagated abundantly. The pond being frozen over did not affect, them, and they did not lose either flavour or quality (Wern. Mem. December 17th, 1825). Mr. Egerton acclimatized these fish in fresh water, in a lake at Roselherne Manor, Knutsford, Cheshire. Many are kept alive in tanks in the Norwich fish-market until required for use (Southwell).

Mr. W. Wankly of Grange-over-Sands, Lancashire, sent an account of these fish to Land and Water, and observed he was much struck with the very rapid growth of the sparling from October to March-in October ten or twelve together weighed no more than $1 \mathrm{lb}$, in March the fish were $4 \mathrm{oz}$. to $6 \mathrm{oz}$. each, and occasionally one or more in a take weighed close on $8 \mathrm{oz}$. He opened a sparling as soon as it was taken out of the net, and found six, seven, and eight herring fry: next he tried the experiment of thus opening one or two alive, and taking others home intact, and always found nothing but digested food when the latter were gutted to be cooked. Opening some of the herring fry taken out of the fresh-taken sparling, i.e., just out of the water, he repeatedly found in the herring fry small shrimps, most neatly stowed away. The gastric juice or fluid of the sparling was so acrid, that when he wiped his hands on his pockethandkerchief and then used the handkerchief to blow his nose, both his nostrils and lips were inflamed and irritated, and more than once his tongue swelled in an extraordinary manner. The sparling were following and feeding on the herring fry, or herring ewes, as they are called there. The sparling are very uncertain and apparently fickle in their visits to their supposed haunts-i.e., in holes near rocks, where fresh-water streams mingle with tidal water. One day $20 \mathrm{lb}$. or $30 \mathrm{lb}$. may be taken; then for a week or ten days only an odd fish or two will be got; then a week of good takes. They are easily driven away, for on one occasion some men left a boat anchored in a hole to reserve the right of first draw. Whilst that boat remained there no sparling rested in the hole, but when it was removed they returned to their haunt.

Means of capture.-In Norfolk the fishery commences in March, and continues until the middle of April, daring which period the fish are full of roe. The smelter, says Lubbock, hour after hour does he persevere, moored exactly in the same spot with a torch attached to the side of his broad flat-bottomed boat (for this is a nocturnal occupation) in flinging his immense casting net, dropping the near side of it at each throw, within three inches of the torch. One fortunate cast, if smelts sell well, may recompense him for hours of fatigue, wet, and cold: and he waits like the losing gambler for the lucky throw which is to brighten his fortune. The smelts captured are kept alive in a tank. They are likewise taken in the estuary of the Ouse and in Breydon by means of stake nets. It appears to be partial to sandy shores, as off the Lincolnshire coast, while the different schools appear to consist of fish much of one size.

At the ontlets of many of our larger rivers were or are smelt fisheries which must have been carried on for long periods, because we find a mesh for the purpose of taking smelts legalized at the time of Queen Elizabeth. They may be caught with a paternoster line and No. 8 or 9 hooks, floats may or may not be used, shrimps either fresh or boiled, gentles, a red worm, or slices of fish form good baits. Bread crumbs have been recommended as ground bait Early mornings and late of evenings have been considered the best times for this fishing.

In the Solway Firth the best fishing season is in September, but they disappear the next month until March and April when they ascend to spawn.

Breeding.-Ova small, of a yellow colour, while the females are said to preponderate largely in numbers over the males. On January 13th, 1882, the season being very mild, I obtained smelts with the ova half developed. They 
generally deposit their spawn about March or April, and mostly near the high water spring-tide mark, subsequent to which they descend to the sea. In March, according to Pa:nell, they ascend the Forth in large shoals, and shed their spawn in immense quantities about two miles below Stirling Bridge, where at that time every stone, plank, and post appear to be corered with their yellowish-coluured ova. The fry are found about 3 inches long, swimming near the surface in shoals in the rivcrs in the month of August, ascending and descending with the tide (Yarrell). In America, at Maryland, the attempt to artificially propagate a species of this genus in 1877 proved nnsuccessful.

As food.-The smelt is justly held in great estimation for the table, but after spawning becomes insipid. It used to be split and dried and was thus considered to add a particular relish to the morning dram of spirits. Spring fishing for smelts is said to be inimical to smolts in Solway Firth, while in autumn the nets kill the parent fish. It is said by the French to be a good bait for eels: while the picked dog fish, Acanthius vulgaris, destroy large numbers of them in estuaries.

Habitat. - Coasts of Northern and Central Europe (probably excluding Tceland), and entering fresh waters, found in all the larger lakes of Finland, as well as along the sea shore (Malm). Along the Atlantic coast of France, abounding in the summer, and in the Seine as higb as Rouen.

Banffishire, rare (Edward). St. Andrews, not uncommon, large numbers being caught in the Tay (McIntosh).

In the Firth of Forth, in the neighbourbood of Alloa, it is taken in great numbers, especially towards the fall of the year. Those captured from November till January seldom exceed 6 incbes in length, but after the end of March the larger ones appear and the smaller ones take their departure (Parnell). Some of the rivers of East Anglia abound in these most beautiful and delicious fish, which are resident and common in the estuaries of the Tees and of the Humber. Also in the Onse and the Humber from Naburn Loch to Spurn Point, and occurs a considerable distance up the Tees (Yorkshire Vertebrata). There is a smelt fishery at Boston in Lincolnshire, from September until May, the fish being full of ova in April. It seems to be absent along our south coast from Dover to Land's End. Dr. Norman, of Yarmouth, in 1881, mentions in Land and Water a fine specimen he saw in Mrs. French's shop window at Yarmouth, scaling over seren ounces. Their cucumber-like smell when first caught is very perceptible. Then they are indeed a treat; but, in a few hours after, become comparatively insipid. Found in the estuaries of the Thames and Medway, in which latter river Pennant observed it never enters so long as snow water is present.

Parfitt (Fanna of Devon, p. 19) observes of this fish, "taken in the Exe: Ross, MSS., i, p. 55." Having been shown the MSS. by Mr. D'Urhan at the Albert Institute, Exeter, I find that it is the sand smelt, or Atherine, which Mr. Ross referred to. It has been asserted that this fish has been captured as far south as Swansea, but the statement is doubted by Dillwyn, who never found it there. Examples from Conway are in the British Museum. Along the west coast this fish is taken in the Dee and in the Mersey, while at Ulverstone they are found heary with spawn about the middle of March, the fishery being concluded by the middle of A pril. There are also smelt fisheries in the estuaries of many of the rivers which enter the Solway, whore they arrive in March or April to spawn, they are very small in June and $\mathrm{Jul}_{5}$, but at their prime in September. They do not appear to ascend above brackish water in order to deposit their ova.

In Ireland, Rutty, in his natural history of the county of Dublin, and Smith in that of Cork, mintions the capture of the smelt, and Templeton (Mag. Nat. Hist. 1837 (2), $i$, p. 411) asserts that it is sometimes taken on the coast in considerable abundance, but often several years intervene during which they are scarcely met with; Thompson suggests that these authors allude to the Atherine or sand smelt (i, p. 225), as he cannot find any authentic record of the true smelt having been captured in Ireland.

It attains to 10 or 12 inches in length. Pennant alludes to one of 13 inches which weighed $1 \frac{1}{2} \mathrm{lb}$. The example figured is 102 inches in leugth. 


\section{Genus III-Coregonds, Artedi.}

Argyrosomus, Agassiz (lower jaw the longer).

Branchiostegals seven to ten: pseudobranchice well developed. Body somewhat elongated. Cleft of mouth shallow: maxilla deep, and posteriorly not extending to behind the orbits. Teeth, when present, minute and deciduous. First dorsal fin with a moderate number of rays, the second adipose. Caudal forked. Scales of moderate size. Air-bladder large. Pyloric appendages numerous. Ova small.

Some authors have believed that the vendace, Coregonus vandesius, was introduced into Lochmaben, Dumfriesshire, from the continent of Europe, by or for the unfortunate Mary Queen of Scots. As the species has not been recognized on continental Europe, is difficult to transport, while it is not restricted to one Scottish loch, this tradition appears to rest on an uncertain foundation. In aquaria a very little matter affects them, a trifling variation of temperature, a little impurity or a difference between the oxygenating surfaces of two tanks, Lloyd proved were matters of life or death.

It has been questioned by some excellent authorities whether the species of this genus may not have been unduly multiplied, and M. de la Blanchere (Dict. des Pêches) observed that after a special study made at the Imperial establishment at Huningen, where he had fishes of all ages under observation, he had come to the conclusion that either the genus Coregonus ought to be composed of many distinct species, these distinctions being based upon fugitive and little marked characters: or else, that a single species is present endowed with great variability.*

Geographical distribution.-Mostly found in lakes, a few periodically migrating to the sea, in the nortbern portions of temperate Europe, Asia, and North America: while some appear to be marine. There are numerous species, several being found living in a single lake. In North America, under the term of "white fish," they are captured throughout the fresh waters. Dr. J. Davy observed that the vendace and skelley are rarely taken by anglers, or any way except by the net, and are of comparatively little value. It cannot be supposed that man ever took the trouble to place the skelley in a tarn such as the Red-Tarn, situated under the brow of Helvellyn, many hundred feet above Ullswater, and so difficalt of access. Much the same reflection presents itself as regards the vendace in Derwentwater and Bassenthwaite Lake, taking into account the distance of these lakes from Loch Maben.

\section{Synopsis of Species.}

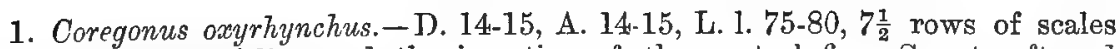
between the lateral-line and the insertion of the ventral fin. Snout soft and produced into a conical form. Marine entering fresh water.

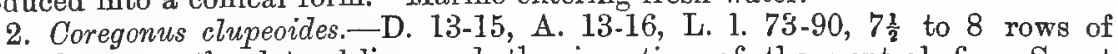
scales between the lateral-line and the insertion of the ventral fin. Snout vertically truncated. Fresh waters of the Lake districts and also of Wales.

3. Coregonus vandesius.-D. 11, A. 13-14, L. 1. 66-70, seven rows of scales between the lateral-line and the insertion of the ventral fin. Lower jaw the larger. Fresh-water lochs of Scotland.

4. Coregonus pollan.-D. 13-14, A. 12-14, L. 1. 80-88, nine rows of scales between the lateral-line and the insertion of the ventral fin. Jaws anteriorly of equal length. Fresh waters of Ireland.

* Collett (Norges Fiske) considers as pertaining to C. lavaretus. C. murana, Bloch, c. Widegrenii, Malmgr. C. lapponicus, Günther, C. gracilis, Günther; also probably $C$. maxillaris, Günther, and $C$. humitis, Günther. 


\section{Coregonus oxyrhynchus, Plate CXXI, fig. 2.}

Oxyrhynchus, Rondel. ii, p. 195; Gesner, p. 771; Willughby, p. 187. Albula nobilis, Schonev. (not Gesner), p. 12 . Coregonus, sp. Artedi, Synon. p. 21, no. 4, Genera, p 10, no. 4. Salmo, sp. Gronov. Zooph. no. 374.

Salmo (Coregonus) oryrinchus, Linn. Syst. Nat. p. 512; Lacép. v, pp. 263, 267 ; Gmel. Linn. p. 1383 ; Bonnat. Ency. Ich., p. 167 ; Gronov. ed. Gray, p. 152.

Tripteronotus hautin, Lacép. $\nabla$, p. 48.

Salmo lavaretus, Bl. i, p. 163, t. $\operatorname{xxv}$ (not Linn.).

Salmo thymallus latus, Bl. i, p. 170, t. xxvi.

Coregonus oxyrinchus, Kröyer, Danm. Fisk. p. 76, c. fig.

Coregonus oxyrhynchus, Ekström, Fische Mörkö, p. 198; Cuv. and Val. xxi, p. 488, pl. 630 ; Sélys-Longch. Fauna Belge, p. 222 and Bull. Acad. Belg. ix, 1842, p. 510; Malm.* Wiegm. Arch. 1864, p. 323, and Fauna, p. 544; Siebold, Süsswasser. f. p. 260 ; Schlegel, Dieren Neder., p. 135, pl. xiii,f. 2 ; Blanchard, Poiss. France, p. 433, f. 112 ; Günther, Catal. vi, p. 173; Collett, Norges Fiske, 1875 , p. 165 ; Day, P. Z. S. 1877 , p. 419, c. caput.; Moreau, Poiss. France, iii, p. 552 .

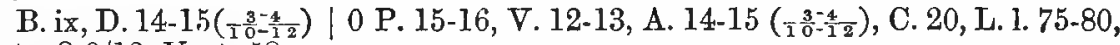
L. tr. 8-9/12, Vert. 58 .

Length of head $4 \frac{3}{4}$ to 5 , of caudal fin $5 \frac{1}{4}$ to $5 \frac{1}{2}$, height of body $5 \frac{1}{2}$ to 6 in the total length. Eyes-diameter of each $44_{4}^{1}$ to $4 \frac{1}{2}$ in the length of the head, $1 \frac{1}{4}$ to $1 \frac{1}{2}$ diameters from the end of the snout, and $1 \frac{1}{4}$ to $1 \frac{1}{2}$ apart. Snout produced into a conical point beyond the upper jaw which is longer than the lower jaw; the maxilla reaching to below the first third of the eye. Length of lower limb of the preopercle $3 / 4$ of that of the vertical limb. Sub opercle rounded posteriorly. Teeth -in the jaws may be present or absent, being very deciduous, when present like little needle points rather far asunder in the upper jaw. Gill rakers not so long as the eye. Fins-first dorsal commences rather nearer the snout than to the base of the caudal fin, its longest ray $2 / 3$ the height of the body below it. Pectoral as long as the head excluding the snout or behind the middle of the eye. Anal commences anterior to the vertical from the commencement of the adipose dorsal. Caudal forked. Scales-about 34 anterior to the base of the rayed dorsal fin; $7 \frac{1}{2}$ between the lateral-line and base of the ventral, where there is an elongated scale. Intestines-stomach siphonal with about 200 short coecal appendages. Colours-gray along the back becoming silvery on the sides and beneath. Snout black. Fins yellow, upper edge of dorsal black; tip of adipose dorsal and caudal gray, a dark mark across ventral, and a slight band along the anal.

Varieties.-Valenciennes observes that two varieties exist: the one blackish with a shorter snout from Lake Mälarn; the other paler in colour, having a longer snout, found in Lake Wenern, and termed $N \ddot{a} b b$-sit.

Names.-Houting or Hautin, from the Dutch, a probable corruption, according to Valenciennes, from Whiting.

Habits.-Mostly marine, but enters fresh waters. It seems to do better in a fresh water than in a marine aquarium.

Habitat.-Coasts of Northern Europe, entering fresh waters in Holland, Germany, and Denmark. I received the first recorded British example April 17th, 1877, from Lincolnshire; in March, 1880, the late Mr. Buckland sent me one captured near Chichester. February, 1881, I obtained a third from the mouth of the Medway, taken from among some smelts.

Rutty (Nat. Hist. Co. Dublin, 1772, i, p. 365) observed, "Thymallus, the Grayling or Umber. With us it is a sea fish, and less than Willughby's, which is a river fish." He may have been referring to Coregonus oxyrhynchus.

The figure is from the Lincolnshire example, 7 inches long, already referred to, but the fish attains to more than twice this length.

* Malm considers Coregonus marcena, Nilsson, and C. Widegrenii, Malmgren, as synonymous for this species, and probably $G$. Lloydii, Güuther. 


\section{Coregonus clupeoides, Plate CXXII.}

Guiniad, Will. p. 183 ; Groyniad, Pennant, Brit. Zool. (Ed. 1776) iii, p. 316, pl. 1xiii (Ed. 1812) iii, p. 419, pl, Ixxiii.

Coregonus clupeoides, Lacep. $\nabla$, p. 698 ; White, Catal. p. 81 ; Thompson, Nat. Hist. Ireland, iv, p. 170 ; Günther, Catal. vi, p. 188; Houghton, Brit. Freshwater Fishes, p. 153, c. fig.

Salmo lavaretus, Turton, Brit. Fauna, p. 104.

Coregonus lavaretus, Flem. Brit. Anim. p. 182; Jenyns, Man. p. 431 ; Yarrell, Brit. Fish. (ed. 2) ii, p. 142.

Coregonus Cepedei, Parnell, Ann. Nat. Hist. 1838, i, p. 162, c. fig.; Yarrell, Brit. Fish. (ed. 2) ii, p. 151 (ed. 3) i, p. 314; Cuv. and Val. xxi, p. 503.

Coregonus microcephalus, Parnell, l. c. p. 163, c. fig.

Coregonus Pennantii, Cuv. and Val. xxi, p. 507 ; Yarrell, Brit. Fish. (ed. 3) i, p. 310 ; White, Catal. p. 80. coxxxii.

Guiniad and Powan, Couch, Fish. Brit. Isles, iv, pp. 286, 295, pls. ccxxix,

B. ix, D. $13-15\left(\frac{\left.3-\frac{4}{1}\right)}{10}-\frac{1}{2}\right)$ 0, P. 17, V. 11-12, A. $13-16\left(\frac{3}{10}-\frac{3}{1}\right)$, C. 19, L. 1. 73-90, L. tr. 9/11, Vert. 38/28.

Length of head 5 to $5 \frac{1}{2}$, of caudal fin 5 , height of body $4 \frac{1}{3}$ to $5 \frac{1}{4}$ in the total length. Eyes-diameter of each 4 in the length of the head, 1 diameter from the end of the snout, and $1 \frac{1}{4}$ apart. Snout truncated : the upper jaw somewhat longer than the lower; the maxilla reaches to beneath the first third of the orbit and is slightly longer than the diameter of the eye, while the length of the mandible is $2 j$ of that of the head. Nostrils close together, midway between the eye and the end of the snout. As, in some examples, there is a slight depression at the nape it gives the appearance as if the back behind the head were somewhat arched. Teeth-absent or very minute. Fins-the first dorsal commences midway between the end of the snout and the termination of the base of the adipose fin, it is twothirds to three-fourths as high as the body beneath it. Pectoral inserted below the middle of the depth of the side, and is as long as the head excluding the snout. Ventral below the middle of the first dorsal, and midway between the posterior extremity of the head and the commencement of the base of the anal fin. Caudal deeply forked. Intestines-cœeal appendages short and numerous. Scales-7 $\frac{1}{2}$ to 8 rows between the lateral-line and base of the ventral fin. Colours-silvery lightest on the sides and beneath, fins dark gray, almost black, externally.

Varieties-Parnell considered that two species were found in Loch Lomond, the first being Lacépède's fish, but as a Coregonus clupeoides, Pallas, existed, he termed the commonest C. Cepedei and the smaller headed one C. microcephalus, subsequently he informed Yarrell that he had received intermediate forms.

I possess an example from Haweswater in which the middle of the dorsal fin is not only deficient but the back is regularly scaled between the end of the base of the seventh ray and the last three, the four or five missing ones having evidently not been developed due probably to some embryonic injury.

Names.-The Welsh name Gwyniad, or white fish, is derived from Gwyn, "white." In Ullswater it is known as the Schelly, a term which is said to refer to its scales. Fresh-water herring.

Habits.-Similar to those of the other fresh-water forms, and as a rule refraining from entering running water or coming to the surface at mid-day. The late Professor Rolleston gave me some examples which he collected at Haweswater, and informed me that in the early spring some came to the surface with the stomach everted, due to expansion of the air-bladder. We examined one and found the pneumatic tube to be pervious.

Means of capture.-Netting. In Loch Lomond the fishing lasts from March until September, the fish being considered in their prime during August and September. Parnell observes that although they are taken by means of drag nets, occasional instances have occurred in which a fow have been secured by the artificial fly, but they had never been known to touch a minnow or other bait. 
Breeding.-December (Pennant).

As food.-Dry and insipid. It soon decomposes.

Habitat.-Loch Lomond, Ulswater, Haweswater, and large lakes in Cumberland, the Red Tarn, a small piece of water upwards of 2600 feet above the sea, near the summit of Helvellyn. Conningham mere, Lancashire; Pemble mere, near Chester; Lyntegid, near Bala, in Merionethshire ; and an instance has been recorded of its straying six miles down the Dee as far as Llandrillo.

The example figured was from Bala lake, and I am indebted for it to Spencer Walpole, Esq.

This fish attains to 3 or $4 \mathrm{lb}$. weight (Pennant), and has been recorded up to 16 inches in length.

\section{Coregonus vandesius, Plate CXXIII, fig. 1.}

Vandesius et Gevandesius, Sibbald, Scot. Tllus. p. 26. Vangis and Jurangis, Pernant, Brit. Zool. (Ed. 1776), iii, p. 317 (Ed. 1812), iii, p. 420. Vendace, Knox, Trans. Roy. Soc. Edin. xii, p. 503.

Coregonus marcenula, Jardine, Edin. Journ. Nat. and Geol. Soc. iii, p. 4, pl. 1 and Brit. Ass. 1834, p. 615 ; Jenyns, Manual, p. 432 ; Swainson, Fishes, ii, p. 287.

Coregonus vandesius, Richards. Faun. Bor.-Amer. ii, p. 213 ; Günther, Catal. vi, p. 194; Houghton, Brit. Freshwater Fishes, p. 155, c. fig.

Coregonus Willughbeii, Jardine, Illus. Scot. Salm. pl. vi; Yarrell. Brit. Fish. (ed. 2), ii, p. 146 .

Coregonus albula, Cuv, and Val. xxi, p. 520, pl. 633; Stewart, El. Nat. Hist. i, p. 373; White, Catal. Brit. Fish. p. 81 ; Yarrell, British Fish. (ed. 3), i, p. 324 .

Vendace, Embleton, Nat. Hist. Trans. Northum. and Durham, iv, p. 147, c. fig.; Couch, Fish. Brit. Isles, iv, p. 289, pl. ccxxx.

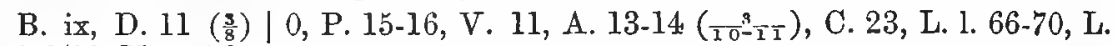
tr. $8-9 / 10$, Vert. 56 .

Length of head $5 \frac{1}{4}$, of caudal fin $5 \frac{3}{4}$, height of body $4 \frac{1}{2}$ in the total length. Eyes-diameter of each 3 to $3 \frac{1}{4}$ in the length of the head, $3 / 4$ of a diameter from the end of the snout, and 1 diameter apart. Lower jaw the longer, the extremity when the mouth is closed forming a portion of the upper profile of the head: the posterior extremity of the maxilla reaches almost to beneath the middle of the eye. Teeth-very minute. Fins-the first dorsal commences nearly midway between the end of the snont and the posterior end of the base of the adipose dorsal fin; it is four-fifths the height of the body below it. Ventrals inserted on a line below the anterior portion of the first dorsal fin and midway between the hind edge of the opercle and the commencement of the anal fin. Cocal appendages numerous. Scales -7 rows between the lateral-line and the insertion of the ventral fin. Colours - greenish blue along the back and upper half of the body, silvery dashed with gold along the sides and beneath. Fins rather dark. Sir W. Jardine observes that where the hottom is mossy they are of a darker tint above and incline more to yellowish brown on the under parts.

Varieties. - In those from the Castle Loch the lateral-line is said to be mesial, while in such as come from Mill Loch it is nearer the dorsal profile, the latter being likewise thicker and possessing longer heads.

Names.-Pennant suggests the term Vendace has been derived from the French Vendoise, "a dace," which it may have appeared to resemble to the Frenchified Scotch Court which attended Queen Mary in her forced retirement when it was said to have been introduced.

Habits.-A gregarious fresh-watcr fish which swims in large shoals retiring to the depths of the lakes as the warm weatber sets in. It has been said that the sexes keep apart, but in a draught made in October nine were females and six males, which would tend to show that they reside togetber. As Knox conveyed some of these fish alive in a bucket of water to the village, it shows they do not, as has been asserted, die immediately on being taken out of the lake. Kuox (Ann. Nat. 
Hist. (2), xv, 1855, p. 57), found the stomach of some he examined distended with thousands of Entomostraca. Jardine observed the same food in those he dissected.

Means of capture.-Netting.

Breeding.-Generally, but not invariably, about the middle of November. Knox examined 22 females captured the middle of December, in 19 the ovaries were small, very soft, and the ova mere points, while the fish were in good condition: in the other three the ova were large and the parents about to spawn: in two males the milts were progressing in size, but not much enlarged.

As food.-It is much esteemed locally, being considered a great delicacy for the table, enhanced possibly by the difficulty in procuring it.

Habitat.-In two of the system of lakes near Lochmaben, Dumfriesshire, namely, the Castle Loch, so termed from the ruined castle of Brus, on its banks: and the Mill Loch; the latter being deeper but less extensive. Also Derwentwater and Bassenthwaite Lakes (Davy).

It attains to about 9 inches in length.

\section{Coregonus pollan, Plate CXXIII, fig. 2.}

Coregonus pollan, Thompson, Proc. Zool. Soc. 1835, p. 77, and Mag. Zool. and Bot. i, p. 247, and Nat. Hist. Ireland, iv, p. 168; Jenyns, Manual, p. 432 ; Yarrell, Brit. Fishes (ed. 1) ii, p. 88, c. fig. (ed.2) ii, p. 156 (ed. 3) i, p. 319 ; Cur. and Val. xxi, p. 502 ; White, Catal. p. 81 ; Günther, Catal. vi, p. 194; Houghton, Brit. F. W. Fish. p. 157, c. fig.

Coregonus cluppeoides, Thompson, Ann. and Mag. Nat. Hist. ï, and l.c. iv, p. 170.

Pollan, Couch, Fish. Brit. Isles, iv, p. 292, pl. cexxxi.

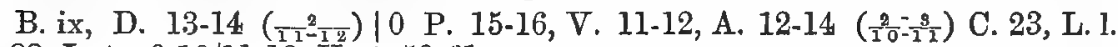
80-88, L. tr. 9-10/11-12, Vert. 59-61.

Length of head 5 to $5 \frac{1}{4}$, of caudal fin $5 \frac{1}{4}$, height of body $5 \frac{1}{4}$ to $5 \frac{1}{2}$ in the total length. Eyes-diameter 4 to $4 \frac{1}{4}$ in length of the head, 1 to $1 \frac{1}{4}$ diameters from the end of the snout, and also apart. The two jaws of the same length anteriorly. Thompson observes that he has seen individuals with the upper rather exceeding the lower jaw, others with the lower slightly projecting beyond the upper, and the difference was not sexual. The posterior extremity of the maxilla reaches to beneath the first third of the eye. Teeth-if present very minute. Fins-the first dorsal commences midway between the end of the snout and the hind edge of the base of the anal fin, it is five-sixths the height of the body beneath it: ventral inserted below the middle of the first dorsal fin, and midway between the hind edge of the head and the middle of the base of the anal fin. Coocal appendages numerous. Scales-nine rows between the lateral-line and the insertion of the ventral fin. Colours-superiorly bluish along its upper third, silvery on the sides and beneath. Dorsal, caudal, and anal fins darkest externally.

Varieties.-The pollan of Lough Erne, was observed by Yarrell to be comparatively rather deeper than those from Lough Neagh. Mr. Ffennell produced specimens of the pollan taken in November, 1881, in Lough Neagh, and some from Killarney, taken May 8th, and pointed out the difference in the shape of the head and gill-covers in the specimens from the two localities (Dublin Nat. Hist. Soc. April, 1852).

Names.-Pollan, from a local Irish term. Thompson obtained two examples, $4 \frac{1}{2}$ and $4 \frac{3}{4}$ in. long, from the Shannon at Killaloe where it was termed a Cunn, this form being reputed to descend the river with the eels during the winter and to refuse all bait. He first proposed to term it Coregonus elegans.

Habits.-This fish approaches the shore in large shoals, not only during spring and summer but late into the autumn. It dies soon after being remored from the water. In Lough Neagh, where it is a permanent resident, it is not generally diffused but approaches the shores at some particular spot, to which it retarns again and again.

A correspondent of the Field (Jan. 29th, 1881) observes respecting this fish in 
Lough Derg:-During the last two seasons I have occasionall $f$ come across instances of the fresh-water herring or "pollen "-a fish that little seems to be known about. Those that I have seen I have always found floating in very deep water about the centre of the lake in a half dead condition; and, though I have been fishing the lake for twenty years, I never before came across one; but I have been told that at times they have been taken in great numbers in nets. I never heard of one having been taken on a hook, nor do I know on what they feed.

Several examples of this fish have been similarly obtained in different years. Thompson examined the stomach of six pollans in June, 1836, and "found them all filled with food consisting chiefly of mature individuals of Gammarus aquaticus, and the larvæ of various aquatic insects : some shells of the genus Pisidium, one of the fry of the three-spined stickleback (Gasterosteus), and a few fragments of stone." In the stomach of one captured at Lough Neagh in July, there were not less than a hundred examples of Mysis and a single Limneus pereger.

Means of capture.-Netted usually in an afternoon, then packed in boxes and transmitted by rail and steamer to Liverpool, Manchester, and other large towns. Has occasionally been taken with the artificial $\mathrm{Hly}$.

The pollan, observes Thompson, approaches the shore in large sboals, not only during spring and summer, but when the antumn is far advanced. The usual time for fishing for it is in the afternoon, the boats returning the same evening. On the days of the 23rd, 24th, and 25th of September, 1834, they were caught plentifully from the shore. A short time previously 17,220 fish were taken at one draught, selling at $3 s 4 d$ the hundred (123), producing £23. $6 s 8 d$.

In a letter from Francis Nevil, Esq., to the Lord Bishop of Clogher, dated February 12th, 1712, writing respecting Lough Neagh, he remarks that among other fish it abounds in pollans. "The English call them fresh-water herrings, for want of another name; for pollan is an Irish name. They catch them in summer with seines as they do herrings, and they are a great relief to the poor, being very cheap; they are much in shape and bigness like to the largest smelts, full of very large bright scales, and pleasant meat, being eat fresh. They were supposed to be a peculiar fish to that lake; but since I came here I find Lough Earne has the same sort, but not in so great plenty. They are generally caught here in the eel-nets, running to the sea."

Breeding.-They spawn in November and December on a hard or rocky bottom, the ova are from $\frac{1}{10}$ to $\frac{1}{8}$ of an inch in diameter. Thompson found $6156^{\circ}$ ova in an example $11 \frac{3}{4}$ in. long taken in Lough Neagh, November 28 th, 1839.

As food.-It is not held in any great estimation as it does not keep well, still if fresh it is thought by some to be a well-flavoured fish. They used to be taken in great quantities to Belfast; large numbers are now exported to England.

Habitat.-Ireland in Loughs Neagh, Earne, and Derg, also in Lough Corrib and in the Shannon. It attains the length of about 12 or 13 in., and its usual weight is abont $6 \mathrm{oz}$.

This fish was first alluded to in Harris's History of the County of Down, 1744; it is also mentioned under the name of Goaske, in Sir Henry Pier's Description of the County of Westmeath, 1744, wherein it is said to be peculiar to Loughs Tron and Direvragh.

Though permanently resident in Lough Neagh, it is not generally diffused there, and Thompson observes that it rarely occurs between the Rivers Mayola and Toone: while from the six-mile-water to Shanes Castle is so favourite a resort, that a few houses which formerly stood near the latter locality, were dignified with the name of Pollans Town. The common eel is stated by a fisherman at Lough Neagh to live chiefly upon the pollan, and he frequently knew it destroy these fish when in the nets, and also injure the nets.

The largest example Thompson heard of was said to have weighed $2 \frac{1}{2} \mathrm{lb}$., but the largest he actually saw were 13 inches long. 


\section{Genus IV.-Thymallos, Cuvier.}

Branchiostegals seven to ten: pseudolranchioe well developed. Body somewhat elongated and compressed. Gape of mouth small: marilla short, rarely extending to beneath the middle of the orbit. Minute teeth on the jaws, near the head of the vomer, and on the palatines: none on the tongue. First dorsal with many rays (20-24rays): second dorsal fin adipose: caudal forled. Stomach siphonal. Scales rather large. Lateral-line well marked. Pyloric appendages rather numerous. Air-bladder very large.

Geographical distribution.-Temperate portions of the northern hemisphere, generally restricted to fresh waters.

\section{Thymallus vulgaris, Plate CXXIV.}

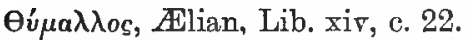

Thymallus seu Thymus, Belon. De Aquat. p. 184; Salvian. fol. 81, t. xvi; Rondel. ii, p. 187; Gesner, pp. 978, 979 ; Aldrov. v, c. 14, p. 594; Jonston, iii, tit. i, c. 3 , p. 128 , t. xxvi, f. 3,4 , and t. xxxi, f. 6 ; Willughby, p. 187 , t. N. 8 ; Ray, p. 62. Coregonus, no. 3, Artedi, Synon. p. 20, Genera, p. 10, Species, p. 41. Salmo, Gronov. Zooph. no. 375. Trulta, Klein, Pisc. MSS. v, p. 21, no. 15, t. iv, f. 5. Grayling, Pennant, Brit. Zool. (Ed. 1776) iii, p. 311, pl. lxi (Ed. 1812), iii, p. 414, pl. lxxii; Low, Fauna Orcad. p. 224; Davy, Salmonia, 1832, p. 198. Duhamel, Pêches, ii, p. 218, pl. iii, f. 2.

Salmo thymallus, Lin. Syst. Nat. i, p. 512 ; Bloch, Fishe Deuts. i, p. 158, t. xxiv ; Gmel. Linn. p. 1379 ; Bonn. Ency. Ich. p. 167, pl. lxix ; Bl. Schn. p. 410; Donovan, Brit. Fish, v, p. Ixxxviii ; Pall. Zoo. Ross.-As. iii, p. 364; Turton, Brit. Fauna, p. 104; Gronov. ed. Gray, p. 153.

Salmo thymus, Bonnaterre, 1. c. p. 167.

Coregonus thymallus, Lacép. v, p. 254 ; Flem. Brit. An. p. 181 ; Jurine, Poiss. Lac Leman, pl. vi.

Thymallus vulgaris, Nilss. Prod. Ich. Scan. p. 13, and Skand. Fauna Fisk. p. 447; Jenyns, Manual, p. 430 ; Bonap. Pesc. Eur. p. 23 ; Kröyer, Dan. Fisk. iii, p. 35, c. fig.; Yarrell, Brit. Fishes (ed. 1), ii, p. 79, c. fig. (ed. 2), ii, p. 136 (ed. 3), i, p. 304; White, Catal. p. 80 ; Thompson, Nat. Hist. Ireland, iv, p. 167 ; Schlegel, de Dier. Ned. p. 133 ; Siebold, Sus. w. f. Mit. Eur. p. 267 ; Günther, Catal. vi, p. 200 ; J. Warnimont, Pub. de l'Inst. de Luxen. xi, pp. 1-48; Collett, Norges Fiske, p. 171; Feddersen, p. 78 ; Canestrini, Fauna Italia, Pesc. p. 23; Houghton, Brit. F. W. Fish. p. 149, c. fig.; Morean, Poiss. France, iii, p. 543 ; Giglioli, Cat. Pesc. Ital. p. 42.

Thymallus vexillifer, Agass. Mem. Soc. Sc. Nat. Neuch. i, t. B, t. D, f. 5-8, and Poiss. d'eau douce, pls. xvi, xvii, xvii $a$; Cuv. and Val. xxi, p. 438; Heckel and Kner, Suss. w. f. p. 242 ; Blanchard, Poiss. des eaur douces, France, p. 437, f. 113. Thymalus gymnothorax, Cuv. and Val. xxi, p. 445, pl. 625; Günther, Fische des. Neckars, p. 117.

Grayling, Couch, Fish. Brit. Isles, iv, p. 280, pl. ccxxviii.

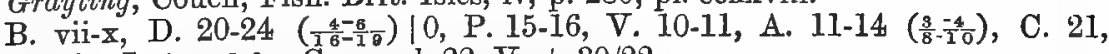

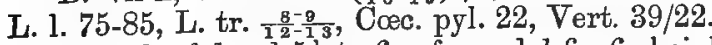

Length of head $5 \frac{2}{4}$ to 6 , of caudal fin 6 , height of body $1 \frac{1}{4}$ to 5 in the total length. Eyes-diameter of each 4 in the length of the head, $1 \frac{1}{4}$ diameters from the end of the snout, and about the same distance apart. Its form is rather elongated and excessively graceful; dorsal profile more curved than the abdominal. Upper jaw very slightly the longer; the posterior extremity of the maxilla reaches to beneath the anterior edge or first third of the orbit. Teeth-fine ones in the jaws, near the head of the vomer, and on the anterior portion of the palatines; none on the tongue. Fins-these vary with the sex, the last dorsal rays are 
somewhat produced in adults. The first dorsal fin commences midway between the end of the snout and on a line above the front cdge of the anal fin, the height of its rays being about two-thirds of that of the body below it. Pectoral inserted in the lower fourth of the height, and as long as the head excluding the snout. Ventrals situated beneath the middle of the rayed dorsal fin, and comparatively small, terminating on a line below the hind edge of the adipose dorsal. Caudal forked. Scales-in regular rows, some small ones being present over the basal portion of the caudal fin. The chest, or that portion of it as far as the pectoral fin, may be entirely destitute of scales or else scaled. In the example figured there were twenty-two rather short cœeal appendages. Walls of the stomach thickened. Colours - these during life are beautifully changeable; head of a bluish purple and a golden tinge along the back, while the horizontal lines along the body are dark, and each of the scales has a golden tinge. Dorsal fins with purplish bands and ocelli which have a purplish red centre, and there are likewise some purplish streaks along the courses of the rays, while the outer edge is likewise purplish. Occasionally there are some black spots on the fins, also scattered over the body. The brighter colours decrease with age, and gray lines show themselves along each row of scales; while the young have transverse bars or bands.

Names.-Thymallus was given to this fish by Ausonius, from the fancied resemblance of its odour to that of the water thyme, upon which it was supposed to feed, an odour which those of the present day fail to detect; but Mr. Pennell considers that he can observe some likeness in its smell when first captured to that of the cucumber. Some who imagine they are able to recognize this odour have suggested that the varying nature of its food may cause the grayling to occasionally possess a strong smell which at other times almost or quite disappears. "Grayling" is said to be a corraption of Gray lines, referring to the longitudinal lines along its gray body. Ouner, Northumberland. Shutts, or Shot, young in the Teme. While St. Ambrose of Milan is recorded to have termed it the "flower of fishes." Aubrey in his MS. says that in his days the nmber was caught in the Madder, between Wilton and Salisbury, \&e. "This kind of fish (he remarks) is found in no other river in England except the Humber in Yorkshire. From that river, therefore, I conclude it takes its name of umber" (Maton, Nat. Hist. of Witss). Salviani in the sixteenth century observed, that being a swift swimmer it disappears like a shadow, from whence it derived its name umbra. Cotton, however, says this name is due to the black or shadowy spots on his belly, and the black colour of his head when out of season. One-yearold fish are in some places known as pinks, at about $\frac{1}{4} \mathrm{lb}$. weight shot or shut, i.e. prior to breeding. De Vlagzalm, Dutch. Ombre, French.

This fish is another whose introduction has been ascribed to the monks, and many of the local grayling fisheries are found in the vicinity of where monasteries formerly stood. But it would be difficult to convey this fish from the continent with the means then at their disposal; while in Kent, Dorsetshire, Devonshire, and Cornwall, where there were many monasteries, grayling are not found.

Hahits.-Although present in many of our rivers, and in some abundantly, the grayling is certainly a local fish, while at times it appears to be gregarious, showing a tendency to congregate in small shoals, which generally drop down stream. In this country it would appear to be a strictly fluviatile fresh-water fish in its habits, never migrating to the sea; but in Scandinavia it is found in lakes also in the North Sea, Cattegat, and Baltic. Sir Humpbrey Davy tried it in brackish water but without success. It prefers clear streams, in which there are a saccession of pools and shallows, with sandy, gravelly, or loamy beds, rocky or stony bottoms being unsuitable. The larger ones seem to resort more to the deeper and quiet spots, the moderately-sized and small ones to the shallows, taking their post behind a rock or a bunch of weeds. Although clear streams are to be preferred, still a moderate temperature of the water seems to be of more consequence, as too much cold or too much heat are asserted to be equally fatal to it. It is not every river that appears suited for the grayling, thus the attempts to acclimatize it in the Thames do not appear, so far, to have been a success. It lives 
somewhat deeper in the water than the trout, and although in some streams the two forms reside together in not unfriendly terms where food is abundant, such is not incariably the case, as in some localities it is popularly said to bully the trout: it may be that being to a great extent a ground feeder, while the trout is breeding it helps itself to the eggs from the trout's redds. It is not of a roving disposition and generally limits its range to within a few miles: it cannot spring out of the water like the trout, consequently is unable to surmount barriers, but its large back fin, aided by its well-developed air-bladder, would seem to show that its formation is that best adapted for rapidly rising or sinking in the water. In spring months it returns to deeper water and seems almost to cease to feed, possibly due to the nearness of its breeding season. It bas been found to live in newly-made ponds, constructed in hard soil, where, however, it is said not to breed, but more investigation is required on this question, as the same was believed of the trout (see page 105) : old and muddy ponds are not suited for their existence, for there they rapidly succumb. It eats insects and their larvæ, small molluscous shell-fish as Physa and Neritina, also Crustacea.

Migrations.-I have already observed that occasionally these fish congregate in shoals and generally drop down stream, in fact, it used to be considered that they never headed up. Mr. Francis Francis (Field, May 28th, 1881) observed, upon one being taken in the Anton, continuing, only a few years ago there were none much above the sheep's bridge at Houghton. This year there are many in the Machine Barn shallow, two miles up; but that they should have headed up something like a distance of ten miles, and out of the Test into another stream, is astonishing. Mr. Brotherton, of Kelso, observes that this fish was introduced there by the late Marquis of Lothian, and it appears to be particularly suitable to its habits, as it is increasing rapidly, and also spreading down into the Tweed.

Breeding.-Generally spawns on the shallows in April or May, or even earlier. On February 26th, 1881, Mr. Bowle Evans sent me two examples from Herefordshire, and I found the ova almost ready for extrusion (the preceding winter bad been a very mild one). The ova are somewhat smaller than those of the trout, and may be white, opalescent, cornelian colour, or even deep orange: they are deposited on the gravel near the tails of shallows, and not in a nest or redd like the salmon, trout, or charr. Neither do these fish attempt to pass up to the heads of streams for breeding purposes, but choose shallow localities near where they usually reside, and where females may be seen waited on by two or even three males. The ora are much more delicate than those of the trout, or charr, dying on the least provocation, and it has been remarked in Herefordshire that should a severe frost occur during their spawning season, the succeeding year's supply of young fish appears to be deleteriously affected. The body of the embryo is visible in the egg on the ninth day, and usually hatches from about the twelfth to the fourteenth day. Due to this rapid development, it becomes almost impossible to transmit eyed grayling ova to any distance, as scarcely three days elapses between the appearance of the eyes of the embryo and the eggs hatching. About the end of July or commencement of August the fry are about four or five inches long. In aquaria it has been observed that young salmon or trout will readily eat young grayling.

Means of capture.-Netting similarly to that employed for trout, but generalls this fish is taken by angling. Although, as has been frequently observed, this fish is to a certain extent fit for eating all the year round, it is most justly protected throughout the spawning months, while during October and November it is in its prime for the table. In the Test, although the Houghton Club used to open this fishing from June 1st, the fish were generally in poor condition, but ready to take almost any fly which was offered: but in July the case became different, the fish were in good condition and much more difficult to please. But it is generally considered that September and October are the two best months for the flyfisher, still in November they will take a fly or a bait, more especially in the middle of the day, and even with a shining sun. The grayling is not quite so shy as the trout nor so game when hooked: a shorter line may be employed, and fishing down stream is mostly adopted. It will rise several times in succession 
at the same fly, and, if not touched by the hook, attempts at its capture may be continued. If a rise occurs, the fisherman should strike gently, play his fish quietly, and land it with a net, because its mouth is tender and readily gives way. The flies employed are much the same as those for trout, but smaller as a rule, althongh they will not always refuse the May fly. The smaller fish are generally taken on the shallows, and with the fly which is usually refused by the larger grayling.

The larger fish frequent the deeper pools or sluggish portions of the stream, sometimes selecting the vicinity of the roots of a tree which juts into the water, sometimes being more in mid-water. What is termed a grasshopper, which looks like a nondescript caterpillar, with the point of the hook covered by gentles, is considered to be the best bait in the Shropshire and Herefordshire districts, and commencing to be employed about September and the two following months on warm days succeeding frosty nights. Having a quill float and a stiffish rod it is worked on the sinking and drawing plan, having sank to the bottom it is raised about a foot and allowed to sink again, while the strean should suffice to carry it on a little way with each successive jerk. In Derbyshire streams it is said not to be much of a success. The principal ground baits are fishing with gentles, worms are likewise employed. The grayling occasionally may be taken with the minnow mostly in clear or else very slightly coloured water.

Life history.-These fish are rapid growers, attaining to four or five inches in length in a few months. Sir H. Davy (Salmonia, p. 188) believed that such as were hatched in May or June become nine or ten inches in length by September, and weigh from five to eight ounces.

Diseases.-It was formerly abundant in the Aire above Bingley, but was entirely destroyed in 1824 by the bursting of a peat bog, and subsequent attempts at reproduction have prored ineffectual (Yorkshire Vertebrata, p. 129). Mr. Francis Francis (Field, December 31st, 1881) olserved that, although there are no very violent pollutions in the $W$ ye above Rowsley, yet both trout and grayling have perished. from fungoid there in myriads, indeed some years ago Rowsley Meadows were pretty nearly cleared out of grayling by it. This fungoid disease, Saprolegnia ferax, has been found affecting these fish in common with trout and other forms.

As food.-Its flesh is white, delicate, and in the best condition about October and November, when the trout are mostly out of season: in fact it is not until Angust that it is generally esteemed worth conking, while it should be dressed as soon as practicable after removal from the water. It is generally boiled: large ones are said to be improved by crimping.

Uses.-It is stated that in Lapland a substitate for rennet used to be obtained by pressure from the entrails of the grayling, with which they converted the milk of the reindeer into cheese.

Habitat.-Lapland, Scandinavia, Germany, Britain, France, Switzerland, Italy, and Hungary.

Were introdnced* into the Upper $\mathrm{Cly}_{y}$ de in 1855, from three dozen fish brought from Rowsley, Derbyshire, and are said to thrive well. They have likewise been introduced in the Teviot and Tweed and are also thriving (Brotherton). In Cumberland in the Eden and in the Esk (Heysham) while two examples from the Tyne, presented by $\mathrm{Mr}$. Knight, are in the British Museum. In varying abundance in the middle waters of the Wharpe, Washburn, Nidd, Ure, and Swale ; also in the Cover, Wiske, and Colbeck, the Rye and other tributaries of the Upper Derwent and the Scalby Back near S'carborough. In a limited amount in the Tees, and has been introduced into the Esk. Formerly common in the Ribble and Hodder, their extreme scarcity-if not extinction-being ascribed to the great increase of salmon (Yorkshire Vertebrata). In Lancashire, the Ribble, in Derbyshire and Staffordshire, the Dove, the Wye, the Trent, the Blithe and the Hodder.

* Orkneys, according to Low, where he stated it to be common.

t A correspondent in the Field (Nov. 25th, 1882) denies the present existence of this fish in the Swale ; the British Museum possesses four reputed specimens from that river, received with Parnell's collection. 
in Shropshire, the Severn, the Teme, the Clun, the Corve and the Onny. In Merionethshire, the Dee and the Vyrmoz. In Herefordshire, the Arrow, the Lug, the Dove, the Wye, and the Irwin contain them. In Hampshire and Wiltshire in the Test, having been introduced from the Avon (Davy), also present in the Itchen and both the Avons.

The Swansea Guide states this fish to be taken in the neighbourhood, but this Dillwyn doubts the correctness of. In 1863, 1470 fry were placed in the Lea rather more than three miles beyond Hertford (Wix). In May, 1866, it was introduced into the Lornan at Tiverton (Parfitt). It appears also to have been introduced into the Thames.

Ireland.-Rutty, 177\%, observes "Thymallus, the Grayling or Umber. With us it is a sea fish, and less than Willughby's, which is a river fish." It seems to me probable that he may refer to Coregonus oxyrhynchus as I received the example figured, as a grayling. Brown two years after Rutty (1774) enumerates the grayling: but Thompson observes that " the parr has been sent to me from the south of Ireland under the name of grayling. Perhaps this name, as applied to the parr, may be a corruption of the word graveling, which is generally applied to that fish in the southern counties."

For the example figured, which is a male $15 \frac{1}{2}$ inches in length, I am indebted to the Earl of Ducie, who captured it in the Test, April 30th, 1879. In the club fishing waters in that river at Stockbridge and Houghton, a memorandum of the largest grayling captured every year from 1834 to 1874 was kept; it shows the annual variation to be between $3 \frac{1}{4} \mathrm{lb}$ : to $3 \mathrm{lb}$. $11 \mathrm{oz}$.

Pennant records one of $4 \mathrm{lb} .6^{\circ} \mathrm{oz}$. from the Tame at Ludlow. Yarrell mentions another one of $4 \frac{1}{2} \mathrm{lb}$. from the Test, and Daniel one of $5 \mathrm{lb}$. from near Shrewsbury. In Lapland it is said to reach to 8 or $9 \mathrm{lb}$. weight.

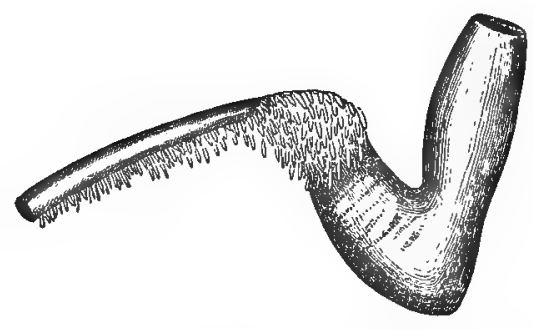

Stomach and cecal appendages of Coregonds oxyrhynchus. 


\section{Genus V.-Argentina, Artedi.}

Silus, Gill. (Scales spiny.)

Branchiostegals six: pseudobranchice well developed. Cleft of mouth small, the upper jaw rather short, not extending to below the orbit, formed by short premaxillaries anteriorly and the maxillaries laterally. Fye large. No teeth in the jaws, minute ones across head of vomer and anterior portion of palatines: a row of curved teeth on the anterior portion of the tongue (except in A. lioglossa). First dorsal fin short and inserted in advance of the ventrals: adipose fin present. Caudal forked. Scales rather large. Stomach large, with a cul-de-sac: pyloric appendages short, and in small or moderate numbers. Ova small, falling into the cavity of the abdomen before extrusion. Air-bladder small, and (according to Cuvier) destitute of a pneumatic duct.

Dr. Günther observes (Introd. Study of Fish. p. 650) that both "Argentina silus and A. Hebrillica have been found occasionally on the North British coasts." I have been unable to ascertain any record of the former, except an example of A. sphyroena, thus termed by Edward, but which he considered identical with my figured species: while A. sphyrcena and $A$. Hebrialica are two names for the same species. The difference between the two species is as follows:-

Argentina silus, D. 11-12|0, P. 17-18, V. 12-13, A. 14, L. 1. 60-65, Vert. 65. 50-52.

Argentina sphyrcena, D. 9-11 ! 0, P. 13-14, V. 11, A. 12-13, L. 1. 50-53, Vert.

Geographical distribution.-Rather small marine forms found in the seas of Europe, often at considerable depths: two species have likewise been taken off the West coast of New Zealand.

\section{Argentina sphyræna, Plate CXXV.}

S'phyrcena parva, Rondel. i, p. 227, c. fig.; Gesner, Aqnat. pp. 883, 1061. Argentina, Willughby, p. 229 ; Ray, p. 108 ; Artedi, Syn. p. 17 and Genera, p. 8. Argentine ou Peis-argent, Duhamel, Pêches, pt. ii, Sec. 3, p. 129.

Argentina sphyrcena, Linn. Syst. Nat. i, p. 518; Lacép. $\nabla$, p. 366 ; Gmel. Linn. p. 1394; ; Bonnat. Ency. Ich. p. 177, pl. 73, f. 301; Brunn. Ich. Mass. p. 79 , no. 96 ; Risso, Ich. Nice, p. 336 and Eur. Mérid. iii, p. 462 ; Cuv. Mém. Mus. i, p. 228, pl. xi, f. 1 ; Bonap. Catal. no. 131; Swainson, Fishes, ii, p. 287 ; Kröyer, Dan. Fiske, iii, p. 100; Günther, Catal. vi, p. 203; Collett, Norges Fiske, p. 171 and Christ. Vid. Sels. Forh. 1879, i, p. 92 ; Malm, Fauna, p. 550 ; Canestrini, Fauna Ital. p. 129; Day, Journ. Linn. Soc. Zool. xv, p. 78, pl. iv ; Giglioli, Cat. Pesc. Ital. p. 42; Morean, Poiss. France, iii, p. 554, f. 208.

Osmerus Hebridicus, Yarrell, Supp. Brit. Fish. and Ed. 2, ii, p. 133.

Argentina Cuvieri and Yarrellii, Cuv. and Val. xxi, pp. 413, 418 .

Argentina Hebridica, Nilss. Skand. Fauna, Fish. p. 474; Yarrell, Brit. Fish. (ed. 3) i, p. 300; Gïnther, Catal. vi, p. 203.

Hebridal smelt, Couch, Fish. Brit. Tsles, iv, p. 297, pl. ccxxxiii.

Goniosoma argentinum, Costa, Fauna Napol. pl. xxxvi.

? Argentina decagon, Clarke, Trans. and Proc. N. Zealand Inst. 1878, xi, p. 296, pl. $x i v, f .2$.

Argentina silus, Edward, Journ. Linn. Soc. Zool. xv, 1881, p. 334 (not Ascanius).

B. vi, D. $9-11\left(\frac{1}{8}-\frac{a}{8}\right) \mid 0$, P. 13-14, V. 10-11, A. $12-13\left(\frac{2}{8}-\frac{3}{10}\right)$, C. 19, L. 1. (45) 50-53, L. tr. $\frac{3}{4}$, Vert. 32, Cœe. pyl. 5-20.

Length of head 4 to $4 \frac{2}{3}$, of cardal fin $7 \frac{1}{2}$, hoight of body $5 \frac{3}{4}$ to 8 in the total length, varying according to age, being deepest in adults. Eyes-with moderately wide adipose lids, the anterior lid overlapping the posterior above the centre 
of the upper edge of the orbit, diameter 3 to $3 \frac{1}{2}$ in the length of the head, l diameter from the end of the snout, and also apart. The shape of the fish is peculiar, the back, sides, and abdominal surfaces being flattened so as to give it a general tetragonal appearance, while keeled ridges divide the various surfaces one from the other. These four surfaces are further subdivided by other parallel ridges, one of which is a short distance internal to the saperior orbito-caudal ridge, and another superior to the pectoral ridge. Irrespective of these, a short ridge passes from the lower edge of the base of the pectoral fin to the anal fin. Upper jaw slightly the longer: the posterior extremity of the maxilla scarcely reaches more than two-thirds of the distance to beneath the front edge of the eye. Snout depressed and somewhat pointed: upper surface of the head flat, its sides compressed. The suborbital ring of bones, the preopercle, opercle, and apper portion of the subopercle with a rather thick adipose covering. Teeth-none in the jaws: a curved row of small ones across the vomer near its head, and continued on to the anterior portions of the palatines, which are contiguous: a single row of about eight large and somewhat recurved ones surround the inner edge of the front portion of the tongue. Gill-openings deeply cleft. Gill-rakers rather widely separated, thick, and equalling in length about one-fourth of the diameter of the orbit. Fins-the first dorsal anteriorly as high as the body below it, its posterior rays rather more than two-fifths the height of its anterior ones: adipose dorsal fin situated on a line above the last anal ray. Pectorals, if turned forwards, reach to the middle of the eye. Ventrals inserted below the last dorsal ray and midway between the end of the snout and the base of the caudal fin. Anal highest anteriorly where the rays equal the length of the base of the fin. Caudal forked. Scales-large, thin, and higher than broad, those along the back adherent, those on the sides more deciduous. Minute ossicles, assuming a stellate or spinate form, are present on the scales of the back and on some of those along the under surface of the abdomen. Those on the sides with roughened or ragged outer margins : the row beneath the lateral-line the largest. Numerous concentric lines upon the surface of the scales. Lateralline-on a row of scales somewhat smaller than those above or below, it is well marked, and passes to the centre of the base of the caudal fin. Air-bladdersmaller than in the trout, from which it also differs in the thickness of its fibres and silvery walls, the latter charged with a brilliant substance that separates with washing, at first in the form of spangles. This is next precipitated by ammonia into a silvery deposit, which is preserved for the manufacture of artificial pearls. Colours - in an example examined a few days after death, but which had been preserved in spirit, it was of a light olive along the back, becoming silvery white along the middle of the sides, while inferiorly and on the head there was a tinge of gold glossed with purple. A black spot on the upper edge of the orbit, and a smaller one on the snout. A dark longitudinal mark along either caudal lobe near to its outer edge. Edward, who received a fresh one, observes that the colours agree with the number of divisions on the fish. That along the back deep amber, the succeeding one greenish-blue, the third or division below the lateral-line, of a pure silvery white with bright metallic lustre, the others similar to those above but fainter. Belly grayish-white with a tinge of greenish-blue and purple. The top of the head nearly the same as the back, its sides silvery. Eyo with a bright silvery iris and blusih-black pupil. It was so transparent that on holding it up to the light the vertebræ could be distinguished.

The fish is figured and described by Rondelet, and this was reproduced by Gesner, while Willughby observes "Pisciculus Romæ Argentina dictus, Sphyrana parva, sive Sphyrona secunda species, Rondeletio, Gesner, 1061." This clearly shows that the species of these three authors were identical with the Roman fish, the air-bladder of which was employed to furnish materials for the manufacture of artificial pearls. Ray copies, almost verbatim, from the above authors. Artedi's Argentina is identical with that of Linnæus, but not with Gronovius's Sphyroena. Gmelin in his edition of Linnæus possibly mixed up, under the designation of Argentina sphyroena, more than one species of fish; still it is clear that the older author's referred to the deep sea fish, trom which materials for false pearls were procured, as stated by Risso. 
Cuvier considered the fish he described in the Memoirs of the Museum as being the same with that of Linnæus, but Valenciennes changed the name from Argentina sphyrrena to A. Cuvieri. Yarrell has described his Osmerus Hebridicus from a Scotch example, and Valenciennes, while pointing out that it was an Argentina, termed it A. Yarrellii, which Nilsson brought back to $A$. hebridica. But the question arises are these two forms, A. sphyroena and $A$. hebridica, distinct? It is evident that no criterion can be drawn from the number of fin rays and scales, while although Nilsson found 14, to 20 cocal appendages in $A$. hebridica and merely 12 have been recorded in $A$. sphyrcena, I only found 5 in the example figured, clearly showing how variable these numbers are. Lastly, it has been stated that the comparative height of the body to that of the total length differs in the different species, but here Collett remarks that this changes with age, the example being comparatively more slim in the young. In an example nearly $6 \mathrm{in}$. long I found the height of the body to be $\frac{1}{8}$, in one $8 \frac{1}{2}$ in. long it was $\frac{1}{6}$, and in one $9 \frac{1}{3}$ in. long $6 \frac{1}{2}$ in the total length (see Journal Linn. Soc., l.c., where more instances are recorded).

Habits.-Of these but little is known, but it is probable that these fish occasionally reside at considerable depths, and the species is generally considered rather a deep sea form. The stomach of Edward's example contained the remains of a few of the smaller crostaceans as Darwinia compressa, Protopedata, \&c., also fragments of Sertularia filieula, Antennularia antennaria, \&c., showing it probably resided among corallines.

Breeding.- In Edward's fish taken in September the milt was said to bave been of a chalky whiteness, $1_{*}^{1}$ in. in length, but scarcely full. Whether the fish was a partly spent one, or the milt not balf developed, could not be ascertained. One of Yarrell's examples taken in June had the roe well developed. Risso states that in the Mediterranean it breeds in spring.

Habitat.-This fish frequents the shores of Norway to both sides of Scotland, the coasts of Yorkshire, and through the Mediterranean to the Balearic Isles, and along the southern shores of Europe, being taken, we are informed, all the year round in the sea off Rome, where it is of moderate frequency.

Mr. Clarke, 1.c., has described and figured as new under the name of Argentina decagon, a fish which scarcely appears to differ from European examples except that the fine teeth are said to be wanting. The number of fin rays and scales, as well as the proportions of the body, are identical, while it must be remembered that several European fish have been discovered off the shores of New Zealand. The unique specimen of $A$. decagon was taken off the west coast of New Zealand.

Yarrell * observes that one 8 in. long was taken in June, 1836, full of roe in the Bay of Rothsay, Isle of Bute, and a second $6_{\frac{1}{2}}^{-}$in. in length in November, 1837, near the same spot, on a hand-line baited with a piece of mussel, in about 12 fathoms water and about 200 yards from the shore; this is probably one of the two specimens now in the Hunterian Museum of the Glasgow University, and is recorded in the Proceedings of the Natural History Society of Glasgow (i, 1867, p. 187). One taken at Kilereggan, November 26, 1867, the second being probably Mr. Ewing's specimen captured in 1837, and sent to Mr. Yarrell for identification. Yarrell likewise records one taken at Redcar in May, 1852. The one here figured was captured in October, 1879, in Loch Alsh, off the Skye shore, on a hook baited with mussel; it was sent to the late Mr. Frank Buckland. Edward has recorded a male full of milt taken near Banff in October, 1879.

The example here figured is $9 \cdot 5$ in. in length, and the fisherman who captured it stated it was only the second he had ever seen.

* Dr. Günther, Catal. 1866, vi, p. 203, quoted Low, Fanna Orcad. p. 225, to show that it has been obtained in the Urkneys, but as he gives the identical reference under Marrolicus|borealis, vol. v, p. 389, for Low's single specimen, evidently some error has occurred. Low says his example was not above an inch in length, and gives as synonymous Pisciculus Romos Argentina dictus, Will. Ich. 229 ; Raii, Syn. Pisc. 108 ; Argentina sphyrcena, Linn. Syst. 518 ; the Argentine, Brit. Zool. 276 ; Brit. Zool. Illust. 42, t. 48." In short, Low accepted Pennant's figure, which is Maurolicus borealis (see page 49 ante) as identical with his Argentine. 


\section{FAMILY, III-ESOCIDE.}

Branchiostegals numerous: pseudobranchiæ glandular and more or less concealed. Gill-openings wide. Edge of the upper jaw formed by small premaxillaries, divided in the median line by the head of the vomer : laterally by the maxillaries. No barbels. The dorsal fin belongs to the caudal portion of the body: no adipose dorsal fin. Scales present on the body. Stomach destitute of a cœcum: no pyloric appendages : intestines short but wide. Air-bladder simple.

This family of fishes is distributed throughout the northern and temperate portions of Europe, Asia, and America.

\section{Genus I.-Esox (Artedi), Cuvier.}

Branchiostegals numerous (13-18): pseudobranchice glandular. Body elongated. Snout broad, depressed and elongated. gape of mouth wide, cleft deep. A row of irregularly-sized teeth, some of a large size, in the mandibles, absent from the maxilla: cardiform ones on the premaxillaries, vomer, palatine, and hyoid bones: also on the tongue. A single dorsal fin placed opposite the anal in the caudal portion of the body. Caudal slightly forled or emarginate. Scales small, cycloid. Lateral-line present.

This fresh-water fish descends to the brackish and even salt water, and is distributed similarly to "that given for the family of which merely this single recent genus is at present recognized.

\section{Esox lucius, Plate CXXVI.}

Lucius, Belon. p. 296 ; Rondel. ii, p. 188 ; Salv. pp. 94, 95 ; Schonev. p. 44; Aldrov. p. 630 ; Johnston, iii, t. 3, c. 5, t. 29, f. 1; Gesner, p. 500 ; Willughby, p. 236, t. P 5, f. 2 ; Ray, p. 112 ; Klein, Miss. Pisc. $\nabla$, p. 74, t. xx, f. 1. Esox no. 1, Artedi, Synon. p. 26, Gen. p. 10, and Spec. p. 53; Gronov. Zooph. no. 361. Pike, Pennant, Brit. Zool. (Ed. 1776) iii, p. 320, pl. Ixiii, and (Ed. 1812) iii, p. 424, pl. lxxiv.

Esox lucius, Linn. Syst. Nat. i, p. 516; Gmel. Linn. p. 1390; Bloch, Fische Deuts. i, p. 229, t. xxxii ; Bonnaterre, Enc. Ich. p. 174, pl. lxxii, f. 296 ; Bl. Schn. p. 390 ; Lacép. $v$, p. 297 ; Donovan, Brit. Fish. $\nabla$, pl. cix; Turton, p. 105; Jurine, Mém. Soc. Phys. et Hist. Nat. Genève, iii, 1825, p. 231, pl. xv; Fleming, Brit. An. p. 184; Cuv. and Val. xviii, p. 279 ; Bowdich, Brit. F. W. Fish, fig. no. zvii ; Bonap. Pesc. Eur. p. 25 ; Jenyns, Man. p. 417 ; Ekström, Mörkö, p. 78 ; Fries and Ekström. Scand. Fisk. p. 49, t. x ; Yarrell, Brit. Fish. (ed. 1) i, p. 383, c. fig. (ed. 2) i, p. 434 (ed. 3) i, p. 342 ; Templeton, Mag. Nat. Hist. 1837 (2) i, p. 410 ; Johnston, Berwick. Nat. F. Clab, 1838, i, p. 172 ; Pallas, Zoo. Ross.-As. iii, p. 336; Parnell, Wern. Mem. vii, p. 272; Swainson, Fish. ii, p. 298; Richards. Fauna Bor.-Amer. iii, p. 124; Kröyer, Dan. Fisk. iii, p. 236; White, Catal. p. 70; Gronov. ed. Gray, p. 146 ; Nilss. Prod. p. 36, and Scand. Fauna, iv, Fisk, p. 348 ; Thompson, Ireland, iv, p. 140; Günther, Catal. vi, p. 226 ; Schlegel, Dieren Neder. p. 151, pl. xiv, f. 4 ; Siebold, Süss. w. f. p. 325 ; Heckel and Kner, Süss. w. f. p. 287 ; Cope, Proc. Acad. Nat. Sc. Phil. 1865, p. 79 ; Blanchard, Poiss. France, p. 483, f. 128; Lunel, Lake Leman, p. 161, pl. xix; Collett, Norges Fiske, p. 175; Malm, Fauna, p. 550 ; Winther, Ich. Dan. Mar. p. 45 ; Houghton, Brit. Fresh-water Fishes, p. 73, c. fig ; Giglioli, Catal. Pesc. Ital. p. 42; Feddersen, p. 81 ; Canestrini, Fauna Ital. p. 21 ; Morean, Poiss. France, iii, p. 466 .

\footnotetext{
Esox boreus, Agassiz, Lake Superior, p. 317.
} 
Pike, Conch, Fish. Brit. Isles, iv, p. 150, pl. ccx.

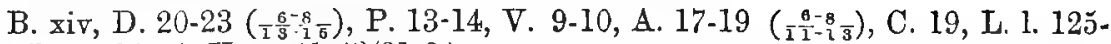
130, L. tr. $13 / 30$, Vert. $41-43 / 21-20$.

Length of head $3_{2}^{1}$ to 4 , of caudal fin 6 , height of body $6_{2}^{1}$ to 7 in the total length. Eyes-situated in about the middle of the length of the head, the diameter of each 7 to 12 times in the length of the bead, 4 to 6 diameters from the end of the snout, and $1 \frac{1}{2}$ to 2 apart. The dorsal and abdominal profiles nearly horizontal and parallel, causing the body to be of an almost equal height from the head to the commencement of the dorsal and anal fins: its head fattened above, while its length is eqnal to nearly twice that of the height of the body. Cleft of mouth very detp, equalling about half the length of the head: lower jaw a little the longer. The middle of the upper jaw is slightly emarginate, and receives the head of the vomer: on either side are the short premaxillaries, which are not nearly so long as the maxilla, which is composed of two pieces, is capable of a considerable amount of motion, and reaches posteriorly to beneath the front edge of the eye. Nostrils large, and nearer the orbit than the end of the snout. Numerous glandular orifices on the head. Teeth*-none on the maxillary: large ones and of unequal sizes on the mandibles: present on the vomer and palatines, the inner row of which are the larger, more or less strong and depressible: also fine ones on the tongue. Fins-the dorsal is situated in the last fourth of the total length (excluding the cauclal fin), and slightly in advance of the origin of the anal. Pectoral placed low down and below the subopercle. The ventral slightly behind the middle of the total length (excluding the candal fin). Caudal emarginate or slightly forked. Scales-small, present on the cheeks, upper portion of the opercle, and over the body. Lateral-line nearly straight. Culours-when in the greatest perfection of a green colour, becoming lighter on the sides and beneath: numerous yellow blotches, spots, or lines along the head and body: dorsal, anal and caudal fins of a light ground colour with irregular blotches, spots and bands of dark. When out of season the green becomes of a gray, and the jellow markings pale or white.

Varieties. - It has been recorded by M. Tilésius that he had frequently seen captured in 1806 and 1807, at St. Petersburg, examples from the Néva in which a single median barbel existed beneath the lower jaw as in the cod. Specimens were not preserved. American examples are said to generally possess 17 anal rays, but occasionally 19; the example figured from Gloucestershire had 18.

Montalambert (Hist. Acad. Sc. 1748, p. 27) observes that in the river Gabard in France there is a pool containing blind pike.

Names.-Hacod, Anglo-Saxon. This fish was first termed a jack, $\dagger$ then a pickerel, and lastly a luce. Geuld or gade in or near the Moray Firth and in Lowland Scotch : gullet, Northumberland. Haked, a large pike in Cambridgeshire. Morris, a large pike (Halliwell). Frie, a very young pike. Picche, or, if only nearly full grown, pod (Halliwell). The term pike is suggested to have been derived from the Saxon word piit, signifying "sharp pointed," having reference to the form of its head. Penhwyad, Welsh. Ansjovis, Dutch. In French it is termed Brochet or Brocheton from its spit-like shape, Lance or Lanceron from its speed, and Becquet from its muzzle bearing somewhat of a resemblance to a duck's bill.

Considerable discussions have from time to time arisen as to whether the pike is an acclimatized or indigenous fish in this country. We are told Edward I fixed its value above that of salmon, and more than ten times that of turbot or cod. Also that in the time of Henry VIII a large one was sold in February for double the price of house lamb, and a pickerel or small pike for more than a fat capon. Probably more attention was paid to inland fisheries in those days than now, and such forms as possessed insatiable appetites were only kept in numbers pl. i.

* See Tomes, On the Hinged Teeth of the Common Pike, Qy. J. Microp. Sc. xviii, pp. 1-16,

† A jack or pickerel becomes a pike at 2 feet (Walton) and $2 \mathrm{lb}$. or $3 \mathrm{lb}$. weight. Some see no distinction, callung all pike, others fix the liuit in different ways. 
sufficient to supply the rich, consequently pike were not so plentiful. As, on the other hand, the salmon fisheries were much more abundant in those days than they are at the present time, this would account for the high price of pike kept in stews, which could only have been within the means of the wealthy should they have to purchase them. If we look at the geographical distribution of this fish it certainly ought to be indigenous, while, so far back as the reign of Edgar, we are told by Leland that one of large size was taken in Remesmere, Huntingdonshire. In heraldry the luce or pilie occurs in the arms of the Lucy or Lucie family so far back as the reign of Henry II.

Habits.-This strong, active and voracious fish possesses an omnivorous appetite, consuming its smaller neighbours, including those of its own species, and often does not hesitate to fatally mutilate such as are too large for it to consume. It prefers slow-flowing, weedy rivers, ponds and lakes, but its haunts vary with the season of the year and the natpre of the water it inhabits. It swims higher in fine warm weather, and may sometimes be seen basking or sleeping at or near the surface, while in winter it keeps at greater depths, and they have sometimes been found associating together in considerable numbers in some sheltered situations. While an annual migration in spring-time has been observed in the Cam; into which river they come in shoals, doubtless from the fens in the neighbourhood of Ely where they are bred (R. Sheppard).

It prefers silent, still, or placid waters where there is abundance of weeds and flags, or reeds, docks, bullrushes, water-lilies, and broad-leaved vegetation : or it will lurk in the shallows among weeds, or where a wall projects into the water, or behind a sunken tree or other suitable object. Its appetite is almost insatiable: it does not refuse the frog, the vole or water-rat, the common house-rat, plump puppies just opening their eyes, tender kittens, even the weasel (Field, October, 1882), a fox (Dr. Genzilk), and in Dr. Crull's Present State of Mascory (1698) it is mentioned that one of these fishes had an infant child in its stomach. The unwary duck* or duckling, gosling, or even geese which swim across its haunts, a swallow skimming along the surface of the water (Mag. Nat. Hist. 1834, vi, p. 400), the dabchick, the coot, and the moorhen alike fall victims; it has even been known to lay hold of a swan by the head occasioning the death of both (Hardwicke's Science Gossip, 1866, p. 139), while one of only $2 \frac{1}{2} \mathrm{lb}$. weight seized a tame cormorant which was engaged fishing and choked itself while endearouring to swallow it. When emboldened by hunger a pike has been known to attack otters, dogs, asses, mules, oxen, horses, and even men, boys bathing have been seriously injured by their teeth, and one embayed by falling water, finding itself being attacked by a man, became in its turn the assailant, and did not retire beaten from the conflict.

It will also take inanimate objects, as a toy-boat which was being sailed across a pool: or a piece of cork attached to a string, and once having seized an object it holds on most tenaciously. It is said to distrust sticklebats, due, it is supposed, to the number of young pike which become choked by these spiny little fishes: while perch are believed not to be a desired food, although it takes it as a bait. It has been known to seize a toad flung into the water, but it is immediately rejected : and sometimes it similarly declines to swallow the rat.

An account was given in the Field (Sept. 2nd, 1882) of two pike each weighing about $10 \mathrm{lb}$. dashing at the same time at a live bait, and then at one another fighting like a couple of dogs. Mr. Stanley (Zool. 1845, p. 1035), on December $25 \mathrm{th}, 1843$, observed a pike lashing the water with his tail. On pulling it out he found two pike of about $1 \mathrm{lb}$.weight each, the head of one being entirely within the

* A curious incident occurred on the River Suir, near Tulla Bridge, about a mile from Thurles. A number of ducks were swimming on the river, when one of them, uttering a loud " quack," was seen suddenly to disappear. Some young men, going through curiosity to the spot where the duck had ranished, fonnd near the bank of the river an enormous pike floundering about, and so utterly helpless that they had very little difficulty in landing it, when they found the duck which it appeared the pike had seized, but was unable to swallow. The monster, whose insatiable roracity had caused its death, weighed nearly forty pounds. 
mouth of the other, the snout coming out at the gills of the fish which was holding it.

Ekström mentions finding a $20 \mathrm{lb}$. pike with the skeleton of an osprey, Falco halioetus, still attached to it. Lloyd likewise observes that Dr. Mellerborg, of the Uddeholm establishment, vouched for having seen an enormous pike with an eagle fastened to its back, lying dead in a piece of ground which had been overflowed but from which the water had retreated.

Pike have been captured by trimmers having swallowed two separate baits, as if showing that they do not suffer much pain when being hooked. Pennell gives an account how a trimmer having been set in the Aron, a heary pike was found captured the next morning, on opening it a second one of considerable size was seen, while inside this second was a third of about ${ }_{4}^{3} \mathrm{lb}$. weight.

It has obtained credit for one good trait (in addition to its eating its younger relatives) and that is that it has been said not to devour tench in consideration of its being its medical attendant. For the popular belief in many localities is that it rubs itself against the pike's wounds and exudes mucus which possesses healing virtues. In a work Civitates, Orbis, Terrarum (Colon, 1572-1606) are representations of a series of English costumes and a view of selling live pike. There the custom is shown of how the vendor cut open the belly of the fish in order to show its condition, this was stiched up again if a purchaser was not found and returned to the water. But unfortunately it has been repeatedly proved that if hungry, the pike will make a meal off the tench, while the troller is aware that this fish may successfully be employed as bait.

During periods of great droughts, pike are often found to disappear mysteriously from some pieces of water reappearing on the recurrence of rain. Mr. Pennell gives an account how one was found jumping and working about in the wet grass, evidently making its way from the breeding ground to the river distant some half dozen yards, two-thirds of which distance it had traversed. It is suggested they may travel like eels over dewy grass, and several instances are related how pike have appeared in ponds or pieces of water in a most unaccountable manner. Isaak Walton observed that it is not to be doubted but that they are bred, some by generation, and some not, as namely, of a weed called "pickerel. weed," unless learned Gesner be much mistaken. No doubt this weed in which the spawn is often deposited, may, if removed to another pond, be a means of stocking it with pike, or such may occur in other ways through the instrumentality of frogs or aquatic mammals (see Introduction).

Considerable differences of opinion exist with reference to the desirability of having pike in fisheries: but there are few who would advocate the cultivation of this voracious monster where salmon and trout thrive. Their introduction into the Teviot, says Stoddart, has, there is no question, conduced very materially to injure the salmon fishing, nor have the trout remained wholly unscathed. He observes upon having taken 5 or 6 salmon fry out of the stomach of a single fish: and also states that in some Scottish Lochs pike have been known to consume their own weight of bait every day. Pennell computes that in stews a $5 \mathrm{lb}$. or $6 \mathrm{lb}$. fish would eat, if permitted, twice its own weight of fish every week. While, as I have already remarked (page 104), pike in trout preserves not only diminish the inhabitants but scare them to that extent that they become timorous of feeding, and frequently occasion great falling off in the general condition of the trout.

On the other hand it has been contended that it gires sport to the angler when the fly-book is closed due to droughts, or else during the cold months of the year, and pike will not destroy fish ova. While it may be introduced into canals, lakes, meres, and sluggish rivers, where no good fish will flourish. In Wild Sports of the Highlands it is observed that in all lakes of considerable size where the pike were plentiful the trout have improved very much in size and quality, and not diminished in numbers to any great extent. There are doubtless localities where this fish is suited for, but their undue increase has to be guarded against, because with their ravenous appetites and rapid digestion they require a 
large stock of food present in the water for their sustenance. Jesse tells us how he threw five roach, each about 4 inches long, to a $5 \mathrm{lb}$. pike, which swallowed one after another of the first four, but the fifth it retained in its mouth for about a quarter of an hour evidently waiting until digestion should make room for its rejoining its companions.

Means of capture.-This fish is taken for food, as sport or with reference to the condition of the fishery in which it resides. If it is desired to diminish its numbers, it stands to reason that such as are captured prior to spawning time, as during February or March, are more valuable for this purpose than should the ova have been deposited. Netting is most easily employed during the winter months, due to the absence of weeds. Also at such times as they ascend ditches, drains, and other localities for breeding they may be destroyed with comparative ease. They may be speared or wired, or snatched or shot while basking, or destroyed by trimmers, a modification of which is termed a ligger in the eastern counties.

The angler, however, generally endeavours to take the pike by means of trolling, divisible into such as are fished for with live or dead bait. Either of these baits may be employed on spinning also termed snap tackle, or else on gorge tackle, which latter, as its name implies, is intended to be swallowed prior to the fish being struck. There are likewise various artificial baits employed as the spoon or imitation fish. While large gaudy flies which may be likened to coarse bodied salmon-flies are occasionally found to be killing.

In Norfolk very great success is sometimes obtained during severe frost on the broads by breaking a hole in the ice and putting down a baited hook (Lubbock). Sharp frosts are sometimes desirable to induce these fishes to feed. Thunder is sometimes auspicious or the time just prior to a flood as the waters commence to swell. The months of November and December are generally considered the best months for the angler.

Baits.--The young pike, gudgeon, gold-fish, dace, roach, rudd, tench, bleak, perch, or a frog. A large fish prefers a good mouthful, consequently a large bait is esteemed preferable to a small one, roach or rudd of a pound weight is not too large. Small baits are attacked and ruined by the small pike; however, if hooked they become excellent lures to their larger relatives.

Breeding.-March and April, sometimes as early as February, especially in Ireland. The ova are small and numerous but very varions in number, a $35 \mathrm{lb}$. fish contained 43,000: a $32 \mathrm{lb}$. fish, 595,200 : a $28 \mathrm{lb}$. fish, 700,000: a $28 \mathrm{lb}$. fish, 292,320 : a $24 \mathrm{lb}$. fish, 224,640 . They quit the open waters in pairs (being as a rule monogamous) when the breeding season arrives, the male which is the smaller following the female, and they seek sinall bays, creeks, shallows and contiguous ditches where their eggs are deposited among the weeds and leaves of aquatic plants. The pike commences to breed at about three years old, while the younger fish spawn prior to the older ones. It has been remarked that spawning being over the female often eats her husband.

After breeding they become unfit for food, hardly returning to condition prior to June.

Monstrosities of the embryos are common, and as pointed out by Lereboullet, (1864) they are either double, the production of a superabundance of the plastic embryonic matter; or simple in which an individual is partially or wholly defective. This disposition to monstrosity does not appear to be consequent upon any external influences but to be inherent in the ova: although some external causes may occasion an arrest of development more or less complete.

Life history. - It has been well observed (Lubbock, Fauna of Norfolk, p. 190) that this fish from the very ovum appears to manifest the stern and solitary energies of its nature. In summer almost every distinct puddle in fens where turf is cut has its tiny tyrant in an infant pike; here it enacts despotic sovereignty, and lords it over tadpoles and fry, till fate arrives in the shape of a heron, or the first floods of autumn sweep it to the river or broad. Of course the rate of growth may be accelerated or retarded by many local circumstances. 
Mr. Southwell informs me (on the authority of the agent of the estate) that when Scoulton Mere, in Norfolk, was cleared out they put in some young pike of about $\frac{2}{2}$ to $1 \mathrm{lb}$. each: after ten or twelve years they had increased to $18 \mathrm{lb}$. Stoddart considered that two-year-old fish were from 3 to $5 \mathrm{lb}$. weight. In some waters they will rapidly attain to a certain size, subsequent to which their further increase is slow. Perhaps in open waters it is not an unsafe estimate of $11 \mathrm{lb}$. yearly for the first two years, and afterwards $l_{\frac{1}{2}}$ to $2 \mathrm{lb}$. for seven or eight years, and subsequently at a less rapid rate. Growth does not always correspond with the amount of food received; such as are well fed in aquaria do not appear to increase so rapidly as such as are in the open waters.

The age to which this fish attains has been variously estimated: Lord Bacon placed the limit of its existence at about forty Jears. Ryaczynski adduces an instance in which there were reasons for believing that a pike was ninety years old. But if we go back to tradition we are told this fish lives for centuries. It is stated that a pilie was captured in 1610 in the Meuse bearing a copper ring on which the name of the city of Stavern was engraved with the date 1448. While a still more incredible account is given how Frederick II, in October, 1230, inserted a brass ring into the gills of a pike bearing a suitable inscription, and that this fish was recaptured 267 years subsequently 17 or $19 \mathrm{ft}$. long and weighing $550 \mathrm{lb}$. The skeleton was preserved in the Cathedral at Mannheim, but on its being examined by a German anatomist, it was found that the length of its vertebral column was obtained by using the bones of several fish.

Diseases.-Valenciennes mentions having an example taken in the autumn of a pale white, the whole of the body being covered with red spots somewlat resembling small-pox. It is tormented with parasites.

As food.-Opinions differ as to its value, possibly due to the character of the flesh for good or for bad being influenced by the waters in which it resides. Those from rivers have a white firm flesh, are easy of disgestion, and as a rule superior to the pond ones, while even various localities, due to local circumstances, affect the character of the fish. Those from the Thames are firm and of good flavour, likewise those from the mouth of the Medway, where they find plenty of smelts, also those from Horsea Mere and Heigham Sound, and Stoddart praises very highly those of the Teviot. Those from Scotch lochs and muddy waters are not generally approved of, being more or less soft, slimy, and disagreeable both in taste and smell. In Ireland it is not esteemed during February and March while spawning, but Stoddart observes that in Scotland they are considered by many epicures as finest in condition when full of roe. The roe is said occasionally to produce vomiting, purging, and other deleterious symptoms, while Linnæus saw it being made into bread at Lyksele, in Lapland.

As soon as a pike of a suitable size has been taken it should be disembowelled and cleaned, while it will be improved by being crimped like a cod. Large fish are coarse. The upper or back part is not edible unless the bones are removed by an expert cook. Boiled, it is insipid; stewed, with spices and a bottle of good old crusted port, it becomes passable; stuffed and baked, it is perhaps a trifle better; filleted, it is almost nice.

Uses.-Its jaw-bones in olden times were recommended to be powdered and given in pleurisy, gravel, stone in the bladder, and other diseases. In some countries it is salted and dried. The heart and galls were used as medicines for agues and other fevers, and the latter likewise for affection of the eyes. Its roe used to be prescribed as an emetic. As the bones of the head form a sort of cross, such have been worn as a preventative against witchcraft. In some parts of Hungary and Bohemia it is considered an unlucky omen to see a pike plunge in stagnant waters before mid-day. Its bite is hard to be cured, being a punctured and jagged wound.

Habitat.-From Scandinavia throughout the continent of Europe and the northern portions of Asia and America, Rondeletius observes that it enters the sea at the month of the Rhine, and is found in salt water pools bordering the Mediterranean, but that such fish are dry and insipid food. 
In Scotland it is widely spread in lochs, rivers and other appropriate localities : in the Forth it is frequently seen in brackish waters and often observed off Stirling bridge basking in the shallows.

It is found throughout England and Wales in suitable pieces of water, especially as in Yorkshire and Norfolk; it is absent from the Isle of Wight and likewise from Cornwall, and a few years since it was said only to be found in Slapton Ley Lake in Devonshire, but now it exists in the Exe where it has driven the trout from certain portions of the river.

In Treland, according to Thompson, in the County of Londonderry, in salt water between Derry and Culmore (Ordnance survey), in all suitable lakes in the northern part of the island-Lough Neagh, L. Derg, \&c.-County Dublin (Ball); the Shannon, Lough Corrib, L. Mask and L. Carra (McCalla).

The size to which the pike attains in these islands* is rather questionable, but certainly some now captured exceed the largest Pennant ever heard of in his time (1776), which weighed $35 \mathrm{lb}$. Some of the statements made by anthors would seem to require explanation. Sir J. Hawkins refers to one $170 \mathrm{lb}$. weight taken in 1765 which one would have supposed Pennant would have heard of. Colonel Thornton alludes to one of $146 \mathrm{lb}$. captnred at Lochmaben. Daniel (Rural Sports) to one upwards of 7 feet long and over $72 \mathrm{lb}$. weight from Loch Ken, Kirkcudbrightshire. Dr. Griersen one of $61 \mathrm{lb}$. from Loch Ken (Thomson's Ann. of Phil. viii, p. 428). One of $78 \mathrm{lb}$. taken in August, 1830, in County Clare (C. Mayne). On February 27th, 1880, two pike were taken angling in Norfolk, the one $30 \frac{1}{2}$, the other $36 \mathrm{lb}$. weight. The example figured is $12 \frac{1}{3}$ inches long and from Gloncestershire.

* "A Abut seventeen years since, when visiting the late Marquis of Clanricarde, at Portumna Castle, two gentlemen brought to the Marquis an immense pike, which they had just caught in the River Shannon, on the banks of which they had been taking their evening walk. Attracted by a noise and splashing of the water they discovered in a little creek a number of perch driven on shore, and a fish which, in pursuit of them, had so entangled himself as to have a great part of its body out of water. They attacked him with an oar, which by accident lay on the bank and killed him. Never having seen any fish of this species so large they judged it worth the observation of the marquis, who, equally surprised at its magnitude, had it weighed, and to their astonishment it exceeded the balance at ninety-two pounds. Its length was such that, when carried across the oar by the two gentlemen, who were neither of them short, the head and tail touched the ground."The Sportsman, 1839. 


\section{FAMILY, IV.-SCOMBRESOCID无.}

Pharyngognathi malacopterygii, Müller.

Pseudobranchim glandular, concealed. Margin of the upper jaw formed mesially by the premaxillaries and laterally by the maxillaries. Barbels present or absent. Lower pharyngeals united into a single bone. Dorsal fin rayed, with or without finlets posterior to it, situated opposite the anal, and in the caudal portion of the vertebral column: no adipose dorsal. Scales present, frequently a keeled row along either side of the free portion of the tail. Airbladder generally present, sometimes cellular internally, and destitute of a pervious pneumatic duct. Stomach and intestines in an undivided tube. Pyloric appendages present or absent.

\section{Synopsis of Genera.}

1. Belone. Both jaws elongated into a beak. No finlets.

2. Scombresox. Both jaws elongated into a beak; finlets behind dorsal and anal fins.

3. Exoccetus. Jaws short. Pectoral fins elongated into organs for flying.

Among the fishes belonging to this famils some are oviparous, others viviparous.

The eggs of many have flaments springing from their outer covering, and which enable numerous ora to adhere together in a mass, or attach themselves to contiguous objects, preventing their subsiding into the mud. It has been suggested that they are thus suspended so that by the ebb and flow of the tide they may be constantly bathed by different water. Professor Hæckel observed these filaments present in the eggs of gar-fish, Delone; saury, Scombresox; halfbeak, Hemiramphus, and fying-fishes, Hxocoetus; while Ryder has remarked on having fond similar filaments in one form of Atherinida, the Chirostoma notata, but in such they are only four in number, and situated close together.

\section{Genus I.-Belone, Cuvier.}

Mastacembelus (Klein) Bleeker; Rhamphistoma, Rafin.; Tylosurus, Cocco; Potamorrhaphis, Günther.

Branchiostegals numerous. Gill-openings wide. Body elongated, sub-cylindrical or compressed. Eyes lateral. The jaws prolonged into a beal, the upper of which is formed by the premaxillaries. Fine teeth (or rugosities) in both jaws, with a single row of long, widely set conical ones; palate toothed or toothless. The anterior dorsal rays may or may not be elevated, forming a lobe to the fin, while the middle and posterior ones may be short or elongated: no finlets : caudal usually forked. Scales small. Lateral-line on free portion of the tail, with or without a keel. No pyloric appendages.

Cope considers that Belone should constitute a distinct family due to its possessing distinct caracoid bones, and vertebræ with zygapophyses, a character unusual among fishes (Proc. Amer. Phil. Soc. xvii, p. 695). Jordan and Gilbert remark upon the absence of gill-rakers in Belone exilis and some other species which it is proposed to unite into one genus Tylosurus.

Geographical distribution.-Temperate and tropical seas; some species resident in fresh waters.

Uses. - Indifferent as food; all forms appear to possess green-bones. They are very destructive among small fishes. 
In the very young the upper jaw is very short, as in the tropical Hemiramphus, but gradually increases with age until it becomes almost as long as the mandible.

1. Belone vulgaris, Plate CXXVII, figs. $1,1 a, 1 b$.

Acus, Rondel. i, p. 257 ; Gesner. Aquat. iv, p. 9 ; Salv. p. 68, f. 8 ; Aldrov. Pisc. p. 106.

Acus vulgaris, Willughby, p. 231, t. P2, fig. 4 ; Ray, Syn. Pisc. p. 109. Esox, Gronov. Zooph. no. 362, and Mus. Ich. i, p. 10, no. 30. Gar-pike, Pennant, Brit. Zool. (Ed. 1776) iii, p. 324, pl. lxiii, fig. 154 (Ed. 1812) iii, p. 429, pl. lxxiv. Mastacembelus, Klein, Pisc. Miss. iv, t. iii, f. 2.

Esox belone, Linn. Syst. Nat. i, p. 517 ; Gmel. Linn. p. 1391 ; Brun. Ich. Mass. p. 79 ; Bloch, t. xxxiii ; Bl. Schn. p. 391 ; Bonnaterre, Ency. Ich. p. 175, pl. lxxii, f. 297 ; Lacép. $\nabla$, p. 308, pl. vii, f. 1 ; Müll. Fauna Dan. p. 49; Donovan, Brit. Fish. iii, pl. lxiv; Turton, Brit. Fauna, p. 105; Risso, Ich. Nice, p. 330; Nard. Prod. Adr. Ich. no. 143.

Belone vulgaris, Flem. Brit. An. p. 184; Jenyns, Man. p. 418; Ekström. Fis. Mörkö, p. 72; Templeton, Mag. Nat. Hist. 1837 (2) i, p. 410; Parnell, Wern. Mem. vii, p. 274; Johnston, Berwick. Nat. F. Club, 1838, p. 172; Yarrell, Brit. Fish. (ed. 1) i, p. 391, c. fig. (ed. 2) i, p. 442 (ed. 3) i, p. 459; Cuv. and Val. xviii, p. 399 ; White, Catal. p. 71 ; Nilss. Skand. Faun. Fisk. iv, p. 354 ; Thompson, Nat. Hist. Ireland, iv, p. 141 ; Schlegel, Dieren Neder. p. 156, pl. xiii, f. 5 ; Günther, Catal. vi, p. 254; Collett, Norges Fiske, p. 176; Winther, Prod. Ich. Dan. Mar. p. 46 ; McIntosh, Fish. St. Andrew's, p. 181 ; Moreau, Poiss. France, iii, p. 470 .

Belone acus, Risso, Eur. Merid. iii, p. 443 ; Cuv. and Val. xviii, p. 414 ; Günther, Catal. vi, p. 251.

Belone rostrata, Faber, Fische Isl. p. 152 ; Ekström, Mörkö, p. 72 ; Kröyer Dan. Fisk. iii, p. 255, c. fig.

Rhamphistoma vulgaris, Swainson, Fish. ii, p. 297.

Macrognathus scolopax, Gronov. ed. Gray, p. 147.

Belone Linnei, Malm, Fauna, p. 553.

Garfish, Couch, Fish. Brit. Isles, iv, p. 146, pl. ccix.

\section{(Young.)}

Hemiramphus Europeus, Yarrell, Mag. Nat. Hist. 1837, p. 505, and Brit. Fishes (ed. 2) i, p. 450, c. fig. (ed. 3) i, p. 469 ; Couch, Zoologist, 1848, p. 1978, figs. $d, e$, and Fish. Brit. Isles, iv, p. 135, pl. coviii; White, Catal. p. 72.

Esox Brasiliensis, Couch, Trans. Linn. Soc. xiv, p. 85.

Hemiramphus obtusus, Couch, Zool. p. 1978, figs. $a_{-c}$, and Fish. Brit. Isles, iv, p. 139 , pl. coviii, fig. 2 ; White, Catal. p. 72.

Hemiramphus balthicus, Hornschuch.

Hemiramphus behnii, Van der Hoeven.

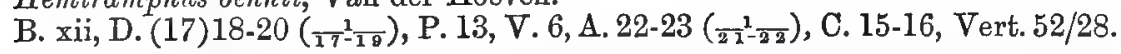

Length of head $3 \frac{1}{4}$ to 4 , of caudal fin $7 \frac{1}{2}$, height of body 15 to 16 in the total length. Eyes-large, $2 \frac{1}{4}$ to $2 \frac{2}{3}$ diameters in the length of the postorbital portion of the head, $6 \frac{1}{2}$ to 7 diameters from the end of the upper jaw, and $1 \frac{1}{4}$ diameters apart. Upper surface of head not grooved: some slight grooves about the superciliary region. Maxillaries concealed by the preorbital. Upper jaw not so long as the lower, which latter has a soft termination. Teeth-small, in some examples a small oval patch is present on the vomer, in others it is absent. Fins-the anterior dorsal rays are elevated forming a lobe, while the posterior ones are of about the same length and terminate opposite the anal ones, which is some distance from the base of the caudal fin. Pectoral, if turned forward, does not reach the eye. Ventral situated nearly midway between the opercle and the base of the candal fin. Caudal forked, lower lobe the longer. The free portion of the tail compressed, nearly twice as long as high, and deeper than broad. Colours-of a sea-green or bluish-green along the back, becoming of a changeable blue and purple along the sides, and silvery white beneath.

Fleming (Brit. Anim. 1828, p. 184) observes upon Esox Brasiliensis, Couch, 
being the young of this species: while many authors seem to have been doubtful whether the various European Hemiramphi were not in reality the young of Belone.

The young.-Couch's magnified figure of the blunt-headed half-beak, the specimen having been half-an-inch in length, shows the fish in the earlier stage, when the lower jaw is commencing to increase in length; while his European half-beak, at a little over $3 \frac{1}{2}$ inches in length, demonstrates the fish with the lower jaw grown, but the upper jaw still almost stationary. In Lütken's "Spolia Atlantica," p. 567, will be found a complete series of illustrations, showing the various stages of evolution of the jaws as they become developed with age.

Steindachner (Sitz. Ak. Wiss. Wien, 1868, lvii, p. 732) remarked upon the identity of Belone acus, Risso, with B. vulgaris, the distinction between the two forms resting principally upon the latter possessing a small ovoid patch of vomerine teeth, which is said to be absent in the latter. It is remarkable that the finest example in the British Museum from the British shores is destitute of this patch of teeth, although it is present in others. They are likewise absent from the Devonshire specimen which I have figured. Canestrini l. c. observed upon finding vomerine teeth in an Adriatic example. Professor Giglioli informs me that these vomerine teeth may be present or absent in Mediterravean and Adriatic forms, aud he looks upon Belone vulgaris, B. acus, and $B$. Euxinus as pertaining to one species.

Names.-Sword fish, green-ben or green-bane, Scotland: green-bone or greenback, guard-fish, gar-pipe, horn-fish, needle-fish or long-nose, gore-bill, sea-needle, mackerel-guide, which name it has received from its coming towards shore a little prior to the appearance of the mackerel. Gerrick, Cornwall. Hornkecke (Palsgrave). Whaup-fish. In Ireland, hom-eel (Belfast BaJ); mackerel-scout (Strangford Lough); spearling (Portrush); Spanish-mackerel, according to Nimmo, at Ronndstone. Its snout is termed gore-bone in some places. Môr nodwydd, or Curn big, Welsh. De geep, Dutch. L'Orphie, French.

Habits.-Gregarions, migratory, and very voracious, frequently approaching the shore in large assemblages, and though stragglers may be taken all the year round, it appears to arrive in shoals about March or April, and retires to deeper water late in the autumn, being absent throughout the winter and spring. In the Northern Herald (Inverness, November 22nd, 1844) it was observed that within the last three weeks this fish had been abundant; its visits are not periodical, either as regards scasons or cycles, in fact twenty-two years had passed since they came in considerable numbers; about sixty years since there were large shoals, and they were known as Gobbaiche ardnasoar, or "snipe-fish." Although as observed the gar-fish is usually gregarious, Thompson remarked that in Belfast Bay it is generally found singly. Mr. Cornish (Zool.1865, p. 9814) well describes the appearance of a shoal of these fishes when chased by the tunny, how they scudded rapidly over the face of the sea as though they were actually swimming on the surface, having the larger portion of their bodies in the air. When in pursuit of shoals of small fish it appears to be springing over the waves after them. It jumps over floating substances sometimes in a peculiar way, shooting itself bolt upright and alighting in the water tail first. Mr. Couch recorded how in 1865 he found the upper jaw of a gar-fish transfixed through the body of a mackerel. Mr. Dunn observed upon another having similarly gone through the body of a pilchard, he also informed me, July 25th, 1881, that he had obtained that morning a mackerel with the jaw of a gar-fish transfixing the body just under the pectoral fin, where it had broken off. The same accurate observer remarked that he has reason to believe that they used their beaks as a ram against their prey, sometimes transfixing their eyes: should they do this, of course both would be penetrated. S. Clogg (Zool. June, 1874, p. 4160) observes upon a salmon-peal having been attacked by a gar-fish. It had run its under jaw completely through the peal, and it must have been broken off either by the force of the blow or by the struggles of each fish to free itself. The peal, which weighed nearly $4 \mathrm{lb}$., was struck behind and quite above the pectoral fin, the jaw 
of the gar-fish thus passing throngh the thickest part of the peal. Couch observed that it is an indiscriminate feeder, eating any animal substances it can seize. Thompson mentions a 15-spined sticklebark having been found in the stomach of one captured August 10th, 1850. Its digestion appears to be very rapid.

Means of capture.-It will tako a bait, but when hooked makes most vigorous efforts at escaping. On the coast of Donegal it is captured in the following way :-Nets are fixed on wooden frames and allowed to float about, these fish jumping over the sides become captured: the same plan is employed at Land's End. They are frequently taken in mackerel nets, and during the last half of the year numbers are captured in Corrwall in seine nets.

Baits.-Pieces of fish, mussels, \&c. It never plays round a bait, but seizes it as if it were living. It strikes obliquely upwards, hence it happens that when it takes the hook, the first notice of the capture is the fish starting into the air with the line, and then beating itself about on the surface to get rid of the hook, and in doing this it always emits a very strong and peculiar odour ( $R$. Couch, Zool. 1847, p. 1613).

Breeding.*-Along the sonth coast of England this fish breeds in May and June, but, according to Andrews, in July in Dingle and Ventry Bays in Ireland. On May 14th, 1881, Mr. Dunn sent me a portion of a mackerel net with many ova of the gar-fish attached to it by tentacular filaments springing from the outer surface of the eggs (plate cxxvii). The fish having become entangled in a mackerel drift net, had voided its eggs while endeavouring to escape, and these latter, owing to their peculiar appendages, are enabled to attach themselves to any object in the vicinity (see page 146). Mr. Dunn obtained another supply on June 25th, and on making some experiments found that the filaments will even adhere to polished metal. These eggs when extruded must float in the sea with their long filaments waving about until they meet with some object to which they can attach themselves; or they may serve to bind together large numbers of eggs into one mass and fix such to some suitable substance.

I have already alluded to the peculiar manner in which the jaws of this fish are developed. Under one inch the upper profile of the snout is somewhat obtuse, the upper jaw very short, the lower a little longer. This stage has been termed Hemiramphus obtusus, R. Conch, although the fishermen assured him they were the young of the gar. As the fish becomes from 2 to 3 inches in length, the lower jaw has much increased in length, being many times longer than the upper jaw, which is almost triangular: at this stage it has been termed Hemiramphus Europeus. On October 28th, 1880, I obtained an example 8.6 inches long from Devonshire: the entire length of its head was $3 \cdot 1$ inches: of the lower jaw from the angle of the mouth $2 \cdot 1$ inches: of the upper jaw from the angle of the mouth 1.6 inches. On November 23rd, 1881, I obtained another from Devonshire, 8.5 inches long: its head being 2.8 inches, lower jaw $1 \cdot 8$, upper jaw 1 inch. The foregoing would lead one to conclude that this fish increases rather rapidly in length, attaining to about 8 inches in length at three months' age. The very yourg Lowe found in Norfolk (July 6th, 1868) had been living upon Entomostraca.

As food.-Pretty good, but owing to the green colour of the bones of this fish, both before and after boiling, a prejudice against eating it is entertained in some localities. They are often plentiful in the London market, especially in the spring. Large numbers used to be sent there from the coasts of Kent and Sussex. Their smell when first captured is not always agreeable. Parnell states that many persons consider them superior to mackerel as food, being firmer, whiter in the flesh and possessing much the same flavour, but it is generally considered more dry.

Uses.-Bait for ground fish when other kinds run short, for which when cut into strips they are found very efficient.

Habitat.-Distributed from Iceland and the Scandinavian coast, the Baltic, North Sea, and Atlantic coasts of Europe to the Mediterranean.

* See article on the Development of the Silver Gal-fisb, Belone longirostris, T. A. Ryder, Bull. United States' Fish Commission, vol, i, 1881, p. 283. 
In the Orkneys and Zetland it is not uncommon (W. Baikie) and extends in more or less abundance during certain seasons around the British coasts. Banff, not scarce at certain seasons (Edward): Moray Firth (Harris): Aberdeen (Sim): St. Andrews, occasionally thrown on the sands after storms (McIntosh). It enters the Firth of Forth in large shoals about the beginning of July in company with the mackerel, and remains till the end of August. It seldom ascends the Firth to any distance. Is taken with net and hook, and sometimes found on the haddock lines which have been baited with mussel (Parnell). Berwickshire occasional (Johnston) : Yorkshire, resident off the coast and not uncommon, approaching the shore in summer : in autumn it has been cast ashore in considerable numbers during heavy gales* (Yorkshire Vertebrata) : Norfolk, off which coast it breeds (Lowe) : one is recorded by Lubbock as having been taken within five miles of Norwich. Along the whole of the south coast. Kent and Sussex very abundant. Devonshire not uncommon (Parfitt). Cornwall common. Off Swansea is not infrequent in the Bay, but never in shoals and usually of a smaller size than on the other coasts (Dillwyn). In the Firth of Clyde, May 25th, 1877, the capture of an example 28 inches in length was recorded as a rarity (Flemyng, Nat. Hist. Soc. Glasgow).

In Ireland it is taken all round the coast, generally in the latter part of the summer and autumn: a few are also obtained in the early months of the year (Thompson). In some seasons it is common from Cork to Londonderry. The example figured is 28 inches long from Devonshire : the largest example I have collected has been 2 feet 9 inches. Pennant records it np to 3 feet.

- Mr. Dunn informs me of an instance in which one of these fishes, just ontside the harbour at Meragissey, was seen and chased by a porpoise. It sprang out of the water and its pursuer followed it npwards of a bundred yards. The gar was now almost in the jaws of the porpoise when a rock jutting a few inches above the sea was arrived at. Over it went the fish, but the heavy porpoise ran its head against the barrier and appeared partially stunned. 


\section{Genus II.-Scombresox, Lacépède.}

\section{Grammiconotus, Costa (Young).}

Gill-opening wide. Body elongated, compressed. Eyes lateral. Jaws prolonged into a slender beal, the upper of which is formed by the premaxillaries. Minute teeth in both jaws. Dorsal and anal fins opposite one another, consisting of few rays, but with several detached finlets posterior to each: caudal forked. Scales small and deciduous. Pyloric appendages present. Air-bladder large.

So far as is known these fishes appear to be exclusively marine, while the young are said to be found dispersed all over the Atlantic and Pacific Oceans.

\section{Scombresox saurus, Plate CXXVII, fig. " 2 .}

\section{Saurus, Rondel. i, p. 232. Acus altera minor, Belon. Aquat. p. 163.}

Lacertus seu sauris, Willugh. p. 232 . Skipper, Ray, Synopsis, p. 165; Borlase, Cornwall, p. 271. Saury, Pennant, Brit. Zool. (Ed. 1776) iii, p. 325, pl. lxiv (Ed. 1812) iii, p. 430, pl. lxxv.

Esox saurus, Walb. Artedi, iii, p. 93 ; Bl. Schn. p. 394, t. lxxviii, f. 2 ; Rackett, Trans. Linn. Soc. vii, p. 60 , t. $\nabla$; Shaw, Zool. $\nabla$, p. 114; Turton, Brit. Fauna, p. 105 ; Neill, Wern. Mem. i, p. 541 ; Donovan, Brit. Fish. $\nabla$, pl. cxvi.

Scomberesox Camperii, Lacép. $\nabla$, p. 345, pl. vi, f. 3 ; Risso, Ich. Nice, p. 334, and Eur. Mérid. iii, p. 444; Cuv. and Val. xviii, p. 464, pl. 551; Kröyer, Dan. Fisk. iii, p. 278, c. fig.; Yarrell, Brit. Fishes (ed. 3), i, p. 465, c. fig.; Nilss. Skand. Fanna, Fish. iv, p. 358, and Öf. Sven. Vet. Acad. Förh. 1864, p. 501.

Scombresox saurus, Flem. Brit. An. p. 184; Yarrell, Brit. Fish. (ed. 1) i, p. 394, c. fig. (ed. 2) i, p. 446; Templeton, Mag. Nat. Hist. 1837 (2) i, p. 410; Parnell, Wern. Mem. vii, p. 276; Swainson, Fishes, ii, p. 297; White, Catal. p. 71 ; Thompson, Nat. Hist. Ireland, iv, p. 142; Beneden, Bull. Acad. Sc. Lett. \&c. Belgium, 1865, xx p. 51; Günther, Catal. vi, p. 257; Collett, Norges Fiske, p. 176; Malm, Fauna, p. 555; Winther, Prod. Ich. Dan. Mar. p. 46; McIntosh, Fish. St. Andrews, p. 181; Moreau, Poiss. France, iii, p. 475, f. 199.

Belone saurus, Jenyns, Man. p. 419; Johnston, Berwick. Nat. Hist. Field Club, 1838, i, p. 173.

Scombresox rondeletii, Cuv. and Val. xviii, p. 472; Günther, Catal. vi, p. 258;

Morean, 1. c. p. 477.

Scomberesox storei, De Kay, New York Fish. p. 229, pl. xxxv, f. 111.

Sayris Camperii, Canestrini, Fauna Ital. Pesc. p. 131.

Shipper, Couch, Fish. Brit. Isles, iv, p. 141, pl. coviii, t. 3.

\section{(Young.)}

Scomberesox scutellatum, Leseur, Journ. Acad. Nat. Sc. Phil. ii, 1821, p. 132. Scombresox scutellatus, Cuv. and Val. xviii, p. 477. i, f. 4 .

Grammiconotus bicolor, Costa, Ann. Mus. Zool. Univers. Nap. 1862, i, p. 55, t.

\section{B. xiii, D. 10-12 + v-vi, P. 12-13, V. 6, A. 12-13 + vi-vii, C. 14.}

Length of head $3 \frac{1}{3}$ to $3 \frac{1}{2}$, of candal fin $9 \frac{1}{2}$, height of body $10 \frac{1}{2}$ in the total

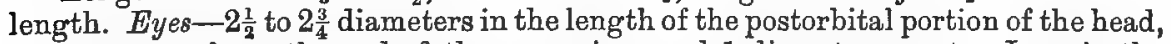
$4 \frac{1}{2}$ diameters from the end of the upper jaw, and 1 diameter apart. Jaws in the adult curved slightly and gradually upwards, the upper being a little the shorter. Posterior extremity of the maxilla not covered by the preorbital, it extends backwards to about 1 diameter of the eye anterior to the orbit. Preorbital large and somewhat quadrangular in shape. Teeth-fine ones in the jaws; none on the vomer, palatines, or tongue. Fins - the dorsal commences slightly behind the beginning of the last third of the total length, its anterior rays rather higher than half that of the body below it, the finlets continued almost to the base of the 
caudal fin. Pectoral as long as two-thirds the height of the body, its posterior margin somewhat concave. Ventrals inserted midway between the angle of the mouth or the front edge of the eye and the posterior end of the caudal fin, the latter being deeply forked. Scales-a somewhat keel-like edge commences on either side of the fish on a level with the lower edge of the gill-covers, and passes along the entire length of the body. Scale-like appendages over the middle of the base of the caudal fin. Colours-back of a deep rich blue, below which is a broad burnished and shining silvery band, having a dark lower edge, abdomen silvery : upper fins dark coloured, lower ones and pectoral yellowish.

The evolution of the jaws in this fish is much the same as described in the gar-pike (see page 149).

Varieties.-Valenciennes separates the Mediterranean from the oceanic form nnder the belief that the former has no air-bladder. Professor Lütken (Spolia Atlantica) has shown however that this organ may be present in the Mediterranean forms. Morean observes that it may be absent. As no other differences exist except this inconstant one I have not considered them to denote distinct species.

Names.-Skipper : saury : saury-pilee: slip-jack : shopster : halion. In Scotland, gowdnook: gosnick : Egyptian herring.

Habits.-Gregarious, migratory, in the summer being mostly at or near the surface, but during the autumn frequenting deeper water: it is usually found further out to sea than the gar-fish, while it has an extensive range: instances are on record in which it has ascended rivers as bigh as fresh-water. It first appears off Cornwall about the latter half of June or commencement of July, and in the autumn frequently shows itself in enormous schools; while it leaves the coast prior to the end of November. It is constantly in motion, moving with great rapidity, frequently springing out of the water by scores at a time and giving much the appearance of a shoal of flying fishes. It has been frequently known to spring out of the water into the fishermen's boats, especially during stormy weather. Mr. Dunn considers the skippers as natural enemies to the pilchards: Couch held the same views. In the year 1825 skippers and pilchards were enclosed in pilchard seines together, and before they could be taken into the boat, thousands of the pilchards had their eyes knocked ont by the skippers, and scores of pilchards were transfixed through the body by the beak of the skipper. The fishermen were first made aware of these fishes being on the coast by the noise they were making in the night, the one attacking, the other running away. This battle continued more or less along the coast each summer from 1825 to 1834. The fishermen consider the presence of the skipper is an hindrance to the successful taking of the pilchard. Entomostraca, small crustacea, and sea-weed have been found in its stomach.

Means of capture.-In Cornwall they are frequently taken in July and Angnst in numbers by drift nets a few leagues from the shore: $\mathrm{R}$. Couch observed that he had seen 8000 enclosed in one pilchard seine net. The largest catch of these fishes at Mevagissey, where they are annual visitors, has been 100,000 (Dunn).

Baits.-It has been taken with a bait.

Breeding.-The eggs of the Scombresox saurus are furnished externally with flaments as in the gar-tish (page 146), while the life-histories of the two are also very similar, but the young of the skipper appear to be found further out to sea, and the base of the maxilla is more concealed by the preorbital. Liutken (Spolia Atlantica) p. 567 has figured the heads of this species from a very early age up to that of the full-grown, showing how the jaws are gradually evolved, the disproportion between the length of the two being much less than occurs in Belone.

As fond.-Said to be fair.

Habitat.-Atlantic coasts of Europe, Africa, and North America. Also the Mediterranean.

Low observed that last year (1775) such a glut of these fish set into the head of Kerston Bay, that they could be caught in pailsful ; numbers were taken and heaps flung ashore. They were from 9 to 12 inches long, and had not been observed there previously. Low considered they had been driven out of their 
course. As a rale in the Orkneys and Zetland rare (W. Baikie) : Banff rare (Edward) : Aberdeen (Sim) : St. Andrews not uncommon (McIntosh) : enters the Firth of Forth almost every autumn in considerable shoals, and being stupid inactive fishes are found in hundreds on the shallows when the tide retires, with their long noses imbedded in the mud (Pennant). The same author records great numbers having been thrown ashore on the Leith sands near Edinburgh, after a great storm in November, 1768. In Yorkshire is occasionally taken in harbours and shallow waters but is reported from Scarborough only (Yorkshire Vertebrata). An example abont 15 inches long was taken off Norfolk in October, 1843 (Fisher) : off Devonshire occasionally appears in large numbers, and Parfitt (Fauna of Devon) remarks that he saw a great many taken in a seine off Seaton in 1870. Not uncommon, often abundant off Cornwall. Mr. Cornish (Zool. p. 1463) observes upon one having been pumped up on board a fishing boat in September, 1868: the same author remarks upon its being well known off Welsh ports. At Swansea Dillwyn never heard of it except on T'urton's authority.

In Ireland Templeton observed that it is seldom found on the coast, and he was never able to procure a specimen until one was caught near Long Bridge, Belfast, in 1820. Thompson received one $12 \frac{1}{4}$ inches long from Belfast, stranded after a gale on September 17th, 1840, a second was also taken, and a third on October 7th. Sampson includes it among the fish of Derry. Ogilby: (Zool. 1876, p. 4753) observes that it is decidedly rare on the north coast: he obtained one example, cast ashore at Portrush, co. of Antrim, during the last week in September, 1875, while but few years pass without some examples being obtained there in this manner. Newcastle, co. Down (Thompson). The specimen obtained was taken on a handline, when fishing for bream, westward of Crowrock, on a fine night. They not unfrequently leap into the canoes (Andrews) : the same author refers to one taken at Ballina in the county of Sligo.

The example figured is 11 inches long from Meragissey. This fish attains to 18 inches in length. 


\section{Genus III.-Exocœrus, Artedi.}

\section{Cypsilurus, Swainson: Halocypselus, Weinland: Parexocoetus, Bleeker.}

Body moderately oblong. Gill-openings very wide. Jaws short, the premaxillaries and maxillaries separate: mandible in some species with a tubercular prolongation. Barbels present or absent. Teeth, when present, nimute and rudimentary. Pectoral elongated, used as an organ for flying: the dorsal fin may be much or only moderately elevated: ventrals long, short, or of moderate length. Air-bladder large. Pyloric appendages absent.

Bleeker instituted the genus, Parexocotus, for some species as E. mento, Cuv. and $V$ al., destitute of barbels but with a short tubular prolongation of the lower jaw, as if an aborted attempt at elongation as seen in Hemiramphus. Barbels and transverse bands may be symptomatic of the immaturity of the specimen. Lütken draws attention to the following important generic characters, which have been overlooked. There are those in which the second ray of the pectoral fin is entire : others in which it is deeply cleft, and when the second ray is thus cleft the third is always the longest (Vid. Medd. 1876, pp. 389-408, pl. x).

Geographical distribution.-Seas of tropical and semi-tropical regions, extending into more temperate zones.

\section{Exocotus volitans, Plate CXXVIII.}

Hirundo, Salv. fol. 185, pl. lxvii. Exocotus, no. 1, Artedi, Genera, p. 8, and Spec. p. 35. Hirondelle de MLer, Duhamel, Pêches, ii, p. 480, pl. xxii, f. 2.

Exocœetus volitans, Linn. Amœn. Acad. i, p. 320, and Syst. Nat. i, p. 520; Bonnaterre, Ency. Ich. p. 181, pl. lxxiii, t. 306 ; Gmel. Linn. p. 1399; Yarrell, Brit. Fish. (ed. 1) i, p. 398, c. fig. (ed. 2) i, p. 453 (ed. 3) i, p. 479 ; Cuv. and Val. xix, p. 83, pl. 559; Swainson, Fish. ii, p. 296 ; Guichen. Exp. Algér. p. 26 ; White, Catal. p. 73; Günther, Catal. vi, p. 293; Malm, Fauna, p. 555; Collett, Norges Fiske, p. 177; Canestrini, Fauna Ital. Pesc. p. 132 ; Lütken, Contr. diag. Poiss. volants, Journ. Zool. vi, 1877, p. 118; Giglioli, Pesc. Ital. p. 43; Morean, Poiss. France, iii, p. 481.

Exocoetus exsiliens, Bloch, t. xxxvii ; Bonap. Catal. no. 724.

Greater Flying Fish, Couch, Fish. Brit. Isles, iv, p. 128, pl. ccrii.

$$
\text { B. } x-x i, \text { D. 11-13, P. 15-17, V. 6, A. 9, C. 19, L.1. 63, Vert. 31/14. }
$$

Length of head $5 \frac{1}{4}$ to $5 \frac{3}{4}$, of caudal fin 4 , height of body 6 to $7 \frac{1}{2}$ in the total length. Eyes-diameter of each 3 to $3 \frac{1}{4}$ in the length of the head, nearly 1 diameter from the end of the snout, and $1 \frac{1}{4}$ diameters apart. The form of the body is liable to modifications, in some having a convex superior profile or it may be broad and flattened almost as far as the origin of the dorsal fin. Upper surface of the head flattened. Snout obtuse: cleft shallow : the lower jaw slightly longer than the upper: the superior maxilla hidden by the preorbital when the mouth is closed. Teeth in jaws minute. Fins-the dorsal commences on a line above the vent, its first ray simple : the pectoral reaches to the base of the caudal fin, its second ray divided, its third the longest. The ventrals are inserted a little posterior to the middle of the distance between the end of the snout and the base of the caudal fin, they are elongated, being more than $\frac{1}{2}$ longer than the head. Anal commences beneath the posterior dorsal rays. Candal lobed, lower lobe much the longer, but the proportions vary in individuals. Colours-bluish-gray along the back, silvery on the sides and beneath. Dorsal fin grayish-white, caudal brown. Pectoral gray with a light outer edge. Ventral and anal whitish or bluish.

Names.-Flying-fish. Hirondelle de mer, ou Hareng volant, French. 
Habits.-A marine gregarious* fish, which leaves the water, springing into the air, due to fear of some danger, not for the purpose of seeking food: it would seem that the distance it can cover in such flights is limited, while some have asserted that they are unable to voluntarily change the direction of their course. Professor Mobius (Zeits. für wiss. Zool. Band. xxx, suppl. p. 343) records his observations on the flight of Exocoeti. He observes that they spring with great velocity out of the water, regardless of the direction of the wind or course of the waves. During their flight they do not make any regular fluttering movements with their pectoral and ventral fins, but merely keep them extended or spread out. Rapid vibrations may however be perceived in their outstretched fins. The hinder part of the body is kept at a lower elevation than the fore part. The cause of these movements through the air is due to the springing movements which they impart to their bodies by means of their very powerful lateral muscles, in the same manner as other fish employ them for propulsion through the water. They spring out of the water with great velocity due to the air presenting less resistance than the water, and when they fall into the sea their outstretched fins act like a parachute. The action of the wind may be favourable or the reverse to their flight. During the day-time they can choose the direction of their spring, and so aroid ships. At night-time, due to the deficiency of such a power, they may fall into a vessel. As any air in strong motion striking against any obstacle (as a wave or side of a ship) rises, this would also raise the fish and thus lift it on to the vessel. It may be a combination of an oblique forward movement of the fish, acted upon by the wind. Mr. Howard Saunders (Zool. 1874, p. 3839) observes that not even the frigate-bird was ever seen by him to swoop at, much less to catch one on the wing, and in South Sea Bubbles, either the "Earl" or the "Doctor" ridicules the very idea of any bird being able to do so.

Means of capture.-Off the British coasts it is merely taken by chance. Mr. Smith (Zool. 1875, p. 4413) details how in January they angled for these fishes, while on a voyage from Peru to Callao, "a vaxiety of baits were employed in their capture-bits of red bunting, small spoon-baits, and artificial minnows, of these the most taking being a large red fly and a small gilt minnow, but all the baits mentioned caught some. In following the minnow through the water, the fish would open their pectoral fins and poise themselves for a rush at it, spreading the wings also had the effect of checking their progress if their suspicions were aroused;' by a near inspection of the bait. When hooked they proved very game fish, taking out several yards of line in their first rush, and often taking a flight in the air, line and all." When swimming under water the pectoral fins are held close to the body.

Breeding.- Eggs with external filaments as in the gar-fish (p. 146).

As food.-Inferior.

Habitat.-Atlantic coasts of Europe, but more common in the Mediterranean. A few stragglers have been captured off our coasts, but the shoals which have been recorded, but none of the members of which have been captured, may not improbably have consisted of skippers, Scombresox saurus (see p. 152).

In July, 1823, a flying-fish, the species not recorded, was taken ten miles from Bridgewater (Taylor, Ann. of Phil. xxii, p. 152). Some were said to have been seen off Portland Island in August, 1825, from the deck of a vessel going down Channel (London Quarterly Journ. of Science, xx, p. 412), but none were procured. Another shoal was obserred at the mouth of the Bristol Channel in August, 1876 (Taylor, Zool. p. 5128). A fine example in October, 1849, was left by the tide in Stonehouse Pool, and was, but is not now in the Plymouth Museum. R. Couch, however, remarks not rare in Mount's Bay, Cornwall, in the summer of 1845 , while about five miles off shore I saw many start from the water into the air, but none seem to have been procured. One was found on the beach at Helford, near Falmouth, and given to Couch: another was thrown on to the

- I do not consider that as yet we have sufficient evidence to prove that shoals of these fishes approach our shores; but rather that such as have been captured were a tew stragglers, mostly arriving singly. 
quay at Plymouth which, according to Couch, leaves no doubt as to its being this species. In September, 1796, one was said to have been seen at Allonby (Heysham, Catal. Cumberland Animals).

In Ireland examples have several times been observed off the south coast.

\section{Exocœtus evolans, Plate CXXIX, fig. 1.}

Flying fish, Pennant, Brit. Zool. (ed. 1776), iii, p. 333, pl. lxvii (Ed. 1812) iii, p. 441, pl. lxxriii ; ? Thompson, Natural History of Ireland, iv, p. 143.

Exocoetus evolans, Linn. Syst. Nat. i, p. 521; Gmel. Linn. p. 1400 ; Bloch, t. ccexcriii ; Bonnaterre, Ency. Ich. p. 182, pl. c, f. 400 ; Bl. Schn. p. 430, t. Ixxxiv; Cuv. and Val. xix, p. 138 ; Bonap. Pesc. Eur. p. 81 ; Gronov. ed. Gray, p. 145; Bleeker, Cape of Good Hope, p. 76, and Atl. Ich. vi, p. 69; Yarrell, Brit. Fish. (ed. 2), i, p. 458 (ed. 3), i, p. 474, c. fig. ; Günther, Catal. vi, p. 282 ; Kner, Novara Fische, p. 326 ; Day, Fish. India, p. 519, pl. exx, f. 5; Giglioli, Pesc. Ital. p. 43 ; Canestrini, Fauna Ital. Pesc. p. 132 ; Liitken, Diag. Poiss. Vol. Journ. Zool. t. vi, p. 110; Moreau, Poisson. France, iii, p. 484.

Exocoetus volitans, pt. Lacép. v, p. 402 , t. xii, f. 2 ; Donovan, Brit. Fish. ii, pl. xxxi ; Turton, Brit. Fauna, p. 106; Fleming, Brit. An. p. 185 ; Jenyns, Brit. Vert. p. 420; Brown, Phil. Trans. lxviii, p. 790, pl. xii; Bennett, Whaling Voyage, ii, p. 284.

B. ix-xii, D. 12-14, P. 14-16, V. 6, A. 13-15, C. 17-19, L. 1. 40-42, Vert. 25/19.

Length of head 5 to $5 \frac{1}{2}$, of caudal fin $4 \frac{1}{2}$ of 5 , height of body 6 to 7 in the total length. Eyes-of each $3 \frac{1}{2}$ to 4 diameters in the length of the head, $3 / 4$ of a diameter from the end of the snout, and 1 to $1 \frac{1}{4}$ apart. Interorbital space flat. The greatest height of the head equals its length anterior to the hind edge of the preopercle. Snout obtuse when the mouth is closed, rendering the dorsal and abdominal profiles equally convex. Teeth-minute or absent. Fins-anterior dorsal rays not balf so long as the head: the fin arises above or slightly in advance of the origin of the anal. Pectoral reaches to the base of the caudal. Ventral short, about half as long as the head, and reaching half-way to the anal. Caudal lobed, the lower much the longer. Scales $-6 \frac{1}{2}$ rows between the origin of the dorsal fin and the lateral-line. Colours - bluish along the back, becoming lighter on the sides and beneath. Pectoral gray or black with a light edge.

Breeding.-Of this but little is known: the eggs have external filaments as observed upon respecting the gar-fish (p. 146). Mr. Howard Saunders (Zool. 1874, p. 3838) says that some years since, when at the Chincha Islands, on the coast of Peru, I observed they appeared about the last week in March, and the water round the rocks was alive with them. At this period of the year, when heavy in spawn, they were not noticed "on the wing." They literally swarmed into the crevices and fissures of the rocks, and were evidently spawning.

Mr. Flower exhibited at the Zoological Society, July 13th, 1858, a flying fish (Exocoetus volitans), to which was attached a specimen of Penellus Blainvillii, Milne Edwards, $2 \frac{1}{2}$ inches long, its head and three hornlike processes being buried in the muscular mass on the right side of the spinal column of the fish, and the whole of the exposed part gave lodgment to a colony of little cirripeds, Conchoderma virgata, Spengler. The specimen was taken in the Atlantic, about $5^{\circ} 17^{\prime}$ outh latitude.

As food.-Of a fairly moderate description, but rather dry.

Habitat.-Tropical and temperate seas. It has been obtained off the Atlantic coast of France.

In June, 1765, Pennant mentions an example of the Aying-fish having been captured a short distance below Carmarthen, in the river Towy, in Wales. $\mathrm{He}$ figures Exocoetus evolans, but does not expressly state that his drawing was from the Welsh specimen; and Couch suggests it was drawn from a preserved example. This may be so, and it is therefore with doubt that I insert this species among the British Fauna. Couch, however, does not state that his figure was made from a British example, but he says there is no doubt but that those captured along the south coast belonged to Exocoetus volitans.

The example figured is one in the British Museum collection. 


\section{FAMILY, IV.-CYPRINID ÆE.}

Branchiostegals three: pseudobranchiæ generally present. Body oblong or elongated : abdomen usually rounded, but if compressed and cutting destitute of ossicles. Margin of the upper jaw formed by the premaxillaries Opercles in four pieces. Mouth toothless, but from one to three rows of teeth in the inferior pharyngeal bones, which latter are strong, free, and parallel to the branchial arches. A single, rayed, dorsal fin : ventrals inserted posterior to the pectorals. Head scaleless: body scaled or scaleless, never covered by osseous plates. No "cul de sac" to the stomach, nor pyloric appendages. Air-bladder, if present, large: it may be divided by a constriction into an anterior and posterior portion, neither of which are enclosed by bone (Cyprining): or in to two lateral portions, partially or entirely enclosed in a bony capsule (Cobitidinæ).

Geographical distribution.-This extensive family includes a large number of forms distributed throughout the fresh waters of the Old World and of North America. As already remarked (page 53), in Europe and Asia it appears to take the place of the Salmonidm of the colder north, increasing in numbers as the tropics are approached, until in Asia the genera are very numerous. Some few forms are said to occasionally to be found in salt lakes, also some are stated to descend to the brackish tidal waters of estuaries, or even to the sea.

Although some forms of European carps are unquestionably vegetable feeders, all are not so, the difference in their food being indicated to a great extent by the character of their inferior pharyngeal teeth, and the extent of their digestive tract. No one who has fished for the Indian barbel or mahseer (a species of Barbus), would for one moment place such among strictly herbivorons forms. We have some Cyprinidae which are omniverous, others carnivorous, insectivorous, and gramminiverous; some which generally associdte in schools, others only doing so at certain seasons, and a few that appear to be more solitary in their habits.

Fatio has observed in carps in Switzerland a greater development in the first pectoral ray in the male than in the female. This is more especially the case in the minnow (Leuciscus phoxinus), which has even seven or eight thus enlarged, and not exclusively at the breeding season. Many of the carps possess cirri or barbels on the snout or jaws, serving as organs of touch.

As regards hybridism among members of the carp family, Siebold has noted as probably such the following 5 in his Fresh-water Fishes of Central Europe:Cyprinus Kollarii, between the common and crucian carps. Abramis Leuckartii, between the bream Brama and a Leuciscus. Abramis abramo-rutilus, between a bream and a rudd or roach. Alburnus dolabratus, between the bleak and German chub. Chondrostoma rysela, between C. nassus and Telestes Agassizii. Researches in this country do not appear to have afforded any grounds for upholding or assailing the above.

As food the carp family are not so much appreciated in Great Britain and Ireland as they are on the continent of Europe and elsewhere, probably due to our cooking being inferior, and likewise to fish not being much esteemed by the lower classes, who also prefer the marine to the fresh-water forms. Thus the despised bream, Abramis blicca, which is considered worthless with us, is made a savoury dish by Dutch cooks. Even the chub Lubbock mentions having tasted after it had been prepared by a French woman, who produced from one of these fishes a dish wherein " the scales and bones were absent, the watery taste was all gone, the flesh was firm and sweet in flavour, and altogether it might be regarded 
as a real victory achieved by the cuisinière over stubborn materials." Perhaps the rud, if similarly treated, would meet with similar success. As it is, the chief use in Norfolk for coarse fish is to bait crab-pots or employ as manure.

It has been observed that the fishes which afford the best evidence of ruminating action are Cyprinoids, as carp, tench, and bream, when peristaltic movements occur in the alimentary canal, and successive regurgitations of the contents of the stomach induce actions of the pharyngeal jaws as the half-bruised food comes into contact with them and excites a succession of swellings and subsidences of the irritable palate as portions of the regurgitated food are pressed against it. On the occiput behind the roof of the palate is a single grinding tooth or plate, which has opposed to it the two inferior pharyngeal bones armed with teeth : while in front of this plate, and forming the roof of the palate, is a thick, soft, vascular, and highly sensitive mass, which becomes thinner anteriorly, and is believed to be useful in taste, being supplied by branches of the glossopharyngeal nerves. This mass is commonly known as the "carp's tongue," and held in great esteem among epicures.

\section{First group-Cyprininæ.}

A. Abdomen rounded and without any compressed edge.

\section{Genus I.-Crpinus, Artedi.}

Branchiostegals three: pseudobranchice present. Body oblong. Mouth small, anterior: lips thick and fleshy. Barbels four. Pharyngeal teeth in three rows: molarform 3.1.1-1.1.3. Dorsal fin long, with its last undivided ray osseous and serrated posteriorly : anal with few branched rays (5-6).

This carp is a native of temperate portions of Asia, and appears to be especially common in China in both its wild and domesticated condition. It has been imported from thence into Europe and America.

Holme observes that in heraldry a carp is the emblem of hospitality, and denotes food and nourishment from the bearer to those in need.

\section{Cyprinus carpio, Plate CXXIX, fig. 2}

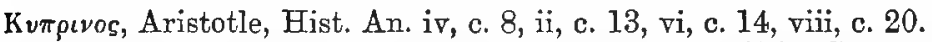

Cyprinus, Rondel. p. 150; Salv. p. 92 ; Belon. p. 273 ; Gesner, p. 309 (Ed. 1608) p. 164, c. fig.; Aldrov. p. 637; Marsil. Danub. Pan,-Mys. p. 57, t. xix; Gronov. Zooph. no. 330; Klein, Miss. v, p. 59, no. 1. Cyprinus nobilis, Schonev. p. 32. Cyprino, Jons. t. iii, c. vi, p. 161, t. xxvii, f. 11, 12, and tit. iv, c. iii, p. 171, t. xxix, f. 3, 4, 6. Carp, Willughby, p. 245, t. Q1, f. 2; Ray, p. 115 ; Pennant, Brit. Zool. (Ed. 1776) iii, p. 353, pl. lxx (Ed. 1812) iii, p. 467, pl. lxxxi ; Gronov. Zooph. no. 330. Cyprinus, Artedi, Synom. no. 1, Gen. no. 4, Spec. no. 13. Carpe, Duhamel Pêches, ii, sect. 3, p. 509, pl. xvi, f. 1 .

Cyprinus carpio, Linn. Syst. Nat. i, p. 525; Gmel. Linn. p. 1411; Bloch, Fische Deuts. i, p. 92, t. xvi ; Bl. Schn. p. 447 ; Bonnaterre, Ency. Ich. p. 190, pl. A, fig. 1 ; Lacépède, v, p. 504; Pallas, Zoo. Ross.-As. iii, p. 289 ; Donovan, Brit. Fishes, v, pl. cx; Shaw, Zool. v, t. 12l; Turton, p. 107 ; Bowdich, Brit. F. W. Fish. pl. ii ; Flem. Brit. An. p. 185 ; Jenyns, Brit. Vert. p. 401 ; Yarrell, Brit. Fish. (ed. 1) i, p. 305, c. fig. (ed. 2) i, p. 349 (ed. 3) i, p. 354; Templeton, Mag. Nat. Hist. 1837 (2) i, p. 410; Ḱröyer, Dan. Fiske, iii, p. 290, c. fig ; Cuv. and Val. xvi, p. 23 ; Thompson, Nat. Hist. Treland, iv, p. 135 ; Swainson, Fishes, ii, p. 284; White, Catal. p. 59 ; Gronov. ed. Gray, p. 177; Nilss. Skand. Fauna, iv, Fiske, p. 284; Heckel and Kner, Süss. w. f. p. 54; Blanchard, Poiss. France, p. 322, fig. 65 ; Günther, Catal. vii, p. 25 ; Schlegel, Dieren. Neder. p. 96, pl. x, f. 1; Siebold, Süsswass. f. Mitteleur. p. 84; Feddersen, Danske Ferskvandsfiske, p. 82 ; Canestriui, Faun. Ital. Pesc. p. 10 ; Collett, Norges Fisk. p. 179 ; Houghton, Brit. Freshwater Fish. p. 15, c. fig; Giglioli, Pesc. Ital. Catal. p. 43; Moreau, Poiss. France, iii, p. 368.

Carp, Couch, Fish. Brit. Isles, iv, p. 4, pl, clexx. 
B. III. D. $21-25\left(\frac{2}{1}-\frac{3}{2}\right)$, P. $15-16$, V. 8 , A. $7-8\left(\frac{2-3}{8}\right)$, C. 20 , L. 1. $35-40$, L. tr. $5 / 9$, Vert. 21-21/16-1\%.

Length of head 4 to $4 \frac{2}{3}$, of caudal fin $5 \frac{3}{4}$ to 6 , height of body 3 to $4 \frac{1}{2}$ in the total length. Eye-small, situated a little before the middle of the length of the

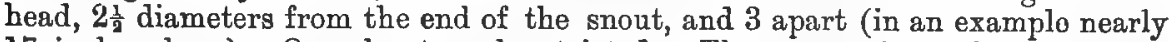
17 inches long). Opercle strongly striated. The proportions of the various parts of this fish are exceedingly diverse, dependent upon age, sex, and locality. Barbels - of moderate length, those at the maxilla the longest, and almost equal. ling one diameter of the orbit. Lips thick and leathery. The maxilla reaches to beneath the front edge of the orbit. Fins-dorsal commences rather nearer to the snout than to the base of the candal, its first two or three or rarely four rays are bony, the last being serrated posteriorly, while the anterior portion of the fin, which is the highest, equals about two-fifths the height of the body below it. Pectoral situated low down, its length equals about that of the head without the snout, and it does not extend to above the ventral, which latter reaches half-way to the anal. First two or three anal rays osseous, the last being serrated posteriorly. Caudal deeply forked. Scales-large, $5 \frac{1}{2}$ to 6 rows between the lateral-line and the base of the ventral fin. Colours - vary, usually brownish or with a bluish tinge along the back, with golden or coppery reflections along the sides. Some have been described of a whitish tint due, perhaps, to age, others as having black spots caused, perhaps occasionally, by parasites.

Varieties in form.-The body in some is much more elongated than in others. Some ichthyologists observe upon the existence of a second continental species Cyprinus kollarii or $O$. striatus, but which is a hybrid between $O$. carpio and Carassius vulgaris, having some very short barbels: it is a bony and inferior fish, and is known in some parts of Germany as the "poor man's carp." The fins are subject to modifications, being very much prolonged in some forms, as will be more particularly alluded to when treating of the gold carp. The chief German varieties of carp which are caltivated are:-(1) The common carp: (2) the mirror-carp, or carp king, Cyprinus rex cyprinorum, O. specularis, C. macrolepidotus, the most highly improved breed in central Germany. A small head, thick body, large scales, and tendency to rapidly grow large. In this race some pisciculturists make a speciality of raising forms with very few scales, sometimes restricted to one row along the lateral-line, in others to a strip along the back. When in the water the mirror carp has its back of a bluish colour tinged with gray or greenish, but more decidedly blue than either of the other two varieties. It is said to be the most hardy form, and to bear injuries the best: (3) the leather-carp, Cyprinus nudus, C. alepidotus, C. coriaceus, or C. nudus, in which scales are absent, but the skin is very much thickened, its a well defined race and not a mirror-carp denuded of scaling : these are sometimes of a goldenbrown colour and are very fashionable in Germany. There have likewise been various forms of monstrosities described.

Names.-Carp has been derived from the Greek term "kuprinos" itself said to be from " kupris" or "Cyprus," where Aprodite or Venus was first worshipped, and may have been given to this fish in order to symbolize its extraordinary fecundity. Holme (1688) gives Seizling as yearlings, next a sprole or sprale from two years of age, terms taken from Gesner's Swiss names of this fish, they not being called "karpf" until four years old. In (Whole Art of Fishing, 1719) the last century we are told it was called the fresh-water fox and queen of rivers. Cerpyn, Welsh. De Karper, Dutch. La carpe, French.

Habits.- Hardy and tenacious of life, cautious and wary in a state of nature, but readily tamed so that it will even take food from the hand. It mostly frequents ponds, canals, sluggish pieces of water, or slow flowing rivers, being especially partial to localities possessing soft, marly, or muddy bottoms. It can also live in water unsuited to other fish, as the pools of bog meadows or sloughs, though the kind will be inferior. During the summer it may be seen lying among the weeds at the surface of the water, at which it lazily sucks making a very distinct noise which has been likened to that produced by a pig. Or else a number may be perceived near the surface quietly swimming about in a shoal, or returning 
to the bottom in search of food. About November, or as winter approaches, it becomes more sluggish, and will even lie dormant in the mud into which it will probably retire along with numerous companions, or else seek its quarters under weeds, roots, or hollows. Occasionally it is found alive in muddy bottoms of ponds almost destitute of water. Carp, says Hessel, during the winter are huddled together in the mud in concentric circles with their heads together, the posterior part of the body raised and held immovably, scarcely lifting the gills for the purpose of breathing and without taking a particle of food. Though it does not feed or grow during its winter sleep when in its natural retreat, it does not diminish in weight: but while kept in large tanks or winter chambers it falls off in a remarkable degree. It will not thrire in overstocked ponds, while owing to its muddy flavour when transferred direct from such places to the kitchen it is found advisable to retain it for some weeks in a stew, through which a supply of water flows. Here it will feed well and fatten. Jesse says that his were very fond of boiled potatoes. It can also be kept for a long time in well-boats through which water is allowed to pass, and may be thus conveyed long distances. It is partial to the shoots of aquatic plants, succulent vegetables, worms, and the larvæ of insects, while occasionally it will make a mouthful of a small fish. Mr. Gurney (Zoologist, 1860) observed a carp devour three young minnows each about $1 \frac{1}{2}$ inches long which were confined with it in the same tank. It will not despise the refuse of kitchens, slaughter-houses, breweries, or even the excrements of cattle and pigs.

One reason given for permitting pike in carp ponds is that the latter fish are apt to become languid and lazy, whereas a few pike would give them exercise, inducing them to seek their natural feeding-places. But as a rule pisciculturists prefer their absence.

Pennant observes upon the following experiment having been twice made, of placing a carp in a net well wrapped up in wet moss, the mouth only remaining out, and then hung up in a cellar or some cool place: the fish being frequently fed with bread and milk, and often plunged into water. Thus treated it has been known to live above a fortnight, * and grow very fat as well as lose its muddy taste. It can be sent alive very long distances packed in moist moss with a mouthful of bread steeped in brandy and occasionally renewed. In the Horticultural Gardens, Sonth Kensington, the stock of carp was found to be too great for the vegetation, so 300 averaging fully $2 \mathrm{lb}$. each and the greater part full of spawn, were transmitted in wet moss to the Colne, near Haresfield, and did not appear to suffer from the journey (Field, April, 1881). Three carp averaging $10 \mathrm{lb}$. each, were sent from Windsor Park at 7 A.M. to the Southport Aquarium, arriving at 8 P.M., they were packed in damp moss in a hamper. On being placed in a tank two immediately swam away, the third appeared exhausted at first, but shortly recovered and did as well as the other two.

Means of capture.- The fisherman finds this fish an adept at escaping from nets, by burrowing below it, or springing over the corks, consequently to have carp completely at command there should be means of letting off the water in which it resides, either partially or entirely. So difficult is it to net that unless some such provision is made one can well understand the Norfolk fen-men regarding it with mysterions awe, how its entrances and its exits into pieces of water puzzle them, and how, as Lubbock remarks, they consider it as something more than a fish, and look upon it as what the Scotch term "no cannie." In angling for this fish various plans have their advocates, but all agree that as a rule the carp is exceedingly wary and difficult to capture. The best time in the day for sport appears to be early in the morning or late in the evening: bright days are inauspicious as it swims near the surface but does not feed, while should there be a cold wind it seems to be somewhat dormant and refuses the tempting bait. Warm cloudy days, with a tendency to rain, appear to be those best suited for angling for carp. A fine line with a quill float should be used, having a light weight (as a shot) about a foot from the hook, and good strong rod, while the depth should be plumbed so that the shot finds rest on the bottom. The rod should be fixed into the bank and the

* In Holland it has been said they are thus kept alive in cellars for months ! 
angler be out of sight keeping quite quiet, while he must not strike at the first symptom of a bite, but wait until the float begins to move away.

Baits.-Many are in rogue, as a paste of bread crumbs, to which may be added honey and gin. Blue-bottle flies, ripe cherries, green peas boiled in sugar, grains, balls of green silk-weed so common in ponds, worms, green gentles, grasshoppers, larvø, small red worms from dry earthy dunghills rolled into a ball.

In the Cherwell, near Oxford, the common carp is far from being a shy fish, and seems to have a peculiar affection for the red and white paste of the roach fishermen (G. F. Field, Sept. 1882). Mr. Jardine (Field, Dec. 11th, 1880) records the capture of a $9 \frac{1}{4} \mathrm{lb}$. carp, with a small artificial dace. A correspondent of the same paper (Dec. 4th, 1880) remarks how using a large yellow Thurso salmon-fly in order to try and take a pike in a pond, he caught a carp of $41 \mathrm{~b}$. and hooked two others, the fly being only six inches below the surface.

Breeding. - A carp is supposed to commence breeding at three years old, returning yearly to the same spot, and during its migration it has been known to spring several feet out of the water in order to overcome obstacles. Some are either temporarily or permanently sterile. But, of those which breed, one of $9 \mathrm{lb}$. had 600,000 eggs (Bloch); one of $16 \frac{\mathrm{s}}{4} \mathrm{lb}$. had 101,200 ova, another of $25 \frac{1}{2} \mathrm{lb}$. 203,109 ova (Harmer); one of $21 \frac{1}{2} \mathrm{lb}$. 1,310,750, another of $16 \frac{1}{2} \mathrm{lb} .2,059,750$ eggs (Buckland). Hessel found a fish weighing from 4 to $5 \mathrm{lb}$. contains on an average 400,000 to $500,000 \mathrm{eggs}$ : in the somewhat larger-bodied scale-carp he generally observed comparatively more eggs than in a mirror carp of the same age and weight. It generally spawns about May or June, in accordance with the nature of the season, and one female attended by two or more males may be observed on warm days among the aquatic weeds where the adhesive eggs are deposited. Some continue extruding ova for several weeks or even months, interruptions occurring during cold or rainy weather, while others may retain it occasioning disease. During the breeding season it is readily taken as it appears to lose all fear. After spawning it returns to the water it usually resides in. During the spawning season numerous wart-like protuberances appear upon the skin of the head and back of the males, disappearing after the expiration of that time; while some little time prior to this period the pharyngeal teeth are shed and which are yearly renewed. The eggs develop quicisly should the weather be propitious, the eyes showing themselves as early as the fifth or sixth day, and on the twelfth or sixteenth day at the furthest, hatching commences in shallow and warm ponds. After a certain number are in a pond they cease to increase; perhaps the parents devour their eggs or their offspring.

Hermaphrodites.—Jäckel (Abh. ntr. Ges. Nurnburg, 1867, iii, p. 245) describes one and likewise (Fische Bayerns, p. 21) gives an account of some hybrids, between a variety of the common carp (Carpio macrolepidotus) and the crucian carp (Carassins vulgaris), and which he terms Carpio Sieboldii, a form almost valueless as food. Pennant mentions hybrids between the carp and tench, and having also beard of some between the carp and the bream. Bloch observed that the carp produced hybrids both with Carassius auratus and $O$. gibelio.

Hessel observes that he placed a female common carp with a male crucian carp, also a female crucian carp with a male common carp, and a female Cyprinus kollarii (see page 159) with a male of the common carp. In the two first cases the young became identical with $C$. kollarii, some approaching more towards one parent, some towards the other; while in the last experiment the product was with difficulty to be distinguished from the genuine carp. He fed these last for three years in order to try their fitness for the table, but they were poor in taste, very bony, and could not be compared by any means to the common carp.

Life-history. - The carp attains to a good old age. Gesner refers to one of a hundred years, and Buffon to another of one hundred and fifty. Buckland observes that in Windsor Park the fishermen informed him that a carp in a certain stew must be nearly one hundred years old; how this was ascertained is not recorded. In Germany and other countries where this fish is cultivated, it is found that if May is mild and warm the greatest increase of growth 
occurs: it appears only to grow during four months, or from May until August inclusive.

Respecting their rate of growth it differs in accordance with the water inhabited, as to if such is warm or cold, a river, lake or pond, the supply of food, quality of the soil, and the race of carp. Under favourable circumstances they will attain from 3 to $3 \frac{1}{2} \mathrm{lb}$. weight in three years. In warm climates carp have been known to attain from $2{ }_{4}^{3}$ to $4 \mathrm{lb}$. in one year, which increase would take twoand-a-half years in colder regions. In 1865 some ponds in Windsor Park were run dry, and the carp in the obelisk pond were of a very similar weight from $4 \mathrm{lb}$. to $6 \mathrm{lb}$, the head fisherman Wheeler asserted they were at least fifty years old : they had been twice removed within his memory from different ponds, the last time about thirty-five years' previous from a pond near Cumberland Lodge when they weighed about $3 \mathrm{lb}$. each. In the Royal stew two brothers and sisters to the foregoing were larger, one turning the scale at $10 \frac{1}{2} \mathrm{lb}$. (Fish. Mag.). They may become gradually white with age.

Diseases.-Is subject externally to fungoid growths, especially old carp; also the same moss-like appearance occasionally attacks young fish which reside in foul or snow water, as well as blindness, epidemic fevers, visceral obstructions due to over-gorging on chickweed, ulcerations of the liver, malignant pustules under the scales termed small-pox by fishermen, carbuncles, and intestinal worms. It appears to be very susceptible to electric influences. On fishing a pond in Dorsetshire a great number of carp were found, each with a frog mounted on it, the hind-legs clinging to the back, the fore-legs fixed in the corner of each eye of the fish, which were thin and greatly wasted (Pennant). Williams (Brit. Angler, 1740) observes, when many carp have been put into a well-watched pond so that they could not have been stolen, at the emptying three or four years subsequently, not a carp would be found. This, he says, is attributed, and in all appearances justly, to their being destroyed by the frogs. The Rev. A. Lloyd (Liverpool Standard, March, 1835) states, that, when engaged with a garden rake in clearing some decayed wood and leares out of the water of a pond, he brought a live trout, about $6 \frac{1}{2}$ inches long, to land with a large frog firmly holding it, grasped tightly round the middle. In 1880 it was stated that, during the draining of Count Schaafgotsche's carp ponds at Warmbrunn, it was observed that frogs were clinging to the backs of many of the larger fish, most of which, thus beridden, being blind, the frogs' fore-feet being firmly fixed in the eye sockets of their victims. Hessel observes that once during his absence a number of large carp were fed upon coagulated blood which had commenced to putrefy; the fish devoured it eagerly, became ill, and most of them died in a few days from inflammation of the intestines. Spoilt food should never be given to fish. Frogs appear to be inimical to the eggs and, perhaps, the very young fish, while dabchicks and other water-birds are destructive to the fry.

As food.- In some countries, especially in those where eating fish forms a portion of the religious creed of the people, this fish is largely cultivated, while a supply is kept in stews, so that when fast or feast days come round it is readily available; they were, likewise, very useful in times when the means of carriage was slow. It is not much esteemed in this country owing to its muddy flavour, but this it loses if kept in a stew through which a stream flows. The best tasted forms are those from rivers; next, such as come from large lakes; and the most inferior taken direct from muddy ponds. Carp is in season from October until April. The palate, commonly termed " the tongue," is considered a delicacy.

Its roe is converted into red caviare by Jews in Italy and Eastern Europe as, by their law, they may not eat caviare made of sturgeon, that being a fish destitute of scales.

To improve their flavour Mr. Tull (Phil. Trans. Roy. Soc. 1754, p. 870) castrated these fish and found that subsequently they grew more rapidly, fattened more readily, and were of a superior flavour.

Habitat.-This fish, which is indigenous to Persia, China, and contiguous countries, even to Java and other islands in the Malay Archipelago, has been 
introduced into and widely disseminated in the temperate parts of Europe and Asia. It appears to have been cultivated in Germany and France as early as 1258; introduced into Sweden in 1560, and into Denmark in 1660, and is now found from Italy to Sweden and Norway, and from France to Russia and the boundaries of Eastern Siberia. A considerable number are taken in the Black Sea and Caspian; and Nordmann remarks upon their presence in the salt lakes of New Russia. Among the older writers Cassiodorus, of the sixth century, terms the Carpa of the Danube a costly fish of delicate flavour and supplied to the table of princes.

When this fish was first introduced into England is involved in obscurity ; it is not alluded to in the Anglo-Saxon Dictionary of Allfric, who, in 1051, died Archbishop of York. The first mention of it seems to be in Dame Juliana Berners' Boke of St. Albans, published in 1496, wherein she speaks of the carp as "a dayntous fysshe, but there ben but fewe in Englonde, and therefore I wryte the lesse of hym." About 1514 * Mascall is said to have introduced it into Sussex, probably extending its range. The Rev. J. Hughes, of Meltham, observed that he had read most of the works of the Welsh poets, from Aneurin down to the last century, but in none had he found the Welsh name for the carp. The doggrel lines of-

\section{"Turkeys, carp, hop, pickerel and beer Came into England all in one year"}

- may be considered interesting as verses, but not faithful representations of facts.

It appears to be absent from the Orkneys, and is not so common in Scotland as it is in England, where it is found in lakes, ponds, canals, railway ponds and rivers throughout the country. It is especially fine in some of our eastern counties, as in Yorkshire and the Norfolk broads. It was formerly said not to be found in Cornwall, but is now present there. Moore observes upon its absence, from the Isle of Wight.

In Ireland it has been noted in County Down, Armagh, Galway, Sligo, Kilkenny and Dublin, and said to have been introduced into the south by the great Earl of Cork. Rutty observes that this fish was acclimatized in Ireland during the reign of James I (A.D. 1603 to 1625).

The example figured is a female full of roe which died in October, 1882, while in transit from Buckinghamshire to the Royal Westminster Aquarium. It is 16.8 inches long, and for it I am indebted to J. Carrington, Esq., F.L.S.

As to the size these fish attain in this country, that raries with localities, one over $20 \mathrm{lb}$. appears to be a very large one. One was taken at Sheftield Park in 1882 which weighed $19 \mathrm{lb}$. (Field, November 18, 1882): on emptying the lake at Bayham Abbey, near Lamberhurst, in July, 1870, one was secured weighing $21 \mathrm{lb} .10 \mathrm{oz}$. (Coombe, Field, November 25, 1822) : Yarrell exhibited one 30 inches long and weighing $22 \mathrm{lb}$. at the Zoological Society, November 22, 1836, it was taken in the Mere, near Payne's Hill, Surrey: in the autumn of 1858, the great pond at Harling, near Petersfield, was fished, and a carp of $24 \frac{1}{2} \mathrm{lb}$. taken (Gordon, History of Harting): in Holland $20 \mathrm{lb}$. fish are not rare, while in the German lakes they attain to $40 \mathrm{lb}$. or $50 \mathrm{lb} . \dagger$

* Dr. Günther places the date a century later, observing, "the year 1614 is assigned as the date of its first introduction into England " (Introduction Study of Fish, p. 590), or 118 years subsequent to the date of Dame Juliana Berners' work wherein she tells the reader how to catch it by angling in this country.

$t$ In 1711 one was said to have been dragged from the Oder, near Frankfort, 9 feet long and 3 deep, and weighing $76 \mathrm{lb}$. : Jovius alludes to another from Lake Como of $200 \mathrm{lb}$. weight ! 


\section{Genus II--Carassios, Nilsson.}

Branchiostegals three: pseudobranchice present. Snout obtuse and rounded. Mouth anterior, arched, and rather narrow: lips thin. No barbels. Pharyngeal teeth compressed and in a single row, 4/4. (Dentes scalpriformes, Bonap.). Dorsal fin commencing opposite the ventrals, having many rays (15-25), its last undivided one being osseous and serrated: last undivided anal ray osseous and normally serrated. Scales of moderate size. Lateral-line continued to the base of the caudal fin.

The two species of this genus found in Great Britain are possibly merely the eastern and western representatives derived at a remote period from a common ancestry: the Carassius vulgaris being more essentially Western Asiatic and European, while the $C$. auratus is of Chinese and Japanese extraction. Very similar in external appearances, it is likewise remarkable that the latter, of which I possess specimens from near Yunam, in China, are of the same green colour in rivers as the wild European form. The C. vulgaris generally has a more elevated body, and from 31 to $35^{*}$ rows of scales along the lateral-line, while the gold carp has usually from 25 to 30 rows. Both, however, are subject to almost innumerable variations as to proportions, while they are likewise somewhat intimately related to the common carp, Cyprinus carpio, with which they interbreed, to the deterioration of the breed in carp fisheries.

\section{Carassius vulgaris, Plate CXXX, fig. 1.}

Karass, Gesner, De Aquat. p. 318; Aldrov. p. 644. Carassius, Willughby, p. 249 ; Ray, p. 116. Cyprinus, Sp. Artedi, Genera, p. 4, no. 7, Synom. p. 5, no. 5, and Species, p. 29, no. 15 ; Klein, Miss. v, p. 59, no. 4, t. xi, f. 1 ; Gronov. Zooph. no. 343. Crucian, Pennant, Brit. Zool. (Ed. 1776) iii, p. 364, pl. Ixxii.

Cyprinus carassius, Linn. Syst. Nat. i, p. 526; Gmel. Linn. p. 1416; Bloch, Fische Deuts. i, p. 96, t. xi ; Bonnaterre, Ency. Ich. p. 192, pl. lxxviii, f. 322 ; Bl. Schn. p. 438; Lacép. $\nabla$, p. 549; Pall. Zoogr. Ross.-As. iii, p. 297 ; Turton, Brit. Fauna, p. 108; Fries och Ekstr. Skand. Fisk. p. 140, t. xxxi; Ekstr. Fische Mörkö, p. 58; Cuv. and Val. xvi, p. 82, pl. 459 ; Jenyns, Manual, p. 403; Yarrell, Brit. Fish. (ed. 2) i, p. 355, c. fig.; White, Catal. p. 59; Nilss. Skand. Fauna, iv, p. 290; Gronov. ed. Gray, p. 179; Schlegel, Dieren Neder. p. 104, pl. x, f. 2; Siebold, Suss. w. f. p. 98; Malm, Fauna, p. 556 ; Canestrini, Faun. Ital. p. 13 ; Giglioli, Cat. Pesc. Ital. p. 43.

Carassius vulgaris, Nord. in Demid. Voy. Russ. Mer. iii, p. 479; Kröyer, Dan. Fiske, iii, p. 294, c. fig. ; Heckel and Kner, Suss. w. f. p. 67; Siebold, Suss. w. f. p. 98 ; Günther, Catal. vii, p. 29 ; Feddersen, p. 82 ; Houghton, Brit. Freshwater Fishes, p. 19, c. fig. ; Moreau, Poiss. France, iii, p. 374.

Carassius Linnai, Bonap. Cat. Met. Cipr. d'Eur. p. 3; Yarrell, Brit. Fish. (ed. 3) i, p. 364, c. fig.

Oyprinopsis carassius, Blanchard, Poiss. France, p. 336, fig. 67.

Crucian carp, Couch, Fish. Brit. Isles, iv, p. 28, pl. clxxxiv.

\section{Variety.-Prussian Carp,}

Cyprinus, Klein, Pisc. Miss. v, t. xi, f. 2. The gibele, Penn. Brit. Zool. (Ed. 1812) jii, p. 480, pl. Ixxxiii.

Cyprinus gibelio, Gmel. Linn. p. 1417; Bloch, l.c. i, p. 71, t. xii; Bl. Schn. p. 438; Lacép. v, p. 64; Ekström, l.c. p. 64; Fleming, Brit. An. p. 185 ; Jenyns, Man. p. 402 ; Cav. and Val. xri, p. 90 ; Yarrell, l.c. (ed. 1) i, p. 311, c. fig. (ed. 2) i, p. 358 (ed. 3) i, p. 368 ; Nilss. 1.c. p. 294; Heckel and Kner, 1.c. p. 70 ; Collett, Norges Fiske, p. 180.

* Out of six examples from Kent one had 28 , one had 29 , thice 30 and one 32 rows of scales along the lateral-line. 
Cyprinus amarus, Koch, Fish. Ratis. p. 39.

Cyprinus moles, Agassiz, Mem. Soc. Sc. Nat. Nench. i, 1835, p. 37.

Carassius oblongus, Heckel and Knөr, l.c. p. 73.

Oyprinopsis gibelio, Blanchard, 1.c. p. 340, fig. 69.

Prussian carp, Couch, l.c. p. 31 , pl. clxxxv.

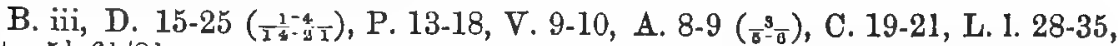
L. tr. $5 \frac{1}{2}-6 \frac{1}{2} / 8 \frac{1}{2}$.

The relative proportions in this fish are subject to great variations, the body being much more elevated in some than it is in others, the dorsal profile being generally more convex than the abdominal. Length of head $4 \frac{1}{4}$ to 5 , of caudal fin $4 \frac{1}{4}$ to $5 \frac{1}{4}$, height of body $2 \frac{1}{2}$ to 4 times in the total length. Eyes-in the anterior half of the head, diameter of each from 5 to 6 in the length of the head, 1 to $1 \frac{1}{2}$ diameters from the end of the snout, and $1 \frac{1}{2}$ to 2 apart. Snout obtuse, the cleft of the mouth shallow, with the upper jaw slightly the longer. Barbels-absent, if present which sometimes occurs, the example is thought to have been crossed with the common carp (see $O$. kollarii). Teeth, pharyngeal-normally 4-4, but in some I have found 4, 2 or 3-2 or 3, 4, and scalpriform having somewhat compressed crowns with a depressed and flattened surface. Fins-the dorsal commences on a line above the insertion of the ventrals and ceases above the termination of the anal: it is higher in some examples than in others, its last undivided ray is serrated posteriorly. The last undivided anal ray osseous and posteriorly serrated. Caudal may be cut almost straight posteriorly, simply notched or almost forked. Colours-vary, generally brownish tinted with green along the back: brown or gray tinged with yellow on the sides and white or yellowish white beneath. Fins dark with a bluish or red tinge.

Varieties.-The Carassius vulgaris is the highest variety of this species, in some the shape of its body being almost quadrangular, and the dorsal profile much more elevated than the abdominal. The gibele differs in the less height of the body, being somewhat starved in appearance, and is not so deep and more carp-like than O. vilgaris, having a blunter head, longer lower jaw, back not so elevated, and the caudal fin more deeply forked. O. moles, C. $\nabla$, is a form having a low dorsal fin, and $C$. oblongus, Heckel and Kner, one in which the body is elongated. The C. kollarii, known by the presence of barbels, is a hybrid between the common and crucian or gold carp, already referred to (p. 159). It is chiefly raised in the neighbourhood of Paris and Metz, also in Belgium, and is a very inferior fish. I have obtained an example, a little over seven inches in length, from Kent, the pharyngeal teeth in which are $4 / 4$.

Names.-Crucian or Prussian or German-carp. Also termed Hamburgh carp, probably from its having been disseminated from that town or the place where it was best known. Crouger, Warwickshire. Byrbysg, Welsh. De steenkarper, Dutch. Le Carassin commun, French.

Habits.-Much the same as those of the common carp, is an indolent fish, which keeps much to the bottom, coming to the surface when there is a warm sun. It is very tenacious of life. Yarrell instances one which survived after having been kept thirty hours out of water. It lives in localities wherein the impurities are sufficient to destroy most other fish: it is said to thrive in the Thames. In Scandinavia it appears to like shallow, muddy, or grassy lakes. And it is asserted that this fish when put into water with a muddy bottom does not acquire a bad taste so soon as the pike, perch, and other piscine forms.

Means of capture.-Netting. A well scoured brandling is recommended as a good bait, but this fish seldom bites freely.

Breeding.-April, May, and June. Depositing its ova among aquatic weeds at this period, and congregating in shoals.

As food. - Said to be good in Sweden and Russia, but is generally considered inferior, tasteless, and bony.

Habitat.-Europe and Siberia, but it is doubtful whether it is indigenous to this country or has been introduced. It is now generally distributed throughout 
favourable localities in this country. It is very common about London and in pieces of water in the vicinity of the Thames.

In Ireland it is mentioned as existing by Thompson.

The example figured is seven inches long, from Kent. Yarrell observes that he obtained a crucian carp in October, 1824, which weighed $2 \mathrm{lb} .1 \mathrm{loz}$.

\section{Carassius auratus, Plate CXXX, fig. 2.}

Cyprinus lineatus and langsdorfi, Cuv. and Val. xvi, pp. 96, 99.

Carassius Bürgeri, Cuvieri, and grandoculis, Schlegel, Fann. Japon.

Gold fish, Pennant, Brit. Zool. (Ed. 1776) iii, p. 374 (Ed. 1812) iii, p. 490.

\section{Domesticated varieties.}

Cyprinus, sp. Klein, Pisc. Miss. $\nabla$, p. 60, no. 8 ; Gronov. Zooph. no. 342.

Cyprinus auratus, Linn. Syst. Nat. i, p. 527; Gmel. Linn. p. 1418; Bl. Fische Deuts. iii, p. 132, t. xciii, xciv ; Bonn. Eucy. Ich. p. 193, pl. 78, f. 324; Bl. Schn. p. 4.39; Lacép. v, p. 553, pl.xviii, f. 2, 3 ; Shaw, Zool. v, t. cxxvi, cxxvii ; Turton, p. 108; Risso, Ich. Nice, p. 364, and Eur. Mérid. iii, p. 436; Yarrell, Brit. Fish. (ed. 1), i, p. 315, c. fig. (ecl. 2), i, p. 361 (ed. 3), i, p. 37l; Cur. and Val. xvi, p. 101 ; Fleming, Brit. An. p. 185; White, Catal. p. 60; De Sauvigny, Hist. Nat. des dorades de la China (89 varieties figured); Jenyns, Brit. Vert. p. 413 ; Thompson, Ireland, iv, p. 135 ; Moreau, Poiss. France, iii, p. 377.

Cyprinus mauritianus, Bennett, Proc. Zool. Soc. i, 1831, p. 167.

Cyprinus thoracatus, Cuv. and Val. xvi, p. 97, pl. 460.

Cyprinus Maillardi, Guichenot, Réun. App. C. p. 14.

Cyprinus chinensis, Gronov. ed. Gray, p. 181.

Cyprinus telescopus and quadrilobus, Lacép. v, pl. xviii.

Carassius aıratus, Bleeker, Atl. Ich. \&c. Cyp. p. 74 ; Günther, Catal. vii, p. 32 ; Day, Fish. India, p. 552 ; Houghton, Brit. F. W. Fishes, p. 23, c. fig.; Feddersen, p. 83; Canesti ini, Fauna Ital. Pesc. p. 13 ; Moreau, Poiss. France, iii, p. 377.

Oyprinopsis auratus, Blanchard, Poiss. France, p. 343, fig. 71.

Gold-fish, Couch, Fish. Brit. Isles, iv, p. 33, pl. clxxrvi.

B. iii, D. 19-22 $\left(\frac{3}{\sqrt{6}-\frac{4}{18}}\right)$, P. 16-17, V. 9, A. $8-9\left(\frac{3}{\frac{3}{6}-\frac{3}{6}}\right)$, C. 18-19, L. 1. 26-30, L. tr. $5 \frac{1}{2}-6 \frac{1}{2} / 7 \frac{1}{2}-8 \frac{1}{2}$.

The proportions in this fish show great anomalies. Length of head $4 \frac{1}{4}$ to $4 \frac{3}{4}$, of caudal fin $4 \frac{1}{2}$ to 5 , height of body $2 \frac{3}{4}$ to 4 times in the total length. Eyes diameter of each from 4 to 5 times in the length of the head, $1 \frac{1}{4}$ to $1 \frac{1}{2}$ diameters from the end of the snout, and the same distance apart. Snout obtuse, cleft of mouth shallow, and the jaws anteriorly of about the same length. Barbels-absent. Pharyngeal teeth -3 or $4 / 4$ or 3 in one row, and similar in form to those of Carassius vulgaris. Fins-similar to $O$. vulgaris except that the dorsal fin is generally a little higher. Colours-various. As already remarked, those liring in their native streams are similar to Carassius vulgaris. In a domesticated state it may be red, vermillion, rose-coloured, pink, white, silvery, sometimes with black marks, while the same tint does not invariably pervade the whole of the fish. If turned out into the open its brilliancy generally decreases. During the first year of its life it is usually black; next mottled with silver. This last colour spreads over the whole fish, and after one or two seasons gradually becomes of a red or brilliant tint: in some they are colonred from the time of their birth.

Varieties.-This fish, due to domestication, is subject to great structural alterations: the vertebral column alone may be deformed but the fish be otherwise perfect; the dorsal fin may be entirely absent or reduced to one spine and a few rays, the fish being otherwise perfect; or with a reduced extent of dorsal fin the anal spine may be double. The caudal fin may be enlarged and divided into three or four lobes, the length of which may be nearly equal to that of the remainder of the fish, while at the same time the dorsal fin may be present or absent. Occasionally the eyes are protruding, forming what are known as the 
telescope goldfish, and this may be conjoined to a three or four-lobed tail fin. Sir R. Heron (Proc. Zool. Soc. 1841, p. 42) remarks respecting his menagerie that two out of five of the specimens of gold-fish hatched are deficient of the dorsal fin, and about two in a hundred, or rather more, have triple tail fins, and as many have the anal fin double. All the deformed fish are separated from the others, and placed in a pond by themselves, but they do not produce a greater proportion of deformed offspring than the parent fish.

As already observed, the Carassins auratus in its wild state is greenish. It may assume a yellow colour termed leucethiopism or xanthochroism: or a red colour, erythrism: or a white colour, albinism: or black, melanism; and these changes are not invariably produced by the same causes. The temperature of the water in which they reside influences colour, gold denoting the warmest, as from $80^{\circ}$ to $88^{\circ}$, and here they increase most rapidly, while bronze or silver is the tint most observable in those that are kept in the open air. In an account of the mode in which one of the gold-fish breeding establishments at Oldenburg is carried on, the correspondent remarks (Land and Water, May 3rd, 1879) that for the purpose of inducing colour the three chief materials needed are iron, gall-nuts, and tan. A fish originally red and white can by proper treatment be rendered black, white and red; but some fail, and these are consigned to a large shallow pond, where they are more exposed to the sun's rays, which have a strong colouring influence; but the treatment is somewhat hazardous, often killing the fish, and that quite suddenly.

Names.-Gold-fish: Gold carp. Eurbysg, Welsh. Le Carassin Doré, French.

Habits.-Much the same as the crucian, but more domesticated. In manufacturing districts, where there is an inadequate supply of cold water for the condensation of the steam employed in the engines, recourse, observes Yarrell, is had to what are termed engine-dams or ponds, into which the water from the steam-engine is thrown for the purpose of being cooled; in these dams, the average temperature of which is about $80^{\circ}$, it is common to keep gold-fish; and here it multiplies very rapidly, and becomes useful in consuming the refuse grease, which by accumulating on the surface would impede the cooling of the water.

It appears to thrive upon insects, but if it is found necessary to supplement artificial fare, blood and refuse meat, worms, or even barley are recommended. Kept in confinement, well or pump water seems to suit it the best, and only in emergencies should stream or river water be employed, while rain-water is quite unsuitable.

Breeding -in May or June. In breeding, many influences exercise an effect upon this fish, thus Thompson observes that "in some ponds near Belfast this species bred the first year of its introduction; in others not for several years; and in one the fishes have never increased. The temperature of the water in the first was warmest, and in the last coldest." As a general rule the gold carp does not spawn in transparent vessels; it requires ponds in which the bottom is not too smooth and where there are weeds suitable for its purpose. In the almost stagnant water of the breeding ponds at Oldenburg, should a little invigorating of the fish be deemed necessary, augmented aëration is found to have this effect, and after receiving a current of aërated water it frequently begins to spawn within an hour's time; by stimulating, a considerable proportion of the fish may be made to reproduce their species when not over twelve months of age. While br high feeding, frequent distribution of the parent fish (the same males and fem: les not being allowed to "keep company" long together), and occasional aëration of the water, it is found possible to pre-arrange the dates of spawning almost to a day, and also to raise a large crop from a comparatively small breeding stock. The first brood is raised in March or April, the second in July or earlier, and the third about the end of August or commencement of September. Many thus stimulated become prematurely barren, but even when comparatively less stimulated it is the exception to use the fish as spawners more than two years. M. Carbonnier (Compt. Rend. 1872, p. 1127) has recorded how he has observed the male of the telescope variety acting as accoucheur to the female. Three 
males pursued one of the other sex which was heavy in spawn, and rolled her like a ball upon the ground for a distance of several metres, and continued this process without rest or relaxation for two days, until the exhausted female (who during this period had been unable to recover her equilibrum for a moment) had at last evacuated all her ova. Mr. Waddington, of Bury (Hardw. Sc. Gossip, 1876, p. 278) instances a pair of gold-fish, kept in an inverted propagating glass, which commenced breeding August 27th, the male pursuing the female with the greatest fury, rubbing against its sides, and at times almost pushing it out of the water. The eggs were laid singly or two or three adherent together, and the male devoured them with the greatest avidity. The eyes in the eggs appeared on the third day and they hatched on the eighth. At Oldenburg, the fry ordinarily attain by the autumn $1 \frac{2}{4}$ to $2 \frac{3}{4}$ inches in length, and if properly coloured the largest are saleable for globes. The gold carp will cross with the common carassin and probably with the common carp.

Diseases. - When at Oxford, in the warm months of $1880, \mathrm{Mr}$. W. Hatchett Jackson showed me some gold-fish affected with the parasitic infusorian Ichthuophthirius multifilits of M. Fouquet. Other fish from the Isis had previously been observed to be similarly affected, and doubtless in many instances of reputed recovery from Saprolegnia ferax, the fish had really been suffering from the above parasitic infusorian.

Owls have been observed to be destructive to these fish (Mag. Nat. Hist. i, 1829, p. 179).

Habitat.-A native of Japan and China, its lively and variable colours, its curiously modified forms, and its generally interesting habits have caused it to be kept in glass vases, fountains, and pleasure grounds in many parts of the world. It is now spread throughout Europe, and not only flourishes domesticated bat also thrives in ponds and suitable pieces of water.

The year in which they were first introduced into England is uncertain and has been stated as 1611, also 1691, but were said to have been destroyed, consequently the fish was not generally known, according to Pennant, till 1728, when a great number were bronght over and presented first to Sir Matthew Dekker, and by him circulated round the neighbourhood of London. The earliest seen in France are said to have been sent to Madame Pompadour. A correspondent of Loudon's (Mag. Nat. Hist. iii, p. 478) suggests that gold carp were probably introduced into Portugal at an early period, after the people of that country had discovered the route to the East Indies by the Cape of Good Hope, as they appear to be now completely naturalized there. Having lived some years at Cochin, on the Malabar coast of India, and investigated the fishes, I must demur to this, as the gold carp is not found wild in any part of India, and I have never even seen it domesticated on the Malabar coast.

It grows to about 10 or 11 inches in length in this country, but in China attains a much larger size. 


\section{Genus III.-Barbus, Ouvier and Valenciennes.}

Puntius, pt. Ham. Buch. Labeobarbus and Varicorhimus, pt. Rüpp. Systomus, pt. McClell. Capoeta, sp. Cuv. and Val. Pseudobarbus, Bielz. Luciobarbus, Heckel. Cheilobarbus, sp. Smith. Balanteocheilus, Hemibarbus, Cyclocheilichthys, Siaja, Anematichthys, Hypselubarbus, Gonoproltopterus, Gnathopogon, Hampala, sp. Bleeker. Enteromius, Cope.

Mouth arched, and anterior or inferior; jaws closely invested by the lips, which may have leathery lobes but no horny covering. Barbels 4, 2, or 0 . Pharyngeal teeth 5 or 4,3 or 4,2 , or $3 / 2$ or 3,4 or 3,4 or 5 . Dorsal fin rather short, commencing nearly opposite the ventrals, its last undivided ray being osseous and sometimes serrated posteriorly, or articulated; anal rather short in some species, its second undivided ray sometimes osseous. Scales of large, medium, or small size; the anal row not enlarged. Lateral-line complete or incomplete.

This most extensive genus has been variously subdivided, and possesses most diverse and interesting forms, which, in British India, Burma, and Ceylon, number at least seventy species. But as in the British Isles we merely possess one species, the reader, if desirous of information respecting the above, must be referred to my work on the Fishes of India, pp. 556-582.

Geographical distribution.-Europe, throughout Asia and Africa.

These fishes are omnivorous in their food, while some forms attain to a very large size; thus the Mahseer or Mahaseer of India, Barbus tor, Ham. Bnch., has been captured more than once over $100 \mathrm{lb}$. in weight, but such must be considered very exceptional examples. Barbels from clear streams in India, when not above 10 or $15 \mathrm{lb}$. weight, are excellent eating, and deleterious effects do not, as in the British species, follow employing them as food, but some forms of Indian hill-carps as certainly are unwholesome, although it would appear that by constant use the individual who eats them as food becomes no longer amenable to their injurious influences.

\section{Barbus vulgaris, Plate CXXXI, fig. 1.}

Barbus, Ansonius, vers. 94; Rondel. ii, p. 194; Salvian, p. 86, f. 19 ; Gesner, Aquat. iv, p. 124; Aldrovandus, p. 598 ; Jonston, Pisc. Lib. 3, tit. i, c. v, p. 130, t. xxvi, f. 6; Willughby, p. 259, t. Q 2, f. 1 ; Ray, Synop. p. 121 ; Schonev. p. 29. Mystus, Belon. i, p. 301 ; Klein, Pisc. Miss. v, p. 64 . Cyprinus, Artedi, Genera, p. 4, no. 11, Synom. p. 8, no. 14; Gronov. Zooph. i, p. 104. Barbeau, Duhamel, Pêches, ii, p. 520. Barbel, Pennant, Brit. Zool. (Ed. 1776) iii, p. 357, pl. lxxi (Ed. 1812) iii, p. 472, pl. lxxxii; Bowdich, Brit. F. W. Fish, fig. no. ix.

Cyprinus barbus, Linn. Syst. Nat. i, p. 527; Bloch, Fische Dents. i, p. 109, t. xviii; Gmel. Linn. p. 1409; Bl. Schn. p. 450; Bonnaterre, Ency. Ich. p. 189, pl. Ixxvi, fig. 317 ; Lacép. v, p. 524 ; Pallas, Zoo. Ross.-Asiat. iii, p. 291 ; Donovan, Brit. Fish. ii, pl. xxix ; Shaw, Brit. Zool. v, t. cxxxii ; Turton, Brit. Fauna, p. 107; Jenyns, Manual, p. 404; Gronov. ed. Gray, p. 177 ; Schlegel, Dieren Neder. p. 99, pl. $x$, f. 3 .

Bartus vulgaris, Fleming, Brit. Anim. p. 185; Yarrell, Brit. Fish. (ed. 1) i, p. 321, c, fig. (ed. 2) i, p. 367 ; Swainson, Fish. ii, p. 284 ; Gunther, Catal. vii, p. 88 ; Houghton, Brit. F. W. Fishes, p. 27, c. fig. i; Giglioli, Cat. Pesc. Ital. p. 43.

Barbus fluviatilis, Agassiz, Mém. Soc. Sc. Nat. Neuch. i, p. 37 ; Cuv. and Val. xvi, p. 125 ; Yarrell, Brit. Fish. (ed. 3) i, p. 378; Kröyer, Dan. Fisk. iii, p. 321, c. fig.; Heckel and Kner, Suss. w. f. p. 79 ; Kessler, Bull. Soc. Nat. Mosc. 1859, xxxii, pt. i, p. 527 ; Siebold, Suss. w. f. p. 109; Canestrini, Fauna Ital. Pesc. p. 12; Blanchard, Poiss. France, p. 302, f. 60; Morean, Poiss. France, iii, p. 379.

Barbus barbus, White, Catal. p. 60.

Barbus cyclolepis, Heckel, Ann. Wien. Mas. ii, p. 155.

Barbus communis, Nord. in Demid. Voy. Russ. Mérid. iii, p. 172.

Barbel, Couch, Fish. Brit. Isles, iv, p. 16, pl. clxxxi.

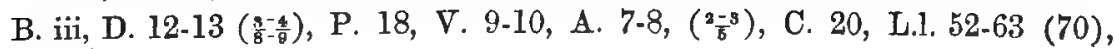
I. tr. 13/15. 
Length of head 4 to $4 \frac{9}{4}$, of caudal fin $4 \frac{3}{4}$, height of body 5 to 6 times in the total length. Eyes - rather high ap, situated in the middle of the length of the head, 8 to 10 diameters in the length of the head, $3 \frac{1}{2}$ to $4 \frac{1}{2}$ diameters from the end of the snout and 3 to 4 apart. Dorsal profle more convex than that of the abdomen, which is almost horizontal. Snout produced and somewhat overhanging the jaws, the maxilla much longer than the mandible. Lips thick. Barbelstwo thick pairs, the maxillary ones extending to beneath the middle of the eye, while the rostral pair are somewhat shorter. Teeth-Pharyngeal-curved, hooked at their extremity and pointed, 4, 3, 2/2, 3, 4. Fins-dorsal commences about midway between the angle of the mouth and the base of the candal fin, the extent of its base $\frac{1}{4}$ shorter than the third undivided dorsal ray, which is the longest, osseous, strong, and serrated along its posterior margin: last ray of the fin half the height of the longest anteriorly. Pectoral inserted low down, broad, and about $4 / 5$ as long as the head but not reaching the ventrals, which latter do not extend to the anal. Anal narrow, the length of its base being only $2 / 5$ of its height. Caudal deeply forked. Scales-about 35 rows anterior to the base of the dorsal fin, and 7 between the lateral-line and the base of the ventral. Lateral-line-complete, continued to the centre of the base of the caudal fin. Gill-rakers-short. Colours-olivaceous shot with gold, lightest along the sides and lower surface. Dorsal fin with a narrow, dark outer edge. The other fins of a reddish colour.

Steindachner (Verh. z. b. Ges. Wien. 1866, p. 385) considers Barbus Mayori, Cuv. and Val. from the Lake of Zug, to be this species: he also notices the supposed hybrid between Barbus and Chondrostoma.

Names.-Barbel, from "barba," a beard, or the "bearded fish." Barfbyfg y Barfog, Welsh. De Barbeel, Dutch. Le Barbeau, French.

Habits.-The barbel generally prefers the bottom of still rivers and their deeper parts, where they live together in schools, rooting in the soft banks with their snouts like swine or turning over gravel and other movable substances under which they search for suitable food. Some delight in rapids below weirs, others are partial to shallows where there is a good stream, and they will even lurk under weeds. During the season of 1880 these fish were rather numerous in the open tideway at Hammersmith. The barbel is not very timorous and roves about at night-time, while it consumes both animal and vegetable substances. An old writer observed that it "delighteth in filth, speciallie in the dung of beastes, as Oppianus among other matters reporteth" (Angler's Note-book, p. 151). It consumes worms, grubs and small fish. When in an aquarium it is often shy, but this is not invariably the case. It is said to be a long-lived fish. As winter sets in and weeds die off they hybernate or congregate together in large numbers under the lee of a sunken boat, below banks and in deep pools, at which periods they are readily netted or poached by snatching. They are said to have been taken by persons diving after them. Under water they are able to produce a sort of guttural sound without occasioning any bubbles to rise.

It is a matter of history that subsequent to a dreadful carnage between the Turks and Austrians on the banks of the Danube, barbels were found of such vast size and in such numbers as to become a subject for record, while their propensity for human flesh being well known, the circumstance was attributed to the heaps of dead bodies which had been thrown into the river.

Means of capture.-The angler requires strong tackle and a fair amount of patience, but it is evidently an occupation that has many votaries, as may be seen along the Thames in the proper season, especially during September and the earlier part of October, where punt-fishing for barbel is indulged in. The angler cannot be at work too early in the morning or too late in the evening for these fish, which are most particular in their choice of food as such must be sweet or they will reject it, and even then they will try and suck off the bait.

It is best to ground-bait the locality to be fished some hours prior to commencing to fish, and in doing this the article employed should be of similar kind but inferior in quality to that which is going to be employed by the angler. When hooked the barbel is strong and dashes towards any cover, as a post in the 
water, a bank or other suitable place and is not unlikely, unless well handled, to break the line, for its leathery mouth affords a secure hold for the hook.

Baits.-Lobworms, greaves, green gentles, cheese, caddis worms, \&c., it will bite at bees, while this fish is not unfrequently taken in the Thames by anglers spinning for trout.

Breeding.--It spawns in May and June, depositing from 7000 to 8000 ova on the gravel, and which are subsequently covered over with great care by the parent fish. In warm seasons the young hatch from the tenth to the fifteenth day. Bloch believed that the barbel does not breed until towards its fourth or fifth year. Having spawned, the spawners make for the swiftest piece of water they can find, and within a few weeks begin to recover condition again. These fish grow very rapidly.

Uses.-Isinglass is said to be made of its air-bladder in the Volga, a statement possibly, if not probably, erroneons. Yarrell observes that the barbel in the coat of Bar, forms one of the quarterings of the arms of Margaret of Anjou, Queen of Henry VI, the founder of Queen's College, Cambridge.

As food.-Not held in esteem, being very coarse. Ausonius tells us that when it grows old it is not absolutely bad. If so, this is exactly contrary to what occurs in Asia, where the old fish are tough, oily, and strong flavoured. Some poor people are said to employ them as food, having boiled them with a piece of bacon to give them a relish. The roe, when eaten, occasionally, but not invariably (as proved by Bloch), is found to be poisonous. It nsed to be taken by the country people to induce a purge and a vomit. Sir J. Hawkins observes that the flesh of this fish set up most dangerous choleraic symptoms in one of his servants in 1754, so that he nearly died. Gesner asserts that his life was endangered from eating its flesh. Dame Juliana Berners remarked that, "The barbyll is a sweet fysshe, but it is a quasy meete and perryllous for manny body ... and yf he be eten rawe he may be cause of manny dethe: whyche hath oft be seen." Badham advises its being boiled in salt and water and eaten cold, after having had a squeeze of lemon juice over it, and he states it to be by no means despicable fare. Its best season is from when it has recovered after breeding until Septemaber or October, when frosty weather drives it to its winter quarters. The Jews, having boiled them with vinegar and oil, eat them not only during their White Feasts, but whenever they can obtain them. Bloch therefore, who was a Jew, may be excused for considering it a prejudice rejecting them, although he remarks their flesh is white and of good flavour, and the eggs he has eaten, besides giving them to his family, when not a single person among them was incommoded. That barbel in some localities are good eating is well known (see page 169), but it appears as certain that they are deleterious in other places, while some persons may consume them with impunity, whereas they would be poisonous to others.

Habitat. - Large rivers in the temperate and warm latitudes of Europe, attaining to a considerable size, as 40 or $50 \mathrm{lb}$. in the Rhine and in the Danube.

Absent from Scotland and Ireland, although it obtains a place in Brown's Catalogue.

It is somewhat restricted in its distribution in England. In Yorkshire it is found locally in the rivers of the central plain, except the Derwent and the polluted waters of the Aire, Calder, Dearne, and Don (Yorkshire Vertebrata). It is largely taken at Sheffeld. It is abundant in the Trent and in the Thames, but absent from the Severn, although it is asserted that this fish in the time of Queen Elizabeth was one of the forms in the latter river protected by legislation; consequently, if it existed, it must have died out, as I cannot hear of it there now. Pennant gives its Welsh name. I have already observed that it has been taken in the open tidal waters off Hammersmith, and it is numerous in the Thames from Putney upwards.

The example figured is 16 inches long, from the Thames, for which I am indebted to Mr. T. Carrington, F.L.s. As to the size this fish attains in this country Jenyns mentions examples up to 2 or $3 \mathrm{ft}$. long. In 1860 , one which weighed upwards of $10 \mathrm{lb}$. was killed at Richmond. Yarrell observes that the largest fish he conld find recorded weighed $15 \frac{1}{2} \mathrm{lb}$., while a $19 \mathrm{lb}$. fish is aaid to have been taken from the Lea in Essex. 


\section{Genus IV.-Gobro, Cuvier.}

Pseudobranchice present. Body more or less elongated. Mouth inferior, upper jaw slightly the longer; when the mouth is open the lower jaw does not project beyond the upper: lips of moderate thickness. A small maxillary barbel at the angle of the mouth. Pharyngeal teeth in two rows, hooked and pointed at their extrewities, 5 or 4, 2 or 3-3 or 2, 4 or 5. Dorsal fin short, with few rays $(9-10)$, all of which are articulated. Anal with few rays. Scales of moderate or rather large size. $A$ lateral-line present.

The fishes which belong to this genus are naturally feeders on animal substances, but they do not, therefore, invariably refuse vegetable food.

\section{Gobio fluviatilis, Plate CXXXI, fig. 2 .}

Gobius fluviatitis, Rondel. p. 206 ; Gesner, p. 399 ; Aldrov. จ, p. 612 ; Jonston, lib. iii, tit. i, c. x, art. i, p. 139, fig. 16; Willugh. p. 264, t. Q8, f. 4. Cyprinus, sp. Artedi, Genera, p. 4, no. 10, Species, p. 13, no. 5, and Synom. p. 11, no. 20; Gronov. Zooph. no. 329; Ray, p. 123. Enchelyopus, Klein, Miss. iv, p. 60, no. 5, t. $x \vee$, f. 5. Duhamel, Pêches, iii, p. 497, pl. xxiii, f. 7. Gudgeon, Pennant, Brit. Zool. (Ed. 1776) iii, p. 361 (Ed. 1812) iii, p. 476.

Cyprinus gobio, Linn. Syst. Nat. i, p. 526; Gmel. Linn. p. 1412; Bloch, Fische Deuts. p. 57, t. viii, fig. 2; Bonn. Ency. Ich. p. 19l, pl. lxxvii, f. 319; Bl. Schn. p. 448; Lacép. $\vee$, p. 533 ; Donovan, Brit. Fish. iii, pl. lxxi ; Turton, p. 107 ; Bowdich, Brit. F. W. Fish. pl. xv; Jenyns, Manual, p. 405; Jurine, Poiss. Lac. Lém. p. 217, pl. xiv; Gronor. ed. Gray, p. 178; Schlegel, Dieren Neder. p. 100 , pl. $x$, f. 4.

Gobio fluviatilis, Flem. Brit. An. (1828), p. 186; Agassiz, Mém. Soc. Sc. Nat. Neuch. i, p. 36 ; Cuv. and Val. xvi, p. 300, pl. 481; Bonap. Pesc. Eur. p. 27 ; Nilss. Skan. Faun. iv, p. 300 ; Thompson, Nat. Hist. Ireland, iv, p. 135 ; Yarrell, Brit. Fishes (ed. 1) i, p. 325, c. fig. (ed. 2) i, p. 371 (ed. 3) i, p. 383 ; Templeton, Mag. Nat. Hist. 1837 (2) i, p. 410; Kröyer, Dan. Fisk. iii, p. 334, c. fig.; Nordman, in Demid. Voy. Russ. Mérid. iii, p. 472; White, Catal. p. 61 ; Blanchard, Poiss. France, p. 293, f. 57 ; Siebold, Süss. w. f. Mit. Eur. p. 112 ; Günther, Catal. vii, p. 172 ; Houghton, Brit. F. W. Fishes, p. 30, c. fig.; Canestrini, Faun. Ital. Pesc. p. 12 ; Giglioli, Catal. Pesc. Ital. p. 44; Moreau, Poiss. France, iii, p. 386.

Tinca gobio, Swainson, Fish. ii, p. 285.

Gotio venatus, Bonap. Faun. Ital. Pesc.

Gobio obtusirostris, Cur. and Val. xvi, p. 311.

Gobio vulgaris, Heckel and Kner, Süss. w. f. p. 90, f. 42, 43.

Leuciscus gobio, Günther, Fische Neckars, p. 44.

Gobio pollinii, De Betta, Ittiol. Veron. p. 77.

Gobio benacensis, Ninni, Cenni, p. 42.

Gudgeon, Couch, Fish. Brit. Isles, iv, p. 20, pl. clexxii.

B. iii, D. $9-10\left(\frac{2}{7}-\frac{3}{8}\right)$, P. $15-16$, V. $8-9$, A. $8\left(\frac{2}{8}-\frac{8}{7}\right)$, C. 19 , L. $1.36-44$, L. tr. $5 \frac{1}{2}-6 \frac{1}{2} / 6 \frac{1}{2}$.

Length of head $4 \frac{1}{3}$ to 5 , of caudal fin $5 \frac{1}{2}$, height of body $4 \frac{1}{2}$ to $5 \frac{1}{4}$ or even 6 times in the total length. Eye-high up, in or slightly behind the middle of the length of the head, diameter $4 \frac{3}{4}$ to 5 in the length of the head, $1 \frac{3}{4}$ to 2 diameters from the end of the snout, and $1 \frac{1}{2}$ apart: interorbital space flattened. Dorsal profile much more convex than that of the abdomen, which is nearly horizontal. The proportions of this fish are subject to great modifications in accordance with the localities it inhabits, the seasons, \&c. Body compressed, becoming more so in its caudal portion. Snout somewhat obtuse. Upper jaw the longer, the maxilla does not extend so far posteriorly as to beneath the front edge of the orbit. Barbels-one at the maxilla usually reaching to below the middle of the eye, but liable to variations in length. Fins-dorsal commences about the centre of the length of the fish excluding the caudal fin: the length of its base nearly equals half its height: its first ray minute, its third, which is undivided, $4 / 5$ the height 
of the body below it, from thence they rapidly diminish in height, the last being only half that of the third. Pectoral inserted in the lower fourth of the body, as long as the head without the snout, and rounded at its extremity, it does not extend to as far as the ventral, which latter is still slightly shorter and does not reach the anal. Anal commences in the last third of the distance between the angle of the mouth and the base of the caudal fin: its anterior portion nearly twice as high as its last rays: caudal deeply forked, with pointed lobes. Scales - large and the exposed portion angular. Lateral-line-continuous to the middle of the base of the caudal fin: tubes simple. Pharyngeal teeth-rounded, curved and pointed at their extremities, 4, 2/2,4. Colours-olive along the upper portions of the head and back, becoming silvery on the sides and beneath. Upper portion of body with numerous irregular brown spots and dark edgings to the scales, and in the young a row of dark spots cross the lateral-line; but in large specimens a wide silvery band runs along the side of the body mostly above the lateral-line : a dark mark under the eye and a few black spots in the pectoral region. Dorsal fin with several irregular rows of black spots, and similar ones exist on the lobes of the caudal fin most distinct externally. Young examples are darker than adults and more blotched and spotted: a line of spots runs across the anal fin while the ventral is dark tipped : opercle nearly black.

Names.- "Gudgeon" is a corruption of the French term Goujon. As gudgeons are an easy prey to even the most inexperienced angler, the common expression "to gudgeon a man" is said to have its origin from this cause. Gogeon (Dict. 1593), googen (Dict. 1608). Blaege, Anglo-Saxon. Crothell, Welsh. The word gudgeon is often used synonymously with "an untruth," or for a joke or tannt. "To swallow a gudgeon" is often employed for being made a fool of: "to gape for gudgeons" to mean to look out for impossibilities. An old term was river smelt. De Grundel, Dutch. Le Goujon, French.

Habits. - A small, gregarions river fish, selecting places where the current is not too strong and the bottom is sandy or gravelly : or else a pond through which a stream flows, while it keeps near the bottom: generally during the day-time the gudgeon seeks the shade becoming more active towards nightfall. During the warm months found in or near shallows but returning to the deeper water in winter. In some years plentiful, in others just the reverse. It will live in very polluted water, even at the mouths of drains, localities in which the mpre cleanly fish, as trout, would inevitably succumb. In Aquaria it is fond of reposing motionless for hours in one place. While it thrives, observes Newman, on the impurities of London water alone. It eats worms, insects, small fry, ova, and some plants, but is a capricious feeder, subject apparently to some atmospheric influences. Fishmongers are able to keep them alive for some weeks in stone or leadenlined tanks, provided there is a good supply of cold water. Mr. Gosden, of Exeter, recorded haring found one of these fish $7 \frac{1}{2}$ inches in length among some berrings taken at Cloverley, which would seem to show that stragglers may occasionally descend to salt water.

M. Valenciennes subjected some of these fish to the following experiment. He placed them in water below the bell of an air-pump, and gradually reduced the aërial pressure. When this was diminished to half or a quarter the fish suffered little, and few air-bubbles escaped. When the reduction of pressure was rapid and carried far, many bubbles escaped; and when the mercury stood very low, the gas in their inside expanded, the belly became blown, and the fish floated on the surface, its back being downwards. Such examples were found to have the air-bladder quite empty. They continued to live, and when replaced in water at the ordinary atmospheric pressure, they resumed their normal position after about twenty-four hours, but remained quiet at the bottom, with the abdomen quite hollow. Slowly their original form and bulk retarned, and in six hours their air-bladder was again filled, the contents of which, on being tested, were found to be azote.

Means of capture.-Although the gudgeon bites all day from the end of March until Michaelmas, the months considered best for this species of fishing are during August, September, October, and sometimes the commencement of 
November. The locality chosen is usually from four to six feet of water, where the stream is only of medium strength, while the bottom should be sandy and free from weeds. It seldom bites in cold weather, or just subsequent to a flood, or in the dark; but during the sunny hours of the warm months delights to lie in the shade, as mnder a plank or boat, while it is by no means shy. It is assembled in shoals by raking the bed of the river, which, setting free desirable food, canses numbers to flock to the place. A small hook should be employed; with some a very light line is used, while others consider a moderately heavy one better or the extent of the swim is reached too rapidly, whilst floats are dispensed with in some instances. Occasionally it will suddenly cease biting from some anascertainable cause, or it may be the effect of a scare produced by a pike or perch having appeared on the feeding ground. In the cold weather when it retires to deeper water, the line should be leaded so that the hook touches the bottom.

Baits.-A small red worm.

Breeding.-A pril, May, and June, depositing its small bluish ova among stones and in the shallow water of streams, the ova, according to French pisciculturists, requiring about a month to hatch. Yarrell found fry about an inch long in August. In some localities they are supposed to breed three times in the year, or to take a long time spawning. Mr. Manley found that some placed in a pond multiplied there although the bottom was clayey.

Uses.-As baits, for perch fishing or on night-lines for eels.

As food.-Much esteemed, easy of digestion, and never out of season if procurable. That from the Thames is considered by some to be far superior to the same fish from other rivers. The following plan has been recommended: take a frying-pan in the boat when gudgeon fishing. Clean, wipe, and let the fish dry until it is almost hard by hanging it out in a wind or exposing it to the sun; then fry it in boiling fat, butter, or oil till crisp and of a light brown colour. Dr. Brookes (Hist. Fish. 1772, p. 113) asserts that it is tender and delicate, and by many swallowed alive, being thought good for a consumption.

Thompson alludes to an instance of a dog in the river Lagan which was accustomed, when the water was low (about nine inches deep), to search for, catch, and eat gudgeons. Eels are very partial to these fish.

Habitat.-Northern and temperate parts of central Europe, extending from Denmark to France and Italy.

Some skins of this species exist in the British Mnseum obtained from Parnell's collection are now labelled Scotland. As the species is not alluded to in his work they may be from elsewhere (see vol. $i$, page 3ll). In Yorkshire it is common and generally distributed in rivers and ponds (Yorkshire Vertebrata): also in Lancashire: in Norfolk very scarce among the broads (Lubbock) but abundant in the higher parts of the rivers where it finds gravel shoals. The finest gudgeons are found in the Trent, Kennet, Thames and Colne, those from the last three growing to a large size, but fine ones are not unfrequently taken in the Wye, while it is generally found in suitable pieces of water. It has only of late years been known in Devonshire, having been probably introduced: a specimen was captured by Mr. King, June 3rd, 1873 (Parfit) : I have already alluded to one from Cloverley. It is said by Couch to have been introdnced into Cornwall and thriving in some ponds near Penzance, but Mr. Cornish remarks that he does not know of it (Cornish Fauna).

In Ireland, noted in county of Antrim, Dublin, Kilkeany. In the Barrow, the Shannon Canal, Taam and Headfort. Templeton observes that these fish appeared in the River Lagan in 1801 having ascended the canal from Lough Neagh where they have been inhabitants, perhaps, for centuries. Introduced from Dublin into the River Dodden about 1822 by an angler who, living in Dublin, disliked the trouble of going so far for bait: 1852 it had become common, often attaining ten inches in length (Kinahan).

The example figured life-size was captured in the Thames in October, 1822, by Mr. T. Carrington, F.L.S. This fish does not usually attain to above eight inches in length, but Pennant alludes to having heard of one half-a-pound weight having been taken at Uxbridge, a weight which some modern authors have doubled. 


\section{Genus V.-Leuciscus (KLgin), Cuv. and Val.}

Phoxinus, Agassiz: Scardinius, Squalius, and Telestes, Bonap.: Idus, Leucos, Heckel: Pseudophoxinus, Bleeker.*

Pseudobranchice present. Mouth anterior, lips of moderate size. Barbels absent. Pharyngeal teeth compressed or conical, in a single or double row. Dorsal fin with few rays (9-14), all being articulated, it commences nearly or quite opposite the ventrals : anal also with few rays (9-15). Oaudal forked or emarginate. Scales of large, medium, or small size, covering the body. Lateral-line complete or incomplete. Intestinal tract short, having only a few convolutions.

The old-world forms belonging to this extensive genus have been subdivided into several smaller genera by various ichthyologists, in accordance with the character of the pharyngeal teeth, and whether they are in one or two rows: the position of the dorsal fin and the number of the anal rays: the number of scales along the side of the body: and whether the lateral-line is complete or incomplete.

Of the indigenous British species we possess the following:- Pharyngeal teeth in a single row - Leuciscus rutilus, D. 11-13, A. 11-14, L. 1. 42-45. Teeth in a double row: L. cephalus, D. 11, A. 11-12, L. 1. 42-46: L. vulgaris, D. 9-10, A. 10-11, L. 1. 48-52: L. erythrophthalmus, D. 11-12, A. 13-15, L. 1. 40-44: L. phoxinus, D. 9-10, A. 9-11, scales small and lateral-line incomplete.

Geographical distribution.-These fishes are widely distributed throughout Europe and the northern portions of Asia and North America. As a rule they are exclusively found in fresh water.

\section{Leuciscus rutilus, Plate CXXXII, fig. 2.}

Lascha, Belon. p. 316. Leuciscus, Rondel. p. 191. Rutilus, Gesner, de Aquat. p. 821 ; Willugh. p. 262, t. Q10, f. 5; Jonston, lib. iii, t. i, c. xiv, p. 145, t. xxvi, f. 9 ; Ray, p. 122. Cyprinus, sp. Artedi, Gen. p. 3, no. 1, Species, p. 10, no. 3, Synom. p. 10, no. 18; Gronov. Zooph. no. 339. Roach, Pennant, Brit. Zool. (Ed. 1776) iii, p. 365 (Ed. 1812) iii, p. 482. Gardon, Durham. Pêches, ii, p. 498, t. xxiv, f. 1.

Cyprinus rutilus, Linn. Sys. Nat. i, p. 529; Gmel. Linn. p. 1426; Bloch, Fische Deuts. i, p. 32, t. ii ; Bl. Schn. p. 435 ; Bonn. Ency. Ich. p. 198, pl. lxxx, f. 334; Lacép. $\nabla$, p. 575 ; Donovan, Brit. Fish. iii, pl. lxvii; Turton, p. 108; Jenyns, Man. p, 408; Ekström, Mörkö, p. 12; Gronov. ed. Gray, p. 183 ; Schlegel, Dieren Neder. p. 113, pl. xi, f. 4 .

Leuciscus rutilus, Flem. Brit. An. p. 188 ; Yarrell, Brit. Fish. (ed. 1) i, p. 348, c. fig. (ed. 2) i, p. 399 (ed. 3) i, p. 433 ; Nord. in Demid. Voy. Russ. Mérid. iif, p. 489 ; Parnell, Wern. Mem. vii, p. 266 ; Cuv. and Val. xvii, p. 130; Kröyer, Danm. Fisk. iii, p. 435, c. fig.; Fries and Eks. Skand. Fisk. p. 72, t. xv : White, Catal. p. 65 ; Nilss. Skand. Fauna, iv, p. 316; Heckel and Kner, Suss. w. f. p. 169 , f. 91 ; Siebold, Suss. w. f. p. 184; Blanchard, Poiss. France, p. 382 ; Günther, Catal. vii, p. 212; Collett, Norges Fisk. p. 180; Malm, Fanna, p. 557; Feddersen, p. 89; Houghton, Brit. F. W. Fish. p. 33, c. fig.; Moreau, Poiss. France, iii, p. 413.

Tinca rutilus, Swainson, Fish. ii, p. 285.

Gardonus rutilus, Bonap. Cyp. Eur. p. 7.

Leuciscus prasinus and decipiens, Agassiz, Mém. Soc. Sc. Nat. Neuch. i.

Leuciscus selysii, jeses, and rutiloides, Sélys-Longch. Faun. Belg. p. 210, c. fig.

Leuciscus pausingeri, Heckel and Kner, l. c.

Leuciscus palleus, Blanchard, 1. c. p. 386.

Roach, Couch, Fish. Brit. Isles, iv, p. 47, pl. cxci.

* The names proposed for subgenera of this genus belonging to the new world are omitted. 


\section{Hybrids with Leuciscus erythrophthalmus.}

Leuciscus affinis, Cuv. and Val. xvii, p. 250.

Scardiniopsis anceps, Jäckel, Abhand. z.-m. Ver. Regensb. 1864, p. 64, and 1865, p. 44.

\section{Hylrids with Abramis blicca.}

Abramis abramo-rutilus, Holandre, Fauna Depart. Moselle, p. 246.

Abramis buggenhagin, Sélys-Longch. Fanna Belge, p. 216.

Bliccopsis abramo-rutilus (pt.), Siebold, l. c. p, 142; Jäckel, 1. c. 1864, p. 53, and 1865, p. 40 .

B. iii, D. $11-13\left(\frac{2-3}{\theta}-\frac{3}{10}\right)$, P. $16-18$, V. $9-10$, A. $12-13\left(\frac{2-3}{6}-\frac{3}{1}\right)$, C. 19 , L. 1. $42-45$, L. tr. $7 \frac{1}{2}-8 \frac{1}{2} / 6 \frac{1}{2}$.

Length of head 5 to $5 \frac{3}{4}$, of caudal fin $5 \frac{1}{4}$ to $5 \frac{1}{2}$, height of body $3 \frac{2}{3}$ to $4 \frac{1}{2}$ in the total length. Eyes-situated very slightly above the centre of the height of the head, the diameter of each $3 \frac{1}{2}$ to 4 times in the length of the head,

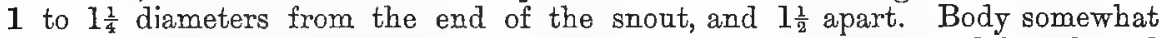
elevated and compressed. Mouth anterior, the jaws of nearly equal length, and the cleft of the mouth a little oblique; the maxilla reaches to beneath the posterior nostril. T'eeth-pharyngeal teeth in a single row 5 or $6-6$ or 5 (only 4 are said to be present in some examples), in some the left side has one more than the right. They are somewhat hooked and pointed at their extremities, but become ground down with age. Fins-dorsal, commences midway between the end of the snout and the base of the caudal fin, its height anteriorly being onefifth more than the length of its base. Pectoral as long as the head, excluding the snout. Ventrals inserted on a vertical line beneath the first ray of the dorsal fin; they are slightly longer than the pectorals, but do not reach to the anal, the length of the anterior rays of which latter fin are a little longer than the extent of its base. Caudal deeply lobed, the length of the central rays being about two-fifths of that of the longest outer one. Scales-4, rows between the lateral line and the base of the ventral fin; about 17 rows anterior to the base of the dorsal fin. The abdominal edge, between the base of the ventral and the insertion of the anal, somewhat compressed, but not sharp. Lateral-line-slightly concave anteriorly above the base of the ventral fin, and situated between the middle and lower third of the depth of the body. Pseudobranchiæ moderately developed. Colours - superiorly bluish or greenish, becoming lighter on the sides and beneath. Lower fins reddish-yellow, in some localities red; dorsal and caudal dusky, with blackish outer margins.

Varieties.-Several have received distinct names owing to the proportions of the body differing, some being more elongated than others, this variation being often due to size or else to the colours being pale or otherwise unlike the typical form.

Names.- "Sound as a Roach," is a proverb that appears to be but indifferently founded, that fish being not more distinguished for its vivacity than many others; yet it is used by the French as well as us, who compare people of strong health to their Gardon, our Roach (Pennant). Some have asserted that the proverb was as "sound as a Rock," and the old Roche Abbey shows that the ancient mode of spelling "rock" was "roche," while Ray gives it as "sound as a trout." Sometimes termed red-dace from the colour of its fins. Mr. A. Walker informs me that at Chester this fish is termed Roach-dace. Rhyfell, Welsh. Braise, Scotland. Scylga, reohha, reohche, heoce, Anglo-Saxon. De Blanti-Voorn, Dutch. Le Gardon commun, French.

In heraldry tbree roach are borne in the arms of the De la Roche family.

Habits.-A gregarious fresh-water fish, preferring clear and deep but still rivers and quiet waters, and although, observes Parncll, the sea is not the natural abode of the roach, yet sometimes it is found there, being carried down from rivers and lakes after high floods. He saw five examples, taken from the salmon nets in the Solway Firth, in the month of June, and stated that they are frequently taken there after a flood. But that this migration must be very gradually effected the following observation from Montagu would seem to show. A small river in 
Devonshire ended in a large piece of water or lake, nearly two miles in extent, close to the sea, but having no outlet except by percolation through a barrier of shingle; here roach throve and multiplied exceedingly. One year the sea broke its boundaries and flowed copiously into the lake at every tide for a considerable time by which every species of fish therein was destroyed. As the cold weather sets in, as about October, the roach seeks the deeper waters where a gravelly or sandy bottom is preferred to a muddy one.

Means of capture.-This fish is capricious respecting biting, although Dame Juliana Berners observed, "the roche is an easy fysshe to take," and later still Isaak Walton tells us that it was accounted the water sheep for its simplicity and foolishness. Bat now, in some localities at least, it has been educated to be more careful of the tempting bait. The angler must employ, in the Thames or Lea for instance, fine tackle, be careful as to his depth, the bait in a river being about 3 inches from the bottom, but less in a pond, while he must be an adept in striking sharply but not violently, on a bite occurring, use a small hook, have a quick eye and nimble hand. In ponds it is often more ready to take a bait than it is in rivers, the following account is taken from a newspaper:-An angler baited a spot at about 5 P.M. on Saturday in August, in Herefordshire, with gentles and wasp grubs, and again on Sunday at 3 P.M. On Monday morning, at 4 A.M., he was in his punt at the spot and baited with wasp grubs, and fished about one inch from the bottom. The fish bit ravenously: at 12 the sun came out brightly and they ceased biting: he had then 241 fish (Field, Sept. 2nd, 1882). As the frost kills aquatic weeds then the anglers opportunity is at hand, for as the roach loses this form of food it becomes less shy in taking a bait.

Baits.-The tail of a lob worm, a bit of bacon fat, gentles, pastes of various kinds, and prepared greaves, boiled wheat and brewers' grains, while ground baits are generally employed. Although it rarely takes a live bait, one weighing $1 \frac{1}{2} \mathrm{lb}$. was thus captured by a paternoster baited with a live minnow at Pangburn, November 27th, 1882 (Field), and the editor of the Field observes that he has taken the roach once or twice in the same way. It will also occasionally take a fly.

Roach preserved in spirit are said to do well as bait for winter trolling.

Breeding.-A very prolific fish, the eggs of which are greenish but become red on being boiled. About the middle of May or in June it commences ascending to the higher portions of rivers or side streams to breed: its scales become rough and it is usually out of season. Buckland found $480 \mathrm{eggs}$ in one of $28 \mathrm{oz}$. weight. In some years this is accomplished earlier. Thus, in the Thames, in 1881, the ascent for this purpose was observed at the end of April (Field, April 30th). At a meeting of anglers held in Birmingham, April 4th, 1881, it was generally agreed that in the Trent this heading up had not been seen before the middle of May. In Norfolk it generally resorts to a river for the purpose of breeding, or selects a situation intermediate between one and a broad but to which it is united by a main dyke. At that time, remarks Lubbock, the roach crowd together in such dense multitudes along the rushes which fringe the bank that every instant one sees small ones raised momentarily half out of the water by the passage of a larger roach. These fish appear to lose all fear in the overwhelming instinct which prompts them to propagate their kind, and may be scooped out in numbers with a landing-net: if a bow-net is put in they will crowd in until the centre can contain no more. Nilsson remarks that the males precede the females in these annual migrations.

But the eggs themselves are subjected to great destruction. Thus, it has been observed near Uxbridge that at spawning time the roach actually cover the weeds near the weir, while water shrimps and other insects come down upon them and in a very short time clear them almost entirely away (Buckland). Having spawned, the roach seeks swift parts of rivers and gravelly shallows to recover itself, which does not take very long (about a fortnight), and it soon retires to quieter quarters.

Hybrids.-Various fishes apon the Continent of Europe have been believed to 
originate hybrids with the roach. The first I shall allude to is said to be the bream, Abramis brama, forming Cyprinus buggenhagii, Bloch, and which has been taken not only in England but likewise in Ireland. There is, however, one little but insuperable difficulty in this identification of Dr. Günther's (Catal. vi, p. 214), which is, that as the roar h* does not occur in Ireland it is difficult to see how it could form a hybrid there with the bream, rendering it much more probable that if the form is a cross it is between the rudd and the bream, to which I have therefore referred it.

Another cross is believel to occur between the roach and the rudd, the Lenciscus affinis C. V., or Scardiniopsis anceps, Jäckel, and which has been found in France and Bavaria. D. 13, A. 14-15, L. 1. 40-42. Origin of the dorsal fin rather more posterior than in $L$. rutilus, the pharyngeal teeth deeply serrated, $5-5$ or.else 5 or 6,1 or $2-1$ or 2,5 .

A hybrid is likewise considered to take place between the roach and Abramis

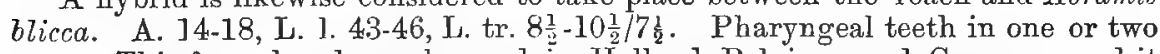
rows. This form has been observed in Holland, Belgiam, and Germany, and it is difficult in some examples to decide whether the Abramis brama or A. blicca can be considered the form which has crossed with the roach.

As food.-Coarse, flabby and insipid, consequently is but rarely eaten. It is in the best condition about October, and when taken from clear water flowing over a gravelly bottom: some have recommended it baked in layers in a pie dish, with intermediate bay leaves and a little spice.

Habitat.- In most rivers in temperate portions of Enrope. Geverally through Great Britain, but absent from Ireland, where the Rudd, L. erythrophthalmus, takes its place and has been recorded as this species.

Early in May immense shoals are observed to leave Loch Lomond and ascend tributaries to breed. This lasts about three days, and anglers remark that during this brief period not a trout can be taken, either with the minnow, worm or fiy as they gorge themselves with the roe of the roach (Ure). Also found in the Union Canal, near Edinburgh (Wilson).

A fresh-water resident in Yorkshire, abundant and generally distributed, except in the North-Western Fell district and the polluted rivers, from which it is absent. Has been introduced into canals, reservoirs, and ponds (Yorkshire Vertebrata). It is common in streams and broads in Norfolk (Lowe), and generally distributed throughout Great Britain. In Devonshire it is found in the Exeter canal, some ponds by the South Devon Railway, and Slapton-Ley Lake, while it is very abundant in the River Axe (Parfitt): it is absent from Cornwall (Cornish Fauna).

Although it is rare to capture one of these fish over $2 \mathrm{lb}$. weight, one of $2 \mathrm{lb}$. $12 \frac{1}{5}$ ounces was taken by Mr. Stead in Bedfordshire in 1881 (Field, Nov. 2nd, 1881). The largest observed by Jesse in the Thames was $3 \mathrm{lb}$. weight, while Pennant remarks that a London fishmonger informed him of one which weighed $5 \mathrm{lb}$.

\section{Leuciscus cephalus, $\uparrow$ Plate CXXXII, fig. 1.}

Squalus, Belon. p. 315 ; Salv. p. 83. Capito fluriatilis, Rondel. Pisc. Flur. p. 190; Gesner, p. 1266 ; Aldrov. p. 603 . Mugil vel Cephali fluviatilis, Willugh. p. 261 ; Ray, p. 119. Chub, Willugh. p. 255, t. Q10, f. 1; Pennant, Brit. Zool.

* The rudd is termed the roach or red roach in Ireland, the true roach, according to Thompson not being found there.

$\dagger$ An example, possibly of this fish, was captured by Dr. Walker at the mouth of the Firth. Dr. Stewart considered it to be the jde Leucisus idus, Linn., and on this account the ide has been introduced by Yarrell and Couch into the British Fanna. Yarrell (ed. i), p. 344, c. fig. from Meidinger (ed. 2), i, p. 395, c. fig. from Ekström (ed. 3), i, p. 418; Couch, iv, p. 63, pl. cxcriii. Buckland, Familiar History of British Fish (ed. 2), p. 360 , remarks that 200 of the beautiful golden variety were deposited in one of the Duke of Bedford's ponds at Woburn Abbey, ill 1874. They bred there last year, 1882, for the first time since their introduction, and although they may at some future date be properly included in a British Fish-fauna, they can acarcely be so at present, as they are not yet found in a wild state as are some other acclimatized foreign forms. 
(Ed. 1776) iii, p. 368, pl. lxxiii (Ed. 1812) iii, pl. 485, pl. lxxxiv. Cyprinus, sp. Artedi, Gen. p. 12, no. 12, Synon. p. 7, no. 10 ; Gronov. Zooph. p. 105, no. 334. Cyprinus cephalus, Linn. Syst. Nat. i, p. 527; Gmel. Linn. p. 1417; Shaw, Zool. v, t. 226 ; Jenyns, Man. p. 411 ; Fries and Ekstr. Skand. Fisk. p. 67 ; Gronov. ed. Gray, p. 184.

Cyprinus idus, Bloch, Fische Dents. i, p. 253, t. xxxvi ; Bl. Schn. p. 439.

Cyprinus chub, Bonn. Ency. Ich. p. 195, pl. lxxvii, f. 323 ; Lacép. v, p. 606;

Risso, Ich. Nice, p. 363.

Cyprinus jeses, Donovan, Brit. Fish. $\nabla$, pl. cxv; Turton, p. 109 ; Fries and Ekstr.

1. c. pl. xiii; Jurine, Poiss. LacLéman, in Mém. Génèv. iii, p. 207, pl. xi ;

Schlegel, Dieren Neder. p. 115, pl. xi, f. 3.

Cyprinus dobula, Nilss. Prod. p. 26 ; Gronov. ed. Gray, p. 185.

Gardonus cephalus, Bonap. Cypr. Eur. p. 8.

Lerciscus cephalus, Flem. Brit. An. p. 187; Yarrell, Brit. Fish. (ed. 1) i, p. 358,

c. fig. (ed. 2) i, p. 409 (ed. 3) i, p. 421 ; Kröyer, Danm. Fisk. iii, p. 482, c. fig.; White, Catal. p. 65; Günther, Catal. vii, p. 220 ; Collett, Norges Fisk. p. 181 ; Malm, Fauna, p. 561; Giglioli, Catal. Pesc. Ital. p. 44.

Leuciscus dobula, Agassiz, Mém. Neuch. i, p. 38 ; Cuv. and Val. xvii, p. 172.

Leuciscus frigidus and squalius, Cuv. and Val. xvii, pp. 191, 194.

Leuciscus latifrons, Nilss. Skand. Fanna, iv, p. 309.

Squalius dobula, meunier, cephalus, thyberinus, cavedanus and albus, Heckel and

Kner, and Heckel.

Leuciscus cavedanus, tiberinus, pareti, squalus, albus, Bonap. Fauna Ital. Pesc.

Tinca cephalus, Swainson, ii, p. 285.

Squalius meridionalis and clathratus, Blanchard, Poiss. France, pp. 396, 398.

Squalius cephalus, Moreau, Poiss. France, iii, p. 422.

Chub, Couch, Fish. Brit. Isles, iv, p. 44, pl. cxc.

Hybrids with Alburnus lucidus (see p. 180).

Leuciscus dolabratus, Holandre, Fauna Depart. Moselle, 1836, p. 248 ; Cuv. and

Val. xvii, p. 248.

Abramis dobuloides, Günther, Würt. Jahr. 1857, p. 50, t. ii.

Alburnus tauricus, Kessler, Bull. Soc. Nat. Mose. 1859 , p. 534.

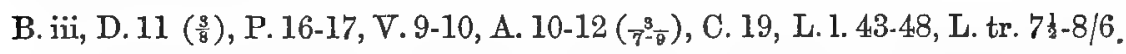

Length of head $4 \frac{1}{2}$ to 5 , of caudal fin $5 \frac{1}{4}$, height of body 4 in the total length. Eyes-diameter of each $5 \frac{1}{2}$ to 6 times in the length of the head, 2 diameters from the end of the snout, and 3 to 4 apart. Snout obtuse. Mouth rather deep, the upper jaw slightly overlapping the lower, and the posterior extremity of the maxilla reaching to beneath the front edge of the eye. The hindermost bone of the suborbital ring the largest. Teeth-pharyngeal teeth pointed and hooked at their extremities (in some slightly denticulated), 5, 2-2, 5. Fins-the dorsal commences midway between the end of the swout and the base of the candal fin, its height exceeds by one-third the extent of its base. Pectoral as long as the head excluding the snout. Ventral inserted on a line slightly anterior to the origin of the dorsal fin, its length equalling about half of that of the head. Lateral-ineslightly concave, 3 rows of scales between it and the base of the ventral fin. Colours-muddy bluish or greenish colour along the upper surface of the head and body, becoming lighter on the sides and beneath. Dorsal and caudal fins dusky or greenish and externally dark; ventrals and anal bluish white tinged with red. Cheeks dashed with red and gold.

Names.-In several languages the size and width of its head appear to have furnished materials for its name, chub being derived from the Anglo-Saxon term copp, "a head." Large-headed dace; loggerhead. S7celly in the north having reference, it is said, to the large size of its scales, while it is also suggested it may be a modification of skully, referring to its head. Chevin and chevenden, possibly from the French "chef," a head. Penci and Cochgangen, Welsh. Le Ohevaine commun ou Meunier, French.

Habits. - Frequents deep holes in the more rapid rivers, preferring a sandy, gravelly, or marly bottom. During the summer month;, after recovering from 
spawning, as in July and August, it appears to delight in lying on the surface beneath the shade of a tree or bank, while it is very sensible to atmospheric changes. It is exceedingly timid, sinking to the bottom on the least alarm, even on observing a passing shadow, but soon returns and re-occupies its former situation. In October, as the weeds die off, it retires to deeper water, as under willow beds, or wherever it can obtain good shelter. It feeds on vegetables, worms, caterpillars, grasshoppers, beetles, and insects which happen to fall into the water. It will occasionally eat small fish and rise to a fly.

Means of capture.-Rod and line, chub fishing being greatly in vogne with some anglers. Extreme caution is necessary, as it possesses very quick vision, and even the shadow of the rod will scare this fish, but it generally returns again to its former position, and the fisherman is able to throw his large fly, dab his cockchafer or grasshopper, or sink his caterpillar, when it will rarely be refused. During the summer months the mornings and evenings are best suited for this description of fishing, but in the winter it will take a bait during the middle of the day. Once hooked, due to its leathern mouth, this fish is usually secured.

Baits.-Gentles; a cockchafer impaled on an arrangement of double hooks; a worm; a grasshopper; a moth; a large artificial fly and even the loach; a young frog; skin of beef; cheese; a black snail. Red cherries, used in clear streams, is one of the best baits, especially for large fish; also blackberries; it will take many berries, particularly strawberries.

Breeding.-It commences about the end of April or beginning of May, selecting a shallow locality under weeds, and where the bottom is gravelly. After spawning it passes to the swiftest streams, when it soon recovers its strength and becomes fit for the angler.

Hybrids have been recorded between this species and the bleak. D. 11, A. 13-16, L. 1. 45-54. Height of borly $4 \frac{2}{3}$ of that of the total length; 3 rows of scales between the lateral-line and base of the rentral fin.

As food.-Coarse and bony, with little, if any, taste, while it rapidly decomposcs. Is said to be best broiled with the seales on. Dame Juliana Berners observes, "the cheryn is a stately fysshe; and his heed is a deyty morsell."

Discases.-Among the Lerneæ, Tracheliastes polycolpus has been found on the fins of one of these fish.

Habitat.-Throughout most of Europe and extending into Asia Minor. It is found in the Annan and other rivers of the south of Scotland: but absent from the north, as well as fiom some parts of the west of England. It is found in Cumberland, in the Caldew and its affuents. In Yorkshire it is abundant, and generally distributed in the fresh waters; it is absent from the rivers of the north-east, and from the polluted portions of those in the manufacturing districts (Yorkshire Vertebrata). In Norfolk it is totally unknown in the Bure, Yare, and the Wareney, except, perhaps, in their higher portions. Is present in the Ouse, Thet, and the Wissey near Stoke Ferry (Lubbock), the Cam, the 'Thames, the Severn, and most Welsh rivers, and generally distributed through kingland. It becomes rare in Devonshire, and does not find a place in the Cornish Fauna.

It appears to be absent from Treland.

The example figured is 14.8 inches long, from the Severn at Shrewsbury. One of $3 \mathrm{lb} .10 \mathrm{oz}$. is recorded (Ficld, August 13th, 1881), which was choked in its encleavour to swallow a rat of about half a pound weight. Pennell observed upon oue of $5 \mathrm{lb} .5 \frac{1}{4} \mathrm{oz}$. weight, which measured 21 inches in length. It has been said to grow to $7 \mathrm{lb}$. weight in this country, and considerably larger in the waters of the continent of Europe.

\section{Leuciscus vulgaris, Plate CXXXIII, fig. 1.}

Vandoise, Belon. p. 314. Leucisci 2nd species, Rondel. Pisc. Fluv. p. 192 ; Ciesner, p. 26. Dace or Dare, Willugh. p. 266, t. Q10, f. 3; Ray, Synop. Pisc. p. I21; Penmant, Brit. Zool. (Ed. 1776) iii, p. 366, (Ed. 1812) iii, p. 483. Ltucisez, Jonston, lib. iii, t. i, c. 7, p. 13f, pl. xxvi, t. 10, 11, 12. Cyprinus, 
Artedi, Gen. p. 5, no. 13. Grairing, Pennant, 1. c. (Ed. 1776) iii, p. 367 (Ed. 1812) iii, p. 484; Bowdich, Brit. Freshwater Fishes, pl. xi.

Cyprinus grislagine, Linn. Syst. Nat. i, p. 592; Gmel. Linn. p. 1425; Bonn. Enc. Ich. p. 197, pl. lxxx, f. 332 ; Fries. and Ekst. Skan. Fauna Fisk. p. 69, pl. xiv.

Cyprinus leuciscus, Linn. 1. c. p. 528; Gmel. Linn. p. 1424; Bloch, Fische Dents. iii, p. 141, t. xcrii, f. 1; Bl. Schn. p. 440 ; Bonn. Ency. Ich. p. 196, pl. Ixxix, f. 331 ; Lacép. v, p. 572 ; Pallas, Zoo. Ross.-As. iii, p. 318 ; Donovan, Brit. Fish. iv, pl. Ixxvii ; Turton, p. 109 ; Risso, Ich. Nice, p. 362 ; Jenyns, Man. p. 410; Gronov. ed. Gray, p. 184 ; Schlegel, Dieren Neder. p. 116, pl. xii, f. 1.

Cyprinus dobula, Linn. l. c. p. 528; Gmel. Linn. p. 1424; Bloch, l. c. i, p. 42, t. $\nabla$; Bl. Schn. p. 435 ; Lacép. $\nabla$, p. 573 ; Jenyns, 1. c. p. 409 ; Yarrell, T'rans. Linn. Soc. xvii, p. 9 ; White, Catal. p. 64; Gronov. ed. Gray, p. 185.

Cyprinus Lancastriensis, Shaw, Zool. v, p. 234; Jenyns, Man. p. 411.

Oyprinus graining, Walb. Artedi, iii, p. 36.

Leuciscus vulgaris, Fleming, Brit. An. p. 187; Yarrell, Brit. Fish. (ed. 1) i, p. 353, c. fig. (ed. 2) i, p. 404, (ed. 3) i, p. 428; Cuv. and Val. xvii, p. 20:2; Günther, Catal. vii, p. 227 ; Houghton, Brit. F. W. Fishes, p. 41, c. fig.

Leuciscus argenteus, rostratus, rodeus, and majalis, Agassiz, Mém. Soc. Sc. Nat. Neuch. i, 1835.

Leuciscus jaculus, Jurine, LacLeman, Mém. Soc. Sc. Nat. Gen. iii, pl, xiv.

Tinca dobula and leuciscus, Swainson, Fish. ii, p. 285.

Leuciscus Lancastriensis, Yarrell, Trans. Linn. Soc. xvii, p. 7, p]. ii, f. 1, Brit.

Fish. (ed. 1) i, p. 355, c. fig. (ed. 2) i, p. 406 (ed. 3) i, p. 4:30; Cuv. and Val. xvii, p. 216; Swainson, ii, p. 285; Thompson, Ireland, iv, p. 140; White, Catal. p. 66.

Leuciscus grislagine, Nilss. Skand. Fann. Fisk. p. 303; Kröyer, Dan. Fiske, iii, p. 472, c fig.; Collett, Norges Fisk. p. 181 ; Malm, Fauna, p. 562.

Lenciscus dobula, Yarrell, Brit. Fish. (ed. 2) i, p. 397, c. fig. (ed. 3) i, p. 425; Kröyer, l. c. p. 463.

Leuciscus burdigalensis, Cur. and Val. xvii, p. 218.

Leuciscus leuciscus, White, Catal. p. 66.

Squalius leuciscus, lepusculus, rodeus, rostratus, chalybaus, Heckel, Sitz. ak.

Wiss. Wien. 1852 ; Feddersen, p. 88 ; Moreau, Poiss. France, iii, p. 425.

Squalius bearnensis and burdigalensis, Blanchard, Poissons France, pp. 400, 405.

Dobule, dace, and graining, Couch, Fish. Brit. Isles, iv, pp. 51, 54, 59, pls. cxciii, cxciv, cxcri; Houghton, Brit. Freshwater Fishes, p. 41, c. fig.

B. iii, D. 9-10 (2-3) , P. 15-16, V. 9-10, A. 10-11 ( $\left.\begin{array}{c}2-3 \\ 8-9\end{array}\right)$, C. 19-20, L. 1. 48-52, L. tr. $8 \frac{1}{2} / 6 \frac{1}{2}$, Vert. $\frac{23}{19-\frac{2}{2}} \frac{4}{0}$.

Length of head $5 \frac{1}{4}$, of caudal fin $5 \frac{1}{2}$, height of body $4 \frac{3}{4}$ in the total length. Eye-situated slightly above the centre of the depth of the head, diameter $\frac{1}{4}$ of the length of the head, $1 \frac{1}{2}$ diameters from the end of the snout and also apart. Suborbital ring of bones narrow. Body oblong and somewhat elongated, sides compressed. Cleft of month rather shallow, the posterior extremity of the maxilla reaching to almost beneath the front edge of the eye, lower jaw shorter than the upper. Teeth-pharyngeal-somewhat hooked at their extremities, 5, 2-2, 5. Fins-dorsal commeuces about midway between the front edge of the eye and the base of the caudal fin, the length of its base equals about two-thirds the height of the longest undivided ray, which equals three-fourths of that of the body below it; its last rays half the height of its front ones; upper edge of fin concave. Pectoral inserted in the lower fourth of the depth of the body, as long as the head excluding the snout, and pointed, it does not extend much more than halfway to the base of the ventral, which latter is inserted on a vertical line beneath the first few rays of the dorsal and does not reach the anal. Front edge of anal in the commencement of the last third of the distance between the front margin of the eye and the base of the candal fin, the length of its base equals three-fourths of the height of its front rays. Caudal rather deeply forked. Scales - four rows between the lateral-line and tho base of the ventral tiu, where 
an angular one exists. Lateral-line slightly concave, continued to the centre of the base of the caudal fin. Colours-bluish along the back, silvery-white upon the sides and beneath. Dorsal, pectoral, and caudal fins tipped with black: the ventral and anal have merely a slight tinge of red or yellowish.

Varieties.-Shaw described the graining, $O$. Lancastriensis, as differing from the dace, and subsequently Yarrell and Thompson have identified examples which they have captured as pertaining to Shaw's species. Yarrell in his figure places the insertion of the ventral fin on a line anterior to that of the dorsal, the latter being identical with what obtains in the dace, which the figure otherwise resembles, and with which Yarrell's examples now in the British Museum agree. Thompson's were several very small individuals taken near Leamington, where the dace abounds.

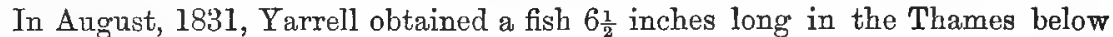
Woolwich, which he considered to be the Squalius dobula, and although the single specimen appears to have been lost, the figure is that of a dace with the ventral fin advanced as shown in the figure (but not in the example) of the graining. Other varieties have been observed on the continent of Europe.

Names.-The term dace appears to be a corruption of some older word. Dart or dare due to its rapid dart-like or arrow-like motion. In Gesner's time it was termed dard and if we turn to Ray (1713) we find he terms this fish dace or dare. Mr. A. Walker informs me with reference to the names of fishes in Cheshire that " the dace here is invariably called by the common people 'the grayling,' the roach being called the roach-dace," and suggests whether the name graining has arisen from this. Darsen and Golenbysg, Welsh. De Serpeling, Dutch. Le Chevaine Vaudoise or dard, Frenclr.

Habits.-An elegant river fish, quick of vision, readily alarmed, and rapid in its movements; it is of a gregarious disposition and delights in clean water. It is not so common as the roach, which it much resembles in its habits. The dace is even found descending to the brackish tidal waters of the Thames at Hammer. smith Bridge, and Yarrell appears to have secured a specimen opposite Woolwich. In the winter it retires to deeper water than it frequents in summer and often selects localities under shaded banks. It feeds upon worms, insects, and their larva, as well as regetable substances.

MIeans of capture.-It rises freely to the artificial fly, especially about August, and when hooked makes a gallant fight: the angler should strike at once on the occasion of a rise or bite. Numbers are taken bottom fishing, a worm, particularly a bright red one, being used as a bait, this is extensively carried on in the Thames during September or October up to January.

Baits.-Flies, gentles, red worms, grasshoppers, paste, malt. As these fish are comparatively small feeders, a large quantity of ground bait is undesirable.

Breeding.-Commences the end of May or during the month of June, while it is a very prolific fish. It deposits its eggs at the roots of aquatic plants, under stones, and in the gravelly beds of rivers. It does not again regain condition before the middle or end of July.

In Devonshire "large numbers of this fish are killed by the poisonous alkaline 'waste' let off from the Countess Weir paper mills. Hundreds of them strewed the banks of the river near and below the bridge on May 31st, 1866; and from information I received on the spot, it appears to be a very rare thing that any other kind of fish is killed by this 'waste.' 'The 'waste,' it would seem, is lighter than the water, and floats and does not mix freely with it. My informant told me that the other fish took advantage of this and sank to the bottom, or swam under the 'waste,' for it was an exceedingly rare thing to find either roach, trout, or salmon killed by it. I examined a great number of the dead fish, and found them to be all dace; I could not find a roach or perch among them " (Partitt, Fauna of Devon, p. 21).

Uses.-Being a very bright, silvery fish, it is a good bait trolling for pike or perch, especially if the water is at all thick; while for night lines it is in demand as being tenacious of life.

As food.- Not held in any repute; irrespective of being soft in flesh, it is full of 
bones; it is best during September and October. The Jews are said to consume numbers, as well as of other species of white-fish, Leuciscus, during their fast months. Habitat.-Most of Europe, except Italy.

Not found in Scotland, but is in England and Wales; is present in the Thames, Severn, Wye, and most of our clear and rapid streams. It is common in Yorkshire, except in polluted rivers and mill streams (Yorkshire Vertebrata). In Norfolk it "is abundant in the higher parts of the rivers, but does not affect the broads or the nearly stagnant parts of the rivers in the vicinity. Is plentiful in a small stream which divides the parishes of Rockland and Claxton, near Buckenham ferry; but does not appear to quit the brook for the wider waters of the Yare" (Lubbock). It is abundant in rivers along our southern districts as in Devonshire (Parfitt), and common in the Tamar and its tributaries (Cornish Fauna).

Absent from Ireland.

This fish attains to about 12 inches in length in the Thames, but is seldom found above $1 \mathrm{lb}$. weight. Very fine ones are taken in the New River.

\section{Leuciscus erythrophthalmus, Plate CXXXIII, fig. 2.}

Erythrophthalmus, Willnghby, p. 249, t. Q3, fig. 1; Ray, pp. 116 and 119. Cyprinus, sp. Artedi, Genera, p. 3, no. 2, Species, p. 9, no. 2, Synopsis, p. 4, no. 3; Gronov. Zooph. i, p. 107, no. 340. Rud, Pennant, Brit. Zool. (Ed. 1776), iii, p. 363, pl. lxxii, f. 170, and frontispiece, no. 172 (Ed. 1812) iii, p. 479, pl. Ixxxiii. Rotengle, Jurine, LacLéman, p. 200, pl. xii.

Cyprinus erythrophthalmus, Linn. Syst. Nat. i, p. 530; Gmel. Linn. p. 1429; Bl. Fische Deuts. i, p. 28, t. 1; Bl. Schn. p. 434; Bonn. Ency. Ich. p. 199, pl. Ixxxi, f. 337 ; Lacép. v, p. 577 ; Donovan, Brit. Fish, ii, pl. xl ; Turton, p. 108; Jenyns, Man. p.412; Ekstr. Fische Mörkö, p. 21 ; Fries and Eks. Skan. Fisk. p. 74, t. xvii; Gronov. ed. Gray, p. 183; Schlegel, Dieren Neder. p. 112, pl. xi, f. 5.

Cyprinus erythrops, Pall. Zoo. Ross.-As, iii, p. 317.

Cyprinus compressus, Holberg, Götheb. N. Handl. $\nabla$, p. 66, c. fig.

Leuciseus erythrophthalmus, Fleming, Brit. An. p. 188; Cuv. and Val. xvii, p. 107 ; Nilss. Skand. Fauna. Fisk. p. 313; Yarrell, Brit. Fish. (ed. 1), i, p. 361, c. fig. (ed. 2), i, p. 412; Thompson, Nat. Hist. Ireland, iv, p. 138; Nord. in Jémid. Voy. Ross. Merid. iii, p. 490 ; Kröyer, Dan. Fisk. iii, p. 421, c. fig. ; Swainson, Fish. ii, p. 285; White, Catal. p. 66; Günther, Catal. vii, p. 23l; Collett, Norg. F. p. 182; Malm, Fauna, p. 563; Giglioli, Pesc. Ital. p. 44; Houghton, Brit. F. W. Fish. p. 45 , c. fig.

Barbus orfus, Flem. Brit. An. p. 186.

Cyprinus cceruleus, Yarrell, Trans. Linn. Soc. xvii, p. 8, pl. ii, f. 2 ; Jenyns, Man. p. 413.

Scardinius erythrophthalmus, Bonap. Faun. Ital. Pesc. iii, p. 146; Heckel and Kner, Suss. w. f. p. 153, f. 79, 80 ; Siebold, Suss. w. f. p. 180; Blanchard, Poiss. France, p. 377, fig. 84; Feddersen, p. 88; Canestrini, Fauna Ital. Pesc. p. 14; Moreau, Poiss. France, iii, p. 410.

Scardinius scardafa, Bonap, 1. c. ; Heckel and Kner, 1. c. p. 157, f. 82 ; Cuv. and Val. xvii, p. 123.

Leuciscus cceruleus, Swainson, ii, p. 285 ; Yarrell, Brit. Fish. (ed. 1), p. 365,

c. fig. (ed. 2) i, p. 416 ; White, Catal, p. 67.

Leuciscus apollonitis, Richards. Pro. Zool. Soc. 1850, p. 374.

Scardinius dergle and plotizza, Heckel and Kner, l. c.

Scardinius hesperidicus, Nardo, Prosp. Sist. pp. $72,91$.

Rudd and Azurine, Couch, Fish. Brit. Isles, iv, pp. 49, 6L, pl. cxcii, cxcrii.

B. iii, D. 11-12 $\left(\frac{2-\frac{3}{8}}{10}\right)$, P. 16-17, V. 9-10, A. 13-15 $\left(\frac{2-3}{10} \cdot \frac{3}{2}\right)$, C. 19-21, Ll. 40-44, L. tr. $7 \frac{1}{2} / 6 \frac{1}{2}$, Vert. $\frac{2}{1} \frac{1}{8}-\frac{2}{1} \frac{3}{6}$.

Length of head 5 to $5 \frac{1}{4}$, of caudal fin 5 , height of body $3 \frac{1}{3}$ to $3 \frac{1}{2}$ in the total length. Eye-rather above the middle of the depth of the head; interorbital space convex: diameter 4 to $4 \frac{1}{4}$ in the length of the head, $1 \frac{1}{4}$ diameter from the end of the snout and 2 apart. Body elevated and compressed, the dorsal profile being much more convex than is that of the abdomen, and mostly a short concavity over 
the eye. Cleft of mouth shallow, the posterior extremity of the maxilla reaches to below the hind nostril. Snout somewhat overhanging the month, the lower jaw very slightly the shorter. Teeth-pharyngeal 4-5, 2-3 | 2-3, 4-5, the sides of some of the crowns of the teeth serrated. Fins-dorsal situated upon the highest portion of the back, it commences midway between the nostrils and the base of the caudal fin, the length of its base equals $2 / 3$ or $3 / 4$ of the height of its anterior rays, which are rather more than twice those of the last: upper edge of fin concave. Pectoral inserted low down and reaching two-thirds of the distance to the ventral, which latter, situated beneath the anterior dorsal rays, extends more than half-way to the commencement of the anal. Anal situated in the last fourth of the total length excluding the caudal fin; the length of its base equals $3 / 4$ of that of the longest ray, while the anterior portion of the fin is twice as high as the posterior. Caudal rather deeply forked. Scales-three or four rows between the lateral-line and root of the ventral fin. Lateral-line-continuous to the centre of the base of the caudal fin. Colours-silvery, darkest along the back, and glossed with gold. Dorsal, pectoral, and caudal fins orange, with black tips : lower fins yellow. Eyes red. Those from deep waters are coloured very similarly to roach or dace, this fish being subject to considerable variations in tints.

Varieties.-It has been held by Izaak Walton and many other anglers that this fish is a hybrid between the bream or carp and the roach. The azurine was added to the list of British fishes, some fish of this variety having been obtained from Knowsley. It is less bright, its abdomen silvery, and its fins white. Mr. Pennell found in some ponds near Romford, in Essex, a lemon or yellow-coloured variety of the rudd.

Names.-Rudd, pronounced Roud in Norfolk, and rudd said to be diminutive of ruddy or red: "The Red eye," finscale, Oxfordshire (Beesley) : shallow (East). Rhuddgoch, Welsh. De Ruisch-Voorn, Dutcb. Le Rotengle, French.

Habits. - Not rare in many rivers, canals, lakes, and ponds throughont the level countries of England. It has been asserted that where rudd exist roach are almost invariably present, whereas the converse does not always hold good.

In Norfolk it is often found along with the Roach, but as a rule the rudd prefers the broads, and the roach the rivers. It lives on the larvm of insects, worms, small molluscs, and vegetable substances; is very lively and active, and rises at flies and sports on the surface.

Means of captwie.-Bites freely.

Baits.-These are similar to those which are useful for the roach, but paste and gentles are most generally relied on. Dr. Norman, in Norfolk, recommends a nice red worm, while the finest fish are taken with a salmon-gut line, and three hooks, a large float, and at least forty yards of strong light line.

Breeding.-April and May, among weeds in ponds, and is very prolific in almost every kind of fresh water: in rivers it frequently ascends for breeding purposes, and after spawning repairs to appropriate shallows, especially if the bottom is gravells, where it scours and subsequently repairs to quieter parts of the river.

Hybrids.-Between this fish and the rudd have been allnded to (page 178); also between the rudd and the bream (page 177).

Uses.- Said to be the best fish for stocking new-made waters with bait for pike, which prefer them to bream or roach. On the broads they are considered the best bait for perch, although in the rivers a gudgeon is superior.

As food.-It is said to be preferable to the roach or bream, its flesh being firmer.

Habitat.-Although widely distributed, this is somewhat a local fish. It is most common in rivers of the north of England or in Scotland (Donovan). In Yorkshire abundant in ponds in Holderness. Reported as in Lake Somerwater aud in ponds in other parts of the county, also in the Codbeck. A few have been caught in the Ouse at York (Yorkshire Vertebrata), the Witham in Lincolnshire, and Cherwell, in Oxfordshire (Pennant): common in broads and rivers of Norfolk (Lowe): Thames and waters near London. In the Cam, where it is termed shrllinu: Isle of Wight (Moore): Deronshire, where in Slapton Ley they breed in enormous numbers 
and attain a considerable size, Ireland, from north to south of the island, chiefly in lakes and slow rivers. It is probably found in every county possessing suitable localities. Rutty mentions the "Roche" as existing in the Liffey and Finglass Brook: while Templeton observed of the Rudd, "exceedingly common in the north of Ireland, where it is mistaken for the roach."

Specimen figured nearly 9 inches long: it attains over $2 \mathrm{lb}$. Mr. Norman took one in Norfolk weighing $3 \mathrm{lb} .1 \mathrm{oz}$. (Lowe).

\section{Leuciscus phoxinus, Plate CXXXIV, fig. 1.}

Phoxinus, Belon. p. 322. Phoxinus belonii, Aldrov. p. 582. Minow, Willugh. p. 268, t. Q8, f. 7 ; Ray, p. 125 ; Pennant, Brit. Zool. (Ed. 1776) iii, p. 373, pl. v, f. 6 (Ed. 1812) iii, p. 489. Cyprinus, sp. Artedi, Gen. p. 4, no. 9, Spec. p. 30, no. 16, and Synon. p. 12, no. 22, 23, and p. 13, no. 29. Veron, Duham. Pêches, ii, p. 515 , pl. xxvi, f. 7 .

Cyprinus phoxinus, Linn. Syst. Nat. i, p. 528; Gmel. Linn. p. 1422; Bl. Fische Deuts. p. 60, t. viii, f. 5; Bonnat. Ency. Ich. p. 194, pl. lxxix, f. 528 ; Shaw, Zool. v, p. 132 ; Bl. Schn. p. 437 ; Lacép. v, p. 571 ; Jurine, Poiss. LacLéman, p. 229, pl. xiv; Donovan, Brit. Fish. iii, pl. Ix; Turton, p. 109 ; Jenyns, Man. p. 4,15 ; Johnston, Berwick. N. H. F. Club, 1838, i, p. 172; Ekström, Mörkö, p. 26 ; Gronov. ed Gray, p. 185.

Cyprinus aphya, Linn. 1. c. p. 528.

Cyprinus rivularis, Pall. Zoo. Ross.-As. iii, p. 330.

Leuciscus phoxinus, Flem. Brit. An. p. 188; Nilss. Skand. Fauna, iv, p. 319; Cuv. and Val. xvii, p. 363 ; Yarrell, Brit. Fish. (ed. 1) i, p. 372, c. fig. (ed. 2) i, p. 423 (ed. 3) i, p. 442 ; Parnell, Wern. Mem. vii, p. 268; Thompson, Nat. Hist. Ireland, iv, p. 138; Swainson, ii, p. 285 ; White, Catal. p. 68; Günther, Catal. vii, p. 237; Giglioli, Catal. Pesc. Ital. p. 45.

Phoxinus loevis, Agassiz, Mém. Soc. Sc. Nat. Neuch. i, p. 37 ; Heckel and Kner, Suss. w. f. p. 210, f. cxix and cxx; Siebold, Suss. w. f. p. 222; Blanchard, Poiss. France, p. 410, t. c.; Canestrini, Fauna Ital. Pesc. p. 16; Moreau, Poiss. France, iii, p. 392 .

Phoxinus marsilii, Heckel, Ann. Wien. Mus. i, p. 232.

Phoxinus chrysoprasius, Nordmann, in Démid. Voy. Russ. Mérid. iii, p, 482.

Phoxinus aphya, Kröyer, Dan. Fiske, iii, p. 524, c. fig.; Collett, Norges Fisk. p. 183; Feddersen, Danske Fersk. Fiske, p. 91 ; Malm, Fauna, p. 564.

Minnow, Couch, Fish. Brit. Isles, iv, p. 64, pl. cxcix, f. i; Houghton, Brit. F. W. Fish. p. 63 , c. fig.

B. III, D $9-10\left(\frac{-3}{-7}\right)$, P. 15, V. $9-10$, A $10-11\left(\frac{3}{7}-\frac{8}{8}\right)$, C. 19 , L. 1,80 to 90 , Vert. 21/19.

Length of head $4 \frac{3}{4}$ to 5 , of caudal fin 6 to $6 \frac{1}{2}$, height of body $5 \frac{1}{4}$ to $5 \frac{8}{4}$ in the total length. Eyes-situated just in front of the middle of the length of the head, about $1 \frac{1}{2}$ or 2 diameters from the end of the snout, and 1 diameter apart. Snout rounded; mouth anterior; the upper jaw projects a little beyond the lower when the moath is closed, the maxilla extends backwards to beneath the first third of the eye. Barbels-absent. Teeth-pharyngeal, in 2 rows, conical and crooked $5-4,2 \mid 2,4-5$. Gill-rakers-few and short. Fins-dorsal commences about midway between the end of the snout and the base of the caudal fin, and slightly behind the origin of the ventral: the base of the dorsal fin terminates in a line above the origin of the anal fin. Caudal emarginate. Scales-in the live fish rather concealed in mucus. Lateral-line-incomplete. Colours- of a silvery pink tint, especially during summer, darkest along the upper half of the body and with numerous vertical bands descending from the back to the lateral-line and a black spot at the centre of the base of the caudal fin. Fins silvery-gray. But the colours are subject to great variation and mostly fine points of black are seen over the entire body. Sometimes there is a black band along the side.

Varieties.-Dr. Morean finds the lateral-line in some instances continued on one (the left) side to the base of the caudal fin. Manley alludes to a golden coloured one caught at the mouth of the Gadd, near Rickmonsworth. 
Names.-Anglo-Saxon, Myna. It appears to have numerous designations. Mennam in the north of England, and Mennawe and Menuse in old MSS. Minnow said to be derived from "minimus" or minute. Ray says a pinl or minima or minnow-pink, so called from its colour. Locally known as Bennick or Binnich, Minim and Peer, Somersetshire; Jack Barnell, Warwickshire (seo Gasterosteus aculeatus, vol. i, p. 241) ; Mealcer and Mengy, Devonshire; Mennard, Gloucestershire; Shabrid, apud Halliwell. Urothell y dom and Bychan byog, Welsh. Le Vairon, French.

Habits.-This pretty and active little fish is not often found near the sources of streams, as in such localities a sufficiency of food is not always present. During the summer months it keeps together in large assemblages and generally in shallows or near the surface. But in the cold winter months it more or less conceals itself, commencing to feed in the rivers about March and April.

In the Severn and other rivers which it frequents, the minnow during the summer months may usually be found lying among the weeds at the tail of a ford, and it is captured by placing a net below these spots and treading these fish out. It feeds on aquatic plants, worms and animal substances. Yarrell observes that no one has succeeded in preserving it beyond three years in an aquarium. Cooper crossing a brook saw from the footbridge, at the bottom of the stream what had the appearance of a flower, and which consisted of an assemblage of these fish, their heads all meeting in a centre and their tails diverging at equal distances. The object which attracted them was a dead minnow which they soemed to be devouring.

Means of capture.-Netting, or with hook and line.

Baits.-A worm, or gentle, or eiven paste.

Breeding.- Very prolific, and breeding about the end of May or commencement of June, at which period the head is usually covered with small tubercles. The ova are said to be adherent together among the interstices of stones in brooks where they have been deposited. In Devonshire, after the month of Jane, when most of them have finished spawning, Parnell observed that the males ascended the shallows in large shoals, occupying sometimes the space of several feet in circumference, and giving the water an appearance with their little white-spotted heads of a bed of Ranunculus aquatilis before the buds have fully expanded. Yarrell records having taken the young $\frac{B}{4}$ of an inch long by the first week in August. Davy found that they hatched on the sixth day. Fatio has observed (Arch. Sc. Nat. lii, 1875) that not only is there an enlargement of one pectoral ray in the male during the breeding season, but from 6 to 8 , and not confined to one period but continuous more or less throughout the year.

Uses.- Excellent as bait for eels or as spinning bait for tront, perch, pike, or even chub, when it is generally hooked throngh the upper lip or back fin. Some anglers keep these fish in a white earthenware jar instead of in bottles or tin cans, as they seem to remain much brighter. Although they afford excellent sustenance to trout it is questioned whether they ought to be kept in large numbers in waters frequented by young salmonidø, as both forms devour the same kind of food and thus the minnow might starve young trout.

As food.-Much esteemed dressed as "Whitebait." William of Wykeham, the founder of Winchester College, at a dinner which he gave the King and Queen and 210 guests, on September 16th, 1394, had served, among other fish, seven gallons of minnows, which cost $11 s$ d.

Habitat.-Disseminated throughout Europe.

In Scotland, near the Moray Firth, "abundant in the Isla, near Keith, and in some other tributaries of the Deveron" (Gordon) ; streams near Banff (Fidward); one in the Glasgow Museum from Lanarkshire is $4 \frac{1}{2}$ inches long; Aberdeen (Sim). Throughout most of the north of Scotland, becoming more plentiful as we advance south, in all the rivers entering the Firth of Forth, but rare in the Teith about fifteen miles from Stirling (Parnell).

In England the minnow is found in the lake district, and Mr. Eagle Clarke observes that he caught about a dozen of the largest he ever saw in the stream running into the Wastwater; they were quite seven inches in length. Yorkshire 
abundant up to 1250 feet elevation; in Norfolk it shuns stagnant water, bat is plentiful in the rivers above Norwich but does not often occur below that city.

Throughout most of the streams, canals, and in many ponds of England and Wales, especially in rivers with gravelly bottoms, and found as far as Cornwall, but said to be absent from the Isle of Wight.

Ireland.-Scarce where calcareous rocks predominate, while in Scotland, where the water is very free from calcareous matter, the minnow is common. Several localities in counties Down and Wicklow. In fact, it is a very local fish in that island and rare in many districts. Introduced into the Dodder from Dublin about 1822 (Kinahan) ; and Dr. Ball mentions one 6 inches in length taken in a pond at Glasnevin Gardens near Dublin; also that when he was at Lough Dan in Wicklow in 1846, a fisherman informed him he had been there twentyfive years (1821) and that they were as plentiful when he came as they were now. Professor Ernst Friedel has stated that at Dublin (1879 or 1880) be "was struck by the thousands of minnows, Leuciscus phoxinus, the more so as this fish has only of late years been introduced into Ireland, and is as yet only found in the rivers of Dublin and Wicklow."

The figure is from a specimen taken in Hampshire. It attains to as much as 6 or 7 inches in length but is rarely seen above 3 or 4 . 


\section{Genus VI-Tinca, Cuvier.}

Pseudobranchice minute. Mouth anterior : lips thick but destitute of any horny covering. Barbels 2 , one at either angle of the mouth. Pharyngeal teet $h$ in one row, 4 or 5 | 5 or 4 cuneiform, with a slightly hooked extremity. Gill-rakers short and lanceolate. Dorsal fin rather short, commencing slightly behind the origin of the ventral; anal short: caudal slightly emarginate: scales small, embedded in a thick skin and covered with mucus. Lateral-line complete.

\section{Geographical distribution.-Fresh waters of Europe and of Asia Minor.}

The tench has been said to have been introduced into England about the year 1514, but there does not appear to be any decisive evidence that it is not an indigenous species. It has been acclimatized in the waters around Ootacamund on the Neilgherry Hills in Madras, where it is thriving (Day, Fishes of India, 1878, p. 594).

\section{Tinca vulgaris, Plate CXXXIV, fig. 2.}

Tinca, Auson. v, p. 125 ; Belon. i, p. 324; Rondel. ii, p. 157 ; Salv. p. 90, t. Ixxxix; Gesner, p. 984; Aldrov. v, p. 646 ; Willugh. p. 251 , c. vi, t. Q5, f. 1 ; Ray, Pisc. p. 117 ; Rutty, Nat. His. Co. Dublin, 1772, i, p. 366.

Cyprinus, sp. Artedi, Gen. p. 4, no. 6, Spec. p. 27, no. 14, and Synon. p. 5, no. 7; Gronov. Zooph. no. 3ะ8. Brama, Sp. Klein, Pisc. Miss. v, p. 63, no. 6. Tench, Pennant, Brit. Zool. (Ed. 1776), iii, p. 359, and (Ed. 1812), iii, p. 474; Bowdich, Brit. F. W. Fish. no. 13. f. 320 .

Tanche, Duhamel, ii, p. 506, t. xxvi, f. 1 ; Bonn. Ency. Ich. p. 191, pl. Ixxvii,

Cyprinus tinca, Linn. Syst. Nat. i, p. 526 ; Müll. Prod. Zool. Dan. p. 50; Gmel. Linn. p. 1413; Bloch, Ich. p. 87, t. xiv, p. 94, t. xv (variety aurata); Bl. Schn. p. 448; Lacép. $\nabla$, pp. 491, 534; Donovan, Brit. Fish. v, pl. cxiii ; Pallas, Zoo. Ross.-As. iii, p. 310; Turton, p. 108; Jenyns, Manual, p. 405; Ekström, Fisk. Mörkö, p. 67 ; Ekstr. and Fries, Skand. Fisk, p. 205, pl. lii; Templeton, M. N. H. 1837 (2), i, p. 410; Johnstone, Berwick. N. H. F. Club, 1838, i, p. 172; Costa, Fauna Nap. Pesc. p. 9 ; Gronov. ed. Gray, p. 179; Schlegel, De Dieren Neder. p. 102, pl. xi, f. l.

Tinca vulgaris, Cuv. Règne Anim. ii, p. 273; Jurine, Poiss. LacLéman, p. 205, pl. x ; Fleming, Brit. An. p. 186 ; Nilss. Skand. Faun. iv, p. 296 ; Cuv. and Val. xvi, p. 322, pl. cccclxxxiv ; Yarrell, Brit. Fish. (ed. 1), i, p. 328, c. fig. (ed. 2) i, p. 375, (ed. 3), i, p. 389; Nord. in Démid. Voy. Ross. Mérid. iii, p. 481; Kröyer, Danm. Fisk. iii, p. 351, c. fig.; White, Catal.p. 62 ; Heckel and Kner, Suss. w. f. p. 75, f. 34 and 35; Nilss. Skand. Fauna, Fisk. p. 297 ; Thompson, Nat. Hist. Ireland, iv, p. 136; Siebold, Suss. w. f. p. 106 ; Canes. Arch. Zool. iv, 1866, p. 69; Malmgren, Wieg. Arch. xxx, p. 310; Blanchard, Poiss. France, p. 317, f. 64; Collett, Norges Fiske, p. 183 ; Günther, Catal. vii, p. 265; Moreau, Poiss. France iii, p. 383 ; Canestrini, Fiuna D'Ital. Pesc. p. 12 ; Giglioli,

Catal. Pesc. Ital. p. 45 ; Feddersen, De Danske F. fiske, p. 84.

Tincta aurata, Cuv. Règ. Anim.

Tinca chrysitis, Agass. Mém. Soc. Sc. Nat. Nench. i, p. 37 ; Bonap. Faun. Ital.

Pesc. iii, p. 93, t. f. 2.

Tinca communis, Swainson, Fish. ii, p. 285.

Tinca italica, Bonap. 1. c.

Leuciscus tinca, Günther, Fisc. Neckars, p. 50.

Tinca Linnei, Malm, Fauna, p. 564.

Tench, Couch, Fishes of Brit. Isles, iv, p. 22, pl. clxxxiii; Honghton, British

Freshwater Fishes, p. 49, c. fig.

Golden tench, Houghton, l. c. p. 51, c. fig.

B. iii, D. $12-13\left(\begin{array}{c}3 \\ 8\end{array}\right)$, $)$ P. 17 , V. 9-10, A. 9-10 $\underset{(6-7-}{\stackrel{9}{6})}$, C. 17, L. 1.90 to 115

L. tr. $30 / 31$. 
Length of head $4 \frac{1}{3}$ to $4 \frac{3}{4}$, of caudal fin $5 \frac{3}{4}$, height of body $3 \frac{8}{4}$ to $4 \frac{3}{4}$ in the total length. Eyes-diameter $6 \frac{1}{2}$ to $7 \frac{1}{8}$ times in the length of the head (but comparatively larger in the young), $2 \frac{1}{4}$ diameters from the end of the snout, and from 2 to $2 \frac{1}{4}$ apart. Interorbital space flat. The thickness of the head equals its length excluding the snout, while its height equals its thickness. Snout obtuse, mouth anterior, jaws anteriorly of the same length, gape wide, cleft rather shallow; the posterior extremity of the maxilla reaches to beneath the hind nostrils. Lips thick. Teeth-pharyngeal, in a single row, 4 or $5 / 5$ or 4 , sometimes 4 on one side and 5 on the other. Gill-rakers-short. Fins-dorsal commences above the end of the base of the ventral, and is continued almost to above the origin of the anal : all the fins are rounded. In the males the first or even more of the ventral rays are thicker than in the female, as will be alluded to. Scalesabout 18 rows between the lateral-line and the base of the ventral fin. Lateralline - at first gradually descends and above the base of the ventral is continued to the centre of the base of the candal fin. From the thickness of its skin it is termed the "shoemaker" in Holland. Colours-leaden or greenish, lightest beneath ; fins blackish.

Varieties.-The golden tench (variety aurata) merely differs from the common form in its colours, which may be simply yellow or red, either without or conjoined with black spots or blotches (variety maculata). These forms are now extensively propagated in this country. Mr. Berney, of Merton Hall, Norfolk, in 1852, imported this variety of the tench from near Breslau, in Lower Silesia; and in 1868 Lord Walsingham introduced some into his Merton estate. According to Siebold (1863) the fine black spotted, or orange-yellow or red variety is indigenous in Upper Silesia. Although this variety renders it a valuable addition to aquaria and pieces of ornamental water, its colours, on the other hand, cause it to be readily perceived by its enemies, including poachers.

Names.-Sliw, pronounced "slew," Anglo-Saxon. Gwrachen and Ysgretten, Welsh. De Zeelt, Dutch. Tanche, French.

Habits. - The tench prefers still waters to running streams, more especially thriving in reservoirs, ponds full of water-weeds, and pits from which clay has been excavated for brick-making. It seems, also, to do better in foul and weedy than in clean water, and in broads and sluggish rivers as the Thames than in those which flow with considerable velocity; while muddy and marly bottoms are especially suitable to its prosperity. Where carp are found such localities are commonly well-adapted for tench.

It is generally seen in small companies, and appears to frequently keep near the bottom, except during the summer, when, more especially during spawning time, it lies near the surface among the weeds. Although possessing a very thick skin and covered with a large amount of slimy mucus, it seems to be very susceptible to cold, and has been credited with passing a considerable portion of the winter months in a semi-lethargic condition buried in semi-aquatic mud. It will dive down into the mud in order to escape from nets, while its "run" differs from that of the rudd or bream, being short and irregular. It is very tenacious of life, in which respect it is but little inferior to the eel among fresh-water fishes. Pennell states that he has known one to live for an entire day with the gimp of a double jack-hook passed under its skin from its gills to its tail, the fish being meanwhile cast about from place to place in the water and suspended in a most unusual position. Tench have frequently been observed to live a whole day out of water.

It feeds on insects, larvæ, worms and vegetable substances, and a correspondent of the Field (November 5th, 1881) remarks that he took " a tench of 4 lb. while perch fishing with a small red worm. This may or may not alter the theory that they do not feed during the winter months ; but this season, in the Lea, a goodly number have been bagged when least expected.

It is curious to observe the contorted positions in which these fish apparently go to sleep; sometimes the head rests on the floor of the aquarium, some are bent into most uncomfortable-looking shapes, while they lie so motionless as to appear to the observer as if they were dead. 
Daniel mentions the capture of a tench 33 inches long to the fork of the tail, and which weighed $11 \mathrm{lb} .9 \frac{1}{2} \mathrm{oz}$, its belly being of a vermilion colour; it was taken under some roots at the side of a pond, in which contracted situation it had literally assumed the shape of the hole in which it had, of course, for many years been confined. It has been computed that these fish can live in water in which the amount of oxygen has been reduced to the 5000th part of the bulk of the water, ordinary river water containing about 1 part in 100 . In some pits they breed but and never attain to any size; in other ponds they grow, but never breed.

Means of capture.-It is rather readily captured, and esteemed a foolish fish by many fishermen; it takes a bait throughout the spring and summer. In Norfolk, according to Lubbock, formerly the fishermen on the broads relied upon the bownet, and occasionally the trammel or flew; bat of late years, and in shallow waters, they prefer their own bands, with a landing net to be occasionally used. A small low-sided steady boat is employed and poled along, the fisherman lying down with only his head over the gunwale and his right arm bared to the shoulder, he gently displaces the weeds and tries to descry a tench. If he sees one, and how its head lies, the chances of success are increased; if not he slowly and cautiously touches it, which is only taken notice of should the tail be touched, when it dashes away. The fisberman tries to insinuate one hand just behind the gills, raising the fish gently but rapidly to the surface, but must not knock the boat or the jar wakes up the tench, which at once struggles.

Baits.-Paste, worms, gentles. In old works tar was recommended to be added to the baits used for this fish as it was said to be very partial to it.

Breeding.-Occasionally at the end of May; more commonly in June, or at the beginning of July. The female tench is generally accompanied by two males. The eggs are small and deposited in the weeds. M. Petit found nearly 350,000 in one specimen. Harmer examined seven and found from 83,104 to 383,252 ova, or an average of 211,826 in each. Bloch, from a $4 \mathrm{lb}$. specimen, obtained 297,000 . It does not breed so rapidly in rivers as in ponds and broads. In the male the outer ventral ray and, in some instances, several more are enlarged and thickened, while at the breeding season the basis of the ventral fn are inflamed and often excoriated. In stocking breeding ponds two males ought to be employed to each female. In places it is found to be rather a rapid grower, this being especially affected by the temperature of the water and the amount of food; it has been known to attain from $\frac{1}{2} \mathrm{lb}$. to $1 \mathrm{lb}$. in twelve months, and an instance has been recorded where one in a pond in six years was $4, \frac{1}{2} \mathrm{lb}$. weight.

Diseases, etc.-Much affected by thunderstorms : the effects on fish contained in trunks appears to be partial. All the fish in one trunk on a particular broad perish during a thunderstorm, while not one of those contained in another trunk in the same water is injured (Lubbock).

Uses.-It has been termed the "Fishes' Physician," and Camden in his Britannia observes that he had seen the bellies of pikes which have been rent open, have their gaping wounds presently closed by the touch of the tench, and by their glutinous slime perfectly healed up. (See also page 143.) A knowledge of this among fish has been said by many ichthyological authors to induce, pike, perch, and eels to spare the tench. Salter asserts, that having laid trimmers baited with live roach, dace, bleak, and tench, the eels and pike refused this latter fish as a bait, and that he only met with one instance to the contrary. Two reasons have been given why pike do not destroy them, one is that they live in the mud where they cannot obtain them: the second, that they purposely abstain from devouring them. Mr. Barr, on the contrary, asserts that you cannot put a better bait on a trimmer than a young tench, while out of the stomach of a trout he took twenty-two of the size of minnows. Mr. Slaney (Zool. 1853, p. 4021) observed a pike which had seized a tench of about $3 \mathrm{lb}$. weight crosswise but was mable to swallow it, and at last the tench got away. "This is the only instance I ever met with in which the tench was attacked by any other fish, though I have constantly had them put together with pike and perch in small streams and other places, where the absence of food for the predatory species 
has induced them to seize upon almost every other living thing; all other kind of fish, rats, young ducks, and moor-hens have fallen a sacrifice to the all-devouring pike, but not the tench; and keepers always avoid setting their trimmers or trolling for pike with a tench for a bait, alleging as a reason that no other fish will touch it."

A few days subsequently he found the above fallacious, as he saw another tench undergoing the same process, and afterwards found a dead one which evidently had been injured by a pike, and on dragging the pond only three or four were caught out of ten or twelve brace that had been put in, the rest appeared to have been destroyed by the pike (Zool. p. 4100). A tench of $7 \mathrm{lb}$. weight was taken at Frogmore Gardens, Windsor, from the pouch of a pike between $30 \mathrm{lb}$. and $40 \mathrm{lb}$. weight (G. Guyon, Zool. 1867, p. 563). Mr. Gurney (Zool. 1853, xi, p. 4124) observes that he has seen a tench taken out of the stomach of a pike. "In the autumn of 1848 I turned into a pit, which I believed to contain no fish of any kind, fifty small tench, and forty or more crucian carp; seven tench and twenty-four crucians were also turned in at a subsequent period. October 13th, dragged the pit and took three lanky pike, $3 \mathrm{lb} .2 \mathrm{lb}$, and $1 \frac{1}{2} \mathrm{lb}$. weight. All that remained of the stock were one tench $1 \frac{1}{2} \mathrm{lb}$. weight and eight crucians of about $1 \mathrm{lb}$. each."

In olden times it used to be applied to the palms of the hands and feet in order to absorb fever : or laid over the liver in cases of jaundice, when the fish, it was asserted, became yellow and retained the disease. A live one tied to the temple has been stated to remove a nervous headache, or worn round the neck to cure sore eyes. It has also been recommended in obstinate cases of worms !

As food.-It has been variously esteemed, being rejected by some as unpalatable or even unwholesome, whereas others have considered it to be among the best of our eatable freshwater fishes. Most of our abbeys and monastic establishments maintained stews where these fish were kept, which would seem to show they considered them to be delicacies. The taste of course considerably depends on the waters it has inhabited and the food on which it has lived. It may be placed in a stew and fattened with a mixture of greaves and meal.

Respecting the effect of the character of the water in which it lives upon its suitability for the table, we are informed that no tench could be better grown or of sweeter flavour than some taken out of Munden Hall, Fleet, Essex, which was so thick with weeds that the flue-nets could hardly be sent through them, and the mud was so intolerably fetid that it had dyed the fish of its own hue, which was that of ink. This, however, differs from the experience of many who generally find that a pond tench is muddy and not always desirable for the table if other fish are procurable.

A quantity of tench averaging about $3 \mathrm{lb}$. each, and of a golden colour, were taken from a clear pond at Leigh's Priory, but when dressed and brought to table smelt and tasted so rank that no one would eat them. This has been given as an instance, showing that clear water will not always render these fish eatable. At the Fisheries Exhibition some tench were placed in one of the cemented tanks and some earth and sods placed for them to grovel amongst. After about six weeks a brace were cooked and better fish could not have been desired. Some of the gold variety were also similarly treated, but they were somewhat inferior. A good tench is certainly by no means despicable as food, while its best season is from the commencement of September to the end of May.

Habitat.-Extended throughout the fresh waters of Europe into those of Asia Minor. Malmgren. l.c. fixes $62^{\circ} \mathrm{N}$. Lat. as the northern limits of this fish in Finland. In Scotland.-A beautiful specimen was captured in the Moray Firth in the middle of June, 1863, from whence it came and how it fared is a mystery (Edward) ; it thrives in Aberdeenshire and a few are found near Edinburgh. One upwards of

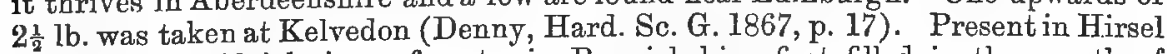
Lough, an artificial piece of water in Berwickshire, first filled in the month of December, 1876. It is not so common in the western as in the eastern counties of England. It was introduced into numerous ponds, reservoirs, canals, and some sluggish streams in Yorkshire (Yorkshire Vertebrata). In Norfolk from 14 to 
17 inches in length is considered that of a good table fish, while a $4 \mathrm{lb}$. fish is a large one. Mr. Gurney says, "The only river locality I know for the tench in Norfolk is the Yare above Trowse." It occurs also in the Ouse above Denver. Mr. Norman took one near Yarmouth weighing $5 \mathrm{lb} .14 \mathrm{oz}$. (Lowe). It is by no means rare in the Thames, and found in many of the midland counties as well as in some parts of Wales. It is also present in our southern counties, and large ones are occasionally captured in Hampshire, while it exists in the Isle of Wight (Moore). In the Exeter Canal and some of the ponds of the South Devon Railway (Partitt). Found in the ponds at Trengwainton, where they were placed by the late Sir Rose Price, Bart. (R. Couch). It is a common pond fish in Cornwall (Cornish).

In Ireland.-Templeton considered that it has been introduced, it is noted in County Down, counties of Dublin, Cork, Westmeath, and in Lough Derg, near Portumna. Templeton observed "Many were caught in the river Lagan after the breaking of the bank of a pond in the demesne of Lord Dungannon at Belvoir."

A correspondent of the Field (June 16, 1883) writing from Lough Derg, says tench were first heard of here three years ago, since then he has obtained a few all about $5 \mathrm{lb}$. weight.

Pennant observed having heard of one $10 \mathrm{lb}$. while Salvianus speaks of a $20 \mathrm{lb}$. tench. 


\section{Genus VII-Abramis, Cuvier.}

Blicca, Bliccopsis, Ballerus, and Alburnus, sp. Heckel. Stilbe, De Kay. Alburnellus, Luxilus, sp. Richardsonius, Girard. Abramidopsis, Siebold.

Body strongly compressed and elevated or oblong. Upper jaw protractile: lips simple, the lower labial fold being interrupted opposite the symphysis of the lower jaw. Barbels absent. Pharyngeal teeth in a single or double row, and notched near their edge. Gill-rakers short. Dorsal fin spineless, situated above and opposite the interspace between the ventral and anal fins; anal fins in European forms with many rays (20-48). Scales of medium size. Lateral-line present and passing to the base of the caudal fin. Abdomen posterior to the ventral fins compressed into an edge, but across which the scales do not extend.

Geographical distribution.-North of the Alps in Europe, contiguous portions of Asia, and also in North America.

As. food, generally not esteemed in this country but more so in parts of Continental Europe, the French even having a proverb that "he who hath bream in his pond may bid his friends welcome."

\section{A. Pharyngeal teeth in one row. - Abramis.}

\section{Abramis brama, Plate CXXXV.}

Abramis fuviatilis, Belon. de Aquat. cap. vi, p. 317 ; Gesner, p. 376. Cyprinus latus, Rondel. de Pisc. Lac. p. 154 ; Schonev. p. 33 ; Aldrov. Pisc. lib. v, c. 42 ; pp. 641, 642 ; Gronov. Zooph. p. 110, no. 345; Jonston, lib. iii, t. iii, c. viii, p. 165 , t. xxix, f. 5 ; Ray, Pisc. p. 116 ; Willugh. p. 248, t. Q10, f. 4. Bream, Pennant, Brit. Zool. (Ed. 1776) iii, p. 362, pl. lxs, (Ed. 1812) iii, p. 478; Bowdich, no. 18. Cyprinus. Artedi, Gen. p. 6, no. 17, Spec. p. 20, no. 10, Synon. p. 4, no. 2. Brama, Klein, Pisc. MSS. v, p. 61, no. 1.

Cyprinus brama, Linn. Syst. Nat. i, p. 531 ; Bloch, Ichthyologie, i, p. 76, t. xiii ; Gmel. Linn. p. 1436; Shaw, v, t. 124; Bonnaterre, Ency. Ich. p. 202, pl. Ixxxiv, f. 346 ; Bl. Schn. p. 438; Lacép. v, pp. 500, 591 ; Pall. Zoo. Ross. As. iii, p. 325 ; Donovan, pl. xciii ; Turton, p. 108; Jenyns, Manual, p. 406; Fries and Ekstr. Skand. Fisk. p. 175, pl. xlii; Templeton, Mag. N. H. 1837, (2) i, p. 410; Cuv. and Val. xvii, p. 9; Schlegel, Dieren Neder. p. 106, pl. xii, f. 3 ; Gronov. ed. Gray, p. 180; MaIm, Fauna, p. 565.

Abramis brama, Flem. Brit. An. p. 187 ; Agass. Wiegm. Arch. 1838, p. 81; Ekström, Mörkö, p. 30; Yarrell, Brit. Fish. (ed. 1) i, p. 335, c. fig. (ed. 2) i, p. 382 (ed. 3) i, p. 397 ; Swainson, Fish. ii, p. 285; White, Catal. Fish. Brit. Mus. p. 62 ; Nilss. Skand. Faun. iv, p. 324; Thompson, Nat. Hist. Ireland, iv, p. 136; Nordm. in Démid. Voy. Ross. Mérid. iii, p. 503 ; Kröyer, Dan. Fisk. iii, p. 369, c. fig.; Heckel and Kner, Suss. w. f. p. 104, f. 54 and 55; Siebold, Suss. w. f. p. 121 ; Malmgren, Wieg. Arch. xx, p. 311 ; Blanchard, Poiss. France, p. 351, fig. 73 ; Günther, Catal. vii, p. 300 ; Feddersen, Danske Fers. Fiské, p. 85 ; Collett, Norges Fiske, p. 183; Moreau, Poissons France, iii, p. 395.

Abramis vetula, Heckel, Ann. Wien. Mus. i, 1835, p. 230, t. xx, f. 6 ; Heckel and Kner, Suss. w. f. p. 108, f. 56 ; Cuv. and Val. xvii, p. 60.

Abramis microlepidotus and argyreus, Agass. Wiegm. Arch. 1838, p. 81; Cuv. and Val. xvii, pp. 43, 45.

Abramis gehini, Blanchard, Poiss. France, p. 355. 
Lake Bream, Conch, Fish. Brit. Isles, iv, p. 36, pl. clxxxvii ; Houghton, British Freshwater Fishes, p. 53, c. fig.

\section{(Immature.)}

Cyprinus farenus, Linn. Syst. Nat. p. 532; Nilss. Prod. Ich. Scan. p. 30; Ekstr. Fiske Mörkö, p. 40, t. iii ; Siebold, Wiegm. Arch. 1836, p. 327 ; Kröyer, Wiegm. Arch. 1837, p. 393.

\section{(Hybrid with Leuciscus erythrophthalmus.)}

Cyprinus Buggenhagii, Bloch, Ich. p. 144, t. zcr.

Abramis Leuckartii, Heckel, Ann. Wien. Mus. i, p. 229, t. xx, fig. 5 ; Cuv. and Val. xvii, p. 59 ; Heckel and Kner, Suss. w. f. p. 117, f. 61.

Abramis Buggenhagii, Thompson, Proc. Zool. Soc. 1837, p. 56 and Nat. Hist. Ireland, iv, p. 137; Yarrell, Brit. Fishes (ed.2) i, p.391, c. fig. (ed.3) i, p. 407; White, Catal. p. 63 ; Blanchard, Poissons, p. 357, fig. 75 ; Moreau, Poiss. France, iii, p. 400. Abramis Heckelii, Selys-Longch. Fauna Belg. p. 217, p. 8.

Leuciscus Buggenhagii, Cuv. and Val. xvii, p. 53.

Abramilopsis Leuchartii, Siebold, Suss. w. f. p. 117, f. 61.

Pomeranian bream, Couch, Fish. Brit. Isles, iv, p. 42, pl. clsxxix ; Houghton, British Freshwater Fishes, p. 58, c. fig.

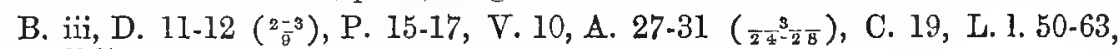
L. tr. $\frac{11-14}{7 \frac{1}{1}-8 \frac{8}{3}}$ Vert. $\frac{2}{2} \frac{1}{1}-\frac{2}{2} \frac{3}{2}$.

Length of head 5 to 6 , of candal fin $4 \frac{2}{3}$ to $4 \frac{2}{3}$, height of body 3 to $3 \frac{2}{3}$ in the total length. Eyes-diameter $4 \frac{1}{2}$ to $5 \frac{1}{2}$ in the length of the head, $1 \frac{1}{2}$ diameters from the end of the snout, and 2 diameters apart. Body oval, elevated and strongly compressed. Head small, snout short and obtuse, mouth protractile and small, upper jaw slightly the longer and reaching posteriorly to below the anterior nostril: lips moderately developed. Teeth-pharyngeal-5/5 compressed and notched at their extremity. Fins-the dorsal commences slightly behind the base of the ventral and about midway between the front edge of the eye and the base of the caudal fin, and just below the end of the highest point of the dorsal profile, while its last ray is on a line with the first of the anal: it is highest anteriorly. Pectoral inserted low down and as long as the head excluding the snout, it reaches to above the commencement of the ventral and the latter to the origin of the anal. The anal fin is falciform, and highest anteriorly. Caudal deeply forked. Scales-of medium size, higher than wide, $6 \frac{1}{2}$ or $7 \frac{1}{2}$ between the lateral-line and hase of ventral fin. On the edge of the abdomen between the ventral and aual fins, the scales do not pass across forming a sharp keeled edge. Lateral-line-curves downwards, passing along the luwer third of the body to the base of the candal fin. Colours-back of a dull olive or sea-green, lighter on the sides and beneath, the abdomen being silvery tinged with pink. In old fish the body becomes more of a yellowish colour. Fins brownish, the pectoral rays being often tinged with scarlet, which colour may be seen in the first few rays of all the other fins.

Varieties.-This fish is subject to considerable local variations of race, so much so that without a series of specimens it might almost be thought that new species were being obtained.

Names.-Common bream, yellow bream when old due to its colour: carp bream, when its colour resembles that of a carp. Brêm, Welsh. De Brasem, Dutch. La Breme, French.

Habits.-This gregarious fish, which is of a hardy nature, is found in many sluggish rivers, canals, ponds, brords, and lakes in this country, but swift running waters and pebbly bottoms are unsuited to it. Donovan observes that the fishermen assert that when the bream ascends rivers they are collected into small shoals, each of which is preceded by a leader who directs the course of the shoal and differs in appearance from the rest. This is called by the fishermen the "Queen bream." This, however, is thought by some to refer to the hybrids which will be presently described. It feeds on the larvæ and adult of water insects, on worms, is also on aquatic vegetable substances, and is very tenacious of life. 
In Norfolk we are told that should a bow-net be set for tench, bream crowd in before they arrive and thus exclude them. In perch-fishing it consumes the anglers' best worms, tries his patience, and soils his fingers. One of the great evils of this fish is its excessive increase, which occasions it to consume all the food which might have been available for better forms of fish.

In Sweden it is considered a timid fish, and Nilsson observes that during the period its fishing is carried on, it is forbidden to ring the church bells lest they might be scared. The shoals of these fishes are said always to have a sentinel on the watch.

Means of capture.-Bottom fishing, one of the best baits being small red worms and brandlings. When hooked in deep water it bores down into the mud, rubbing the line with its tail, thus causing it to be muddy for some distance above the hook, while it is a very suspicious fish, and considerable caution is necessary in order to avoid letting one's presence be detected. From July to October are perhaps the best angling months for the bream; the warmer the day the better, while it bites best of a morning and evening. Thompson remarks that it is taken with the greatest success in the Lagan by ground baiting with balls of grain from the distilleries, seeds (cast off from flummery), or boiled oats, being mixed up with potatoes in the form of balls, and thrown into the river at night. Bream collect from all quarters to partake of it, and the next day anglers employ worms as bait, generally with success. In Ireland it is netted in large numbers.

Baits.-Worms. Dr. Norman, of Yarmouth, says they must be worms of the largest size, not those dug out of the ground. They must be picked up off the grass at night. A good ground bait is half a pailful of bullock's blood, a pailful of fresh grains, half a pailful of very clean clay, a handful of dogs' greaves well broken up, three handfuls of meal, and a little oilcake. This is worked into a pudding and divided into balls not quite so large as a child's head, and partially baked in the sun. In June and July it will take a grasshopper from which the legs have been removed. Small hooks and light but strong tackle are necessary, and the angler that strikes at once on receiving a bite will have most chance of success.

Breeding.--When preparing to spawn about May, Lubbock observes, "they roll about like miniature porpoises, and the water is discoloured by their workings. Here a nose appears, and there a back fin, while at intervals a plunge of affright amongst the multitude shows that a large pike is busy." In Norfolk it generally selects a broad as a breeding-place, while the eggs are of a reddish colour, and Bloch observed 130,000 in one fish. One female is frequently attended by as many as three or four males. During the breeding season the scales feel rough to the touch, due to small whitish tubercles. which appear upon them at this period.

Hybrids. -I have already remarked (p. 177) how hybrids between the roach, Leuciscus rutilus, and other Cyprinidæ cannot occur in Ireland because the roach of that country is L. erythrophthalmus, or the rudd, which is termed a roach in the Emerald Isle. It is not, however, improbable, that elsewhere the L. rutilus may also assist in the creation of hybrids with the bream. The following, which has been found in Ireland, may be deemed a cross between the bream and the rudd.

B. iii, D. 13-14 $\left(\frac{3-4}{10}\right)$, P. 15-17, V. 9-10, A. $17-22\left(\frac{3}{14-18}\right)$, C. 19, L. 1. 45-52, L. tr. $\frac{8-1-1}{\overline{5}-7}$, Vert. 41 .

Pharyngeal teeth usually in one row, but in rare exceptions a second row, formed by means of a single additional tooth.

Thompson observes that in Ireland this form has been captured in the river Lagan, where the common bream is abundant. It has also been taken at Cossey, above Norwich (Lubbock), Dagenham Breach in Essex (Yarrell), Cambridgeshi1e (Jenyns), Wolverhampton (Edwardes), and some other districts in England, Holland, and Germany.

Uses.-Food for pike and ohter rapacious fishes. Mr. Gurney observes that once, when trolling for a pike in a pond where brean was found, the keeper 
insisted that they never took the latter; so to test this he employed a small bream for a bait, with which he took a pike. Numbers are employed in Norfolk as bait for crab and lobster pots, for which they fetch $2 s 6 d$ a bushel, while there is likewise a considerable demand for them as food in the Midland counties.

As food.-Employed for this purpose to a considerable extent on the Continent, but, due to its numerous bones and the softness and insipidity of its taste, it is not much thought of in this country, and one authority likens it in shape to a pair of bellows, and with much the same flavour. However, opinions have and will differ on this point, and its best season for the table is during the spring and autumn. Walton observes that in the autumn they become as fat as a hog, when they afford a not unpleasant dish.

In the Book of St. Alban's " the breeme" was considered " a noble fysshe and deynteous." Chaucer spoke well of it as food, and Dugdale informs us that about 1419, when the daily hire of a mason or carpenter was less than sixpence, that a single bream was valued at twenty pence. Also that a bream pie containing four of these fish was sent from Warwickshire to a distant part of Yorkshire at the cost of sixteen shillings, which included the wages of two fishermen for three days in catching the fish, together with the cost of the flour and spices for making the pie, and also its carriage.

Habitat.-The middle districts of Europe, and northwards to St. Petersburgh, Finland, and Scandinavia. Here it is local in its distribution, being found in the lakes of Cumberlind. In Yorkshire it is only recorded from the lower reaches of the Jon, Wharfe, Ure, Colbeck, Derwent, and Hull, as well as in canals. 'The commonest fish of the lake Somerwater (Yorkshire Vertebrata). In Norfolk found in immense shoals in all the broads. It is found in the Trent, the Ouse, the Thames, the Wey, the Lea, the Mole, the Medway, and in the Pulborough and Amberley waters. Also in our central counties, but is absent from Devonshire and Cornwall. In Wales, Swansea (Dillwyn); it has also been recorded from Brecknock and other places. In Ireland it is found in many of the lakes and slow running rivers, as Cavan and Fermanagh in the north, while in Lough Erne it attains a large size. In 1835 Thompson observed that there were numerous bream in the Lagan; but an old fisherman assured him that twenty years previously there had been none.

At Cossey, in Norfolk, it has been twice captured at $7 \mathrm{lb}$. weight, and $\mathrm{Mr}$. Norman, of Yarmouth, took one, a female, of $8 \mathrm{lb} .12 \mathrm{oz}$. (Lowe). One, a male, was taken near Cromer on June 17th, 1879, which weighed $11 \frac{1}{2} \mathrm{lb}$., and must have been at least 26 years old; it was $26 \mathrm{in.} \mathrm{long} \mathrm{and} 10 \mathrm{in.}$ deep. Jenyns observes their weight sometimes exceeds $12 \mathrm{lb}$, and on the Continent to $14 \mathrm{lb}$. Thompson alludes to Irish specimens of $7 \mathrm{lb}$., and Yarrell to $12 \mathrm{lb}$, or even $14 \mathrm{lb}$. Baily (Anglers' Instructor) mentions one of $17 \mathrm{lb}$. in the Trent.

\section{b. Pharyngeal teeth in two rows-Blicca.}

\section{Abramis blicca, Plate CXXXVI.}

Ballerus, Rondel. ii, p. 154 ; Schonev. p. 28 ; Aldrov. $\nabla$, p. 645 ; Jonston, lib. iii, t. iii, c. ix, p. 165. Blicca, Gesner, p. 167. Cyprinus, Artedi, Gen. p. 3, no. 3, Spec. p. 20, no. 9 , Synon. p. 13, no. 27.

Cyprinus björkna, Linn. Syst. Nat. p. 532 ; Gmel. Linn. p. 1438.

Cyprinus plestya, Leske, Ich. Lips. p. 69.

Cyprinus blicca, Bloch, Ichthy. i, p. 61, t. x; Bonnaterre, Ency. Ich. p. 202, pl. lxxxiii, f. 345; Bl. Schn. p. 437 ; Jenyns, Manual, p. 407 ; Ekstr. Mörkö, p. 44; Fries and Ekstr. Skand. Fisk. p. 64, t. xii ; Schlegel, Dieren Neder. p. 108, pl. xii, f. 2.

Cyprinus latus, Gmel. Linn. i, p. 1438 ; Lacép. v, pp. 501, 604; Jenyns, Brit. Vert. p. 26; Gronov. ed. Gray, p. 179.

Oyprimes laskyr, Pall. Zoo. Koss.-As, iii, p. 326.

Abramis blicca, Agass. Wiegm. Arch. 1838, p. 81 ; Ekström, Mörkö, p. 44, t. iv ; Nord. in Démid. Voy. Ross. Mérid. iii, p. 504, pl. xxii, f. 1 ; Kıöyer, Danm. 
Fisk. iii, p. 389, c. fig.; Yarrell, Brit. Fish. (ed. 2), i, p. 387, c. fig.; White, Catal. p. 63 ; Günther, Catal. vii, p. 306 ; Feddersen, Danske Fers. Fiske, p. 86.

44,58 .

Abramis micropterya and erythropterus, Agassiz, l. c.; Cuv. and Val, xvii. pp.

Leuciscus blicca, Cur. and Val, xvii, p. 31.

Blicca argyroleuca, Heckel and Kner, Suss. w. f. p. 120, f. 62, 63; Yarrell, Brit. Fishes (ed. 3) i, p. 403, c. fig.

Abramis björkna, Nilss. Skan. Fanna, iv, p. 328; Malm, Fauna, p. 565 ; Blanchard, p. 359, f. 76 ; Moreau, Poiss. France, iii, p. 398.

Blicca björkna, Siebold, Suss. w. f. Mit. Europe, p. 138.

White bream, Couch, Brit. Fishes, iv, p. 40, pl. elxxxviii ; Houghton, British Freshwater Fishes, p. 57, c fig.

B. iii, D. $11\left(\frac{2-8}{8-8}\right)$ P. 15 , V. 9-10, A. $22-27\left(\frac{2-8}{18-\frac{8}{4}}\right)$, C. 19, L. 1. 43-52, L. tr. $\frac{9-10}{7}$

Length of head $5 \frac{1}{2}$ to $5 \frac{3}{4}$, of caudal fin 5 , height of body $3 \frac{1}{4}$ to $3 \frac{1}{2}$ in the total length. Eyes-diameter $3 \frac{1}{4}$ to $4 \frac{1}{4}$ in the length of the head, $1 \frac{1}{2}$ diameters from the end of the snout, and $2 \frac{1}{2}$ diameters apart. Body oblong, elevated, and compressed; dorsal profile in an almost regular curve to the commencement of the dorsal fin from whence to the caudal it is somewhat concave; head rather small; snout short and obtuse; upper jaw slightly the longer, extending backwards almost to beneath the front edge of the orbit; mouth protractile, lips rather thick. Teeth -plaryngeal, in two rows 5-4, 2-3/3-2, 4-5. Fins-dorsal commences behind the insertion of the ventral and about midway between the front edge of the eye and the base of the caudal fin, and just beyond the termination of the highest point of the dorsal profile, while it extends usually to above the third or fourth anal ray, but occasionally not quite so far. Pectoral inserted low down, and as long as the head from behind the nostrils, it reaches to above the commencement of the ventral, which latter does not extend to so far as the anal. Anal falciform, highest anteriorly. Caudal forked. Scales-of medium size, higher than wide, 5 to 6 rows between the lateral-line and the base of the ventral fin. On the abdominal edge between the ventral and anal fins the scales do not pass across forming a keel. Lateral-line-passes downwards and is continued to the base of the caudal fin. Colours-silvery, darkest along the back, sides tinged with rose red, fins of a bluish colour, the dorsal anal and caudal with dark outer margins, the pectoral and ventrals tinged with red.

Varieties.-The Rev. R. Sheppard (Linn. Trans. xiv, p. 587) observed that there exists in the river Trent in the neighbourhood of Newark, two species or varieties of bream. The common one is known by the name of the "carp-bream" from its yellow colour, and has been taken of nearly 8 pounds weight. The other species or variety, which I believe to be a nondescript, never exceeds a pound in weight. It is of a silvery hue and goes by the name of the "white bream."

Names.-Taylor, in the Thames valley on the border of Bucks and Berks. Breamflat, Cambridgeshire. Shude, Ireland. YMerfog aughrion, Welsh. Bremettis, Book of St. Albans. De Blei, Dutch. La Brême Bordeliére, French.

Habits.-Does not appear to collect in large shoals, and is more commonly found with the rudd and roach than the true bream. It is lively, sportive, and tenacious of life. Lubbock observes that its mode of biting when angled for is singular, as it appears more prone to rise than to descend, and the float consequently, instead of being drawn under water, is laid horizontally on the surface.

Means of capture.-Tikes a bait readily but said to be too indolent to swallow it, still the s'wedish fishermen term it Aetare or glutton.

As food.-Worthless.

Breeding.-Bloch found 108,000 eggs in one fish. A hybrid between this fish and the rudd (see p. 176) has been observed in Holland and Germany.

Habitat. - In Europe the same as the common bream. It has been ohtained from Loch Maben in Dumfriesshire; from the Trent near Newark; the Cam, where it was termed the "breamflat" (Jenyns); and from the Norfolk boards. It rarely exceeds a pound in weight. 


\section{Genus VIII-ALboRnus, Heckel.}

Body rather elongated and compressed. Upper jaw protractile. Lower jaw projecting beyond the upper: lips thin, the lower labial fold being interrupted opposite the symphysis of the lower jaw. Barbels absent. Pharyngeal teeth hooked, and in two rows. Gill-rakers slender and closely set. Dorsal fin spineless, with few rays (10-11) and situated above and opposite the interspace betweer the ventral and anal fins; anal fin with many rays (19-23). Scales of medium size. Lateral-line present and passing to the lower half of the base of the caudal fin. Abdominal edge, posterior to the ventral fins, compressed into a keel, across which the scales do not extend.

Geographical distribution.-The rather numerous species of this genus are found in Europe and Western Asia; they are silvery fishes of small size.

\section{Alburnus lucidus, Plate CXXXVII, fig. 1.}

Alburmus, Auson. v, p. 126 ; Rondel. Pisc. Fluv. p. 208. Cyprinus, Jonston, lib. iii, t. iii, c. iv, p. 159, t. xxix, f. 13 ; Willugh. p. 263, t. Q10, f. 7 ; Ray, Piscium, p. 123 ; Gronov. Zooph. p. 106, no. 336 ; Artedi, Gen. p. 6, no. 18, Spec. p. 17, no.7, Synon.p. 10, no. 19. Leuciscus, sp. Klein, Pisc. MSS. v, p. 68, no.16, t. xviii, f. 3. Bleak, Pennant, Brit. Zool. (Ed. 1776) iii, p. 370, pl. lxxiii (Ed. 1812) ii, p. 487, pl. Ixxxiv. Able ordinaire, Duhamel, Pêches, ii, pl. xxxii, f. 1.

Cyprinus alburnus, Linn. Syst. Nat. i, p. 531 ; Bloch, Ichthy. Deuts. i, p. 47, t. viii, f. 4; Gmel. Linn. p. 1434; Shaw, v, t. 132 ; Bonnaterre, Ency. Ich. p. 201, pl. Ixxxiii, f. 343; Bl. Schn. p. 437; Lacép. v, pp. 500, 589; Donovan, Brit. Fishes, pl. xviii; Turton, Brit. Fauna, p. 109; Jenyns, Manual, p. 414; Pall. Zoo. Ross.-Ass. iii, p. 321 ; Fries. and Eks. Skan. Fisk. p. 203, t. li; Gronov. ed. Gray, p. 184; Schlegel, Dieren Neder. p. 117, pl. xii, f. 1.

Leuciscus alburnus, Fleming, Brit. Anim. p. 188; Cuv. and Val. xvii, p. 438; Swainson, Fish. ii, p. 285 ; Yarrell, Brit. Fishes (ed. 1) i, p. 368, c. fig. (ed. 2) i, p. 419 (ed. 3) i, p. 438 ; White, Catal. p. 67.

Aspius alburnus, Agass. Mém. Soc. Sc. Nat. Neuch. i, p. 38 ; Kröyer, Dan. Fisk. iji, p. 485 ; Feddersen, Danske Fers. Fiske, p. 90.

Abramis alburnus, Ekstr. Mörkö, p. 53; Nilss. Skan. Faun. ir, p. 337. p. 186 .

Aspius alburnoides, Sélys-Longch. Faun. Belg. p. 214; Cuv. and Val. xvii,

Alburnus lucidus, Heckel and Kner, Suss. w. f. p. 131, f. 67 and 68; Siebold, Suss. w. f. p. 154; Malmgr. in Wiegm. Arch. xxx, p. 315 ; Blanchard, Poiss. France, p. 364, figs. 78, 79; Günther, Catal. vii, p. 312; Collett, Norges Fiske, p. 184; Morean, Poissons France, iii, p. 403.

Alburnus breviceps, Heck. and Kner, Suss. w. f. p. 134, f. 69.

Alburnus Linnci, Malm. Fauna, p. 568.

Alburnus mirandella and falrcei, Blanchard, 1. c. pp. 369, 370, figs. 80, 81.

Bleak, Couch, Fish. Brit. Isles, iv, p. 56, pl. cxcv; Houghton, British Freshwater Fishes, p. 61 , c. fig.

B. iii, D. $10-11\left(\frac{2-9}{7-\frac{9}{8}}\right)$, P. 16-17, V. 9-10, A. $19-23\left(\frac{\left.-2-\frac{9}{1}-\frac{1}{2}\right)}{0}\right)$ C. 19, L, 1. 47-57, L. tr. $\frac{8-9}{4-5}, \operatorname{Vert}, 2 \frac{0}{2} \frac{2}{2}$.

Length of head, $5 \frac{1}{4}$ to 6 , of caudal fin $5 \frac{1}{4}$ to $5 \frac{3}{4}$, height of body $4 \frac{2}{3}$ to $5 \frac{1}{4}$ in the total length. Liyes-diameter $3 \frac{1}{4}$ to $3 \frac{1}{2}$ in the length of the head, 1 diameter from the end of the snout, and $1 \frac{1}{2}$ apart. Body rather elongated and compressed. Mouth anterior, directed obliquely upwards, lower jaw with a slight 
hook at its anterior extremity which projects slightly beyond the upper jaw; posterior extremity of the upper jaw reaches to beneath the front edge of the eye, while it is somewhat emarginate to receive the knob at the extremity of the lower jaw. Teeth-pharyngeal, in two rows $4-5,2 / 2,4-5$, pointed and crooked at their extremities. Fins-the dorsal commences behind the insertion of the rentral and on a line about midway between the hind edge of the eye and the base of the caudal fin: its last rays are above the first of the anal. Pectoral falciform, nearly as long as the head, and reaching to above the base of the ventral, which latter does not quite extend to the anal. Anal highest in front. Caudal forked. Scales-of medium size, $3 \frac{1}{2}$ rows between the lateral-line and the base of the ventral fin. Lateral-line-concave anteriorly and continued to the base of the caudal fin somewhat below its centre. Colours-upper surface of the head and back greenish; a steel-blue band, with a dark upper edge, along the side a little above its middle, sides below this silvery. Fins without colour.

Varieties.-This fish is subject to great modifications in the proportions of its body, some being comparatively much lower than others.

Names.-Bleak also spelt blick, bleit or bleis, a term derived by some from the old Saxon word "blâc" which signifies "white," or according to Merrett from the northern word "blick," which means to "bleach" or whiten. From this word "bleak" have sprung local terms as blaze, blay, willow blade. Ablet, Westmorland. While Izaak Walton called it the "freshwater sprat." Gorwynbysg, Welsh. Het Alvertje, Dutch. L'Ablette commune, French.

Habits.-Is very common in many rivers, living in shoals, revels at outlets of drains and is somewhat of a surface swimmer. Ever in motion, never at rest, darting about at the surface of the water, especially during sunny weather, so as to have obtained the name of the "river swallow," and springing out at flies, or infesting rivers in shoals, near the openings of drains. Siebold asserts that it occasionally springs out of the water to escape some rapacious fish as perch which is about attacking it from beneath, and thus eludes its enemy. The bleak is infested with parasitic worms which some authors consider to be frequently the cause of its eccentric gyrations in the water, and have gained it the epithet of "mad bleak." It has, however, been remarked that they are only in this wild condition during certain states of the water. Buckland observes that at the Severn at Shrewsbury he went to the mouth of a sewer : the water was ink black from waste dye, and so warm that steam was on the surface; bleak were here in vast shoals. In. June, 1881, it was remarked in the Field, that the dace which used to afford so much sport to anglers when the river was in a natural state, are not now to be found except in a very limited degree, and the migrating fish as bleak, twaite shad, lamperns and lampreys are becoming scarce. This jear, however, the little bleak has shown itself in large shoals ascending to considerably above Shrewsbury.

Means of capture.-Netting, or it will rise to the fly.

Baits.-A common fly, a bit of fat bacon, or a small artificial gnat, a gentle at the end of a casting line, or a bit of kid on the end of the hook.

Breeding.-May, June, and even July, during which period its head and gill-covers are rough to the touch. In Sweden Nilsson remarks that the largest and oldest are the earliest to breed. The young grow very rapidly.

Hybrids.-Jäckel describes from Bavaria a reputed hybrid between Alburnus lucidus, and probably Scardinius erythrophthalmus, which he terms Alburnus Rosenhaueri (Zool. Garten, 1866, p. 20).

Uses.-A good spinning bait due to its silvery whiteness, but it dies too soon to succed as live bait. The silvery pigment with which its scales are lined has been extensively used in the manufacture of artificial pearls. One thousand bleak are computed to yield $1 \mathrm{lb}$. of scales, and this four ounces of precipitated white powdery pigment. Yarrell remarks in his time first the slime and dirt was carried off from the scales by a run of water, they were then soaked for a time when the pigment was found at the bottom of the vessel. Into this glass tubes were dipped and the pigment injected into thin hollow glass beads of various forms and sizes. These were then spread on sieves and dried in a current of air. If greater weight were required an injection of wax was added. Pigment from the 
scales of the roach and dace was said to be the best, but that from the bleak in greater request. So great was the demand formerly at particular times that the price of a quart measure of fish scales has varied from one guinea to five. Of late years the silvery pigment lining the air-bladder of the Argentine has superseded to a great extent the colouring substance from fish-scales. Blanchard gives as an estimate of the value of these fishes taken in the Moselle in 1860 at 5000 francs.

As food.-Izaak Walton terms it excellent meat, others liken it to sprats ; while it has been recommended marinated. Some who have failed to appreciate the bleak, assume that it is neither worth cooking nor eating, that its taste is muddy, while it is too large to employ as whitebait, and too small to afford a good mouthful. It dies quickly, and its flesh soon decomposes.

Habitat.-Generally found in rivers which contain roach and dace, and in Europe north of the Alps.

Absent from Scotland and Ireland. Is a freshwater resident in Yorkshire, common in the lower waters of the Tees, Leven, and of the Central Plain; also in the Hull (Yorkshire Vertebrata); very abundant in ditches at North Wootton, in Norfolk, the Ouse, below Denver sluice, at low water (Lowe); the Thames, certainly as high as Oxford, the Lea, and New River, the Severn, and many of our rivers.

Its common size is up to 5 or 6 inches. Jenyns mentions specimens up to 8 inches. The figure, life size, is from one taken in the Thames. 


\section{Second Group-Cobitidinæ.}

The loaches, or the second group of the true carps, is comprised of forms in which the two lateral portions of the air-bladder are partially or entirely enclosed in bone, enabling it to be employed as an acoustic organ. These are mostly small fishes, and the two genera represented in Great Britain may thus be recognized :-

With an erectile spine near the orbit

Without any
Cobitis.

Nemacheilus.

\section{Botia, sp. Gray.}

\section{Genus IX-CoBitis, sp. Artedi.}

Body elongated and moderately compressed: back not elevated. Six barbels, all of which belong to the upper jaw. A large erectile, bifid, suborbital spine. Dorsal fin short, and commencing nearly or quite opposite the ventrals. Caudal fin truncated or rounded. The internal ray of the pectoral fin may be modified into a flat osseous spine.

\section{Cobitis tænia, Plate CXXXVII, fig. 3 .}

Cobitis aculeata, Rondel. ii, p. 204; Gesner, pp. 404, 482; Aldrov. v, p. 617 ; Jonston, lib. iii, tit. i, c. xii, art. iii, p. 143, t. 26, f. 22, 23; Willughby, p. 265, t. Q8, f. 3; Ray, Pisc. p. 124. Tonia cornuta, Willugh. 1. c. p. 226. Cobitis, sp. Artedi, Gen. p. 2, no. 1, Species, p. 4, no. 1, and Synon. p. 3, no. 2; Gronov.Zooph. no. 202. Enchelyopus, Klein, MSS. iv, p. 59, no. 4.

Cobitis tcenia, Linn. Syst. Nat. i, p. 499; Gmel. Linn. p. 1349 ; Bloch, Ich. i, p. 326, t. xxxi, f. 2; Bonnaterre, Ency. Ich. p. 148, pl. Ixi, f. 242; Bl. Schn. p. 434; ; Lacép. v, p. 9 ; Pallas, Zoo. Ross.-Asi. iii, p. 166 ; Müll. Prod. Zoo. Dan. p. 47 ; Turton, Brit. Fauna, p. 103 ; Flem. Brit. An. p. 189 ; Jenyns, Manual, p. 417; Nilss. Skand. Fauna, iv, p. 345 ; Cuv. and Val. xviii, p. 58 ; Yarrell, Brit. Fish. (ed. 3) i, p. 452, c. fig.; Thompson, P. Z. Soc. 1837, p. 59; Heckel and Kner, Suss. w. f. p. 303, f. 163; Costa, Faun. Nap. p. 31 ; Siebold, Suss. w. f. p. 338; Schlegel, Dieren Neder. p. 124, pl. ix, f. 6 ; Malmgren, Wieg. Arch. 1864, p. 306 ; Steind. Sitz. Ak. Wiss. Wien. 1865, Nov. 3rd; Canestrini, Arch. Zool. iv, 1866, p. 148, and Faun. Ital. Pesc. p. 20; Malm, Fauna, p. 569; Blanchard, Poiss. France, p. 285, fig. 54; Günther, Catal. vii, p. 362 ; Giglioli, Pesc. Ital. Catal. p. 45 ; Morean, Poiss. France, iii, p. 434.

Botia toenia, Gray, Zool. Misc. p. 8; Yarrell, Brit. Fish. (ed. 2) i, p. 432, c. fig.;

Kröyer, Danm. Fisk. iii, p. 564; White, Catal. p. 69 ; Feddersen, Danske F. Fiske, p. 92 .

Acanthopsis tcenia, Agassiz, Mém. Soc. Sc. Neuch. i, p. 36 ; Nord. in Démid.

Voy. Ross. Mérid. iii, p. 468; Bonap. Pesc. Eur. p. 26.

Cobitis elongata, Heckel and Kner, 1. c. p. 305 , f. clxiv.

Cobitis barbatula, Gronov. ed. Gray, p. $4 \mathrm{I}$.

Cobitis larvata, De Filipi, Mem. Acc. Turin, xix, p. 71 ; Canestrini, 1. c. p. 152.

Spined loach, Couch, Fish. Brit. Isles, iv, p. 72, pl. cxcix, f. 3; Houghton, British Freshwater Fishes, p. 66, c, fig.
B. iii
D. $9-10$
$\left(\frac{2-3}{6}-\frac{3}{8}\right)$, P. $8-9$, V. 6-7,
A. $7-8\left(\frac{2-8}{\overline{5}}\right)$,
C. 16.

Length of head $5 \frac{1}{2}$ to 6 , of caudal fin $6 \frac{1}{2}$ to 7 , height of body 7 to 9 in the total length. Eyes-5 to 6 diameters in the length of the head, and situated about its centre, from $1 \frac{1}{2}$ to 2 diameters from the end of the snout, and 1 diameter apart. Body strongly compressed, more especially posterior to the dorsal fin. Mouth 
overhung by the snout, both its cleft and gape small, the posterior extremity of the maxilla reaching to beneath the hind nostril. A strong bifurcated suborbital spine situated beneath the hind nostril, and extends to beneath the first third of the orbit. Barbels-short, six in number, all inserted on snout and apper jaw. Teeth-pharyngeal, in a single row, 8-10/10-8. Fins-the dorsal commences above the origin of the ventral and about midway between the end of the snout and the base of the caudal fin. Pectoral almost as long as the head in the males: the upper pectoral ray is osseous, enlarged and flattened.* Caudal cut square or slightly emarginate. Scales-very minute. Lateral-line-present, passing along nearly the middle of the side. Colours - of a light brown, becoming white along the abdomen : two rows of dark spots along the back and upper half of the sides, and a third of larger marks below the lateral-line: these marks are sometimes converted into transverse bands: a black streak from the eye to the snout: a black blotch on the upper portion of the base of the caudal fin. Pectoral, dorsal and caudal fins banded with dark marks.

Names.-Spined loach, denoting its preorbital spine; ribbon-shaped loach, having reference to its shape. De Kleine modderkruider, Dutch. La Loche de Rivière, French.

Habits.-Bat little is known of the habits of this species of loach in this country, where not only is it local but rare. It appears to be more of a mudloving form than our groundling, while it is tenacious of life. When touched it is said to emit a peculiar guttural sound.

Breeding.--March and April in France, and very prolific.

As food.- Said to be inferior to the common loach, but still it is much esteemed.

Halitat.-Distributed throngh most of the continent of Enrope. In Finland it is rare and local, but generally found through Denmark and the northern half of Sweden.

It is a much rarer form in Britain than the common groundling, Nemacheilus barbatula. Parnell observes that he thought he saw one in the River Teith in Scotland, but he failed to obtain it. It has been recorded from the Trent near Nottingham: from fish ponds at Ely and in other pieces of water in Cambridgeshire (Jenyns): clear streams in Wiltshire, and Thompson obtained it from near Guy's Cliff' in Warwickshire in July, 1836: Conch also observes that he believes it is found in Gloucestershire. Newman (Zool. 1855, xiii, p. 4836) remarked that he took this species at Dorking in a little muddy stream that runs into the Mole, just below the bridge at Brockham Lodge. But although he describes it he omits any reference to the spine below the eye (? next species). It has not been recorded from Ireland.

Rarely exceeds three inches in length.

* Cederström, AEfv. Ak Förh. xxxi, 1874, p. 47, pl. xi, f. 5-8, observes on the habits of this fish, and how the sexes are differentiated by external characters. 


\title{
Genus X-Nemacheruus, Van Hasselt.
}

\begin{abstract}
Acoura and Acourus, Swainson. Acanthocobitis, Peters. Oreias, Sauvage. Diplophysa, Kessler.

Body elongated. Dorsal profile nearly horizontal. Barbels six: none on the mandibles. No spine on the head. Dorsal fin short or of moderate length, and situated opposite the ventrals.

This genus, which includes a large number of species, has been subdivided into such as possess upwards of twelve dorsal rays, Acanthocobitis, and those with less : also into those that have forked or entire caudal fins.
\end{abstract}

Geographical distribution.-Fresh waters of Europe and Asia.

\section{Nemacheilus barbatula, Plate CXXXVII, fig. 2.}

Cobitis barbatula, Rondel, ii, p. 204; Gesner, p. 404; Aldrov. $\nabla$, c. xxxi, p. 618 ; Jonston, lib. iii, t. i, c. xii, art. ii, t. xxvi, f. 21 . Cobitis fluviatilis, Schonev. p. 31 ; Rutty, $i$, p. 366 ; Ray, Pisc. p. 124; Willugh. p. 265, t. Q8, fig. 1. Loche, Pennant, Brit. Zool. (Ed. 1776) iii, p. 282, pl. lviii (Ed. 1812) iii, p. 379, pl. lxix. Cobitis, sp. Artedi, Genera, p. 2, no. 2, Synon. p. 2, no. 1. Enchelyopus, Klein, MSS. i $\nabla$, p. 59, no. 3, pl. xv, f. 4. Duhamel, Pêches, ii, sect. iii, p. 521, pl. xxvii, f. 3.

Cobitis barbatula, Linn. Syst. Nat. i, p. 499; Gmel. Linn. p. 1348; Bloch, Icthyol. i, p. 329, t. xxxi, f. 3 ; Bonnaterre, Ency. Ich. p. 148, pl. lxi, f. 241 ; Bl. Schn. p. 434 ; Lacép. $\nabla$, p. 8 ; Müller, Futun. Danm. p. 47 ; Pall. Zoog. Ross.As. iii, p. 164 ; Donovan, Brit. Fish. i, pl. xxii; Turton, Brit. Fauna, p. 103; Flem. Brit. An. p. 189 ; Jenyns, Manual, p. 416; Parnell, Wern. Mem. vii, p. 270; Yarrell, Brit. Fishes (ed. 1), i, p. 376, c. fig. (ed. 2) i, p. 427 (ed. 3), i, p. 446; Swainson, Fishes, ii, p. 310 ; Fries and Ekstr. Skan. Fisk. pl. liii ; Templeton, Mag. Nat. Hist. 1837 (2), i, p. 410 ; Johnston, Berwick. N. H. F. Club, 1838, i, p. 172 ; Nilss. Skand. Faun. iv, p. 343; Thompson, Nat. Hist. Ireland, iv, p. 139; Nord. in Démid. Voy. Russ. Mérid. iii, p. 470; Cuv. and Val. xviii, p. 14, pl. 520 ; Kröyer, Dan. Fisk. iii, p. 539; Heckel and Kner, Suss.w. f. p. 301, f. 162 ; Siebold, Suss. w. f. p. 337 ; Malmgren, Wieg. Arch. 1864, p. 306 ; Canestrini, Arch. Zool. iv, 1866, p. 146, and Faun. Ital. Pesc. p. 20; White, Catal. p. 69; Blanchard, Poiss. France, p. 280, fig. 52; Feddersen, Danske F. Fiske, p. 92 ; Moreau, Poiss. France, iii, p. 432. p. 46.

Nemachilus barbatula, Günther, Catal. vii, p. 354; Giglioli, Pesc. Ital. Catal.

Loach, Couch, Fishes British Isles, iv, p. 69, pl. cxcix, f. 2 ; Houghton, British Fresh Water Fishes, p. 65, c. fig.

B. iii, D. $10\left(\frac{2-4}{6-\frac{4}{8}}\right)$, P. $10-12$, V. 8-9, A. $7-8\left(\frac{2-3}{\overline{6}}\right)$, C. 17.

Length of head 5 to $5 \frac{1}{2}$, of caudal fin 6 to $6 \frac{1}{2}$, height of body 6 to 8 in the total length. Eye-5 to $6 \frac{1}{3}$ diameters in the length of the head and situated about its centre, from 2 to 3 diameters from the end of the snout, and $1 \frac{1}{4}$ to 2 apart. Body rounded anteriorly, but compressed in its posterior half. Mouth overhung by the snout, which is obtuse : cleft shallow : the posterior extremity of the maxilla reaches to beneath the hind nostril. No spine on the head. Barbels six, all inserted into the snout and upper jaw. Teeth-pharyngeal; in one row 8-10/10-8, pointed and crooked at their extremities. Fins-the dorsal commences above the insertion of the ventral and rather nearer the base of the caudal fin than the end of the snout, or midway between the two. Pectoral as long as the head excluding the snout. Caudal cut almost square at its posterior extremity, with its corners rounded. Scales-minute, and mostly concealed in the large amount of slime with which the fish is covered. Lateral-line-distinct along the middle of the side of the body. Colours - these are subject to great variation, mostly of an 
olive-green blotched all over with dark markings: abdomen white. Fins blotched and banded with darker. Occasionally it is more yellow, with ill-defined spots and blotches. Generally a black mark at the base of the caudal fin above and below, but most distinct above.

Varieties. - Siebold observed one from Munich of a reddish colour, and having a red pupil: Baldner, of a pale-coloured loach.

Names.-Groundling, from its remaining at the bottom of streams or waters: stone-loach, due to its fondness for secreting itself beneath a stone: ground-bait, or ground gudgeon, Northumberland : lie-still, South Hampshire: also locally as beardie, tommy loach, or tommy lurker. La Loch Franche, French.

Habits.-Clear rivulets with gravelly bottoms, which it prefers to broad rivers, and keeps near the ground, rapidly darting away if disturbed; it is also found in pools. Appears to be very susceptible to atmospheric changes; thus, when kept in an aquarium, Couch found that it would throw itself over the walls of its prison, especially at the approach of, or during any remarkable changes of wind or weather. It similarly commits suicide by springing out of ponds or streams. Newman (Zool. 1855) says that in an aquarium it remains motionless at the bottom for the greater part of the day; but towards evening, and in showery weather, it presently comes to the surface, with a wriggling movement of its eel-like body-then drops languidly to the bottom. The loach has been kept alive in aquaria as a living barometer from the supposition that certain movements and alterations of position or situation indicate particular changes which are about to occur in the weather. It is very voracious, and will feed on larvæ and adult insects, as well as consume an incredible number of small worms, i.e., from $1 \frac{1}{2}$ to 2 inches long. As soon as one is seized it stirs up the mud, and so becomes invisible. In a state of nature it lurks in long floating grass quite as commonly as under stomes, and when rivers are flooded and very muddy, it often seeks refuge at the sides, under banks, and among small tufts of grass.

Means of capture.-A fine hook and line: baling out streams, or netting. Boys spear it with an ordinary fork tied on the end of a stick.

Baits.-A small worm.

Breeding.-Spawns in March and April : depositing numerous small ova. It has always been considered one of the most prolific of our freshwater fishes.

Uses.-Very good spinning bait for trout, perch, and small pike. Large pike high up streams will sometimes take them after refusing roach and dace. It is said to be rendered more killing if steeped in sweet oil, which changes its colour into a golden tint. A good bait on night lines for eels, while chub will also take it. Owls have been observed to feed their young with this fish.

As food.-Excellent flavour and very delicate. Rutty remarks that "it is customary with many to take it alive in a glass of generous wine" (i, p. 366); but Pennant observes that sportsmen do so through frolic. Izaak Walton considered it a dainty dish at table, and Gesner terms it the "invalid fish," the best being fed and bred in little clear and swift brooks or rills orer gravel. Frederick the First of Sweden went to the expense of having this fish imported into his country from Germany for his own particular eating. It is occasionally preserved as anchovies, and considered superior both in flarour and richness.

Habitat.-Absent from Scandinavia and Denmark, but distriluted over most of Europe. In many of the streams of the north of Scotland, and in all the rivers entering the Firth of Forth (Parnell), the Tweed, and the burns of Berwickshire (Johnston); in the waters of Leith (Neill).

In Yorkshire abundant in shallow waters. Found in the North-Western Fells up to 900 feet; also in Malham Tarn, 1250 feet (Yorkshire Vert.). In Norfolk found in the smaller streams, wherever stones afford a lurking place" (Lubbock); and it has been specially meztioned in many other localities to so far as Cornwall: also in Wales.

In Ireland taken in counties of Londonderry, Monaghan and Caran; Florence Court: counties of Dublin, Kildare, Cork and Wicklow. I found it abundant at Edgeworthstown, county of Longford. It rarely exceeds 5 inches in length. 


\section{Family, V-CLUPEID $\mathbb{E}$, Cuvier.}

Gill-openings usually very wide; pseudobranchiæ, when present, well developed. Abdomen mostly compressed, generally into a sharp edge, and usually serrated. Opercular pieces, four. Eyes lateral, with or without an adipose covering or lateral lids. Margins of the upper jaw formed mesially by the premaxillaries, laterally by the maxillaries, which latter are composed of three pieces not ossified together. Mouth may have a deep cleft, with small premaxillaries and the maxilla elongated, and either the upper or lower jaw projecting; or the mouth may be transverse. Barbels absent. Fin rays articulated. A single dorsal, with a few or moderate number of weak rays, and sometimes many rayed. Scales on the body: none, as a rule, on the head. Lateral-line mostly absent. Stomach with a "cul de sac." Air-bladder more or less simple. Pyloric appendages, when present, numerous.

Although in our seas the herrings are merely represented by six species, still one, or the true herring, is among the most valuable of our marine fishes; another, the pilchard, is likewise of considerable importance; and a third, or the sprat, is of great economic use. An account of each of these fisheries will have to be detailed, consequently it is merely necessary in this place to draw attention to some phenomena which are common to the members of the entire family.

Most of the fishes of which the family of herrings is composed are gregarious forms that congregate in shoals, and, as a rule, swim more or less near the surface. They have no means of defence against predaceous foes, and are preyed upon by numerous enemies, to counterbalance which they are endowed with great prolific powers. It appears somewhat improbable that man, with his present implements of capture, will be able to annihilate the herring shoals in our seas, but without doing this he can scare them, and so break up the shoals by injudicious modes of fishing. He can likewise drive them from certain shores into the deeper water, where they may form a deep-sea race; or he may occasion their entirely forsaking a locality.

Geographical distribution.-Herrings are found in most seas, and many enter fresh waters.

\section{Synopsis of Genera.}

1. Engraulis, or anchovy.-Upper jaw prominent, mouth with a very deep cleft, eyes covered by skin.

2. Clupea, or true herrings.-Upper jaw not projecting. Eyes with free lateral adipose lids.

\section{Genus I-Engraulis, Cuvier.}

Stolephorus, Lacépède. Thryssa and Telara, Cuvier. Setipinna, Swainson. Pterengraulis, Lycengraulis, Lycothrissa, and Heterothrissa, Günther.

Branchiostegals short and rather numerous. Gill-openings wide, the membrane connecting the two sides being short, thus leaving the isthmus uncovered. Body oblong or elevated, and the abdominal edge compressed. Cleft of mouth lateral: snout conical, the upper jaw the longer. Maxillaries of varying length, but always long, having a membraneous attachment to the cheels. Teeth small, sometimes of unequal size, usually present in the jaws, vomer, palatine, and pterygoid bones. The dorsal fin may be wholly or partially in advance of, or entirely posterior to, the origin of the anal. The upper pectoral rays may or may not be prolonged: anal with many or a moderate number of rays. Scales large or of moderate size. 


\section{Pacific.}

Geographical description.-Seas and coasts of Europe, also in the Southern

Engraulis gryoporus, Cope, Pro. Amer. Phil. Soc. xiii, 1873, p. 25, is said to be the first species of anchovy from the Northern Pacific.

\section{Engraulis encrasicholus, Plate CXXXVIII, fig. 1.}

Halecula, Belon. pp. 168, 169. Encrasicholus, Rondel. vii, c. ii, p. 211; Gesner, p. 78; Aldrov. ii, c. xxxiii, p. 214; Jonston, lib. i, tit. iii, art. 18, p. 78, t. xix; f. 17 ; Willughby, p. 225, t. P2, f. 2; Ray, Piscium, p. 107. Lysostomus balticus, Schonev. v, c. ii, p. 46. Clupea, sp. no. 3, Artedi, Synon. p. 17, no. 3, Genera, p. 7, no. 4. Argentina, sp. Gronov. Zooph. no. 349. Bylling or Moderlöse, Müll. Prod. Faun. Dan. p. 50. Anchovy, Pennant, Brit. Zool. (Ed. 1776) iii, p. 347, pl. Ixvii (Ed. 1812) iii, p. 459. L'anchois, Duhamel, Pêches, ii, § 3, pl. xvii, f. 5.

Clupea encrasicholus, Linn. Syst. Nat. i, p. 523 ; Fabr. Faun. Grönl. p. 183; Bloch, Ich. p. 316, t. xxx, f. 2 ; Gmel. Linn. p. 1405 ; Bonnaterre, Ency. Ich. p. 185 , pl. $\operatorname{lxxv}$, f. 313 ; Bl. Schn. p. 423 ; Lacép. $\nabla$, p. 455 ; Donovan, Brit. Fish. iii, pl. 1 ; Turton, Brit. Fauna, p. 107 ; Pallas, Zoo. Ross.-As. iii, p. 212 ; Risso, Ich. Nice, p. 354, and Eur. Mérid. iii, p. 454.

Engraulis encrasicholus, Cuv. Règre Anim. ii, p. 322 ; Risso, Eur. Mérid. iii, p. 454; Jenyns, Manual, p. 439 ; Cuv. and Val. xxi, p. 7, pl. 607; Yarrell, Brit. Fish. (ed. 1) ii, p. 140, c. fig. (ed. 2) ii, p. 217 (ed. 3) i, p. 151; Bonap. Pesc. Eur. p. 34; White, Catal. p. 86 ; Nilss. Skand. Fauna, p. 531 ; Swainson, Fishes, ii, p. 293 ; Kröyer, Danm. Fiske, iii, p. 221, c. fig.; Schlegel, Dieren Neder. p. 150, pl. xiv, f. 4; Günther, Catal. vii, p. 385; Steind. vi, p. 738; Collett, Norges Fiske, p. 194; Malm, Fauna, p. 569 ; Winther, Ich. Dan. Mar. p. 47 ; Canestrini, Fauna Ital. Pesci, p. 135 ; Giglioli, Catal. Pesc. Ital. p. 46; Morean, Poiss. France, iii, p. 460.

Engraulis meletta, Cuv, Règne Anim. (variety).

Encrasicholus encrasicholus, Flem. Brit. Anim. p. 183.

Engraulis vulgaris, Nilss. Prod. p. 25.

Argentina sphyrcena, Gronov. ed. Gray, p. 141.

Anchovy, Couch, Fish. Brit. Isles, iv, p. 125, pl. ccvi, f. 2.

B. xii-xiij, D. 15-18 $\left(\frac{2-9}{13-15}\right)$, P. 16-17, V. 7, A. 16-18 (- $\left.\frac{2}{1-16}\right)$, C. 21, L. 1. 48-50, Vert. 46-47.

Length of head $4 \frac{1}{2}$ to 5 , of caudal fin 7 to $7 \frac{1}{2}$, height of body 7 to 8 times in the total length. Eyes-diameter 1/4 of the length of the head, 3/4 to 1 diameter from the end of the snout and 3/4 of a diameter apart. Form slender, compressed, and thicker along the back than along the abdomen. Snout overlapping the mouth, very prominent and pointed. Cleft of mouth very deep, extending to beyond the hind edge of the eye. Upper jaw much longer than the lower. Teeth-in both jaws, being very fine in the lower, also present on the palatines and sometimes on the vomer. Fins-the dorsal commences in about the middle of the distance between the end of the snout and the base of the caudal fin, and slightly behind the insertion of the ventral. Anal rays very low. Candal deeply forked. Scales-rather large : very deciduous: abdomen rounded without any carinated edge. Two large scales on the base of the caudal fin. Coloursgreenish along the back when alive, silvery on the sides and beneath; a burnished steel blue band, having a dark upper edge, divides the dark back from the silvery sides. After death the back becomes of a very dark steel-blue, almost black.

Varieties.-The form in the southern hemisphere has 18 to 20 anal rays.

Names.-Anchovy, perhaps derived from the French. De Ansjovis, Dutch. L'Anchois vulgaire, French.

Habits.-A gregarious marine fish which hangs about our south coast from September until February, in dark nights appears to give a phosphorescent light to the sea: while Dillwyn observes that off Swansea in some sunmers there are vast 
numbers in the Bay. Couch obtained one in Cornwall in March, from the stomach of a mackerel. It approaches our shores somewhat later than the pilchard (was plentiful in October, 1883), and continues off the coast generally till February.

Mr. Wilcocks (Field, Jan. 13th, 1883) only met with them twice in his life along the south-west coast of England, once at Exmouth, the other time at Teignmouth, and found them both poor in taste as well as bitter. They are only taken by chance in drift nets or seines for sand-eels, as their small size enables them to pass through the meshes of such nets as are generally used by the drift net fishermen. In November, 1871, Mr. Dunn reported that upwards of 150,000 were taken in the seines set in Mevagissey Bay for pilchards, and were used as manure. It is seldom, however, they come so close in shore, although quantities hang in the offing off the coast from September until February. Said to eat small crabs, fry and sea insects.

Means of capture.-In the Mediterranean from May until July, dark nights are selected, and each boat carries a torch to attract the fish, when the shoals are surrounded by small meshed nets, while the fishermen splash the water in order to draw the fish which dart about and become gilled.

Breeding.-In the Mediterranean from May until July (Bloch) and very prolific : off our coasts from September until December. Mr. Jackson remarked that on June 9th, 1878, off Southport, he took some dozens in a shrimp trawl on a sandy bottom, about half a mile off shore. Unfortunately nearly all the scales came off in the net. Many were full of spawn and so tender that they burst with the slightest strain.

Uses.-Anchovies are prepared by drawing off the head and removing the viscera, they are not washed or wiped, but packed into small casks of $5 \mathrm{lb}$. to $20 \mathrm{lb}$. weight, in layers alternately with a mixture of $\overline{3}_{\mathrm{ij}}$ sal prunella (saltpetre deprived of water of crystallization by heat), and should be well pressed down and air excluded. Anchovy sance is made by bruising fish and simmering with melted butter on a slow fire, a little vinegar and flour being added. The fish dissolves in the process.

It is one of the fishes from which the Greeks and Romans prepared the sauce, garum, which was held in so much estimation.

As food.-It is rarely eaten fresh; in fact, it is strongly scented and so bitter that it has been said to carry its gall in its head. But prepared anchovies and anchovy paste are much relished.

Habitat.-Taken in innumerable quautities in the Mediterranean and extending northwards off Norway and the Baltic. It is found on both coasts of France, but most numerous on the Mediterranean side, also along the Iberian peninsula from Gibraltar, and from thence eastwards to Greece and the Black Sea, while a variety has been found in Tasmania. This fish was first obtained on our coasts by Ray from the estuary of the Dee. Mr. Peach has taken it from the herring nets off Wick, while there is one in the Newcastle Museum, taken in 1834 from some sprats being sold in the market, Durham (Jenyns). It appears to extend its range around our coasts, especially in the south and south-west, and has been specially referred to as present in Yorkshire (Yorkshire Vertebrata); three taken at Bridlington Bay, October 17th, 1866 ; rare at Yarmouth (Turner); frequently taken in the stow nets during the summer months in the river opposite Lynn (Lowe); Boston, Lincolnshire (Adcock), coasts of Essex; and Yarrell received an example from the mouth of the Thames, where, however, it was not known by the fishermen; Hampshire (Domovan). Often captured in drift nets in the west portion of the British Channel. Sometimes taken in the Exe (Parfitt): quite a common fish in the autumn from Polperro to Falmouth (Dunn); while the same authority reported the capture of at least 150,000 in November, 1871, at Mevagissey, where they were employed as manure: occasionally taken in St. Ives' Bay (Cornish). In Wales it has been recorded off Glamorganshire: Swansea, where it is abundant in some seasons: Flintshire (Pennant).

In Ireland Andrews reported it found oft the coast.

The anchovy is common up to $4 \frac{1}{2}$ or 5 inches in length, rarely exceeds $6 \frac{1}{2}$; but Mr. Dunn has obtained it from pilchard nets off the Cornish coast 8 inches long. 


\section{Genus II-Clupea, sp. Artedi.}

Clupanodon, pt. Lacépède. Harengula, Rogenia, Spratella, Sardinella, Clupeonia, Kowala, Meletta, and Alausa, Cuv. and Val. Clupalosa, Amblygaster, and Clupeoides, Bleeker. Opisthonenema, Brevoortia, and Alausella, Gill.

Branchiostegals numerous: pseudobranchice well developed. Body oulong or somewhat elongated, with the serrature of the abdomen extending anteriorly into the thoracic region: upper jaw projecting leyond the lower. Mouth anterior or antero-superior. Eyes with free adipose lids. Teeth, when present, rudimentary and deciduous. Dorsal fin situated opposite to the ventrals; anal with a moderate or large number of rays : caudal fortied. Scales large, of moderate, or more rarely, of small size.

Hyrtl (Denkschr. Ak. Wiss. Wein. x, 1855, p. 49) has recorded a rudimentary accessory branchial organ in one species of this genus from Brazil, Clupea aurea, Agassiz.

This genus has been subdivided in accordance with its dentition, but as the teeth are small and deciduous, such a procedure is open to very great objection.

In the ensuing British species there are two distinct forms of serrative along the abdominal edge, examples of which are well seen in the herring and in the sprat.

In the herring, Clupea harengus, and in the pilchard, C. pilchardus, the seales along the abdominal edge do not pass across from one side to the other, bat are divided by an interspace in which are the scutes. These scales may quite overlie and conceal the scutes, the latter not being formed by the coalescence of the scales from the two sides of the body.

In the sprat, Clupea sprattus, and both the shads, $C$. alosa and $O$. finta, we find that the scales along the abdominal edge pass across from one side to the other, and in the middle line are produced with a tooth-like or spinate process, which pertains equally to the scales on either side of the body.

Uses.-As food, either fresh or preserved, also for the production of oil.

Geographical distribution.-Cosmopolitan, many forms ascending into fresh waters, where some now permanently reside.

\section{Clupea harengus, Plate CXXXVIII, fig. 2.}

$2 a$ keeled scales along the abdominal edge.

Harengus, Rondel. p. 222 ; Gesner, p. 486 ; Jonston, Lib. i, tit. i, art. iii, p. 9, t. i, f. 6 ; Willughby, p. 219, t. Pi, f. 2 ; Ray, Pisc. p. 103. Clupea, sp. Artedi, Synon. p. 14, no. 1 (part), Genera, p. 7, no. 1, Species, p. 31, no. 1; Gronov. Zooph, no. 348; Rutty, Nat. Hist. Co. Dublin, 1772, i, p. 360. Harengus, Klein, Pisc. Misc. v, p. 71, no. I, t. xix, f. 1. Herring, Pennant, Brit. Zool. (Ed. 1776), iii, p. 335, pl. lxviii (Ed. 1812) iii, p. 444, pl. Ixxix; Low, Fanna Orcad. p. 226. La Hareng, Duhamel, Pêches, iii, p. 335.

Clupea harengus, Linn. Syst. Nat. i, p. 522 ; Gmel. Linn. p. 1402 ; Bloch, Ich. p. 278, pl. xxix, f. 1; Bonn. Ency. Ich. p. 184, pl. 1xxv, f. 310 ; Bl. Schn. p. 422; Lacép. v, p. 427 ; Faber, Fische Isl. p. 182; Pallas, Zoo. Ross.-As. iii, p. 209 ; Shaw, v, t. cxix ; Turton, Brit. Faun. p. 106 ; Flem. Brit. An. p. 182 ; Jenyns, Manual, p. 434; ; Yarrell, Brit. Fishes (ed. 1) ii, p. 110, c. fig. (ed. 2) ii, p. 183 (ed. 3) i, p. 98; Templeton, M. Nat. Hist. 1837 (2) i, p. 411; Parnell, Wern. Mem. vii, p. 315, t. $\times x \times v$, or Fish. Firth of Forth, p. 155, t. xxxv; Johnston, Berwick. N. F. Club, 1838, i, p. 173; Kröyer, Danm. Fisk. iii, p. 138, c. fig.; Thompson, Ireland, iv, p. 175; Cuv. and Val. xx, p. 30, pl. 591, 592, 593; Swainson, Fish. ii, p. 295; Nilss. Skand. Fauna, iv, p. 491; White, Catal. p. 83 ; Gronov. ed. Gray, p. 139 ; Schlegel, Dieren Neder. p. 138, pl. xiv, f. 1 ; Malmgren, Wieg. Arch. 1864, p. 341 and Efv. Svensk. Vet. Akad. Förd. 1865, p. 535; Günther, Catal. vii, p. 415 ; Collett, Norges Fiske, p. 185; Malm, Fauna, p. 570; Winther, Prod. Ich.

Danm. Mar. p. 47 ; Moreau, Poiss. France, iii, p. 443.

Clupea Pallasii, Cuv. and Val. xx, p. 253.

Herring, Couch, Fishes Brit. Isles, iv, p. 95, pl. ccii. 
Young.

Whitebait, Pennant, Brit. Zool. (Ed. 1776) iii, p. 3 '1, pl. 1xix.

Cyprinus esca, Walb. Artedi, iii, p. 36 ; Bl. Schn. p. 446.

Clupea alba, Yarrell, Zool. Journ. iv, pp. 137, 465, pl. $\nabla$, f. 2 and Brit. Fishes (ed. 1) ii, p. 126, c. fig. (ed. 2) ii, p. 202 (ed. 3) i, p. 121; Jenyns, Manual, p. 436 ; Parnell, Wern. Mem. vii, p. 325, t. $\operatorname{x\times xv}$, Fish. Firth of Forth, p. 165, t. $\mathbf{x} \times \mathbf{x}$, and Mag. Nat. Hist. ix, 1836, p. 318.

Rogenia alba, Cuv. and Val. xx, p. 34l, pl. 598.

Rogenia esca, White, Catal. p. 84.

Whitebait, Couch, Fish. Brit. Isles, iv, p. 114, pl. cciii, f. 2.

Synonymy for American Specimens.

Clupea harengus, Fabr. Faun. Grœenl. p. 182; Mitchell, Amer. Monthly Mag. ii, p. 323 ; Richards. Frank. Journ. p. 716 and Faun. Bor.-Amer. iii, p. 229.

Clupea elongata, Leseur, Journ. Acad. Nat. Sc. Phil. i, p. 234; Storer, Fish. Mass. p. 111, and Mem. Amer. Ac. vi, p. 330, pl. xxvi, f. 1; De Kay, New York Fauna, Fish. p. 250 ; Cuv. and Val. xx, p. 247.

\section{Varieties.}

Clupea Leachii, Yarrell, Zool. Journal, v, p. 278, pl. xii, Proc. Zool. Soc. 1830, p. 34, and Brit. Fish. (ed. 1) ii, p. 117, c. fig. (ed. 2) ii, p. 193 (ed. 3) i, p. 111 ; Jenyns, 1. c. p. 434; Cuv. and Val. xx, p. 243; White, Catal. p. 83.

Leach's herring, Couch, 1. c. iv, p. 107, pl.

$$
\text { British works on the herring. }
$$

Dodd, Essay towards Natural History of Herring, Lond. 1768, 8vo.

James Sola, Essay towards Natural History of the Herring.

Mitchell, The Herring, Edinburgh, 1864.

De Caux, The Herring and Herring Fishery, 1881.

B. viii, D, 17-20 $\left(\frac{3-4}{1-\frac{4}{15}}\right)$, V. 9, P. 17, A. 16-18 $\left(\frac{2-\frac{3}{1}}{1-\frac{1}{16}}\right)$, C. 18-19, L. 1. 53-60, Cæc. pyl. 18-23, Vert. 54-56.

Length of head 5 to $5 \frac{1}{2}$, of caudal fin $6 \frac{1}{2}$, height of body $4 \frac{3}{4}$ to 5 in the total length. Eye-situated half in front of the middle of the length of the head, and with an adipose lid on either side. Lower jaw prominent; the upper somewhat notched in its centre; the hind edge of the maxilla reaches to beneath the middle of the eye. Opercles smooth, and destitute of radiating striations. Teeth-small deciduous ones on the jaws, a patch on the vomer and also on the tongue, while generally minute ones are present on the palatines. Fins-the dorsal commences midway between the end of the snout and the base of the candal fin; the ventral is inserted on a line beneath the centre of the base of the dorsal fin. Scalesthere are 13 rather soft scutes posterior to the base of the ventral fin, along the abdominal edge, and which are partially concealed by the neighbouring seales from either side of the body, which more or less overlap them. The air-bladder has an opening on its lower side at about its centre, where a long but narrow canal forms a communication with the end of the stomach; it has also another orifice on the left side near the vent,* which canal is lined with a silvery pigment to within a short distance of its termination. The vessels of the air-bladder being scanty, gas is not secreted, but air believed to be swallowed. In some specimens at Aberdeen I perceived the food in the stomach covered by a membrane as in the pilchard, but of a finer consistence. Colours-of a rich blue or green along the back, becoming lighter on the sides and beneath, where it is shot with purple, blue, and gold lines. Lower jaw with a black tip.

Varieties.-There are considerable variations in the proportion of different. races even from adjacent localities. Some of them have been considered species.

Names.-Hcering, Anglo-Saxon (Herr, or heer, "an army"), or from the French hairang, an old term for a troop or army; cuddy legs, "a large herring;" corphun, herring cobs or young herring in Northumberland, where 
they are likewise termed silk-shag. Sgadan, or scattan, Moray Firth. Small ones not larger than a sprat are termed sills, or sile; fat herrings destitute of roe, maties, or matties, a corruption of the term "maiden," or those which have never spawned. Full herrings are those possessing a welldeveloped milt or roe; shotten-herrings, or spent fish which having just bred, are very inferior; it is likewise a term sometimes applied to such as have been gutted and dried for keeping. Green herrings is a term sometimes employed for "fresh herrings." Red-finned-herrings are known as wine drinkers in Scotland, and as loaders in Norfolk and Lincolnshire, while in the western counties they are called kings and queens. Overday tarts is applied by costermongers to such as have remained unsalted for over twenty-four hours, and consequently are dark red about their fins and gills, due to extravasated blood. A "blown herring" is termed, according to Halliwell, a tow-blowen in Suffolk. A gut-pock-herring in Scotland is one which has its stomach distended with small crustaceans, or other food. A red herring, or a black herring are trade terms for particular descriptions of cured fish, while the former is also known as a Norfolk capon, and sailors usually designate it as a sodger, or soldier. Bloaters used to be applied to herrings which were smoke-dried but not split open, from "bloat," to dry by smoke : kippered herrings, such as are split and salted. White herring generally implies a fresh herring, but in the north pickled ones are sometimes thus termed. In Scotland the highest brand is given to mazy herrings, or those full of roe; and what are known as crown-full; those which have not yet developed ova or milt as matties, such as have spawned as shotten, but which find a ready salo in the great continental markets. Local name of young yawling and Britt; scuddawn, Irish. Pennog, yfgaden, Welsh; De Haring, Dutch; Le Haering, French. At Great Yarmouth 4 herrings make 1 warp; a large basket containing 100 is termed a swill, or long

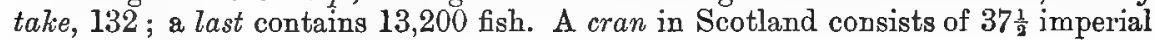
gallons, and generally contains from 900 to 1000 herrings; a barrel holds about 800 ; a maize, or mease, 500 . A cade, or barrel of herrings, appears to have contained 600 in the middle of the 15 th century.

Habits.-The herring is a gregarious, lively fish, a rapid surface swimmer, but somewhat timorous. Whole shoals, it is asserted, may be scared and turned from the course they had intended to pursue. The wake of these fish is often marked during the day time by long lines of gulls and sea birds hovering above them and occasionally swooping down upon some as prey; while at night time, especially if very dark, a slight gleam, "brimming," or "flame," is seen on the surface of the sea where the shoals are. But the herring is not always to be found at the surface, for it seeks its food at any depth where it obtains the best supply; it may even sink down to the bottom, provided such be not too profound, while it is not uncommon both for it and the mackerel to be captured by the beam-trawl. Thus, in the autumn of 1859 , more than 1000 large and full herrings were caught off Lowestoft in a beam-trawl net, and in the spring of 1870 upwards of 5000 shotten herrings were similarly taken at the Well Bank off Great Yarmouth, and in March, 1881, a large number of both shotten and full herrings were thus taken on the Brown Bank (De Caux). It has been remarked along our south and south-west coasts that herrings and pilchards do not intermingle. The noise made by herrings when captured is peculiar, and has been likened to various things-to the cry of a mouse, to the word "cheese," a sneeze, or a squeak, and may be occasioned either by the escape of air through the posterior opening of the air-bladder near the vent, or else, as seems more probable, by some movement of the gills and gill-covers.*

The food upon which herrings subsist has been variously characterized, but is generally held to consist of minute shrimp-like crustaceans, often of forms belonging to the same division as the common Cyclops of our fresh waters. It is evident that they exist on very varied forms of animal life, and are probably not particular provided they can obtain sufficient. About the middle of February, 1882, I found that some from the S.W. coast had been feeding on Annelids; from

* It has been asserted that it is possible to blow air from the stomach into the air-bladder. 
the same locality in the middle of May their stomachs were crammed with sand launces, Ammodytes, some of which were up to $2 \frac{1}{2}$ inches in length, and as many as nineteen were inside one herring, while the sand-launces in their turn were full of the remains of crustacea. A month later from the same place, and captured about eight miles off shore, the food had again changed, and consisted almost entirely of the young of a very rare gobioid fish, Crystallogobius Nilssonii, the largest of which was $1 \frac{1}{3}$ inches long, there were likewise a few young herrings and sand-launces.

Goodsir (Edinburgh New Philosophical Journal, July, 1843) gives the result of his examination of the Maidre, or food of the herrings in the Firth of Forth, with which the stomachs of the fish were found to be filled. Cirripeds, Crustaceans, and Acalepha were detected, of which crustaceans were in the largest number, and consisted of masses of Amphipoda and Entomostraca. Among the Acalepha the different species of Beroce were seen in the greatest numbers.

Off Lofodens Sars found the sea swarming with microscopic animals, especially small crustaceans termed "herring food," Calanido, chiefly Calanus finmarchius and Temora longicomis.

Carpenter writing upon what they consume in North America, remarks that their food sometimes consists of smaller fishes, but generally of more minute animals, especially Entomostraca and Radiolaria, of which small reddish-brown aggregations are often found floating in the waters which they frequent.

H. Widegren observed in Scandinavia that the food of the young as well as of the grown herring consists chiefly of small crustaceous animals, invisible to the naked eye, which are found in enormous quantities in the sea, both in shallow and deep water, and may be detected by straining water through a straining cloth. Their quantity varies at different seasons, and during a change of temperature at different depths. Axel Broeck (Tids. Fisk. Kjöbsch. i, p. 154, or Wiegm. Arch. 1862, p. 72) describes the various kinds of food on which he considered this fish subsisted. Breeding herrings do not feed to the extent those not in this condition do, but they do not invariably cease feeding, as some authors believe.

In an aquarium it was found (Zool. 1876, p. 4856) that the young or whitebait's diurnal and nocturnal movements were very dissimilar : in the former period they were quiet and uniform in going round their tank in one shoal, but at night the shoal was broken up, each fish taking an independent course for itself, darting about from side to side, striking against the rockwork with effects fatal to themselves, and which was only stopped by placing a dim light to illuminate the outline of the rockwork. Then they are most ravenous.

Herrings live in an aquarium provided. while being captured their scales are not rubbed off, and Mr. Jackson suggests that the best plan is to dip them out of the sea in a bucket or can, and subsequently allow them to swim into the tank they are to occupy. He invariably observed that they swam round and round their place of confinement in a circle from left to right. Ocćasionally one might turn for a moment, but it speedily resumed its place, and he never perceived the shoal to swim in a contrary direction.

Migrations.-Many theories have been broached to account for the migrations of the herrings, it having been formerly supposed that they yearly changed their residence from the poles to southern waters. Even now some consider that it is not, strictly speaking, migatory, that is, that it does not travel comparatively far from the locality in which it was hatched, reared, and came to maturity, but simply changes from shallow to deeper water, in accordance with temperature and the supply of food. One proof advanced being that certain definite varieties are present in certain waters. Where they conceal themselves is certainly remarkable, thus along the Devonshire and south-west coast of England, Mr. Dunn observes that should a gale spring up numbers are taken in nets purposely anchored parallel to the shore, and that they are meshed on the land side, although this locality had been unsuccessfully swept by seines and nets a very short time previously.

That herrings, in common with other species of the family, occasionally disappear from one locality, sometimes re-appearing in another, is well known, to account for which many surmises have been made. From 1690 to 1709 , a very 
extensive herring fishery existed at Cromarty; about the latter year an immense shoal was driven ashore near the town: they left the vicinity in a single night and for upwards of half a century no shoals re-appeared. Still this may have been simply a coincidence.

Many reasons have been adduced in order to account for these fishes deserting certain localities. In Long Island, one of the Hebrides, it was asserted they were driven away by the manufacture of kelp, although kelp fires did not drive them away from other places. The firing of guns, or an old Highland idea the shedding of blood. Steam-boats have been supposed to disturb the shoals.

The two main objects of migration wonld appear to be seeking some locality where eggs may be safely deposited for the species to be continued: or else a search for food in order to maintain the growth and existence of the individual. But it would seem that fish may seek new ground, due to that they usually reside in becoming unsuited from any cause (see page 218), as absence of food, or constant attempts at their capture by incessant netting. If, having selected waters further from the shore than formerly, the ova were deposited and hatched, it does not seem unreasonable to suppose that the progeny would locate themselves where they were reared. In time, perhaps, this new location might be found unsuited, and the shoal return to the spot they first inhabited, and where possibly a more abundant supply of surface-food exists.

Respecting the effect of temperature and various meteorological conditions of the atmosphere as affecting migrations and captures, so little has yet been ascertained on these points that I think it better to refrain from speculating upon them. Fishermen assert that prevalent winds are a cause of migrations, and if so this is probably effected through acting on their food. Also that unusually severe and long-continued rrost during winter and spring induce movements among large shoals, and bring them nearer in shore. Seasonal changes, however, doubtless have an effect in hastening or retarding the advent of herrings; while diurnal variations may likewise be coincident with the bathymetrical depths at which they are found; storms may drive them from shallow to deeper water; while the herring season commences and also terminates earlier in the north than it does in the south; but much more than this facts scarcely warrant us to assume.

The Scotch Meteorological Society observe that the results of examining the daily register of thermometers used in twenty fishery districts on the east coast, go to show a close relation between the fluctuations of the catches and changes of temperature, wind, sunshine, cloud, thunder, and other weather phenomena. Maximnm catches having been recorded when the temperature of the sea was about 55.5 degrees, while thunderstorms if widespread were followed for days with small catches over the area which had been covered by them.

$\mathrm{Mr}$. Cleghorn concluded an interesting report upon these fisheries with a comprehensive summary. Some of his conclusions were as follows:-That there were fishing stations some years ago on the Scotch coast which are now exhausted, a steady increase having taken place in their produce up to a certain point, then riolent fuctuations and finally extinction. The races of herrings near our large cities have disappeared first, and in districts where the tides are rapid, as among islands and in lochs. Where the fishing grounds are circumscribed the fishings are precarious and brief; while on the other hand extensive sea-boards having slack tides, with little accommodation for boats, are surer and of longer continuance as fishing stations.

I will now refer to the herring fisheries along the north-east and east coast of Scotland respecting which we are told that, "at the beginning of the present century herrings were so abundant along the north-east coast of Scotland, and came so close in shore that numbers of them were caught by people standing upon the rocks having no other instrument of capture than baskets tied on long poles," a condition of affairs which hardly applies to the present time.

At Wick, the largest race usually arrives with the new year, remaining until about March and then disappears. Mr. Reid found in Jannary, 1889, that some were a foot in length and thick in proportion, but all were full of milt or roe. The next herrings come in May or June in the shape of a few small ones of little value as 
food, although useful as bait for other fishes, and which appear to be the forerunners of the summer fish, as they grow better, larger, and fatter as the season ardvances until they are in perfection about July and August, spawning about the end of the latter month or early in September, after which they disappear until the succeeding January (Reid MSS.). If we turn to the Herring Fishery Report of 1878, we are informed that "it is a very remarkable circumstance that the yield of the fishery at Wick began to decline at the very period at which the produce of the Aberdeenshire fisheries began to increase" (lxiii). Here Mitchell, who wrote in 1864, observed they are at first so small that the nets cannot catch them, but they begin to be of sufficient size in July (at this time the mesh of the nets was not less than one inch between knot and knot).*

In the fourteen years from 1849 to 1862,1003 boats were annually employed in fishing at Wick with an average catch per boat of 133 barrels. During this period no winter fishing was carried on : it now commenced, and in the fourteen years from 1863 to 1876,885 boats were annually similarly employed, and the average catch per boat was 108 barrels. Mr. Reid tells us that in 1883 great success has again attended the Wick herring fisheries in 1880 (the heaviest fisheries), the average to the same date (end of August) was 170 crans a boat, but in 1883 it has risen to 230 crans arerage to the 518 boats, but the fish were at least 70 miles from land. Further to the south, however, a different account was given at the same date, for after an exceptionally poor season the herring fishery at Aberdeen was brought to a close in September, when an average catch of 89 crans for 463 boats was announced, as against $166 \frac{1}{2}$ for 433 boats last year. Fish having been scarce and the weather unfavourable. The herring shoals further north have been much larger, and less distant from shore. It was noticed that the Wick Chamber of Commerce for some years gave a premium to the fisherman who landed the first herrings of the season: thus fishing gradnally changed from July to the third week in June, the quality at first being small and mostly only fit for bait. This, it is stated, prematurely disturbs the shoals and injures the future prospect of the fisbing. $\dagger$

Herring shoals appear on the north-west coast of Scotland at the beginning or middle of May when during that and the subsequent month they are mostly "matties." The great fishery there is in the Minch between Long Island and the main land, continuing until the commencement of July. While on the east coast the chief fishery begins about the middle or end of July until the end of September, the fish being full of roe, while the fishery at Loch Fyne and the south-west coast of Scotland coincides with that on the east, the fish likewise being in a similar condition. Off the coast of Ayrshire on the Ballantrae Bank the great fishery is during February and March. A short supply of summer herrings, observes Holdsworth, has been frequently accounted for by the preceding fishery having been largely worked. On the other hand it has been contended that the summer fish are often as abundant as they ever were before the spring fishery came into fashion. Recent experience, however, does not support this statement, as with a more or less successful series of spring fisheries, the summer herrings have been exceedingly scarce for the last seven years. (Deep-sea Fishing, 1873, p. 123.)

In the Moray Firth (Gordon, Zool. 1852, x, p. 3480) these fish are generally sought for during six weeks subsequent to the middle of July. They gradually move westwards and congregate on the far-famed Gwillam Bank, about half a square mile in size and opposite the Bay of Cromarty. A storm sends them away and they do not return that year. About the middle of August they swim lower in the water and generally disappear in September. He likewise alludes to winter herrings, a stronger and larger variety with fewer scales. In looking at

* M. De Canx observes that for the purpose of capturing herrings the mesh of the nets since 1864 has diminished off the Norfolk coast to forty or forty-four to the yard: ten to twenty years ago five-sixths of the catch were full fish, but for the last ten years the proportion has not been above two-fifths, due to the change in the mesh of the net; these immature herrings will take the salt but they will not keep.

$t$ The same opinion seems to have found favour at Peterhead, $\Lambda$ berdeen, and Montroe, that the early fishing has a bad effect on the off-shore banks increased by the repeal of the enactments against garvie fishing, which occupation commences in November and occasionally lusts until Marcl. 
the conformation of the Scotch coast we observe on the west numerons narrow lochs, whereas on the east we perceive three large firths. From some cause it is evident that the augmented captures of late years have been among fish out at sea, as 60 to 80 miles or more from the coast.

The Yarmouth herring fishing in 1881 commenced June 16th, but the fishing there and at Lowestoft generally extends from October to December 16th, during which period nearly 218 millions of fish were delivered at the wharves, which at the wholesale price of $£ 15$ a last, shows a total of $£ 250,000$. Along the Devonshire coast in 1880 this fishing commenced about November 13th, and a fortnight earlier than in 1879 (as was likewise the mackerel fishery).

In Devonshire and Cornwall there are two annual migrations of herring. The first, or large herring, with undeveloped roe, matties, approach the coast in May or June, a few being secured in the mackerel nets, while some continue to be so taken until the mackerel fishery ceases, about July. About the same time, May or June, quantities pass up St. George's Channel to the Irish Sea, and are supposed by fishernucn to re nain in deep water. In June or July they proceed in a northerly direction, very few remaining off Cornwall, and do not return there until October or November, or even as late as December, their migration towards the coast occurring especially if the weather is fine. Should a storm arise they at once retire to the deep and do not reappear off the coast until fine weather has recommenced. By February or March they become "shotten," poor and thin. Besides these large herrings there is a migration of the smaller ones early in November which, as Mr. Dann has observed in Cornwall, migrate to the west at the extreme northern extremity of the county. Various schools pass by Port Isaac, New Quay, St. Ives, around Land's End, and eastwards into Mount's Bay or by Falmouth and Mevagissey, finally stopping at Bigsbury Bay, the bottom of which is rocky, uneven, and covered with flexible corals (Gorgonia), and here they congregate until the January spawning season.

Means of capture.-For the purpose of indicating where the shoals of herring are the presence of whales or flocks of sea birds are often useful, but if no such indications are present the nets are frequently shot at a venture. Formerly it was the invariable custom to cast their nets by night for fear of scaring the fish, but now this rule is being broken by some vessels. On very dark nights the phosphorescence of a shoal if near can be readily perceived, in fact off the east coast the majority of fishermen assert that they always wait until "the flame" is visible, and consider that they are able to tell the difference between "full " and "shotten" fish, a shoal of the former swimming close together in a compact body, whereas in the latter the individual fish are constantly dashing about. In some places the shad is termed the damon herring, and popularly believed to lead the shoals.

In fishing for herrings a number of drift nets are joined together and these are termed a "fleet," the length of each being about 20 yards, while from 101 to 181 comprise a fleet, the length of which off the east coast varies from $1 \frac{1}{4}$ to 2 miles. The Scotch fleet consists of 48 pieces, each 40 yards long. They are made of cotton, which is found much more destructive than hemp which was formerly employed. The mesh should be of sufficient size to allow the herring to obtain entrance for its head as far as its gills. During the autumnal herring season it has been computed that there are frequently from 8000 to 10,000 miles of nets in the North Sea at one time. In 1809 it was enacted that the size of the mesh should be 1 inch from knot to knot or 4 inches all round; and in 1839 France signed a convention with Great Britain constituting it the law for both countries; this was abrogated in 1864, and in 1868 the regulation was repealed. Since then the fishermen have reduced the size, and off the east coast the mesh has become from 40 to 44 to the yard, catching large fish by the snout but allowing them to drop out and be lost.

Shoals of herrings have occasionally been met with of such considerable size that they have broken the warp rope of the nets, and the whole of the gear has been carried to the bottom.

As herrings are canght at sea they are put into the hold and mixed with salt: 
ice may likewise be employed for this purpose. The fish first removed are the most valuable, as having been subjected to less pressure and a purer atmosphere. As a rule when the sea is calm and the temperature high, the takes become more or less spoiled before they can be landed; in some places the use of steamers has obviated this, and communications between the fishing fleet and the shore may be maintained, as at Montrose, by the employment of carrier pigeons. If the steamers were furnished with a double set of gear so that the tanks containing the captured fish could be removed at once and fresh ones substituted, a tide would be gained to the manifest advantage of the fisheries, as the steamers could at once return to the fishing fleets. M. De Caux has given it as his opinion that the alterations in the fishery laws have been so mischievous that now, although the killing powers of drifters in the same district (Yarmouth) have increased six-fold, the quantity of herrings captured has augmented but slightly, even if it has at all.

On the Devonshire and Cornish coasts drift nets and moored nets in the bays are employed occasionally up to the end of February; even as late as the middle of March, 1882, small boats were still capturing them with drift nets off Plymouth, but the moored nets had been laid ap antil the next season.

Along the Cornish coast there is no special fishery in the spring for herrings; some stragglers are taken in the mackeral nets and subsequently in the drift nets employed fishing for the early shoals of pilchards in July and August, when they are chiefly found in deep water. Boats from Mount's Bay, Cornwall and St. Ives leave for the Irish shores about the first week in June and rendezvous at Howth to the north of Dublin Bay, where the best fishing is about the last week in June or the first week in July; subsequently it generally decreases and the boats go north.

Herring fishing may frequently have to be suspended, or even entirely given up, due to stormy weather preventing fishermen from venturing out to sea. In 1880, the Scotch fishermen had a most successful year, but it was remarkable that the greatest amount of success attended the efforts of the drift-net boats. The trawl-net boats were continually coming in clean, and, with rare exceptions, were very poorly fished until the recent cold, frosty weather set in, when some splendid takes were secured, yielding to each crew for one night's fishing from $£ 100$ to $£ 200$. Such a marked difference between the two modes of fishing has never been observed before, and as yet no real cause has been assigned for it.

The "dandy-line" is used in herring fishing at Peterhead, during April, May, and June. A piece of lead about $1 \frac{1}{2} \mathrm{lb}$. in weight is attached to a line, which carries at short intervals transverse pieces of whalebone or cane, having unbaited hooks at either end. Herrings are such hungry fish that they fly at the naked hooks and are easily canght in this manner (Anglers' Note-book, p. 48). The hooks must be kept moving about and the water should be a little discoloured.

Along the coasts of Down and Antrim, large quantities used to be taken by means of hand-lines. The hooks being dressed with feathers, and the time of fishing being evening or sunrise (Thompson). Neill remarked that off the Scotch coast they were often taken on hooks baited with limpets.

Off Northumberland and Durham, we are told that herrings used only to be fished when in their prime, or from July to September: now from 100 to 150 large boats come from Scotland every spring, and young herrings are captured from May right on, but they are poor and tasteless ( $G$. Rowell, Land and Water, July, 1881). Mr. Southwell, off Norfolk, considers that there can be no two opinions as to the small size and inferior quality of the "spring herrings," and thinks that it is a matter of regret that they should be taken at that season.

Superstition enters largely into the composition of fishermen, and in the Banff Journal of 1855, it was recorded that the herring fishery being very backward, some of the fishermen of Buckie dressed a cooper in a flannel shirt, with bars stuck all over it, and in this condition he was carried in procession through the town in a hand-barrow. This was done to bring "better luck" to the fishing. A century or two ago not merely effigies, but living men and women, were burnt on suspicion of casting a blight on the herring-fishery; even at the present day it is common for whale-fishers to burn an effigy in order to "bring luck." If a ship has fallen in with few whales, the crew attribute their bad fortune to having some 
anlucky individual on board, and by burning his effigy they believe that his malign influence is got rid of. The most unpopular man in the ship is generally pitched upon as the offending party. Sometimes two or three "pictures" are burnt, one after the other, if luck is very bad. The practice is a very old one, and is said to have taken its rise from a similar custom which prevailed among the herring-fishers of Banffshire, by whom it was introduced on board of the Peterhead whalers.

In Norfolk (Notes and Queries, October 7th, 1865) we are told existed a fancy that fleas and herrings come together. "Lawk, Sir," said an old fellow near Cromer, "times is as you may look in my flannel shirt and scarce see a flea, and then there ain't but a very few herrings; but times that'll be right alive with 'em, and then there's certain to be a sight of fish." Low, in his tour through the Orkneys (1774), says that as much as $£ 50$ was paid for the first barrel of herrings of the season that arrived from Shetland, this first instalment of the herring market being regarded there as medicine. Red-finned ones appear to be considered as omens of success on some parts of our coasts, and Mr. De Caux tells us that as soon as one is perceived, it is taken from the net, carefully prevented from touching anything made of wood, and passed round the scudding-pole as many times as the fishermen desire to get lasts of herrings at their next hanl.

A Manx man going herring fishing dares not proceed to sea without taking a dead wren in the boat for fear of disasters or storms. There exists a tradition of a sea-spirit that haunted the herring.tack, attended always by storms. Finally it assumed the form of a wren and flew away. It is imagined that the presence of a dead wren makes all snug (McTaggart).

Breeding.-The period at which the herring breeds is subject to great diversity, inasmuch that some persons have questioned whether it may not do so twice in one year. At Wick on the north-east coast of Scotland, Mr. Reid informed me (January 18th, 1882) that early in January this year they were in a spawning condition but no shotten ones as yet to be found, while they again spawn there in August and early in September. The same has been observed in the Moray Firth by Gordon. Herrings taken on the Ballantrae Bank off the Ayrshire coast in February and March are either spawning or shotten. Herrings spawn on the east coast of England and Scotland (taking the extreme dates) from the latter end of May to December, that is, measuring from the Shetlands to the North Foreland; these Ballantrae herrings never spawn in August, but, on the contrary, begin about the 1st of February, and the spawning goes on till the 1st of April. This spawning bank is ten miles long and two miles broad. The average depth is ten fathoms at low water (Buckland).

On January 5th, 1882, I found that most of the herrings in the fish shops and which bad been received from Cornwall were shotten, others were fall of milt or roe. At the end of August, 1881, many were in full roe, and on December 13th I first saw some shotten* ones, but was informed some had been received previously. Mr. Dunn observed that all the herrings which visit the south coast of Devonshire late in November, throughout December, and early in Jannary are in spawning condition. Six hundred thousand were landed in Plymouth one day last week and the spawn was almost ready for extrusion in the whole of them (Land and Water, Dec. 24th, 1881). A month later he found at Mevagissey that the spawn was running from them. He considers that there are two herrings which spawn on the Cornish coast, the smaller in December and January and which is not so regular and certain a visitor as the larger one, which spawns in February and March. The lesser ones seem to migrate along the coast, the larger ones to come from the deep sea. Andrews (Feb. 14th, 1882), writing from Swanage, in Dorsetshire, stated that he had two dozen brought to him fire days previously all fullroed, and many on the 14th, while the pier-master informed him that the first signs of spawning were noticed yesterday, and the fishermen reckon, as a rule, upon taking full fish more or less up to March. Mr. Wilcocks (Field, Feb.

* M. Bertrand, in his article on Alose, published in 1776, remarked that " it appoared certain that in the English Channel many herrings begin to spawn about November 25th, although in certain jears some are still found full in February." 
25th, 1882), remarked from Plymouth that the herrings have not yet left the coast, and many among them have not yet spawned. It is evident that off Great Britain there are two chief periods for spawning, but that at various places some spawning fish may be captured at any month throughout the year. The autumn breeding time would appear to be the most extensive.

The number of eggs which have been found in a single herring has varied from ten to thirty thousand, when shed it sinks to the bottom of the sea, while along with it is a glairy fluid which enables the ova to adhere to any object with which it may come in contact. Ropes or nets drawn through herring spawn become thickly coated with it, and large quantities are brought on to the decks of fishing boats. Nets set in water where spawn exists in a very short time become heated similarly to what occurs when heary catches of fish have been made. The locality selected is often over rough ground, while sea-weed may be found covered with this adhering spawn. In the Baltic and localities where the water is brackish and almost fresh they have been observed to select two or three feet of water for this purpose. It seems highly probable that they deposit their spawn wherever they happen to be, as herrings in which this was exuding were taken at least forty miles ont at sea, or in forty to fifty fathoms of water, while it is very attractive to other fish especially cod. Spawning fish are captured in shore and far out to sea at the same time, while shotten and maxy ones are frequently found together.

The escape of the young from the eggs, either in spring or aatamn, can be considerably delayed by keeping the water very cold, while its saltness or reverse* exercises no appreciable difference. Three to four weeks has been suggested as the probable time at which hatching normally occurs after extrusion. While if these eggs are heaped together they become mouldy. Meyer found that in a few days after being hatched they commenced preying upon microscopic forms existing in the water, after a month on small crustacea, and at the end of the third month they were a little over $I_{2}^{1}$ inches in length. Beyond five months he could not keep them alive. The young, known as whitebait, swarm along our shores in certain localities, sometimes to a great extent mixed up with sprats, at other time in independent assemblages.

Mr. Stevenson (Mansion House Street) hatched some. The spawn was obtained November 10th, 1870; by the 17th the eyes and movements of the young fish were plainly visible through a hand-magnifier, and on the evening of the 24th (fourteen days after they had been taken from the parent and impregnated) many shells were found empty, but only one little one could be seen, for they are so minute and transparent that there is but little chance of finding them in a large body of water. By enclosing the ova in a suspended muslin receptacle in the tank several more were hatched out by the 29th. Dr. Meyer, respecting the experiments made in the North Sea, observes that no one has succeeded in rearing herrings from artificially fecundated eggs, owing to the impossibility of arresting the formation of hyphr of some fungus, and the difficulty of obtaining suitable food: very soon after the jolk was consumed they died.

H. Widegren, in Scandinavia, found that certain races of herring, particularly the larger ones, spawn near the land on a bottom overgrown with sea-weed. If this bottom is made unfit for spawning by taking op or destroying the sea-weed, either by nets or any other way, the herring becomes obliged to migrate to more suitable places, and consequently deserts the inlets where he formerly visited regularly. "By experience gained in Bohuslän and other places, it is proved that the herring is extremely sensitive in this respect, and deserts old spawning places entirely if their character is changed." Vegetation ought not to be disturbed nor refuse cast into the water.

It now becomes necessary to consider, What do we understand by whitebait, or "white bite" as it has been termed? Here we must first seek for the origin of

* In the Baltic the German Commissioners ascertained that with the water at $53^{\circ}$ the eggs hatched in a week, whereas at $38^{\circ}$ they took six weeks, while raising the temperature above $53^{\circ}$ did not quicken the batching process. 
the term, and at the outset $\mathrm{I}$ am inclined to admit that such appears to be lost in obscurity.

It is stated that at the funeral feast of the founder of the Charterhouse in 1612 , six dishes of "Whitebait" were included in the bill of fare. If we refer to Pennant's British Zoology, vol. iii, p. 371, 1776, we read as follows :-“During the month of July there appear in the Thames, near Blackwall and Greenwich, innumerable multitudes of small fish which are known to the Londoners by the name of whitebait. They are estecmed very delicious when fried with fine flour, and occasion, during the season, a vast resort of the lower order of epicures to the taverns contiguous to the places they are taken at."

Pennant stated they belong neither to the shad nor the sprat, nor are they the young of smelts, but bear a great similarity to the bleak, to which fish he appended them, although with doubt. Donovan (1808) obtained as whitebait the young of the shad, and calmly expressed his opinion that Pennant never saw a whitebait, or, if he did, his examples were bad, or his investigations hasty and negligent, while his figure conveyed no just idea of the fish. Next we have Yarrell (1828), who considered that both Pennant and Donovan were in error, as he saw in these fish a new species of Clupea, which he termed Clupea alba. M. Valenciennes (1847) went still further, instituting a genus (Rogenia) for its reception, while he remarked that some young sprats were captured along with the true forms during the months of April, May, and June. Dr. Günther did not coincide with any of the four previous writers, and considered it to be the young of the common herring.

It is unquestionable that the true whitebait belongs to the herring family, but are such mature forms as asserted by Yarrell and Valenciennes; or immature fish, as believed in by the majority of inquirers, and as such were formerly protected by legislative enactments? In this investigation we must not lose sight of the fact that the herring family, more especially among the species composing the genus Clupea, possess many pelagic forms, which lire together in large assemblages or schools, the young of which but rarely enter brackish, and never as a rule fresh water. Another peculiarity is that, the teeth being small and deciduous, a considerable diversity as regards their existence may occur in examples of the same species.

Are whitebait mature fish? This question has been answered by most investigators in the negative, by Yarrell in the affirmative, while fortunately the specimens of this last author, being still in the British Maseum, are open to re-examination. All are certainly the young of the common herring. Yarrell remarked that these fish are taken in the Thames "from the beginning of April to the end of September . . . and specimens of the young fish of the year, four or five inches long, are then not uncommon, but mixed even at this late period of the season with others of very small size, as though the roe had continued to be deposited throughout the summer. Yet the parent fish are not canght." I have now a fine series of whitebait captured during the months referred to by Yarrell, and from the same locality (the Thames), and these I now propose enumerating, premising that, as the migrations of members of the herring family are variable, occasionally forsaking their usual spawning grounds, it does not appear improbable that one species may have left and given place to another, to be again changed to the original form on the return of the water to some condition which suited its first occupants. Thus Yarrell observes: "Formerly great quantities of the Twaite shad were caught with nets in that part of the Thames opposite Millbank, Westminster." At Teignmouth in Devonshire, in August, 1882, all the "britt" or whitebait were young of the herring, while in Angust, 1883, every one were small sprats.

I examined 138 examples of whitebait from the Thames, taken during the months of May and June, 1878, the longest of which was $2 \frac{1}{2}$ inches; out of these about one in ten were sprats, the remainder the young of the herring. In August I examined forty-six examples from 2 to $3 \frac{1}{2}$ inches in length; out of these twentyfour, from 2 to 2.7 inches long, were sprats, and twenty-one, from 2.8 to $3 \frac{2}{2}$ inches long, were young herrings, these latter now commencing to grow to a larger size 
than their smaller relatives, the sprats. In October, out of forty-one examples from $2 \frac{2}{2}$ to $3 \frac{1}{2}$ inches in length, all were herrings. It appears that both sprats and young herrings find their way into the London market as whitebait. Some inquirers may obtain one species, some the other, while a third may receive both forms, in accordance with the locality the fishermen were working their nets and whether schools of one or both were present at the time.

Of the thirty-one examples of "Winter whitebait" received from the Medway, twenty-six varied from 2 to $4 \frac{1}{2}$ inches in length, the larger ones possessing welldeveloped roe; all these were sprats : the remaining five were young herrings from 5 to $7 \frac{1}{2}$ inches long, the largest having slightly developed roe.**

How are these young fish to be distinguished? may be asked, and to this question a very simple reply will suffice. The sprats have sisteen to eighteen rays in the fin of the back, and seventeen to eighteen in that behind the vent. The ventral fins are situated beneath the first rays of the back fin. They have fortyseven or forty-eight vertebræ, no teeth in the front part of the palate (the romer), and in a single or double row along the tongue, while internally they only possess seren or eight cæcal appendages at the pyloric end of the stomach, while the edge of the abdomen has very sharp points, entirely dissimilar in the two forms as I have pointed out (page 209). The young herrings have seventeen to twenty rays in the fin of the back, and sixteen to eighteen in that behind the vent. The ventral fins are situated beneath the middle rays of the back fin. They have fiftysix vertebræ, teeth in the front part of the palate (the vomer) and in a long oval patch along the tongue, while internally they possess seventeen to twenty or more cæcal appendages at the pyloric end of the stomach. The keeled abdominal edge is not nearly so sharp as in the sprats, while the scales do not fall off the body quite so readily as in the latter species, in which but few are seen on the sides in captured examples. Due to the position of the back fin fishermen can recognize these two forms by holding them up by the dorsal fin, when the sprat trims by the head, but the herring by the tail.

That Pennant's was the whitebait of the present time there can be but little doubt, and likewise that it was the young herring. It is also certain that Donovan's figure is that of a young shad, the immature of which, if in sufficient numbers, would do as well as those of the herring or sprat served up as whitebait, while I certainly possess the young of these last two forms which I have received as this fish.

During the summer and autumn of 1874 several hundred small whitebait were imported to Manchester from Colwyn Bay, North Wales. During the first eighteen months of their captivity they grew to at least half the size of a fullgrown herring, with which species there was no gainsaying their identity (Zool. 1876 , p. 4855). Meyer states his grew only to $1 \frac{1}{2}$ inches in length in five months. Mr. Sim, of Aberdeen, observes that he found herring fry in the rock pools in great numbers in the months of June and July, all from $1 \frac{1}{2}$ to $2 \frac{1}{2}$ inches long, and which he concluded were from the March spawning, or four to five months old.

As these fish arrive at maturity, very conflicting evidence has been adduced respecting the time at which they first breed. Some (as De Caux) have believed this to be well within twelve months, a supposition somewhat confirmed by my examination of whitebait and detecting ova (see above) : eighteen months has likewise been suggested (Mitchell); also that they are approaching the expiry of their second year before they shed their first ova (Sim). While some observers believe they spawn twice a year, others as positively affirm the contrary.

Hermaphrodites. - Yarrell refers to one (Proc. Zool. Soc. 1845, p, 91), as does also Malm, who describes and figures it (GEv. Ak. Förh. 1876, pl. v) : likewise J. A. Smith (Journ. Anat. and Phys. iv, 1870, p. 258).

Herring fisheries.-It would appear from the Commissioners' report that young herrings along the east coast of Scotland were first permitted to be captured in small meshed, sprat, or garvie nets in 1868: the true garvie being the sprat, Clupea sprattus. Some of the witnesses averred that when garvies are scarce

* Yarrell remarked that if whitebait die in fresh water the air-bladder collapses (P. Z. S., 1830, p. 73). 
many young herrings are sent away with them, while it is impossible to take garvies without taking the young herring. One witness asserted baving purchased thirty barrels of garvies in one day, and found they were all young herrings. My only personal experience consists of some garvies from the north-east coast, most of which were undoubtedly young herrings. They were about three inches each in length, requiring 288 to weigh a pound. Whilst from Inverness we are informed that in three years ending 1876-77, the Highland railway carried on an average 267 tons of garvies annually to London.

I would here venture to suggest that it would be very desirable that an inquiry should be made as to whether or no the cessation of the in-shore herring fisheries has been coincident with the extension of the garvie fisheries.*

There are, it appears, two chief periods when herrings appear off the east coast of Scotland, while the winter, June, and garvie fisheries are partially or wholly new institutions. Whether they have or have not any bearing upon the cessation of the in-shore herring fisheries I have not sufficient evidence to adduce. Still it is by no means impossible that some fishes, especially such as are of gregarious natures, mostly return to the place where they were reared.

Respecting the capture of the herrings off the east coast of Scotland, it is evident that the great bulk of the fishing is carried on much farther out to sea than it was a few years since. Still it does not seem at all proved that the in-shore fishing has been neglected, but the probabilities are that the fish are no longer there in sufficient numbers to repay the fishermen's labours.

If we take the average capture of herrings as shown in the Scotch Fishery Reports, $\dagger$ we find them as follows :-

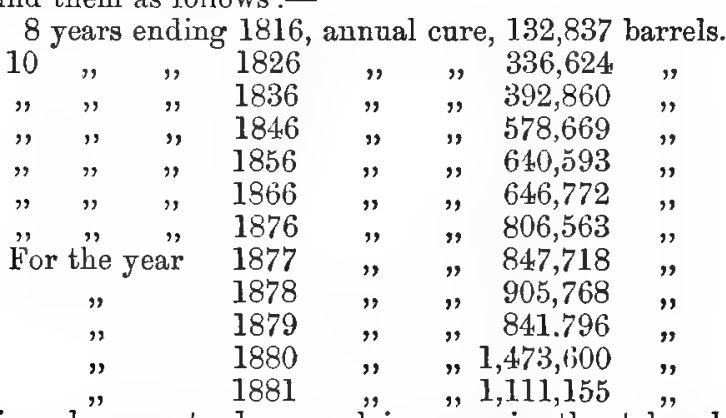

The foregoing shows a steady annual "increase in the takes, but it mast not be overlooked that during this period some questions omitted by the Commissioners appointed to investigate the condition of the Scotch berring fishery force themselves upon one's attention. First of all, one is led to ask what proportion of persons are now engaged in this occupation to the numbers that were thus employed at the commencement of the present century? Is the augmentation of captures due to increased facilities of capture, larger ventures in fisheries, or simply becanse the fish are more abundant?

The earliest date on which any confidence can be placed in the returns as to the number of fishermen $\ddagger$ employed is from $1825, \S$ and I find that the number of barrels of cured herrings has gradually increased from about 379,000 in Scotland and the N.E. coast of England until they have reached to upwards of a million during each of the last two years, while the fishermen and boys have

* In Norway it has been found that a diminution of herrings in the creeks has been coincident with an extension of the whale fishery. It is believed the fish escaped into the inlets from their pursuers. The terror of the nets in the inlets was less than that of the whales in the ocean, but these latter being killed the herrings do not now swarm into the creeks.

$\dagger$ These returns were from April to April up to 1843 ; those up to 1849 include those of the N.E. of Fingland; from 1850 to 1868 tbey include those of the Isle of Man; from 1869 they refer to Scotland only.

$\ddagger$ I do not allude to figures handed down prior to the commencement of this century. As, for instance, we are told that in 1667 the Scotch had 800 fishing boats, manned by upwards of 5000 men, engaged in the herring fishery.

\$ This includes the line fishing, but the two are not separatel; the proportions frobably continue much the same. 
increased by almost 4000 . The proportion of number of fishermen to barrels of herrings cured has averaged as follows :-

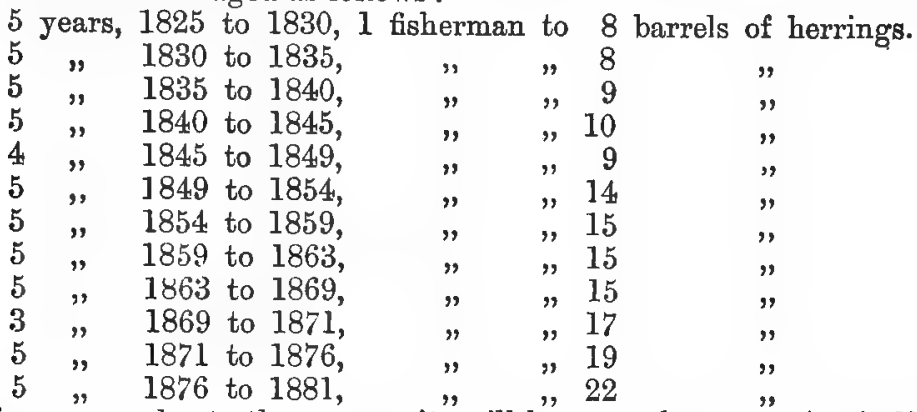

The immense value to the community will be seen when attention is directed to the value of the fishing gear in Scotland having averaged $£ 1,263,737$ for the last five years, while each barrel of cured herrings is estimated to be worth about $25 \mathrm{~s}$.

But when we inquire into the gear employed, we are told that cotton nets came into use about 1856, and rapidly superseded the hempen ones. A boat which used to carry 24 hemp nets, 40 yards long, equivalent to 960 yards of netting, now employs 50 to 60 cotton nets each 60 yards long, equivalent to 3300 yards. The nets per boat we are told " used to present a catching surface of 3000 square yards ; they now present a catching surface of 33,000 square yards." The Commissioners estimated when giving the foregoing figures that "each boat has increased its power five-fold." But the amount captured does not appear to have kept pace with the increased killing powers, for if so the fishermen who from 1825 to 1850 while employing hemp nets obtained from eight to ten barrels per man, should now, were the proportions equal, be capturing from 40 to 50 barrels, instead of about 22. It has been computed that there are 30,000 fishing vessels of about 280,000 tons tonnage, manned by 165,000 men and boys, engaged around our islands, and most of which are or have occasionally engaged in the capture of herrings. Numerous trades are dependent on the success or the reverse of this fishery.

It would be an exceedingly interesting investigation as to what is the effect on the eggs of herrings deposited in depths over 50 fathoms. This can only be ascertained by a series of experiments carried on in the ocean, as I have already but uselessly advocated. If this deeper water has no deleterious effects upon the hatching of the eggs the question arises whether such has any action on the fry, or if when hatched they are in as good a locality for being reared as if they were nearer in-shore. Lastly, I would remark that if the herrings have, due to changes in our fishery laws and consequent methods of fishing, been unduly interfered with, so that the shoals are now further out to sea than was formerly the case, thus necessitating the employment of larger boats, has not such occasioned a great loss of life? That going further out to sea to obtain these fish is a necessity is now admitted, while the harbour accommodation remains the same, boats are thus unable to enter during storms and a great sacrifice of life is the result. This is another and most important factor which onght to be taken into consideration when deciding upon the necessity or the reverse for investigating the results which have followed the legislation of the last 18 or 20 years.

As food.-Herrings are very largely employed as food either in a fresh or cured condition. Of course in different localities these fish may be and often are differently treated. Usually care is taken in selecting and assorting such fish as have to be cured and also in obtaining the services of competent gutters, while the rapidity with which the various processes are carried on, the seasoning of the barrels when such are used, and period at which they are fastened down, all are important factors in the condition in which the cured fish will be found.

In the north of Scotland the herrings on arrival are placed in a heap near the troughs of the curers, next they are gutted by individuals who at one cut remove the intestines and gills. They are then "roused" with salt in a tab and lastly packed in layers in barrels, a handful of salt being sprinkled over each 
layer. All broken or inferior fish, or those which have received too small an amount of salt, should be rejected. As the contents subside a fresh layer of fish is added, for the barrel must be kept full.

Yarmouth bloaters are variously prepared, but one of the best solutions in which this can be effected is mixing $29 \mathrm{lb}$. of common salt with $71 \mathrm{lb}$. of water, in large vats; in this the herring will float, so they are kept down by wooden battens weighted with bags of salt, which gradually dissolve and keep the solution at its proper density. When the fish have become rigid the pickle is run off and the herrings are suspended in a current of air until they are removed to a chimney and smoked from 12 to 18 hours, the fuel employed being two parts of oakwood, beechwood, and turf. These bloaters will keep four or five days, but are best if hanging in a current of air.

Red herrings are bloaters more strongly cured, the pickle having about $\frac{1}{16}$ of its weight of saltpetre added to the salt. They are dried for 24 or 48 hours and then smoked to the requisite tinge.

Kippered herrings are such as are pickled, dried, and split down the back almost to the tail fin, showing the back bone, the gills and intestines are removed, they are then cleaned with salt and water, and suspended for a night in a current of air and then smoked until they are of a light brown. They do not keep long.

The date of 1794 is given as that in which ice was first employed in Scotland to add to the herrings which were packed in boxes and sent by fast sailing vessels to London.

The present railway rates are levied in a most incomprehensible manner on the carriage of fish, rendering their being thus carried, except at a loss, often a matter of certainty; while in Land and Water (August, 1881) we read :--"The charge for the carriage of herrings from Berwick-on-Tweed to London being the same as that from the extreme north of Scotland, although the distance is about 300 miles less, several herring buyers have complained of the unfairness, and have taken steps to obtain a revisal of the rate. This week they have sent their fish to London by steamer at a cost of $2 s 4 d$ per barrel. The railway rate varies from $7 s$ to $9 s$ per barrel."

Uses.-Largely employed as bait for cod, ling, and long lines generally, and they have, when very numerous, been boiled down for the oil which they contain.

Lacépède inquires "what honours are not justly his due who first taught mankind the art of impregnating the solids of the herring with sea salt?" Unhappily, the subject is so interwoven with discrepancies as to date and nationality that no answer worthy of credit can be given. At the beginning of the twelfth century there were herring fisheries in the Baltic, to which many foreign vessels resorted; these herrings must, therefore, have been salted; in fact, in 1155 Louis VII of France prohibited his subjects purchasing anything but mackerel and salted herrings at Estampes. In 1290 part of the dried fish shipped at Yarmouth, in the victualling of a vessel to bring the infant Queen of Scotland from her Norwegian sire, were herrings, and these, of course, were cured. In the time of Edward III, mention is made of some white herrings found in vessels captured by the Cinque Ports; and in the same reign red herrings are also specified by name, so that both sorts of curing were practised before the time of William Berkelszoon, of Biervliet, in Flanders (he died 1397), who has been credited with the distinction of introducing them. There is, however, no doubt that he greatly improved the methods he found in use, by curing the fish in small kegs instead of piling them in heaps, which so extended the trade in them that Charles V erected a statue to his memory, and, with his sister, visited his tomb, and offered up prayers for his soul; while Mary of Hungary, during her visit to the Low Countries, paid a more characteristic tribute to his memory, namely, that of eating a salt herring on his tomb.

In our own country the herring fishery certainly flourished in the twelfth century, for in 1195, according to historians, the town of Dunwich, in Suffolk, was obliged to furnish the king with twenty-four thousand herrings. Mention is also made of the herring fishery in a chronicle of the Monastery of Evesham, in 709. The herring fair in Yarmouth was regulated in the reign of Edward III 
by the Statute of Herrings. On the old arms of the town were figured what are proverbially known as "Yarmouth capons," az. three herrings, arg.

In 1563 green or fresh herrings were so scarce, that at Yarmouth, the great mart, they sold at an unusually high rate; a last, or eighty bushels, brought $£ 9$.

In France, until the close of the seventeenth century, fish diet was scrupulously observed on fast days. Thibaut VI, Count de Blois, gave annually (by charter, 1215) five hundred herrings to the hospital of Beangency. Among the extensive charities of Saint Louis to monasteries and hospitals were sixty-eight thousand herrings. In olden times the soldiers engaged in warfare observed their Lent. Thus history informs us that while the English were besieging Orleans in 1428 one of the convoy of provisions destined for their camp was attacked by the Duke de Bourbon. It consisted chiefly of salted herrings, which gave rise to the conflict being called the "Battle of the Herrings."

A curious notice respecting the connection of herrings with marriages appeared in the Times (November 28, 1871), showing the results of the Scottish registers. In the return for the third quarter of the year, the registrar of Fraserburgh stated that the herring fishery was very successful, and the value of the catch, including casks and curing, amounted to $£ 130,000$ sterling, and the marriages were eighty per cent. above the average. On the other hand, the registrar of Tarbet reported a steady falling off in the fishing at that creek, and consequently the quarter passed without an entry in the parish register. The registrar of Lochgilphead stated the herring fishery to have been a failure in the loch, and this accounted for a blank in the marriage column for the quarter. One registrar, in his return for the quarter, reported marriages in his district "like angels' visits, few and far between." At the fishing villages it might be put more briefly-no herring no wedding.

Diseases and causes of destruction.-Whales, porpoises, seals, members of the cod family, dog-fishes, in short all predaceous fishes, especially hakes and whiting, feed on them from the time of their birth and throughout their entire existence, and in this they are assisted by birds of various sorts. Gannets are occasionally so gorged with herrings that they are actually unable to fly. In the North Sea the cod fishes leave the sea bottom at night time and ascend to the herring nets, from whence they violently pull out quantities of the meshed fish, and at the same time occasion much damage to the lighter kinds of cotton nets, in which they tear large holes.

Habitat.-White Sea, and perhaps extending into some parts of the Arctic Ocean: the colder to the temperate portions of the Atlantic : the North Sea and the Baltic, in which latter locality they are a small and inferior race. Also the North Pacific.

In the Orkneys, Low observed that the Shetland Isles swarm with them in April and later, the east coast of Caithriess in August, the Hebrides at the latter end of the year. The Sounds at certain seasons are alive with the fry. I have already alluded to their distribution along Scotland, the west coast of which country is studded with lochs, from which it is asserted they have commenced more or less to absent themselves, while along the east coast, possessing but three large bays or firths, they have latterly forsaken their haunts about 7 miles out to sea, and receded to 20,30 , or even 100 miles. I have also alluded to the distribution of the herring on the British coast, while it is common round Ireland. Along the southern shores of England I have already observed these fish are in diminished numbers.

The size to which herrings attain varies. De Caux observes that the largest he has personally seen was $15 \frac{1}{2}$ inches in length, but that $\mathrm{Mr}$. Utting, of Great Yarmouth, had one which was 17 inches long, but the usual average off our east coast is from 10 to 11 inches, and, if full, weighing from 4 to 6 ounces: a full one, $11_{2}^{1}$ inches long, will weigh 8 ounces. Buckland stated that the largest herrings submitted to him were from the Shetlands, the milt and roe were but slightly developed, they were very fat, and as long as $9 \frac{1}{4}$ inches and $7 \frac{1}{4}$ ounces weight. Sim, at Aberdeen, weighed some full ones $12 \frac{1}{4}$ inches long, and they were only $8 \frac{1}{4}$ ounces : the largest example he found in 1880 was $12 \frac{1}{4}$ inches, and weighed $9 \frac{8}{4}$ ounces. It was a full one. 


\section{Clupea pilchardus, Plate CXXXIX, figs. 1 and $1 a$, stomach and food.}

Sardina, Belon. p. 161 ; Rondel. pp. 217, 218; Gesner, p. 822 ; Ray, Syn. Pisc. p. 104. Harengus minor seu Pilchardus, Willughby, p. 223, t. P1, f. 1 ; Rutty, Co. Dublin, ii, p. 362. Pilchard, Pennant, Brit. Zool. (Ed. 1776) iii, p. 343, pl. lxviii (Ed. 1812) iii, p. 453, pl. lxxix. Sardine, Dubamel, Pêches, ii, pl. xvi, f. 4 .

Clupea sprattus, Brün. Pisc. Massil. p. 82 ; Risso, Ich. Nice, p. 352.

Clupea pilchardus, Walb. Artedi, iii, p. 38 ; Bloch, Ausl. Fische, ix, p. 40, pl. ccccvi; Bl. Schn. p. 425; Donovan, Brit. Fishes, iii, pl. lxix; Shaw, v, t. cxix; Turton, Brit. Fauna, p. 106 ; Fleming, Brit. An. p. 183; Jenyns, Manual, p. 437; Yarrell, Brit. Fishes (ed. 1) ii, p. 96, c. fig. (ed. 2) ii, p. 169 (ed. 3) i, p. 137; Templeton, Mag. Nat. Hist. (2) i, p. 411 ; Parnell, Wern. Mem. vii, p. 320 and Fish. Firth of Forth, p. 160; Johnston, Berwick. N. H. F. Club, 1838, i, p. 173; White, Catal. p. 83 ; Kröyer, Danm. Fis. iji, p. 175, c. fig.; Nilss. Skan. Fauna, iv, p. 522 ; Thompson, Nat. Hist. Ireland, iv, p. 177 ; Günther, Catal. vii, p. 439; Collett, Norges Fiske, p. 194; Winther, Prod. Ich. Dan. Mar. p. 49; Malm, Fanna, p. 585; Giglioli, Catal. Pesc. Ital. p. 46. p. 189.

Clupea sardina, Cuv. Règne Anim. ii, p. 319; Lowe, Trans. Zoo. Soc. ii,

Clupanodon sardina and pilchardus, Risso, Eur. Mérid. iii, p. 451.

Alausa pilchardus, Cuv. and Val. xx, p. 445, pl. 605.

Alosa sardina, Moreau, Poiss. de la France, iii, p. 458.

Pilchard, Couch, Brit. Fishes, iv, p. 79 , pl. cci.

B. vi-viii, D. $17.18\left(\frac{1}{1-\frac{3}{4}-\frac{1}{1}}\right)$ P. 16-17, V.6-8, A. 17-18 $\left(\frac{8}{14-15}\right)$, C. 19, L.1. 29-30, Corc. pylori numerous, ${ }^{*}$ Vert. $\frac{1}{3} 1_{1}^{\circ}$.

Length of head $4 \frac{3}{3}$ to $5 \frac{1}{2}$, height of body $4 \frac{3}{4}$ to 5 , length of caudal fin 6 to $6 \frac{1}{2}$ in the total length. Eyes - with adipose lids, diameter of each $3_{*}^{1}$ to 4 in the length of the head, $1 \frac{1}{4}$ diameters from the end of the snout, and 1 apart. Lower jaw slightly prominent; the maxilla reaches to beneath the first third of the eye. Opercle with distinct and well-developed striæ descending towards the subopercle. Body rounder than is that of the herring. Teeth-in jaws excessively fine, sometimes absent, none on the palate nor on the tongue. Fins-origin of the dorsal fin nearer the snout than it is to the base of the caudal fin. Ventral inserted below the middle of the dorsal fin. Anal low, its last two rays slightly prolonged. Caudal deeply forked with two or three large scales at its base. Gill-rakersabout 70 in the outer branch of the lower branchial arch and as long as the eye. Scales-17 to 19 scutes before and 14 posterior to the base of the ventral fin, they are very similar to those in the herring but a little stronger. Coloursgreenish olive, with a blujsh band along the body and silvery sides. Lowe gives 50 to 51 vertebræ, and Cuvier and Valenciennes 53. I find 50. In examining the digestive organs one finds the stomach as depicted: the proventricular glands in the rsophageal portion are well developed, while the walls of the pyloric portion are thickened and the mucons membrane is densely studded with glandular prominences. This portion of the stomach, after feeding, is distended by what may be likened to a sausage-shaped mass, consisting of an outer secreted membrane enveloping the food. The air-bladder has the same posterior opening into the progenital canal as recorded in the herring. (See Zoologist, 1882, vi, p. 24, on the digestive organs of the pilchard.)

Varicites.- In form. - It has been asserted that the sardine has the ventral fin inserted below the middle of the dorsal, and the gill-rakers rather shorter than the eye; but it is merely the young of the pilchard, which latter has the ventrals inserted rather behind the middle of the dorsal fin, and the gill-rakers a little

* Günther, Catal, l. c. gives cce. pylori 7, but probably he must have been examining a splat, the only British Clupea which possesses such a small number of uppenilages, and this is rendered more probable as he gives L. l. 47-48. The pilchard and sardine in many old works were included under Clupea sprattus. 
longer than the eye. In colour-it is by no means rare to see pilchards, even as many as one in five among thousands, sparingly marked with black spots, and which become still more apparent on the scales being removed. In some the eyes are black-ringed, in others white, the former, according to Mr. Dunn's observations, being most numerous in the summer months, the latter in the autumn. Mr. Couch, June 8th, 1868, observed: "I have also obtained a box of sardines from Marseilles, and am rather surprised to find them only so many small pilchards. I cannot find in them any difference from our pilchard, except that they are about five inches long and of poorer quality." That the sardine is the young or small pilchard has been asserted from the time of Belonius in 1553 to the present; it has also been so considered by all modern ichthyologists, and Dr. Günther in 1868, in Proc. Zool. Soc. expressed his surprise that it was not ntilized in the same manner as the sardine. Mr. Dunn, of Meragissey, appears to have been the first to propose preparing sardines in this country.

Names.-A dried pilchard in Devonshire is sometimes termed a fair maid, derived from fumado; smaller forms go by the name of sardines when tinned. Halliwell gives surding as symonymous with the pilchard. In Cornish it is known as hern, hernan, and llean. The term pilchard has been variously derived, some considering it to be from "pittch," an old English word signifying a piece of cloth to wrap round a young child, because these fish were formerly cooked in paper, similarly to red mullets of the present day. It has also been derived from peltzer, a name by which it was known to some early Northern Continental authors. It has been termed a "Looe trout," when impressed on a token struck at Looe in the reign of Charles II. Garvie-herring, Gipsy herring and Crue herring, Scotland. Pennog mair, Welsh. The springing of pilchards out of the water has been termed stoiting (East) or poppling in Devonshire.

Habits.-Gregarious but very timid fishes, and believed to be easily alarmed by noises.* They congregate in dense masses by day, but as evening sets in spread out along the shore ( $1 \mathrm{am}$ here alluding to St. Austell's Bay), apparently feeding from off the land, and so retire to the deeper waters with the return of the morning's light. At sundown nets are shot outside these feeding-places, thus arresting the shoals in their progress towards the deep sea, while during the daytime these fish are taken on the deep-sea side of the nets. As I have already alluded (note, page 220) to the herrings being driven from the open sea into creeks by whales, pilchards likewise have been known to ascend into brackish water when under the influence of fear. Thus, in 1722, a large number were taken in the Dart at Totnes Weir, haring been chased there by porpoises; and in $\mathrm{July}, 1880$, when it was nearly low water, one was seen coming down the same river by persons standing on Totnes Bridge, which is twelve miles from the sea, pursued by an otter; the pilchard leaped on the bank and was secured. They will eat small crustacea, and their stomachs are found gorged with such food, and also any similar to that eaten by the herring. The roe of the cod or ling they devour voraciously, also crumbs of bread. Off the French coast salted fish roe, mostly of the cod but also of the mackerel, mixed with the pounded flesh of that fish, is employed to attract pilchards. It is termed resure, rave, or more conmonly rogue, and is largely brought from Norway, more especially from Dronthein. The fishermen say that they have seen pilchards in multitudes quiescent at the bottom of the sea, as if examining with their mouths the sand and small stones in the shallow water, and probably hunting for food. During the colder months of the year they are frequently found in the stomachs of large ground fish that have

* In "Natural History of Ireland" (1755, p. 192) exists an extract from a letter by the Archbishop of Dublin, wherein he observes, "there was a good fishery of pilchards on the south coast of Ireland before the year 1688, but since the fight in Bantry Bay between some of the English fleet under Sir George Rook and the French in 1689, the pilchards, I understand, have not been on that coast : the reason of their leaving it is supposed to be the shock given by the firing of guns; and it was observed that some gentlemen having provided a yacht for their pleasure and firing their guns frequently in the Bay of Dublin, the herring fishing in the Bay failed entirely that season." Couch observes that the firing of a heapy gun at the distance of twenty miles bas been known to cause the fish to sink, and thus disappoint the hopes of the fishermen. 
been taken with ground lines some distance from the shore: the largest fish, similar to the mackerel, being furthest out to sea. Mr. Dunn found that at Mevagissey pilchards of late years have averaged, from August 1st to November 1st, from 3300 to 3800 per hogshead.

Migrations. - These fish are found off the coasts of Cornwall and Devonshire throughout the year. In January they keep near the bottom, and are frequently taken from the stomachs of line-caught fish. Considerable assemblages, mostly of spentfish, have been observediin February, becoming more abundant in March; but the chief fishery commences with drift-nets in July and with seines in the succeeding month. During the summer they may be met with from 20 to 50 miles from the coast, as outside the Scilly Isles, and a considerable distance up St. George's Channel. In or about August large schools of smaller fish extend from the Lizard so far as Bolt Head, in Devonshire, further to the eastwards of which no very extensive fishery is carried on, although considerable numbers are taken at Torbay, Teignmouth, and Dawlish. Another large fishery -in fact a continuation of that already referred to-stretches from the Lizard to the Land's End, while a third is present on the north coast of Cornwall, having its chief seat at St. Ives, where the fishermen assert the large pilchards arrice in October and November, about three days subsequent to their appearance at Kinsale, in Ireland. Sometimes one of these districts is full of fish, none being present in either of the others. Irrespective of these larger migrations there are lesser ones, influenced by currenta, tides, and searchings for food; they appear rircly to go directly against a current.

Parnell (Fish. Firth of Forth, 1838) remarks that the pilchard has become of late a very rare fish in the Firth of Forth, as well as along the whole eastern line of the Scottish shores; yet, about thirty years ago, it was found in equal abundance in certain localities as the common herring. A few are taken occasionally in the summer months on the Berwick and Dunbar coasts, but since the year 1816 no appearance of a pilchard has been observed in the Firth of Forth. We are likewise informed that pilchards were more than usually abundant at Yarmouth in 1780, 1790, and 1799 .

From inquiries he had made, Couch tells us that some considerable changes have taken place in the times at which the larger bodies of these fish have arrived. 'Thus, for upwards of thirty years, at the middle of the last century, the most successful portion of the pilchard fishery was carried on after the antumnal equinox, and consequently by drift nets, since the seines could scarcely have been exposed to the risks inevitable from stormy weather and long dark nights. Towards the end of the century the principal fisbing was from the beginning of August to the end of September, and at that time a great increase took place in the number of seines. Now (1868) the winter fishery along the southward coast is the chiefly successful one, with the necessary result of a diminution in the number of seine nets, there not being a fourth part in use that there were fifty years ago.

Many of the fishermen assert that the number of pilchards now captured in Cornwall is much less than used to be the case. They point out numerous small landing-stages, all of which during the last or present century were used for disembarking the fishermen's spoils, but have now fallen into ruin or crumbled to decay, owing to there being no longer any need for their services. It has been said that the pilchards in some seasons swim low, due to diminished temperature in the upper waters, or from some other cause, and consequently escape beneath the nets. The amount taken of the summer fish is not an invariable index to the quantity present, but more depending upon the course they select; for if they keep in deep water they avoid the seines, and should they swim low they escape the drift nets. Mr. Dunn observes that during May and June these fish appear to be in the deep waters of the English Channel; that at this period the mackerel nets used off Penzance have a large mesh for the purpose of taking the large mackerel, and through this pilchards can easily pass. Whereas at Mevagissey the nets used are for the lesser-sized mackerel, for which purpose a smaller mesh is necessarily employed, in this the pilchards mesh or entangle themselves when full of roe, being unable to pass through. The fishermen returning from the east 
coast towards Cornwall in the autumn, often pass quantities of pilchards in the Finglish Channel, especially off and beyond Portland. Couch observed that for several years, in the early part of this century, the larger proportion of the shoals consisted of such small fish that they passed through the meshes of the seines. Mr. Wilcocks also met with similar sardine-sized pilchards in Guernsey.

Means of capture.-This is carried on by means of drift or driving nets which can be employed over any depth of water, and in which the fish are meshed or gilled. Bright nights are not so favourable for pilchard fishing as cloudy ones, but in very dark nights the brimming is so bright that the nets look like a wall of fire and deter the fish. In coast fishing they are shot as already observed (page 225) and after sunset, between the shoals of pilchards and the deeper water into which they retire at daylight after feeding. Seines or circle nets are also used near the shore, the mesh of these latter being smaller, as $\frac{3}{4}$ of an inch between knot and knot, which is of this size in order to prevent their being able to mesh themselves, for if a shoal were encircled and they contained gilled fish, they would soon die, and such a weight of pilchards would be too heavy for the net and cause it to sink. Seine nets are shot between sunrise and sunset, the smallest legal ones at St. Ires being 160 fathoms along the cork rope with a depth of 8 fathoms at the centre or bunt, and 6 at the end of the wings. Some are as long as 200 fathoms, the mesh being $\frac{3}{4}$ of an inch between knot and knot, or 18 to 20 rows to a foot. 18 feet of netting are attached to each 11 feet of back rope and the same amount on each ten feet of foot rope. A line of corks goes along the upper edge, and the foot line is weighted with leads.

The following regulation exists in the Sea Fisheries Act, 1868, 31 and 32 Vict. cap. 45 , sect. 68 :-

"On the coast of Cornwall, except so much of the north coast as lies east of Trevose Head, no person between the 25th of July and the 25th of November in any year-

"'(a) Shall, from sunrise to sunset, within the distance of two miles from the coast, measured from low water-mark (whether in bays or not) use a drift net or trawl net; or $(b)$ shall, within half a mile of any sea fishing-boat stationed for seine fishing, anchor any sea-fishing or other boat (not being a boat engaged in seine-fishing), or lay, set, or use any net, boulter, or implement of sea-fishing (except for the purpose of seine-fishing).'

"Any person who acts in contravention of this section shall be liable, on summary conviction, to a penalty not exceeding twenty pounds."

As there are only six stations (locally termed stems at St. Ives) where seining can be carried on, and nearly 250 registered nets, they are arranged in groups, each of which is worked so many times in accordance with its size. In this mode of fishing, observes Couch, a whole shoal may be enclosed, and when the evening has set in, and at low tide, the fish are removed. This is done by a small boat passing inside the enclosure and laying its net or tock seine round the inner side of the large or stop seine so as to gradually contract the limits within which the fish are and raise them towards the surface. When disturbed they dash violently about, and care is necessary that they do not break out, while, to prevent them passing from the tuck net into the stop seine, stones suspended from ropes, termed minnies, are constantly kept plunging towards the only aperture. The tuck net is raised so that the fish are brought to the. surface, from which they are removed into the boats with baskets by the fishermen, who are in pairs on the gunwales of the boats (Couch). There is no necessity to remove the whole of the fish that day, in fact a net containing these fish has been kept a week, and a portion of its contents removed as required every night. At St. Ives one end of the seine warp is left on shore and the net rowed round the shoal.

Huers, also termed Balkers, are employed for the purpose of keeping a look-out from the eliffs along the shore for the schools of pilchards, similarly, as already described, for observing the mackerel. They receive each about $£ 3$ a month and one-hundredth part in kind of the fish taken by their respective companies. Fish being seen the cry is raised "Hev-ah, hev-ah." And, about 1601, it was enacted 
that no action for trespass would lie against these people for going on any lands when in pursuit of their calling. It was also permitted to fishermen to haul their nets on the nearest shore. The fishery carried on during the last six months of the year is the most important, because pilchards are then in a condition in which they will cure or "save" best, being fat and with undeveloped roes. Of late years large quantities have been taken during the first six months of the year, they are purchased by local dealers, and forwarded by rail to provincial and Welsh markets under the term of "white herrings."

Mr. Dunn observes that off Mevagissey he has known three pilchards having been captured by hook and line, the bait being a small bit cut out of the side of another pilchard. Couch had been informed of two or three instances in which this fish has been known to swallow the fishernan's hook baited with a worm. Rutty, in 1772, observed that their best bait is the spawn of a cod, stock-fish, or mackerel, which is salted and kept in barrels for this purpose.

Brerting.-Off the coast of Cornwall Mr. Dunn observed that it appears to breed at two seasons of the year, May and June, also in December, and the young are tirst seen in September, 3 or 4 inches in length and about one-eighth of an onnce in weight. On January 16 th, 1882, these fish were returning to the bays skotten, and one boat took 6000 . Couch placed the winter breeding as commencing ais early as October, but this, of course, would vary with the temperature of the season. I opened large numbers in the month of Angust, but in only one single instance did I find developed roe. The pilchard deposits about 60,000 eggs, and falls off in condition as spawning time is approached, when it becomes dry and tasteless. Off Mevagissey it has seldom been observed to spawn within 10 miles of land, usually from 20 to 30 miles off shore: the first named of these localities is generally chosen in the summer, the latter in the winter or spring, "and off the coasts of Devon and Dorset instead of Cornwall" (Dunn). Mr. Coraish (Zool. 1883, p. 431) gives his reasons for supposing these fish to spawn in the mackerel season, i.e. between February and June, in the deep sea, eight or more leagues S.W. and round to the W. of the Scilly Isles. Couch observed that the males exceed the females in number, and he believed that the $y$ did not attain their full growth until their second or third year. Mr. Dunn lecorded that he has wien the rue pressed from the fish when alive into a bucket of water, and each egg rests just below the surface: also that the spawn, on first being shed, actually floats like cork on the water. He likewise informed me, Sept. 29th, 1883, that large shoals of young fish from 2 to 4 inches in length, and believed to be young pilchards, were then in Mevagissey Bay and mackerel were preying on them.

Hybrils.-Dr. Günther, Proc. Zool. Soc. 186, p. 377, describes what he belieres to be the hybrid between the pilchard and a shad.

Pilchard fisheries. - To a stranger visiting the fisbing-quay at Mevagissey an hour or so after milnight, when the pilchards are being landed and sold by their captors, the scene is by no means devoid of interest. The Jowters, with their light traps and fast-trotting hacks, are assembled ready to purchase the fish they require, and scour the country in order to retail them to the inhabitants of every village and hamlet. The pilchards, having been washed, are packed in layers, between each of which salt is sprinkled; this assists in retarding decomposition in these fish, which are so prone to become putrid. At the Barbican at Plymouth, much the same scene may be witnessed, but pilchards are not to be had in sufficient quantities, and cartloads of the coarser description of fish are circulated by means of these Jowters: 12,000 to 15,000 hogsheads of pilchards are annually exported from Cornwall, and the autumn fish, being more firm and less oily, are generally prepared for the Italian market. A merchantable pilchard must be 8 inches long, well-coated, washed, cured and pressed. A hogshead contains from 2900 to 4000 summer, and 2300 to 2900 winter fish ; it measures 54 gallons, and should weigh, when filled and pressed, 476 1b. gross. Its length is :33 inches, diameter of bilge (stare included) 24 inches, of head (stave included) $22 \frac{1}{2}$ inches, of head within 22 inches (Fox).

A large trade in pickled pilchards is carried on between Cornwall and the Italian ports, the idea haring originated at Mevagissey as follows:-In 1876, observed Mr. 
Dunn (Land and Water, Nov. 18th, 1882), a fish-curer here found there was a demand in the Mediterranean fish markets for bright salted pilchards. He first thought the matter out and then cured several tous of pilchards by throwing them, with salt, into barrels and allowing the brine to rise over them. After keeping them steeped for some weeks they were washed, packed, and pressed into clean barrels. just as was formerly done to the old-fashioned funiadoes. On their being put on the market it was at once seen they were the article wanted, for these fish, instead of having the dirty yellow hue of the fumade, had the desired bright and clean silvery colour, hence they have been in demand ever since. The fish-curer in question took out no patent rights, but allowed all to use his discovery, so much so that for some seasons past not less than 1000 hogsheads of fish yearly have been shipped for the Mediterranean from Mevagissey alone. The barrels first used have been superseded by large steeping vats, one of which here will hold over 500,000 fish. Since the business in question has been progressing, it has been discovered that the Spaniards cure sardines much after the same manner.

Fumadoes* are thus prepared, a layer of salt is first placed on the floor, then a layer of fish, and so on up to from 3 to 5 feet high-the outermost row of fish having their heads out and slightly turned up, and the inner rows at right angles to them. French or Spanish salt, being of a coarser grain than English, is preferred. The bulk remains thus about a month, and the oil as well as the brine which drains from them is collected into a receiver. They are now cleaned, the dry salt is removed by a seive, they are subsequently washed, and packed in regular order in fifty gallon casks, the fishes' tails being directed to the centre. Pressure is now made by means of levers to which weights are hung, the casks being refilled and pressed three times during nine days. A hogshead should weigh $476 \mathrm{lb}$, while the number of fish in each cask varies from 2500 to 3000 . All fish under 8 inches in length are excluded (Fox).

Sardines are prepared at Mevagissey as follows:-Immediately the fish are landed they are taken to the factory and cleaned, then the washer arranges them in light trays, head downwards, to drain and dry. They are next boiled, then packed in tin boxes, which are filled up with the best olive oil and subsequently soldered down. These tins are again boiled, and the fish are ready for the market. An experiment made to smoke them like herrings failed, as the weight of the body caused the fish to give way and fall into the fire.

The pilchard fishery in Ireland in the 17th century brought in from the French and Hollanders in some years $£ 15,000$ or even $£ 20,000$ as observed by the Earl of Cork in 1631. Smith in his History of Cork, 1750, refers to the pilchards having left Bantry, due to which the town had fallen into decay. "The fishery began about St. James's day, or the first dark day in July: for the first three months the fish were large, fat and full of oil, and were saved with difficulty, being darker and worse coloured than those taken in the winter months and less prized in foreign markets; notwithstanding which they afforded more profit having a much greater quantity of oil than those taken in the fishery held to the end of the year."

As food.-These fish are much esteemed in Cornwall eaten fresh. Halliwell mentions a Cornwall dish as starry-gazy-pie, being one made of pilchards and leeks, the heads of the fish appearing through the crust as if they were studying the stars. The chief market for cured pilchards is Italy, where there is a great demand both before and during Lent.

Uses.-As bait pilchards are found to be more attractive than herrings, probably dne to the large amount of oil which exudes from them. Pilchard oil possesses a more greasy nature than that of other fishes, so is considered excellent for coarse painting, and used to be in vogue for lamps in Cornwall. It is also employed by curriers in preparing leather. This oil was one of the chief items calculated upon towards defraying curing charges, and although its value has

* The name indicates that these fish were formerly smoked. Borlase, in 1758, observed "fuming them being for many years laid aside." 
become reduced during the last twenty years it has not fallen below $£ 20$ a ton. Mr. Dunn remarks at Mevagissey that in seasons of plenty 3 gallons of oil are obtainable from every hogshead of pilchards,* whereas in bad seasons, the fish being few, merely about 1 gallon can be extracted from the same quantity. In this computation only the summer shoals are alluded to, as the yield in winter is bardly more than half what it is in the summer. In a MS. note in my copy of Pennant's Zoology, 1776, I found it stated, "If the fish are very fat 8 hogsheads of pilchards will produce one hogshead of oil." Rutty, 1772, observed in the county of Dublin that the oil serves curriers and for lamps: while the fish are preserved in casks of beech wood.

Diseases and cutuses of destruction.-The picked dog-fish, Acanthias vulgaris, is partial to these fish, pursuing the shoals and even tearing them out of the fishermen's nets. Mr. Dunn, writing from Mevagissey (December 4th, 1882), observed how these predatory vermin in many instances rushed in numbers at the netted fish, eating all the captives and doing so much mischief that some boats had their nets entirely destroyed. Others left the ground, which is within a few miles of the Eddystone rocks, while at one time it was thought probable that the fishery would have to be entirely given up. Other forms of predatory fishes, porpoises, whales, and birds likewise prey extensively upon them.

It is not unusual to see these fish remored from the nets with one or both eyes gone-not, I think, due to the gar-fish, Belone, or the saury Scombresox, having pierced their heads but consequent upon attacks of fish parasites. In several instances in which both eyes were gone I found the bony interorbital septum still intact which it could not be had the fish been pierced through the two eyes. It is found with Lernece perforating its eye as seen in sprats.

Habitat.-It is found from the seas of Northern Europe extending to Madeira, also off the French and Spanish coasts, and the variety sardine is found through the Mediterranean.

At Aberdeen an example was taken among some herrings in November, 1881 (Sim): Firth of Forth (Parnell): Berwickshire (Johnstone). A casual visitor off Yorksbire, occasionally in some numbers (Yorkshire Vertebrata), and every year off Yarmonth (Yarrell), Harwich (Dale), also a few have been taken off Dover, in the Downs, and in the Isle of Wight by herring fishers. In May, 1838, Yarrell obtained one from the Thames. Under the head of migrations I have alluded to their distribution along the south and south-west coasts of England, as it is more especially a Devonshire and Cornish fish. A few occur in Swansea Bay, but I believe never in shoals (Dillwyn).

In Ireland it is local and chiefly taken along the south coast, where a few occur every year, while occasionally large numbers are captured, especially near Cork. It has been recorded from Belfast Bay, Newcastle (County Down), Youghal, and the south-west of the counties of Cork and Galway. Andrew (Ich. S.W. Coast of Ireland, P. Roy. Dub. Soc. V, 1866-70, p. 382) observes that small fry of the herring and pilchard are met with in the month of October in great quantities in Dingle and in Ventry Harbours and the Short Strand.

The pilchard rarely exceeds 11 inches in length; but Mr. Cornish (Zool. 1879, p. 62) observed that on December 29th, 1878, he measured the largest he had ever seen, and that it was $11{ }_{8}^{7}$ inches long, while $\mathrm{Mr}$. Dunn has seen one of the length of 14 inches, taken in a mackerel net.

\footnotetext{
* Couch observes (iv, p. 92) that when these fish are in bulk 8 or 9 gallons of oil have been obtained from a hogshead.
} 


\section{Clupea sprattus, Plate CXXXIX, fig. 2.}

Sprattus, Willugh. Hist. Pisc. p. 221. Spratti, Ray, Piscium, p. 105. Clupea quadriuncialis, Artedi, Synon. p. 17, Gen. p. 7, Spec. p. 33. Sprat, Pennant, Brit. Zool. (Ed. 1776) iii, p. 346 (Ed. 1812) iii, p. 457. Sardina, Rutty, Nat. Hist. Co. Dublin, i, p. 362. De Sprat, Duhamel, Pêches, pt. ii, sect. iii, p. 471, pl. xvi, f. 2.

Clupea sprattus, Linn. Syst. Nat. i, p. 523 ; Bloch, Fische Deuts. i, p. 206, t. xxix, f. 2; Gmel. Linn. p. 1403 ; Bonn. Enc. Ich. p. 185, t. Ixxv, f. 311 ; Bl. Schn. p. 423 ; Lacép. v, p. 444; Turton, Brit. Fanna, p. 107; Nilss. Prod. p. 22 and Skan. Fauna, Fisk. p. 516 ; Risso, Ich. Nice, p. 352 ; Faber, Fisc. Isl. p. 178; Jenyns, Brit. Vert. p. 435 ; Yarrell, Brit. Fish. (ed. 1) ii, p. 12l, c. fig. (ed. 2) ii, p. 197 (ed. 3) i, p. 115; Templeton, Mag. N. H. 1837 (2) i, p. 411; Parnell, Wern. Mem. vii, p. 322, t. $\times x \times \nabla$, or Fish. Firth of Forth, p. 162, t. xxxv; Bonap. Pesc. Eur. p. 34; Gaimard, Voy. Scand. Poiss. pl. xviii, f. 2; Kröyer, Danm. Fisk. iii, p. 177, c. fig.; White, Catal. p. 84; Thompson, Nat. Hist. Ireland, iv, p. 176 ; Schlegel, Dieren Ned. p. 146, pl. xiv, f. 2; Malmgren, Wieg. Arch. 1864, p. 341 ; Günther, Catal. vii, p. 419, and Proc. Zool. Soc. 1871, p. 672 ; Winther, Prod. Ich. Dan. Mar. p. 49 ; Malm, Fauna, p. 582.

Clupea macrocephala, Swainson, Fish. ii, p. 387 ; White, l. c. p. 84; Higgins, Zool. 1861, p. 7317; Couch, iv, p. 124.

Clupea S'choneveldii, Kröyer, l. c. $\nabla$, p. 193, c. fig.; Gaimard, l. c. pl. xviii.

Harengula sprattus, Cuv. and Val. $\mathbf{x x}$, p. 285.

Spratella pumila, Cuv. and Val. xx, p. 357, pl. 600 (marked Meletta vulgaris).

Meletta vulgaris, Cuv. and Val. xx, p. $366^{\circ}$ (not pl. 603); Moreau, Poiss. de

la France, iii, p. 447.

Sprat, Couch, Fish. Brit. Isles, iv, p. 109, pl. cciii.

B. vi-vii, D. $16-18\left(\frac{4}{12}-\frac{8}{13}\right)$, P. 16-17, V. 7, A. $17-20\left(\frac{\frac{3}{16}-\frac{8}{17}}{17}\right.$, C. 19, L. 1, 47, L. tr. 13, Cœe. pyl. 7, Vert. $47-48$.

Length of head $4 \frac{1}{2}$ to $5 \frac{1}{4}$, of caudal fin 6 , height of body $4 \frac{1}{2}$ to $5 \frac{1}{4}$ in the total length. Eyes-with narrow anterior and posterior adipose lids, diameter $3 \frac{1}{2}$ in the length of the head, 1 diameter from the end of the snout, and $\frac{3}{4}$ of a diameter apart. Lower jaw prominent. Opercular pieces smooth; subopercle almost triangular, its posterior and inferior borders being continuous. Lower jaw rather prominent. The posterior extremity of the maxilla reaches to beneath the first third of the orbit. Teeth-absent from the jaws, tongue, and palate (an elongated oval patch of very minute teeth on the tongue has been recorded; also rugosities or small teeth on the maxillaries and palatines); in an example $4 \frac{1}{2}$ inches in length none are visible under a $\frac{1}{2}$-inch power of the microscope. Gill-rakers -closely set, rather shorter than the eye. Fins-The dorsal* commences above the ventral and about midway between the hind edge of the eye and the base of the cardal fin, being rather longer at its base than it is high anteriorly. Ventrals inserted in a vertical line below the anterior dorsal rays, the fin reaches about half-way to the vent. Pectoral shorter than the head. Caudal forked. Scalesdeciduous, smooth; the keeled row along the ventral surface well developed, making the edge like a saw, 21 to 23 being before the base of the ventral fin and 11 or 12 behind it. Intestines - 7 rather long coecal appendages; Parnell found 12. Colours-bluish along the back, becoming silvery on the sides and beneath, in the young a yellow or bronze band divides the blue of the back from the silvery abdomen, this band being frequently more intensely golden during the breeding season.

Varieties.-Moreau divides $O$. phalerita, Risso, from this species, as he considers the subopercle in the first is twice as long as high and in the sprat three times.

* Neill (Mem. Wern. Soc. p. 545) observed that if a straight line be dropped from the forepart of the dorsal fin it will in the herring fall a little in front of the ventral fins, but in the sprat it will fall just behind them. 
Fleming, following Willughby and Ray, observed that the fry of the herring and pilchard are confounded together under the epithet sprat, consequently he ignored this species, although Pennant had previously contested this view. The sprat and the sardine were considered synonymous by Lacépède and others.

Names.-Ghrvie, garvock, or garvie-herring, Scotland. Sprat, besides being the name of this fish, is in places erroneously employed for the young of the herring. At Teignmouth, in Devonshire, this fish is termed the London sprat, as the sand-eel, Ammodytes, goes by the designation of "sprat." Britt along the Deronshire coast, and which ascends the mouths of rivers, consists either of young sprats or young herrings. Whitebait likewise may be wholly or partially composed of small sprats. In Ireland the fishermen at Youghal distinguish several varieties as true, soft, or hard-headed sprats. Coog Bennog, Welsh. De Sprot, Dutch. L'Esprot, French.

Habits.-Gregarious; often in enormous shoals, while it is very common to find young and old together, although the larger examples do not generally come off our coasts until the autumn and winter months. They ascend rivers as high as the tide flows. Britt, which consists of young herrings or young sprats, ascend rivers along the Devonshire coast, and are found as high in the Exe as Exeter, unless a flood occurs, when they are unable to face the fresh water.

Migrations.-Although during the very cold months herrings and pilchards more or less retire to the deep, sprats, on the contrary, come towards the shore; but even when present the shoals are capricious in their movements, as well as in their extent. Thus, in 1832, it was observed in Taunton that after an absence of nearly fifty years this fish visited the neighbouring coast in exhaustless shoals. Norfolk, Suffolk, Essex and Kent are noted for the large shoals which occasionally show themselves, while they disappear more completely from the western side of the kingdom during their season of absence than they do from the eastern. Even the time of appearance varies considerably in different years at the same place. During the summer and autumn months young or small in-shore sprats are rarely absent from our coasts. In the Moray Firth, and elsewhere, shoals are frequently discovered by seeing flocks of gulls and other sea-birds hovering abore them.

Means of capture.-These fish are mostly captured during the winter months, whether in Scotland or in England. In 1880 this fishery commenced in the Beauly Firth on October 12th, but on the south-west of Ireland it is earlier, and in Donegal Bay continues from August until nearly the end of Decembir. When fished for in the sea they are generally taken from close in shore to about three miles out. Sprats are mostly captured by means of a large bag-net, made with small meshes, and termed a stow-net, the use of which was formerly forbidden between November 10th and February 10th, but which is now the principal time it is carried on; while ground seines were legal between November lst and April 1st. The stow-net is placed in a tideway, its mouth towards the tide. In Scotland the seine net is used for taking these fishes, while off Ramsgate drift nets are also employed for sprat fishing, dark and foggy nights especially being suited for its capture. In Ireland the sprat fishing is carried on during the autumn months, and Mr. Sinclair, writing from Donegal (Field, November 5th, 1881), observes that the sprat fishing is now over. One method adverted to by Mr. Yescombe, in Land and Water (November 26th, 1881), is to choose the vicinity of an old wooden pier, or some such structure, round the supports of which small shoals of sprats frequent. Secure your boat to the end of one of these piles on a fine day; use a net attached to a thin iron frame about 3 yards in circumference, and which is suspended by three cords fixed to it at about 3 feet apart. About a foot above the ring of the net these cords are tied together and attached to a single strong one. The net is lowered into the water to about 2 feet below the surface, and some fine-boiled mealy potatoes thrown in, which attracts the sprats above it. Then allow it to be quietly drawn up with the fish that are swimming above it, and the shoal does not become alarmed.

Said not to be taken by a bait, probably from the small size of its month.

Breeding.-I have obtained sprats with developed roe from both the north and south coasts of Cornmall, during the months of December and January, but 
it is not common to find them in this condition. Neither Pennant, Turton, Jenyns, or White, advert to the breeding of these fish, but Yarrell states he caught some off the Dorsetshire coast in June which were then in roe, also young sprats off Ramsgate, Hastings, and Weymouth, in the months of August and September. Lowe (Fauna of Norfolk, 1873, p. 29) remarks, "Mr. Dowell says, that though he has seen vast quantities of this fish caught, he never yet saw one with roe." Couch observes that in May, 1860, he obtained one 5 inches long and heavy in roe taken 30 miles off shore. Parnell remarked that in the Firth of Forth the sprats spawned early in the month of March. In October, 1879, I examined a number from St. Ires; a few males had some milt, bat the ovisacs of the females were empty and red as if spawning were over.

Diseases.-Mr. Warren (in Thompson's Ireland) observes that "about Christmas, 1846, vast numbers of sprats died in Cork Harbour, and were carried off in bucketsful dying and dead. The people ate them, and considered them very good: it was the year of the famine. They had mostly a 'pearl' or white appearance in the eye while living: some had both eyes, and others only one of them, diseased."

One form of parasitic Entomostraca, Lerneonema monilaris or sprat Lernea, is often found attached to the eye of this fish. The whole head of this parasite is inserted into the tissues of its host, and retained there by the barbs or horny prolongations with which it is furnished. This Lernea is luminous at night-time, and fishermen assert that shoals of sprats are often preceded by several of these fishes infested by parasites and which have occasioned their being termed "lanthorn sprats."

The britt in Devonshire and Cornwall have been considered by some to be the young of the "herring," but those which I received from Plymouth were sprats. The Town Council of Exeter annually make an official whitebait repast upon " britt," rospecting which discussions have arisen as to whether they are or are not similar to the genuine Thames and Medway species. It appears that in the Exe they ascend with the tide so far as the entrance of the Exeter canal, where they are found from May until September. Mr. Ross (Misc.) recorded in 1838 that he took some of these fish to London to Mr. Yarrell, who decided they were the fry of the shad. Mr. Couch subsequently considered them to be whitebait, but not the young of the herring. Mr. D'Urban, the curator of the Albert Memorial Maseum at Exeter, transmitted specimens to me, which were the young of the herring.

Continuing my investigations into the britt along the S.W. coast, I arrived on August 23, I881, at Dawlish. At the beach I was in time to see the seine net hauled on shore, and as the bagged portion came to the surface innumerable little silvery fishes seemed to shoot through the meshes into the sea, but hundreds were landed with the refuse, some of which I secured. This gave me another opportunity of examining the August britt. The fishermen considered they were all young sprats, and such I found them to be, while their gize varied from threequarters of an inch to $2 \frac{1}{2}$ inches in length. Again in August and September, 1883, at Teignmouth, the britt up to $1 \frac{8}{4}$ inches in length were all sprats.

It may be that the britt present at the mouth of the Exe from May until September vary with the season, for when investigating the whitebait question in 1878, among examples from the Thames and Medway, I found the proportions of herrings to sprats to be about as follows :- May and June, ten to one ; August, sprats rather more than half; October, all herrings; while of the winter whitebait given me by $\mathrm{Mr}$. Charles from the Medway, all were sprats. On August 13, 1881, at St. Ives, innumerable young sprats were being taken as bait for gurnards, although they appeared to be entirely absent from Penzance, which was locally attributed to the bay being too sandy ; and I saw a solitary example at Mevagissey, captured among pilchards.

As food.-These fish are very deservedly esteemed, especially when not too large. As they are nutritious and cheap, they are a boon to the poorer classes. They are sold by measure. They come into the market just after the herring season is over. 
In Norfolk considerable quantities are prepared and sold as anchovies and anchory paste (Lowe).

In some parts of Scotland they are thus preserved: selected fish are washed in salt and water, then threaded on wire skewers and suspended for two hours in a pickling vat, so that no two fishes touch one another. On being removed they are hung up in a current of air until the next day, when they are smoked like bloaters until they assume a yellow colour. They will keep four or five days, and additional pickling and smoking will enable them to keep longer.

An important trade appears to be springing up at Lowestoft, where they are being tinned as anchovies. Three million tins of sprats similarly cured as anchovies on the west cuast of France are annually imported into this country. Those taken off Finisterre are found to possess a muddy flavour, but they are exported by some second-rate mercantile houses.

A so-called anchory paste may be made as follows, sufficient for a peck of sprats :-2 lb. common salt, $3 \mathrm{oz}$. bay-salt, $1 \mathrm{lb}$. saltpetre, $2 \mathrm{oz}$. of prunella, and a few grains of cochineal, pounded well together in a mortar ; into a stone jar place first a layer of fish, then of the pounded ingredients, and so on until the jar is filled; press them hard down and cover closely. After six months they will be ready for use.

Uses.- As baitfor ground fish, for which purpose their oily natare makes them very acceptable. Large quantities in some years are disposed of for manure, which may be due to the markets being glutted, or else that by the time the fish have been landed, those which were first caught are fit for nothing else. In some localities they are even fished for solely with the view of being employed as manure. It has been observed in Berwickshire that they are largely eaten by the salmon.

Habitat. - From the Finnish coast, through the North Sea and Baltic, also along the coasts of the British Isles, France, and the Iberian Peninsula. It is also found in Tasmania (Günther). A large fishery exists in the Zuyder Zee : in 1882 it closed in August and fish valued at $£ 70,000$ were secured.

In the Moray Firth it is abundant on the east side towards the end of the herring season, subsequently it passes westwards towards the more sheltered parts. Parnell remarks that it is found in the Firth of Forth throughout the year, but like many small animals, it appears to be very susceptible to cold; while during the warm summer months it may be seen sporting about in large shoals. It is common along the east coast, while some of the largest fisheries are in the Solent, the mouth of the Thames and off Margate. Off Folkestone, in January, 1879, the sea appeared alive with them, and they were sold at $1 \frac{1}{2} d$ a 1000 . In the British Channel, or rather on the southern shores of Cornwall, it is rare; on the northern coast it is more common. Having personally investigated the distribution of this fish along this portion of England in the autumn of the last four seasons, I found the young very common along the south coast of Devonshire; also sprats are numerous at St. Ires. But at Mevagissey and Penzance it seems to be rare. On the west coast of England it is occasionally abundant, but not to so great an extent as on the east coast (see migrations).

In Ireland it has been recorded round the coast, but there is no sprat fishery off the counties of Antrim or Down; still it is taken in large quantities along the south coast. Templeton observes that it appears during the autumnal months in the bay, and as far up the rivers as the tide flows.

Largest specimens personally obtained $5 \frac{1}{2}$ inches in length, but three are mentioned as sent from Aldborough over $6 \frac{1}{2}$ inches in length (Field, January 21st, 1882).

\section{Clupea alosa, Plate CXL.}

Alausa, Anson. v, $v 127$; Belon. p. 300 ; Salvian. fol. civ; Willugh. p. 227, t. P3, f. i ; Ray, Piscium, p. 105. Trichis, Belon. p. 306. Thrissa, Rondel. p. 220. Clupea, sp. Gronov. Zooph. no. 347. Harengus, sp. Klein, Pisc. Miss. v, p. 72, no. 5, t. xix, f. 4. Allis, Pennant, Brit. Zool. (Ed. 1776) iii, p. 348, pl. lxix (Ed. 1812) iii, p. 460 , pl. lxzx. 
Clupea alosa (pt.), Linn. Syst. Nat. i, p. 523 ; Bonn. Enc. Ich. p. 185, pl. 1xxv, f. 322 ; Lacép. v, p. 4477 Turton, p. 106 ; Cuv. Règne Anim. p. 275 ; Jenyns, Manual, p. 438; Johnston, Berwick. N. F. C. 1838, i, p. 173; Gronov. ed. Gray, p. 139 ; Schlegel, Dieren Neder. p. 148, pl. xiv, f. 3; Günther, Catal. vii, p. 433; Giglioli, Fauna Ital. Catal. p. 46.

Alosa communis, Yarrell, Brit. Fish. (ed. 1) ii, p. 136, c. fig. (ed. 2) ii, p. 213 (ed. 3) i, p. 133; Parnell, Wern. Mem. vii, p. 330 and Fish. Firth of Forth, p. 170 ; White, Catal. p. 85; Kröyer, Dan. Fiske, iii, p. 220; Thompson, Nat. Hist. Ireland, iv, p. 177.

Alausa vulgaris (pt.) Cuv. and Val. xx, p. 391, pl. 604; Heckel and Kner, Suss. w. f. p. 228, f. cxxxiii; Blanchard, Poiss. de France, p. 480, f. 127 ; Collett, Norges Fiske, p. 195.

Clupea communis, Swainson, Fish. ii, p. 294.

Alosa vulgaris, Troschel, Wiegm. Arch. 1852, p. 228; Selys-Longch. Faun. Belg. p. 220 ; Siebold, Suss. w. f. p. 328 ; Moreau, Poiss. de la France, iii, p. 453.

Alosa Cuvieri, Malm, Fauna, p. 654.

Clupea vulgaris, Winther, Prod. Ich. Dan. Mar. p. 49.

Allis shad, Couch, Fish. Brit. Isles, iv, p. 117, pl. cciv; Honghton, British Freshwater Fishes, p. 69, c. fig. $70-80$.

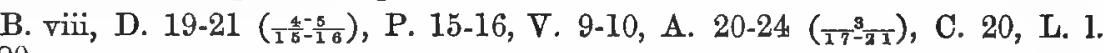

Length of head $5 \frac{1}{2}$, of caudal fin $5 \frac{2}{2}$, height of body 4 to 5 in the total length. Eyes-with adipose lids, diameter $5 \frac{1}{2}$ in the length of the head, from $2 / 3$ to 1 diameter apart. Opercle with radiating ridges descending downwards and somewhat backwards. Cleft of mouth oblique ; lower jaw slightly prominent; maxilla reaching posteriorly to below the hind edge of the eye. Teeth-minute and deciduous in both jaws, none on the palate nor on the tongue. Gill-rakersProfessor Troschel first demonstrated that the most distinctive characters between the two forms of shad might be found in the number and form of their gill-rakers. On the lower branch of the outer branchial arch of this species they are long, thin and numerous, being from 60 to 80 , the number of which Canestrin suggests increases with the age of the fish. Fins-dorsal commences nearer to the end of the snout than to the base of the candal fin. Ventral inserted behind the origin of the dorsal. Scales-15 to 17 strong carinated scales along the abdominal edge posterior to the insertion of the ventral fin. Fine ones extended over the basal two-thirds of the caudal fin: back greenish blue; sides silvery, dashed with purple and gold. Colours-occasionally one, sometimes two, dark shoulder spots, while a succession along the side has been recorded, more especially in the young. This and the next species belong to the genus Alausa, or Alosa of some authors, separated from the true herrings owing to an emargination in the centre of the upper jaw to receive a knob existing above the symphysis in the mandibles. Teeth in the front portion of the jaw only, and very decidnous. Shad are not unfrequently considered giant sprats, herrings or pilchards.

Names.-This and the next species are known as Rock-herrings in the Moray Frith (Gordon). Allice-shad, alewife, mother of herrings, daming-herring, or possibly "dame of the herrings," king of the herrings, Scadina. Herlyn or Herling, Welsh. De Elft, Dutch.

Habits. - Not generally found in shoals in the sea, but becomes gregarious when entering rivers: one hundred shad are observed to make more commotion at sea than 1000 mackerel. Some authors have observed it in the Severn during April and May, and as high as Worcester. Off Cornwall it appears earlier than the Twait-shad, and is equally common (Couch); often plentiful in May and June. But the time of its ascent depends to a great extent upon the condition of the water, as in the Severn, if in flood, it waits until such is over, or even returns to the sea. It is reputed to take pleasure in music, bat should it thander while it is in the course of ascent it immediately retrogades to the ocean. McIntosh found in the stomach of a large example captured in the Tay 
Confervæ, Desmids, and a quantity of vegetable debris, also many sprats and herrings. In Germany Barfurth remarked that its food mostly consists of Temora velox Li]j. and other marine Entomostraca.

Mrcuns of capture. - In fresh waters mostly netted, especially in seines at night time; it has also been taken in a trammel, as well as when whiffing at sea for pollack, with a slice from a mackerel or sand eel: and Mr. Dunn has known as many as 600 secured in one haul of a mackerel seine.

Breeding.-Usually from May until the middle of June, and for which purpose it ascends rivers. Barfurth showed that not only do salmon and trout more or less cease feeding during the breeding season, but that in the Rhine the same phenomenon has been observed in the Maifische or shad.

As food.-Opinions vary, and for several reasons. Being full of bones it is more troublesome to eat without being choked (nnless properly carved) than most persons approve of, but if carved properly this unpleasantness is avoided. Taken from the sea during the winter it is poor and dry, but after sojourning in fresh water it becomes plump and delicate, while the higher it ascends streams the better it is. The supply in our markets mostly comes from Holland; last April they were selling in London retail fish shops at $6 a \mathrm{a} \mathrm{lb}$.

Habitat. - Said to be absent from Sweden, but found on most of the western coasts of Europe, entering rivers in the spring.

Off Banff it is rare, but one was captured there in a salmon net, June $7 \mathrm{th}$, 1866 (Edward) ; at St. Andrews it is not uncommon (McIntosh), Firth of Forth rare (Parnell), Berwickshire (Johnston). It is found off Yorkshire (Yorkshire Vertebrata), and at Yarmouth is not uncommon with the herrings (Paget). A pair, male and female, were taken at the New Mills in Norwich, in 1840 (Lubbock); it is found along our south coast, but becomes rare in Mount's Bay and St. Ives. Said to be abundant in the Cevern in some seasons during April and May. Yarrell obtained a specimen in 1831, captured above Putney Bridge on the Thames, and Jesse recorded one taken at the end of June, opposite Hampton Court Palace, full of spawn.

In Ireland taken on the north-east coast and is not uncommon off Derry (Ordnance Survey); it is by no means rare on the west coast and has been seen in Kenmare river, Ventry harbour, and Dingle Bay; is often abundant in Limerick harbour and Brandon creek, coast of Kerry; and has been taken near Killaloe on the Shannon (Mayne). It attains to as much as four feet in length (Couch) and up to $8 \mathrm{lb}$. in weight, but generally is seen to about half this size.

\section{Clupea finta, Plate CXLI.}

Agonus, Belon. p. 304; Salvian. fol. $105 b$ and 106 ; Ray, Piscium, p. 106. Shad, Willughby, p. 227, t. P3, f. 1; Pennant, Brit. Zool. (Ed. 1776) iii, p. 351 (Ed. 1812) iii, p. 307; Bowdich, Fish. no. 27. Clupea sp. (part) Artedi, Synon. p. 15, no. 2 (in part), Genera, p. 7, no. 3, Spec. p. 34, no. 3. Alose, Duhamel, Pêches, iii, p. 316.

Clupea alosa, Linn. Syst. Nat. i, p. 523 (pt.); Bloch, Ich. p. 312, t. хxx, f. 1 ; Gmel. Linn. p. 1404; BI. Schn. p. 423; Lacép. v, p. 447; Risso, Ich. Nice, p. 353 and Eur. Mérid. iii, p. 453; Donovan, Brit. Fish. iii, pl. lvii and pl. xeviii (young) ; Turton, Brit. Fauna, p. 106; Fleming, Brit. An. p. 183; Malm, Fauna, p. 587.

Clupea fallax, Lacép. v, p. 452.

Clupea finta, Cuv. Règne Anim. ii, p 320 ; Jenyns, Man. p. 437; Swainson, Fish. ii, 1. 294; Günther, Catal. vii, p. 435 ; Feddersen, p. 81.

Alosa finta, Yarrell, Brit. Fishes (ed. 1), ii, p 131, c. fig. (ed. 2), ii. p. 208; Parnell, Wern. Mem. vii, p. 329 or Fish. Firth of Forth, p. 169; Kröyer, Danm. Fiske, iii, p. 202, c. fig. ; Nilss. Skand. Faun. iv, p. 527 ; Troschel, Wieg. Arch. 1852 , p. 228 ; Thompson, Ireland, iv, p. 177; Selys-Longch. Faun. Belg. p. 220; Collett, Norges Fiske, p. 195 ; Martens, Wieg. Arch. 1857, p. 182 ; Malm, p. 587 ; Siebold, Suss. w. f. 332 ; Winther, Prod. Ich. Dan. Mar. 1. 50; Blanchard, Poiss. de France, p. 481 ; Morean, Poiss. de la France, iii, p. 456. 
Alosa vulgaris (pt.), Cuv. and Val. xx, p. 391; Yarrell, Brit. Fish. (ed. 3) i, p. 127, c. fig.

Twait-shad, Couch, Fish. Brit. Isles, iv, p. 122, pl. ccv; Houghton, British Freshwater Fish. p. 71, c. fig.

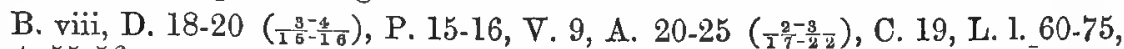
Vert. 55-56.

Length of head 5 to $5 \frac{1}{4}$, of caudal fin $5 \frac{1}{2}$, height of body 4 to $4 \frac{1}{4}$ in the total length. Eyes-with adipose lids, diameter $4 \frac{1}{2}$ to $5 \frac{1}{2}$ in the length of the head. Opercle with some raised and radiating lines descending towards the sub-opercle. Upper jaw with a notch in its centre, to receive the end of the somewhat prominent under jaw; the maxilla reaching to beneath the hind edge of the eye. Teeth-small and deciduous in jaws: absent from the palate and the tongue. Gill-rakers thick, osseous and from 20 to 28 along the horizontal branch of the outer branchial arch. Fins-dorsal commences nearer to the end of the snout than to the base of the cardal fin. Ventral inserted slightly behind the origin of the dorsal. Anal fin low. Caudal deoply forked. Scales-15 to 17 carinated scales on the abdominal edge posterior to the base of the ventral fin. Small ones over the basal two-thirds of the caudal fin. Colours-steel blue along the back, becoming silvery along the sides and below, a large black blotch on the shoulder, generally succeeded by about 5 or 6 more (Donovan says 10) along either side; in some specimens there are two dark spots at the base of the tail, one above the other below.

Varieties.-Couch has noticed a scattered row of irregularly placed small spots along the sides, instead of large dark spots in one specimen which he supposed to belong to this species.

Names.-Twaite in the Severn, shad signifying the last species. Maid. Bony Norsemen, Ireland. L'Alose feinte, French.

Habits. - These anadromous fish leave the sea at the end of May or commencement of June, and ascends some of our large rivers as the Thames and Severn, for the purpose of depositing their ova; formerly they went in the Severn far above Shrewsbury, but since about 1846 have been more or less stopped by the Tewkesbury river. All have usually returned to the sea by the end of July. Mr. Miller, who has the fishing at Newnham, in the Severn near Gloucester, says that it commences from the 14th to the 20 th of April, according to the heat of the season, for if cold winds blow it is deferred. Small males come first, so small that two only equal one female; at first the wholesale price is $6 s$ a dozen, later on $4 s$, as one hen counts for two cocks and thirteen to the dozen.

Means of capture. - Similar to the other form of shad. Yarrell observes, that in the Thames great numbers were taken every season, especially opposite the Millbank Penitentiary, Westminster, also above Putney Bridge. But the state of the water has caused a more or less complete cessation of their visits. Formerly their capture in the Thames was prohibited after June 30th, in order that spawners might breed in security.

We are told that in Germany this fish is believed to be terrified at storms and troubled waters, delighting in quiet and musical sounds. Therefore to the nets are fastened bows of wood, to which are suspended a number of small bells which chime in harmony together on the nets being moved: the fish are thought to be thus attracted to their destruction, and as long as the alluring sounds continue they cease all efforts at escape.

Baits.-Whiffing with a slice of mackerel has been found successful at the mouth of the Dart (Holdsworth). This fish is capricious in taking a bait in the Severn, being occasionally hooked at almost any cast, at another time playing around the bait but refusing to touch it; when hooked it affords some play.

Breeding.-June and July. On June 3rd, 1879, I opened several from the Severn, the ova was almost ready for being deposited. Yarrell observed, that about the second. week in July used to be when they mostly spawned in the Thames when they appeared to disencumber themselves of their roe by violent muscilar action, and on a calm still evening or night, the noise they made night be heard at some 
distance. He obtained the young $2 \frac{1}{2}$ inches long in October, and only 4 inches long the following spring.

Hybrid. - Scale-finned shad, Alosa squamapinnata, Couch, iv, p. 123, pl. cevi, from Bristol, the skin of which is now in the National Collection, may be a hybrid between one of the shads and a pilchard as suggested by Dr. Günther, but its gill-rakers have been removed.

Another example in the same collection is considered a hybrid between the two shads, with 40 gill-rakers, longer than C. finta but shorter than C. alosa. D. 21, A. 25, L. 1.68 , L. tr. 22.

As food. - Owing to its numerous bones is not held in much reputation in English markets, while its flesh is somewhat dry and tasteless. In Russia it is considered unwholesome.

Habits.-From Scandinavia throughout the seas and coasts of Europe, the Mediterranean and the Nile; it enters many rivers to breed, as already remarked upon.

It has been reported around the coasts of Scotland, as at Banff where it is rare (Edward) ; appearing in the Firth of Forth at the end of $\mathrm{Jul}_{\mathrm{f}}$, and disappearing about August (Parnell). Also round the English and Welsh coasts, as off Cumberland (Heysham), Yorkshire (Yorkshire Vertebrata), Yarmouth not uncommon (Paget); the Thames and along the south coast as far as Cornwall, where, observes R. Couch, the "twaite shad" Alosa finta, or "Daming-herring," is found in the west part of Cornwall in rather large numbers towards the latter part of the summer pilchard fishery and early in the autumn mackerel fishery. Frequently taken in mackerel drift-nets off Scilly, moving E. or W.E.

In Ireland it is taken chiefly along the south coast where a few occur annually, but occasionally in great numbers. It has been recorded from Belfast Bay; Newcastle, Co. Down; Youghal; south-west of the County of Cork and Galway, Dublin, and is common in northern rivers (Andrews). Likewise Blackwater (Ball), and Donegal, where 2 or 3 have been taken (Thompson). It attains to 16 inches (Yarrell), it never exceeds $2 \mathrm{lb}$. in weight. 


\section{Family, VI-MUR里NID无, Mïller.}

Body elongated, cylindrical or band-shaped: the humeral arch not attached to the skull. The branchial openings in the pharynx may be wide or narrow slits. Margin of the upper jaw constituted anteriorly by the premaxillaries* which are more or less coalescent with the vomer and ethmoid, while laterally the sides of the upper jaw are formed by the maxillaries which are furnished with teeth. Vertical fins, when present, confluent or separated by a projecting tail: pectorals present or absent. Ventrals absent. Scales, when present, rudimentary. Vent may be situated close to the base of the pectoral fins, or a long distance posterior to the head. The heart may be just, or far behind the gills. Stomach with a blind sac. No pyloric appendages. Ovaries destitute of oviducts.

Cuvier placed the eel.shaped fishes (including the tropical Symbranchidoe) in one Family, Murænide, while they have likewise been termed Apodal, owing to a deficiency of the ventral fins, which latter phenomenon is perceived in species of various other families, for being the last evolved or most immaterial among the fins, they are most commonly absent. Thus in Ceylon and China the genus Channa among the Ophiocephalidm is distinguished from Ophiocephalus by the absence of the ventrals. The Indian Siluroid genus Ailichthys differs from Aitia due to the same cause. Genus Neochanna differs from Galaxias for a similar reason. In the Cyprinodontids, Tellia is a Cyprinodon without ventrals. Apua among the Cobitidinæ is closely allied to Acanthophthalmus but has no ventrals, while the chief distinction between the Clupeoids Opisthopterus and Pellona is that the former is without ventrals while the latter has very small ones. Calamoichthys is Polypterus without ventrals. Doubtless in some instances this deficiency of the fin may be an individual monstrosity or a local race, as I have observed (vol. i, p. 24.5) as regards Gasterosteus pungitius. It may, perhaps, be a sexual character, thus Troschel (Wiegm. Arch. 1871, pp. 276-280) remarked upon having received a female Siluroid of Copidoglanis brevidorsalis destitute of these fins. It may be present in the young as Stromateus niger, but be lost with age, and absent from other species of the same genus. Attention has likewise been drawn to the fact "that in numerous groups of fishes which live in mud, forms occur, devoid of, or with only rudimentary ventral fins" (Günther, Annals and Mag. Natural History, 1867, xx, p. 308).

Eels by some authors have been looked upon as, sometimes at least, hermaphrodites. But Syrski, Dareste, and others have observed upon what they deem to be the male organs of the eels. A number of larval fishes have been termed Leptocephali or "Glass eels." Some of these may be forms in which development has been arrested in an early stage of existencet, the fishes never attaining the perfect state, but such are generally, if not invariably, in Great Britain confined to the salt water. It is an error however to consider them as usually restricted to some distance out in the ocean, as along the coasts of the Bay of Bengal they are innumerable and to be found close in shore.

The Family MuRAnID are divisible into two groups: (1) Those in which the branchial openings in the pharynx are wide slits, Murcenida platychistoe, among the genera composing which is Anguilla. (2) Those having the branchial openings in the pharynx as narrow slits, Murcenidae engyschistoe, an example of which we possess in the genus Murcena.

* Meckel, Peters, and Jacoby consider the lateral portion only of the upper jaw is formed by the maxillaries, the front part being the premaxillary which coalesces with the vomer and ethmoid, but may always be distinguished.

$\dagger$ Carus, Brit. Asso. 1860, Gill, 1864. 


\section{Genus I-Awguilla.}

Murano, sp. Artedi. Terpolepis, pt., McClelland. Paranguilla, Bleeker.

Gill-openings of moderate extent, situated near the base of the pectoral fins. Upper jaw not projecting beyond the lower. Teeth small and in bands. Dorsal fin commencing at some distance behind the nape: pectorals present. Small scales imbedded in the slin.

Geographical distribution.-Fishes of this genus appear to be distributed throughout the fresh waters of the habitable globe, being reputed to be absent only from the Arctic regions, and intensely cold districts such as Turkestan, and a few other localities.

Species.-As may be perceived by the most casual observer, these fishes have been subdivided to such an extent that it is difficult to comprehend the plans upon which authors have founded their species. Yarrell divided the British forms into the "sharp-nosed eels," "the broad-nosed eels," and "the snig," observing that in the comparative brealth of the nose (snout) the last is intermediate between the other twn. Günther remarked "the form of the snout, the size of the eyes, and the width of the bands of teeth, are evidently subject to much variation," and subsecpuently continued, "I am more inclined to consider the situation of the origin of the dorsal fin and the development of the lips to indicate a distinct species," and following out this method of division he looks upon A. latirostris as an inhabitant of Europe, the Nile, China, New Zealand, and the West Indies; and A. vulgaris as resident in Europe to $60^{\circ} 30^{\prime}$ N. Lat. but found neither in the Danube nor in the Black or Caspian Seas, Mediterranean region, Northern Asia, or North America, while he considered these two to constitute the sole British species. It has appeared to myself, while examining numerous eels of this genus in Asia, that considerable local and individual variations occur as to the position of the origin of the dorsal fin and the comparative proportional size of one part of the body to the remainder, rendering this character by no means symptomatic of species.

Habits.-Eels are very tenacious of life, are found in nearly all our fresh waters, and during their feeding months are exceedingly voracious. In an account of some domesticated examples of this genus kept in a pond in a walled garden for nine or ten years, * they were observed to remain torpid throughout the winter, and although they occasionally emerged at the bottom of the water from under the large stones which formed their hiding places, they did not feed. About the latter end of April they first began to take worms, but ate sparingly until the warm weather set in, when they became quite insatiable (in some waters they commence feeding certainly as early as March), while if no other food was procurable they devoured one another; they also consumed fish roe and occasionally vegetable substances. About August they become restless, apparently attempting to migrate to the sea, and at the end of that month or during September they retired to their winter quarters. Eels usually make two migrations yearly, one in the spring as April or May, when the young, termed Elvers, ascend from the sea and estuaries up rivers. Couch states that "very young eels have been obtained at the ebb of the tide as early as the 2nd of January; after watching a river with great care they have not been observed passing up the stream until the middle of March, and rarely even then." The second migration is from the fresh waters to the sea and takes place in the autumn, this is performed by adults for the purpose of depositing their spawn, when they select the mixed water at the confluence of the fresh and salt, where the temperature is a few dogres's higher than that in the vicinity.

On the banks of the Thames the migration of the young eels is termed "Eel-fare," "fare" being a Saxon or Anglo-Saxon term signifying "to go" or "to travel," and Yarrell suggests that the term "Elver" is a corruption of "eel-fare." Eels do not like a muddy condition of the water, in fact, old ones 
will quit a pool to avoid it. In the cold months of the year they remain imbedded in the mud, into which they descend some 12 to 16 inches. In Somersetshire their retreats (for they retire in large communities) on the banks of rivers are said to be ascertained by observing that the hoar frost does not lie over the mouths of the holes into which they have retreated as it does elsewhere. Eels, although often killed by frost, still at times are able to endure a low temperature, having even been frozen, buried for several days in the snow, and then gradually thawed to life again; while it has been asserted that in Russia they are frozen, and thas conveyed long distances, packed in straw, and are thawed on arrival at their destination. Eels have been known to occasionally quit the water and travel over moist places in search of food, as frogs or snails, or to find more suitable localities in which to live, for some waters are very obnoxious to them. They may be tamed and taught to come for their food at certain sounds, while they appear to recognize those who feed them.

\section{Anguilla vulgaris, Plate CXLII, fig. 1.}

Anguilla, Belon. p. 295 ; Rondel. ii, p. 198 ; Salvian. Fol. 64; Jonston, lib. ii, tit. ii, civ, p. 120, t. xxiv, f. 7, 8; Willugh. p. 109, t. G5; Ray, Syn. Pisc. p. 37 ; Rutty, Nat. Hist. Co. Dublin, i, p. 351 . Muroena, sp. no. 1, Artedi, Gen. p. 24, spec. p. 66, Synon. p. 39. Conger, Klein, Mis. lib. iii, p. 27, no. 6; Gronor. Zoop. no. 166. Common eel, Pennant, Brit. Zool. (Ed. 1776) iii, p. 142 (Ed. 1812) iii, p. 191; Low, Orkneys, p. 184. Sharp-nosed-eel, broad-nosed-eel, and snig-eel, Bowdich, Brit. F. W. Fishes, no. 7, 22, 28.

Murcena anguitla, Linn. Syst. Nat. i, p. 426 ; Bloch, Ich. pt. iii, p. 610, t. 73; Gmel. Linn. p. 1133; Bonnaterre, Ency. Ich. p. 34, pl. xxiv, f. 81 ; Bl. Schn. p. 486 ; Lacép. ii, p. 226 ; Jurine, Poiss. du LacLeman, pl. i ; Faber, Fisch. Isl. p. 59 ; Pall. Zoo. Ross.-Asi. iii, p. 71 ; Ekström, Vet. Ak. Handl. 1831, p. 285 and Fische Mörkö, p. 139; Nilss. Skan. Fauna, iv, p. 661; Gronov. ed. Gray, p. 18.

Anguilla vulgaris, Tarton, Brit. Fauna, p. 87 ; Shaw, Zool. iv, p. 15 ; Fleming, Brit. An. p. 199; Johnston, Berwick. N. H. F. Club, 1838, i, p. 175; Bonap. Pesc. Eur.; Costa, Faun. Nap. Pesc. pl. lv and lix, fig. 1; Siebold, Suss. w. f. p. 342; Malmgren, Wieg. Arch. 1864, p. 303; Blanchard, Poiss. de la France, p. 491, fg. 129; Günther, Catal. viii, p. 28; Schlegel, Dieren Neder, p. 87, pl. ix, f. 1; Winther, Prod. Ich. Dan. Mar. p. 50; Feddersen, p. 93; Collett, Norges Fiske, p. 196 ; Canestrini, Fauna D'Ital. Pesci, p. 29 ; Giglioli, Cat. Pesc. Ital. p 46; Houghton, Brit. F. W. Fish. p. 187, c. fig.; Morean, Poiss. de la France, iii, p. 560 .

Anguilla latirostris, Risso, Ich. Nice, p. 89, and Eur. Merid. iii, p. 199; Yarrell, Proc. Zool. Soc. 1831, p. 133, Zool. Journal, iv, p. 409, British Fishes (edition 1) ii, p. 298, c. fig. (ed. 2) ii, p. 396, (ed. 3) i, p. 62; Johnston, Berwick. N. H. F. Club, 1838, i, p. 175; Parnell, Wern. Mem. vii, p. 387 ; Thompson, Ann. Nat. Hist. 1839, ii, pp. 21, 270 and Nat. Hist. Ireland, iv, p. 225; Jenyns, Manual, p. 476; White, Catal. p. 111 ; Kröyer, Dan. Fisk. iii, p. 656, c. fig.; Kaup, Ápodal Fish, p. 38, f. 26; Günther, Catal. viii, p. 32; Malm, Fauna, p. 59l ; Houghton, Brit. F. W. Fish, p. 188, c. fig.; Giglioli, 1. c. p. 47.

Anguilla Canariensis, Val. Isles Canar. p. 88, pl. xx, f. 1.

Anguilla callensis, Guichenot, Poiss. Alger, p. 111, pl. vii, f. 1.

Angurlla acutirostris and mediorostris, Risso, Eur. Mérid. iii, pp. 198, 199;

Yarrell, Proc. Zool. Soc. 1831, p. 133, Zool, Journ. iv, p. 469, Brit. Fishes (ed. 1) ii, pp. 284 and 301, c. fig. (ed. 2) ii, pp. 381, 399 (ed. 3) i, pp. 44, 65; Templeton, Mag. Nat. Hist. 1837 (2) i, p. 412 ; Parnell, Wern. Mem. vii, p. 384 ; Jenyns, Manual, pp. 474, 477; White, l. c. p. 1]1; Kröyer, Danm. Fisk. iii, p. 642, c. fig.; Thompson, Ireland, iv, pp. 222, 227 ; Blanchard, 1. c. pp. 496, 497, f. 131, 132, p. 474; Costa, Fanna Nap. Pesc. pls. lvi, lix, fig. 4, 5.

Muroena oxyrhina and platyrhina, Eks. Fisch. Mörkö, p. 142.

Murona acutirostris and latirostris, Nilss. 1. c. p. 663.

Anguilla anguilla, Swainson, Fishes, ii, p. 333.

Anguilla miqratoria, Jröyer, Danm. Fisk. iii, p. 616. 
Anguilla fluviatilis, Heckel and Kner, Suss. w. f. p. 319.

Anguilla cuvieri, bibronii, savigni, morena, marginata, microptera, altirostris, platycephala, nilotica, Egyptiaca, Kaup, Apodal Fish. pp. 32-41, fig. 16-29.

Anguilla hibernica, Couch, Fishes Brit. Isles, iv, p. 328, pl. coxxxv.

Anguilla sinensis, and macroptera, McClelland, Cal. Journal, Nat. Hist. iv, pp. 406,407 , pl. $x \times v$, f. 1-2.

Anguilla Ininnei,* Malm, Fauna, p. 590.

Sharp-nosed-eel, Dublin-eel, Broad-nosed-eel, Snig-eel, Couch, Fish. Brit. Isles, iv, pp. 326, 328, 330, 331, pls. ccxxxiv, ccxxxv, ccxxxvi.

\section{(Young.)}

Beardless Ophidium, † Penn. Brit. Zool. (Ed. 1776) iv, Appendix, p. 346, pl. xciii (Ed. 1812) ii, p. 208, pl. xxix.

\section{(Monstrosities.)}

As already observed (page 3 ) the eel is subject to so many variations depending upon local causes that I do not think we possess more than one freshwater species in these islands, and which is almost cosmopolitan in its range.

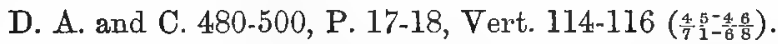

Lower jaw the longer: the length of the head $2 \frac{1}{2}$ to $2 \frac{8}{4}$ in the distance from the snout to the origin of the dorsal fin, and from $3 \frac{1}{2}$ to $3 \frac{2}{3}$ to the commencement of the anal fin. Body cylindrical as far as the anus, posterior to which it becomes more and more compressed. Lips broad and fleshy, (latirostris,) or narrow, (vulgaris:) the maxilla extends backwards to beneath the middle or hind edge of the eye. Eye-rather small, diameter 8 to 12 times in the length of the head: about 1 to 2 from the end of the snout, $1 \frac{1}{2}$ apart. Teeth-cardiform in the jaws and vomer. Fins-the dorsal commences far behind the head as already observed. The anal arises about the length of the head behind the origin of the dorsal fin, and a little in front of the middle of the total length. Scalessmall ones under the epidermis and imbedded in mucus. Colours-variable, generally dull olive along the back, and white or yellow along the abdomen, fins darker than the body, except the first third of the anal. Among the outward signs by which a male eel may be recognized, says $O$. Hermes, is a very striking metallic or bronze colour.;

Varieties.-In colour, piebald, yellow, white, silver, green-bellied, or with a longitudinal yellow band along the back. I obtained a yellow one at Cheltenham, February 1st, 1880. Rutty observed white-bellied or silver eels are the best because they live on a sandy and gravelly bottom, whereas those that live in mud are yellow-bellied and of a less grateful taste.

Several distinct species of common eel have been reputed to occur in this country (see page 240), but which appear to be differences due to sex or dependant on sterility. The following are the more striking forms:-(1) The "grig" or "glut-eel," Anguilla latirostris, a variety of a small size, having a broad head and snout, the dorsal fin commencing further back than in the next variety, the distance between its origin and that of the anal fin being less than the length of the head, while its dorsal fin is lower and its eyes larger than in the sharp-suouted form. It is mostly found in brackish water and in the vicinity of the sea, rarely ascending rivers any distance above the tides. This is the male. (2) The "sharp-snouted eel," $A$ acutirostris, which is the common form that is taken when descending in large numbers to the sea in the autumn for breeding purposes. Its snout is sharp, its dorsal fin higher and its eye : maller than is seen in the male. This is the female. (3) There is also a well-

* Anguilla kieneri, Günther, Fishes of the Porcupine Expedition from the North Atlantic, is a small Gadoid, as previously observed by Couch, and the young of a Lycodes (Day, Proc. Zool. Soc. 1862 , p. 536 , c. fig.).

$\dagger$ See P. Z. S. 1849 , p. 84, also ante vol. i, p. 209, respecting Ophidium imberbe of Montague al $d$ others.

+ See Proceedings Royal Society, 1868, pp. 230 and 343, for an account of the lymphatic heart in the eel's tail. 
marked, generally very broad-snouted when large, non-migratory, fierce and voracious form, which is not choice in its food, and the flavour of which is anything but satisfactory. These appear to be sterile females who have taken up their abode in fresh waters, but as some have been observed migrating seawards at the annual breeding season their sterility may only be temporary. It is rather remarkable that so long ago as 1740 Williamson (British Angler) observed "he and she eels may be distinguished by their fins."

Names.-Ael, Anglo-Saxon: German and Dutch, Aal: Finnish, ilja or iljakka, "slimy," or the Esthonian illa, "slime." Snig means a snake. Easgann, Celtic, Moray Firth. Oliver, "a young eel," Devonshire : Eeleator, "a young eel," in Northumberland, also Brawat : eel-fare, a brood of eels : Elvers or Elvene, young eels: Fansen, a young eel (Chapman) and in Cheshire, scaffling: grig or glut, "a small eel," Suffolk: yel in Somersetshire: whiffers or whuffers in Cornwall: known in Lough Neagh as weed-eel the same as snig-eel in England (A. mediorostris): while eel, sliull-eel, or brown-eel (A. vulgaris) according to Thompson, Kemp, also means a sort of eel (Pasgrave): and the fishermen of the Worcestershire Avon term the large-headed variety, frog-mouthed eels. Llysowen, Welsh. A bind, according to Kenneth, MSS. A.D. 1053, signifies a quantity of eels numbering about 250. Anguille vulgaire, French.

The term eel has been thus described, the noble or adel of Italy, corrupted into the aal of Germany and the eel of Great Britain.

Habits.-Adult eels prefer pure fresh water with a muddy bottom and appear to be averse to cold. They burrow out holes or tunnels where they rest during the day or conceal themselves under roots, bushwood, planks, or other suitable places, sallying out for food at night-time. During the summer months they may often be seen basking near the surface and lying on the vegetation growing in the water. When on the feed they move about at the bottom, inserting their snouts under stones, and have been seen to put up a loach and pursue it from place to place as if hunting by scent. In December, 1860, an eel $39 \frac{1}{2}$ 'inches long was taken alive in the middle of a stubble field: there was an old pit in the vicinity containing very little water (G. Hoult, Field, Dec. 1860). Especially on the approach of stormy weather, they have been known to migrate over newly ploughed fields or gardens, where they have been reported to consume the peas. During their migrations they have not infrequently entered water pipes and so cut off the supply. Their mode of escaping in an aquarium is remarkable: if possible they commence by throwing their tail over the end of the vessel, and that organ being a prehensile one, they subsequently lift themselves over and so escape by their usual tortuous movement ( $R$. Couch, Zool. p. 1829). Queckett likewise remarked that elvers often progress tail foremost. Eels live a long time in confinement: one resided 22 years in an aquarium, dying on August 1st, 1877, of old age (Hardwicke, Science Gossip, 1877, p. 261). Mr. Daniel mentions one which lived upwards of 31 years in a well and was then choked by a frog that was larger than it could swallow.

Thompson observes that from February 6 th to the 8th, 1841, great quantities of these fish, in a dead state, floated down the river Lagan to the quays at Belfast. Four of them, measuring from one to two feet in length, were placed in water warmed to a high summer temperature, but none exhibited signs of life. During these two days the thermometer was $10^{\circ}$ higher than it had been for the three previous days, but there was a gale from the east accompanied by a hard frost: to the human body the cold felt extreme and piercing; the eels would appear to have been in the mud which was uncovered and of course subject to evaporation. Dr. Kirtland, of Cleveland, states that last winter (1850) as the frost set in, a number of eels in a mill-pond, incommoded by the subsidence of the ice, migrated to other ponds from which he obtained eight or ten bushels half frozen. Having been placed in a cold exposed room they were as stiff and almost as brittle as icicles in the morning. A tub was flled with them and water from a well added, then they were placed in a warm store room for the purpose of thawing. In the course of an hour or two they were resuscitated and as active as if just taken during the summer (Chambers' Edinburgh Jourmal, Nov. 29th, 
1851). H. Frere (Zool. 1846, iv, p. 1216) considers that cold deadens hearing in fish and where some ecls were simply lying beneath the surface of the ice some way from the edge which is usually the last to freeze, he found that a hole could be cut in the ice only two or three inches from the fish, which were easily pulled out with a pair of nippers. Where there were reeds projecting through the ice the concussion carried down by any blow startled the fish, but where the ice was uninterrupted they usually lay quite still until extracted.

Lubbock considered the common eel in Norfolk not to be so voracious as the snub-nosed variety, and more regular in its migrations. In the winter, numbers of them are sometimes found laid up in the mud by the side of navigable channels, and several stones' weight have been speared within the compass of a few yards. They may almost be said to be omniverous, for several observers have distinctly stated from personal observation, that they occasionally eat vegetable substances. O. Melsheimer (Rhenish and Westphalia Natural History Society, 1877) remarks that after a series of years of observation he had come to the conclusion that the food of this fish is exclusively animal. They feed on the ova of fish and crustacea, and are excessively partial to crabs when they are shedding their shells: also to frogs and snails, and are said to prefer their food fresh, usually rejecting it if tainted. Mr. J. Banister (Zoologist 1843, p. 108) mentions a large rat struggling to escape from a hole a little elevated above and near the edge of the water. It dragged after it an eel about $\frac{3}{4}$ of a pound weight, which appeared to have the greatest portion of the rat's tail in its mouth. After dragging it out about six inches it let go. In another instance a rat was found inside an eel. A skinned mouse, or plucked young sparrow are said to be good bait in Lancashire. MIr. Longstaffe, while walking by the side of Thirston Burn, May $27 \mathrm{th}, 1875$, saw an eel which looked peculiar : he shot it. It was on the point of swallowing a large water vole, and had so far succeeded as to leave only the hind limbs and tail sticking out of its mouth. It was 30 inches long. Eels have also been known to devour moor-hens, young waterfowl, snakes, and fish of any description. McIntosh (St. Andrew's) gives an instance of one swallowing another smaller than itself. The captive one doubled up its tail, thrusting it from inside through the gill-opening of its captor and choked it.

Migrations.-Fels, as from $33_{2}^{1} \mathrm{lb}$. weight to those of smaller size, descend streams and rivers (as the Severn, for instance) during the first rise in October or November, during which period they cease feeding, but the take is more succcissful when the floods occur late, because then the weeds have disappeared to a considerable extent. Arriving at tidal waters they continue descending with the ebb, but cease "running" when the tide flows. In Norfolk this downward migration commences in July and continues to the end of November, and it has been observed that as soon as the lamperns begin to run the eel stops. After spawning, but few eels return again to the river. In "the Y are and Waveney, the cels come down in large solid balls from one to two feet in diameter, heads inside and tails out; and these living balls roll down the river and plump into the nets with such force as to carry them away, for which reason the eel-fishers at the mills dread their coming." A gentleman from Ireland informed me that he had personally witnessed during the months of September and October balls of eels similarly rolling seawstrds. Pennant remarks that in the river Nyne, in Northamptonshire, there is a variety of small eel that is found in clusters at the hottom of the rirer and is called the Bed-eel, and is sometimes roused up by violent floods. Pliny observed it in October and suggested they did so to ward off the cold.

During the early months of the rear young eels, which are transparent, having some minute dark spots on the back and sides, so as to appear longitudinally striped, commence ascending' rivers in incredible numbers, which migration, or "eel fare," has been already alluded to (see page 240). Thus " they pass up the Parret with the tides of March, April, and May; a few (the fishermen tell me) ascend in February, and those by Jnne are about 3 or 4 inches long. They come in a continual shoal, about 18 inches wide, without cessation, for some days, always against the stream, and close to the left bank. The woum catch them at night 
by means of a canvas bag, attached to a hoop, at the end of a long stick to which a lantern is fixed. They are thrown into a tub of salt which cleanses them; they are then boiled, and pressed into cakes, which are cut into slices and fried, making most delicious food. Sometimes they are so abundant that the people about get tired of eating them, and actually feed the pigs with them " (Buckland). "At an early period in the summer it is an interesting sight (at the Cutts near Coleraine, on the lower Bann) to mark the thousands of young eels then ascending the stream. Hay ropes are suspended over rocky parts to aid them in overcoming such obstructions. At these places the river is black with the multitudes of young eels, about 3 or 4 inches long, all acting under that mysterious impulse that prompts them to push their course onward to the lake" (Patterson, Zool. for Schools). In migrations elvers appear to be diurnal in their habits, whereas old eels choose the darkest nights after a flood, while in stews they die most in frosty weather should they have no sand or mud to creep into. Thompson remarks that he has been informed that a run of eels at night-time has been completely stopped in its progress by placing three large lamps so that the rays of light fall upon the surface of the water. Similarly at the great eel fisberies of Commachio it is stated that migrations are suspended or interrupted either by a full moon or fires accidentally lighted in the vicinity; while thunder likewiso prevents their " running" when all else is apparently favourable. The direction of the wind is also of importance; it is favourable when with them or from any point from the south, but if a sudden change occurs they will cease to migrate for the night.

Some excellent authorities upon fish and fishing are disposed to believe that all eels do not ascend from the sea, some being raised in fresh waters; and many curions localities have been recorded where detached waters have contained eels. Thus a correspondent of Land and Water (July 15th, 1882) observes: "Last week I saw eel and carp fishing going on in the Co. Wexford marl holes. Many of these holes are at great distances from the streams and river, and have no connection with them, so that the eels must go over the land to get to them, and I learn from the people in the neighbourhood that some of the largest eels they get are caught in the grass in summer after rain." Mr. Cornish, among several cases he records, tells us "that at the famous Botallack Mine in St. Just, in Penwith, eels occur in a pond fed by chance supply, situated on the top of a hill close to the blacksmith's shop. And I placed on record some years ago the capture of a large eel in a freshwater pool fed not from the surface, but from the bowels of the earth in one of the old deep levels (or workings) of Wheal Mary Mine, near this place" (Land and Water, June 10th, 185\%). Mr. Berry (Mag. Nat. Hist. 1834, vii, p. 301) says he has taken eels of all sizes, from that of a needle upwards, in ponds totally unconnected with and distinct from either river or brook.

It has been supposed that as eels as large as $11 \mathrm{lb}$. or more are captured migrating seaward they must have bred in fresh water; but this does not follow-they may be sterile temporarily or permanently, as the one kept over 22 years in an aquarium. Young eels have, as already observed, been known to ascend the flood-gates of lochs, to ereep up water-pipes-in short, mechanical difficulties scarcely obstruct them; they will even quit the water and travel over herbage. Lakes which formerly were well stocked with eels have become destitute of them, due to impassable barriers having been erected between them and the sea, preventing migrations to and fro.

Means of capture.-Eels are in places taken in the largest numbers after heavy storms and floods. These may be in the form of "eel-bucks," as used in the Thames, which consists of a number of wicker baskets or "weals," externally somewhat in the form of a sugar-loaf, and internally like a mouse-trap; several of them are supported with a wooden framework, the whole crossing the stream. The open side of these baskets is tarned up stream, as it is when these fishes are descending that they are trapped. These wicker-work baskets have to be soaked some weeks before being used, or eels will not enter them. At some mills one of the water-gates is left open and a hoop-net fitted to a frame inserted, 
Which is often successful in obtaining good catches of descending fish. Thompson says at Toome "they are taken in nets which may be compared to sugar-loaves, with the tops cut off, each from 14 to 16 yards long, and placed between weirs." A blow on the tail is said to quiet an eel. In appropriate localities snigs are stated to be sometimes taken when the openings of the eel-buck are down stream.

In the rivers and broads of East Anglia "eel-sets" are employed: these are wall-nets of small meshes set across the stream, the foot rope being weighted and resting on the bottom, while wooden floats are used along its upper edge, and these are fixed to three stakes, one being near each bank and the third in the centre of the stream. They are used for the silver eel, and arrest them during their anturan migration seawards, and in this way tons are occasionally captured in Norfolk. The opinion prevails that it will not readily take a bait or be speared.

Baits. - Trimmers baited with roach or other silvery fish; the bait being near the bottom, also night lines. Atkinson (Zoologist, 1844, p. 528) remarks upon never having caught very large eels in the spring or early summer, or on moonlight nights, except the water was foul. They often remove the bait without being hooked, while gudgeons are preferred to minnows. In one piece of water he could not induce them to take Prussian carp. In some of the shallower Norfolk broads, according to Lubbock, the fisherman has a bundle of osier wands in his boat, each about 7 feet in length and sharpened at the thicker end; about a yard of strong string is attached to each. Hooks baited with small fish are beside him, and as he floats along he attaches it to one of his lines and sticks his osier twig down wherever he perceives an opening among the weeds at the bottom. The adrantage is that no struggles of eels entangle his line, each being independent of the other. In Norfolk babbing or bobbing is thus carried on : a number of lob worms are threaded by means of a needle on worsted, until a bunch is formed. A weight is attached and the bait lowered to the bottom. The babber sits in his boat all night with a short rod in each hand, and every now and then lifts the bab a little. If a bite, he lifts it gently into the boat, the eel's teeth having become entangled in the worsted. The great time for this is when roach and bream are ronding or spawning in the spring, then the eels follow them; it is useless babbing anywhere except in the spawning beds. You can hear the eels sucking away at the spawn in the weeds, and they gorge themselves to such an extent that they will lie motionless on their backs in the gravel. There are two kinds of eel-spears employed in the Broads' district, the prick is constructed of four broad serrated blades or tines spread out like a fan, and the eel becomes wedged between them. The dart is made of a cross piece with barbed spikes set in it like the teeth of a rake. The spearer watches for bubbles, which denote the presence of an eel, and then uses his spear. In some places the eel-spear is known as "eelshear" or "elger." Brogging or sniggling is thus performed: when the water is low, and on a hot summer's day, a small hook baited with a redor dew-worm is affixed to a long line, one end of which is held in the hand. Then the apper end of the hook is loosely inserted into the cleft of a long hazel-wand. Holes or appropriate places for eels are searched for and the bait quietly placed therein. The eels must have time to gorge the bait and be very leisurely extracted from their retreat, for lying doubled up in the hole, they will, if much force is exerted, break the line. Powdered beef, a frog, minnow, intestines of fowl or fish, particularly the offal of mackerel, herrings, or pilchards, while a pride, Petromyzon branchialis, exceeds every other bait for night lines.

Breeding.-From the time of the Greeks this has been a difficulty to naturalists. Thus, Aristotle thought they sprang from mud. Pliny had an idea that fragments of the skin of the parents rubbed off against the rocks developed into young ones, while Hclmont gives the following curious recipe:- "Cut up two turfs covered with May dew, and lay one upon the other, the grassy sides inwards, and then expose them to the heat of the sun; in a few hours there will spring up an infinite quantity of eels."

Horsehair from the tail of a stallion was asserted to be a never-failing source of joung cels. 
Parasitic worms, Ascaris, have been constantly pointed at in the intestines of these fish as the developing young; while other fishes have likewise been the reputed parents of eels. Jacoby tells us that this last opinion is even very prevalent at the present day among eel fishermen, especially such as reside near the mouths of rivers. A slimy fish, Zoarces viviparus (see vol. i, p. 211), owes the name by which it is generally known in Commachio-the "eel-mother", - to this opinion. It is a very old opinion, prevalent to this day, that eels copulate with water-snakes, but it seems incredible, and is nevertheless a positive fact, that the Sardinian fishermen consider a beetle, Dytiscus Roeselii, as the procreator of the eel.

In the seventeenth century Redi and Paullini both expressed their opinions that eels must have both semen and ova; while Mondini, at Bologna, in 1777, read an accurate description, accompanied by excellent illustrations of the ovaries of the eel discovered by himself, and which was published in 1783. O. F. Müller almost simultaneously (1780) published a description of the ovaries of this fish, which appear in the shape of a frill-shaped band, extending in the abdomen anteriorly to the forepart of the liver and posteriorly to the vent, * while in this band are numerous eggs, but no duct, as the ova falls into the abdominal carity. Rathke, in 1850, described the first gravid female eel which up to that period had come into the hands of a competent investigator. For some time it was contended that this fish was an hermaphrodite, and it was not until 1873 that Syrski, at Trieste, obtained an eel 15 inches long possessing an undescribed organ as well as being deficient in an ovary. This lobe-organ consists of tubes in areolar tissues, contains a seminal duct, shows no trace of frill-like folds, but appears as a light band with a free edge. Care has to be taken not to mistake two fatty bands, which are always present in either sex of eels, for the lobe-organ. The largest male seen by Syrski has been from 17 to 19 inches in length. Since they were first detected numerous male examples have been found.

Günther, in his "Introduction to the Study of Fishes" (1880), disposes of the investigations made up to that period, remarking:- "Their mode of propagation is still unknown. So much only is certain, that they do not spawn in fresh water, that many full-grown individuals, but not all, descend rivers during the winter montbs, and that some of them spawn in brackish water, or in deep water in the sea." The common opinion seems to be that the eel only spawns once in its- lifetime, a peculiarity it shares with the lamprey, and this process takes place in the sea. The proportion of male to female fish rapidly decreases with the distance from the sea. When the young are hatched they ascend the rivers to reach the inland streams and ponds, where they grow in size but never increase in numbers. It would seem, considering the state of the ovaries so long as these fish continue in rivers, that salt water is needed to develop the procreative powers.

Life history.-It has been disputed whether young eels grow rapidly or slowly. $\dagger$ M. Coste says that placed in reservoirs with plenty of food, in four or five years they weigh from 4 to $6 \mathrm{lb}$. I received alive through the post a little elver, $2 \cdot 1$ inches long, on May 15th, 1879, at Cheltenham. It did well when placed in an aquarium, usually lying on the top of the Valisneria in the water, and darting away and hiding its head under a stone if frightened: occasionally it ascended to the surface and discharged a bubble of air. By May 27th it had grown to $3 \frac{1}{2}$ inches in length, during this period having been kept in a tumbler with about two inches of tank water changed daily. It was now taken to Westonsuper-Mare, but did not thrive, the water apparently being unsuited. At the end of June it was brought back to Cheltenham, but during my absence died, due to rain water only having been supplied.

Fisheries. - There are many celebrated ones distributed over Europe, more especially that of Commachio, near Venice : those of the Seine in France, Nar-

- The genital opening is a simple orifice which communicates with both halves of the abdominal cavity by means of a transverse fissure between the rectum and the urinary bladder, and opens iuto the urethra.

$\dagger$ Cultivation of Eels, Souberain, A. M. N. H. (3), 1865, xvi, p. 384. 
bonne and Montpellier: many likewise in Germany and Holland. In this country the Kennet has long been celebrated for its eels as well as the Isle of Eels, now termed Ely, and other localities, as Cambridgeshire and the Eastern broads.

The largest supply is obtained from Holland, and Mr. Mayhew (London Labour and London Poor, i, p. 66) has given a good description of the Dutch eelboats in the Thames. For in the time of Queen Elizabeth a free mooring was given for Dutch schuits in this river when bringing over eels, a privilege that is still made use of. The holds are fitted up with long tanks of muddy water, and the heads of the eels may be seen breathing on the surface, a thick brown bubble rising slowly and floating to the sides. At the stern of one boat was moored a coffinshaped barge pierced with boles, and hanging in the water were baskets, shaped like olive-jars, to keep the stock of fish both alive and fresh. In the centre of the boat stood the scales, a tall, heavy apparatus, one side fitted up with the conical net-bag to hold the eels, and the other with the weights, and pieces of stone to make up for the extra draught of the water hanging about the fish. The Scotch will scarcely eat them or even capture them for sale.

"Mr. Gurney informs me that he used to find the sharp-nosed eel at Lowestoft along the coast, sometimes nearly a mile from the harbour's mouth-very healthy but never large; $2 \mathrm{lb}$. would be the maximum weight of these salt-water eels" (T. Southwell). Paget has likewise remarked that eels are found iu Yarmouth at the harbour's month and even at sea.

It has been observed that an eel will live and grow in any water, however warm, and though it prefers a muddy or boggy bottom, such is not indispensable. It requires no special food, being omniverous, is an excellent scavenger, besides capturing living prey. It grows rapidly, while the young are easily transported. But it is found undesirable in rivers where gill-nets are much employed, as it eats the captives.

As food.-A Are largely eaten potted, stewed, or in eel-pies; are rather rich, wholesome and nutritious, except when captured near drains, when they ought to be avoided. "Very seldom eaten in Orkney" (Low). The Jews reject the eel although they are aware that it has scales. Hilvers "may be eaten boiled in milk and pressed into a sort of cheese" (Ball). Fancy, as regards their appearance somewhat resembling a snake, causes many to reject these fish as food, al though they are otherwise esteemed by the South Britons but loathed by those in the North, while in some parts of Ireland the supposition seems still to hold good that they are the lineal descendants of the serpents on which St. Patrick served a writ of ejectment, depriving them of any local habitation on dry land. A tradition exists in Cambridgeshire that when the priests refused to accede to the Pope's order to put away their wives, the latter, as well as their offspring, were turned into eels, whence originated the name Ely! Their skins, in the Orkneys, are worn around the ankles as a preservative against cramps. Even the Ancients were superstitions respecting eels, deeming them to be the embodiment of evil spirits.

Highly esteemed by the Greeks and Rnmans, they were rejected by the Egyptians, but enrolled among their numerous gods, and esteemed by most people, except Jews and Scotch. They are always in season, but least in winter and are worst in May.

Uses.-Their skins, oiled and dried, are used in Tartary as glass.

Diseases and, causes of destruction.-Their greatest enemies, irrespective of man, are otters, polecats, and rats, both of which attack them in winter when dormant. Herons and swans likewise eat them, as well as pike, salmon, and large trout. A water spaniel has been known to feed greedily on young eels waiting to ascend a pass. But herons have not invariably captured eels with impunity, as it is on record how one pierced through the eye by the bill of its captor, twisted itself round its neck and strangled it during its dying agonies. It is asserted that tar in the water destroys or repels eels. Thus they were formerly abundant in the harbour at Mevagissey, but since boat-building has been much carried on they have disappeared, the water now being constantly polluted with tar. A disastrous epidemic among the eels has been observed this summer (1882) in the Nakskoofjord in Laaland, an island of considerable size in the Baltic, 
belonging to Denmark. "The eels are dying away in enormous numbers without suffering from any apparent disease. Many thousands of dead eels could be seen a few days ago along the strand between Sandby Sletnäs and Rosnäs, only a few miles distant from each other. Great quantities of eels forwarded as usual to the German ports in the East Sea were discovered dead upon the arrival of the transports at their destination, although when shipped they all appeared to be in a fresh and healthy condition. The eel fishery, which is of considerable importance in the fiords of Laaland, has therefore collapsed altogether this season. All the foreign eel fishermen who have been in the habit of frequenting the island have returned home. Nothing has as yet been ascertained which might throw any light upon the cause of the death of the eels" (V. B., in Land and Water, July 15th, 1882). An epidemic is reported to have attacked pike and eels in the river Barrow. The latter fish were seen very lifeless for a day or so, and subsequently dead in shoal water, the under part of the body, from the mouth to the tail, being speckled with blood-red spots, and the mouth sometimes fall of coagulated blood. Numbers are killed and eaten by rats and polecats in the winter. They are very much disturbed by electricity. In the winter they come to the surface for air, and polecats have been observed to hunt for them. Mr. Bannister (Zoologist, 1846) observes, that " in tracing the foot-prints of the polecat, it will soon be ascertained that he halts at every hole or opening he meets with in the ice, and at once commences fishing, by introducing a forefoot into the water, and no doubt groping all round under the ice as far as he can reach in search of such eels as may have come to the aperture for air."

Habitat.-Generally distributed in Europe, except in the Aretic regions, the Danube and its tributaries, the Black Sea, and the Caspian.

In the Orkneys eels "are common in all our lochs, burns, and in the sea. They are found in many of our lochs, especially where no other fish are, and even in those whose efflux into the sea is over such precipices as to allow of no passage for any living thing, which puzzles many of our country sages to account for their getting there; and indeed this is no easy task, if we do not consider the manners of the eel : how difficult it is to be retained in the claws, or even the stomachs of birds which prey upon it; how tenacious of life it is, which makes it capable of being carried a great way without being the worse; and if dropped, its ability in this case to seek out a proper habitation for itself" (Low).

In Ireland it is abundant both in the fresh waters and around the coast. In the north they commence taking them in large numbers about August. The greatest number Thompson states he had heard of being captured at Toome in one night was 70,000 . Mr. Ogilby says that he has only detected the broadnosed form in the rivers of the Donemanagh district. The fry run up in June, and are eaten by larger eels, trout, etc.

As to the size which eels obtain, many of the largest recorded examples are probably congers. August 17th, 1866, one netted the previous day in the River Bure, Horning (? Norfolk), was 3 feet 8 inches long, and 10 inches in girth at the thickest part, and $7 \frac{1}{4} \mathrm{lb}$. weight (T. E. Gunn, Zool. 1866, p. 510). Mr. Clarke Kenedy observed one from Downbam 5 feet 8 inches long and $36 \mathrm{lb}$. weight (Zool. 1868, p. 1061). The largest seen by Buckland weighed 10 lb., and I have not personally observed any larger.

The example figured is a female from Norfolk, $13 \frac{1}{2}$ inches in length. 


\section{Genus II-Conger, Cuvier.}

Gill-openings large and extending low down. Eyes large. Cleft of mouth wide and reaching to at least so far as the centre of the eye. Posterior nostril patent and opposite the middle of the front edge of the eye: the anterior nostril tubular. Teeth in rows in both jaws, one of which in the upper forms a cutting edge due to their so closely approxinating together: no canines: a shurt band on the vomer. Dorsal fin commences behind the insertion of the pectoral: the pectoral and also the vertical fins (which are continued round the tail) well developed. Scaleless.

Geographical distribution.-Seas of temperate and tropical regions. The species found off our coasts has been recorded from the seas of such distant countries as Japan and Tasmania.

Berkenhout (Syn. i, p. 64) included the small-headed Mediterranean Conger myrus among British fish, in which he was followed by Turton (p. 87), bat the authority for this is still wanting, consequently I have followed recent authors in omitting to insert it.

\section{Conger vulgaris, Plate CXLII, fig 2.}

Congro, Belon. p. 162 ; Rondel. i, p. 308. Broncho, Salvian. p. 66. Conger, Willugh. Hist. Pise. p. iii, t. G4; Ray, Syn. Pise. p. 37 ; Pennant, Brit. Zool.

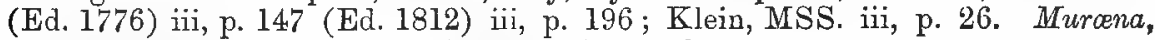
sp. Artedi, Gen. p. 24, no. 2; Synon. p. 40, no. 2.

Murcena conger, Linn. Syst. Nat. i, p. 426 ; Bloch, Ich. p. 999, t. clv; Gmel. Linn. p. 1135 ; Bonn. Ency. Ich. p. 35, pl. xxiv, f. 82; Bl. Schn. p. 487; Lacép. ii, p. 268; Donovan, Brit. Fish. $\nabla$, pl. cxix; Risso, Ich. Nice, p. 92; Nilss. Skand. Fauna, iv, p. 680; Gronov. ed. Gray, p. 19; Pallas, Zool. Ross.-Asi. iii, p. 72 .

Anguilla conger, Mitchell, Lit. and Phil. Trans. N. York, i, p. 360; Shaw, Zool. jv, pt. i, p. 20, pl. i; Turton, Brit. Fanna, p. 87; Flem. Brit. An. p. 200 ; Jenjns, Man. p. 478; Kröyer, Danm. Fisk. iii, p. 603, c. fig.

Conger valgaris, Cuv. Règne Anim. t. ii, p. 231 ; Yarrell, Pro. Zool. Soc. 1831, p. 158, Brit. Fishes (ed. 1), ii, p. 304, c. fig. (ed. 2), ii, p. 402 (ed. 3), i, p. 68; Parnell, Wern. Mem. vii, p. 388; Schleg. Fauna Japon. p. 259; White, Catal. p. 112 ; Bleeker, Vehr. Bat. Gen. xxv, Japan, p. 53 and Atl. Ich. Mur. p. 26, pl. $\nabla$, f. 2 ; Thompson, Nat. Hist. Ireland, iv, p. 227 ; Schlegel, Dieren Neder. p. 90, pl. ix, f. 2 ; Günther, Catal. viii, p. 38 ; Canestrini, Fauna d'Italia, p. 200; Collett, Norges Fiske, p. 199; Winther, Ich. Dan. Mar. p. 51; Giglioli, Catal. Pesc. d'Ital. p. 47 ; Moreau, Poiss. de la France, iii, p. 565.

Conger niger and verus, Risso, Ich. Nice, p. 93 and Eur. Mérid. iii, p. 201 ;

Kaup, Apodal Fish. p. 113.

Echelus glaucus and macropterus, Rafin. Caratt. pp. 64, 65, t. xvii, f. 2.

p. 107.

Congrus vulyaris and leucophceus, Richard. Voy. Ereb. and Terror, Fish.

Conger communis, Costa, Fauna Nap. Pesc.

C'onger occilentulis, De Kay, New York Fauna, Fish. p. 314, pl. liii, f. 172.

Conger Linnéi, Malm. Fauna, p. 591.

Conger, Couch, Fish. Brit. Isles, iv, p. 340, pl. cexxxviii.

\section{(Immature.)}

Leptocephalus Morrisii, Pennant, Brit. Zool. (Ed. 1776), iii, p. 158, pl. xxv (Ed. 1812), iii, pl. 212, pl. xxviii; Gm. Syst. Nat. i, p. 1150; Bl. Schn. p. 133, t. criii, f. 2 ; Montague, Wern. Mem. ii, p. 436, pl. xxii, f. I ; Leach, Zool. Misc. iii, p. 10 , pl. cxxvi; Fleming, p. 200 ; Deere, Lond. Mag. Nat. Hist. vi, p. 530 ; Yarrell, Brit. Fishes (ed. 1), ii, p. 311 , c. fig. (ed. 2), ii, p. 405 ; Jenyns, Brit. Vert. p. 480 ; P(ach, Ann. and Mag. Nat. Hist. 1854 (2), xi, p. 238; Kaup, Apodal 
Fish. p. 147 and Ann. and Mag. Nat. Hist. 1860, vi, p. 271; White, Catal. p. 114; Couch, Fish. Brit. Isles, iv, p. 348, pl. ccexl.

B. ix-x, D. 170, P. 16-19, D+A + C. 525-546. Vert. 154-164.

Length of head 7 to 8 , height of body 16 to 20 in the total length.

Body anteriorly rounded, becoming compressed in its posterior portion. Head depressed. Mouth wide, the upper jaw very slightly the longer, its cleft extending to below the middle of the orbit. The posterior nostril patent, the anterior tubular. Teeth-cardiform in the upper jaw, one regular row of teeth of the same size and placed close together form a cutting edge: a short band on the vomer : cardiform likewise in the lower jaw similar to those in the upper Finsthe dorsal commences above the last quarter or end of the pectoral : the anal in the middle of the total length. Colours-generally grayish, becoming lighter or even white beneath. A row of white spots mark the openings from the lateralline. The margins of the vertical fins black.

Varieties.-In colour, the body may be dark and the vertical fins blackish or with a black edge: or the whole fish may be uniformly black, due to the character of the locality where it resides. Couch alludes to a rock on the coast of Cornwall about five leagues from land, and rising up from a large plain of submerged sand. The summit of this rock is full of gullies shaded with weeds, and congers caught there are always black, while those taken close to its base are always white. Occasionally these fish are spotted with white. "In 1876 a conger of about $20 \mathrm{lb}$. weight, of a lead colour, approaching to white, was brought in from the deep sea and placed in a large wicker basket close to land: in six weeks he was as black as he possibly could be" (Dunn). In form.-In some there is a deficiency of the upper jaw or snout, while the dorsal fin is frequently deformed, the anterior portion being often absent or malformed, sometimes only a few rays existing near the tail. Occasionally the tail is found to end without any fin.

Names.-Conger, Haaf-eel (and Easgann faragidh, Celtic) Moray Firth. Evil-eel, Aberdeen (Sim). Cungyr or kunger, Mor Lysowen and Cungyren, Welsh. De Zeepaling, Dutch. Congre commun, French.

Habits. - Prefers deep waters where the bottom is rocky, or sandy spots surrounded by rocks which are covered by weeds. Is found from the borders of the tide up to fifty fathoms or more, but it very rarely ascends into fresh water; and although it appears to frequent farourite localities, still it is more common there at some times than it is at others. It is most active and appears to principally feed at night-time, even the presence of a bright moon has been known to interfere with the success of the fishing. It enters lobster pots to secure the contents, and is very destructive to soles and plaice in Cornwall. When in boats it feels about with its tail, and, if able, will lay hold of the gunwale with it, and so lift itself overboard, and this is one reason why the fisherman at once knocks it on the tail or orer the vent when captured: it is by means of the tail that it likewise makes its exit from a crab pot in which it has entered to devour the contents; it thrusts its flattened tail between the willow-rods of which it is composed and thus pushes itself backward through the opening. It is sometimes left stranded an hour or more by the tide, but this does not appear to occasion any inconvenience, while it will even conceal itself under the sand, awaiting a return of the tide. In the Moray Firth Gordon remarks that the fishermen believe that this fish is fond of swimming after newly tarred boats.

The conger is very sensible to atmospheric changes, and is inert during cold weather, while prior to storms it is more than usually active. During severe frosts conger have been seen floating down rivers half dead or "blown," this term signifying the air-bladder being tightly distended. Near Cork, in 1841, many died of cold; others were readily captured where the water was from forty to sixty feet deep and brackish.

Pennant observes that congers and eels in general are particalarly fond of carcases of any kind, being frequently found lodged in such that are accidentally taken up. In an aquarium it will even devour dog-fishes, swallowing its prey head first; while at Southport they could only keep sturgeons, angel-fishes, skate, 
and huge turbots safe in such company, their digestion being very rapid. It does great injury to the net-fishermen, tearing the captives out of the meshes. It feeds upon fish, especially pilchard, hake, and herring along the south coast, lobsters, crabs, and, in short, almost any form of animal life. Templeton recorded that a vessel loaded with salt herrings was wrecked on the coast of Rathlin, and these fish gorged themselves on them in great numbers, and for several days subsequently were washed ashore dead.

Mr. Ogilby informs me of one $5 \% ! \mathrm{lb}$. weight, and measuring over six feet long, which was taken in a net at Portrush, July 21st, 1876, while in the act of trying to swallow a marked $6 \mathrm{lb}$. salmon, which it has succeeded in doing so far as the mesh of the net. Mr. Dunn, at Mevagissey (October 9th, 1883), found they had swallowed stones from one to four ounces in weight, and also that it was a common occurrence as observed at the fisb factory. Eleven days subsequently, on a conger being hooked, it tried to free itself by ejecting something from its stomach, but the stone which it was trying to force out wis broader one way than the other, evidently the small end haring been swallowed first, but on coming up it turned and completely choked the conger; and after death, so firmly was it found jammed that after the fish's head was cut off, it could not be moved, and is still imbedded in the skull of the creature. It would appear likely that these stones have been swallowed for the purpose of obtaining the animal life attached to them, while they are subsequently ejected.

Mr. Dunn, at Meragissey, kindly kept a list of the various kinds of food taken from congers' stomachs in one day in August at the fish factory. Goldsinny wrasse, skulpin, lesser sand launce, father lasher, one-spotted goby, pollachs, rocklings of sorts, powers, lesser fork-beard, carter, pilchards, very small congers, pipe fishes, small squid, five varieties of crab including the bermit-crab, a whelk without its shell, and other animal substances. Small congers are frequently found in the stomachs of their larger relatives, while it is not uncommon for a small one, after having been hooked, to be swallowed by one which exceeded it in size: while the five-bearded rockling is a favourite food, also the large pipe fish.

Many instances, observes Thompson, have been recorded of the decapitated heads of these fish closing upon foreign bodies being inserted between the jaws; and Mr. Patter'son of how a boy, seeing on the shore the head of one of these fish just left by fishermen, pushed his toe into it; his yells soon brought assistance and release.

Means of capture.-Along our south coast, althongh occasionally taken handlining, it is chiefly canght by long lines or bulters baited with pilchards, mackerel, or sand launce: its mouth is rather tender for handlining, still this is the favourite method of pursuing it in the Channel Islands; but at the sea bottom it gorges the bait, which must be quite fresh. A conger can bite through a cord as thick as the finger, and twist the line round into a ball, and in this manner often drags the hook from the jaws. In most places on being captured it is knocked on the head or over the abdomen; but not so in the Channel Islands, where such a proceeding, it is considered, would spoil its appearance. Taken in Ireland mostly in May and June. Thompson mentions that congers have been known to destroy $£ 5$ worth of nets in a single night, and seven or eight hooks have been removed from a single fish.

Baits.-Red sea bream, pieces of almost any fish, as pilchards, herrings, and likewise cuttles. At Portrush, where it is very common, Mr. Ogilby observes that the lines set for it are only let down about an hour and in a slack tide : the bait should be perfectly fresh, as it will not look at anything stale.

Breeding.-In June, 1876, a female died in the Southport Aquarium, which weighed $15 \frac{1}{4} \mathrm{lb}$., while the ova were full $7 \mathrm{lb}$, showing a total of $6,3336,512 \mathrm{eggs}$. Dr. Otto Hermes found $3,300,000$ in one, the ovaries of which weighed $22 \frac{1}{2}$ lb. Yarrell asserts that they spawn in December and January. In Germany, Otto Hermes refers to female congers dying, unable to deposit their ova, while one at Frankfort-on-the-Maine burst in consequence of the unnatural development of its ovaries. It would seem to be a rapid-growing fish when abundantly supplied with food, thus Mr. Jackson at the Southport Aquarium observed that in about sixteen 
months the conger-eels have increased from about 7 or $8 \mathrm{lb}$, each to something like $25 \mathrm{lb}$. or $30 \mathrm{lb}$, and one which died in March, 1880, had grown in $5 \frac{1}{2}$ years from 2 or $3 \mathrm{lb}$. to $90 \mathrm{lb}$. weight. The supposed male organs of the common eel were observed by Syrski, as already described (page 247), but no one had detected spermatozoa in them. It was not until June 20th, 1880, that Dr. Ott.o Hermes finally set this question at rest respecting congers, when he found on cutting into Syrski's organ, that a white fluid flowed out, which, under the microscope with a power of 450 diameters, showed a great number of spermatozoa in the liveliest motion, and in which head and tail were evidently visible. The male conger is considerably smaller than the female, as has been observed in the common eel.

Fisheries.-During the fourteenth century in the West of England, this was an important dish, and was even received as the chief rent at underletting of land. At Sir T. F. Aubyn's, Mount's Bay, Cornwall, is a large one stuffed, which was paid as a heriot according to the terms under which the land was beld. Pennant observes that the following quantities were sent from Mount's Bay in Cornwall, in five years : 1756, 46 cwt. ; 1757, 164 cwt. ; 1758, 164 cwt. ; 1759, $213 \mathrm{cwt}$; 1760, $71 \mathrm{cwt}$. Before congers decreased off our shores or the sale became limited, they were exported to Spain and Portugal. Roand the Channel Islands and among the rocks in the vicinity congers abound, and King John in the charter of privileges to the people of this locality dwelt upon the right to capture and salt these fish, and prior to the extension of the Newfoundland fisheries this was very valuable.

As food.-Donovan considered its flesh to be simply delicious when roasted. The fat around its milt and roe is employed in some particular cookery due to its not possessing any disagreeable taste or smell. Much of the "stock" for turtle soup for hotel or public dinner tables is said to be made from conger. As food it, in common with the eel, is rejected in many parts of Scotland and the West of England, but in Edinburgh it finds a ready sale : in the Channel Islands the black variety is preferred.

Uses.-Conger doust is a local term for dried conger; the Portnguese and Spaniards used to employ these dried congers after they had been ground into a powder for the purpose of thickening and giving a relish to their soup. Small ones, according to Pennant, were slit and then hung on a frame until dry, for having much fat it is necessary all should exude before they are fit for use; they were then stitched together by their edges into a sheet. In Ireland the skins are preserved and employed for the hanging of tlails, etc.

Diseases and causes of destruction. - Sudden cold is often very destructive to congers, which become blown, so drift on shore and are left dead by the tide or knocked on the head and captured, or fall a prey to the lower animals. Otters in the Orkneys bring them on shore and leave them after they have eaten a small portion, subsequently the country people search for these. Porpoises, likewise, feed on them: thus, on April 20th, 1881, one weighing $35 \mathrm{lb}$. ran ashore and several yards up the beach of Colwyn Bay when pursued by one of these animals and, after a tough fight, was secured by Captain Davis, who gaffed it with a sail-hook.

Dareste refers to rickets, rachitis, existing in these fish. Such fish are remarkable by reason of the great reduction in the number of teeth, and remain smaller than is natural.

Habitat.-This fish has a very wide geographical range, extending from the coasts of Europe, the Mediterranean, and the shores of the Atlantic Ocean, to the East Indian Archipelago, Japan and Tasmania.

In the Orkneys the largest measure about 6 feet in length (Low). It is common round the coasts of Britain and Ireland, and abundant along our southern shores. This fish attains a large size : in October, 1877, one which was $6 \frac{1}{2}$ feet long was captured at Portrush, in Ireland, which weighed $53 \mathrm{lb}$. In January, 1880, one weighing $84 \mathrm{lb}$. was taken in a net at Burnham, in Somersetshire. Borlase alludes to one near Mount's Bay of $100 \mathrm{lb}$. weight; Couch to another of $104 \mathrm{lb}$; Buckland to one at Mevagissey, by Dunn, $112 \mathrm{lb}$; and in 1879 a conger weighing $128 \mathrm{lb}$. and 8 feet 3 inches long was received in the London market; Donovan asserts one of $130 \mathrm{lb}$. was captured at the Nore. 


\section{Genus III-MUrжina, sp. Artedi.}

Gymnothorax, Bloch. Murcenophis, Lacépède. Echidıza, Forster. Thcorodontis, Strophidon and Lycodontis, McClelland. Sidera, Eurymyctera, Thysoidea, Limamurcena, Polyuranodon, Pcecilophis, Gymnomurana, Priodonophis and Tceniophis, Kaup. Pseudomurcena, Johnson.

Body moderately or exceedingly elongated. Gill-openings narrow slits. A tubular nostril on either side of the upper surface of the snout: the posterior nostril a round orifice opposite the antero-superior edge of the eye, while it may or may not be furnished with a tube. Teeth well developed, and either acute or molariform: the maxillary teeth may be in one or two rows. Dorsal fin elevated, or not so; the end of the tail surrounded by fin, and is occasionally rudimentary: pectorals absent.

Geographical distribution.- Seas of temperate and tropical regions, some species ascending tidal rivers. One form has been captured off our coast. The spotted sea-eel, Ophisurus ophis, an inhabitant of the Indian Ocean, was incladed by Merret (Pinax, p. 185), subsequently by Sibbald (Scot. 23), and also by Berkenhout (Syn. i, p. 185) among the British fish, but the authority in all is omitted. It may, however, have been due to the capture of a Murcena helena at some antecedent date.

The dentition of these fish alters considerably with age, while it is not always identical in every individual of the same species. They are reputed to attack fishermen and others when in the water, a character, Mr. Carrington (Zoologist, September, 1876) thinks, they do not deserve.

\section{Muræna helena, Plate CXLIII.}

Múpaıva, Aristotle, i, c. 5, etc.; AElian. i, c. 22, etc.; Athen. lib. vii.

Muræna, Pliny, ix, c. 16, 19, 20, 23, 54, 55, and xxxii, c. 2, 5, 7 and 8 ; Belon. p. 158; Rondel. xiv, c. $\nabla$, p. 402 ; Salvian. pp. 59,60; Willughby, Hist. Pisc. p. 103 , t. G1 ; Aldrov. iii, c. 27 , pp. 356,357 ; Artedi, Sp. no. 6, Synon. p. 4l ; Gronov. Zoo. no. 164. Conger, Klein, Pisc. iii, p. 28.

Murcena helena, Linn. Syst. Nat. i, p. 425 ; Brün. Pisc. Mass. p. 11 ; Bloch, Ich. p. 993, t. cliii; Gmel. Linn. p. 1132 ; Bonn. Ency. Ich. p. 33, pl. xxiii, f. 79 ; Risso, Ich. Nice, p. 366 and Eur. Mérid. iii, p. 189 ; Costa, Fauna Nap. Pesc. pl. xxviii, f. 3; Jenyns, Manual, p. 479; Yarrell, Brit. Fishes (ed. 1) ii, p. 308, c. fig. (ed. 2) ii, p. 406 (ed. 3) i, p. 73 ; Guichen, Explor. Algér. Poiss. p. 114; Gronov. ed. Gray, p. 18; Richardson, Voy. Erebus and Terror. Ich. p. 80, pl. xlix, f. 1-6; Kaup, Apodal Fish, p. 55; Günther, Catal. viii, p. 96; Canestrini, Fauna d'Italia, p. 202 ; Giglioli, Faun. Ital. Pesc. p. 48 ; Morean, Poiss. de la France, iii, p. 575, f. 209.

Murcenophis heleno, Lacep. v, p. 631 ; White, Catal. p. 113.

Gymnothorax murcena, Bl. Schn. p. 525 .

Murcena romana, Shaw, Zool. iv, p. 26.

Murcena guttata, Risso, Eur. Mérid. iii, p. 191.

Murona, Couch, Fish. Brit. Isles, iv, p. 335, pl. ccxxxvii; Carrington, Zoologist, 1876, p. 5053.

$\mathrm{D}, \mathrm{C}$, and $\mathrm{A}=552$, Vert. 140-143.

Height of body varying from 9 to 12 or more times in the total length and the length of the head about 7 to 12 in the same distance. Eye-diameter about $\frac{1}{15}$ in the length of the head and 3 diameters from the end of the snout. Anteriorly the body of this fish is rounded, becoming flattened posteriorly ' its skin is rei'y thick, snout pointed, the cleft of the mouth deep and extending behind the eye : the upper jaw rather longer than the lower. A row of pores along both jaws. Both nostrils tubular, the anterior the longer. Teeth-in a single row, strong, compressed and 
pointed : those in the premaxillaries, and the canines in the lower jaw a little - larger than the lateral teeth: 17 to 19 along either side of the mandible. A row along the vomer, the anterior of which are the largest. Gill-opening small. Vent situated a little in front of the middle of the total length. Colours-a rich chocolate brown, lightest along the lower surface, and covered with irregularly shaped yellow marks or spots: near the tail the colours frequently take on a banded appearance. Gill-opening in a black spot as are also the corners of the mouth, and folds of skin on the throat which resemble black lines. The yellow spots are also extended on to the vertical fins.

Varieties.-There are many forms of colour in this fish, some being spotted others plain.

Name.-The Murry.

Habits.-Generally reputed fierce and voracious, but capable of being domesticated, and even it is asserted of showing affection, while Mr. Carrington considers it usually of the latter description. It frequents holes in rocks, and takes its food not by reiterated snaps but in a gentle and peculiar way, by a curiously quiet movement of the head, so as to bring the cheek down upon the object about to be eaten, seizing it with the side of its mouth and never by the front. It is very retentive of life and most readily dispatched by a blow on its tail. A wound from the teeth of this fish has been deemed dangerous, and we have the tale handed down to us, that on one occasion, when Augustus Cæasar dined with his favourite follower Vedius Pollio, and a slave chanced to break a valuable crystal wine vase, the latter flung himself at the emperor's feet and supplicated that he might not be thrown to the Murænas. On inquirry it was found that his master in this manner treated offending slaves who broke the decanters. The emperor having heard the suppliant, first set him free, next saw the eel-ponds filled in, and lastly had all the crystals broken in the presence of the guests.

As it gets old it is said occasionally to have a propensity to become fat and even to float on the surface. It is said to delight in waging war with crabs, cuttles, and congers : it devours small fishes, mussels and shrimps.

Vivaria.-Kept by the Romans as delicacies, and objects of amusement or even of affection. This fish is found to live and even thrive in fresh water.

As food.-A delicacy, its flesh being white and of good flavour.

Habitat.-It is common in the Mediterranean, especially off the coasts of Italy and Sicily. Not rare at Madeira (Lowe). An example, 4 feet 4 inches long, was captured on a line at Polperro, October 8, 1834, and brought to Mr. Conch, who subsequently noted in bis journal that Mr. Laughrin in $186^{\circ} 6$ informed him that the preceding spring a large example of this fish was caught in a trammel at Fowey, and cut up as bait for crab-pots.

The example figured died in the Royal Westminster Aquarium, and I am indebted for it to Mr. Carrington, F.L.s. 


\section{Order IV-LOPHOBRANCHII, Cuvier.}

Fishes possessing a dermal, segmental skeleton, and the opercular pieces reduced to a single plate. Gill-openings small: gills consisting of small and rounded tufts attached to the branchial arches. Muscular system very slightly developed. Snout produced: mouth terminal, but small. Teeth absent. Airbladder stated to be destitute of a pneumatic duct (but it is present in some forms, as Syngnathus acus).

The fishes which belong to this order, and popularly known as pipe-fishes and sea-horses, normally swim in a vertical position, the dorsal fin being the principal propeller, and which while in motion is rapidly undulated from end to end. The tail fin, remarks Gray, seems to be used rather as a foot than as an organ of propulsion, and when the species with a rayed caudal fin employs this part, it expands the rays giving the end of the tail the appearance of a webbed foot. The action of the mouth is similar to that of a common syringe, due to the dilatation of the throat; the water eriters the tubular-formed mouth, while it is ejected again by compressing and so emptying the cavity.

As regards propagating their species Professor Canestrini considered that a coitus occurs, when the ova are transferred from the female to the male, the latter fecundating them after they have entered the origerous sac. Kaup remarked that in most of the species the males perform the function of hatching the eggs, which for that parpose are deposited, up to the time of the evolution of the young, either between the ventrals (Sulenostomus), or in tail pouches (Hippocampus), or in pouches on the breast and belly (Doryrhamphus), or in rows on the breast and belly (Nerophis), and are thus carried about by the fish. Dr. Günther in his observation on Solenostoma cyanopterum remarks, "Kaup states that in the males of Solenostoma parailoxum the egg pouch is formed by the union of the inner edge of the ventrals to the skin of the belly, and that in the females the ventrals are free as in other fish. All the specimens from Zanzibar which have been examined have the ventrals attached to the skin of the belly, and all of them are females: so that if the first part of Dr. Kaup's remarks prove to be true, both sexes in this species carry eggs." Canestrini observed a caudal fin in young Hippocanni, and Fries the rudiments of fins in the young of Nerophis.

The fishes of this order have been divided into two families:-

1. Syngnathidac.-Small gill-openings : one dorsal fin, no ventral, and some of the other fins may be absent.

2. Solenostomida.-Wide gill-openings: two dorsal fins, and the other fins well developed.

\section{FAMILY I-SYNGNATHID无.}

Gill-openings small and situated at the posterior superior angle of the gillcover. A single dorsal fin. Ventrals and occasionally one or more of the other fins absent.

Along our shores these fishes are mostly found on Zostria beds, from low watermark to deep water.

$\mathrm{Mr}$. Andrews says all British forms are common in harbours and estuaries of S.W. coast of Ireland-S. acus and S. typhle. They pass ova thus: "In shoal water or a low tide these fish may sometimes be seen in pairs, side by side, apparently stationary on some rocky stone. At this time the ova-the capsules but imperfectly matured-are liberated from the female, and received into the abdominal sac of the male, the male fish having the power of expanding the lappings of the sac and attaching the ova by a highly viscid or glutinous secretion. As the process of maturation advances, the capsules of the ova enlarge, forming hemispherical depressions in the sac, and eventually the pouch is forced open by the full development of the ora and the extrication of the young."-Zool. xviii, 1860, p. 7053. 


\section{A. Tail not prehensile (Syngnathina).}

Genus I-Siphonostoma, Kaup.

Body with more or less distinct ridges: the dorsal ridge of the trunl ceasing opposite the hind end of the back fin, and the lateral ridge of the body being continuous with the upper caudal edge. Humeral bones movable and not united into a breast ring. Pectoral and caudal fins present. An egg-pouch on the tail of the males, the eggs being covered by cutaneous folds.

Moreau has found the lateral-line in Siphonostoma typhle occasionally interrupted, which I have not observed in numerous British examples.

Geographical distribution.-Coasts of Europe.

\section{Siphonostoma typhle, Plate CXLIV, fig. 3.}

Acus Aristotelis, Johnson, Pisc. p. 57, t. xマ, f. 14; Willnghby, p. 158, t. i, 25, f. 1; Salvian. fol. 68, pl. Pvii. Typhle marina, Belon. De Aquat. p. 446; Ray, p. 46. Syngnathus, sp. Artedi, Syn. p. 1, no. 2, Gen. p. 1, no. 4, Species, p. 2, no. 2. Syngnathus typhle, Linn. Syst. Nat. i, p. 416 ; Bonn. Ency. Ich. p. 30 , pl. xxi, f. 70; Donov. Brit. Fish. iii, pl. lvi; Turton, British Fauna, p. 1l6; Flem. Brit. Anim. p. 175; Jenyns, Manual, p. 485; Yarrell, Brit. Fish. (ed. 1) ii, p. 332 , c. fig. (ed. 2) ii, p. 439 (ed. 3) ii, p. 406 ; Parnell, Wern. Mem. vii, p. $396^{\circ}$; Fries. Wiegm. Arch. 1838, p. 241, t. vi, f. 2 ; Risso, Ich. Nice, p. 62 and Eur. Mérid. iii, p. 178; Swainson, ii, p. 333 ; Kröyer, Danm. Fiske, iii, p. 673, c. fig. ; White, Catal. p. 42 ; Thompson, Pro. Zool. Soc. 1837 , p. 58 and Nat. Hist. Ire. iv, p. 240; Malm, Wiegm. Arch. 1864, p. 343; Nilss. Skan. Faun. iv, p. 689.

Syngnathus acus, Ekstr. Fische Mörkö, p. 123, t. vi, f. 1, 2.

Syngnathus typhloides, Bennett, Pro. Zool. Soc. 1835, p. 92.

Siphonostorna typhle, Kaup, Lopho. p. 4.9 ; Yarrell, Brit. Fish. (ed. 3) ii, p. 406 ; Günther, Catal. viii, p. 154 ; McIntosh, Fish. N. Uist, Proc. Roy. Suc. Edin. v, 1862-66, p. 614; A. Dumeril, Hist. Nat. ii, p. 576 ; Winther, Prod. Dan. Mar. p. 52 ; Moreau, Poissons de la France, ii, p. 55, fig. 87. fig. 2 .

Broad-nosed pipe-fish, Couch, Fishes British Isles, iv, p. 355, pl. cexxxix, Donovan).

D. 38-46, P. 15, V. 4, C. 9-10. Osseous plates, 18-19 + 36-37 (17-19 + 36-42,

Length of head 6 to $6 \frac{1}{2}$, of body including head $2 \frac{1}{4}$ to $2 \frac{1}{2}$ in the total length. Eyes-3 diameters in the postorbital portion of the head, $4 \frac{1}{2}$ in the length of the snout, and $\frac{3}{4}$ to 1 diameter apart. Snout much compressed, and nearly as deep as the postorbital portion of the head: cleft of mouth nearly vertical. A raised ridge passes across the opercle, which is roughened in irregular lines, passing downwards and backwards. A low and short ridge along the occiput. Finsdorsal commences a little in front of the vent and on 10 to 12 rings, the rays divided near their outer ends. The length of the base of the dorsal fin is considerably longer (Dumeril says of equal length) than that of the snout, whereas in $S$. argenteus and $S$. Rondeletii it is shorter. Ventral with 4 rays situated in the male at the front end of the egg sac and a little posterior to the vent in females. The lateral-line runs into the upper caudal ridge, while the dorsal ridge does not run into the upper caudal ridge. Air-bladdercomparatively large. The abdomen of the male is much broader than that of the female and furnished on either side with a cutaneous flap which meet along the central line and form a receptacle for the ova. Colour-dark brown, with numerous light spots along the under surface of the bead and body.

Names and origin.- "Broad-nosed pipe-fish," due to its great depth, almost equalling the beight of the head. At Aberdeen pipe-fishes are known as young green-beans, i.e, young gar-fish. 
Habits.-Of these but little is known, but they appear to resemble other forms, as Syngnathus acus, which will be more fully detailed.

Means of capture-Dredging and trawling.

Breeding.- For this the reader must be referred to a paper on its development and reproduction as observed on the Finnish coast (Malm, Wiegm. Arch. 1864, p. 34:3).

Habitat.- The coasts of Europe, but is rather a local species, becoming rare in the Mediterranean.

In the Orkneys this is said to be more frequently found than S'yngnathus acus and from 6 to $15_{2}^{1}$ inches in length (Low). Orkneys and Shetland rare (Baikie): Banff not rare, excellent as bait (Edward) : Firth of Forth rather rare (Parnell): Scarborough (Woodall): Norfolk Estuary and Yarmouth (Gurney): I have received many specimens from the Susser coast: Dorsetshire and Hampshire abundant (Yarrell). At Wermouth common, chiefly in Zostera beds from low water-mark to deep water (T. Gosse) and not uncommon in Cornwall. Also recorded from Swansea (Dillwyn).

Treland.-Coasts of Antrim and Cork, but not so common as Syngnathus acus.

This fish has been recorded by Yarrell to 13 inches in length. The largest I have taken is $10 \frac{1}{2}$ inches. 


\section{Genus II-Srngnathus, Artedi.}

\section{Corythoichthys, Trachyrhamphus and Halicampus, Kaup.}

Body with more or less distinct ridges: the dorsal edge of the trunt not being continuous with that on its caudal portion. Humeral bones firmly united into the breast ring. The opercle may be entirely crossed by a distinct ridge or only at its base, or the ridge may be absent. Dorsal fin nearly or quite opposite to the vent: its base elevated or not so: pectorals well developed: caudal present. An egg-pouch on the tail of the males, the eggs being covered by cutaneous folds.

Geographical distribution.-Seas of temperate and tropical regions, some species entering fresh waters.

\section{Syngnathus acus, Plate CXLIV, figs. 1, 2 (young).}

Acus, Ray, Pisc. p. 47 ; Sibbald, Scotia, 24, t. xix. Syngnathus, sp. Artedi, Synon. p. 2, no. 3, Gen. p. 1 , no. 2, Spec. p. 3, no. 3 ; Gronov. no. 172. Longer pipe-fish, Pennant, Brit. Zool. (1776) iii, p. 138, pl. xxiii (Ed. 1812) iii, p. 184, pl. xxvi.

Syngnathus acus, Linn. Syst. Nat. i, p. 416 ; Bl. t. xci, f. 2 ; Bonnaterre, Ency. Ich. p. 31, pl. xxi, f. 71; Lacép. ii, p. 39, pl. 2, f. 1; Shaw, v, t. clxxix ; Bl. Schn. p. 514; Gmel. Linn. p. 1455; Turton, p. 116; Risso, Ich. Nice, p. 63 ; Flem. Brit. An. p. 175; Jenyns, Man. p. 484; Ekst. Mörkö, p. 123 ; Yarrell, P. Z. S. 1835, p. 183, Brit. Fish. (ed. 1) ii, p. 325, c. fig. (ed. 2) ii, p. 432 (ed. 3) ii, p. 400; Fries, Wiegm. Arch. 1838, p. 239 ; Nilss. Skan. Fanna, iv, p. 682 ; Parnell, Wern. Mem. vii, p. 394 ; Templeton, M. N. H. 1837 (2) i, p. 412 ; Johnston, Berwick. N. F. C. 1838 , i, p. 175; Thompson, Ireland, iv, p. 239 ; Kaup, Loph. p. 41 ; Schlegel, Dieren Neder. p. 177, pl. xvii, f. 1; White, Catal. p. 42 ; Günther, Catal. viii, p. 157 ; Collett, Norges Fiske, p. 200; Winther, Prod. Dan. Mar. p. 53 ; Giglioli, Catal. Pesc. Ital. p. 49 ; Morean, Poiss. de la France, ii, p. 42.

Syngnathus typhle, Bl. t. xci, f. 1; Bl. Schn. p. 514 (young); Gmel. Linn. p. 1454; Malm, Fauna, p. 594.

Syngnathus pelagicus, Donovan, Brit. Fish. iij, pl. lviii, Turton, p. 117 ; Flem. Brit. An. p. 176; Jenyns, Man. p. 486.

Syngnathus major, Swainson, ii, p. 333.

Syngnathus rostellatus, Nilss. Skand. Faun. Fiske, p. 687 ; Schlegel, 1. c. p. 179, pl. xvii, f. 2; Malm, p. 595.

Siphostoma acus, Kröyer, Danm. Fiske, iii, p. 692, c. fig.

Greater pipe-fish, Couch, Fishes British Isles, iv, p. 351, pl. ccxxxix, f. 1.

D. 40-44, P. 13, V. 3, C. 3-10, Osseous plates $19-20+44-46$.

Length of head $7 \frac{1}{4}$ to $7 \frac{1}{2}$, of head and body $2 \frac{1}{2}$ in the total length. Eyesdiameter $3 \frac{1}{2}$ in the post-orbital length of the head, $5 \frac{1}{2}$ to 6 in the length of the snout, and 1 diameter apart. A low and usually rugose ridge passes along the middle of the upper side of the snout to the occiput, and another similar ridge over the orbit joining the one from the opposite side at the same place. A ridge along the front half of the opercle, which is roughened in lines. Fins-the dorsal fin stands on 10 or 11 rings, and commences above or slightly in advance of the vent; it is considerably higher in the males than it is in the females. The male has the abdomen from the vent to the anal fin broader than in the female, and two soft flaps about two-thirds of its length, which when brought together form a pouch. Here the ova are received. Colours-superiorly brownish becoming lighter on the sides and beneath. A black stripe runs forward from the eye, the npper half of the opercle gray, the lower half silvery. About twenty dark bands pass from the back down the sides, which are nearly as wide as the ground colour. Dorsal fin with bands of spots and a black spot at the base of the first ray. 
Varieties.-The example figured life-size as young is a male, and has osseons rings $13+40$, dorsal fin 41 rays and standing on portions of 12 rings, length of head and body $2 \frac{2}{3}$ in that of the total. A second specimen is a female $3 \cdot 1$ inches long, rings $15+40$, D. 41 and on portions of 11 rings. Length of head and body $2 \frac{2}{3}$ in that of the total length. While a third is also a female 7 inches long, and has osseous rings $19+44$; dorsal fin with 43 rays and on portions of 11 rings; length of head and body $2 \frac{2}{3}$ in that of the total length. Without further specimens I cannot resist thinking that the differences in the number of rings may be due to age. At the same time I do not find this to be so apparent in the young of S. typhle.

Names and origin of.-The great pipe-fish, needle-fish, tangle-fish, Scotland. South of Ireland termed earl, which is the generic name of Syngnathi. Pibellbysg, Welsh. De Groote Zeenald, Dutch.

Habits.-Prefers deep water, but often found in shallows, especially in rocky ground, or in weedy bottoms; and when searching for food among rocks and stones, Couch has remarked, that every attitude is adopted, with the head up or down in each kind of the perpendicular, and with much contortion, while the snout is thrust into the chinks where the prey is likely to be met with. It will go skimming along the water of a summer evening 20 or 30 yards at a time like a slate thrown horizontally. It eats crustacea. Patterson relates how, having captured one in 1846, be placed it in a basin of sea-water along with a long-bodied crustacea, a species of Gammarus. The last becoming tired of swimming, fixed itself on the back of the fish near its tail, which the latter lashed out to dislodge his visitor; as soon as the fish became a little quiet the gammarus crept a little further up the back; the fish lashed again, but in vain, and the crustacea crept up still nearer its head. Now the pipe-fish gave its whole body the kind of movement it might have had if fixed on a Lilliputian spit or in the act of being roasted. The body revolved on its logitudinal axis, but still the visitur held on, but was now removed by Mr. Patterson. Is said by Parnell to keep in deeper water in warm weather, a characteristic I have not observed. It is retentive of life, but said to be killed by fresh water.

Means of capture.-The tow net, trawls, dredges, and often taken in seines.

Breeling.-Templeton says, "seems to breed in spring." Moggridge, at Swansea, found the pouch in the male full on June 8th, 1849 , and on July 8th some minute young alive and some still in the pouch (An. Nat. Hist. (2) iii, 1849). Couch observed pregnancy as late as September. Some males observed to be carrying ova were received at the Westminster Aquarium seven weeks prior to the extrusion of the young; after birth they dispersed. At about three weeks old (July 4th) they were $1 \frac{3}{8}$ inches in length, having doubled their own length in fourteen days (J. Carrington, Zool. 1877, p. 390).

As food. - In August, 1881, I saw one removed at Meragissey from inside the stomach of a conger.

Habitat.-Coasts of Northern Europe, Great Britain and France.

Orkneys common (Low). Binff not rare, excellent bait (Edward). Has been taken in the Moray Firth twice from the stomach of a cod-fish (Gordon). Occasionally seen on the beach after storms at St. Andrew (McIntosh). Not infrequent in the Firth of Forth (Parnell). Berwickshire not common (Johnston). Common in Yorkshire (York. Vertebrata); also in the Norfolk Estuary (Lowe) and along our south coast. Has been recorded from Swansea (Dillwyn).

Ireland, taken around the coast: Templeton considered it rather a scarce fish, though found in both the northern and southern extremities of the island. Ogilby says that at Portrush he only canght one immature example in a shrimp net, and supposed that its rarity was caused by the absence of the beds of Zostera in which this species delights (Zool. 1876, p. 4754).

Has been recorded up to 16 inches in length (Buckland). The specimen figured is a female I took at Teignmouth among many more and is 14 inches in length. 
Genus III-Nerophis, Rafinesque.

Nematosoma, Eichwald: Scyphins, Risso: Entelurus, A. Dumeril: Acus, (Willugh.) Swainson.

Body rounded and the ridges when present very indistinct : the tail tapering to a point without any or with a ver! rudimentary caudal fin. Dorsal fin of moderate length placed opposite the vent: pectorals absent. Ova attached to the loose integument of the abdomen in the males, and not covered by lateral cutaneous fulds.

Gengraphical distribution.-Coasts of Enrope, the Atlantic and Indian Oceans.

M. de la Blanchere considers that these fish possess a peculiar smell or taste, because if chopped up and given as food to aquarium fishes as turbot, gurnard, \&c., should any chance bits be swallowed they are immediately rejected. But they are very commonly found in the stomachs of marine fishes, rendering this view somewhat problematical.

1. Nerophis æquoreus, Plate CXLIV, fig. 4.

Shorter pipe-fish, Pennant, Brit. Zool. (Ed. 1776) iii, p. 140, pl. xxiii (Ed. 1812) iii, p. 188 , pl. xxivi.

Syngnathus aquoreus, Linn. Syst. Nat. i, p. 417 ; Lacép. ii, p. 39 ; Mont. Wern. Mem. i, p. 85, t. iv, f. 1; Risso, Ich. Nice, p. 66 ; Fleming, Brit. An. p. 176 ; Jenyns, Man. p. 486; Yarrell, Brit. Fishes (ed. 1) ii, p. 335, c. fig. (ed. 2) ii, p. 442 (ed. 3) ii, p. 409 ; Fries, Vet. Akad. Handl. 1837, p. 35, and Wiegm. Arch. 1838, p. 246, t. vi, f. 3 ; Parn. Werm. Mem. vii, p. 398 ; Kröyer, Danm. Fiske, iii, p. 705 ; Thompson, Mag. N. H. 1839 (2) iii, p. 586 and Nat. Hist. Ireland, iv, p. 240; Schlegel, Dieren Neder. p. 179, pl. xvii, f. 3; White, Catal. p. 43.

Syngnathus sibbaldi, Walb. Artedi, iii, p. 6.

Syngnathus ophidion, Bonnaterre, Enc. Ich. p. 31, pl. xxi, f. 73 : Jenyns, Man. p. 487 ; Parnell, Wern. Mem. vii, p. 390.

Syngnathus anguineus, Jenyns, Brit. Vert. p. 30 ; Yarrell, Brit. Fish. (ed.2), ii, p. 445 (ed. 3) ii, p. 414 .

Scyphius cequoreus, Nilss. Skand. Faun. Fisk. p. 692.

Acus oequoreus, Swainson, ii, p. 333.

Nerophis oquoreus, Kaup, Lopho. pp. 65, 66; Günther, Catal. viii, p. 191; Collett, Norges Fiske, p. 202 ; Winther, Prod. Dan. Mar. p. 53; Malm, Fauna, p. 596.

Nerophis anguineus, Kaup, 1. c. p. 65 .

Syngnathus brevicaudatus, T. Cornish, Zoologist, p. 3724 and 1879, p. 476.

Entelurus oequoreus and anguineus, A. Dumeril, ii, pp. 605, 606; Moreau, Poiss. de la France, ii, pp. 62, 63.

Ocean pipe-fish and snatee pipe-fish, Couch, Fish. Brit. Isles, iv, pp. 356, 359, pls. cexl and ccxli.

D. $37-44$, C 6 . Osseous rings, $28-31^{\circ}+56-61$.

Length of head $12 \frac{1}{2}$ to 13 , of head and body $\frac{1}{2}$ of the total length in the adult as at $12 \frac{1}{2}$ inches long, while at 10 it is $4 \cdot 3,9 \cdot 8$ it is $4 \cdot 2,9 \cdot 4$ it is $4 \cdot 1$, at 8.9 it is 3.8 , at $8 \cdot 4$ it is $3 \cdot 6$, at $8 \cdot 2$ it is $3 \cdot 8$, showing that the proportionate length of the body to that of the tail increases with age. Eyes-diameter $\frac{1}{3}$ of the postorbital portion of the head, $3 \frac{1}{2}$ in that of the snout, and $\frac{2}{3}$ of a diameter apart. Body somewhat rounded, tapering posteriorly to a fine tail: the ridges very indistinct until the fish is dry. Fins-the dorsal stands on 11 to 13 or 14 rings of which 9 or 10 belong to the trunk. Caudal mostly absent in large specimens, with 6 rays in smaller ones. Vent opposite the posterior third of the dorsal fin. All the shields smooth. Colours-olive, darkest along the back, and with narrow transverse bluish bands having black edges which are coutinued along the entire length of the body and a portion of the tail. Dorsal rays yellow. A purple stripe from the eye along the side of the snout. The young are not so vividly coloured as the adults. 
Varietics.-Mr. Cornish's Syngnathus brevicaudatus differs from some examples in having no caudal fin, which appendage is frequently absent. Having seen the two described specimens at Mount's Bay, my opinion is that they belong to this species. Moreau observes that $S$. cequoreus has 6 and $S$. anguineus 5 caudal rays.

Names.-Painted sea adder, Cornwall. De Adder-Zeenald, Dutch.

Habits. - R. Couch tells us they live in deep water from 15 to 50 fathoms, and consequently are rarely seen. In May, June, often in July, and sometimes in Angust they rise to the surface and bask in the sun. Here they retain their position by clasping with their tails cords, buoys of crab-pots, seaweeds, sticks or floating substances. I have taken many off the Devonshire coast in shallow water with the dredge during August and September. Andrews remarks upon having noticed this fish greedily stripping the stems of Zostera marina of the young of Anthea vereus, which were attached in a semi-glutinous state.

Means of capture.-Ogilby observes " that at Portrush he took them in a curious way: namely, in open net-work lobster pots, where, though in no way detained by the meshes, they were invariably found clinging, with the end of their tails curled once or twice round the net-work, preferring to trust to this rather than swim away" (Zool. 1876, p. 4754). Mr. Cornish has taken it in a trammel.

Breeding.-W. Andrews, 1. c., observes (see page 256), "A similar process as to the transfer of the ova takes place in the fish as described in the last, with the exception that the males have no abdominal sac to enclose the ova. These fish, under favourable opportunities of calmness and of tides, may be seen side by side clinging with their tails to the tufts of Zostera marina, in which position the male is enabled to attach to the abdomen the ova, by the same influence of viscid secretion alluded to in the marsupial species" (Zool. l. c. p. 7053).

Habitat.- Northern Seas, British Isles, Havre. Not rare in the Orkneys and Shetlands (Baikie) : not uncommon along the east coast of Scotland: Norfolk estuary (Lowe), Scarborough (Yarrell), the estuary of the Thames, the south coast of England, at Teignmouth, where I took many dredging in shore; at Weymouth common (Gosse), also in Cornwall (Couch), Guernsey (Lukis), Swansea (Dillwyn), and the Isle of Man (Wallace).

Ireland.-Occasionally taken on all sides of the island: not rare off Dublin. "Last winter I met with an immense fish of this kind: seeing a boy whacking a donkey with a gutta-percha stick, as I thonght, I asked him where he got it. 'It's only the stalk of a snot (seaweed), sir; see:' and I did see a fine æequoreal 3 feet 5 inches long. Of its toughness you may judge. It is not uncommonly taken in the baskets with whelks and crabs" (Blake-Knox, Zool. 1866, p. 508). Common Portrush, co. Antrim (Ogilby). A beautiful and perfect specimen, 20 inches long, found dead along with a larger one on the beach near Ballantrae, in the summer of 1838 ; it had a distinct caudal fin with 5 rays (Thompson). Common at Portrush (Ogilby). Attains to 24 inches (Jenyns): 41 inches (Blake-Knox).

\section{Nerophis ophidion, Plate CXLIV, fig. 5.}

Syngnathus, sp. Artedi, Genera, p. 1, no. 2, Synon. p. 2, no. 4, Species, p. 1, no. 1 .

Syngnathus ophidion, Linn. Syst. Nat. i. p. 417; BI. iji, p. 146, t. xci, f. 3 ; Lacép. ii, p. 48; Bl. Schn. p. 515 ; Ekström, Vet. Akad. Handl. 1831, p. 280, t. ii, f. 3, 4, and Fisch. Mörkö, p. 134, t. vi, f. 3, 4, Fries, Vet. Akad. Handl. 1837, p. 36, t. iii, f. 4, and Wiegm. Arch. 1838, p. 248, t. vi, f. 4; Templeton, Mag. Nat. Hist. 1837 (2), i, p. 413 ; Thompson, Pro. Zool. Soc. 1837, p. 58, and Nat. Hist. Ireland, iv, p. 24.1 ; Parnell, Wern. Mem. vii, p. 399 ; Yarrell, Brit. Fish. (ed. 1), ii, p. 338, c. fig. (ed. 2), ii, p. 447 ; Jenyns, Manual, p. 487; Risso, Ich. Nice, p. 68; White, Catal, p. 44 .

Scyphius ophidion, Nilss. Skand. Faun. iv, p. 694; Malm, p. 597.

Acus ophidion, Swainson, ii, p. 333. 
Nerophis ophidion, Kröyer, Danm. Fisk. iii, p. 716 ; Kaup, Lophobranchiate Fish, p. 70 ; Yarrell, Brit. Fish. (ed. 3) ii, p. 416, c. fig.; Malm. Wiegm. Arch. 1864, p. 343 ; Günther, Catal. viii, p. 192 ; Collett, Norges Fisk. p. 202; Winther, Prod. Dan. Mar. p. 54, Canestrini, Faun. d'Ital. p. 145; A. Duméril, ii, p. 602; Moreau, Poiss. de la France, ii, p. 68.

Scyphius littoralis, Guich. Expl. Algér. p. 119.

Straight-nosed pipe-fish, Couch. Fish. Brit. Isles, iv, p. 363, pl. ccxli, f. 3.

D. 34-38, osseous rings $28-29+65$.

Length of head $14 \frac{1}{3}$ to 16 , of head and body 2 to $2 \frac{1}{4}$ in the total length. Eyes-situated in the middle of the length of the head; $2 \frac{1}{2}$ diameters in the postorbital length of the head and 1 apart. Snout turned very slightly upwards. Fins-dorsal well developed, sitaated upon 12 rings, 4 of which belong to the body, which is from $\frac{4}{8}$ to $\frac{5}{8}$ of the total length, being shortest in adults. Caudal fin absent. Body smooth. Colours-greenish, numerous white dots, spots, and blotches along the lower surface of the body; a black band across the opercle.

Name-Stiff sea-adder, Cornwall.

Habits.- In Devonshire and Cornwall mostly found in moderately deep water, but extending its range into the shallows, and is frequently captured under stones between high and low-water mark.

Uses.-As Low observes, they have none; are never eaten, while their coat of mail prevents their being employed as bait, for no fish will snap at so well-defended a creature.

Habitat.-Coast of Europe. Recorded from Banffshire (Harris). One taken at Whitby, one at Scarborough, and one at Redcar (Yorkshire Vertebrata). An example taken in the Norfolk estuary by Mr. King, Jnne 19th, 1871. Most of my specimens were received from Brighton at the Westminster Aquarium, and given me by Mr. Carrington. Some I took at Teignmouth : is not uncommon in Cornwall : has been taken at Swansea (Dillwyn).

Ireland.-Thompson records two examples from the coast of Down, one 11 the

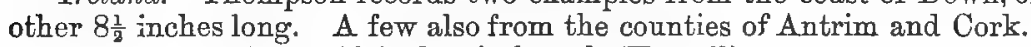

This fish attains to 12 inches in length (Yarrell).

\section{Nerophis lumbriciformis, Plate CXLIV, fig. 6.}

Acus lumbriciformis aut serpentinus, Willugh. Hist. Pisc. p. 160. Little pipe-fish, Pennant, Brit. Zool. (Ed. 1776) iii, p. 14l, pl. xxiii (Ed. 1812) iii, p. 187, pl. xxvi.

Syngnathus ophidion, Turton, Brit. Fauna, p. 117; Flem. Brit. An. p. 176.

Syngnathus pelagicus, Donovan, Brit. Fish. pl. Iviii ; Turton, l. c.

Syngnathus lumbriciformis, Yarrell, Brit. Fish. (ed. 1) ii, p. 340, c. fig. (ed. 2) ii, p. 450; Fries, Wiegm. Arch. 1838, p. 249, t. vi, f. 5-8; Jenyns, Man. p. 488 ; Thompson, Nat. Hist. Ireland, iv, p. 241.

Scyphius lumbriciformis, Nilss. Skan. Faun. iv, 695; White, p. 44; Malm, Fauna, p. 598.

Acus lumbriciformis, Swainson, ii, p. 333.

Nerophis lumbriciformis, Kröyer, Danm. Fisk. iii, p. 723; Kaup, Lopho. p. 69 ; Yarrell, Brit. Fishes (ed. 3) ii, p. 420; Günther, Catal. viii, p. 193; Collett; Norges Fiske, p. 203 ; Winther, Prod. Dan. Mar. p. 54; A. Duméril, t. ii, p. 604; Moreau, Poiss. de la France, ii, p. 65, f. 90.

Worm pipe-fish, Couch, Fishes Brit. Isles, iv, p. 361, pl. ccxli, f. 2.

D. 24-26, osseous rings $18-19+49$.

Length of head 8, of head and body $2 \frac{3}{4}$ in the total length. Eyes-situated in the anterior half of the head, 2 diameters from the end of the snout and 1 diameter apart. The postorbital portion of the head equals half its length. Snout somewhat turned up. Fins-the dorsal situated on 8 rings, of which the two first belong to the trunk. No caudal fin. Body covered with thin skin, 
rendering the shields indistinct. Colours-olive-brown, with white lines and dots across the lower portion of the head and body.

Jenyns doubted whether Syngnathus pelagicus, Donovan, is anything more than the young of $S$. acus.

Habits.-It frequents rocky pools under stones and seaweed, and lurks between tide-marks. Couch considered that it is unable to raise itself off the ground where it creeps about with a serpentine motion, and there is no proof it ever goes deeper than low water-mark. Thompson observes, "this and S. acus are by far the most common, indeed they are the only species to which the term common can be applied on the Irish coast. S. lumbriciformis seems to be the most littoral species, which may perhaps account for my having seen even more of it than of S. acus." Dr. Corrigan is said to have been the first who observed that this fish has the power of inflating its pouch or gullet, and this appears analogous to the vesicular inflation exercised by the hyoid bone in the howling monkeys, which communicates with the larynx and produces the sound which gives the appellation to the animal (Andrews, Zool. 1860, xviii, p. 7053).

Breeding.-At Swansea, in 1849, Mr. Moggridge found the pouch empty May 14th, but full June 10th (An. Nat. Hist. (2) iii, 1849).

Life history.-Fries, in 1837, remarked that the young on their escape from the egg have the entire tail covered by a fin-like membrane, which extends partly np the back and also along the under surface as far as the anal aperture: they have also pectoral fins. Except the portion required to form the permanent dorsal fin, all this at a subsequent unknown period is thrown off in a way similar to the rejection of their tails by tadpoles on becoming frogs.

Halitat.-German coasts of the North Sea. Orkneys and Shetland common (Baikie) : also along the east coast of Scotland, and often taken by a hand-net among seaweeds bordering pools and rocks (McIntosh): along the south coast of England at Weymouth common (Gosse) : in Cornwall common under stones near low water-mark: has been recorded from Swansea (Dillwyn).

Ireland.-On all sides of the island.

This fish attains to 9 inches in length (Jengns). 


\section{B. Tail prehensile (Hippocampina.)}

Genus IV-Elippocampus, Leach.

Trunk compressed and somewhat elevated, having from 10 to 12 rings. The shields furnished with tubercles or spines. Occiput compressed and forming a coronet at its posterior superior angle, which is usually surmounted by spines or knobs. Dorsal and pectoral fins present: the tail prehensile, finless, and longer than the trunl. Males furnished with an egg-sac situated below the tail and opening near the vent.

Geographical distribution.-Throughout temperate and tropical seas. Owing to their attaching themselves, by means of their prehensile tails, to floating substances as pieces of seaweed or sticks which either are or become loosened from their attachments, they may be carried away long distances by currents, thas widening their limits of distribution.

The Rev. M. Lockwood (Amer. Naturalist) gives an account of how the young appear. At first they were very minute, and from the time of their extrusion the parent kept sending his progeny adrift: at the bottom of the vessel was a broken shell put there for the attachment of the animal's tail when fatigued by swimining, as this fish is very easily tired: this, monkey-like, is its favourite mode of taking rest. The shell afforded real help in the labour of extruding the young which is in no sense a parturient process, but on the contrary is eminently mechanical. The parent pressed them out by means of the shell, stopping now and again-five or six being extruded at a time. They employ their tails for holding on by the first day they are born (Zool. 1868, p. 13444).

Newman, Zool. 1873, p. 3494, remarks on having examined a living and healthy Hippocampus ramulosus in an aquarium with "an abundant growth of a small and delicate zoophyte on its head, neck, and the anterior part of its body." He believed the zoophyte to be Serialia lendigera.*

\section{Hippocampus antiquorum, Plate CXLIV, fig. 7.}

Hippocampus, Rondel. De Pisc. ii, p. 114. Hippocampus Rondeletii, Willugh. Pisc. lib. iv, c. ix, p. 157, t. I25, f. 3 ; Ray, Synop. Pisc. p. 46 ; Gronov. Zooph. no. 170. Syngnathus, sp. Artedi, Synon. p. 1, no. 1, Spec. p. 3.

Syngnathus hippocampus, Linn. Syst. Nat. i, p. 417; Brünn, Pisc. Mass. p. 10; Bonn. Ency. Ich. p. 31; Lacép. ii, p. 42, pl. ii, f. 2 ; Bloch, Ausl. Fische, iv, p. 6, t. cix, f. 3 ; Bl. Schn. p. 515 .

Hippocampus antiquorum, Leach, Zool. Misc. i, 1814, p. 104; Günther, Catal. viii, p. 199.

Hippocampus brevirostris, Cuv. Règ. Anim. ; Yarrell, Brit. Fish. (ed. 1) ii, p. 342 , c. fig. (ed. 2) ii, p. 452 (ed. 3) ii, p. 394; Ch. Bonaparte, Cat. Met. Pesci Europ. p. 89; Temm. and Schleg. Fauna Japon. Poiss. p. 274; Swainson, ii, p. 332 ; Kaup, Lophobranchiate Fish. Brit. Mus. p. 7 ; Jenyns, Manual, p. 489 ; Thompson, Nat. Hist. Ireland, iv, p. 242; Duméril, Hist. Nat. Poiss. ii, p. 504; White, Catal. p. 45; Giglioli, Catal. Pesc. Ital. p. 50 ; Morean, Poiss. de la France, ii, p. 38.

Hippocampus, Couch, Fish. British Isles, iv, p. 364, pl. ccxli, f. 4 (this figure is of H. guttulatus).

D. 18-20, P. 15-17, A. 5. Osseous rings 11-12/36-37.

The length of the snout equals the distance from the middle or hind edge of the eye to the gill-opening. Simple fleshy filaments, of various lengths (some-

* For the method by which the fumales introduce the eggs into the ovigerous pouch of the male, -e Franzazo, Atti Suc. l'ad. 1874, p. 161. 
times absent), exist at the ends of the supraorbital spines, on those of the crest and along the back nearly as far as the dorsal fin. Tubercles well developed on the head and body, also along the back, and in the anterior two-thirds of the caudal region, most distinct in the young. Fins-dorsal on a somewhat elevated base and situated on three osseous rings. Anal distinct in the female with about five rays. Colours-nearly black or dull olive, covered with small white or bluish-white dots, which form bands on the cheeks. Dorsal fin with a black inter-marginal band, which has a light inner and white outer edge; the basal two-thirds of each ray with three or more white spots. Mr. Saville Kent recorded how some of these fishes received alive at the Manchester Aquarium from the Mediterranean were bright red, others pale pink, bright or light yellow, and even almost pure white, with many other interblending shades, but which tints gradually disappeared when in confinement. It has also been remarked that the tail is frequently white in prehensile forms.

Names.-Sea-horse, from the appearance of its head: short-snouted sea-horse, to distinguish it from an allied form. Cheval marin, French.

Habits.-While swimming the body is kept in a rertical position, and the prehensile tail is torned about ready to seize any passing object, while it can move its ejes each independently of the other. Their tails are likewise used to cling to one another, and several thus attached raise themselves together in a mass. I observed some rubbing their heads together, and even calling to one another by a sort of cough. At the Westminster Aquarium they were fed on sand hoppers, but the opossum shrimp is considered the best food.

Breeding.-This fish does not appear to refuse breeding in Aquaria, as it did so in $\mathbf{1 8 6 0}$ at Vienna; next in the Jardin des Plantes at Paris; thirdly, in the Crystal Palace Aquarium, where their parents prevented them from suffering future troubles by at once devouring them; Mr. King has bred them in London in Great Portland Street; and lastly at the Manchester Aquarium, July 21st, 1873, where Mr. Brittain observed on this day a young one rise upwards through the water and swim about with great activity-vertically as is the custom of the parent. It hovered about the top of the water, occasionally descending an inch or two and again soon returning to the top as if for air. During the day 13 left the ponch of the parent, and on the two subsequent days more, until the number amounted to above 200. They were not observed to again enter the pouch. The young bred in confinement do not appear to have ever been reared. $\mathrm{Mr}$. Lockwood considers that the embryos are nourished by the fat deposited in the walls of the pouch, which becomes considerably thinner as the embryos grow. Dr. Günther, on the contrary, believes it more probable that the walls become thinner in consequence of the increasing pressure of the growing contents of the pouch. Mr. Ryder, "Bulletin of the United States Fish Commission," 1881-82, p. 191, has given an elaborate account of the development of this fish.

Habitat. - Temperate and warm portions of Europe through the Mediterranean, also the Atlantic and Pacific Oceans to Australia and Japan. One obtained dead in the Orkneys (W. Baikie, Zool. 1853, p. 384.7) ; two cast ashore at Banff after a severe storm (blward); three times at Whitby, and once at Bridlington (Yorkshire Vertebrata). Yarmouth (Paget); has been frequently taken along the Sandwich Flats in Kent. Devonshire, one specimen (Parfitt). Hampshire (Walcott). Dillwyn says the specimen he gave Yarrell came from Dorsetshire, not Swansea. Common in Guernsey.

Ireland.-Dublin Bay, Antrim, Belfast Bay, Youghal and probaby in other localities. "Dublin Bay is a pet locality of this curious species. Many were found dead among the sea-weed last winter" (J. Blake-Knox, Zool. 1866, p. 508).

The specimen, figured life size, was one among many which were captured in Guernsey in 1879, and kept for some time alive in the Westminster Aquarium. But on Sept. 15th, by an accident, much hot steam was turned on which occasioned the death of the whole of them. I am indebted to Mr. Carrington, r.L.s., for several specimens. 


\section{Order V-PLECTOGNATHI.}

Teleostean fishes, with an incompletely ossified skeleton and few vertebræ. Gill-openings narrow, situated in front of the pectoral fins: gills pectinate. Mouth narrow: the bones of the upper jaw mostly united, and sometimes produced into a beak-like form. Teeth may be distinct in the jaws, or absent. There may be a single soft-rayed dorsal fin belonging to the caudal portion of the body and placed opposite the anal: while in some a spinous dorsal is likewise present: ventrals may exist, in the form of spines. Skin smooth, with rough scales, or ossified in the form of plates or spines. Air-bladder without any pneumatic duct.

Geographical distribution.-Mostly oceanic, but some are found in large rivers and many in estuaries and tidal pieces of water in temperate and tropical portions of the globe. They are only seen as occasional wanderers to our shores.

\section{Synopsis of Families.}

1. Sclerodermi-Distinct teeth in the jaws.

2. Gymnodontes-Jaws modified into a beak.

\section{FAMILY I-SCLERODERMI.}

Body compressed or angular: snout somewhat produced. Distinct teeth in small numbers in the jaws. A barbel in one genus. A spinous dorsal and ventral fins generally present but variously modified. Skin rough or spinate, or the scales in the form of a firm carapace.

\section{Genus I-Balistes, $s p$. Artedi.}

Balistapus, Tiles. Xenodon, Erythrodon and Pyrodon, Rüppell. Melichthys and Leiurus, Swainson. Sub-genera Parabalistes, Pseudobalistes and Canthidermis, Bleeker.

Branchiostegals six. Body compressed. Barbels absent. Sometimes a groove before the eyes. Upper jaw with a double rovo of incisor-like teeth, 8 in the outer and 6 in the inner row: mandibles with 8 similar teeth in one row: these teeth may be white, uneven, and more or less notched (Balistes): or white, even, and incisorlike (Melichthys) : or of a burnt sienna colour, with the supero-lateral pair projecting (Erythrodon). The first dorsal fin consisting of a strong spine, succeeded by two weal ones: ventrals as an osseous appendage. There may or may not be oval, flattened, osseous productions behind the gill-openings. Scales forming a carapace: in some species there are rows of spines or tubercles on the side of the free portion of the tail, which is either compressed or depressed.

Eating the flesh of these fishes occasions at times symptoms of the most virnlent poisoning. Dr. Mennier, at the Mauritius, considered that the poisonous flesh acted first on the nervous tissue of the stomach occasioning virulent spasms of that organ, and shortly afterwards of all the muscles of the body. The frame soon becomes racked with spasms, the tongue thickened, the eye fised, the breathing laborious and the patient expires in a paroxysm of extreme suffering. The first remedy should be a strong emetic, and subsequently oils and demulcants to allay irritability.

The two forms which are said to have been taken in our isles are:

1. Balistes maculatus-D. 3/26-27, A. 24-25, L. 1. 46-55: no osseous plates behind the gill-openings.

2. Balistes capriscus-D. 3/28, A. 24-25, L. 1. 52-62. Osseous plates behind the gill-opening.

\section{Balistas maculatus, Plate CXLV.}

Guaperva longa, Willugh. Append. p. 21, t. I 20. Sabaco, Parra, p. 17, lam. 10. 
Baliste's maculatus, Gmel. Linn. i, p. 1468; Bloch, t. cli; Bl. Schn. p. 464; Bonnaterre, Enc. Ich. p. 18, t. xi, f. 37 ; Lacép. i, pp. 334, 361 ; Kaup, Sclero. p. 223 ; Bleeker, Atl. Ich. v, p. 122, t. ccxviii, f. 4; Kner, Novara Fische, p. 401 ; Günther, Catal. viii, p. 213; Day, Fishes of India, p. 687, pl. clxxvi, f. 3.

Balistes sufflamen, Mitchell, Lit. and Phil. Trans. New York, i, p. 4677, t. $v i$, f. 2.

Balistes oculatus, Gray and Hard. Ill. Ind. Zool.; Bleeker, Atl. Ich. v, p. 121, t. cexviii, f. 2.

Balistes Willughtii, Bennett, Proc. Zool. Soc. i, p. 168, and Voy. Blossom, Zool. p. 68 , t. xxi, f. 2.

Canthidermis oculatus, Swainson, Fishes, ii, p. 325.

Batistes azureus, Less. Voy. Coq. Zool. ii, p. 1:1, t. x, f. 2.

Balistes adspersus, Tschudi, Faun. Pesc. Pisc. p. 31.

Balistes conspicillum, Cantor, Mal. Fish. p. 344 (not syn.).

Balistes longus, Gronov. ed. Gray, p. 37.

Balistes senticosus, Richards. Voy. Sam. Fish, p. 23, pl. ix, f. 5-8; Bleeker, Nat. Tyd. Ned. Ind. $\nabla$, p. 93.

Balistes longissimus, Holland, An. Sc. Nat. p. 60, pl. iii, f. 3.

Balistes sobaco and macrops, Poey, Cuba, pp. 324, 326.

B. vi, D. 3/26-27, P. 15, A. 24-25, C. 12, L. 1. 46-55, L. tr. 28.

Length of head $3 \frac{2}{3}$ to 4 , of caudal fin $6 \frac{1}{2}$ to 7 , height of body $2 \frac{1}{2}$ to 3 in the total length. Eyes-2 to $2 \frac{1}{2}$ diameters from the end of the snout and 2 apart. A groove in front of the eye. Teeth-white, uneven, notched. Fins - the first dorsal commences above the gill-opening, its anterior spine is strong and nearly half as long as the head. Ventral spine usually movable. Posterior edge of caudal convex or undulated. Second dorsal and anal high anteriorly, especially in adults. Scales-cheeks entirely scaled; no osseous scutes behind the gill-openings. Scales rough and granulated but without spines or prominent tubercles except in the immature. Colours-bluish-black, young examples are covered with numerous light-blue blotches, more especially in the lower half of the body, these spots are less numerous and larger in adults. Dorsal spines black. Eyes hazel.

Habitat.-Atlantic and Indian Oceans, more especially in their tropical and subtropical portions, also the Pacific, and perhaps on the British coast. It has been recorded in Scandinavia (H. Malm, Efv. Ak. Förh. 1875, no. vii, p. 8).

A half-grown and stuffed example is stated by Dr. Gïnther to have been received at the British Museum from Polperro in Cornwall, and it is observed in the Catalogue (viii, 1870, p. 214) of this species "occasionally on the British coast," and again in his "Introduction to the Study of Fish" this statement is repeated. I include the species (although with great hesitation) in the British Fauna. Having through the kindness of Mr. R. Couch (of Bodmin) been allowed to examine the late Mr. T. Couch's zoological journals which were kept at Polperro up to March 31st, 1870 (he died on April 13th), and not finding any allusion to this fish in them, I conclude the stuffed example in the National Collection was not captured at that place. I know of no other recorded British instance. Malm observes it has been taken off Scandinavia.

The figure is from a specimen I took among many others at Madras. It attains at least 16 inches in length.

\section{Balistes capriscus, Plate CXLVI.}

Seba, iii, 24, 26. Capriscus, Salv. fol. 206 B; Willughby, p. 152, t. J19. Balistes, sp. Gronov. Zooph. no. 187. File-fish, Shaw, Zool. v, pt. ii, p. 411, pl. clxviii.

Balistes capriscus, Gmel. Linn. i, p. 1471 ; Cuv. Règne An. ii, p. 372 ; BI. Schn. p. 476 ; Lacép. i, p. 372, pl. xiii, f. 3 ; Jenyns, Manual, p. 492 ; Yarrell, Brit. Fishes (ed. 1), ii, p. 357, c. fig. (ed. 2) ii, p. 472, (ed. 3) ii, p. 422 ; Risso, Ich. Nice, p. 51 ; White, Catal. p. 118 ; Gronov. ed. Gray, p. 30 ; Costa, Fauna Nap. Pesc. t. Ixi, lxii ; Günther, Catal. viii, p. 217; Griy, Ann. and 1liag. 4th series $1 \varepsilon 73$, xii, p. 267 ; Cunestrini, Faun. Ital. p. 146; Moreau, Poiss. de la France, ii, p. 7?, fig. 91. 
Balistes buniva, Lacép: 1. c. p. 357.

Balistes lunulatus, Risso, Eur. Mérid. iii, p. 175.

Balistes Rondeletii, Swainson, Fishes, ii, p. 326.

Balistes Carolinensis, Gronov. ed. Gray, p. 29.

Balistes fuliginosus, De Kay, Now York Fauna, Fish, p. 126, pl. lix, figs. 5, 6.

File-fish, Couch, Fishes Brit. Isles, iv, p. 369, pl. ccxliii.

B. vi-vii, D. 3/27-28, P. 15, A. 24-26, C. 12, L. 1. 52-62, Vert. 7/11.

Length of head $4 \frac{1}{2}$, of caudal fin $4 \frac{1}{2}$, height of body about $2 \frac{1}{2}$ in the total length. Eyes-rather high up and situated in the posterior fourth of the head. A groove before the eye. Cleft of mouth shallow. Teeth-white, uneven, and more or less notched. Fins-anterior spine of the first dorsal fin strong, elevated, equalling the length of the snout and roughened anteriorly, the next two are much shorter. The front portion of the soft dorsal and anal fin rather elevated: ventral spine movable. Caudal lobes most produced in old examples. Scalesabout 22 scutes in a transverse line from the origin of the second dorsal fin to the vent. Two large osseous patches behind the gill-opening. No spine or tubercles on the side of the tail, but in some specimens a rudimentary lateral-line. Colours - the one figured, according to Couch, was as follows : for the most part of a dull pale yellow, dark on the back and top of the head, more dusky towards the tail : pectoral fin with a tinge of yellow, the other fins dark. The colours, however, are liable to vary.

Hippolyte Salviani (a Roman Physician, born 1513, died 1572) discovered that the spines of the first dorsal fin are so contrived as to act in concert, with considerable force, in suddenly elevating the fin at the pleasure of the animal: though the largest spine be pressed hard it will not move, but if the smallest be pressed slightly the other two immediately fall down with it, as a cross-bow is let off by pulling the trigger (Cocks, Roy. Corn. Pol. Soc., 1870, p. 121).

Names.-File fish due to the roughness of the front surface of its first dorsal spine, and trigger-fish due to the formation of its first dorsal fin.

Habits.-Of these but little is known, but their strong teeth are said to enable them to break off pieces of coral for food, or even to work through the shells of molluses to obtain their inhabitants. They have been deemed injurious to pearl fisheries.

As food.-Canestrini says it is not used, but Companyo considers it very recherché, and Risso that it is delicate.

Habitat.--Occasional on the British coast, more abundant in the Mediterranean, although even there it is not common. Taken in Orkneys in 1827 or 1828 (Baikie, Zool. 1853, p. 3847). The first recorded British example was $9 \frac{1}{2}$ inches long, from the Sussex coast, taken in Angust, 1827, and was placed in the British Museum (Yarrell). In August, 1865, one was taken at Port Looe, on the south coast of Cornwall, and came into Couch's possession and which is now in the British Museum. Mr. Cordeaux (Zoologist, 1868, p. 1027) observes upon having seen the drawing of a fish of this species at Flamborough, that had been captured two or three years previously: while another was likewise said to have been taken there in 1868 and sent to Manchester. It has also been captured at Weymouth in 1873 on a line baited with a lob-worm, and "two half-grown skins, Great Britain? and one half-grown, stuffed, from the collection of the Zoological Society" are in the national collection.

Ireland.-Obtained by Professor Melville at Galway in 1853 (Ball).

The example figured is $16 \frac{1}{2}$ inches long, stuffed from Port Looe, in Cornwall, and now in the National Museum.*

* Ostracion quadricornis, Linnoeus.

Conch obtained an example of this fish which be was inforned had been captured at Mevagissey at some considerable distance from land, by a man named Barron. Mr. Matthias Dunn distrusting the account investigated the matter and ascertained from Captain Ball, of the "Roseland," that Barron when employed in his ship obtained the specimen at the Island of Ascension and brought it in salt to this country (see Proc. Linn. Soc. 1880). This species has since then been brought trom the same loculity to this country by Staff-Surgeon J. Coury (An. and Mag. Dec. 1881 (5), xlviii, p. 431 ). 


\section{FAMILY II-GYMNODONTES.}

Body more or less short. Some possess the means of dilating an elastic portion of the æsophagus, or an abdominal sac, with air: or this power may bo wanting. Bones of both jaws in the form of a beak, having a cutting edge, and being covered with a layer of ivory-like substance, in which a median suture may be present or absent. A spineless dorsal, anal, and caudal fin: pectorals present: ventrals absent. Dermal covering modified into small or large spines or laminæ. Pelvic bones and air-bladder present or absent.

- This family is composed of several genera, most of which are exclusively exotic, only a single species being found in our waters and that a rare visitor.

\section{Genus I-Térrodon, linnceus.}

Leiosomus, Lagocephalus, Cirrlisomus, and Psilonotus, Swainson. Kolacanthus, Gray. Prilonotus and Anchisomus, Kaup. Tropidichthys, Bleeker. Promécocéphale, Dilobomycterè, Amblyrhynchote, Geneion, Catophorhyne, Batrachops, Rhynchote (Bibron) Duméril. Rhynchotus, Apsicephalus and Brachycephalus, Hollard.

Back broad or compressed into a ridge. A median suture in either jaw. Shoulh a conspicuous nasal organ exist, there may be two on either side in a papilla (Tetraodon, Bleeker); or a single tulular one (Crayracion, Bleeker); or an imperforate one having a fringed edge, while the body of the fish is spinate (Chelonodon, Mäller). or a simple round cavity and the body of the fish smooth (Monotretus, Bibron): or two imperforate tentacles on either side (Arothron, Müller) : or the nasal organ may be inconspicuous, and the back compressed into a keel (Anosmius, Peters). Dorsal and anal fins with few rays. Body wholly or partially covered with fine dermal spines, or such may be absent. There may be a more or less distinct fold along the lower side of the tail and very apparent nasal organs (Gastrophysus, Müller): or the fold be absent, but the body spinate and the rasal organs very distinct (Cheilichthys, Müller): or the fold be absent and the skin smooth (Leiosaccus, Günther). A portion of the aesophagus dilatable and capable of being distended with air. Air-bladder present and horse-shoe shaped.

The Tetrodons in some portions of India are occasionally eaten by the lower classes, but are said to occasion indigestion, so are usually avoided: while all emit an odour the reverse of agreeable. The Burmese in some districts think they are poisonous, while in other localities they attribute these deleterious qualities to the gall-bladder. The Japanese eat one species as a means of enabling them to commit suicide. The Andamanese eat then freely, appearing rather to prefer them to other tish forms. In Bataria and Malayan countries some are certainly poisonous, also in Egypt and at the Cape of Good Hope.

In the Proceedings of the Linnean Society (v. no. 18, November, 1860), Mr. Jamieson, of H.M.S. Winchester, gives an account of how, in Simon's Bay, two Dutch sailors were poisoned by eating part of Tetrodon Cuvieri. The liver of a single fish was said to have been eaten, but both died in from seventeen to twenty minutes. It was also stated that the cook who had fried the liver for the others, and had eaten a small portion, exhibited no alarming symptoms.

\section{Tetrodon lagocephalus, Plate CXLVII.}

Scla, iii, pl. xxiii, f. 6 (young). Orbis lagocephalus, Willagh. Ich. p. 144, t. iii, f. 2 ; Ray, Pisc. p. 43. Ostrucion, Artedi, Genera, p. 58, Svnon. p. 86. Globe diodon, Pemant, Brit. Zool. (Ed. 1776) iii, p. 1:32, pl. xx (Ed. 1812) iii, p. 173, pl. xxiii. 
Tetrodon lagocephalus, Linn. Amøn. Acad. i, p. 310, t. xiii, f. 4, and Syst. Nat. i, p. 410 ; Bloch, Ich. iv, p. 954, pl. cxl; Gmel. Linn. p. 1444 ; Günther, Catal. viii, p. 273.

T'etrodon stellatus, Donovan, Brit. Fish. iii, pl. Ixvi; Turton, Brit. Fauna, p. 116 ; Flem. Brit. An. p. 174; Jenyns, Manual, p. 489; Thompson, Nat. Hist. Ireland, iv, p. 243.

Tetrodon curvus, Mitchell, Fish. New York, p. 472.

Lagocephatus Pennantii, Swainson, Fishes, ii, p. 328; Bonap. Faun. Ital. iii, t. f. 2 ; Canestrini, Faun. Ital. p. 147.

Tetrodon Pennantii, Yarrell, Brit. Fish. (ed. 1) ii, p. 347, c. fig. (ed. 2) ii, p. 457 (ed. 3) ii, p. 426; White, Catal. p. 116.

Promecocephalus lagocephalus, Bibron, Mis. p. 108; Morean, Poiss. de la France, ii, p. 72.

Pennant's Globe Fish, Couch, Fish. Brit. Isles, iv, p. 373, pl. cexliv.

D. 12-14, P. 14-15, A. 12-14, C. 12.

Length of head $4 \frac{1}{2}$ to $4 \frac{3}{4}$, of caudal fin $5 \frac{1}{2}$ in the total length. Eyes-partly situated in the hind half of the head. Nasal organs distinct, sitnated in a prominent papilla, in which one is at each end. Back broad and not compressed. Teeth-the beak or jaws divided by a median suture. Fins-the dorsal and anal in the posterior half of the total length, and placed opposite one another. Pectoral two-thirds as long as the head. Caudal somewhat forked. A distinct fold of skin along the side of the tail. Under surface of throat and abdomen covered with four-rooted fixed spines placed at a short distance apart, otherwise the body is unarmed. Colour-of a deep steel blue along the back and upper third of the body, silvery white on the sides and beneath: sometimes there are round dark spots. Fins unspotted. The young have eight or nine cross bands, and usually black spots on the abdominal surface.

Names.-Globe-fish, from its being able to distend itself into a globular form : Stellated globe-fish, due to its spinate dermal armature. Crop-fish, due to the distension of its æsophagus. Heulbysg crothog, Welsh.

Habits.-Those of the tetrodon in British waters have not been observed, as it is very rare, but in tropical countries where it is common, it distends its crop and floats securely on the surface of the waves, while should it be assailed by an enemy it turns towards such that portion of its body which possesses a spinate covering.

Habitat.-Coasts of Britain and also of East Africa, but is very rare in European seas.

Two have been recorded from the Orkneys (Baikie, Zool. 1853, p. 3847): a stuffed one 13 inches in length was in the Aberdeen University Museum, in May, 1881. 1859, August, a specimen 2012 inches long was left by the tide in the Solent (Penny, Zool. xvi, 1860, p. 6892) : the first British example recorded was from Penzance, and 1 foot in length (Pennant): October 20, 1867, one 19 inches long was taken near Truro in Cornwall : an example from Mount's Bay was recorded by Boase (P. Z. S. 1833, p. 115): October 26, 1868, one 19 inches

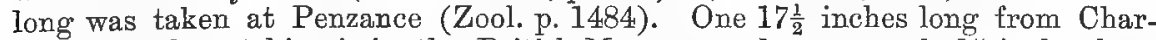
mouth in Dorsetshire is in the British Museum, and an example 15 inches long is in the museum of Weston-super-Mare, and may be a local one. At Amroth, near Tenby, Mr. Loch says that one was taken lately (Land and Water, Oct. 26). Couch tells us, without mentioning the years, that one has been taken near Polperro, and several in Mount's Bay, two being captured there within a month, one $22 \frac{1}{2}$ inches long on August 27, the other on Sept. 17, while on the 29th of the same month a third was secured at St. Ives.

Ireland.-County of Waterford from Tranmore Strand by Dr. Stokes (Templeton, Mag. N. Hist. 1837 (2) i, p. 413) : in 1852, Sept. 26, one 21 inches long was washed ashore at Waterford after a N.E. gale (Sargent, Zool. xi, p. 3848) : in 1850 one 18 inches long was recorded from near Wexford (Hopkins, An. and Mag. (2) p. 311): in December, 1854, one was washed ashore at Ardmore, Co. Wexford, but smaller than the example in 1852 (E. Sargent).

The figure is from the Charmouth specimen in the National Collection. 


\section{Genus II-Or'Thagoriscts, $B l$. Schn.}

Cephalus, Shaw. Tympanomium, Diplanchias, Trematopsis, and Ozodura, Ranzani. Ranzania, Nardo. Pendalion, Guilding.

Body short and compressed, covered with a rough or else with a smooth tessellated stin which cannot be distended with air: tail portion of the body very short, and truncated. Jaws without any median suture. Vertical fins more or less confluent. Ventrals absent. No pelvic bones. No air-bladder. An accessory opercular gill.

The young of these fishes or Orthagoriscus ("a little pig," which name it has obtained from its grunting), undergo very great changes in form before they attain that which is found in the adult, insomuch that they have been placed in a distinct family. The species forming this genus have been thus subdivided:-

A. Orthagoriscus.-Skin rough.

B. Ranzania.-Skin smooth and tessellated.

Lütken, however, considers these fish should be in two distinct genera, for besides other characteristics, one has an osseous, the other a cartilaginous skeleton.

Geographical distribution.-Cosmopolitan and pelagic bat frequently approaching the shore, where they are seen basking or sleeping on the surface of the sea. They attain a large size, and oil can be obtained from their livers.

\section{A. Skin rough (Orthagoriscus).}

\section{Orthagoriscus mola, Plate CXLVIII.}

Orthagoriscus s. Lnma piscis, Rondel. p. 424; Gesner, p. 640. Mola, Salv. fol. 155; Aldrov. lib. iii, c. 45, p. 410. Mola Salviani, Willughby, p. 151, t. I 26 ; Jonston, lib. i, tit. i, cap. 3, t. ix, f. 2; Ray, Pisc. p. 51 ; Borlase, Cornwall, p. 267, t. xxvi, f. 7; Brün. Pisc. Mass. p. 8. Ostracion, sp. Artedi, Synon. p. 83, no. 4, Gen. p. 61 , no. 22 ; Gronov. Zooph. nos. 185 and 186. Short diodon, Pennant, Brit. Zool. (Ed. 1776) iii, p. 129, pl. xix (Ed. 1812) iii, p. 172, pl. xxii. Mole, Duhamel, Pêches, ii, sect. ix, p. 306, pl. xxiii.

Tetradon nula, Linn. Syst. Nat. i, p. 412 ; Gmel. Linn. p. 1447 ; Lacép. i, p. 509 ; Bonnaterre, Ency. Ich. p. 25, pl. xvii, f. 54 ; Donovan, Brit. Fishes, ii, pl. $x \times v$.

Jiodon mola, Pallas, Spec. Fas. viii, p. 39, t. iv, f. 7 ; Bloch, t. cxxviii.

Orthagoriscus mola, Bl. Schn. p. 510; Flem. Brit. An. p. 175; Jenyns, Manual, p. 490; W. O. Bellingham, Mag. Nat. Hist. 1840 (2) iv, p. 235; Schlegel, Fauna Japon. Poiss. p. 28x, t. 127, and De Dieren Neder. p. 182; Yarrell, Brit. Fish. (ed. 1) ii, p. 3io, c. fig. (ed. 2) ii, p. 462 (ed. 3) ii, p. 432 ; Parnell, Wern. Mem. vii, p. 401 ; Storer, Mass. Reports, p. 170, pl. iii, f. 1, and Mem. Amer. Acad. viii, p. 420, pl. xxxiv, f. 2; Templeton, Mag. Nat. Hist. 1837 (2), i, p. 413; De Kay, New York Fauna, Fish, p. 331, pl. lix, f. 193; Bennett, Whaling Voyage, ii, p. 262; Kröyer, Danm. Fiske, iii, p. 732; Nilss. Skand. Fauna, iv, p. 1.17 ; Parlby, Proc. Zool. Soc. 1849, p. 6 ; Swainson, Fishes, ii, p. 3:9; Costa, Fauna Nap. Pesc. tar. lxiii, lxiv; White, Catal. p. 117; Thompson, Nat. Hist. Ireland, iv, p. 243 ; Klunzinger, Fisch. Rothen Meeres, p. 648; Günther, Catal. viii, p. 317 ; Winther, Pro. Ich. Dan. Mar. ii, p. 54 ; Andrews, Proc. Dub. Soc. 1871, vi, pl. ii ; Canest. Faun. Ital. p. 148; Malm, Fanna, p. 599 ; Collett, Norges Fisk. p. 203 ; Moreau, Poiss. de la France, ii, p. 74; Giglioli, Catal. Pesc. Ital. p. 50 .

Orthragoriscus fasciatus, BI. Sehn. p. 511.

Tetrodon mola, Gmel. Linn. p. 1447. 
Cephalus brevis, Shaw, Zool. v (2) p. 432, pl. clxxv; Neill, Wern. Mem. i, p. 546; Turton, Brit. Fauna, p. 116 ; Mitch. Lit. and Phil. Trans. New York, $i$, p. 471 .

Ozodura orsini and ursini, Ranzani, Nov. Comm. Ac. Sc. Inst. Bonom. iii, 1839. p. 80 , t. vi.

Cephalus ortagoriscus, Risso, Eur. Mérid. iii, p. 173.

Tympanonium planci, Ranzani, l. c.

Diplanchias nasus, Ranzani, I. c.

Trematopsis Willughbii, Ranzani, l. c.

Orthragoriscus Retaii, ghini, Rondeletii, Blochii, and redi, Ranzani, 1. c.

Orthragoriscus solaris, Gronov. ed Gray, p. 165.

Ale.ton Storeri and capensis, Castlenau, Poiss. Afri, Aust. pp. 75, 76.

Mola aspera, Bonap. Pesc. Eur. p. 87.

Mola nasus, and retzii, Steenstrup and Lütken, Overs. Dansk. Vid. Selsk.

Förh. 1863 , p. 36 ; F. Wahlgren, Act. Uni. Lund. F. 1867, p. 18, c. fig.

Orthragoriscus ozodura, Harting, Verh. Ak. Wet. Amst. 1868, p. 1, pl. i-viii.

Short Sun-fish, c. fig. Embleton, Tyneside Field Club, ii, p. 110.

Sun-fish, Couch, Fish. Brit. Isles, iv, p. 377, pl. cexlv.

\section{(Young.)}

Mola aculeata, Kölreuter, Nov. Comm. Petr. x, 1.766, p. 337, t. viii, f. 2, 3.

Diodon mola, Pallas, Spic. Znol. Fasc. viii, p. 39, t. iv, f. 7.

Orthragoriscus hispidus, Bl. Schn p. 511.

f. 1 .

Diodon cavinatus, Mitchell, Amer. Lyc. Nat. Hist. New York, ii, p. 264, pl. v,

Acanthosoma spinosus, Cuv. Règne Anim. p. 333 ; Richards. Voy. Snlphur.

Fish. p. 125, pl lxxii, figs. 10-12.

Ostracion boops, ${ }^{*}$ Richards. Voy. Erebus and Terror, Fish. p. 52, pl. xxx,

f. 18-21; Günther, Catal. viii, p. 268: Putnam, Am. Nat. iv, 1870, p. 629.

Orthragoriscus aculeatus, Ranzari, l. c.

Centaurus boops, Kaup, Wiegm. Arch. 1855, p. 221.

Pallasia, Nardo, Ann. Sc. Reg. Lomb. Venet. x, 1840, p. 112. p. 320 .

Orthagoriscus (on the young of), Lütken, Ann. and Mag. Nat. Hist. 1871, viii,

\section{B. v. D. 16-18, P. 11-13, V. 15-17, C. 12-16, Vert. $10 / 7$.}

Body compressed, oblong and elevated, appearing posteriorly as if truncated: its height, in large examples, equal to $\frac{4}{7}$ of its total length, but in the young it is sometimes even higher than long. Head in large specimens $1 / 3$, or rather less in the total length. Eyes-small, situated between the end of the snout and the base of the pectoral fin, in the one figured, which was of large size, it is situated considerably nearer the dorsal than the abdominal profile : a ridge runs from the snout above the eye, which in large specimens develops an osseous tubercle. A species of nictitating membrane, or third lid, exists on its anterior side, and which can be brought all over the eye. Mouth small, jaws feeble, and covered to the margin by a narrow band of enamel. Teeth-supplementary teeth inside the jaws in the young, but absent in the adult, or after $1 \frac{1}{2}$ to 2 feet in length. Fins-dorsal and anal narrow, high, more or less pointed, and becoming comparatively shorter with age. Pectorals short and rounded. Vent situated in a vertical line under the first ray of the dorsal fin. Skin-minutely granulated and rough, in the very young, with conical spines. Colours - of a dull brown or leaden colour, darkest along the back. Couch observes that when lying on its side basking, its colours shine brilliantly. In small ones he has seen beautiful variegations of tints in stripes and blotches of yellow, blue, and white.

Names.- "This fish is called by Ray and others, the sun-fish," as being round, and emitting a kind of splendour in a dark room : by others (with Rondeletius) the

* The young is so dissimilar from the adult that Dr. Günther asserted of Richardson's figure " it is evidently a young Ostracion," while Gill placed it in a distinct family Molacanthidos. Lütken, An. and Mag. Nat. Hist. 1871, t. viii, p. 320, maintains it to be a young Orthagoriscus. 
moon-fish, "because not only round and shining by night, but having the shape of the crescent betwixt its little pectoral fin and eye" (Borlase, N. H. Cornwall, p. 268). Molebut. Heulbysg byrr, Welsh. De Maanvisch, Dutch. La Lune, French.

Habits.-Mr. Gosse (Zool. 1852, p. 3579) records one taken at Ilfracombe. "It was slowly moving at the time of its discovery, with a waving motion from side to side, ' like a man sculling a boat,' to use the comparison of the sailor who helped to take it: the back fin appearing above water. The fish permitted the boat to come close up without exhibiting alarm, nor was he even disturbed when her side came into contact with his bulky person. The fellows made a bowlineknot, and slipped it over his head, tightening it before his dorsal and anal, so that the knot came in the middle of his side. Thus they hauled him in, not without a wetting, for with a flapping action of his ample fins (again a sort of sculling) he scooped up the water, and threw it over them, and into the boat."

This fish appeared in large numbers along the southern coast of England in 1850, and "a comparison of dates and longitudes of the captures would lead to a supposition that the course taken by these strange fishes was from west to east, and at a very slow rate" (Zoologist, 1850, viii, p. xi). Couch (Misc. 1868) observed that a fisherman infor med him of a fact he witnessed close at hand in a smooth sea. A fish about two feet long, and about the same depth of body, which was bright white, leaped above the surface to what he supposes might be the beight of two feet, when it fell down flat on its side. He never saw any fish like it except the common sun-fish. The only remarkable thing abont it is its leaping out of the water, and although a fisherman of several years' standing, he nerer saw a sun-fish do this in any other instance. $\mathrm{Mr}_{r}$. Dunn on the contrary asserts such to be not uncommon, and due, he believes, to its being attacked by some other fish.

Major Parlby (Proc. Zool. Soc. 1849, p. 6) refers to one (now in the British Maseum) which he remarks was almost daily seen in West Bay, Dorsetshire, sometimes sailing about slowly with half its dorsal fin abore the surface of the water, sometimes moving with great rapidity, playing about and splashing the water violently, or blowing like a whate or grampus. As it generally kept off and on between the mackerel and the shore, the fishermen attributed their illsaccess with the shoals, which never left the deep water, to the presence of this unusual visitor; and it is remarkable that on the day after its capture, they took upwards of $20,0 n 0$ fish. It got entangled in the nets, and forty fishermen co-operated to drag it ashore; even here its vigour was so great that it dashed about the pebbles, according to the fishermen, like a shower of grape. It expired in about three hours, after uttering "hideous groans" like those of a horse dying of the staggers. In other instances the sounds these fishes utter, when gaffed or hooked, have been compared to sighs, or even to the grunting of swine. Coralline fragments were observed in the mouth of one ; in another, the claw of a minute lobster, but generally merely some mucous substance has been recorded from its stomach.

Means of capture.-When basking or lying on the surface of the water it occasionally permits a boat to approach very closely, and even allows itself to be touched without showing any fear. Dr. Neill informs us that he possessed one which a sailor lifted out of the sea into his boat. The sun-fish has been known to suffer itself to be secured with comparative ease by means of a boathook, or to be harpooned or gaffed. In some instances it has exerted itself to escape, which it does along the surface, and often with considerable speed. On October 17th, 1856, one was brought up with the lead line of H.M.S. cutter Woodlark, at the mouth of the Frith, off the Isle of May. The line had passed over one of its fins. The fish was secured with a boathook, and weighed about $500 \mathrm{lb}$.

Baits.-Couch (Mss. Journal, 1869) records how a fisherman from Polperro was fishing with a line over the stern with a hook baited with a lask, a slice cut from near the tail of a mackerel, when a sun-fish took the bait. It was captured and was of good size. Another instance has been thus recorded by Fal, in the Field (April 17th, 1880). His son last autumn captured one weighing $53 \mathrm{lb}$. It took a red eel.

\footnotetext{
* The sun-fish of the west const of Ireland is the "basking shark.' Selache maxima.
} 
Life history.-In young specimens the vertical diameter of the body, excluding the fins, exceeds the length, but in adults it is somewhat more than half the length. Young fish have a spine over the snout (but in adults this is merely a hump above the mouth containing a bony tubercle), while conical spines are scattered over the body. The teeth likewise alter with age, for in the very young there are supplementary ones inside the cutting jaws, and are generally present until the fish attains about a foot and a balf or two feet in length.

Diseases. - Is much infested by parasites (see Cobbold, Intellectual Observer, ii, p. 82, on the "Sun-fish as a host"). Couch in 1869 sent a specimen of Lernea pennatula from one to the British Museum; Sim took one from a sun-fish at Aberdeen in 1881, and in $1883 \mathrm{I}$ observed another on a specimen at Mevagissey. McIntosh remarks upon one captured at St. Andrew's in October, 1862, which measured $4 \mathrm{ft} .8 \mathrm{in}$. high and $3 \frac{1}{3} \mathrm{ft}$. long. Externally there were several specimens of Tristoma coccineum on it; numerous examples of Gymnorhynchus horridus wero found in the muscles on dissection. It is often accompanied by the Pompilus.

Uses.-An oil may be extracted from its liver. Dr. McIntosh found this organ weighed $3 \frac{2}{2} \mathrm{lb}$. in a specimen $4 \frac{2}{3}$ by $3 \frac{1}{3} \mathrm{ft}$. in size.

As food.-A writer in the Field (February 4th, 1882) observes on taking a sun-fish near Plymouth, that his friend cut off a large portion and sent it as a present to an acquaintance who was fond of turtle soup. It was boiled by his cook, and he asserted that it was the best turtle soup he had tasted for a long time, having that delicate green tinge always characteristic of the best turtle. A.s no ill results ensued it was supposed the fish must be wholesome. Couch mentions that a gentleman informed him that in the Mediterranean he procured a portion of a large one, which he had cooked, and thought it good, the taste being much like a crab. I have been told that the smell of this fish when captured is often exceedingly offensive; it was not so, however, of the one I examined. Risso states that at Nice they are taken in great numbers, yield much oil, but that their flesh is bad.

Habitat.-This pelagic fish has a wide range, being found in temperate and tropical regions; a specimen at the late Fisheries Exhibition came from New South Wales, where it is not uncommon. In Great Britain it has been captured from the Orkneys and Wick to the extreme end of Cornwall, increasing in numbers along the south coast. It would be an unnecessary waste of space to enumerate the various localities from which this fish has been recorded, while it is often seen in the Channel, and numerous examples are annually killed around our coast, of course more so in some years than in others, the majority of those recorded being from the commencement of June until the middle of September, or. even until October, while Buckland received one in December, 1863, taken off Folkestone. In 1851, on September 19th, a sun-fish $5 \mathrm{ft} .9$ in. long was taken at Gamrio on the east coast of Scotland (G. Harris, Zool. p. 3280). In November, 1874, one was captured off Pittenweem, on the coast of Fife. A fisherman, when fishing a little to the west of the town, saw a big dorsal fin swimming, or rather drifting along the surface. At first he thought a shark was a near neighbour to him, but on closer inspection he saw what the stranger was, and caught it with the boathook. The hook caught the fish by entering its eye, and it was thus towed to the harbour: it measured fully $4 \mathrm{ft}$. from the snout to the edge of the tail, and at least $8 \mathrm{ft}$. across the fins, while it weighed between $300 \mathrm{lb}$. and $400 \mathrm{lb}$. It was exhibited to the curious as a penny show in Pittenweem, and also in the towns of Anstruther and St. Monance, and a large sum was thus realized, after which it was sold to a speculative cadger for three guineas and taken north to Dundee for a show to the good people of that town. The odour, however, emitted from the fish by that time was quite offensive. One was recorded on June 13th, 1850, weighing four or five cwt., which was captured while being pursued by a conger. In October, 1843, one only 18 in. long and 13 deep, was secured at Yarmouth (Zool. p. 85), and in 1850 one only $2 \mathrm{ft}$. in length was taken at Hastings. One $23 \mathrm{in}$. in length is now in the Exeter Museum-it was captured August 10th, 1877, some miles up the Exe. Borlase mentions it from Mount's 
Bay, in fact in Cornwall it is not uncommon during the summer and autumn months.

Ireland.-Has been taken on each side of the coast, but is an uncertain visitor; one weighing $3 \mathrm{cwt}$., taken September 15th, 1851, off the Gobbins, co. of Antrim, was preserved in Queen's College, Belfast. One taken in Connemara weighed $6 \mathrm{cwt} .42 \mathrm{lb}$. A correspondent of Land and Water remarked on having seen many during the summer months in the counties of Cork and Kerry; and last summer, while staying for two weeks on the Arran Islands, Galway Bay, he was three times asked to buy one, as the Arranites could not believe a stranger would stay any time on the islands unless they came to buy fish or kelp. From inquiries made at the time, he learned that formerly a trade was carried on in catching them, the weapon used being a harpoon or fishing-spear; but now none of them seem to have that kind of weapon (at least he could not find any man that had), but they get chances, when out gurnet and bream fishing, of finding the sun-fish at the surface of the water asleep; then they bear down quietly on thern, strike in a gaff, and get a rope round them and tow them into land if they are too large to take into their boats.

One captured in June, 1846, off Chesil Bank, Dorsetshire, was $6 \mathrm{ft}$. 3 in. long : this is the stuffed specimen, now $7 \mathrm{ft}$. long, in the British Museum, and labelled from Portsmouth; while in July, 1870, one was captured basking off Devonshire, which was $5 \mathrm{ft} .6 \mathrm{in}$. long (A. Bell, Zool., p. 2260), and in August the same year one $6 \mathrm{ft}$. $10 \mathrm{in}$. long and $4 \mathrm{ft} .5 \mathrm{in}$. high was taken at Swanage. It has, however, been stated to attain to a very large size, measuring 7 or $8 \mathrm{ft}$. in length, and weighing as many hundredweights.

The specimen figured was $5 \mathrm{ft.} 1$ in. long and $f \mathrm{ft.} 3 \mathrm{in}$. high. It was captured near Mevagissey, in September, 1883, and I made a drawing of it when brought to the latter place. It weighed between 2 and $3 \mathrm{cwt}$, and was taken to the Sydney Museum, New South Wales.

\section{B. Slin smooth and tesselluted (Ranzania).}

2. Orthagoriscus truncatus, Plate CXLIX.

Rondeletii sun-fsh from Mount's Bay, Borlase, Cornwall, p. 267, pl. xxvi, f. 7. Ostracion, no. 185 (part) Gronov. Zooph. Oblong diodon, Pennant, Brit. Zool. (Ed. 1776), iii, p. 129, pl. xix, f. 54, and oblong tetrodon (Ed. 1812) iii, p. 170, pl. xix.

Tetrodon truncatus, Retz. Svensk. Vet. Ak. Nya Handl. vi, 2, p. 116; Grmel. Linn. p. 1448 ; Donovan, Brit. Fishes, ii, pl. xli.

Orthragoriseus oblongus, Bl. Schn. p. 511, t. xevii; Jenyns, Manual, p. 491; Yarrell, Brit. Fishes (ed. 1) ii, p. 354, c. fig. (ed. 2) ii, p. 469 (ed. 3) ii, p. 439 ; White, Catal. p. 118 ; Thompson, Nat. Hist. Ireland, iv, p. 244; Moreau, Poissons De la France, ij, p. 77.

Le T'etrodon lune, Lacépède, i, pp. 476, 509 (part) pl. xxij, f. 2.

Cephalus oblongus, Shaw, Zool. v, p. 439, pl. clxxvi; Turton, Fauna, p. 116 ; Swainson, Fishes, ii, p. 330 .

Cephalus elongatus, Risso, Eur. Mérid. iii, p. 173.

Orthagoriscus truncatus, Flem. Brit. An. p. 175; Günther, Catal. viii, p. 320 ;

Andrews, Proc. Roy. Soc. Dublin, 1871, vi, p. 56, pl. i.

Orthagoriscus varius, Cuv. Règne Anim.: Giglioli, Catal. Pesc. Ital. p. 50.

Mola planci, Nardo, Férussac, Bull. Sc. Nat. xiii, 1828, p. 437 ; Canestrini, Fauna d'Italia, Pesci, p. 149.

Cephalus cocherani, Trail, Wern. Mem. vi, 1832.

Orthragoriscus elegans and battarre, Ranzani, l. c.

Ranzania truncata, Nardo, An. Sc. Regn. Lombard. Venet. 1840, x, p. 105.

Orthragoriscus lunaris, Gronov. ed Gray, p. 165.

Ublong sun-fish, Couch, Fishes British Isles, iv, p. 381, pl. ccxlvi.

D. 16-19, P. 12-13, A. 19, C. 18-22.

Body of an elongated ovate form, with the sicles compressed. The height of the body cqual to about nne-half, length of head not quite one-thind of the total length. 
Eyes -about 2 to 3 diameters from the end of the snout: the mouth anterior and opposite the centre of the eye. Fins-the dursal and anal at the extreme end of the dorsal and abdominal profiles, and connected to the caudal, which is very short. Pectoral somewhat pointed. Skin smooth and divided into small hexagonal plates like mosaic. Colours - "Immediately before death the colour's were most brilliant, the back being of a dark purple, gradually decreasing in intensity to the belly, which was white with golden reflections, the sides marked with green lines on the purple: towards the tail there were several irregular white spots about the size of a threepenny piece: the dorsal, anal, and pectoral fins were of a pale lead-colour, but the caudal fin was most brilliant, being of a bright burnished silver, with prismatic reflections, the rays tinged with purple, whilst between the rajs there were keyhole-shaped marlsings, edged with gold, forming such a brilliant combination of colours as is not easily imagined. But this brilliancy entirely vanished a few minutes after the death of the fish, when it assumed the dull blue colour of the figure in Couch's 'Fishes of the British Isles,' which is exceedingly good, but might have been a few shades darker" (S. Clogg, Zool. 1883, p. 342). Borlase's specimen was dapple, spotted darker on the back, with streaks half an inch wide from the eye to the pectoral fin.

Habits.-Has not been observed basking on the surface of the sea like the O. mola. Mr. P. Dawson sent one captured off Pembrokeshire to the Field (June 23rd, 1883). The editor observes that it was a young one, weighing $18 \mathrm{lb}$. and 25 inches in length. Another "taken in Looe harbour, June '23rd, 1883, was seen swimming on the surface of the water, having come in with the evening tide. Two fishermen at once followed it in a boat and captured it, in what is here known as a keep net" (S. Clogg, Zool. 1883, p. 342). "Length from snout to end of caudal fin, 25 in. : depth of body close behiud pectoral fin, 15 in. : distance between tips of dorsal and anal fin, 22 in. : from base to base of same fins 9 in., the space between being filled up by the caudal fin : from snout to eye, 4 in. : pectoral fins, $6 \frac{1}{2}$ in. : dorsal and anal fins, 7 in." It appears to feed upon small crustacea, worms, testaceous and other tribes.

Habitat.-From the British shores and coasts of France into the Mediterranean, and is rather widely distributed in the Atlantic and Pacific oceans.

On our shores it is uncommon and much rarer than the $O$. mola. One was captured in the Orkneys (Baikie, Zool. 1853, p 3847) and Couch remarks that Dr. Duguid recorded one from there. In August, 1846, and October, 1850, examples were taken in the Moray Firth and at Elgin. It has more commonly been captured along the south coast, but some of the species recorded as of this form I have omitted, for want of sufficient evidence that they were not 0 . mola. It was first recorded in this country from Cornwall, by Borlase, as taken at Penzance in May, 1743: he observed that the specimen was a small one, but alludes to others of great weight, possibly the last species. Two were taken in Mount's Bay in 1855 (Couch), one 22 inches long wandered up the newly-made lock of the canal at Charlston, in Cornwall, and was secured for the Truro Musenm. One 25 inches long was taken June 23rd, 1883, in Looe harbour (Clogg, Zool. p. 342 ), and on the same day another also, 25 inches in length, was captured off Pembrokeshire and sent to the Field. Donovan obtained it from the British Channel, and in 1842 a young male, $25 \frac{1}{2}$ inches long, was washed ashore at Swansea (Dillwyn).

Ireland.-In September, 1845, one was found in the county of Waterford, among some seaweed. One was taken by Mr. S. Wright, at Youghal, in ]837, which weighed about $112 \mathrm{lb}$, and was said to be this species, but does not appear to have been preserved (Harvey). One from Wexford in the Dublin University Museum, as recorded in the list of donations.

The figure is from a stuffed specimen, 18 inches in length to the centre of the tail, and which is in the National collection. 


\section{Sub-Class II-CHONDROPTERTGII.*}

Skeleton cartilaginous or osseous. Heart with a contractile conus arteriosus. Optic nerves united, or should they decussate, do so only slightly. Intestines with a spiral valve.

Among this sub-class, British waters possess representatives of two orders :less free.

I. GANOIDEI-having a single gill-opening on either side, and the gills more or

II. Elasmobranchil-several gill-openings, as a rule, on either side, or on the lower surface, with the gills externally, more or less attached to the skin.

\section{ORDER I-GANOIDEI.}

Skeleton cartilaginous or osseous. Gills mostly free, rarely having a slight connection with the walls of the gill-cavity: a gill-cover and a single gill-slit on either side. Median and paired fins: the posterior pair abdominal. Airbladder with a pneumatic duct. Ova small. Embryo may have external freegills.

\section{Sub-Order I-CHONDROSTEI.}

Skeleton notochordal: skull cartilaginous. Branchiostegals, when present, few in number. Teeth generally absent, sometimes only found in the young stage. Nostrils in front of the eyes with two openings. Caudal fin heterocercal with fulcra. Integuments scaleless, or with dermal ossifications which are also present on the head.

\section{FAMILY I-ACIPENSERID $\mathbb{E}$.}

Body sub-cylindrical and elongated. Branchiostegals absent. Snout conical or produced. Mouth inferior, transverse and protractile. Teeth (except in the very young) absent. Barbels four in a row on the ventral surface of the snout. Gill-membranes confluent and attached to the isthmus. Gills four, two accessory gills; a spiracle at the upper border of the gill-cover. Dorsal and anal fins approximate to the caudal; vertical ones with a single row of fulcra. Airbladder large, simple and furnished with a pneumatic duct that communicates with the dorsal wall of the æsophagus.

In these fishes, the skeleton is partly cartilaginous and partly osseous. Professor Kitchen-Parker (Nature, May 19, 1881, p. 71) observed that "the sturgeons, as a group, cannot be said to be directly between any one family of the Selachians and any one family of the bony Ganoids, yet on the whole that is their

* Palaeichimiss, Günther, is equivalent to Chondropterygii as it has generally been regarded, except that the aberrant Cyclostomata bave been removed, an order which some systematists consider ought hardly to be placed among the class Pisces, while they discard the headless Leptocardi. Prof. Huxley read a paper at the Zoological Society of London, March 20, 1883, on the oviduct of the Common Smelt (Osmerus eperlanus), and tonk occasion to remark on the relations of the Teleostean with the Ganoid Fishes. He pointed out the spinal valve in the intestines of the Teleostean, Chirocentrus dorab, and came to the conclusion that the proposal to separate the Elasmobranchs, Ganoids, and Dipnoans into a group, apart from and equivalent to the Teleosteans, was inconsistent with the plainest anatomical relations of these fishes. 
position. The Bony Ganoids on the whole approach the Teleostei, especially such forms as Lepidosteus and Amia, which have lost their 'spiracle,' and, in other things are less than typical, as Ganoids." Respecting the development of the skull, larval sturgeons have, for a few weeks, their lips and throat beset with true teeth, which are moulted before calcification has fairly set in.

\section{Genus I-Acipenser, Artedi.}

\section{Huso, Sturio, Sterleta and Helopa, Brandt and Ratzeburg. Lioniscus and Antaceus, Fitzinger. \\ Definition as in the family. The rows of hony plates along the sides of the tail not confluent. The end of the tail surrounded by fin rays.}

The sturgeons were divided by Rafinesque into two groups: Sturio with five, Sterletus with three rows of bony plates. Brandt divided them into five:(1) Body shields distinct. Huso, snout acute or obtuse, more or less cartilaginous and pellucid. Sturio, snout obtuse or awl-shaped, covered with bony shields : not pellucid. Helops, snout elongated and covered with bony shields. (2) Body shields overlapping. Sterlata, snout awl-shaped, covered with bony plates, not pellucid. Fitzinger placed them in two sections-(A) Dorsal scutes sloping in front, and highest behind, ending in a point, and open up to it. (B) Dorsal scutes sloping on both sides, highest in the middle, ending in a point. These sections were subdivided into five more. But great variation in the form of the dorsal scutes occurs with age, while they are most prominent in the young. Also the form of the snout is subject to considerable modifications in specimens of the same species.

The species in this genus appear to have been rather unduly multiplied. Dr. Günther observes that "the number of lateral shields, considered by some naturalists (who have compiled their descriptions from the accounts given by different authors) to be variable, proves to be very constant, young immature examples having generally a few less, the hindmost on the tail not being developed." In a specimen in my own collection from Torbay, 4 ft. 10 in. long, there are 31 scutes on one side, and 33 on the other; in a second, from Margate, $5 \mathrm{ft}$. $4 \mathrm{in}$. long, there are 27 on one side and 28 on the other. In the three specimens described by Sir J. Richardson, they had respectively 29-32, 30-32, 38-40.

Some sturgeons appear to pass their entire lives in fresh water, but the majority are anadromous, ascending from the sea to breed in rivers and lakes: while hybrids have been recorded.

A sturgeon is a Royal fish, and by an unrepealed Act of Edward II, it is enacted that "the king shall have the wreck of the sea throughout the realm, whales and great sturgeons" taken in the sea or elsewhere in the realm, except in certain places privileged by the king.

The size to which sturgeons attain partly depend upon the waters in which they reside: one of the islinglass form, Acipenser huso, was captured in 1869 at Saratoff which weighed $2760 \mathrm{lb}$, while one in 1813, near Sarepta, was $3200 \mathrm{lb}$. Some which have been hooked in Russian waters are asserted to have been too large to permit of their being dragged out. This species has been said to have occurred in British waters, but the information is not conclusive: judging from the size of some captured, it does not seen improbable that one or more have wandered to our shores.

During the summer of 1869 attempts were made by Mr. Murray to introduce the sterlet Acipenser ruthenus from Russian waters into the Duke of Sutherland's river Fleet, by importing artificially impregnated ova. From 150 to 200 lively young sterlets are said to have been turned out. This attempt was not successful (Land and Water, July 23rd, 1881).

Dr. Günther, in 1870, introduced Acipenser maculosus, an Arctic and American form, among the British fishes, this opinion being founded on a specimen now 
in the Free Kirk Museum in Edinburgh and figured in the last edition o: Yarrell's "British Fishes" by Sir J. Richardson. 'The authority for the habitat of this specimen is as follows:- "Dr. Duns has the very strongest impression that the specimen was obtained from the Firth of Tay." But Richardson, who described it in 1859 , does not appear to have ascertained from whence it had come, merely observing that it is "about 18 inches long, which may probably be the young of the Firth of Forth species, described at much length in the preceding pages." A single specimen with such a doubtful history can hardly be accepted as sufficient authority for including this sturgeon among the British Fauna. However, in Dr. Günther's "Introduction to the Study of Fish," p. 362, he observes that A. maculosus "sometimes crosses the Atlantic to the coasts of Great Britain," but he omits the authority for such a statement unless it be the solitary instance referred to above, respecting which a strong impression exists that it was taken on the east coast of Scotland.

\section{Acipenser sturio, Plate CL, fig. 1, 2, 3.}

Attilus, Rondel. p. 173; Belon. De Aquat. p. 102 ; Willughby, p. 241, t. P7, f. 2 ; Aldrov. v, p. 363 ; Jonston, t. xxviii, f. 4 . Sturio, Salvian. fol. 113 , t. cxii ; Willughby, p. 239, t. P7, f. 3 ; Ray, p. 112; Rondel. p. 410 ; Gesner. Aquat. p. 73; Jonston, Lib. ii, tit. i, cap. vii, p. 111, t. xxiii, f. 8 ; Rutt.y, Nat. Hist. Co. Dublin, 1772, p. 363. Acipenser, sp. Artedi, Synon. p. 91, no. 1, Genera, p. 65, no. 1 ; Gronov. Mas. i, p. 60, no. 131, and Zooph. p 39, no. 140. Sturgeon, Pennant, B1it. Zool. (Ed. 1776) iii, p. 124, pl. xix (Ed. 1812) iii, p. 164, pl. xxii; Low, Orkneys, p. 176. Esturgeon, Duhamel, Pêches, iii, p. 221, pl. i.

Acipenser sturio, Linn. Sjst. Nat. i, p. 103 ; Gme]. Linn. p. 1483 ; Bloch, Ich. $\dddot{11}$, p. 726, t. Ixxxviii; Lacép. i, p. 411, pl.xx, f. l ; Bl. Schn. p. 34.7; Donovan, Brit. Fish. pl. Ixvi; Shaw, Zool. t. clix; Turton, p. 114; Risso, Ich. Nice, p. 56, and Eur. Mérid. iii, p. 166 ; Nardo, Prod. Adr. Ich. p. 10; Flem. Brit. An. p. 173; Faber, Fische, Isl. p. 46; Elkström, Fisch. Mörkö, p. 118; Brandt and Ratzeb. ii, pp. 17, 352, t. iii, f 1; Templeton, Mag. Nat. Hist. 1837 (2), i, p. 41:3; Johnston, Berw. N. F. C. 1838, i, p. 175 ; Parnell, Fish. Firth of Forth, p. 247, and Wern. Mem. vii, p. 403; Swainson, Fishes, i, p. 123, c. fig. and ii, p. 322; Jenyns, Manual, p. 493 ; Yarrell, Brit. Fishes (ed. 1) ii, p. 360, c. fig. (ed. 2) ii, p. 475; Nilsson, Skand. Fauna, iv, p. 699 ; Thompson, Nat. Hist. Ireland, iv, p. 245; Kröyer, Danm. Fiske, iii, p. 747 ; White, Catal. p. 121; Gronov. ed Gray, p. 3; Heckel and Kner, Suss. w. f. p. 362, c. fig. ; S'́lys-Long. Faun. Belg. p. 185; Schlegel, Dieren Neder. p. 184, pl. xvii, f. 5 ; Siebold, Suss. w. f. p. 363 ; Blanchard, Poiss. de la France, p. 505, f. 133, 134, 135; Günther, Catal. viii, p. 342 ; A. Duméril, Poiss. ii, p. 184, t. xvii, f. 10; Houghton, British Freshwater Fishes, p. 169, c. fig.; Winther, Prod. Ich. Dan. Mar. p. 55 ; Collett, Norges Fiske, p. 205; Feddersen, Danske Ferskvanspike, p. 13 ; Malm, Fauna, p. 604; Canestrini, Fauna d'Italia, Pesc. p. 7 ; Giglioli, Pesc. Ital. Catal. p. 51 ; Moreau, Poissons de la France, i, p. 471 .

Acipenser Lichtensteinii, Bl. Schn. p. 348, t. lxix; Brandt and Ratzeb. ii, p. 21, t. ii, f. 1 (young).

Acipenser latirostris, Parnell, Wern. Mem. vii, p. 405 and Fish. Firth of Forth, p. 245, pl. xxxix (head), and Trans. Royal Soc. Edinburgh, xiv, pl. iv; White, Catal. p. 121 ; Yarrell, l. c. (ed. 2), ii, p. 479 (ed. 3) ii, p. 460.

Acipenser Thompsoni, Ball, Proc. Roy. Irish Acad. no. 25, p. 21, and in

Thompson's Nat. Hist. Ireland, ir, p. 245; Yarrell, Brit. Fish. (ed. 3) ii, p. 442, c. fig.

Acipenser huso (no. 2), Bonnat. Ency. Ich. p. 16, pl. ix, f. 29 ; Thompson,

Ann. Mag. N. H. 1845, xvi, p. 213, and 1847, xx, p. 172; White, Catal. p. 121. Acipenser hospitus, Kröyer, Skand. Faun. iii, p. 780.

Acipenser atillus, Gray, Chond. Fish. Brit. Mus. p. 13.

Acipenser Yarrellii, Duméril, Nouv. Arch. Mus. iii, p. 164.

Sturgeon, Couch, Fish. Brit. Isles, i, p. 157, pl. xxsv. 


\section{(Synonymy of American examples.)}

Acipenser oxyrhynchus, Mitchell, Trans. Lit. and Phil. Soc. New York, i, p. 462; Lesuener, Trans. Amer. Phil. Soc. (new series) i, p. 394; De Kay, New York Fauna, Fish. p. 346, pl. Iviii, fig. 189; Ayres, Boston, Journ. Nat. Hist. iv, p. 287 ; Storer, Mem. Am. Acad. ii, p. 499, and viii, p. 431, pl. xxxv, f. 4.

Huso oxyrhynchus, Duméril, p. 172 (? old specimen).

Acipenser (Antaceus) Lecontei, Duméril, 1. c. p. 177, pl. xvi, f. 1.

D. $35-40$, P. $\frac{\overline{2}}{\overline{8}-\overline{1}} \overline{8}$, V. $23-24$, A. $23-25$, C. $100-125$.

Shape of the body somewhat pentagonal with five rows of osseous plates or shields, one at each angle; the body tapers off gradually to the base of the caudal fin, while the head similarly tapers to the end of the elongated snout. Length of head $4 \frac{1}{2}$ to $5 \frac{1}{2}$, of caudal fin $4 \frac{1}{2}$ to $5 \frac{1}{2}$, height of body 8 to 10 times in the total length. Eye-small* and possessing peculiarities pointing to its affinity to Amphibia and Reptilia (Max Schultze, Meder. Ges. Bonn. 1872). Opercle large, flat, and rugose, due to depressions, resembling thimble marks, or else granulated or striated. Snout usually pointed and about half the length of the head or even one-third or less, as it varies considerably in different specimens. The osseous shields on the surface of the head are not invariably similar in each specimen. Mouth placed on the under-surface of the head below the eyes; its jaws protractile, the premaxillaries passing round the front and upper edge of the mouth, while the maxillaries are small, placed laterally and articulated with the premaxillaries and also with the palatines. The lower jaw chiefly formed of two bones united at the symphysis, laterally there is a cartilage. Lips fleshy, lobate, while in the lower jaw there is usually a median depression. Barbels-four placed in a transverse line across the ventral surface of the snout, about midway between its extremity and the anterior edge of the mouth. Teeth-absent except in very young. Fins-dorsal situated near the commencement of the caudal, which latter is heterocercal, and bilobed, the upper being the longer, at its base anteriorly is a bony plate having a posterior blunt npward but short prolongation, which is followed by eleven or twelve short undivided bony rays, the whole constituting a fulcrum. Anal below the posterior half of the dorsal and anteriorly with several undivided rays. Pectoral inserted low down, on a level with the lower edge of the gill-cover, its first ray strong. Ventral, when laid flat, reaches about halfway to the base of the anal. Shields-the dorsal plates or shacles are those most developed, consisting of from eleven to thirteen, and with the highest point of their keel nearest the front edge in the anterior plates, but near their hind edge in the posterior plates; however, the shape varies inuch with age. The lateral shields consist of from twenty-six to thirty-three along the middle of the side and are continued to the caudal fin, while there exists an interspace between them. The ventral rows of shields are less developed than the lateral or dorsal rows. The skin may be either smooth, granulated, pointed, or more or less covered with small rough osseous points, which, in some specimens, are frequently star-shaped, and occasionally arranged in oblique rows. Colours-brownish, lightest beneath.

This species has been sub-divided into the sharp-nosed form and the bluntnosed, Acipenser latirostris, Parnell, who considered it differed from the common form, in having the tip of the nose broader than the mouth; in the keels of the dorsal plates being but slightly elevated, and its barbels placed nearer the tip of the snout than the mouth. Ball remarked that he did not think the broadness or sharpness of the nose a specific distinction, as no two of his specimens could be said to agree in the form of the nose or the arrangement of the scales on the nose and head. Thompson remarked that he had long felt certain that the precise form (of the bony plates on the heads of stargeons) is of no value as a specific character; the form, too, of the anterior extremity of the fish is also liable to much variation from being pointed to rounded. These views have since been generully accepted.

* For observations on the structure of the Retina in Sturgeons, see H. Müller, Comptes Rendus, 1856, p. 743, also Ann. and Mag. Nat. Hist. 1856, xviii, p. 492. 


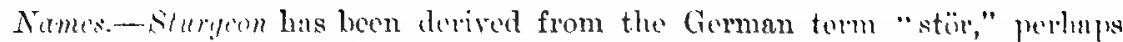
from the rerb "storen," to poke or rummuge about, as it constmntly den's with its lomer snout: in old works it was semetime's spelt storyin or sturjuin. Iotursion,

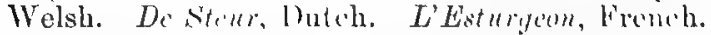

Ilabits.-A slugrish, wandering fish, which resides in tho sem during tho winter months and commences aserending rivers in the spring, probubly for tho purpose of bowding. On referring to the muthe when sturgeon haire ben coptured in our waters, I tind records in Jnmuary and in erery month of the year, although the most prolific wonld seem to be May, June, and July. In British waters it sometimes ascents some considerable distance from the orenn,

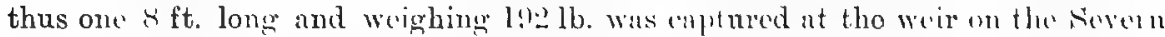

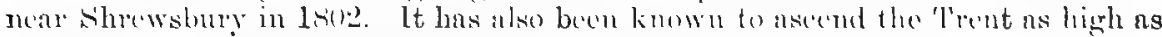
Nottingham. It lives some tinc aftor removal from its mative dement. 'T'hunipson mentions one which lived thirty-six hours ont of witer, nud was at list killed by

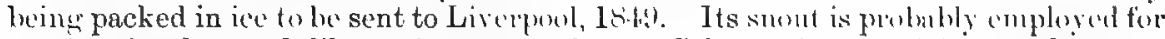
routing in the mud like swine on lami. A. Schutz observes ( $\mathrm{N}$ itume, Jumunry,

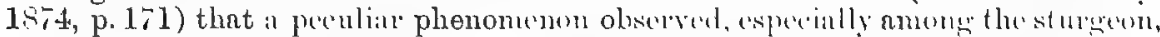

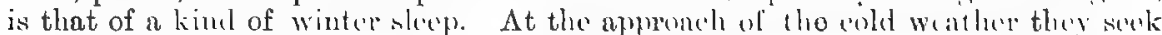
de'p portions of the river and remain there in $a$ state of toregre, during which time they secrete a riscid mueus which forms $\Omega$ conting over the entire body, anlled by

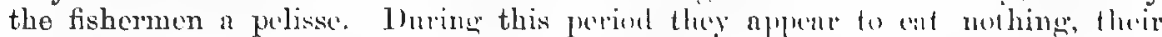
stomachs being invarialoly foum to he empty. "llompson, lithi, lomml in tho

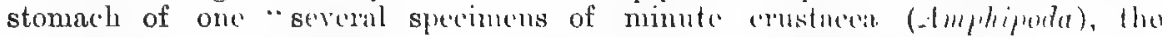

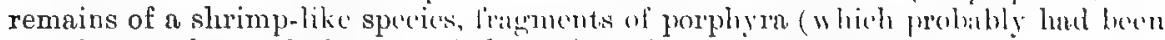

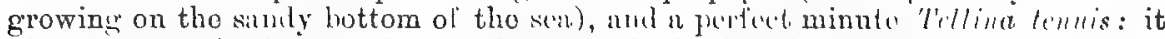
likewise contained some fine sand, with which also the intestines were wholly

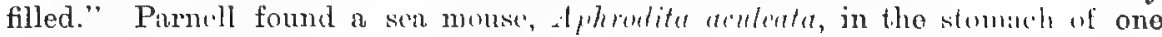

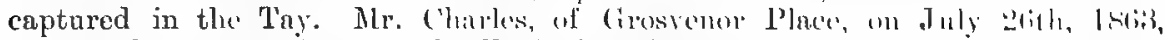
presented one :i lt. long to the Zoological Gardens, where it lived until dane, 1870, when it measured 4 ft. 22 in. long and weighed $14 \mathrm{lb}$.

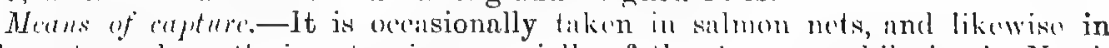
stake netis, and mostly in estuatries, esperially of the serern; whilo in the North Seva some aro aptured by trawlers. It may be anfured by buits, and when

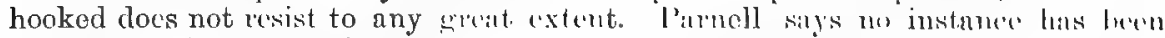

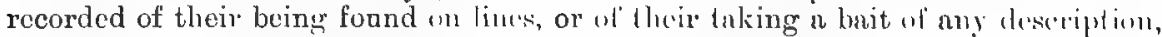

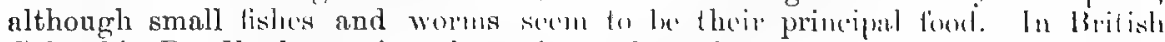
Columbia Dr. Ford mentions how they tnke a bait. (Jue! in. leng, from the 'yo to the tip of the tail, was laken in Junc, 1880, in the 'l'hane's nngling with $n$ worm, and has beon prencreved. (Field, $\lambda_{\text {pril }} 9$ th, 1881.)

Fisherese- Those of the British Isles are not importnnt. Aecording to M.

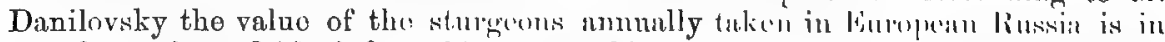

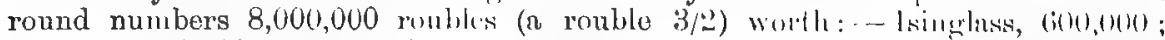

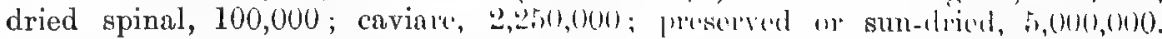

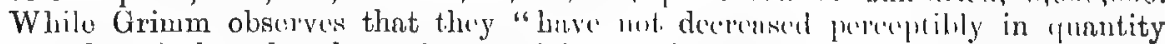

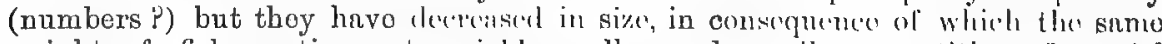
weight of fish continues to yicld smaller and smaller quantition of uscful

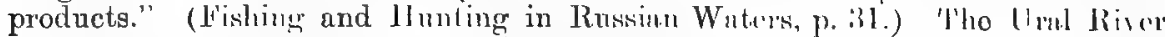
produces the best sturgeon. One-third of tho lemeth of the Unal River, from tho

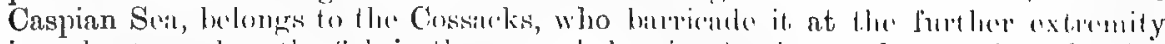

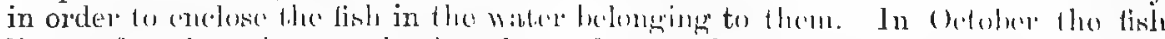

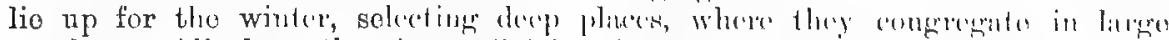

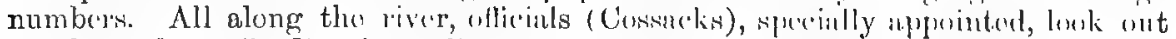

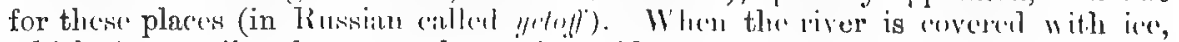

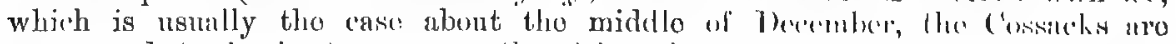
summoned to begin to alghere the fish, who nsisomble in thousmols at the

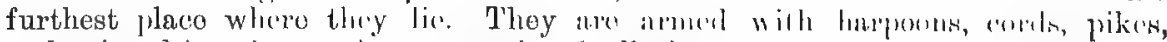

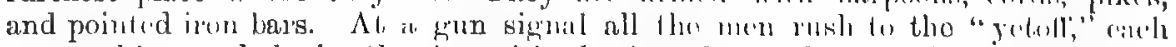

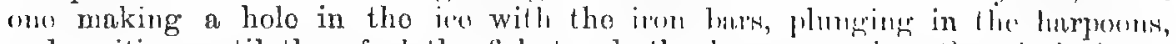
and waiting until thoy feel tho fish touch the lin'poun, when they jork it up 
suddenly, dodging the fish on to the hook. If one man is unable to bring it up, another helps with harpoon and cords. After exhansting one "yetoff" they proceed to the next, and so on along the river. (Land and Water, April 26th, 1879.)

Breeding.-In the north of Europe it breeds in the winter or in the early spring. Mr. Parfitt (Fauna of Devon, p. 4(J) observes that a fine specimen, $7 \mathrm{ft}$. long, was captured off Exmouth, June 25th, 1873. It was a female, full of eggs, the ova varying in size from small shot to the size of small peas, the whole mass weighing 18 or $20 \mathrm{lb}$, and he surmises that the fish under consideration could hardly have carried her eggs to the winter. On May 8th, 1851, one was captured in the Mersey full of ova; in January, 1884, another was taken in a similar condition at Torbay.

As food.-It is a firm, somewhat hard-fleshed, but well-flavoured fish, from the flesh of which it has been asserted that a good cook can obtain beef, mutton, pork, or poultry; while its roe, preserved under the name of "caviare," is a most delicious relish,* which is prepared near the moutbs of the Volga, Danube, Dnieper, and Don, that from the Caspian being the most esteemed. The eggs are washed in vinegar or white wine, and then spread upon a board to dry; subsequently salt is well rubbed in by hand labour; they are then put into a bag and slightly pressed, in order to remove the liquor, and subsequently packed in kegs for the market. There are two kinds of caviare made; the one which is eaten in a semi-liquid state, and called the "Fresh Caviare," is less salted than the other, which is pressed, and therefore keeps longer, and is that which is imported to England. The price of the fresh varies from one rouble twenty kopecks to three roubles per pound, according to the season, and in any case can only be obtained during the winter. The other varies from eighty kopecks to two roubles, according to quality. The amount of caviare produced from the Caspian has reached, in some years, $15,000 \mathrm{cwt}$.

Uses.-In the Russian factories of the Caspian and Volga the fresh sounds are first split open, well washed, in order to separate the blood and impurities, then (according to Royle) spread out and exposed to the air to dry, with the inner, silvery-white membrane turned upwards. This, which is nearly pure gelatine, is carefully stripped off, laid in damp cloths (or left in the outer covering), and forcibly kneaded with the hands. It is then taken out of the cloths, dried in the form of leaf isinglass, or rolled up and drawn out in a serpentine manner in the form of a heart, horse-shoe, or lyre (long and short staple) between three pegs, on a board covered with them; here they are fixed in their places by wooden skewers. When they are somewhat dried there, they are hung on lines in the shade, till their moisture is entirely dissipated. The oblong pieces are sometimes folded in the form of book-isinglass. According to Pallas, at the lower part of the Volga, a fine gelatine is boiled out of the fresh swimmingbladder, and then poured into all kinds of forms. In Gurief, a fine boiled fishglue is prepared, which is perfectly transparent, having the colour of amber, and which is cast into slabs and plates. The common cake-isinglass is formed of the fragments of the other sorts; these are put into a flat metallic pan, with a very little water, and heated just enough to make the parts cohere, like a pan-cake when it is dried.

Diseases.-Lampreys are said to fix themselves on to sturgeon, and, having consumed the slime continue eating into the flesh. Some of the parasites which affect their gills have been described (Zool. Journ. iv, p. 259). Several specimens of Dichelestium sturionis were found on the gills of one captured at Exmouth, and on those of another taken this year at Torbay.

Habitat.-The Baltic and rarely in the Black Sea and rivers which flow into them, the Mediterranean, Northern and Western Europe, and Eastern America, from Cape Cod to Florida.

In the Orkneys said by Wallace and others to be driven ashore on the rocks. Low only saw the head of one which came ashore on one of the north

* The above opinion is not invariably coincided in. Thas Mr. Houghton, l. c., describes caviare as "disgusting in appearance, offensive to the smell, and horrible to the tnste." 
islands (Baikie, Zool. 1853). Along the east coast of Scotland now and then, at Banff once (Edward), at Aberdeen (Sim), occasionally in the salmon nets at St. Andrew's (McIntosh). At Findhorn, Scotland,* one $8 \frac{1}{2} \mathrm{ft}$. long and weighing $203 \mathrm{lb}$. was taken in the stake nets, July 18th, 1833 (Mag. Nat. Hist. vi, p. 530). Moray Firth, in 1833, 1836, and 1844, specimens from the south side of this Firth. In the Firth of Forth, on an average, one is taken every three years (Parnell), and in Berwickshire one or more occasionally (Johnstone). Yorkshire, not uncommon off the coast, also at the mouth of the Tees and in the Humber (Yorkshire Vertebrata). In fact, this fish occurs more or less all round our coasts, and the instances recorded are too numerous to insert. A correspondent of the Field remarked that in the spring of 1832, when at a private school at Kew, he remembered a sturgeon being caught two or three miles below in the Thames. It was about $7 \mathrm{ft}$. long, and was taken to the Lord Mayor as his perquisite, due to its being captured above London Bridge. This Mr. Francis Francis believed to be the last captured so high up, and corresponds with the time that salmon disappeared from that river due to impurities. In July, 1883, one $6 \frac{1}{2} \mathrm{ft}$. long and $117 \mathrm{lb}$. weight was captured floating down the Thames in an almost lifeless condition; it was believed to have been suffocated from the sewage which runs into the river at Crossness (Harting, Zool. 1883, p. 341). Examples exist in the British Museum from the North Sea, two from the Thames, $5 \mathrm{ft}$. and $6 \mathrm{ft}$. long, two from Teignmouth, also the upper part of a head of one of the variety, A. latirustris, from Berwick-on-Tweed, and another from an unrecorded locality. These fish must have been at least 7 or $8 \mathrm{ft}$. in length. Is frequently taken in Norfolk (Lowe), occasionally in Devonshire (Parfitt), rare in Cornwall (Cornish Fauna), not infrequent in the estuary of the Severn, and is found in the Wye and the Usk. Occasionally taken at Swansea (Dillwyn), and in 1881 at Ferryside, South Wales.

In Ireland is taken occasionally in the large rivers from north to south (Thompson). It has been recorded at Derry (Sampson), Kilkenny (Tighe), Dublin (Rutty), Cork (Smith), Belfast, also Cushendall, co. Antrim ; Dundrum, co. Down, Dundalk, Carrick-on-Suir, and Wexford. Mr. D. Ogilby remarks that it is not unfrequently taken in the salmon nets of the Foyle and Bann. In the former it has been captured as far up as Strabane.

The cast of one $11 \frac{1}{\mathrm{~g}} \mathrm{ft}$. long is present in the South Kensington Museum, taken in 1879 off Heligoland, it weighed $5 \mathrm{cwt} .2 \mathrm{qr}$. and $7 \mathrm{lb}$., and Lowe (Fanna of Norfolk) alludes to one taken off the Suffolk coast $12 \mathrm{ft.} 2 \mathrm{in}$. long, but which weighed only $156 \mathrm{lb}$. Pennant mentions one which weighed $460 \mathrm{lb}$. taken in the Esk about 1774. "A head prepared by Mr. Stirling, of the Anatomical Museum of the University of Edinburgh, was cut from a sturgeon caught near Alloa, said to weigh, when entire, 50 stones, or $700 \mathrm{lb}$.; its length was $9 \mathrm{ft."}$ (Sir J. Richardson). My figure (Plate $\mathrm{CL}$ ) is from a Margate example $5 \mathrm{ft}$. 4 in. long, and Fig. 3 from a Torbay specimen 4 ft. 10 in. long.

* In vol. i, p. 311, I remarked upon Sibbald having at the end of his list of Scotch fish, Siluris sivi glanis, and I may remark here that Silurus was one of the terms employed by ancient writers for the sturgeon. 


\section{Order II---ELASMOBRANCHII.}

Skeleton cartilaginous: no cranial sutures. Rarely a single gill-opening as the gills are attached by their outer edges to the skin, and an intervening gill-opening exists between each : no gill-cover. Two or more series of valves at the conus arteriosus. Optic nerves, united, but do not decussate, or only slightly so. Body with vertical and paired fins, the posterior pair abdominal: caudal with an elongated upper lobe. Intestines with a spiral valve. Male sex with intromittent organs attached to the ventral fins. Ova large, fertilized, and in some likewise developed, internally. Embryo with external deciduous gills. No air-bladder.

The fishes which compose this order, have been divided into two sub-orders, as follows :-

I. Holocephala-jaw and palate attached to the skull. One external gillopening.

II. Plagiostomata-palatal apparatus detached from the skull, and from five to seven gill-openings.

\section{Sub-Order I-HOLOCEPHALA.}

A single external gill-opening and a rudimentary gill-cover. Inside the single gill cavity four gill-openings. The maxillary and palatal apparatus attached to the skull.

The living fishes appertaining to this sub-order are confined, so far as is known, to the representatives of one family, the Chimæridæ, which has been generally considered to form a connecting link between the Ganoids and the sharks and rays. For although externally possessing but a single gill-opening and a rudimentary opercle, four orifices may be seen at the bottom of the gill-pouch. These orifices correspond to the intervals between the gills, which are not free at their outer extremities as described in the sturgeons and bony fishes, but are adherent to the skin as observed more readily in the sharks and rays. Chimæras possess three complete biserial gills, also an accessory uniserial gill at the inner side of the opercle, and a second attached to the fourth arch or infering pharyngeal. In the skin of the young are placoid granules along the middle of the back as perceived in some of the rays. The ova are few but large, encased in a horny covering, and impregnated within the oviduct, while the male possesses claspers. In several characters, in addition to those enumerated, they approach the Ganoids, as, for instance, in the spine of the dorsal fin being articulated to the neural apophysis of an anterior vertebra, and not simply implanted into the skin: in the dental apparatus consisting, as in some Dipnoids, of plates and some cutting teeth in the npper jaw. Skeleton notochordal and cranial cartilages continuous.

\section{FAMILY I-CHIM ERID $A$.}

Body elongated. Mouth on the lower surface. Dental apparatus consisting of two plates in the upper, and one in the lower jaw. No spiracle. Males with a filament on the upper surface of the snout, also with claspers. Skin scaleless in adults.

This family consists of two genera: (1) Callorhynchus, in which the snout ends anteriorly in an elongated flap: and (2) Chimera, destitute of such appendage. 


\section{Genus I-Chiy}

Snout prominent, soft, and anteriorly destitute of any applendage. Dorsal fin occupying almost the entire dursal surface, and armed anteriorly with a strong serrated spine. Anal fin low, and nearly similar to the posteriur portion of the dorsal. Tail in the same axis as the body.

Geographical distribution.-Fishes which do not appear to exceed four or five feet in length, and often reside at great depths. They have been recorded from the arctic, northern and temperate regions of Europe, the Mediterranean, the Pacific coast of North America, Cuba, the Cape of Good Hope, and Japan.

\section{Chimæra monstrosa, Plate CLI.}

Simia marina, Gesner, De Aquat. p. 877 ; Aldrov. pp. 402, 403, 405; Jonston, p. 16 and 26 , t. vii, f. 6 , and viii, f. 8 . Galeus acanthias, Willugh, p. 57, t. B 9, f. 6 ; Ray, Pisc. p. 23 ; Jonston, t. xlv, f. 2. Northern chincera, Pennant, Brit. Zool. (Ed. 1812), iii, p. 159.

Chimora monstrosa, Lin. Mus. Ad. Frid. i, p. 53, pl. xxv, and Syst. Nat. i, p. 401 ; Bloch, Ich. iii, p. 882 , t. cxxiv ; Bonn. Ency. Ich. p. 14, pl. viii, f. 25 ; Gmel. Linn. p. 1483; Bl. Schn. p. 349 ; Lacép. i, p. 392, pl. xix, f. 1 ; Donovan, Brit. Fish. v, pl. cxi; Turton, Brit. Fauna, p. 114; Flem. Brit. An. p. 172 ; Faber, Fische Isl. p. 41; Gaimard, Voy. Isl. and Grœnl. Zool. pl. xx; Jenyns, Manual, p. 494; Swainson, Fish. ii, p. 323; Costa, Fauna Nap. Chimeridei, p. 1-47, tar. i-vii ; Schlegel, Fauna Japon. Poiss. p. 300, pt. cxxxii ; Bennett in Beechey, Voy. Fish. p. 72, pl. xxiii, f. 3 ; Yarrell, Brit. Fish. (ed. i), ii, p. 364, c. fig. (ed. 2), ii, p. 483, c. fig. (ed. 3), ii, p. 464*; Bleeker, Nat. Tyd. Ned. Ind. iii, p. 309; Kröyer, Danm. Fisk. iii, p. 784; White, Catal. p. 122 ; Gray, Chondrop. p. 21 ; Nilss. Skan. Fauna, iv, p. 705; Duméril, Hist. Poiss. i, p. 686, pl. xiii, f. 3-4, pl. xiv, f. 1 ; Günther, Catal. viii, p. 349 ; Collett, Norges Fiske, p. 206; Malm, Fauna, p. 605 ; Canestrini, Fauna Ital. Pesc. p. 62 ; Poey, An. Soc. Esp. v, p. 378, pl. xiii; Winther, Pro. Dan. Mar. p. 56; Giglioli, Catal. Pesc. Ital. p. 51 ; Moreau, Poiss. de la France, i, p. 455, fig. 79.

Chimara argentea, Ascan. Icon. pl. xv.

Chimcera borealis, Shaw, Zool., , 2, p. 365, pl. clvii.

Chimcera mediterranea, Risso, Ich. Nice, p. 53, and Eur. Mérid. iii, p. 168.

Chimoera cristata, Faber, Fish. Isl. p. 45 ; Duméri], 1. c. p. 688.

Callorhynchus centrina, and atlanticus, Gronov. ed Gray, pp. 15, 16.

Arctic chimcera, Couch, Fish. Brit. Isles, i, p. 1 45 , pl. xxxiv.

Head large and conical, body compressed, tapering off to a fine tail. Eyeslarge, about 3 diameters from the end of the snout. On the upper surface of the head, a little anterior to the orbit, there exists in the male a fringed tuftlike process. Mouth inferior, small, furnished with two dental plates in the upper and one in the lower jaw. Several rows of pores on the head. Gillopening just in front of the base of the pectoral fin. Fins - first dorsal triangular, anteriorly with a strong spine which posteriorly is finely serrated. The second dorsal commences just behind the termination of the first, it is low, and continued some distance, when a third and still smaller one commences. Pectorals large, nearly triangular, and almost reaching the ventral; the latter in the male* with claspers, each of which consists of two branches rather longer than the snout; the inner one of which is subdivided into one with a spinate covering, and another which is cartilaginous and styliform. Two low anal fins, the second commencing under the third dorsal. The tail ends in a finless filament often

* The figure of a female is in C. Bonaparte's Fauna Italica, and which is reproduced in Yarrell's Brit. Fish. ed. 3 , vol. ii, p. 468 . 
longer than the body. Scales-very minute in the young along the back, but absent in the fall grown. Colours-are said to be of great beauty when newly captured, so much so that the Norwegians term it the gold and silver fish.

Name.- King of the Herrings, rabbit-fish, Zetland. Pontoppidan tells us that, from the length and form of its tail, this fish is sometimes called the sea rat.

Hlabits.-Theso are but little known. Sometimes, at least, it must be a deepsea form, as a young one was obtained in the voyage of the "Knight Errant" at 555 fathoms depth. It is generally supposed to feed upon small fishes; Bloch, however, considered that it consumes crustaceans and medusæ.

Modes of capture.-Said to be usually taken while in pursuit of shoals of herrings or other fishes.

As food.-Its flesh is hard and coarse.

Uses.- Norwegians are said to extract an oil from its liver, which is highly prized for treating some disorders of the eyes, and also, according to Pontoppidan, for all wounds and bruises.

Breeding.-Eggs large and covered with a horny shell, flattened on the edges and velvety.

Habitat.-Coasts of Europe, as indicated under the head of the geographical distribution of the genus. Has been taken in Zetland (Fleming), and also in the Orkneys (W. Baikie), while off Banffshire one has been secured when floating, but dead (Edward). Attains to 3 or $4 \mathrm{ft}$. in length. The one figured was from a male specimen in the National collection.

\section{Sub-Order II -PLAGIOSTOMA TA.}

Body more or less cylindrical or depressed: the trunk may or may not pass gradually into the tail. From flve to seven external gill-openings, which may be lateral or inferior. Jaws distinct from the skull.

In these fishes the gills are not situated in a common cavity, but in separate sacs which do not communicate one with another. In those forms possessing five sacs the four anterior ones are lined in front with parallel rows of adherent gills, while in the fifth only it has three processes solely in its proximal side. Water for respiratory purposes is taken in by the mouth, and passes through pharyngobranchial slits into these sacs, from whence it passes out externally through the external gill-openings or stigmata. The scapular arch, which is suspended to the front part of the vertebral column, divides these respiratory sacs from the carity of the abdomen. Although no opercular pieces exist, there are sometimes cartilaginous rings surrounding the gill-openings.

The fishes of this sub-order have been divided as follows :-

Group I-SELACHOIDEI. Sharks. The truak gradually passing into the tail. Gill-openings lateral.

Group II-BatoIder. Skates and rays. Gill-openings ventral. Pectoral fins largely developed and constituting a flat disc.

Group I-Selachoidei, as defined above. This group has been sub-divided into several families, representatives of five of which have been taken on our shores. They are as follows :-

Family I-Carcharirder. Two dorsal fins. and one anal. Eye with nictitating membrane.

Family II-Lamnid w. Two dorsal fins and one anal. Eye without nictitating membrane.

Family III-Notidanide. One dorsal fin and one anal. Eye without nictitating membrane.

Family IV-SCYLLiId - Two dorsal fins, one anal. Eje without nictitating membrane. Teeth small, and in several rows.

Family $\nabla$-Spinacid 2 . Two dorsal fins, no anal.

The sharks found off our shores chiefly consist of true sharks, dog-fishes, and the hammer-headed forms: some being residents or summer visitants, while a 
few are stragglers from the Arctic, or else from the warmer regions of Europe or of the Atlantic Ocean. Among them some frequent the open seas, migrating long distances often in pursuit of shoals of fishes; others, again, more frequent our shores and bays, while but few ascend into our fresh waters, as they are fond of doing up the larger rivers of tropical countries. It has been observed that one of the curious consequences of the construction of the Suez Canal has been the introduction into the Mediterranean Sea of sharks which were formerly almost unknown there. The sharks have proved very destructive to the edible fish, and it is now difficult for fishermen to supply the demand. The teeth with which they are armed give an insight into their character, and the size to which these fishes attain is not always an index as to the ferocity or the reverse of the species; some of the apparently most powerful sharks having small teeth, demonstrating that, even if they are exclusively carnivorous, the forms of animal life upon which they subsist must be small and weak; while the obtuse teeth of other species are more calculated for crushing shells, crustacea, and worms than waging war with other fishes.* Their bodies are extensively armed with peculiar scales, each of which has a sort of tooth-like appearance, covered by a coating of enamel. This in some forms is termed shagreen and employed in trades, as for the covering of small boxes, scabbards of swords, or even for smoothing down wood. Several instances are on record where partaking of shark's flesh or liver is said to have occasioned illness, and even death. Personally I have witnessed no bad effects from it, although I have observed European sailors at sea eat it, and in Bombay it is the common food of the Africans. The liver has been accounted the most unwholesome portion.

The means of propulsion in the different orders and groups among the British Chondropterygians is varied. For in Ganoids, as the sturgeon, the tail and pectoral fins assist; in the Chimæra the pectorals and ventrals would appear to act without the assistance of the tail : in the true sharks the tail seems to be the chief means, while in the rays the pectorals alone.

In some forms of sharks the dorsal fins are armed with spines, which render them dangerous to the fishermen, while they are very destructive to nets; and it is to be hoped that it may be found feasible to institute off our coasts large fishings for these vermin, when possibly their bodies, livers, or their skins might be turned to some profitable use. In the East the fins are exported to China, where they obtain a good sale, due to the gelatine they yield.

Among Plagiostomes, when breeding, a congress occurs between the sexes, the arrangement of the sexual organs being somewhat sinilar to what obtains among the higher vertebrata. The male organs are compact, placed far forwards in the abdominal cavity, while, mostly attached to the ventral fos, are claspers shown to to have intromittent functions. In the females different parts of the oviduct may be functionally modified, for although the ova are fertilized within this oviduct the development of the young is not carried out in invariably the same plan, some being perfected prior to extrusion, while in others the ovum is encased in a horny covering and so deposited in the sea. In these last forms the semi-transparent egg cases, variously known as mermaids-sailors-or sea-purses, are somewhat in the form of a parallelogram, having a long filament from each corner, which serves for the purpose of attaching them to seaweeds, corallines, rocks, or other suitable objects which prevents their being carried away by the waves and lost prior. to the birth of the young. Although the females lay many eggs, only two appear to be perfected at a time. Inside this borny case the foetal shark lies coiled up, while from its umbilical region depends the umbilical sac from which it receives its nourishment. When the proper time arrives, the case opens at one end and the young fish emerges. In the other forms wherein the young are produced alive, as in the hounds, Mustelus, one species has a placenta. Larral plagiostomes bave external decidnous gills.

* It haq been observed by Mr. Porter (Field, May 20th, 1882), that as the ship "Taranaki " was coming home from New Zealand, and all but becalmed, a Portuguese man-of-war came floating past. A shark snapped at it; the latter stung him severely with one of its long feelers, causing the shark to thrash the water with its tail in evident pain. 


\section{FAMILY I-CARCHARIID A.}

The snout may be produced longitudinally (Carchariida, "true sharks") or laterally (Zygrenina, "hammer-headed sharks"). Spiracles absent or present. Eye with a nictitating membrane. A small pit may or may not exist above the root of the tail, and a groove behind the angle of the mouth may be present or absent. Mouth crescentic, inferior. Teeth may be erect or oblique, with a single cusp, having sharp and smooth or serrated edges: or they may be small, the cusps being obsolete: or with one in the centre and one or two lateral ones: or even obtuse. The first dorsal fin, destitute of a spine, is placed opposite the interspace between the pectoral and ventral: anal fin present.

The fishes belonging to this family, which are found in British waters, are confined to the following genera:-

I. Carcharias.-No spiracle. Teeth with a single cusp. Snout longitudinally produced. A pit at the root of the tail.

II. Galeus.-Small spiracles. Teeth with a single cusp. Snout longitudinally produced. No pit at the root of the tail (p. 292).

III. Zyganu.-No spiracles. Teeth with a single cusp. Snout laterally produced. Nostrils on the front edge of the head. A pit at the root of the tail (p. 294).

IV. Mustelus.-Spiracles small. Teeth obtuse. Upper lip well developed. No pit at the root of the tail (p. 295).

\section{Genus I-Carcharias, Müll. and Henle.}

No spiracles. A pit before the root of the caudal fin. Snout longitudinally produced. Mouth crescentic: the labial fold or groove rarely extends beyond the angle of the mouth. Teeth with a sharp triangular cusp, sometimes dilated. The first dorsal fin, destitute of a spine, is placed opposite the interspace between the pectoral and ventral: caudal with a distinct lower lobe.

The genus has been divided as follows:-

Teeth in the jaws entire without swollen bases, Scoliodon, or with them, Physodon: or the bases of upper teeth serrated, Aprionodon. Some or all the teeth serrated, as the base of the upper ones, Hypoprion, or the base and cusps, Prionodon.

Although the white shark, Carcharias lamia, has been admitted into works on British fishes, evidence is deficient that it bas been taken off our coasts. Grew, in his "Rarities of Gresham College," p. 90, remarked that it is sometimes found on the Cornish coast; Low, on hearsay, that it was found off the Orkneys, but no descriptions appear to be extant from a British specimen. I have, therefore, omitted it.

\section{Carcharias glaucus, Plate CLII.}

Galeus glaucus, Rondel. p. 378; Gesner, De Aquat. p. 609; Aldrov. p. 394; Willughby, lib. 3, cap. ii, t. B 8, p. 49 ; Ray, Synop. Piscium, p. 20. Squalus, sp. Artedi, Synon.-p. 98, no. 13, and Gen. p. 69, no. 13. Blue shark, Watson, 
Phil. Trans. lxviii, pt. ii, p. 786, pl. xii ; Pennant, Brit. Zool. (ed. 1776), iii, p. 109 (ed. 1812), iii. p. 143. Le B7uet, Duhamel, Pêches, p. 298, pl. xix, f. 6. Squalus glaucus, Linn. i, p. 401 ; Gmel. Linn. p. 1496; Bloch, Ich. iii, p. 712, t. Ixxxvi; Bonnaterre, Ency. Ich. p. 9, pl. vii, f. 22 ; Lacépède, i, p. 213, pl. ix, f. I ; Bl. Schn. p. 131 ; Turton, Brit. Fauna, p. 113; Risso, Ich. Nice, p. 26 ; Bonaparte, Fanna Ital. Pesc. iii, p. 140, t. f. 2 ; Swainson, ii, p. 312.

Carcharias glaucus, Cuv. Règne Anim.; Flem. Brit. An. p. 167; Yarrell, Brit. Fishes (ed. 1), ii, p. 381, c. fig. (ed. 2), ii, p. 498; Jenyns, Manual, p. 499; Gay, Hist. Chile, Zool. ii, p. 364; White, Catal. p. 125 ; Thompson, Nat. Hist. Ireland, iv, p. 250 ; Günther, Catal. viii, p. 364; Giglioli, Catal. Pesc. Ital. p. 51 ; Moreau, Poiss. de la Erance, i, p. 329, fig. 50.

Squalus (Carcharinus) cceruleus et glaucus, Blainv. Fauna, Fr. i, pp. 90-92, pl. xxiii; Gray, Cart. Fish. p. 44.

Carcharias (Prionodon) glaucus, Müll. and Henle, p. 36, pl. xi ; Yarrell, l. c. (ed. 3) ii, p. 482, c. fig.; Duméril, Ich. i, p. 353.

Carcharias (Primodon) hirundinaceus, Duméril, l. c. p. 354.

Blue shark, Couch, Fish. Brit. Isles, i, p. 28, pl. vi.

Form elongated. Snout longitudinally produced and covered with numerous fine punctures. Eyes-midway between the end of the snout and the anterior gill-opening. Cleft of month deep, its gape wide; no labial fold at the angle of the mouth. Nostrils transverse, pleced midway between the front edge of the eye and the end of the snout, or rather nearer the month. Teeth-in four or five rows, and altering with age. In the very young the edges are smooth, while the teeth in both jaws are oblique and not swollen at their bases. Next a few denticulations appear at their bases, when, from 4 to 6 feet long, the whole teeth are serrated; but in old examples these serrations become obsolete, and the teeth in the lower jaw are narrow, and either stand obliquely or erect apon a broad base. Fins-two dorsals: the first somewhat quadrangular, placed in about the centre of the distance between the snout and the base of the caudal, and in about the centre of the interspace between the pectoral and the ventral; second dorsal about half the size of the first and placed above the anal, half the distance nearer the caudal than the first dorsal. Pectoral large and falciform, reaching to beneath the first dorsal. Ventrals small. Caudal with a notch or pit at its base, its length equalling about one-fourth of the total, its lower lobe short, and the lower surface of its upper lobe notched near its extremity. Skin moderately rough. Colours - back and upper balf of body of a deep blue, sides and abdomen white: snout sea-green, fins dark, pectoral nearly black.

Names.-Blue shark, from its colour. Morghi glas, y Dierc, Welsh. Le Bleu, French.

Habits.-A migratory and voracious form being found off our shores mostly during the warm months of the year, at which time should it be calm and warm they come to the surface in the daytime, and move gently along with the end of the tail and tip of the dorsal fin out of the water (Dunn). Although Couch had known one in Cornwall as early as the first week in March, it is not generally present before June. It is but rarely seen off our shores of sufficient size to be dangerous to man. It is said to bave a great affection for its young, and it has even been asserted that in times of danger they enter its mouth and seek refuge in its stomach. "When in pursuit of prey or excited, they continually cover and uncover their eyes with their nictitating membrane. The time of their greatest activity is at night, when they may be seen stealing through our summer seas like beasts of prey: their bodies not even disturbing the pbosphorescence which at that time of the year so fills the ocean. A most puzzling circumstance; and but for the flexible part of the dorsal fin and tip of the tail, it would be impossible to detect their prosence in the darkest night" (Dumn). It feeds on sardines, herrings, mackerel, even tearing them out of the nets. Couch has removed from the stomach of one, which monsured 6 feet in length, a large picked dog-fish and a conger, each bitten across the middle, also a gray gurnard. They are tenacious of life, and Couch instances one which, having been thrown into the sea after its liver had becn removerl, pursued and tried ti secure a mackerel. 
Means of capture.-Often by drift nets of pilchard fishers, when it does great injury to the fishing gear by rolling itself in the net, or cuts it with its teeth. After capture, if large, care has to be taken that it does not injure anyone with its tail. It is generally killed by a blow on the snout. It takes a bait readily, and Mr. Dunn has noted that ten were thus caught in one day in Angust, 1883, off Meragissey.

Diseases.-The nostrils are subject to disease, resulting from the irritation of animalculø, and Mr. G. Bennett recorded how a specimen of this fish was affected from this cause. In Ireland (vol. i, page 109) a sucking fish, Echeneis remora, was found attached to one.

Uses.-Oil is extracted from its liver in Cornwall for medicinal purposes; its flesh is not eaten.

Habitat.-Atlantic and Pacific Oceans and temperate waters of Europe, not being rare in the Mediterranean.

It appears to have been once captured in Jutland, but is not generally found in the northern seas, while some of those taken on the east coast were possibly "topes." At. St. Andrew's, not uncommon in the bay : captured by the fishermen in the salmon nets (McIntosh). One 4 feet long taken by line fishermen off South Shields, November 3rd, 1881 (W. Yellowby). Has been frequently caught off Whitby, and occasionally off other parts of the Yorkshire coast (Fauna, p. 99). One 5 feet 4 inches long was recorded as stranded at Yarmouth, December 19th, 1866 (T. S. Gunn). One, which was 6 feet long, and weighed 60 lb., was similarly left by the tide, November 3rd, 1867 (Zool. p. 1256). Found more frequently on the Devonshire and Cornish coasts than on any other part of the British Isles (Yarrell). One 8 feet long was taken off Plymouth, September, 1876 (Gatcombe, Zool. 1877, p. 26), and another between 7 and 8 feet long on November 13th, 1883 (Gatcombe); while in Cornwall it is abundant during the latter part of the summer and early in the autumn (Couch). Isle of Man (Garner).

Ireland.-Taken on the coast, chiefly southwards (Thompson); Nymph Band and Youghal (Ball); Courtmasherry and Galway (Allman). "Some examples were taken by me on conger lines this year; the largest was over 6 feet long. I do not think it is rare. They do great mischief to nets" (J. Blake-Knox, Zool. 1866, p. 509, on the Fishes of Dublin Bay).

The one figured is a young male, 37 inches long, captured in a pilchard net at Mevagissey in August, 1883. Although this species is said to attain to 25 feet or even more, in length, it is not seen so large off our coasts. One 8 feet 3 inches long was taken at Fowey on a line, September, 1868 (Chimo). Thompson mentions one 10 feet 1 inch long, captured near Clontarf Wall in July, 1846, and a stuffed specimen 11 feet long from the English coast is in the British Museum. 


\section{Cenus II-Galeus, Cuvier.}

\section{Galeor7inus, Blainvillo.}

Small spiracles present. Mouth crescentic. Eye with a nictitating membrane. Teeth in both javs oblique, notched and serrated. The first dorsal fin spineless and situated above the interspace formed between the insertion of the pectoral and ventral fins. A single notch in the caudal fin, and no pit at its root. Oviviparous.

Geographical distrilution.--Seas of temperate and tropical climes.

\section{Galeus vulgaris, Plate CLIII.}

Galeus canis, Rondel. p. 377. Canis galeus, Salvian. p. 130, f. 41; Willughby, lib. iii, c. 4, p. 51, pl. B6, f. I; Ray, Synop. Pise. p. 20. Squalus, sp. Artedi, Genera, p. 68, no. 9 and Synon. p. 97. Milandre, Duhamel, Pêches, ii, pl. $x \mathrm{x}$, f. 122. The tope, Pennant, Brit. Zool. (Ed. 1576), iii, p. 111 (Ed. 1812), iii, p. 146.

Squalus galeus, Linn. Syst. Nat. i, p. 399 ; Brünn. Pisc. Massil. p. 9; Bloch, Ich. iii, p. 820, pl. cxviii ; Gmel. Liun. p. 1492; Lacépède, i, p. 237; Bl. Schn. p. 128; Turton, p. 112; Risso, Ich. Nice, p. 32 ; Jenyns, Manual, p. 501; Johnston, Berwick. Nat. Field Club, 1838, i, p. 176 ; Schlegel, Dieren Neder. p. 188 , pl. xviii, f. 1 .

Galeus vulgaris, Flem. Brit. An. p. 165 ; Yarrell, Brit. Fish. (ed. 1) ii, p. 390, c. fig. (ed. 2) ii, p. 509 (ed. 3) ii, p. 491 ; Templeton, M. N. Hist. (2) 1837, i, p. 413 ; Parnell, Wern. Mem. vii, p. 414; Swainson, Fish. ii, p. 315 ; Kröyer, Danm. Fisk. iii, p. 834, c. fig.; Thomp. Nat. Hist. Ireland, iv, p. 252; Collett, Norges Fiske, p. 207.

Carcharias galeus, Risso, Eur. Mérid. iii, p. 121.

Galens canis, Bonap. Faun. Ital. Pesc. 1832, iii, t.; Müller and Henle, p. 57 ; Nilss. Shand. Fauna, iv, p. 714; Gaimard, Vor. Isl. and Groenl. Poiss. pl. xxi ; Gray, Cart. Fish. p. 52; Wright and Eks. Skand. Fish. p. 185, pl. xlv; Whitc, Catal. p. 126; Duméril, Ich. i, p. 390; Günther, Catal. viii, p. 379 ; Canestrini, Fauna d'Italia, Pesc. p. 48; Winther, Prod. Danm. Mar. p. 56; Giglioli, Catal. Pesc. Ital. p. 51 ; Moreau, Poissons de la France, i, p. 317, figs. 45, 46.

Galeus Linnei, Malm, Fanna, p. 618.

Toper, Couch, Fish. Brit. Isles, i, p. 45, pl. ix.

Greatest width of body in the pectoral region. Length of the head, 6 to 7 in the total length. Snout conical and produced longitudinally. Eyesoval, pupil lozenge-shaped; a well-dereloped nictitating membrane. Nostrils small, and nearer the mouth than to the end of the snout. Mouth large, extending posteriorly to nearly or quite beneath the spiracle, which is small and situated a short distance behind the eye. Branchial slits short. Teeth-in 3 or 4 rows; they are somewhat triangular, with the inner margin deeply serrated. Fins-pectoral falciform and nearly as long as the hend. First dorsal somewhat quadrangular, commencing on a line just bebind the insertion of the pectoral, but not extending to above the ventral ; second dorsal one-third the size of the first and slightly in advance of the anal; ventral inserted somewhat nearer the anal than the hind edge of the first dorsal. Lower lobe of caudal developed, the fin notched. Length of the entire fin equals the distance from the front end of the snout to the last gill-opening. Slin--somewhat rough, covered with three-pointed scales (fg. 1,b). Vertebræ, 140. Colours-dark or dull gray; under surface of head and belly dirty white.

Names.-Tope or toper: whithound: penny-dog, or, if young, miller's-dog, from its light gray colour. Iilue homless log-tish (Blakc-Knox). A rig at 
Folkestone (Buckland). Pennant observes that its skin and flesh have an offensive, rank smell; therefore he supposed that M1. Dale ("History of Har wich," page 420) gave it ironically the title of Sweet William. De Ruwe Haal, Dutch. Le Milandre, French.

Habits. - A fierce and ravenous fish, which appears to swim low, as it is more frequently found attacking baits than being entangled in drift-nets. The young have been observed off our shores all the year round, but the larger ones appear to be more common in summer, and especially along the south coast : for they are said during winter to retire to deep water, where tho ground is sandy. When fresh caught this fish is said to emit a strong and peculiar odour. The skin is somewhat rough; in fact, as Blake-Knox observes, it scours wooden bowls and platters white and makes fine burnishers for gun-barrels, which latter use shows that it cannot be very rough. It feels somewhat like sand-paper when the hand is passed from behind forwards. This fish is sail to more frequently devour dead food than does Carcharias glaucus, but it will eat crabs, star-tishes, and such like.

Means of capture.-Off Norfolk, said to take a bait best in June and early in July, after which time it ceases biting (Lowe). When hooked it twists the line round and round its body in its endeavours to free itself. Mr. Ogilby observes that these sharks hunt in couples, and if one is caught on a boulter its mate is pretty sure to be found within a few hooks. He has known the unhooked one to follow to the surface so as to be gaffed with ease. When hauling a codline on one occasion a fish, presumably of this species, made a rush in sight at a hooked cod of about 10 lbs., and cut it in two at the middle as clean as if it had been done with a knife.

As food.-Not esteemed; but Willughby asserts its flesh to be tender, and not unpleasant, while it is eaten by the French.

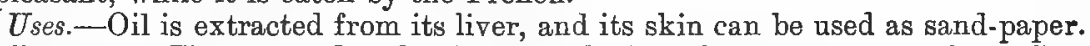

Breeding.- Young produced alive and during the summer months. Conch found 32 in one female, but as many as 52 have been recorded.

Habitat.-This fish has an extensire range in temperate and tropical seas, having been captured so far off as Tasmania and California.

It has been taken in the Orkneys, but it is doubtful if it has at the Shetlands (W. Baikie): only in two instances off Banff (Edward): Aberdeen (Sim): St. Andrew's, frequently canght (McIntosh) : Firth of Forth, common (Parnell) : Berwickshire, occasionally from 5 to 6 feet in length (Johnston). Common at Scarborough and in Bridlington Bay, but not reported from elsewhere in the county (Yorkshire Vertebrata): large numbers taken on night-lines off Hunstanton (Lowe, Fauna of Norfolk). Is not infrequent along the south coasts of England and Ireland, but is less plentiful to the north (Buckland): is common in Devonshire (Parfitt) : but though taken in Cornwall it is not a common fish (Cornish Fauna). One a little over 5 feet in length was captured off Anglesea on a long line in July, 1879 (Buckland): Pennant also obtained it in Flintshire.

In Ireland it is found around the coast (Thompson): is common in Dublin Bay (Blake-Knox) : Templeton recorded one 5 feet long taken in Belfast Lough: while Mr. Ogilby observes that it is not uncommon at Portrush, where it is called Famrie.

Blake-Knox records it to 7 feet long in Dublin Bay (Zoologist, 1866, p. 509) : it is not rare up to 6 feet in length. The specimen figured was taken in the Bay of St. Andrew's. It is a female, which had live young inside when captured, and it measured 4 feet 9 inches in length. 


\section{Genus III-ZyGENA, Cwvier.}

Cestracion, Klein: Cestrorhinus, Blainv. : Sphyrna (Rafin.) Müll. and Henle: Eusphyra and Reniceps, Gill.

The anterior portion of the head broad, flattened, and laterally elongated with the eyes situated at its lateral extremities and the nostrils at its fore border. A membrana nictitans present. Spiracles absent. Mouth crescentic. Teeth similar in both jaws, placed obliquely and notched. The first dorsal fin spineless, situated above the interspace between the insertions of the pectoral and the ventral: caudal with one notch, and a pit at the commencement of the fin.

\section{Zygæna malleus, Plate CLIV.}

Libella, Belon. p. 61 ; Salvian. p. 128, t. xl; Aldrov. p. 408; Jonston, t. vii, p. 8 ; Zyggcena, Willughby, lib. iii, c. vii, p. 55, pl. Bl; Rondel. p. 389 ; Gesner. p. 1050 ; Ray, Synop. Pisc. p. 20. Squalus, sp. Artedi, Genera, p. 44, no. 7, and Synon. p. 96, no. 7; Gronov. Mus. Ich. i, pp. 63, 139, and Zooph. p. 146. Zygène, Dohamel, Pêches, ii, Sect. ix, pl. xxi, f. 3-8. Cestracion, sp. no. 1, Klein, Pisc. Miss. iii, p. 13. Corunda, Parra, Lam. 32. Koma sorra, Russell, Eish. Vizag, pl. xii.

Squalus zygcena, Linn. Syst. Nat. p. 399; Bl. t. cxvii; Bonnaterre, Ency. Ich. p. 9, pl. vi, f. 15; Bl. Schn. p. 131; Lacép. i, p. 257, pl. viii, f. 3; Gmel. Linn. p. 1494; Brün. Pisc. Mass. p. 4 ; Risso, Ich. Nice, p. 34; Mitchell, Trans. Lit. and Phil. Soc. New York, i, p. 284; Gronor. ed Gray, p. 6.

Zygoena malleus, Shaw, Nat. Misc. pl. celxvii ; Val. Mém. Mus. ix, 1832, p. 223, pl. ii, f. 1; Risso, Eur. Mérid. iii, p. L25 ; Paget, Natural History of Yarmouth, p. 17 ; Jenyns, Manual, p. 507; Yarrell, Brit. Fish. (ed. 1) ii, p. 405, c. fig. (ed. 2) ii, p. 504 (ed. 3) ii, p. 486 ; De Kay, New York Fanna, Fish. p. 362, pl. lxii, f. 204; Storer, Proc. Bost. Soc. Nat. Hist. i, p. 36 ; Günther, Catal. viii, p. 381 ; Klunz. Fisch. Roth. Meer, 1871, p. 666; Day, Fish. India, p. 719, pl. clxxxvi, fig. 4; Giglioli, Catal. Pesc. Ital. p. 51 ; Moreau, Poiss. France, i, p. 324, fig. 48, 49.

Zygrena leweni, Griffith in Cuv. An. King. x, p. 460, pl. i.

Squalus malleus, Risso, Ich. Nice, p. 34.

Sphyrna zygcena, Bonap. Faun. Ital. Pesc. iii, t. f. 1; Müll. and Henle, p. 5l; Graf, Cart. Fish. p. 48; White, Catal. p. 126; Canestrini, Fauna d'Italia, Pesc. p. 47.

Cestracion zygcena, Gill, Ann. Lyc. Nat. Hist. New York, vii, p. 403; Duméril, Ich. i, p. 382 ; and Cestrurion llenwenii, Duméril, p. 383.

Hammer-head, Couch, Fish. Brit. Isles, i, p. 70, pl. xvi.

Head hammer-shaped and about three times as wide as it is long. The hind edge of the laterally expanded head, nearly or quite equals its width near the eyes. A groove exists along almost the entire extent of its anterior edge. Nostrils close to the eyes. Teeth-oblique, externally notched, otherwise smooth in their entire extent. Fins - the dorsal arises on a line slightly behind the base of the pectoral, and extends two-thirds of the distance to above the ventral; second dorsal inserted above the last third of the anal than which it is much smaller. Colours-body and fins slatey-gray; under surface of a dull white.

Names.-It has been termed the zygcna, or balance fish. Le Marteau, French.

Habits.-Fierce, and large ones generally inhabit deep water.

Breeding.-The yelk-bag is connected to the walls of the uterus (Grey). There were thirty-one young ready for exclusion inside the Welsh specimen.

Habitut.-Cosmopolitan. One five feet long was found dead off. Banffshire in 1861 (Edward); in October, 1829, one was taken at Yarmonth, the head and tail of which were presented to the Norwich Museum. In 1834 another at Newlyn, in Cornwall. July 31st, 1865, one, $13 \mathrm{ft} .7$ in. long, was perceived floundering among the rocks at Ilfracombe; it was secured by ropes and towed inland. The eyes were nearly covered by crustacean parasites: two thornbacks and a bass were found inside it, together with numerous large intestinal worms. 1839 one, $10 \mathrm{ft.} 3$ in. long, taken in Angust in Carmarthen Bay (Dillwyn). 


\section{Genus IV-Mustelos, Cuvier.}

\section{Pleuracromylon, Gill.}

Membrana nictitans present. Small spiracles behind the eyes. Mouth crescentic, arith long labial folds. Teeth small, numerous, similar in both jaws, pavement-like, obtuse, or with indistinct cusps. The first dorsal fin spineless, situated somewhat behind the origin of the pectoral, or above the interspace between that fin and the ventral: the second nearly as large as the first: caudal without a distinct lower lobe, and no pit at the commencement of the fin.

Two species of this genus are common off our coasts and inhabit the European seas, the $M$. vulgaris, in which the young are developed without any placenta; and the $M$. loevis, the embryo of which possesses a placenta attached to the walls of the uterus. This latter form has not yet been observed on our shores, although common in some of the European seas So long aro as the times of Aristotle and Rondeletius the distinctive marks between thes a two species were recognized; but subsequent to the time of Gesner they became overlooked, and the two species were classed as one. At the commencement of this century Risso, and subsequently others, ascertained the correctness of the opinion held by Aristotle. The dorsal fin is placed somewhat more forward in $M$. vulgaris than it is in M. loevis.

\section{Mustelus vulgaris, Plate CLV.}

Galeus asterias, Rondel. p. 376. Mustelus lcevis, Salv. p. 137, pl. xliv; Willugh. Hist. Pisc. lib. iii, c. xiii, p. 60, pl. B5, f. 2; Jonston, De Pisc. p. 26, t. viii, f. 6 ; Ray, Synopsis Pisc. p. 22. Galeus stellatus, Gesner, 1598, p. 77, c. fig. Squalus, Artedi, Gen. p. 66, Synom. p. 93. Smooth-hound or shark, Pennant, Brit. Zool. (Ed. 1766) iii, p. 151, pl. xvi (Ed. 1812), iii, p. 151.

Squalus mustelus, Bonnaterre, Enc. Ich. p. 7, pl. vii, f. 21 ; Lacép. i, p. 242; Gmel. Linn. p. 1492; BI. Schn. p. 128; Risso, Ich. Nice, p. 33; Turton, Brit. Fauna, p. 112 ; Jenyns, Brit. Vert. p. 502 ; Johnston. Berwick. N.. F. Club, 1838, i, p. 176; Schlegel, Dieren Neder. p. 190, pl. xviii, f. 2.

? Mustelus stellatus, Risso, Eur. Mérid: iii, p. 126.

Galeorhinus hinnulus, Blainv. Fauna France, Poiss. p. 83, pl. xx, f. 2.

Mustelus loevis, Flem. Brit. An. p. 166; Templeton, Mag. N. Hist. 1837 (2) i, p. 413; Yarrell, Brit. Fishes (ed. 1) ii, p. 393, c. fig. (ed. 2) ii, p. 512; Swainson, Fishes, ii, p. 316 ; Parnell, Wern. Mem. vii, p. 416; Thompson, N. H. Ireland, iv, p. 252.

Galeus mustelus, Leach, Wern. Mem. ii, p. 63, pl. ii, f. 3.

Mustelus plebejiüs, Bonap. Fann. Ital. Pesc. iii, p. 43, t. f. 1 ; Giglioli, Catal. Pesc. Ital. p. 51 ; Canestrini, Faun. Ital. Pesc. p. 49.

Mustelus vulgaris, (pt.) Müller and Henle, Plagiost. p. 190, pl. xxvii, f. 1; Müller, Abh. Ak. Wiss. Berlin, 1840, p. 187, pl. iii, f. 2; Yarrell, Brit. Fishes (ed. 3) ii, p. 495, c. fig.; Kröyer, Danm. Fisk. iii, p. 930; White, Catal. p. 127; Duméril, Ich. i, p. 400, pl. iii, f. 1-3 (teeth); Bocage and Capello, Peix. Plagiost. p. 16; Günther, Catal. viii, p. 386 ; Moreau, Poiss. de la France, i, p. 311.

Smooth-hound, Couch, Fish. Brit. Isles, i, p. 47, pl. x.

In form this fish considerably resembles the tope, Galeus vulgaris, but the snout is not so much produced. Eyes-rather large: oval. Nostrils one-third of the distance between the anterior extremity of the mouth and the snout. Spiracles small; gill-openings rather short, the last three being over the base of the pectoral. T'eeth-pavement-like, small and numerous. Fins-the first dorsal 
commences above the posterior edge of the insertion of the pectoral; the second dorsal inserted somewhat anterior to the anal, terminating over its hind third, and is about half the size of the first dorsal. Pectoral rather large, extending two-thirds of the distance to the ventrals, which latter are placed nearer the first dorsal than the second. Anal much smaller than the second dorsal. Caudal without any lower lobe, while its npper lobe is notched near its extremity. Skin smoother than in the tope. Colours-bluish-gray, becoming lighter beneath, having numerous white spots along the upper half of the body, which disappear with age.

Thompson obtained an example in Belfast Bay, June 16th: "It combined in colour Mr. Jenyns' description of S. lcevis and S. hinnulus, having, as the former is described, the 'upper parts of a uniform pearl gray,' and being 'paler or almost white beneath;' at the same time presenting with the $S q$. hinnulus a row of small whitish spots from the eye towards the first of the branchial openings; lateral-line indistinct7y (?) spotted with white; also a moderate number of small, scattered white spots between the lateral-line and the dorsal ridge." He continues, that there were numerous small white spots above the lateral-line to end of second dorsal; another row along upper edge of tail-fin.

Names.-Smooth or unpricllly hound, due, observes Pennant, to its not possessing spines to its fins; ray-mouthed-dog or sliate-toothed dog, in allusion to its dentition. Stinkard, in Ireland, due to its odour. Ci Llyfn, Welsh. De Toonkai, Dutch. L'Emissole commune, French.

Habits.-Does not appear to be a very voracious form of shark, keeping somewhat near the ground, and in the Firth of Forth Parnell observed that it is generally found in the salmon nets along with the common dog-fish. It usually appears about May or June, but, has been taken as early as February or March. Mr. Saville Kent observes that in 1875 a pair were captured at Colwyn Bay, North Wales, and sent to the Manchester Aquarium. Soon after arrival at their destination eleven young ones were produced, which, witb the exception of one, which was apparently devoured by the male fish, were successfully reared. It feeds on molluscous and crustaceous animals, which it crushes with its teeth. Thompson found one filled with brachjurous crastacea, including a perfect and full-grown Corystes cassivelanus.

Means of capture.-Baited hooks.

Breeding.-Couch observes that in November he has found one with eleven young just ready for exclusion. Moreau refers to their producing twenty or more, and Risso up to sixty. Although the fotus has no placenta, "the bursa entiana is well developed."

As food.-Fleming observes that its flesh is eaten in the Hebrides, and esteemed a delicacy.

Halitat.-Atlantic coasts of Europe, extending into the Mediterranean, and is said to have been taken at the Cape of Good Hope, the Brazils, and New Zealand.

Orkneys and Shetland Isles (W. Baikie, Zool. 1853): Aberdeen (Sim) : not uncommon at St. Andrew's (McIntosh), or off the coast of Berwickshire (Johnston): Firth of Forth (Parnell).

In the summer it is not uncommon in the west and south of Great Britain. Common in Bridlington Bay and off Scarborough (Yorkshire Vertebrata): Norfolk estuary (Lowe) Kent and Sussex (Yarrell). Frequent along the south coast (Parfitt, Fauna of Devon): common in Cornwall during summer and autumn, especially in the pilchard season. Occasionally occurs in Swansea Bay (Dillwyn).

Ireland.-Occasionally taken on the north and south. Sometimes caught in Carrickforgus Bay (Templeton): at Portrush common (Ogilby). The Londonderry specimen, alluded to in Simpson's Derry, had five or six rows of teeth, so probably belonged to another genus.

Off our shores it attains to 3 or 4 feet in length, sometimes more (Jenyns) : to 6 feet (Fleming). Moreau refers to one he saw at Arcachon which was $6_{2}^{1}$ feet. The one figured is 15 inches long, and from the Channel Islands. 


\section{FAMILY II-LAMNID $\mathbb{E}$.}

Mouth inferior, crescentic. Spiracles, if present, small. No nictitating membrane to the eye. Gill-openings as a rule wide. The first dorsal fin situated above the interspace between the pectoral and the ventral: an anal fin present.

The following Genera have representatives in our seas :-

1. Lamna.-Teeth lanceolate, large, and with smooth edges.' A keel at the side of the tail.

2. Alopias.-Teeth triangular, flat, and of moderate size, with smooth edges. Caudal fin of great length. No keel at the side of the tail (p. 301).

3. Selache.-Teeth very small, numerous, conical and smooth. A keel at the side of the tail (p. 304).

\section{Genus I-Lamna, Cuvier.}

Oxyrhina, Agassiz: Isurus, Rafin.

Mouth wide. Spiracles, if present, minute. Teeth large, lanceolate, and with smooth edges, occasionally with basal cusps. Gill-openings very large. Second dorsal and anal fins small. A pit at the root of the candal fin, the lower lobe of which is well marked. A keel at the side of the tail.

Geographical distribution.-Temperate and tropical seas.

\section{Lamna cornubica, Plate CLVI.}

Cunis carcharias, Aldrov. p. 383, c. fig. Habrand, Ascan. Icon. pl. xxxi. Porbeagle, Borlase, Cornwall, p. 265, pl. xxvi, f. 4; Pennant, Brit. Zool. (Ed. 1776) iii, p. 117 (Ed. 1812) iii, p. 152, and Beaumaris shark (Ed. 1776) iii, p. 118, pl. xvii (Ed. 1812) iii, p. 154, pl. xx; Goodenough, Trans. Linn. Soc. iii, p. 80, pl. xv. Touille-bceuf, Loutre, and Taupe de mer, Duhamel, Pêches, ix, p. 298, pl. $\mathrm{xx}, \mathrm{f} .4$.

Squalus cornubicus, Gmel. Linn. i, p. 1497; Lacép. i, p. 216 ; Bl. Schn. p. 132; Donovan, Brit. Fish. v, pl. cviii; Turton, Brit. Fauna, p. 113; Risso, Ich. Nice, p. 29 ; Neill, Wern. Mem. i, p. 549 ; Blainville, Fauna France, p. 96, pl. xiv, f. 2; Jenyas, Manual, p. 500; Fries and Ekstr. p. 135, t. xxx; Templeton, M. N. H. 1837 (2) i, p. 413 ; Johnston, Berwick. N. H. F. C. 1838, i, p. 175.

Squalus nasus and Pennantii, Walb. Artedi, iii, p. 517 ; Bonnaterre, Ency. Ich. p. 10, pl. Ixxxv, f. 350 .

Squalus glaucus, Gunner, Norsk. Vid. Selsk. Skr. iv, p. 1.

Squalus monensis, Shaw, Zool. v, 2, p. 350; Jenyns, 1. c. p. 501; Yarrell, Brit. Fish. (ed. 1) ii, p. 387, c. fig.

Isurus oxyrinchus, Raff. Caratt. p. 12, t. xiii, f. 1.

Lamia cornubicus, Risso, Ich. iii, p. 124.

Lamna cornubica, Cuv. Règne Anim.; Fleming, Brit. An. p. 168; Müller and Henle, p. 67 ; Yarrell, Brit. Fishes (ed. 1), ii, p. 384, c. fig. (ed. 2), ii, p. 515 (ed. 3), ii, p. 498; Parnell, Wern. Mem. vii, p. 413 ; Swainson, Fishes, ii, p. 314 ; Bonap. Faun. Ital. Pesc. pl. cxxxiv, fig. 2; Schlegel, Fauna Japon. Poiss. p. 304; Thompson, Nat. Hist. Ireland, iv, p. 251 ; Richards. Fish. China and Japan, p. 304 ; Kröyer, Danm. Fisk. iii, p. 852, c. fig.; Nilss. Skand. Faun. iv, p. 718; Duméril, Ich. i, p. 405; Bocage and Capello, Peix. Plagiost. p. 12 ; 
Günther, Catal. viii, p. 389 ; Collett, Norges Fisk. p. 208; Canestrini, Fauna d'Ital. Poiss. p. 45 ; Winther, Ich. Danm. Mar. p. 57 ; Malm, Fauna, p. 618; Giglioli, Pesc. Ital. Catal. p. 51 ; Moreau, Poiss. de la France, i, p. 296.

Salanonius Walkeri, Flem. l. c. p. 169.

Squalus (Oarcharinus) lamia et cornubica, Blainv. l. c. pp. 88, 96, t. xiv, f. 2.

Carcharias griseus, Ayres, Bost. Journ. N. H. iv, 1844, p. 293, pl. xii, f. 4.

Isurus cornubicus, Gray, Catal. Chondr. p. 58; White, Catal. p. 128.

Porbeagle, Couch, Fishes Brit. Isles, i, p. 4tl, pl. viii.

Body thick and high anteriorly, becoming very narrow near the tail. Snout conical, and with numerous small punctures. Eye-rather large, oval and placed over the middle of the mouth. Nostrils one-third of the distance between the mouth and the end of the snout. Teeth-lanceolate, with a smail basal cusp in large examples : $\frac{15-16}{12} \frac{16}{14}$, the third on either side of the median line in the upper jaw is small, while there is no central tooth. Small spiracles placed midway between the eye and first gill-opening have been observed (Turner, Journ. Anat. and Physiol. 1875, p. 301): Günther has found them absent. Gill-opening rather long, equalling about half the distance between the base of the pectoral and dorsal fins, the last is close to the base of the pectoral fin. Fins - first dorsal somewhat triangular, it commences on a line slightly behind the insertion of the pectoral, rather falciform, and does not extend to above the ventrals, which latter are rhomboidal. Second dorsal small, situated above the anal. Caudal lunated, the lower lobe the shorter, the upper notched near its extremity. A well-developed keel along the side of the tail, commencing opposite the second dorsal fin: a notch above the commencement of the caudal fin. Vertebræ 155. Colour-generally dull gray above and white beneath. Mr. Dunn in 1880 sent me a small one from Mevagissey, it had a light edge to the hind portion of the dorsal fin, which he suggested may be a sign of immaturity or the sexual indication of females. In July, 1881, the same excellent observer examined two large examples: a male, 9 feet 5 inches long, entirely gray; and a female, 8 feet 4 inches long, in which the back part of the dorsal fin was white, as observed existed in the young. It had a large hook in its jaws, which certainly did not seem to be of British manufacture. In its stomach was a large dog-fish, partially digested.

This species was first described by Dr. Caius, from a specimen stranded in Suffolk, between Lowestoft and Pakefield, February, 1570. Pennant gave a description and figure of the Beaumaris shark, received from the Rev. H. Davies, while he describes the Porbeagle, from the figure in Borlase's Cornwall, wherein the snout is more pointed; but Donovan observes "there is in fact not the slightest difference between the original drawing of the Beaumaris shark by Mr. Davis and the Squalus cornubicus-they are both the same species."

Narres.-Beaunaris shark, so termed by Pennant, due to the locality of the one he described: porbeagle apparently so termed by Borlase as a compound of porpoise and a beagle or hunting dog. Morgi mawr, Welsh. Lamie long-nez, French.

Habits. - This fish is a summer and autumn visitor to our west coast, and wanderers are frequently taken on the east of England and Scotland. It is often found in small companies. It is said to be a fierce and wary species. Couch mentions an instance in which one, in the prospect of being taken, sprang at a fisherman and tore a piece out of his clothing. In the stomach of one taken at Mevagissey, mentioned below, were only dog-fishes in a partly digested condition, so that even these vermin find an enemy and destroyer. Mr. Dunn has observed that it seems to prefer rough slimy fishes for food as picked-dogs and John Dorees. Cuttles, Sepiidar, have likewise been found in their stomachs, and Couch observed in one instance three full-grown hakes.

Means of capture.-Baited lines, often taking those laid for other fishes as whiting. The head of one was given me in August, 1881, by Mr. Hearder of Plymouth. This shark was captured on a whiting line, off the "Stone," in the act of taking a whiting off the hook. Its length was 3 feet 6 inches, and its weight $58 \mathrm{lb}$. On investigating the contents of its intestinal tract, three 
spinners were found, two of which had Mr. Hearder's name, and 195, High Street, still visible upon them; while no mark was present to indicate who had been the manufacturer of the third. There were also several whiting hooks, a good indication of how it had been employing its time attending upon the line fishers. One 9 feet long was captured on a mackerel line, July 14, 1881, about twelves miles north of Deadmans, and landed at Mevagissey, from it Mr. Dunn obtained an Echeneis remora. On the Galway coast it is taken both on long lines and in nets.

Breeding.-The female specimen, described by Pennant, is said to have contained two embryos.

As food.-Is not eaten in this country, but esteemed in some parts of France.

Habitat.-North Atlantic, Mediterranean, Japan, and New Zealand (Haast).

Not rare in the Orkneys and Shetlands (W. Baikie, Zool. 1853, p. 3846): has

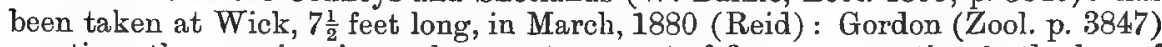
mentions the securing, in a salmon net, one out of five seen sporting in the bay of Lossiemouth, August 25th, 1825: is occasionally captured off Banffshire, usually about the herring season (Edward) : Aberdeen (Sim): Firth of Forth now and then, once taken in a salmon net and twice on haddock lines (Neill): Berwickshire examples are seen in the bay from 5 to 8 feet in length (Johnston) : Wallis's shark was taken in the Tweed, a little above the bridge, in September, 1757: a

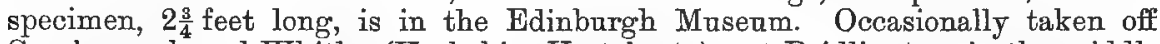
Scarborough and Whitby (Yorkshire Vertebrata) : at Bridlington, in the middle of August, 1883, four specimens were captured in the bay, one of which was 8 feet long (W. Eagle Clarke, Miss.) : Yarmouth (Paget) where, July 4th, 1867, a crew of a lugger engaged mackerel fishing took one 11 feet 5 inches long (Gunn): November 11th, 1880 , one $25 \frac{1}{2}$ inches long was stranded alive at Overstrand (T. Southwell) : in September, 1867, one $8 \frac{1}{2}$ feet long has been recorded from off Margate (Gerrard) : Hastings (Pennant and Goodenough) : Bowerbank recorded one a little over 4 feet in length taken off the same place, June 18th, 1873, and a

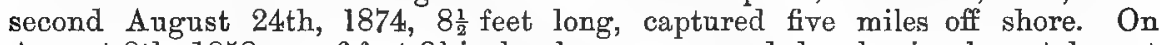
Angust 8 th, 1858, one 6 feet $8 \frac{1}{2}$ inches long was recorded as having been taken at night in a mackerel net in Seaford Bay (Sussex Express, August 15) : two or three taken on the north coast of Devonshire at Cloverly in 1871, and on April $27 \mathrm{th}, 1835, \mathrm{Mr}$. Bellamy recorded one 8 feet long, containing five young ones (Parfitt) : at Mevagissey Mr. Dunn observed on a pair taken in June, 1881, the male was $9 \frac{1}{3}$ feet long, female $8 \frac{1}{3}$ long: Cornwall, common (Conch) : at Swansea one was washed against the east pier in a storm in October, 1835, and picked up nearly dead (Dillwyn) : Beaumaris (Pennant).

In Ireland.-Occasionally taken on different parts of the coast: one 5 feet 11 inches long in 1815, in Belfast Lough in a herring net (Templeton): one 45 inches long in Dublin Bay in September, 1838: one abont 4 feet long at Youghal in 1824 (Ball); on long lines off Galway, also in nets (Nimmo).

The example figured is 33 inches long, a young male, received from Mr. Dunn. The fish must attain to 11 or 12 feet in length if Mr. Gunn's was this species; it has several times been captured up to 10 feet. 


\section{Genus II-Alopias, Rafinesque.}

Mouth crescentic. No membrana nictitans to the eye. Spiracles minute, close behind the orbit. Teeth of rather small size, flattened and trianyular, having smooth edges. Gill-openings of medium size. The first dorsal fin spineless, inserted above the interspace between the pectoral and ventral fins: the second dorsal abuve the interspace between the ventral and anal, the latter being small. Caudal very long, with a pit at its commencement. No keel on the side of the tail.

Some authors consider this genus of sharks is the type of a distinct family.

Geographical distribution.-Temperate and tropical seas.

\section{Alopias vulpes, Plate CLVII.}

Vulpes, Rondel. p. 387 ; Gesner, De Aquat. 1598, p. 80, c. fig. Simia, Belon. p. 65. Vulpeculı, Salv. p. 134, pl. xlii; Aldrov. p 396; Jonston, p. 27, t. vii, f. 3 ; Will. p. 54, t. B6, f. 2 ; Ray, Synop. Pisc. p. 20 . Cercus, J. Caius, De rar. anim. hist. 1570, p. 111. Squalus, Artedi, Gen. p. 68, Synon. p. 96. Galeus cauda longa, Klein, Mss. iii, p. 10. Renard marin, Dubamel, Pêches, ii, sect. ix, p. 303, pl. xxi, f. 1, 2. Sea-fox, Borlase, Cornwall, p. 265. Long-tailed shark, Pennant, Brit. Zool. (Ed. 1776) iii, p. 110, pl. xiv (Ed. 1812) iii, p. 145, pl. xvii.

Squalus vulpes, Gmel. Linn. p. 1496; Bonnaterre, Ency. Ich. p. 9, pl. lxxv, f. 349 ; Lacépède, i, p. 267 ; Bl. Schn. p. 127 ; Turton, p. 112; Mitchell, Phil. and Lit. Trans. New York, 1815, i, p. 482 ; Risso, Ich. Nice, p. 36 ; Blainville, Fauna France, p. 94, pl. xiv, f. l ; Jenyns, Brit. Vert. p. 498.

Carcharias rulpes, Cuv. Règne Anim.; Risso, Eur. Mérid. iii, p. 120; Flem. Brit. An. p. 167; Templeton, Mag. Nat. Hist. 1837 (2) i, p. 413; Yarrell, Brit. Fish. (ed. 1) ii, p. 379, c. fig. (ed. 2) ii, p. 522; Storer, Mem. Amer. Acad. ix, 1867, p. 221, pl. xхxvi, f. 3; De Kay, New York Fauna, Fish. p. 348, pl. lxi, f. 190; Guichen. Expl. Algér. p. 124, and in Gay's Chile, Zool. ii, p. 363; Thompson's Nat. Hist. Ireland, iv, p. 250.

Alopias vulpes, Bonap. Fanna Ital. Pesc. iii, p. 66, c. fig.; Müller and Henle, p. 74, pl. xxxv, f. 1. (teeth) ; Swainson, Fish. ii, p. 313; Gill, Catal. Fish. N.-East Coast North America, p. 60 ; Kröyer, Danm. Fisk. iii, p. 929, c. fig.; Gray, Cat. Chond. p. 64; White, Catal, p. 131; Storer, l. c. ii, p. 505 ; Duméril, Ich. i, p. 421 ; Bocage and Capello, Peix. Plagiost. p. 14 ; Moreau, Poiss. de la France, i, p. 287.

Alopecias vulpes, Yarrell, Brit. Fish. (ed. 3) ii, p. 512, c. fig.; Günther, Catal. viii, p. 393; Collett, Norges Fiske, p. 208; Giglioli, Cat. Pesc. Ital. p. 52.

Alopias macrourus, Rafin. Caratt. p. 12.

Squalus alopecias, Gronov, ed Gray, p. 7.

Thrasher, Couch, Fish. Brit. Isles, i, p. 37, pl. vii.

Body fusiform, gradually diminishing to the caudal fin, the great length of which, about half of the total, gives the shark a very elongated appearance. Snout short and conical. Eyes-rather large. Nostrils beneath and nearer the anterior border of the mouth than to the end of the snout. The gill-openings of median size, the last two being over the pectoral fin. Spiracles very small, situated at a short but varying distance behind the orbit. Teeth-about $\frac{22+22}{19+18}$ in the two jaws (Moreau), the third or fourth tooth on either side of the centre in the upper jaw is small, the remainder are of rather small size, triangular in shape, standing on a wide base, flattened and with smooth edges. Fins-first dorsal inserted above the commencement of the interspacc between the pectoral and the ventral, it is 
highest in front and with a concave upper edge; second dorsal very small. Pectoral Iarge and falciform. Anal very small. Caudal very elongated, often équalling in length the remainder of the fish, occasionally even more: its lower lobe distinct, as is a notch at the end of its upper lobe. A notch at the base of the caudal fin. Colours - gray, dull brown, or even bluish along the back, becoming lighter and occasionally of a dull white beneath.

One 12 feet long was captured off Slapton Sands, Devonshire, in a net, it was "dark blue, mottled with white over the belly" (H. Nicholls, Zool. 1869).

Names.-Thresher, due to the use it is said to make of its tail; also slasher, sea-fox, from the appearance of its tail : fox-shark, sea-ape. Llwynog-mor, Welsh. Le Renard, French.

Habits.-It follows shoals of gregarions fishes, and as a consequence is mostly entangled in the nets along our southern and western shores, during the mackerel, herring, pilchard, and sprat seasons. One of the first English authors who has remarked upon the habits of this fish appears to be Borlase, who observes that with itsl ong fox-like tail, it strikes or threshes its larger and less agile enemy, the grampus, whenever it ascends to the surface of the water to breathe. De Kay gives the same account, adding that it pursues schools of mackerel, mossbankers, and shad, and devours them in great numbers. Couch remarks that the lashing of the sea with its tail, has been known to put to hasty flight a berd of sportive dolphins (Delphini). It has been asserted to swim round shoals of fishes, gradually diminishing the size of its circles, when it uses its tail for splashing the water. Mr. Blake-Knox saw one, in the winter of 1865 , rise and kill a wounded diver in Dublin Bay with a stroke of its tail, and then swallow it (Zool. 1866, p. 509).

Many observers have recorded how this shark attacks whales and porpoises, and their allies, and in such enconnters it is assisted by sword-fishes in the warmer seas, concerning which a recent author, following the views of Mr. Buckland (Günther, "Introduction to the Study of Fishes," p. 322), observes that the "statements that it has been seen to attack whales and other large cetaceans rest upon erroneous observations." Lord A. Campbell (Scotsman, 1880) witnessed such an encounter, or at least observed from the bridge of the steamship "Peruvian," off Belleisle, a fish leaping high out of the water, and which he was able to see was no whale. He made a rough sketch of what he personally witnessed, computing the fish's length at about 30 feet, and that of the whale as much longer. The sketch shows a large fish with a heterocercal tail that sprang out of the sea: the form of the tail excludes its being a cetacean, which could not possibly use that appendage as a species of sledge hammer: it must therefore have been a shark or a skate. "The crew of a trawler in 1878 reported a thresher and sword-fish attacking a rorqual whale in Mevagissey Bay. The crew were well acquainted with each of these creatures" (Dunn). As it has been abundantly proved that thresher sharks do spring out of the water to strike down prey or scare shoals of fishes, I think it open to doubt whether all such observations are to be summarily dismissed as erroneous, until the accounts are refuted, or another agent is convicted of the assaults in question. Mr. Layard (Land and Water) asserts having witnessed such a conflict on more than one occasion, and to have been so near as to see very distinctly, that besides the assailant which was pummelling the unfortunate whale from above, there was more than one attacking it from below. He asserts he knows the thresher shark well, and it was certainly one of the aggressors in the fight he once witnessed off the Cape of Good Hope. Many other authorities have likewise seen these enconnters, as Mr. Pascoe and Mr. Howard Saunders. Couch found some young herrings in the stomach of the one he examined, and Mr. Gerrard twenty-seven mackerel in another, $13 \frac{1}{2}$ feet long, from Folkestone.

Means of capture.-In olden times, says Pennant, it was believed that when it had the misfortune to have taken a bait, it swallowed the hook until it arrived at the cord, which it severed with its teeth, and so escaped. Is rarely captured off our shores with a baited hook; and Oppian asserts that the lower portion of the line was formed of hair, while, to guard the hook from being cut away, the line for some distance above it was armed, or, remarks Couch, as the fishermen now 
say, was "ganged" with flexible brass wire twisted regularly and firmly round it. Mr. Gatcombe records how one, 5 feet 6 inches long, was taken at Mevagissey with a common whiting hook, baited with a piece of pilchard, and at the depth of 35 fathoms (Zool. p. 3697).

Breeding.-Its egg case is similar to that of the dog-fish (Buckland).

As food. - The Greek fishermen are said to have sought it for this purpose. Dr. Caius, in 1569, compared its flesh to that of the salmon, but admitted that it was not quite so agreeable to the palate.

Habitat.-The Atlantic Ocean, on both shores, but does not appear to extend far towards the north: an example was taken, in 1868, off Bergen, in Norway, and it has been received in Paris, from the Cape of Good Hope. It is also found in the Mediterranean, and it has been obtained from San Francisco Bay, California, and New Zealand.

It is not common in the Orkneys and Shetlands (W. Baikie, Zool. 1853, p. 3846) : very rare off Banff (Edward) : one was taken off Fortrose, in the Moray Firth, in 1846 (Masters); and in July the same year, one 11 feet 1 inch Iong, got entangled in the herring nets, and was killed off Berwick-on-Tweed (Proc. Berwick. Nat. Hist. Club). It is somewhat rare off Yorkshire : in September, 1854, one was seen off Scarborough (Briggs, Zool. p. 4513). On October 15th, 1868 , one 12 feet long was captured off Bridlington, and is now in the Leeds Museum (Stephenson); and Nelson records a third, which was 5 feet long, washed ashore in October off Redcar (Yorkshire Vertebrata). On October 20th, 1881, one 12 feet long was taken off Lowestoft (T. Southweli). Mr. Gunn reported one 14 feet 5 inches in length, captured by the crew of a lngger engaged mackerel fishing, July 4th, 1867 (Lowe): October 24th, 1882, one nearly 12 feet long was secured by some Walmer fishermen: one, $13 \frac{1}{2}$ feet long, was captured off Folkestone in October, 1867, a second, 14 feet 10 inches long, off the same place in October, 1867, and a third, 5 feet 1 inch long, in August, off Hastings (Buckland) : in 1864 a male, 15 feet 4 inches long, became entangled in the rope of a mackerel net, having become twisted around its tail, nine miles from $\nabla$ entnor (Zool. p. 96:30, G. Gwyon). July 16th, 1881, one about 10 feet long was taken in a mackerel net oft Christchurch (Land and Water): and on June 30th, 1882, one over 10 feet in length, in a mackerel seine off Poole, where it is not uncommon during July and August (L. and W.); in 1870, one, 10 feet 3 inches long, was taken in West Bay, Portland, on September 13th (Cornish, Zool. p. 2348): it is occasionally taken in Devonshire: November, 1876, one, 7 feet in length was entangled in the herring nets two miles west of Teignmouth: in 1869, on August 20th, one, 4 feet 7 inches long, was captured at Torbay (Hugel, Zoologist): on July 29 th, 1879 , one, 12 feet in length, was taken in a herring net off the Start (Gatcombe, Zool. p. 383) : on September 13th, 1883, one, 14 feet long, was taken off Dawlish, in a drift net; and another of about equal size was captured and exhibited at Plymouth (Gatcombe): it is not uncommon off Cornwall, and a few are taken every year by the mackerel and pilchard drivers (Cornish Fauna) - in June, 1874, one, 13 feet long, was captured off Scilly (Cornish, Zool. p. 4080).

In Ireland.-Mr. J. Blake-Knox observes that it is often very common in Dublin Bay (Zool. 1866, p. 509). On June 16th, 1876, one, 57 inches long, was captured at Portrush, county of Antrim, in a salmon net (J. Ogilby, Zool., p. 3049).

As to the size this fish attains :-Lacépède refers to one taken at Dieppe, which measured 15 feet in length; it does not appear to have been captured quite so large off our shores; but one, 14, feet 10 inches long, has been recorded above. My figure is from the large stuffed specimen in the Westminster Aquarium. 


\section{Genus III-SeLache, Owier.}

\section{Cetorhinus, Blainville: Polyprosopus, Couch.}

Eye destitute of membrana nictitans: a small spiracle between the eye and the first gill-opening. Gill-openings very large. Gills furnished with gill-rakers for filtering purposes, and consisting of an elastic opparatus of dentine. Teeth small, conical, without dilated bases, and their sides smooth. First dorsal fin above the interspace between the pectoral and the ventral: second dorsal and anal small. Candal with a lower lobe and a pit at its root: sides of the tail keeled.

Geographical distribution.-From the Arctic seas and. North Atlantic to the Mediterranean.

On the gills of this fish are elastic appendages or gill-rakers (pl. clviii, f. la and $1 b$ ) consisting of dentine ;* so that each may, to a certain extent, be regarded as the analogue to an elongated and modified tooth. These act like the blades of baleen in the mouth of the whalebone whale, as sifting organs serving to filter the water passing through the gills, and thus enabling them to retain the small marine organisms on which they subsist. This structure bas attracted the notice of many naturalists. Pennant, in 1776, observed that "within side the mouth, towards the throat, was a very short sort of whalebone:" and Low, that its gills were fringed with a sort of short bristles approaching the nature of whalebone. In $1870 \mathrm{Mr}$. Cornish likewise alluded to this structure in one taken at Penzance. Professor Steenstrup (Overs. Dan. Selsk. 1873, No. 1) gives an account of these organs and their uses, as did also Professor Turner (Journ. Anat. and Phy. April, 1880, xiv, pt. iii, p. 273); and it is observed that the presence of bodies possessing the structural character of teeth or gills (as gillrakers) is not very aberrant, as they are not infrequent in osseous fishes, in which there is a tendency for dental structures to spring from the mucous membrane covering this part of the skeleton. Allusion to this sifting apparatus has been omitted by Sir E. Home in his Memoir on this shark, also by Vrolik, De Blainville, and others. Judging from the small size of its teeth, also the large size of its gill-openings to permit the passage of a great amount of water, and this sifting apparatus to detain minute structures, as well as what has been obtained from its stomach after death, it would appear that this fish is not a rapacious monster, but a devourer of minute animals and perhaps herbage.

\section{Selache maxima, Plate CLVIII, fig. 1.}

Squalus maximus, Gunner, Trond. Selsk. Skrift. 1765, iii, p. 33, t. ii, and iv, p. 14, t. iii ; Linn. Syst. Nat. (Ed. xii) i, p. 400 ; Gmel. Linn. p. 1498; Lacép. i, p. 209 ; Bonnaterre, Ency. Ich. p. 10, pl. vii, f. xix ; Bl. Schn. p. 134; Turton, p. 112 ; Flem. Brit. Anim. p. 164; Mitch. Lit. and Phil. Trans. New York, i, p. $480^{\circ}$; Schlegel, Dieren Neder. p. 191, pl. xix, f. 1.

Basking shark, Pennant, Brit. Zool. (Ed. 1756) iii, p. 101, pl. xiii (Ed. 1812) iii, p. 134, pl. xvi; Low, Fauna Orcad. p. 171 ; Shaw, Zool. v, pt. (2) p. 327, pl. cxlix (male) and 150 (female).

Squalus peregrinus, Blainv. Ann. Mus. xviii, p. 88, pl. vi.

Cetorhinus gunneri, homianus, et shavianus, Blainv. Bull. Soc. Phil. 1810, p. 169.

Selache maxima, Cuv. Règne Anim. Ill. pl. cxv; Faber, Fisch. Isl. p. 10; Yarrell, Brit. Fishes (ed. 1) ii, p. 396, c. fig. (ed. 2) ii, p. 518 (ed. 3) ii, p. 508; Jenyns, p. 503 ; Templeton, M. N. Hist. 1837 (2) i, p. 413 ; Parnell, Wern. Mem. vii. p. 418; Swainson, Fishes, ii, p. 314; Müller and Henle, p. 71 ; Richards. 
Faun. Bor.-Amer. Pisc. p. 291 ; Nilss. Skand. Fauna, iv, p. 720; Thompson, Nat. Hist. Ireland, iv, p. 253; Storer, Mem. Amer. Acad. ix, 1867, p. 229, pl. xxxvii, f. 3 ; Duméril, Ich. i, p. 413 , pl. iii, f. 18 (teeth); Bocage and Capello, Peix. Plagios. p. 14; Günther, Catal. viii, p. 394; Cornish, Zool. 1870, pp.2253, 2260 ; Collett, Norges Fiske, p. 209 ; P. Pavesi, An. Mus. Genov. xii, pp. 348, 418, pl. iii, c. fig.; Canest. Faun. Ital. p. 44; Giglioli, Catal. Pesc. Ital. p. 52 ; Moreau, Poiss. de la France, i, p. 305.

Squalus isodus, Saverio Macri, Att. Acad. Sc. Nap. 1819, i, p. 55, t. i, f. 1, t. ii, f. 2.

Squalus elephas, Lesueur, Journ. Ac. Nat. Sc. Phil. ii, p. 343, c. fig.; De Kay, New York Fauna, Fish, p. 357, pl. lxiii, f. 208.

Squalus selanonus, Leach, Wern. Mem. ii, p. 64, pl. ii, f. 2.

Squalus cetaceus, Gronov. ed Gray, p. 6.

Cetorhinus maximus, Gray, Catal. Chond. p. 61 ; White, Catal. p. 129 ; Gill,

Catal. Fish. E. coast of North America, p. 60.

Cetorhinus Blainvillei, Capello, Journ. Ac. Sc. Lisb 1869, p. 233, c. fig.

Basking shark, Couch, Fish. Brit. Isles, i, p. 60, pl. xiv.

\section{(Monstrosities.)}

Squalus rashleighanus, Couch, Trans. Linn. Soc. xir, p. 91.

Polyprosnpus rashleighanus and macer, Couch, Brit. Fish. i, pp. 67-68, pl. xr.

This shark is largest in circumference about the situation of the pectoral fins, diminishing in size towards each extremity. Head conical. 'The snout (especially in the young) appears like a beaked projection, being of much less circunference than the anterior end of the jaws; it is also covered with small pores. Eyesmall, situated over the anterior end of the mouth: nostrils situated at the edge of the upper lip. Spiracle small, and situated midway between the eye and the first gill-opening. Teeth-small and conical, with smooth edges, and in from four to six rows. Gill-openings-very long, extending down the entire side of the neck. Fins-the first dorsal is of medium size: it commences on a line just posterior to the insertion of the pectoral, is highest in front and concare along its upper border. The second dorsal, which is about one-third the size of the first, is inserted just anterior to the anal, than which it is larger. Pectoral placed low down, rather small and nearly triangular. Caudal, with the lower lobe the longer and the upper notched, a pit at the root of the fin. Skin rough, especially when the hand is passed from behind forwards; a keel along the side of the tail. Colours-dusky black, brown, or blue along the back, becoming lighter on the sides and beneath. Snout of a dull reddish, becoming dull white beneath.

The proportions of the Isle of Wight specimen, now in the National Museum, were as follows when fresh:-Entire length, 28 feet 10 inches; of head, 6 feet 10 inches; of upper jaw, 3 feet 2 inches; of lower jaw, 2 feet $4 \frac{1}{2}$ inches; width of mouth, 1 foot 10 inches; size of eye, $2 \frac{1}{2}$ inches. Greatest height of first dorsal fin, 4 feet; of second dorsal tin, 1 foot 4 inches; interspace between dorsal fins, 6 feet 9 inches. Length of pectoral fin, $5 \frac{1}{2}$ feet; of ventral, 2 feet 9 inches ; of anal, $1 \frac{1}{4}$ feet; of upper caudal lobe, 5 feet 10 inches; of lower, about 4 feet 5 inches. Greatest circumference, just behind pectoral fins, 15 feet; below ventral fins, $5 \frac{1}{2}$ feet (Zool. 1875, p. 4415).

Lütken (Vid. Medd. 1879-1880) observes that, as Fabricius only introduced this fish into the Fauna of Greenland, due to his interpretation of fabulous stories told by the Esquimos, it ought to be erased. Only a single specimen has been recorded as captured in Iceland during the last half-century.

I consider the fish described by Walker as having "Dentes numerosi acuti," and termed by Leach Squalus selanomeus, Flem. l. c. p. 168, must belong to this species, and not to the Porbeagle, with which some authors have classed it.

P. Paresi l.c. gives a detailed description of a shark, captured in the Bay of Spezia, near Lerici, which was determined as Squalus rostratus, Macri, while he

In 1800 the vertehra of a large undescribed cartilaginous fish, generally termed the "sca serpent," was cast-nshore at the ()rkneys, and is now in the Edinburgh Museum. It belongs to this upecie: 
considered the forms known as Polyprosopus, not as monstrosities, but as constituting species of Selache. Mr. T. Gatcombe has observed that, should the mouth of one of these fish be left open, by inserting a piece of wood between the jaws the peculiar appearance as described by Couch in Polyprosopus is obtained, and of this he has kindly forwarded me two drawings made from this fish when fresh, and which confirm his statement.

This condition or appearance of the snout has been observed upon by Sir T. Browne, so long ago as 1662 , when one was taken entangled in the herring nets, which was particularly remarkable in the vastness of the optic nerves, and three conical hard pillars which supported the extraordinary elevated nose. The seaman named it a scrape.

Names.-Basking shark, due to its remaining motionless at the surface of the water, and sun-fish in Ireland for the same reason; sail-fish because, when swimming, its dorsal fin protrudes out of the water like a sail, causing it to be seen from a considerable distance. Hoe mother and homer, signifying "the mother of the Dog-fish" (Low, Orkneys). Heulgi, Welsh. De Reuzenhaal, Dutch. Le Pêlerin, French.

Habits.-It appears to be a quiet, inoffensive fish, which is frequently observed lying motionless on the surface, apparently basking in the sun's rays, sometimes even its belly appearing to be uppermost. At certain seasons this unwieldy looking animal may be seen leaping out of the water to the height of several feet, and when swimming its dorsal fin is frequently perceived above the surface. In some years it is much more abundant than others. Thus Pennant speaks of the vast shoals which visited the coasts of Wales in the summer of 1756 and a few succeding years: while the period they are off the coast is about from June to the setting in of cold weatber. It is said to migrate regularly from along the west coast of Ireland to the western isles of Scotland.

Should the April sun be hot, the sun-fish, says Mr. Brabazon, are certain to show above the water, and they remain on the Clew bank, Ireland, until the middle of May. A large shoal of sharks pass annually at this season along the west coast on their way from the sonthern to the northern seas. They are taken on the sun-fish bank, situated about one hundred miles west of Clew Bay, extending many miles north and south, and a day's sail from the land. They are found on the bank in great numbers, and the large dorsal fin is seen at a great distance, as it rises 3 or 4 feet out of the water while they lie motionless basking in the sun.

De Kay observes that its large size and habit of swimming near the surface, with its upper jaw projecting out of the water as it moves with open mouth in pursuit of its prey, has suggested to ignorant credulity the idea of some huge aquatic monster which has received the name of " sea-serpent." Possibly its thus swimming near the surface is because the small marine animals, on which it, certainly partially, subsists, are to be found in that situation, and then it strains the water through its gills in order to obtain them. (See p. 303.)

Low found the stomach of one full of red stuff, like bruised crabs or the roe of the sea urchin, but no fragments of fish. Captain Hadfield, remarking on the Ventnor specimen, says he is inclined to believe that it feeds on seaweeds, though nothing but a glutinous substance, of a yellowish-white colour, was found in its stomach, and the great width of the intestinal canal, 8 inches, he considered tended to prove that it is a vegetable feeder (Zool. 1875, p. 4415). Thompson observes that in Ireland it bas been stated that they frequent the berring bays in the fishing season, and not only destroy a good deal of fish, but mar the fishing. The first of these accusations is, however, probably erroneous, but that the mere presence of very large fish does injure fisheries has frequently been asserted.

Means of capture.-Pennant remarks, they will permit a boat to follow them without accelerating their motion, till it comes almost within contact, when a harpooner strikes his weapon into them, as near to the gills as possible; but they are often so insensible as not to move till the united strength of two men have forced the harpoon deeper. As soon as they perceive themselves to be wounded, they fling up their tail, plange headlong to the bottom, and frequently coil the rope round them in their agonies, vainly attempting to disengage the harpoon by 
rolling on the ground, for it is often found greatly bent. As soon as they discover that their efforts are in vain, they swim away with amazing rapidity, and with such violence that there has been an instance of a vessel of seventy tons having been towed away against a fresh gale. They sometimes run off with two hundred fathoms of line, and with two barpoons in them, and will employ the fishers for twelve and sometimes twenty-four hours before they are subdued. Low gives an account of one, a male, 23 fect long, which remained a whole day in the harbour of Stromness, which it went slowly round several times, allowing boats to approach close without seeming the least disturbed, every now and then setting up its large back fin, and sometimes having great part of its back above water. In this manner it proceeded without the least disturbance, till several boats were manned and went after it with harpoons and lances. From its liver six barrels of oil were obtained. Another, the same length, was noosed, and from it twelve barrels of oil were taken. Females are said to give more than males. The Isle of Wight example, which was 28 feet 13 inches long, made no resistance to a rope being passed round its tail, and was dragged quietly along. Forty or fifty men could not move it when on shore. Twenty-horse power had to be employed to drag it out of reach of the tide. Care has to be taken to keep boats out of reach of a blow of the tail of this fish which, when wounded, might stave them in.

Uses.-A very fine oil is obtained from their livers. One is recorded by Pennant as having been caught off the coast of Anglesey, measuring 26 feet in length, and producing 150 gallons of oil ; a large fish generally yields about eight barrels of oil. A fish, 30 to 40 feet long, Dr. Ball estimated, in 1839, would be worth $£ 80$. Couch's specimen, captured in Cornwall, was 31 feet 8 inches long, and from its liver 198 gallons of oil were obtained; two examples of about 30 feet, taken at Broadhaven, in Scotland, yielded almost nineteen barrels, of which eight went to the ton (Couch). The Isle of Wight fish, 28 feet 10 inches long, gave about 102 gallons of oil.

As food.-Low says its flesh looks partly like beef and partly like turbot, and is eaten by the poorer classes in the Orkneys.

Fisheries.-Those off the Irish and Scotch coasts would appear to be only occasionally utilized. These sharks are said to have been counted, off Tory Island, in shoals of from sixty to one hundred basking in the bright morning sun of June. Off Norway, according to a correspondent in Land and Vater, it is found along the coast from Ryvarden, latitude $59 \mathrm{deg} .31$ min. 35 sec., up to Finmarken; but in some localities it has become more rare than in others. This fishery a century ago was almost unknown. We first hear of its being carried on in the north, in the district of Namdal, about the year 1760 . In the southern parts of the country it was at the same time pursued with great avidity and perseverance, and with such success as for a series of consecutive years to form the staple and chief support of the inhabitants of the district in which it was carried on. Of late year's, however, this shark has either been driven away from its favourite baunts in the south, or its numbers have so far decreased as to diminish the importance it had for years maintained.

Not being a voracious fish, it is neither to be enticed nor caught by the same kind of bait or mode of fishing as pursued with the Lemargus microcephalus, but rather that followed for the whale. About the end of the dog days, this shark makes its appearance on the coast, when the fishery immediately commences. Large open boats are generally employed, from 37 to 42 feet in length, each boat being manned by four men, and furnished with harpoons similar to those used in harpooning the sturgeon. The harpoon is attached to a line proportioned to the depth of water on the ground selected, which usually is from 300 to 400 fathoms. This rope lies coiled up in the bow of the boat.

Thus equipped the fishermen, selecting a slight breeze and warm weather, cruise about under a triangular sail, near the mouth of the fjords the fish are in the habit of seeking. They are generally found lying perfectly still near the surface, apparently basking in the sun, and slowly follow the wake of the boat as ooon as discovered. When the fish approaches close enough, the harpooner, watching bis opportunity, urges his harpoon as deep into the body of the fish as 
to is able. Then arrives the perilous moment, as the fish no sooner feels the weapon than he dives with great celerity.

Everything must be clear to allow the line to run out freely. Should the line unfortunately catch in any projecting piece of wood or meet with any impediment, the boat is invariably capsized; or should either of the men, through carelessness or accident, be caught by the line round the leg or arm, which has occasionally happened, he gets hauled down with the fish. Another man, therefore, always stands ready with an axe to cut the line; but when such an accident does occur generally both man and fish are lost.

The fish drags the boat with him until his strength becomes exhausted. A lean fish holds ont better than a fat one, and will sometimes continue dragging the boat for twenty-four hours, while a fat one generally gets tired out in three or four hours. When exhausted, the fish is hauled up to the surface alongside the boat, and with a long sharp knife the fin is instantly cut off to prevent his striking, as a blow would readily smash the boat. He is then speared until quite dead.

Before commencing to extract the liver the fish is fastened by sundry ropes to the mast and turned, when one of the men, provided with a long knife for the purpose, opens the forepart of the stomach, which enables him to take out a large piece of the liver. He then puts his arm in and separates all the fibres and integuments, so as to effectually release the liver, which operation requires to be carefully performed. When completed the stomach is ripped up from end to end; the liver then floats out, the belly fills with water, and the carcase is cast adrift and immediately sinks. The liver is next got into the boat, and the operation is concluded.

Young fish are never met with; they doubtless keep in deep water until of mature growth. The size of the liver depends greatly upon the condition of the fish.

Habitat.-The Mediterranean. According to Low, in the last century, this appeared to be one of the commonest forms of shark in the Orkneys, being frequently seen in the harbour of Stromness, and other creeks of these islands and in the open sea. W. Baikie (Zool. 1853, p. 3846) latterly has considered it to be rare in the Orkneys and Shetlands. It is common in the Scottish seas, occasionally, though seldom, entering the Firth of Forth (Neill): also the Firth of Clyde and the Hebrides in droves or in pairs from June until the end of July (Pennant). It is supposed to have occurred near Scarborough on two occasions, but the evidence as to identification is insufficient (Yorkshire Vertebrata); Yarmouth (Paget), and Sir T. Browne records it off Norfolk so long ago as 1662; off Hastings (Home) ; several times off Sussex (Yarrell); on Fobruary 27th, 1875, one, $28 \mathrm{ft} .13 \mathrm{in}$. long, was captured near Shanklin, Isle of Wight (Hadfield, Zool. p.4415), the skin of which specimen was purchased (for £15) for the British Museum; Dorsetshire (Shaw); Devonshire (Yarrell); not uncommon off Cornwall during the summer (Cornish Vertebrata); one 9 feet long was captured in Mount's Bay, June 11th, 1870 (Cocks, Cornwall Poly. Soc. 1870, p. 110); on the Welsh coast, in some years, they are abundant, in others only stray fish. They have been recorded in Carnarvonshire and Anglesea (Pennant).

Ireland.- Taken especially off the west coast, or off Achill and Boffin Islands, in the former of which one 27 feet long was washed ashore in September, 1868 (Buckland); also captured in considerable numbers off the coast of Connemara (Templeton). One $5 \frac{1}{2}$ feet long was taken in Lough Foyle in July, 1849. In August another, nearly 30 feet long, became entangled in a trammel in Courtmacsherry harbour and was towed to shore; while it is not rare off Kinsale Head (Mr. More). A specimen 27 feet long is in the Dublin Musenm of Science and Art.

It attains to from 35 to 36 , or even 40 feet in length. My figare is from a stuffed specimen over $5 \frac{1}{2}$ feet long in the National Collection. 


\section{FAMILY III-NOTIDANID AE.}

Spiracles small and on the side of the neck. No membrana nictitans. Gill-openings, six or seven. A single spineless dorsal fin, placed nearly opposite the anal. Lower caudal lobe present. No pit at the root of the caudal fin.

\section{Genus I-Notidanos, Cuvier.}

Hexanchus and Heptanchus, Rafin.: Monopterhinus, pt. Blain.: Notorhynchus, Ayres.

Spiracles small. Mouth crescentic, without any labial fold. Teeth in the upper jaw consisting of one or two awl-shaped pairs, followed by six broader ones, which have one strong and several smaller cusps. In the lower jaw six large comb-like ones on either side, followed by some smaller lateral ones.

Geographical distribution.-Seas of temperate and tropical regions.

\section{Notidanus griseus, Plate CLVIII, fg. 2.}

Piscis vacca, Scilla, De Corp. Marin. Lap. t. i, xxvii, xxviii. Le Griset, Bronss. Ac. Sc. 1780, p. 663 .

Squalus griseus, Gmel. Linn. p. 1495 ; Lacép. i, p. 269 ; Bl. Schn. p. 129 ; Risso, Ich. Nice, p. 37.

Squalus vacea, Bl. Schn. p. 138.

Monopterhinus griseus, Blainv. Faun. France, p. 77.

Notidanus griseus, Cuv. Règne Anim.; Bonap. Faun. Ital. Pesc. pl. cxrxvii, f. 1; Couch, Zool. 1846, iv, p. 1337, c. fig. and Fish. Brit. Isles, i, p. 21, pl. iv; Yarrell, Brit. Fish. (ed. 3) ii, p. 515 ; Bocage and Capello, Peix. Plagios. p. 15 ; Günther, Catal. viii, p. 397 ; Canestrini, Faun. Ital. p. 42.

Notidanus monge, Risso, Eur. Mérid. iii, p. 129.

Hexanchus griseus, Rafin. Caratt. p. 14; Müller and Henle, Plagios. p. 80; Gray, Cat. Cart. Fish. p. 67, and Ann. and Mag. Nat. Hist. 1868 (4) i, p. 76; White, Catal. p. 130; Duméril, Ich. i, p. 431, pl. iv, f. 9.12 (teeth); Moreau, Poiss. de la France, i, p. 336, c. fig. 55, 56; Giglioli, Catal. Pesc. Ital. p. 52.

Snout rounded; head flattened. Eyes-rather large. Nostrils nearer snout than to the angle of the mouth. The spiracle small and intermediate between the hind edge of the eye and the first gill-opening, or somewhat nearer to the latter. Teeth-no single median pointed tooth in the upper jaw. In the succeeding serrated teeth the first cusp the largest, as it is also in the lower jaw, although not much larger than the succeeding ones. Central tooth in lower jaw serrated at its edges. -Gill-openings wide, the anterior one the highest. Fins-dorsal situated behiud the ventral, than which it is rather smaller, and extending to slightly above the anal. Pectoral somewhat quadrangular, its corners being rounded. Upper caudal lobe long and notched near its extremity. Skin rough, the scales being small and leaf-shaped, with a central keel that extends to the sharp end. Colours-of the Banff specimen olive-iron or reddish-gray, inclining to a leaden hue along the abdomen. It is a savage and voracious species.

Names.-Six-gilled shark, brown or Mediterranean shark. Le Griset, French.

Breeding.--Producing living young several times during the year.

As food.-Rejected, and those who have tried of it find it a strong purgative.

Habitat.-From the British coasts to the Mediterranean, where it is common. A large one was captured at Banff in December, 1857, and placed in the Museum. November, 1845, a female nearly 11 feet long was secured off the Isle of Wight.

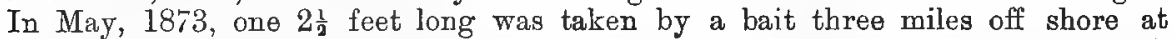
Mevagissey (Dunn). February 19th, 1846, one 26 feet 5 inches in length captured at Polperro, in Cornwall. Another 6 feet long was taken at the same place, and is in the National Collection, it is the one figured. It is said to grow to a large size. 


\section{FAMILY IV-SCYLLTID $\approx$.}

Spiracles present. Eye without any nictitating membrane. Mouth inferior. Teeth small, several rows being generally in use. The first dorsal fin spineless, placed above or behind the ventrals: an anal present, which may be in front of, below, or behind the second dorsal.

The following Genera have representatives in our seas :-

1. Scyllium.--Upper edge of caudal fin smooth.

2. Pristiurus.- Snout much produced. A row of small flat spines along the upper edge of the candal fin.

\section{Genus I-Scrllidm, Cuvier.}

Scylliorhinus, Halcelurus, Poroderma, and Cephaloscyllium, Gill.

Spiracles behind the eyes. Nasal cavities distinct from that of the mouth. Teeth small, in many rows, usually with a central and one or two lateral cusps. Origin of anal fin in advance of that of the second dorsal: upper edge of caudal not serrated.

Geographical distribution.-Temperate and tropical seas.

These sharks or "dog-fishes" do not attain to a large size. Their ova arn enclosed in a horny capsule. Of the two British forms, the first, S. canicula, has a single nasal flap and ventral fins separated; the other, $S$. catulus, has the nasal flap in two and the ventral fins almost conjoined.

\section{Scyllium canicula, Plate CLIX, fig 1.}

Galeus stellaris major, Belon. p. 53. Canicula Aristotelis, Rondel. p. 380. Catulus minor, Salv. i, fol. 137, t. xlvi ; Aldrov. iii, c. xxxiv, p. 390 ; Jonston, p. 25, t. viii, f. 2; Willughby, c. xvii, p. 64, t. B4, f. 2; Ray, Synop. Pisc. p. 22. Galeus capito rostroque brevissimis, Klein, Mss. iii, p. 10, no. 4. Squalus, sp. Artedi, Gen. nos. 10 and 11 ; Gronov. Mus. ii, p. 44, no. 199, and Zoo. p. 32, no. 144. Spotted dog-fish (male) and Lesser spotted dog-fish (female), Pennant, Brit. Zool. (Ed. 1776) iii, pp. 113, 115, pl. xv, no. 46, 47, and Lesser spotted shark (Ed. 1812), iii, pp. 148, 150, pl. xix. Lesser dog-fish, Low, Orkneys, p. 175. Grande rousette, Duhamel, Pêches, sect. ix, p. 304, pl. xxii, f. 1 .

Squalus canicula, Linn. Syst. Nat. i, p. 399 ; Bonn. Ency. Ich. p. 6, pl. vi, f. 18 ; Turton, p. 112 ; Risso, Eur. Mérid. iii, p. 116.

Squalus catulus, Linn. i, p. 400 ; Brünn. Ich. Massil. p. 5 ; Bloch, pl. exiv; Gmel. Linn. p. 1490; O. Müller, Zool. Dan. Prod. p. 37 ; Lacép. i, p. 221; Shaw, Zool. v, pt. 2, p. 334, pl. cli ; Bl. Schn. p. 127 ; Risso, Ich. Nice, p. 29 ; Donovan, Brit. Fish. iii, pl. 1v; Fleming, p. 165 (male) ; Templeton, M. N. H. 1837 (2), i, p. 413 ; Gronov. ed Gray, p. 5.

Scyllium canicula, Cuv. Règne Anim.; Bonap. Faun. Ital. Pesc. iii, pl. cxxi, f. 1; Müll. and Henle, p. 6, pl. vii; Jenyns, Brit. Vert. p. 495; Yarrell, Brit. Fish. (ed. 1) ii, p. 367, c. fig. (ed. 2) ii, p. 487, (ed. 3) ii, p. 470; Parnell, Wern. Mem. vii, p. 407; Johnston, Berwick. Nat. Field Club, 1838, i, p. 175; Nilss. Skand. Faun. iv, p. 710 ; Swainson, Fishes, ii, p. 316; Thompson, Nat. Hist. Ireland, iv, p. 247 ; Kröyer, Danm. Fiske, iii, p. 814, c. fig. ; White, Catal. p. 123; Duméril, Ich. i, p. 315 ; Schlegel, Dieren Neder. p. 194, pl. xviii, f. 4 ; Bocage and Capello, Peix. Plagios. p. 11 ; Günther, Catal. viii, p. 402 ; Collett, Norges Fiske, p. 210; Winther, Prod. Dan. Mar. p. 57 ; Canestrini, Fann. d'Italia, Pesc. p. 50; Giglioli, Catal. Pesc. Ital. p. 52; Malm, Fauna, p. 619; Moreau, Poiss. de la France, i, p. 278, f. 34,35 .

Galeus catulus and caniculus, Rafin. Ind. Ittiol. Sicil. p. 16.

Scyllium caniculum, Gray, Catal. Cart. Fish. p. 29.

Scylliorhinus catulus, Blain. Fauna Fran. p. 69, pl, xvii, f. 1. 
Squalus eleyans, Blainv. 1. c. p. 73.

Kough hound, Couch, Fish. Brit. Isles, i, p. 14, pl, ii.

Anterior portion of body somewhat rounded, becoming compressed towards the tail; bead broad and flattened superiorly; snout rounded. Eyes-rather large, and as far from the end of the snout as they are apart. Spiracles present. Nasal valves destitute of a cirrhas and forming a single broad tap, which inferiorly reaches as low as the mouth. Nostrils on the lower surface of the head, and much nearer to the mouth than to the end of the snout. A fold at the side of the lower jaw. Mouth semi-circular. Teeth-in several rows in both jaws, with a central and lateral cusp on either side. Gill-openings-of moderate size, the last the smallest, it and the fourth being situated over the base of the pectoral fin. F'insfirst dorsal commencing about the centre of the total length, and is rather larger than the second. Ventrals a little in advance of the first dorsal, obliquely truncated posteriorly, their margins meeting at an acute angle like a lozenge, in the centre of which is the vent. Anal entirely anterior to the second dorsal, being below the interspace between the two dorsals. Skin rough if the hand is passed towards the head. Lower caudal lobe rather large, trapezoid in shape; posterior lobe cut square at its extremity. Colours-body and fins more or less stone-coloured or grayish-red, finely blotched and spotted with red, gray, black, or brown, becoming less numerous posteriorly. These spots are said to be generally fewer and somewliat larger in the female than they are in the male. It has been pointed out that in the male sex the ventral fins are larger than in the female, and are likewise united along the entire, or almost entire, extent of their inner edge one to the other, whereas in the female the last third of their inner edges are separated one from the other.

Names.-Spotted, small-spotted, and lesser-spotted dog-fish: row-hound: roughhound: morghi. Rider terms the dog-fish the cur-fish, hennett, and daggar. It is likewise known as the hund or hund-fish, or huss. Dau-fish, Orkneys; Blin' e'es, Aberdeen; Sea-nurse, Redcar ; Rolin huss, Sussex; Suss, Isle of Wight; Morgay, Cornwall and Scotland; Land-dog, Penzance. Morghimeiaf, Welsh. De hondshaal, Dutch. La grande Rouselte, French.

Habits.-Migratory, and said to remain longer in the Orkneys than its cogeners, as all through the summer single examples are captured. In aquaria it is found to be nocturnal in its habits. It seems to prefer a sandy bottom. It is very tenacious of life, and Mr. Ggilby remarks that one taken from the stomach of a skate, which had been caught at least three hours, although at first appearing, and not unnaturally, rather sick, on being thrown into the dock, swam gaily away after the lapse of a few minutes apparently none the worse. When seized, it throws its body round the arm that holds it, and, should it not be at once dropped, by a contractile and reversed action of its body, it grates over the surface with the rugged spines of its skin like a rasp, by which the surface is severely lacerated. Mr. Dunn remarks that the water which drops from these fishes when taken from the sea will turn a cod or pollack almost white, and will injure their sale. Thompson found in one a Gunnellus vulgaris and many opercula of the whelk, Buccinum unlutum. It is a voracious feeder, subsisting largely on small fisbes. In a specimen I received from Mr. Dunn, Mevagissey, in February, lor 4, I found a moderately-sized squid, Loligo vulgaris, several annelides, Nereis, one isopod, Conilera cylindracea, some' small bits of crustacea, and many intestinal worms. It is very partial to sea-worms, and its flat nose is well udapted to rout them out of the sand.

Means of capture--Nets, within two or three miles of the coast, especially during or after a storm: and also by hooks and lines.

Baits.-Takes a bait freely.

Breeding.-It breeds in captivity, as observed by Meyer (Zool. Garten, 1872, p. 371). Likewise, M. Costa (Compt. Rend. 1867, January 2 lst, p. 99) remarked that "at the commencement of April, 1866, M. Guillon writes to me, "We put into one of the compartments of the rivarium a pair of the little spotted dog-fish, Squalus catulus, Linn. The female laid eighteen eggs in the course of the month. These cggs hatched at the beginning of December: the incubation, 
therefore, lasts about nine months." The late Professor Peters, writing to me ftom Berlin, observed (November 11th, 1881) that "in our aquarium Dr. Harmer has noted the day of the laying of the eggs and their opening. This varies from 156 to 186 days." In adult females nva may be observed in different stages of growth, and generally passing down the oviducts in pairs, or one in each oviduct becoming there enclosed in a horny covering. Mr. Jackson observes that "at the Southport Aquarium they take from seven to ten months to hatch, and the young fish is never visible until several months after the eggs have been laid. The first appearance of the egg.case is of four long tendrils hanging from the body of the female; she herself will be found wriggling round and round any suitable object, until she has securely attached these tendrils. She then draws the two eggs (I have always seen two laid at once) from her body, and the few remaining tendrils soon get attached also." Mr. Dunn sent me from Mevagissey a beautiful specimen of flexible coral, Gorgonia, to which the egg of one of these fishes is attached. Couch also has observed the same nccurring off Polperro.

These egg-cases or pixy purses possess slits, which $O$ wen considered admitted streams of water into the egg at these openings, and that the cloacal apertures of the uteri would seem adapted to allow the free ingress of sea-water and that the external temporary branchix of the embryo may perform the respiratory function. Couch has observed that the presence of even a small quantity of seawater at an early stage is fatal to their life. In October, $1881, \mathrm{Mr}$. Hearder dispatched to me by post from Plymouth one of these egg-cases with the young an inch long within, and it arrived on the 29 th in a very lively condition. It had been placed in a wide glass tube $3 \frac{1}{2}$ inches long by $l$ inch in diameter, and secured at both ends. The egg-case was sufficiently transparent to enable one to see what was going on within, it contained a long oval cavity slightly constricted near its inferior third; below this constriction was the nutrient vesicle, which was thus prevented from passing forwards into the anterior part of the chamber where the embryo was. The interior of the chamber was filled with a yellowish-white fluid, and here the young was in almost constant motion, as if its main object were to agitate the contained fluid. Uuder the microscope the motion of the blood through the ressels was plainly perceptible, loops passed out from each of the gill-openings as well as from the spiracle, and along them the course of the red blood corpuscles could be clearly traced, as well as through the heart and large vessels of the body. After the death of the embryo I cut the egg-case across and could not discover that the slits were yet pervious. Where these slits exist they may be for the purpose of more readily admitting oxygen to the contained fluid.

Mr. Jackson, at Southport, kindly made some investigations into this question, and came to the conclusion that the slits are open from a very early age but difficult to see. He obtained one of the eggs of this tish, about as much developed as the one I have described, this was carefully dried and oiled all over except the slits; after eighteen hours no effect had been produced. He then dipped the ends in oil, and twenty-four hours after the fish was all right. The oil appeared to have dissolved whatever holds the ends together, for on lifting the egg-case a good deal of liquor escaped. The whole was then immersed in oil, and for nearly three hours little effect was produced, but then the oil appeared to have dissolved the ends sufficiently to make its way inside the case, and the young fish was thus drowned. On further examining live specimens at an early age, Mr. Jackson remarked that when lifting the egg-case out of the water the slits were so large that the fluid escaped, and on returning the case into the water it was found to be half-full of air. Possibly the period at which the slits first become pervious is subject to variation.

Uses.-Of little value either as food or for oil. Are employed on the Irish coast as bait in "buckie" creels to capture shell-fish, Buccinum undatum, and crabs. At Rathlin are said to be valued for their oil. Parnell remarks that the skin of this and other species of sharks are used as a substitute for glass paper, and by turners for polishing rood.

As food. - Said to be eaten by the poor at Roundstone, in Ireland, and other 
places where they are captured on a soft oozy bottum, also at the Isle of Man. Off Scotland, according to Parnell, it is rarely eaten, but along the coast of Devonshire and Cornwall it is not quite rejected, but made into morghi, or sea-dog soup.

Hatitat.-The coasts of Europe, extending through the Mediterranean.

Very common in the Orkneys and Shetlands (W. Baikie, Zool. 1853, p. 3846), occasionally found at Banff (Edward); Aberdeen (Sim); not uncommon in the Bay at St. Andrew's (McIntosh), but rare off Berwickshire (Johnston); Firth of Forth comparatively rare (Parnell). Not uncommon off Yorkshire (Yorkshire Vertebrata); found off Norfolk (Lowe), common off Devonshire (Parfitt) and along our south coast (Yarrell) ; commonest form of small shark in Cornwall, also at Guernsey; Swansea (Dillwyn).

In Ireland it is common around the coast. Ogilby observes that at Portrush it is common, especially on rocky or mixed ground, and is termed Morlog.

The example figured is a male 27 inches long, from Mevagissey. It attains to at least $3 \frac{1}{2}$ feet in length off our coasts.

\section{Scyllium catulus, Plate CLIX, fig. 2.}

Galeus stellaris minor, Belon. p. 74. Canicula saxatilis, Rondel. p. 383. Catulus major, Salvian. i, p. 138, c. fig.; Aldrov. p. 390 ; Willughby, p. 62, t. B4, fig. 1 ; Ray, Synop. Pisc. p. 22. Squalus, sp. Artedi, Genera, p. 69, no. 12 ; Gronov. Mus. Ich. ii, p. 45, no. 200 and Zoo. p. 32, no. 145. Spotted dog-fish, variety, Pennant, Brit. Zool. (Ed. 1776), iii, p. 114, and (Ed. 1812) iii, p. 150. Rock shark, Shaw, Gen. Zool. $\nabla$, p. 336. Le Chat rochier, Duhamel, Pêches, iii, sect. ix, p. 304, pl. xxii, f. 2, 3.

Squalus stellaris, Linn. Syst. Nat. i, p. 390 ; Bonn. Ency. Ich. p. 7, pl. vi, f. 17 ; Lacép. i, p. 233, pl. x, f. 1; Risso, Ich. Nice, p. 312, and Eur. Mérid. iii, p. 116 ; Gronov. ed Gray, p. 5.

Squalus canicula, Brünn. Ich. Massil. p. 4; Bloch, t. cxii ; Gmel. Linn. p. 1490; Bl. Schn. p. 126.

Squalus catulus, Turton, p. 112.

Scyllium catulus, Cuv. Règne Anim.; Parnell, Wern. Mem. vii, p. 410 ; Johnston, Berwick. N. F. Club, 1833, vi, p. 15 ; Müll. and Henle, p. 9, pl. vii ; Gray, Catal. Cart. Fish. p. 50; Bocage and Capello, Peix. Plagios. p. 11; Yarrell, Brit. Fishes (ed. 1) ii, p. 373, c. fig. (ed. 2) ii, p. 493 (ed.3) ii, p. 477; White, Catal. p. 124; Templeton, Mag. Nat. Hist. 1837 (2) i, p. 413; Duméril. Ich. i, p. 316 ; Costa, Compt. Rend. 1867, p. 90, and Ann. and Mag. 1867, xix, p. 227; Moreau, Poiss. de la France, i, p. 280, fig. 36.

Scyllium stellare, Flem. Brit. An. p. 165 ; Jenyns, Brit. Vert. p. 496 ; Bonap. Faun. Ital. Pesc. pl. cxxxi, fig. 2; Günther, Catal. viii, p. 402 ; Malm, CEfv. Ak. Förh. 1875, no. 10, p. 33 and Fauna, p. 622 ; Thompson, Nat. Hist. Ireland, iv, p. 247; Canestrini, Fauna d'Italia, Pesci, p. 50 ; Giglioli, Pesc. Ital. Cat. p. 52.

Nurse-hound, Couch, Fish. Brit. Isles, i, p. 11, pl. i.

Resembles the last species, with the following exceptions:- Snout not so obtuse; valves of nostrils separated in the median line, and not reaching to the mouth : a short labial fold at angles of lower jaw. Teeth-small; those of lower jaw destitute of any lateral cusp. Fins-ventrals cut nearly square, their posterior edges meeting at an obtuse angle, while they are united or not so according to the sex. Anal fin terminates beneath the middle of the dorsal. Skin somewhat rougher than in the S. canicula. Vertebræ 134. Colours-brownish or reddishgray, under surface whitish; spots larger and darker than in the last species. Their colour varies with that of the ground which they frequent, being lighter when from sandy localities.

Names.-Large-spotted dog-fish, owing to the large size of the marks on its body: nurse-hound, bounce, cat-fish: bull-huss (Folkestone). Ci ysgarmes, Welsh. La petite Rousette, French.

Halits.-A bottom-feeder, frequenting rocky ground, and having the same nocturnal habits as the last species, but appears to keep in deeper waters.

Means of capture.-Trawls and lines, being often taken on a baited hook. 
Breeding.-In a large marine reservoir at Concarneau a female deposited her eggs, which were hatched about nine months subsequently (Costa, Comp. Rend. 1867, p. 99, and An. and Mag. N. H. 1867, xix. p. 227). Couch mentions (May 30th, 1864) his receiving an egg, or rather purse, with the young just ready for exclusion; and as he had formerly found them in this condition in April, it appeared to be the usual time and continued till the autumn. Parnell opened a female in September, and found two purses of large size, but the fœtus was not in the slightest developed. Mr. Dunn has found the young ready to swim in March.

Uses.-The skin of this fish, according to Rutty, "is used for rasping and polishing wood and alabaster, and is capable of cutting iron; and though the skin of that from the coast of Portugal is sought for, and more used by our cabinet-makers and gunsmiths as preferable to ours, I have seen one of these from the shore of Howth which did not only cut yew, but silver. The same skin is also used to raise the hair of beaver hats instead of pumice-stone, which was formerly used for this purpose." "The skin was formerly highly valued in Cornwall by coopers for polishing their work. A tradesman from Truro once told me that a pound of rubskin (which was the local name he gave it) was worth a cwt. of sand-paper" (Dunn). Some oil may be obtained from its liver. It and the last species are largely employed, along the coast of Cornwall, for baiting crab pots.

As food.- Its flesh, says Couch, is too coarse to be eaten; but Moreau observes that it is used for food along the coasts of France. Although it is not delicate, still it is not exactly bad. It is hard, and gives off an ammoniacal and musty smell, which, however, is lost on being cooked. Lacépède informs us of a whole family having once been nearly poisoned, due to eating the liver of this fish.

Habitat.-Coasts of Europe; but off our shores not so common as the last species, and does not appear to extend so far towards the north.

Rare in the Orkneys and Shetlands (W. Baikie); has been taken at Wick (Parnell); Aberdeen (Sim); Berwickshire (Johnston); and in the Firth of Forth, occasionally in the salmon nets at Queensferry (Parnell). Murray includes it among his Scarborough fishes (Fauna of Yorkshire); is found in Norfolk (Lowe); Devonshire, in the trawl net, but not so commonly as the last species (Parnell); and also in Cornwall.

In Ireland, frequents the north-east coast, and not improbably the coast generally. Mr. Ogilby has only seen two examples at Portrush, both caught in deep water far off shore, on the same line, in January, 1877, both young and barely a foot long.

The example figured is $20 \frac{3}{4}$ inches long, and in the National Collection. It is said to attain to three-quarters of a cwt. in Cornwall (Cornish Fauna, p. 52). The largest recorded off our shores appears to be about $3 \frac{1}{3}$ feet long, but it sometimes reaches as much as 5 feet. The figure of the egg-purse is from one sent me by Mr. Dunn in March, 1882, and drawn half-size.

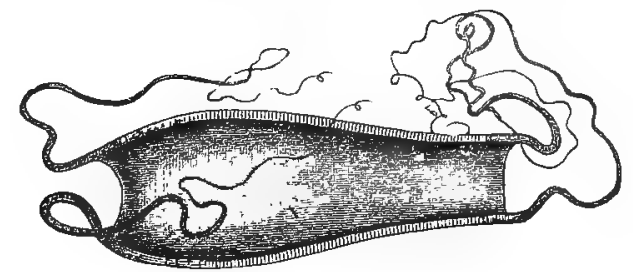

EGG C.ISE OF NURSE-HOUND. 


\section{Genus II-Pristidrus, Bonaparte.}

Spiracles present. Nostrils inferior, large, and covered by a valve. Snout elongated. Teeth small and tricuspid. Two spineless dorsal fins, the first above the hind end of the ventral, and the second above the hind end of the anal. One or two rows of small flat spines arranged like a saw, and reclining on each side of the upper edge of the caudal fin.

\section{Pristiurus melanostomus, Plate CLX, fig. 1.}

Squalus catulus, Günner, Trondth. Selsk. Skrift. ii, p. 249. Haae-gjäle, Ström, Söndm. i, p. 283. Rödhaae, Ascan. Ic. iv, p. 5, t. xxxviii. Squalus prionurus, Otto, Conspect. p. 5.

Galeus melastomus, Rafin. Caratt. p. 13.

Scyllium artedi, Risso, Eur. Mérid. iii, p. 117.

Syualus arnulatus, Nilss. Prod. p. 114.

Scylliorhinus delarochianus, Blainv. Fauna France, p. 74, pl. xviii, f. 2.

Scylliorhinus melanostomus, Bonap. Fasc. vii ; Blainv. 1. c. p. 75 , pl. xviii, f. 3.

Pristiurus melanostomus, Bonap. Fauna Ital. Pesc.; Müller and Henle, Plagios. p. 15, pl. vii ; Yarrell, Brit. Fishes (ed. 1) ij, p. 375, c. fig. (ed. 2) ii, p. 495, (ed. 3) ii, p. 479; Thompson, Nat. Hist. Ireland, iv, p. 250 ; Duméril, Icb. i, p. 325 ; Günther, Catal. viii, p. 406 ; Collett, Norges Fiske, p. 211 ; Malm, Fauna, p. 623; Winther, Prod. Dan. Mar. p. 58 ; Canestrini, Fauna d'Italia, Pesc. p. 50 ; Giglioli, Catal. Pesc. Ital. p. 52 ; Moreau, Poiss. de la France, i, p. 285, f. 37.

Pristidurus melanostomus, Bonap. Selach. tab. Anal. p. 11 ; Gray, Cat. Cart. Fish. p. 32; White, Catal. p. 124.

Scyllium annulatum, Nilss. Skand. Fauna, iv, p. 713.

Sicyllium melanostomum, Jenyns, Manual, p. 497; Kröyer, Danm. Fisk. iii, p. 832 , c. fig.

Pristiurus artedi, Bocage and Capello, Peix. Plagiost. p. 11.

Black-mouthed dog-fish, Couch, Fish. Brit. Isles, i, p. 18, pl. iii.

Body elongated, snout depressed and more than half the length of the head, which is flat on its dorsal surface. Eye-large. Spiracle placed just behind the orbit. Mouth arched, or rather angular, and sitnated below the eyes. A small labial fold round the angles of the mouth. Nostrils placed one-half nearer the mouth than to the end of the snout. Gill-openings rather narrow, the last close over the base of the pectoral fin. Teeth-in adults with one central and two lateral cusps on each side. Fins-pectoral large, its length equalling about that of the head, but not quite reaching the ventrals. Dorsal fins situated as described generically, the anterior being slightly longer than the posterior: anal rather long, commencing beneath the hind end of the first dorsal fin and terminating close to the caudal; this latter fin is well developed. Skin-rough, on the hand being passed from behind forwards. Colours-grayish-brown, becoming white on the sides and beneath. Three rows of elongated black spots, having a light outer edge, pass from the head along the sides, decreasing in number to one below the first dorsal fin; posterior to this are a few black blotches continued on to the caudal fin.

Names.-Black-mouthed, or eyed-dog-fish, terms referring to its colours.

Means of capture.-Couch refer's to two examples taken on hooks.

Breeding.-Embryo case (as figured by Yarrell) destitute of tendrils.

Habitat.-Seas of Europe, being common in the Mediterranean. West coast

of Scotland (Malcolm), one of two examples from there haring been sent to Yarrell. Off Banff Edward observes that he is led to believe that it occasionally occurs. One specimen, $25 \frac{3}{4}$ inches long, was taken at Polperro, in Cornwall, February 8th, 1834 .

Ireland.-Two specimens were obtained at Portrush, by Captain Portlock.

The figure in plate clx is from a male specimen, $18 \frac{1}{2}$ inches in length, in the

National Collection from Madeira ; that of the egg-case is reduced from Yarrell's "British Fishes." 


\section{FAMily $V$-SPINACID E.}

\section{Spiracles present. Gill-openings narrow. A deep groove along either side of the mouth. Two dorsal fins and no anal. \\ This family is divisible into two, the SPINACID , wherein each dorsal fin is preceded by a spine, and the SCYMND出, which have no spines. But in accord- ance with the plan heretofore adopted, I adhere to the nomenclature employed. in the National Collection.}

The British genera belonging to this family are as follows :-

\section{A. Each dorsal fin is preceded by a spine.}

1. Acanthias.-Teeth rather small, their points placed so obliquely that their inner margin, which is smooth, forms the cutting edge.

2. Centrina.-Body somewhat three-sided, with a fold of skin at each angle. Teeth in lower jaw triangular, erect and with finely serrated edges.

\section{B. No spine before either dorsal fin.}

3. Loemargus.-Teeth in upper jaw small and conical; those in the lower jaw in several rows, their points placed so obliquely that their inner margin, which is smooth, forms the cutting edge.

4. Echinorhinus.-Skin with irregularly placed round osseous tubercles. Teeth large, oblique, and several small cusps on each side of the main one.

\section{A. Each dorsal fin precented by a spine.}

\section{Gends I-Acanthias, Risso.}

Acanthorhinus, sp. Blainville: Eutoxychirus, Gill.

Spiracle wide and placed immediately behind the eye. Gill-openings narrow. Mouth somewhat arched; no labial fold to jaws, but an oblique groove on either side. No nictitating membrane to eye. Teeth of moderate size with smooth edges, and similar in both jaws; their points are placed obliquely, so that their inner edge becomes their cutting one. Each dorsal fin with a spine.

Geographical distribution. - The temperate seas of the northern and southern hemispheres.

\section{Acanthias vulgaris, Plate CLX, fig. 2.}

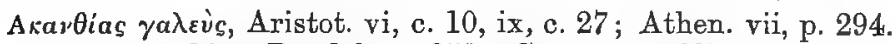

Galeus acanthias, Rondel.p. 373 ; Gesner, p. 607 ; Aldrov. p. 399 ; Jonson, lib. i, p. 27, t. viii, fig. 5; Willughby, lib. iii, p. 56, t. B5, f. 1 ; Ray, Synop. Pisc. p. 21 ; Klein, Mss. iii, p. 8, t. i, fig. 5, 6. Mustelus spinca, Belon. pp. 69, 70. Squalus, sp. Artedi, Genera, p. 66, no. 3, Synon, p. 94, no. 3 and Spec. p. 102 , no. 1 ; Gronov. Zooph. no. 149 and Mus. Ich. i, p. 61, no. 134. Piclied dog-fish, Pennant, Brit. Zool. (Ed. 1776) iii, p. 100, t. $\nabla$, fig. 11, and Picked shark (Ed. 1812) iii, p. 133 ; Low, Orkneys, p. 170 . Spinax, Duhamel, Pêch. iii, p. 299, pl. xx, f. 5. Squalus acanthias, Linn. Syst. Nat. p. 397 ; Bloch, t. Ixxxv; Gmel. Linn. p. 1500 ; Bonnaterre, Enc. Ich. p. 11, pl. v, fig. 12 ; Lacép. i, p. 270, pl. x, f. 2 ; Bl. Schn. p. 135 ; Donovan, Brit. Fish. iv, pl. lxxxii ; Turton, Brit. Fauna, p. 114; Risso, Ich. Nice, p. 40 ; Blainv. Fauna France, p. 57 ; Johnston, Berwick. Field Club, 1838, i, p. 176; Faber, Fische Isls. p. 29; Fries and Eks. Skand. Fisk. p. 187, t. xlvi; Gronov. ed Gray, p. 8.

Spinax acanthias, Cuv. Règ. Anim.; Bonap. Faun. Ital. Pesc. pl. cxxxix; Fleming, Brit. An. p. 166 ; Richards. Faun. Bor.-Amer. p. 291 ; Jenyns, Manual, p. 505; Templeton, M. N. Hist. 1837 (2) i, p. 413; Parnell, Wern. Mem. vii, p. 420; Swainson, Fishes, ii, p. 315 ; De Kay, New York Fauna, Fish. p. 359, pl. lxiv, fig. 210 ; Yarrell, Brit. Fish. (ed. 1) ii, p. 400, c. fig.; Ayres, Boston Journ. Nat. Hist. iv, p. 288 ; Thompson, Nat. Hist. Ireland, iv, p. 254 ; Schlegel, Dieren Neder. p. 192, pl. xviii, f. 3.

Acanthias vulgaris, Risso, Eur. Mérid. iii, p. 131 ; Müll. and Henle, p. 83 ; 
Schleg. Fauna Japon. Poiss. p. 304, pl. cxxxv; Yarrell, Brit. Fish. (ed. 2) ii, p. 524 (ed. 3) ii, p. 518; Gray, Chond. p. 70; White, Catal. p. 131; Kessler, Bull. Soc. Nat. Mosc. 1859, ii, p. 473; Kröyer, Danm. Fisk. iii, p. 868, c. fig.; Nilss. Skand. Faun. iv, p. 731; Duméril, Ich. i, p. 437; Bocage and Capello, Peix. Plagiost. p. 21 ; Günther, Catal. viii, p. 418; Collett, Norges Fiske, p. 211 ; Winther, Prod. Dan. Mar. p. 58 ; Canestrini, Fauna d'Italia, p. 39 ; Giglioli, Cat. Pesc. Ital. p. 52 ; Moreau, Poiss. de la France, i, p. 342, f. 58.

Spinar Fernandezianus, Guichen. in Gay's Chili, Zool. ii, p. 365.

Acanthias Americanus, Storer, Mem. Amer. Acad. ii, p. 506, ix, p. 232, pl. xxxviii, f. 1 and Proc. Bost. Soc. Nat. Hist. iii, p. 270.

Acanthias suchlii, Girard, Proc. Ac. Nat. Sc. Phil. 1854, p. 196 and U.S. Proc.

R. R. Exp. Fish. p. 368.

Acanthias Linnéi, Malm, Fauna, p. 624.

Picked-dog, Couch, Fish. Brit. Isles, i, p. 49, pl. xi.

Body elongated and somewhat rounded. Head flattened above. Spiracle rather large and placed a little behind the orbit. Eyes-large and situated nearly midway between the first gill-opening and the end of the snout. Mouth as long as it is broad at its base, rounded anteriorly, mouth arched, with a deep lateralgroove on either side. Nostrils on the ventral surface, and considerably nearer to the snout than to the front of the mouth. Teeth-in two rows similar in both jaws, flattened, with smooth edges, and their points placed obliquely, so that their inner edge is the cutting one. Gill-openings-rather narrow, the posterior one being situated just before the base of the pectoral fin. Fins-the first dorsal commences above the inner edge of the pectoral, it has a strong spine at its anterior edge which rather exceeds half the height of the fin: the second dorsal is placed above and just behind the termination of the ventral, its spine is somewhat larger and stronger than is that in the first dorsal fin, these spines are somewhat triangular and grooved along their posterior edge. Pectoral large if laid forward, reaching to the eye. Candal lobed, upper the longer. Skin rough if the hand is passed from behind forwards. Colours-grayish or brownish along the back and sides, becoming light or even white below the lateral-line : young examples have white spots sparsely scattered over them which mostly decrease or disappear with age.

Varieties.-Couch alludes to one that was intensely black all over except a line of dusky yellow that passed along the belly.

Monstrosities.- Yarrell mentions a young one with two heads, the separation continuing so far back as behind the pectoral fins. In another specimen the eyes were on the ventral surface of the head, before the mouth, and were not visible when the fish was laid on its belly.

Names-The name of this fish or " picked dog-fish" appears to be a corruption of "Piked dog-fish" as it seems to have been termed so late as in Low's time. The word "piked " or "spiked" being derived from the two sharp spines on its back, one placed before each dorsal fin. Common dog-fish: Spur-spear-or bonedog : Hoe (in Orkney) : Skittle-dog (male in Cornwall). Cu-maire, Celtic, or seadog in Firth of Forth, also Gobag or vivarach pronounced beerach (Gordon, Zool. p. 3488). Ci pigog, Picewd, Welsh. De Doornhaal, Ditch. L'Aiguillat, French.

Habits.--It is a gregarious fish which rambles through the seas for prey. Occasionally, says Low, it is in such shoals at the Orkneys that the fishermen load their boats to the water's edge, while it is the commonest shark around our shores. $R$. Couch says that in Cornwall "in winter it retires to deep water, and feeds near the ground: in summer it approaches the shores in multitudes." But $\mathrm{J}$. Couch also remarks that it is not affected by cold or heat in the severest seasons, and he has known them taken when, due to severe cold, every fish except a few stragglers of the cod family had retired to deeper water. Mr. Dunn observed in Land and Water, Dec. 4th, 1882, that the fishermen report that a fair season for pilchards has been nearly spoilt by the violent ravages of the picked-dog. These predatory vermin, in many instances, the moment the pilchards entered the net rushed on them by the thousand, and not only ate up every fish that had been meshed, but also the net itself, thus a great many of the boats have some nets 
entirely destroyed. In fact, often a part of the night had to be entirely given up to these creatures, and the work of catching fish suspended. At one time it was feared that the fishery would have to be abandoned by the entire fleet for the season. While some boats did leave the fishery grounds as the consequence, and bave not returned to it since. Last autumn these dogs were bad in their attacks on the fish and nets, but this year they seem to exceed everything known of them before. These creatures are very obnoxious to all the fisheries. Of late the herring fisheries of the other parts of the kingdom have been suffering from them. These pickeddogs have peculiar habits, and are not shy and fearful, like many other fishes, but by day or night will go anywhere and will attack anything for food, and I believe would congregate in millions around large quantities of fishy matter. Mr. Barber, writing from Mevagissey in the Field, Jan. 12th, 1884, observing upon the unsuccessful take of pilchards although there had never been larger shoals off the coast within living memory; continued, but the picked-dog surrounded them in untold numbers, destroying the fishermen's nets to an alarming extent, and the fishing had to a great extent to be abandoned. Only about 12,000 hogsheads of pilchards were secured during the season, about 4000 of which were taken at St. Ives. About ten years since (1875) they took possession of Mevagissey Bay for two months, during which period herring fishing had to be entirely suspended. Some fishermen at this period captured them with hook and line for manure, and Mr. Dunn has seen two men fill a boat in this manner in three hours.

In the Manchester Aquarium this fish was found to knock its head at nighttime against the rockwork of the tank until it lays the nasal cartilages bare: but placing a small light, enabling it to see and avoid the rocks, was found an effectual preventive remedy (Saville Kent).

When the mother has been killed the young have been observed swimming round her body, even so long as six hours, instead of going off.

Low observes that when caught it writhes itself across the fishermen's hands, often, if they are not attentive, wounding them very severely, which, if it happens in a part near a joint, is always dangerous and difficult to heal: the parts swell and become red and fiery endangering gangrene. As a consequence the fishermen always fear to be thus wounded, and when the fish is hooked and brought up they commonly rap it on the head.

Lowe (Fauna of Norfolk) is of opinjon that the accounts of how these fish inflict wounds with sagacity are imaginary. It is a very voracious form, and feeds on other fish which it hunts in companies.

Means of capture.-Baited hooks, but care has to be taken that the line is properly secured against being bitten through. W. Sinclair, writing from Drumbey, Donegal (Field, November 5th, 1881), observes that "for the last two months line-fishing has been an impossibility owing to the swarms of dogfishes which are in such numbers that no other fish can get near a bait." "I had on two No. 9 hooks tied on gimp, and the bait was sprats: at the end of fifty minutes one of my hooks was carried away, so we counted the spoil and found we had forty-five fish, average weight $3 \mathrm{lb}$. each." The Squalus acanthias, which in former times was in great abundance along the whole coast of Sweden from Gothenburg, afforded lucrative employment to the fishermen during the whole of the summer from the Naze to the North Cape, in the fjords, as well as along the coast. It is caught in various ways. About Midsummer it is observed to swim near the surface, and can be taken in nets as well as with lines, precaution being taken to protect the line by proper serving for a short distance beyond the hook, to prevent it being bitten off. This fish is eaten sometimes fresh, but skinned before being cooked. It is, however, mostly smoked, and in this way it is considered rather a delicacy. It is also dried and split like stockfish for consumption in the country, as well as for export to varions parts of Sweden, where it is generally appreciated. The yolk of the egg, which is about the size of a pigeon's egg, is used by the inhabitants as a substitute for other eggs in the domestic economy.

Breeding.-Through summer and autumn, or, as Mr. Dunn believes, in every month of the year. Thompson opened one captured December 28th, 1838, at Carrickfergus. It contained eight eggs of a roundish-oval form, from $1 \frac{1}{2}$ to 
$1 \frac{3}{4}$ inches long, and from this size numbers down to a mere speck. Also nine young, $9 \frac{1}{2}$ inches long each, in the oviduct, some of them so slightly aclhering that in a very short time they would have been extruded. Five were males and four females. Mr. Eagle Clarke (Sept. 26th, 1883) observes "the other day, I examined a young Acantlias vulgaris, which along with five others had been taken from the uterine cavity of a female specimen, captured off the Isle of Man about the middle of this month. This embryonic specimen was $9 \frac{1}{4}$ inches in length, a perfect miniature of the mature fish, and having the pikes well developed. From the anterior half of the beliy it was connected by an umbilical cord or tube, $1_{2}^{1}$ inches long, to an umbilical vesicle or yolk sac, about the size of a pigeon's egg. On the back it was pale blue-gray, spotted, especially above the lateral-line, with white spots: beneath it was white." Dr. Ball (Proc. Roy. Irish Acad. April 27th, 1846) describes the apparatus by which the mother is defended from laceration from the spines of her young. The spines of the fotus are of as hard and bony a consistence as in adults.

$U_{s e s .-O i l}$ in places (as the Orkneys) is made from the liver, while the skin used to be employed to polish wood, and the garbage makes excellent manure. Mitchell observes that the greater number taken at New York in December were females in a gravid state. Storer says they are so numerous about Cape Cod that they form in the spring and autumn an important fishery for the oil they furnish. They are true scavengers of the sea.

As food.-This fish is dried and eaten on many parts of our coasts ; it is rather strong tasted, but largely employed by the poor as food in the Hebrides, and sold as Daruin salmon. It is cut open and dried, and is so full of oil that it does not decompose. In the west of England it is a common article of food with the fishermen; it is used both fresh and salted. Also in Ireland it is consumed in some parts by fishermen.

Diseases, \&c.-Couch has taken this shark from the stomachs of ling, blue-sharks, and other fishes. In a healthy female example, heary with young, captured March, 1868, there was seen at the base, and clinging all round the spine of the second dorsal, a healthy growing specimen of the sea-hair coralline, Sertularia operculata (Cornish, Penzance, Zool. 1868, p. 1222).

In January, 1884, Mr. Dunn sent me from Mevagissey one of these fishes, 27 inches long, in which the entrails and flesh were entirely consumed, only the skin and skeleton remaining, and numerous isopods, Conilera cylindracea, which had caused this destruction. It appeared that the dog-fish had been captured in a mullet-net, which had been set to secure some smaller spotted dng-fish, of which as many as a hundred had been netted at one time, but every fish, except the smaller spotted dog-fishes and two picked-dogs, were consumed like the specimen sent to me.

Habitat.-This species has been recorded from the temperate seas of both the northern and southern hemispheres, but not from the intermediate localities. It is found in abundance all round the British coast, and especially so off Cornwall, where as many as two thousand have been taken at one time, and that without apparently diminishing the stock. Mr. Saxby remarks of this fish that at Newfoundland, during the last five or six years, it is thought to have been "cursed away" (Zool. 1871, p 2553). In the Orkneys and Shetlands very abundant (W. Baikie, Zool. 1853, p. 3846), and Pennant observes that it swarms on the coast of Scotland. Banffshire plentiful (Edward). In March, 1858, the newspapers reported a prodigious school of dog-fishes reaching westward to Uig, from whence it extended from twenty to thirty miles seawards, and in an unbroken phalanx eastward to Moray, Banff, and Aberdeen (Yarrell), at which latter place it is termed sea-dog (Sim). Often canght on the deep-sea lines of the fishermen at St. Andrew's (M'Intosh) : Berwickshire, very common (Johnston). Abundant off Yorkshire, and termed sea-dog (Yorkshire Vertebrata); also off Norfolk estuary and along the east coast; it is found in numbers at most of the fishing-stations along the south-eastern coast, round to Kent and Sussex (Yarrell). Very common off Devonshire (Parfit) and Cornwall. Swansea (Dillwyn).

In Ireland it is found around the coast.

It attains to at least 4 feet in length off our shores. The ore figured is a young specimen, 12 inches long, from the roast of Sussex. 


\section{Genus II-Centrina, Cuvier.}

\section{Oxynotus, Rafinesque.}

Spiracles wide and placed immediately behind the eye. Gill-openings narrow. Mouth narrow, with a deep lateral groove. No nictitating membrane to the eye. Teeth in lower jaw rather small, triangular, erect, and with their edges finely serrated. Those in the upper jaw in a group anteriorly and of a slender and conical form. Each dorsal fin with a strong spine arising at or behind the centre of its base. A fold of slin runs along either edge of the abdomen as well as along the back between the dorsal fins.

\section{Centrina salviani, Plate CLXI.}

Centrina, Rondel. p. 384; Salvian. p. 157 ; Gesner, De Aquat. p. 609 ; Aldrov. p. 401 ; Jonston, Pisc. lib. i, p. 28, t. vii, f. 4, 5 ; Willughby, lib. iii, p. 58, t. B2, and Bis; Ray, Synop. Pisc. p. 2l. Vulpecula, Belon. pp. 63, 64. Galeus centrina, Gesner, p. 1046. Squalus, sp. no. 5, Artedi, Synon. p. 95 and Genera, p. 67. Galeus, sp. no. 7, Klein, Mss. iii, p. 10.

Squalus centrina, Linn. Sjst. Nat. i, p. 398; Bloch, t. cxv; Grmel. Linn. p. 1502 ; Lacép. i, p. 276 , pl. ix, f. 3 ; Bonnaterre, Ency. Ich. p. 12, pl. v, f. 13 ; Shaw, Zool. v, pt. ii, p. 340, pl. cliii ; Bl. Schn. p. 134; Brünn. Pisc. Mass. p. 3 ; Risso, Ich. Nice, p. 4 .

Oxynotus centrina, Rafin. Ind. pp. 45, 60 ; Gray, Catal. Cart. Fish. p. 72 ; Gill, Anal. Syn. Squa. Ann. Lyc. N. York, vii, p. 405; Duméril, Ich. i, p. 444, pl. $\nabla$, f. 8,9 (scales).

Squalus (Acanthorhinus) centrina, Blainv. Faun. France, p. 61, t. xv, f. 1 .

Centrina salviani, Risso, Eur. Mérid. iii, p. 135 ; Bonap. Fauna Ital. Pesc. pl. cxli, f. 2 ; Müller and Henle, p. 87 ; Bocage and Capello, Peix. Plagiost. p. 32 ; Guichen. Explor. Sc. Algeria, Poiss. p. 126; Günther, Catal. viii, p. 417; Canestrini, Pesc. Ital. p. 41; Giglioli, Pesc. Ital. Catal. p. 52.

Centrina humantin, Cloquet, Dict. Sc. Nat. vii, p. 385, pl. xxxi.

Centrina oxynotus, Swainson, Fishes, ii, p. 315.

Centrina vulpecula, Moreau, Poiss. de la France, i, p. 355, f. 61.

Body somewhat triangular. Head flattened; snout short and obtuse. A bony ridge over the orbits. Eyes - rather large. Spiracles large, nearly triangular, and placed a short distance behind the orbit. Mouth small, with rather fleshy lips. Nostrils near to the end of the snout. Teeth-a single row of about nine flattened, erect, triangular teeth in the lower jaw, which have their edges serrated: those in the upper jaw slender, conical, and in a group anteriorly. Gill-openings-small. Fins - the first dorsal fin commences in the form of a ridge at the occuput and is higher than its base is long, a strong spine commences from behind the middle of its base and passing upwards emerges somewhat forwards near the upper third of the anterior edge of the $f n$ : second dorsal having its anterior portion above the ventral and a spine commencing behind the centre of its base, which passing upwards and somewhat backwards emerges near the upper third of the anterior edge of the fin. Caudal lobes not well developed. Along the back and at each angle of the abdomen is a keel of skin. Skin covered with somewhat rough scales. Colours - when just captured the Cornwall specimen was dark cinereous in blotches over the back and ot a light cinereous ou the belly; whereas now it is very dark brown. Name-La Humantin, French.

Habits.-Is supposed to inhabit great depths. As food-useless.

Habitat.-Mediterranean and coasts of Portugal, and the Bay of Biscay so far north as the mouth of the Loire (Moreau). A straggler in 1877 was obtained by Mr. Cornish off Cornwall where it was trawled in 26 fathoms-water near the Wolf lighthouse (Zool. 1877, p. 221). In Pontoppidan's "Natural History of Norway," this fish is figured plate ciii, as the Haae-karing, which is described at p. 115, and Bloch (Ich. pt. iii, p. 310) says it is termed Purk-Haae or Haa-kiaering in Norway. The example figured is 25 inches long, and in the collection of Sir J. St. Aubin. This fish is said to attain to 4 or 5 feet in length. 
B. Dorsal fins spineless.

Genus III-Lemargus, Müller and Henle.

Dalatias, Rafinesque. Scymnus, sp. Cuvier (1817). Somniosus, Lesueur, and Rhinoscymnus, Gill.

Spiracles present. Mouth transverse, with a deep groove at its angle. No nictitating membrane to eye. Teeth conical and in several rows in the upper jaw; flattiened, with smooth edges, and in about six rows in the lower jaw with the points so turned aside that the lateral margin forms the cutting edge. All the fins comparatively small : two spineless dorsals. Gill-openings narrow. Skin with fine tubercles.

Geographical distribution.-Northern seas, extending to temperate ones.

\section{Læmargus microcephalus, Plate CLXII, fig. 1.}

Squalus carcharias, Müll. Prod. Zool. Danm. p. 38 (not Linnæus). S'qualus microcephalus, Bl. Schn. p. 135.

Somniosus brevipinnis, Lesueur, Journ. Ac. Nat. Soc. Phil. 1818, i, p. 222 ; Storer, Rep. Fish. Mass. p. 189.

Squalus borealis, Scoresby, Arct. Reg. 1820, i, p. 538, pl. xv, f. 3, 4; Jenyns, Manual, p. 506.

Scymnus borealis, Flem. Brit. An. p. 166; Yarrell, Brit. Fish. (ed. 1) ii, p. 403 , c. fig. (ed. 2) ii, p. 527 ; Swainson, Fishes, ii, p. 315; Nilss. Skand. Fauna, iv, p. 724 ; Thompson, Nat. Hist. Ireland, iv, p. 255.

Scymnus glacialis, Faber, Fisch. Isl. p. 23 ; Nilss. Prod. Ich. Skand. p. 116.

Scymnus gunneri, Richards. Faun. Brit.-Amer. iii, p. 313.

Squalus norwegianus, Blainv. Fauna France, p. 61 ; Gronov. ed Gray, p. 8 (norvegicus).

Scymnus micropterus, Val. Nouv. Ann. Mus. 1832, i, p. 454, pl. xx.

Scymnus (Lœenargus) borealis, Müll. and Henle, p. 93.

Lamargus borealis, Bonap. Cat. Met. p. 16 ; Gaim. Voy. Gron. Poiss. pl. xxii ; Yarrell, 1. c. (ed. 3) ii, p. 524; Duméril, Ich. i, p. 455, pl. v, f. 1, 2 (teeth); Günther, Catal. viii, p. 427.

Leiodon echinatum, Wood, Proc. Bost. Soc. Nat. Hist. ii, p. 174.

Scymnus Urevipinna, De Kay, New York Fauna, Fish. p. 361, pl. lxi, f. 202 ; Storer, Mem. Amer. Acad. 1867, ix, p. 235, pl. xxxviii, f. 2.

Scymnus microcephalus, Kröyer, Danm. Fisk. iii, p. 914, c. fig.; Malmgren, Efv. Sven. Vet.-Ak. Förh. 1864-65, p. 536; Collett, Norges F'iske, p. 212; Winther, Prod. Dan. Mar. p. 59 ; Malm, Fauna, p, 626.

Dalatias microcephalus, Gray, Chond. Fish. p. 76 ; White, Catal. p. 132.

Laemargus brevipinna, Duméril, 1. c. p. 456, pl. $\nabla$, f. 3,4 ; Moreau, Poiss. de la France, i, p. 361, f. 63 .

Greenland shark, Couch, Fish. Brit. Isles, i, p. 57, pl. xiii.

The body is largest in circumference just behind the pectoral fin; the head is rather large, snout much smaller in circumference than is the head just behind it. Mouth transverse, arched, its angle being about midway between the end of the snout and the fourth gill-opening. Eye-small and placed above the angle of the mouth; spiracle some little distance behind and above the orbit. Nostril near the end of the snout. Gill-opening-small, the last being before the base of the pectoral fin. Teeth-rather narrow and conical in the upper jaw and in six or seven rows, in the lower jaw flattened, with the point turned aside, as described in the generic definition. In the skull of a specimen 14, feet long, from Aberdeen, there are three rows anteriorly, including the one in use in the upper jaw, but the lower of these rows is deficient opposite the symphysis.

* Preoccupicd in Crustacea by Fröyer. 
Internally there are six rows, consequently nine in all, while the number of teeth in each row is about 50, or about 450 teeth. Fins-first dorsal fin small and situated nearly midway between the end of the snout and the base of the caudal fin, and some distance in front of the ventral; second dorsal smaller than the first; it commences above the hind edge of the ventral. Pectoral and ventral small; candal but little developed. Slcin-the scutes end in curved spines, having a star-shaped base, which gives the fish a very rough feel when the band is passed from behind forwards. Colours-when first captured of a slaty-gray, darkest on the back, becoming lighter on the sides and beneath. Scattered white dots have been observed dispersed over the sides, and to be most characteristic of the young fish (as in large ones they appear to be absent), which are brown along the back, shading to gray or blue on the sides, but which soon fade to gray.*

Names.-Greenland shark, due to the locality where it was first observed.

Habits. - Of the habits of this shark in our own seas we know but little, but it would seem to be sluggish, judging from the size of its fins, while it appears to be a determined foe to the whale in the Arctic Ocean. For, as observed by Captain Scoresby (Arctic Regions), it bites and annoys it while living, and feeds on it when dead. It scoops hemispherical pieces out of its body nearly as big as a person's head, and continues scooping and gorging lump after lump, until the whole cavity of its belly is filled. It is so insensible to pain, that though it has been run through the body with a knife and escaped, yet after awhile he has seen it return to banquet again on the whale at the very spot where it received its wounds. In no instance had he ever heard of these sharks attacking human beings. When a whale is being cut up in the northern seas these sharks soon assemble around the vessel to eat the flesh. They are said to attack any carcases that come in their way. Mr. Brotherston, in an interesting paper upon one of these fish captured off Berwick, observes that in its stomach were a lump-sucker, Oyclopterus lumpus, in a partially digested state, which had been disgorged during transit, and the bones of several other fish, one of them about two feet in length. Elsewhere numerous fish have been taken from the stomach of this species of shark.

Means of capture.-Baited hooks, with a chain to the lower end of the line to preclude its being bitten through. Off Norway there are regular fisheries for this shark.

As food.-According to Crantz, it is eaten by the Icelanders and Norwegians but rejected by the Greenlanders.

Breeding.-Lütken (Vid. Medd. 1879-80, pp. 56-61) observes that the propagation of the $L$. microcephalus must be different from that of all other Selachians. While S. rostratus and Scymnus lichia are known to be viviparous in the ordinary way, this mode of generation is unknown in L. microcephalus. No fœtus of it is known, nor egg enclosed in a corneous egg-case, as seen in Scyllium, Raia, \&c., but merely a large number of great soft globular eggs, without any hard shell, in the abdomen of a "Haakal." It might have been supposed, from the earlier accounts of the anatomy of this shark, that these eggs were dropped into the abdomen, carried outwards through the pori abdominales, and fecundated after deposition, but the discovery of the oviducts now leaves it questionable whether fecundation takes place outside or inside the body. Anyhow the eggs are deposited without any solid covering in the soft mud at the bottom of the deep sea, and this fact agrees with the apparent want of any uterine dilatation, shell-secreting glands, \&c., in the uviducts of this great northern shark (Zool. Record, 1874).

Diseases.-The eye appears very subject to attacks of a peculiar parasite, Lerneopoda elongata, Grant, and which eventually occasions blindness.

Habitat.-Common in the Arctic Seas, and is frequently taken in the herring nets in Newfoundland (H. Saxby, Zool. 18/1, p. 2553). Occasional stragglers have been taken off our shores, and in 1832 one was captured in the estuary of the Seine. One has been recorded from the Orkneys (W. Baikie, Zool. 1853, p. 3846), and one, $13 \mathrm{ft}$. long, in 1824 was found dead at Barra Firth, Uist. Fleming recorded one in 1803 from the Pentland Firth. In May, 1849, one $13 \mathrm{ft.} 9 \mathrm{in.long}$ was 
taken off Troup Head, Banffshire (J. Smith, Zool. p. 3057). Buckland mentions one taken at Elgin. Mareh 2nd, 1870, one $11 \mathrm{ft} .2 \mathrm{in}$. long was captured at Aberdeen, and a second, December, $1880,14 \mathrm{ft}$. long and $6 \frac{1}{2} \mathrm{ft}$. in girth : one of these is now in the Aberdeen University Museum; on April 15th, 1882, a female, $14 \frac{1}{2} \mathrm{ft}$. long, was secured at the same place, the jaws of which were sent to me by Mr. Sim : it is occasionally caught off St. Andrew's Bay, near the estuary of the Forth (McIntosh) : May 5th, 1859, one $10 \mathrm{ft}$. long was taken in the Firth of Forth, entangled on a fishing.line (R. Brown, Zool. 1860, p. 6861); in 1874 a female was captured near the Bass Rock (Turner); and on April 12th, 1882, one $7 \frac{1}{2} \mathrm{ft}$. long was taken in or near the Firth of Forth and shown at the Edinburgh Fisheries Exhibition. A female $6 \frac{1}{2} \mathrm{ft}$. long was taken off Berwick, March 21st, 1877, and is now in the museum of that town (A. Brotherston). In April, 1840, one was captured off the Durham coast, and is now in the Durham Museum (J. Hutchinson). In 1868 one was taken at Newbiggin, and is in the Newcastle Museum, and in February, 1876, a second was captured at the same place (Wright, Trans. North. and Durh. Nat. Hist. Soc. iii, p. 340); two were captured off Scarborough in 1878 and sent to Oxford (Fauna of Yorkshire). In 1880, on March 4th, one, now in the museum, was taken at Whitby (Stephenson), and on April 6th, 1881, another. An immature specimen, caught at Sherringham, is in the Norwich

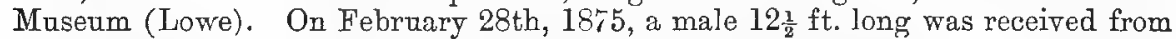
off Kessingland, Suffolk (T. Southwell, Zool. 1875, p. 4424). Mr. Cordeaux recorded two from the Dogger Bank in February, 1866, neither being under 12 or $14 \mathrm{ft}$. in length, a quantity of cod and ling were found in their stomacbs (Zool. p. 230). In Ireland Dr. Ball reported a specimen taken at Youghal which he considered to be this species, but Mr. More informs me that it is not.

The specimen figured is about $14_{2}^{2} \mathrm{ft}$. long, and in the National collection. It is said to attain to $25 \mathrm{ft}$. in length. 


\section{Genus IV-Ecnivoreinus, Blainville.}

Goniodus, Agassiz. Centrophorus, Swainson.

Spiracles present. Mouth crescentic, with a well-devcloped labial groove. No nictitating membrane to the eye. Teeth in both jaws flattened from side to side, with smooth cutting edges and with the points turning outwarls, and below which are two or more cusps. Two dorsal fins, both spineless and small, and siluated in the hind portion of the body, either opposite to or behind the ventrals. Pectoral and caudal but slightly developed and no pit at the base of the latter fin. Gill-openings of moderate width. Shin with scattered round or oval osseous tubercles of varying sizes, some of which have a spinate centre.

\section{Echinorhinus spinosus, Plate CLXII, fig. 2.}

Le chien de mer bouclé, Broussonet, Mem. de l'Acad. des Sci. 1780, p. 672.

Squalus spinosus, Gmel. Linn. p. 1500; Lacépède, i, p. 283, pl. iii, f. 2; Bl. Schn. p. 136 ; Risso, Ich. Nice, p. 42.

Squalus brucus, Bonnaterre, Ency Ich. p. 11.

Scymnus spinosus, Cuv. Règne Anim.; Risso, Eur. Mérid. iii, p. 136.

Echinorhinus spinosus, Blainville, Bull. Sci. 1816, p. 121, and Fauna France, p. 66; Bonap. Fauna Ital. Pesc. pl. cxxxviii ; Müller and Henle, p. 96, pl. lx (slin); Yarrell, Brit. Fish. (ed. 2) ii, p. 532, c. fig. (ed. 3) ii, p. 529; Strickland, An. Nat. Hist. 1840, iv, p. 315; Cocks, Ann. and Mag. Nat. Hist. 1850, v, p. 71 ; Costa, Fauna Nap. Chond. t. xvi; Gray, Chond. p. 78; White, Catal. p. 132 ; Duméril, Ich. i, p. 459; Günther, Catal. viii, p. 428; Canestrini, Fauna d'Ital. Pesc. p. 42 ; Moreau, Poiss. de la France, i, p. 363, f. 61, 65; Giglioli,. Pesc. Ital. Cat. p. 53.

Goniodus spinosus, Agassiz, Poiss. Foss. iii, t. E, f. 13.

Centrophorus spinosus, Swainson, Fishes, ii, p. 315.

Echinorhinus obesus, Smith, Ill. Zool. S. Africa, Pisc. pl. i.

Spinous shark, Couch, Fish. Brit. Isles, i, p. 54, pl. xii.

Considerable differences, perhaps due to age or condition, are apparcnt in this fish, some of which are more elongated than others, but all intermediate shapes appear to have been captured off our shores. The one figured is an elongated example. Yarrell figures both forms. Body fusiform with the dorsal and abdominal profiles nearly parallel. Gape of mouth wide, a deep pit above the angles. Eyes-oval, rather large and placed above and rather in front of the angle of the mouth. Spiracle small, situated a short distance behind the eye. Nostrils midway between the mouth and the end of the snout. Teeth-similar in both jaws, flattened from side to side with the upper edges smooth and cutting, and ending in a strong point laterally on either side and two or three cusps below it. There are several rows but only one in use at a time. Those figured (plate olxii, 2 a.) are from a specimen nearly seven feet long. Branchial openings rather wide, the first shortest and further from the second than the last two are apart, and all anterior to the pectoral fin. Fins-the pectoral rather small, and somewhat quadrangular. Ventral with rather an elongated base equalling the distance from the spiracle to the end of the snout, it commences midway between the front gill-opening and end of the candal fin in elongated forms; or anterior end of the snout and middle of the caudal fin as observed in the Plymouth and Aberdeen stouter specimens. First dorsal small and situated above the middle of the ventral, second dorsal of nearly similar size and midway between the first and base of the caudal fin, the latter badly developed and no pit at its base. S7inirregularly studded with rounded and flattened button-shaped bony scales, many of which have a spine, often broken, rising from the centre and with radiated bases somewhat similar to what is seen in the thornback and other rays; some of these spines are straight, others curved, and though most are directed backwards, some look downwards and a few forwards. In some places many coalesce 
togetber, while their size is very varied; some are seen on the fins. Risso observes that there are fewer spines in the female than in the male. Lateral-linewith marks of small tubes and quite white. T'he colours of a specimen taken in 1867, when fresh, were as follows:-Deep gray darkest along the back; a few patches of pale reddish on the sides, brown along the belly, a defined line of separation running between the sides and the belly from the ventrals towards and obliquely upwards to the pectorals. In Dr. Smith's specimen from the Cape Seas, the belly was pale copper - -yellow clouded with purple and brownish tints and marked with blotches of verinilion red. Mr. Cornish suggests "whether there are not two permanent varieties, one a ground shark, the other a round or swimming fish."

Names.-Spinous shark, dne to the spines over its budy.

Habits.-Although this shark is not a common visitor, it can scarcely be considered rare off our south coast, and judging from the instances recorded would appear to be present at any season of the year, while it has heen mostly captured by baits while swimming near the bottom. The specimen trawled off Brixham in $18: 37$ had a portion of a gurnard in its stomach. Mr. Fox found in one, in 1835, no fishes but the remains of crustacea.

Habitat. - This species of shark is widely distributed; in fact, from the North Sea and the Atlantic to the Cape of Good Hope, also in the Mediterranean.

In 1851 a dead one was cast ashore at Gamrie, in the Moray Firth (Smith, Zool. p. 3057); July, 1875, one was secured off the river Ythan, and is now in the University Museum at Aberieen; on August 31st, 1883, a female 6 feet $8 \frac{3}{4}$ inches long, and in whose stomach were the rewains of fish, was taken in a trawl at Stains, 14 miles north of Aberdeen; in 1874 a female from near the Bass Rock (Turner, Journ. Anat. and Phys. 1875, p. 297); in July, 1876, a female, about 6 feet long, got entangled in a salmon net at the mouth of the Tyne, and made great havoc with the meshes, its spiny tubercles cutting and tearing them to pieces; this specimen is now in the Newcastle Museum; another was taken at the same place in 186! (Trans. North. and Durham Nat. Hist. Soc. v, p. :342). A stuffed specimen, $4 \frac{1}{2}$ fect long, is in the Edinburgh Museum of Science and Art. One was taken off Yorkshire prior to 1828 , and a second in the summer of 1830 in Filey Bay (Yarrell), and on August 11th, 1838, a third in Bridlington Bay (Strickland, Rep. Brit. Ass. 1838, p. 1U7), and in June, 1853, a fourth at Scarborough (Murray, Morris Nat. 1853, p. 275). MLr. Gatcombe remarked that one $6 \frac{1}{2}$ feet long was captured in a trawl off Plymouth, January 25th, 1877, and in its stomach were four picked dog-fish; this, he observed, was the third taken off Plymouth in eight jear's (Zool. p. 108). In Couch's journal it is stated, on the authority of $\mathrm{Mr}$. Gatcombe, that the female spinous shark in the museum at Plymonth, $7 \frac{1}{2}$ feet long, was captured near Land's End in July, 1866 ; nothing was found in its stomach. In November, 1837, one was trawled off Brixham; also on November 9th, 1838, one was taken on a line off Berryhead, in Deronshire (Holdsworth); one was trawled off Brixham, March, 1872, 5 feet 3 inches long (Parfitt); and on December 6th, 1819, another, 81 feet long, in a trawl off Falmouth Harbour (W. Cocks); November 7th, 1867, a female, 7 $\frac{1}{2}$ feet long, taken on a line at Polperro, it had nothing in its stomach; a female, 9 feet long, containing 17 eggs, was talken on a conger line January 1st, 1869, off the Eddystone, inside it were several dog-fishes, some 3 feet in length. Mr. Fox obtained one $5 \frac{1}{2}$ feet long, taken about a mile from land, near Halford, in Cornwall (Couch); on June 2nd, 1881, one, 6 feet long, was caught 16 miles off the Deadmans on a hook and line when fishing near the bottom for congers. The bait used was a piece of mackerel; the creature showed considerable violence before capture, and after being taken into the boat it took a deal of mauling before the hook could be extracted, when it was thrown aside and left for dead; ten hours after, on being landed, it was found to be still alive. Mr. Cornish has likewise recorded the five following:-December 15th, 1865, one 6 feet 2 inches long, and having two lar'e lobes of milt, in 10 or 12 fathoms water, and on a shingly bottom, in Mount 's Bay, Cornwall, taken with a conger bait, while in its strmach wel' a grey gurnard and portions of other fish (Zool. 1866, p. 102). On 
September 7th, 1870, a second, 8 feet long, also taken with hook and line, about one mile off shore, and on about the same spot as the previous specimen (Zool. 1870 , p. 2347), and a third on May 17th, 1875, 5 feet 1 inch long, when he observes " this is the third that I have seen, and it confirms my opinion that there is a spinous ground shark and a spinous swimming shark ; it was caught on a hook and line, and the man who took it asserted he took one 7 feet long earlier in the year, and observed that the spines of the fins of the two sharks were phosphorescent after night, even when the fish was fresh" (Zool. 1875, p. 4501). On January 17th, 1877, a fourth, 8 feet long, also in Mount's Bay, captured on a hook and line (Zool. p. 108). A fifth on December 12th, 1881, 8 feet 4 inches long, with hook and line, also in Mount's Bay, in about 14 fathoms of water (Zool. 1882, p. 22). July 23rd, 1836, one was taken near Land's End (Yarrell). Mr. More has recorded one from Ireland, captured September 25th, 1882, near Skerries, about 15 miles to the north of Dublin (Zool. 1882, p. 424).

The specimen figured is $7 \frac{1}{2}$ feet long, stuffed and in the National Collection; the teeth $(2 a)$ and skin $(2 b)$ are from the Aberdeen example, and were sent me by Mr. Sim. The largest British specimen I can find recorded is one 9 feet long, taken off the Eddystone in 1869. Couch's figure is from one $8 \frac{1}{2}$ feet long, obtained by Mr. Cocks at Falmouth. Risso mentions one from the Mediterranean which weighed $400 \mathrm{lbs}$. 


\section{FAMILY VI-RHINID Æ.}

Spiracles large. Gill-openings wide, lateral, and partly concealed from above by the pectoral fins. Body flat. Month anterior. Nostrils situated at the front edge of the snout and with skinny valvular coverings. Pectoral fins large and laterally expanded but not attached to the head. Dorsal fins spineless, situated in the caudal region of the body: no anal. Males with claspers.

Squatina, Duméril.

Genus I-RHina, Klein.

Definition as in the family. Spiracles a short distance behind the eyes. Teeth conical, and placed at some distance asuncler.

The angel-fish of our coasts, although evidently one of the shark family, in form more nearly approaches the rays and skates.

Geographical distribution. -Throughout the temperate and tropical seas.

\section{Rhina squatina, Plate CLXIII.}

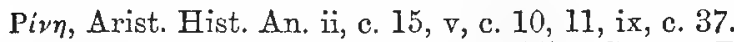

Squatina, Belon. p. 78 ; Rondel. p. 367 ; Gesner, De Aquat. p. 899 ; Salvian. p. 152, f. 53; Aldrov. iii, p. 472; Jonston, p. 39, t. xi, f. 7; Willughby, p. 79, t. D3; Ray, p. 26; Rutty, i, p. 349. Squalus, sp. Artedi, Gen. p. 67, no. 6, Synon. p. 95, no. 6; Gronov. Zooph. no. 151, p. 34. Likina, Klein, Pisc. Miss. iii, p. 14, sp. 1, t. ii, f. 5, 6. Angel fish (Squalus Rondeletii), Borlase, Cornwall, p. 265, t. xxvi, f. 5; Pennant, Brit. Zool. (Ed. 1776) iii, p. 98, pl. xii, and Angel sharh (Ed. 1812) iii, p. 130, pl. xv. Squatine, Duhamel, Pếch. ix, iii, p. 291, pl. xiv, f. 1-4.

Squalus squatina, Linn. i, p. 398 ; Brünn. Ich. Mass. p. 5; Gmel. Linn. p. 1503; Bloch, Ich. p. 811 , t. cxvi ; Bonnaterre, Enc. Ich. p. 12, pl. v, f. 14 ; Lacép. i, p. 293, pl. xii; f. 1; Bl. Sclin. p. 137; Donovan, Brit. Fish. i, pl. xvii ; Turton, Brit. Fauna. p. 114; Shaw, Nat. Misc. xxi, pl. 906.

Squatina loevis and aculeata, Cov. Règne Anim.; Lesueur, J. A. Sc. Phil. i, t. 1, Squatina vulgaris, Risso, Ich. Nicc, p. 45; Flem. p. 169; Müll. and Henle, p. 99, pl. xxxv, f. 4 (snout) ; Kröyer, Danm. Fisk. iii, p. 935 ; Gray, Cut. Chond. p. 79; Schlegel, Fauna Japon. Pisc. p. 305, pl. cxxxvi; White, Catal. p. 133; Shaw, Gen. Zool. t. clv.

Śquatina angelus, Duméril, Zool. An. p. 102 ; Blainv. p. 53, pl. xiii, f. 1, 2; Risso, Eur. Mérid. iii, p. 139; Jenyns, Manual, p. 507 ; Bonap. Faun. d'Ital. Pese. iii, p. 147, t. f. I; Yarrell, Brit. Fishes (ed. 1) ii, p. 407, c. fig. (ed. 2) ii, p. 539 (ed. 3) ii, p. 536 ; Templeton, Mr. N. H. 1837 (2) i, p. 417; Parnell, Wern. ILem. vii, p. 42 l; Thompson, N. H. Ireland, iv, p. 255 ; Gronov. ed Gray, p. 14; Schlegel, Dieren Neder. p. 195, pl. xix, f. 1; Canestrini, Fauna Ital. Pesc. p. 51 ; Morcau, Poiss. de la France, i, p. 369, f. 66.

Squatina europea, Swainson, Fish. ii, p. 321 .

S'quatina lcevis, Couch, Linn. Traus. xiv, p. 90.

Squatina dumerilii, Lesueur, J. A. N. Sc. Phil. i, p. 225, pl. x ; De Kay, New

York Fauna, Fish. p. 363, pl. lxii, fig. 203; Leidy, J. A. N. S. Phil. 18-47, p. 247. Squatina fimluricta, Müll. and Henle, pp. 101, 192, pl. xxxv (snout).

Strutina oculata, Bonap. l. c.

S'quatina japonica, Blecker, Act. Soc. Sc. Ind. Neerl. iii, Japan, iv, p. 40.

Thina squatina, Raf. Iud. p. 45 ; Duméril, Ich. i, p. 464, pl. v, f. 5 (scales);

Günther, Catal. viii, p. 430; Winther, Ich. Dan. Mar. p. 59 ; Giglioli, Cat. Pusc. 1tal. p. 53.

Iilina aculeata, Duméril, 1. c. p. 465, pl. v, f. 7 (scales).

Thina californica, Ayres, l'roc. Calif. Ac. Nat. Sc. Phil. 1859, p. 29, 1860, f. 7. 
Rhina dumerilii, Gill, Cat. Fish. E. C. N. Amer. p. 61 ; Duméril, l. c. p. 467, pl. $\nabla$, f. 6 (scales).

Monk-fish, Couch, Fish. Brit. Isles, i, p. 73, pl. xvii.

Body broad and flattened horizontally. The width of the disk somewhat exceeds its length. Vent about midway between the anterior extremity of the snout and the posterior end of the caudal fin. Eyes-very wide apart. Spiracles wide, somewhat crescentic in shape and about one diameter of the orbit behind the eyes. Mouth wide and anterior. Nostrils with a skinny flap and barbel-like prolongations. Teeth-conical, sharp, and laterally at some distance apart but in several rows. Fins - the two dorsals are of nearly the same size. Caudal lobed, the lower somewhat the longer. Slin-that of the upper surface with fine asperities and a row of rather enlarged ones, approaching to spines, along the median line of the back. Male claspers small and weak. Colours-brownishgray, with dark blotches and whitish but irregular lines and spots. Fins-mostly light-edged. The colour of this fish is subject to variation, dependant upon the nature of the ground on which it lives, while the sexes also show a little difference.

Varieties.-Besides those of colour, the eye in some specimens is larger than in others as S. oculata, etc.

Names.-Angel-fish, due to its pectoral fins resombling wing. Monk-fish, from the fancied appearance of a cowl on its head. Shark-ray, from its relationship to both families. Fiddle-fish, from its shape. Puppy-fish; Sea-devit, Cornwall. Kingston, Kent and Sussex. Mongrel-slcate, Firth of Forth. Maelgi, Welsh. De Zee-ëngel, Dutch. L'ange, French.

Habits.-A very voracious ground-feeder, which arrives off our coasts from the deep sea during the spring months, and is especially partial to flat-fishes, to obtain which it conceals itself in the sand or mud. While swimming it does so by a powerful sculling action of its oar-like tail, and not by the aid of its pectoral fins as in the rays. It is said to have a strong ammoniacal odour. Thompson found in the stomach of one, a female, several dabs and plaice, five of which were nearly whole and had been from $5 \frac{1}{3}$ to $8 \frac{1}{2}$ inches long, portions of other fish, scales of mullet, not less than fifty eyes of other fish, and a bundle of Zostera marina about 4 inches long and 3 broad. On July 14th, 1881, some fishermen visiting their crab pots near St. Austin's Cove saw a cormorant splashing in the water, and on using a gaff secured an Angel-fish abont three feet long which had seized the bird by the wing and then held it under water (Field, July 23rd, 1881). Couch found in one, which was $4 \frac{1}{2}$ feet long, twenty-eight opercula of whelks, fragments of small fishes, and two stones about the size of nutmegs. Pennant mentions how a fisherman was severely bitten in the leg by one he was removing from his net.

Means of capture. - Frequently trawled or taken in trammels and seine nets, or. on the long lines set for rays and ground fish.

Breeding.-Buckland mentions having received in August, 1880, from Yarmouth one of these fishes in which there "were several eggs with soft skins like crocodile eggs." Couch observes that it brings forth about twenty-five young at a birth, and upon having found the eggs about the size of walnuts in May and the young expelled about July. Bloch asserts that it produced in the spring and autumn from seven to eight young.

As food.-Willughby says its flesh is hard and unsavoury; Dillwyn that from the coarseness and rankness of its flesh he has found evidence for nearly a century to show that it has only been purchased at Swansea by the poor, and rarely sold for more than $\frac{1}{2} d$ a pound; but Rutty states that the French had a way of dressing them, and to this day they are seen in the Dieppe markets.

Uses. -Off Cornwall it is taken in trammels by the crabbers for bait. Elsewhere it is mostly employed for manure; formerly its skin, which is rough, was used for polishing wood and ivory as well as covering the hilts of swords, instrument cases, and sheaths for knives. Its eggs in times gone by were dried and used medicinally, while its skin was also dried and when powdered prescribed for itch and other skin diseases. 
Habitat.-Both sides of the North Atlantic, while specimens from the Mediterranean, Golden Horn, Lanzarote, Japan, Surinam, Sydney, Georgetown, Van Diemen's Land, and California are in the National collection. Rare in the Orkneys and Shetlands (W. Baikie, Zool. 1853, p. 3845) : sometimes procured in Banffshire, where a large example was cast ashore during the winter of 1851 (Edward): Aberdeen, January 20th, 1883 (G. Sim) : Firth of Forth, two small examples taken on hooks, but it is generally rare on the east coast of Scotland (Parnell): in the Firth of Clyde it is by no means uncommon, and is frequently found there after gales; one was harpooned while asleep, but broke away (A. Norman, Zool. $x v, 1857$, p. 5366). In fact it is common in the North Sea and British Channel. Occasionally taken off Yorkshire, and is common on the Dogger Bank (Yorkshire Vertebrata) - two captured at Yarmouth since 1817 (Paget), and one 4 feet long in the Norfolk Estuary in 1865 (Lowe) : taken on the coasts of Kent and Sussex (Parnell), Hampshire (Yarrell), and common at all times along the south coast (Parfitt). At Teignmouth I counted one day last autumn twenty-six lying on the beach, left there as useless, having been dragged ashore in the seine net. Common in Cornwall, and found off Swansea (Dillwyn).

In Ireland Thompson states it to be of rare occurrence from north to south: he notices five from Belfast Bay, the longest of which was 5 feet 4 inches. Templeton asserts it to be often taken, and Rutty states it to have been frequent in the county of Cork. In the county of Dublin it is often met with among rays and skates, and monsters are sometimes exhibited (Blake-Knox, Zool. 1866, p. 509) : has also been taken off Waterford (Ball) and Kerry (Smith).

The one figured is from a specimen about 12 inches long from Teignmouth. It is said to attain to 8 feet in length. 


\section{Group II-Batoidei.}

Spiracles present: gill-openings in five pairs, and on the ventral surface of the body. Body depressed, forming (due to largely-dereloped pectoral fins) a more or less flat disk, and having usually a slender and elongated tail. Dorsal fins, when present, on the tail : anal absent.

Rays and skates exist in considerable numbers in the seas around our coasts, and some attain to a large size. Their skins, used for shagreen, are considered superior to those of sharks, owing to the scales being of somewhat larger dimensions. The horny case which encloses the fotal ray are more square in form than what are observed in sharks, while the projections at the corners are wanting in the long tendrils. In August, 1881, I observed an old man at the Barbican at Plymouth removing the livers from rays and skates, from which be extracted the oil, which he stated to be much used by shoemakers, especially in the manufacture of cobbler's wax. It is also employed for boats, and a variety of other purposes.

\section{Synopsis of Families.}

I. Torpedinide.-Trunk a broad smooth disk. Generally both dorsal and caudal fins. An electric organ. Page 330.

II. RAIIDE.-Trunk a broad and generally rough disk. Pectoral fins extend on to the snout. A fold of skin along either side of the tail; no serrated caudal spine. No electric organ. Page 334.

III. Trygonider.-Pectoral fins extend on to and are confluent at the snont. No fold along the side of the tail, which latter is usually armed with a serrated spine. Page 350 .

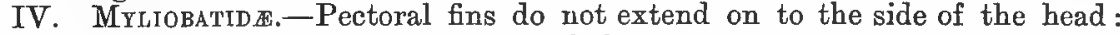
snout with a detached pair of fins. Page 352.

Montagu (Wern. Mem. 1815) observed upon how the colours of these fish vary, and how sexual distinctions had been overlooked. The males are provided with claspers, "a most curious structure, hanging pendant one on each side of the tail, between it and the anal fins; the testes are enclosed at the base of these, not obvious but by dissection. What accompanies this truly masculine distinction is a series of large, reclined, hooked spines, never to be found in the other sex, and which begin to show themselves early in all the species hitherto examined. These are placed in four distinct series, one on each shoulder or fore-part of the wing or pectoral fin, and one at each angle of the wing." They lie with their points reclined inwards in two, three, and sometimes four parallel lines, the number in each row being dependant on age. They may be developed during the breeding season, at which period, observes Darwin, * they are brought into use for prehensile purposes, by doubling inwards and downwards the two sides of the body. In some species, as Raia clavata, the females have their backs studded with large, hook-formed spines. The teeth of the different sexes usually show considerable differences.

$$
\text { * "Descent of Man," p. } 331 .
$$




\title{
FAMILY. VII-TORPEDINID AE.
}

\author{
Trunk broad and disk smooth. Anterior nasal valves confluent and forming a \\ quadrangular flap. Tail with a rayed dorsal (except in Temera) and caudal fin, \\ also a longitudinal cutaneous fold along either side. An electric organ situated \\ between the pectoral fin and the head.
}

The electric organs of these rays are somewhat kidney-shaped, one being placed on either side of the body, occupying its thickness, and circumscribed by the pectoral fin, the head, and the gill cavity. They are comprised of many hexagonal or pentagonal prisms, each of which is divided into cells by transverse membraneous subdivisions, and these cells contain a trembling, jelly-like, fluid substance. These prisms are placed perpendicularly to the dorsal and ventral surfaces of the fish. Each electric orginn receives a large branch of the fifth pair of nerves, and four branches of the vagus division of the eighth pair. It has been asserted that when a shock is given it moves its pectoral fins convulsively, that the convex part of the upper surface becomes gradually depressed, and subsequently the convexity suddenly returns. Should the torpedo be on a metallic plate, so that its ventral surface touches the metal, the hand which supports the plate does not feel any shock, even although another insulated person may excite the animal. By passing the discharge through a spiral of copper wire enclosing a steel needlc, the needle becomes magnetized in such a manner as to show the direction of the current to be from the dorsal to the ventral surface.

The electrical powers of this fish diminish as its strength decreases, while the presence of this property does not deteriorate from the use of its flesh as food; in fact, in the time of Galen, its flesh was recommended to be eaten by epileptic persons, who were likewise to have shocks from the living fish applied to their heads. Even prior to this time, Dioscorides had recommended its external application for pains in the head. In more recent times persons suffering from gout were advised to place the affected part on one of these fish, and keep it there until the numbness exteuded as high up as the knee. This electric power serves to assist these fishes in obtaining food, as they benumb their prey; while the same power protects them from their enemies. Plutarch mentions that their numbing influence has been known to pass from the net to the fisherman's arms; and Pliny that it can be conveyed along a stick or other substance.

An old writer (quoted in the "Anglers' Note Book," p. 151) remarked that " Elianus affyrmeth, that he who dippeth his hande into licor of Cyrenaicum doth turn to nought the power of the Torpedo, and may touch him unharmed."

These fish are said to be sluggish, and conceal themsclves in sand and mud, where they lic in wait for passing prey. But little is known of their habits.

\section{Genus I-Torpedo, Duméril.}

Narcobatis, Blainville: Narcacion, Bleeker.

Disk distinct from the tail, which has a lateral cutaneous fold along either side. Spiracles a short distance behind the eyes. Nasal valves confluent, forming a quarrangular flat. Teeth small, conical, and pointed. Turo dorsal fins on the tail purtion of the body, and both destitute of spines. Caudal fin well developed. An clectric organ situated between the pectoral fin and the head. S7in smooth, and clestitute of spines.

Although Pennant figures and describes Torpedo marmorata as the only British form, he does not distinctly stato whether his spccimen was not one brought by Walsh from France. It is true he alludes to two British examples, but it is 
questionable whether he figured or described from one. He observes that Torpedoes are frequently taken off Torbay, once off Pembroke, and, according to Smith, near Waterford in Ireland. Montagu (Mss.) refers to one which was small, captured at Torcross in Devonshire; and another, about $100 \mathrm{lb}$. weight, at Tenby in Wales; but it is doubtful to what form he alluded.

Although two British species have been thus recognized, I have been unable to obtain positivo proof that $T$. marmorata has ever been obtained off our coast.

1. Torpedo nobiliana.-Spiracles not fringed at their margins. First dorsal fin placed behind root of ventral, and much larger than second dorsal.

2. Torpedo marmorata. - Spiracles fringed at their margins. First dorsal fin, with its first half opposite the root of ventral, and only a little larger than the second dorsal.

Professor Fritsch exhibited at the Physiological Society of Berlin (1883) specimens of the development of these fishes, showing that they possess a squaliform stage, a raiiform stage, and a torpediform stage. He remarked that the electric organ is developed from muscle, and indeed from the outer gill-muscles of the fifth gill-arch. The gill-arch muscle, which develops in rays and sharks into the powerful lower-jaw muscle, is wanting, and in its place is the electric organ. In plate clxv I have shown the external and deciduous gills of a fotal torpedo.

\section{Torpedo nobiliana, Plate CLXIV.}

2. Torpedo nobiliana, Bonap. Faun. Ital. Pesc. pl. cliv; Müller and Henle, p. 128; Yarrell, Brit. Fish. (ed. 2) ii, p. 546, c. fig. (ed. 3) ii, p. 544; Gray, Chond. p. 100; White, Catal. p. 135 ; Duméril, Ich. i, p. 512 ; Canest. Fauna Ital. Pesc. p. 53 ; Giglioli, Cat. Pesc. Ital. p 53; Moreau, Poissons de la France, i, p. 386.

Torpedo Walshii, Thompson, An. Nat. Hist. 1840, v, p. 292, and Nat. Hist. Ireland, iv, p. 256.

Torpedo hebetans, Lowe, Trans. Zool. Soc. ii (1841), p. 195 ; Günther, Catal. viii, p. 449.

Torpedo emarginata, McCoy, Ann. Nat. Hist. 1841, vi, p. 407.

Torpedo nigra, Guichen. Expl. Algér. Poiss. p. 131, pl. viii.

Torpedo, Couch, Fish. Brit. Isles, i, p. 119, pl. xxx.

The breadth of this species is about two-thirds of its entire length. Eyessmall. Mouth crescentic. Spiracles kidney shaped or oval, and having smooth edges and situated a short distance behind the eyes. Fins-the first dorsal, which is nearly twice as large as the second, commences above the last portion of the ventral fin; the interspace between the first and second dorsal is short. CaudaI fin well developed. Skin smooth. Colours-dull reddish gray or of a dull ash above, dashed with purple, and white below; sometimes there are one or more ill-defined blotches on the dorsal surface.

Ball observed that should a Torpedo die in a state of spasm he thinks it would present the form which has been named $T$. emarginata, but which when flaccid is this species.

Names.-Torpedo, cramp- or numb-fish, electric ray. New British Torpedo, Yarrell. Swrthbysg, Welsh.

Habits.-Most of such as have been ascertained have been already referred to. It inhabits flat sands or muddy places at from 20 to 40 fathoms in dejth. Some investigators have observed that it dics soon after removal from the water, while others have recorded it living at least 24 hours. Mr. Wilson, of Stockton-on-Tees (Land and Water, January 9th, 1869), found in one of these fishes an eel $2 \mathrm{lb}$. and a flounder nearly $1 \mathrm{lb}$; in another a salmon between $4 \mathrm{lb}$. and $5 \mathrm{lb}$., and none of these fish had any blemish, so they were probably killed by an electric current. A red mullet and a plaice have been found in the stomach of one of them. Mr. Harvey recorded (Proc. Zool. Soc. 1836, p. 109) that part of a small spotted dogfish was hanging from the mouth of one captured at Teignmouth.

Means of capture.-Cornish (Zool. 1875, p. 4500) mentions one taken on a ginged hooked (one in which the line for about six inches from the hook is closely whipped with copper wire), as the captor got the ginged part of the hook in his 
right hand he felt his hand give way, he then caught the line with his left hand and attempted to lift the fish into the boat with his right, which now tingled up to his wrist. When removing the hook both hands, which touched the wired portions of the line, tingled. Inside it was a gray gurnard uninjured. Pennant, Montagu and Cornish have each known of single instances of these fish taking a bait.

Breeding.-Four to fourteen ova a season (Owen).

Habitat.-Coasts of Great Britain and the Atlantic, certainly so far south as Madeira, also the Mediterranean. In January, 1884, one was trawled off Lybster which weighed $13 \mathrm{lb}$. and was 28 inches long and $19 \frac{1}{2}$ inches across. It was sent to the Edinburgh Museum (Professor Archer, Mss.). One was taken off Banffshire, near Cullen, in 1817, and others are stated to have been caught (Edward). Two were recorded from Stockton-on-Tees (J. Wilson, L. and W. 1869), and on April 14th, 1862, one 29 inches long was secured from among the breakers on the beach at E'ssington in Yorkshire (W. Eagle-Clarke, Zool. p. 193), while a second was cast ashore in April, 1863. From inquiries which I have made along the south coast, I have reason to believe that the torpedo is frequently taken by trawlers, but is usually cut up for bait. While enumerating every specimen known to have been captured would occupy too much space, Couch alludes to five taken in one year in Monnt's Bay, and two or three which came under Mr. Cock's observation at Falmouth, as well as one obtained by Mr. Allen Thompson at Weymouth. Yarrell, in September, 1808, received two from the coast of Devonshire; one was large, and had been captured in a trawl net. On October 28th, 1879 , a female was taken at Beer in the same county ; it was 2 feet $9 \frac{1}{2}$ inches long and $20 \frac{1}{4}$ inches across (D'Urban, Zool. p. 491). July 20th, 1865, one 25 lb. weight was captured at Dudleigh Salterton, and although the fisherman only touched it with one finger, he received a severe shock, and his arm was left quivering for ten minutes (Watkins, Hardw. Sc. Gossip, p. 236). A specimen from Plymouth was in the National collection, and Couch's example, which was a female 30 inches long, came from the same locality. In August, 1873, one was taken in a trawl between the Lizard and Land's End (J. Cornish, Zool. p. 4500), a second near Penzance, in twenty fathoms water, which was 3 feet long and 2 feet 2 inches wide. It weighed $33 \mathrm{lb}$, and was caught on a hook and line. In July, 1881, one was taken at Falmouth. On August 6th and 10th one each day at Penzance. September 29th, one at St. Ives, and in August one at Polperro and two at Mevagissey, from which last place Mr. Dunn has several times reported its capture. In the Cornish Fauna it is stated not to be uncommon in Cornwall, but is rarely observed because most fishermen cut it away as soon as they see it. A male was taken at the weir at Swansea, July 17th, 1840, and five or six young are said to be annually captured there (Dillwyn).

In Ireland, in 1740, one (or possibly a Trygon) was taken off Dungannon, Waterford (Dr. Smith), and Templeton records that since then he had known of a few specimens being caught. It is rare in Dublin Bay (Knox-Blake, Zool., December, 1866). One was taken there in October, 1838, and Ogilby states that in December, 1875, a female, 34 inches long and 23 wide, was trawled off the south-east coast (Zool. 1876, p. 4806). Thompson observed that this fish has in a few instances been obtained off the east and south-east coasts. The example figured is in the National collection. Buckland records one from Mevagissey taken in July, 1870, which measured $4 \frac{1}{4}$ feet long, 2 feet 10 inches wide, and weighed $82 \mathrm{lb}$.

\section{Torpedo marmorata, Plate CLXV.}

Narce, Belon. i, p. 90. Torpedo tertia et quarta, Rondel. p. 363. Torpedo, Walsh, Phil. Trans. 1773, p. 461, t. xix ; Hunter, Phil. Trans. p. 481, t. xx; Pringle, Phil. Trans. 1774; Cavendish, Phil. Trans. 1776. Narcacion, Klein, Pisc. Mss. iii, p. 32, no. 3, 4. Electric Ray, Pennant, Brit. Zool. (ed. 1776) iii, p. 89 , pl. x (ed. 1812) iii, p. 118, pl. xii. Torpillo, Duhamel, Pêches, ii, p. 286, t. xiii. 
Raia torpedo, Linn. Syst. Nat. i, p. 395 ; Brünn. Ich. Mass. p. 1 ; Donovan, iii, pl. liii ; Shaw, Brit.Zool. $\nabla$, t. 146; Turton, p. 110 ; Jenyns, Manual, p. 509. Torpedo marmorata, Risso, Ich. Nice, p. 20, pl. iii, f. 4, and Eur. Mérid. iii, p. 143. f. 9; Olfers, Torped. p. 14; Henle, Narcine, p. 30; Müll. and Henle, p. 128; Gray, Chond. p. 100 ; Dumér. Rev. Zool. 1852, p. 236, and Ich. i, p. 508; Yarrell, Brit. Fish. (ed. 1) ii, p. 410, c. fig. (ed. 2) ii, p. $5 \pm 2$ (ed. 3) ii, p. 539 ; White, Catal. p. 135 ; Günther, Catal. viii, p. 450; Giglioli, Cat. Pese. Ital. p. 53 ; Moreau, Poiss. de la France, i, p. 381.

Torpedo galvani, Risso, Ich. Nice, p. 2l, pl. iii, f. 5, and Eur. Mérid. iii, p. 144; Bonap. Fauna Ital. Pesc. pl. cliii, f. 3, 4, 5 ; Canestrini, Faun. Ital. Pesc. p. 53. Torpedo immaculata and punctata, Raf. Ind. pp. 60, 61.

Torpedo vulgaris, Flem. Brit. An. p. 169 ; Templeton, M. N. H. 1837 (2) i, p. 413.

Torpedo diversicolor, Davy, Phil. Trans. 1834, ii, p. 550.

Torpedo picta, Lowe, Proc. Zool. Soc. 1843, p. 93.

Torpedo trepidans, Val. in Webb. and Berth. Iles Canar. Poiss. p. 101 ; Duméril, Rev. Zool. 1852, p. 238, and Ich. i, p. 511.

Torpedo hebetans, Val. l. c. pl. xxiii (not Lowe). pl. i.

Narcacion polleni, Bleeker, Ned. Tyds. Dierk. iii, p. 171, and Fauna Mad. p. 1,

This species of torpedo is subject to great variation in its form. The disk is nearly circular or oval. Eyes-small, equalling one-third to one-fourth of the width of the interorbital space. Spiracles behind the eyes, large and oval, with seven or eight tentacles attached along their inner border. Fins - the first dorsal fin not twice as large as the second; its anterior half is situated above the hind portion of the ventral fins; the interspace between the first and second dorsal short. Caudal well developed. Skin smooth. Colours-variable, spotted, or marbled. Spots dark or even white and all intermediate shades.

Müller and Henle consider Donovan's figure to represent Torpedo oculata, Belon, and remark that it is a marbled variety which they have not seen, while Donovan does not record from whence the specimen was received. Though Pennant certainly figures this species, and it has been admitted into our fauna by all our Ichthyologists since his time, I cannot resist being doubtful of its occurrence off our shores, and that further evidence is required. Couch only admitted a single form, the one last described.

Habits. - See last species.

Habitat.-Mediterranean and along the Atlantic to Madeira, the Cape of Good Hope, and Madagascar. The existence of British specimens is doubtful.

Example figured is $9 \frac{3}{4}$ inches, and in the National Museum from Madeira. 


\section{FANILY VIII-RAIID 2 .}

Disk broad and depressed, of a rhombic or circular form : tubercles or spines usually present. The pectoral fins extend to the snout. Tail with a longitudinal skinny fold along either side. No serrated caudal spine. Electric organs absent.*

The forms of rays and skates existing in the seas around our coasts consist of species which appear to be more or less sedentary ground-feeders, carnivorous and very voracious in their habits, and although mostly consuming molluses and crustacea, devour likewise large quantities of fish.

Geographical distrilution.-They are fonnd in the seas of both hemispheres, but are more numerous in the northern than in the southern, while they are rarely taken far from the coast unless off banks in the ocean.

\section{Genus I-RAIA, sp. Artedi.}

\section{Uraptera, Müller and Henle.}

Tail listinct from the disli. Teeth pointed or obtuse. Nasal valves united in the median line where no interior free edge exists. Pectoral fins surround the outer margin of the disk, but are not extended on to the front edge of the snout. Two spineless dorsal fins situated on the tail. End of tail with or without a rudimentary caudal fin.

These fishes having the gill-openings, as well as the mouth, on the lower surface of the body, and generally lying at the bottom of the sea, require the assistance of breathing holes or spiracles at the top of the hear, for the purpose of supplying the gills with water for respiration; these are placed near the hind edge of the orbit, are of large size, and can be closed at will. Doubtless living at the bottom of the sea these fishes on rising to the upper waters or coming into shallower places might find the stimulus of light too much, were it not that they possess a modification of the iris, which by means of a veil or curtain which has been compared to a vine-leaf, surrounded by 12 digitations, can be expanded or contracted as required, and prevents an excess of light obtaining an entrance be especially serviceable to these autumn months when they come sun. They progress by an unfins, as seen in pleuronectoid

\section{ETE OF RATA MACULATA.} through the pupil. This would fishes during the summer and to the surface and bask in the dulating motion of the pectoral fishes as soles.

Montagu in 1815 (Mem. Wern. Soc.) drew attention to the differences which were present, in accordance with their sex, in some of these fishes. He remarked that the males were to be distinguished by their genitals being of a most curious structure, pendant one on either side of the tail, between it and the anal fin (see page 329). Another sexual character which he pointed out is to be found in the tecth of the sexes, and he described the blunt

* See article on "the existence of an electric apparatus in the flapper skate and other rays." Stark, Proc. Roy. Soc. Edinburgh, 1844-50, p. I. 
ones in the females and the pointed ones in the males, in several forms. Lütken (Vidd. Medd. 1873, 1-4) described the differences dependant on sex as secn in Raia Batis, and $R$. radiata, as well as in $R$. clavata, in which last they are less conspicuous.

The female is found to be generally about one-third larger than the male. The eggs of these fishes are in horny envelopes, and of a somewhat quadrilateral shape, with a prolongation at each corner, from the termination of which tendrils do not spring as in the dog-fishes. In some sea-side places these egg-cases have received the expressive name of skate-barrows. The young are mostly produced at the end of the spring or during the summer.

As food these fishes are held in different degrees of estimation in different places. It appears probable that the Saxons rejected skates and rays as food, the term slitan meaning "to reject," but others consider such may be from Sceadda, or "gliding motion." The term "ray" may be derived from reoh or "rough." Yarrell observes that in London they are considered delicate during the autumn and winter, but that in the spring when they are maturing their eggs they are soft and woolly. Colonel Montagu, in 1809, observed upon the immense quantity of these fishes taken in Devonshire, and chiefly employed for baiting crab-pots. He computed that four boats in a season used not less than forty tons of ray, at the small hamlet of Torcross alone, besides such as were consigned to the deep immediately on being taken, as useless. He found that in seasons of scarcity some of the small ones were eaten by the fishermen's families, but never offered for sale. Now they are consigned to the London markets. These fish from the nature of their skins, which continue to exude mucous for some days after death, will not salt well, and in the north of Scotland are merely dried by being hung up in the air. This sour-sluate is universal in the Highlands and in the Isles, forming a favourite article of diet. It is pungent and smells strongly of ammonia. Couch (1862), speaking of the fisheries in the west of England, remarked that the grey gurnard, scad, comber, power, the wrasses, dog-fishes, rays, and skates, are collectively known to the fishermen as rabble-fish, as being rejected for the market. Things are altered now, much of this rabble-fish going to Billingsgate and other large inland markets. On the west coast of Ireland, the peasantry are said to have an insuperable objection to eat skate under any conditions.

The fishermen at Lossiemouth, according to Gordon (Zool. p. 3488), enumerate three kinds of skates:- the common or blue skates, $R$. batis, which they consider the best and largest, is most abundant in March, and in condition at that season, after which, having deposited their ova, they deteriorate. The thornback, $R$. clavata, continues good until May, but is never so esteemed as the blue-skate. The white skate, $R$. alba, is the rarest of the three. Some of them also describe a ray which they call Hornies (horned or full of spines?), about four or five inches broad, round in shape, with two black spots on the back, and both back and belly full of spikes (spines?); when taken into the boat they contract themselves into a lump.

Couch (Mss.) observes that fishermen inform him that rays and skates, when held and drawn up by a line, are in the habit of turning their bodies so as to hide and shelter their coloured surface, consequently it is difficult to get them into a position so as to have this part exposed. As a blow on the head disables them, they are probably trying to protect their most vulnerable spot by the same instinct which induces them to move and waive their armed tails above these parts, over which likewise they waive their armed pectorals. When hooked, it becomes very difficult, often impossible, to raise the fish should it be able to fix itself to a stone or to the bottom, but once raise its head and it comes up like a kite. Defence is conducted by the point of the snout, and the base of the tail being bent upwards towards each other, causing the upper surface of the body to be concave. The tail is then lashed about in all directions, the spine of which may inflict very severe wounds.

A correspondent of the Field (12th April, 1884) observes that off the Lincolnshire Fens, skates are caught in muddy creeks as follows :- A stout stake is tightly bound round with straw to prevent a struggling fish dragging it out of the mad, into which it is driven at low water. To this stake a line, baited with a small 
flounder, is fastened. This is found to be very killing, the fish being obtained as the ebb occurs.

Mr. Saville Kent (Nature, July 17th, 1873) describes how the porpoises in the Brighton Aquarium take skates and rays. Some large skate, Raia clavata and R. maculata, so long as they maintained their usual habit of lying sluggishly on the floor of the tank, escaped molestation; but no sooner did they display any unwonted actirity, than the porpoises were on them, and making a convenient handle of their attenuated tails, worried them incessantly. He once witnessed a skate being thus worried, when it swam close to the surface and lifted its unfortunate caudal appendage high out the water.

The rays and skates found around our coasts may be divided with (A) Longsnouted species, which include Raia batis, $R$. macrorhynchus, $R$. alba, R. oxyrhynchus, and R. fullonica: (в) Short-snouted species exist in $R$. clavata, R. maculata, $R$. radiata, and $R$. circularis.

\section{A. Long-snouted Species.}

\section{Raia batis, Plate CLXVI.}

Raia clavata, Willughby, p. 74, t. C5; Ray, Synopsis Piscium, p. 25. Raia, sp. no. 9, Artedi, Gen. p. 73, and Synon. p. 102. Skate, Pennant, Brit. Zool. (Ed. 1776) iii, p. 82, pl. ix (Ed. 1812) iii, p. 111; Duhamel, Pêches, iii, sect. ix, p. 284, pl. xi, f. 14 .

Raia batis, Linn. Syst. Nat. i, p. 395 ; Bloch, t. lxxix; Bl. Schn. p. 369; Risso, Ich. Nice, p. 3; Hollb. Göt. Vet. N. Handl. 1822, p. 21; Turton, p. 110; Faber, Fisch. Isl. p. 33; Flem. Brit. An. p. 171; Jenyns, Man. p. 510; Nilss. Skand. Fauna, iv, p. 738 ; Fries, Vet. Ak. Handl. 1838, p. 158, pl. iii, f. 6; Müll. and Henle, p. 146 ; Templeton, M. N. Hist. 1837 (2) i, p. 413; Parnell, Wern. Mem. vii, p. 424, pl. xl ; Yarrell, Brit. Fish. (ed. 1) ii, p. 421, c. fig. (ed. 2) ii, p. 561 (ed. 3) ii, p. 560 ; Blainville, Fauna France, p. 13; Johnston, Berwick. N. F. C. 1838 , i, p. 176 ; Kröyer, Danm. Fisk. iii, p. 978 , c. fig. ; White, Cat. p. 137 ; Malm. CEfv. Vet. Ak. Förh. 1857, p. 193; Nilss. Skand. Faun. iv, p. 739; Schlegel, Dieren Neder. p. 200, pl. xxi, f. 1 ; 'Thompson, Nat. Hist. Ireland, iv, p. 259 ; Duméril, Ich. i, p. 563; Günther, Catal. riii, p. 4633, Collett, Norges Fiske, p. 216; Winther, Prod. Dan. Mar. p. 6\%) Moreau, Poiss. de la France, i, p. 409 , f. 73 .

Raia gaimardi, Val. in Gaim. Voy. Isl. et Grœnl. Poiss. pl. 2, 3 (young male).

Raia leiobatos, Gronov. ed. Gray, p. 10.

Dasybatis batis, Bonap. Catal. no. 18 (not Fauna d'Ital.).

Loeviraja batis, Malm, Fauna, p. 615.

S7ate, Couch, Fish, Brit. Isles, i, p. 87, pl. xviii.

Shape rhomboidal, the disk being about one-fourth wider than it is long: the snout produced and pointed, more so in females than in males, and in adults than in the young. The anterior edge of the disk undulated and deeply emarginate below a line drawn from the end of the snout to the angle of the pectoral fins, which are rounded; the hind edge of the disk is rounded, and one-third shorter than the front edge. Tail shorter than the body in adults, of about equal Jength in the young. Eyes-in adults equal to about one-seventh or one-eighth in the length of the snout, but much larger in the young; while in adults it equals one-third of the interorbital space, but two-thirds in the young. The eye of the male is somewhat larger than that of the female. Spiracles just behind the orbit, than which they are smaller. Mouth horizontal, much wider in adults than in the young, and in females than in males. The distance between the outer margins of the nostri?s equals about the length of the snout. Teeth-from 44 to 54 rows in either jaw; pointed in both sexes, but distinct: in those in the male the crown is more developed than in the female, its spinate portion is longer and more curved, and the distance intervening between each vertical row is greater in males than in females. Fins-two dorsal fins well-developed on the tail and of ahout similar size. Skin 
smooth, except in front of and above the eyes of the young; a row of strong spines along the centre of the tail, and usually a lateral row on either side of the tail pointing externally or even anteriorly. In males there is the usual patch of spines on each wing with the points directed inwards; while in some females, especially old ones, the skin is rough. Colours - subject to considerable variation, brownish or grayish above and stained with brown (never white) beneath, where numerous black spots appear, which are the orifices of the tubes of Lorezini. In the young (which I have purposely figured) there may be a large ocellated spot on either wing, and many more smaller ones. Malformations are not uncommon, and mostly in the form of a deep fissure along the anterior profile which divides the line of continuity from the snout to the outer angle of the pectoral fin.

Varieties.-Ray remarked upon some being streaked with black.

Names. - The skate, or true sluate; also blue skate in Scotland and gray skate in England; Flanie and skider, Northumberland; Tinlier, due to its colour, at Lyme Regis; also flaire, dinnan, or blunt-nosed dinnan, Aberdeen. Cath fâr, morcath, and Rhaien, Welsh. De Vleet, Dutch. Le Raie batis, French.

Habits.-A resident at the bottom of the sea, usually on soft, sandy, or muddy ground at some distance from the land, but is not so common as the flapper or homelyn. It becomes less numerous to the north. Is very tenacious of life and capable of sustaining a great amount of injury. Fishermen assert it to be rather particular in regard to its food, and Sir J. Dalyell found that a young one he kept would eat nothing but whiting. Couch found in one a fishing frog weighing $6 \mathrm{lb}$. ; in another two large plaice, a lobster, a couple of mackerel, a thornback ray about 18 inches long, and half a salmon, which appeared quite fresh as if but lately deroured. One, $5 \mathrm{ft}$. across, was exhibited at Gravesend, in December, 1881, which had a dog-fish $2 \mathrm{ft}$. in length, a small skate, and a lobster inside its stomach, it being a large consumer of crustacea. Mr. Dunn, of Mevagissey, informs me of a stone, nearly a pound in weight, which has been taken from the stomach of one of these fish. One $7 \mathrm{ft}$. long, in the Dublin University Museum, had inside it a large hake.

Means of capture-Long lining or trawling. It takes a good deal of trouble to capture after being hooked, as it often entangles the line to a rock, where it fixes itself like a sucker, and can only be raised by first elevating its head and thus allowing the water to get beneath it. Subsequently its head must be kept well up, as if it again gets down to the rock the probabilities are the fish will be lost. The skate is frequently taken off the Irish coast having a hook in one of its fins, for the natives of Ireland, when they find them on their lines, cut them off close to the hook sooner than be troubled with unhooking the fish. These hooks are so common near the end of the fin that it has been inferred that the skate has used the waving motion of the fin to bring the bait near its mouth, and so doing has got the hook into its body.

As bait.-Whiting, or other fish.

Breeding.*-They" generate in March and April, at which time they skim near the surface of the water, several of the males pursuing one female; and adhere so fast during coition, that the fishermen frequently draw up both together, though only one has taken the bait. The females begin to cast their purses, as the fishermen call them (the bags in which the young are included), in May and continue doing so till September. In October they are exceedingly poor and thin, but in November they begin to improve and grow gradually better till May, when they are in the highest perfection. The males go sooner out of season than the females" (Pennant.) Off the Irish coast the females are said to cast their eggs from May to September, and the young appear some time during the following spring (Parnell). Couch gives an instance, on the authority of a fisherman, wherein the purse had become diseased before extrusion, and the embryo, about twice the usual size of fresh born ones, was contained within the oviduct, and the only anomaly perceptible was that its eyes appeared to be obscure.

* For the development'of this species, see Wyman, Mem. Amer. Acad. 1864, ix, p. 31, and An. and Mag. Nat. Hist. 1864, xiv, p. 399. 
Uses.-They are not much brought to market in Ireland, and when sold are usually imperfect. Some are salted and sent to Germany, while large ones are often disposed of as bait for lobster or crab pots, for which they are well adapted. Parnell observes that in the spring months the Edinburgh market has a daily supply, and so great is the demand that no less than a dozen cartloads a week are disposed of. Some are cooked fresh, others salted, while others allow them to hang in the open air for weeks until they have acquired a green putrescent appearance, and in this state they are considered a luxury.

As food.-This fish is held in different countries and districts in various degrees of estimation, and appears to be coming more and more in use in our markets to meet the increased demand for fish. Conch in 1862 recorded in Cornwall that those of full size were purchased for the crab and lobster pots, and Mr. Dunn observes (1884) that only a few years since at Mevagissey, it was customary for the fishermen to secure large skates alongside their boats by ropes, and when fishing was over to cut them adrift, boing of no money value. We are told by Willughby of one which weighed $200 \mathrm{lb}$., and sufficed at St. John's College, Cambridge, for the dinner of 120 persons. In some parts of the Mediterranean these fishes are considered to be a delicacy, and off Schleswig-Holstein they were said to be salted for the German market. Their value as food depends on the cook and the resources at his disposal; while the young, termed maids, are excellent either fresh or salted. Mr. Rowell, at Newcastle, observes (Land and Water, July 16th, 1881) that they used to sell at 1 ld a share of about $1 \mathrm{lb}$., but now the price is $4 d$ to $5 d$ a lb. The pectoral fins, says Parnell, when cut into a peculiar form, are sold in Edinburgh under the name of crimped skate, which is esteemed a delicate morsel.

Diseases.-It is much affected by the fish leech, Hirudo muricata.

Habitat.-Found around the coasts of western Europe, and all round the British Isles, in France it is common, extending to the shores of the Mediterranean. In Orkneys and Shetlands abundant (W. Baikie, Zool. 1853, p. 3845). Occasional off Banff (Edward): Aberdeen (Sim): common at St. Andrew's (McIntosh) : also off Berwickshire (Johnson): Yorkshire abundant (Yorkshire Vertebrata) : also off Norfolk (Lowe): Kent (Yarrell): Sussex and along the south coast: and very common off Devonshire, although not so much so as on the east coast of England (Parfitt): Cornwall common: Swansea (Dillwyn).

Ireland.-All round the coast, but less commonly (in the north at least) than R. maculata and R. clavata (Thompson). In March, 1849, one, weighing 224 lb., $7 \mathrm{ft} .3 \mathrm{in}$. long from nose to tail, and $5 \mathrm{ft.} 8 \mathrm{in}$. wide, taken as follows :- "A small skate got meshed, and was swallowed with a piece of the trammel of the net by the large one, and being thus entangled in the netting, it was easily secured by the fishermen." One in Dublin University Museum measured upwards of 7 feet in length, in its stomach was a large hake.

The dimensions of these fish are often great. Buckland received one from Suffolk, in November, 1864, which was $5 \frac{1}{4}$ feet across and 6 feet 10 inches from the end of its snout to the base of its tail, and weighed $90 \mathrm{lb}$. without the intestines. One was taken off Peveril Point, in Swanage Bay, December 21st, 1883, which measured 4 feet 10 inches arross and 6 feet 2 inches from its snout to the root of its tail, and weighed $119 \mathrm{lb}$. (Land and Water, December 29, 1883). Mr. E. Scott was present off North Harris when two skate were captured by means of deep sea lines, one was 7 feet by $5_{2}^{1}$ feet and weighed $165 \mathrm{lb}$; t the other 7 feet by $6 \frac{1}{2}$ and weighed $175 \mathrm{lb}$. (Field, January 1, 1882). A stuffed female in the National collection is $6 \frac{1}{2}$ f'etlong and $5 \frac{1}{2}$ across. In the Precurseur d'Anvers, July, 1837, one is alluded to from the Faroes, weighing $423 \mathrm{lb} .6 \mathrm{oz}$. (Mag. Nat. Hist. 1837 (2) i, p. 435). The specimen figured is a young male, but a little reduced in size in the figure.

\section{Raia macrorhynchus, Plate CLXVII.}

Raia macrorlynchus, Raf. Ind. ittiol. Sicil. p. 47, no. 358; Günther, Catal. viii, p. 468; Moreau, Poiss. de la France, i, p. 405, f. 71 ; Giglioli, Cat. Pesc. Ital. p. 54. 
Raia rostrata, Blainv. F. France, p. 30 .

Raia intermedia, Parnell, Proc. R. S. Edin. 1837, p. 166, and Trans. R. S. Edin. 1839, xiv, p. 148, pl. vi and Wern. Mem. vii, p. 429, pls. xi and xli; Yarrell, Brit. Fishes (ed. 3) ii, p. 557; Kröyer, Danm. Fisk. iii, p. 1015; McCoy, Ann. and Mag. Nat. Hist. 1841, vi, p. 406; White, Catal. p. 139.

Raia batis, Yarrell, 1. c. (ed. 1) ii, p. 421, c. fig. (ed. 2) ii, p. 561.

Loviraja macrorhynchus, Bonap. Faun. Ital. c. fig.; Canestr. Faun. Ital. Pesc. p. 54. Flapper-slate, Couch, Fish. Brit. Isles, i, p. 87, pl. xviii.

Shape rhomboidal; disk about one-fourth wider than long. The length of the tail from the origin of the ventral fin equals about one-half of the total, or even less. The anterior edge of the disk concave and of greater extent than the posterior edge, which latter is rounded. Eyes-rather small in the young, equalling about one-fifth of the distance to the end of the snout, and onc-sixth to one-seventh in adults; spiracles placed close behind the orbits, and in size are less than the eye. Mouth slightly arched and situated a little anterior to the middle of the distance between the end of the snout and the vent. The length of the snout, anterior to the mouth, slightly exceeds that of the preorbital space. The distance between the nostrils equals one-half to two-thirds of the distance from the end of the snout. Teeth-differ with age ; in the young of both sexes they are in oblique rows; while in large specimens they are more in vertical rows; in the young males they have a little point directed backwards; in adults the form is angular, with a central point similarly directed, while each tooth is in more or less direct contact with six others. I find 48 rows in the upper, and 40 in the lower jaw, of a large example from $\mathrm{Plymouth}$, but they are said to increase with age. Generally two spines near the anterior angle of the orbit; usually none along the middle of the back, but many little asperities on the disk. The tail has three rows of spines, the centre one usually commencing above the base of the ventrul fin; the lateral rows are often more or less deficient. Fins - the two dorsals of about the same size, separated by a short space where there exists a spine : a small caudal. Coloursvary with age, being generally brown above and white beneath where there are numerous black dots: or the upper surface many have numerous white spots.

McCoy observes that two specimens of this skate, taken in Dublin Bay, agreed perfectly with each other: neither of them were spotted; besides the one large spine before the eye, each had another of equal size behind the orbit, and one small blunt one external and a little anterior to the one before the eye. Those two specimens, it will be found, agree perfectly with two fishes obtained by Dr. Parnell at Queensferry, considered by him as a mere variety of his $R$. intermedia. Length, 13 inches.

Names.-Flapper skate. La Raie nacrorhynchus, French.

Habits. - These have not been recorded, but are probably identical with those of the common skate.

Habitat.-It is found around the French coast to the Mediterranean. It has been recorded in our seas by Parnell from the Firth of Forth. I have obtained it at Plymouth. McCoy has recorded it from Dublin Bay. It is said to attain to a large size. I have figured one of Parnell's specimens which is 26 inches long.

\section{Raia alba, Plate CLXVIII.}

Raia lovis, major, Duhamel, Pêches, p. 2, sect. ix, p. 285, pl. xi, f. 3, 4. Sharpnosed ray, Pennant, Brit. Zool. (Ed. 1776), iii, p. 83 (Ed. 1812), iii, p. 113, pl. xi; Low, Orkneys, p. 160.

Raia alba, Lacép. $\nabla$, p. 663, pl. ×x, f. 1; Blainv. F. France, p. 14; Moreau, Poiss. de la France, i, p. 412.

Raia marginata, Lacép. v, p. 663, pl. xx, f. 2 ; Blainv. 1. c. p. 19, pl. iii, f. 2 ; Risso, Eur. Mérid. iii, p. 148; Müller and Henle, p. 140; F'lem. Manual, p. 172 ; Bonap. Faun. Ital. Pesc. c. fig.; Yarrell, Brit. Fishes (ed. 1), ii, p. 426, c. fig. (ed. 2), 
ii, p. 564 (ed. 3), ii, p. 564; White, Catal. p. 138; Jenyns, Brit. Vert. p. 512 ; Duméril, Ich. i, p. 568; Günther, Catal. viii, p. 465.

Raia rostellata, Risso, Ich. Nice, p. 8, pl. i, ii.

Raia oxyrhynchus, Turton, p. 111; Montagu, Wern. Mem. ii, p. 423; Flem. p. 171; Yarrell, Brit. Fishes (ed. 1), ii, p. 424, c. fig (ed. 2), ii, p. 556 ; Johnston, Berwick. N. F. F. Club, 1838, i, p. 176 ; Parnell, Fish. Firth of Forth, Wern. Mem. vii, p. 427 ; Jenyns, Brit. Vert. p. 511 ; Thompson, Nat. Hist. Ireland, iv, p. 259 ; Couch, Fish. Brit. Isles, i, p. 97, pl. xxi (not Linn.).

Raia lintea, Yarrell, l. c. (ed. 3), ii, p. 555, c. fig. (not Fries); Kröyer, Danm. Fisk. p. iii, p. 1005, c. fig.

Burton skate and borlered ray, Couch, l. c. pp. 97, 110, pls. xxi, xxvi.

Shape rhomboidal, disk about one-fifth wider than long, and the end of the snout contracted into a narrow point; tail not so long as the body. The anterior edge of the disk one-half longer than the posterior, it is likewise deeply undulated, so that between the snout and the angle there are two convexities, while a line from the snout to the outer angle of the fin would not touch any portion of it in its course. The posterior margin of the disk is nearly straight, and the external angle somewhat pointed. Eyes-of moderate size, about two transverse diameters apart, and five from the end of the snout. Spiracles rather smaller than the orbits. Mouth rather wide. Teeth-pointed in both sexes; from 42 to 46 rows in the upper, and somewhat less in the lower jaw. Under surface of the snout furnished with fine spines. S'kin generally smooth, occasionally a spine before and another behind the eye; but these may be absent. Three rows of spines on the tail, and in the male a patch on either wing. Colours-grayish superiorly, sometimes with light spots, or a pale brown; below, pure white.

In young specimens the disk is not so undulated along its border as in adults; while it is quite smooth above and below. The rows of spines on the tail are more distinct. T'he colours differ from the adult, being bordered along its edges with dark or even black, while the upper surface is rosy or orange coloured.

Pennant's figure of the skate (Edition 1776) which is also copied into Shaw's Zoology, becomes his sharp-nosed ray in bis second edition (1812). W. Thompson, writing to Couch respecting the bordered ray, observed: "The fishermen here (Weymouth) will have it to be the young of some other species, but can give no reason." Couch also considered it probably to be the young condition of another ray.

Names.-White shate (Moray Firth), May skate, Burton skate, said to have its origin from the name of a French fishing village from whence fishermen came to purchase them off our shores. Friar slate, Mavis slate, sharp-nosed ray. In Moray Firth termed scad, pronounced slaclut, Celtic (Gordon). The Doctor, Aberdeen (Sim). Morcath drwynfain, Welsh. La Raie Blanche, French.

Habits.-Similar to those of the common skate, than which it is more powerful.

Means of capture.-Small ones are taken thronghout the year, but the larger ones, which keep in deep water, are only captured during summer and autumn. The trawl and baited hooks are used for this purpose.

Breeding.-Buckland remarked upon having received from $\mathrm{Mr}$. Dunn, of Mevagissey, two purses of this species, which measured 16 inches long and $6 \frac{1}{\overline{2}}$ wide.

As food.-Much esteemed by the French, who, as long ago as the time of Ray, 1658, observed that French vessels used to arrive at St. Ives, in Cornwall, to purchase this fish; and which commerce has been continued up to the present time. They cover this skate with moist sand, and thus, when exported, it appears as if it had been freshly captured.

Habitat.-This species extends through the seas of western Europe, extending from the north to the British shores and round the coasts of France to the Mediterranean.

Not uncommon in the Orkneys and Shetland Isles (Baikie, Zool. 1853, p. 3845) : Firth of Forth (Neill) : large individuals are occasionally taken at Banff, and one is alluded to 7 feet long and 5 feet across (Edward): Aberdeen (Sim). Not unconimon in Berwickshire: one is mentioned 7 feet 9 inches long, by 8 feet 
3 inches broad (Johnston). A fine example was taken off Yarmouth, October 20th, 1883, the first taken for 25 years (Eastern Daily Press, Oct. 22nd). Also along the south coast, where it has been recorded from several localities. Weymouth (Gosse); Lyme Regis (Yarrell). Plentiful in Portland Roads, where the young are taken throughout the year (Thompson); and in Cornwall not uncommon in deep water (Cornish Fauna). Pennant obtained it off Caernarvonshire, and records one from the Menai Straits, taken in July, 1768, nearly 7 feet long, and 5 feet 3 inches broad; when first brought on shore it made a remarkable snorting noise. On its body were Hirudo muricata, which adhered very strongly, and when taken off, left a black impression. Yarrell also records this fish from Liverpool.

In Ireland it has been recorded in Smith's Waterford; and Thompson observes that in September, 1851, he saw the perfect tail and other remains of an immense ray of this species on the beach at Annalong. The claspers were about a foot long.

This is the largest British form of skate, and has been taken nearly $500 \mathrm{lb}$. in weight. It is much thicker than the common skate. Montagu examined one 6 feet long to the base of its tail and $5 \frac{1}{2}$ feet across, and which weighed about $100 \mathrm{lb}$.

The specimen figured is in the National collection.

\section{Raia oxyrhynchus, Plate CLXIX.}

Lacviraja, Salvian. p. 149, t. lii ; Gesner, p. 933 ; Willughby, p. 71, t. C4; Ray, p. 26. Raia, spec. no. 8, Artedi, Genera, p. 72, Synon. p. 101.

Raia oxyrhynchus, Linn. Syst. Nat. i, p. 395 ; Brün. Ich. Mass. p. 2 ; Blainville, Faun. Franc. p. 18, pl. iii, f. 1; Nilss. Skand. Fauna, iv, p. 740 ; Günther, Catal. viii, p. 469 ; Moreau, Poiss, de la France, i, p. 403 ; Giglioli, Cat. Pesc. Ital. p. 54.

Raia chagrinea, Turton, p. 111; Yarrell, Brit. Fishes (ed. 1) ii, p. 4.14.

Raia vomer, Fries. Vet. Akad. Handl. 1838, p. 161; Müller and Henle, p. 144; Kröyer, Danm. Fiske, iii, p. 1011, c. fig.; Malm. Ef v. Vet. Ak. Förh. 1857, p. 193 ; Duméril, Ich. i, p. 571; Yarrell, Brit. Fish. (ed. 3) ii, p. 548; Günther, Catal. vii, p. 468.

Raia rostrata, Risso, Ich. Nice, p. 7 and Eur. Mérid. iii, p. 156.

Raia salviani, Müll. and Henle, Plag. p. 143 (part); Duméril, Ich. i, p. 560; Capello, Peix. Port. p. 22.

Laviraja oxyrhynchus, Bonap. Faun. Ital. Pesc.; Canestrini, Fauna d'Italia, Pesc. p. 54 .

Raia mucronota, Yarrell, Brit. Fish. (ed. 2), ii, p 550, c. fig.; Couch, Cornish Fauna, p. 25.

Long-nosed skate, Couch, Fish. Brit. Isles, i, p. 93, pl. xix (exclude Synon.).

The breadth of the fish about equals its length to the root of the tail. The profile from the snout to the angle of the pectoral fin is deeply concave. Snout rery elongated and pointed: the width of the interorbital space equals about 6 in the length of the snout. Eyes - of mediuma size, rather more than one diameter apart. Spiracles a short distance behind the eyes, than which they are larger. The distance from the rather narrow month to the end of the snout equals about $2 \frac{1}{2}$ in the extreme width of the body. Teeth-about 46 rows in the upper jaw, which have a prominent central keel. Fins-outer angle of the pectoral fins angular. Skin-without large spines, but fine ossicles scattered over both the upper and lower surface of the body. In males there is a roughness at the border of the disk. Tail without any median series of spines, but a lateral row along either side. Colours-grayish brown superiorly, with roundish light or dark spots, and sometimes lines. Under surface grayish.

Names.-Long-nosed skate. La Raie oxyrhynque, French.

Habits.-Frequents deep waters, is not taken during the winter months, and is not so numerous as the common skate.

Means of capture.-Mostly trawled: when hooked is said to make very violent 
efforts to escape. Off Cornwall Couch observes that the earliest he had met with was taken in April.

Uses.-Oil is extracted from its liver.

Habitat.-The seas of western Europe, from those of the north to France where it is pretty common, and through the Mediterranean, also as far south in the Atlantic as Madeira. Resident in Yorkshire, and reported to be common in the North Sea (Yorkshire Vertebrata) : it is also found along our south coast, and has been obtained in Cornwall (Couch).

The specimen tigured is one-fifth natural size, and in the National collection.

\section{Raia fullonica, Plate CLXX.}

Raia, sp. no. 6, Artedi, Gen. p. 72, and Synon. p. 101. Shagreen Ray, Pennant, Brit. Zool. (Ed. 1776) iii, p. 87 (Ed. 1812) iii, p. 117 ; Shaw, Zool. $\nabla$, p. 281.

Tiaia fullonica, Linn. Syst. Nat. i, p. 396 ; Ascan. Icon. t. xliii; Bl. Schn. p. 367; Turton, p. 111 ; Risso, Icl. Nice, p. 6; Fries. Vet. Al. Handl. 1838, p. 150, t. ii, f. 2 ; Müll. and Henle, p. 145 ; Yarrell, Brit. Fishes (ed. 1) ii, p. 578, c. fig. (ed. 2) ii, p. 578 (ed. 3) ii, p. 577 ; Kröyer, Danm. Fisk. t. iii, p. 996, c. fig.; White, Catal. p. 138; Nilss. Skand. Fauna, iv, p. 737 ; Collett, Norges Fiske, p. 217 ; Günther, Catal. viii, p. 467; Winther, Prod. Dan. Mar. p. 61 ; Giglioli, Catal. Pesc. Ital. p. 54.

Raia granulosa, Bl. Schn. p. 368.

Raia .lossada, Risso, Eur. Mérid. iii, p. 145.

Taia chagrinea, Pennant, l.c.; Lacép. i, p. 81; Turton, p. 111 ; Montagu, Wern. Mem. ji, p. 420, pl. xxi; Pamell, Trans. Roy. Soc. Edin. 1840, xiv, p. 144, and Wern. Mem. vii, p. 43l, pl. xli ; Jenyns, Man. p. 513; Thompson, Nat. Hist. Ireland, iv, p. 260 ; Dumérill, Ich. i, p. 560 ; Moreau, Poiss. de la France, i, p. 401.

Iacui aspera, Flem. Brit. An. p. 172.

Lucoraje fullonica, Malm, Fauna, p. 609.

Shayrech Ray, Couch, Fish. Brit. Isles, i, p. 117, pl. xxix.

Form of body rhomboidal; the front edge of the disk concave and undulated, and one-third longer than the hind edge, which is conrex. Snont cone-shaped and sharp. Disk rather wider than the distance from the end of the snout to the posterior extremity of the anal fin. The tail not quite so long as the disk. Eyes -large, $4 \frac{1}{2}$ to 5 diameters from the end of the snout, and 3 to $3 \frac{1}{2}$ apart. Spiracles close behind orbits, than which they are slightly smaller. Mouth large. Teethpointed, and in about 6.1 rows in the upper and 56 in the lower jaw. Finsdorsals rather close together, small, and of equal size; a rudimentary caudal. slin-on upper surface granulated to the touch, except at the base of the ventral and anal fins, where it is smooth. About four or six large and bent spines on the snout, and ten or twelce round the upper margin of the orbit. Along the centre of the back a row of about six spines, which about opposite the base of the rentral fin change into two rows, are continued as far as the dorsal fins, and increase in size posteriorly; while two or three irregular rows of spines are situated along either side of the tail. No spines along the central line of the tail. Colon's-yellowish brown superiorly; pure white beneath. Mortagu mentions a specimen which had a few black spots.

Numes.-The term Fuller's ray is dericed from the instrument fullers use in smoothing cloth, the back being rough and spiny (Pennant). Long-nosed dinnan, Aberdeen (Sim). Rough flapper, Edinburgh (Parnell). Dun cow, West country (Montagu). Morcath forreinig, Welsh. La Raie Chagrinée, French.

Habits.-Frequents deep waters, and is not captured during the winter.

As food.-Inferior.

Habitat.-Along the coasts of western Europe and British Isles; is taken off France, but becomes rare in the Mediterranean. In the Moray Firth Mr. McGregor on]y observed one specimen, which was taken in February on a line at 50 fathoms depth, it was 2 fet $8 \frac{1}{2}$ inches long (Couch) : Aberdeen (Sim): Firth of Forth occasionally captured in the stake nets in deep water, more 
especially during May and June (Parnell) : Yorkshire at Scarborough (Pennant), and is occasionally taken along the coast: it is termed French Ray at Whitby and Grimsby (Yorkshire Vertebrata). Montagu observes upon having obtained several on the coast of Devonshire, the largest being a male 3 feet long and 2 feet across. It is rare in Cornwall (Couch).

Ireland.-One obtained in Portrush in May, 1839 : Captain Portlock remarked in reference to this species, that it "seems to take the place of $R$. oxyrhynchus on the northern coast" (Thompson).

The specimen figured is a male 37 inches long from the Firth of Forth, and is in the National collection.

\section{B. Short-snouted species.}

\section{Raia clavata, Plate CLXXI.}

Raja, Belon. p. 79 ; Rondel. pp. 35̆3, 35t, Gesner, pp. 795, 797; Aldrov. p. 460 ; Willughby, pp. 74, 78, t. D2, f. 2, 3; Ray, Synop. Pisc. p. 26 ; Salvian. p. 149; Artedi, Gen. p. 71, no. 2, Synon. p. 99, no. 2, Spec. p. 103, no. 1; Gronov. Mus. Ich. i, p. 140 and Zooph. no. 154. Thomback, Pennant, Brit. Zool. (Ed. 1776) iii, p. 93, pl. xii (Ed. 1812) iii, pp. 122, 124, pl. xiii, xiv; Low, Orkneys, p. 169; Duhamel, Pêches, iii, Sect. ix, pl. viii, f. 1-4, pl. ix, f. 1, 2.

Raia clavata, Linn. Syst. i, p. 397; Bloch, t. lxxxiii (female); Bonnaterre, Enc. Ich. p. 4, pl. iii, f. 9 ; Lacép. i, p. 128 ; Bl. Schn. p. 366 ; Donovan, Brit. Fish. ii, pl. xxvi; Turton, p. 111; Montagu, Wern. Mem. ii, p. 416; Risso, Icb. Nice, p. 11, and Eur. Mérid. iii, p. 146 ; Fleming, p. 170; Fries. Vet. Akad. Handl. 1839, p. 15, pl. ii, f. 1-3, 7 ; Jenyns, Man. p. 516; Fries. and Eks. Skan. Fisk. p. 154, t. x×xv; Müll. and Henle, p. 135; Yarrell, Brit. Fish. (ed. 1) ii, p. 436, c. fig. (ed. 2) ii, p. 582 (ed. 3) ii, p. 581 ; Blainville, Fauna France, p. 528 ; Parnell, Wern. Mem. vii, p. 436, t. xlii ; Templeton, Mag. Nat. Hist. 1837 (2) i, p. 413; Johnston, Berwick. N. F. Club, 1838, i, p. 176; Gronov. ed Gray, p. 9 ; Kröyer, Danm. Fiske, iii, p. 962, c. fig.; White, Catal. p. 136; Kessler, Bull. Soc. Nat. Mosc. 1859, ii, p. 495 ; Nilss. Skan. Fauna, Fisk. iv, p. 735 ; Thompson, N. H. Ireland, iv, p. 262 ; Schlegel, Dieren Neder. p. 198, pl. xx, f. 1 ; Collett, Norges Fiske, p. 214 ; Duméril, Ich. i, p. 528 ; Günther, Catal. viii, p. 456 ; Moreau, Poiss. de la France, i, p. 39l, f. 69; Winther, Prod. Dan. Mar. p. 60; Malm, Fauna, p. 606 ; Giglioli, Cat. Pesc. Ital. p. 54.

Raia rubus, Bloch, t. Ixxxiv, iii, p. 67 (male); Bl. Schn. p. 366 ; Neill, Wern. Memoirs (male).

Raia cuvieri, Lacép. i, p. 141, pl. vii, f. 1; BI. Schn. p. 367 ; Neill, Wern. Mem. i, p. 554; Flem. Brit. An. p. 172 (monstrosity).

Raia aspera, Risso, Ich. Nice, p. 5, and Eur. Mérid. iii, p. 14i7.

Dasybatis clavata and ruber, Blainv. F. Fr. pp. 21, 33, t. iii, f. 1, and t. $\nabla$, f. 2 ;

Bonap. Faun. Ital. c. fig.

Raja punctata, Hollb. Göth. Vet. N. Handl. iv, p. 25 (young).

Raja pontica, Pall. Zool. Ross.-As. iii, p. 58, pl. viii ; Ratlike, Mém. Sav. étran. Ac. Sc. Pétersb. 1837, iii, p. 309, pl. ix, x.

Thornback ray, Couch, Fish. Brit. Isles, i, p. 99, pl. xxii.

Disk wide, being from one-third to one-fourth wider than long, front of head obtuse with the snout slightly produced at its extremity. Tail of somewhat varying length, but equal to about one-half of the total length. Anterior edge of the disk undulated and scarcely passes beyond a line drawn from the end of the snout to its rounded angle: the hind margin of the disk convex, one-fourth shorter than the front edge. Eyes-rather large, their diameter being about onefourth of that of the snout, and from $1 \frac{1}{4}$ to $1 \frac{1}{2}$ in the interorbital space. The spiracles placed close behind the orbits, than which they are somewhat smaller. Mouth arched, and its width equals nearly half its distance from the end of the snout. Nostrils rather wide asunder, the distance between their outer border's equalling about that from the ond of the snout. Teeth-large, those in young males 
very similar to those in the females. In the males, about 40 rows of teeth in either jaw, they are of two forms, the outer ones being lozenge-shaped, whereas the middle ones are conical with the points turned inwards, and the rows not being quite so close together. In the females the teeth are flat and in oblique rows, appearing much like the heads of large nails, those in the centre being larger than the lateral ones. Fins-the two dorsals of about the same size, the length of the base of each equalling about that from the front end of the orbit to the hind edge of the spiracle: they are separated by a short space where there are generally one or two spines. Usually a small caudal fin. Skin more or less covered with spiny tubercles and asperities, which are very numerous on the snout and along the anterior border of the wings. One or two large claw-like spines on the snout, one or two at the anterior angle of the orbit, also at its posterior angle, and above the spiracle. A strong median row passes from behind the head along the centre of the back and tail, also a strong shoulder spine. Opposite the end of the insertion of the anal fin, a lateral row commences along the side of the tail, and is generally of smaller dimensions than that along the back of the tail. In the males a patch of strong spines on the wings. All the spines are liable to modification, while in the young the body, except the median line of the back and the snout, may be nearly smooth or covered with asperities: for the spines both increase in size and number with age. Those on the tail are also variable, and specimens are seen with one, three or five rows, rarely without any: the males generally bave three rows. Colours - variable, the upper surface brownish and marbled all over: the under surface being white. In the young there may be round brown or white spots or blotches. On each wing is sometimes seen a large white spot, externally margined with black.

Tarieties.-Parnell observes that he had met with three full-grown examples of males in which the teeth were as blunt as those of the females. The anterior portion of the pectoral fins may be abnormally detached from the head as shown in figure 2. Cuvier's Ray, Raia Cuvieri, Lacépède, was 12 inches broad, and the same length excluding the tail, taken in Firth of Forth, 1808, distinguished by the position of its dorsal fin which is upright, of an oval shape and placed in the middle of the back. M. Gervais has evidently a similar form in view, when he remarks upon a case of notomely in this species, the example had a pair of rudimental pectoral fins on its back (Compt. Rend. 1864, iii, p. 802). In fact, these monstrosities are not very rare. MIontagu observes as for the tubercular spines with which both sexes are occasionally furnished on the lower surface as well as on the upper, there is no dependance in them, since some specimens have none or either: others very sparingly above and none beneath, and it is only occasionally that many spines are observable.

Names.-Thornback, from spines or thorns on its back: thorny, Aberdeen. The young termet maids, maidens or maiden-skates: ray-maids. Morcath bigog, Welsh. De Roq, Dutch. Le Raie Bouclée, French.

Habits.- It keeps to shallower water than most of the other species of the genus, and is taken at all seasons. Low obserres, that "skates of all kinds are taken on the ordinary fishing-grounds round the Orkneys, but, like other flat-fish, are most frequently met with in the eddies of the tides, or where two tides meet; especially, when the tides run strong they are obliged to withdraw to these calmer spots, their shape hindering them to sustain themselves against the force of the current." Mr. Dunn observes, "I have known quantities of the common thornback-ray glutted with scad (Caranx trachurus), thirty miles south from the Deadmans in winter, so they must have been down at the sea bottom " (Misc.). Very voracious, feeding on every kind of flat-fish, is very partial to herrings and sand-eels, while Pennant observes that it sometimes eats crustacea, also worms and shells:

Means of capture.-Trawling; or with hooks and lines. In the Firth of Forth Parnell observes that large quantities are taken during. May and June, and form a cheap and wholesome food to numbers of the lower classes.

Baits.-Pilchards and herrings, crabs and other crustacea, and as it is rather dainty respcting its food on a change of bait the captives have sometimes becomo abundant. 
Breeding.-Begins to germinate in June, and brings forth its young in July and August (Pennant). Eggs deposited May and June (Couch), and it has been said that the number of females is in excess of that of the males. The remarks made at page 337, of how the common skate have been captured during coition, have been found at Mevagissey to likewise apply to this species.

Diseases, \&c.-Couch, writing from Cornwall in 1862, observed that its numbers have much lessened of late years : the cause of which is supposed to be the increased practice of fishing with beam trawls; by which not only the young ones, too small to be used as food, are destroyed, but the ground is torn up and the food on which the fish must subsist dispersed, with the destruction of shelter necessary for the perfection of the eggs.

As food. - Good eating when not too large, for as in all these fish they become coarse with age : they are best during the autumn and winter months. In Ireland it is said to be the most preferred of all of the genus as food. It is often salted by fishermen, and is best preserved under heavy pressure. In some parts of Scotland it is not salted, but merely subjected to great pressure and kept dry.

Habitat.-Is found around the coasts of Europe, and extends round France, into the Mediterranean. Abundant in the Orkneys and Shetlands (Low): sometimes taken in great numbers off Banffshire (Edward) : Aberdeen (Sim): frequent at St. Andrew's (McIntosh) : common in the Firth of Forth (Parnell) : and in fact on both coasts of Scotland and Ireland, in which last country it is found in almost every sandy bay. Abundant in Yorkshire (Yorkshire Vertebrata): common in Norfolk (Lowe): along the south coast is numerous off Devonshire (Parfitt), and common off Cornwall. Swansea (Dillwyn), and is in fact found round our coasts.

The specimen (fig. 1 ) is a male $36^{\circ}$ inches long, stuffed and in the National collection : the monstrosity (fig. 2) is likewise in the same collection.

\section{Raia maculata, Plate CLXXII.}

Raia asterias, Rondel. lib. xii, p, 350, c. fig. Fuller's ray, Pennant, Brit. Zool. (Ed. 1776) iii, p. 86 (Ed. 1812) p. 116 (male); Shaw, Zool. v, p. 275.

p. 17].

Raia rubus, Donovan, Brit. Fishes, i, pl. xx; Turton, Brit. Fauna, p. 111; Flem.

Raia miraletus, Donovan, 1.c. $\nabla$, pl. ciii ; Turton, p. 111 ; Jenyns, Manual, p. 518; Yarrell, Brit. Fishes (ed. 2) ii, p. 570 (ed. 3) ii, p. 570.

Raia maculata, Montagu, Wern. Mem. ii, p. 426; Jenyns, 1.c. p. 514; Parnell, Wern. Mem. vii, p. 434, t. xliii; Yarrell, Brit. Fishes (ed. 1) ii, p. 429, c. fig.; Thompson, Nat. Hist. Ireland, iv, p. 260 ; Schlegel, Dieren Neder. p. 199, pl. xx, f. 2 ; Giglioli, Catal. Pesc. Ital. p. 54 .

Raia fullonica, Turton, p. 111.

Raia oculata, Fleming, p. 172.

Raia asterias, Müll. and Henle, pp. 139, 194, pl. xlvi, f. 2 (excl. syn.); Duméril, Ich. i, p. 543 (excl. syn.); A. Moreau, Poiss. de la France, i, p. 429.

Raia oxyrhynchus, White, Catal. p. 138.

Spotted ray, Couch, Fish. Brit. Isles, i, p. 104, pl. xxiv.

The width of the disk is one-fifth more than its length, or it equals its length as well as a distance equalling the extent of the snout. The tail of about equal length to that of the disk, but in some young it is shorter. The front edge of the disk is a little more than that of the hind edge, it is undulated in its outline, and projects beyond a straight line drawn from the end of the snout to its outer angle, which is somewhat rounded : posterior edge of disk convex. Eyes-of moderate size, rather less than their distance asunder: the width of the interorbital space equals $2 \frac{1}{4}$ to $2 \frac{1}{2}$ in the length of the snout. Spiracles rather larger than the orbit: mouth wide, equalling about half the length of the head. Teeth-pointed in both sexes, even in the young, in which there are from 65 to 70 rows in either jaw, in large specimens the number of these is increased. Nostrils one-fourth more distant from the end of the snout than they are apart, and having a short valve. Skin 
nearly smooth on the surface of the disk, except a spine at either shoulder, and a single row down the centre of the back: two spines in front of the orbit, and two near to its hind edge and to the margin of the spiracle, a few small ones along the snout and sometimes a few along the edge of the pectoral fin, but not continued beyond its angle. A central row of strong spines passes along the tail on which a spine divides the two dorsal fius which are well developed: no caudal fin. Along either side of the tail, are one sometimes two rows of spines which are smaller than those along its upper surface. In the adult male there are four rows of hooked spines on either wing, increasing in number and size with age. Coloursvarious : generally of a rich brown covered all over with black spots, and' which in the specimen figured are rather close together. Donovan observed they were distant asunder. A variety is figured by Donovan, showing a large ocellated spot on the wing. Montagu observes a white circle may exist surrounding a large dark spot, or a black spot may be within a white circle, the whole surrounded by five equidistant dark spots.

Varieties.-Thompson l. c. remarks upon several Irish varieties of the Homelyn. Names.-The Homelyn ray: rough ray: sandy ray: taily: spotted ray, denoting its mode of colouring: land ray, Pembrokeshire and Devonshire: eel-pot, Aberdeen. Ceffyl gwyn, Welsh. De Gladde Rog, Dutch.

Habits.-Is found nearer inshore than the thornback, with which, observes Couch, it is equally valued by the fishermen. It is very partial to sand launces.

Means of capture.-Similar to those employed for the preceding forms.

Breeding.-Couch remarks that the purse is smaller than in the thornback and shed in such shallow water as, during winter storms, to be often thrown on shore with their precious burdens within them. He obtained young from the purses in November and January, the length at that time being about five inches, of which the tail was two inches and three-eighths, the breadth three inches, with the spines even then developed. In the first week in June, 1873, one of these fishes deposited an egg in the Brighton Aquarium, and five months subsequently a young one emerged from its horny case (Hardw. Sc. Gossip, 1873, p. 276).

As food.-This species is esteemed in places.

Habitat. - From the British coasts to the Mediterranean.

Banff occasionally taken (Edward) : Aberdeen (Sim) : Firth of Forth, one of the rarest species (Parnell): Yorkshire (Pennant) : common in Norfolk (Lowe) : Hampshire and Sussex (Yarrell): common from Deronshire along the south coast to Cornwall : Pembrokeshire (Donovan). In Ireland it appears to be found around the coast.

The example figured is one-fifth the natural size, and came from Plymouth. Montagu observes that this fish attains to a much larger size than the thornback, but is not so large as the skate. Couch's specimen was 3 feet 9 inches long.

\section{Raia microcellata, Plate CLXXII A.}

Raia microcellata, Montagu, Wern. Mem. ii, p. 430 ; Fleming, p. 171 ; Jenyns, Manual, p. 515; Mïll. and Henle, p. 142; Yarrell, Brit. Fish. (ed. 1) ii, p. 433, c. fig. (ed. "2) ii, p. 567 (ed. 3) ii, p. 567 ; White, Catal. p. 139; Duméril, Ich. i, p. 538 ; Moreau, Poiss. de la France, i, p. 417.

Painted-ray, Couch, Fish. Brit. Isles, i, p. 107, pl. xxv.

Disk of moderate width, being about one-fourth wider than long, but these proportions varying with size. Front of the head obtuse, the snout being slightly produced at its extremity. The length of the tail rather less than that of the disk. Anterior edge of the disk undulated, and scarcely passes beyond a line drawn from the end of the snout to its rounded angle: the hind edge of the disk convex, and of less length than its anterior border. Eyes-small, 3 diameters apart and 5 diameters from the end of the snout. Spiracles placed close behind the orbits, than which they are larger. Mouth wide, and equalling two-thirds of its distance from the end of the snout. Teeth-45 to 55 rows, flattened in the females, pointed in adult males. 'T'he body and tail covered with rough grains, occasionally quite smooth : about midway between the hind edge of the spiracles and the base of the tail a single row of small spines commences, 
increasing in strength posteriorly and forming a single row of sharp spines along the centre of the tril: some specimens have likewise a row on either side. Colours-the apper surface light gray or greenish-gray: two or three white lines pass from near the eye circularly to near the angle of the pectoral fins, with their convexity inwards, the shortest line being nearest the border. On the hind edge of the pectorals are two or three similar lines which pass from behind the angle circularly to the neighbourhood of the abdominal fins, the convexity also being inwards. Within these segments are several brown spots and white streaks or spots. Large ones are said to be of an uniform gray. The under part of the body white.

Habits.-A moderately deep sea form, extending its range inshore, but not generally frequenting such shallow and sandy spots as the Homelyn.

Habitat. - From the southern shores of England to the coasts of France. Mr. Cornish says this form, or "the owl" as it is locally termed, is abundant in some places, as off Pra-sand in Mount's Bay, where they are quite three-fourths of the rays captured and are held in high esteem as food.

Mr. Dunn informs me that they were plentiful last summer (1883) at Mevagissey, and sent me the specimen figured on May 16th, 1884, which had been taken in a trammel: it is a female, 18 inches long and 12 inches across the disk. Couch states he obtained an example $33 \frac{1}{2}$ inches long, and saw several others during the month of April.

\section{Raia radiata, Plate CLXXIII.}

Raja fullonica, Fabr. Faun. Grœn. p. 125 ; Faber, Fisch. Isl. p. 38. Rongh ray, Pennant, Brit. Zool. (Ed. 1776) iii, p. 85.

Raja clavata, Hollb. Göth. Vet. N. Handl. iv, p. 29.

Ruia radiata, Donovan, Brit. Fish. v, pl. cxiv ; Fleming, Brit. An. p. 170; Yarrell, Brit. Fishes (ed. 1) ii, p. 439, c. fig. (ed. 2) ii, p. 585 (ed. 3) ii, p. 587 ; Johnstom, Mag. Nat. Hist. 1883, vi, and Berwick. N. H. F. Club, 1838, i, p. 176 ; Parnell, Trans. Roy. Soc. Edin. 1840, p. 145, and Wera. Mem. vii, p. 439, pl. xliii ; Jenyns, Man. p. 517 ; Fries. Vet. Ak. Handl. 1839, p. 146, pl. iii, f. 4; Nilss. Skan. Faun. iv, p. 736 ; Wright and Eks. Skand. Fisk. p. 100, pl. xliii ; McCoy, An. and Mag. Nat. Hist. 184l, vi, p. 405 ; Müll. and Henle, p. 137; Kröyer, Danm. Fisk. iii, p. 938, c fig.; White, Catal. p. 137 ; Collett, Norges Fiske, p. 214; Duméril, Ich. i, p. 531, pl. xii, f. 15 (spines); Günther, Catal. viii, p. 460; Moreau, Poiss. de la France, i, p. 394; Winther, Prod. Dan. Mar. p. 60; Giglioli, Cat. Pesc. Ital. p. 54.

Dasybatis radiata, Ch. Bonap. Catal. no. 13.

Amblyraja radiata, Malm, Fauna, p. 607.

Starry ray, Conch, Fish. Brit. Isles, i, p. 103, pl. xxiii.

Of a somewhat regular rhomboidal shape, and an obtuse angle at the end of the snout. Disk, one-fourth wider than long, and its anterior edge one-third longer than the posterior, while the angles are rounded. Eyes-of medinm size, about three diameters from the end of the snout, while their length equals about two-thirds the width of the interorbital space. Spiracles smaller than the eye and situated a short distance behind them. Teeth-in about 40 or 45 rows of pointed ones in either jaw. The length of the tail does not equal that of the disk. In adult males the claspers are half as long as the tail. Slin-body and tail armed with large thorny spines, each with a stellated or radiated base, but not placed upon a button-shaped one; these spines are curved backwards. A large row of rather distantly separated ones passes along the middle of the back and tail, and to the end of the disk; it has a smaller but similar row on either side. A strong one at the anterior and superior angle of each eye; two smaller ones over the hind edge of the orbit and spiracle; a pair of large ones on either shoulder. Most of the disk and snout with similar but smaller spines, which are not so developed in the female as they are in the male, the latter when adult has likewise some claw-like spines above the outer angle of the pectoral fin. Colours —of a pale sandy brown.

Varieties.-McCoy (Annals and Mag. Nat. Hist. 1841, vi, p. 405) observes 
that " a small specimen of this ray, 5 inches in breadth, taken with the species mentioned below in Dublin Bay, is remarkable for having the body almost destitute of spines; those, however, which are found on the snout and the anterior margin of the pectorals preserve the peculiar character of the species. This want of spines on the body is the more remarkable, as Donovan's original specimen was of even smaller size and was abundantly supplied with spines. In all other respects the specimens are identical."

Names. - Starry ray, due to the stellate character of the bases of the spines with which it is armed. Morcath arw, Welsh. La Raie Radiée, French.

Habits.-Of these but little is known. Mr. Sim writing from Aberdeen, in November, 1881, remarks that this fish is not rare there; on Saturday, October $29 \mathrm{th}$, he counted forty-four in one lot in the market, rather more than half of which were males.

Habitat.-This is essentially a northern species, being found in Iceland, Greenland, Norway, and the Baltic as far as Scania. It becomes rare in the Channel, but has occasionally been captured along the coast of France and during winter in the Gulf of Gascony.

It has been recorded as occasionally found off Banff (Edward) : Moray Firth (Gordon) : at Aberdeen Sim recorded (Aberdeen Nat. Hist. Soc. 1878, p. 93) "this species is quite abundant, their time of appearance being flom the beginning of May to the end of July. This season (1877) I have taken note of all brought to market, and from May 14 to July 31, 107 were seen, 14 being the highest number in one day." At the end of May, 1881, I found them equally numerous when visiting Aberdeen. Not uncommon in the sandy flats at St. Andrew's (McIntosh): Berwick Bay and Firth of Forth (Yarrell) : Yorkshire (Meynell).

The specimen figured is a young male, for which I am indebted to Mr. Sim of Aberdeen: it is rather larger than the drawing.

\section{Raia circularis, Plate CLXXIV.}

Raia rubus, Lacép. i, p. 79, pl. ₹, f. 1, 2, 3 (not Linn.).

Raia circularis, Couch, Mag. Nat. Hist. 1838, ii, p. 71, and Cornish Fauna, p. 53 ; Van Beneden, Bull. Ac. Sc. Belg. 1865, xx, p. 48; Collett, Norges Fiske, p. 214 ; Duméril, Ich. i, p. 536 ; Günther, Catal. viii, p. 462 ; Moreau, Poiss. de la France, i, p. 397, p. 70 ; Giglioli, Cat. Pesc. Ital. p. 54.

Raia spinosa, Yarrell, Brit. Fishes (ed. 2), ii, p. 574, c. fig.

Raia falsanela, Bonap. Faun. Ital. Pesc. c. fig.; Duméril, Ich. i, p. 550; Canestrini, Fauna d'Italia, Pesc. p. 56.

Raia noevus, Müll. and Henle, pp. 138, 194; Duméril, I. c. p. 549.

Raia, sp. McCoy, Ann. and Mag. Nat. Hist. 1841, vi, p. 495.

Raia radula, Thompson, Nat. Hist. Ireland, iv, p. 262 ; Yarrell, Brit. Fishes (ed. 3), ii, p. 574; White, Catal. p. 136.

Raia miraletus, Couch, Fish. Brit. Isles, i, p. 112, pl. xxvii.

Amblyraja circularis, Malm, Fauna, p. 608.

Cuckoo-ray and Sandy-ray, Couch, l. c. pp. 112, 115, pl. xxvii, xxviii.

Disk large, one-fourth wider than long, its posterior edge about one-third shorter than its anterior, outer pectoral angles obtuse. Snout obtuse, but with its end projecting; length of tail slightly exceeding half of the total length. Eyerather large, its diameter slightly less than the width of the interorbital space, which latter is $2 \frac{1}{4}$ in the length of the snout. Spiracles close behind the orbit, and nearly as wide. Mouth slightly arched in the middle, but otherwise transverse. Teeth-pointed, about 70 rows in the upper and a few rows less in the lower jaw. The length of the interspace between the nostrils is rather less than their distance from the end of the snout. Vent about two-sevenths nearer the end of the snout than to the extremity of the tail. Fins-the two dorsals rather close together, near the end of the tail a rudiment of a caudal fin. Slin-numerous very fine spines over most of the surface of the disk, a few larger ones on the 
snout: a row along the anterior and inner edges of the orbit, and forming a patch in the hind part of the interorbital space. In the centre of the back, above one diameter of the eyes posterior to the orbits, is an irregularly-shaped triangular patch of large spines being the anterior termination of those along the back, where there are two rows of large spines increasing at the root of the tail to four rows, and soon to six, which become very large on the tail. The male has the usual patch on the pectoral fin. Colours-of a brownish yellow on the upper surface, and a short distance behind the head on either side a black blotch, with one or more broad yellow lines in its centre, and generally surrounded by yellow spots; also many scattered brown spots may be present or absent on the disk. This spot may be absent. Under surface white, usually with a dark margin.

Names.-Sandy-ray and cuckoo-ray. Le Raie circulaire, French.

Habits.-Appears to prefer sheltered bays, and though common in the west of England is rarely taken during winter. Couch remarks that the earliest captures are in the spring, and at about 12 leagues from land. Mr. Dunn considers that the cuckoo-ray and sandy-ray are distinct species, observing that he never saw one of the former above $3 \mathrm{lb}$. weight, whereas the latter attains to $10 \mathrm{lb}$. or $15 \mathrm{lb}$. As food. - Not much esteemed, while it will not take salt.

Breeding.-Couch remarks that it deposits its eggs in December, but yet in July he saw one with eggs, some of which seemed almost ready to be shed.

Habitat.-From the coasts of western Europe and round the British Isles to the Mediterranean. Is said to be rare off France.

Broadhaven on the north coast of Scotland, and from four or five other localities in Banffshire (Peach): Aberdeen very common (Sim): not uncommon at St. Andrew's (McIntosh) : Yorkshire from three localities, mentioned as abundant in Bridlington Bay, frequently met with at Scarborough and once at Whitby (Yorkshire Vertebrata) : Plymouth (Spence) : Cornwall in deep water, especially if the soil is sandy.

In Ireland has been obtained on the N.E. and E. coasts: Dublin Bay (Thompson). length.

The specimen figured is $20 \frac{1}{2}$ inches long: Couch records one over 3 feet in 


\section{FAMILY V-TRYGONID E.}

Disk wide: pectorals continued to the end of the snout, where they become confluent. Tail long, slender, and without any lateral folds. Vertical fins, when present, imperfectly developed or modified into a serrated spine.

These fishes are found in tropical and temperate seas.

$$
\text { Genus I-Trigon, Adanson. }
$$

Himantura, Hemitrygon and Hypolophus, Müll. and Henle: Dasyatis, Rafin.: Paratrygon, Duméril : Pastinaca, Swainson.

Disk oval or rhomboidal : tail elungated and tapering. Nasal valves coalescent, forming a quadrangular flap. Teeth flattened or with a central point or transverse ridge. Pectoral fins united anteriorly: tuil destitute of a fin, or if with a cutaneous fold, such does not extend to its extremity: it is armed superiorly with one or tuo lanceolate spines serrated on both sides. Boly smooth or with tubercles.

Geographical distribution.-Temperate and tropical seas, being more common in the latter than in the former.

\section{Trygon pastinaca, Plate CLXXV.}

Pastinaca marina, Belon. p. 94; Rondel. p. 331 ; Salvian. p. 144, t. xlix; Jonston, p. 32, pl. ix, f. 7; Willughby, p. 67, t. C3 ; Ray, Synop. Pisc. 24. Raia, sp. 324, Artedi, Synon, p. 100, Genera, p. 71 ; Gronov. Mus. Ich. i, p. 64, no. 141 and Zoo no. 158. Sting-ray, Pennant, Brit. Zool. (ed. 1776) iii, p. 95 (ed. 1812) iii, p. 125; Duhamel, Pêches, iii, sect. ix, p. 282, pl. ix, f. 8.

Raia pastinaca, Linn. i, p. 396 ; Bloch, t. 82 ; Bonnaterre, Ency. Ich. p. 3, pl. ii, fig. 8; Gmel. Linn. p. 1509; Lacépède, i, p. 114; Bl. Schn. p. 460; Donovan, Brit. Fishes, v, pl. xcix; Turton, Brit. Fuuna, p. 112; Risso, Ich. Nice, p. 10.

Trygon vulgaris, Risso, Eur. Mérid. iii, p. 160; Moreau, Poiss. de la France, i, p. 448 , fig. 77.

Trygonobatus pastinaca, Blainr. Fauna France, p. 35, pl. vi, f. 1, 2.

Trygon lymma, Geoff. St. Hil. Desc. Eg. Poiss. p. 219, pl. xxvii, f. 1.

Trygon pastinaca, Cuv. Règne Anim.; Flem. Brit. An. p. 170; Bonap. Fauna Ital. Pesc. p. 33, c. fig.; Jenyns, Manual, p. 518; Yarrell, Brit. (ed. 1) ii, p. 442 c. fig. (ed. 2) ii, p. 588 (ed. 3) ii, p. 591 ; Müll. and Henle, p. 161 ; Nilss. Skand. Fauna, iv, p. 741 ; Templeton, Mag. Nat. Hist. 1837, (2) i, p. 4.13; Parnell, Wern. Mem. vii, p. 440, pl. xliii ; Kröyer, Danm. Fisk. iii, p. 1018, c. fig.; Gray, Cat. Cart. Fish. p. 118; White, Catal. p. 142 ; Thompson, Nat. Hist. Ireland, iv, p, 263; Schlegel, Dieren Neder. p. 201 , pl. xix, f. 3; Duméril, Ich. i, p. 600 ; Günther, Catal. viii, p. 478; Malm, Fauna, p. 617; Winther, Prod. Ich. Dan. Mar. p. 61 ; Canestrini, Fauna d'Ital. Pesc. p. 59; Giglioli, Cat. Pese. Ital. p. 55.

Raia sayi, Lesueur, Journ. Ac. Nat. Sc. Phil. 1817, i, p. 42.

Trygon akajei, Müll. and Henle, p. 165, t. liii ; Schlegel, Fauna Japon. Poiss. p. 308; Bleeker, Act. Soc. Sc. Indo-Neerl. ii, Japan, iv, p. 44; Duméril, l. c. p. 604 .

Trygon sayi, Müll. and Henle, l. c. p. 166 ; Duméril, 1. c. p. 603.

Myiliobatis sayi, Storer, Mem. Amer. Acad. ii, p. 514.

Pastinaca olivacea, Swainson, Fishes, ii, p. 319.

Pastinaca lavis, Gronov. ed. Gray, p. 11.

Sting-ray, Couch, Fishes Brit. Isles, i, p. 130, p!. xxxi. 
Disk almost quadrangular with the angles rounded, slightly wider than long, and the front line to the pectoral angle rather longer than the hind one, while the body along the middle line of the back is rather elevated. Snout angular but short. Length of tail exceeding the width of the disk. Eyes-small, about 2 diameters apart and 3 from the end of the snout. Spiracles close behind the orbits, than which they are larger. Mouth small, its width equalling about twothirds the length of the snout: nasal valves well developed. T'eeth-small, blunt, and in several rows. Fins-ventrals absent: anal small. No fin on the tail, but a strong, sharp-pointed osseous spine, the sides of which are strongly serrated, the points of the serratures being directed towards the body of the fish. Also there is a cutaneous fold along the tail both above and below the latter, beginning beneath the base of the spine, while the superior commences behind it. Shin-smooth, except occasionally there exist some tubercles along the middle line of the back in the scapular region. Colours - bluish black, brown, or said to be sometimes dirty yellow; under surface white. The young are spotted either with white, or else dark spots.

Varieties. - It has been supposed that two spines being present at one time on the tail of these fishes is due to their shedding this weapon periodically, and the new one has appeared prior to the old one having dropped off.

Names. - Sting ray owing to the spine on its tail: fire flare, and fiery flaw, possibly due, according to Yarrell, to the very red character of its flesh. Those possessing two spines on the tail were said to have been known in Cornwall as Cardinal Trilost or " three-tailed" (Pennant). Morcath lefn, Welsh. De Pijlstaartrog, Dutch. La Pastenaque commune, French.

Habits. -This species keeps on sandy or oozy ground at no great distance from land, and is of ten taken in shallow waters. The serrated spine on the tail of this fish occasions severe lacerated wounds of which fearful accounts have been transmitted by the Ancients. Pliny, Elian, and Oppian asserted that the venom with which it was endowed was capable of causing injury to even vegetakle and mineral substances, trees losing their verdure, and rocks being even affected. Circe armed ber son with a spear which she pointed with a Trygon's spine as the most formidable weapon she could place in his bands, and with which he subsequently unintentionally slew his father, Ulysses. Anyhow, these wounds are dangerous, for at Cochin I have had to amputate the arm of a native which was mortified owing to a wound from one of these fishes having divided the muscles and other structures almost to the bone.

Means of capture.-Trawls, or by baits.

As food.-Useless, as its $\exists$ lesh is rank and disagreeable.

Uses.-Oil from its liver, which, Dillwyn observes, is considered by the Welsh fishermen as a cure for burns and other wounds.

Habitat.-This fish has a wide range having been captured from the Norwegian coast, not only around our shores but on both sides of the Atlantic, in the Mediterranean, and likewise in China and Japan. Firth of Forth where Parnell secured one specimen (Parnell). Resident in Yorkshire, and occasionally taken off Whitby and in Bridlington Bay (Yorkshire Vertebrata): Norfolk (Lowe): Mr. Gurney mentions one weighing $28 \mathrm{lb}$., which he saw taken off Kessingland, Suffolk, September, 1856, which had a double spine : Mr. Gunn records one from

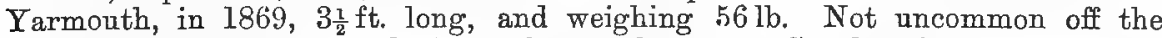
mouth of the Thames and along the south coast. Couch refers to one from Whitsand Bay: one was taken off Porthourrow sands, nine miles from Penzance, August 22, 1870 (Cornish Zool. p. 2347) : one was brought me on August 10, 1881, at Penzance, while about ten days previously two had been captured in St. Ires Bay. Swansea, common in the bay : one with two caudal spines is also recorded (Dillwyn).

Ireland.-Occasionally taken on the coast (Templeton): Carrickfergus (Meenan): Smith's Cork, which locality Thompson considers as probably erroneous: off Waterford a number were taken in 1846-47 at one haul of a trawl net (Good).

The specimen figared is from Penzance. Pennant observes that the largest he ever saw was $2 \mathrm{ft}$. 9 in. long, and 20 in. across the fish. 


\section{FAMily I-MYLIOBATIDE.}

Pectoral fins large, developed along the sides of the body, occasioning it to appear very broad: these fins are not present on the sides of the head, but reappear at the end of the snout as a pair of detached fins.

These fishes are more numerous in tropical than in temperate seas, often attaining to a very large size, when they are known as Devil fish and Eagle rays. When harpooned they dash off with great rapidity, and unless cut loose often upset the boat. Isles :-

We possess representatives of the two following genera around the British rays.

I. Myliobatis. Snout with a soft prolongation, supported internally by fin

II. Cephaloptera. Pectoral fins not extended on to the head, which latter is truncated in front, with on either side a horn-like projection, which is internally supported by fin rays. Page 354 .

Genus I-Myliobatis, Cuvier.

Etolatis, Blainville: Leiobatus, Rafin.

Head distinct from disle: snout with a soft prolongation, internally supported by fin rays: nasal valves coalescent, forming a quadrangular flap. Teeth hexagonal, flat, the central ones being broader than long: the external rows narrow. Tail very long and whip-like, having a dorsal fin near its base, and usually a serrated spine posterior to it. Body smooth or tuberculated superiorly.

The dentition alters considerably with the age of the fish. In the very young all the teeth are hexagonal, and of about equal size.

\section{Myliobatis aquila, Plate CLXXVI.}

Aquila marina, Belon. pp. 96, 97 ; Gesner, pp. 75, 76 ; Salvian. p. 147 ; Rondel. p. 338 ; Jonston, p. 33, pl. ix, f. 8, 9; Willughby, p. 64, t. C2 ; Ray, Synop. Pisc. p. 23. Raia, sp. no. 5, Artedi, Gen. p. 72, Synon. p. 100. Whip-ray, Pennant, Brit. Zool. (1776) iii, p. 88 (Ed. 1812) iii, p. 128 ; Jenyns, Brit. Vert. p. 519. Mourine, Duhamel, Pêches, iii, sect. ix, p. 283, pl. x.

Raia aquila, Linn. i, p. 396 ; Brünn. Pisc. Mass. p. 3 ; Bloch, t. lxxxi ; Gmel. Linn. p. 1508; Bonnaterre, Ency. Ich. p. 4, pl. iv, f. 10; Bloch, Schn. p. 360; Risso, Ich. Nice, p. 9.

Myliobatis aquila, Cuv. Règne Anim. ; Risso, Eur. Mérid. iii, p. 162 ; Yarrell, Proc. Zool. Soc. 1839, p. 145 and Brit. Fishes (ed. 1) ii, p. 445, c. fig. (ed. 2) ii, p. 591 (ed. 3) ii, p. 595; Johnston, Proc. Berwick. Nat. Club, 1839; Müll. and Henle, p. 176; Gray, Cat. Cart. Fish. p. 128; White, Catal. p. 141; Thompson, Nat. Hist. Ireland, iv, p. 263; Swainson, Fishes, ii, p. 320; Lowe, Fishes of Madeira, t. xv ; Capello, Peix. Port. Cat. p. 23; Duméril, Ich. i, p. 634; Günther, Catal. viii, p. 489 ; Canestrini, Fauna d'Ital. Pesc. p. 60 ; Giglioli, Cat. Pesc. Ital. p. 55 ; Moreau, Poiss. de la France, i, p. 442, f. 75 . p. 60 .

Myliobatis noctula, C. Bonap, Fauna d'Ital. c. fig.; Canest. Faun. d'Ital. Pesc.

Pastinaca aquila, Gronov. ed Gray, p. 12.

Whip-ray, Couch, Fishes Brit. Isles, i, p. 135, pl. xxxii.

Body rhomboidal, rather elevated along the middle line of the back, disk very wide, but with varying proportions, the width being nearly twice its length: 
pectoral angle acute, the line from the snout to the angle of the pectoral rather concave opposite the eyes from thence straight; posterior edge rather concave and undulated. Snout produced. Tail from half longer to twice as long as the body (Lowe), and becoming rounded and much thinner posterior to the spine. Eyes-lateral, being protected by a bony ridge which overhangs them. Spiracles large. Teeth-in adult specimens in seven transverse rows, and in each jaw they form a portion of a circle, the centre ones in the upper jaw from four to six times as broad as long, while the three lateral rows on either side are hexagonal. Fins-ventrals rather small, square dorsal; a small fin on the anterior fourth of the tail posterior to which is a strong spine serrated on both sides as in Trygon. Skin smooth. Colours-generally olive-green above, white beneath; but subject to great variation, the young being sometimes spotted with white.

Varieties. - The spine on the tail is occasionally double, which may be accounted for similarly to that of the Trygon (see page 351).

Names.-MFill-skate, due to the rolling and crushing nature of its teeth; whipray, from the length of its tail: eagle-ray, or sea-eagle, from the form of its extended pectoral fins: toad fish. Myliobate aigle, French.

Habits. - Swims rapidly, and when first captured it flourisbes its tail about in every direction, while wounds from its spine are dangerous, as in the Trygon.

Breeding.-In December, 1867, Buckland observed that Mr. Henry Lee obtained what they considered to be an egg of this fish at Margate, the purse which contained the embryo being eight inches long and five wide, while from it were flat tendrils about ten inches in length. Their common name is "Devil's purses." The surface of the centre of the purse is thickly set with raised longitudinal lines, with closely set dotted or raised lines crossing them. Near the ends and sides of these purses squares are formed which grow finer at the borders and are lost at the edge. Mr. Couch received one of these purses dredged from Fowey, which contained an embryo. Moreau observes that this is an error, and cites an instance of a fisherman who having captured one of these fish placed it in his boat, when it brought forth seven young at the same time.

As food.-Of medium quality according to Risso, but rejected in most places.

Habitat.-This fish has an extensive range, extending through the Atlantic Ocean, the Mediterranean, and Australian seas. In Berwick Bay, on September 11, 1838, one was found dead, but fresh-length of disk 13 inches, of tail $21 \frac{1}{2}$ inches, breadth of disk 21 inches (Johnston). Another is recorded in the "Natural History Transactions of Northumberland and Durham" (vol. v, p. 338), as captured off Cullercoats: another was taken there on November 5 , 1875, the breadth of which was $18 \frac{1}{2}$ inches (Wright). Scarborough (Travis and Pennant) : one taken from the Norfolk estuary is in the Lynn Museum, and the skeleton of one found dead on Lowestoft beach, June 19, 1867, was in the possession of Mr. Harper, of Norwich (Gunn). In 1871, November 1, one was taken at Torbay $27 \frac{1}{2}$ inches across, and it is now in the Exeter Museum. Another from the same locality has been recorded by Swayne (Proc. Bristol Nat. Soc. 1878, p. 126). Mr. Gatcombe (Land and Water, October 9, 1880) observes that he had examined three or four examples of this rare species caught at various times off Plymouth, the last of which was taken on May 1, and measured 18 inches across. One weighing $7 \mathrm{lb}$. was stated to have been taken off Christchurch, Hants, in October, 1880-length of body 14 inches, of tail 25 inches (R. Sharp, Land and Water, October 16, 1880). A fine female example, $34 \frac{1}{2}$ inches across and $26 \frac{3}{4}$ inches long, excluding the tail, was taken at Torbay, and received in Cheltenham on November 3, 1883, this I believe to be the largest British specimen recorded. It has been captured once off Cornwall (Cornish Fauna).

In Ireland it has been stated to have been taken in a bag-net set for salmon at Ardfry; but M'Calla (on being interrogated) was unable to determine the species.

The specimen figured is from Mr. Rodda's collection at Plymouth, and 9 inches from snout to base of caudal, the latter being $15 \frac{1}{2}$ inches long, while the breadth of the fish is $15 \frac{1}{4}$ inches. 


\section{Genus II-Cephaloptera, Duméril.}

Dicerobatis, Blainville: Molula, Rafin. . Pterocephala, Swainson.

Pectoral fin not extended on to the sides of the head, which latter is truncated in front, while on either side is a forwardly-pointing horn-like projection, which is internally supported by fin rays. Mouth wide, nostrils not confluent. Teeth in jaws very small, flat or tuberculated, and in many rows. Tait whip.like, with a dorsal fin situated above and between thie ventrals, and with or destitute of a serrated spine.

\section{Cephaloptera giornæ, Plate CLXXVII.}

Raia giorno, Lacép. v, p. 666, pl. xx, f. 3; Jenyos, Manual, p. 519.

Cephaloptera gioma, Cuv. Règne Anim.; Risso, Ich. Nice, p. 14, and Eur. Mérid. iii, p. 163, pl. v; Jenyns, Brit. Vert. p. 519; Yarrell, Brit. Fishes (ed. 2) ii, p. 595, c. fig. (ed. 3) ii, p. 600 ; Müll. and Henle, p. 184; Val. in Webb and Berthel. Tles Canar. p. 97, pl. xxii ; Gray, Catal. Cart. Fish. p. 133; Thompson, Proc. Z. Soc. 1835, p. 7 8 , and Ann. and Mag. Nat. Hist. $\mathbf{x x}$, p. 173, Nat. Hist. Ireland, iv, p. 263; McCoy, Ann. and Mag. 1847, xix, p. 176, pl. xi ; White, Catal. p. 141 ; Duméril, Ich. i, p. 653, pl. vi; Canestr. Faun. d'Ital. Pesc. p. 61 ; Moreau, Poiss. de la France, i, p. 439.

Raia cephaloptera, Bl. Schn. p. 365.

Dicerobatis mobular, Blainv. Fauna Franç. p. 41.

Pterocephala giorna, Swainson, Fishes, ii, p. 321.

Cephaloptera fabroniana, Duméril.

- Dicerobatis giornce, Günther, Catal. viii, p. 496; Giglioli, Catal. Pesc. Ital. p. 55.

Ox ray, Couch, Fish. Brit. Isles, i, p. 139, pl. xxxiii.

Disk much expanded laterally, the width equal to at least twice the length, and the outer angles pointed. The pectorals measured from their insertion behind the head to their angles, equal half the width of the disk, sometimes less. Tail equals nearly three times the length of the body, it is smooth in the first quarter of its length, and with a spine which is serrated along its edges. Eyes-small, spiracles situated behind the ejes, than which they are larger. Mouth wide. Teeth-small, and in about 150 or 160 rows, the central ones being rounded. Fins-dorsal triangular, situated anterior to the spine; ventrals of small size. Skin smooth, with peculiar and minute scales porteriorly that are rough to the touch. Colour-bluish green superiorly, white beneath.

Names.-Ox-ray, from their horn-like heads: horned-ray. This fish was first described by Professor Giorna in the "Mémoires de l'Académie des Sciences de Turin," 1805-8, p. 4.

Habits. - Said to roam about in pairs, and dies almost immediately on being removed from the water. As only one example of this fish has been observed wandering to our shores, its habits, as may be expected, have not been recorded.

Breeding.-Have been observed to occasionally go in pairs, the male being usually the smaller of the two, and Risso alludes to one case in which, after the female had been captured, the male lingered for three days around the boat, at the end of which time it was observed floating dead on the surface.

Habitat.-Mediterranean. One was captured on the southern coast of Ireland about 1830, and is now in the Royal Dublin Society's Museum, it is 45 inches broad.

The specimen figured is 57 inches broad, from Algiers, and in the National collection. The caudal fin being partly removed, is restored in accordance with the length observed by Duméril. This fish attains to an enormous size. 


\section{Sub-Crass III-CYCLOSTOMATA.}

Skeleton cartilaginous, notochordal, the skull not separated from the vertebral column; is destitute of ribs, true jaws, or limbs. Mouth suctorial, a single nasal opening. No bulbus arteriosus to heart. Six or seven gills on either side in the form of fixed sacs, and destitute of branchial arches. Rays in the vertical fins. Alimentary canal simple. No pyloric appendages, pancreas, spleen, or air-bladder. Generative opening peritoneal.

These cyclostomatous or circular-mouthed fishes are of a low type as evidenced by the persistent notochord, absence of vertebral centra's, no traco of limbs and no mandible, while their respiration is carried on in sacciform or lateral pouches, and their mouths show their semi-parasitic habits. And although morphologists may consider their position is distinct from that of the true fishes, still here they will still have to find a place in fish faunas. Kitchen-Parker" (Nature, 1883, p. 331) remarked that "the suctorial mouth has its highest development in the lamprey; in the Myxine and Bdellostoma there is no circular disk with horny teeth, but merely an oval fissure surrounded by barbels, and having inside it a huge tongue beset with two oblique rows of recurved and inturned horny teeth, antagonized by a single ethnoidal tooth. In the larva of the lamprey the mouth is not circular, and the lower lip is covered far back by the upper which is like a hood; there are no teeth of any kind, only moss-like barbels or papilloe under the upper lip." When breathing, the branchial currents are independent of the region concerned in deglutition. According to many observers, these fish would appear usually to die after breeding. Panizza remarks that both male and female lampreys after breeding are found dead. Benecke that the river lamprey $P$. fluviatilis, after breeding, gradually declines and finally dies. The metamorphoses these fish undergo, require from four to five years. Lampreys were first artificially propagated in Schleswig-Holstein, by Herr M. Franen, May 24th, 1879 , some hatched by June $3 \mathrm{rd}$, and all by the 17 th.

These fish are divisible into two families:-

I. Petromyzontidae, the stone suckers or lampreys in which the single external nasal opening terminates in a blind duct.

II. Myxinidae or the hags wherein the nasal duct penetrates the palate. 


\section{FAMILY I-PETROMYZONTID E.}

Body eel-shaped: scaleless. The single nasal aperture on the top of the head, and terminates in a blind sac. A metamorphosis occurs in members of this family attaining adult age when the mouth is suctorial, and armed with teeth besides the maxillary, mandibular and lingual ones. Eyes present in adults. Seven branchial openings on each side of the neck, the gill being in a sac, the inner duct ending in a common tube. Eyes small.

The larval forms are destitute of teeth, and the eyes are almost invisible: the young, even of a nadromous forms, said to remain several years in the fresh water.

\section{Genus I-Petromyzon, ${ }^{*}$ Artedi.}

Lampetra, Gray. For larval forms Ammoccetes, Duméril : Scolecosoma, Girard.

Definition as in the famity. Marillury teeth two, placed close together. Mandibular ones in a semi-ci,cular ritge, serrated ones on the tongue. Two dorsal fins, the posterion continuous with the dursal.

\section{Petromyzon marinus, Plate CLXXVIII.}

Lampetra s. IIustela, Belon. p. 76; Rondel. p. 398; Willughby, p. 105, t. G2, f. 2; Ray, Synop. Pisc. p. 35. Lampetra maculosa and major, Salvian. f. 63a, $63 b$; Aldrov. p. 539 ; Jonston, p. 117, t. xxiv, f. 5 ; Rutty, Nat. Hist. Co. Dublin, 1772, i, p. 351. Petromyzon, sp. no. 2, Artedi, Synon. p. 90 and Genera, p. 64. Sea-lamprey, Pennant, Brit. Zool. (Ed. 1776) iii, p. 76, pl. viii (Ed. 1812), iii, p. 102 , pl. x.

Petromyzon marinus, Linn. i, p. 304; Bloch, Ich. pl. lxxvii, and Hist. Nat. p. 653, t. Ixxvii; Bonnaterre, Fncy. Ich. p. 1, pl. i, f. 1; Gmel. Linn. p. 1513 ; Lacép. i, p. 3 , pl. i, f. 1 ; BI. Schn. p. 530 ; Donovan, Brit. Fish. iii, pl. Ixxxi ; Turton, p. 109; Mitchell, Lit. and Phil. Trans. New York, i, p. 481; Risso, Ich. Nice, p. 1, and Eur. Mérid. iii, p. 114; Fleming, Brit. An. p. 163; Jenyns, Manual, p. 520 ; Parnell, Wern. Mem. vii, p. 442 ; Yarrell, Brit. Fishes (ed. 1) ii, p. 448, c. fig. (ed. 2) ii, p. 598 (ed. 3) i, p. 32; Templeton, Mag. Nat. Hist. 1837 (2) i, p. 413; Johnston, Berwick. N. H. F. Club, 1838, i, p. 176; Gray, Catal. Chondr. p. 138 and Proc. Zool. Soc. 1851, p. 235, pl. iv, f. I; Swainson, Fishes, ii, p. 338; Nilss. Skan. Faun. iv, p. 743; Sélys-Long. Fauna Belg. p. 226; Kröyer, Danm. Fisk. iii, p. 1025 c. fig.; White, Catal. p. 143; Heckel and Kner, S. W. F. p. 374, f. 200, 201; Siebold, S. W. F. p. 368; Thompson, Nat. Hist. Ireland, iv, p. 264; Schlegel, Dieren Neder. p. 204, pl. xxi, f. 2, 3; Blanchard, Poiss. Franc. p. 512, fig. 137; Canestrini, Faun. d'Ital. Pesc. p. 31 ; Günther, Catal. viii, p. 501 ; Collett, Norges Fiske, p. 218; Houghton, Brit. F. W. Fish. p. 193, c. fig.; Winther, Prod. Ich. Dan. Mar. p. 61 ; Feddersen, p. 94 ; Giglioli, Cat. Pesc. Ital. p. 55 ; Moreau, Poiss. de la France, iii, p. 602, fig. 217.

Petromyzon lampetra, Pall. Zoo. Ross.-As. iii, p. 66.

Petromyzon Amerirana, Lesueur, Trans. Amer. Phil. Soc. i, p. 382 ; De Kay, New York Fauna, Fish, p. 379, pl. lxvi, f. 216; Storer, Mem. Amer. Acad. ix, 1867 , p. 251, pl. xxxviii, f, 4 .

Petromyzon maculosus, Gronov. ed Gray, p. 2.

Lampetra marina, Malm, Fauna, p. 630.

Sea-lamprey, Couch, Fishes Brit. Isles, iv, p. 385, pl, ccxlvii, f. 1.

Body eel-shaped, round anteriorly, becoming compressed posteriorly. Eyes not much larger than one of the branchial orifices and covered by the skin. Nasal aperture on the anterior portion of the interorbital space. Mouth surrounded p. 349 .

* See notes on the Iamprey, by G. Brown Goode, Bull. United States Fish Commission, 1883, 
with a suctorial disk and flexible lips. Teeth-in the maxilla two pointed teeth placed close together, while the mandibular one forms a crescentic ridge with from seven to nine cusps along its summit, on the tongue are four angular ridged teeth placed in pairs, and their upper edge has several conical cusps. From seven to nine rows of sharp teeth placed in oblique line, on the inner side of the sucking disk, those nearest the mouth being largest and also some of them have two cusps. Fins-the distance between the two dorsal fins equals about two-thirds the length of the base of the first dorsal, while the second dorsal is conjoined to the caudal. Slin-tough and smooth. Colours-body gray, yellowish-gray, or greenish, marbled and spotted with black or brown and occasionally with yellow, as there is considerable variation observed not only in accordance with the localities they are found in but also with the seasons of the year.

Names.-Lampreda, Anglo-Saxon: Lamprey, "lambere," to lick; "petra," a stone: stone-sucker. Llysowen bentoll and Llamprai, Welsh. Sucking-fish. I was informed (November, 1880) that a stuffed example existed in Cheltenham of a fish which about two ycars previously adbered to an individual when bathing at Margate, but the owner did not know whit the fish was. It was sent to me for inspection, and I found it to be $P$. marinus, 18 inches in length. Mere-nudler, see "adder," Anglo-Saxon. De Zeeprit, Dutch. La Lamproie marine, French.

Habits.-An anadromous fish which ascends rivers to breed; the Severn fishery is considered to commence in February, at Worcester, and lasts until May, when the fish having completed spawning it descends in $J$ une, a few occasionally being stated to remain. In the Scotch rivers it ascends about June, according to Sir W. Jardine. The mouth, when open, forms an expanded disk, the teeth being brought in contact with the substance it is lajing hold of; so that by an exhausting action air and water are removed, a vacuum becomes produced, and the fish consequently remains fixed without the need of any muscular action. One fixed to a tarry boat has been found to taste of tar, and Conch nsierts that although vegetable tar attracts these fish, coal-tar drives them away. They have been known to attack mackerel, gurnards, coal-fish, cod, haddock, and other fish. They adhere to their victims, and eat into their substance. Lampreys will eat almost any soft animal matter. They manage to tear away and swallow mouthfuls of mashed ap flesh, something like force-meat balls, taken from the body of their victims, and fish have been captured which have recovered from these injuries. This is one of the forms which lays hold of vessels so firmly as to be hardly separated from them; but it and the true sucking fish are occasionally mixe't up by observers. However, Pennant says, "One weighing $3 \mathrm{lb}$., which was taken out of the $E s k$, adhering to a stone of $12 \mathrm{lb}$. weight suspended at its mouth, from which it was forced with no small pains." It is often taken at sea, at some considerable distance from land, but generally such specimens have been of small size.

Means of capture.-In the Severn these fish are sometimes netted along with the salmon and shad, or else in weels or wicker traps laid at the bottom of the river, these last being preferred, as the fish are said not to be so bruised, for in the nets they roll about. In France Duhamel asserted the exact contrary opinion prevails. They are mostly fished for at night. The first lamprey I saw in 1881 from the Severn was on March 15th, but on going to the fishermen they asserted it to have been a chance capture, as at Tewkesbury they consider the season to be from April to the middle of June. On May 12th some fine ones were obtained. On warm sunny days a person may be gently punted to over where these fishes are resting, when they are easily gaffed or speared.

Breeding.-About April or May in the south, June in Scotland (Jardine). They are in pairs at each breeding-place. About the month of May they form a furrow for the reception of their ova, by removing stones with their suctorial mouths. They soon descend to the sea after spawning, much reduced. Thompson states that a fisherman declared they remove stones by mere strength, not by suction. I have already adverted to their being said to die after breeding.

M. L. Ferry records (C. Rend. March 12th, 1883, p. 721) how in the early part of June, 1874, a keeper caught in the Allier, a female lampiey arlhering by its 
mouth to a boat near Moulins, he opened it and placed the ova in a large pan. As it rained the pan was soon filled with water, and in about twenty days the ova were hatched. He supposes the ora are fecundated while both sexes are adbering side by side to the same rock or the same tree, a situation in which they are sometimes found in groups, where they remain attached and interlaced in such a manner that it is easy to capture them.

As food.-In the Forth, above Alloa, observes Parnell, when captured they are returned to the water by the fishermen who have a prejudice against them. The Irish are said to reject the lamprey as being so ugly, while in Cornwall they are only used as bait. Pennant observes that they are in their best season during March, April, and May, being more firm on their arrival from the sea, subsequently, as after breeding, they are much wasted and flabby. Along the banks of the Severn they are said to be in their greatest perfection until "Ascension Day," after which they fall off in condition.

Lampreys are a great delicacy when potted or stewed but a surfeiting food. The death of Henry lst has veen attributed to his having made too plentiful a repast on these fishes. Henry IV granted protection to such ships as brought over lampreys for the table of his Royal Consort, while his successor issued a warrant to William of Nantes to supply him and his army with lampreys whenever they should happen to march. The vertebral column should be entirely removed before these fish are cooked, as it is said to be very indigestible, some assert it to be even poisonous.

A single lamprey was mude a present from the Earl of Chester to King John, who in return sent a gool palfrey. The city of Gloucester at one time, annually at Christmas, presented the reigning monarch with a dish of lampreys, also a pie of the same fishes to the Prince of Wales. In the Archives of the Record Office (date not given) is the following:- "Five out of every hundred of lampreys shall go to the bailiffs for their own behoof."

Halitut.--Seas of Europe, North America and West Africa, entering rivers for breeding purposes. One occurred several years ago off Stromness, and one has since been taken by Dr. Duguid (Baikie, Zool. 1853, page 4020) : off the Shetlands, a seit lamprey 14 inches long was thus captured, the fishermen hauling their lines found that a saithe (coal-fish) romited it on deck, quite alive, and they kept it so for two days in a bucket of salt water, when it died (Land and Water, July '21st, 1×8:3): Banff, common (Edward) : one 33 inches long was captured in Feb. 1849, at Lossiemouth, where the fishermen have never taken it with a bait, but they assert that they have seen it fix itself by its mouth to a board that has not been tarred, as a new rudder, and when thus seen they are taken by a basket or "skoo" (Gordon, Zool. p. 3488). Aberdeen (Sim) : at St. Andrew's one was captured attaching itself to a boat (McIntosh). Berwickshire not uncommon (Johnston): Firth of Forth (Parnell). In Yorkshire resident and not uncommon along the coast (York. Vertebrata): in Norfolk abundant in the Yare in April aud May, when they run up to breed (Lowe): mouth of Thames (Donovan). A correspondent of the Field (Jan.21st, 1882) remarking on the fishes of North Devon, among those captured in the tidal waters of the Torridge includes "great quantities of eels and large lamrreys." Rare, according to Couch, in Cornwall, common as stated in the Cornish Fauna: two have been recorded from St. Ives, and on December 28th, 1881, Mr. Dunn, at Mevagissey, took one of these fishes measuring 15 inches in length from the stomach of a hake. The Severn was the most noted British river for them, but now they are rare there, the price being from $2 s 6 d$ each upwards: Couch, in 1862, remarked that from 30 to 40 were regarded as a successful adventure for one night at the price of $1 s$ to $1 s 6 d$ for each fish.

In Ireland, in suitable localities, they are taken in all quarters of the island and in numbers, as in the larger rivers connected with Lough Neagh where they are of regular occurrence. T'hey go up the Ballinderry river not only as far as Coagh, about five miles from Lough Neagh, but four or five miles further (Thompson). The same author received one 2 feet 5 inches long, taken on May 2.3rd, ]831, at Conswater, Belfast. It was seen with its dorsal fin above the 
surface where the water was about four feet deep, and was struck by a fisherman under the impression that it was a mullet. Found also in the Shannon; also in Dublin Bay and Liffey (Ball).

It is usually seen from about 20 to 30 inches in length; and bas been recorded from Devonshire 3 feet long, and from the Severn, at Gloucester, 37 inches long (Holland) and up to about $5 \mathrm{lb}$. weight. The specimen figured is a female 36 inches long, from the Severn.

\section{Petromyzon fluviatilis, Plate CLXXIX, fig. 1.}

Mustela, Auson. Mosell. v, p. 107. Mustela fluviatilis minor, Belon. p. 75. Lampetra parva et fluviatilis, Rondel Pisc. Fluv. p. 202 ; Aldrov. p. 581 ; Jonston, p. 117, t. xxiv, f. 6, t. xxviii, f. 10, 11; Willnghby, lib. iv, p. 104, t. G2, fig. 1 and G3, f. 2; Ray, Synop. Pisc. p. 35 ; Rutty, Nat. Hist. Co. Dublin, 1772, i, p. 351. Lampetra subcinerea, Salvian. fol. 63a. Petromyzon, sp. no. 1, Artedi, Synon. p. 89, Genera, p. 64 and Species, p. 99 ; Gronov. Miss. Ich. no. 114 and Zoophyl. no. 159 ; Klein, Pisc. Miss. ii, p. 29, t. i, f. 3. Lesser Lamprey, Pennant, Brit. Zool. (Ed. 1776) iii, p. 79, pl. viii, and (Ed. 1812) iii, p. 106, pl. x.

Petromyzon fluviatilis, Linn. Syst. Nat. i, p. 394; Bloch, Ich. pl. lxxviii, fig. 1, and Hist. Nat. p. 658, t. lxxviii, f. 1 ; Bonnaterre, Ency. Ich. i, p. 1, pl. i, f. 2; Gmel. Linn. p. 1514; Bl. Schn. p. 531; Donovan, Brit. Fish. iv, pl. lxxx; Turton, p. 110; Pall. Zoo. Ross.-As. iii, p. 66; ; Ekström, Fische Mörkö, p. 267 ; Flem. Brit. An. p. 163 ; Jenyns, Man. p. 521 ; Parnell, Wern. Mem. vii, p. 444; Yarrell, Proc. Zool. Soc. 1831, p. 133, Brit. Fish. (ed. 1) ii, p. 454, c. fig. (ed. 2) ii, p. 604 (ed. 3) i, p. 28 ; Templeton, Mag. Nat. Hist. 1837 (2) i, p. 413; Johnston, Berwick. N. F. Club, 1838, i, p. 176 ; Swainson, Fishes, ii, p. 338; Nilss. Skand. Fauna, iv, p. 745 ; Richards. Faun. Bor.-Amer. Fish. p. 294; Sélys-Longc. Faun. Belg. p. 226 ; Kröyer, Danm. Fisk. iii, p. 1042, c. fig.; Heckel and Kner, s. w.f. p. 377, f. 202 ; Siebold, s. w. f. p. 372 ; Schlegel, Dieren Neder. p. 205, pl. xxi, f. 4, 5 ; Gronov. ed Gray, p. 1 ; Thompson, Nat. Hist. Ireland, iv, p. 265 ; Blanchard, Poiss. Franc. p. 515 ; Canest. Fauna d'Italia, Pesc. p. 31 ; Günther, Catal. viii, p. 503 ; Collett, Norges Fiske, p. 219; Houghton, Brit. F. W. Fishes, p. 195, c. fig.; Feddersen, Ich. Dan. p. 94; Giglioli, Cat. Pesc. Ital. p. 55; Malm, Fauna, p. 632 ; Moreau, Poiss. de la France, iii, p. 604.

Petromyzon argenteus, Bloch, t. cccexv, f. 2 ; Bl. Schn. p. 532, t. cii, f. 1.

Petromyzon pricka, Lacép. i, p. 18.

Petromyzon jurce, M'Culloch, West. Isles, ii, p. 186, pl. xxix; Gray, Catal. Chond. p. 139.

Petromyzon nigricans, Lesueur, Trans. Amer. Phil. Soc. i, p. 385 ; Storer, Mem. Amer. Acad. ix, 1867, p. 253, pl. xxxix, f. 6; De Kay, New York Fauna, Fish, p. 381 , pl. Ixxix, f. 247 ; Gray, l. c. p. 139.

Lampetra fluviatilis, Gray, l. c. p. 140, and Proc. Zool. Soc. 1851, p. 237, pl. iv, f. 2 ; White, Catal. p. 144.

Petramyzon omalii, Van Beneden, Mem. Ac. Belg. ii, 1857, p. 549, f. 1-3, xx, 1865 , p. 46 and xxxviii, 1870, pl. viii ; Malm, Farna, p. 635. f. 2.3 .

Lampern and silver lamprey, Couch, Fish. Brit. Isles, iv, pl. 395, 400, pp. ccxlvii,

The first two-thirds of the body cylindrical, subsequently compressed. Eyerather larger than a branchial orifice. The nasal opening is situated rather in front of the eyes, on the top of the head. Teeth-a single one in the maxilla, in the form of a ridge, having a conical cusp at either end; the mandibular tooth a crescentic ridge with about seven conical cusps; tongue with a transverse cutting tooth, having a median conical cusp. Two or three teeth having two or three cusps on either side of the gullet. Small teeth in the inside of the sucking disk. Fins -an interspace separates the two dorsal fins, the anterior of which is the lowest, while the second is united to the caudal. Skin-smooth. Colours-bluish, often glossed with bronze and purple along the back, silvery on the sides and bencath; sometimes obscurely streaked. A dark stripe passes backwards from the cye along the gill-openings. Dorsal and anal fins with a dark mark in their 
bighest part. In March and April the difference of the sexes was readily apparent, the females were the more distended, while the lips of the males were the more tumid, and the mouth the larger.

Names-Lampern, lampron and lamper-eel: nine-eyes, nine-holes, the eye and nasal orifice appear to he here counted: seven-holes when only the gill-openings are enumerated. Barling, cunning, and spanker-eel, Northumberland: say-nay, Lancashire. Lleprog, Welsh. De Prix, Dutch. La Lamproie I'luriatile, French.

Habits. - Yarrell observed that they are taken every month in the year in the Thames, and doubted its being anadromous. Higgins (Zool. 1861, p. 7318) records its capture in the sea near Weston-super-Mare. Dr. Ball alludes to one 10 inches long, taken in the sea at Yonghal. In Norfolk they have been observed to mostly frequent gravelly shoals, but this has been during the breeding season. Thompson received one which was taken adhering to a large trout. He continues: "In a large, deep pond made for gold fish, at the falls, near Belfast, a portion of the surface of which was covered with the leaves of the white water lily, I observed, on a warm day in summer, an extraordinary appearance, caused, as I believed, by this species. To the under surface of each floating leaf of the plant, several (in some instances so many as a dozen) lampreys, about a foot in length, the adult size of this species, attached themselves by the mouth, while the wriggling of their dangling bodies had a strange effect. They were too far from the edge to be captured by any available means, but I have no doabt that they were all fullgrown individuals of this species." In an aquarium respiration at first was from 190 to 210 a minute; on the third day, with the head and branchial portion entirely ont of the water, it was reduced to 100 a minute. On aïrating the water with a garden syringe, cich fish withdrew its head under water, and the number of respirutions was still further decreased to 80 . Should water be foul they raise their heads in an aquarium above the surface. On breathing a peculiar noise is occasioned by bubbles being forced out of the gill-sacs. They will live several hours after having been removed from the water. They will hold on by their sucking wouths, feeling very similar to leeches. They consume worms, insects, and the flesh of dead fishc's, and affix themselves to living fish, among which they are accused of doing much injury.

Modes of capture.-Mostly in cruives or weels; while they are kept in the river at Tewkesbury in large wicter baskets.

Baits.-Dame Juliana Berners observes, upon recommending a worm or minnow for trout, continues: "In Aprill take the same baytes; and also Juneba, other wise vii-eyes."

Fisheries. - Very few ascend alove the navigation weirs on the Thames and Severn, while they deteriorate in value the higher they go. Formerly they reached Montgomergshire, and are said to have been taken in the Verniew (Field, $\operatorname{Jan} .28,15 \times 2)$. In the Thames they were formerly captured in quantities from Battersea Reach to Taplow mills, and Yarrell observes that this river formerly supplied from 1,000,000 to 1,200,000 annually. A Parliamentary Committee ascertained that formerly one person, during a single season in the Thames, took as many as 130,000 fish. Now they have decreased, from being detained and captured at the Teddington weir, in a sort of bason, and so are unable to reach their breeding-grounds as of old. But as they decrease in numbers they augment in price. The Dutch used to pay from $£ 3$ to $£ 5$ a thousand for the cod and turbot fishing, and have expended as much in one year at the Thames as $£ 4000$ on these fish. At the end of March, 1867, in the Thames below Surley Hall, five or six lampreys were found in eel-pots which had been in the water all the winter. Fishermen had not seen any for the ten previous years in the Thames at this spot (A. Clark-Kennedy, Zool. 1867, p. 836). In 1882, up to the middle of January, 120,000 fish were stated to have been captured, and they were still coming in (Field, Jan. 21st, 1882).

Uses.-Irrespective of food, an excellent bait for cod and turbot, for which purpose vast quantities used to be taken in the Thames. Large quantities are taken in the Trent from August until March, and sent alive to Great Grimsby for bait. They are conveyed in wicker baskets, but a man goes with them 
who constantly stirs them up or the centre ones are suffocated. A good many are taken in Norfolk and sold to the eel-fishers as bait (Lubbock, p. 181), "for which purpose it is first-rate; cut into pieces of about an inch in length, it is so tough upon the hook, as generally to baffle any attempt in the eel to suck or nibble it off. This bait will also last good for two or three nights' trial, whilst a roach or other small fish is water-sopped" (p. 184).

Diseases, \&r.-Are much destroyed by rats which prefer their gill-sacs to any other part of the body.

Breeding.-From April to June and has been known to do so as late as July, at Tewkesbury. At this season they collect in small communities as of 10 or 12 . A correspondent of Loudon's "Magazine of Natural History" (vol. v) observed that one twists its tail around another, during which the sand and gravel are stirred up by their movements, and that this occurs when they are depositing milt and ovä, as the two fish are invariably of opposite sexes. Müller discovered the larval or ammocætus-form of this fish in Prussia about thirty years since. Yarrell examined some of these fish from the Thames every week from March to the middle of May, and found that up to April 19th, the females exceeded the males in number, subsequently the females were nearly ready to deposit their ova, and then the proportions were two males to one female. By April 26th, the ova were ripe and the milt fluid, while by May 10th, nearly all were shotten. Sometimes they go in pairs, sometimes in numbers to the breeding-ground, while they act together in removing the stones in order to prepare the spot.

As food-Milder than the sea lamprey, $P$. marinus, and are excellent stewed. During the last few years they have been for sale in the Cheltenham fish shops on and off from September, but usually from the middle of October until the middle of April. In Norfolk " a prejudice prevents their being eaten, unless by a few of the initiated. These delicacies, when taken, are sometimes beaten to death, kicked about, and cut in pieces, as if, in lieu of causing an epicure's heart to beat within him, they were altogether nauseous and disgusting" (Lubbock, p. 183) "whereas in former days people wore better acquainted with their real merits. Sir T. Browne mentions them as "plentiful and highly prized, whether collared or in pyes."

Pennant (1776) observes on the cost being $£ 2$ per 1000 for them from the Thames. At Tewkesbury they are chiefly employed for two purposes, as bait for cod for which purpose they realize $50 s$ a 1000 , or else for potting ( 6 s per 100 January, 1884). They have to be very carefully cleaned for potting, and the vertebral column ought to be removed. A correspondent in the Field (January 28 th, 1882) observes that the price at Worcester is about $£ 4$ per 1000 , or $1 d$ each. Kept in rivers in wicker baskets or creels: they only cross weirs when the water is so high as to leave the erection unseen.

Habitat. - This fish has an extensive range, having been found on the coasts and fresh waters of Europe, North America, and Japan.

Abounds in many rivers in England, Scotland, and Ireland, particularly the Thames, Severn, and Dee; also in the Tweed and several Scottish rivers. Rare at Banff (Ldward): common in Spey, Lossie, and in Moray Firth, Aberdeen (Sim) : larger rivers entering Firth of Forth and also in the Firth (Parnell). Found two or three specimens in the Tweed (Johnston). A freshwater resident, and the Dutch fishermen have for more than a century visited the Ouse for the purpose of purchasing these fish for bait (Yorkshire Vertebrata). In Norfolk they are often caught at low water in stow-nets opposite Lynn (Lubbock). In the Exe, Plym, and Axe, in Devonshire, they are sometimes abundant (Parfitt): in the eastern part of Cornwall they are common in spring (Cornish Fauna): Swansea (Dillwyn). Ireland, found from north to south of the island, sometimes adhering to other fishes and devouring them (Thompson). One taken in Lough Neagh adhering to trout (Thompson). Rutty (1772) remarked, found in rivers as the Liffey, Finglass, and at Dundrum. Templeton says that it is not plentiful in Irish rivers.

The specimen figured from Tewkesbury is twelve inches long, but this fish attains to as much as fifteen inches in our waters. 


\section{Petromyzon branchialis, Plate CLXXIX, figs. 2 and 3.}

Petromyzon planeri, Bloch, Ich. pl. lxxviii, f. 3, and Hist. Nat. p. 664, t. lxxviii, f. 3 ; Bonnaterre, Ency. Tch.i, p. 2, pl. i, f. 4; Gmel. Linn. p. 1516; Turton, p. 110 ; Bl. Schn. p. 532 ; Lacép. i, p. 30, pl. iii, f. 1 ; Blainv. F. Franç. ii, p. 8, pl. i, f. 3 ; Jenyns, Manual, p. 522; Yarrell, Brit. Fish. (ed. 1) ii, p. 457, c. fig. (ed. 2) ii, p. 607 (ed. 3) i, p. 19 ; Parnell, Wern. Mem. vii, p. 446 ; Nilss. Skand. Fauna, iv, p. 747 ; Thompson, P. Z. S. 1837, p. 58, and Nat. Hist. Ireland, iv, p. $266^{3}$; SélysLongc. F. Belg. p. $220^{\circ}$; Kröyer, Danm. Fiske, iii, p. 1052, c. fig.; Johnston, Berwick. N. H. F. Club, 1838, i, p. 176 ; Heckel and Kner, S. W. Fisch. p. 382, f. 204 ; Siebold, S. W. Fis. p. 375 ; Gronov. ed Gray, p. 2 ; Blarchard, Poiss. Fran. p. 517, f. 138-14.9; Canestrini, Faun. Ital. Pesc. p. 31 ; Feddersen, Ich. Dan. p. 95 ; Moreau, Poiss. de la France, iii, p. 606.

Petromyzon sanguisuga, niger and septocuille, Lacép. ii, p. 101, iv, p. 667, t. $x \nabla$, f. 2.

Petromyzon bicolor and plumbeus, Shaw, Zool. v, p. 263. p. 144

Lampetra fluviatilis et planeri, Gray, Chond. pp. 140, 141; White, Catal.

Petromyzon branchialis, Lacép. i, p. 26, pl. ii, f. 1 ; Günther, Catal. viii, p. 504; Houghton, Brit. F. W. Fishes, p. 196, c. fig.; Collett, Norges Fiske, p. 220; Giglioli, Cat. Pesc. Ital. p. 55 ; Malm, Fauna, p. 636.

Ylaner's lamprey, Couch, Fish. Brit. Isles, iv, p. 402, pl. cexlviii, f. 1.

\section{(Immature forms.)}

Lamproyen, Rondel. Pisc. Flur. p. 202. Lampetra cceca, Willugh. p. 107, t. G3, f. 1 ; Ray, Synop. Pisc. p. 36. Petromyzon, no. 3, Artedi, Synon. p. 90, and Genera, p. 64; Gronov. Zooph. no. 160. Pride, Pennant, Brit. Zool. (Ed. 1776) iii, p. 80, pl. viii (Ed. 1812) iii, p. 107, pl. x.

Petromyzon branchialis, Linn. i, p. $394 ;$ Bl. l. c. pl. Ixxviii, f. 2, and Hist. Nat. p. 662 , t. Ixxviii, f. 2 ; Bl. Schn. p. 532 ; Bonnaterre, l. c. p. 1, pl. i, f. 3 ; Gmel. Linn. p. 1515; Turton, p. 110; Gronov, ed Gray, p. :

Petromyzun ruber, Lacép. ii, p. 99, pl i.

Petromyzon lumbricalis, Pall. Zoo. Ross.-As. iii, p. 69.

Petromyzon caecus, Couch, Mag. Nat. Hist. r, p. 23, f. 10.

Ammocetes branchiulis, Cuv. Règne Anim.; Nilss. Skand. Fauna, iv, p. 748; Fleming, p. 164; Jenyns, p. 522 ; Parnell, 1. c. 447 ; Yarrell, 1. c. (ed. 1) ii, p. 459, c. fig. (ed. 2) ii, p. $6 \cup 9$; Templeton, M. N. Hist. 1837 (2) i, p. 4133; Sélys-Longc. l. c. p. 227 ; White, Catal. p. 145 ; Swainson, Fishes, ii, p. 338; Kröyer, iii, p. 1060, c. fig.; Heckel and Kner, l. c. p. 382, f. 204; Gray, Chondr. p. 145; Thompson, Proc. Zool. Soc. 1835, p. 82 and Nat. Hist. Ireland, iv, p. 266.

Mud lamprey, Couch, Fish. Brit. Isles, i, p. 404, pl. cexlviii, f. 2.

In appearance this much resembles the last described form, but is smaller; while its eye, nasal orifice, and first branchial opening are nearer to the snout than in either of the two preceding forms. Lips wide and fringed. Teeth-as in the $P$. fluviatilis, but the points are blunter. Fins - the two dorsal fins continuous or only separated by a notch, the first commencing about or a little before the total length, while the second dorsal is continuous with the caudal, and inferiorly a tin is present as far as the vent. Colours-silvery along the back, becoming white beneath; the fins sometimes with a brown tinge. The larral form is distinguished by being edentulous, and the upper lip merely covers the upper portion and sides of the mouth, while it is surrounded by numerous short cirri. The fins are likewise small and not well developed. It has been questioned whether this fish is not the young form of the river lamprey.

Names.-The pride, or blind lamprey, or fringe-lipped-lamprey. This fish has been termed the Pride of the Isis (Plot's "Hist. of Oxfordshire"), but the term pridt: was eridently employed in a wider sphere than the County of Oxford alone, 
as in Elyote's Dictionarie, London, 1559, it is observed, "lumbrici are littell fyshes taken in small rivers, whiche are lyke to lampurnes, but they be muche lesse, and somewhat yeolowe, and are called in Willshyre prides." Llamprai' $r$ Uaid, Welsh. The term branchialis was given it on the supposition that it attached itself to the gills of other fishes.

Habits.-Pennant remarks that instead of concealing themselres under stones they lodge in the mud, and have never been observed to adhere to anything like other lampreys. Couch however found that they did so adhere when in an aquarium. Ball, in Thomson's "Nat. Hist. of Ireland," gives an account of two of these fish placed in a globe of water along with a pair of gold fish. "The two species continued together for two or three weeks, the lampreys never for a moment intentionally molesting their more brilliant companions, though in their gambols they would occasionally dash against them, apparently through a deficiency or total want of sight, as they did against objects of every description placed within the range of their evolutions. These evolutions are always similar, the fishes dashing violently from the bottom of the vase with a rapid wriggling motion to the surface of the water and back to the bottom again obliquely, and thus continuing for a short time, although apparently as long as they have the power; for in the midst of their most lively motions, they seem as if suddenly paralyzed; they invariably fall in a seemingly senseless manner to the bottom, and whether they alight on back, belly, or sides, it is indifferent to them, as they continue to remain in whatever position their body reaches the bottom, until roused again to activity, which sometimes does not occur for a considerable time."

It may be kept alive in a pan of water for months, being very hardy. It should be in a cool but dark place, and have fresh water at first twice weekly; afterwards once will suffice, or less.

Means of capture.-Obtained from mud banks in brooks by enclosing banks by means of a dam and subsequently digging the fish out.

Breeding.-Professor Wiedersheiner believes it to die after breeding. Thompson remarked that in the river Frome, close to Dorchester, they attached themselves to the stones, and then by wriggling their bodies detached it from its bed, when making a spring for about 18 inches they dropped the stone. He states they were not making a nest, as they did not drop two stones in the same place; he thought they were searching for food (Zool. xiii, 1855, p. 4705). In the "Wild Sports of the Highlands," the author remarks, when watching some lampreys in a small ditch of clear running water: "They were about six inches in length and as round as a pencil. The two little creatures were most busily employed in making little triangular heaps of stones, using for the purpose irregularly shaped bits of gravel about the size of a large pea. When they wished to move a larger stone, they helped each other in endearouring to roll it into the desired situation; occasionally they both left off their labours and appeared to rest for a short time and then to return to the work with fresh vigour.

Uses.-Bait for pollack in Cornwall, also cod fish. Employed as towing bait in Cornwall, the boat being slowly propelled. It is very tough, and the same bait may be employed for capture after capture.

Habitat.-This fish is distributed through the rivers of Europe and likewise those of North America.

Throughout the rivers and streams of these islands. Has been recorded at Banff (Edward) : at Gamrie, Banffshire: about the middle of April, 1853, large colonies of its young were to be seen in the burn of Blackton, Aberdeenshire (Harris, Zool. 1854, xii, p. 4260) : Aberdeen (Sim) : Berwickshire not uncommon (Johnston): is occasionally met with in the Forth, Teith, Allan, and several other Scottish rivers (Parnell) : Lancashire (Yarrell): Yorkshire (York. Vert.) : Norfolk (Lowe): Sussex (Linwood): Surrey (Yarrell): Gloucestershire : Oxfordshire, especially in the Isis : common in Cornwall.

In Ireland from north to south (Thompson): an inhabitant of its rivulets (Templeton).

Attains from 8 to 10 inches long and to nearly as thick as the little finger. 


\section{FAMILY II-MYXINID Æ.}

Body vermiform: scaleless. Branchial orifice a considerable distance behind the head and opening internally into the æsophagus. No lips. Nasal orifice at the anterior end of the head, which is furnished with four pairs of barbels. The nasal duct, which is provided with cartilaginous rings, perforates into the palate. Along either side of the abdomen is a row of mucous sacs. No spiral valve to the intestine. Ova large and possessing adhesive filaments at both extremities.

\section{Genus I-Myхine, Linnceus.}

Gastrobranchus, Bloch.

Definition as in the family. A single external branchial opening on either side, which leads internally by six ducts into as many respiratory sacs.

Geographical listribution.-North Atlantic, Straits of Magellan and Japan.

\section{Myzine glutinosa, Plate CLXXIX, fig. 3 .}

Myxine glutinosa, Linn. Syst. Nat. i, p. 1080; Fabr. Fauna Groenl. p. 344; Fleming, Brit. An. p. 164; Jenyns, Man. p. 523; Fries and Ekstr. Skand. Fish. p. 121, t. xxviii ; Johnston, Mag. Nat. Hist. vi, 1833, p. 15; Templeton, Mag. Nat. Hist. 1837 (2) i, p. 413 ; Yarrell, Brit. Fishes (ed. 3) i, p. 12; Swainson, Fishes, ii, p. 338; White, Catal. p. 145 ; Nilss. Skand. Fauna, iv, p. 750; Kröyer, Danm. Fisk. iii, p. 1068, c. fig. ; Thompson, Nat. Hist. Ireland, iv, p. 267 ; Gray, Cat. Chond. p. 147 ; Steenstr. CEfv. Dansk. Vid. Selsk. Förh. 1864, p. 233; Günther, Catal. viii, p. olo; Collett, Norges Fiske, p. 220; Malm, Fauna, p. 637; Winther, Prod. Ich. Dan. Mar. p. 62.

Sleepmarlen, Günner, Trond. Hand. ii, p. 250, t. iii... Ilidual, Ström, Sönd. p. 287. Glutinous hay, Pennant, Brit. Zool. (Ed. 1812) iii, p. 100.

Gastrobranchus ccecus, Bloch, t. cccexiii ; Lacép. i, p. 5:5; Bl. Schn. p. 534, t. civ ; Turton, p. 110; Shaw, Nat. Misc. x, pl. ccclxii ; Yarrell, 1. c. (ed. 1) ii, p. 462 , c. fig. (ed. 2) ii, p. 612.

Myane ceeca, Blainv. Fauna Fran. ii, p. 2, t. 1 a.

Myxine limosa, Girard, Proc Ac. Nat. Sc. Phil. 18.8, p. 2.23.

Borer, Couch, Fish. Brit. Isles, iv, p 4(J), pl. ccxlriii,

Body vermiform, cylindrical, rounded anteriorly, and slightly compressed and tapering posteriorly. Head obliquely truncated anteriorly, with a large mouth surrounded by three pairs of barbels, while a fourth pair are placed cluse to the nasal orifice. Wyes-absent, or very rudimentary. T'reth-a single curved tooth on the palate, and two crescentic-shaped rows on the tongue containing eight or nine rather slender teeth in each, the two front ones the stoutest. Fins-a narrow dorsal fin commencing about the middle of the total length and continued round the tail to the vent. Skin scaleless; two rows of pores along the abdominal surface. Colouis - of a pale yellowish or pinkish white.

Names.-Hag, glutinous hag, owing to this character Linnæus (who at first placed it among the worms) asserted it would turn water into glue, being misled by the viscous flaid which it exudes; devourer from its habits; brer from its boring into the bodies of fish; pirate fish; termed Eeliart and Pousion Ramper,
Moray Firth.

Habits.-This parasitic fish enters the mouths of such forms of fish (especially of the cod family), as may have been hooked, or fusteus itself into wounds on 
sores, or obtains access by the gills and devours its victim with the excoption of the bones and skin. In many places fish left a tide when on the hooks are found to have been totally devoured.* It seems to prefer a muddy or clayey to a sandy bottom. Off Flamborough Mr. Bailey remarks, "Talking to one of our old fishermen, he tells me that some years ago borers were so numerous in various places in the North Sea that fishermen had frequently to remove their fishing lines on to some other ground, on account of the borers getting at their fish while caught on the hook, and destroying the whole catch." The amount of slime it exudes from its body is very great. $\dagger$

Although Thompson refers to this fish having been taken with a baited hook, such an instance must be extremely rare. Mr. Cocks, at Falmouth, found one partly digested in the stomach of a cod.

Breeding.-Steenstrup (CEfvers. Dansk. Vid. Selsk. Förh. 1863, p. 233, c. fig.) remarks on the eggs of this fish in situ, which were in a state of maturity. They were ovate in form, about $15 \mathrm{~mm}$. long, and $8 \mathrm{~mm}$. broad, enveloped in a horny case, at either end of which were a bundle of short threads, each of which ended in a treble hook, causing them to adhere one to another, and also to any contiguous objects. The males are said to be the smaller, and to be but seldom found.

Habitat.-Northern and western coasts of Europe, and Atlantic coast of North America. Very numerous off Norway. It has been more frequently recorded from the eastern than from the western shores of the British Isles. Wick (Reid): common in the Moray Firth (Zool, 1851): also off Banffshire (Edward): Aberdeen (Sim), and occasionally on the cod at St. Andrew's (McIntosh) : Firth of Forth (Goodsir): Berwickshire (Johnston). An example from Newcastle is in the British Museum. Resident and abundant from Redcar to Flamborough (Yorkshire Vertebrata). I have obtained it from Weymouth. Rare in Cornwall (Cornish Fauna): Swansea (Dillwyn).

Ireland.-Dalkey, County of Dublin (Wright): Carrickfergus (Templeton).

The specimen figured was obtained among several others at Weymouth. One 14 inches long was taken from a cod fish in the Moray Firth in January, 1849. Couch alludes to one 15 inches long. 1884.

* Some forms of sessile-eyed crustaceans similarly devour fish, see Day, Proc. Zool. Society, $\dagger$ See J. E. Blomfield "on the thread-cells and epidermis of Myxine" (Quarterly Journal Micros. Sc. 1882, xxx, pp. 355-361, pl. xxx). 


\section{Sub-Crass IV-LEPTOCARDII.}

Skeleton semi-cartilaginous and notochordal : destitute of jaws or ribs. Brain absent. Blood colourless, and distributed by pulsating sinuses. Respiratory and abdominal cavities confluent; numerous branchial clefts, and the water discharged by an opening in front of the vent.

\section{FAMILY I-CIRROSTOMI.}

An elongated compressed body; having a low rayless dorsal fin, continued round the tail past the vent to the respiratory opening. Mouth a longitudinal slit on the inferior surface with cirri. Eyes rudimentary. Vent near the end of the tail.

$$
\text { Genus I-Branchiostoma, Costa. }
$$

Amphiowus, Yarrell.

Definition as in family.

\section{Branchiostoma lanceolatum, Plate CLXXIX, fig. 4.}

Limax lanceolatus, Pallas, Spicil. Zool. x, p. 19, t. i, f. 11.

Branchiostoma lubricum, Costa, Cenni, Zool. Nap. p. 49.

Amphioxus lanceolatus, Yarrell, Brit. Fish. (ed. 1) ii, p. 468 (ed. 2) ii, p. 618 (ed. 3) i, p. 1; Thompson, Nat. Hist. Ireland, iv, p. 268; Couch, Fish. Brit. Isles; iv, p. 415 , pl. cexlviii.

Brachiostoma lanceolatum, Gray, Catal. Chond. p. 150; White, Catal. p. 146 ; Günther, Catal. viii, p. 513.

This creature is introduced here, due to its being included in other works on British fishes. The structural resemblance between Amphioxus and the Ascidians was pointed out by Goodsir. In 1866-67, Kowalevsky published in the "Memoirs of the Academy of St. Petersburg," essays on the development of this animal, and of Ascidiuns, as spanning the gulf between the vertebrates and invertebrates, and giving positive foundation to the doctrine of a phylogenetic connection between apparently entirely different circles of life.

Of a compressed form, pointed at both ends; vent at the commencement of the last quarter of the body. The abdominal pore for the exit of the water from the branchiæ, opens at about the middle of its entire length. Colours-opalescent.

Habits.-Couch found his specimen in December, 1831, at Polperro, buried in a small quantity of sand, at about 50 feet from the receding tide, and on turning over a small flat stone that was on the sand, its tail was seen. The specimen figured among some others, was dredged at Meragissey in 1883, and when brought on shore with the remainder of the refuse, showed great signs of activity, and rapidly disappeared in the moist sand. Mr. Ogilby observed that in an aquarium they buried themselves in the gravel, emerging as soon as darkness came on, but the approach of a candle caused them at once to again retreat into the gravel.

Habitat.-Cosmopolitan in most temperate and many tropical regions. It has been recorded from Norway and Sweden, and along our shores in the Isle of Man (Forbes): Firth of Clyde (White) - the Moray Frith: St. Andrew's (McIntosh): Redcar in Yorkshire, Hampshire, along the west of Cornwall and Guernsey. Also along the south coast of Ireland; and Mr. Douglas Ogilby on March 16th, 1868 , obtained two between the tide-marks in Portrush harbour : they were about $2 \frac{1}{2}$ inches in length. 


\section{ADDENDA.}

While this work has been passing through the press the following additions have been made to the British Fish Fauna.

\section{Volume I, page 120.}

\section{SChedophilus medUSOphagus, Vol. I, p. 117.} p. 57.

Centrolophus medusophagus, Cocco, in Giorn. Innom. Mess. Ann. iii, no. 7,

Schedophilus medusophagus, Cocco, l. c.; Bonap. Faun. Ital. Pesc. c. fig.; Günther, Catal. ii, p. 412, Fisch. d. Südsee, p. 149 and Trans. Zool. Society, xi, p. 223, pl. xlvii ; Lütken, Vid. Selsk. Skr. 1880, p. 525 ; Canestrini, Fauna d'Italia, Pesc. p. 108; Giglioli, Catal. Pesc. d'Ital. p. 26 ; Morean, Poiss. de la France, ii, p. 502, f. 139 .

B. vi-vii, D. $45-50$, P. 18, V. 1/5, A. 27-29, C. 21.

Length of head about $1 / 6$, of caudal fin $6 \frac{1}{2}$, height of body $2 \frac{3}{4}$ in the total length. Eyes-about $1 / 4$ of the length of the head, $1 \frac{1}{4}$ diameters from the end of the snout, and the same distance apart. Posterior and lower margins of preopercle spinate, also the lower edge of the interopercle, and the subopercle slightly so. Body of an elongate ovoid shape, strongly compressed. Cleft of mouth of moderate depth, the hind edge of the maxilla reaching to below the middle of the orbit. Teeth-minute, in a single row in the jaws, none on the palate. Gill-openings wide. Fins-dorsal low, it commences above the root of the pectoral and is continued to the caudal peduncle, which latter is about as long as deep. Ventrals small. Anal commences slightly behind the middle of the total length. Caudal rounded. Scales-small, cycloid. Lateral-line-at first slightly arched, becoming straight opposite the hind edge of the pectoral fin. Colours-greenish-olive marbled with darker, also with spots and irregular longitudinal bands. The vertical fins spotted with dark.

Habitat.-Mediterranean, in the open Atlantic, and in the South Sea. Moreau obtained bis example from Marseilles, where it was taken in July, 1877.

The above example, which is $9 \frac{1}{2}$ inches in length, was captured on the south coast of Ireland, and exhibited at the Zoological Society in June, 1881, and it had been procured in August, 1873, by Mr. Donglas Ogillby from a salmon net at Portrush, co. Antrim.

\section{Volume II, page 51.}

\section{Paralepis coregonoides.}

Coregonus marcenula, Risso, Ich. Nice, p. 328.

Paralepis coregonoides, Risso, Eur. Mérid. iii, p. 472, pl. vii, f. 15 ; Cuv. and Val. vii, p. 357, pl. lxvii; Bonap. Fauna Italia, Pesc. c. fig. ; Günther, Catal. v, p. 418; Canestrini, Fauna Italia, Pesc. p. 127 ; Giglioli, Catal. Pesc. Ital. p. 41; Moreau, Poiss. de la France, iii, p. 519, fig. 205 ; Day, Zoologist, 1883, pp. 381 and 506 .

B. vii, D. 10/2-3 (?), P. 13, V. 9, A. 23-25.

The proportions of this fish are subject to great variations. Body slender and moderately compressed, the abdominal edge being sharp. The following is taken from Mr. Couch's description of the specimen soon after it was captured. Eyelarge, and situated one inch from the end of the snout. The lower jaw projecting a little beyond the upper : cleft of mouth very deep. Teeth-a single row along either jaw, also present on the palate. Fins-first dorsal commences rather nearer the end of the caudal fin than the end of the snout, its posterior border incurved as are those 
of the second dorsal and anal: both the last-named end near the tail, this posterior portion being so low as to be scarcely perceptible, and even the anterior portion of the dorsal very slightly so. Ventrals under the first dorsal: the tail rather wide, incurved, the anterior border of it, above and below, narrow and almost touching the lower rays of the second dorsal and anal. Scales-of moderate size and very deciduous. Lateral-line-commences above the hind edge of the gill-covers, and passes direct to the centre of the tail. Colourssilvery, darkest along the back, and a row of spots or marks along the lateral-line.

Habitat.-Mediterranean, where it is rare. The Cornish specimen alluded to is 10 inches long, and in spirit. It was caught by the hand when alive in 1869 , by Mr. Dunn at Polkerris pier, near Mevagissey, and was supposed to have been wounded by some other fish. Mr. Dunn sent it to Couch, who presented it to the British Museum. But it was not included in the British Museum catalogue. After my having been allowed access to Mr. Couch's Journals, and published his account in the Zoologist, Dr. Günther showed me the identical specimen in the National collection. 


\section{N D E X.}

Abramidopsis, ij, 193

Abramis, ii, 193

Abramo-rutilus, Abramis, ii, 157,176

abramo-rutilus, Bliccopsis, ii, 176

Abyssal fish, lxxxi, lxxxi

Acanthias, ii, 315

acanthias, Galeus, ii, 315

acanthias Spinax, ii, 315

Acanthocepola, 213

Acanthocobitis, ii, 203

Accinthocottus, 45

Acanthogobius, 158

Acantholabrus, 252, 266

ACANTHOPTERYGII, 1

ACANTHOPTERYGII GOBIIFOR. MES, 158

Acanthopteritgil Sol AniFORMES, 149

ACanthopterygil , TrichIURTFORMES, 153

Acanthorhinus, ii, 315

acarne, Pagellus, 35, 36, 38, 39

accessory respiratory organs, xlviii

Acentrogobius, 158

Acerina, 11

acerina, Perca, 11

Acipenser, ii, 279

ACIPENSERID $4, \mathrm{ii}, 278$

Acoura, ii, 203

acoustic function, $x$ xliii

Actiniæ, 9

Actinogobius, 158

aculeata, Mola, ii. 273

aculeata, Rhina, ii, 326

aculeata Squatina, ii, 326

aculeatus, Gasterosteus, 169, 237,238 ; ii, 186

aculeatus, Leinurus, 238

aculeatus, Orthragoriscus, ii, 273

aculeatus, Rhombus, ii, 12

Acus, ii, 261

acus, Belone, ii, 147, 148

scus, Fierasfer, 328

acus. Siphonostoma, ii, 259

acus, Syngnathus, ii, 256, 257, 258,259

acuta, Perca, 3

acutirostris, Anguilla, ii, 241

adag, 284

adder pike, 82

adhorens, Lepadogaster, 191

adriatica, Trigla, 56

adspersus, Balistes, $\mathrm{ii}_{2} 268$

स्glefinus, 274

xglefinus, Gadus, 275, 283

cegle-fin, 284

æglefinus, Melanogrammus, 283 æglefinus, Morhua, 283

cegyptica, Anguilla, ii, 242

æquoreus, Acus, ii, 261

æंquoreus, Entelurus, ii, 261

æquoreus Nerophis, ii, 261

æquoreus, Scyphins, ii, 261

æquoreus, Syngnathus, ii, 261

Eitobatis, ii, 352

Agassiz, L. Prof., 4

agassizii, Telestes, ii, 157

Agonomalus, 67

Agonus, 67

affinis, Leuciscus, ii, 176, 178

affinis, Cottus, 46

air-bladder, $x l$

air-bladder, gases in, xlii

ałcajei, Trygon, ii, 350

alalonga, Thynnus, 97

alatunga, Scomber, 97

Alausa, ii, 208

Alausella, ii, 208

alba, Clupea, ii, 209, 218

albacora, Thynnus, 97

albacore, 98

alba, Raia, ii, 339

alba, Rogenia, ii, 209, 218

albidus, Merluccius, 300

albicore, 132

albidus, Gadris, 303

albula, Coregonus, ii, 128

Alburnellus, ii, 193

alburnoides, Aspins, ii, 198

Alburnus, ii, 193, 198

a bournus, Abramis, ii, 198

alburnus, Aspins, ii, 198

alburnus, Cyprinus, ii, 19.8

alburnus, Leuciscus, ii, 198

albus, Gobius, 169

albus, Latrunculus, 169

albus, Leuciscus, ii, 179

albus, Merlangus, 292

albus, Salmo, ii, 54, 58, 85, 86,88

albus, Squalius, ii, 179

alepidotrus, Cyprinus, ii, 159

alevin, ii, 104

alewife, ii, 235

aller-float, ii, 103

aller-trout, ii, 103

alliciens, Ammodytes, 332

allis, ii, 234

allis shad, ii, 235

alopecias, Squalus, ii, 300

Alopias, ii, 297, 300

alosa, Clupea, il, 208, 234, 235, 236,238 alpinus, Salmo, ii, 108, 109 ,

$112,113,114$

alpine charr, $\mathrm{ii}, 112$

alpinus, Salvelinus, ii, 112

altirostris, Anguilla, ii, 242

amarus, Cyprinus, ii, I65

Ambassoidei, I
Amblychoeturichthys, 158

Amblygaster, ii, 208

Amblygobius, 158

Amblyodon, 150

Americana, Petromyzon, ii 356

americanis, Acanthias, ii, 916

americanus, Amphibrion, 17

americanis, Brosmius, 323

americanus, Lophius, 73

amethystino-punctatus, Mauro-

licus, ii, 49,51

Amia, 102\} ii, 279

amia, Caranx, 124

amia, Lichia, 132

amia, Porthmeus, 132

Ammoccetes, ii, 356

Ammodytes, 329 ; ii, 232

Ammodrtina, 329

Amphisile, 249

Amphisiloidei, 249

Amphioxris, ii, 366

AnaCanthini, 271

Anacanthini, Gadoidei, 271

Anacanthini, Pleuronectoidei, ii, 1

anadromous fish, $1 \mathrm{xxx}$

Anarrhichas, 194

anceps, Scardiniopsis, ii, 17.6, 178

ancestral forms, lxxxii

anchovy, ii, 206

Anichisomus, ii, 270

ancient wife, 255

Andrews, iv

Anematichthys, ij, 169

Angel-fish, ii, 326, 327

angelus, Squatina, ii, 326

anger, lxxiv

angler, 73,74

Anglorum, Lumpus, 180

Anguilla, ii, 239, 240

anguilla Murcena, ii, 241

anguineus, Entelurus, ii, 261

anguineus, Nerophis, ii, 261

anguineus, Syngnathus, ii, 261

anguilla, Anguilla, ii, 241

annulatus, Liparis, 187

annulatus, Squalus, ii, 314

Antaceus, ii, 279

antarctica, Sciæna, 151

antecessor, Gasterosteus, 127

Antennarius, 72

Antigonia, 134

antiquorum, Hippocampus, ii, 265

Apeltes, 236

aper, Capros, 134, 250

aper, Labrus, 253

aper, Zeu's, 134

Aphia, 158, 169

aphya, Cyprinus, ii, 185

aphya, gobius, 165 
aphya, Phowinus, ii, 1 apodal fish, ii, 239 apollonitis, Leuciscus, ii, 183 Apsicephalus, ii, 270 aquarum, Perdix, 7 aquila, Cheilodipterus, 150 aquila; Myliobatis, ii, 352 aquila, Pastinaca ii, 352 aquila, Raia, ii, 352 aquila, Sciana, 17, 150 Araneus, 79 Arctic chimcera, ii, 286 arcticus, Liparis, 185 arcticus, Gymnetrus, :217 arcticus, Gymnogaster, 217 arcticus, Trachypterus, 217 ; ii, 49

arctumus, Salmo, ii, 113 argentata, Couchia, 313, 317 argentatus, Larus, 75 argentatus, Merluccius, 300, 301 argentea, Chimæra, ii, 286 argentea, Hypsiptera, 317 argenteola, Motella, 314;317 argenteolus, Gadus, 317 argenteus, Ammodytes, 334 argenteus, Fario, ii, 85 argenteus, Lepturus, 154, 157 argenteus, Lepidopus, 156, 157 argenteus, Leuciscus, ii, 181 argenteus, Petromyzon, ii, 359 argenteus, Porthmeus, 132 argenteus, Salmo, ii, 55, 67, $80,82,85$

argenteus, Sparus, 30

argenteus, Trachinotus, 130 argenteus, Trichiurus, 154

Argentina, ii, 52, 136 argentine, $\mathrm{ii}, 50,136$ argentinum, Goniosoma, ii, 136

argenti-vittatus, Thynnus, 97 argyrea, Scarcina, 156 argyreus, Abramis, ii, 193 argyreus, Lepidopus, 156 Argyropelecus, ii, 46, 47 Argyroleuca, Blicca, ii, 197 Argyrops, 30

Argyrosomus, ii, 125 armatus, Aspidorphorus, 68 armatus, Trachinus, 80 armed bull-head, 67, 68 armed gurnard, 70,71 Arnoglossus, ii, 5, 21 arrnoglossus, Hippoglossus, ii, 23 arnoglossus, Pleuronectes, ii, 23 arnoglossus, Rhombus, $\mathrm{ii}_{2} 23$ artedii, Blennius, 200 artedi, Pristiurus, ii, 314 artedi, Scyllium, ii, 314 artificial cultivation, cviii ascanii, Carelophus, 206 ascanii, Blennius, 206 ascensionis, Scomber, 132 Aseraggodes, ii, 37 aspera, Mola, ii, 273 aspera, Raia, ii, 342,343 aspera, Trigla, 62 Aspicothus, 45 Aspidophorus, 67 Aspredo, 13 assimilis, Liparis, 185 asterias. Raia, ii, 345

\section{Astrodermus, 121}

Atherina, 224

Atherine, 225 ; ii, 124

ATHerinid $x, 224$; ii, 146

atlanticus, Callorhynchus, ii, 286

atmospheric disturbances, $\mathrm{cv}$ atillus, Acipenser, ii, 280

attac, 284

attenratus, Gobius, 165

Aurọtomatrom, 1 aurantiaca, Solea, ii, 42 aurata, 32

aurata, Sparus, 32,36

aurata, Tincta, ii, 188, 189

auratus, Carassias, ii, 161,164 ,

166,167

auratus, Cyprinopsis, if, 166 auratus, Gobius, 160, 167 auratus, Mugil, 228, 229

auratus, Pagrus, 32, 33

auratus, Sparus, 33, 34

Ausonia, 121

ausonii, Salar, ii, 96

ausonii, Salmo, ii, 55

australis, Maurolicus, ii, 50

australis, Zeus, 140

Auxis, 104

Awoous, 158

axillary bream, 39

azevia, Solea, ii, 40

azureus, Balistes, $\mathrm{ii}, 268$

azurine, ii, 183

baars, 4

bace, 9

baggit, ii, 69

Baikie, W., iii

baillonii, Crenilabrus, 262

baillons wrass, 260 .

Bairdiella, 150

bait for cod, 273

Baker, iii

balance-fush, ii, '294

balance of nature, XcF

Balanteocheilus, ii, 169

balbis, Lepadogaster, 189, 190

Balistes, ii, 267

Balistapus, ii, 267

balkers, ii, 227

ballanus, Labrus, 253

ballan, Labrus, 253

ballan wrasse, $-252,253,255$

balle-eries, 176

Ballerus, ii, 193

balteatus, Thynnus, 97

balthicus, Hemiramphus, ii, 147

banksii, Gymnetrus, 220

banksii, Regalecus, 220, 222 ; ii, 49

bank's oar-fish, 220

bannis, 241

banstickle, 241

banticle, 241

barce, 241

bards, 212

Barilius, ii, 107

barbata, Morhua, 287

barbatula, Cobitis, ii, 201, 203

barbatum, Ophidium, 326

barbatus, Enchelyopus, 326

barbatus, Gadus, 276, 286

barbatus, Liparis, 54

barbatus, Liparis, 184 barbatrs, Lophius, 73

barbatus, Mullus, 22

barbatus, Rhombus, ii, 15

barbel, ii, 169

barbolt, 308

Barbus, ii, 157, 169

barbus, Barbus, ii, 169

barbus, Cyprimus, ii, 169

barling, ii, 360

barncocte, ii, 12

barracuda, Sphyræna, 107

barsch, 4

barse, 4

barwin, 37

base, 4

basking shark, ii, 303, 304, 305

bass, 8,9

bass, black, 19

bosse, 9

bastard sattie, ii, 10

bastard sole, ii, 29,44

bostard turbot, ii, 16

batis, Dasybatis, ii, 336

batts, Lceviraja, ii, 336

batis, Raia, ii, 335, 336, 339

BATOIDEI, ii, 287, 329

Batrachoides, 320

Batrachops, ii, 270

battarce, Orthragoriseus, ii, 276

baud, 315

baudie, 241

bavin, 255

beam trawling, xcrii

bearded ophidium, 327

beardie, ii, 204

beardless ophidium, 209

bearnensis, Squalins, ii, 181

bears, 4

beaumaris shark, ij, 297, 298

becker, 31, 35, 41

behnii, Hemiramphus, i, 147

Belone, ii, 57, 146

belone, Esox, ii, 147

belonii, Mullus, 22

belted bonito, 1.03

bellow's fish, 250

benacensis, gobio, ii, 172

bennick, ii, 186

berda, Sparus, 39

berg-galt, Labrus, 253

bergle, 255

bergylt, 42

bib, 286, 287

bibronii, Anguilla, ii, 242

bibus, Gadus, 286

bicolor, gobius, 162

bicotor, Grammiconotus, ii, 151

bicolor, Petromyzon, ii, 362

biciliatus, Lepadogaster, 189, 190

bifurcus, Gadus, 303

bifurcus, Phycis, 303

bigger-fleuk, ii, 35

bil, 295

bitinearis, Stomodon, 300

billard, 295

billet, 295

bimaculata, Mirbelia, I 92

bimaculated sucker, 192, 193

bimaculated wrass, 25 .

bimaculatus, Cyclopterus, 192

bimaculatus, Gobieson, 192

bimaculatus, Labrus, 257, 258 
INDEX.

bimaculatus, Lepadogaster, 192
binnick, ii, 186

binotatus, Centronotus, 132

biocellatus, Gobius, 161

bipunctatus, Gobius, 161

bird-bolt, 309

birt-fish, ii, 12

bishoped, 82

bismore, 247

bison, Aspicottus, 52

bisus, Auxis, 104

bisus, Scomber, 104

bjortena, Abramis, ii, 197

bjorkna, Blicca, ii, 197

bjorkna, Cyprinus, ii, 196

black back, ii, 35

black-fin, 82 ; ii, 68

black-fish, 111

black goby, 163

black-herring, ii, 210

black jack, 295

black-mouthed dog-fish, ii, $3 \mathrm{l} 4$

black pilot, 130

black pollach, 295 .

black sea-bream, 26

blactesmiths, ii, 7

black-tail, ii, 85, 90

blade-fish, 154

blainvillei, Cetorhinus, ii, 304

bleak, ii, 198

bleck, 295

Bleekeria, 329

bleis, ii, 179

Blennitide, 194

blennioides, Batrachocephalnes, 320

blennoid fork-beard, 303, 304

blennioides, Batrachoides, 320

Blenniops, 206

blennoides, Gadrus, 303

blennoides, Phycis, 303

Blennius, 194, 198

blens, 278, 287

Blepharis, 123

Blicea, ii, 193

blicca, Abramis, ii, 157, 176 178,196

blicca, Cyprinus, ii, 196

blicca, Leuciscus, ii, 197

Bliccopsis, ii, 193

blick ii, 199

blinds, 287

blind lomprey, ii, 362

blob-litie, 309

blockan, 295

bloch's gurnard, 62

bloch's topknot, ii, 18, 19

blochii, Orthragoriscus, ii, 273

blochii, Trigla, 62, 63

blue-backs, 294

blue-cock, ii, 87 .

blue-fin, ii, 68

blue hornless dog-fish, ii, 292

blue-paidle, 181

blue-poll, ii, $85,86,87$

blue-shark, ii, 290

blue-skate, $\mathrm{ii}, 337$

blue striped urasse, 258

boar-fish, 134, 135

bod, 315

Bodianns, 14

bogaraveo, Pagellus, 35, 37

bogaraveo, Pagrus, 37 boga, 28

boger, 37

Bogmarus, 217

bogmarus, Trachypterus, 217

- 3ogue, 28, 29

bogaraveo, Spamus, 37

boiers atherine, 227

Bola, 150

Bond, $i$

bone-dog, ii, 316

bonito, 100, 101

bonnet fruek, ii, 16

Boops, 28

boops, Boops, 28

boops, Centaurus, ii, 273

boops, Ostracion, ii, 273

borboniensis, Echeneis, 108

bordered-ray, ii, 340

borealis, Chimæra, ii, 286

borealis, Læmargus, ii, 49, 320

borealis, Maurolicus, ii, 51,138

borealis, Motella, 3.14

borealis, Scopelus, ii, 49

borealis, Scymnus, ii, 320

borealis, Squahrs, ii, 320

Boreocottus, 45

Boreogadus, 274

Boreogobius, 169

borer, ii, 364

boreus, Esox, ii, 139

Borlase, ii

boscii, Arnoglossus, ii, 21

boscii, Hippoglossus, ii, 21

boscii, Pleuronectes, ii, 21

botcher, ii, 68

bothock. 287

bothriocephalus, ii, 81

Bothus, ii, 11

Botia, ii, 201

bottle nose, 247

bounce, ii, 312

Bowdich, Mrs., ii

Box, 25, 28

boyeri, Atherina, 224, 227

brachycentrus, Leinurus, 239, 240

Brachygobins, 158

Brachygradus, 274

brachypoma, Salmo, ii, 55, 58, $85,86,88$

Brachyprosopon, $\mathrm{ii}, 25$

brachycentrus, Gasterosteus, 237, 239

Brachycephatus, ii, 270

Brachyochirus, 169

brachypterus, Thynnus, 94, 104

bradan leathan, ii, 7

bragay, 287

braize, 31,35 ; ii, 176

Brama, 114

brama, Abramis, ii, 178, 193

brama, Cantharus, 26

brama, Cyprinus, ii, 193

brama, Sparus, 26, 115

branchial arches, xvi

branchialis, Ammocates, ii, 362

branchialis, Petromyzon, ii, 362

Branchiostoma, ii, 366

brandling, ii, 68

brandstichle, 241

brasiliensis, Esox, ii, 147

brassie, 287

brat, ii, 12

brawat, ii, 243 brazier, 37 .

breams, sea, 35

bream, ii, 193

breamflat, ii, 197

breat, ii, 13

breeding, lvi

Bregmaceros, 310

brett, ii, 12, 16

brevicaudatus, Syngnathus, ii, 261,262

breviceps, Alburnus, ii, 198

breviceps, Pagellus, 39

brevipinna, Læmargus, ii, 320

brevipinna, Scymnus, ii, 320

brevipinnis, Somniosus, ii, 320

brevirostris, Hippocampus, ii, 265

brevis, Cephahus, ii, 273

Brevoortia, ii, 208

bridegroom, 176

brill, ii, 15

brismak, 324

britannicus, Centrolophas, 11,0

britannicus, Gobius, 164

britannicus, Mugil, 230

britt, 210, 232

broad-finned goby, 161

- broad-nosed eel, ii, 242

broad-nosed pipe fish, ii, 257

brood, ii, 69

Brooks, G., ir

brosme, Brosmius, 323

brosme, Centronotrus, 206

brosme, Enchelyopuis, 323

brosme, Gadus, 323

brosmiana, Lota, 309

Brosmius, 323

broussonettii, Ophidium, 327

brown-eel, ii, 243

Browne, Sir T., i

brown-shark, ii, 308

browny, ii, 19

brown-whistler, 315

brucus, Squalus, ii, 323

brunnich, Perca, 134

bubalis, Aspicottus, 52

bubalis, Cottus, 51, 185

Buckland, iii

buck-mackerel, 125

buckthorn, 284

buddagh, ii, 96

budegassa, Lophius, 72

buggenhagii, Abramis, ii, 176

buggenhagii, Cyprinus, ii, 178, 194

buggenhagii, Leuciscus, ii, 194

buglossa, Solea, ii, 39

bulcard, 204

bull-huss, ii, 312

bull-jub, 48

bull-knob, 48

bulls, 15

bull-trout, ii, 84, 90

bully, 204

bully cod, 204

buniva, Balistes, ii, 269

burbot, 308, 3.09

burbot eel, 212

burdigalensis, Leuciscus, ii, $18 \mathrm{I}$

burdigalensis, Squalius, ii, 181

burgeri, Carassius, ii, 166

burton-skate, ii, 340 
but, ii, 6, 35

butter fish, 209

butterfly blenny, 202

byrte-fish, ii; 12

\section{cabot, 164}

cabrilla, Perca, 14

cabrilla, Serranus, 14

cadan, 295

cade, ii, 210

coeca, Myxine, ii, 364

cecifer, Salmo, ii, 92

crecus, Gastrobranchus, ii, 364

cacus, Petromyzon, ii, 362

cceruleus, Cyclopterus, 180

coruleus, Cyprinus, ii, 183

comuleus, Labrus, 256

ccruleus, Leuciscus, ii, 183

ceruleus, Sparus, 264

coruleus, Squalus, ii, 290

calcar, Lichia, 132

californica, Rhina, ii, 326

callarias, Gadus, 276, 277, 324

callarias, Morhua, 276

callensis, Anguilla, ii, 241

Callionymider, 174

Callionymas, 174

Callogobius, 158

Callorhynchus, ii, 285

Cambricus, Salmo, ii, 53, 54,

$55,82,86,87,88,112$

camperii, Sayris, ii, 151

camperii, Scomberesox, ii, 151

camrel, 284

canariensis, Anguilla, ii, 241

canariensis, Boops, 28

canarensis; Pagellus, 40

candlemass fish, ii, 87

candle-fish, ii, 121

canicula, Squalus, ii, 309, 312

canicula, Scyllium, ii, 309

caniculus, Galeus, ii, 309

caninus, Serranus, 16

canis, Galeus, ii, 292

Cantharina, 25

Cantharus, 25, 26

cantharus, Sparus, 26

Canthidermis, ii, 267

capelanus, Gadus, 288

capelanus, Morua, 288

capensis, Aledon, ii, 273

capensis, Scimna, 151

capensis, Trigla, 61

capensis, Zeus, I40, 142

capito, Mugil, 228, 229, 230, 231,232

Capoeta, ii, 169

capriscus, Balistes, ii, 267, 268

Caprophonus, 134

Capros, 134

Carangider, 123

Carangichthys, 123

Carangoides, 123

Carangus, 123

Carangops, 123

Carassius, ii, 164

carassius, Cyprinus, ii, 164

Caranx, 123, ii, 57

carbonnarius, Gadus, 293

carbonnarius, Meriangus, 294

carbonnarius, Pollachius, 294

Carcharias, ii, 289 carcharias, Squalus, ii, 320

Carcharild es, $\mathrm{ii}, 287,289$

cardinal trilost, ii, 351

cardina, Rhombus, ii, 17, 21

Carelophus, 194, 206

carf, 37,119

carnaria, Platessa, ii, 34

carneus, Labrus, 257

carinatus, Diodon, ii, 273

carolinensis, Balistes, ii, 269

carp, ii, 158,159

carp-bream, ii, 194

Carpio, Cyprinus, ii, 158,159

Carrington, J., iv

carter, ii, 21, 22

case-charr, ii, 108, 109

castaneola, Sparus, 115

casurus, Pleuronectes, ii, 23

catadromous fish, lxxx

cat-fish, 80, 196, 32t, ii, 312

cataphracta, Trigla, 70

Cataphracti, 6 '

cataphractum, Peristedion, 70

cataphractum, Peristethus, 70

Cataphractus, 67

cataphractus, Agonus, 67

cataphractus, Aspidophorus, 68

cataphractus, Cottus, 67

catulus, Galeus, ii, 309

catulus, Scylliorhinus, ii, 309

catulus, Scyllium, ii, 312

catulus, Squalus, ii, 309, 312

cardacuta, Rhinonemus, 316

caudata, Motella, 316

candatus, Lepidopus, 156

caudatus, Trichiurus, 156

cavedanus, Leuciscus, ii, 179

cavedanus, Squalius, ii, 179

caviare, ii, 283

Centrina, ii, 315, 319

centrina, Callorhynchus, ii, 286

centrina, Omynotus, ii, 319

centrina, Squalus, ii, 319

Centriscider, 249

Centriseus, 236, 249

centrodontus, l'agellus, 31, 33, $35,36,38$

centrodontus, Sparus, 36

Centrogobius, 158

Centrolabrus, 252, 267

Centrolophus, I10

Centronotus, 194, 208

cepedei, Coregonus, ii, 127

Cepola, 213

Cepolide, 213

Cephalogobius, 158

Cephalopholis, 14

Cepinaloptera, ii, 352, 354

cephaloptera, Raia, ii, 354

Cephaloscyllium, ii, 309

Cephalus, ii, 272

cephalus, Cyprinus, ii, 179

cepbalus, Gardonus, ii, 179

cephalus, Lepadogaster, 191

cephalus, Leuciscus, ii, 87, 175, 178,179

cephalus, MIngil, 230, 232, 233

cephalus, Squalius, ii, 179

cephalus, Tinca, ii, 179

Cestracion, $\mathrm{ii}, 294$

Cestrorhinus, it, 294

ceratococcus, 45

cernioides, Serranua, 16 cernium, Polyprion, 17

Cernia, 11

cernua, Acerina, 11

cernua, Gymnocephalus, 11

cermua, Perca, 11

cetaceus, Squalus, ii, 304

cetti, Dentex, 19

cetti, Sparus, 19

Cetorhinus, ii, 303

chabrontera, Peristedion, 70

chaboisseau, 50

chabot, 46, 48

chad, 35, 37

chceturichthys, 158

chagrinea, Raia, ii, 341, 342

chalybous, Squalius, ii, 181

channus, Perca, 14

chanticleer, 176

charr, ii, 112

charr of Windermere, ii, 113

Cheilobarbus, ii, 169

Cheilotrema, 150

chelo, Mugil, 228, 229, 231, 232

chelynge, 278

cherne, 18

chernotte, 18

chevenden, $\mathrm{ii}, 179$

chevin, ii, 179

childrenii, Zeus, 134

Chimæra, ii, 285, 286

CHIMARID Ai, ii, 285

chinensis, Cyprinus, ii, 166

chiquer, 176

Chirolophis, 206

Chironectoidei, 72

CHONDROPTERTGII, ii, 278

CHONDROSTEI, ii, 278

Chonephorus, 158

chrysitis, Tinca, ii, 1:8

Chrysoblephus, 30

Chrysophrys, 30, 35

chrysoprasius, Phoxinus, ii, 185

Ohrysostosus, 118

chub, ii, 179

chub, Cyprinus, ii, 179

cicerellus, Ammodytes 333

Ciliata, 313

ciliatus, Lepadogaster, 189

cimbria, Motella, 316

cimbricus, Enchelyopus, 316

cimbrius, Gadus, 316

circularis, A mblyraja, ii, 348

circularis, Raia, ii, 348

circulation, $x$ lix

Cirrhisomus, ii, 270

cirrhosa, Umbrina, 155

CIRRostomi, ii, 366

cithara, Callionymus, 177

Clarke, Eagle, iv

clathratus, Squalius, ii, 179

clavata, Dasybatis, ii, 34.3

clavata, Raia, ii, 335, 343, 347

classification, Ixxix

Clidoderma, ii, 25

Clupalosa, ii, 208

Clupanodon, ii, 208

Clupea, ii, 205, 208

Clupeider, ij, 205

Clupeoides, ii, 208

clupeoides, Coregonus, ii, 125 , 127,129 
Clupeonia, ii, 208

coalfish, 294, 295

coalman, 295

coalsay, 295

coal-whiting, 295

cob, 48

Cobitidin $\pi$, $\mathrm{ii}, 201$

Cobitis, ii, 201

coccys alter; 62

cocksii, Ausonia, 121

Cockerani, Cephalus, ii, 276

cocksper. ii, 69

cod fisheries, 272

codlings, 278

cod-pole, 48

cod, preparation of, 273

coitor, Sciæna, 150

cold, effect on fish, 33

cole-fish, 294

colemie, 295

coles charr, ii, 114

colias, Gadus, 287

colias, Scomber, 85, 91, 93

colii, Salmo, ii, 108, 114

colinus, Gadus, 293

colnzey, 295

colours, xxiii

Cottid A, 45

Cottus, 45

Comber, 14, 253, 255

comber, Labrus, 252

comber wrass, 253

commensals, lxxvii, 106

common angler, 73

common bream, ii, 194

common carp, ii, 159

common cod-fish, 276

common dog-fish, ii, 316

common eel, ii, 241

common fork-beard, 304

common sea-bream, 36,37

common weaver, 81

communis, Alosa ii, 235

communis, Barbus, ii, 169

communis, Clupea, ii, 235

communis, Conger, ii, 250

communis, Liparis, 184

communis, Lota, 308

communis, Merlangus, 292

communis, Tinca, ii, 188

compressa, Lota, 308

compressus, Cyprinus, if, 183

compressus, Nanuclerus, 127

condollii, Lepadogaster, 191

conductor, Centronotus, I 27.

coney-fush, 309

conger, ii, 250, 25 I

conger, Anguilla, ii, 250

conger, Murcena, ii, 250

connemara sucker, 191

conner, 262

conspicillum, Balistes, ii, 268

cook, 257

cook conner, 258

cook wrasse, 135, 258

cooth, 295

coquillad, Blennins, 206

coquis, Labrus, 257, 258

Coracinas, 150

coras, Trigla, 59, 60

cordytus, 83

coregonoides, Paralepis, ii, 367

Coregonus, ii, 52, 125 coretta, Thynnus, 94

coriaceus, Cyprinus, ii, 159

Coricus, 260

Coris, 252, 269

corkling, 253

corkwing, 261

cormorant, 75

Cornish centrolophus, 110

Cornish sálmon, $30 \mathrm{I}, \mathrm{ii}, 87$

Cornish sucker, 189, 190

cornubica, Isurus, 'ii, 298

cornubica, Lamna, ii, 297

cornubicus, Crenilabrus, 261

cornubicus, Cyncedus, 261

cornubicus Cyclopterus, 189

cornubicus, Labrus, 261

cornubicus, Lamia, ii, 297

cornubicus, Lophius, 73

cornubicus, Squalus, ii, 297, 298

cornubiensis, Labrus, 253

cornubiensis, Lepidogaster, 186,

189

cornubiensis, Pindelepterus, 130

cornubiensis, Salmo, ii, 97, 98

cornutus, Macrorhamphosus, 250

coronatus, Cyclopterus, 180

corphun, ii, 209

corsula, Mugil, 228

CORY P H AENID更, 114

Coryphrnoides,, 335

coryphonoides, Astrodermus, 121

Corythoichthys, ii, 259

Corvina, 150

corvus, Trigla, 60

Couch, iii

Couchia, 313

couchii, Acantholabrus, 266

couchii, Crenilabrus, 261

couchii, Serranus, 17

Couch's sea-bream, 30

craig fleuk, ii, 30, 31

crake herrings, 126

cramp-fish, ii, 331

cran. ii, 210

crassapuil trout, ii, 100

crassirostris, Chrysophrys, 32

Crellin, iv

Crenilabrus, 252, 260

crescent-tailed bull-trout, ii,

87

cristata, Chimæra, ii, 286

cristatus, Pleuronectes, ii, I5

crooner, 63,65

croonyal, 63

crop-fish, ii, 271

crouger, ii, 165

crown-full herrings, ii, 210

crucian carp, ii, 164, 165

crue-herring, ii, 225

crutchet, 4

Cryptocentrus, 158

Crystallogobius, 158, 172

Ctenogobins, 158

Ctenolabrus, 264

cuckoo-fish 135,258

cuckoo gurnard, 59

cuckoo-ray, ii, 348,349

cuckoo wrass, 257

cuculus, Trigla, 58, 59, 62, 65

cudden, 295

cuddy, 295 cuddy-legs, ii, 209

cull, 48

cumberlandi, Trachinotus, 130

cumberland, Salmo, ii, 92, 93

cunn, ii, 129

cunning, ii, 360

curtus, Mugil, 228, 233

cuntrus, Pagellus, 36

curved-spotted bull-trout, $\mathrm{ii}, 87$

curvus, Tetrodon, ii, 271

cuvieri, Alosa, ii, 235

cuvieri, Anguilla, ii, 242

cuvieri, Argentina, $\ddot{i} ;, 136,138$

cuvieri, Caranx, 124

cuvieri, Carassius, ii, 166

cuvieri, Chrysophrys, 30

cuvieri, Luvarus, 121

cuvieri, Raia, ii, 343, 344

cuvieri, Tetrodon, ii, 270

cyanopterum, Solenostoma, ii, 256

Cyclocheilichthys, ii, 169

Cyclogaster, 184

Cyclogobius, 158

Cyclolabridae, 251

cyclolepis, Barbus, ii, 169

cyclops, Pleuronectes, ii, 3, 12

cyclops, Platessa, ii, 12

Cyclopterus, 179

Crclostomata, ii, 355

Cyncedus, 19, 260

Cynodon, 20

cynoglossus, Platessa, ii, 30

cynoglossus, Pleuronectes, if, $25,28,30$

CrPRINIDE, ii, 157

Crprininde, ii, 158

Cyprinus, ii, 158

Cypsilurus, ii, 154

Crttide, 138

$d a b, \mathrm{il}, 32$

dace, ii, 181, 182

Dalatias, ii, 320

Dale, ii

daming herring, ii, 235

dandy line, ii, 215

dare, ii, 182

darg, 291

dargie, 295

dart, ii, 182

Dasyatis, ii, 350

daurades, 33

daw-fish, ii, 310

Day, F., iv

deal-jish, 217, 218

decagon, Argentina, ii, 136

decandolii, Lepadogaster, 191

'decandolii, Murbelia, 191

Decapterus, 123

decipiens, Leuciscus, ii, 175

declivis, Caranx, 124

decorus, Liparis, 185

decussata, 'Venus, 33

deillion, 287

delarochianus, Scylliorhinus, ii, 314

Dentalium, 301

dentatus, Fierasfer, 328

development arrested, lxxix

Dentex, 19,20

dentex, Cichla, 19

dentex, Salmo, ii, 102 
dentex, Sparus, 19

derbio, 132,133 .

dergle, Scardinius, ii, 183

desfontanii, Lepadogaster, 192

desfontanii, Mirbelia, 192

dextral, flat-fish, ii, 1

diacantha, Perca, 8

diacantha, Scicena, 8

diamond plaice, ii, 26

Diana, 121

diaphanus, Pleuronectes, ii, 23

diaphasia, 328

Dicentrarchrs, 8

Dicerobatis, ii, 354

diego, Scomber, 91

diffusion of fish, 1xxxii

digitatus, Lophius, 73

Dillw yn, ii

dimidiatus, Gasterosteus, 239

diminutive lump-sucker, 187

diminutive blenmy, 200

dinnan, ii, 337

Diplanchias, ii, 272

Diplogrammus, 174

Diplolepis, 150

Diplophysa, ii, 203

Disconoli, 179

diseases, civ, cvi

dispar, Labrus, 256

dispersion of fish, lxxxiii

distribution of fish, lxxxiii

diversicolor, Torpedo, ii, 333

dobula, Cyprinus, ii, 179, 181

dobula, Leuciscas, ii, 179 , 181

dobuld, Squatius, ii, 179, 182

dobula, Tinca, ii, 181

dobule, ii, 181

dobuloides, Abramis, ii, 179

doctor, ii, 340

dogsteeth, 301

dolabratus, Alburnus, ii, 157

dolabratus, Leuciscus, ii, 179

dole-fish, 278

Donovan, ii

donovani, Labrus, 253, 254, 261

dorab, Chirocentrus, ii, 278

doree, 139

dorse, 276

Doryrhamphus, ii, 256

dotted mackerel, 84

double tlat-fish, ii, 1, 3

double-spotted goby, 161

doubly-spotted sicleer, 192, 193

doulie, 166

dublin-eel, ii, 242

Dubordieu, iv

duckins, 247

ductor, Centronotus, 127

ductor, Gasterosteus, 127

ductor, Naucrates, 127

ductor, Scomber, 127

dumerilii, Rhina, ii, 327

dumerilii, Squatina, ij, 326

duncan, 278

dun cow, ii, 342

Dunn; M., iii, iv

Dusky perch, 16

dusky sculpin, 175, 176

Dússumieri, Brama, 114

draco, Trachinus, 79, 80, 81

dracunculus, Callionymus, 175 , 177 dragonet, 176

drift nets, ei

drizzle, 306

drummonds echiodon, 328

drummondii, Echiodon, 328

dry spawning, cix

Dyce, Dr., iii

eagle-ray, ii, 353

earl, ii, 260

Echeneida, 106

Echeneis, 106, 108

Dchidna, ii, 254

echinatrm Leiodon, ii, 320

Echinorhinus, ii, 315, 323

Echiodon, 328

eckstrom's topknot, ii, 17

Fdward, iii

eeleator, ii, 243

eel-fare, ii, 243

eel-mother, ii, 247

eel-pot, ii, 346

eelpout, 211

eggs and how deposited, lxii

eggs, changes in, lxiv

eggs, how cared for, ix

eggs in mud, lxvii

eggs, number of, lxiii

eggs of Salmonidæ, incubation

of, ii, 106

eggs of Salmonidæ, size of, ii, 105

eggs, protection for, lxiii

eggs, size of, lx viii

eggs, sterile, lxiv

egling, 4

Egyptian herring, ii, 152

ekstromii, gobius, 165

elestromi, Liparis, 187

Elaphocottus, 45

Elasmobranchir, ii, 278, 285

electric ray, ii, 331,332

elegans, Astrodermus, 121

elegans, Callionymus, 175

elegans, Coregonus, ii, 129

elegans, Coryphana, 121

elephas, Squalus, ii, 304

elegans, Squalus, ii, 310

elegans, Orthragoriscus, ii, 276

elleck, 58,59

elongata, Clupea, ii, 209

elongata, Cobitis, ii, 201

elongata, Perca, 8 .

elongata, Platessa, ii, 30

elongatus, Cephalus, ii, $27 \dot{6}$

elongatus; Pleuronectes, ii, 30

elvers, ii, 243

emarginata, Torpedo, ii, 331

Enchelyopus, 153, 303

encrasicholus Clupea, ii, 206

encrasicholus Engraulis, ii, 206

Engraulis, ii, 205

etgyshistæ, ii, 139

Enneacentrus, 14

Entelurus, ii, 261

Enteromius, ii, I 69

entozor, cri

Epinephelus, 14

eperlano-marinus, ii, 121

eperlanus, Osmerus, 224, 225 ; ii, 121,278

eperlanus, Salmo, ii, 121

Epicopus, 300 epizoa, cri

eriox, Salmo, ii, 54, 85, 86, 88

erythrinus, 40

erythrinus, Pagellus, $31,36,38$,

40

erythrinus, Pagrus, 40

erythrinus, Sparus, 40

Erythrodon, ii, 267

erythrogaster, Baione, ii, 119

erythrops, Cyprinus, ii, 183

erythrophthalmus, Cyprinus, $\mathrm{ii}$, 183

erythrophthalmus, Leuciscus,

ii $175,178,183,195$

erythrophthalmus, Scardinius,

ii, 183, 199

erythropterus, Abramis, ii, 197

esca, Oyprinus, ii, 209

esca, Rogenia, ii, 209.

esculentrus, Merluccius, 300

Esocid-2, ii, 139

Esox, ii, 139

estuarins, Salmo, ii, 54, 83, 99

Encyclogobius, 158

Eumicrotremus, 179

Euoxymetopon, 216, 22:

Eupleurogrammus, 153

eurben, 33

europea, Squatina, ii, 326

europeus, Aspidophorus, 68

europeus, Gunnellus, 208

europeus, Hemiramphus, ii, 147, 149

europeus, Trachwrus, 124

Eurymyctera, ii, 254

eurypterus, Lophius, 73, 76

Eusphyra, ii, 294

Eutoxychirus, ii, 315

evil-eel, ii, 251

evolans, Exocætus, ii, 156

exilis, Belone, ii, 146

Exocatus, ii, 57, 146, 154

exoletus, Acantholabrus, 267

exoletus, Centrolabrus, 267

exolcetus, Crenilabrus, 266, 267.

exoletus, Labrus, 257, 267

exotic forms, ex

exsiliens, Exocætus, ii, 154

eyed dog-fish, ii, 314

eyeless forms, xxxi

faber, Zeus, 137, 138 ; ii, 47

fabrei, Alburnus, ii, 198.

fabroniana, Cephaloptera, ii, 354

fage, ii, 26

farenus, Cyprinus, ii, 194

Fario, ii, 53

fario, Salmo, ii, $53,54,82,83$, 95,109

fario, Trutta, ii, 96

fair-maid, ii, 225

fallas, Clupea, ii, 236

falsavela, Raia, ii, 348

fanfarus, Naucrates, 127

fansen, ii, 243

fasciatus, Orthagoriscus, ii, 272

fasciatus, Pleuronectes, ii, 43

father-lasher, 49, 51, 52

fear, lxxi

ferax, Saprolegnia, cvii ; ii, 81

Ferguson, iii 
fergusonis, Lophius, 73

fernandezianus, Spinax, ii, 316

ferow, Salar, ii, 96

ferox, Salmo, ii, 55, 56, 84, 96,

98,110

ferox, Trutta, ii, 97

ferrugineus, Cottus, 46

festiva, Julis, 269

ferv-spotted bull-trout, ii, 87

fiddle-fish, ii, 327

Fierasfer, 328

Finerasfina, 328

fiery-flaw, ii, 351

filaris, Trigla, 65

file-fish, ii, 268, 269

filicauda, Trachypterus, 218

fimbriata, Squatina, ii, 326

fimbriatus, Serranus, 16

fifteen-spined stickleback, 246, 247

fingerling, ii, 68

finnon haddocks, 284, 285

fin rays, $x$

fins, viii

finscale, ii, 184

fins may change with age, ix

finta, Alosa, ii, 236, 238

finta, Clupea, ii, 208, 236, 238

fire-flare, ii, 351

fisheries, xciii

fishes' physician, ii, 190

Fish, body of, viii

Fish, external characters, vi

Fish, general remarks on, $v$

Fish, head of vii

Fish, modifications of form, vi

Fish, mouth of, vii.

Fish, tail of, viii

fish-ponds, ex

fishing-frog, 73,74

Fistularia, 249

fittin, 291

five bearded' cod, 314

five bearded rock-ling, 314

fixed engines, cii

flanie, ii, 337

flaire, ii, 337

flapper-skate, ii, 339

flat-fish, trawled, ii, 4

flavescens, Bodianus, 3

flavescens, Perca, 3, 4

flavescens, Grobius, 160

flavus, Serranus, 14

-Fleming, ii

flesh-coloured wrasse, 258

flesus, Platessa, ii, 33

flesus; Pleuronectes, ii, 25, 33, 34

fleuk, $\mathrm{ii}_{2}, 12,35$

flossada, Raia, ii, 342

flounder, ii, 34, 35

flounder lantern, ii, 35

fluviatile fish, Ixxxi

fluviatilis, Anguilla, ii, 242

fluviatilis, Barbus, ii, 169

furiatilis, Cernua, 11

fhuviatilis, Cottus, 46

fluviatilis, Gobio, ii, 172

fuviatilis, Lamipetra, ii, 359, 362

fluviatilis, Perca, 2, 43

fluviatilis, Petrom yzon, ii, 359

fruviatilis, Trutta, $\mathrm{ii}_{2,95}$ flying fish, ii, 154, 156

fontinalis, Hucho, ii, 119

fontinalis, Salmo, ii, 86, 108 , $109,115,119$

food of fish, lxxxviii

fordwich trout, ii, 92

forestensis, Sälmo, ii, 96

forked-hake, 304

fork-taits, ii, 69

formosus, Sparus, 257

fossilis, Saccobranchus, 48

four-bearded roctling, 316

four-horned cóttus, 53

four spined stichleback, 239

four-toothed gilt-head, 20

four-toothed scabbard fish, 156 . fox, 176

fox-shark, ii, 301

frectiled goby, 166

free messmates, lxxvii, 328

french sole, ii, 29,42

french gurnard, 5.

french ray, ii, 343

fresh water fleuk, ii, 35

fresh water fow, ii, 159

fresh water fish, lxxx

fresh water fish in sea water, lxxxiv

fresh water herrings, ii, 114, 127

friar-stcate, ii, 340

frie, ii, 140

- frigidus, Leuciscus, ii, 179

fringe-lipped lamprey, ii, 362

frog mouthed eels, ii, 243

frog fish, 74

fuliginosus, Gadas, 320

fuliginosus, Gobius, 164

fuller's ray, ii, 342,345

full herrings, ii, 210

fullonica, Leucoraja, ii, 342

fullonica, Raia, ii, $342,345,347$

fumado, ii, 225, 229

furcatus, Phycis, 303

fusca, Phycis, 320

fuscus, Blennius, $\mathbf{3 2 0}$

fuscus, Gadus, 314

fuscus, Liparis, 185

fuscus, Raniceps, 320

Gadidæ, 27

gadoides, Blennius, 303

Gadulus, 274

Gadus, 274, 275

Gadus, 313

gaimardi, Salmo, ii, 55

gaimardi, Raia, ii, 336

Galeorhinus, ii, 292

galerita, Adonis, 200

galerita, Blenniops, 206

galerita, Blennius, 198, 200

galerita, Blennius, 206

Galeus, ii, 289, 292

galests, Carcharias, ii, 292

gaterus, Squalus, ii, 29.2

Gallichthys, I23, 158

gallivensis, Salmo, ii, 55, 83, 99

galvani, Torpedo, ii, 333

gamrel, 284

GANOIDEr, ii, 278

gapemouth, 9

gaper, The, 15

gardenii, Salmo, ii, 85 gar fish, ii, 147

gars-pike, ii, 148

Garman, Prof, 4

garvie, ii, 232

garvock, ii, 232

garvie-herring, ii, 225

Gasterostea, 236

Gasterosteidia, 236

gasterosteus, 236

gastrea, 236

Gastrobranchus, ii, 364

gattorugine, 198, 199

gattorugine, Blennius, 198

gayi, Epicopus, 300

gayi, Merlus, 300

gedd, ii, 140

gehini, A bramis, ii, 193

gemmous Dragonet, 174, 176

Genyonemus, 150

geological appearance, lxxxi geographical distribution,

Ixxxvi

germon, 98

germo, Orcynus, 97, 98

germo, Scomber, 97

germo, Thynnus, 98

gerling, ii, 68

Gerres, 251

gerrick, ii, 148

gerrocles, 295

ghini, Orthragoriscus, ii, 273

gibbiceps, Dentex, 19

gibbosus, Sparus, 19

gibbus, Crenilabrus, 261

gibbus, Cyncedus, 261

gibbus, Labrus, 261

gibelio, Carassius, ii, 161, 165

gibelio, Cyrinopsis, ii, 165

gib-fish, ii, 68

gigas, Hippoglossus, ii,

gigas, Holocentrus, 16

gigas, Perca, 16

gigas, Serranus, 16

Giglioli, Prof., iv .

Gill, iii

gill-covers, vii

Gillia, 158

gills, xlvii, xlviii

gillaroo, ii, 99, 104

gilpin, 295

gilt charr, ii, 108, $10 \dot{9}$

gilt-head, 32, 33, 262

gilt-hoad, lumilated, 33

gilt-poll, 33

ginkin, ii, 69

giofredi, Coris, 269

-giofredi; Julis, 269

giofredi, Labrus, 269

giornæ, Cephaloptera, ii, 354

giorna, Dicerobatis, ii, 354

giorna, Pterocephala, ii, 354

gipsy herring, ii, 225

girnat, 63

gizzard trout, ii, 100

glacialis, Cottus, $49^{\circ}$

glacialis, Scymnus, ii, 320

gladius, Histiophorus, 144

gladius, Xiphias, 146

gladius, Trichiurus, 156

glanis, Silurus, 311, 312, ii, 281

glasbach salmon, ii, 87

glashan, 295

glass-eele, ii, 239 
glassock, 295

glanca, Couchia, 314

glauca, Lichia, 132

glauca, Motella, 314, $315^{\circ}$

glaucus, 133

ylaucos, Centronotus, 132

glauicus, Carcharias, ii, 289, 290

glaucus, Echelus, ii, 250

glancus, Gasterostens, 132

glaucus, Scomber, 132

glancus, Squalus, ii, 290,297

glesne, Uphidium, 222

glesne, Regalecus, 220, 222

globe diodon, ii, 270

globe-fish, ii, 27

globiceps, Pagrus, 33

glossan, 295

Glossogobius, 158

glut, ii, 243

glutinosa, Myxine, ii, 364

glutinous hag, ii, 364

Glyptocephalus, ii, 25

Gnathanodon, 123

Gnathopogon, ii, 169

goaske, ii, 130

GOBIESOCID $\mathbb{R E}, 188$

Gobiesow, 188

Gobiichthys, 158

GOBIID必, 158

Gobio, ii, 172

gobio, Cottus, 46; ii, 106

gobio, Cyprinus, ii, 172

gobio, Leuciscus, ii, 172

Gobionellus, 158

Gobiopsis, 158

Gobiosoma, 172

gobio, T'inca, ii, 172

Gobius, 158

gobius, Liparis, 185

gold-carp, ii, 167

golden maid, 262

golden tench, $\mathrm{ii}, 188$

gold-fish, ii, 166, 167

goldfinny, Labrus, 261

goldsinny. 261, 264

Gonoproktopterus, ii, 169

gonostomus, ii, 49,51

Gordon, iii

gore-bill, ii, 148

gosnick, ii, 152

gossat, 318

gottsche, Zeugopterus, ii, 21

gouanii, Lepadogaster, 189, 190, 19.

gouani, Lepidopus, 156.

gouanianus, Lepidopus, 156

gowdie, 63, 176

gowdnook, ii, 152

gracilirostris, Histiophorus, 146

gracilis, Coregonus, ii, 125

gracilis, Cottus, 47

gracilis, Gobius, 165, 167

gracilis, Gobius, 169

gracilis, Perca, 3,4

gracitis, Salmo, ii, 67

grcnlandicus, Acanthocottus, 49

grcenlandicus, Cottus, 49

graining, ii, 181

graining, Cyprinus, ii, 181

Grammiconotus, ii, 151

grandoculis, Carassius, ii, 166

aranulata, Perca, :3

yramulosa, Raia, ii, 342 graveling, ii, $68,69,135$

grawl, ii, 69

Gray, Dr., ,iii

gray gurnard, 62, 63

grayi, Salmo, ii, 108, 114

grayling, ii, $131,132,182$

gray-lord, 295

gray mullet, 230, 231

grays charr, ii, 114

gray-skate, ii, 337

greater flying-fish, ii, 154

greater forked beard, 303

great lant, 330

greater pipe-fish, ii, 259

greater sand-eel, 330

greater weever, 80

great sea adder, 247

greenback, ii, 148

green bone, $212, \mathrm{ii}, 148$

green-cod, 295

green-fish, 297

green-herrings, ii, 210

Greenland bull-head, 49 .

Greenland cod, 293

Greenland shark, ii, 320, 321

green-ling, 297

green pollack, 294, 295

green-strealed wrass, 254

green wrass, 254

gregagh, 255

grey bàck, ii, 32

grey fleuk, ii, 32

grey salmon, ii, 86

grig, ii, 243

grillii, Gymnetrus, 222

grillii, Regalecus, 222

- grilse, ii, 68

griseus Carcharias, ii, 298

griseus, Cantharus, 26

griseus, Henanchus, ii, 308

griseus, Monopterhinus, ii, 308

griseus, Notidanus, ii, 308

griseus, Squalus, ii, 308

grislagine, Cyprinus, ii, 181

grohmanni, Arnoglossus, ii, 388

grislagine, Leuciscus, ii, 18 L

ground-bait, ii, 204

ground-gradgeon, ii, 204

groundling, 161 ; ii, 204

ground seine, $\mathrm{s}$

growth, xci

guard-fish, ii, 148

gudgeons, 4 ; ii, 172

guffer, 212

guffer-eel, 212

guiniad, ii, 127

gullet, ii, 140

gulo, Holocentrus, 17

gull.fish, 295

gundie, 50

gunnel, 209

Gunnellus, 206, 208

gunnellus, Blennius, 208

gunnellus, Centronotus, 208

gunnelius, Ophisomus, 209

gunnellus, Pholis, 209

gunner, 37

gunner-fleuk, ii, 12

gunneri, Cetorhinus, ii, 303

gunneri, Scamber, 118

gunneri, Scymnus, ii, 320

Günther, Dr., i, iii

guntheri, Pagellus, 40 gurnards, 55

gurnardus, Trigla, 62

gurnets, 5

gut-pock-herring, ii, 210

guttata, Muræena, ii, 2.54

guttata, Murcenoides, 208

guttatus, Lampris, 118

guttatus, Zeus, 118

guttulatus,Hippocampus, ii, 265

Gymnetrus, 2:20

Gymnocephalus, 11

Gymnocranius, 19

Grunodontes, ii, 267, 270

Gymnogaster, 217

Gymnomurcena, ii, 25

Gymnothoraw, ii, 254

gymnothoraw, Thymallus, ii. 131

gymnurus, Gasterosteus, 239,240

haaf-eel, ii, 251

haberdine, 278

hackle, 241

haddie, 284

haddock, 283, 284, 295

Hcemulonidce, 1

hag, ii, 364

hair-tail, 154

hake, 300

halced, ii, 140

hakes, Bay of, 302

hakes dame, 304

Halcolurus, ii, 309

Halichoeres, 269

half-armed stickleback, 239

half-fish, ii, 69

Halicampus, ii, 259

halion, ii, 152.

Halocypselus, $\mathrm{ii}, 154$

hamata, Trigla, 70

hamatus, Salmo, ii. 67

hamela, Trichiurus, 15:3

hamburg carp, ii, 165

hammer head, ii, 294

Hampala, ii, 169

Haploinodotus, 150

harbine, 295

hard head, 63

Harengula, ii, 208

harengus, Clupea, ii, 208, 209

Harria, iii, iv

haustin, Tripteronotus, ii, 126

hawkenii, Gymnetrus, 220, 222

hearìng, $\mathrm{xxxyiii}$

hebetans, Torpedo, ii, 331, 333

hebridica, Argentina, ii, 50, 136,138

hebridicus, Osmerus, ii, 136, 138

heckelii, Abramis, ii, 194

helena, Muræna, ii, 254

helenæ, Muronophis, ii, 254

Helopa, ii, 279

helvetica, I'erca, 2

Hemibarbus, ii, 169

Hemicaranx, 123

Hemigobius, 158

hemigymmus, Argyropelecus,

138 ; ii, 47

hemigymnus, Sternoptyx, ii, $\mathbf{4 7}$

Hemiramphus, ii, 146

Hemitrygon, ii, 350

hen fish, 116

hopper, ii, 68 
hepsetus,Atherina, 169, 225,227

Heptanchus, ii, 308

herling, ii, 85, 88, 90

hermaphrodites; Ivi

hern, ii, 225

hernan, ii, 225

hexring, ii, 208

herring cobs, ij, 209

herring fisheries, $\mathrm{xciv}$

herring-hake, 295, 301

herring-sprod, ii, 90

herring-tack, ii, 216

hesperidicus, Scardinius, ii,183

heterocereal fins, ii, 14

Heterothrissa, ii, 205

hexacornis, Cottus, 53

Hewanchus, ii, 308

hibernica, Anguilla, ii, 242

Higgins, jii

hitur 157

Himantura, ii, 350

hinnulus, Galeorhinus, ii, 295

Hippocampus, ii, 256, 265

hippocampus, Syngnathus, ii, 265

Hippoglossoides, ii, 5, 9

Hippoglossus, ii, 5

hippoglossus, Pleuronectes, ii, 6

hirtus, Pleuronectes, ii, 18

hirtus, Rhombus, ii, 19

hirtus, Scophthalmus, ii, 19. .

hirtus, Zeugopterus, ii, 19

hirundinaceus, Carcharias, ii, 290

hirundo, Trigla, 59

hispidus, Orthragoriscus, ii, 273

Histiophorus, 143, 145

hoe, ii, 316

hoe-mother, ii, 305

hog-backed trout, 98, 101

Hogg, ii

holibut, ii, 6

Holocepha La, ij, 285

Hologymnosus, 269

hololepidota, Sciæna, 151

hololepidotus, Labrus, 150

homelyn ray, ii, 346

homer, ii, 305

homianus, Cetorhinus ii, 303

homocercal fins, ix

Homoprion, 150

hoodii, Salmo, ii, 119

Hoplonotus, $\mathbf{5 5}$

- horbearu, 48

horn-eels, 330 ; ii, 148

horned-ray, ii, 354

horn-fish, ii, 148

horners, 330

horridus, Trachinus, 81

horse mackerel, 1.25

hospitus, Acipenser, ii, 280

Houghton, Revd. ; iv

houting, ii, 126

Howietoun, ii, 95, 105

Hubrecht, Prof., iv

hucho, Salmo, ii, 54, 85

huers, ii, 227

humantin, Centrina, ii, 319

humbolti, Scopelus, ii, 49

humbolti, Serpe, ii, 49

humilis, Coregonus, ii, 125

hund-fish, ii, 310 huntia, Molva, 308

hurling, 4

hurry bannings, 241

hush bagaty, 181

Buso, ii, 279

huso, Actpenser, ii, 280

huso, Owyrhynchus, ii, 281

huss, ii, 310

hybridism, ii, $59,80,87,88$, $103,107,117,120$

hybrids, lxxi, lxxii

hydrostatic function, xliii

Hynnis, 123

hyoid arch, $x$ vi

Hyperoplus, 329

Hypogymnogobius, 158

Hypolophus, ii, 350

Hypselobarbus, ii, 169

Bypsiptera, 303, 313

Ichthyococeus, ii, 49

Idus, ji, 175

idus, Cyprinus, ii, 179

idus, Leuciscus, ii, 178

illustrations to work, i

imberbe, Ophidinun, ii, 242

imberbis, Gymnelis, 209

inberbis, Mullus, 56

imbricatts, Acantholabrus, 266

immaculata, Torpedo, ii, 333

impar, Solea, ii, 39, 42

imperialis, Bothus, ii, 11

imperialis, Luvarus, 120, 121

imperialis, Zeus, 118

incequalis, Blennius, 200

incubating, period of, lxvii

indented striped wrasse, 270

indicus, Naucrates, 127

infusoria, cvi

ingens, Gunnellus, 209

inherited instinct, lxx vii

inornata, Lota, 309

instincts and emotions, lxxiv

intermedia, Raia, ii, 339

intestinal tract, li

iris, Trachypterus, 217,218

islandicus, Bogmarus, 217

islandicus, Vogmarrus, 217

istayensis, Salmo, ii, 102

isodus, Squalus, ii, 304

isopods eating fish, ii, 318

is the sea inexhaustible ? xciii

Isurus, ii, 297

itaiara, 14

italica, Perca, 2

italica, Tinca, ii, 188

italicus, Pleuronectes, ii, 26, 34

jack, ii, 140

jack barnell, ii, 186

jack-chit, 241

jackie-downie, 287

Jack-ruffe, 12

jack sharp, 241

jack-sharplin, 241

jack-sharpnails, 241

jacobea, Echeneis, 108, 109

jaculns, Leuciscus, ii, 181

Jago, Revd. G., ii

jago, Raniceps, 320

jago's goldsinny, 264

jupunita, Brama, IIt japonica, Squatina, ii, 326

japonicus, Caranx, 124

japonicus, Selar, 124

japonicus, Zeus, 139, 140

Jardine, Sir W., ii

jeffreysii, Gobius, 168

Jenyns, ii

jerlin, ii, 69

jerusalem haddock, 119

jeses, Cyprinus, ji.' 179

jeses, Leuciscus, ii, 175

Jew-fish, 18

jig, to, 18

john dory, 140, 287

Johnius, 150

johnsoni, Dentex, 19

jothnsoni, Sparrs, 19

Johnston, ii

jozo, Gobius, 164

jubatus, Gadus, 317

judy, ii, 69

julis, Coris, 252, 269

julis, Julis, 269

julis, Labrus, 269

jura sucker, 189, 190

jurce, Petromyzon, ii, 359

juissieui, Lepadogaster, 191

karfe, 42

karrat, Anarrhichas, 195

keeling, 278

kellin, ;06

kelts, ii, 62, 69

kemp, ii, 243

Kermode, is

kethrie, 74

kettle net, cii

kidneys, lv

leienerị Anguilla, ii, 242

killinensis, Salmo, ii, 108 113

kilmaddy; 74

king-fish, 119

king of breams, 41

king of the mullets, 9

lling of the herrings, ii, 235 , 287

kingston, ii, 327

kipper, ii, 69,80

kippered herring, ii, 210

kitit, ii, 29, 30

kite, ii, 16

kitt, Pleuronectes, ii, 18

kleg, 278, 287

knerii, Polyprion, 17

knoud, 61, 63

teoelreuteri, Nancrates, 127

koelreuteri, Scomber, 127

Kolacanthus, ii, 270

kollarii, Cyprinus, ii, 157, 159,

161,165

kuth, 295

Labeobarbus, ii, 169

labradoricus, Acanthocottus, 49

Labrax, 8

labrax, Perca, 8

labran, Sciona, 8

LABR1D告, 251

Labroidei cycloidei, 251

Labroperca. 14

labrosus, Mugil, 232 
Labrus, 252, 260

LabrRinthici, 1

lacustrine fish, lxxxi

lacustris, Gadus, 308

lacustris, Salmo, ji, 54, 84, 96 , 97,102

lacustris, Trutta, ii, 85

lady fluke, ii, 7

Læmargus, ii, 315, 320

Levis, Gasterosteus, 245

leevis, Pastinaca, ii, 350

levis, Pholis, 203

levis, Phoxinus, ii, 185

lcevis, Platessa, ii, 28 .

levis, Pleuronectes, ii, 28

lævis, Rhombus, ii, 11, 14, 15

lavis, Squatina, ii, 326

lcevis, Trigla, 60

Lagocephalus, ii, 270

lagocephalus, Promecocephatus, ii, 271

lagocephalus, Tetrodon, ii, 270 , 271

lahan, 306

laits, 297

Lake bream, ii, 194

lake trout, $\mathrm{ii}, 96$

Lamna, ii, 297

lamia, Carcharias, 107

lamia, Squalus, ii, 298

LAMNID $A$, ii, 287, 297

lammasmen, ii, 90

lamper eel, ii, 360

lampern, ii, 359

Lampetra, ii, 356

lampetra, Petromyzon, ii, 356

Lampetræformis

Lampris, 118

lamprey, ii, 357

lanatus, Merluccius, 300

lancastriensis, Cyprinus, ii, 181, 182

lancastriensis, Leuciscus, ii, 181

lancea, Ammodytes, 332

lanceolatum, Branchiostoma, ii, 366

lanceolatus, Ammodytes, 329, 330

lanceolatus, Amphioxus, ii, 366

lanceolatus, Limax, ii, 336

land-dog, ii, 310

land-locked salmon, lxxii

langsdorfii, Cyprinus, ii, 166

lant, 332

lantern, ii, 22, 23

lanthorn gurnard, 65, 66

lapponicus, Coregonus, ii, 125

large-headed bulb-trout, ii, 87

large-headed dace, ii, 179

larger launce, 330

large-spotted dog-fish, ii, 312

larvata, Cobitis, ii, 201

larvatus, Labrus, 257

lascaris, Pleuronectes, ii, 42

lascaris, Solea, ii, 42

laskyr, Cyprinus, ii, 196

lasioring, ii, 68

last, ii, 210

lastoviza, Trigla, 56

lateral-line, $x x i i$

laterna, Arnoglossus, ii, 22, 23

laterna, Pleuronectes, ii, $2: 3$ laticeps, Gobius, 167

latidens, Microstomus, ii, 28

latifrons, Leuciscus, ii, 179

latirostris, Acipenser, ii, 280

iatirostris, Anguilla, ii, 240,

241,242

Latrunculus, 169, 172

latus, 150

latus, Cyprinus, ii, 196

latus, Salmo, ii, 126

launce, 331

launce, Lesser, 332

laurel, ii, 69

- Lauta, Lampris, 118

larre net, c.

lavaretus, Coregonus, ii, 125 , 127

lavaretus, Salmo, ii, 126, 127

leachii, Clupea, ii, 209

leách's herring, ii, 209

least hake, 320

leather carp, ii, 159

lecontei, Acipenser, ii, 281

lects, 297

legalised poaching, criii

leiobatos, Raia, ii, 336

Leiobatus, ii, 352

Leiocottus, 45

Leioglossus, 123

Leiostomus, 150 ; ii, 270

Leiurus, 236 ; ii, 267

leiurus, Gasterosteus, 237, 239.

lemanus, Fario, ii, 96, 97

lemanus, Salmo, ii, 102

lemon-dab, ii, 29

lemon sole, ii, 10, 29, 42

leotardi, Pleuronectes, ii, 23

Lepades, 18

Lepadogaster, 188

lepadogaster, Cyclopterus, 189

Lepidogobius, 158

Lepidopodince, 15 :

Lepidopus, 156, 216, 222

Lepidorhombus, ii, 17

Lepidosteus, ii, 279

Lepidotrigla, 56

Leptocardi, ii, 366

leprosy, ii, 71

Leptecheneis, 106

leptocephali, ii, 239

Lepturus, 153

lepturus, Trichiurus, 151, 156

$216,218,220,221$

lepus, Blennius, 202

lepusculus, Squalius, ii, 181

lesser dog-fish, ii, 309

lesser fork-beard, $3 \geq 0$

lesser grey mullet, 232

lesser lamprey, ii, 359

lesser spotted dog-fish, ii, 309 310

lesser weever, 82

Leuciscus, ii, 175

leuciscus, Cyprinus, ii, 181

leuciscus, Leuciscus, ii, 181

leuciscus, Squalius, ii, 181

leuciscus, Tinca, ii, 181

leuckartii, Abramidopsis.ii, 194

leuckartii, Abramis, ii, 157

leucophaus, Congrus, ii, 250

Lerucos, ii, 175

levenensis, Salmo, ii, $54,55,57$, 92,101 leveni, Zygæna, ii, 294

Lichia, 132

lichtensteinii, Acipenser, ii, 280

lie-still, ii, 204

Limamurcena, ii, 254

Limanda, ii, 25

limanda, Hippoglossoides, ii, 9

limanda, Platessa, ii, 32

limanda, Pleuronectes, ii, 25 31,32

limandoides, Hippoglossoides, ii, 9

limandoides, Platessa, ii, 9

lìmandoides, Plew'onectes, ii, 9

limandulus, Hippoglossoides, ii, 9

limosa, Myxine, ii, 364

linearis, Gobius, 172

lineata, Echeneis, 107

lineata, Trigla, 56, 58

lineated gurnard, 57

lineatus, Cantharus, 26

lineatus, Cuculus, 56 .

lineatus, Cyprinus, ii, 166

lineatus, Labrus, 253,257

lineatus, Lepadogaster, 192, 193

lineatus, Liparis, 181, 185, 187

lineatus, Pagrus, 26

lineatus, Sparus, 26

lineatus, Tracbinus, 80

ling, 305, 306

lingual teeth of trout, ii, 83

ling-drizzle, 306

linguatula, Monochir, ii, 45

linguatula, Pleuronectes, ii, 9

'inguatulus, Monochirus, ii, 44

lingula, Monochimus, ii, 4.3

lingula, Pleuronectes, ii, 43

lingula, Solca, ii, 43, 44, 45

lingula, Synaptura, ii, 45

ling, 5-bearded, 313

ling, 3-bearded, 313

linnei, Acanthias, ii, 316

linnei, Eglefunus, 283

Iinnei, Alburnus, ii, 198

linnei, Anguilla, ii, 242

linnei, Belone, ii, 147

linnei, Carassius, ii, I64

linnei, Conger, ii, 250

linnei, Galeus, ii, 292

linnei, Hippoglossus, ii, 6

linnei, Merlangus, 290

linnei, Pollachius, 297

linnei, Rhombus, ii, 15

linnei, Solea, ii, 39

linnei, Tinca, ii, 188

tintea, Raia, ii, 340

lioderma, Pleuronectes, ii, 15

Lioniscus, ii, 279

liparoides, Cyclopterus, 186,187

Liparis, 184

liparis, Centrolophus, 111

liparis, Cyclogaster, 184

liparis, Cyclopterus, 184

little goby, 167

little gurnard, 61

little hairy fluke, ii, 19

little pipe-fish, ii, 263

little sole, ii, 45

littoral fish, lxxx, lxxxvi

littoralis, Scyphius, ii, 263

liver, lvi

livery fish, 258 
liwery servant, 258

lizard-bait, 332

llean, ii, 225

lloydii, Coregonus, ii, 126

loach, ii, 203

lob, 295, 297

lob-keeling, 295

lobsters, ii, 40

locomotion, xii

loggerhead, ii, 179

london sprat, ii, 232

long-angler, 73

long-finned captain, 66 .

long-finned tunny, 97

long fleuk, ii, 10

long flounder, ii, 30

longicauda, Cepola 213

longipinnis, Brama, 114

longirostris, Belone, ii, 149

longissimus, Balistes, ii, 268

long-nose, ii, 148

long-nosed dinnan, ii, 342

long-nosed skate, $\mathrm{ii}, 341$

long rough dab, ii, 10

long-spined cottus, 52

long-tailed shark, ii, 300

long take, ii, 210

longus, Balistes, ii, 268

Lophiopsis, 72

Lophius, 72

LophomRanchit, ii, 256

LOPHOIDEI, 72

lophotes, Arnoglossus, ii, 23, 388

loquette, 212

Zord-fish, 277, 278

Lota, 305, 308

Zota, Enchelyopus, 308

lota, Gadus, 308

lota, Molva, 308

loup, 9

Lowe, Dr., iii

lower jaw, $x v i$

Low, Rev. G., ii

Lubbock, if

lubb, Gadus, 323

lub, Enchelyopus, 323

luce, ii, 140, 141

lucerna, Trigla, 65

lucidus, Alburnus, ii, 198, 199

Luciobarbus, ii, 169

lucius, Esox, ii, 139

lucky proach, 52

lug, 287

lug-a-leaf, ii, 16

luggatee, $\mathrm{ii}, 12$

lumbricalis, Petromyzon, ii, 362

lumbriciformis, Acus, ii, 263

lumbriciformis, Nerophis, ii, 263

lumbriciformis, Syngnathus, ii, 263

lumbriciformis, Scyphius, ii, 263

lumbricum, Branchiostoma, it, 366

Iuminosity, $\mathrm{xx \nabla}$

Lumpenus, iii

lumpenus, Lampetriformis, iii ; ii, 388

lump fish, 180

lump sucker, 180, 181

\section{Lumpus, I79}

lumpus, Cyclopterus, 179, 180

luna, Chrysostosus, 118

Iuna, Lampris, 118

lunaris, Orthragoriscus, ii, 276

luna, Zeus, 118

lunulated gilt-head, 33

lunulatus, Balistes, ii, 269

Iupus, 8

lupus, Anarrhichas, 195 '

lupus, Centropomus, 8

lupus, Labrax, 8

Insca, Morhua, 286

luscus, Crenilabrus, 266

luscus, Gadulus, 287

luscus, Gadus, 275, 286, 288

luscus, Labrus, 266

luscus, Pleuronectes, ii, 34

Insitanicus, Lepidopus, 156

lusitanicus, Vandellius, 156

lutea. Solea, ii, 39, 44, 45

luteus, Monochirus, ii, 45

luteus, Pleuronectes, ii, 44

luteus, $R$ hombus, ii, 44

- Luvarus, 121

Luxilus, ii, 193

Lycengrantis, $\mathrm{ii}, 205$

Iycodes, ii, 242

Lycodontis. ii, 254

Lycothrissa, ii, 205

lymna, Trygon, ii, 350

lyra, 58

lyra, Callionymưs, 174, 177

lyra, Trigla, 64

lyra, Uranoscopis, 175

lyrie, 68

lythe, 297

\section{mackerel, 83}

mackerel-guide, ii, 148

mackerel midge, 86,314

mackerel scout, ii, 148

mackrel, 83, 85

mackerelsture, 94

macrocephala, Clupea, ii, 231

macrocephala, Morrhua, 277

macrocephalus, Cephus, 276

macrocephalus, Gadus, 276, 278

macrolepidotus, Cyprinus, ii,

159,161

maicrophthalma, Motella; 319

macrops, Balistes, ii, 268

macropterus, Echelus, ii, 250

macropterus, Thynnus, 97

macrorhynchus, Lceviraja, ii, 339

macrorhynchus Raia, ii. 338

macrosoma, Gerres, 251

macrourus, Alopias, ii, 300

maculata, Motella, 313, 314 317

maculata, Raia, ii, 334,345

maculata, Tinca, ii, 189

maculatus, Anarrbichas, 195

maculatus, Balistes, ii, 267, 268

maculatus, Callionymus, 177

maculatus, Labrus; 252, 258, 263

maculatus, Lepadogaster, 192 ,

193

maculatus, Liparis, 187

maculatus, Scomber, 91

macritis x, Blennius, 203 maculosa, Molva, 308

maculosa, Perca, 261

maculosus, Acipenser, ii, 279

maculosus, Acentrolophus, 11

maculosus, Gadus, 308

maculosus, Petromyzon, ii, 356

Marnides, 1

maid, ii, 237, 344

- maiden-skates, ii, 344

maigre, 150, 151

mailed gurnapd, 71

maillardi; Cyprinus, ii, 160

Maitland, Sir J. R., iv

maize, $\mathrm{ii}, 210$

majalis, Leuciscus, ii, 181

major, Perca, 2

major, Syngnathus, ii, 259

major, Trachinus, 80

Malacopterygii, 1

malarmat, Peristedion, 70

malleus, Squalus, ii, 294

malleus, Zygøena, ii, 294

Mallotus, ii, $110^{\circ}$

Maltheoidei, 72

Manley, Mr., 5

mangili, Pleuronectes, ii, 43

mangiti, Rhombus, ii, 43

mangiti, Solea, ii, 43

Manochir, ii, 37

marcenula, Coregonus, ii, 128 , 367

marginata, Anguilla, ii, 242

marginata, Raia, ii, 339

marginatus, Ctenolabrus, 264, $2 € 5$

marginatus, Serranus, 16

marina, Brama, 114

marina, Lampetra, ii, 356

marina, Perca, 42

marina, Trutta, ii, 85

marine fish, lx xx

marine fish in fresh water

Ixxxiii, 54

marinus, Gasterosteus, 247

marinus, Holocentrus, 14

marinus, Petromyzon, ii, 356

marinus, Scorpius, 51

marinus, Sebastes, 42

marimes, Serranus, 14

marmorata, Platessa, ii, 34

marmorata, Torpedo, ii, 330 , $331,332,333$

marsilii, Phoxinus, ii, 185

marsilii, Salmo, ii, 84

mary sole, $\mathrm{Zi}, 29$

massa, Crenilabrus, 260

massiliensis, Aurata, 36

massitiensis, Scorpena, it

massitiensis, Sparus, 36

Mastacembelus, ii, 146

maties, ii, 210

mauritianus, Cyprinus, ii, 166

maurolici, Scopelus, ii, 50

Maurolicus, ii, 46, 49

- mavis state, ii, 340

maxillaris, Coregonus, ii, 125

maxima, Psetta, ii, 12

maxima, Selache, ii, 303

maximus; Cetorhinus, ii, 304

maximus, Hippoglossus, ii, 6

maximus, Pleuronectes, ii, 11

maximus, Rhombus, ii, 11

maximus, Scophthalmus, ii, $\cdot 1$ 
mayock fleuk, ii, 35

may-skate, ii, 340

mazy herring, ii, 210

McIntosh, iii

Mcskimmin, iv

meaker, ii, $1: k 6$

median fish, lxxxi

mediorostris, Anguilla, ii, 241

mediterranea, Julis, 269

mediterranea, Sternoptym, ii, 47

Mediterranean, Chimcera, ii, 286

mediterranean shark, ii, 308

mediterraneus, Enchelyopus, 317

mediterraneus, Scomber, 102

mediterraneus, Thynnus, 93

medusæ, refuge foripollack, 297

medusophagus, Centrolophus, ii, 367

medusophagus, Schedophilus,

$117 ; \mathrm{ii}, 367$

Megalaspis, 123

megastoma, Arnoglossus, ii, 21

megastoma, Pleuroneetes, ii, 21

megastoma, Zeugopterus, ii, 21

megrim, ii, 23

melanio, Gobius, 162

melanogaster, Platessa, ii, 34

Melanogrammus, 274

melanostomurn, Scyllium,ii,314

melanostomus, Gadus, 292

melastomus, Galeus, ii, 314

melanostomus, Pristiurus, ii, 314

melanostomus, Pristinurus, ii, 314

melanostomus, Scylliorhinus, ii, 314

melanura, Julis, 269,270

Meletta, ii, 208

meletta, Engraulis, ii, 206

Melichthys, ii, 267

melops, Crenilabrus, 260, 265

melops, Labrus, 260

melops, Lutjanus, 260

Menephorus, 14

mennam, ii, 186

mennard, ii, 186

mengy, ii, 186

meridionalis, Aphia, 169

meridionalis, Squalius, ii, 179

Merlangus, 274

merlangus, Gadus, 275, 290, 292

Merluccius, 300

merluce, 301

merlus, Gadus, 300

merou, Holocentrus, 16

Merrifield, Mrs., iii

merry-sole, ii, 22, 30

messaniensis, Cicerellus, 333

meunier, Squalins, ii, 179

Meynell, ii

Microbuglossus, ii, 37

microcellata, Raia, ii, 346

microchir, Monochir, ii, 43

microchirus, Pleuronectes, ii, 43

microcephala, Cynoglossa, ii, 28

microcephala, Platessa, ii, 28

microcephalus, Coregonus, ii., 127

microcephalus, Dalatias, ii, 320

microcephalus, Læmargus, ii, 320 microcephalus, Pleuronectes, ii, 25,28

microcephalus, Scymnus, ii, 320 microcephalus, Squalus, ii, 320 microlepidotrs, A bramis, ii, 193 microps, Gobius, 166 microps, Salmo, ii, 85 microptera, Anguilla, ii, 242 - micropterus, Scymnus, ii, 320 micropterygius, Uranoscopus, 175

micropteryx, Abramis, ii, 197

microstoma, Acantholabrus, 267 microstoma, Crenilabrus, 267

Microstomus, ii, 25,

microstomus, Cottus, 46

microstomus, Pleuronectes, ii,28

MICR URIDAE,, 335

migrations, lix, Ixxxviii

migratoria, Anguilla, ii, 241

miller's-dog, ii, 292

mill-skate, ii, 353

miller's thumb, 46, 48, 164, 287

milt, Ivii, Ixvii

milenus, 56

milvus, Trigla, 62

minim, ii, 186

minimus, Gadus, 320

minnis, 241

minor, Couchia, 314

minor, Mullus, 22

minnow, 4, 5, 241; ii, 185

minnoro-pink, ii, 186

minuta, Atherina, 169

minuta, Eleotris, 165

minuta, Morrua, 288, 289

minuta, Solea, ii, 45

minutus, Brachygradus, 289

minutus, Cottus, 46

minutus, Cyclopterns, 180

minutus, Gadulus, 289

minutus, Gadus, 275, 288

minútus, Gobius, 160, 165, 166 ,

167,180

minutus, Lepadogaster, 180

minutus, Monochivus, ii, 44

miraletus, Raia, ii, 345,348

mirandella, Alburnus, ii, 198

Mirbelia, 188

mirbelia, Lepadogaster, 192

mirror-carp, ii, 159

mixtus, Labrus, 256, 257, 270

mixtus, Liparis, 185

Nobula, ii, 354

mobular, Dicerobatis, ii, 354

modes of fishing, xcvi.

moist spawning, cix

mola, Diodon, ii, 272, 273

mola, Tetrodon, ii, 272

Molva, 305

molva, Enchelyopus, 305

molva, Lota, 305

molva, Gadus, 305

mola, Orthagoriscus, ii, 272, 277

molebut, ii, 274

moles, Cyprinus, ii, 165

monensis, Squalus, ii, 297

monge, Notidanus, ii, 308

mongrel-steate, ii, 327

monk-fish, 74, ii, 327

Monochirus, ii, 37

Monopterhimus, ii, 308 monstrosa, Chimæra, ii, 286

monstrosities, lxxix

Montagu, ii

Montague's blenny, 200

montagui, Blennius, 200

montagui, Cepolophis, 209

montagui, Cyclopterus, 186

Montagui, Ichthyocoris, 200

montagui, Liparis, 184, 186

187

Montagu's sucker, 186

moon fish, ii, 272

Moored nets, cii

mop, 284

morcena, Anguilla, ii, 242

More, iv

morgay, ii, 310

morghi, ii, 310

Morhua, 274

morhua, Gadus, 275, 276

morio, Centrolophus, 111

morio, Coryphana, 111

Morone, 8

morrian, 255

morris, ii, 140

morrisii, Leptocephalus, ii, 250

morts, ii, 69

Motella, 313

mother of herrings, ii, 235

moudie-trout, ii, 85

moutrush, 295

mouth, $x$ vi, li

Movella, 313

mucronata, Raia, ii, 341

mud-flounder, ii, 35

mud-lamprey, ii, 362

Mugil, 228

Mugilid e, 228

mülleri, Maurolicus, ii, 50

II uller's topknot, ii, I9

mullet, 230

mullet, plain red, 23

mullet, red, 22

mullet, striped red, 23

mulleus, 31

mullgrannoc, 204

MUldide, 21

Mullus, 21

multidentatus, Crenilabrus,

mulvel, 284

muræna, ii, 239, 254

murana, Coregonus, ii, $\mathbf{1 2 5}$, 126

murcena eels, 212

murana, Gymnothoraw, ii, 254

Murdenid $x$, ii, 239

murconoides, Blennius, 208

murconophis, ii, 25t

Murie, Dr., 4

murranroe, 37, 255

murry, ii, 255

muscular system, $\mathrm{x}$ viii

Mustela, 211

mustela, Enchelyopus, 314

mustela, Gadus, 314, 317

mustela, Motella, 314

Mustelus, ii, 289, 295, 313

musteirs, Gateus, ii, 295

mustelus, Squalus, ii, 295

Mycteroperca, 14

Mrliobatid 2 , ii, 329, 352

Myliobatis, ii, 352

Myxine, ii, 364 


\section{INDEX}

MrXINID AB, ii, 355, 364

ncevus, Raia, ii, 348

naked bait, 330

Narcacion, ii, 330

Narcobatis, ii, 330

nass-fish, 74

nassus, Chondrostoma, ïi, 157

nasus, Diplanchias, ii, 273

nasus, Mola, ii, 273

nasus, Squalus, ii, 297

nasuta, Solea, ii, 42

nasubus, Pleuronectes, ii, 42

Nauclerus, 12 ?

Naucrates, 127

naucrates, Echeneis, 108

nebulosus, Gasterosteus, 245

needle-fish, ii, 148, 260

Neill, A. C., iv

Neill, Patrick, ii

Ne!̣nacheilus, ii, 201, 203

Nematosoma, ii, 261

Nerophis, ii, 256, 261

nervous system, $x$ viii

nests, $1 \mathrm{x}$

network sucker, 186

neustrice, Labrus, 253

new british torpedo, $\mathrm{ii}, 331$

nine holes, ii, 360

nobiliana, Torpedo, ii, 331

nobilis, Salmo, ii, 66

noble, 68

nockies, 284

noctula, Myliobatis, ii, 352

nor'foll capon, ii, 210

noggle-head, 48

nonnat, 170,224

northern Chimora, ii, 286

norway bull-tronit, ii, 87

norway haddock, 43

norwegian carp, 43

nomvegianus, Squalus, ii, 320

norwegica, Perca, 15, 42

norwegica, Scorpcena, 42

norwegicus, Crenilabrus, 261

norvegicus, Coryphænoides, 335

norwegicus, Holocentrus, 42

norwegicus, Labrus, 261

norvegicus, Lepidoleprus, 335

norwegicus, Lutjanus, 261

norvegicus, Macrourus, 335

norwegicus, Sebastes, 7, 15, 42

norwegicus, Serranus, 42

notata, Chirostoma, ii, 146

NotidaNIDA, ii, 287, 308

Notidanus, ii, 308

notochord, $x$ vii

Notorhynchus, ii; 308

novemboracensis, Naucrates, 12 ?

novemcinctus, Serranus, 14, 15

niger, Centrolophus, 111

niger, Conger, ii, 250

niger, Gobius, 160, 161, 162, 163

niger, Holocentrus, 111

niger, Petromyzon, ii, 362

niger, Raniceps, 320

niger, Scomber, 128

niger, Sparus, 115

nigra, Perca, 111

nigra, Torpedo, ii, 331

nigrescens, Salmo, ii, 119

nigricans, Huro; 19 nigricans, Petromyzon, ii, 359

nigricans, Xiphias, 146

nigripinnis, Salmo, ii, 55, 98

nigromanus, Pleuronectes, ii, 30

nilotica, Anguilla, ii, 242

nilssonii, Crystallogobius, 172

nilssonii, Gobiosoma, 172

nilssonii, Gobius, 172

nilsonii, Latrunculodes, 172

nilsonii, Latrunculus, 172.

nine eyes, 209 ; ii, 360

nudus, Cyprinus, ii, 159

nudus, Rhombus, ii, 23

numb-fish, 'ii, 331

nuptial season, lxxvii

nurse-hound, ii, 312

obesus, Fchinorhinus, ii, 323 , oblongus, Cephalus, ii, 276

oblongus, Orthragoriscus, ii, 276

oblong diodon, ii, 276

oblong sun-fish, ii, 276

oblongus, Carassius, ii, 165

obscura, Trigla, 65

obscurus, Liparis, 187

obtusirostris, Gobio, ii, 172

obtusus, Hemiramphrus, ii, 147, 149

occidentalis; Conger, ii, 250

oceanica, Inmanda, ii, 32

ocean pipe-fish, ii, 261

ocellaris, Blennius, 198, 201

ocellatus, Acanthocottus, 49

ocellatus, Blennius, 202 .

ocellatrus, Cyclopterus, 189

ocellatus, Lepadogaster, 192

occidentalis, Gasterosteus, 245

occidentalis, Pygosteus, 245

octo-radiatus, Mugil, 228, 230, 231

oculata, 'Raia, ii, 345

oculata, Squatina, ii, 326

oculatus, Balistes, ii, 268

oculatus, Canthider"mis, ii, 268

Oreias, ii, 203

Odontogobius, 158

odour, xxxvii

ogak; Gadus, 276

old-ewe, 255

old-wife, 26, 255, 287

olic, 306

Olistus, 123

olivacea, Pastinaca, ii, 350

olivaceus, Lepadogaster, 191

olivet, ii, 243

omatii, Petromyzon, ii, 359

omorus, Caranx, 124

one-spotted goby, 165, 166

Onisci, 9

Onos, 313

onos, Mustella, 317

oolachan, ii, 121

Opah, 118

opah, Zeus, 118.

opercular pieces, $x$ vii

OPHIDIIDA, 326

Ophidium, 326

Ophidium, Beardless, ii, 242

ophidium eel, 209

ophidion, Acus, ii, 262

ophidion, Nerophis, ii, 262, 263 ophidion; Syngnathus, ii, 261, 262,263

ophidoides, Liparis, 184

UPHIOCEPHALID \&, I

Ophioscion, 150

Ophisomus, 208

ophis, Ophisurus; ii, 254

Ophthatmolepis, 269

Opisthonenema, $\mathrm{ii}, 208$

Oplopomus, 158

orange-fins, ii, 90

orcadensis, Salmo, ii, 55, 83, 96

Urcynus, 93, 100

orfus, Barbus, ii, 183

ormals, 332

Orphrs, 30, 36

orphus, Aurata, 30, 31, 32

orphus, Pagrus, 30

orphus, Sparus, 36

orcini, Brama, 114

orsini, Ozodura, ii, 273

Orientalis, Thynnus, 93

ortagoriscus, Cephalus, ii, 273

Orthagoriscus, ii, 272

Osmerus, ii, 52,.121

ossiphagus, Labrus, 256

otterpike, 81,82

oumer, ii, 132

Owenii, Pagellus, 35, 38

ox-sole, ii, 22

oxygeneios, Epinephelus, If

Uaynotus, ii, 319

oxynotus, Centrina, ii, 319

ox-ray, ii, 354

Owybeles, 328

Oxyrhina, ii, $29.7 \mathrm{H}$

oxyrhina, Murcena, ii, 241

oøyrhynchus, Acipenser, ii, 281

oxyrhynchus, Coregonus, ii, 125;

126,135

oxyrhynchus, Lceviraja, ii, 341

oxyrhynchus, Raia, ii, 340, 341 , 345

oxyrinchus, Isurus, ii, 297

Oxyuricht7ys, 158

Ozodura, ii, 272

ozodura, Orthragoriscus, ii, 273

pacificus, Thynnus, 9

paddle-cock, 181

paddock, 321

poecitoptera, Trigla, 57, 60

poecilopus, Cottus, 46, 47

paganellus, 162

paganellus, Gobius, 160, 162, 164

Pagellus, 25, 35

pagellus, Sparus; 40

Paget, ii

Pagrina, 25, 30

Pagrus, 25, 30, 35

pagrus, Pagrus, 30

pagrus, Sparus, 30, 31, 36, 37, 40

paidle, Cock.and hen, 181

painted ray, ii, 346

painted sea adder, ii, 262

palamitus, Thynnus, 102

Palinurichthys, 130

Palinurus, 130

Pallasia, ii, 273

pallasii, Clupea, ii, 208

pallens, Leuciscus, ii, 175 
pallida, Echeneis, 108, 109

palloni, Acantholabrus, 266

palloni, Lutjanus, 266

palmicosnis, Blennius, 206

Pammelas, 130

pancreas, lvi

pandora, 41

pantherinus, Anarrhichas, 195

papitio, Blennius, 202

Parabalistes, ii, 267

Parachosturichthys, 158

Paranguilla, ii, 240

Paranthias, 12

Paradentex, 19

Paragonus. 67

Paralabrax, 14

Paralepis, ii, 51

Paraserranus, 14

parasitic fungi, cvi

Paratractus, 123

Paratrygon, ii, 350

par becoming smolts, ii, 78

pareti, Leuciscus, ii, 179

Parexocatus, ii, 154

Parfitt, iii

Pargobius, 158

Parnell, ii

parnelli, Gobius, 160, 167

parr, 295 ; ii, 68, 90

parrot-fish, 204

parsia, Mugil, 228

parva, Echeneis, 108

passer, Pleuronectes, ii, 15, 34

Pastinaca, ii, 350

pastinaca, Raia, ii, 350

pastinaca, Trygon, if, 350

pastinaca, Trygonobatus, ii, 350

parsingeri, Leuciscus, ii, 175

paro, Blennius, 201

pavonina, Pleuronectes, ii, 16

pavoninus, Adonis, 202

pavoninus, Cyclopterus, 180, 181

pavo, Labrus, 257

Peach, iii

peal, ii, 82

pearl, ii, 14, 16

pearl-sides, ii, 51

Pedrculati, 72

pegusa, Pleuronectes, ii, 42

pegusa, Solea, ii, 42

pelagic fish, l $\mathrm{xxx}, 1 \mathrm{xxx}$

pelagicus, Cyprinus, 42

pelagicus, Scomber, 113

pelagicus, Syngnathus, ii, 259

263,264

pelamid, 102, 103

pelamides, Scomber, 100

pelamis, S'comber, 100

Pelamys, 102

pelamys, Thynnus, 100, 102

pellucida, Aphia, 169, 224

pellucidus, Gobius, 169

pellucidus; Latrunculus, 169

pellucidus, Pleuronectes, ii, 23

Pennant, ii

Pendalion, ii, 272

pennantii, Argentina, ii, 49

pennantii, Blennius, 206

pennantii, Coregonus, ii, 127

pennantii, Crevilabrus, 261

pennantii, Lagocephalus, ii, 271 pennantii, Maurolicus, ii, 49, 51

pennantii, Scopetus, ii, 50

pennantii, Squatus, ii, 297 pennant's globe-fish, ii, 271 penny-dog, ii, 292

pentacanthus, Labrus, 267

peer, ii, 186

Pegusa, ii, 37

perc, 4

Perca, 2, 14

Perca marina, 14, 15

Perch, 2

perch, hunch-backed, 4

Percidax, 1

Perciforales, 1

perciformis, Coryphycena, 130

perciformis, Palinurichthys, 130

perciformis, Palinurus, 130

perciformis, Pammelas, 130

Pecoidei, 1

Perdiso acuarum, 7

peregrinus, Squalus, ii, 303

perisii, Salmo, ii; 108, 112

Peristedion, 70

Peristethus, 70

peronii, Lepidopus, 156

pertsh, 4

peruanus, Centrolophus, 110

peter nets, ci

Peters, Plof., iv

Petrometopon, 14

Petromyzon, ii, 356

Petromizontide, ii, 355, 356

pettifogger, 3 I 5

Pharyngognathi, 251

Phalangistes, 67

phalerita, Clupea, ii, 231

phinock, ii, 85, 90

phinoc, Salmo, ii, 54, 85

Phobeter, 45

pholis, Adonis, 203

pholis, Blennius, 198, 203

Phoxinus, ii, 175

phoxinus, Cyprinus, ii, 185

phoxinus, Leuciscus, 241 ; ii, $157,185,187$

Phrynorhombus, fi, 17

Phtheirichthys, 106

Phycis, 303

phycis, Blennirus, 303

Pbysoclisti, xliii

Plıysostomi, xliii, xliv ; ii, 46 picche, ii, 140

picked-dog, ii, 316

pickerel, $\mathrm{ii}, 140$

pickey, 295

picta, Torpedo, ii, 3.33

picturata, Seriols, 124

pictus, Gobius, 160, 167

pictus, Liparis, 187

pike, ii, 140,141

pilchard, ii, 224,225

pilchardus, Clupea, ii, 208, 224

pilot fish, 127

piltock, 295

pincher, 225

pine-leaved.gurnard, 58,59

pini, Trigla, 58

pinte, ii, 68, 132, 186

pink brame, 265

pinckeen, 241 piper, 64

pirate-fish, ii, 3.64

piscatorius, Batrachus, 73

piscatorius, Lophius, 73

Plagioscion, 150

Plagiostomata, ii, 285, 287

plaice, ii, 26

plain bonito, 102, 104

planci, Tympanomium, ii, 273

planci, Mola, ii, 276

planer $i$, Lampetra, ii, 362

planeri, Petromyzon, ii, 362

planers-lamprey, ii, 362

plash fleuk, ii, 26

Platessa, ii, 25

platessa, Pleuronectes, ii, 25, 26

platessoides, Pleurcnectes, ii, 32

Platichthys, ii, 25

platycephala, Anguilla, ii, 242 .

Platychistæ, if, 2:39

Platygobius, 158.

platyrhina, Murcena, ii, 241

Platysomatichthys, ii, 5

plebejius, Mustelus, ii, 295

Plectognathi, ii, 267

plestyo, Cyprinus, ii, 196

Pleuracromnylon, ii, 295

Pleuronectidæ, 216

Pleuronectid as, ii, 1

pleuronectoids, development of ii, 1

Pleurothysis, ii, 47

plinlimmon trout, 98, 101

plotizza, Scardinius, ii, 183

pluck, 68

plumbeus, Petromyzon, ii, 362

plumbeum. Astroderma; 121

plumieri, Gerres, 251

pneumatophorus, Scomber, 85 91

poachers, criii

Pecilophis, ii, 254

pod, ii, 140

podlie, 295

podling, 295

pogge, 68

poisoned brame, 265

poison-pate, 50

pola, Platessa, ii, 30

pole, ii, 30, 31

pole- $d a b$, ii, 31

polewig, 166

Pollachins, 274, 293

pollachius, Gadus, 275, 294,

296

pollachius, Nerlangus, 296

pollack, 296, 297

pollan, ii, 129, i30

pollan, Coregonus, ii, 125, 129

polleni, Narcacion, ii, 333

pollinit, Gobio, ii, 172

pollybait, 166

Polyacanthus, 236

Polyprion, 17

Polyprosopus, ii, 303,305

Polyuranodon, ii, 254

Pomatoschistus, 158

pomeranian bream, ii, 194

Pompilus, I10, 127

pompilus, Centrolophus, 111

pompilus, Coryphoena, 111

pompilus, Thynnus, 127 
pontica, Raia, ii, 343

ponticus, Scomber, 102

poodler, 295

poor-cod, 288

pope, 12

porbeagle, ii, 298

porosus, Cottus, 49

portaferry chicleen, 225

Porthmeus, 132

Porobranchus, 328

Porocottus, 45

Porogobius, 158

Poroderma, ii, 309

pos, 12

post, Holocentrus, 11

Potamocottus, 45

Potamorrhaphis, ii, 146

potassoa, Gadus, 292

poullacli, 278

pout, 286,287

poutassou, 292

pontassou, Boreogadus, 292

poutassou, Gadus, 275, 292

poutassou, Merlangus, 292

poutassou, Pollachins, 292

pow, 241

powan, ii, 127

power-cod, 288, 289

- prasinus, Lenciscus, ii, 175

presbyter, Atherina, 224, 225, 227

Priacanthichthys, 14

priame, ii, 122

prictca, Petromyzon, ii, 359

prickleback, 241

pricky, 241

pride, ii, 362

Prilonotus, ii, 270

prim, ii, 122

prinkle, 295

Priodonophis, ii, 254

Pristipamatida, 1

Pristiurus, ii, 309, 314

Proctostegus, 121

prognathus, Perca, 18

Promicrops, 14

Prospinus, 14:

prototypus, Proctostegus, 121

provencialis, Mugil, 232

prussian carp, ii, 165

Psetta, ii, 11

Pseudobalistes, ii, 267

Pseudobarbus, ii, 169

pseudobranchiæ, xlviii

Pseudocoris, 269

Pseildomugil, 224

Pseudomurcena, ii, 254

pseudopalus, Pleuronectes, ii, 21

Pseudophoxinus, ii, 175

Psendopleuronectes, ii, 25

Pseudoscicena, 150

Pseudosebastes, 42

Psilonotus, ii, 270

psittacus, Labrus, 253

Pteraclis, 114

Pterengraulis, ii, 205

Pterocephala, ii, 354

Pterycombus, 114

Ptyonotus, 45

pug, ii, 68

pumila, Spratella, ii, 231

punctata, Morhua, 276

punctata, Raia, ii, 343 punctata, Scarcina, 157

punctata, Torpedo, ii, 333

punctatus, Gadus, 276

punctatus, Labrax, 8

punctatus, Lepadogaster, 192 , 193

punctatus, Pleuronectes, ii, 17 18

punctatus, Rhombus, ii, 17, 19

punctatus, Scomber, 84, 85

punctatus, Zeugopterus, ii, 17,

18,19

punctipinnis, Gobins, 162

pungio, Zeus, 139

pungitia, Gasterostea, 245

pungitius, Gusterosteus, 236,

$237,240,244,245$, ii, 239

pungitius, Leinerus, 245

Puntius, ii, 169

puppy-fish, ii, 327

pusilla, Perca, 134

pusillus, Gobius, 161

pusillus, Labrus, 253

putts and putchers, ii, 91

Pygosteus, 236

pyloric coeca, liii

pyramidatus, 'Cyclopterus, 180

Pyrodon, ii, 267

quadricornis, Cottus, 53, 272

quadricornis, Ostracion, ii, 269

quadridens, Pleuronectes, ii, 28

quadrilobus, Cyprinus, ii, 166

quadrimaculatus, Gobius, 160,

168

quadrimaculatus, Labrus, 257

quarter-armed sticlileback, 239

queen fish, ii, 30

queen of rivers, ii, I59

quenselii, Pleuronectes, ii, 38

quid, 225

- quinque-cirrhata, Motella, 314

rabble fush, ii, 335

rabbit fish, 57 ; ii, 287

rack, ii, 104

rack-rider, ii, 104

radiata, Amblyraja, ii, 347

radiata, Dasybatis, if, 347

radiata, Raia, ii, 335,347

rodula, Raia, ii, 348

rafinesqui, Lepadogaster, 191

Raia, ii, 334

RAIIDE, ii, 334, 329

raii, Blennius, 320

raii, Brama, 114, 115

raii, Sparus, 114

Rainbow wrasse, 269,270

ramada, Mugil, 230

ramulosus, Hippocampus, ii, 265

Rana, 73

Raniceps, 320

ranina, Phycis, 320

raninus, Blennius, 320

raninus, Gadus, 320

raninus, Raniceps, 320

Ranzania, ii, 272

rappii, Salmo, ii, 102

raptor, Gadus, 305

raschii, Brama, 114

rauning poilack, 294

ravenous wolf fish, 195 rawn fleuk, ii, 12

Ray, i

ray-maids, ii, 344

ray-mouthed dog, ii, 296

roys-bream, 115

red band-fish, 213, 214

red charr, ii, 108, 109, 112, 113

red dace, ii, 176

red-finned herrings, $\mathrm{ii}_{9}, 210$

red gilt-head, 37,38

red.gurnard, 58

red herring, ii, 210

redi, Orthragoriscus, ii, 273

red mullet, 22

red paidle, 181

red perch, 43

red snake fish, 213, 214

red sole, ii, 45

red-tubs, 61

red-wame, ii, 116

red wrasse, 258

Regalecus, 216, 220

Remitegia, 106

remeligo, Echeneis, 109

Remora, 106, 108

remora, Echeneis, 107, 108 ; ii, 299

remoroides, Echeneis, 108

- Remoropsis, 106

Reniceps, ii, 294

respiration, xlvii

reticulatus, Callionymus, 177

reticulatus, Gobius, 165, 166

reticulatus, Lepadogaster, 192

retzin, Mola, ii, 273

retzii, Orthragoriscus, ii, 273

reversed fish, ii, 1

rex-cyprinorum, ii, 159

Rhamphistoma, ii, 146

RHINIDE, ii, 326

Rhinogubius, 158

Rhinoscion, 150

Rhinoseymrus, ii, 320

rhodopterus, Gobius, 165, 167

Rhombochirus, 106

Rhombus, ii, 5, 11

rhombus, Psetta, ii, 15

rhombus, Pleuronectes, ii, 12,1

rhombus, Scophthalmus, ii, 15

Rhynchotus, ii, 270

ribbon fish, 220

ribbon pout, 289

ribbon-shiaped loach, ii, 202

Richardson, ii

richardsonii, Scciæna, 150

Richardsonius, ii, 193

rickets in fish, ii, 253

rig, ii, 292

rionnach, 85

rivularis, Cyprinus, ii, 185

roach, ii, 175

roach-dace, ii; 176,182

roan-fleuk, ii, 12

robbie wamberg, 247

robin-huss, ii, 310

robusta, Perca, 16

Roceus, 8

rocheanus, Thynnus, 104

rochei, Auxis, 104

rochei, Scomber, 104

rochii, Ophidium, 327

rock-cook, 267, 268

rock fish, 164 
rock goby, 164

rock gurnard, 57

rock-salmon, 295

rock-shark, ii, 312

rod, ii, 12

roddan, ii, 12

rodeus, Leuciscus, ii, 181

-rodeus, Squatius, ii, 181

Roebuck, D., iv,

Rogenia, ii, 208

romana, Muræna, ii, 254

rondeletii, Balistes, ii, 269

rondeletii, Orthragoriscus, ii, 273

randeletii, Pompilus, 111

rondeletii, Pagellus, 30

rondeleti $i$ Belone, ii, I5 1

rondeletii, Xiphias, 146

rone, Crenilabrus, 260, 261

rone, Labrus, 260

rosenhaueri, Alburnus, ii, 199

roseus, Pleuronectes, ii, 34

rostellata, Raia, ii, 340

rostellatus, Syngnathus, ii, 259

rostrata, Belone, ii, 147

rostrata, Raia. ii, 339, 341

rostratus, Lepadogaster, 189

rostratus, Leuciscus, ii, 181

rostratus, Pagellus, 40

rostratus, Squalius, ii, 181, 304

rough dab, ii, 10

rough flapper, ii, 342

rough-hound, ii, 310

rough ray, ii, 346

rough tailed stickleback, 238

row-hound, ii, 310

ruber, Dasybatis, ii, 343

ruber, Gadus, 276

ruber, Petromyzon, ii, 362

mous, Raia, ii, 343, 345

rubescens, Cepola, 213

rubescens, Hypsinotus, ii, 134

rud, ii, 183

rudaborre, 4

rudder-fish, 130

ruff, 11,12

ruff, tame, 12

rumolo, Bothus, ii, 15

rupestris, Ctenolabrus, 264

rupestris, Coryphænoides, 335

rupestris, Crenilabrus, 264

rupestris, Cyncedus, 261

rupestris, Labrus, 264

rupestris, Lutjanus, 264

rupestris, Perca, 264

rupestris, Scicena, 264

ruthensparri, Gobius, 160, 161

ruthenus, Acipenser, ii, 279

rutiloides, Lenciscus, ii, 175

rutilus, Cyprinus, ii, 175

rutilus, Gardonus, ii, 175

rthtilus, Leuciseus, 242 ; ii, 175 , 195

rutilus, $T$ inca, ii, 175

Rutty, iv

rysela, Chondrostoma, ii, 157

sagitta, Callionymus, 174

saidhean, 295

sail-fish, ii, 305

sail fuke, ii, 21, 22

saint Mary's trout, 318

saithe, 295
Salar, ii, 53

salar, Salmo, ii, 53, 54, 55, 63, 66

Salmo, ii, 52, 53

salmon, ii, 66,67

salmon breeding in ponds, scardafa, Scardinius, ii, 183

Ixxii

salmon breeding in sea, lxviii ;

ii, 63

salmon bull-trout, ii, 87

Salmones, ii, 53, 63, 66, 108

salmon-fry, ii, 68, 69

SaLMONIDA, ii, 52

salmon laws, ii, 72

salmon-peal, ii, 68

salmon-spotted bull-trout, ii, 87

salmon-spring, ii, 68

salmon-trout, ii, 85, 90

salmo, Salmo, ii, 66

salmulus, Salmo, ii, 54, 66

salt-water fleuk, ii, 32

Salvelini, ii, 53, 108

salvelinus, Salmo, ii, 108, 109, 112

salviani, Aurata, 34

salviani, Centrina, ii, 313

salviani, Rais, ii, 341

Samaragdus, 158

samlet, ii, 68; 69

sand dab, ii, 33

sand-eel-bill, 80

sand-eel, Lesser, 332

sand fleuk, ii, 29

sand smelt, 225

sand sole, ii, 42

sandsucker, ii, 10

sandy-ray, ii, $346,348,349$

saneels, 332

sanguineus, Holocentrus, 42

sanguisuga, l'etromyzon, ii, 362

sapphirine gurnard, 59

Saprolegnia ferax, cvi

saragus, Lepodus, 115

sarda, Palamys, 101, 102

sardina, Alosa, ii, 224

sarảina, Clupea, ii, 224

Sardinella, i1, 208

sardines, ii, 225, 229

sargon, Aurata, 33

sattie, ii, 32

sauguene, 33

Saurus, 124

saurus, Belone, ii; 151

saurus, Esox, ii, 151

saurus, Scombresox, ii, 151, 152

saury, ii, 152

saury-pike, $\mathrm{ii}, 152$

saxiccla, Glyptocephalus, ii, 30

saxicola, Platessa, ii, 30

sacicola, Pleuronectes, ii, 30

savala, Trichiurus, 153

savigni, Anguilia, ii, 242

Sawyer, F., iv

sayi, Myliobatis, ii, 350

sayi, Raia, ii, 350

sayi, Trygon, ti, 350

say-nay, i, 360

scabbard fush, 156

$\operatorname{sca} a, 124$

scald fish, ii, 22,23

scale-foot, 157 scale-rayed wrasse, 266

scales, $\mathrm{xx}$

scaffing, ii, 243

scapular arch, xvii

Scarcina, 156

Scardinius, ii, 175

Scaroidei, 251

scattan, ii, 210

schelly, ii, 127

schiffermuelleri, Salmo, ii, 88

Schistorus, 14

schoneveldii, Cataphractus, 67

schoneveldii, Clupea, ii, 231

Sciæna, 150, 151

ScImenide, $I t 9$

Sciceniops, 150

Scicenoidei,

sciandra, Sparus, 26

SCLEROdermi, ii, 267

Sclerogenida, 42

Scolecosoma, ii, 356

scolopax, Centriscus, 249

scolopam, Macrognathus, ii, 147

scolopax, Solenostomus, 250

scolping, 53

Scomber, 83

scomber, Scomber, 83

Scombresocides, ii, 146

Scombresox, ii, 146, 151

Scombrid 83

scombrus, Cordylus, 84

Scophthalmus, ii, 11

Scopelidre, ii, 47

SCORP ENID 24,42

scorpioides, Liparis, 185

scorpius, Cot: 1 : 49,51

scotica, Brosmius, 323

sgadan, ii, 210

scrape, ii, 305

scriba, Perca, 17

scriba, Solea, ii, 42

scribbled mackerel, 84

scriptus, Liparis, 185

scriptus, Scomber, 85

scriptus, Sparus, 32

scurf, ii, 90

scutellatum, Scomberesox, ii, 151

SCYLLIID F, $7 \mathrm{i}, 287,309$

Scyllium, ii, 309

Scylliorhinus, ii, 309

Scymnus, ii, 320

Scyphius, ii, 261

Scyris, 123

sea ape, ii, 301

sea bague, ii, 35

Sea-bream, black, 26

Sea-bream, common, 36

sea-bream, sharp-toothed, 37

sea-cat, 80,196

sea-crow, $6 \mathrm{l}$

sea-dace. 9

sea devil, 74 ; ii, 327

sea-eagle, ii, 353

sea fish, propagation ot, exii

sea fish in sea water, $27 \mathrm{I}$

sea-for, ii, 300

sea gudgeon, 164

sea-her, 65

sea horse, ii, 266

sea-lamprey, ii, 356 scorpius, Acanthocottus, 49 
sea loach, 318

sea-luce, 301

sea-needle, ii, 148

sea-nurse, ii, 310

sea owl, 181

sea partridge, 262

sea-pert, 119

sea poacher, 68

sea-pile, 301

sea scorpion, 50, 51

sea serpent, $\mathrm{ii}, 304$

sea snail, 184, 185

sea, swine, 255

sea tench, 26

sea-trout, ii, 84, 88

sea wife, 257

sea wolf, 9, 196

Sebastes, 42

secondary sexual characters, xei

secundi-dorsalis, Orcynus, 93

seine net, $\mathrm{c}$

seizling, $\mathrm{ii}, 159$

Selache, ii, 297, 303

SelachoIdeI, ii, 287

selanonus, Squalus, ii, 304

Selar, 123

Selaroides, 123

selection of parents, 1xix

selysii, Lenciscus, ii, 175

semiarmatus, Gasterosteus, 237, 238

semiloricatus, Gasterosteus, 238

semilunata, Diana, 121, 122

senticosus, Balistes, $\mathrm{ii}, 268$

septentrionalis, Mugil, 228, 232, 233

septentrionalis, Sebastes, 42

septocuille, I'etromyzon, ii, 362 serpentiformis, Tania, 213

Serranichthys, 14

Serranus, 14

serranus, Lntjanus, 12

serrato-granulata, Perca, 3

servellan urass, 255

sethe, 295

setigerus, Lophins, 72

Setipinna, ii, 205

seven-holes, ii, 360

sewen, ii, $85,86,88$

sexual characters, ii, 239, 329 , 334

sey, 293

sey-pollach, 295

shabrid, ii, 186

shade fish, 151

shagreen ray, ii, 342

shallow, ii, 184

shair, 203

shanny, 203

shark-ray, ii, 327

sharplin, 241

sharp nosed eel, ii, 242

sharp nosed ray, ii, 339, 340

shaw fish, 204

Shaw, G., ii

shavianus, Cetorhinus, ii, 303

shed, ii, 68

shedder, ii, 69

shell-backed, bull-head, 68

sheppy argentine, $\mathrm{ii}, 5 \mathrm{l}$

she-sole, ii, 22

shewen, ii, 54 shiners, 85

shining gurnard, 66

short diodon, ii, 272

short finned tunny, 94, 102

short-snouted sea-horse, ii, 266

short spined cottus, 50

short spined stickleback, 239

short sun-fish, ii, 273

shorter pipe-fish, ii, 261

shot, ii, 104

shotten-herrings, ii, 210

shude, ii, 197

shutts, ii, 132

Siaja, ii, 169

sibbaldi, Syngnathus, ii, 261

Sibbald, Sir R., i

sibi, T'hynnus, 97

siculus, Ammodytes, 334

Sidera, ii, 254

Sieboldii, Carpio, ii, 161

sile, ii, 210

silk-shag, ii, 210

Sillago, 78

siller-fish, 37, 287

siller fluke, ii, 16

sillock, 294, 295

sills, ii, 210

Silus, ii, 136

silus, A rgentina, ii, 136

silver charr, ii, 108

silver-eyes, 35

sitver lamprey, ii, 359

silver-sides, 225

silver-white, ii, 85, 90

silvery gade, 317

silvery hair-tail, 154

Sim, G., iii, iv

simen, ii, 69

sinuatus, Merluccius, 300

sinensis, Anguilla, ii, 242

sinistral, flat-fish, ii, l

sinuosa, Perca, 8

Siphonostoma, ii, 257

six-gilled shark, ii, 308

size of eggr, lx

strate, ii, 336,337

skate-toothed dog, ii, 296

skeet, 297

skegger, ii, 68

sivelacto; 289

skelchie, 289

skeleton, xiv

sleelly, ii, 179

sluerlung, ii, 68

skider, ii, 337

skin, viii, $\mathrm{xx}$

skinners, 278

skip-jack, ii, 152

skipper, ii, 151

skittle-dog, ii, 316

skopster, ii, 152

skcrae-fish, 295

skull, xvi

stoull-eel, ii, 243

skurring, ii, 122

slat, ii, 69

sleep, xix

slender goby, 169

stippery jemmy, 318 .

slips, ii, 40

sloanii, Auwis, 97

small intestines, liii

small mouthed wrasse, 268 small-spotted dog-fish, ii, 310

small suck-fish, 189

smear dab, ii, 18, 28, 29

smell, $\mathrm{xxxyi}$

smelt, ii, 68; 69, 90, 121, 122

smeltie, 287

smolt, ii, 68, 78

smooth blenny, 203

smooth dab, ii, 29

smooth-hound, ii, 295

smooth serranus, 15

smooth shark, ii, 295

smooth sides, 61

smooth sole, ii, 22,23

smooth-tailed stickleback, 239

smoulds, 330

snake bait, 330

snake pipe-fish, ii, 261

snedden, 330

snig eel, ii, 242

snipe nosed trumpet fish, 249

snipe fish, 250

snip-nosed mullet, 130

sobaco, Balistes, ii, 268

soft roe, Ivii

soil, 295

solaris, Orthragoriscus, $\mathrm{ii}, 273$

soldier, ii, 210

sole, $\mathrm{ii}, 39,40$

Solea, ii, 5,37

solea, Pleuronectes, ii, 39

sole-fleuk, ii, 29

Solenostomidz, ii, 256

Solenostomus, ii, 256

soles, sort of $\mathrm{x}$ cix

solonette, ii, 44, 45

Somniosus, ii, 320

sordid dragonet, 174, 176

spanish bream, 37

spanish mackerel, 91, 92; ii, 14 .

spanker-eel, ii, 360

SPARIDE, 25

sparling, ii, 68, 129

Sparus, 30

sparus, Boops, 28

spatula, Cyclopterus, 189

spearling, ii, 148

species, lxxix

speciosa, Coris, 270

speciosa, Julis, 269

speckled goby. 167

speckled-cod, 278

specularis, Cyprinus, ii, 159

speldrings, 284

sphyrana, Argentina, ii, 49. $136,137,138,206$

Sphyrna, ii. 294

Spinachia, 236

spinachia, Gasterosteus, 236, $237,246,247$

spinachia, Gastroea, 247

spinachia, Polyacanthus, $247^{\circ}$

SPINACIDAE, ii, 287, 315

spined loach, ii, 201, 202

spinolæ, I'rachypterus, 218

spinosus, Acanthosoma, ii, 27:?

spinosus, Centrophorus, ii, 323

spinosus, Cyclopterus, 179

spinosus, techinorhinus, ii, 323

spinosus, Goniodus, ii, 323

spinosa, liaia, ii, 348

spinosus, Scymnus, ii, 323

spinosus, Squalus, ii, 323 
spinosus, Zeus, 138

spinous shark, ii, 323, 324

spimulosus, Gasterosteus, 237, 239

spinulosus, Leirurus, 239, 240

spinulosus, Trachinus, 124

spirinches, ii, 122

spirinchus, Salmo, ii, 121

spirinchus, Osmerus, ii, 121

spitalfield wearers, 81

spleen, lvi

spotted blenny, 208

spotted dog-fish, ii, 309, 310,

312

spotted goby, 166

spotted ling, 306

spotted ray, ii, 345, 346

sprag, ii, 68

sprat, ii, 231, 232

Spratella, ii, 208

sprattus, Clupea, ii, 208, 219 , 224,231

sprattus, Harengula, ii, 231

spricklebag, 24l

sprods, ii, 69, 90

sprole, ii, 159

sprot, ii, 122

spur-dog, ii, 316

Squalius, ii, 175

squalius, Leuciscus, ii, 179

squalipeta, Echeneis, 108

Squatina, ii, 326

squatina, Rhina, ii, 326

squatima, Squalus, ii, 326

stake, 306

stand, 211

stane ahecker, 209

stangster, 82

stansticlcle, 241

starry-ray, ii, 347,348

sterleta, ii, 279

stellare, Ncyllium, ii, 312

stellaris, Squalus, ii, 312

stellated globe-fish, ii, 271

stellatus, Liparis, 185.

stellatus, Mustelus, ji, 295

stellatus, Tetrodon, ii, 271

Stellifer, 150

stenloch, 295

Stenogobius, 158

Sternoptychider, ii, 46

sticlileback, 241

stickling, 4, 241

stiff sea-adder, ii, 263

Stigmatogobius, 158

Stilbe, ii, 193

sting-bull, 80

sting-fish, 50, 82

sting-ray, ii, 350, 35

stink-alive, 287

stinkard, ii, 296

stocking waters, cx

Stolephorus, ii, 205

stomach, lii

stomachicus, Salmo, ii, 55, 99

stone-bass, 17

stone-fish, 204

stone-loach, ii, 204

stone-sucker, ii, 35 \%

stony-cobbler, 82

stop senie, $c$

storeri, Aledon, ii, 273

storei, Scomberesox, ij, 151 stow net, $x \operatorname{cix}$

streaked gurnard, 56, 57

straight-nosed pipe-fish, ii, 263

striatus, Cyprinus, ii, 159

striatus, Liparis, 187

strigosus, Anarrhichas, 195, 196

striped-bellied-tunny, 101

striped wrasse, $256,257^{\circ}$

stripping fish, cix

stroemii, Gunnellus, 206

stroemii, Macrourus, 335

STROMATEIDAe, 110

stromii, Carelophus, 206

Strophidon, ii, 254

struanensis, Salmo, ii, 108 ,

113,116

sturgeon, $\mathrm{ii}, 280,282$

Sturio, ii, 279

sturio, Acipenser, ii, 280

sturiones, Agonus, 67

stuttleback, 241

stuvitzii, Atherina, 169

stuvitzii, Gobiosoma, 169

stuvitzii, Latrunculus, 169

subfuscus, Liparis, 185

subredaurades, 33

sucking-fish, ii, 357

sucklii, Acanthias, ii, 316

suckstone, 109

suftamen, Balistes, ii, 268

suillus, Labrus, 264

summer-cock, $\mathrm{ji}, 68$

sun-fish, 119, 135'; ii, 273, 305

surface fish, Ixxxi

surmuletus, Mullus, 22

surnullet, 22,23

surmullet, red, 23

susiformis, Lepidopus, 156

suss, ii, 310

suyeen, 295

Swainson, ii

swaledale trout, $\mathrm{ii}, 100$

sweet lips, 255

sweet william, ii, 293

swill, $\mathrm{ii}, 210$

swine fish, 196

sword-fishes, 143, 146, 147, 209 ;

ii, 148

swordick, 209

symmetricus, Caranx, 124

symmetricus, Trachurus, 124

Synagris, 19

Synchiropus, 174

Synechogobius, 158

Sygnathidæ, ii, 256

Synguathus, 313 ; ii, 259

Systomus, ii, 169

tacared, Gadus, 286

tænia, Acanthopsis, ii, 201

tænia, Botia, ii, 201

tonia, Cepola, 213

tænia, Cobitis, 5 ; ii, 201

tænia, Trachypterus, 218

Tanioidei, 216

Taniophis, ii, 254

taily, ii, 346

tail-spotted goby, 165

tamlin-cod, 278

tancoides, Labrus, 253

tangle-fish ii, 260

tanticle, 241

Taraxes, 114 taris, 241

taso, Auxis, 104

taste, $\mathrm{xxxv}$

tauricus, Alburnus, ii, 179

Tauridea, 45

taurina, Trutta, ii, 91

Tautogolabrus, 264

taylor, ii, 197

tazo, Scomber, 104

teeth, 1

tegumentary gystem, $\mathrm{xx}$

Telara, ii, 205

Teleostei, 1

telescopus, Cyprinus, ii, 166

Telestes, ii, 175

temperature of fish, xlix

Templeton, iv

tench, ii, 188

ten-spined stickleback, 244, 246

Terpolepis, ii, 240

tetradens, Lepidopus, 156

Tetrodon, ii, 270

Thorodontis, ii, 254

Theraponida, 1

thickbxck, ii, 44

thin-lipped mullet, 231, 233

thickly spotted bull-trout, ii, 87

thirst, $\mathbf{x x}$

Thompson, iv

thompsoni, Acipenser, ii, 280

thompson's midge, 317

thoracatus, Cyprinus, ii, 166

thormback, 241 ; ii, 343,344

thorny, ii, 34t

thrasher, ii, 300, 301

three bearded cod, 318

three bearded gade, 318

three bearded rock cod; 317

three bearded rockling, 317

three spined stickleback, 238

three spotted wrass, 257

Thryssa, ii, 205

thunning, Thyonus, 101

thunor-bodu, 33

thyberinus, Squalius, ii, 179

Thymallus, ii, 52, 58, 126, 131 . 135

thymallus, Coregonus, ii, 131

thymallus, Salmo, ii, 131

Thynnichthys, 100

thynnoides, Auxis, 104

thynnus, Salmo, ii, 131

Thynnus, 100

thynnus, Orcynus, 93, 94, 144

thynnus, Thynnus, 93

Thysoidea, ii, 254

tiberinus, ieuciscus, ii, 179

tibrie, 295

Tinca, ii, 188

tinca, Crenilabrus, 260

tinca, Cyncedus, 260

tinca, Cyprinus, ii, 188

tinca, Labrus, 253, 260

tinca, Leuciscus, ii, 188

tinca, Phycis, 303

tinker, 245,246 ; ii, 337

tittlebat, 241

toad-fish, 74 ; ii, 353

tobianus, Ammodytes, 330,331 , 332,334

tom-cull, 48

tommy-bars, 12

tommy toach, ii, 204 
tommy-logge, 48

tormmy-lurker, ii, 20t

tonimy noddy, 321

tompot, 199

tongue soles, ii, 40

toothed gilt-head, 114

tope, ii, 292

toper, ii, 292

topknot, ii, 18

tor, Barbus, ii, 169

torgoch, ii, 108, 112, 113, 116

TORPEDINIDE, ii, 329, 330

Torpedo, ii, 330, 331

torpedo, Raia, ii, 333

torsk, 323

torsk, Blennius, 323

torsk-fish, 323

torsk, Gadus, 323

touch, $\mathrm{xxii}$

tow-blowen, ii, 210

town dab, ii, 29

Trachinid an, 1,78

Trachinus, 78, 123

Trachurops, 123

Trachurus, 123

trachurus, Carenx, 124

trachwrus, Gasterosteus, 237, 238

trachurus, Scomber, 124

trachurus, Trachurus, 124

Trachypterus, 216, 217

TRACIYPTERID止, 216

Trachyrhampus, ii, 259

trammel, cii

tranling, 4

trasling, 4

trawling, ii, 37

Trematopsis, ii, 272

trepidans, Torpedo, ii, 333

TrichidaId $/ 5,153$

Trichinurus, 153, 216

trichodactylus, Pleuronectes, ii, 45

tricirrata, Motella, 313, 314, 317

tricirratus, Gadrus, 317

tricolor, Holacanthus, 41

tricuspis, Cottus, 46

tridactylus, Blennius, 320

tridigitatus, Polynemus, 58

trifurcatus, Blennius, 320

trifurcatus, Raniceps, 320

trifurous, Gadus, 320

trigger-fish, ii, 269

Trigla, 55

triglia, 22

toimaculated urasse, 257, 258

Trochus, 31

tropica, Remora, 108

Tropidichthys, ii, 270

trout to Tasmania, ii, 56

trumpet-fish, 249, 250

truncata, Ranzania, ii, 276

truncatns, Orthagoriscus, 276

truncatus, Tetrodon, ii, 276

Trutta, ii, 53

trutta, Salmo, ii, 54, 55, 58, 63 ,

$81,82,83,84,85,96$

trutta, Trutta, ii, 85

truttula, Salmo, ii, 85

Trygon, ii, 350

TRYGONID $x$, ii, 329, 350 tub-fish, 60

tuberculatus, Pleuronectes, ii, 11,12

tumbling, 278

tunnyfish, 63,94

turbot, ii, 6, 12

turbot, Pleuronectes, ii, 11

turbrat, ii, 12

turdus, Labrus, 260

Turton, ii

tusk, 324

twait-shad, ii, 237

two-spot brame, 265

two-spotted goby, 161

two-spotted wrasse, 258

Tytosurus, ii, 146

Tympanomium, ii, 272

typhle, Solenostoma, ii, 256, 257

typhle, Syngnathr, ii, 257, 259

typhloides, Syngnathus, ii, 257

umbla, Salmo, ii, 54, 108, 109 , $112,113,114$

umbra,. Sciæna, 150

umbratus, Chatodon, 115

Umbrina, 149

unctuous sucker, 185

unicornis, Blennius, 198

unimaculatus, Phrynorhombus, ii, 17

unimaculatus, Pleuronectes, ii, 17

unimaculatus, Rhombus, ii, 17

unimaculatus, Scophthalmus, ii, 17

unimaculatus, Zeugopterus, ii, 17

uniocellatus, Rhombus, ii, 17

unipunctatus, Gobius, 161, 165,

166,167

United States Fishery Depart-

ment, cxii

epsicephalus, Lophius, 73

Uranidea, 45

Uraptera, ii, 334

Uraspis, 123

urinary organs, $1 \nabla$

ursini, Ozodura, ii, 273

\section{vaagmaer, 218}

vacca, Squalus, ii, 308

vadigo, Lichia, 132

vagans, Thynnus, 100

valenciennessi, Astrodermus, 121

Vandellius, 156

vanloo, Perca, 150

vandesius, Coregonus, ii, 125,

$$
128
$$

variabilis, Acanthocottus, 49

variabitis, Cottrus, 49

variabilis, Labrus, 253

variabilis, salmo, ii, 102

variabilis, Trutta, ii, 85

variegata, Solea, ii, 39, 43,

$$
44
$$

variegated sole, $\mathrm{ii}, 43$

variegatus, Grammistes, 257

variegatus, Labrus, 256

variegatus, Monochirus, ii, 43

variegatus, Pleuronectes, ii, 43 varieties, lxxix

Varicorhinus, ii, 169

varius, Orthagoriseus, ii, 276

varus, Blennius, 199

vassalli, Ophidium, 326

veau, 315

velivolans, Zeugopterus, ii, 21

venatus, Gobio, ii, 172

vendace, ii, 128

venernensis, Salmo, ii, 84, 85

ventralis, Cottus, 46

ventralis, Phobetor, 46

vernalis. Merlangus, 292

vernatis, Scomber, 84

verus, Conger, ii, 250

vertebre, $\mathrm{xi}$

vetula, A bramis, ii, 193

vetula, Labrus, 257, 258

vetula, Sparus, 26

veaillifer, Thymallus, ii, 131

vipera, Trachinus, 81

viper weaver, 81

virens, Gadus, 275, 293, 299 ; ii 78

virens, Pollachines, 294

virescens, Holocentrus, 14

virens, Merlangus, 294

viridescens, Osmerus, ii, 121

viridis, Gadus, 297

vision, $\mathrm{xxviii}$

vivaria in Yorkshire, ii, 123

vivaria salt water, cxi

vivarium, 279

vittatus, Labris, 257

vividus, Trachinus, 81

viviparsus blenny, 211

viviparus, Blennius, 21

viviparus, Enchelyopus, 211

viviparus, Gunnellus, 21

viviparus, Sebastes, 42,43

viviparus, Zoarcoeus, 2 II

viviparus, Zoarces, 196, 211,

309 ; ii, 247

vognarus, Trachypterus, 217

voice, $\mathrm{xxxix}$

volitans, Exocæetus, ii, 154, 156

vomerinus, Lophius, 73, 74

vomer, Raja, ii, 341

vulgaris, Acanthias, ii, 315, 318

vulgaris, Acerina, 11

vulgaris, Acus, ii, 147

vulgaris, Alausa, i1, 235, $237^{\circ}$

vulgaris, Anguilla, ii, 240, 241

vulgaris, Auxis, 104

vulgaris, Barbus, ii, 169

vulgaris, Belone,.92; ii, 147 , 148

vulgaris, Blennius, 198

vulgaris, Box, 28, 29

qulgaris, Brosmius, 323

vulgaris, Cantharus, 26

vulgaris Carassius, ii, 159, I61, $164,165,166$

vulgaris, Clupea, ii, 235

vulgaris, Conger, 75 ; ii, 250

vulgaris, Dentex; 19

vulgaris, Engraulis, ii, 206

vulgaris, Eperlanus, ii, 121

vulgaris, F'lesus, ii, 34

vulgaris, Galeus, ii, 292

vulgaris, Gobio, ii, 172

vulgaris, Gunnellus, 208 
vulgaris, Hippoglossus, ii, 6 vulgaris, Julis, 269

vulgaris, Leuciscus, ii, 175, 180, 181

vulgaris, Limanda, ii, 32

vulgaris, Liparis, 184, 187

vulgaris, Lota, 308, 311

vulgaris, Mæna, 29

vulgaris, Merlangus, 290

vulgaris, Merluccius, 300

vulgaris, Meletta, ii, 231

vulgaris, Molva, 305

vulgaris, Morhua, 275, 276

vulgaris, Motella, 317

vulgaris, Mustelus, ii, 295

valgaris, Pagrus, $30,31,36,40$

vulgaris, Perca, 2

vulgaris, Platessa, ii, 26

vulgaris, Platyglossus, ii, 5

vulgaris, Rhamphistoma, ii, 147

vulgaris, Rhombus, ii, 15

vulgaris, Scomber, 84

vulgaris, Siolea, ii, 39

vulgaris, Spinachia, 247

vulgaris, Squatina, ii, 326

vulgaris, Thymallus, ii, 131

vrtgaris, Thynmus, 93

vulgaris, Tinca, ii, 188

erilgaris, Torpedo, ii, 333

vulyaris, Trachurus, 124

vulgaris, Trygon, ii, 350

vulpeeula, Centrina, ii. 31 ?

vulpes, Alopecias, 144 ; ii, 300

vulpes, Alopias, ii, 300

vulpes, Carcharias, ii, 300

vulpes, Squalus, ii, 300

walkeri, Salanonius, ii, 298

Wallace, ii

walshii, Torpedo, ii, 331

warp, ii, 210

water unwholesome, civ

wauffs, 196 weasel-fish, 309,318

webbianus. Lepadugaster, 189

weed-eel, ii, 243

weever, 80

weirs, cii

whaup-fish, ii, 148

whiff, ii, 19, 21, 2.

whiffers, ii, 243

whip-ray, ii, 352

whistle-fish, 314, 318

whistler, 318

White, A., iii

whitebait, ii, 209, 218

white breann, ii, 197

white-ling, 306

white-mullet, 9

white-salmon, 9 ; ii, 85

white-skate, ii, 340

white-sole. ii, 22, 31

white-trout, ii, 90

whiting, 290, 291 ; ii, 85

whiting, Couch's, 293

whiting mop, 294, 29

whiting, pollack, 297

whiting pout, 287

whitling, ii, 90

whithound, ii, 292

wide-gab, 74

widegrenii, Coregonus, ii, 125, 126

willie-wan-beard, 247

willoughby's charr, $\mathrm{ii}, 113$

Willughby, i

willughbii, Balistes, ii, 268

willughbii, Coregonus, ii, 128

willughbii, Trematopsis, ii, 273

willughbii, Salmo, ii, 108, 110 ,

113

wine drinkers, $\mathrm{ii}, 210$

wolf, 9

wolf-fish, 195

wolfian bodies, $\mathrm{lv}$

woodcock-fish, 250 workhouse turbot, ii, 7

worm pipe-fish, ii, 263

twrasse, Gibbous, 261

wreck-fish, 18

wren, ii, 216

wriggle, 332

Xenodon, ii, 267

Xiphias, 145,146

XIPHIID E, 143

Xiphirformes, 143

xystophorus, 127

Yarrell, ii

yarrellii, Acantholabrus, 257 yarrellii, A cipenser, ii, 280

yarrellii, Argentina, ii, 136, 138

yarrellii, Chirolophis, 206

yarrell's blenny, 206

yawling, ii, 210

yellow-bream, ii, 194

yellow dab, ii, 10

yellow-fins, ii, 90

yellow goby, 165

yel, ii, 243

Zebrinus, Lepadogaster, 189 , 190

zee-bars, 9

zeekarpel, 9

Zeugopterus, ii, 5, 17

Zeus, 138

zilli, 307

zipotheca, 156

Zoarces, 194, 211

zones of depth, lxxx

Zonogobius, 158

Zygæua, ii, 289, 294

zygcena, Cestracion, ii, 294

zygana, Sphyrna, ii, 294

zygcena, Squalus, ii, 294

\section{ADDENDA AND CORRIGENDA.}

Vol. i, page xlv, first line, for " accoustic " read " acoustic."

Vol. i, page lxxv, 17 lines from bottom, jur " it lord "read "lord it." .

Vol. i, page 11, 23 lines from top, erase line " 3 Rhombus megastoma," etc.

Vol. i, page 210, add Lumpenus Lampetriformis obtained by Dr. McIntosh off the east coust of Scotland in May, 1884. See description and figure Proc. Zool. Soc., 1884, page 445, plate xli.

Vol i, page 293, 23 lines from bottom, for "no barbel," read "a barbel."

Plates lxxxviii and lxxxix lave the numbers transposed.

Vol, ii, page 22, dinoglossus Grohmanni $=$ A. lophotes, Günther, was procured off Lundy Island in 1882. See description and figure, Proc. Zool. Soc., 1882, page 718, plate liii.

Vol. ii, page 84, 11 lines from bottom, for plate cxi, "fig. 1," read " fig. 2."

Vol. ii, page 96,25 lines from bottom, for plate "cxvi, fig. 1," read " cxiv, fig. 2.")

Vol. ii, page 98, 11 lines from bottom, for plate "cxi" read " exvi."

Vol. ii, page 278, 4 lines from bottom, fur "spinal" read "spiral."

Vol. ii, page 307 , last line, " $5 \frac{1}{2}$ feet" read " $10_{3}^{1}$ feet."

Vol. ii, page 364, 14 lines from top, for "fig. 3 " read " fig. 4." 


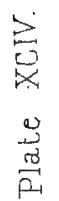

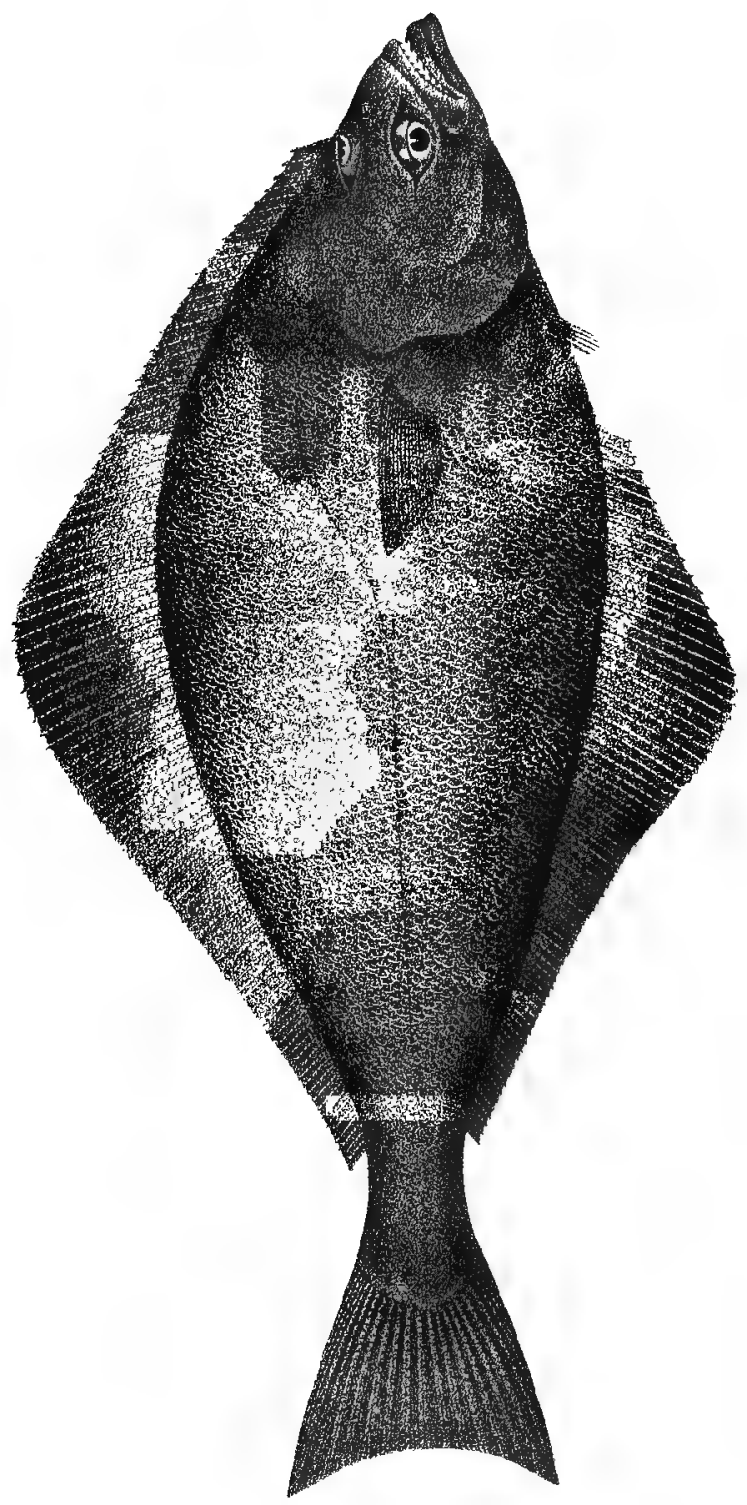



3
0
5
0
0
0

冒

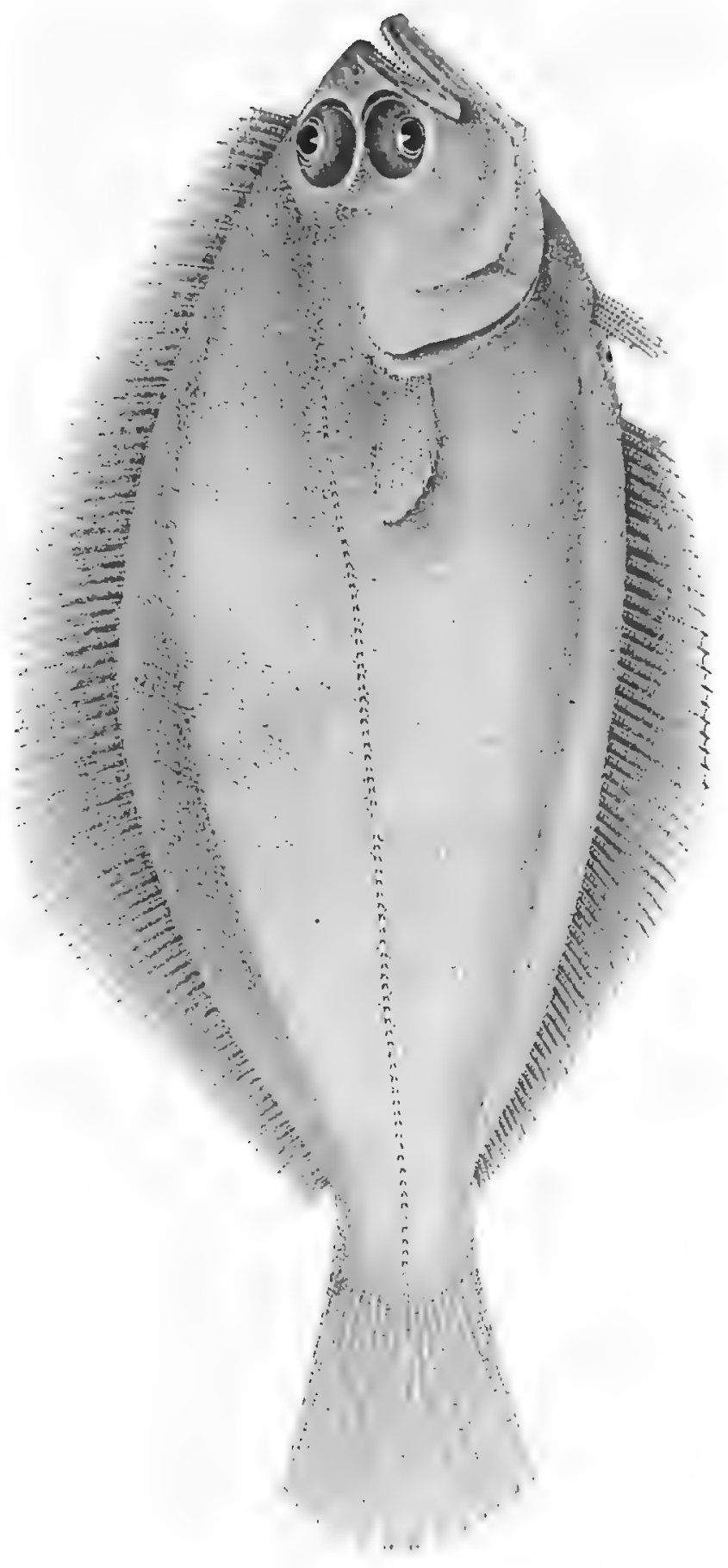

鹳

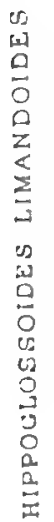

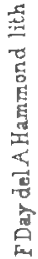





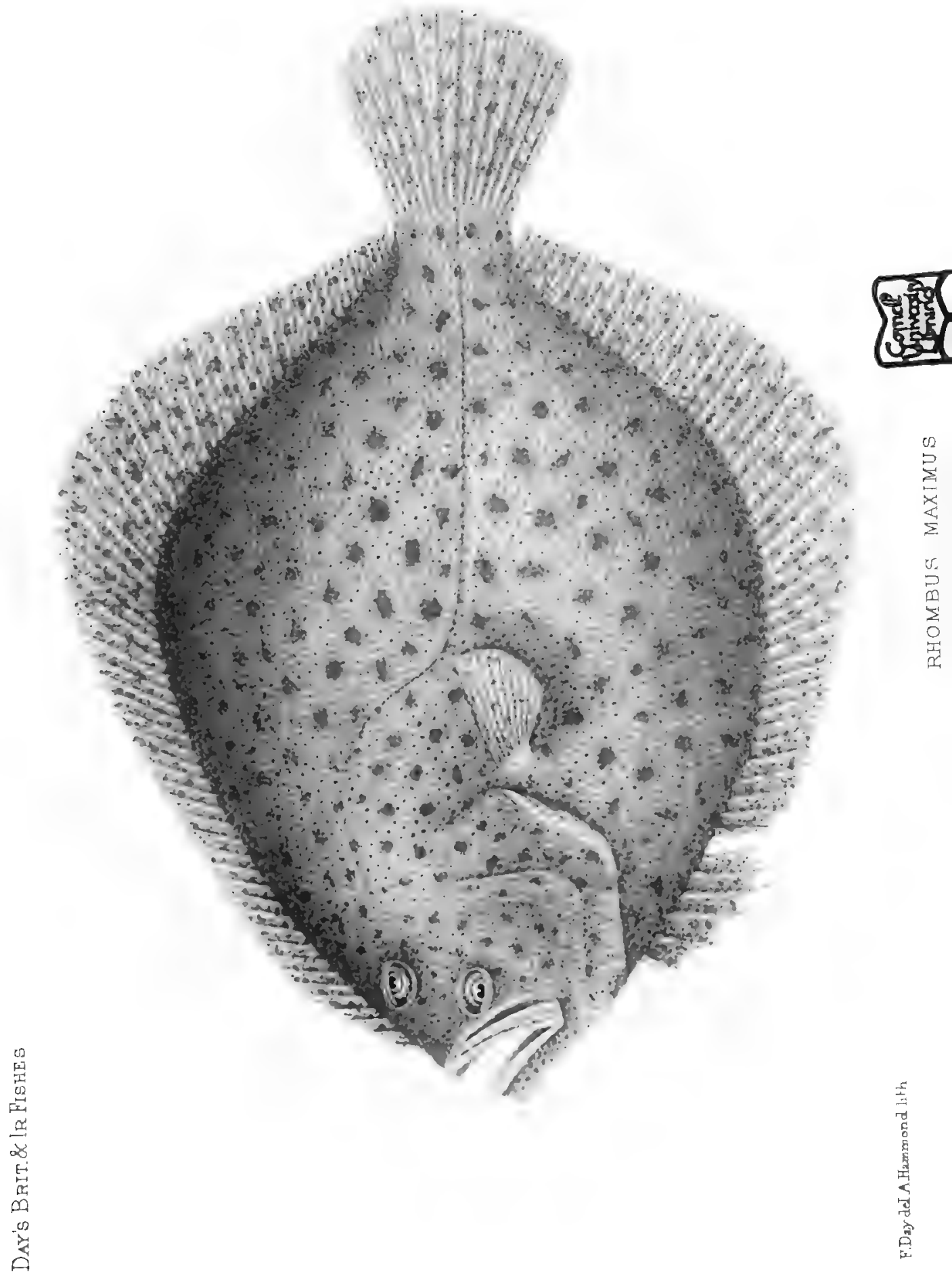



岂

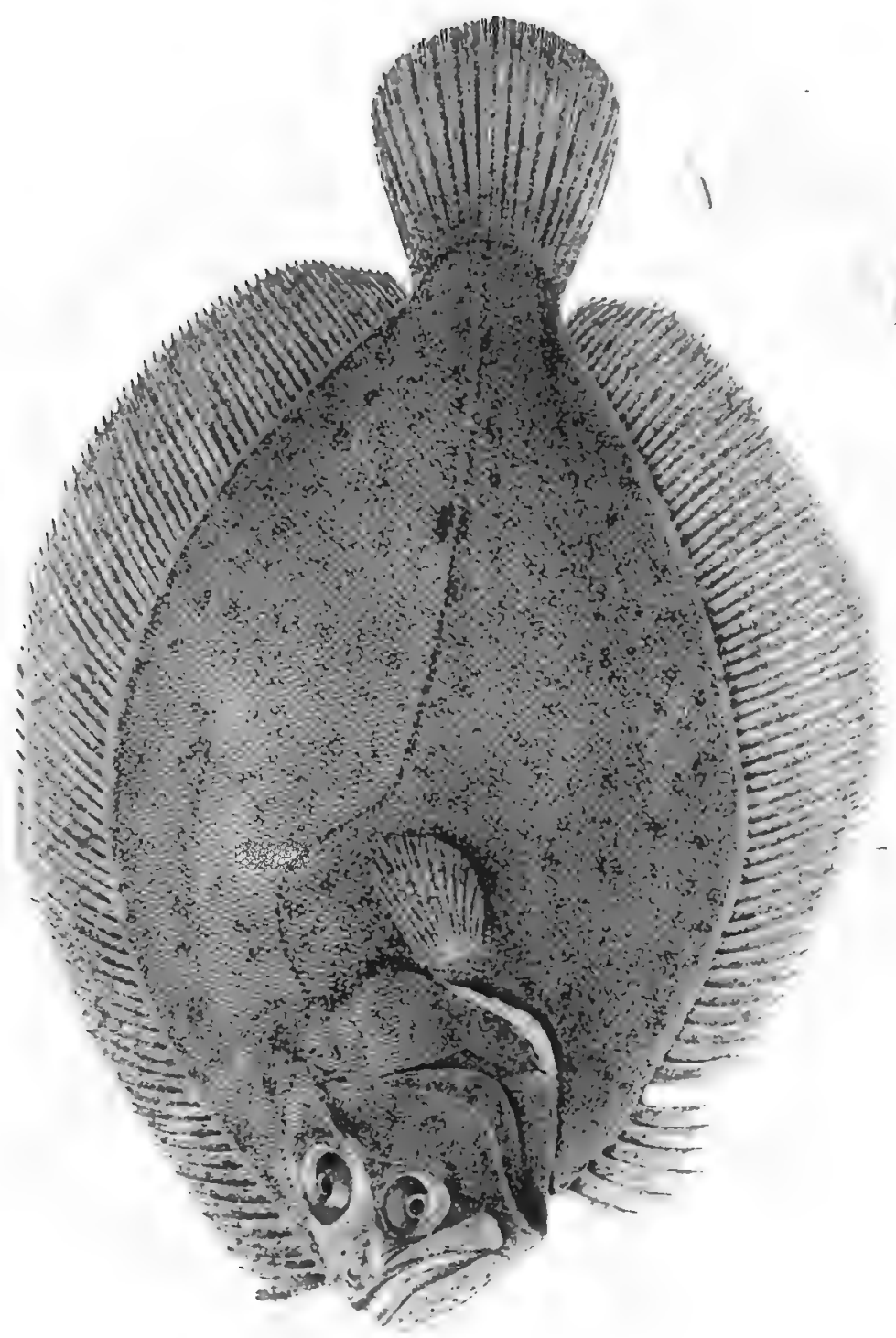

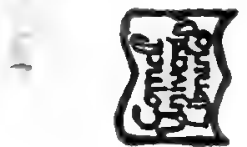

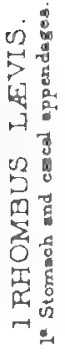

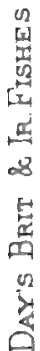



是

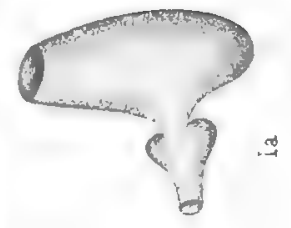

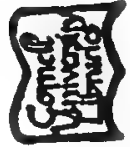

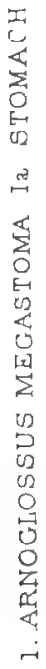

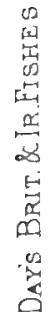



总

竞

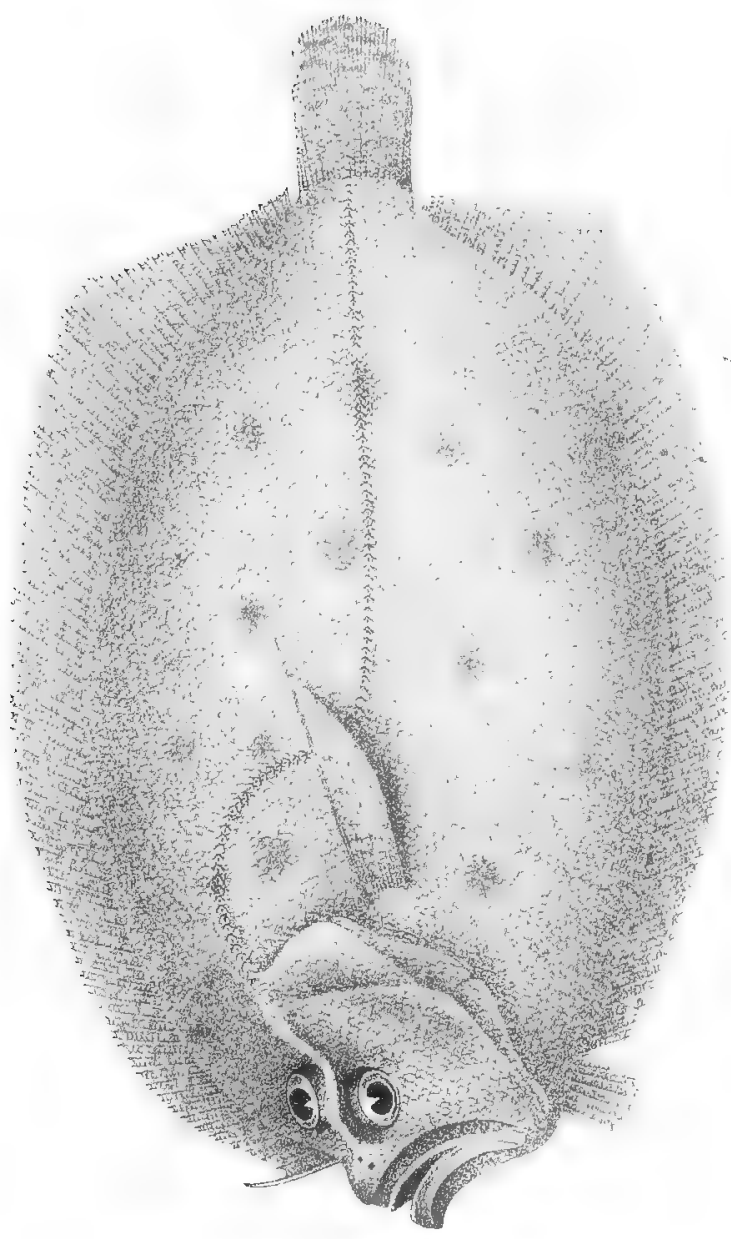

\section{融}

4

2

照

逢

i

2

?

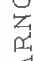



$\frac{1}{3}$

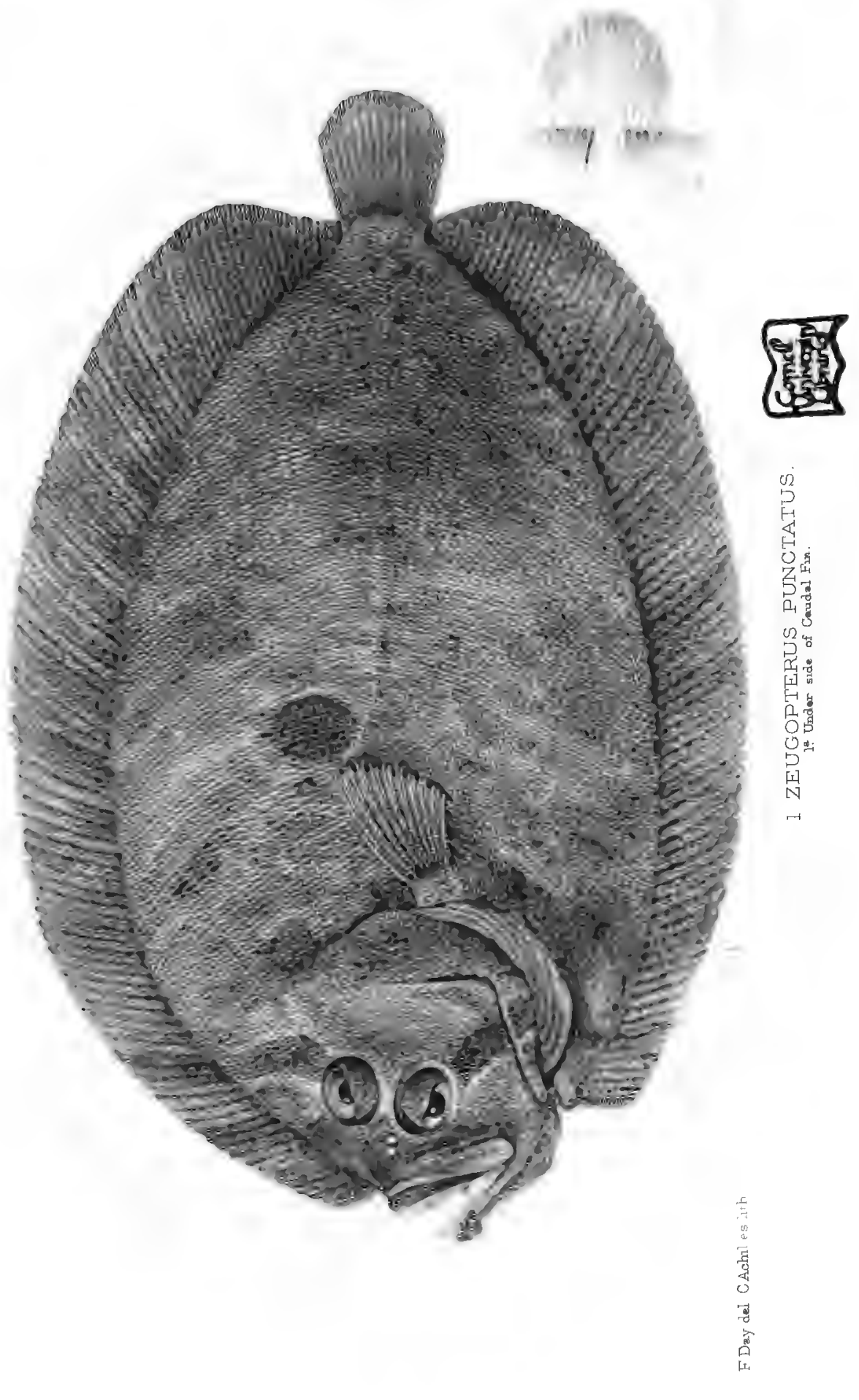





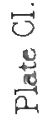

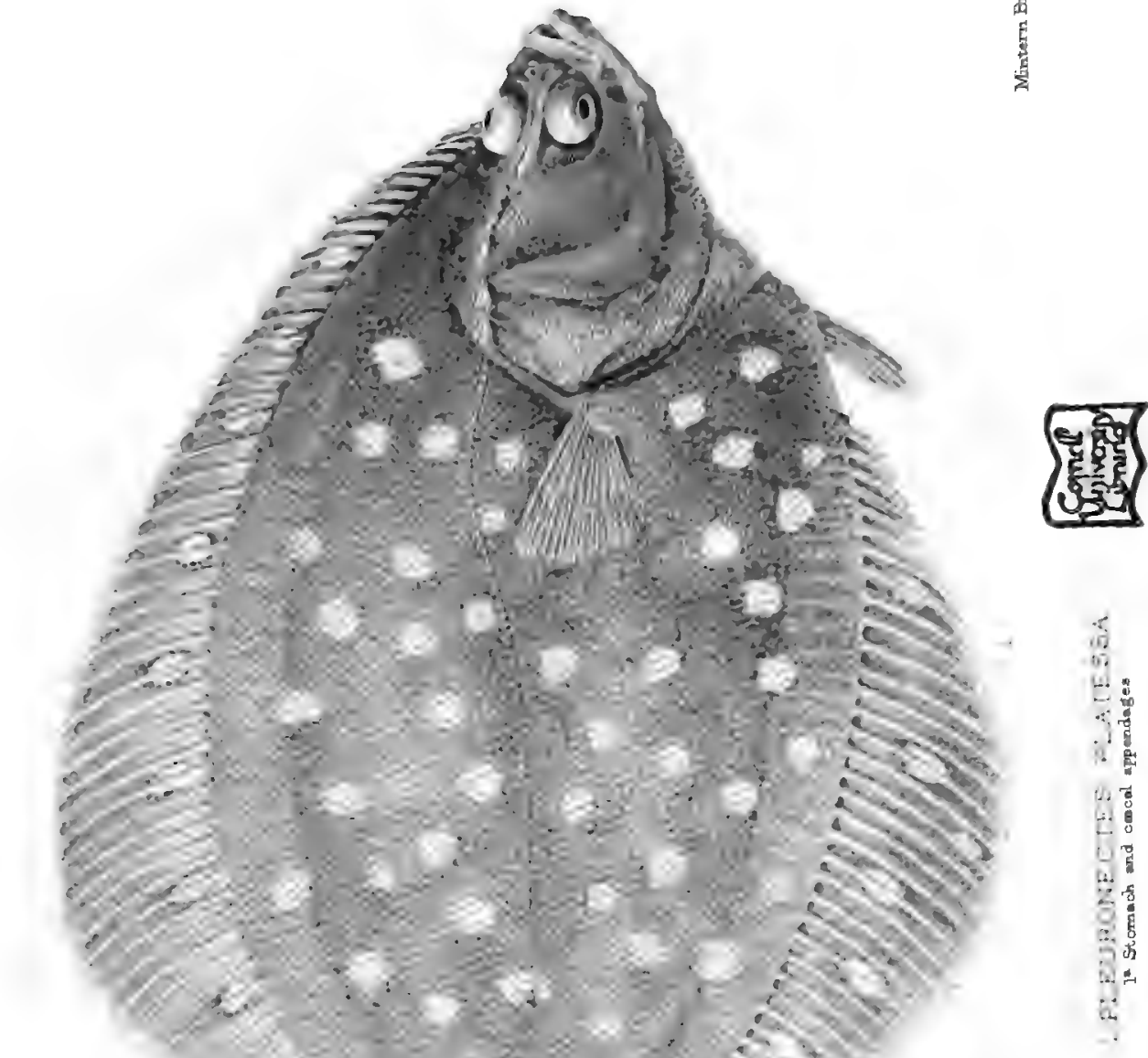

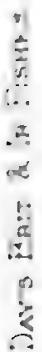

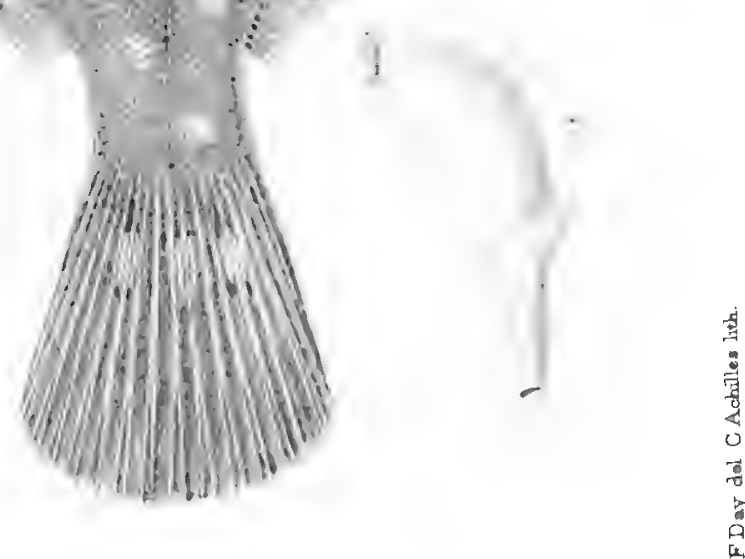



0
0
0
0
0

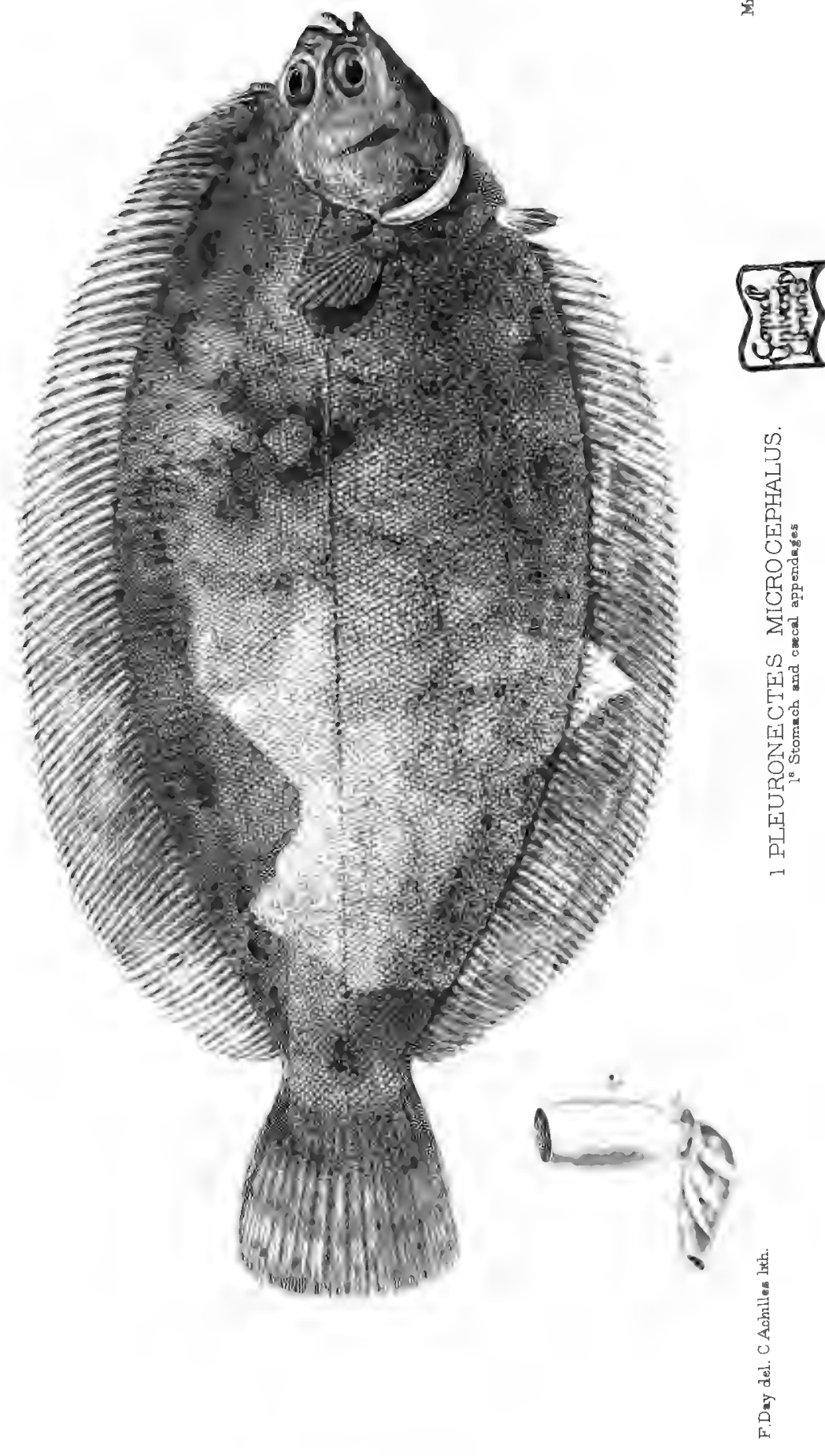



星
0
0
0

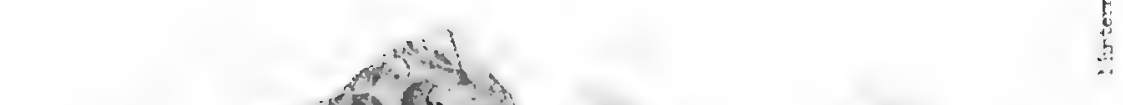

皇

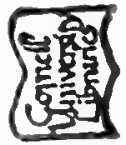

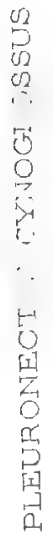

盗

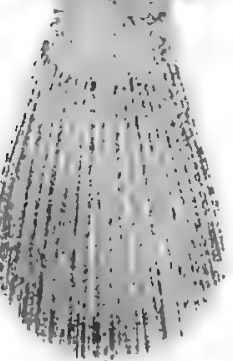



2

萿

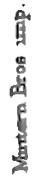

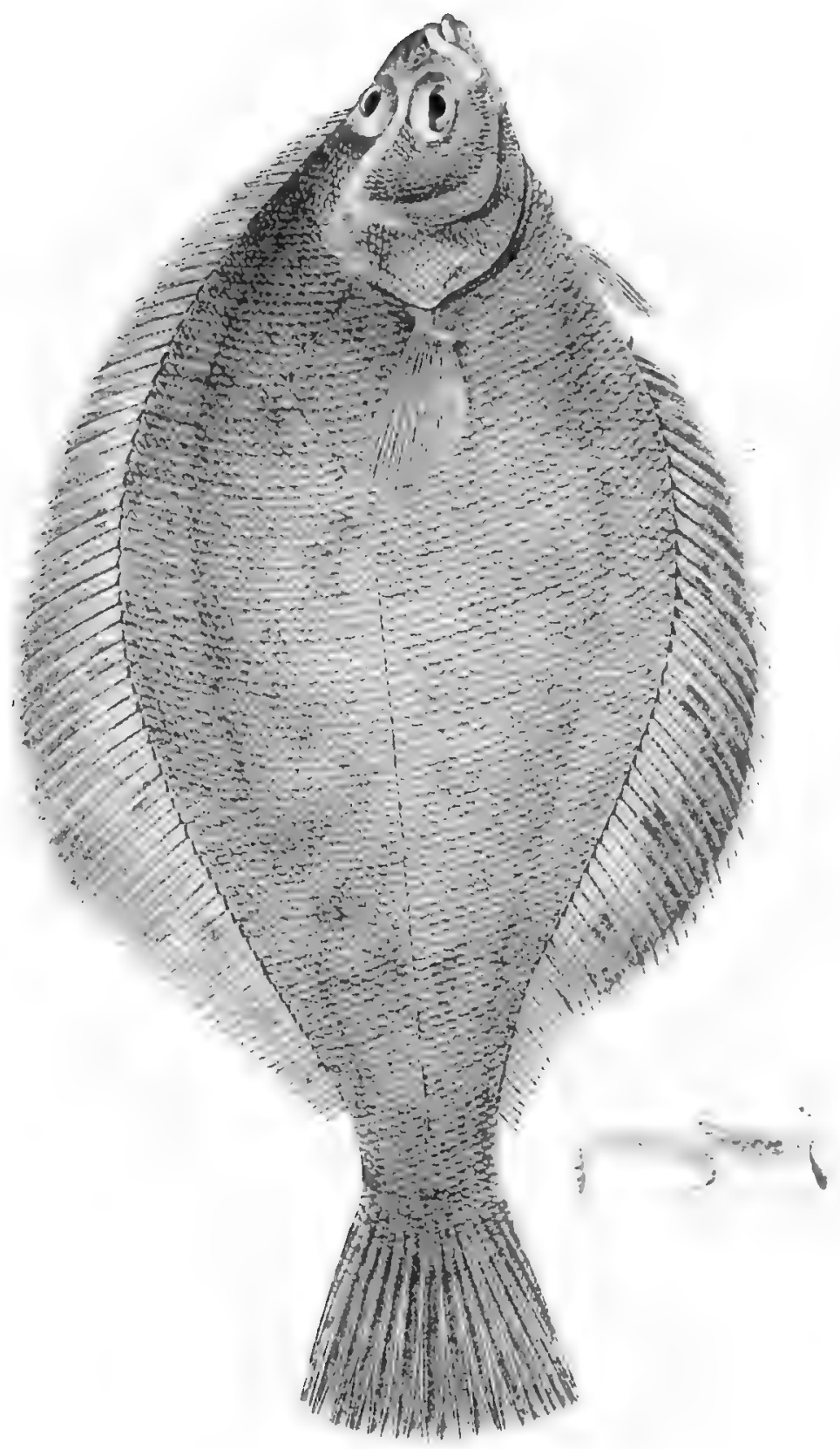

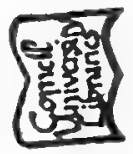

发

니굴

0

国

至里

过

简

2

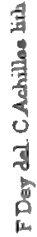



它

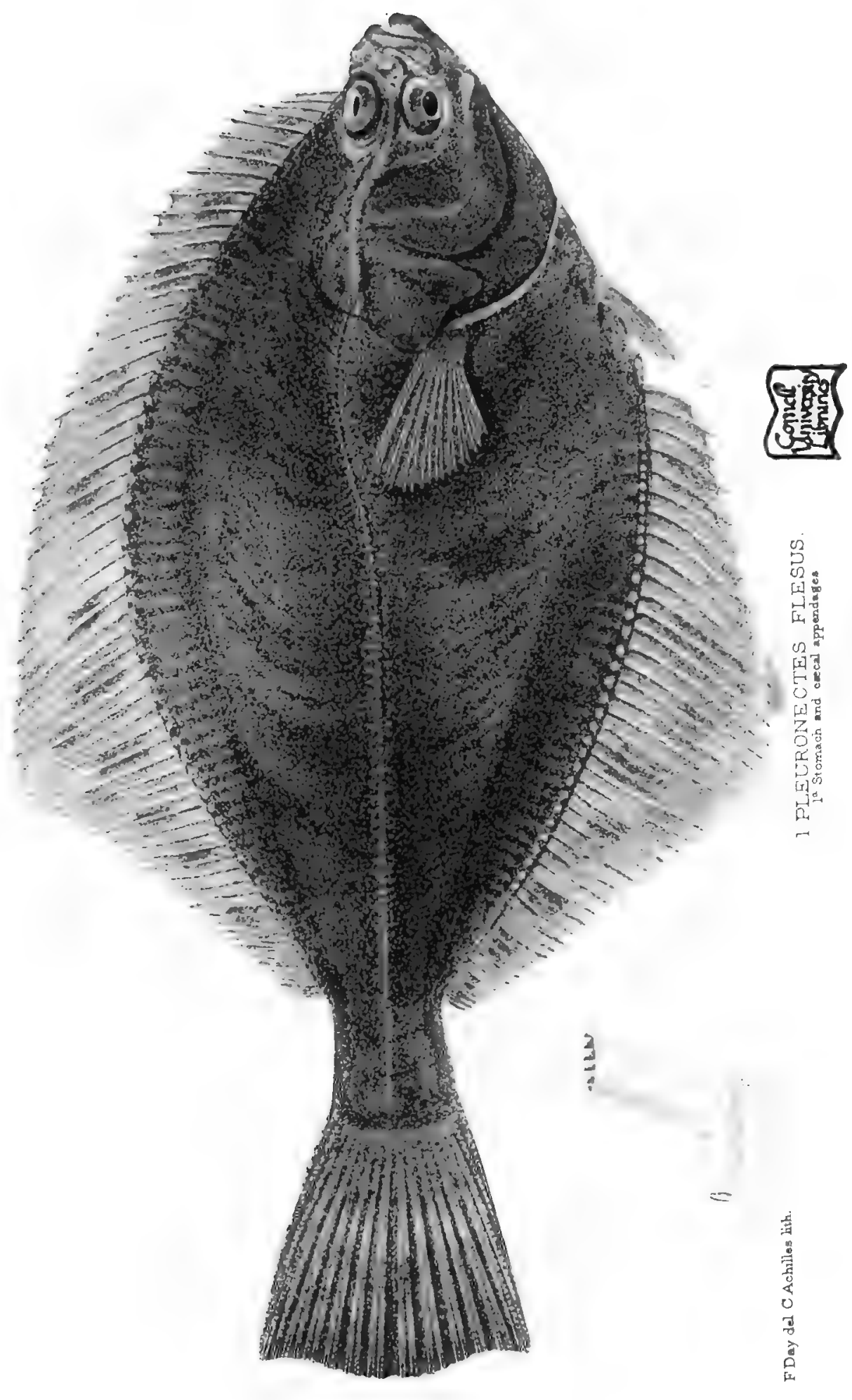



5
0
0
0
0
0

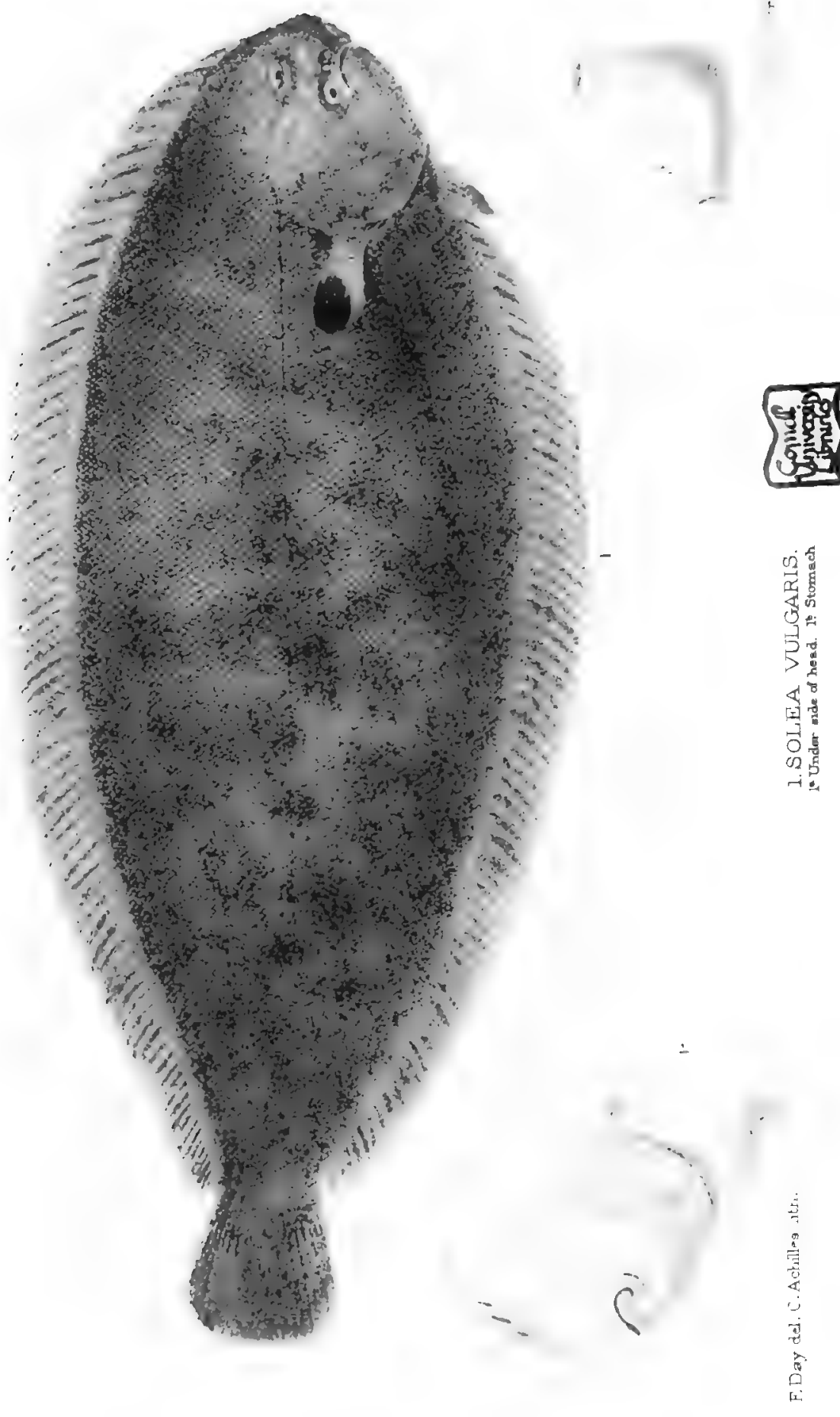





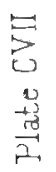

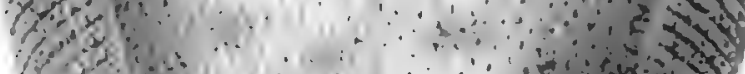

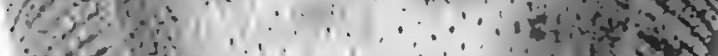

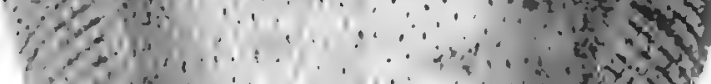

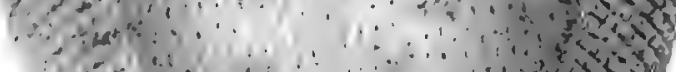

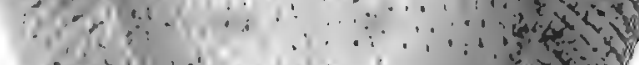

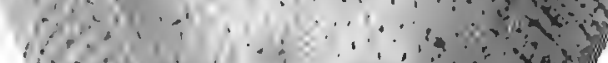

it:

19 
8 

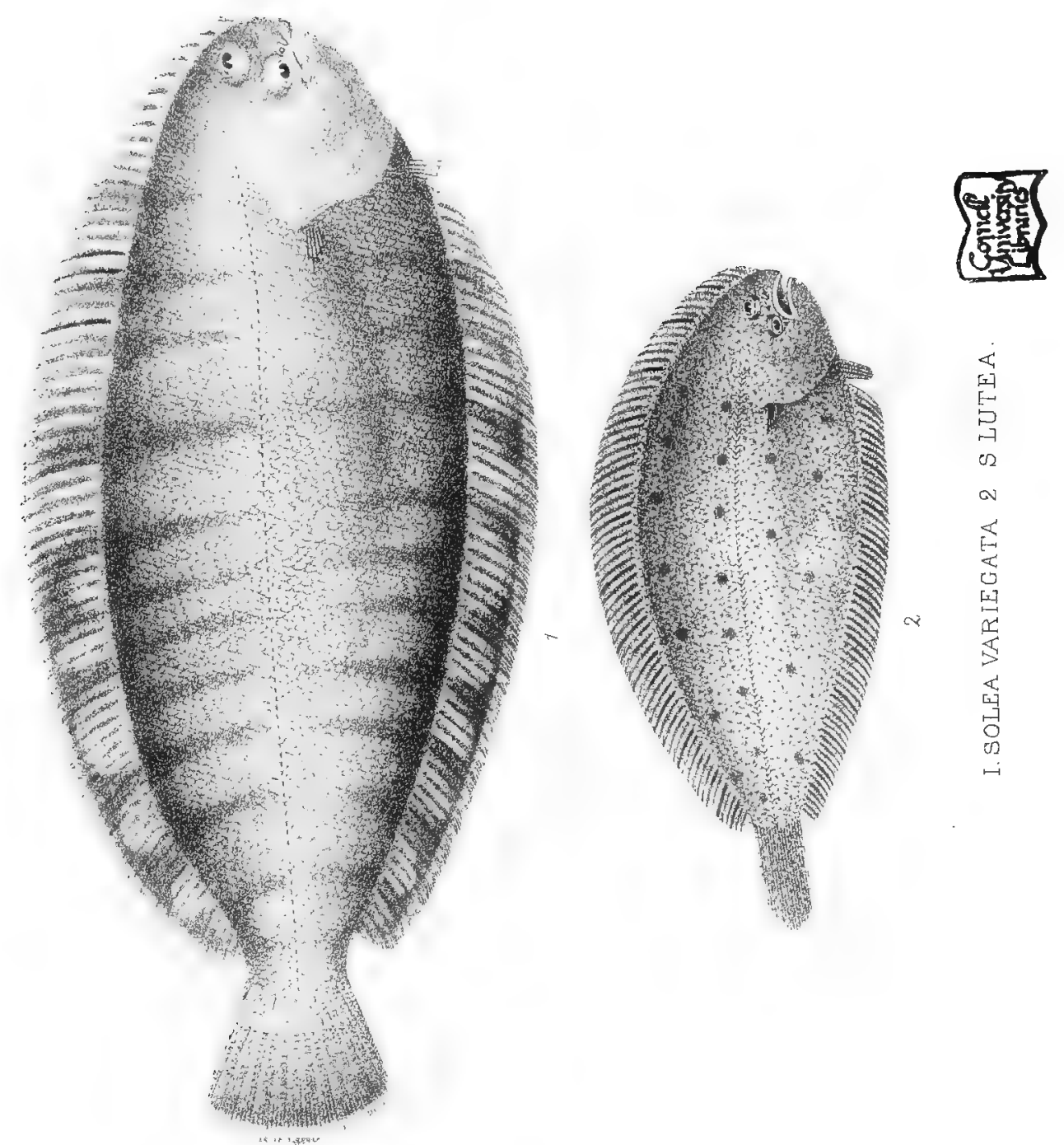

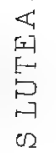

我




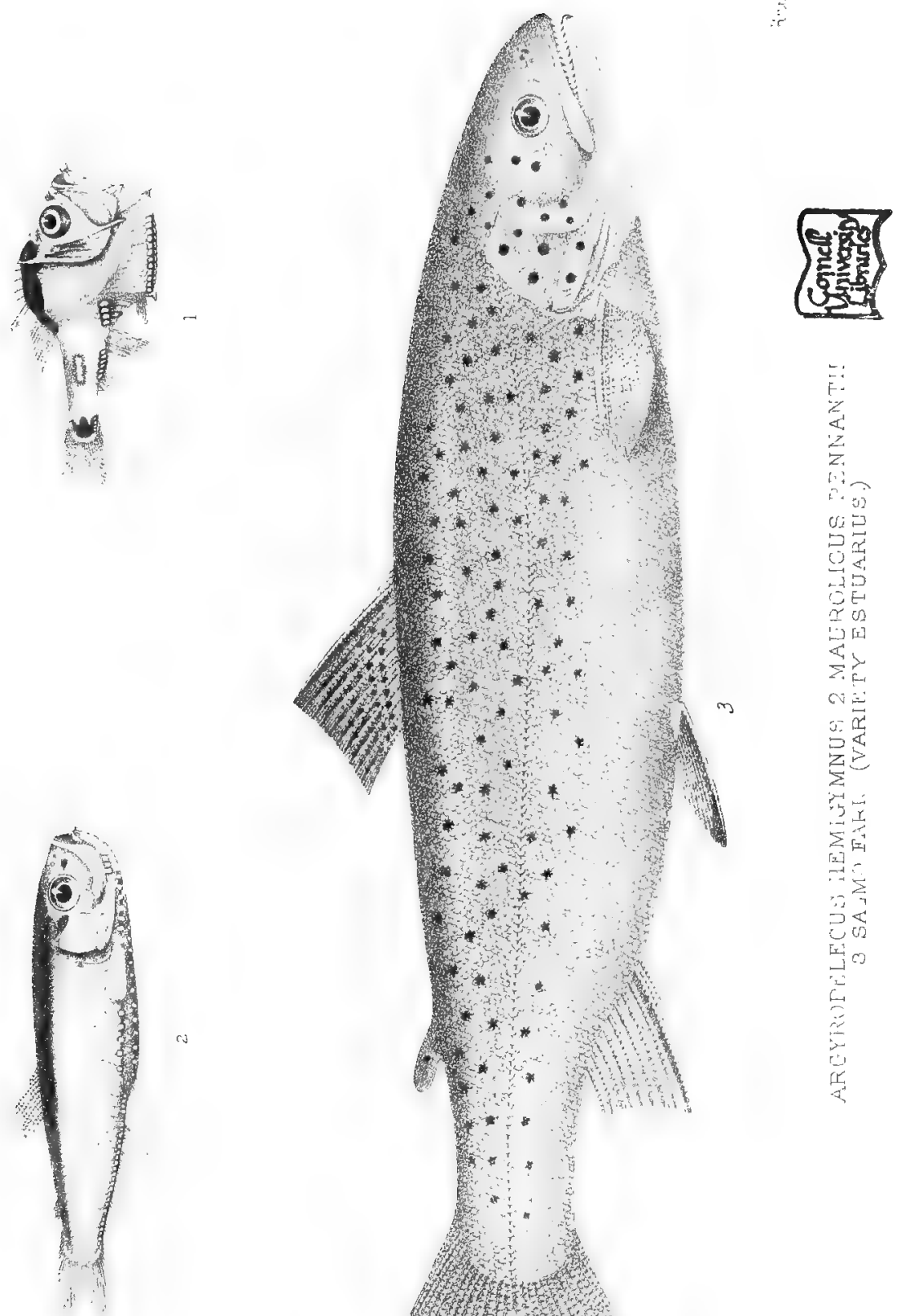



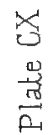

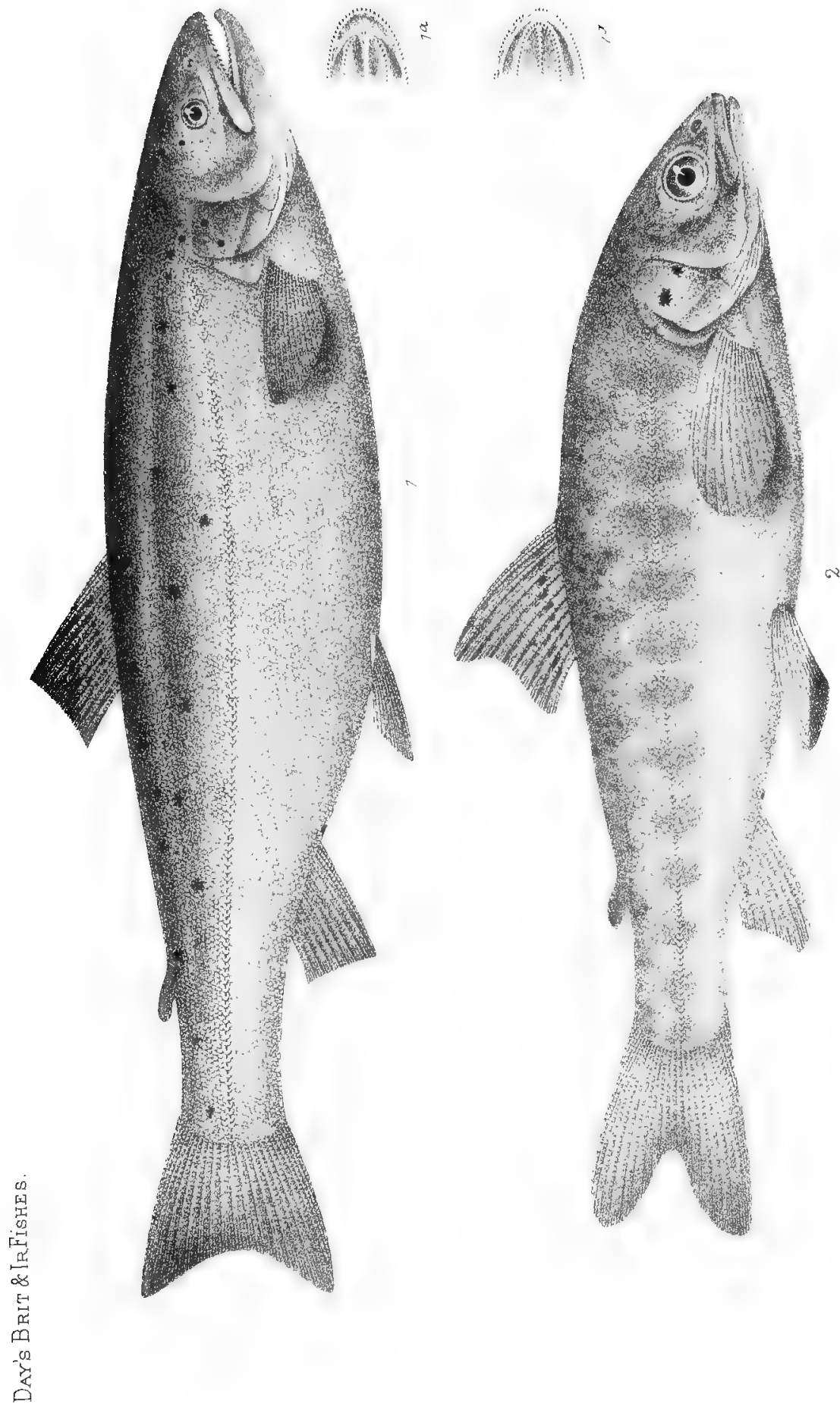

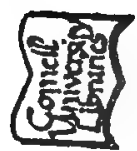

z

点 

要
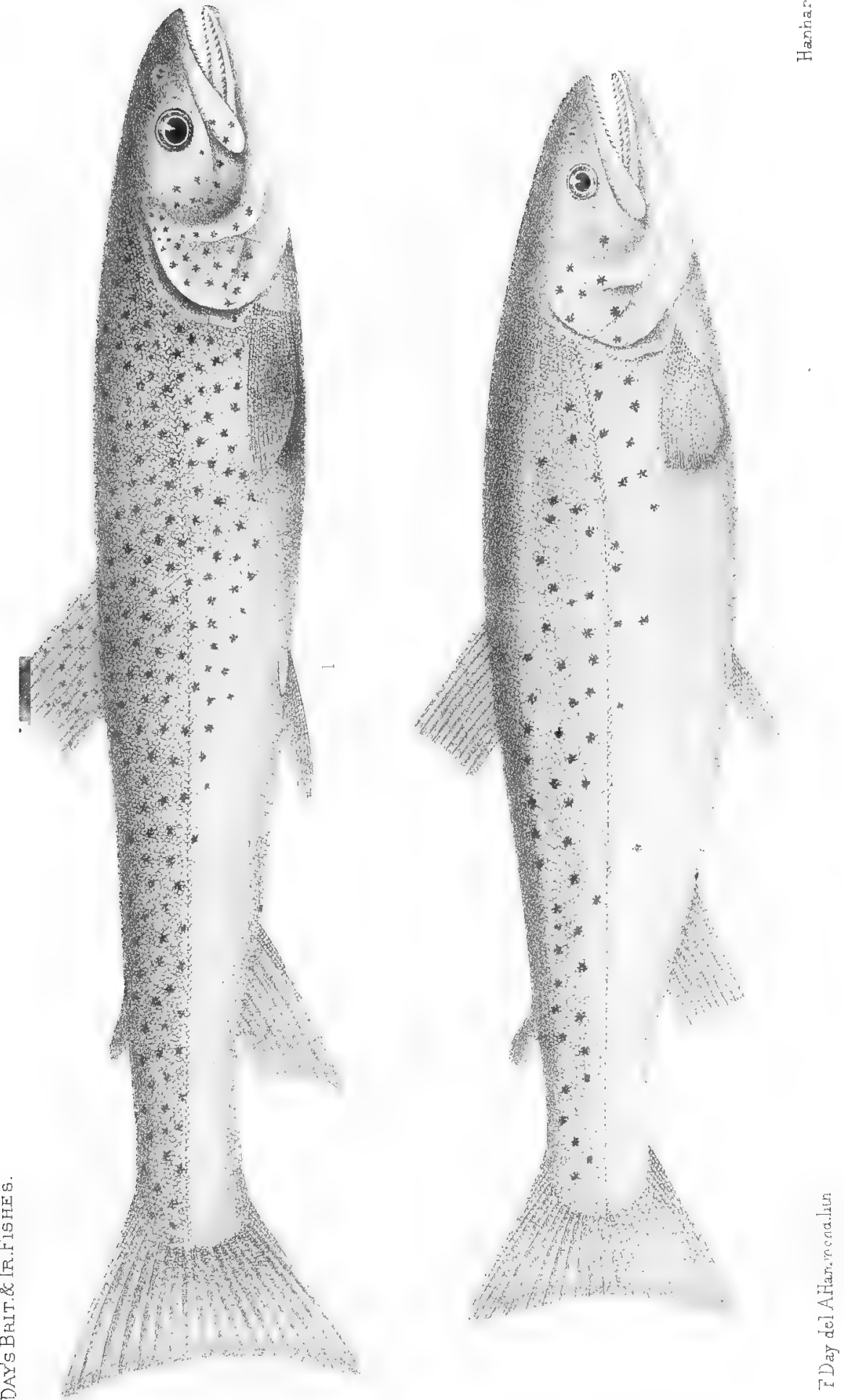

일

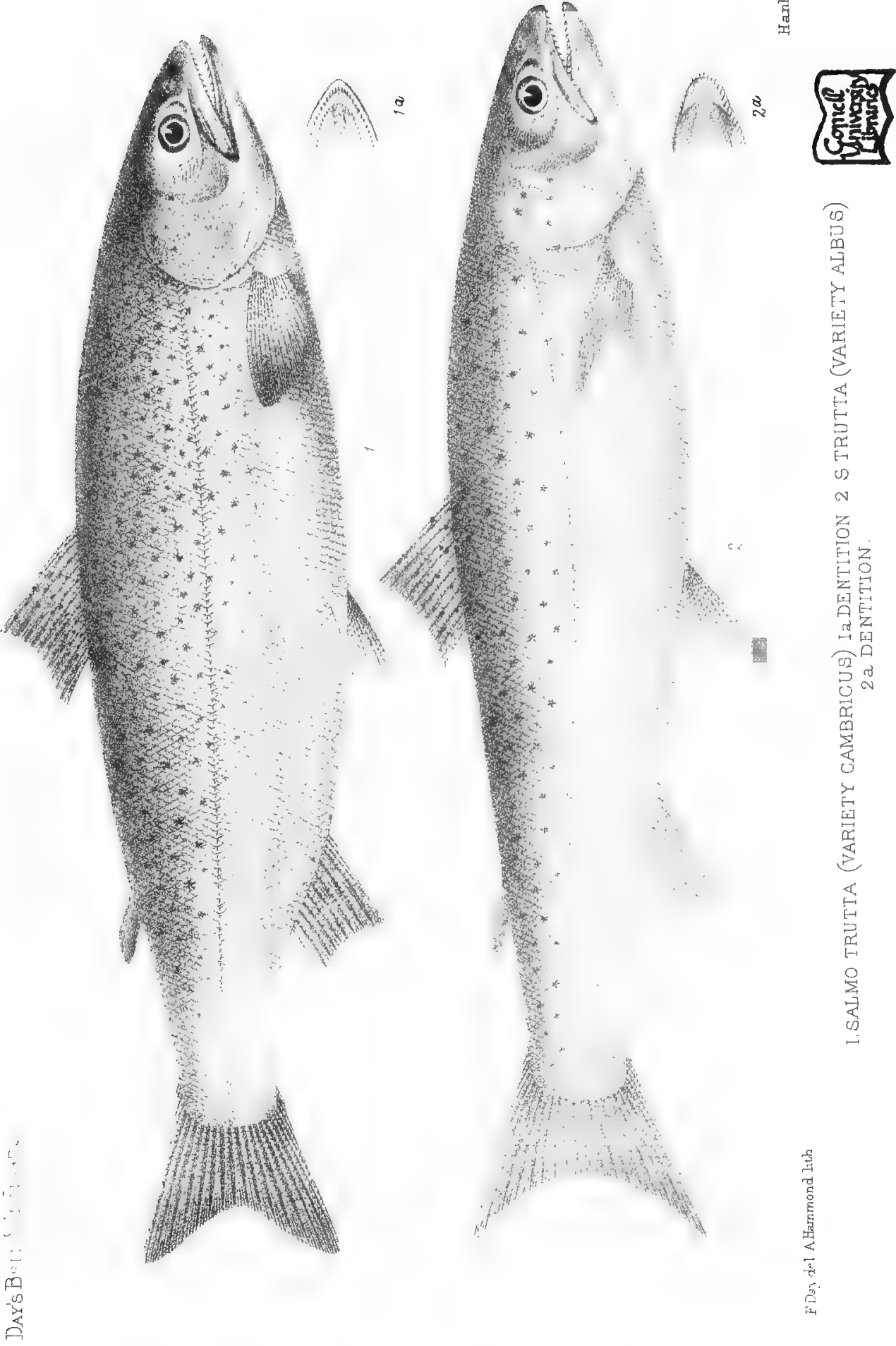



晴
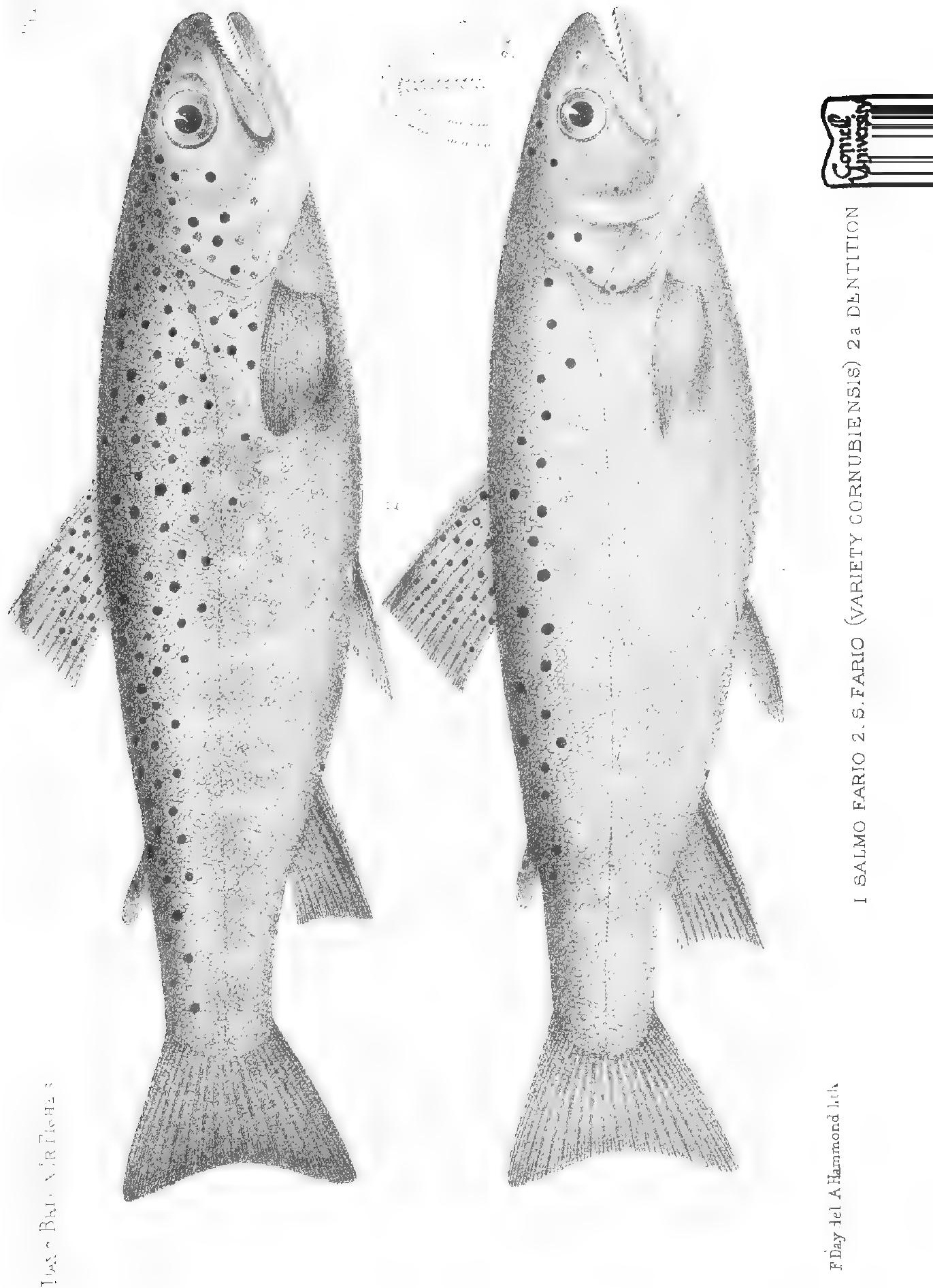

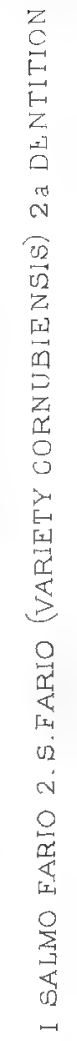


$\because$ 
总
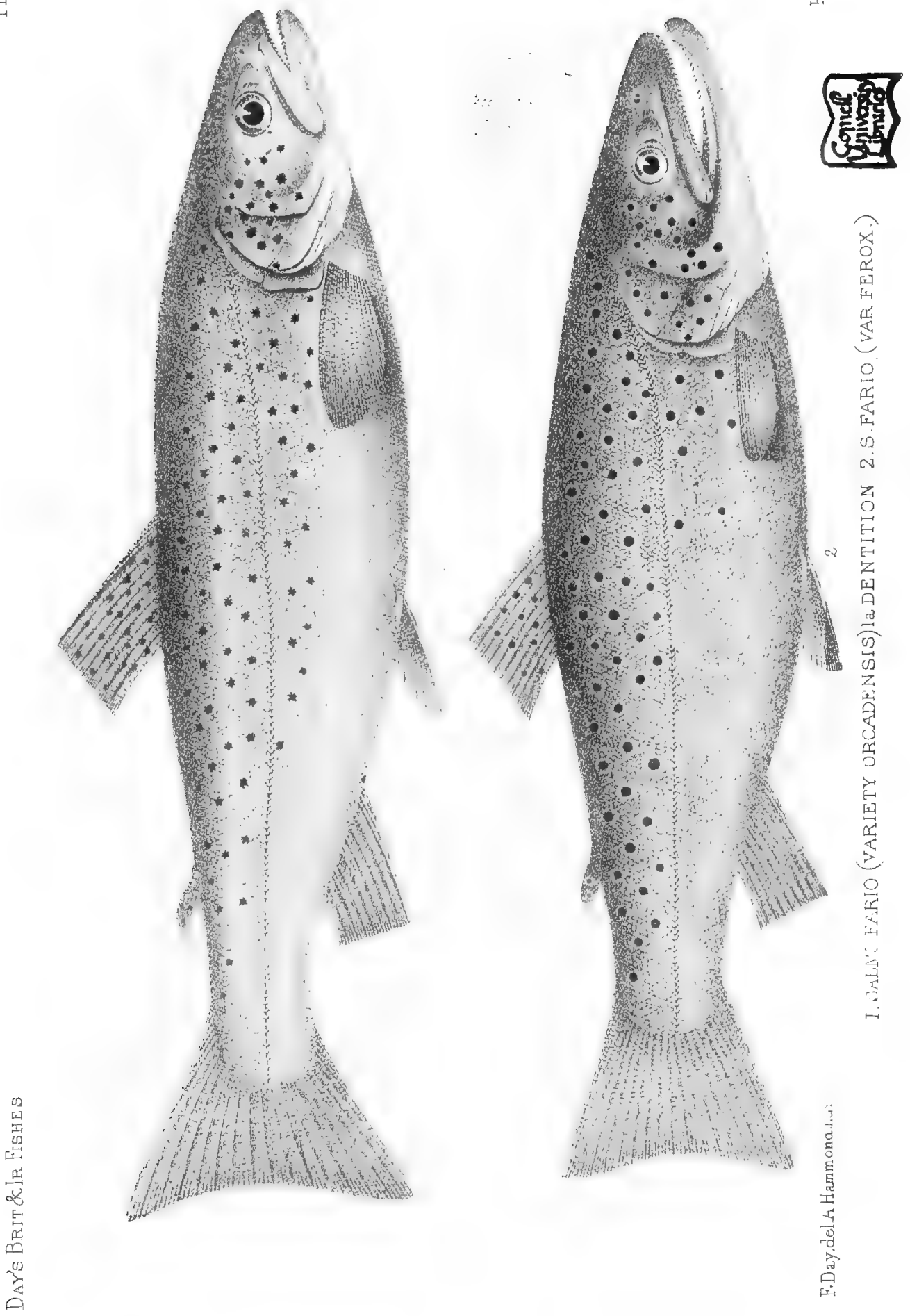

3
0
4
4
5
3
0
0
0
0

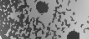

the
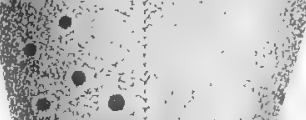

.
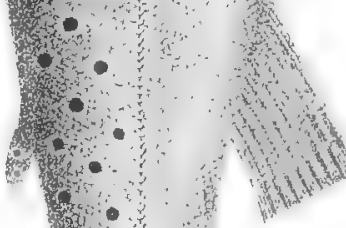


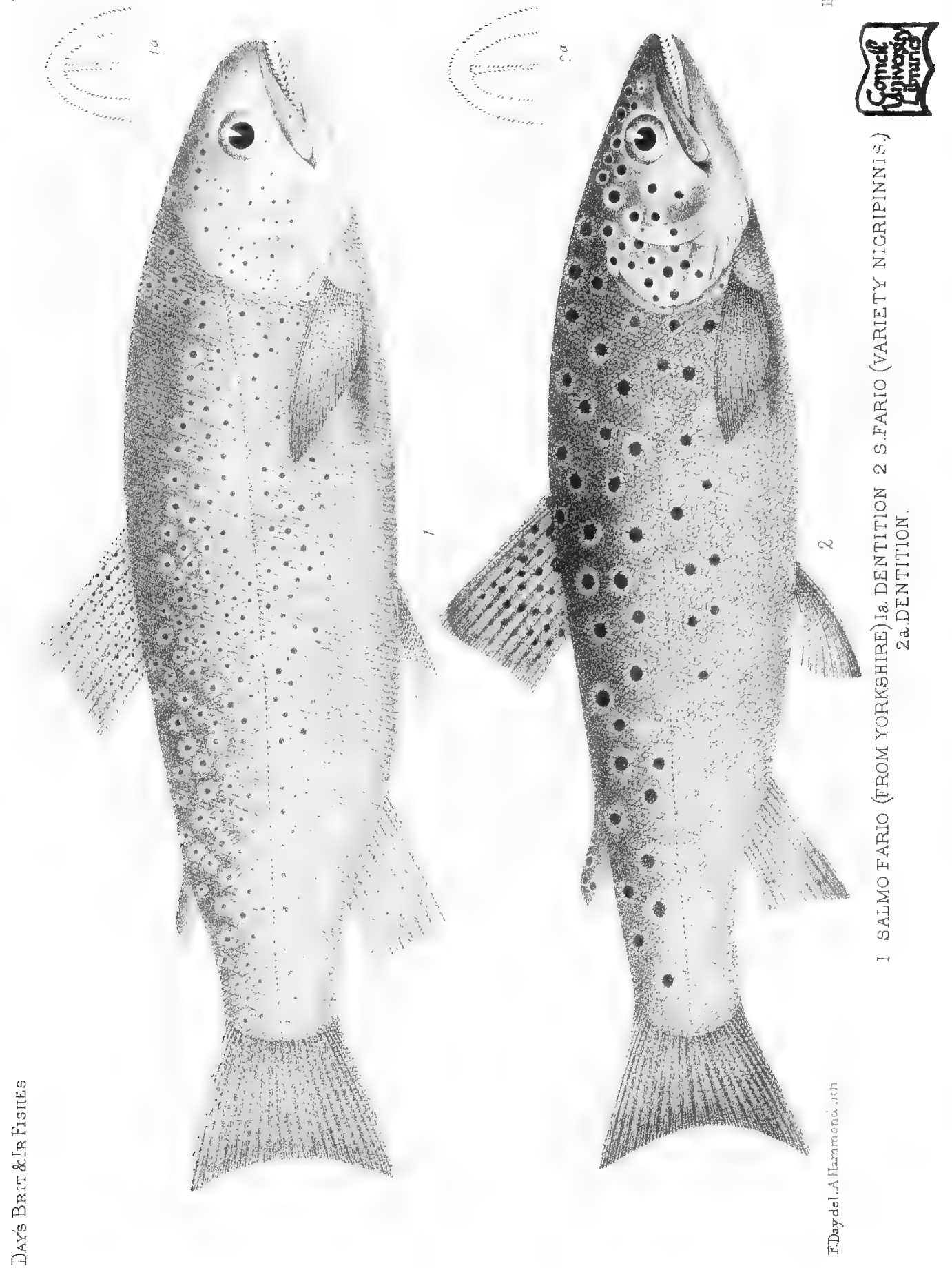

気

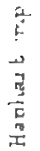
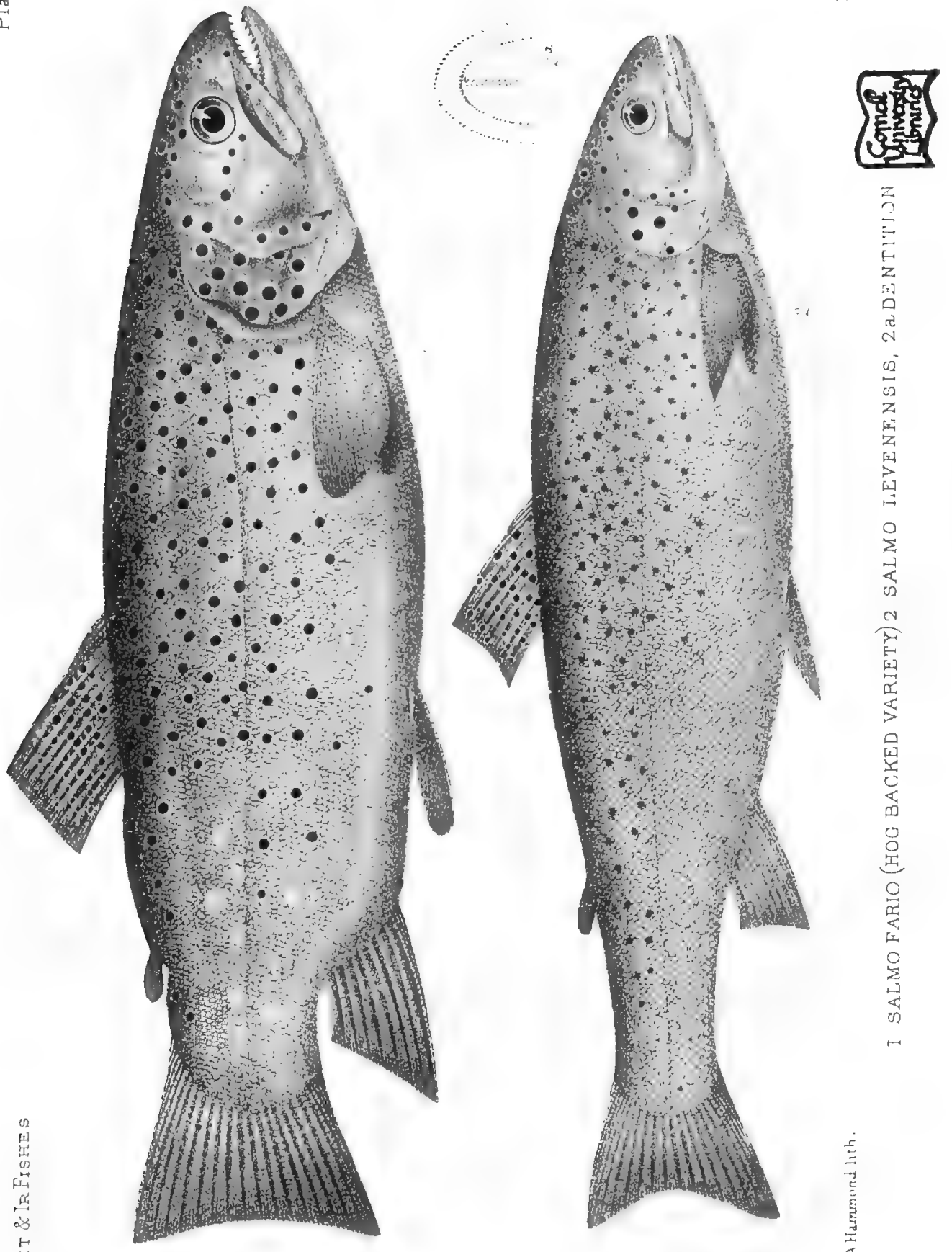

学

3

案

$z_{s, j}$

究

is

is

垔

空

3

可

$\stackrel{\circ}{9}$

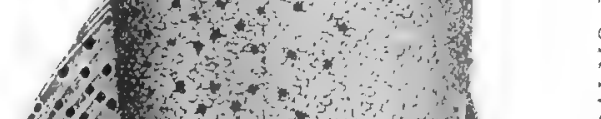

$00+2+0+1$

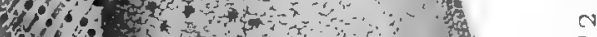

$\frac{3}{40}+4$

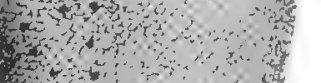

$4 x, \ldots, \cdots$

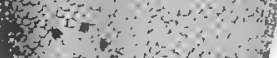

ort

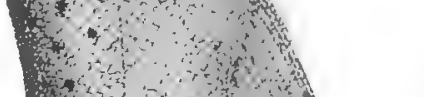

1

rat
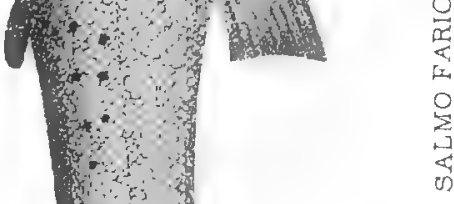

. 



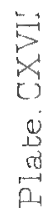
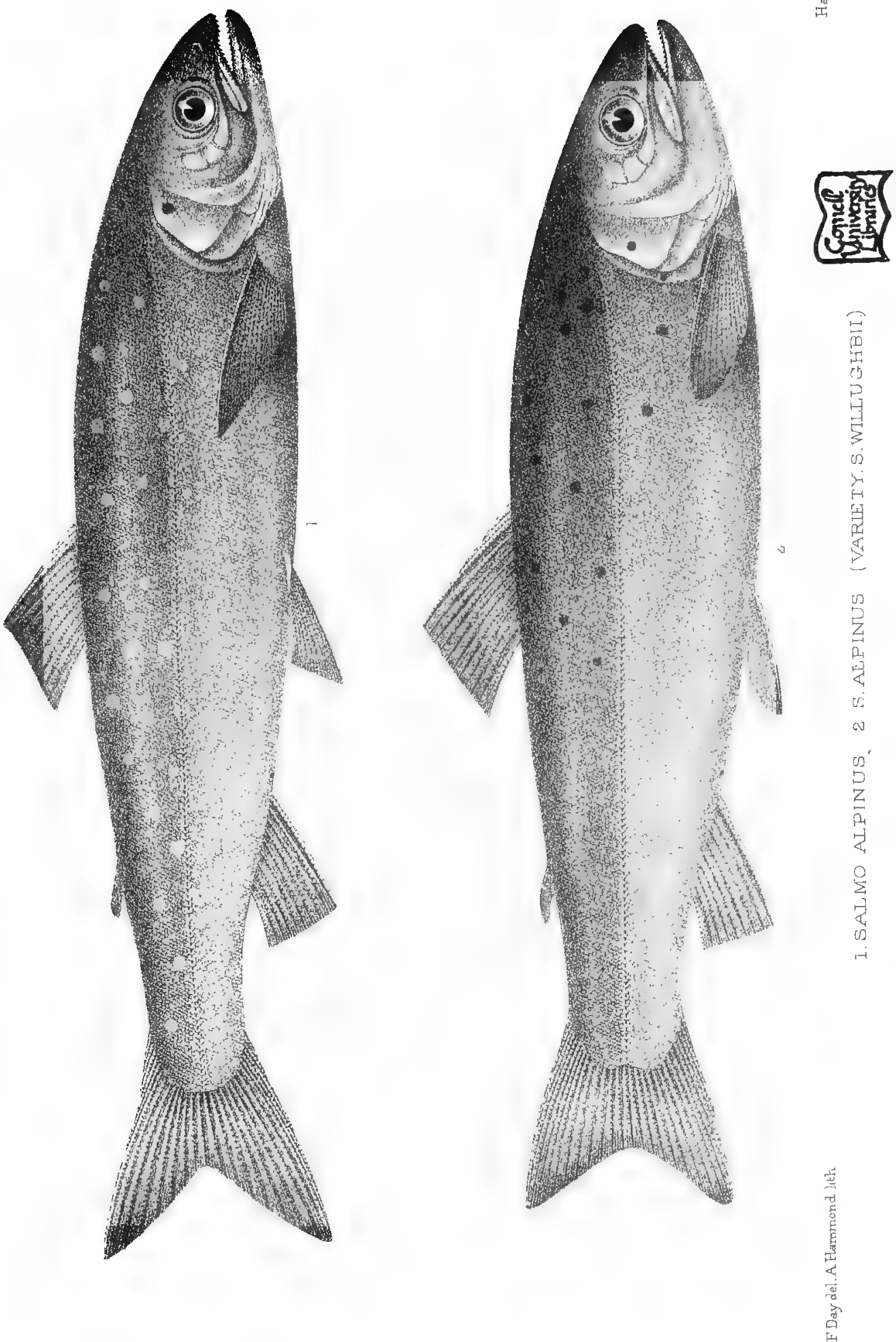

焉

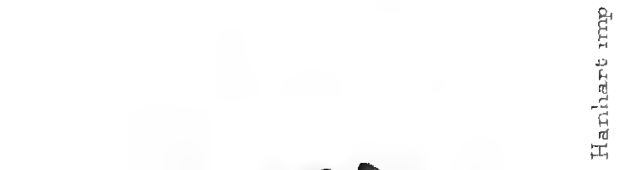






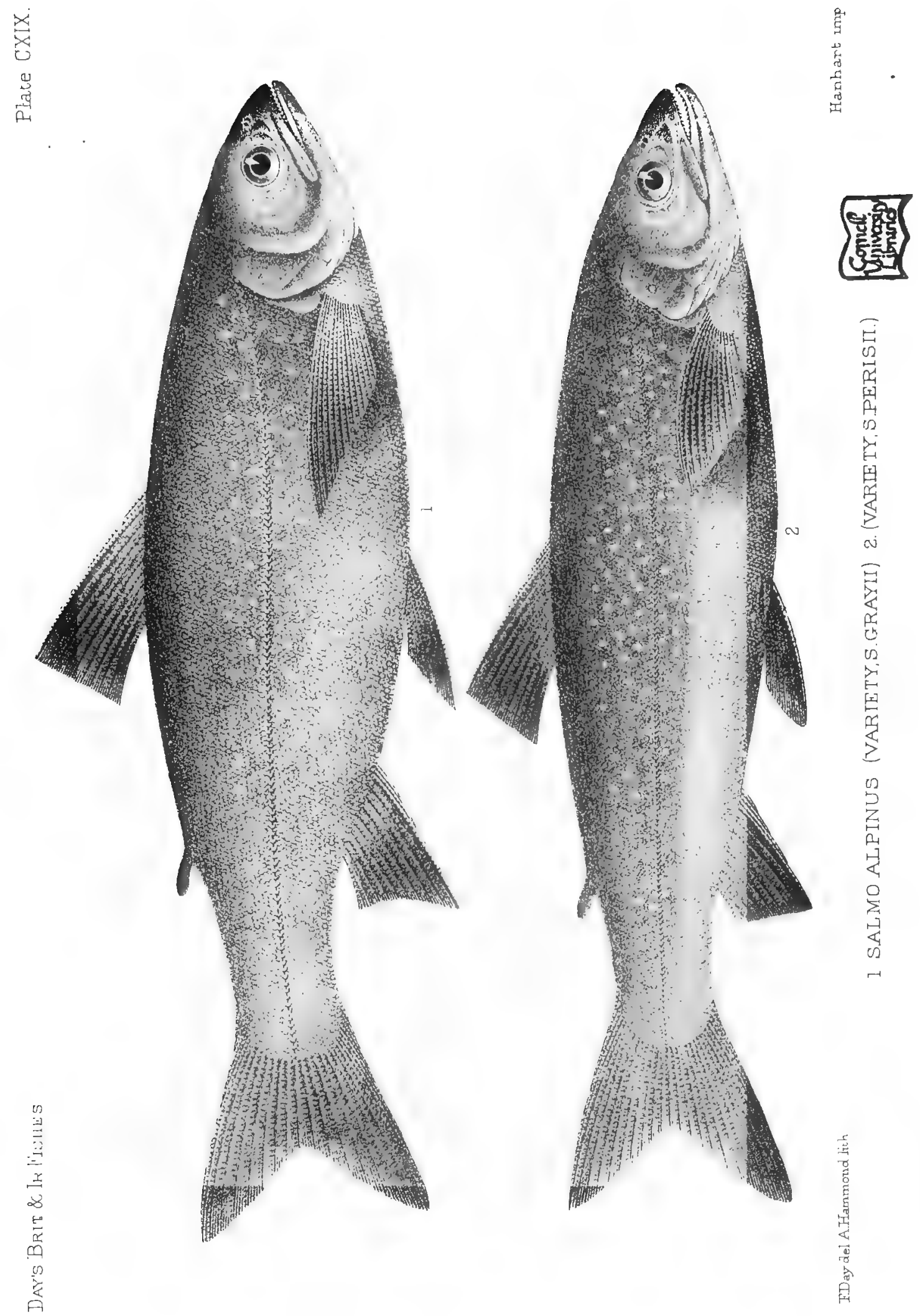




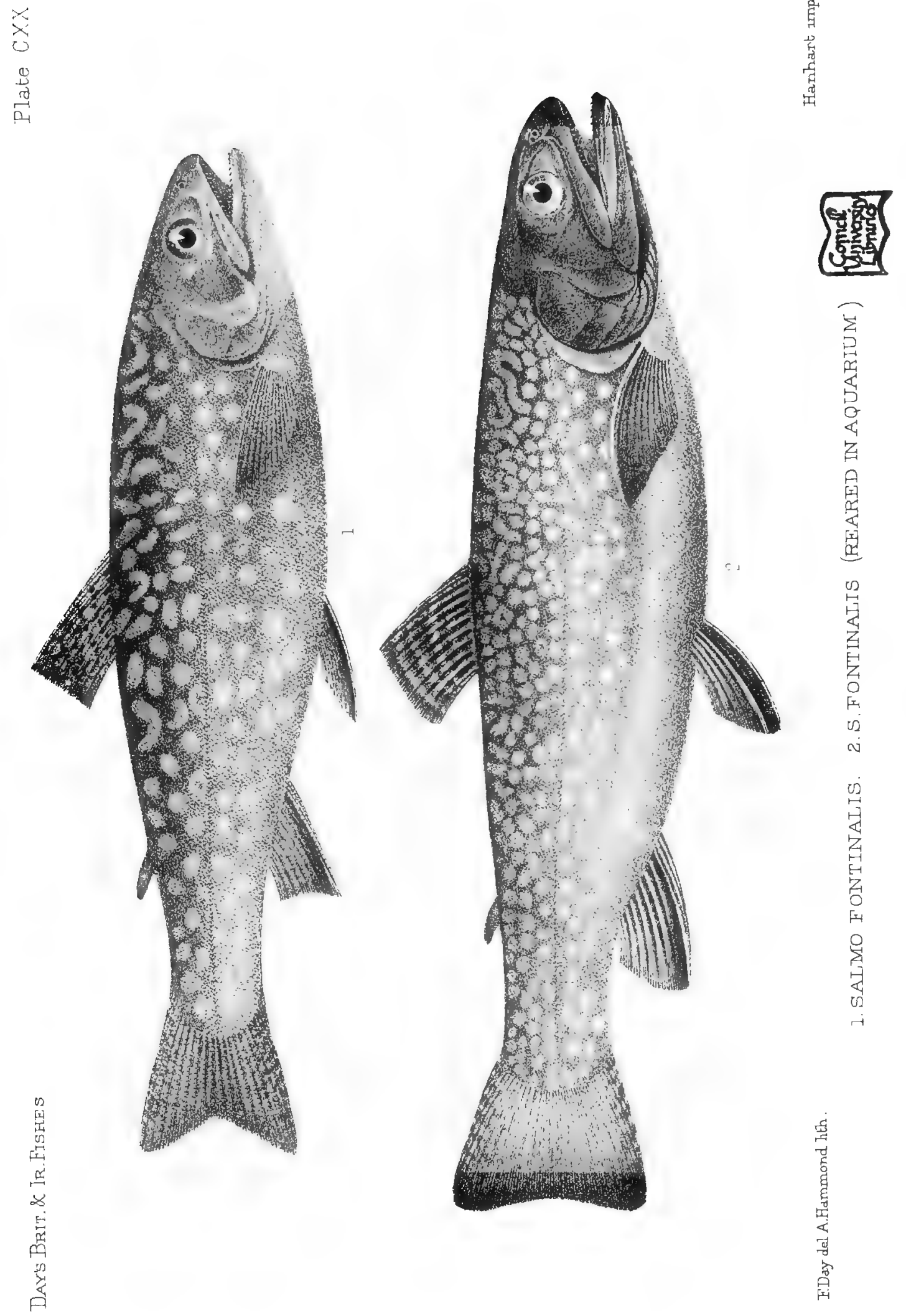

焉

莣

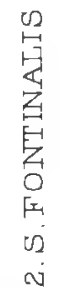

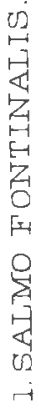

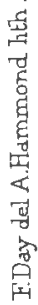





0
0
0
0
0

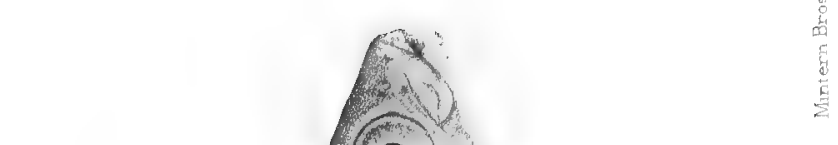

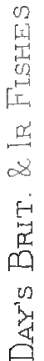

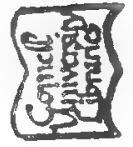

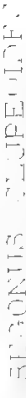





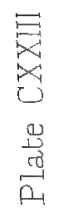
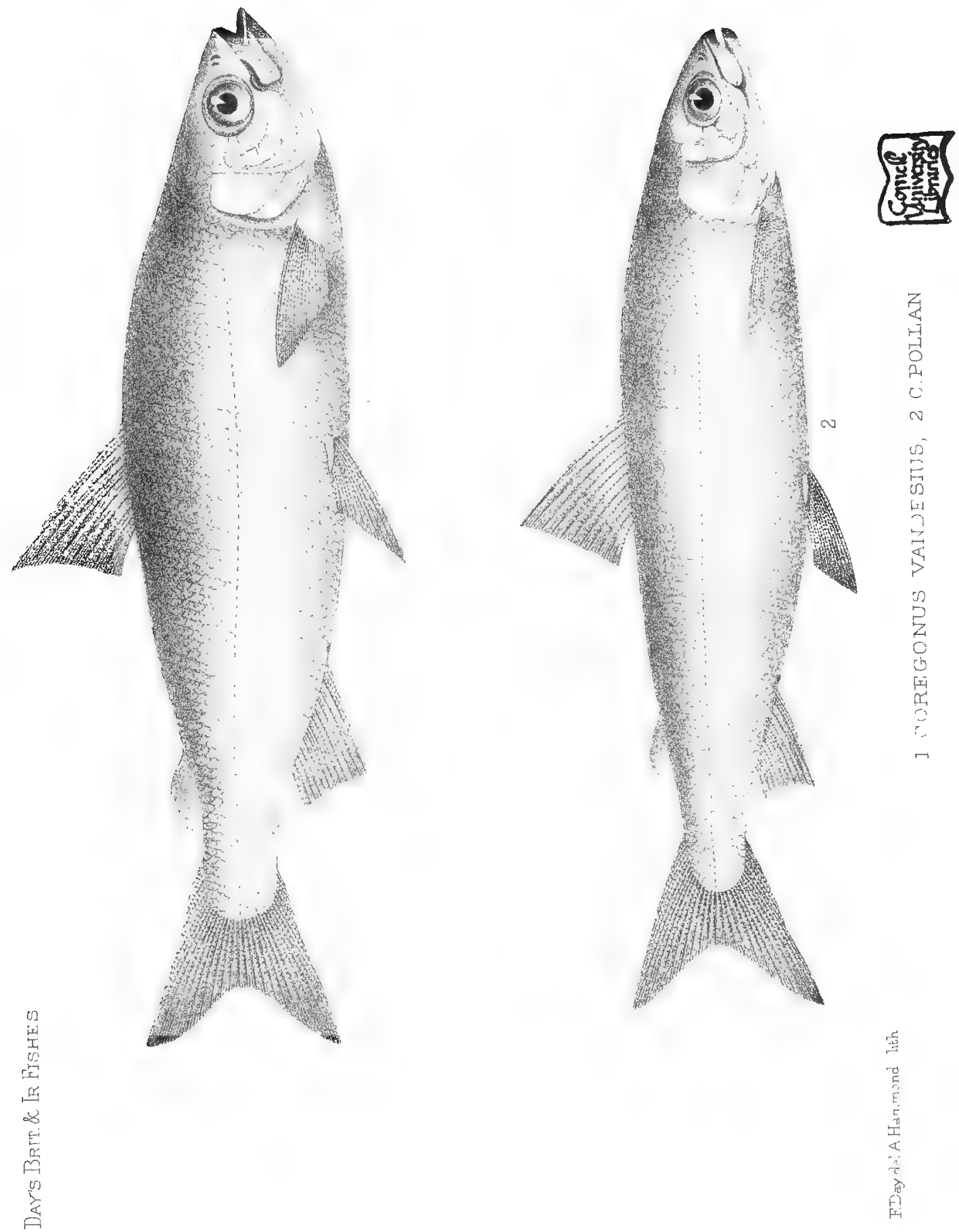

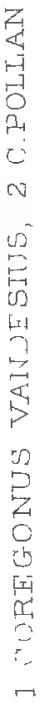





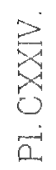

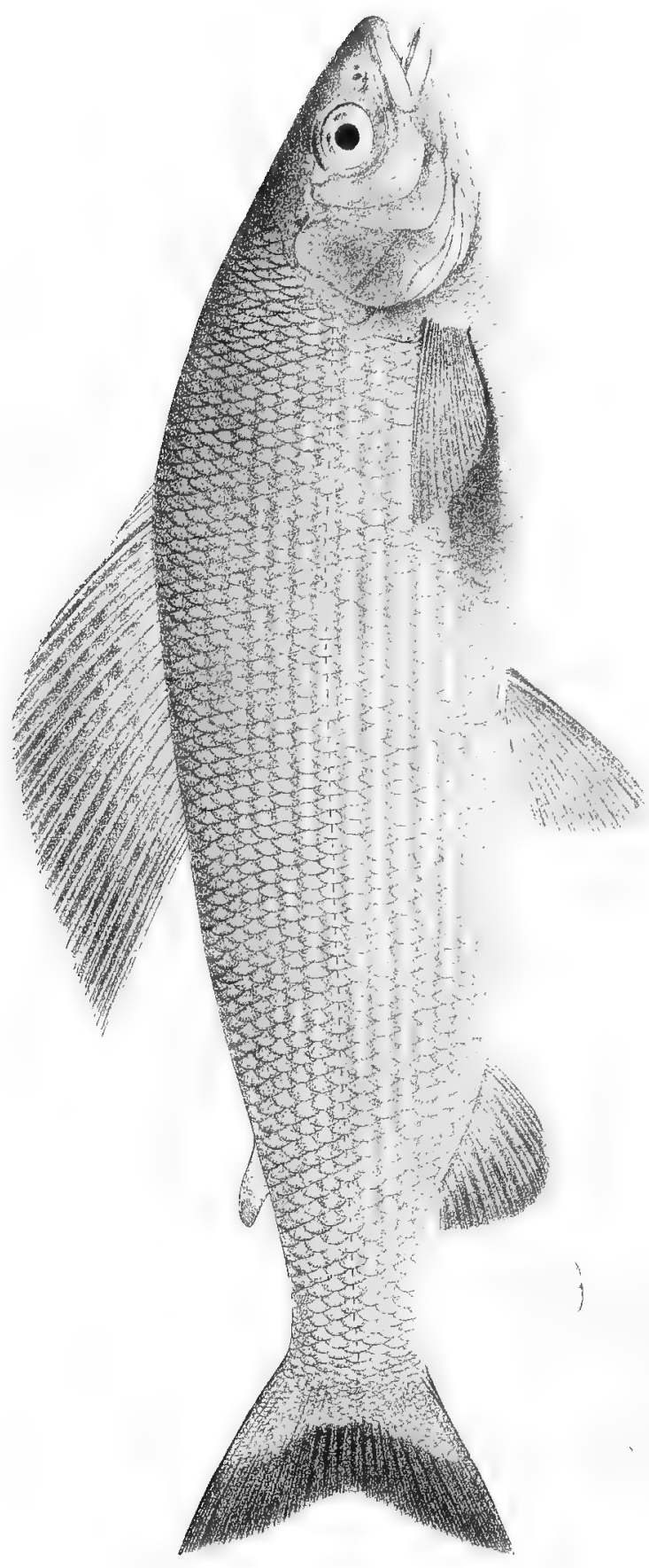

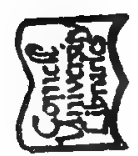

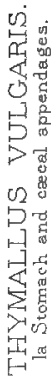




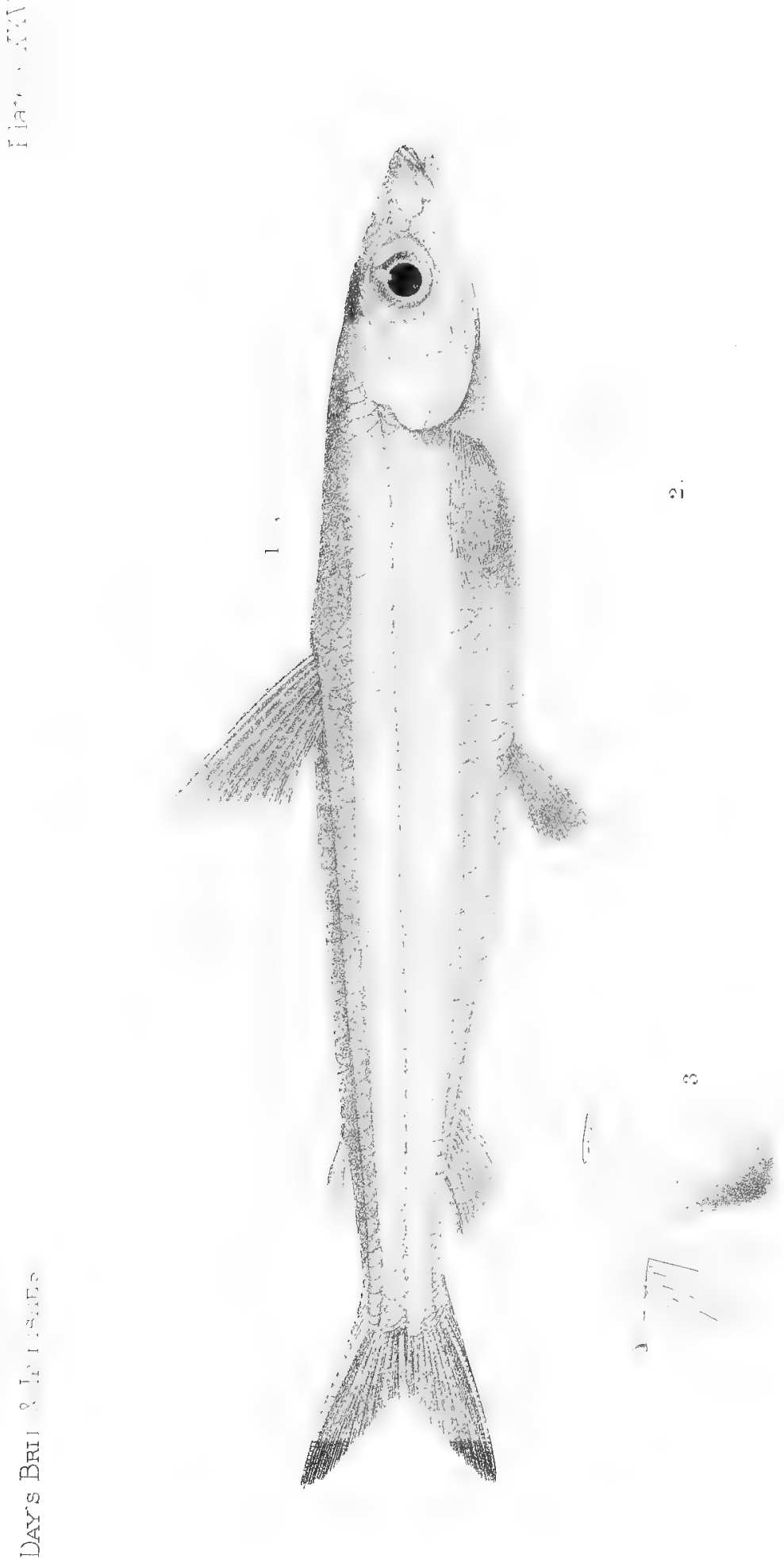

鹪

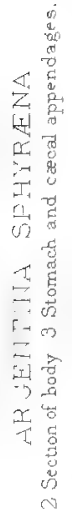




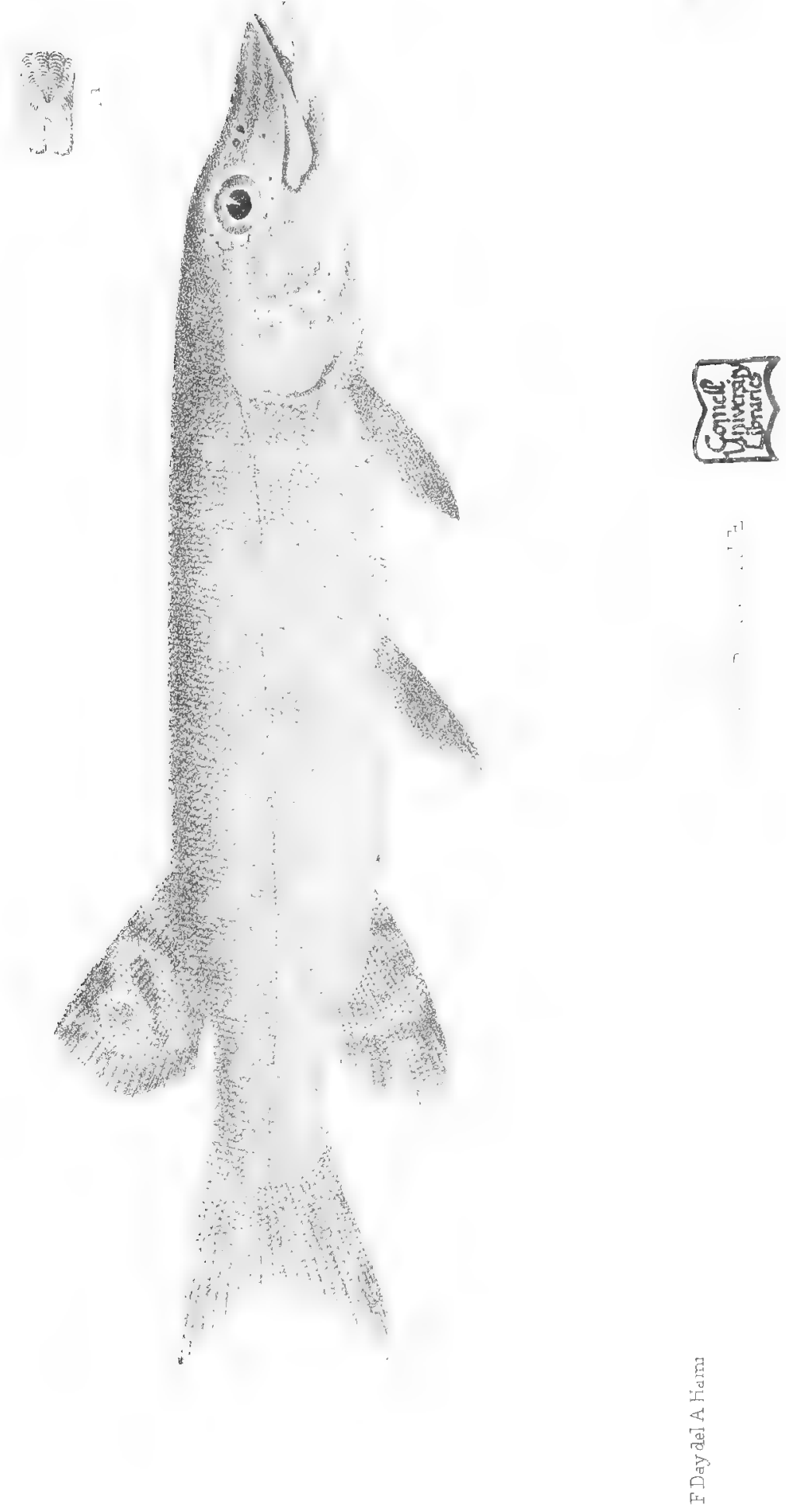

永

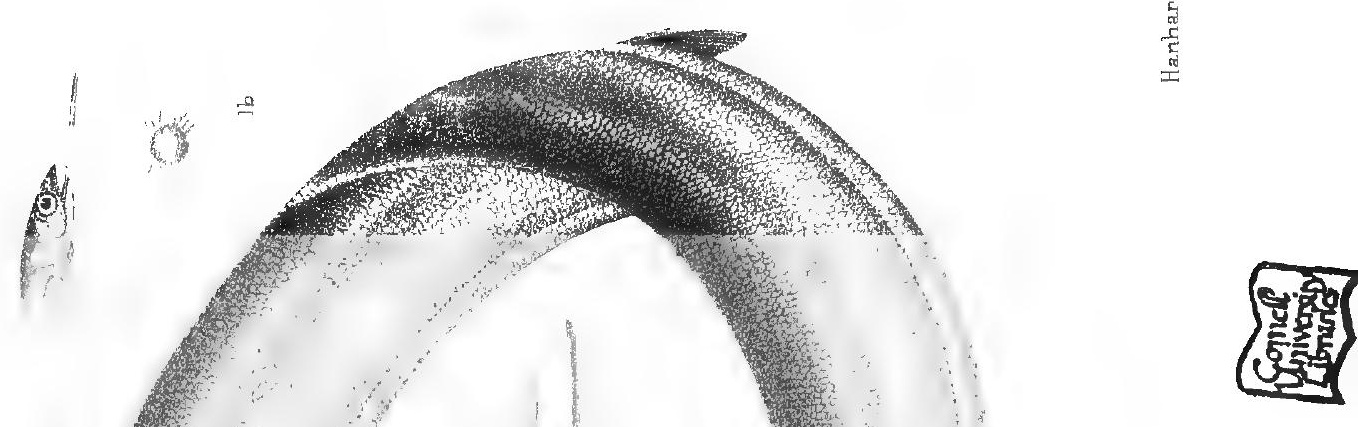

它 



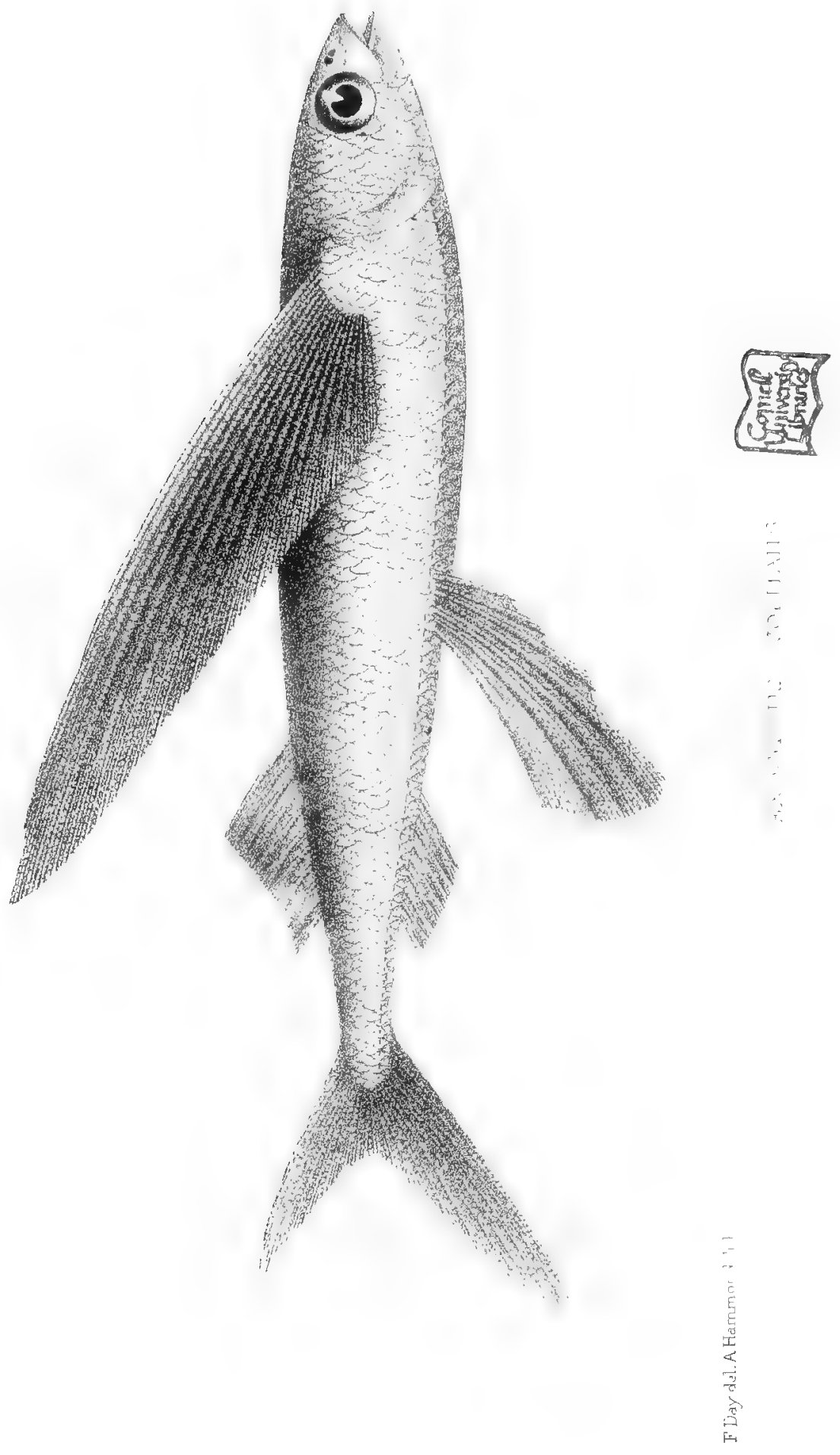




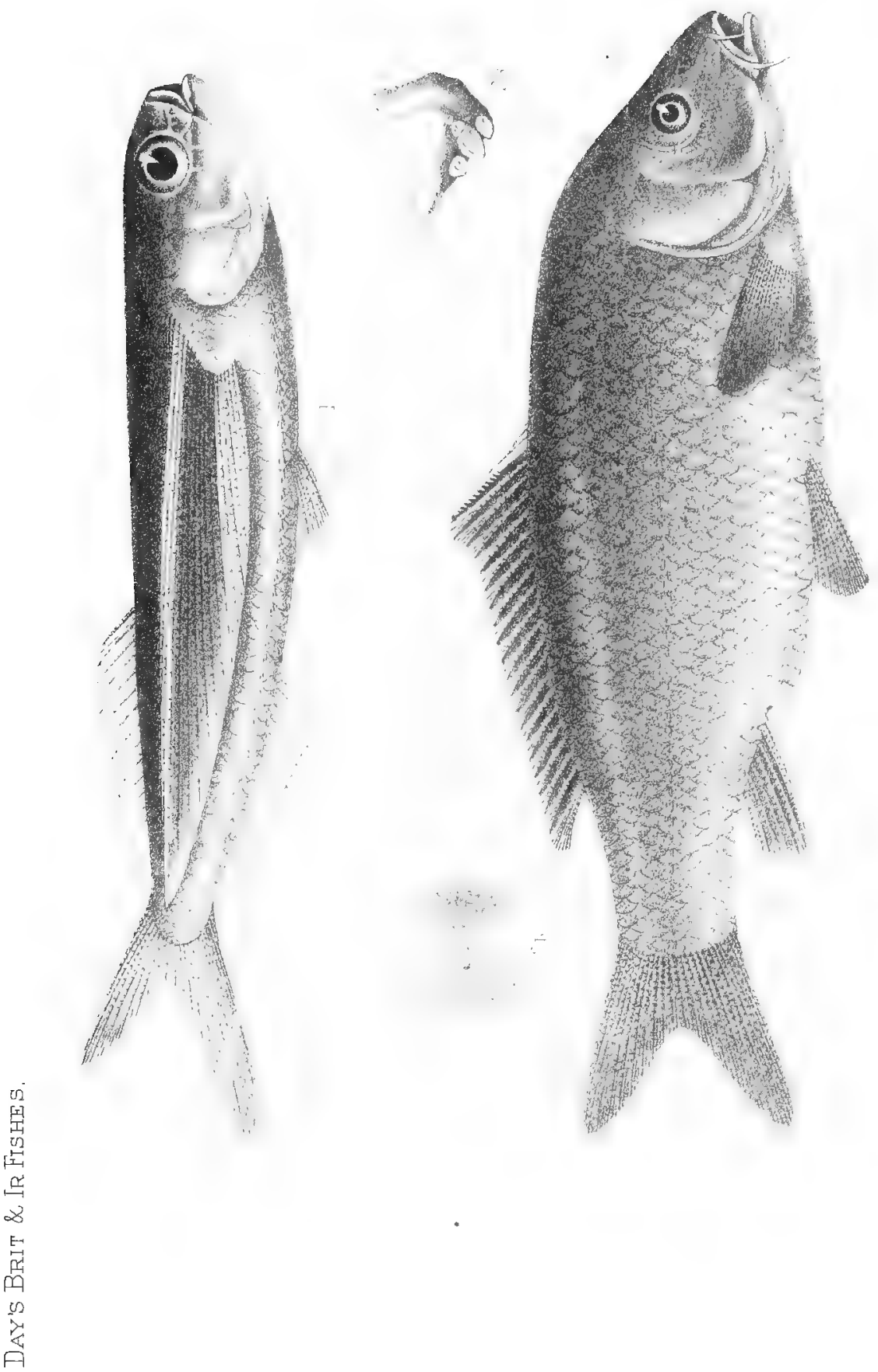

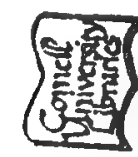

디

芘

is

오

㘴

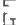

[T]

自

语

z

栗

空

$\pi$

是

W

学

$\rho_{4}$

걱

$\infty$

先

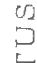

벅

0 

$x$
0
0
0
0
0

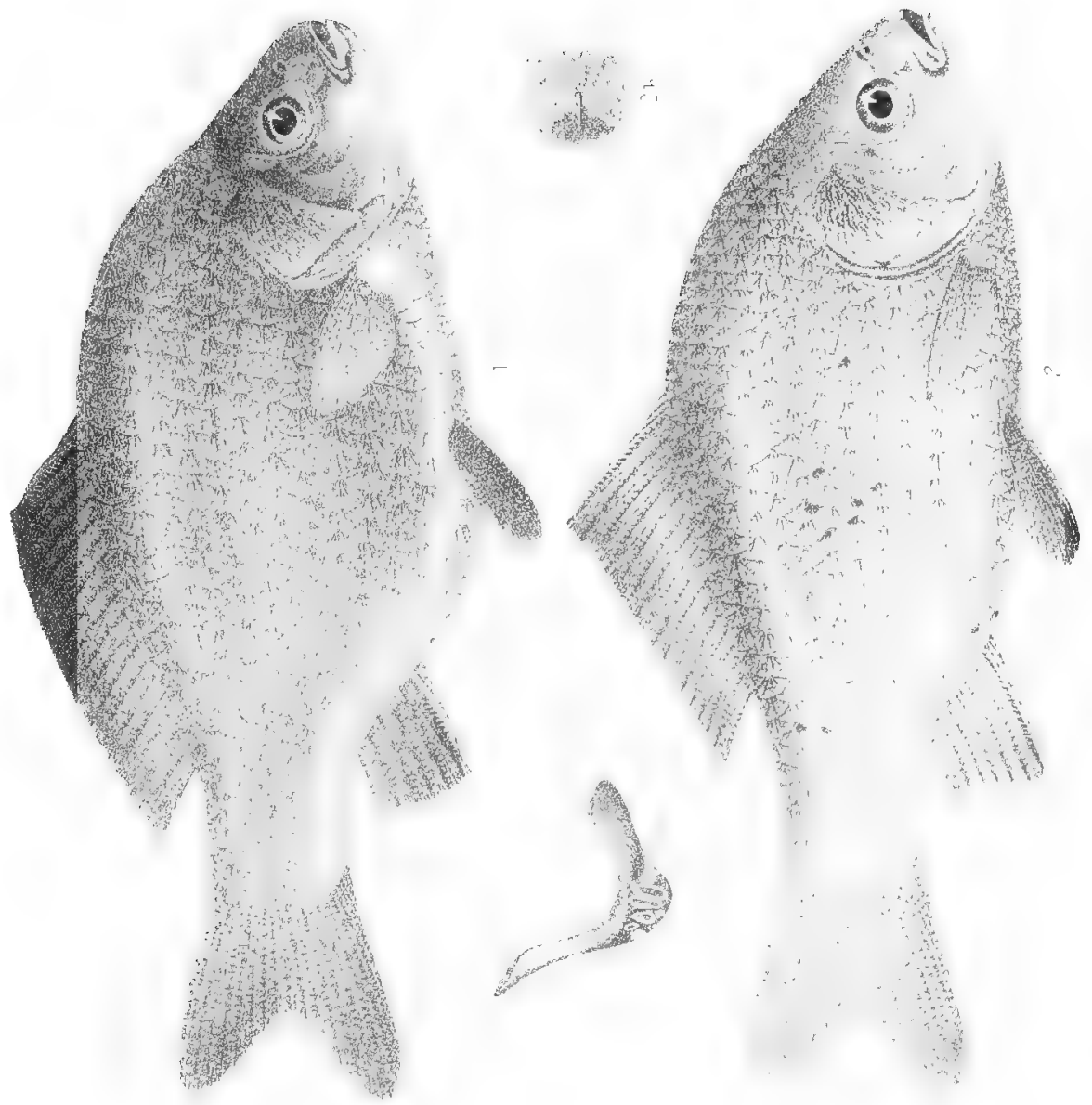

纴 



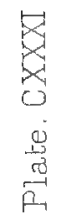
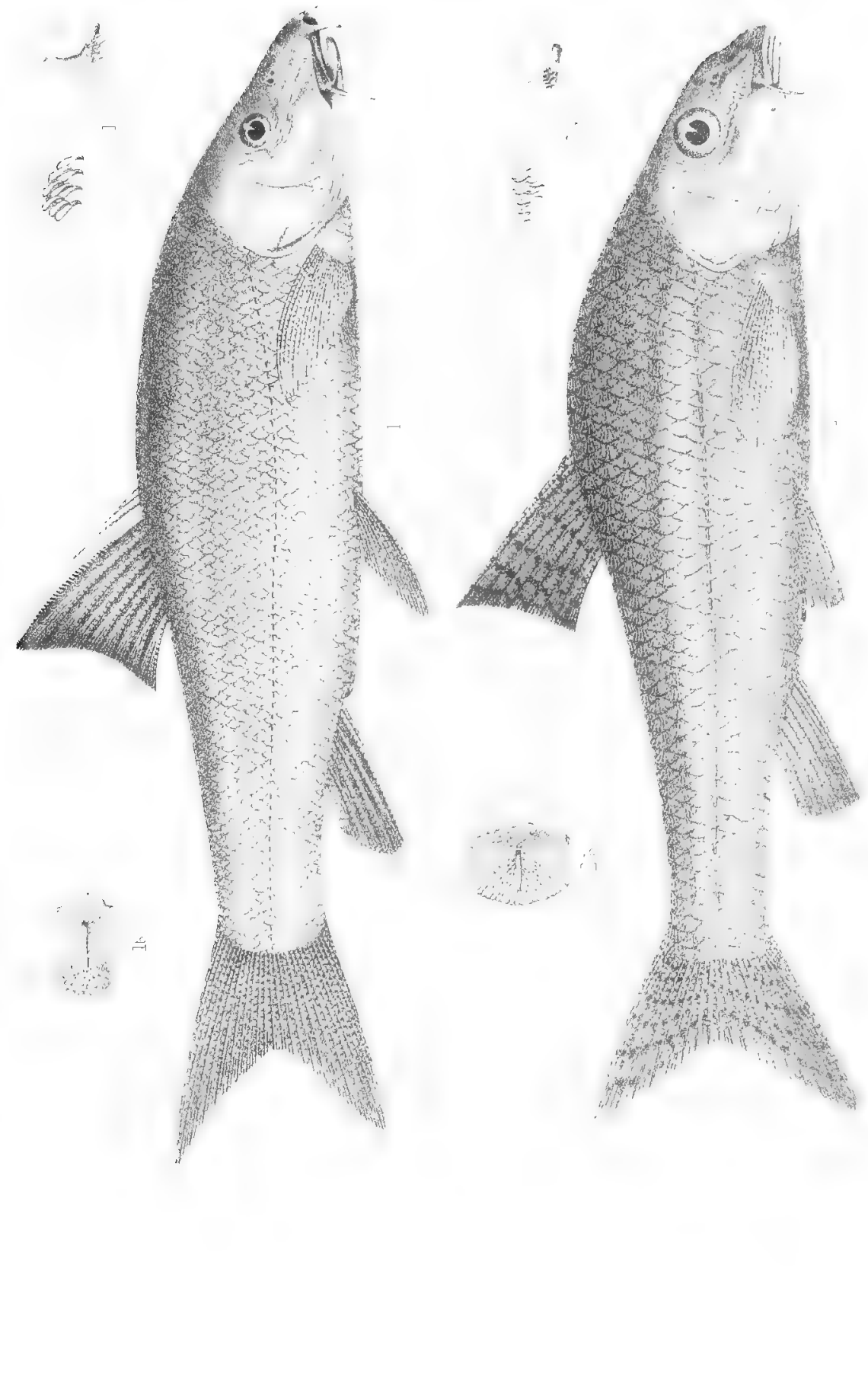

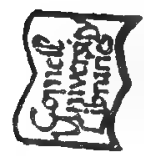

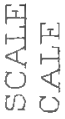

号

令

讧杢

다 디

타

4

证

द

- $z_{1}$

os

4

尿

ब

- త్ర

u

岱

号昆

号昰

93

讨寻

응

동

다난

$\rightarrow$ o 



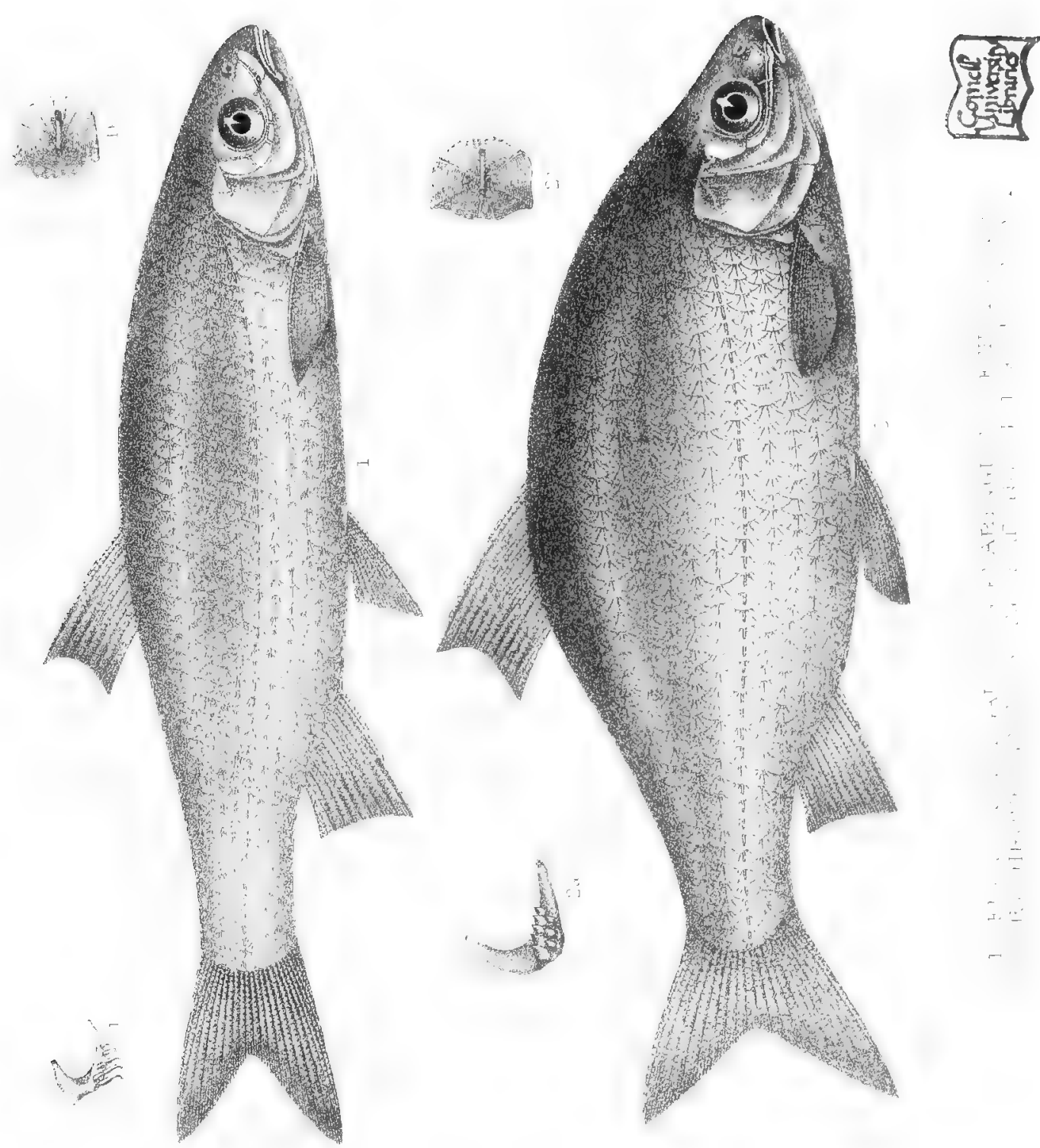



$$
19
$$





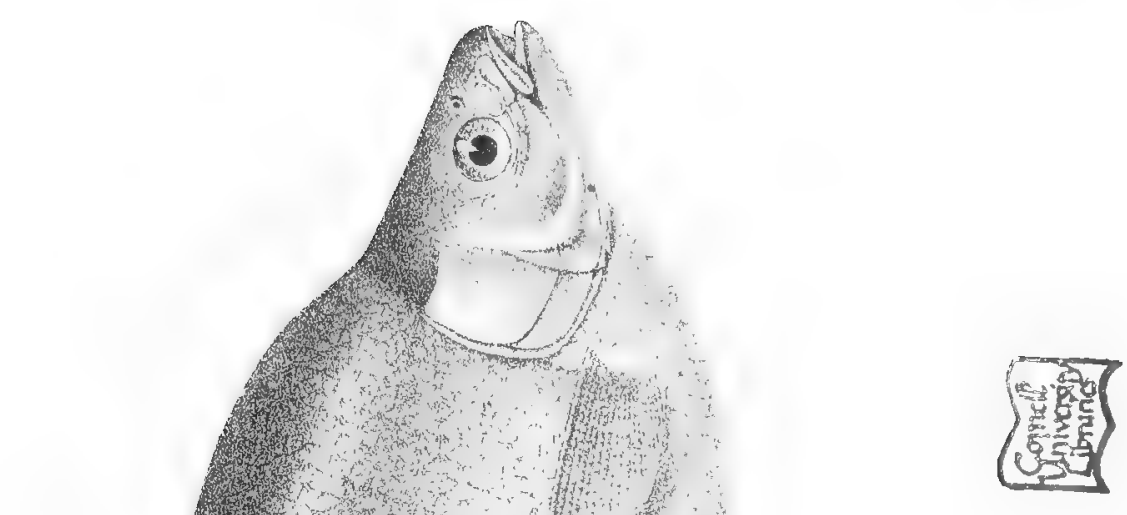





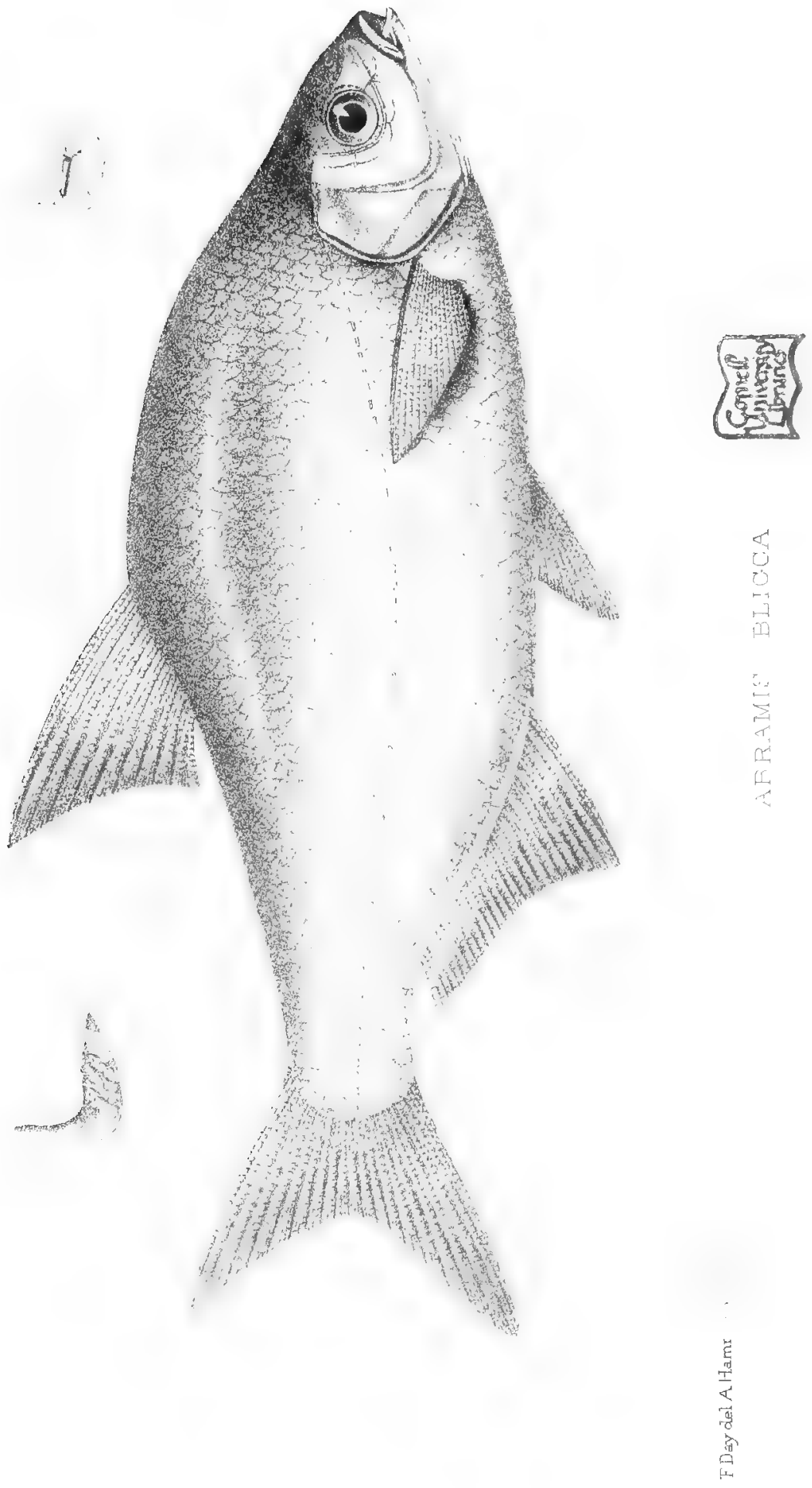




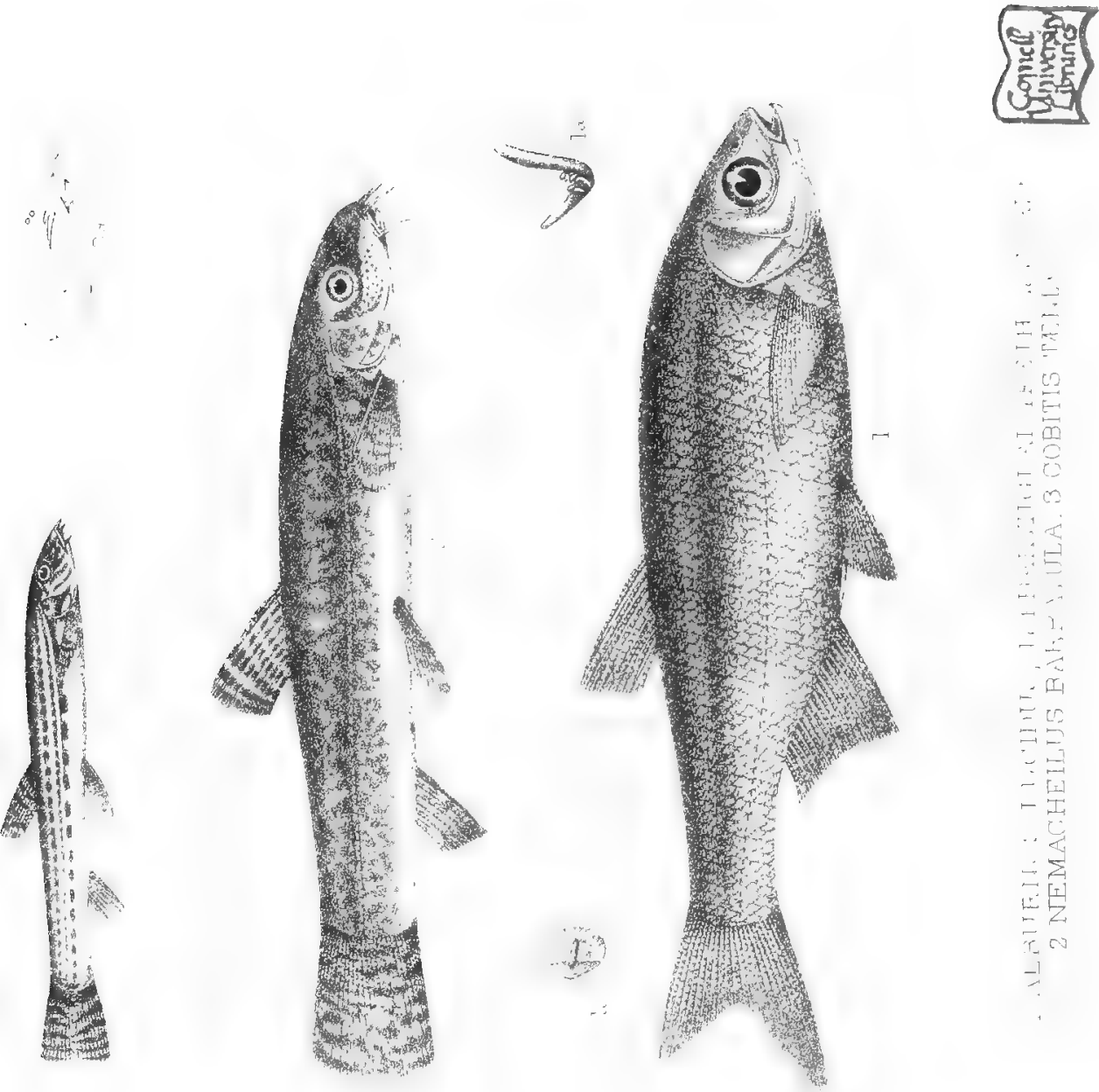



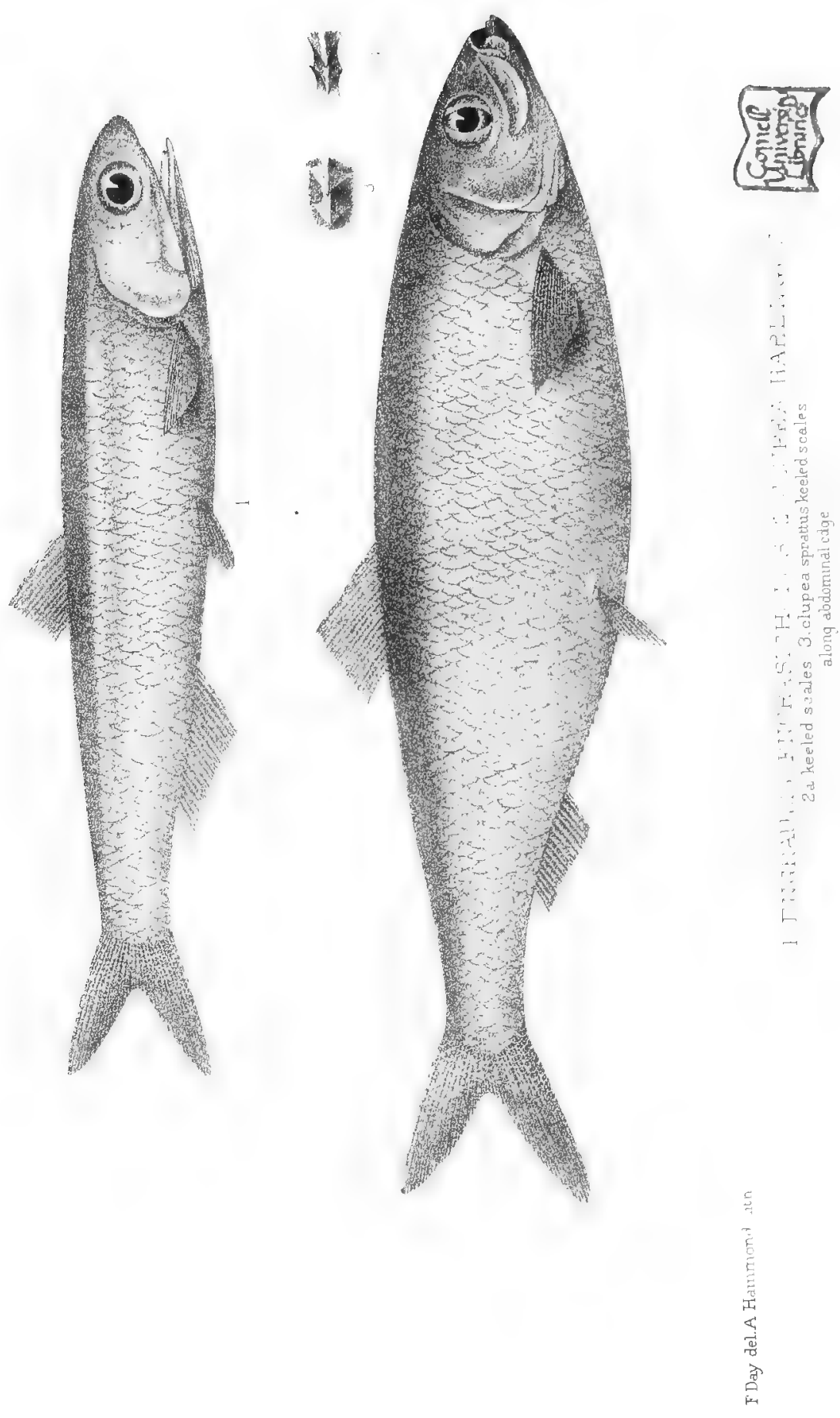





$$
f^{4} \int^{2}
$$



\begin{tabular}{l} 
L \\
0 \\
0 \\
0 \\
0 \\
\hline 1
\end{tabular}

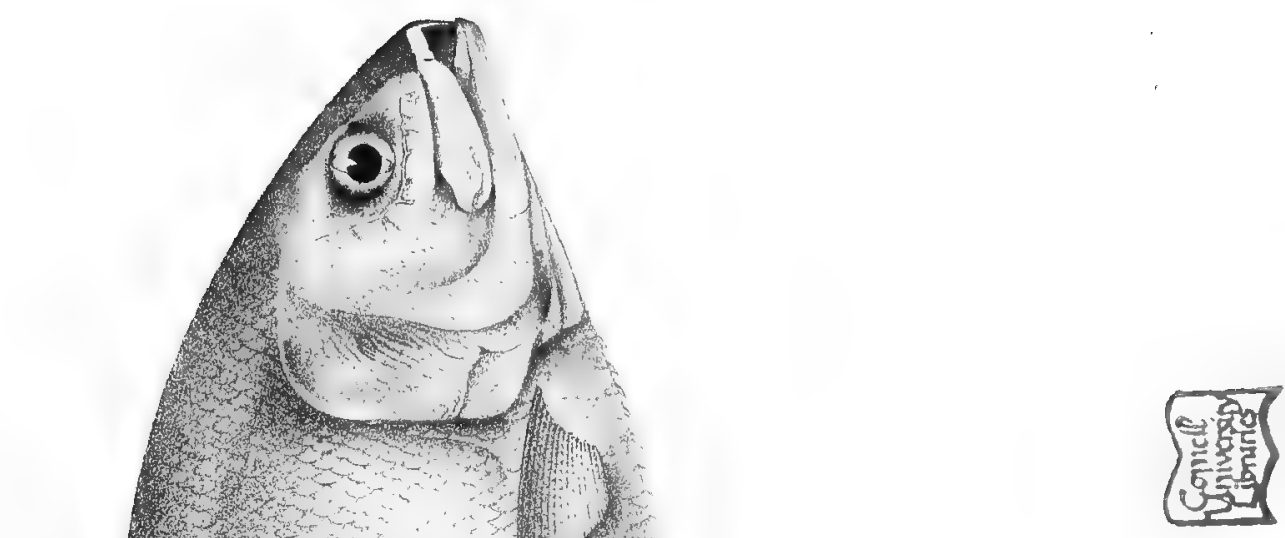

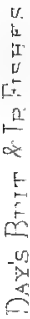

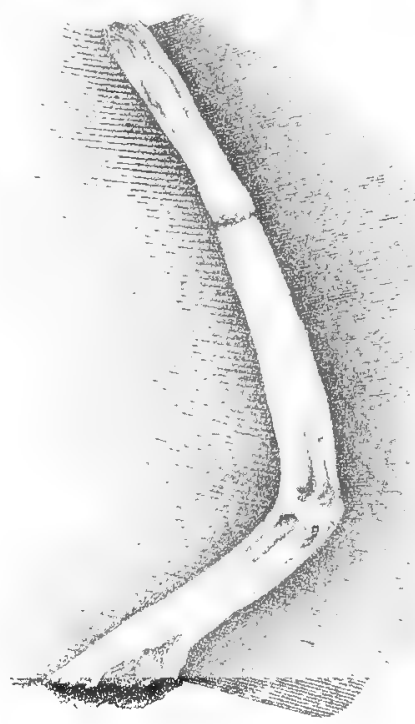





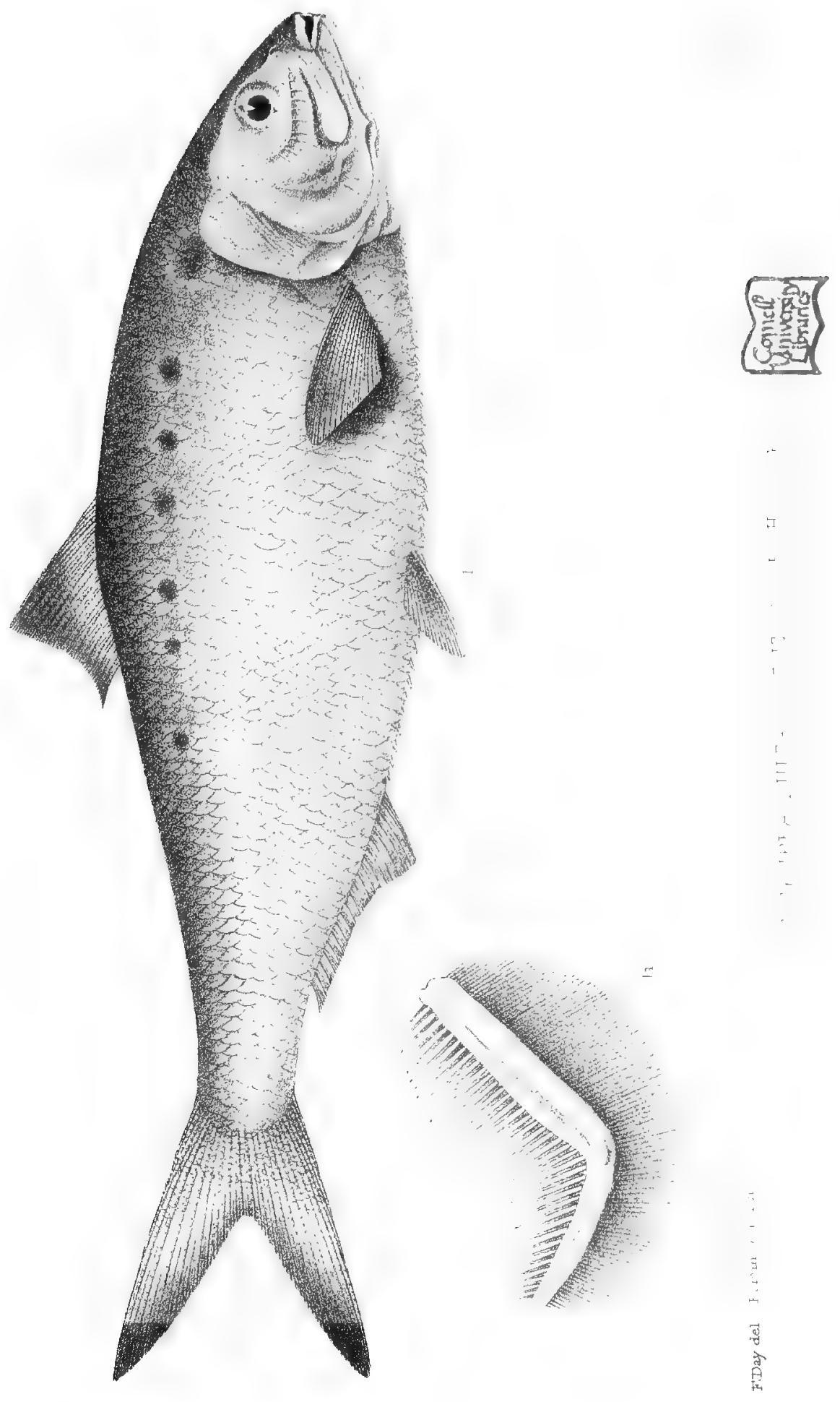





$$
99
$$



曷
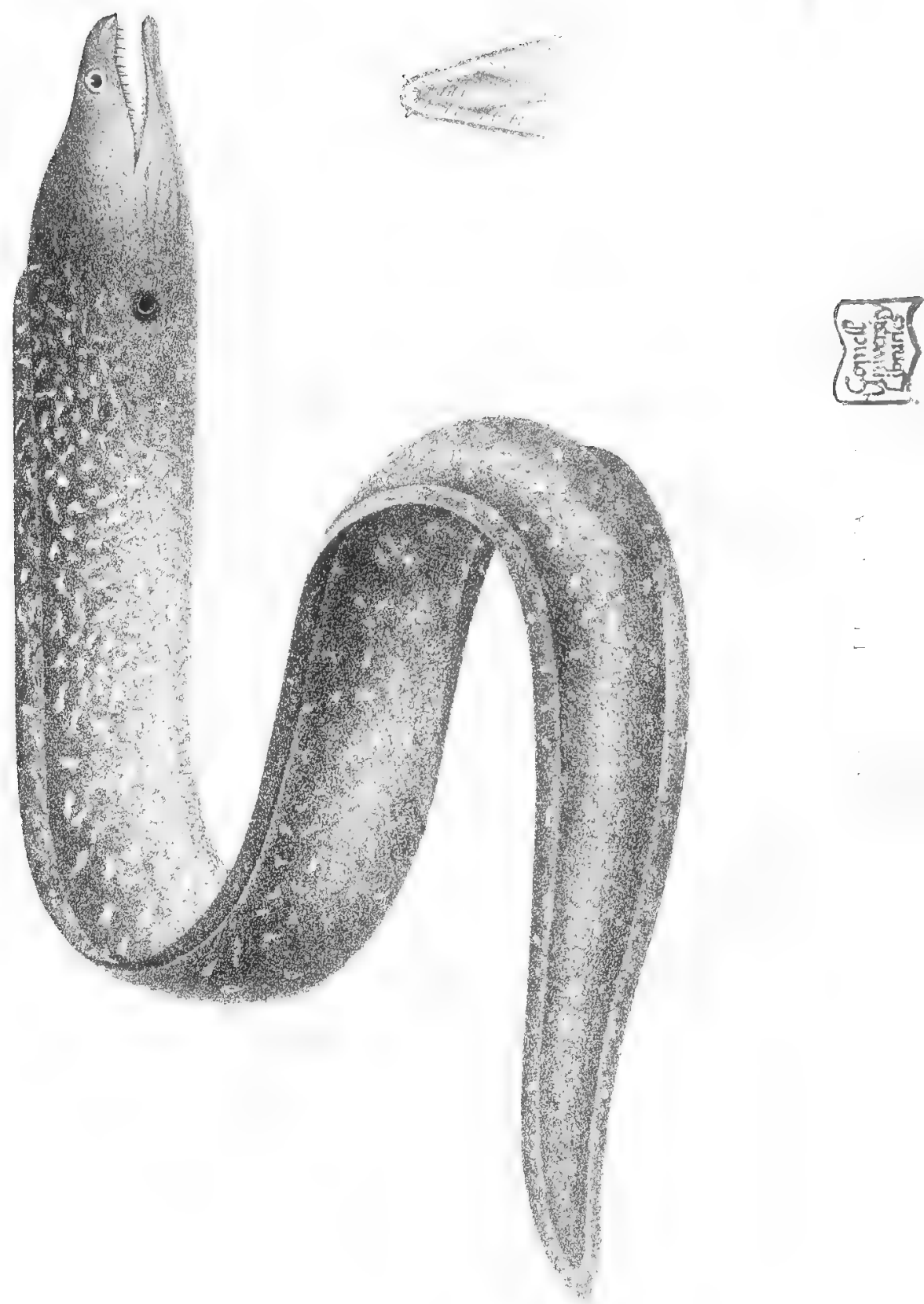

$\geq$
3
0
0
0
$\frac{0}{2}$
2

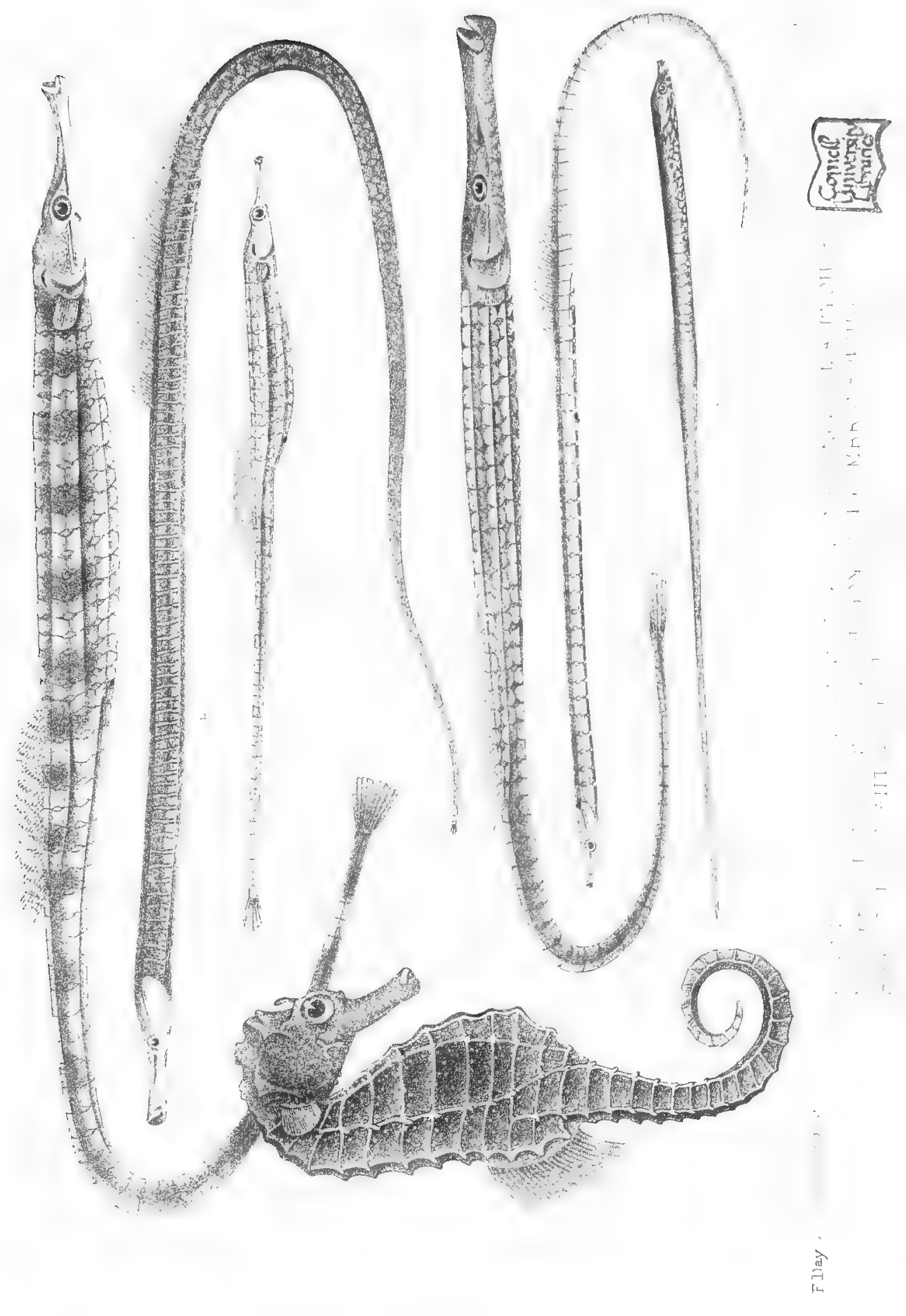




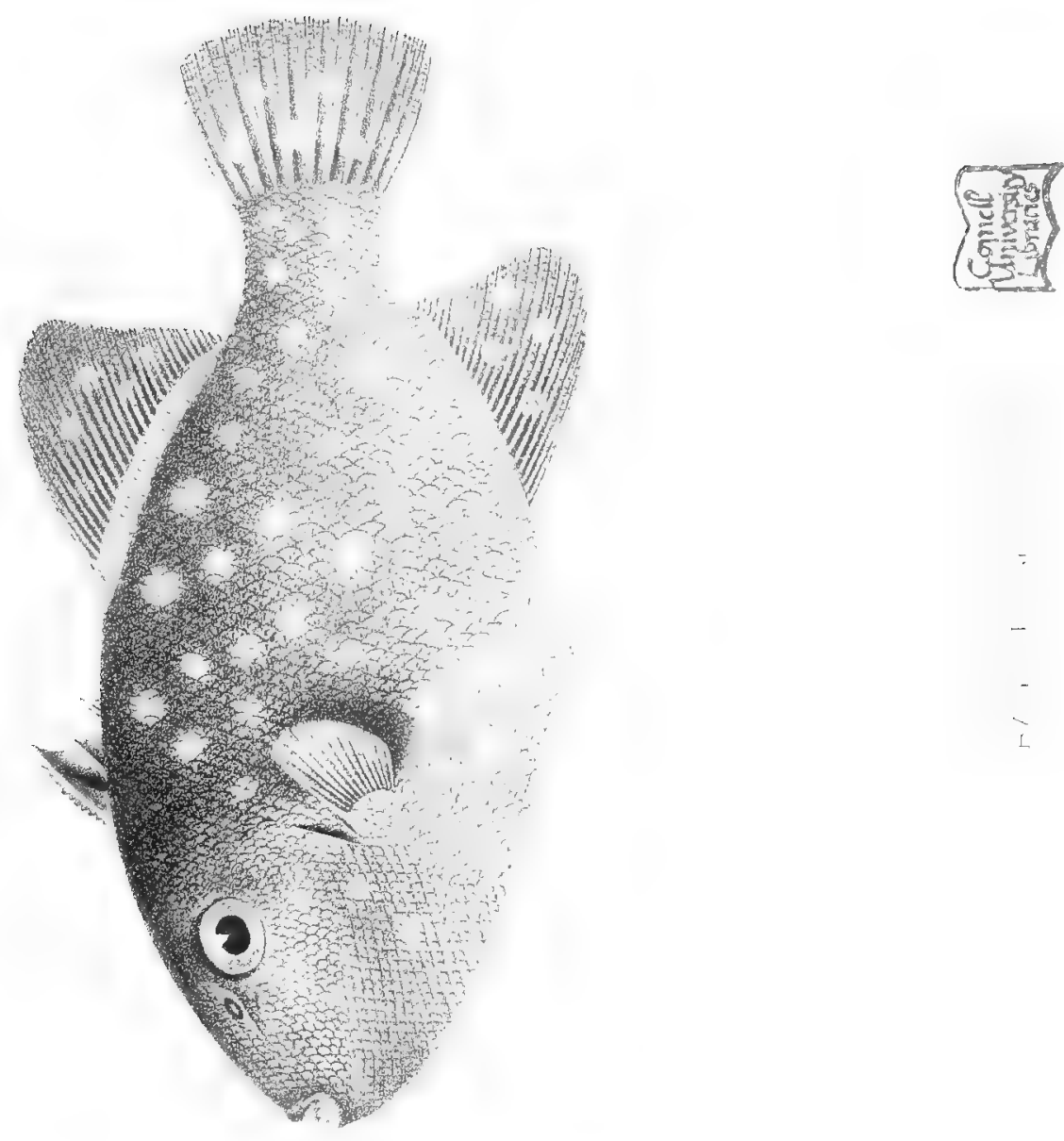

告 



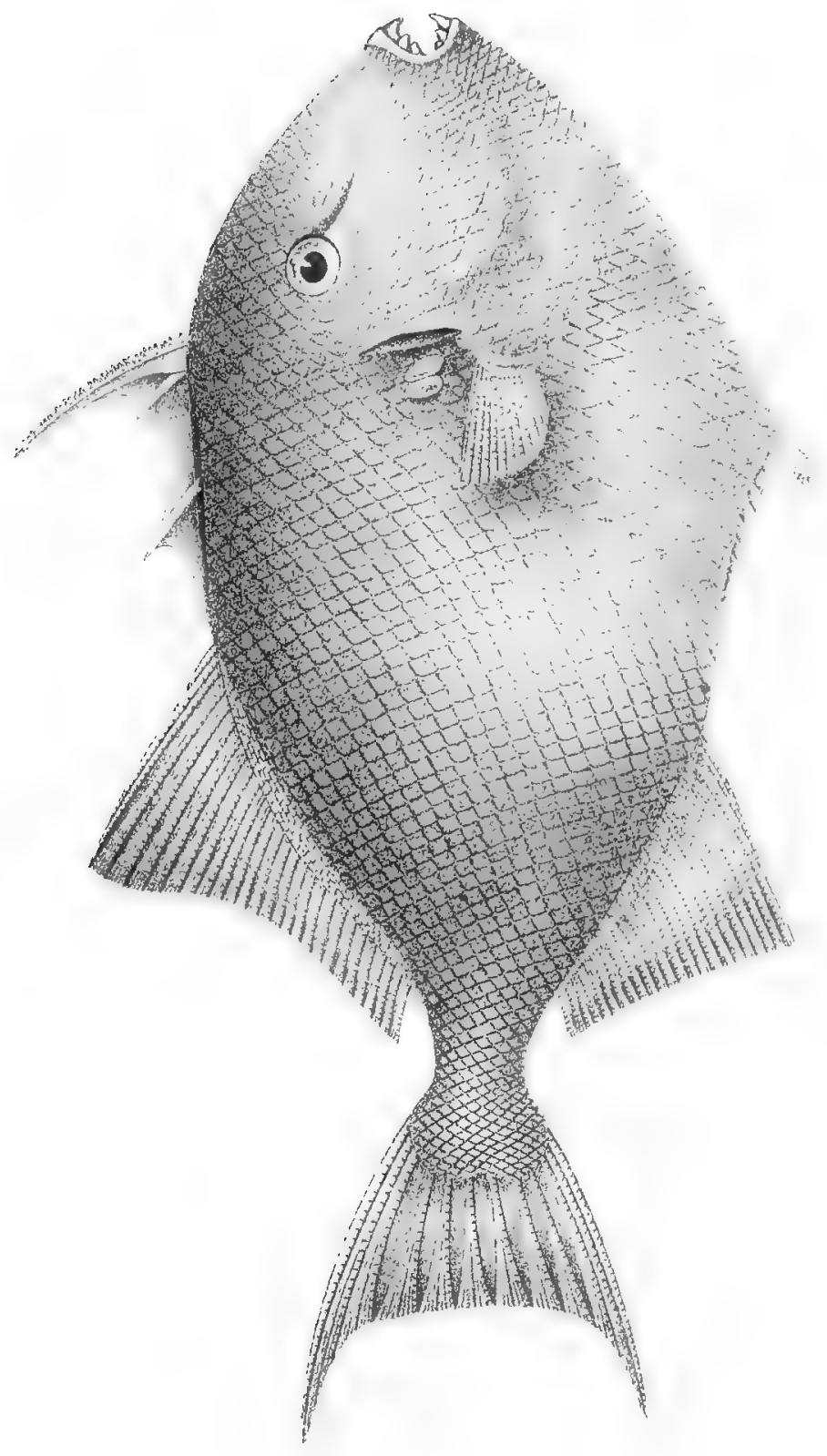

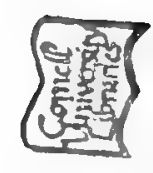


: 

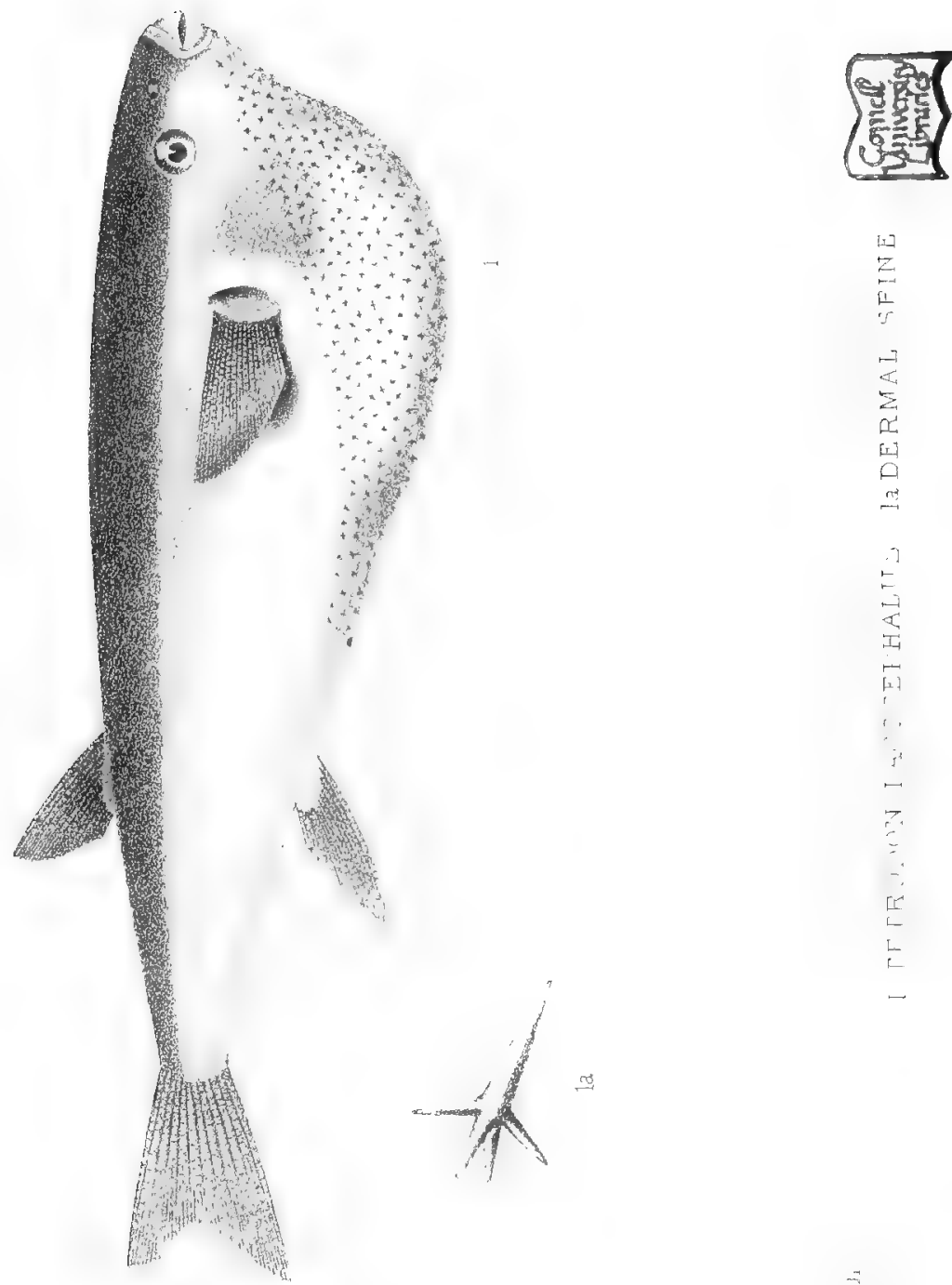

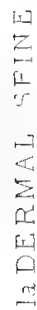





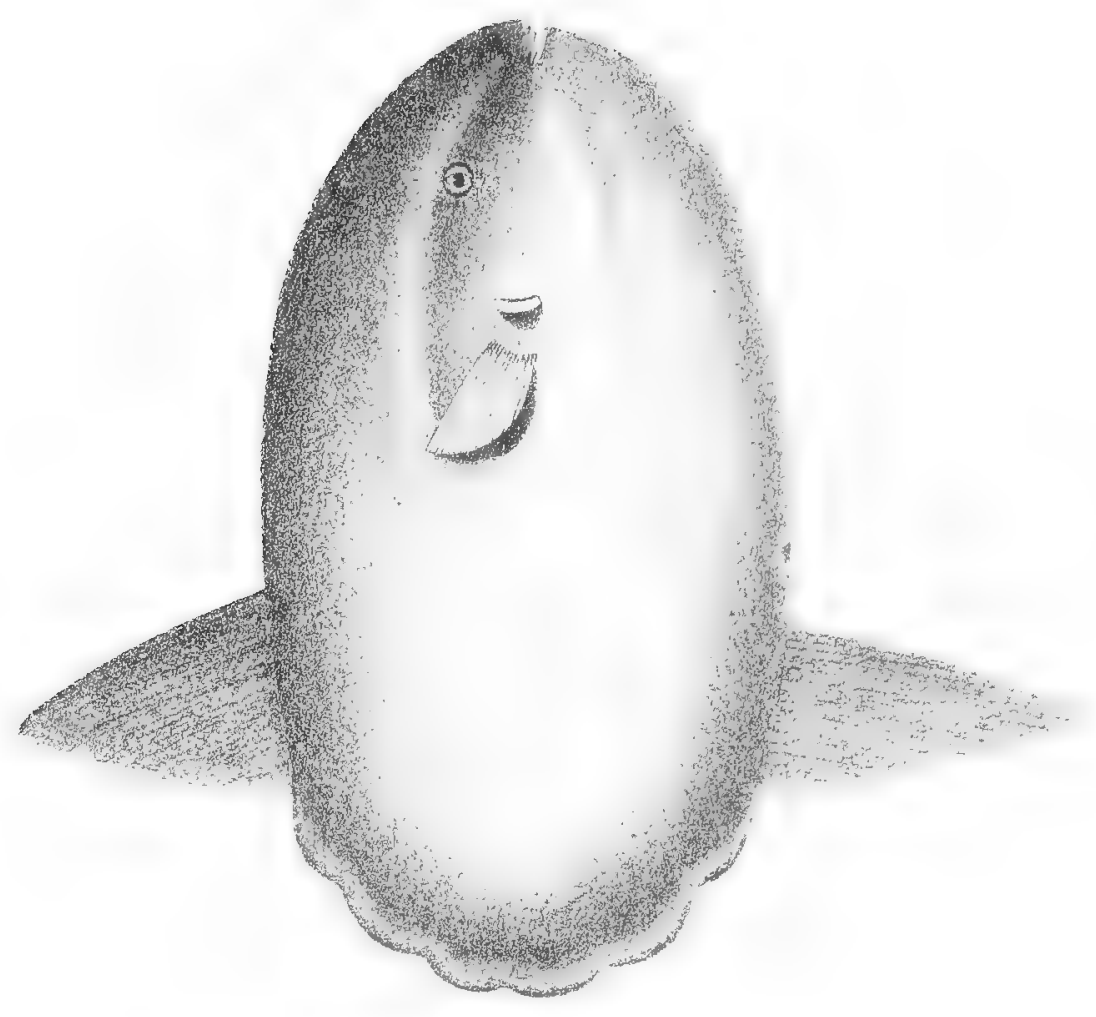

㩆 



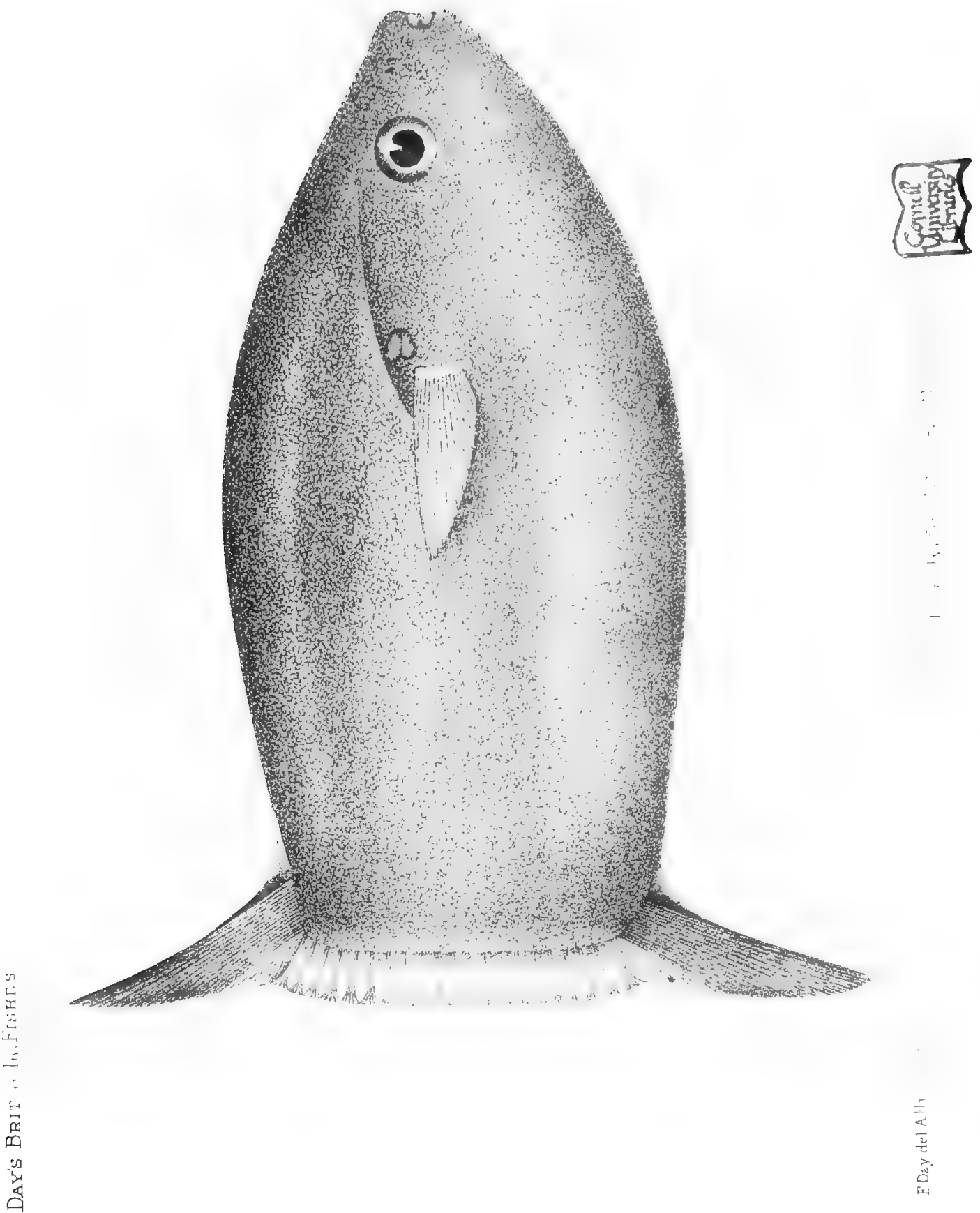




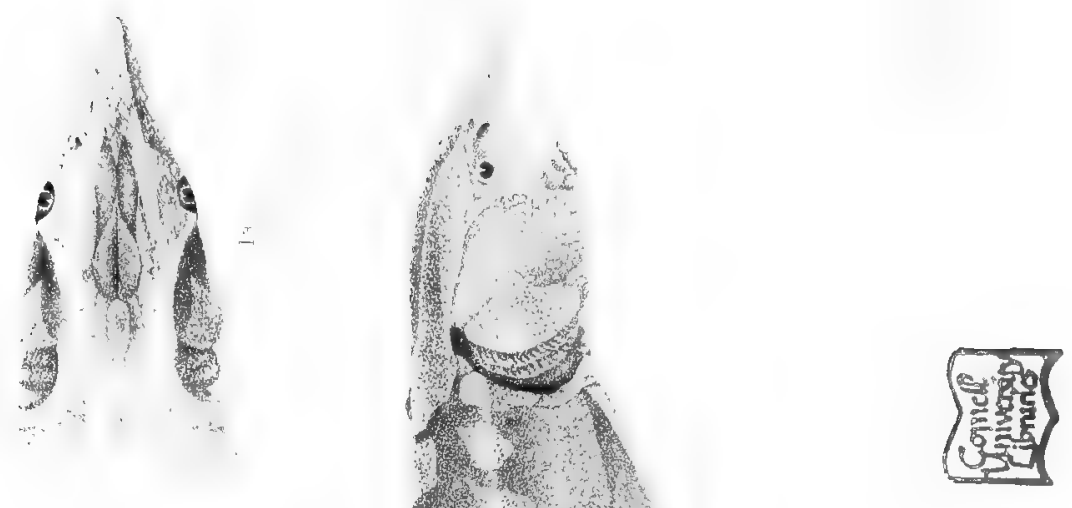

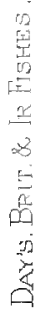
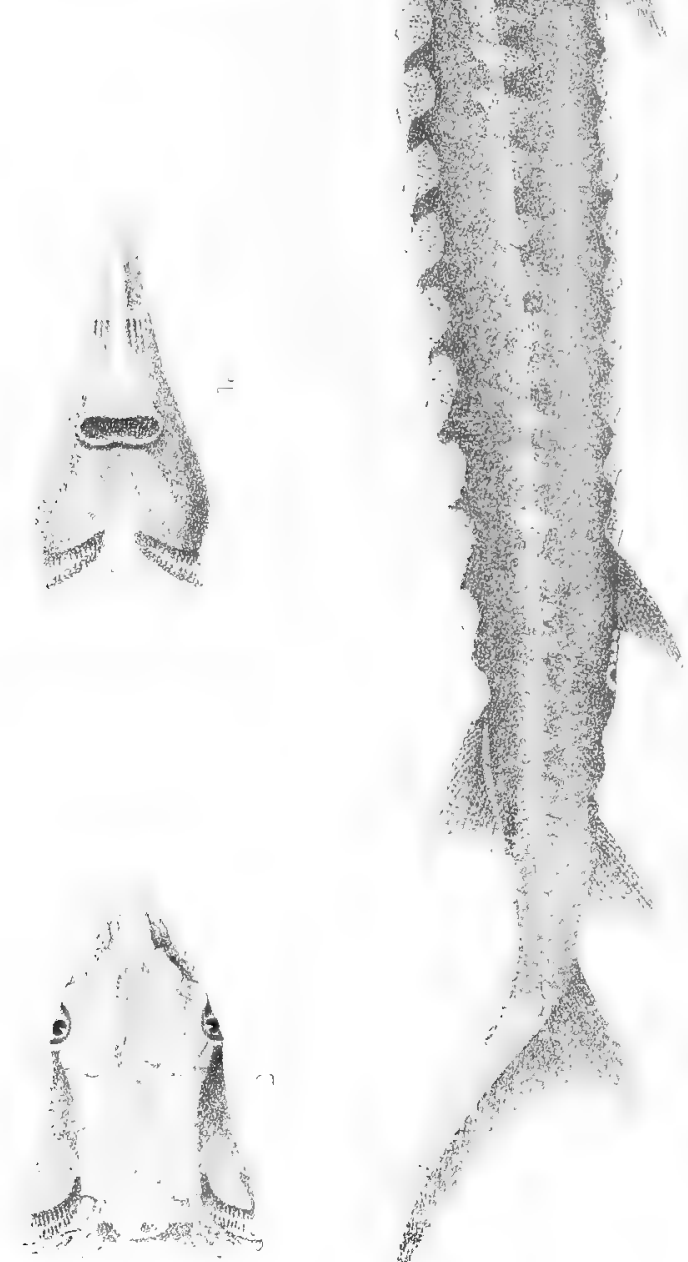



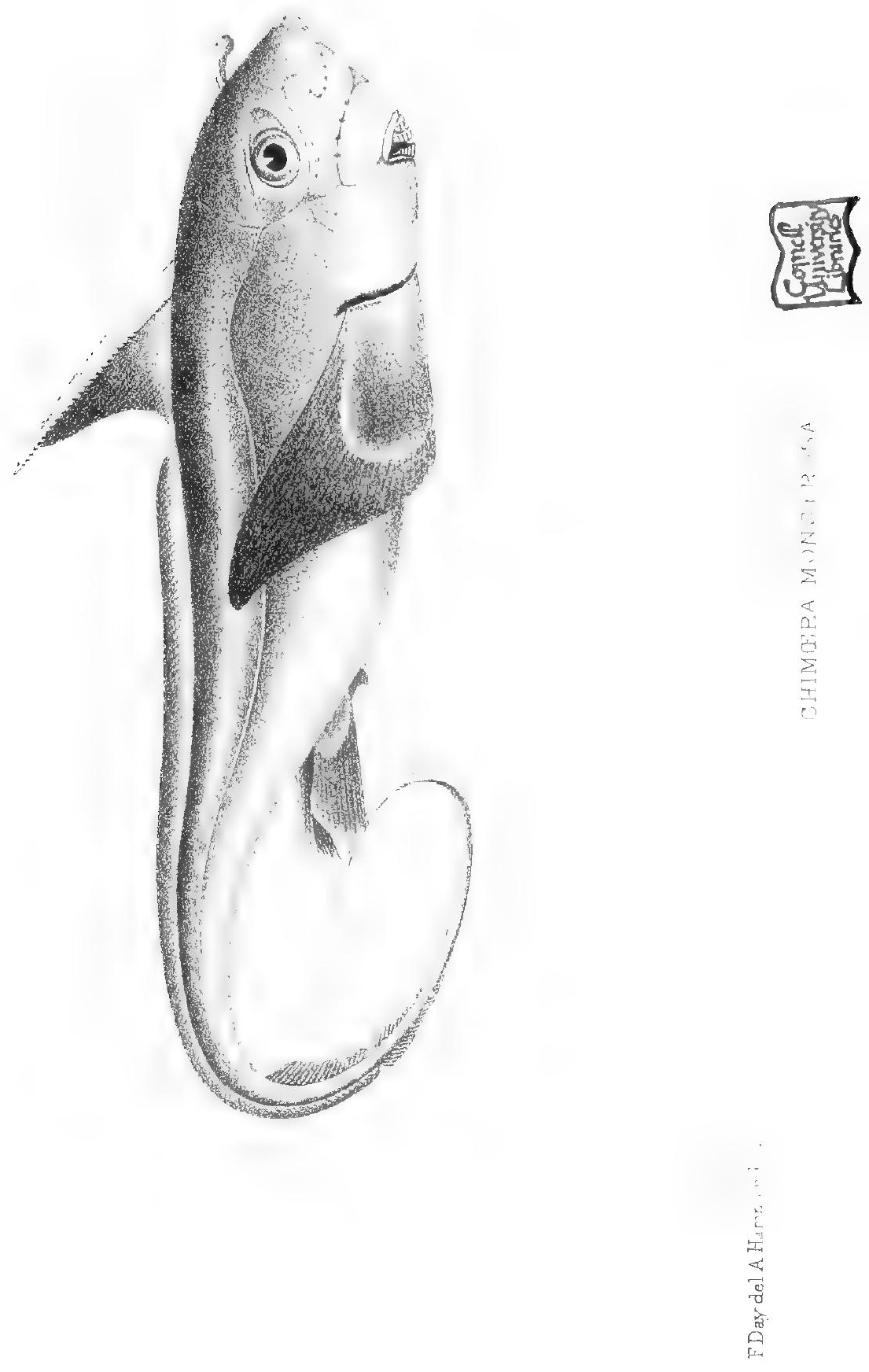





$\equiv$
0
0
$\overrightarrow{0}$
$\overrightarrow{0}$

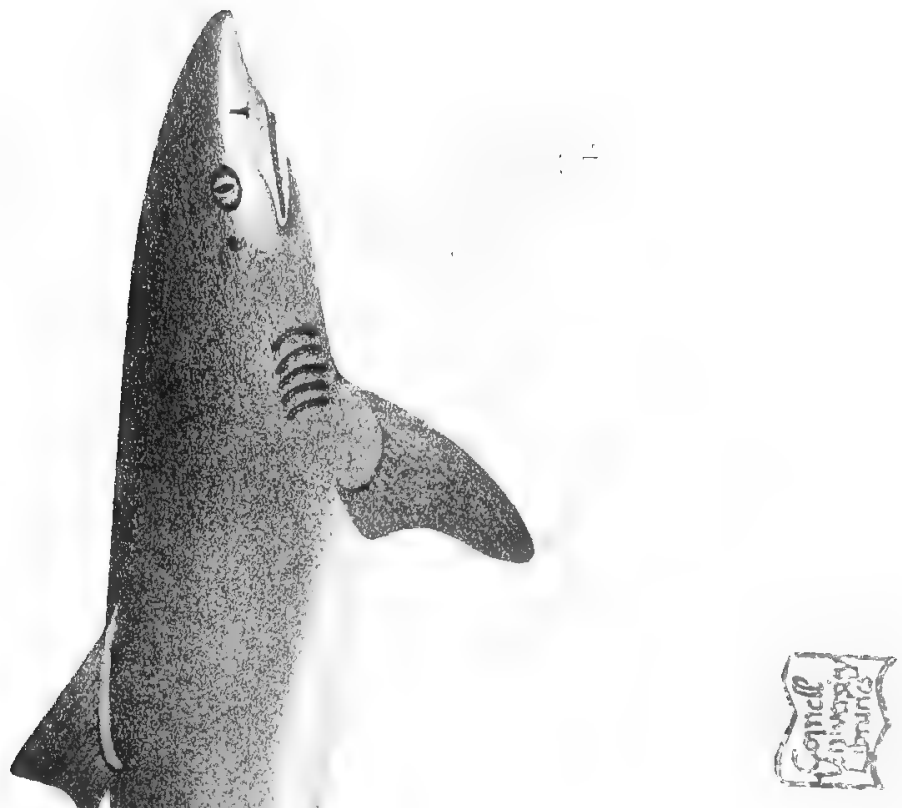

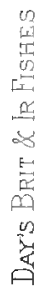

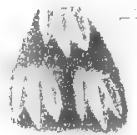





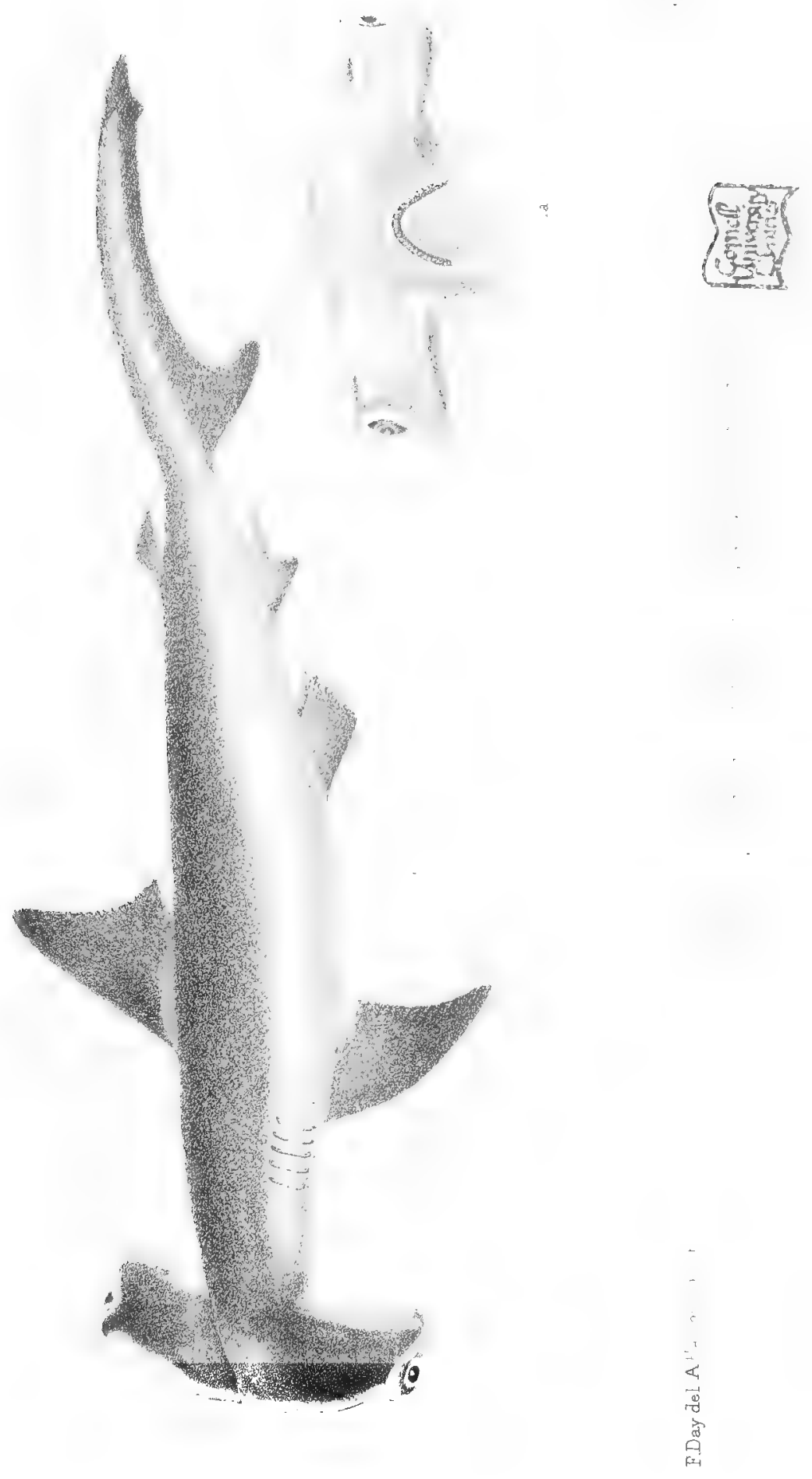




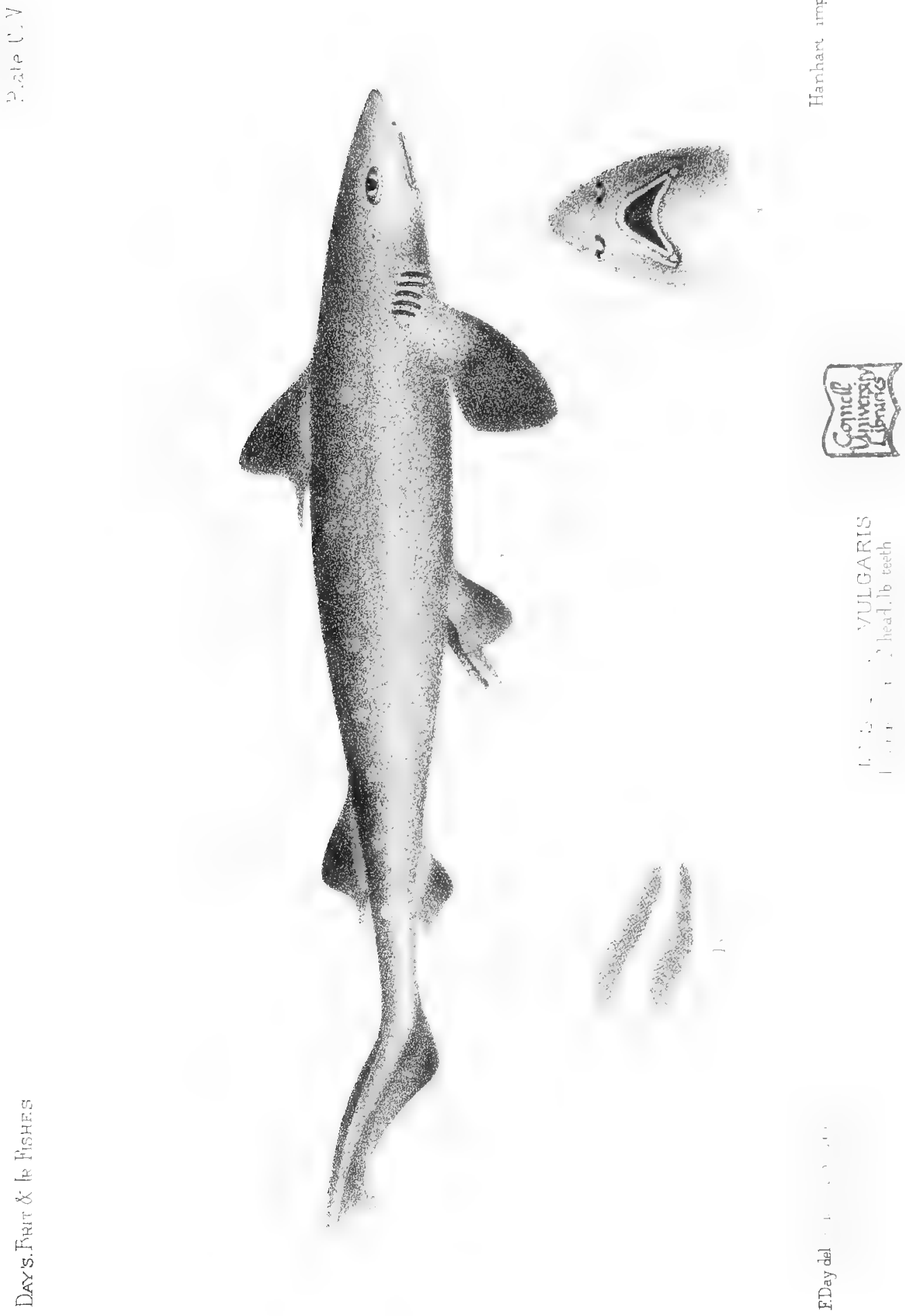



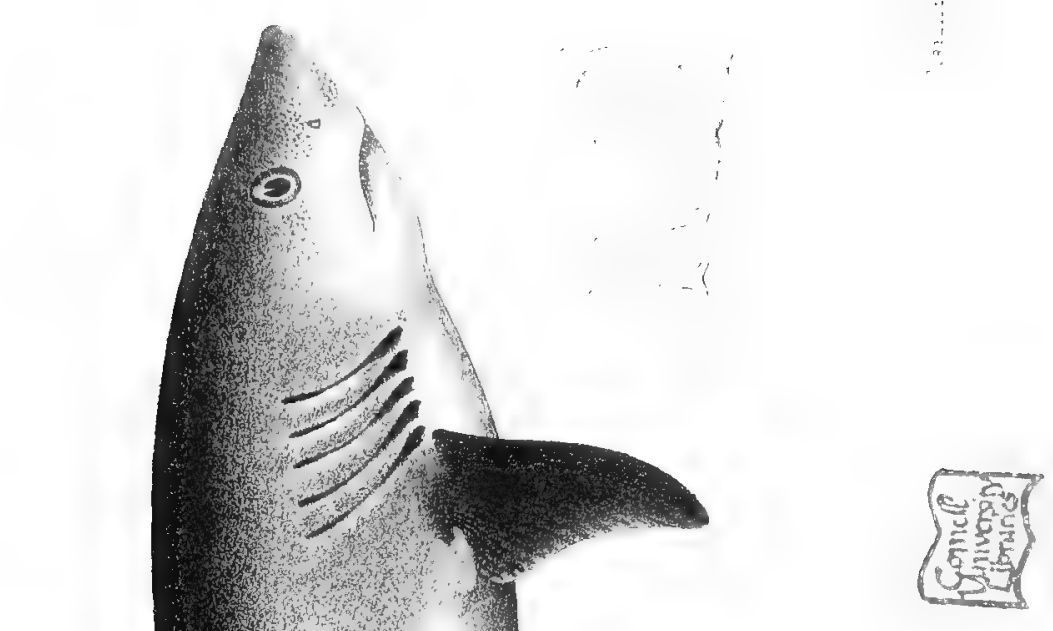

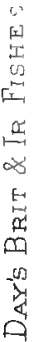





$$
1
$$



$\overline{5}$
$\frac{1}{3}$
$\frac{0}{2}$
$\frac{0}{2}$
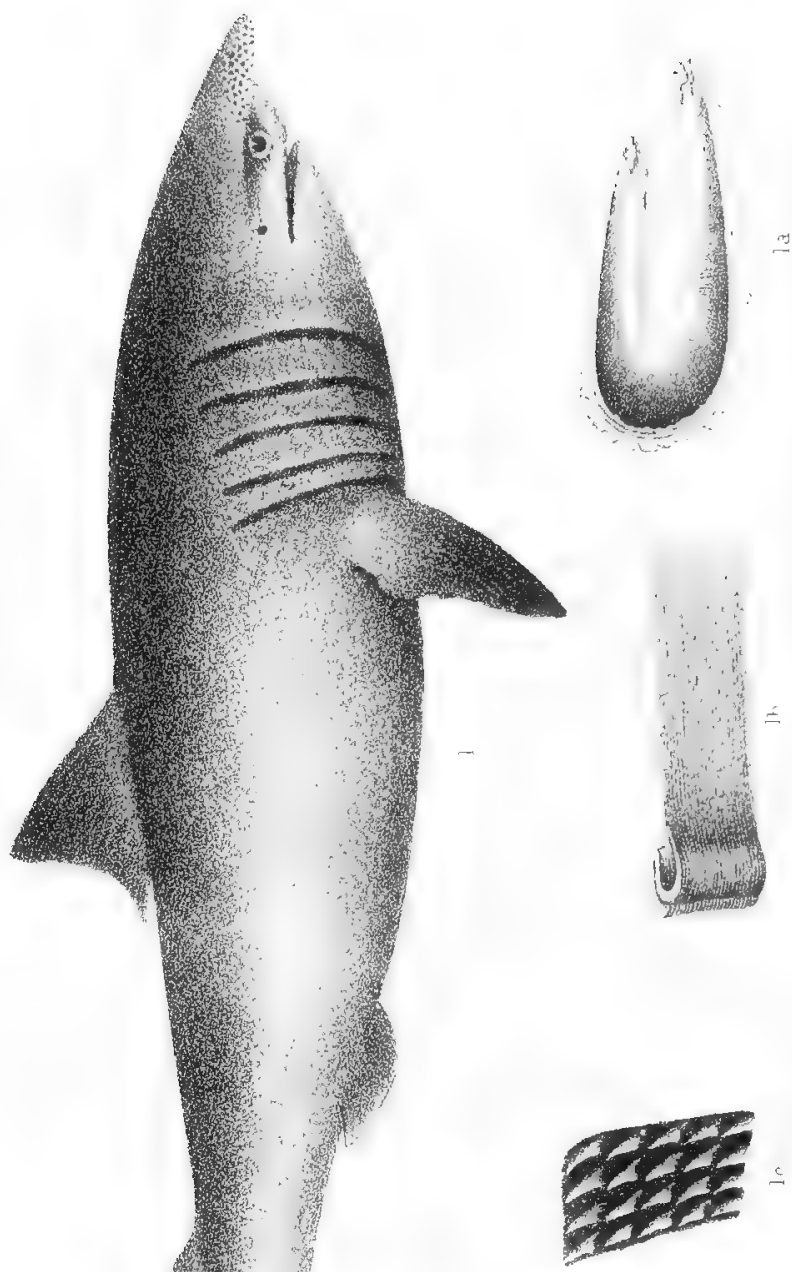

20.
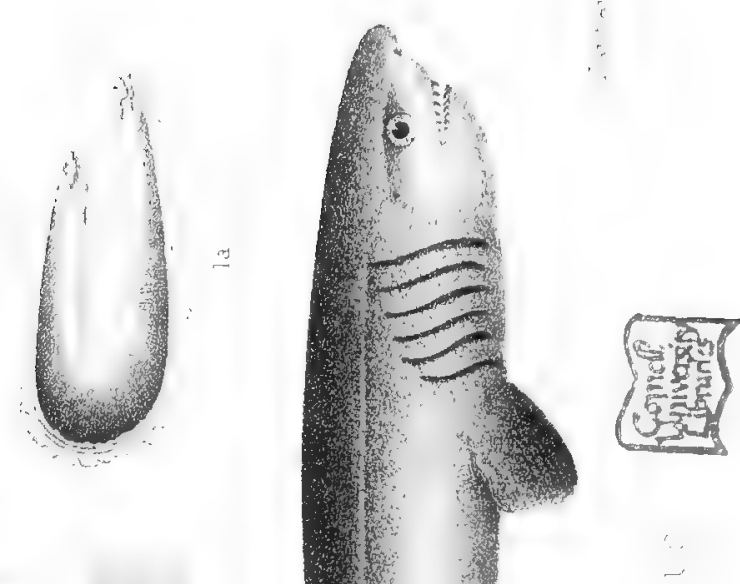

I
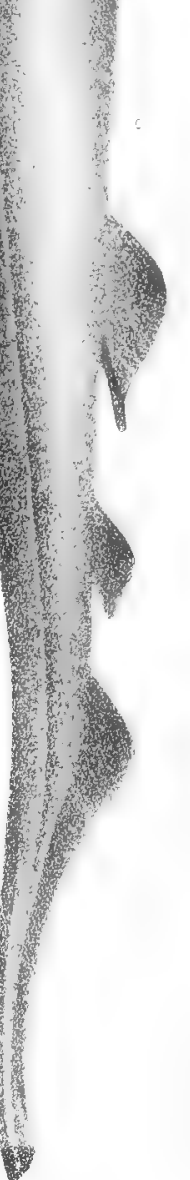

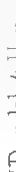



0
$\frac{1}{0}$
$\frac{0}{2}$
$\frac{\pi}{2}$

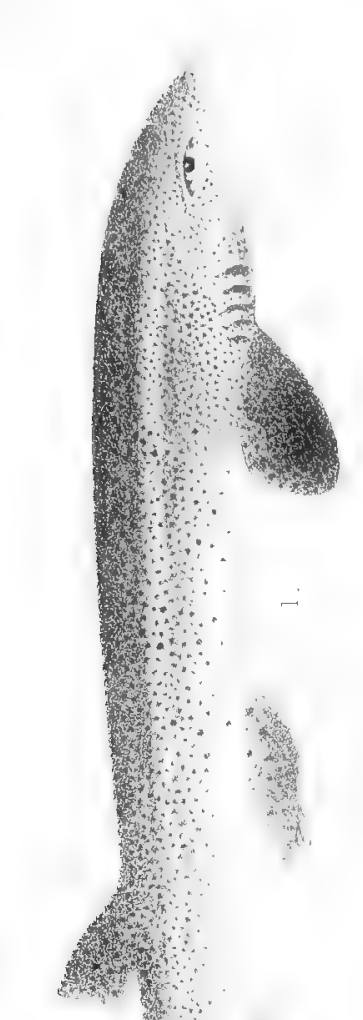

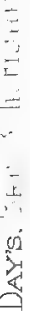

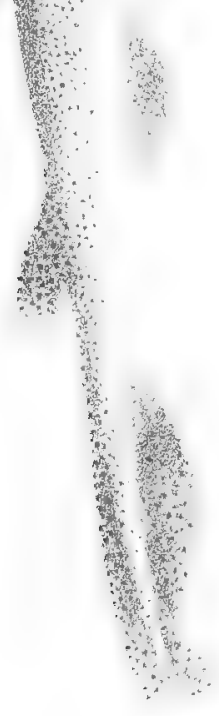

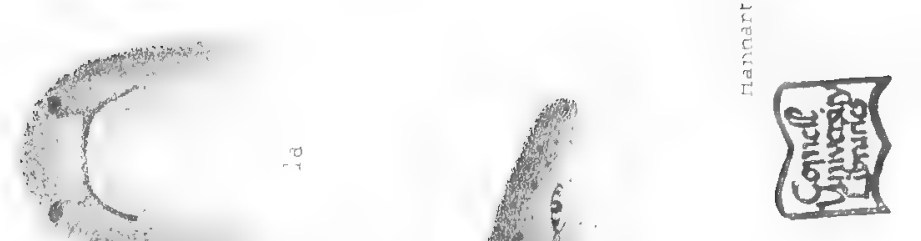
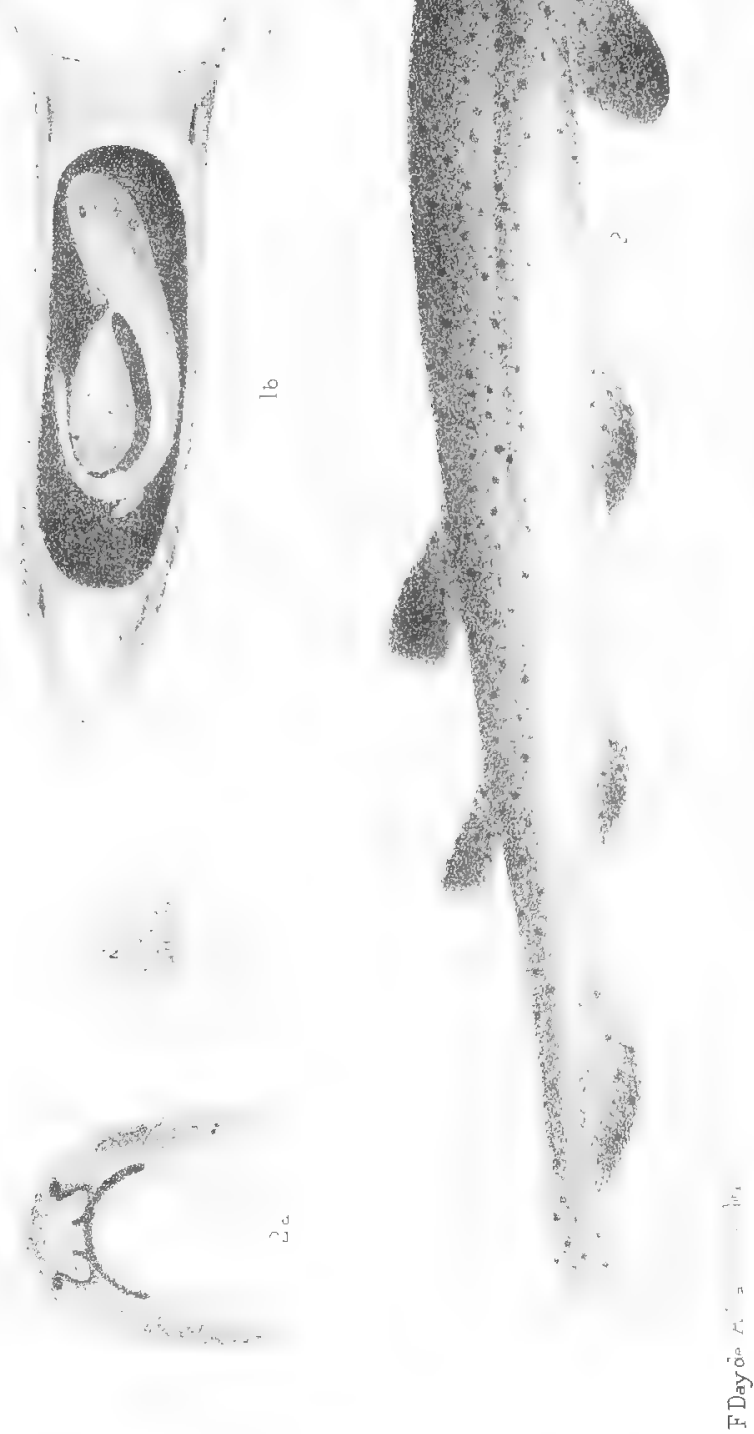

$x$
0
0
0
0
0
0

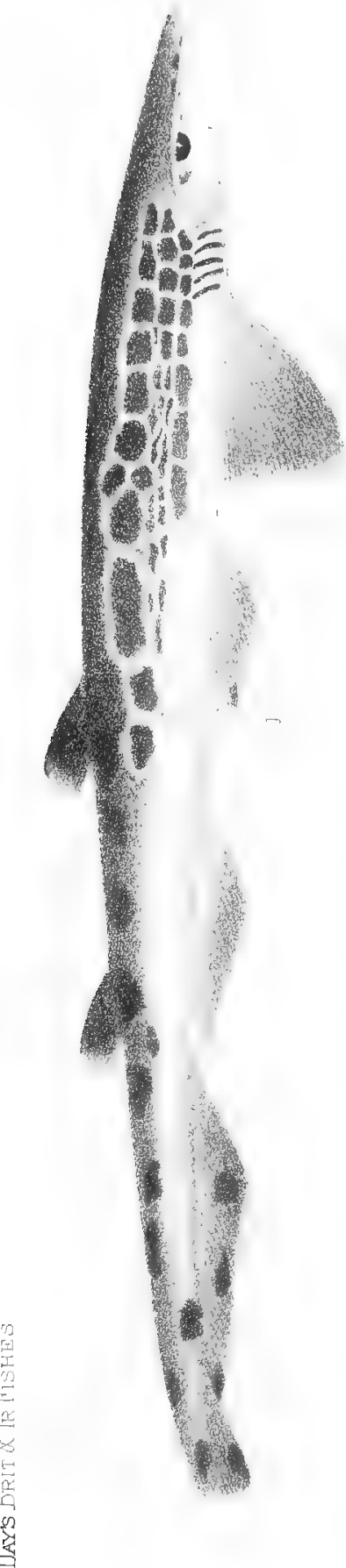

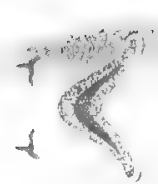

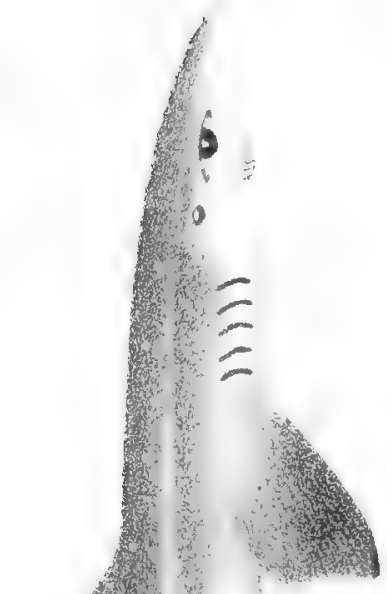

裔
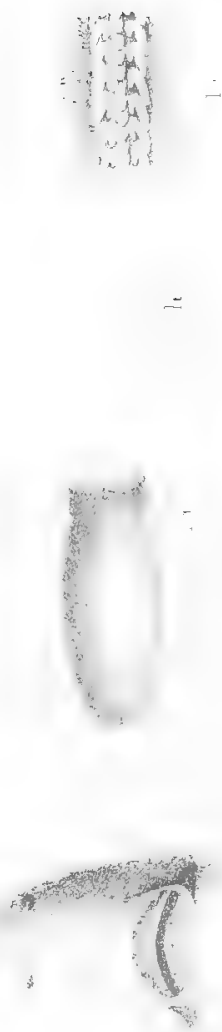

$\underset{0}{\overrightarrow{0}}$ 

5
0
0
0
0
0

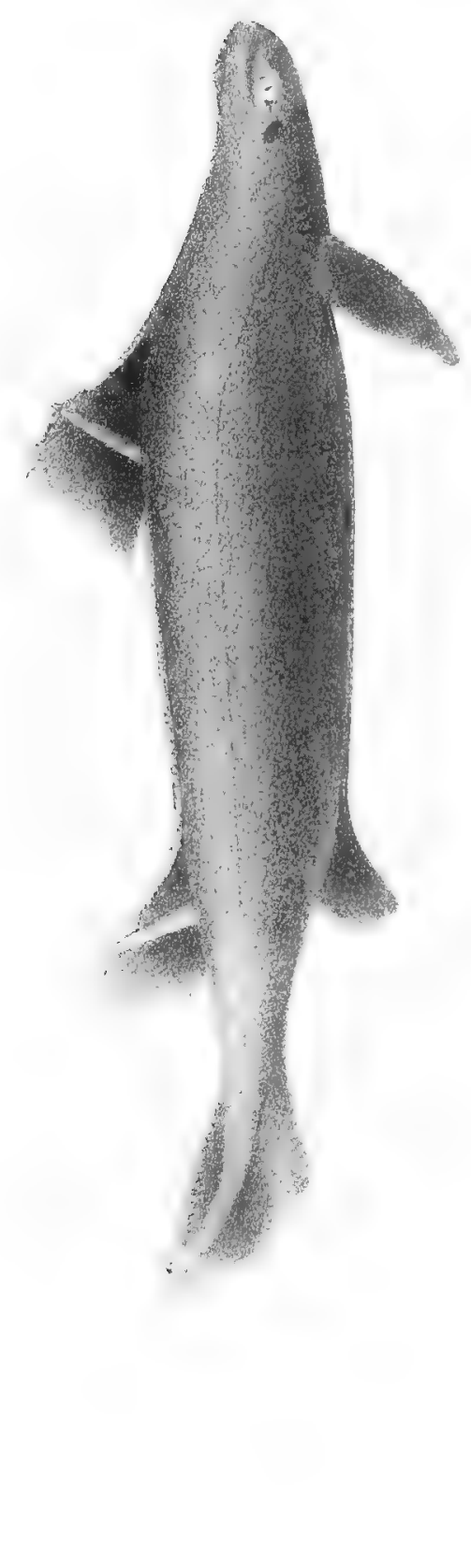

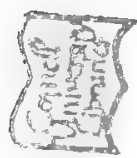

年 



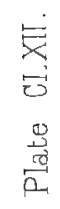

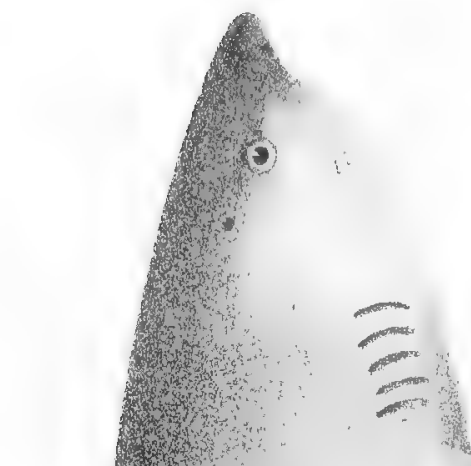

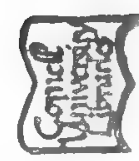
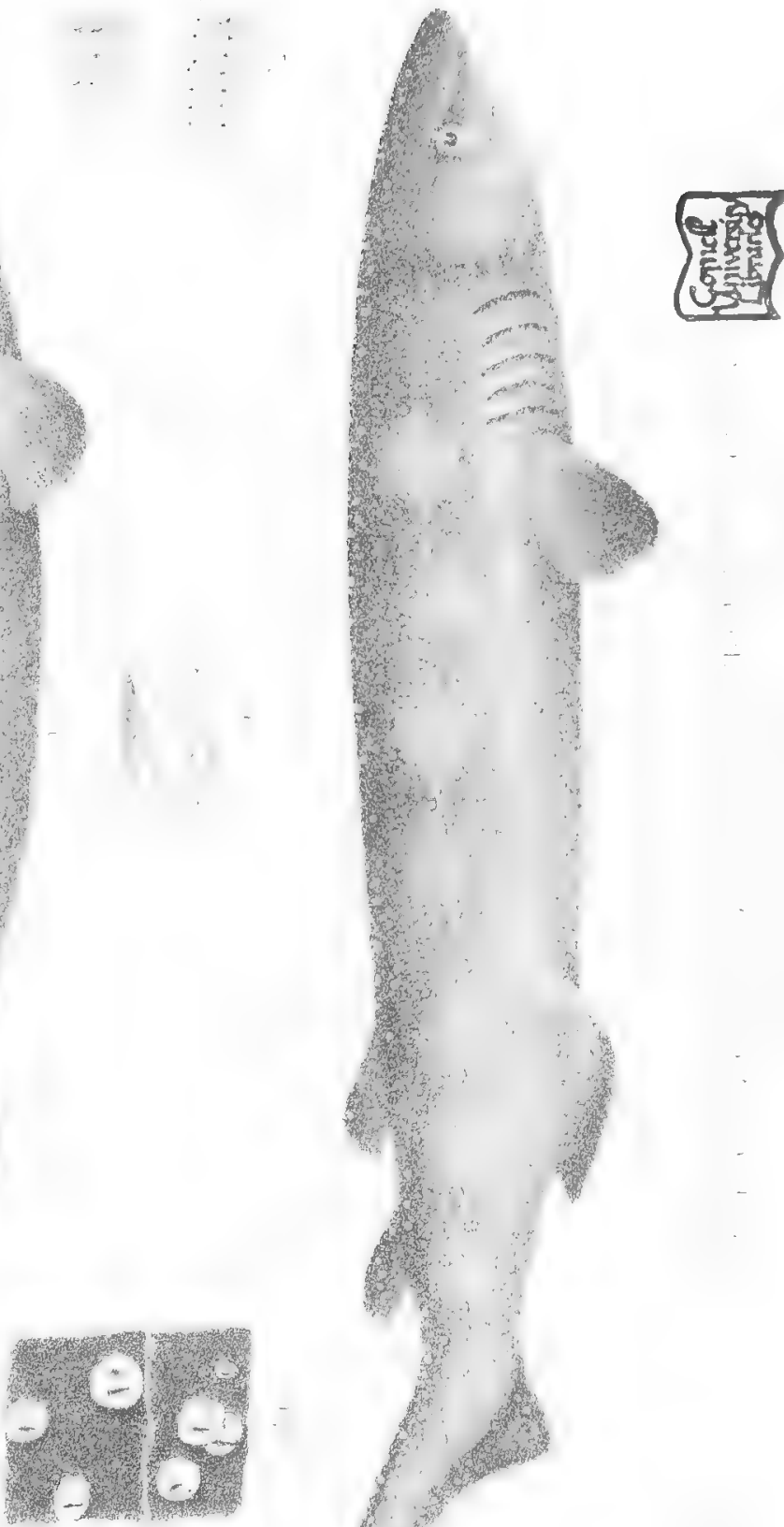

列

1.

3.

m

iv

E

tit

(5)

(x)

M.

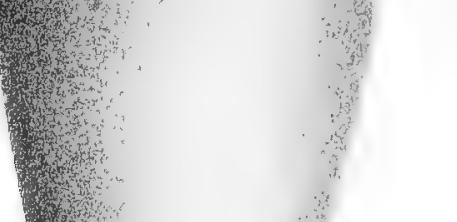

0
0
0
0
0
0
0
0
0
0
0
0
0
0

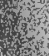

r.
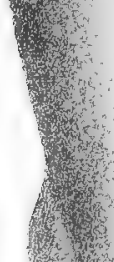

.
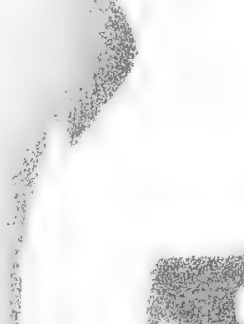

政 



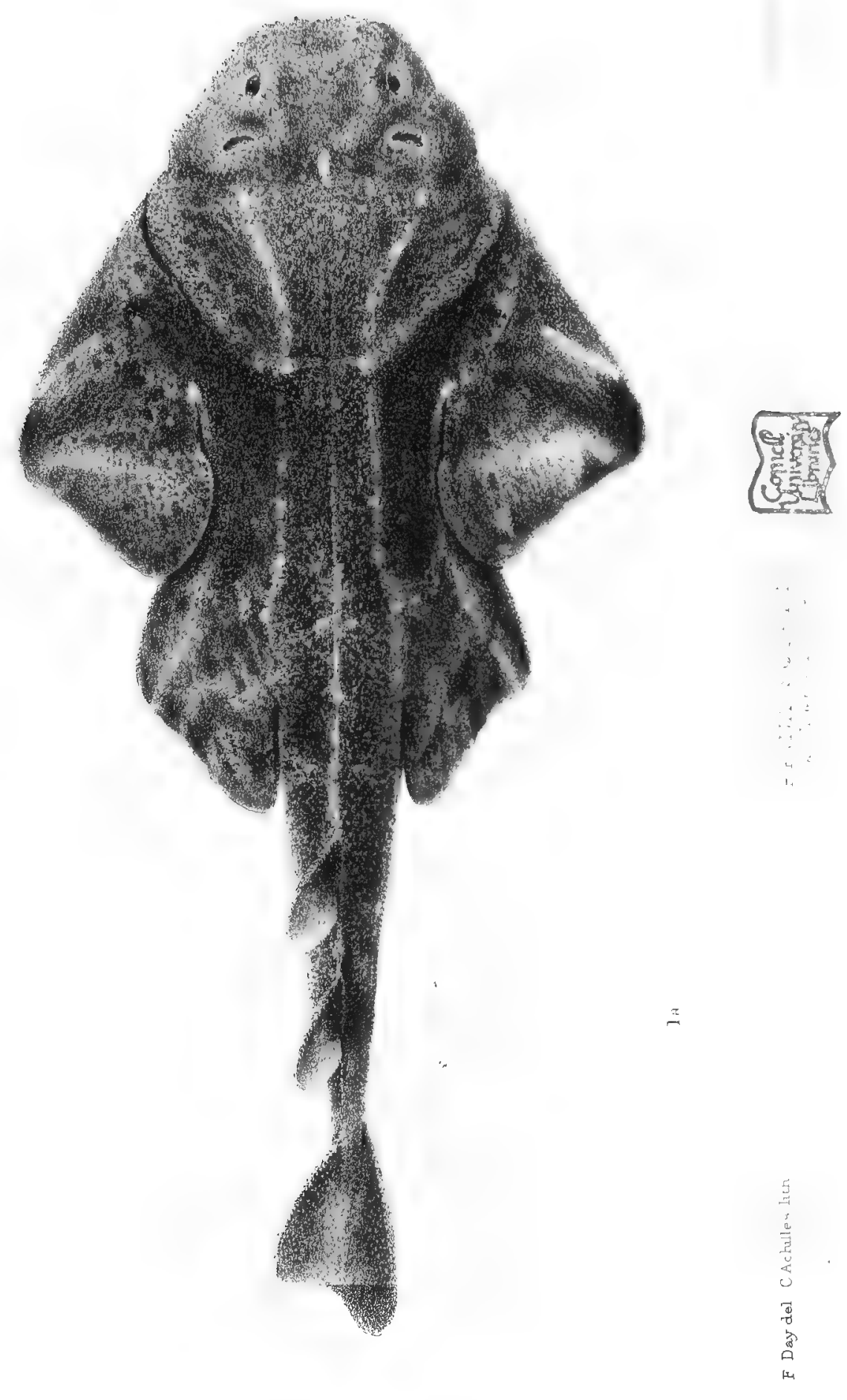




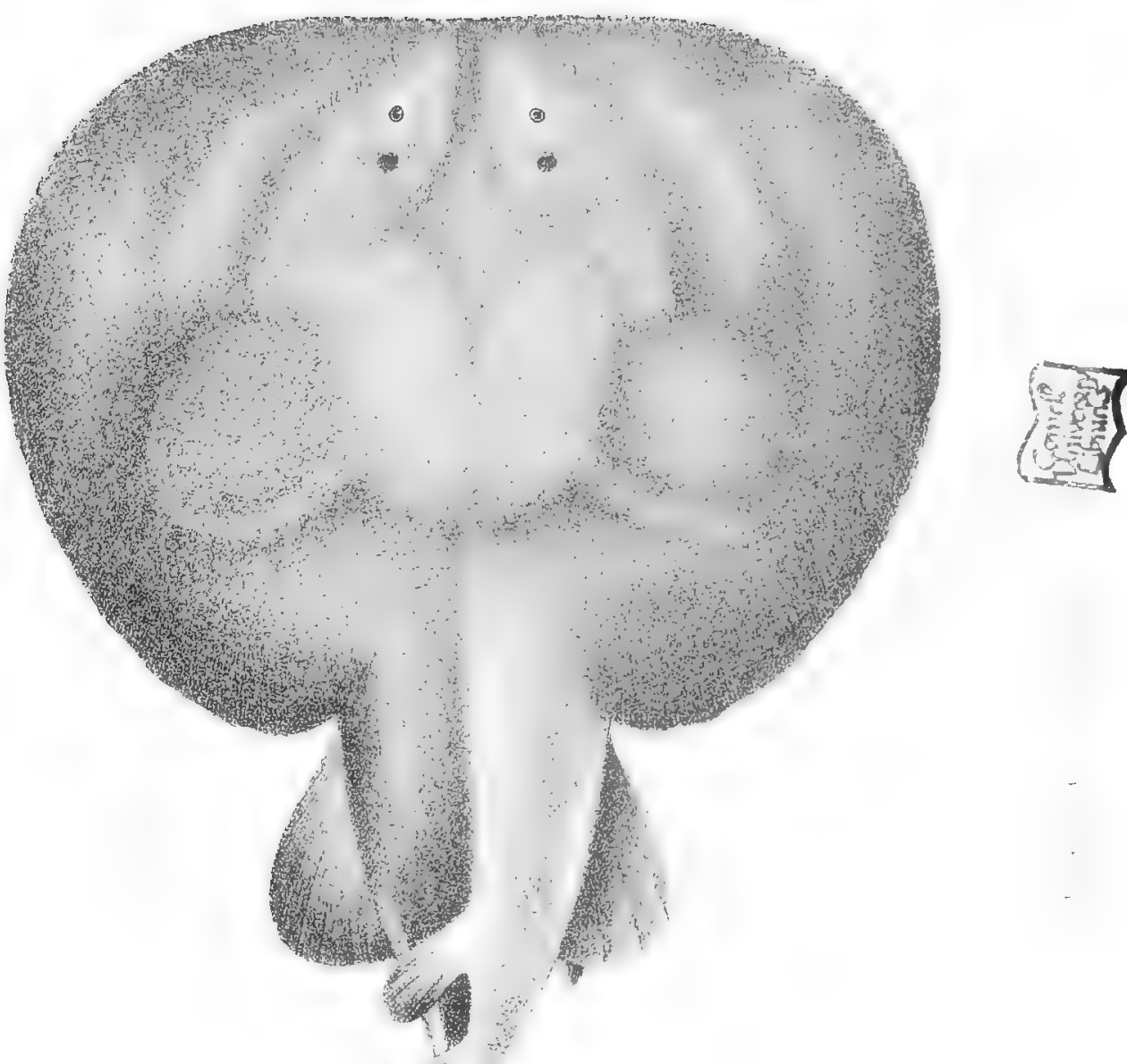

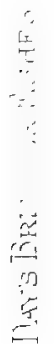

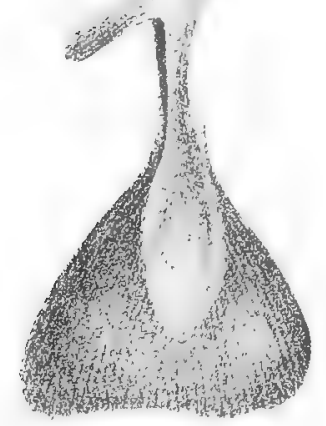



$\overrightarrow{3}$
$\cdots$
$\frac{0}{20}$
$\frac{0}{2}$

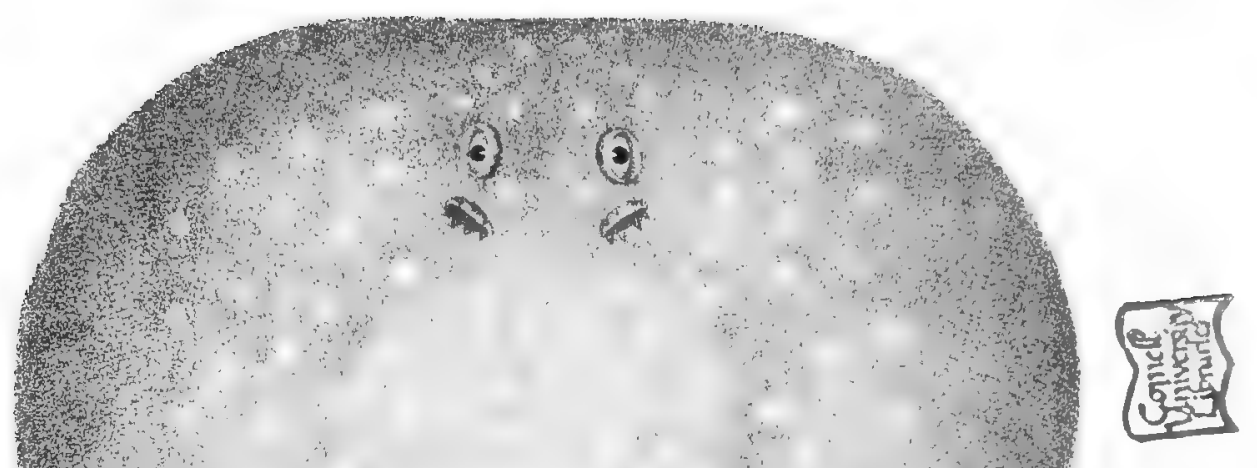

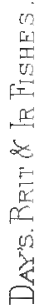



$\sum$
$\frac{3}{3}$
$\frac{0}{3}$
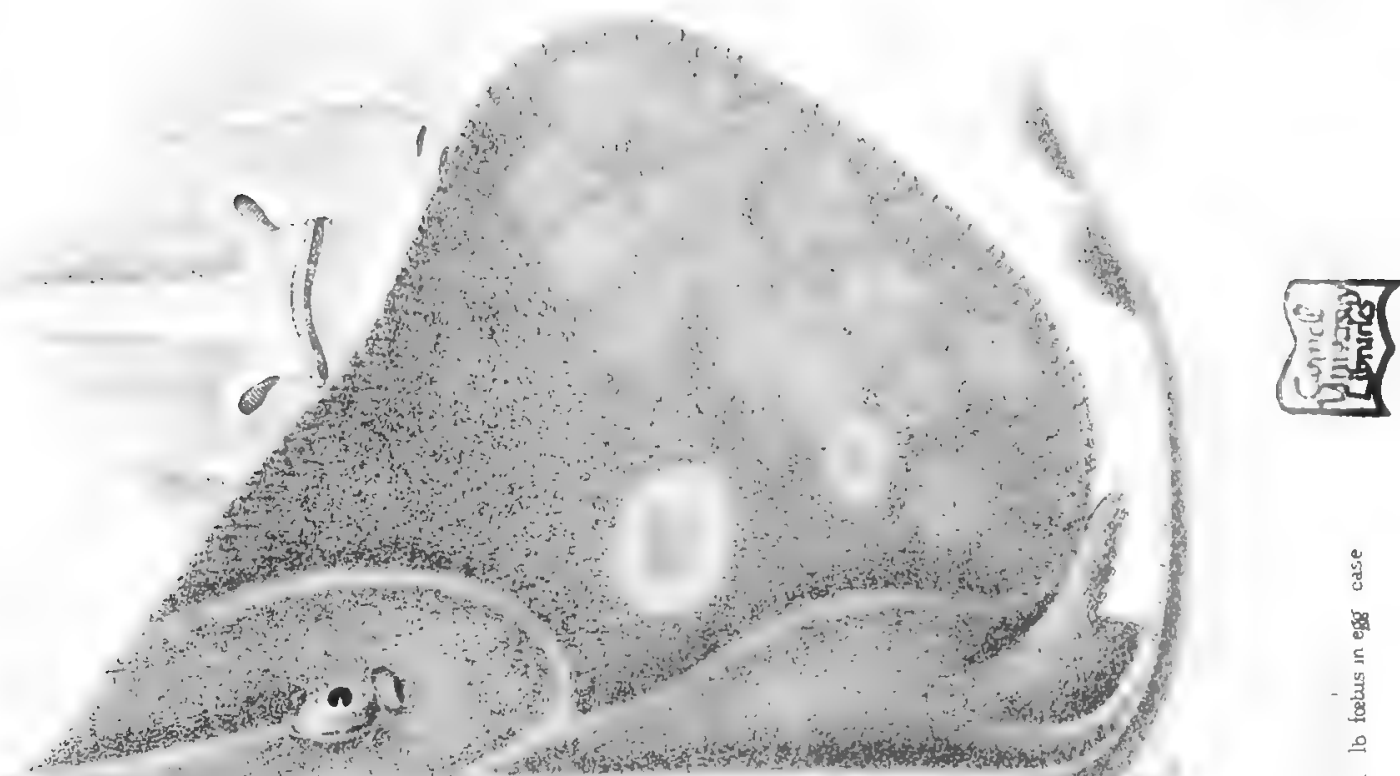

a

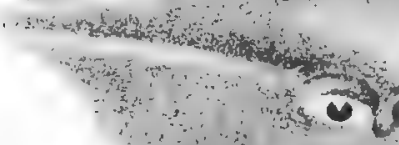

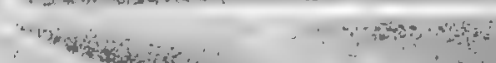
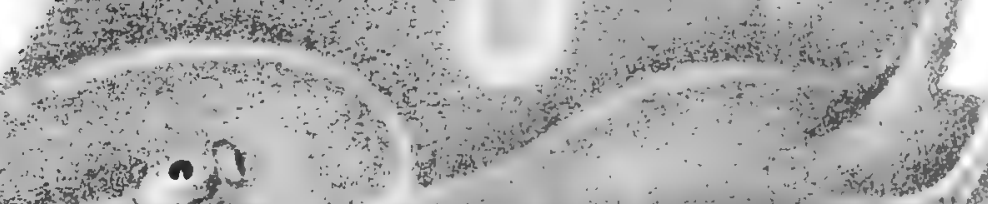

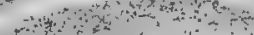
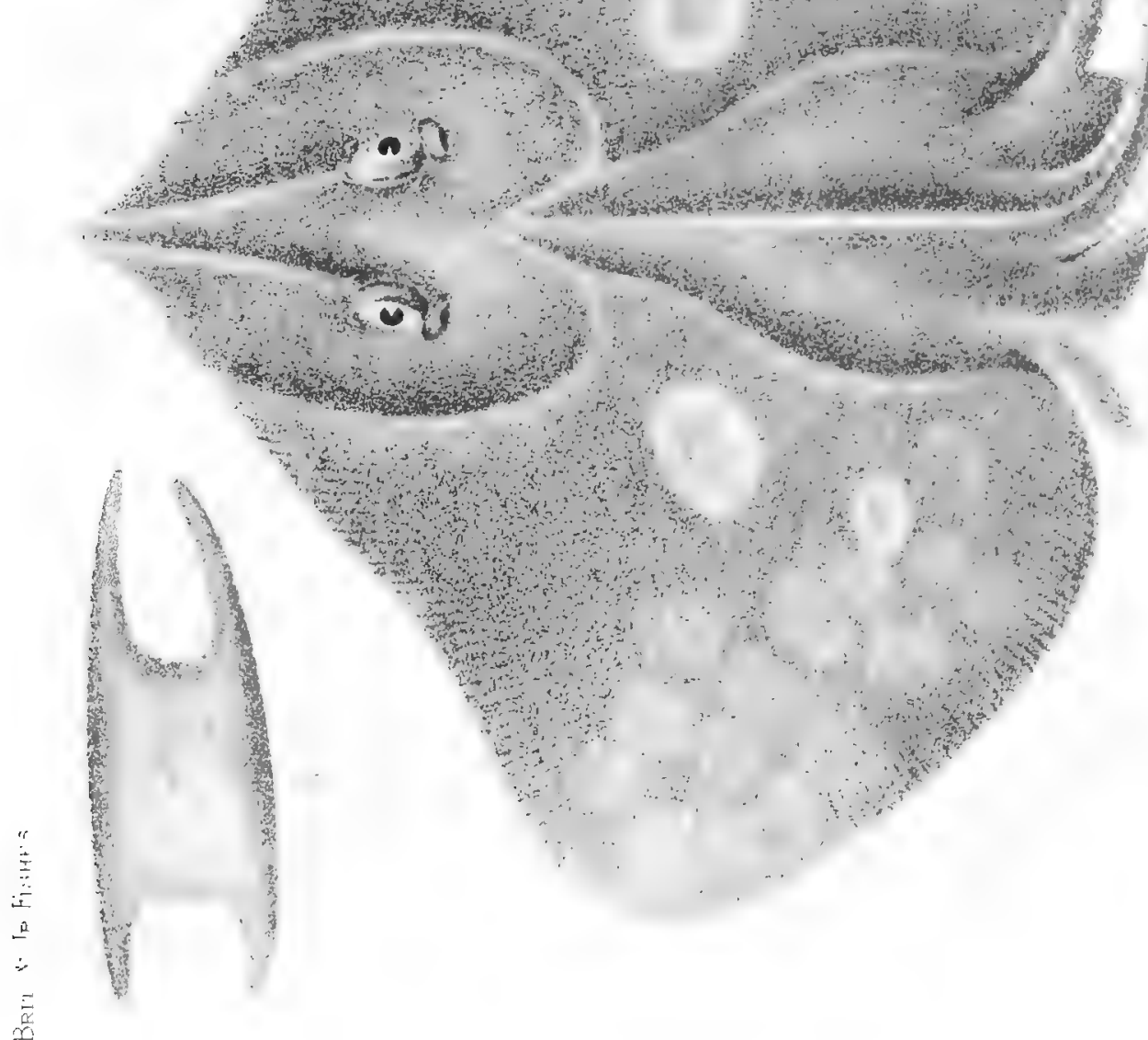

DAY'S BRIT \& IR. FishES

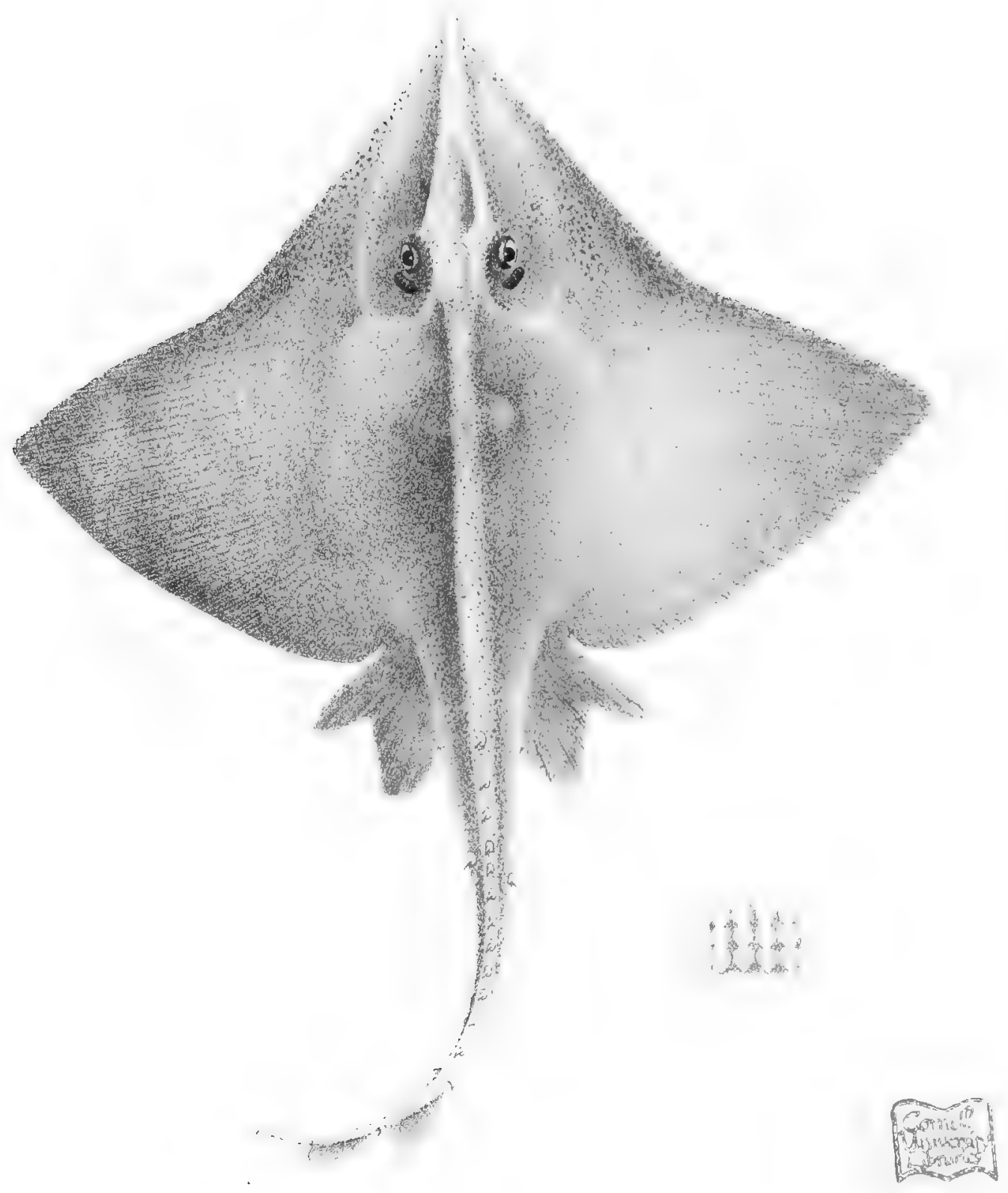

Fanhart imp 



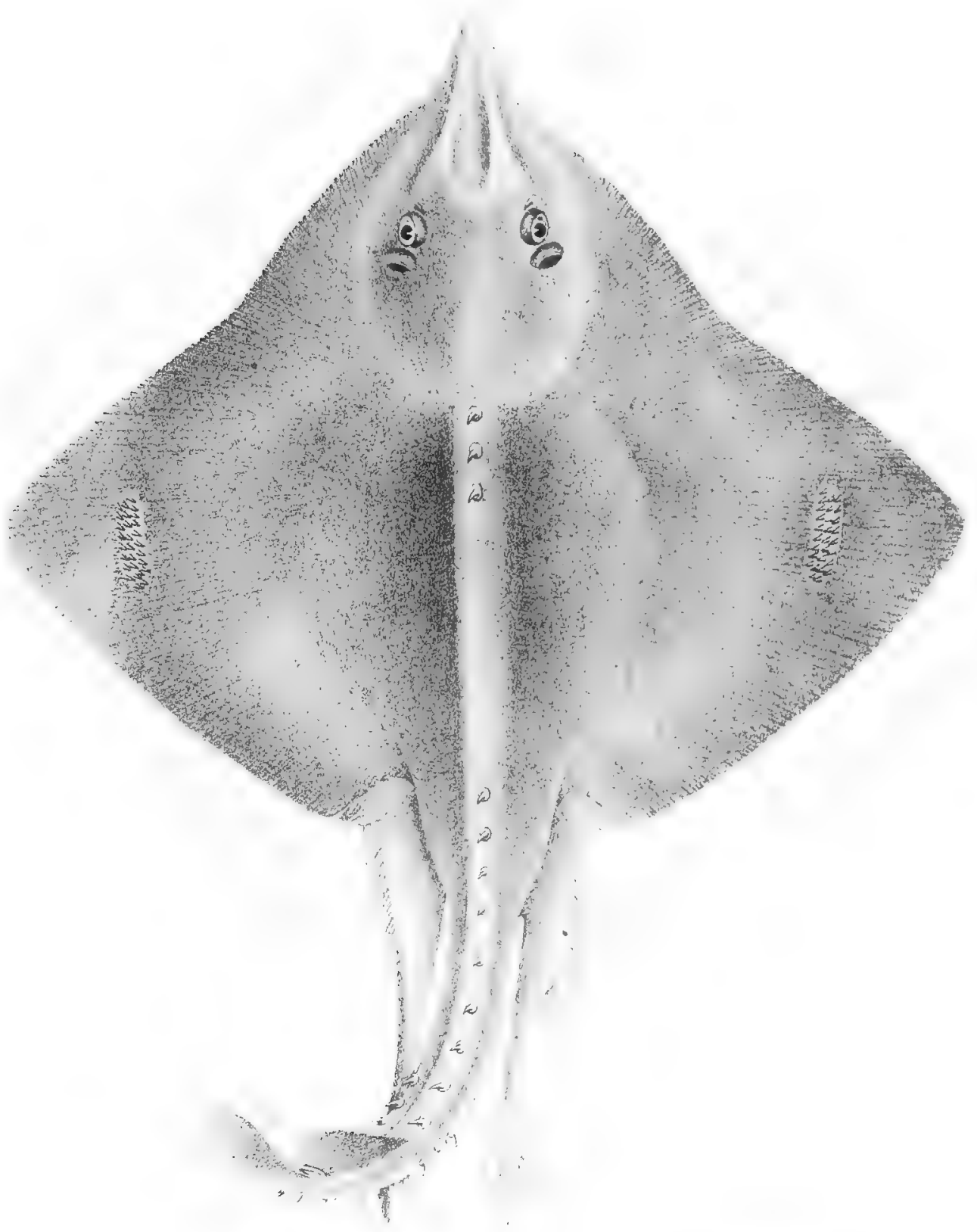





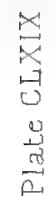

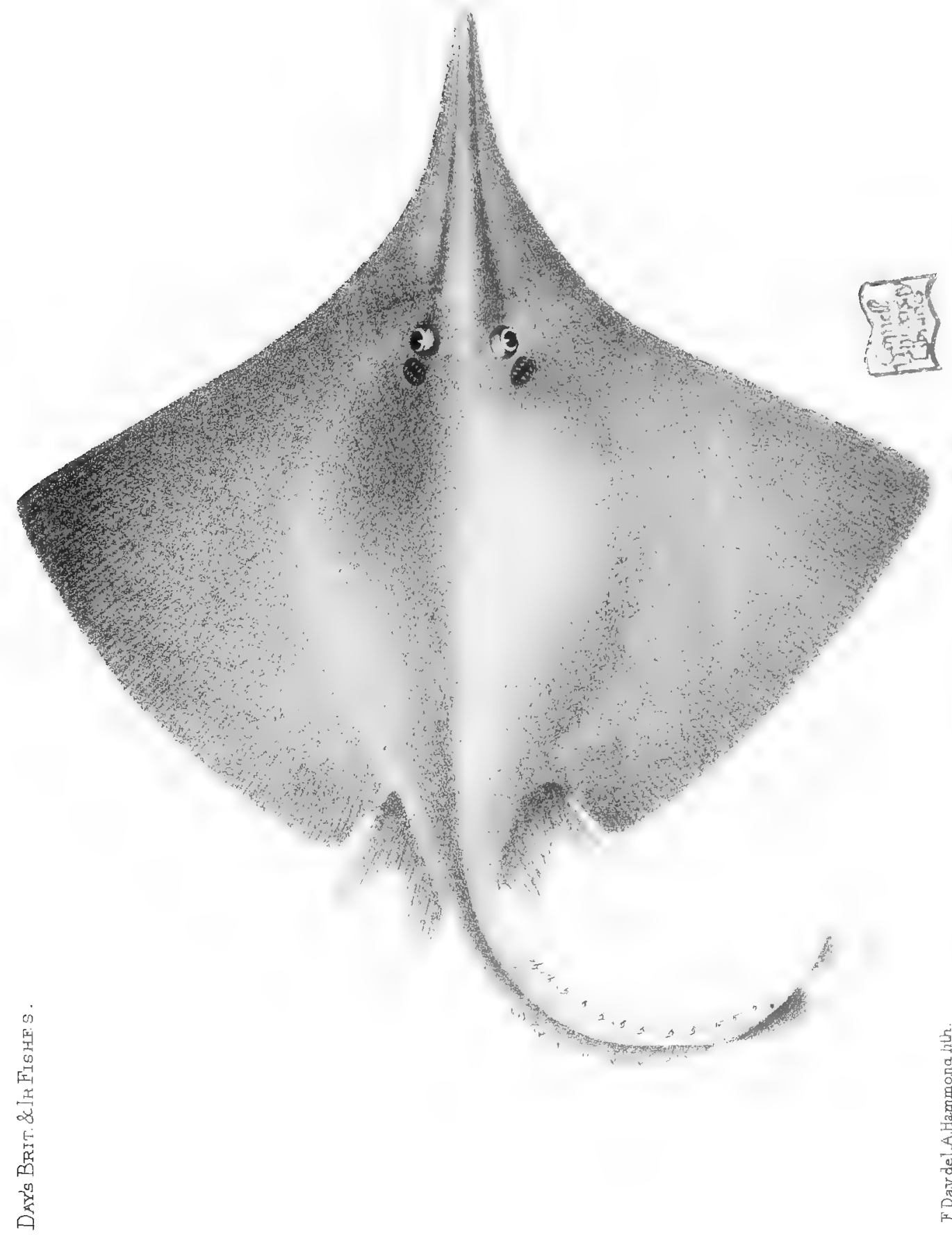





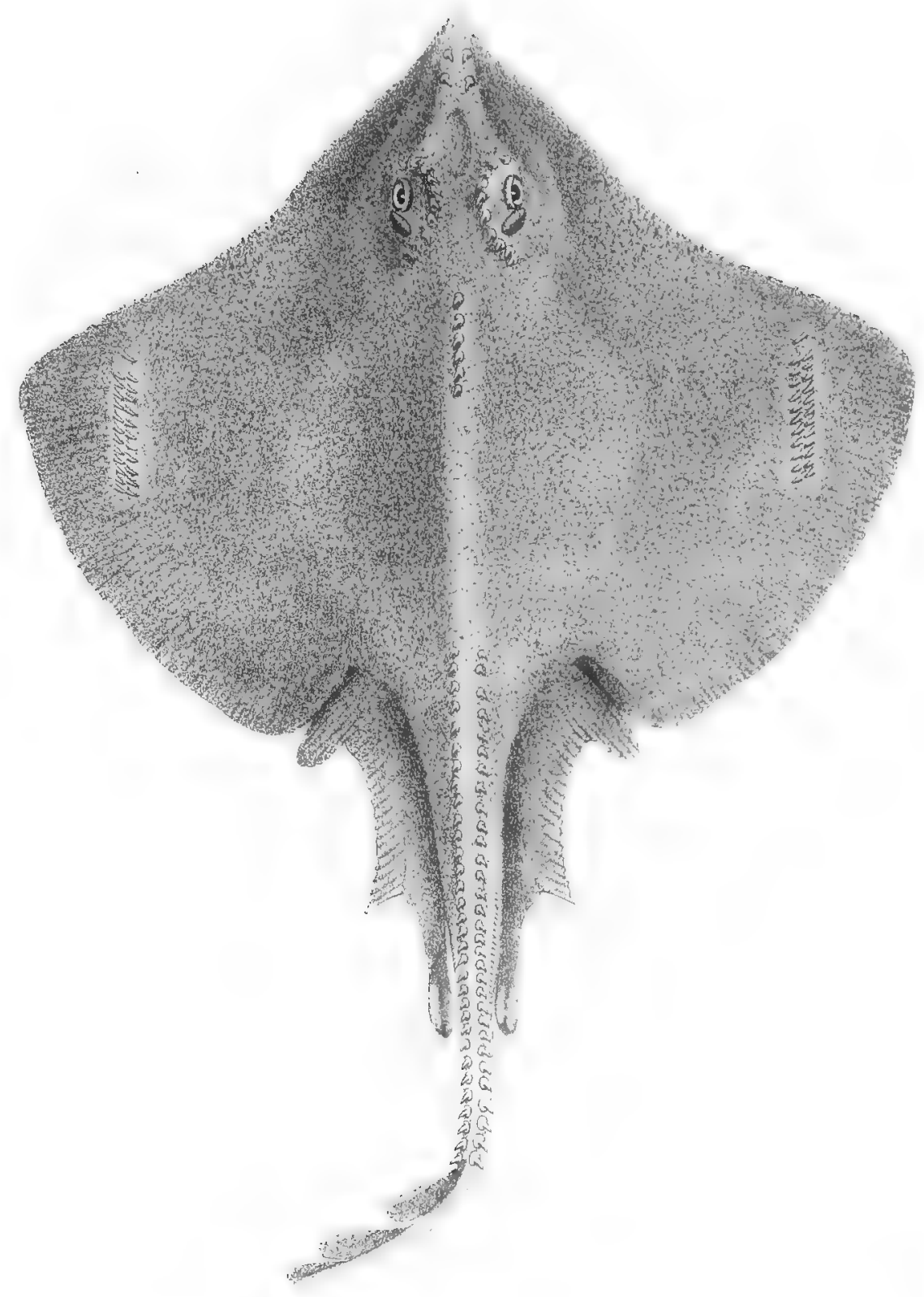

F Day del A Hammond lith 


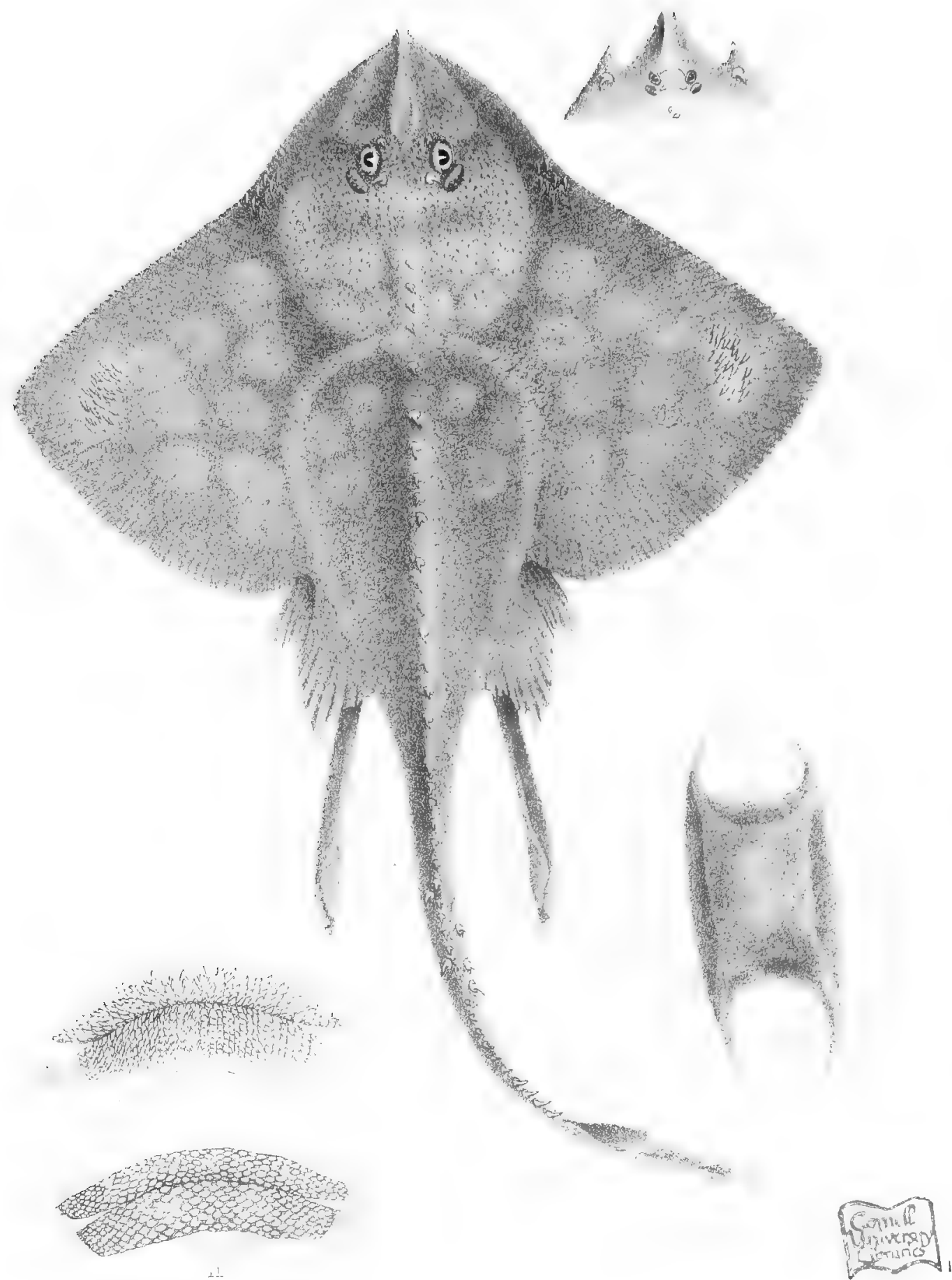

Hankist arre

F Day del A.Hammond lith 



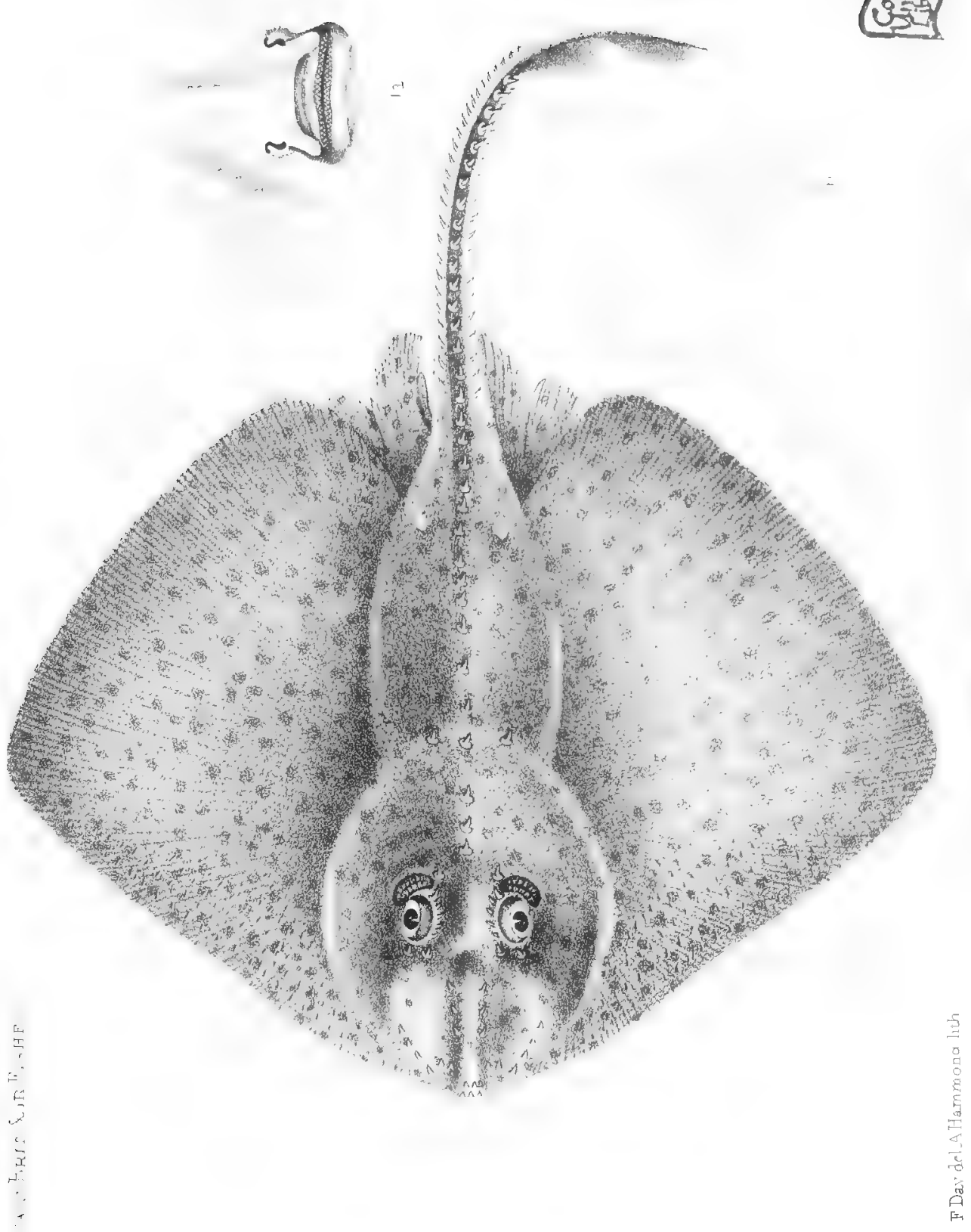





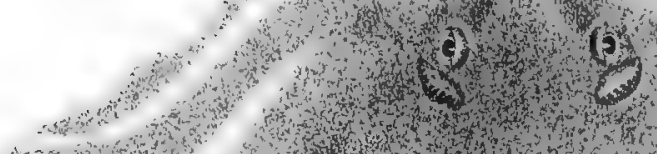

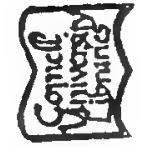

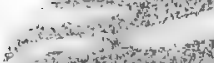

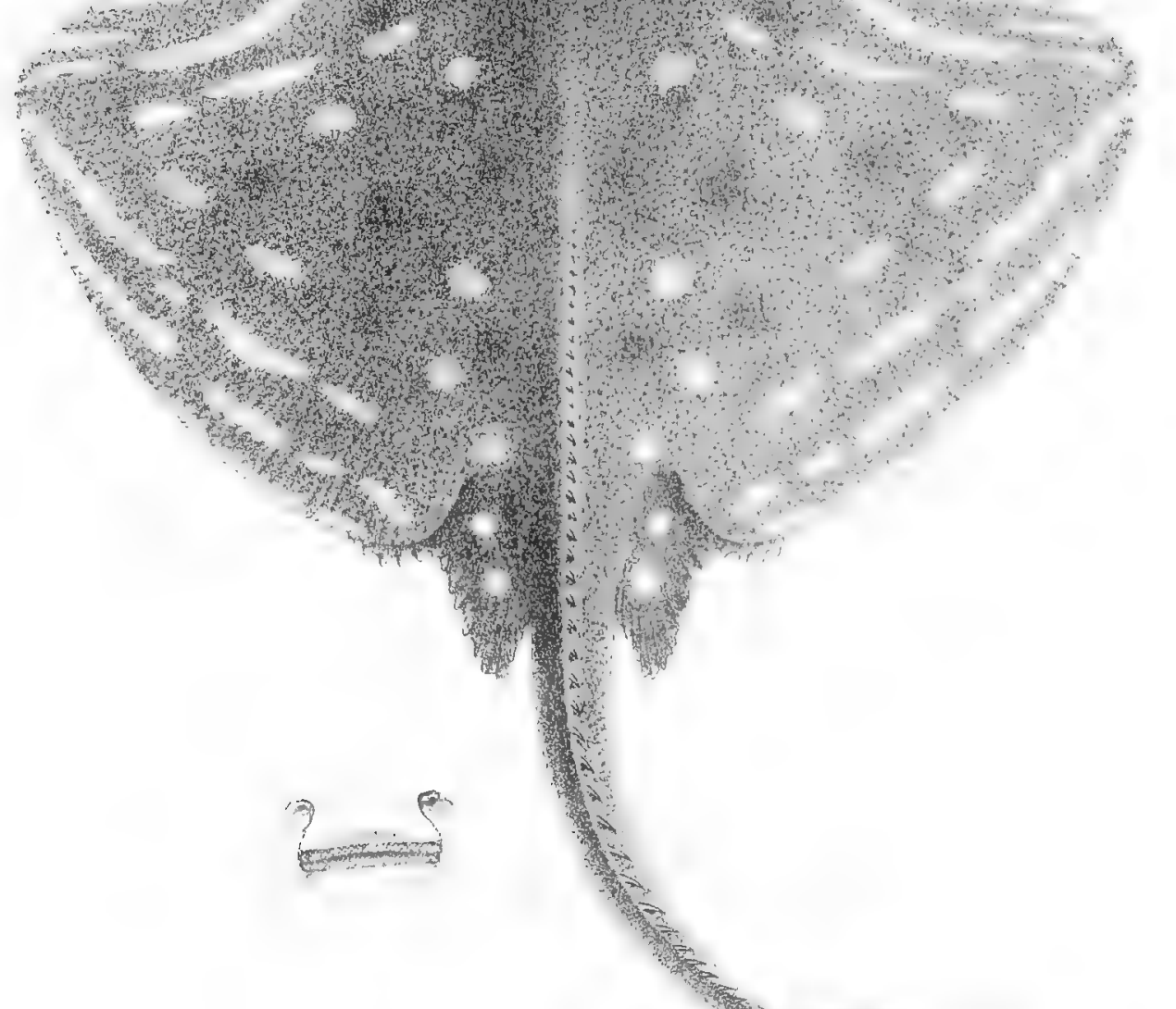

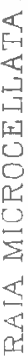
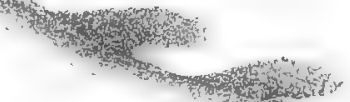



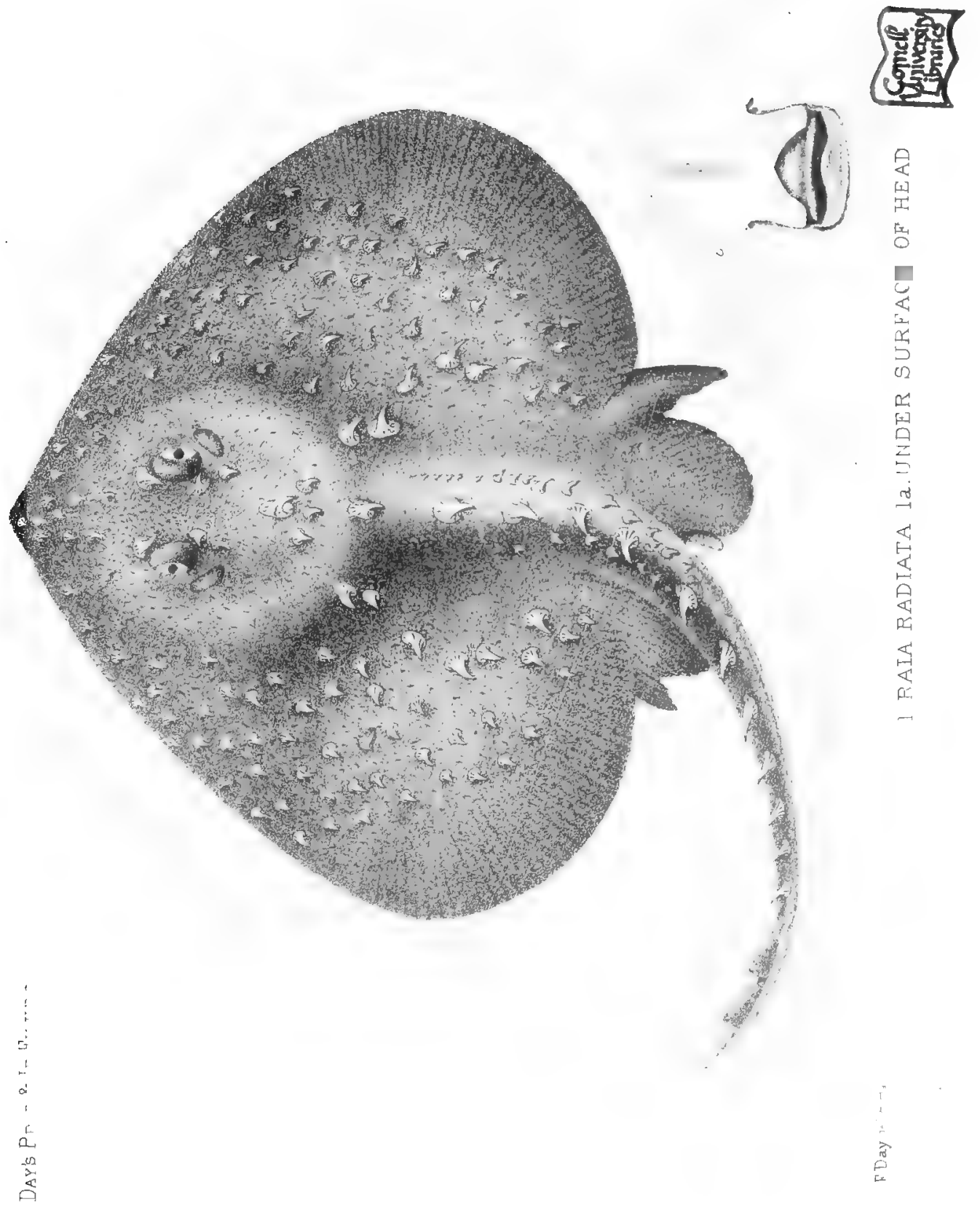




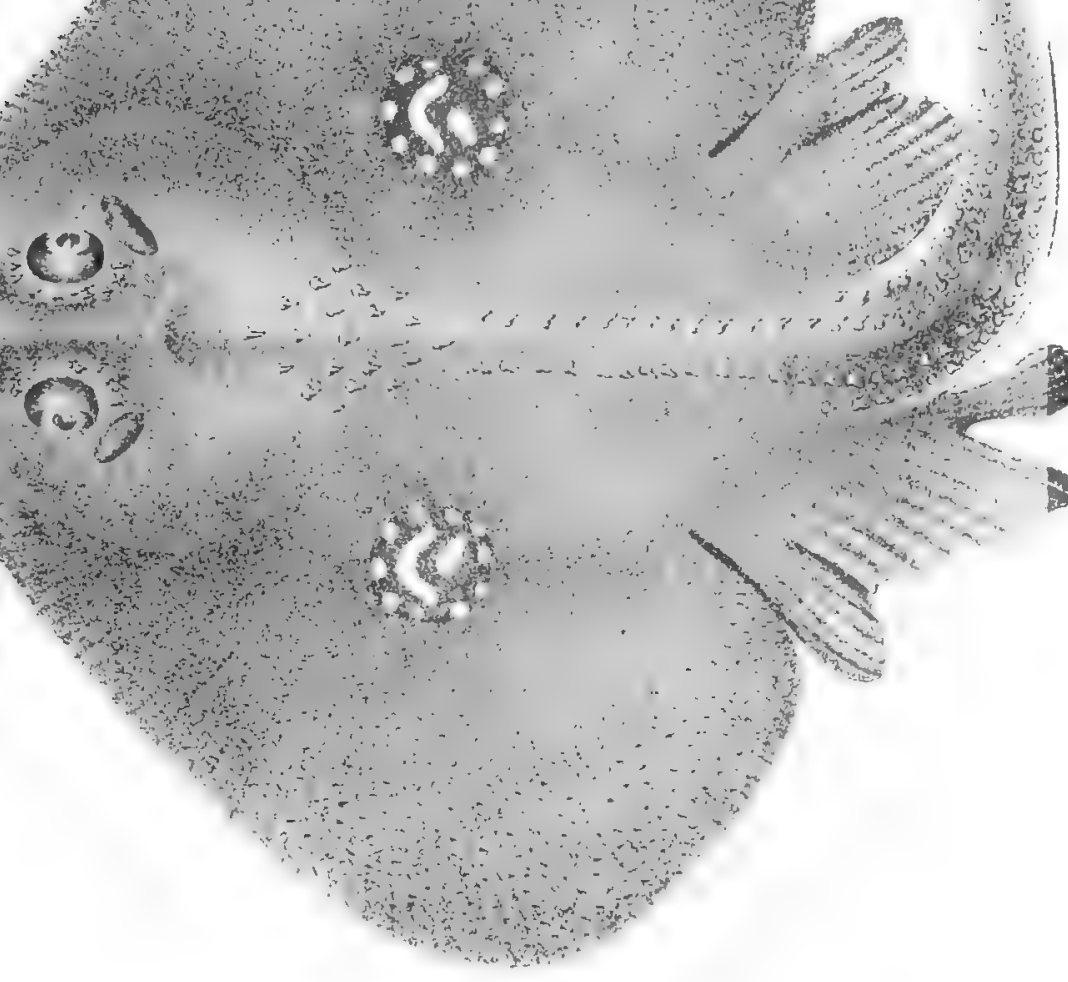



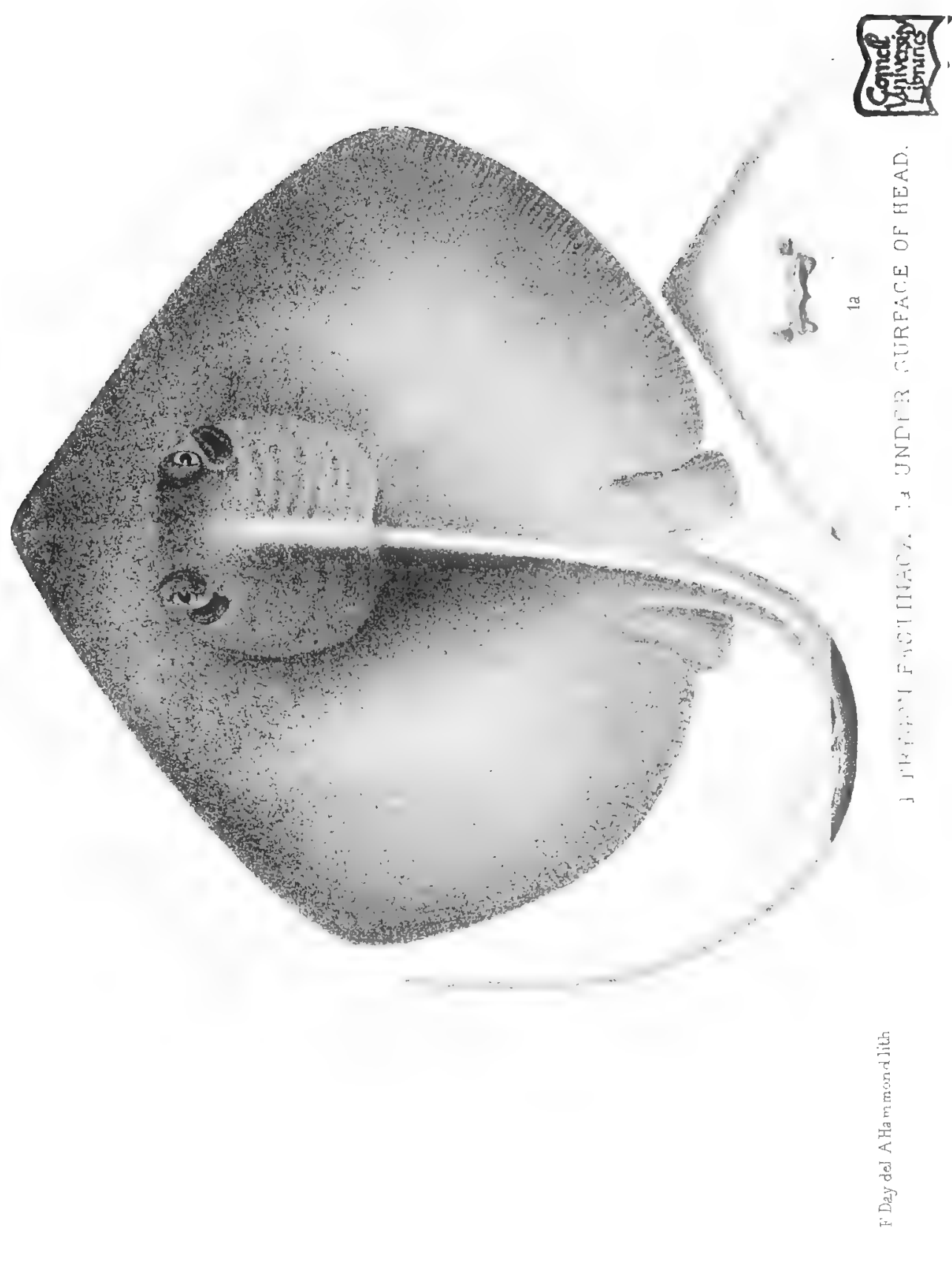



嵌

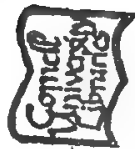

出

E

[I]
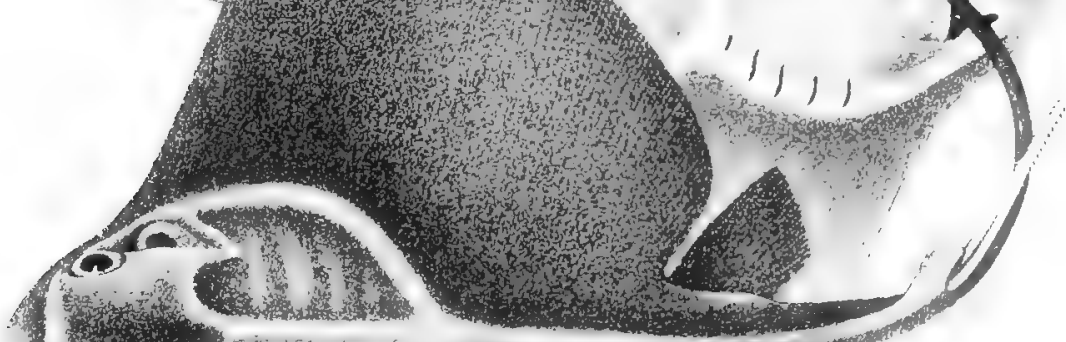



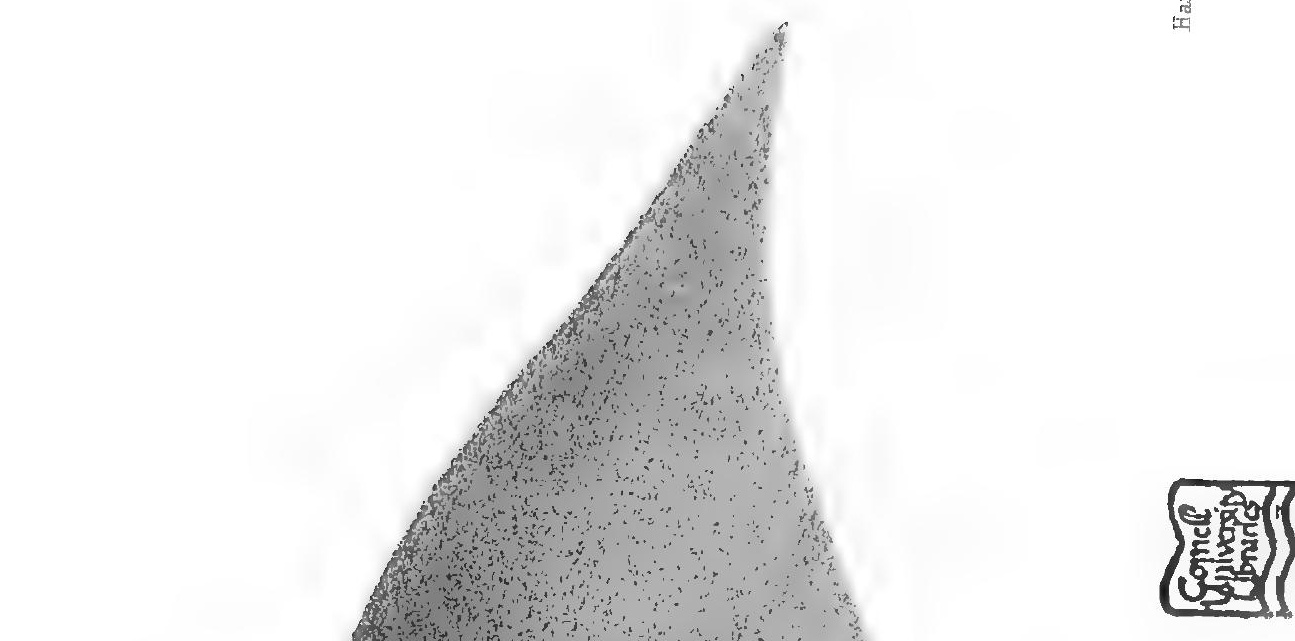



留

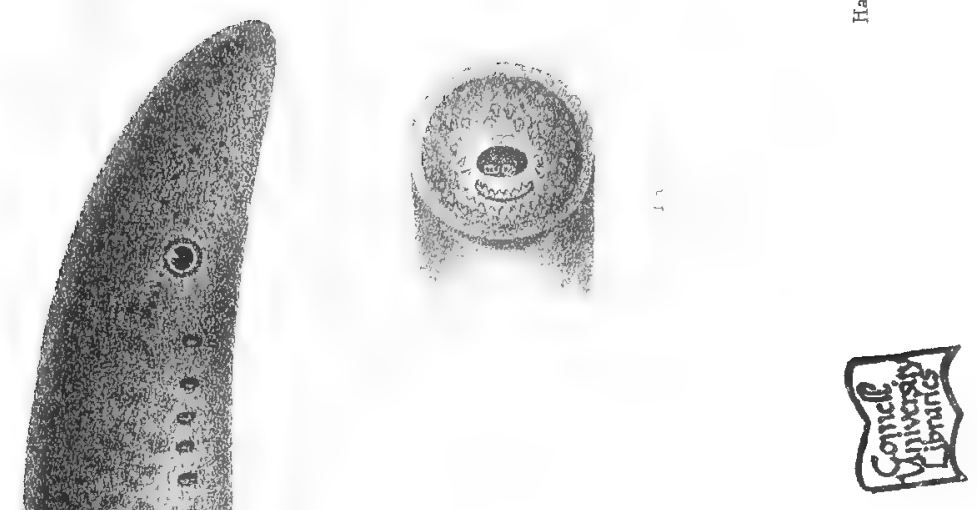

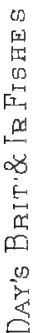



ט

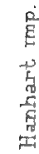

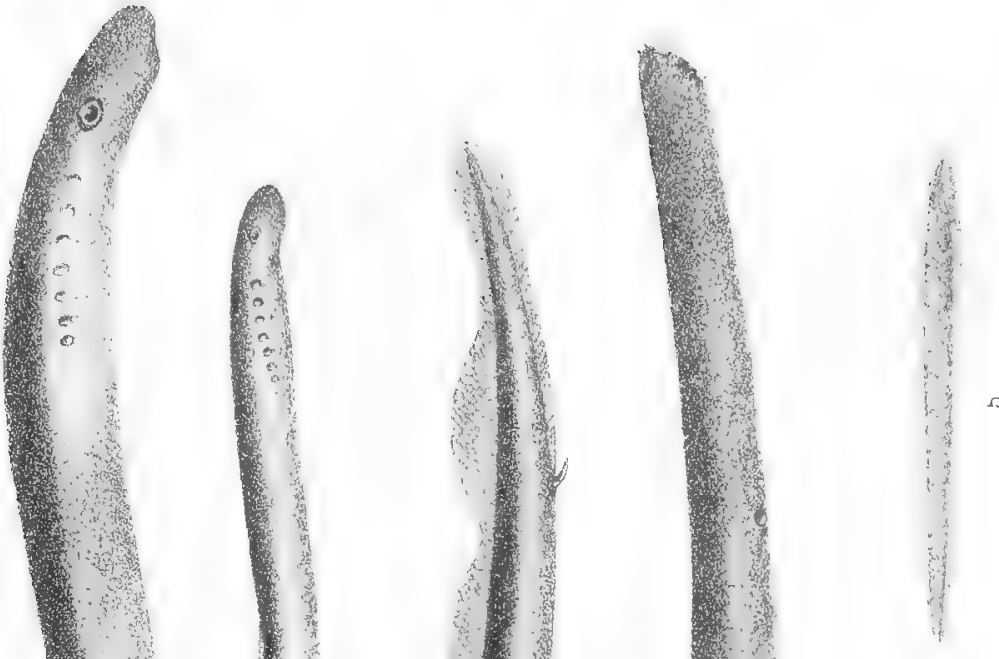

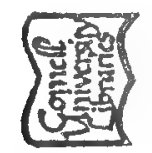

4
0
0
0
0
0
0
0
0
0

孟管

$\leq 0$

空

स

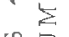

D

要

空

0

点号

出

1) m

ㄱ.

\%

N

号星

密

装杂

s.

50

年穴

䂞忿

NO

新

स

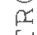

된

告

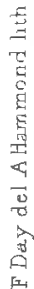






